SANTA BARBARA STATE COLLEGE LIBRAR

35872 

Digitized by the Internet Archive in 2007. with funding from Microsoft Corporation 


\section{MATERIALS OF CORPORATION FINANCE}

BY

\section{CHARLES W. GERSTENBERG}

MEMBER OF THE NEW YORK BAR; DIRECTOR OF THE DEPARTMENT OF FINANCE, NEW YOLK UNIVERSITY BCHOOL OF. COMMERCE, ACCOUNTS AND FINANCE

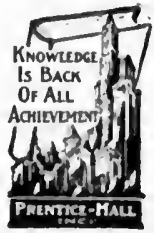

192.4

PRENTICE-HALI, INC. NEW YORK CITY 
COPYRIGHT, 1915, BY

Charles W. Gerstenberg

All Rights Reserved 


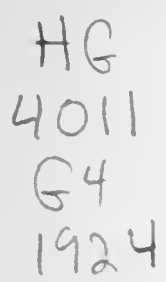

\section{THIS DEDICATION}

\section{to}

Dean Joseph French Johnson

Dean Clarence D. Ashley and

Dean Archibald L. Bouton

Leaves me still immeasurably in their debt 



\section{PREFACE}

This source bouk has been compiled to facilitate the study of corporation finance in classes where the use of the original documents is impossible or impracticable. Commenting upon the very recent publication of an English compilation of select documents in English Economic History, The New Statesman says: "It may not be so valuable as a means of passing examinations, but it is ten times as instructive to get the student to read some of the actual documents about the manor or gild, instead of composing the most elegantly expressed essay upon the subject." The reviewer then suggests that a source book of "Political Economy itself . . . might put some 'élan vital' into economic teaching. It would at least enable us to realize what it was that the professors were talking about."

That this compilation will do for the subject of corporation finance what a source book of economics is promised to do for the field of economics is the desire of the compiler. To sustain the student's interest I have refrained from editing except, as in the cases of acknowledgments and of the similarly expressed clauses in the long mortgages and equipment trust agreements, where much valuable space would be unnecessarily wasted. For the most part, the student may rely upon having a faithful transcript of the original documents; the form, in many cases, unhappily, has been changed on account of the limitations of the size of the printed page.

The contents of this book have bcen collected in various ways during the seven years last past. I have many people to thank for assistance- too many to enumerate here. Not the least part of the book is made up of contributions from my students. To those who have made direct contributions I express my hearty thanks; but to all my students, who have always helped to make corporation finance an entrancingly interesting subject, I acknowledge my large debt of gratitude for their assistance and inspiration.

I have leaned heavily on the ready assistance of Messrs. Richard P. Ettinger and Hugh D. Hite, and to them, as well as to Miss Ethel $A$. Watson and Mr. Lars P. Meyer, who have helped in the difficult task of proofreading, I express my deep thanks.

New York University,

C. W. G.

January 12, 1914. 



\section{INTRODUCTION}

\section{WITH SUGGESTED BIBLIOGRAPHY}

THE habit of searching for truth and of energizing it, of marshalling facts in logical order and of extracting a principle, of seeing where that principle can be applied and of applying it, is the real goal of education. Ladling science, Laputa-wise, into the brain of a student to save time is as harmful as ladling soup into his gullet to save teeth. To save our teeth we must use them; to know truth we must find it; to win in the long struggle of life we must struggle until we love the struggle. All these seeming paradoxes are equally true. Education should not-indeed, cannot-be made easy.

The purpose of this book is to provide a field for vigorous training in finance. It can best be used with an instructor to drive and to guide. The lash of the interrogation should be constantly felt by the student, especially where the aim is utilitarian. He who can give the reason for the difference between one form and another when both seem to have the same general purpose, who can discover a general principle involved in a given excerpt, will have a training far more useful than that of the student who has the principles supplied to him predigested. What would happen if this paragraph or this sentence were omitted? If a corporation acquired property or lost property or sold or exchanged property, what effect would this provision have on its stockholders or its creditors? Can you think of a method whereby the directors can evade the limitations placed on them by this provision? How have the drafters of this agreement anticipated such a method of evasion and provided against it? If the figures were thus and so instead of those giren, would the plan have to be changed? Questions such as these should constantly be asked and answered.

No claim is made that the order of presenting the various forms and reports is the best possible order. Indeed it will be found necessary to refer to different parts of the book adequately to conquer any given subject. The question of bonds, for example, will probably be discussed in full in connection with the Jones-Laughlin Steel Company mortgage, but many other parts of the book will be used for collateral reading, for example, the certificate of incorporation of the Atchison, Topeka \& Santa Fé Railway, the plan of readjustment of the Hudson \& Manhattan Company, the bond circular of Spencer Trask, etc. The parts of the book, therefore, have not been numbered. 
It will be found, however, that in general the following order has been observed: Kinds of business associations; organization and legal management of corporations; kinds of stock and rights of stockholders; corporate bonds, notes and mortgages; control of the issue of securities by the State; sale of stocks and bonds to stockholders and to the public; prospectuses; Wall Street market; promotion; intercorporate relations; financial management and provision of working capital; readjustments and reorganizations.

A brief commentary on each form will aid the student in preparing his work. First of all be it said that with hardly an exception these forms and reports have been used in actual practice. In a very few cases, where personal relations are involved, the names have been changed, but in most cases the originals have been faithfully reproduced.

The partnership agreement (p. 1) with which the book opens was drawn by a firm of New York lawyers and was used for a period of over ten years. The names have been changed. The certificate of limited partnership (p. 4) is interesting because it illustrates a form of business association which is growing in favor in this country, and has been extensively used in Germany. It is a product of the civil law and was first adopted into the common law in the United States by the State of New York. The joint stock company articles (p. 6) are not very important in present-day finance. The most important joint stock companies at present are the large express companies. The so-called "Massachusetts Trust" (p. 11) has been extensively heralded in certain quarters as "an effective substitute for incorporation," giving the benefits of incorporation without the concomitant disadvantages of public interference. One of the most important Massachusetts Trusts in existence is the New England Investment and Security Company, which is one of the financial corporations of the New York, New Haven \& Hartford Railroad system. A complete legal explanation of the Massachusetts Trust is contained in a book entitled Trust Estates as Business Companies, by John H. Sears.

In the chart showing the legal attributes of the various forms of business associations (p. 22) the most important attributes only have been included. A working explanation of the legal problems involved can be found in any elementary book on commercial law.

The New York classification of corporations (p. 24) does not follow the old classical classification into corporations sole and aggregate, etc. It does, however, give the modern practical classification. Notice that in the business man's language the words "public," "quasi public" or "public service" and "private" are frequently applied to corporations. These words correspond closely to "municipal," "trans- 
portation" and "business" as used in the statute. The statute takes no cognizance of the classification of corporations on the basis of products produced, e. g., railroad, public utilities, mining and lumbering, real estate and industrial. This classification, from the standpoint of finance, is most important and could be carried out with more detail to advantage.

The early corporations were formed under special act of the legislature. The constitutions of most States now provide that the legislature cannot create corporations by special act (p. 26) "except in cases where, in the judgment of the legislature, the object of the corporation cannot be attained under the general laws." (Constitution of the State of New York, Article 8, Section 1.) The object of this provision undoubtedly is to prevent the creation of such banking companies as Aaron Burr's Manhattan Company. Notice that the legislatures frequently give special charters to philanthropic institutions and to business concerns which are to carry on several businesses that would necessitate incorporation under two different general acts.

At this time, when France, Germany and England are at war, as they were one hundred years ago, the first general corporation law (p. 31) is doubly interesting. The belligerents in that day had as little respect for the rights of others as they have at this time. Unfortunately-or perhaps fortunately-America was the principal victim. The Berlin and Milan decrees and the Orders in Council produced in America a famine of European manufactures, and everywhere the cry was for "goods made in America." New York did its share by providing an easy method for the incorporation of manufacturing corporations. (For a history of the general corporation acts in the United States, see Kent's Commentaries, Volume II, page 272. For a general history of corporation laws, see Machen's Modern Law of Corporations, Chapter I.)

While the Illinois law (p. 34) has been given in the book, the laws of the State in which the students reside should generally be studied in relation to the organization and legal management of the corporation. A convenient and inexpensive book is Where and How. published by the Broun-Green Company, New York (fifty cents). It gives a digest of the corporation laws of the nine most important incorporating States with outlined forms of eertificates of incorporation, object clauses, etc. The charted digest (p. 51) of corporation laws may well be used as the basis of the question of where to incorporate.

One of the remedies proposed by the Federal Railroad Securities Commission (see report of November 1,1911 ) for the evil of stock- 
watering was the plan for the issuance of shares of stock without par value. Shortly afterwards the State of New York (p. 43 and p. 47) passed a law providing for the formation of corporations issuing stock without par value. The method of determining the amount of stockholders' income, stockholders' liabilities, etc., under this statute should be carefully observed.

The Atchison, Topeka \& Santa Fé charter (p. 54) is a good example of a charter procured through reorganization. Notice the retoing power of the preferred stock and the use of "adjustment" income bonds. For an account of the reorganization see Stuart Daggett's Railroad Reorganization, Chapter VI.

The United States Steel Corporation (p. 59) is the largest industrial in the world. It was originally formed as a $\$ 3,000$ company in order that contracts could be made before the news of the creation of the gigantic corporation got abroad; but within a few months the capital stock was increased. The corporation has been written up a number of times. See Wilgus' United States Steel Corporation, Report of the Commissioner of Corporations, and the report of the Stanley Committee of Congress.

The bylaws of the United States Steel Corporation (p. 66) are not unusual. The student will do well to make a chart showing the relation of the committees and officers to each other. Section 8 of Article 2 is worthy of special study. For a study of the legal principles involved, see Machen's Modern Law of Corporations, Chapters XXIV, XXV and XXVI. See also the account of the United States Steel Corporation bond conversion, Chapter VIII of Ripley's Trusts, Pools and Corporations.

The minutes of organization meetings (p. 80) must always be drawn up with the utmost care. Important property rights are usually at stake and frequently become involved in litigation, the outcome of which depends on the care with which the minutes have been drafted.

It has been brought out very clearly in recent investigations that one company can control another without owning fifty per cent of its stock. The reason for this is to be found partly in the American system of sending out notices of meetings, attaching thereto proxies directed to persons associated with the management (p. 88). These proxies are returnable in envelopes addressed to the company and properly stamped. Thousands of stockholders in this way, without questioning the expediency of the appointment, regularly send in their proxies to persons in control.

The eare with which notices of meetings (p. 89) are drawn up is very important. An improper notice may invalidate subsequent ac- 
tion taken at the meeting. (Sce Chapter XXI of Machen's Modern Law of Corporations.)

The form of ballot used by the Erie Railroad (p. 90) is used where cumulative voting is not practiced, though it may be used even in connection with cumulative voting. For a description of cumulative voting, see the General Corporation Laws of the State of Illinois (p. 35). See an article on The Mathematics of Cumulative Voting, Journal of Accountancy, January, 1910.

Modern corporate monopolies became known as "trusts" because the first form of organization of importance and stability was a voting trust agreement (p. 91) wherein the stockholders in sevcral corporations surrendered their right of control to trustees who elected the directors in the constituent companies and in that way were able to establish harmony of action. The common law of voting trusts, aside from any question of monopoly that may be involved, was established by the New Jersey cases of Chapman vs. Bates, $61 \mathrm{~N}$. J. Eq. 658; Warren vs. Pim, 66 N. J. Eq. 353.

The Great Northern Iron Ore Certificate (p. 98) is a certificate of interest in properties held in trust, similar to the Massachusetts Trust. It is a certificate without par value. For a description of the properties and other matters relating to the trust, see the Report of the Commissioner of Corporations on the Steel Industry.

Mr. W. H. Lyon, in his Capitalization, A Book on Corporation Finance, very clearly brings out the attributes of ownership in a corporation, whether it is the immediate ownership of a stockholder or the contingent ownership of a bondholder. The three attributes of interest are control, income and risk; one security-a stock or a bond -differs from another security through some variation in control, risk or income. The control of stockholders is direct or indirect. Where a proposition is brought forward involving all the property of the company, stockholders usually have direct control; that is, there must be a referendum of the proposition to the body of stockholders. Matters involving ordinary management are subject to the stockholders' indirect control only; that is, they are passed on by the board of directors. The New York statutes (p. 99) are typical of the statutes of most States in respect to the questions that must be decided by a referendum to the stockholders.

The excerpts from the certificate of incorporation of the California Petroleum Company (p. 101), the Chicago, Milwaukee \& St. Paul Railway Co. (p. 105), and the May Department Stores (p. 107) are given to illustrate the different kinds of preferred stock. The student will do well to analyze these excerpts very carefully and to make a table of the different kinds of stock illustrated. At the same time 
he ought to undertake to tell whether a given provision in the charters has been included for the purpose of varying the control, the income, or the risk.

The Uniform Stock Transfer Law (p. 111) made certificates of stock wholly negotiable. If $\mathrm{A}$ endorsed a certificate in blank and then lost it, under the common law it would appear that his title would never be divested except if the loss was occasioned through his own negligence. Nobody could get title unless the finder or a subsequent holder procured a transfer of stock to his own name, and then with the certificate in his own name made assignment to an innocent purchaser for value. It would appear that this last-named person would get title as against the corporation, not as against $\mathrm{A}$. Under the Uniform Law, the first bonafide purchaser for value gets title as against the original holder.

More stock is transferred in New York than in any other State, or perhaps than in all the other States taken together. The Transfer Tax Law (p. 114) of New York State and the regulations of the State Comptroller (p. 122) are therefore very important to the student of corporation finance. Transfers of stock are governed by statute, by bylaws, and by the Stock Exchange rules when the transfer is being made between members of the Exchange. A great many of the large corporations have found the rules of the Stock Exchange governing transfers (p. 126) at once safe and convenient, and therefore have adopted their own code of rules (p. 171) based on the Stock Exchange Regulations. See generally on this subject Goldman's A Handbook of Stock Exchange Laws.

The rules governing the listing of stock on the New York Stork Exchange (p. 151) are interesting to the student of corporation finance because they outline the practical considerations involved in an issue of stock. When a corporation makes an application to list its stock, the members of the Exchange are notified through a statement, an illustration of which is given on page 162. The whole subject of the control of the Stock Exchange over listed securities is important at this time on account of the agitation to get greater public control of the exchanges of the country, especially of the New York Stock Exchange. Notice in the application of the Pacific Light and Power Company (p. 163) the protection offered to bondholders through the modern device of the improvement fund. See generally on this subject Chapter VII of Meade's Corporation Finance.

The form of real estate bond and mortgage (p. 180 and p. 176) was prepared by the Lawyers' Title Insurance and Trust Company of New York. Before the student undertakes to study the corporate mort- 
gage, he should master the ordinary real estate mortgage, and study the rights of the mortgagee thereunder.

The corporate mortgage of the Jones Laughlin Stcel Company (p. 183) is given in full, except that part of the description of the property pledged was omitted as being of no value to the student. This mortgage is a thoroughly typical mortgage and can well be made the basis of a study of bonds and of the subject of the rights of bondholders of insolvent companies. Notice particularly the restrictions on the issue of the second $\$ 15,000,000$ worth of bonds to be issued and compare these restrictions with those placed on the issue of the first $\$ 15,000,000$. (See generally Chapter V of Meade's Corporation Finance.)

Bonds may be classified on the basis of their purpose, their security of principal and interest, their manner of payment of principal and their manner of payment of interest. Besides the words listed below, many other words are used in the titles of bonds; the words given are most frequently used in practice.

Purpose of bonds: Adjustment; consolidated refunding; construction; extension; improvement; purchase money.

Security of principal: Prior lien; first, second, third mortgage, etc.; underlying; overlying; senior; junior; bridge; ferry; dock; wharf; divisional ; terminal; general mortgage; first and consolidated, and other phrases indicating that the mortgage is not the first mortgage on all the property; debenture ; collateral trust ; equipment or car trust; sinking fund; income; participating or profit sharing; joint; assumed; guaranteed; endorsed; stamped; receiver's certificate.

Manner of payment of principal: Gold; silver; currency or legal tender; redeemable or irredeemable; serial or equal installment; convertible.

Manner of payment of interest: Registered; coupon; interchangeable; registered as to principal with negotiable interest coupons.

In studying the mortgage try to discover the attributes of the various bonds above enumerated. For a complete deseription of all kinds of corporate bonds sce Chamberlain's Principles of Bond Investment.

The mortgage of the Mortgage-Bond Company (p. 255) brings out the international nature of large flotations. It is also important as illustrating a method of securing bonds with shifting assets.

The subject of collateral trust bonds (p. 255) may be studied in connection with this mortgage as well as in connection with the Jones Laughlin mortgage, and should be coupled with a complete discussion of the financing of subsidiary companies. For a complete description of corporate mortgages, see Jones' Corporate Bonds and Mortgages. 
Short term notes (p. 291) are temporary substitutes for bonds and their place in corporation finance is very important. It is said that they are used amongst the banks in New York to settle clearing house balances.

The reason why a safe investment like an equipment bond pays a high rate of interest should be understood by the student.

Equipment trust agreements (p. 299 and p. 313) do not take the form of an ordinary mortgage on account of the effect of the afteracquired clause in the usual corporate mortgage. The equipment trust device is used in order to provide a first lien on the equipment before it can be subjected to the lien of the general mortgage of the corporation. The device should be clearly worked out by studying the various transfers of the legal title to the property from the time it leaves the car company to the time the corporation gets physical possession. Another question of importance is, why are equipment trust notes (p. 301) well treated in reorganizations?

The subject of refunding and the function performed by the banker is a subject that may well be considered in connection with the advertisement of the Toledo Traction Company (p. 320). What is the object of the Toledo Traction Company in refunding the bond issues of its subsidiaries? Why do corporations refund their bonds instead of paying them? The theory of funding and refunding is thoroughly discussed in Chapter II of Lyon's Capitalization. See also pages 398 and 399 of Meade's Corporation Finance.

Convertible bonds make up a large part of the security issues of corporations. Their advantages are well pointed out in the Spencer Trask circular (p. 324). For a thorough discussion see Lyon's Capitalization, p. 43 et seq. and p. 90 et seq.

The advertisements printed on page 336 should be used in connection with a discussion of Article 4 of the Jones Laughlin Steel Company mortgage.

A complete compilation and analysis of the laws of forty-three States and of the Federal Government for the regulation, by central commissions, of railroads and other public utilities has been published by the National Civic Federation (1913) under the title Commission Regulation of Public Utilities. The complete New Jersey Public Utilities Act is given on pages 337-349, and is typical of public service commission laws of other States. The rulings of the New York Public Service Commission on the issuing of securities have been abundant, and therefore the New York statute bearing on that point has been given (p. 350).

The general orders of the New Jersey Utilities Board on the issue - of securities (p. 351) is a fair summary of the attitude of public ser- 
vice commissions toward new issues of securities or bonds, and may well be made the basis of a study of the formation of the financial plan for new corporations. For example, the corporation to be created referred to in the Engineer's Report (p. 457).

The whole subject of stockholders' rights (p. 358) has been thoroughly worked out by the New York Court of Appeals in the case of Stokes vs. Continental Trust Co., 186 N.Y. 285. The theoretical value of a right may be found from the following formula: $\frac{P \times R}{1+R}$, where $P$ is the premium on the old shares and $R$ is the rate or percentage of increase. For a discussion of rights and of the application of this formula see Lough's Corporation Finance, Chapter XXIV.

The various documents beginning with the newspaper advertisement announcing the sale of the United Dry Goods Company preferred stock (p. 367) down to and including the bond letter of N.W. Halsey and Co. (p. 404) should be considered carefully in connection with the problem of selling securities to the public. Compare the dignified letter of N. W. Halsey and Co. with the delightfully ingenuous letters of the Sterling Debenture Corporation (pp. 383-4). The editor has frequently wondered why that corporation did not more abundantly exult in the discovery of natural rubber trees. Probably only a quotation from Holy Writ could adequately express the Company's joy in finding itself in partnership with Nature. Apply to all these documents the fact and opinion test; to what extent does the corporation or its agents make representations based on past facts instead of cunningly twisting expressions of opinion, upon which action for fraud cannot be based, into apparent statements of fact.

The subject of syndicate underwriting, illustrated by documents on pages 410-411, was first strongly called to public attention by the insurance company investigation of the State of New York, in which investigation Charles E. Hughes, now Supreme Court Justice, was inquisitor. For a statement of management, profits and losses, etc., of underwriting syndicates, see the report, entitled Testimony Taken by the Legislative Insurance Investigating Committee, New York, 1905. See also Chapters XVIII and XIX in Lough's Corporation Finance, Chapter II of Cleveland and Powell's Railroad Finance, and Chapter XIII of Meade's Corporation Finance.

Wall Street Ways (p. 421) will be especially interesting to those who care to use the book in a study of speculation and investment. This document, with those following down to and including those on puts and calls, might well be studied in connection with the Stock Exchange rules mentioned above. See generally on this subject Con- 
way and Atwood's Investment and Speculation, and Nelson's $A B C$ of Stock Speculation.

Corporations depend largely on savings banks, insurance companies and private trustees for the "digestion" of their securities. It will be interesting for the student to study carefully the rules governing legal investments for trustees (p. 447) and then to analyze the lower part of the Baltimore and Ohio Ry. income statement for 1908 (p. 625). He will probably discover the reason why the railroad paid its dividend that year although it did not earn it.

Things necessary to be done to promote a public utility corporation are summarized in the excerpt from the brief of the Public Service Corporation of New Jersey (p. 455). For the steps taken in promotion see Lough's Corporation Finance, Chapter XII.

The report of the engineers ( $p .45 \%$ ) may be taken as a typical engineer's report to the bankers who are asked to participate in the promotion of a new enterprise.

The complaint in Haskins vs. Ryan (p. 489) is included as an illustration of the method of "discovering" a consolidation. The student who has failed to read Meade's Trust Finance should do so at once. He will find Chapters IV, V, and VI of great importance in connection with this complaint.

The whole subject of intercorporate relations is too large to permit of any extensive commentary in this introduction. All the important forms of intercorporate relations are illustrated, from pools ( $p$. 496) to the holding company (p. 570). Undoubtedly the best book that has ever been written on the subject-although it is now somewhat old-is Noyes on Intercorporate Relations (second edition, 1909). Sterens' Industrial Combinations and Trusts is a source book on that subject in the industrial field. See Interstate Commerce Commission's special report on Intercorporate Relationships of Railways in the United States as of June 30, 1906. For a concrete study of a number of industrial consolidations see Dewing's Corponate Promotions and Reorganizations. Anti-trust literature is boundless. The problem is well treated in Jenks' The Trust Problem, and in Haney's Business Organizations and Combinations. For a solution see Wyman's Control of the Market and Van Hise's Concentration and Control. For a historic and international survey of monopolies see Levy's Monopoly and Competition, Macrosty's Trusts and the State, and Hirst's Monopolies, Trusts and Kartells.

The subject of corporate financial management can best be studied in connection with annual reports. A comparison of the extremes of good and bad reports may be had by studying, on the one hand, the Westinghouse (p. 62\%) and New Haven (p. 663) reports, and, on the other, the report of the American Glue Company (p. 782). 
It is likely that the Federal Trade Commission will in the course of the next ten years make such rules and regulations as will enable the stockholders of industrial companies to get the same information out of their annual reports as can the stockholders of the railroad companies, thanks to the Interstate Commerce Commission. The first book on the analysis of corporate reports was Woodlock's Anatomy of Railroad Reports; it has been entirely superseded by Sakolski's American Railroad Economics. Concrete studies in the analysis of reports will be found in Moody's Analyses of Public Utilities and Industrials, and Moody's Analyses of Railroad Investments, each published annualiy.

A wealth of material will be fourd in Professor Bemis' report ( $p$. 783). It is recommended at once as a field for the study of financial management and as a concrete example of the analysis of financial statistics. The whole subject of physical valuation is ably treated in Whitten's Valuation of Public Service Corporations.

The three problems of financial management are those of maintenance, provision of working capital, and the distribution of surplus. The study of maintenance can be made in connection with annual reports (pp. 62\%, 663) and with Professor Bemis' Report (p. 783). The study of working capital may be taken up in connection with short term loans. See forms beginning with the application for bank loan (p. 902) down to and including the settlement of open accounts (p. 908). See generally Lough's Corporation Finance, Chapters VIII and XX. In connection with the registration of commercial paper, see Trust Companies Magazine, Volume XII, page 101.

Readjustment may be necessary on account of (1) desire for profit (p. 910), (2) existence of illogical capital account growing out of piece-meal financing (p. 929), (3) financial failure, imminent or actual (pp. 933, 966), or (4) disintegration in pursuance of a court decree after an anti-trust prosecution (p. 1001). On this subject see Lyon's Capitalization, Chapter III; Meade's Corporation Finance, Chapter XXXI; Dewing's Corporate Promotions and Reorganizations, and Daggett's Railroad Reorganization.

Since the publiention of the first edition, Materials of CorporaTION Finance has been adopted in many colleges throughout the country and the author has frequently been consulted upon the best method of using it in class work. For his own class, the author has prepared a Syllabus of Corporation Finance containing a very concise statement of principles, and a book of problems based on Materials of Corporation Finance, which problems are mate the basis of classroom discussion.

The above books are published ly Pinentice-Hald, Ine. 



\section{TABLE OF CONTENTS}

Articles of Co-Partnership ............................... I

Certificate of Limited Partnership in the State of New York......... 4

Articles of the Pierce Fordyce Oil Association-A Joint-Stock Company.. 6

Form of Declaration of Trust Establishing a Holding Company........ 11

Chart Showing Principal Forms of Business Associations with a Comparative Summary of Leading Features ................... 22

Classification and Definitions of Corporations ................... 24

An Act to Ineorporate the General Electric Company............... 26

First General Corporation Law ............................ 31

General Corporation Law ............................... 34

Certificate of Incorporation with Shares of Stock without Par Value.... 43

An Act in Relation to Corporations Having Shares of Capital Stock without Nominal or Par Value $\ldots \ldots \ldots \ldots \ldots \ldots \ldots \ldots \ldots \ldots, 47$

Comparison of So-called Ineorporating States ................ 51

Certificate of Incorporation of the Atchison, Topeka \& Santa Fe Rail-

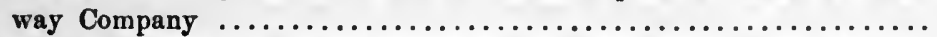

Amended Certificate of Incorporation of United States Steel Corporation. .

By-Laws of United States Steel Corporation .....................

Form of Organization Papers of a Corporation, including Minutes of

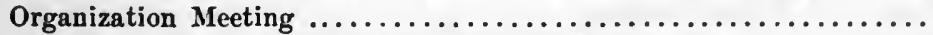

Minutes of the First Meeting of the Board of Directors.............

United States Steel Corporation, Notice of Annual Meeting............

United States Steel Corporation, Notice of Special Meeting ...........

Erie Railroad Company's Form of Ballot .....................

Voting Trust Agreement, International Harvester Company, Dated August

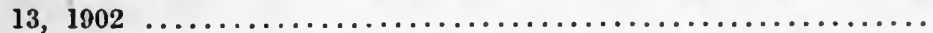

Great Northern Iron Ore Properties-Trustees' Certificate of Beneficial

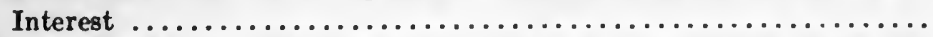

Corporate Acts Requiring Consent or Vote of Stockholders under the

New York Statute ............................. 99

From the Articles of Incorporation of the California Petroleum Corporation 101

From the Articles of Assoeiation of the Chicago, Milwaukee \& St. Paul

Railway Company .............................. 105

From the Certificate of Incorporation of the May Department Stores

Company .................................... 107

Transfers of Certificates and Shares of Stoek ................... 111

Stock Transfer Tax Law of New York ..................... 117

Rulings of the State Comptroller Governing the Colleetion of Taxes on

Transfers of Stock ................................ 122

Stock Exchange Bylaws and Rules ....................... 126

Certificate of Stock of British Ameriean Mines ................ 150

Rules of Committee on Stock List of New York Stoek Exchange ..... 151

Application for Listing Paeifie Light \& Power Company's First and Re-

funding 20 Year $5 \%$ Bonds on New York Stoek Exelıange ........ 162

Regulations Governing the Transfer of Stocks and Bonds........... 171

Real Estate Mortgage ............................... 176 
Bond to Accompany Real Estate Mortgage ................ 180 Corporate Mortgage-Jones \& Laughlin Steel Company............. 183 Trust Agreement-The Mortgage Bond Company of New York with United

States Trust Company of New York .................. 255

Agreement Securing Short Term Notes .................. 291

Conditional Sale Agreement ......................... 299

Agreement between Standard Steel Car Company and Bankers Trust Com-

pany and Erie Railroad ............................. 313

Illustration of the Method of Refunding with the Aid of a Banker..... 320

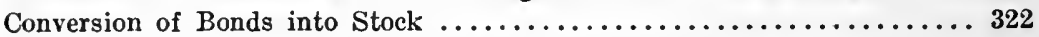

Convertible Bonds-Spencer Trask \& Company Circular............. 324

Specimen of Offer to Purchase Bonds Where the Mortgage Gives Trustees

the Right to Invest Sinking Funds in Bonds. Bonds Are not Re-

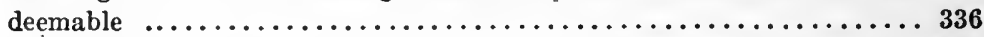

Public Utilities Commission Act of New Jersey .............. 337

Approval of Issues of Stocks, Bonds and other Forms of Indebtedness. . . 350

Interpretation of Security Restrictions $\ldots \ldots \ldots \ldots \ldots \ldots \ldots \ldots \ldots \ldots \ldots$

Stockholders' Rights-New York, New Haven \& Hartford Railroad Com-

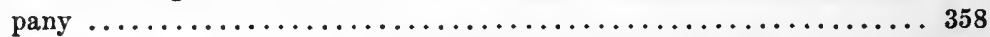

Stockholders' Rights_Union Pacific Railroad Company ............ 363

United Dry Goods Company Preferred Stock-Newspaper Advertisement

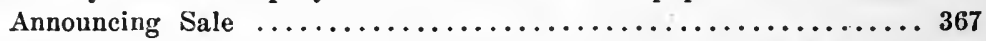

Bond House Circular (Blair and Company) Announcing Jones \& Laugh-

lin Steel Company Bonds .......................... 374

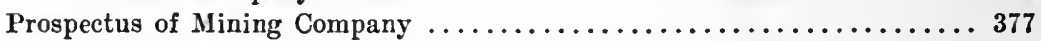

Promoter's Letters-Sterling Debenture Corporation ............ 383

Bartica Company Annual Report, January, $1912 \ldots . \ldots \ldots \ldots \ldots . \ldots 38$

Mining Prospectus-Black Wonder Mill and Mines .............. 398

Example of Direct Appeal ........................... 399

Bond Letter-N. W. Halsey \& Company ................... 404

Underwriting Syndicate Agreement-Republic of Cuba Five Per Cent

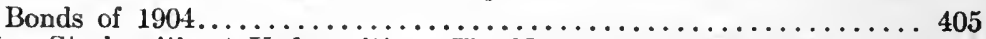

Selling Stock without Underwriting-The Kansas City, Mexico \& Orient

Railway Company .............................412

American Wolves .................................. 415

Stillwell's Road is in Receiver's Hands ................... 418

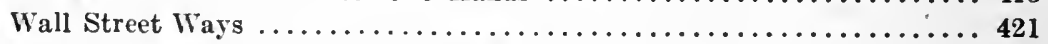

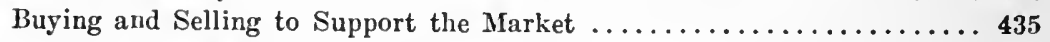

Stock Pooling Agreement-Hocking Valley Railroad ............. 436

Puts and Calls ................................... 438

Options ...................................... 441

Puts and Calls-Facsimile "Call" made by Jay Gould.............. 444

Puts and Calls_Facsimile "Put" made by Daniel Drew............. 446

Legal Investments for Trustees........................ 447

Elements of the Cost and Value of a Gas Plant................. 455

Engineers' Preliminary Report-with Maps, etc............... 457

Promotion-Complaint of Haskins vs. Ryan, Illustrating the Technical

Method of Discovering a New Consolidation..............489

Steel Rail Pool................................ 496

Agreement between Deering Harvester Company and William C. Lane,

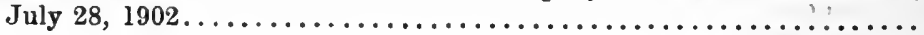


Supplemental Agreement between Deering IIarvester Company and Wil.

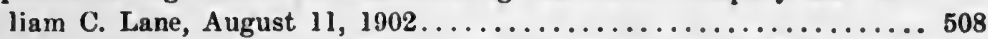

Agreement Preliminary to the Formation of the American Snuff Company 511

Agreement Preliminary to the Formation of the American Cigar Company 516

Consolidation by Sale of Assets....................... 522

Plan for the Consolidation of the Electric Railway Companies, the Gas and Electric Light Companies of the City of New Orleans, La., under the Control of the New Orleans Railways Company, a Corporation Organized under the Laws of the State of New Jersey..........526

Basis of Consolidation.............................. 536

Agreement to Consolidate.......................... 538

The New York Central \& Hudson River Railroad Company's Notices Con-

cerning Proposed Consolidation of New York Central Lines........ 542

Purpose and Method of Consolidation-Report of The Interstate Commerce

Commission to the Senate of the United States............ 548

Lease-West End Street Railway ..................... 555

Holding Companies in the Public Utility Field.............. 570

Partnership between Municipality and Public Utility Corporation..... 583

The Sherman Anti-Trust Law....................... 500

Clayton Law Supplementary to Sherman Anti-Trust Act.......... 595

Federal Trade Commission Law........................ 610

What an Investor Should Know Regarding a Public Utility........... 020

Forty-sixth Report of the Nippon Yusen Kaisha...............622

Income Statement of the Baltimore \& Ohio for $1908 \ldots \ldots \ldots \ldots \ldots \ldots \ldots 625$

Annual Report Westinghouse Electric \& Manufacturing Company, March

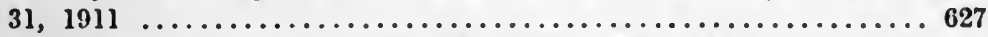

Complete Annual Report of the New York, New Haven \& Hartford Rail-

road Company, 1914..........................663

Chicago, Milwaukee \& St. Paul Ry. Analysis.................. 753

American Smelting \& Refining Co. Statements............... 759

Bethlchem Steel Corp. Analysis........................ 761

United Light \& Railway Co. Statement.................... 764

Midwest Refining Co. Statement..................... 766

May Dept. Stores Analysis......................... 767

Joint Account Letters and Forms...................... 769

Valuation of Public Utility Property-Complete Report on the Physical

Valuation of the Chicago Telephones.................. 783

Divergent Views on Depreciation by Engineering Experts. . . . . . . . . 899

Form of Application for Loans for Corporations, Adopted by the New

York State Bankers' Association. . . . . . . . . . . . . . . . . 902

Note Used to Protect Overdrafts. . . . . . . . . . . . . . . . . 904

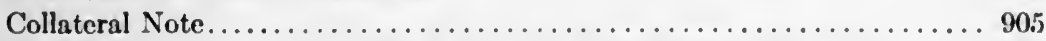

Registration of Commereial Paper-International Paper Company....... 907

Assignment of Accounts Receivable by Way of Discount............. 905

The Facts Concerning the Recapitalization of the Chicago \& Alton Rail-

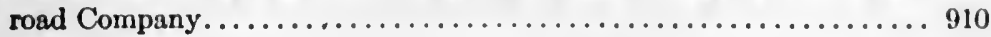


Condemnation of Chicago-Alton Recapitalization.

Readjustment of Public Utility......................... 929

Readjustment of Debt of Hudson \& Manhattan Railroad Company ...... 933

Reorganization of the Baltimore \& Ohio Railroad Company........... 966

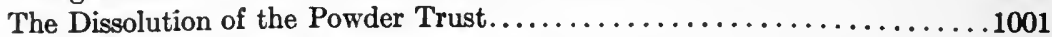

Refunding without the Aid of a Banker..............................

From the Certificate of Incorporation of the Western Maryland Railway Co..1011 From the Certificate of Incorporation of American International Corpora-

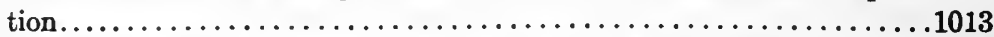

Stockholders' Rights-American Telephone and Telegraph Co............1014

Stockholders' Rights-Form of Warrant of American Coal Products Co....1017 Valuation of Dissenting Stock-Seaich v. Mason-Seaman Transp. Co....1019 Redemption and Sales Prices of Short Term Notes-Bethlehem Steel Corp. .1022 Sinking Fund Computation. . . . . . . . . . . . . . . . . . . . . . . . . 1023 Interest, Annuity and Sinking Fund Tables.................. 1024

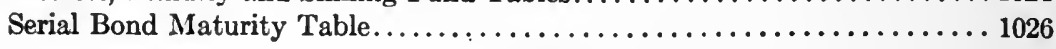




\section{MATERIALS OF CORPORATION FINANCE}

\section{ARTICLES OF CO-PARTNERSHIP}

Articles of Co-partnership, made this first day of June in the year One Thousand, nine hundred and ten, by and between William $\mathrm{H}$. Hull and Edward T. Moran, both of the Borough of Brooklyn, City of New York.

\section{Witnesseth :}

That the said parties have mutually agreed and hereby do mutually agree to continue a co-partnership heretofore entered into by and between them and carried on at Nos. 712-724 Bedford Avenue, in the City of New York, Borough of Brooklyn, for the manufacture of carriages, under the firm name and style of Hull \& Moran; upon the following terms and conditions:

\section{First:}

Said Co-partnership shall continue until the same shall be dissolved by the mutual consent of the parties hereto, or ended in pursuance of some of the provisions hereinafter contained.

\section{Second:}

Each partner may terminate the Co-partnership by giving thirty (30) days written notice to the other partner of his intention so to do.

\section{Third:}

The Co-partnership shall be dissolved by the death of one of the partners; and in that case the surviving partner shall liquidate the business and pay over to the legal representatives of the deceased partner within six months or sooner, the interest of such deceased partner in said business.

\section{Fourth:}

All losses and profits shall be shared equally.

\section{Fifth:}

The business shall be carried on under the firm name and style of Hull \& Moran. 


\section{Sixth:}

In case the Co-partnership be dissolved during the lifetime of both partners, then and in that case, both partners shall act as liquidating partners for the purpose of winding up the business.

\section{Seventh:}

In case of the death of one of the partners, the legal representatives of that partner shall have the right during business hours, to inspect the books of the firm, and to make an inventory, at their own proper expense, and the surviving partner shall assist them in every way possible by giving them all necessary information for the purpose of ascertaining the exact standing of the firm at the time of the death of such deceased partner.

\section{Eighth:}

The assets, which are to constitute the working capital of the firm, shall be contributed equally by the partners and said assets shall be the present business assets of said Firm, which shall be taken over and be subject to this agreement.

\section{Ninth:}

Each partner shall be entitled to draw a salary of sixty dollars $(\$ 60.00)$ per week.

\section{Tenth:}

It is further agreed that a certain note bearing even date with these presents and made by said Edward T. Moran to the order of said William H. Hull, amounting to One Thousand Dollars, shall be paid out of the surplus earnings of said Moran in said business, over and above the said salary of $\$ 60.00$ per week to be paid to him; and all such surplus earnings shall be applied in payment or in part payment of said note and interest; and in case of a dissolution of said Firm, the share of said Moran in the undivided profits and assets thereof, shall first be applied in payment of said note, and the interest of said Moran in said Firm shall constitute the security for said note; and said Hull shall at all times have a lien upon the interest of said Moran in said Firm to the extent of the unpaid portion of said note; and a transfer or assignment of the interest of said Moran in said Firm shall be subject to such security and lien.

\section{Eleventh:}

Both partners shall give all their time and attention to the prosecution of said business and the affairs of said Firm and shall not 
engage in any other business, and shall not make any accommodation notes or become accommodation endorsers, or become surety on any bond or undertaking, or embark in any speculation, without the consent of the other partner.

\section{Twelfth:}

True, full and accurate books of account shall be kept by the Firm of all dealings and transactions by it, and shall be accessible and open to the inspection and examination of both partners at all times.

\section{Thirteenth:}

Neither party shall loan or use the funds or the credit of the Firm, or the Firm's name, for any purpose whatsoever, excepting only the business of the Co-partnership

\section{Fourteenth:}

All business operations, contracts, bargains, agreements, purchases, sales and other transactions relating to the co-partnership business, shall be the subject of mutual consultation, advice and agreement.

IN WITNESS WHEREOF, the parties hereto have hereunto set their respective hands and seals the day and year first above written In presence of

EDITH REARDON.

WilliaM H. Hull Edward T. Moran.

$\left.\begin{array}{l}\text { State of New York, } \\ \text { County of New York, }\end{array}\right\}$ ss.:

On this first day of June, 1910, before me personally came William H. Hull and Edward T. Moran, both to me personally known and known to me to be the same individuals described in and who executed the foregoing instrument, and they severally duly acknowledged to me that they had executed the same.

Charles E. Wallace,

Commissioner of Deeds, New York City. 


\section{CERTIFICATE OF LIMITED PARTNERSHIP IN THE STATE OF NEW YORK 1}

We, whose names are severally undersigned, are desirous of renewing and continuing, and we do hereby renew and continue, beyond the time fixed for its duration, the limited partnership which was heretofore formed and now exists between us, under the name or firm of Post \& Flagg, by making, severally signing and acknowledging, and causing to be filed and recorded in the Clerk's office of the County of New York, in the State of New York, this certificate by which such partnership is renewed and continued, pursuant to "An Act in relation to partnership, constituting chapter thirty-nine of the Consolidated Laws," and we do hereby certify and state:

I. That the name or firm under which such partnership is to be conducted is Post \& Flagg, and that the county wherein its principal place of business is to be located is the County of New York.

II. That the general nature of the business intended to be transacted is a general commission and brokerage business, including the dealing in stocks, bonds and other securities, as generally carried on in the City of New York.

III. That the names of all the general and special partners interested therein (all of whom are of full age) and their respective places of residence are as follows, to wit:

George B. Post, Jr., who is a general partner, and who resides at Bernardsville, Somerset County, State of New Jersey.

Arthur Turnbull, who is a general partner, and who resides in the City and County of New York.

Benson B. Sloan, who is a general partner, and who resides in the City and County of New York.

1 From Gerstenberg's Commercial Law. It should be noticed that this certificate was executed for the purpose of renewing and continuing an old partnership which had consisted of two partners, Post and Flagg. Where a new partnership is formed the firm name should contain the names only of the general partners. Section 20 of the Partnership Law (Chapter XXXIX of the Consolidated Laws of the State of New York), provides in part: "Where any limited partnership shall hereafter be formed under the laws of this State, it may use the firm or corporate name of any general or limited partnership or of any corporation, domestic or foreign, which may theretofore have carried on its business within this State. Where said general or limited partnership or corporation is discontinued or shall be about to discontinue its business within the State, and where a majority of the partners, general or special, in either of such last mentioned co-partnerships, or of the survivors thereof, shall be members of the new limited co-partnership, or where a majority of the members of such co-partnership theretofore existing, or of the surviving members thereof, or where stockholders holding a majority of the stock of such corporation shall consent in writing to the use of such firm or corporate name by such new co-partnership." 
Alfred L. Dennis, who is a general partner, and who resides in Newark, Essex County, State of New Jersey.

Neville G. Higham, who is a general partner, and who resides in the City and County of New York.

Henry Shaw, who is a general partner, and who resides in Morristown, Morris County, New Jersey.

Nathaniel L. McCready, who is a special partner, and who resides in the City and County of New York.

IV. That the amount of capital which Nathaniel L McCready, the special partner, has heretofore contributed to the common stock of said limited partnership is the sum of three hundred and fifty thousand dollars $(\$ 350,000)$, which he paid in cash, and that the said amount, namely, three hundred and fifty thousand dollars $(\$ 350,000)$ has been contributed by the said special partner to the common stock of the partnership as renewed and continued.

V. That the time for which the said limited partnership is to be renewed and continued is five (5) years from December 31, 1910on which date such renewed and continued partnership is to beginto January 1,1916 , and that the time at which, as so rencwed and continued, it is to end is December 31, 1915.

In witness whereof, we have hereunto set our hands and seals this thirtieth day of December, 1910.

$\begin{array}{ll}\text { George B. Post, Jr. } & \text { [L. s.] } \\ \text { Artilur Turniuli. } & \text { [L. s.] } \\ \text { Benson B. Sloan. } & \text { [L. s.] } \\ \text { Henry Shaw. } & \text { [L. s.] } \\ \text { Neville G. Higham. } & \text { [L. s.] } \\ \text { Alfred L. Dennis. } & \text { [L. s.] } \\ \text { N. L. McCready. } & \text { [L. s.] }\end{array}$

In the presence of:

Charles A. Neville.

(Acknowledgments.)

Clerk's Office, County of New York, ss.:

Let the terms of the foregoing limited partnership be published once a week for six successive weeks in the New York Law Jaurnal and Mail and Express, two papers published and having a circulation in the County of New York.

Dated New York, December 31, 1910.

[SRAL]

WM. F. Schineider,

Clerk.

Certificate of Clerk of the County of Essex, showing authority of master in chancery, attached.

Marked, filed and recorded December 31, 1910, 9h. 25m. 
ARTICLES OF THE PIERCE FORDYCE OIL ASSOCIA. TION,-A JOINT-STOCK COMPANY ${ }^{1}$.

\title{
NAME
}

We, whose names are hereto subscribed, do hereby form a Copartnership Association to be known and styled

Pierce Fordyce Oil Association

which shall continue in existence until the 2nd day of April, 1960, unless sooner dissolved as herein provided.

\section{Purposes}

The general purpose of this Copartnership Association is: to engage in the general merchandise of petroleum and the products thereof and other such articles as may be advantageously sold or handled in connection therewith; to purchase, own and mine lands supposed to contain or containing oils or other minerals and to construct and operate refineries or other manufacturing plants for refining or reducing such oils or minerals and to engage in any other industrial manufacturing, mining or merchandising enterprise or exploitation that may be determined by the Board of Managers appointed or chosen as hereinafter provided.

\section{Capital}

The Capital is Three Million Dollars divided into Thirty Thousand Shares of One Hundred Dollars each, all of which has been paid in, by the subscribers hereto. The Capital may be increased from time to time by increasing the number of shares and the admission of new members, as may be determined by a vote of the majority of the then shares at any meeting of the shareholders called pursuant to these articles of Association or such By-Laws as may be adopted hereafter by a majority of the shares.

\section{Shares}

The Certificates of Membership shall be issued by the President of the Board of Managers and countersigned by the Secretary of said Board and shall be in substantially the following form; viz:

\author{
PIERCE FORDYCE OIL ASSOCIATION \\ (Copartnership) \\ Capital, \\ $\$ 3,000,000$, or Thirty Thousand Shares
}

1 Reprinted from Haney's Business Organization and Combination. 


\section{Member's Certificate of Interest}

This is to certify that — is the owner of $\_$full paid shares of beneficial interest in the Pierce Fordyce Oil Association, transferable on the books of the Association by the owner thereof in person or by duly authorized attorney upon surrender of this certificate properly indorsed.

This certificate of interest is subject to the provisions and covenants contained in the Articles of Copartnership of the Pierce Fordyco Oil Association dated the Second day of April, 1910, and any amendment thereto and the By Laws of said Association and the provisions hereof. No member of said Association or owner or holder of this certificate shall have any authority, power or right whatsoever to do or transact any business whatever for, on behalf of or binding on the Association or any member thereof, and no member of this Association shall be liable for any debts, covenants, demands or torts of this Association beyond the amount of his shares.

This certificate shall be the sole and only evidence of membership in said Association and shall be surrendered upon the call of the Board of Governors at any time to the Association upon the payment or tender of payment to the amount of its face or par value and a premium of fifteen per cent thereof.

In Witness Whereor the said Association has caused this certificate to be signed by its duly authorized officers and to be sealed with the seal of the Association this - day of 19

President.

Secretary.

\section{Deatil of Member}

The decease or insolvency of a nember of the Association shall not work a dissolution of it or have any effect upon the same, its operation or mode of business; nor shall it entitle his legal representatives or heirs or assigns voluntary or involuntary to any account or to take any action in law or equity or otherwise against the Association, its members, officers, Board of Governors, Trustees or its property or assets; but they shall simply and only succeed to the right of the deceased, to the certificate of membership and the shares it represents, subject to this agrecment, the amendments thereto and the By Laws of the Association, now or hereafter adopted.

\section{Boand of Governors}

The entire affairs of this Association shall be managed by a Board of Governors, consisting of seven members, each of whom shall own 
at least, certificate or certificates for not less than ten shares, who shall be elected by a majority of shares held by members at a regular annual meeting of the certificate holders every two years after the expiration of the term of the first Board of Governors.

The first Board of Governors shall be composed of the following named persons, viz:

\author{
H. C. Pierce, \\ SAMUEL W. FordYce, \\ SAMUed W. Fordyce, Jr., \\ George T. Priest, \\ Robert E. MoLoney, \\ Henry W. Allen, and \\ JoHN H. HollidaY,
}

who shall continue for the period of five years, next ensuing the date of this agreement.

Each Board shall elect its own President, Vice President, Secretary and Treasurer and may create such other offices, filling them by appointments and prescribing the duties appertaining thereto as they may deem wise, necessary or convenient to carry on the business of the Association and may likewise fill any vacancy in its membership occasioned by death or resignation until the next election of a Board of Governors. The Board may also fix the salaries of all officers, including its own members, and may remove any officer and fill all vacancies which may occur in any office.

The first Board of Governors shall appoint such a number of its members as it may deem proper, not exceeding three, as Trustees, in whose name or names all investments and title to all property are to be made and held under a declaration of trust for and on behalf of this Association.

The Board of Govenors shall be held to be Trustees for and on behalf of this Association and may in that capacity be sued and sue in any court of law or equity.

The Board of Governors shall have full power and authority in the conduct of the business of the Association to borrow money and issue mortgage debentures therefor if deemed advisable and any debt for money so borrowed or liability created shall be and remain until paid a lien upon all funds, moneys and properties there or thereafter belonging to or held in trust for this Association in preference to the claims or claim of any shareholders as such.

(1) The Board of Governors shall have no power to bind the shareholders or members personally; and in every written contract or undertaking they shall enter into relating to the business of this 
Association, its property or any part thereof, reference shall be made to this agreement; and the person, firm or corporation so contracting with the Board of Governors shall look only to the funds and property legal and equitable of this Association for the payment of any debt, damage, judgment or decree or of any money that may become due and payable in any way by reason of the contract or undertaking; and neither the Board of Governors nor the shareholders or members present or future shall be personally liable therefor or for any debt incurred or engagement or contract made by said Board of Governors.

(2) The Board of Governors may fix and regulate their own time and place of meeting and a majority thereof shall constitute a quorum and possess and exercise all the powers of a full Board.

(3) The Board of Governors shall whenever they may be so minded convene all of the registered share or certificate holders in general meeting without specifying the purpose thereof upon notice to that effect deposited in the Post Office at the place of the general offices of the Association addressed to each shareholder at his registered Post Office address, ten days before the date of the proposed meeting; and the majority of the shares present or represented at any such meeting so called, shall have and exercise the right, power and authority of the entire body of share or certificate holders.

(4) The share or certificate holders shall meet annually on the second Tuesday of each year without further notice to consider the affairs of the Association and transact such business as may then be inaugurated by them or that may be submitted for their consideration by the Board of Governors. At each meeting of the share or certificate holders, each member present or represented by duly accredited agent or attorney shall be entitled to cast as many votes upon any proposition as he may have shares of membership interest.

(5) At any meeting of members, By Laws may be passed or amended by a majority of those present or represented; and any amendment may be made to this agreement by a vote of three-fourths of those present or represented.

(6) The Board of Governors may from time to time declare and pay such dividends from the earnings of the Association as they deem expedient.

\section{Officers and Their Duties}

\section{President and Vice President}

The President or in his absence the Vice President shall sign all certificates of membership, preside at all meetings of the members of the Board of Governors and shall do and perform and render such 
acts and services as the Board of Governors shall prescribe and require and shall receive such compensation for services as may from time to time be fixed upon by the Board of Governors.

\section{SECRETARY}

The Secretary shall countersign all certificates of membership and shall keep such minutes, records and books as the Board of Governors may require, attend all meetings of the Board of Governors and render such services as may be imposed upon him.

\section{Treasurer}

The Treasurer shall perform such duties as the Board of Governors may impose upon him.

\section{Title Trustees}

The members of the Board of Governors appointed to hold the title to all property of the Association shall at all times be subject to the orders of the Board of Governors who may any time and for any cause remove any or all of them from office and appoint and devolve upon other members of the Board of Governors the duties and functions of the office. In the case of the death, resignation or other disability of any such Trustee, the Board of Governors may fill the vacancy caused thereby.

\section{Dissolution}

This Association shall continue for a period of Fifty years from the date of the execution thereof unless sooner dissolved by the vote of the majority of membership certificates or shares.

In Witness Whereof we have hereunto set our respective signatures and attached our several seals, this the 2nd day of April, 1910. Henry C. Pierce,

S. W. Fondyce,

Samuel W. Fordyce, Jr., Georae T. Priest, (seal) (seal) (seal) (seal) Robt. E. Moloney, Henry W. Alleen, (seal) JoHN H. Holliday, 
FORM OF DECLARATION OF TRUST ESTABLISHING A HOLDING COMPANY

AGREEMENT AND DECLARATION OF TRUST OF THE

\section{MASSACHUSET'IS ELECTRIC COMPANIES}

Dated June 29, 1899.

This Agrenment, made this twenty-ninth day of June, A. D. 1899, by and between E. Rollins Morse, Henry Russell Shaw, Robert W. Emmons, 2d, and George W. Parker, co-partners under the firm name of E. Rollins Morse and Brother, and William A. Tucker, S. Reed Anthony, Philip L. Saltonstall and Nathan Anthony, copartners under the firm name of Tucker, Anthony and Company, together with their assigns, herein designated as the "SuBscribErs," and Gordon Abbott, Charles Francis Adams, 2d, S. Reed Anthony, John N. Beckley, Amos F. Breed, Everett W. Burdett, Charles E. Cotting, Eugene N. Foss, Walter Hunnewell, Stillman F. Kelley, E. Rollins Morse, Richard Olney, Percy Parker, S. Endicott Peabody, and Philip L. Saltonstall, together with their successors, herein designated as the "Trustees," witnesseth: That

Whereas the subscribers propose to transfer, assign, and deliver to the Trustees, under the designation of "MASSACHusetTs Electric Companies," certain shares of the capital stock and other securities of sundry street railways and other companies and contracts to purchase the same and also other property, as shown in a schedule identified by the signatures of the parties hereto and filed with the Trustees; and the Trustees for the purpose of defining the interests of the Subscribers and their assigns in such property, have agreed to issue to the Subscribers negotiable certificates for two hundred and forty thousand $(240,000)$ shares, of which one hundred and twenty thousand $(120,000)$ shall be preferred and one hundred and twenty thousand $(120,000)$ shall be common, each share to be expressed of the par value of one hundred $(\$ 100)$ dollars, and all of said shares to be issued to the Subscribers in the following proportions, viz.:

To said E. Rollins Morse and Brother, or order, 60,000 preferred shares and 60,000 common shares; to said Tucker, Anthony \& Company, or order, 60,000 preferred shares and 60,000 common shares.

Now, THEREFone, the Trustees hereby declare that they will hold said property so to be transferred to them, as well as all other prop-

${ }^{1}$ Quoted from Trust Estates as Business Companies, by John H. Sears. 
erty which they may acquire as such Trustees, together with the proceeds thereof, in trust, to manage and dispose of the same for the benefit of the holders, from time to time, of the certificates of shares issued hereunder, according to the priorities expressed in said certificates, and in the manner and subject to the stipulations herein contained, to wit:

First.-The Trustees, in their collective capacity, shall be designated, so far as practicable, as the "Massachusetts Electric CoMPANIEs," and under that name shall, so far as. practicable, conduct all business and execute all instruments in writing, in performance of their trust.

Second.-The Trustees shall always be fifteen in number, and of the Trustees herein mentioned by name, S. Reed Anthony, Everett W. Burdett, E. Rollins Morse, S. Endicott Peabody, and Philip L. Saltonstall, shall hold office until the first annual meeting of the shareholders; Gordon Abbott, John N. Beckley, Amos F. Breed, Walter Hunnewell, and Stillman F. Kelley, shall hold office until the second annual meeting of the shareholders; and Charles Francis Adams, 2d, Charles E. Cotting, Eugene N. Foss, Richard Olney, and Percy Parker, shall hold office until the third annual meeting of the shareholders; except that said Trustees, as well as any Trustees hereafter elected, shall in all cases hold office until their successors have been elected and accepted this trust.

The shareholders shall, at each annual meeting, or adjournment thereof, elect five Trustees to serve for the term of three years next ensuing. In case of death, resignation, or inability to act of any of said Trustees, the remaining Trustees shall accept any resignation and fill any vacancy for the unexpired term. As soon as any Trustees elected by the shareholders or by the remaining Trustees to fill a vacancy have accepted this trust, the trust estate shall rest in the new Trustees or Trustee, together with the continuing Trustees, without any further act or conveyance.

Third.-The Trustees shall hold the legal title to all property at any time belonging to their trust, and shall have and exercise the exclusive management and control of the same; they shall assume all contracts for and obligations and liabilities in connection with or growing out of the purchase of the stock or securities assigned to them by the Subscribers and mentioned in the annexed schedule, and to the extent and value of such stock and securities, but not personally, shall agree to hold the Subscribers and any person associated or acting with them harmless and indemnified from and against any loss, cost, expense, or liability upon, by reason of, or in connection with, any such contract, obligation or liability; they may adopt and 
use a common seal; they shall have power to vote in person or by proxy upon all shares of stock at any time belonging to the trust, and to collect, receive, and receipt for the dividends thereon, and may contract with each or any of the controlled companies in respect of any matter or matters relating to the operation of the road or the conduct of the business of any such company or companies, to collect, sue for, receive and receipt for all sums of money at any time coming due to said trust; to employ counsel to begin, prosecute, defend and settle suits at law, in equity or otherwise, and to compromise or refer to arbitration any claims in favor of or against the trust; they may also, with the consent of not less than ten of their number given at a meeting called for that purpose, but not otherwise, exchange, upon such terms as may be agreed upon, the stock or securities held by them in any corporation for the stock or securities of any other corporation, taking over the property of such corporation by consolidation or otherwise; and with such consent, but not otherwise, may loan money to any corporation of which they may own a majority of the capital stock, and may subscribe for or scquire additional stock or the securities or obligations of such corporations; and with such consent, but not otherwise, may subscribe for, purchase, and acquire shares in the capital stock of any corporation (1) owning or operating railways or railroads, or engaged in the business of transporting merchandise, mails or express matter, or (2) engaged in whole or in part in supplying light, heat, power or other public service, or (3) manufacturing, selling or repairing machines, equipments, supplies or other articles used by corporations of either or both the classes above named, or (4) engaged in the business of insuring corporations of any or all of the foregoing classes against loss by fire or casualty, or (5) engaged in the business of advertising in the cars or upon the premises of railways, or railroad companies; and with such consent, but not otherwise, may borrow money for any of the purposes aforesaid. With the consent of the holders of at least two-thirds of each class of shares outstanding, at a meeting called for that purpose, but not otherwise except as herein otherwise provided, the Trustees may sell, mortgage, pledge, encumber, or dispose of any shares or stock securities or other property from time to time held by them upon such terms and for such purposes as the shareholders at such meeting may approre.

So far as strangers to this trust are concerned, a resolution of the Trustees authorizing a particular act to he done shall be conclusive evidence in favor of such strangers that such act is within the powers of the Trustees, and no purchaser from the Trustees shall be bound to see the application of the purchase money or other con- 
sideration paid or delivered by or for said purchaser to or for said Trustees.

Fourth.-Stated meetings of the Trustees shall be held at least once a month, and other meetings shall be held from time to time upon the call of the President or any three of the Trustees. A majority of the Board constitutes a quorum, and the concurrence of all the Trustees shall not be necessary to the validity of any action done by them, but the wish of a majority of the Trustees present and voting at any meeting shall be conclusive except as hereinbefore specifically provided. The Trustees may make, adopt, amend, or repeal such by-laws, rules, and regulations, not inconsistent with the terms of this instrument, as they may be deemed necessary or desirable for the conduct of their business and for the government of themselves and their agents, servants, and representatives.

Fifth.-The Trustees shall annually elect from among their number a President and Vice-President of the Board, and shall also annually elect a Treasurer and Secretary, and they shall have authority to appoint such other officers, agents, and attorneys as they may from time to time deem necessary or expedient for the conduct of their business. They shall have authority to accept resignations and to fill any vacancy in the office of President, Vice-President, Treasurer, or Secretary, for the unexpired term; and shall likewise have authority to elect temporary officers to serve during the absence or disability of regular officers. The President, Vice-President, Treasurer, and Secretary shall have the authority and shall perform the duties usually incident to those offices in the case of corporations, so far as applicable thereto, and shall have such other authority and perform such other duties as may from time to time be determined by the Trustees. The Trustees shall fix the compensation of any, or all officers and agents whom they may appoint, and are likewise authorized to pay to themselves such compensation for their own services as they may deem reasonable. The Trustees shall also appoint from among their number an Executive Committee of three or five persons, to whom they may delegate such of the powers herein conferred upon the Trustees as they may deem expedient, except so far as those matters are concerned in which the concurrent action of at least ten Trustees is required.

The Trustees shall not be liable for errors of judgment either in holding property originally conveyed to them or in acquiring and afterward holding additional property, nor for any loss arising out of any investment, nor for any act or omission to act performed or omitted by them in the execution of this trust in good faith, nor shall they be liable for the acts or omissions of each other or of any 
officer, agent, or servant appointed by or acting for them, and they shall not be obliged to give any bond to secure the due performance of this trust by them.

Sixth.-Shares hereunder shall be of the par value of one hundred $(\$ 100.00)$ dollars each, and shall be divided into preferred and common shares. The preferred shares shall entitle the holder to accumulative semi-annual dividends at the rate of 4 per centum per annum, and no more, the same to be paid or set apart before any dividend shall be paid or set apart for the common shares; and in case of liquidation, the proceeds of the liquidation shall be first applied to the payment to the holder or proferred shares, of the sum of one hundred dollars per share and any acerued and unpaid dividends thereon, and the balance remaining thereafter shall be divided among the holders of common shares in proportion to their holdings. As evidence of the ownership of said shares, the Trustees shall cause to be issued to each shareholder a negotiable certificate or certificates, which certificates shall be in form following, to wit:

(Form of Certificate of Common Stock.)

\section{MASSACHUSETTS ELECTRIC COMPANIES.}

No.

Shares.

Not subject to assessment.

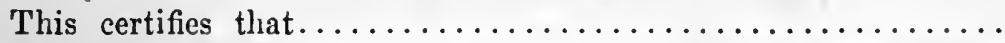
is the holder of ............................... shares in the Massachusetts Euectric Companies, which he holds subject to an Agreement and Declaration of Trust, dated June 29, 1899, and on file with the Old Colony Trust Company, which is hereby referred to and made a part of this certificate.

The shares in said Massachusetts Electric Companies are divided into two classes, known as preferred and common, and the holders of the preferred shares are entitled to receive semi-annual dividends out of the net earnings of the Companies, at the rate of four per centum per annum, and no more, payable semi-annually, on the first days of January and July in each year, which shall be paid or set apart before any dividends shall be paid or set apart on the common shares.

The dividends on the preferred shares are cumulative, and if, in any period of six months, semi-annual dividends at the rate of four per centum per annum are not paid on said preferred shares, the acerued and unpaid dividends are a charge on the net earninge of the Companies, payable subsequently before any dividends are paid upon the common shares.

In the event of liquidation, the proceeds of liquidation will be 
first applied to the payment to the holders of preferred shares of the sum of one hundred dollars $(\$ 100)$ per share and any accrued and unpaid dividends thereon; and the balance remaining thereafter will be divided among the holders of common shares in proportion to their holdings.

The holders of preferred and common shares are entitled to equal voting powers.

This certificate will not be valid until countersigned by the old Colony Trust Company, Transfer Agent, and the American Trust Company, Agent to Register Transfers; and no transfer hereof will be of any effect as regards the Massachusetts Electric Companies until this certificate has been surrendered and the transfer recorded upon their books.

In Witness Whereof, The Trustees under said Declaration of Trust, herein designated as the Massachusetts Electric Companies, have caused their common seal to be hereto affixed and this certificate to be executed in their name and behalf, by their Treasurer, thereto duly authorized.

\section{MASSACHUSETTS ELECTRIC COMPANIES.}

$$
\text { By.................... Treasurer. }
$$

Countersigned :

Old Colony Trust Company, Transfer Agent.

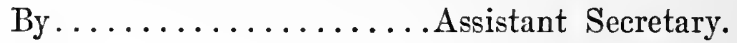

By................... Transfer Clerk.

Countersigned:

American Trust Company, Agent to Register Transfers.

By..........................

(Form of Transfer.)

For value received, I hereby sell, assign, transfer, and deliver to........................ of the within-named shares of the Massachuset's Electric Companies, and I hereby request that said transfer be recorded on the books of said Companies.

Witness my hand, this............ day of.........

Witness :

(Form of Certificate of Preferred Shares.)

\section{MASSACHUSETTS ELECTRIC COMPANIES.}

No.

Shares.

Not subject to assessment.

This certifies that................... is the holder

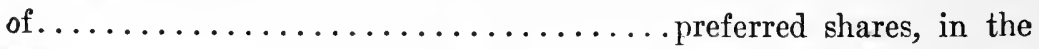
Massachusetts Electric Companies, which he holds subject to an Agreement and Declaration of Trust, dated June 29, 1899, and on 
file with the Old Colony Trust Company, which is hereby referred to and made a part of this certificate.

The shares in said Massachusetts Electric Companies are divided into two classes, known as preferred and common, and the holders of the preferred shares are entitled to receive semi-anmual dividends out of the net earnings of the Companies, at the rate of four per centum per annum, and no more, payable semi-annually, on the first days of January and July in each year, which shall be paid or set apart before any dividends shall be paid or set apart on the common shares.

The dividends on the preferred sliares are cumulative, and if, in any period of six months, semi-annual dividends at the rate of four per centum per annum are not paid on said preferred shares, the accrued and unpaid dividends are a charge on the net earnings of the Companies, payable subsequently before any dividends are paid upon the common shares.

In the event of liquidation, the proceeds of liquidation will be first applied to the payment to the holders of preferred shares of the sum of one hundred dollars $(\$ 100)$ per share and any accrued and unpaid dividends thereon; and the balance remaining thereafter will be divided among the holders of common shares in proportion to their holdings.

The holders of preferred and common shares are entitled to equal roting powers.

This certificate will not be valid until countersigned by the old Colony Trust Company, Transfer Agent, and the American Trust Company, Agent to Register Transfers; and no transfer hereof will be of any effect as regards the Massachusetts Electric Companies until this certificate has been surrendered and the transfer recorded upon their books.

Is Witness Wirereof, the Trustees under said Declaration of Trust, herein designated as the Massachusetts Electric Companies, have caused their common seal to be hereto affixed, and this certificate to be executed in their name and behalf, by their 'Treasurer, thereto duly authorized.

MASSACHUSET'IS ELECTRIC COMPANIES.

By ..................... T'reasurer.

Countersigned :

Old Colony 'Trust Company, Transfer Agent.

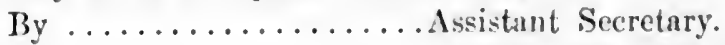

By ................. Transfer Clerk.

Countersigned :

American 'Trust Company, Agent to Register 'Transfers.

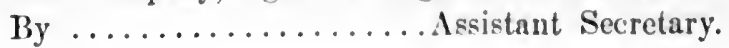


(Form of Transfer.)

For value receired, I hereby sell, assign, transfer and deliver to .................... of the within-named shares of the Massachusetts Electric Companies; and I hereby request that said transfer be recorded on the books of the Companies.

Witness my hand, this............ day of...........

Witness:

Seventh.-In addition to the shares to be originally issued to the subscribers as hereinbefore provided, the Trustees shall issue and sell, at public or private sale, upon such terms and for such prices as they may deem expedient, such additional preferred or common shares, or both, as may be necessary to provide means to pay for the stock of the New Bedford, Middleborough, and Brockton Street Railway Company, the contract for the purchase of which is to be assigned to and assumed by the Trustees.

Except as aforesaid, no share shall be issued by the Trustees in excess of the amount to be originally issued to the Subscribers as hereinbefore stated. But the Trustees may from time to time, for the purpose of acquiring means for the acquisition of additional property or otherwise accomplishing the purpose of this trust, with the consent of at least two-thirds of the preferred stockholders and two-thirds of the common shareholders, present and voting, at any meeting called for that purpose, issue and dispose of additional shares upon such terms, in such manner as the shareholders at such meeting may determine.

In case of the loss or destruction of any certificates of shares issued by the Trustees, the Trustees may, under such condition as they may deem expedient, issue a new certificate or certificates in the place of the one lost or destroyed.

Eighth.-The Trustees may from time to time declare and pay dividends out of the net earnings from time to time received by them, but the amount of such dividends and the payment of them shall be wholly in the discretion of the Trustees; except that the dividends on the preferred shares shall be payable semi-annually on 'the first days of January and July in each year, at the rate of 4 per cent. per annum, and no more, and shall be cumulative, and said semi-annual dividends shall be paid or set apart before any dividends are paid on the common shares.

Ninth.-The fiscal year of the Trustees shall end on the thirtieth day of September in each year. Annual meetings for the election of five Trustees and for the transaction of other business, shall be held in Boston, on the Wednesday following the first Monday of November, in each year, beginning with the year 1900, of which 
meeting notice shall be given by the Secretary, by mail, to each shareholder, at his registered address, at least ten days before said meeting.

Special meetings of the shareholders may be called at any time, upon seven days' notice given as above stated, when ordered by the President or Trustees. At all meetings of the shareholders, each holder of shares, whether preferred or common, shall be entitled to one vote for each share held by him, and any shareholder may vote by proxy.

No business shall be transacted at any special meeting of the shareholders unless notice of such business has been given in the call for the meeting.

No business except to adjourn shall be transacted at any meeting of the shareholders unless the holders of a majority of all the shares outstanding are present in person or by proxy.

Tenth.-The death of a shareholder or Trustee during the continuance of this trust shall not operate to determine the trust, nor shall it entitle the legal representative of the deceased shareholder to an accounting, or to take any action in the courts, or elsewhere, against the Trustees; but the executors, administrators, or assigns of any deceased shareholder shall succeed to the rights of said decedent under this trust, upon surrender of the certificate for the shares owned by him.

The ownership of shares hereunder shall not entitle the shareholders to any title in or to the trust property whatsoever, or right to call for a partition or division of the same, or for an accounting.

Eleventh.-The Trustees shall have no power to bind the shareholders personally, and the subscribers and their assigns and all persons or corporations extending credit to, contracting with, or having any claim against the Trustees shall look only to the funds and property of the trust for payment under such contract or claim, or for the payment of any debt, damage, judgment, or decree, or far any money that may otherwise become due or payable to them from the Trustees, so that neither the Trustees nor the shareholders, present or future, shall be personally liable therefor.

In every written order, contract, or obligation which the Trustees shall give or enter into, it shall be the duty of the Trustees to stipulate that neither the Trustees nor the shareholders shall be held to any personal liability under or by reason of such order, contract or obligation.

Twelfth.-This trust shall continue for the term of twentyone years, at which time the then Board of Trustees shall proceed to wind up its affairs, liquidate its assets, and distribute the same 
among the holders of preferred and common shares according to the priorities hereinbefore expressed, Provided, However, that if prior to the expiration of said period, the holders of at least two-thirds of the shares then outstanding shall, at a meeting called for that purpose, vote to terminate or to continue this trust, then said trust shall either terminate or continue in existence for such further period as may then be determined.

For the purpose of winding up their affairs and liquidating the assets of the trust, the then Board of Trustees shall continue in office until such duties have been fully performed.

This agreement and declaration of trust may be amended or altered except as regards the liabilities of the Trustees at any annual or special meeting of the shareholders with the consent of the holders of at least two-thirds of the shares of each class then outstanding; provided notice of the proposed amendment or alteration shall have been given in the call for the meeting; and in case of such alteration or amendment, the same shall be attached to and made a part of this agreement, and a copy thereof shall be filed with the OLD Colony Trust Company.

In Witness Whereof, the said Gordon Abbott, Charles Francis Adams, 2d, S. Reed Anthony, John N. Beckley, Amos F. Breed, Everett W. Burdett, Charles E. Cotting, Eugene N. Foss, Walter Hunnewell, Stillman F. Kelley, E. Rollins Morse, Richard Olney, Percy Parker, S. Endicott Peabody, and Philip L. Saltonstall, Trustees, hereinbefore mentioned, have hereunto set their hands and seals, in token of their acceptance of the trust hereinbefore mentioned, for themselves and their successors, and the said E. Rollins Morse, Henry Russell Shaw, Robert W. Emmons, 2d, and George W. Parker, as co-partners under the firm name of E. Rollins Morse and Brothers, and William A. Tucker, S. Reed Anthony, Philip L. Saltonstall, and Nathan Anthony, as co-partners under the firm name of Tucker, Anthony and Company, Subscribers, have hereunto set their hands and seals, in token of their assent to and approval of said terms of trust, for themselves and their assigns, the day and year first above written.

(Signed)

E. Rollins Morse, $\left.\begin{array}{l}\text { Henry Russell Shaw, } \\ \text { Robert W. Emmons, 2d; } \\ \text { George W. Parker, }\end{array}\right\} \begin{gathered}\text { Co-Partners Under the Firm Name } \\ \text { of E. Rollins Morse \& Brothers. }\end{gathered}$ William A. Tucker, S. Reed Anthony, Philip L. Saltonstall, Nathan Anthony, of Tucker, Anthony \& Company. 
Gordon Abbott,

Charles F. Adams, 2d,

S. Reed Antliony, John N. Beckley, Amos F. Breed, Walter Hunnewell, Stillman F. Kelley,

E. Rollins Morse,
Richard Olney, Percy Parker, Everett W. Burdett, Charles E. Cotting, Eugene N. Foss, S. E. Peabody, Philip L. Saltonstall.

Agreement and

Declaration of Trust of the MASSACHUSETTS ELECTRIC COMPANIES.

For three years:

Richard Olney, Charles E. Cotting,
Eugene N. Foss, Percy Parker,

Charles Francis Adams, 2d.

For two years :

Gordon Abbott, Amos F. Breed,
John N. Beckley, Stillman F. Kelley,

Walter N. Hunnewell.

For one year:

Everett W. Burdett, Philip L. Saltonstall,
S. Endicott Peabody,

S. Reed Anthony,
E. Rollins Morse.

\section{OFFICERS :}

President-Amos F. Breed.

Vice-President-Charles E. Cotting.

Secretary-Everett W. Burdett.

Treasurer-Joseph H. Goodspeed.

General Manager-P. F. Sullivan.

Executive Committee:

Gordon Abbott, Chairman.

Charles F. Adams, 2d, Percy Parker, Eugene N. Foss, 


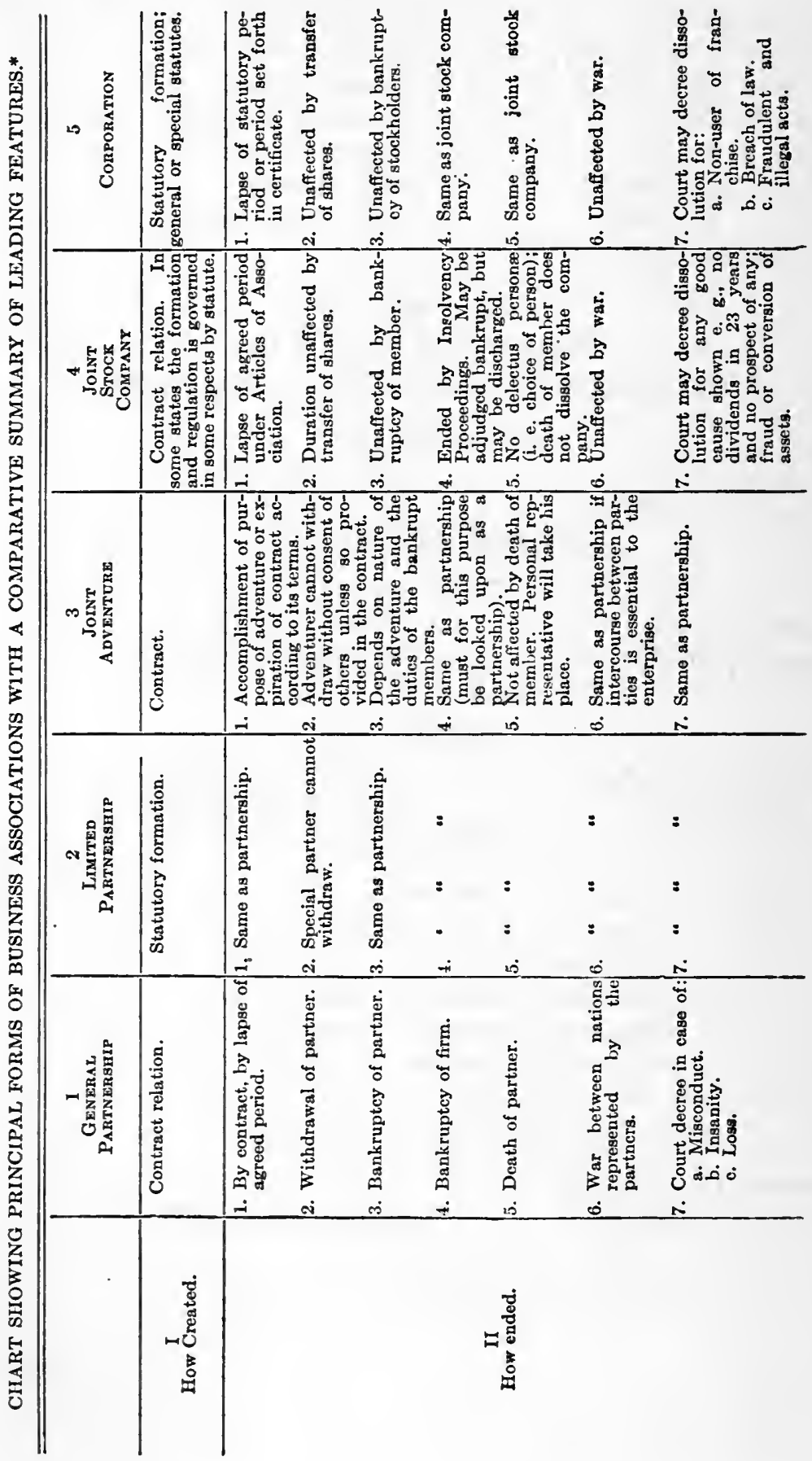




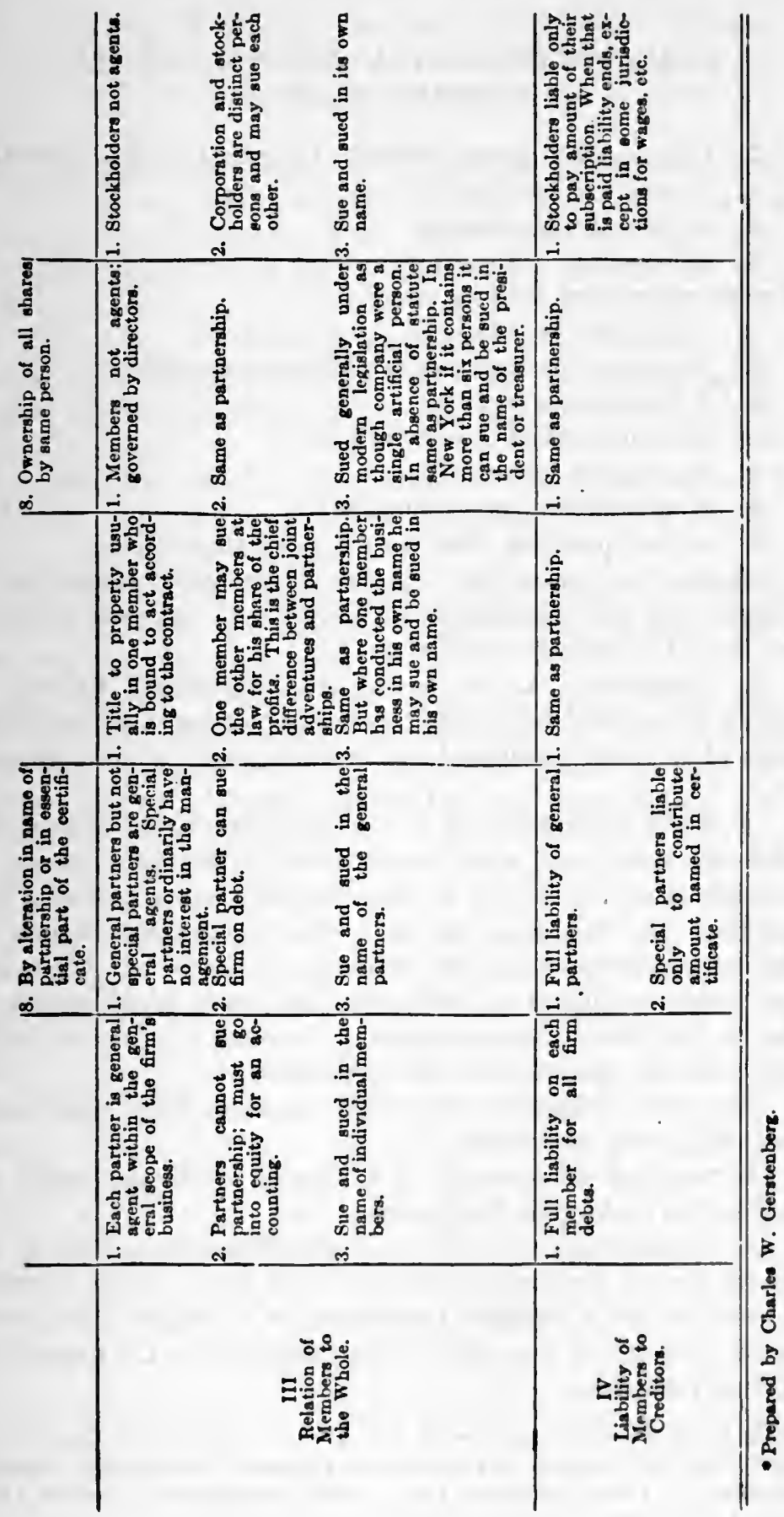




\section{CLASSIFICATION AND DEFINITIONS OF CORPORATIONS ${ }^{1}$}

$\S$ 2. Classification of corporations. A corporation shall be either,

1. A municipal corporation,

2. A stock corporation, or

3. A non-stock corporation.

A stock corporation shall be either,

1. A moneyed corporation,

2. A railroad or other transportation corporation, or

3. A business corporation.

A non-stock corporation shall be either,

1. A religious corporation,

2. A membership corporation, or

3. Any corporation other than a stock corporation.

A reference in a general law to a class of corporations described in accordance with this classification shall include all corporations theretofore formed belonging to such class.

$\S$ 3. Definitions. 1. A "municipal corporation" includes a county, town, school district, village and city and any other territorial division of the state established by law with powers of local government.

2. A "stock corporation" is a corporation having a capital stock divided into shares, and which is authorized by law to distribute to the holders thereof dividends or shares of the surplus profits of the corporation. A corporation is not a stock corporation because of having issued certificates called certificates of stock, but which are in fact merely certificates of membership, and which is not authorized by law to distribute to its members any dividends or share of profit3 arising from the operations of the corporation.

3. The term "non-stock corporation" includes every corporation other than a stock corporation.

4. A "moneyed corporation" is a corporation formed under or subject to the banking or the insurance law.

5. A "domestic corporation" is a corporation incorporated by or under the laws of the state or colony of New York. Every corporation which is not a domestic corporation is a foreign corporation, except as provided by the code of civil procedure for the purpose of construing such code.

1 From General Corporation Law of New York. Laws of 1909, Chapter 28, Entitled: "An Act Relating to Corporations Generally, Constituting Chapter Twenty-three of the Consolidated Laws," with Amendments. General Corporation Laws, Article 1, Section 2 and 3. 
6. The term "directors," when used in relation to corporations. shall include trustees or other persons, by whatever name known, duly appointed or designated to manage the affairs of the corporation.

7. The term "certificate of incorporation" shall include articles of association or any other written instruments required by law to be filed, to effect the incorporation of a corporation, including a certified copy of an original certificate of incorporation filed for such purpose in pursuance of law.

8. The term "member of a corporation" shall include every person having a right to vote at a meeting of the corporation for the election of directors, other than a person having a right to vote only upon a proxy.

9. The term "office of a corporation" means its principal office within the state, or principal place of business within the state if it has no principal office therein.

10. The term "business of a corporation," when used with reference to a non-stock corporation, includes the operations for the conduct of which it is incorporated.

11. The term "corporate law" or "laws," when used in any law forming a part of the consolidation of the general laws of the state of which this chapter is a part, means the general statutes of this state relating to corporations included in such consolidation. 


\section{AN ACT TO INCORPORATE THE GENERAL ELECTRIC COMPANY ${ }^{1}$}

The People of the State of New York, represented in Senate and Assembly, do enact as follows: Secrion 1. Joseph P. Ord, S. Endicott Peabody, Frank S. Hastings, James Jackson, S. Dana Greene and Eugene Griffin, their associates and successors and assigns, are hereby constituted a body corporate under the name of "General Electric Company," and, as such, are authorized to carry on business for the following purposes, or any of them: The manufacturing, buying, selling, leasing and using of machinery, generators, motors, lamps, apparatus, devices, supplies, and articles of every kind appertaining to or in any wise connected with the production, use, distribution, regulation, control or application of electricity or electrical apparatus for the purpose of light, heat, power, locomotion, telephony, telegraphy, metallurgy, or for any other use or purpose; of constructing, acquiring, using, selling, buying, or leasing any works, construction or plant, or part thereof, connected with or involving such use, distribution, regulation, control or application of electricity, or the control or use of electrical apparatus, for any purpose; and of producing, furnishing and supplying electricity or electrical apparatus in any form and for any purpose whatsoever, and generally to manufacture, buy, sell, lease and use machines, engines, mechanical devices and articles of every other character, and to carry on a general manufacturing business. Of acquiring by purchase or otherwise, and of owning, using, selling, granting, assigning and licensing others to use, letters patent, patent rights, inventions, processes and contrivances relating to electrical apparatus, and the production or application of electricity for the purpose of light, heat, power, locomotion, telegraphy, telephony, metallurgy or any other purpose, or any such letters patent or patent rights, inventions, processes or contrivances which may be used or employed in connection with any such use or application of electricity or electrical apparatus; and in consideration of any such license, sale, grant or assignment, of receiving royalties, shares of the capital stock, bonds or other securities of any other corporation, or any other consideration, and of contracting therefor. Of acquiring, owning, holding, buying, selling, pledging and disposing of shares in the capital stock and the bonds or other securities of any corporation owning, leasing, using or employing any letters patent or patent rights relating to or in any way connected with electrical apparatus, or the application or use of

1 Laws of the State of New York, 1892, Chapter 323. 
electricity in any form, or suitable for any portion of the business of this Company, and the stocks, bonds and other securities of any corporation owning, leasing, manufacturing, purchasing, using or employing any machinery, apparatus, devices, materials or other property of any kind relating to electrical apparatus, or the use, distribution or application of electricity for any purpose, or for use in connection therewith, or necessary for the business of this Company; and in respect of such shares of capital stock, of exercising all the rights, powers and privileges which a holder, being a natural person, might have or exercise. Of constructing, purchasing, operating, leasing and selling for itself or others, manufactories or other properties suitable for any of the foregoing objects; of acquiring, holding, using and conveying in this State, and in any and every State, Territory, district or country in which the corporation may carry on business, such real and personal estate, property, rights, privileges, consents and franchises as the purposes of the Company, or the convenient transaction of its business may require; of investing the funds of the Company in stocks, bonds or securities of any other corporation owning any such lands or other property; and to mortgage any part of its real or personal estate with or without its franchises, to secure the payment of any debts, obligations or liabilities incurred by it in its business, as its Board of Directors may direct, under and pursuant and subject to the provisions of its by-laws made in relation thereto. Said Company may borrow money, incur debts and liabilities and issue its bonds or obligations therefor, to such amounts, at such rates, and on such terms as its Board of Directors. may from time to time direct, and secure the payment of the same as above provided. Nothing in this act contained shall be construed to confer upon the corporation hereby created any authority to construct, maintain or operate any telegraph or telephone lines or lines for the use, distribution or application of electricity for any purpose in any of the streets or highways within the limits of this State, or right to use said streets or highways for any purpose whatsoever.

SEc. 2. The rights, powers and privileges herein granted to said corporation shall not be controlled, limited or restricted by any existing statute or law of this State; but so far as such statute or statutes or law are, or might otherwise be inconsistent with the provisions of this act, or any of them, they are and shall be deemed to be altercd and amended so far as they are or might be applicable to said corporation, so as to conform to the provisions of this act, which provisions shall be in lieu of all provisions in saia statutes relating to the same subject matters. Except as last above provided, and except upon subjects or matters relating to which special provision is made 
in this act, the said corporation shall be subject to and governed by the general provisions of the law of this State applicable thereto.

SEC. 3. The capital stock with which said Company shall commence business shall be one hundred thousand dollars, divided into one thousand shares, each of one hundred dollars. The said capital stock may be increased from time to time by the vote of the holders of two-thirds of the then existing capital stock, in person or by proxy, at a meeting of the stockholders duly called for that purpose, to such an amount as may be determined necessary for the Company's business; any such meeting to be held upon a notice given to the several stockholders not less than ten days before the day of the meeting, by delivering the same personally or mailing the same, postage prepaid, to the respective stockholders at their last known residence or place of business, provided a certificate of such increase, signed and sworn to by a majority of the directors, and the president and secretary of said corporation, shall be filed in the office of the Secretary of State, and a duplicate thereof in the office of the Clerk of the City and County of New York. Said corporation may issue a portion of its original or increased capital stock, not exceeding onefifth part thereof, as preferred stock, such preferred stock to entitle the holders thereof to a cumulative preferential dividend out of surplus earnings, not exceeding seven per centum per annum, but without any other preferential right. The amount of preferred stock to be issued from time to time within the limit above fixed, and the manner of issuing the same may be determined and directed by the Board of Directors of such corporation. . Each share of stock, whether preferred or common, shall entitle the holder thereof to one vote at all meetings of stockholders and at all elections of the Company. The capital stock of said corporation may be issued or caused to be issued by its directors, for money, labor done, or property actually received for the use and lawful purposes of such corporation, at its fair value, subject to such restrictions as may be provided in the by-laws of said Company. The holders of any stock so issued shall not be subject to any liability upon the same, or by reason of being such stockholders; except that such stockholders shall jointly and severally also be personally liable for all debts due and owing to any of its laborers, servants or employees other than contractors, for services performed by them for such corporation. Before such laborer, servant or employee shall charge such stockholder for such services, he shall give him notice in writing within thirty days after the termination of such services that he intends to hold him liable, and shall commence action therefor within thirty days after the return of an execution unsatisfied against the corporation upon a judgment recovered against 
it for such services. No person holding stock in said corporation as collateral security, or as exeeutor, administrator, guardian or trustee, unless he shall have voluntarily invested the trust funds in such stock, shall be personally subject to liability as stockholder; and no stockholder of said corporation shall be liable for any such debt due to a laborer, servant or employee, if he shall neglect to bring suit against the corporation for such debt within three months after the termination of such services.

SEo. 4. The stock, property and affairs of said corporation shall be managed by a Board of Directors consisting of not less than three nor more than thirteen, as may be provided by the by-laws to be adopted by said corporation. All vacancies happening in such board may be filled as may be provided in such by-laws.

SEc. 5. The persons first above named, and such other persons as shall be elected or appointed in accordance with the by-laws of said corporation shall be the first directors of said corporation, and their term of office shall continue until the first day of February, eighteen hundred and ninety-three, and until others shall be chosen in their place. On or after the said first day of February, eighteen hundred and ninety-three, the Board of Directors of said corporation shall be elected annually at a meeting of the stockholders thereof to be held at such time and place as the corporation by its by-laws may appoint.

SEo. 6. The said Board of Directors appointed by and under the provisions of this act for the first year, may adopt by-laws not inconsistent with this act, or with the laws of this State for the regulation of a corporation. The said by-laws may be altered, amended or repealed by a vote of the holders of a majority of the stock, represented in person or by proxy, at any meeting of said stockholders duly called.

SEc. \%. The annual report, if any, at any time required to be filed by such corporation under the general laws of this State, or any of them, shall state:

1. The amount of its capital stock actually issued.

2. The amount of its debts, or an amount which they shall not exceed.

3. The amount of its assets, or an amount which its assets shall at least equal. Such report shall be signed, verified and filed in the manner and within the period required by the general laws applicable thereto. In case the directors shall fail so to file any such required report, the directors who shall have neglected or refused to make and file the same and who shall also have neglected or refused to máke or file any alternative individual report, as permitted by gen- 
eral law, shall be jointly and severally liable, as provided by general law, and every officer and director of such corporation signing any certificate, report or public notice required by law which shall be false in any material representation, shall jointly and severally be personally liable to the creditors of the Company for any damages caused to them thereby. There shall be a president, secretary and treasurer of such corporation, and such other officers as shall be provided by its by-laws. The president shall be selected by, and from, the directors. The other officers shall be elected or appointed, and have such qualifications as may be provided by the by-laws of the corporation. The directors of said corporation shall keep, or cause to be kept, at its office, books of account of its business and transactions, and a book to be known as the "stock-book," containing the names, alphabetically arranged, of all persons who are, or within two years have been stockholders of the corporation, showing their places of residence, the number of shares of stock held by them respectively, and the time when they respectively became the owners, and the time when the same was transferred to them respectively on the books of the Company. The stock-book of such corporation shall be open daily during business hours for the inspection of its stockholders and creditors, who may make extracts therefrom.

SEc. 8. The directors of said corporation may declare and cause to be paid dividends in money or property, but only from the net profits of its business.

SEc. 9. The said corporation may go into liquidation, and may wind up its affairs and business, and may sell, convey and dispose of all its property upon the consent thereto of its stockholders holding two-thirds of all its capital stock, such consent to be given at a meeting of said stockholders duly held for that purpose; and the Board of Directors, or such other officers or persons as may be authorized and directed by a vote of its stockholders owning two-thirds of its capital stock shall be duly authorized as trustees to so dispose of the property of said corporation, and liquidate and wind up its affairs and business.

SEc. 10. The sald corporation shall not commence business until it shall have paid to the Treasurer of this State the sum of ten thousand dollars as a franchise tax, and it shall thereafter, from time to time, pay such further sum to the said State Treasurer as shall make the aggregate sum so paid by it to the State Treasurer, equal at all times to one-twentieth part of one per centum upon its existing capital stock. This act shall not be construed as granting to the corporation hereby created the right to create or maintain any monopoly, or unlawful combination in restraint of trade.

SEc. 11. This act shall take effect immediately. 


\section{FIRST GENERAL CORPORATION LAW'}

An act relative to incorporations for manufacturing purposes. Passed March 22, 1811.

1. Be it enacted by the people of the State of New York represented in Senate and Assembly, That at any time within five years hereafter, any five or more persons who shall be desirous to form a company for the purpose of manufacturing woolen, cotton or linen goods, or for the purpose of making glass, or for the purpose of making from ore bar-iron, anchors, mill irons, steel, nail rods, hoop iron and iron mongery, sheet copper, sheet lead, shot, white lead and red lead, may make, sign and acknowledge, before a justice of the Supreme Court, a judge of the Court of Common Pleas, or a master in Chancery, and file in the office of the Secretary of State a certificate in writing in which shall be stated the corporate name of the said company, and the objects for which the company is formed, the amount of the capital stock of the said company, the number of shares of which the said stock shall consist, the number of trustees and their names who shall manage the concerns of the said company for the first year and the names of the town and county in which the manufacturing operations of the said company are to be carried on.

2. And be it further enacted, That as soon as such certificate shall be filed as aforesaid, the persons who shall have signed and acknowi edged the said certificate and their successors, shall for the term of twenty years next after the day of filing such certificate, be a body corporate and politic, in fact and name, by the name stated in such certificate, and by that name they and their successors shall and may have continual succession, and shall be persons in law capable of suing and being sued, pleading and being impleaded, answering or being answered unto, defending and being defended, in all courts and places whatsoever, in all manner of actions, suits, complaints, matters and causes whatsoever; and they and their successors may have a common seal, and the same may make, alter and change at their pleisure, and that they and their suecessors, by their corporate name, shall in law be capable of buying, purchasing, holding and conveying any lands, tenements, hereditaments, goods, wares and merchandise whatever, necessary to enable the said company to carry on their manufacturing operations mentioned in such certificate.

3. And be it further enacted, That the stock, property and concerns of such company shall be managed and conducted by trustees who, except those for the first year, shall be eleeted at such time and

1 This is the first General Corporation Law ever passed by any legislative body. 
place as shall be directed by the laws of the said company, and public notice shall be given of the time and place of holding such election, not less than ten days previous thereto, in the newspaper printed nearest to the place where the manufacturing operations of the said company shall or are to be carried on, and the election shall be made by such of the stockholders as shall attend for that purpose, either in person or by proxy, and all elections shall be by ballot, and each stockholder shall be entitled to as many votes as he owns shares of stock of the said company, and the persons having the greatest number of rotes shall be trustees; and wherever any vacancy shall happen among trustees by death, resignation or removal out of the State, such vacancy shall be filled for the remainder of the year in such manner as shall be provided by the laws of the said company; Provided always, That the number of trustees shall not exceed nine, and that they shall respectively be stockholders in such company.

4. And be it further enacted, That in case it shall at any time happen that an election of trustees be not made on the day when by the by-laws of the said company it ought to have been done, the said company for that cause shall not be dissolved, but it shall and may be lawful on any other day to hold an election for trustees, in such manner as shall be directed by the by-laws of such company.

5. And be it further enacted, That the capital stock of such company shall not exceed one hundred thousand dollars; and it shall be lawful for the trustees to call and demand from the stockholders respectively all such sums of money by them subscribed at such time and in such proportions as they shall deem proper, under pain of forfeiting the shares of the said stockholders and all previous payments made thereon, if such payments shall not be made, within sixty days after a notice requiring such payment shall have been published in such newspaper as aforesaid.

6. And be it further enacted, That the trustees of such company for the time being shall have power to make and prescribe such bylaws, rules and regulations as they shall deem proper respecting the management and disposition of the stock, property and estate of such company, the duties of the officers, artificers and servants by them to be employed, the election of trustees, and all such matters as appertain to the concerns of the said company to appoint such and so many officers, clerks and servants for carrying on the business of the said company, and with such wages as to them shall seem reasonable; Provided, That such by-laws be not inconsistent with the Constitution and Laws of this State and of the United States.

7. And be it further enacted, That the stock of such company shall be deemed personal estate, and be transferable in such manner 
as shall be prescribed by the laws of the company; and that for all debts which shall be due and owing by the company at the time of its dissolution, the persons then composing such company shall be individually responsible to the extent of their respective shares of stock in the said company, and no further; and that it shall not be lawful for such company to use their funds, or any part thereof, in any banking transactions, or in the purchase of any stock of any bank, or in the purchase of any public stock whatever, or for any other purpose than those specified in such instrument as aforesaid.

8. And be it further enacted, That the copy of any certificate filed in pursuance of this act, and certified to be a true copy by the Secretary of this State, or his deputy, shall together with this act, be received in all courts and places as legal evidence of the incorporation of such company. 


\section{GENERAL CORPORATION LAW.'}

AN ACT concerning Corporations. [Approved April 18, 1872, in force July 1, 1872, and amendments thereto in force July 1, 1905.

Section '1. Be it enacted by the People of the State of Illinois, represented in the General Assembly: That corporations may be formed in the manner provided by this Act, for any lawful purpose except banking, insurance, real estate brokerage, the operation of railroads and the business of loaning money: Provided, that horse and dummy railroads, and organizations for the purchase and sale of real estate, for burial purposes only, may be organized and conducted under the provisions of this act: And, provided, further, that corporations formed for the purpose of constructing railroad bridges shall not be held to be railroad corporations. [As amended by act approved April 19, 1879, in force July 1, 1879.

$\S 2$. Whenever any number of persons not less than three, nor more than seven, shall propose to form a corporation under this act, they shall make a statement to that effect under their hands and duly acknowledged before some officer in the manner provided for the acknowledgment of deeds, setting forth the name of the proposed corporation, the object for which it is to be formed, its capital stock, the number of shares of which such stock shall consist, the location of the principal office and the duration of the corporation, not to exceed ninety-nine years, which statement shall be filed in the office of the Secretary of State. If the object for which said corporation is proposed to be organized is clearly and definitely stated, and is a lawful object, the Secretary of State shall thereupon issue to such persons a license as commissioners to open books for subscription to the capital stock of said corporations at such times and places as they may determine; but no license shall be issued to two companies having the same or a similar name, nor shall any foreign corporation having the same or a similar name as any domestic corporation be admitted to this State under any foreign corporation law and no domestic corporation shall hereafter be organized with the same or a similar name as any foreign corporation previously admitted to do business in this State. Upon the filing of any statement with the Secretary of State for the purpose of obtaining a license to incorporate, he may propound such interrogatories as he shall deem necessary to ascertain the true

1 The Illinois Act is quoted on account of its brevity. A full and complete digest of the statutory provisions relating to corporations in the United States is to be found in "The Corporation Manual," published bi-annually by the Corporation Manual Company, New York City. 
object: Provided, that the Attorney General may file a bill in chancery in the name of the People of the State of Illinois, against any corporation authorized to confer degrees, diplomas or other certificate or certificates of qualification in the seience of medicine, pharmacy or dentistry which conducts a fraudulent business or abuses, misuses or violates the terms of its charter, in any court having jurisdiction of the corporation and subject-matter of such bill, for an injunction to restrain said corporation from conducting its business fraudulently or abusing, misusing or violating the terms of its charter and also for the dissolution of said corporation, and thereupon it shall be the duty of the court in which said bill is filed to grant such injunetion and to hear and determine the same as in other eases in chancery: And provided, further, that this act shall apply to schools, colleges or universities which now are, or may hereafter be, licensed in this State, notwithstanding any provisions that may exist in their charters. [As amended by act approred May 16, 1905; in force July 1, 1905.

$\S 3$. As soon as may be, after the eapital stock shall be fully subscribed, the commissioners shall convene a meeting of the subscribers, for the purpose of electing directors or managers, and the transaction of such other business as shall come before them. Notice thereof shall be given by depositing in the postoffice, properly addressed to each subscriber, at least ten days before the time fixed, a written or printed notice, stating the object, time and place of such meeting. In all elections for directors or managers of corporations organized under this Act, every subscriber or stockholder shall have the right to vote in person, or by proxy, for the number of shares owned or subseribed by him, for as many persons as there are directors or managers to be elected, or to cumulate such shares and give one candidate as many votes as the number of directors or managers multiplied by the number of his shares of stock shall equal, or to distribute them on the same principle among as many candidates as he shall think fit; and such directors or managers shall not be elected in any other manner. It shall be lawful for any such corporation, by resolution of the stockholders, to divide its board of directors or managers into three classes, numbered consecutively, the term of office of the first elass to expire on the day of the annual election of said company then next ensuing; the second class one year thereafter, and the third class two years thereafter. At each annual election, after such classification, the stockholders of such company shall elect, for a term of three years, a number of directors or managers equal to the number in the class whose term expires on the day of such election. All other vacancies to be filled in accordance with the by-laws of the corporation.

$\S 4$. The commissioners shall make a full report of their proceed- 
ings, including therein a copy of the notice provided for in the foregoing section, a copy of the subscription list, a statement of the amount of the capital, not less than one-half actually paid in, the amount of such capital not paid in, what disposition has been made of stock subscribed and not paid, and if any proportion of the capital has been paid in property, the same shall be appraised by said commissioners and they shall report the fair cash value thereof; the names of the directors or managers elected and their respective terms of office, which report shall be sworn to by at least a majority of the commissioners and shall be filed in the office of the Secretary of State. The Secretary of State shall thereupon issue a certificate of the complete organization of the corporation, making a part thereof a copy of all the papers filed in his office in and about the organization of the corporation, and duly authenticated under his hand and seal of State, and the same shall be recorded in a book for that purpose, in the office of the recorder of deeds of the county where the principal office of such company is located. Upon the recording of the said copy, the corporation shall be deemed fully organized and may proceed to business. Unless such company shall be organized and shall proceed to business as provided in this act within two years after the date of such license, then such license shall be deemed revoked, and all proceedings thereunder void. [As amended by act approved May 16, 1905; in force July 1, 1905 .

$\S 5$. Corporations formed under this act shall be bodies corporate and politic for the period for which they are organized; may sue and be sued; may have a common seal which they may alter or renew at pleasure; may own, possess and enjoy so much real and personal estate as shall be necessary for the transaction of their business, and may sell and dispose of the same when not required for the uses of the corporation. They may borrow money at legal rates of interest, and pledge their property, both real and personal, to secure the payment thereof; and may have and exercise all the powers necessary and requisite to carry into effect the objects for which they may be formed: Provided, however, that all real estate, so acquired in satisfaction of any liability or indebtedness, unless the same may be necessary and suitable for the business of such corporation, shall be offered at public auction at least once every year, at the door of the court house of the county wherein the same be situated, or on the premises so to be sold, after giving notice thereof for at least four consecutive weeks in some newspaper of general circulation published in said county; and if there be no such newspaper published therein, then in the nearest adjacent county where such newspaper is published; and said real estate shall be sold whenever the price 
offered for it is not less than the claim of such corporation, including all interest, costs, and other expenses: And, provided, further, that in case such corporation shall not, within such period of five years, sell such land, either at public or private sale as aforesaid, it shall be the duty of the State's Attorney to proceed by information, in the name of the people of the State of Illinois, against such corporation, in the circuit court of the county within which such lands, so neglected to be sold, shall be situated, and such court shall have jurisdiction to hear and determine the fact, and to order the sale of such land or real estate at such time and place subject to such rules as the court shall establish. The court shall tax as the fees of the State's Attorney such sum as shall be reasonable; and the proceeds of such sale, after deducting the said fees and costs of proceedings, shall be paid over to such corporation. The provisions of this section shall apply to and be binding upon all corporations now existing by virtue of any special charter granted by this State. [As amended by act approved June 5, 1889; in force July 1, 1889.

$\S 6$. The corporate powers shall be exercised by a board of directors or managers: Provided, the number of directors or managers shall not be increased or diminished, or their term of office changed, without the consent of the owners of a majority of the shares of stock. The officers of the company shall consist of a president, secretary and treasurer, and such other officers and agents as shall be determined by the directors or managers, and the directors or managers may adopt by-laws for the government of the officers and affairs of the company: Provided, they are not inconsistent with the laws of this State. The directors or managers may require of the officers and agents bonds, with such sureties and conditions as they shall deem proper and may remove any officers when the interest of the corporation shall require. The officers shall hold their respective offices for the period provided by the by-laws.

$\S \%$. The shares of stock shall be not less than ten nor more than one hundred dollars each, and shall be deemed personal property, and transferable as such in the manner provided by the by-laws, and subscriptions therefor shall be made payable to the corporation, and shall be payable in such installments and at such time or times as shall be determined by the directors or managers, and an action may be maintained in the name of the corporation to recover any installment which shall remain due and unpaid for the period of twenty days after personal demand therefor, or, in cases where personal demand is not made, within thirty days after a written or printed demand has been deposited in the postoffice properly addressed to the postoffice address of the stockholder. The directors may, by by-law prescribe other 
penalties for a failure to pay the installments that may from time to time become due, but no penalty working a forfeiture of stock, or of the amounts paid thereon shall be declared as against any estate before distribution shall have been made or against any stockholder before demand shall have been made for the amount due thereon either in person or by a written or printed notice duly mailed to the proper address of such stockholder at least thirty days prior to the time when such forfeiture is to take effect: Provided, that proceeds of said sale over and above the amount due on said shares shall be paid to the delinquent stockholder.

$\S 8$. Every assignment or transfer of stocks on which there remains any portion unpaid shall be recorded in the office of the recorder of deeds of the county within which the principal office is located, and each stockholder shall be liable for the debts of the corporation to the extent of the amount that may be unpaid upon the stock held by him, to be collected in the manner herein provided. No assignor of stocks shall be released from any such indebtedness by reason of any assignment of his stock, but shall remain liable therefor, jointly with the assignee, until the said stock be fully paid. Whenever any action is brought to recover any indebtedness, against the corporation, it shall be competent to proceed against any one or more stockholders at the same time to the extent of the balance unpaid by such stockholders upon the stock owned by them, respectively, whether called in or not, as in cases of garnishment. Every assignee or transferee of stock shall be liable to the company for the amount unpaid thereon, to the extent and in the same manner as if he had been the original subscriber.

$\S 9$. The General Assembly shall at all times have power to prescribe such regulations and provisions as it may deem advisable, which regulations and provisions shall be binding on any and all corporations formed under the provisions of this Act: And, provided. further, that this act shall not be held to revive or extend any private charter or law heretofore granted or passed concerning any corporation.

$\S 10$. All corporations organized under this law, whose powers may have expired by limitation or otherwise, shall continue their corporate capacity during the term of two years for the purpose only of collecting the debts due said corporation and selling and conveying the property and effects thereof.

$\S 11$. Such corporations shall use their respective names for the purposes aforesaid, and shall be capable of prosecuting and defending all suits in law or equity.

$\S 12$. The dissolution, for any cause whatever, of any corporation 
created as aforesaid, shall not take away or impair any remedy given against such corporation, its stockholders or officers, for any liabilities incurred previous to its dissolution.

$\S 13$. It shall be the duty of the directors or trustees of every stock corporation to cause to be kept at its principal office or place of business in this State, correct books of account of all its business, and every stockholder in such corporation shall have the right at all reasonable times, by himself or by his attorney, to examine the records and books of account of the corporation.

$\S 14$. A failure to elect directors, trustees, or officers in lieu of trustees, on the day named and designated in the by-laws, or on the day for which notice was given for election, shall not have the effect of dissolving the corporation; but such election may be held at any time after proper notice.

§. 15. All assessments or installments of the stock of any stock corporation shall be levied by the directors in accordance with the provisions of the by-laws, but any assessment or installment required to be paid shall be levied pro rata upon all the shares of such stock.

$\S 16$. If the indebtedness of any stock corporation shall exceed the amount of its capital stock, the directors and officers of such corporation assenting thereto, shall be personally and individually liable for such excess to the creditors of such corporation.

$\S 1 \%$. The president, secretary or treasurer of every stock corporation shall annually, within twenty days from the first day of December, make a statement in writing, setting forth a description of all real estate to which title was acquired in securing any debt or liability due such corporation, together with the time of acquiring title thereto; which statement shall be verified by the oath or affirmation of such president, secretary or treasurer, and be recorded in the office of the recorder of the county, and filed in the office of the Secretary of State.

$\S 18$. If any person or persons, being or pretending to be an officer or agent or board of directors of any stock corporation, or pretended stock corporation, shall assume to exercise corporate powers, or use the name of any such corporation, or pretended corporation, without complying with the provisions of this act, before all stock named in the articles of incorporation shall be subscribed in good faith, then they shall be jointly and severally liable for all debts and liabilities made by them and contracted in the name of such corporation or pretended corporation.

$\S 19$. If the directors or other officers or agents of any stock corporation shall declare and pay any dividend when such corporation is insolvent, or any dividend the payment of which would render it insolvent, or which would diminish the amount of its capital stock, 
all directors, officers or agents assenting thereto shall be jointly and severally liable for all debts of such corporation then existing, and for all that shall thereafter be contracted while they shall, respectively, continue in office.

$\S 20$. The by-laws of every corporation shall provide for the calling of meetings of the directors, trustees, or other officers corresponding to trustees; and when all such officers shall be present at any meeting, however called or notified, or shall sign a written consent thereto on the record of such meeting, the acts of such meeting shall be as valid as if legally called and notified: Provided, that the action of any meeting held beyond the limits of this State shall be void, unless such meeting was authorized, or its acts ratified by a vote of two-thirds of the directors, trustees, or officers corresponding to trustees, at a regular meeting.

$\S 21$. If any certified report or statement made, or public notice given by the officers of any corporation, shall be false in any material representation, all the officers who shall have signed the same, knowing it to be false, shall be jointly and severally liable for all damages arising therefrom.

$\S 22$. The stockholders of any stock corporation, owning twothirds of the stock in such corporation, upon which all assessments have been fully paid up, may call a meeting of the stockholders of such corporation by signing a call therefor with their proper names, stating the number of shares neld by each and filing the same with the president or secretary of such corporation and publishing the same in a newspaper in this State where the principal office of such corporation is kept, and at the seat of government, for three successive weeks prior to the time fixed for holding such meeting, and mailing a copy thereof to each of the directors of said corporation at his usual place of abode. And the secretary of such corporation shall enter such call upon the records thereof, and the fact of such publication, and mailing such notice, giving the name of such paper, with the dates and places of publication, which shall be prima facie evi. dence thereof.

$\S 23$. No person holding stock in any corporation as executor, administrator, conservator, guardian or trustee, and no person holding such stock as collateral security, shall be personally subject to any liability as stockholder of such corporation; but the person pledging such stock shall be considered as holding the same and shall be liable as a stockholder accordingly, and the estate and funds in the hands of such executor, administrator, conservator, guardian or trustee, shall be liable in like manner and to the same extent as the testator or intestate, or the ward or person interested in such trust fund, would 
have been if he had been living and had been competent to act and held the stock in his own name.

§ 24. Every executor, administrator, conservator, guardian or trustee shall represent the stock in his hands at all meetings of any stock corporation, and may vote accordingly as a stockholder, and every person who shall pledge his stock may, nevertheless, represent the same at all meetings, and may vote accordingly as a stockholder.

$\S 25$. If any corporation, or its authorized agents, shall do or refrain from doing any act which shall subject it to a forfeiture of its charter or corporate powers; or shall allow any execution or decree of any court of record for a payment of money, after demand made by the officer to be returned "no property found," or to remain unsatisfied for not less than ten days after such demand, or shall dissolve or cease doing business, leaving debts unpaid, suits in equity may be brought against all persons who were stockholders at the time, or liable in any way for the debts of the corporation by joining the corporation in such suit; and each stockholder may be required to pay his pro rata share of such debts or liabilities, to the extent of the unpaid portion of his stock, after exhausting the assets of such corporation, and if any stockholder shall not have property enough to satisfy his portion of such debts or liabilities, then the amount shall be divided equally among all the remaining solvent stockholders; and courts of equity shall have full power, on good cause shown, to dissolve or close up the business of any corporation, to appoint a receiver therefor who shall have authority, by the name of the receiver of such corporation (giving the name), to sue in all courts, and do all things necessary to closing up its affairs as commanded by the decree of such court. Said receiver shall be in all cases a resident of the State of Illinois, and shall be required to enter into bonds, payable to the people of the State of Illinois, for the use of the parties interested, in such penalty and with such securities as the court may, in the decree or order appointing the same, require. In all cases of suits for or against such receiver or the corporation of which he may be receiver, writs may issue in favor of such receiver or corporation, or against him or it, from the county where the cause of action accrued to the sheriff of any county in this State for service. [As amended by act approved May 22, 1877; in force July 1, 187\%.

$\S 26$. Foreign corporations, and the officers and agents thereof, doing business in this State, shall be subjected to all the liabilities, restrictions and duties that are or may be imposed upon corporations of like character organized under the general laws of this State, and shall have no other or greater powers. And no foreign or domestic corporation established or maintained in any way for the pecuniary 
profit of its stockholders or members, shall purchase or hold real estate in this State except as provided for in this act.

$\S 2 \%$. The certified copy of any articles of incorporation, and changes thereof, together with all indorsements thereon, under the great seal of the State of Illinois, shall be taken and received in all courts and places as prima facie evidence of the facts therein stated.

$\S 28$. Nothing in this act shall be construed to allow the construction or operation of any street railroad in any city, town or incorporated village, without the consent of the local authorities thereof.

$\S 28 \frac{1}{2}$. It shall be unlawful for the Secretary of State to issue a license for any person or persons to incorporate, under the name of any heretofore existing corporation organized under any general law of this State, until the expiration of thirty days from and after the expiration of the existence of such corporation: Provided, that the corporation enjoying such name shall have the exclusive privilege of becoming incorporated under the same name at any time within the said thirty days, according to the provisions of the act to which this is an amendment. [Added by act approved June 16, 1887; in force July 1, 1887.] 


\section{CERTIFICATE OF INCORPORATION WITII SHARES OF STOCK WITHOUT PAR VALUE'}

We, the undersigned, all being of full age and at least two-thirds being citizens of the United States of America and at least one being a resident of the State of New York, desiring to form a corporation pursuant to the provisions of the Business Corporations Law of the State of New York, DO HEREBY CERTIFY:

First: The name of the proposed corporation is The Wisconsin Edison Company, Incorporated.

Second: The purposes for which it is to be formed are as follows: To acquire by purchase, subscription, or otherwise and to invest in, hold for investment or otherwise, and to trade and deal in and to use, sell, pledge or otherwise dispose of the stock, bonds and other evidences of indebtedness of any corporation, domestic or foreign, and issue in exchange therefor its stock, bonds or other obligations, and while owner of any such stocks, bonds, and other evidences of indebtedness to exercise all the rights, powers and privileges of ownership, including the right to vote thereon for any and all purposes; to aid by loan, subsidy, guaranty or in any other manner whatsoever, so far as the same may be permitted in the case of corporations organized under the Business Corporations Law, any corporation whose stocks, bonds, securities or other obligations are in any manner held or guaranteed, and to do any and all other acts or things for the preservation, protection, improvement or enhancement in value of any such stocks, bonds, securities or other obligations; and to do all and any such acts or things designed to accomplish any such purpose.

To acquire, hold, own, dispose of and gencrally deal in grants, concessions, franchises and contracts of every kind; to cause to be formed, to promote and to aid in any way in the formation of any corporation, domestic or foreign.

To act as financial or business agent for domestic and foreign corporations, individuals, partnerships, associations, states, governments or other bodies.

To borrow money, to issue bonds, debentures, notes and other obligations, secured or unsecured, of the corporation, from time to time, for moneys borrowed, or in payment for property acquired, or for any of the other objects or purposes of the corporation, or for any of the objects of its business; to secure the same by mortgage or mortgages, or decd or deeds of trust, or pledge or other lien upon any

1 Certificate of Incorporation of the Wisconsin Edison Company, Incorporated. 
or all of the property, rights, privileges or franchises of the corporation, wheresoever situated, acquired or to be acquired; to confer upon the holders of any debenture or other bonds of the corporation, secured or unsecured, the right to convert the principal thereof into preferred or common stock of the corporation upon such terms and conditions as shall be fixed by the Board of Directors; to sell, pledge or otherwise dispose of any or all debenture or other bonds, notes and other obligations in such manner and upon such terms as the Board of Directors may deem judicious; and to guarantee the payment of any dividends upon stocks, or the principal or interest upon bonds, or the contracts or other obligations of any corporation or individual, so far as the same may be permitted in the case of corporations organized under the Business Corporations Law.

To conduct its business and all or any of its branches, so far as permitted by law in the State of New York and in other states of the United States of America and in the territories and the District of Columbia and in any and all dependencies, colonies or possessions of the United States of America and foreign countries; and for and in connection with such business to hold, possess, purchase, mortgage and convey real and personal property, and to maintain offices and agencies either within or anywhere without the State of New York.

In general to do any and all things and exercise any and all powers which may now or hereafter be lawful for the corporation to do or exercise under and in pursuance of the Business Corporations Law of the State of New York, or of any other law that may be now or hereafter applicable to the corporation.

Third: The number of shares of capital stock that may be issued by said corporation is three hundred thousand $(300,000)$, of which one hundred thousand $(100,000)$ of the amount or par value of one hundred dollars $(\$ 100)$ each are to be preferred stock, and two hundred thousand $(200,000)$ which shall have no nominal or par value are to be common stock.

Fourth: The holders of the preferred stock shall be entitled to cumulative dividends thereon at the rate of six dollars (\$6) per share or six per centum of the amount or par value for each and every fiscal year of the life of the corporation and no more, payable out of any and all surplus or net profits, quarterly, half-yearly or yearly, as and when declared by the Board of Directors, before any dividends shall be declared, set apart for, or paid upon the common stock of the corporation. Said dividends on the preferred stock shall be cumulative, so that if the corporation shall fail in any fiscal year to pay such dividends on all of the issued and outstanding preferred stock, such deficiency in the dividends shall be fully paid, but with- 
out interest, before any dividends shall be paid or set apart on the common stock. Subject to the foregoing provisions said preferred stock shall not be entitled to participate in any other or additional earnings or profits of the corporation.

In the event of the dissolution or liquidation of the corporation, or a sale of all its assets (whether voluntary or involuntary) or in event of its insolvency or upon any distribution of its capital, there shall be paid to the holders of the preferred stock the par value thereof, to wit, one hundred dollars $(\$ 100)$ per share and the amount of all unpaid accrued dividends thereon, before any sum shall be paid or any assets distributed among the holders of the common stock; and after the payment to the holders of the preferred stock of its par value and the unpaid accrued dividends thereon, the remaining assets and funds of the corporation shall be divided among and paid to the holders of the common stock according to their respective shares.

The Board of Directors may in their discretion declare and pay dividends on the common stock concurrently with dividends on the preferred stock, for any dividend period of any fiscal year when such dividends are applicable to the common stock; provided that all accumulated dividends on the preferred stock for all previous fiscal years and all dividends on the preferred stock for previous dividend periods for that fiscal year shall have been paid in full.

The whole of the preferred stock may be redeemed on any dividend day at the option of the Board of Directors, upon sixty (60) days' notice by mail to the holders of record of such stock as may be prescribed by the by-laws or, in the absence of any by-law upon the subject, by resolution of its Board of Directors, by paying for each share of the preferred stock one hundred and fifteen dollars (\$115) in cash, and in addition thereto all unpaid dividends accrued thereon at the date fixed for such redemption.

From time to time the preferred stock and the common stock may be increased according to law and may be issued in such amounts and proportions as shall be determined by the Board of Directors and as may be prescribed by law.

Fifth: The amount of capital with which the corporation will carry on business is twelve million dollars $(\$ 12,000,000)$.

Sixth: The corporation may issue and may sell its authorized shares from time to time for such consideration as may from time to time be fixed by the Board of Directors, and the consideration so fixed for shares of the preferred stock may be either greater or less than their par value.

Seventh: The principal business office of the corporation is to be 
located in the Borough of Manhattan, City, County and State of New York.

Eighth: The duration of the corporation is to be perpetual.

Ninth: The number of its directors is to be nine. Three directors shall be elected in each year, and the term of office of each director, except as provided in the next section hereof, shall be three years or until his successor shall be chosen.

Tenth: The names and post office addresses of the directors for the first year and the term of office of each are as follows:

\section{NAMES}

\section{ADDRESSES}

To serve until the first annual meeting.

Henry H. Pierce, Edward H. Green,

Frederick H. Piske,
49 Wall Street, New York, N. Y. 49 Wall Street, New York, N. Y. 30 Broad Street, New York, N. Y.

To serve until the second annual meeting.

James D. Mortimer, John Foster Dulles, Thomas H. Ryan,
30 Broad Street, New York, N. Y.

49 Wall Street, New York, N. Y. 30 Broad Street, New York, N. Y.

To serve until the third annual meeting.

James Campbell, John K. Byard, Emerson D. Pray,
30 Broad Street, New York, N. Y. 49 Wall Street, New York, N. Y. 30 Broad Street, New York, N. Y.

Eleventh: The names and post office addresses of the subscribers to this certificate, and the number of shares of stock which each agrees to take in the corporation are as follows:

\section{NAMES \\ ADDRESSES \\ NO. OF SHARES}

Here follows names and addresses of subscribers.

Twelfth: No preferred stockholder shall be entitled to subscribe for, purchase, or receive any part of any new or additional issue of stock, or of any issue of bonds or debentures convertible into stock.

The Board of Directors may appoint an Executive Committee from among their number, which Committee, to the extent provided in the By-laws of the Corporation, shall have and may exercise all of the powers of the Board of Directors in the management of the business and affairs of the corporation during the intervals between the meetings of the Board of Directors, so far as may be permitted by law.

In Witness Whereof, we have made, signed and acknowledged this certificate this 4th day of Norember, 1912.

Here follows names of subscribers and their acknowledgments. 


\section{AN ACT IN RELATION TO CORPORATIONS HAVING SHARES OF CAPITAL STOCK WITHOUT NOMINAL OR PAR VALUE'}

The People of the Stale of New Yori, represented in Senate and Assembly, do enact as follows:

Section 1. Article two of chapter sixty-one of the laws of nineteen hundred and nine, entitled "An act relating to stock corporations, constituting chapter fifty-nine of the consolidated laws," is hereby amended by adding at the end of said article five new sections, to be sections nineteen, twenty, twenty-one, twenty-two and twentythree of such chapter, to read respectively as follows:

$\S$ 19. Issuance of Shares of Stock Without Nominal or Par Value. - Upon the formation or the reorganization of any stock corporation, other than a moneyed corporation, and other than a corporation under the jurisdiction of any public service commission, the certificate of incorporation may provide for the issuance of the shares of stock of such corporation, other than preferred stock having a preference as to principal, without any nominal or par value by stating in such certificate:

(1) The number of shares that may be issued by the corporation, and if any of such shares be preferred stock, the preferences thereof. If such preferred stock or any part thereof shall have a preference as to principal, the certificate shall state the amount of such preferred stock having such preference, the particular character of such preferences, and the amount of each share thereof, which shall be five dollars or some multiple of five dollars, but not more than one hundred dollars.

(2) The amount of capital with which the corporation will carry on business, which amount shall be not less than the amount of preferred stock (if any) authorized to be issued with a preference as to principal, and in addition thereto a sum equivalent to five dollars or to some multiple of five dollars for every share authorized to be issued other than such preferred stock; but in no event shall the amount of such capital be less than five hundred dollars.

Such statements in the certificates shall be in lieu of any statements prescribed by the law under which the corporation shall have been formed or reorganized as to the amount or the maximum amount of its capital stock or the number of shares into which the same shall be divided, or of the amount or the par value of such shares.

Each share of such stock without nominal or par value shall be

1 Laws of the State of New York, 1912, Chapter 351. 
equal to every other share of such stock, subject to the preferences given to the preferred stock if any authorized to be issued. Every certificate for such shares without nominal or par value shall have plainly written or printed upon its face the number of such shares which it represents and the number of such shares which the corporation is authorized to issue, and no such certificate shall express any nominal or par value of such shares. The certificates for preferred shares having a preference as to principal shall state briefly the amount which the holders of each of such preferred shares shall be entitled to receive on account of principal from the surplus assets of the corporation in preference to the holders of other shares, and shall state briefly any other rights or preferences given to the holders of such shares.

Such corporation may issue and may sell its authorized shares, from time to time, for such consideration as may be prescribed in the certificate of incorporation, or as from time to time may be fixed by the board of directors pursuant to authority conferred in such certificate, or if such certificate shall not so provide, then by the consent of the holders of two-thirds of each class of shares then outstanding given at a meeting called for that purpose in such manner as shall be prescribed by the by-laws. Any and all shares issued as permitted by this section shall be deemed fully paid and non-asssessable and the holder of such shares shall not be liable to the corporation or to its creditors in respect thereof.

$\S 20$. Commencement of Business; Authorized Debts.-No corporation formed pursuant to section nineteen hereof shall begin to carry on business or shall incur any debts until the amount of capital stated in its certificate of incorporation shall have been fully paid in money, or in property taken at its actual value. In case the amount of capital stated in its certificate of incorporation shall be increased as herein provided, such corporation shall not increase the amount of its indebtedness then existing until it shall have received in money or property the amount of such increase of its stated capital. The directors of the corporation assenting to the creation of any debt in violation of this section shall be liable jointly and severally for such debt; but no action shall be brought under the foregoing provision of this section unless within one year after the debt shall have been incurred the creditor shall have served upon the director written notice of intention to hold him personally liable for such debt. Any director who, because of any such liability under this section, shall pay any debt of the corporation, shall be subrogated to all rights of the creditor in respect thereof against the corporation and its property and also shall be entitled to contribution from all other directors 
of the corporation similarly liable for the same debt and the personal representative of any such director who shall have died before making such contribution.

No such corporation shall declare any dividend which shall reduce the amount of its capital below the amount stated in the certificate as the amount of capital with which the corporation will carry on business. In case any such dividend shall be declared, the directors in whose administration the same shall have been declared, except those who may have caused their dissent therefrom to be entered upon the minutes of such directors at the time or who were not present when such action was taken, shall be liable jointly and severally to such corporation and to the creditors thereof to the full amount of any loss sustained by such corporation or by its creditors respectively by reason of such dividend.

§21. Taxation.-The organization tax payable under section one hundred and eighty of the tax law by any corporation issuing such shares without designated monetary value shall be at the rate of five cents on each such share which the corporation is authorized to issue, and a like tax upon any subsequent increase thereof. The tax payable under section two hundred and seventy of the tax law in respect of any sale or agreement of sale or any memorandum of sale or delivery or transfer of shares or certificates of any share without designated monetary value hereafter issued by any such corporation issuing such shares shall be at the rate of two cents for each and every share of such stock so transferred. The franchise tax upon any corporation issuing such shares of stock payable under section one hundred and eighty-two of the tax law shall be determined by the amount of the gross assets of such corporation employed in any business within this State, less such proportion of its liabilities as shall represent the ratio of its gross assets employed in any business within this State to its entire gross assets wherever employed in business, and the rate of such franchise tax shall be fixed in the manner provided in said section one hundred and eighty-two of the tax law. For this purpose the rate of dividends shall be computed by dividing the total amount of dividends which have been paid during the year by the amount of assets of the corporation upon the first day of such year.

$\S 22$. Increase or Reduction of Shares or Capital.-Any corporation formed or reorganized pursuant to section nineteen may amend its certificate of incorporation so as to increase or to reduce the number of shares which it may issue, or so as to increase or to reduce the amount of its stated capital, by filing, in the manner provided for the original certificate of incorporation, a certifieate of amendment under seal executed by its president or a vice-president and by its 
secretary or its treasurer, stating the amendment proposed and that the same has been duly authorized by a vote of a majority of the directors and also by the vote of the holders of at least three-fifths of the outstanding shares of each class issued by the corporation, at a meeting of the stockholders called for the purpose in the manner provided in section sixty-three hereof, and by filing with such certificate of amendment a copy of the proceedings of such meeting, made, signed, verified and acknowledged by the president or a vicepresident and by the secretary or the treasurer of the corporation; but an amendment cannot be made under this section unless as so amended the certificate of incorporation could lawfully have been filed under section nineteen of this chapter. In case of a reduction of the amount of capital of a corporation, a certificate setting forth the whole amount of the ascertained debts and liabilities of the corporation shall be made, signed, verified and acknowledged by the president or a rice-president and by the secretary or the treasurer of the corporation and shall be filed with the certificate of amendment; and such certificate of amendment shall have endorsed thereon the approval of the comptroller to the effect that as so stated the reduced amount of capital is sufficient for the proper purposes of the corporation and is in excess of its ascertained debts and liabilities.

$\S 23$. Amount of Capital Stock and of Shares Within Meaning of Other Laws.-For the purpose of any rule of law or of any statutory provision (other than the foregoing sections nineteen, twenty, twenty-one and twenty-two) relating to the amount of the capital stock of a corporation or the amount or par value of its shares, the aggregate amount of the capital stock of any such corporation formed pursuant to section nineteen hereof shall be deemed to be the aggregate amount specified in the certificate or amended certificate of incorporation or of reorganization as the amount of capital with which the corporation will carry on business; the amount or the par value of each share of preferred stock having a preference as to principal shall be deemed to be the amount thereof so specified in such certificate or such amended certificate; and the amount or the par value of each other share shall be deemed to be an aliquot part of the aggregate capital so specified in such certificate or in such amended certificate in excess of the specified amount (if any) of the preferred stock therein authorized to be issued with a preference as to principal.

SEction 2. This act shall take effect immediately.

Approved by the Governor April 15, 1912. 


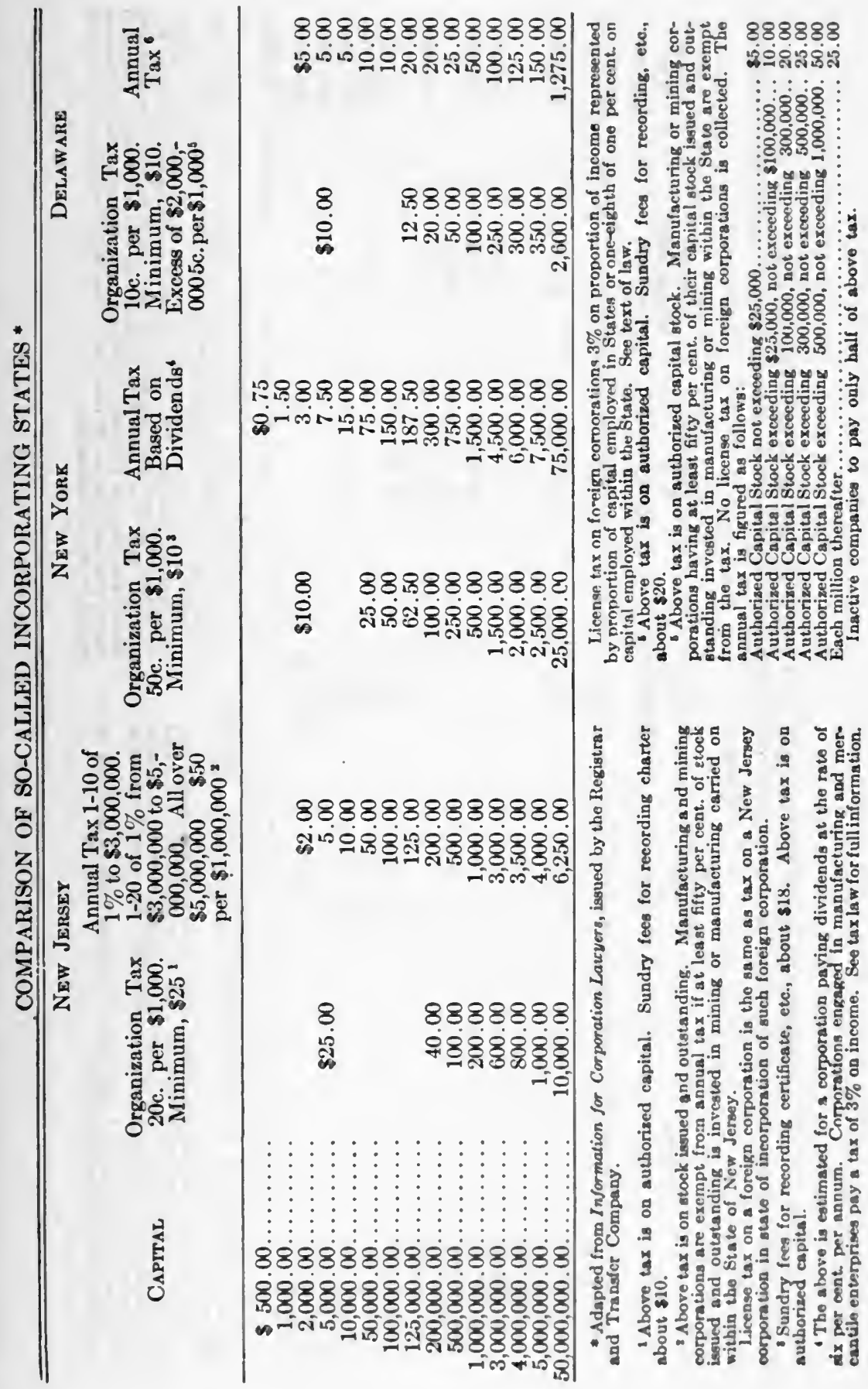




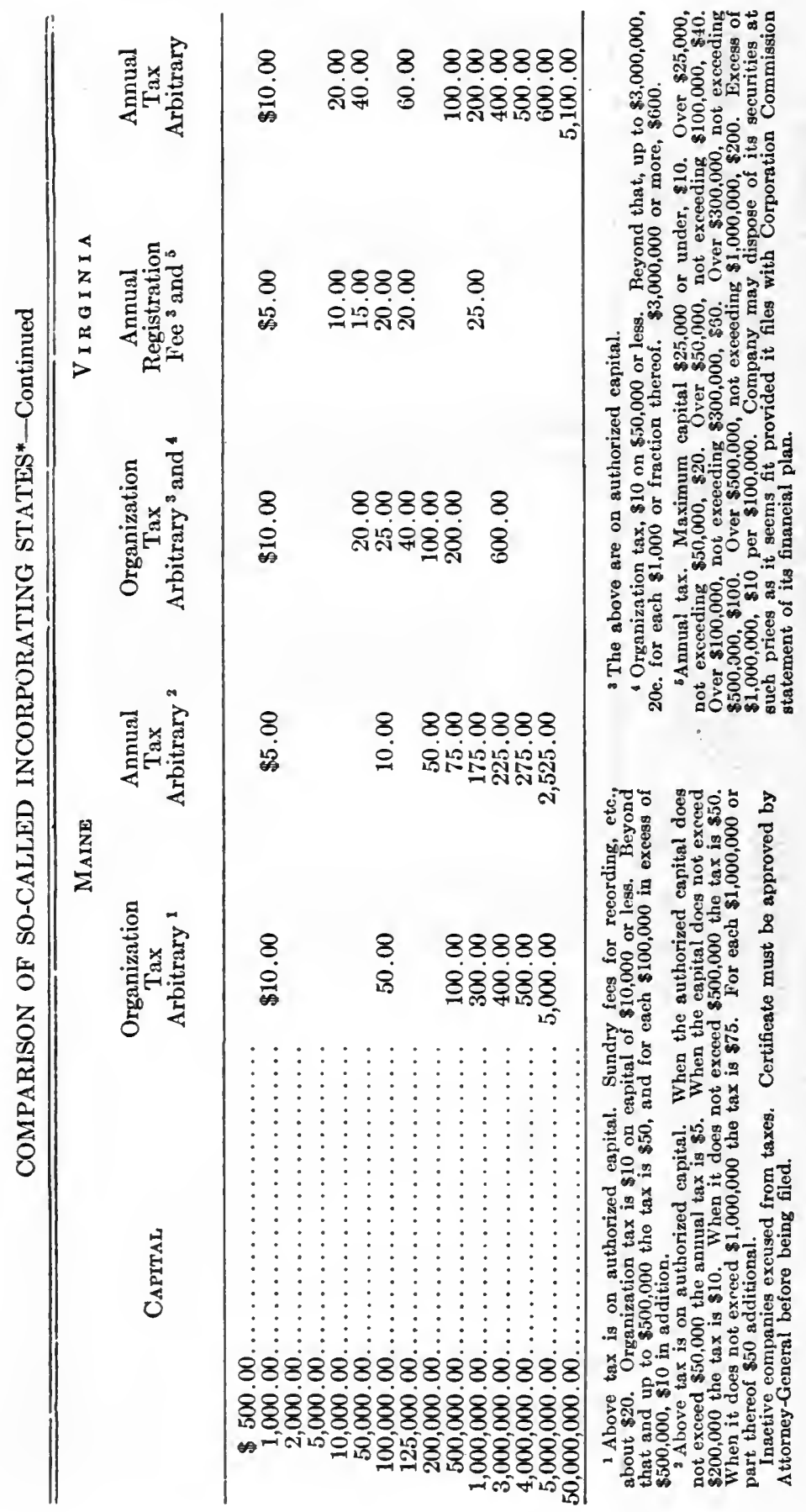




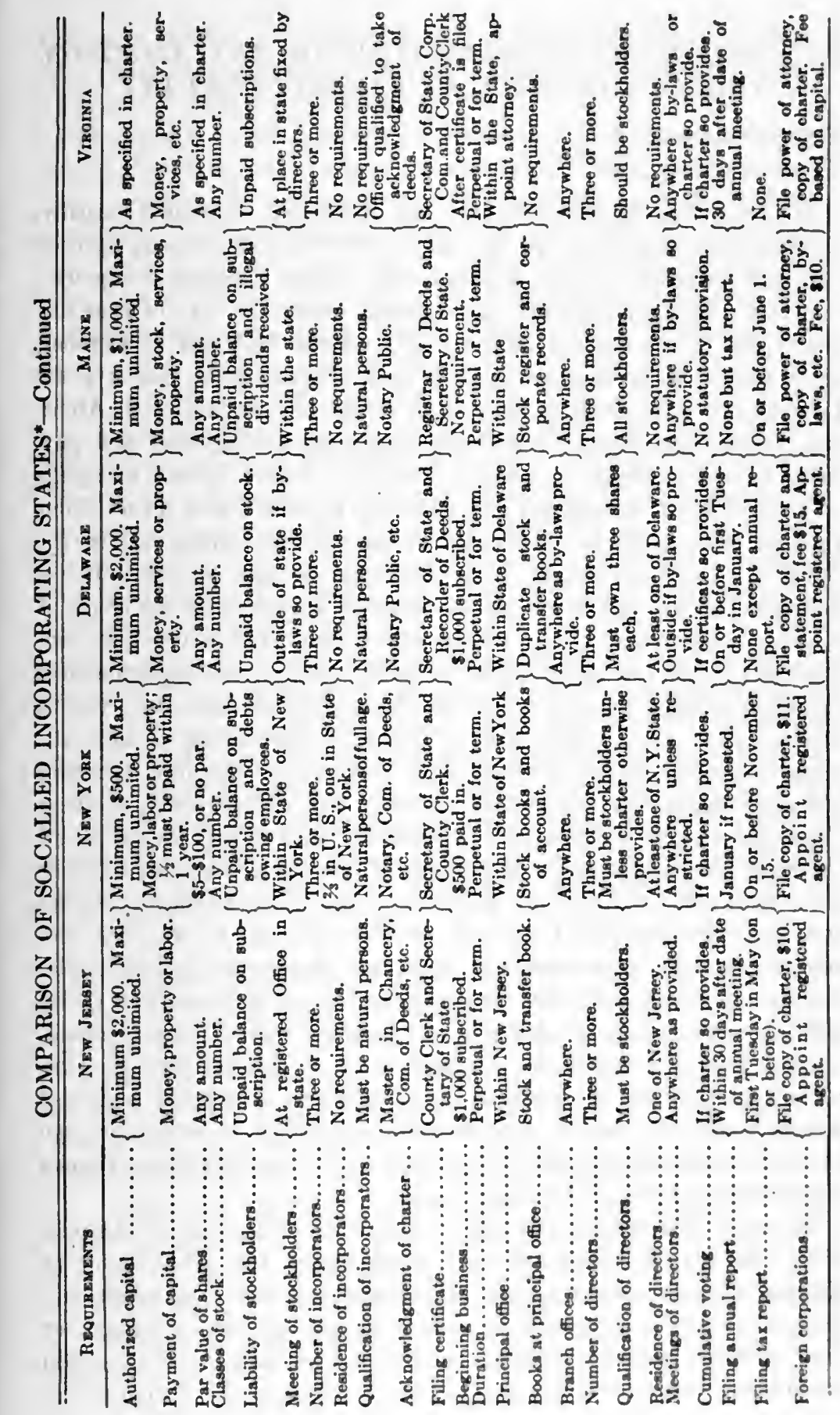




\section{CERTIFICATE OF INCORPORATION OF THE ATCHISON, TOPEKA AND SANTA FE RAILWAY COMPANY}

$\left.\begin{array}{l}\text { State of Kansas, } \\ \text { Shawnee County, }\end{array}\right\}$ ss.:

Whereas, The Atchison, Topeka and Santa Fé Railroad Company, a corporation created by an Act of the Territory of Kansas, entitled "An Act incorporating the Atchison and Topeka Railroad Company," approved February 11, 1859, and existing under the laws of said territory and of the State of Kansas, did, on the 15th day of October, 1889, execute its certain mortgage or deed of trust to the Union Trust Company of New York, as trustee, to secure the bonds of said Atchison, Topeka and Santa Fé Railroad Company, issued under and pursuant to said mortgage or deed of trust, and in and by said mortgage or deed of trust, mortgaged and conveyed to said Union Trust Company of New York, as trustee, all of its railroad constructed in the State of Kansas, running from Atchison on the Missouri River, through Topeka, to a point on the western boundary of the State of Kansas, being about four hundred and seventy and fifty-eight hundredths (470.58) miles in length, together with all the appurtenances thereof, including telegraphs and telephones, and all franchises, rights, privileges and immunities, then or thereafter pertaining to said railroad, telegraphs, telephones and other property, or the appurtenances and appendages thereof; and all property, real and personal, of every name and nature whatsoever and wheresoever situated, including all shares of the capital stock and bonds of other corporations, whether then possessed or thereafter acquired by the said Atchison, Topeka and Sante Fé Railroad Company, for the purposes of the construction, equipment, maintenance or operation of the said railroad, telegraphs, telephones and other property, or for use in connection therewith, or with any or all of the same; together with all the revenues, income, profits, benefits and advantages of, or in any way growing out of, any or all of the said above-described property; and also certain stocks and bonds mentioned and described in said mortgage and then owned or thereafter to be acquired by said Atchison, Topeka and Santa Fé Railroad Company; and

Whereas, Thereafter, and on or about the 27th day of August, 1895, the Circuit Court of the United States for the District of Kansas, the same being a court of competent jurisdiction, made and entered a certain judgment or decree foreclosing said mortgage or deed of trust, which judgment or decree was entered in a certain consolidated cause pending in said court, wherein the Union Trust 
Company of New York, the trustee under said mortgage or deed of trust, was a complainant, and said Atchison, Topeka and Santa Fé Railroad Company was a defendant; and

Whereas, The said railroad, properties and franchises, on the tenth day of December, 1895, were duly sold in pursuance of the said judgment or decree of said court to Edward King, Charles C. Beaman and Victor Morawetz, all of the City of New York, N. Y., and such sale having been duly confirmed by said court, the said railroad, properties and franchises, in pursuance of said judgment or decree and the orders of said court made thereon, were conveyed by deed, executed by John B. Johnson, Special Master in Chancery, appointed by said court in said cause, to the said Edward King, Charles C. Beaman and Victor Morawetz, as joint tenants and not as tenants in common, who thereby acquired title to said railroad, properties and franchises under such sale; and the said purchasers, and their associates, successors and assigns, under and by virtue of the laws of the State of Kansas in such case made and provided, did thereby have and acquire and become entitled thereafter to exercise and enjoy, all the rights, privileges, grants, franchises, immunities and advantages in and by said mortgage or deed of trust conveyed, which belonged to and were enjoyed by said Atchison, Topeka and Santa Fé Railroad Company, so far as the same relate and appertain to said railroad, described in and conveyed by said mortgage or deed of trust as above set forth; and

Whereas, The said Edward King, Charles C. Beaman and Victor Morawetz, the said purchasers, for the purpose of organizing a new corporation under and in pursuance of the laws of the State of Kansas, have associated with themselves the following named persons, viz.:

EDWARD P. RIPLEY, who is a citizen of the State of Illinois, residing at the City of Chicago.

ALDACE F. WALKER, who is a citizen of the State of Illinois, residing at the City of Chicago.

BENJAMIN P. CHENEY, who is a citizen of the State of Massachusetts, residing at the City of Dover.

EDWARD N. GIBBS, who is a citizen of the State of New York, residing at the City of New York.

CHARLES S. GLEED, who is a citizen of the State of Kansas, residing at the City of Topeka.

R. SOMERS HAYES, who is a citizen of the State of New York, residing at the City of New York.

GJORGE G. HAVEN, who is a eitizen of the State of New York, residing at the City of New York. 
CYRUS K. HOLLIDAY, who is a citizen of the State of Kansas, residing at the City of Topeka.

THOMAS A. OSBORN, who is a citizen of the State of Kansas, residing at the City of Topeka.

WILLIAM ROTCH, who is a citizen of the State of Massachusetts, residing at the City of Boston.

EDWARD WILDER, who is a citizen of the State of Kansas, residing at the City of Topeka.

Whereas, The said purchasers and their said associates have organized themselves and do hereby organize themselves as a new corporation as hereinafter in this certificate set forth:

Now, therefore, The undersigned, being the said purchasers, and their associates, do hereby certify and state as follows:

First. The name of the corporation formed by the undersigned is The Atchison, Topeka and Santa Fé Railway Company.

Second. The purposes for which such corporation is formed are as follows:

To acquire, construct, own, maintain and operate a railway running from the City of Atchison on the Missouri River, in the State of Kansas, through Topeka to a point on the western boundary of the State of Kansas, through the counties of Atchison, Jefferson, Shawnee, Osage, Lyon, Chase, Marion, Harvey, Reno, Rice, Barton, Pawnee, Edwards, Ford, Gray, Finney, Kearney and Hamilton, and a telegraph line in connection with said railway, together with all the appurtenances thereof, the estimated length of which railway is four hundred and seventy and fifty-eight hundredths (470.58) miles; and also to acquire, own, use and enjoy the railroad and appurtenances, franchises, rights, privileges and immunities, stocks and bonds, and all other properties acquired by said purchasers at said sale as above recited;

Third. The place or places where the business of said corporation is to be transacted are the City of Topeka, in the County of Shawnee. in the State of Kansas, and such other places and cities upon the line of said railway, or any of its branches, or leased, operated or controlled lines, as may from time to time be deemed desirable, and at such other points or places where any business may be legally done by it in the exercise and enjoyment of its rights, powers and privileges. 
Fourth. The term for which this corporation is to exist is nine hundred and ninety-nine (999) years.

Fifth. The number of its directors shall be fifteen, and the names and residences of those who are appointed for the first year are as follows:

Names.

Residences.

Edward P. Ripley................................ Ill.

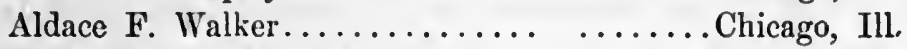

Benjamin P. Chency................ Dover, Mass.

Edward N. Gibbs................. New York, N. Y.

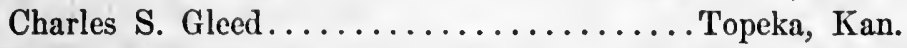

George G. Haven............... New York, N. Y.

R. Somers Hayes................ New York, N. Y.

Cyrus K. Holliday................. Topeka, Kan.

Victor Morawetz................. New York, N. Y.

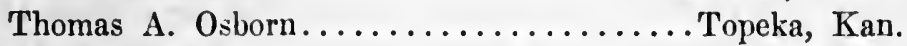

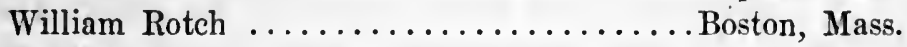

Edward Wilder............................. Kan.

Robert Fleming......................

John Luden .................. Amsterdam, Holland.

and Herman Kobbé............... New York, N. Y.

Sixth. The amount of the capital stock of such corporation shall be two hundred and thirty-three million, four hundred and eighty-six thousand $(\$ 233,486,000)$ dollars, and the same shall be divided into two million three hundred and thirty-four thousand eight hundred and sixty $(2,334,860)$ shares of the par value of one hundred $(\$ 100)$ dollars each.

Of such capital stock one million, three hundred and fourteen thousand eight hundred and sixty $(1,314,860)$ shares, amounting in the aggregate to one hundred and thirty-one million, four hundred and eighty-six thousand $(\$ 131,486,000)$ dollars, shall be five per cent. non-cumulative preferred stock and

One million, twenty thousand $(1,020,000)$ shares, amounting in the aggregate to one hundred and two million $(\$ 102,000,000)$ dollars, shall be common stock.

The holders of the preferred stock shall be entitled to non-cumulative dividends in each and every fiscal year beginning after the 30th day of June, 1896, at such rate, not exceeding five per centum per annum, as shall be declared by the Board of Directors of such corporation, in preference and priority to any payment in or for such fiscal year of any dividend on the common stock or on any other stock of said company, but only from undivided net profits when and 
as determined by the said Board; and in case of dissolution or liquidation of said corporation, the holders of the preferred stock shall be entitled to receive the par amount of their stock out of the assets of such corporation in priority to the common stock.

No mortgage, other than a mortgage to secure an issue of seventeen million dollars of four per cent. thirty-year prior lien gold bonds and an issue of one hundred and sixty-five million four hundred and ninety thousand five hundred dollars of general mortgage four per cent. one hundred year gold bonds, and another mortgage to secure an issue of not to exceed seventy-one million seven hundred and twenty-eight thousand dollars of four per cent. one hundred year adjustment bonds (bearing interest payable only out of surplus net earnings if earned), shall be executed by the corporation hereby formed, nor shall the amount of the preferred stock of said corporation be increased, unless the execution of such mortgage or such increase of the preferred stock shall have received the consent of the holders of a majority of the whole amount of the preferred stock which shall at the time be outstanding, given at a meeting of the stockholders called for that purpose and the consent of the holders of a majority of such part of the common stock as shall be represented at such meeting.

In testimony whereof, We have hereunto subscribed our names this 12th day of December, 1895:

\author{
Edward King, \\ Charles C. Beaman, \\ Victor Morawetz, \\ E. P. Ripley, \\ Aldace F. Walker, \\ Benj. P. Cheney, \\ Edward N. Gibbs, \\ C. S. Gleed, \\ R. Somers Hayes, \\ G. G. Haven, \\ Cyrus K Holliday, \\ Thomas A. Osborn, \\ William Rotch, \\ E. Wilder.
}

(Here follows the acknowledgment and the Certificate of Authenticity of the Secretary of State.) 


\section{AMENDED CERTIFICATE OF INCORPORATION OF UNITED} STATES STEEL CORPORATION.

We, the undersigned, in order to form a corporation for the purposes hereinafter stated, under and pursuant to the provisions of the Act of the Legislature of the State of New Jersey, entitled "An Act concerning corporations (Revision of 1896),", and the acts amendatory thereof and supplemental thereto, do hereby certify as follows:

I. The name of the corporation is

\section{United States Steel Corporation.}

II. The location of its principal office in the State of New Jersey is at No. 51 Newark Street, in the City of Hoboken, County of Hudson. The name of the agent therein and in charge thereof, upon whom process against the corporation may be served, is Hudson Trust Company. Said office is to be the registered office of said corporation.

III. The objects for which the corporation is formed are:

To manufacture iron, steel, manganese, coke, copper, lumber and other materials, and all or any articles consisting, or partly consisting, of iron, steel, copper, wood or other materials, and all or any products thereof.

To acquire, own, lease, occupy, use or develop any lands containing coal or iron, manganese, stone or other ${ }^{\circ}$ ores, or oil, and any wood lands, or other lands for any purpose of the Company.

To mine, or otherwise to extract or remove, coal, ores, stone and other minerals and timber from any lands owned, acquired, leased or occupied by the company, or from any other lands.

To buy and sell, or otherwise to deal or to traffic in, iron, steel, manganese, copper, stone, ores, coal, coke, wood, lumber and other materials, and any of the products thereof, and any articles consisting, or partly consisting thereof.

To construct bridges, buildings, machinery, ships, boats, engines, cars and other equipment, railroads, docks, slips, elevators, water works, gas works and electric works, viaducts, aqueducts, canals and other water-ways, and any other means of transportation, and to sell the same, or otherwise to dispose thereof, or to maintain and operate the same, except that the Company shall not maintain or operate any railroad or canal in the State of New Jersey.

To apply for, obtain, register, purchase, lease, or otherwise to acquire, and to hold, use, own, operate and introduce, and to sell, assign, or otherwise to dispose of, any trade-marks, trade names, 
patents, inventions, improvements and processes used in connection with, or secured under letters patent of the United States, or elsewhere, or otherwise; and to use, exercise, develop, grant licenses in respect of, or otherwise to turn to account any such trade-marks, patents, licenses, processes, and the like, or any such property or rights.

To engage in any other manufacturing, mining, construction or transportation business of any kind or character whatsoever, and to that end to acquire, hold, own and dispose of any and all property, assets, stocks, bonds and rights of any and every kind; but not to engage in any business hereunder which shall require the exercise of the right of eminent domain within the State of New Jersey.

To acquire by purchase, subscription or otherwise, and to hold or to dispose of, stocks, bonds or any other obligations of any corporation formed for, or then or theretofore engaged in or pursuing, any one or more of the kinds of business, purposes, objects or operations above indicated, or owning or holding any property of any kind herein mentioned; or of any corporation owning or holding the stocks or the obligations of any such corporation.

To hold for investment, or otherwise to use, sell or dispose of: any stock, bonds or other obligations of any such other corporation; to aid in any manner any corporation whose stock, bonds or other obligations are held or are in any manner guaranteed by the Company, and to do any other acts or things for the preservation, protection, improvement or enhancement of the value of any such stock, bonds or other obligations, or to do any acts or things designed for any such purpose; and, while owner of any such stock, bonds or other obligations, to exercise all the rights, powers and privileges of ownership thereof, and to exercise any and all voting power thereon.

The business or purpose of the Company is from time to time to do any one or more of the acts and things herein set forth; and it may conduct its business in other States and in the Territories and in foreign countries, and may have one office or more than one office, and keep the books of the Company outside of the State of New Jersey, except as otherwise may be provided by law; and may hold, purchase, mortgage and convey real and personal property either in or out of the State of New Jersey.

Without in any particular limiting any of the objects and powers of the corporation, it is hereby expressly declared and provided that the corporation shall have power to issue bonds and other obligations, in payment for property purchased or acquired by it, or for any object in or about its business; to mortgage or pledge any stocks, bonds or other obligations, or any property which may be 
acquired by it, to secure any bonds or other obligations by it issued or incurred; to guarantee any dividends or bonds or contracts or other obligations; to make and perform contracts of any kind and description; and in carrying on its business, or for the purpose of attaining or furthering any of its objects, to do any and all other acts and things, and to exercise any and all other powers which a copartnership or natural person could do and exercise, and which now or hereafter may be authorized by law.

IV. The total authorized capital stock of the corporation is eleven hundred million dollars $(\$ 1,100,000,000)$, divided into eleven million shares of the par value of one hundred dollars each. Of such total authorized capital stock, five million five hundred thousand shares, amounting to five hundred and fifty million dollars, shall be preferred stock, and five million five hundred thousand shares, amounting to five hundred and fifty million dollars, shall be common stock.

From time to time, the preferred stock and the common stock may be increased according to law, and may be isssued in such amounts and proportions as shall be determined by the board of directors, and as may be permitted by law.

The holders of the preferred stock shall be entitled to receive when and as declared, from the surplus or net profits of the corporation, yearly dividends at the rate of seven per centum per annum, and no more, payable quarterly on dates to be fixed by the by-laws. The dividends on the preferred stock shall be cumulative, and shall be payable before any dividend on the common stock shall be paid or set apart; so that, if any year dividends amounting to seven per cent. shall not have been paid thereon, the deficiency shall be payable before any dividends shall be paid upon or set apart for the common stock.

Whenever all cumrulative dividends on the preferred stock for all previous years shall have been declared and shall have become payable, and the accrued quarterly installments for the current year shall have been declared, and the company shall have paid such cumulative dividends for previous years and such accrued quarterly installments, or shall have set aside from its surplus or net profits a sum sufficient for the payment thereof, the Board of Directors may declare dividends on the common stock, payable then or thereafter, out of any remaining surplus or net profits.

In the event of any liquidation or dissolution or winding up (whether voluntary or involuntary) of the corporation. the holders of the preferred stock shall be entitled to be paid in full both the par amount of their shares, and the unpaid dividends accrued thereon 
before any amount shall be paid to the holders of the common stock; and after the payment to the holders of the preferred stock of its par value, and the unpaid accrued dividends thereon, the remaining assets and funds shall be divided and paid to the holders of the common stock according to their respective shares.

V. The names and post-office addresses of the incorporators, and the number of shares of stock for which severally and respectively we do hereby subscribe (the aggregate of our said subscriptions, being three thousand dollars, is the amount of capital stock with which the corporation will commence business), are as follows:

Number of Shares.

Name.

Post Office Address.

Preferred Common Stock. Stock.

Charles C. Cluff... 51 Newark Street, Hoboken,

William J. Curtis. New Jersey

Charles MacVeagh

Ditto

Ditto

5

5

5
5

5

5

VI. The duration of the corporation shall be perpetual.

VII. The number of the directors of the Company shall be fixed from time to time by the by-laws; but the number, if fixed at more than three, shall be some multiple of three. The directors shall be classified with respect to the time for which they shall severally hold office by dividing them into three classes, each consisting of onethird of the whole number of the board of directors. The directors of the first class shall be elected for a term of one year; the directors of the second class for a term of two years; and the directors of the third class for a term of three years; and at each annual election the successors to the class of directors whose terms shall expire in that year shall be elected to hold office for the term of three years, so that the term of office of one class of directors shall expire in each year.

The number of the directors may be increased as may be provided in the by-laws. In case of any increase of the number of the directors the additional directors shall be elected as may be provided in the by-laws, by the Directors or by the stockholders at an annual or special meeting and one-third of their number shall be elected for the then unexpired portion of the term of the directors of the first class, one-third of their number for the unexpired portion of the term of the directors of the second class, and one-third of their number for the unexpired portion of the term of the directors of the third class, so that each class of directors, shall be increased equally. 
In case of any vacancy in any class of directors through death, resignation, disqualification or other cause, the remaining directors, by affirmative vote of a majority of the Board of Directors, may elect a successor to hold office for the unexpired portion of the term of the director whose place shall be vacant, and until the election of a successor.

The Board of Directors shall have power to hold their meetings outside of the State of New Jersey at such places as from time to time may be designated by the by-laws or by resolution of the Board. The by-laws may prescribe the number of directors necessary to constitute a quorum of the Board of Directors, which number may be less than a majority of the whole number of the directors.

Unless authorized by rotes giren in person or by proxy by stockholders holding at least two-thirds of the capital stock of the corporation, which is represented and voted upon in person or by proxy at a meeting specially called for that purpose or at an annual meeting, the Board of Directors shall not mortgage or pledge any of its real property, or any shares of the capital stock of any other corporation; but this prohibition shall not be construed to apply to the execution of any purchase-money mortgage or any other purchase-money lien. As authorized by the Act of the Legislature of the State of New Jersey passed March 22, 1901, amending the 17th section of the Act Concerning Corporations (Revision of 1896), any action which theretofore required the consent of the holders of two-thirds of the stock at any meeting after notice to them given, or required their consent in writing to be filed, may be taken upon the consent of, and the consent giren and filed by the holders of two-thirds of the stock of each class represented at such meeting in person or by proxy.

Any officer elected or appointed by the Board of Directors may be removed at any time by the affirmative vote of a majority of the. whole Board of Directors. Any other officer or employe of the Company may be removed at any time by vote of the Board of Directors, or by any committec or superior officer upon whom such power of removal may be conferred by the by-laws or by vote of the Board of Directors.

The Board of Directors, by the affirmative vote of a majority of the whole board, may appoint from the directors an executive committee, of which a majority shall constitute a quorum; and to such extent as shall be provided in the by-laws, such committee shall have and may exercise all or any of the powers of the Board of Directors, including power to cause the seal of the corporation to be affixed to all papers that may require it.

The Board of Directors, by the affirmative vote of a majority of the 
whole board, may appoint any other Standing Committees, and such Standing Committees shall have and may exercise such powers as shall be conferred or authorized by the by-laws.

The Board of Directors may appoint not only other officers of the Company, but also one or more vice-presidents, one or more assistant treasurers and one or more assistant secretaries; and, to the extent provided in the by-laws, the persons so appointed respectively shall have and may exercise all the powers of the president, of the treasurer and of the secretary, respectively.

The Board of Directors shall have power from time to time to fix and to determine and to vary the amount of the working capital of the Company; and to direct and determine the use and disposition of any surplus or net profits over and above the capital stock paid in; and in its discretion the Board of Directors may use and apply any such surplus or accumulated profits in purchasing or acquiring its bonds or other obligations, or shares of its own capital stock, to such extent and in such manner and upon such terms as the Board of Directors shall deem expedient; but shares of such capital stock so purchased or acquired may be resold, unless such shares shall have been retired for the purpose of decreasing the Company's capital stock as provided by law.

The Board of Directors from time to time shall determine whether and to what extent, and at what times and places, and under what conditions and regulations, the accounts and books of the corporation or any of them, shall be open to the inspection of the Stockholders, and no Stockholder shall have any right to inspect any account or book or document of the corporation, except as conferred by Statute or authorized by the Board of Directors, or by a resolution of the Stockholders.

Subject always to by-laws made by the Stockholders, the Board of Directors may make by-laws, and, from time to time, may alter, amend or repeal any by-laws; but any by-laws made by the Board of Directors may be altered or repealed by the Stockholders at any annual meeting, or at any special meeting, provided notice of such proposed alteration or repeal be included in the notice of the meeting.

Is witness whereof, we have hereunto set our hands and seals the 23rd day of February, 1901.

Charles C. Cluff

[SEAL]

William J. Curtis

[SEAL]

Charles MacVeagi

[SEAL] 
Signed, sealed and delivered in the presence of

\section{Francis Lynde Stetson}

Victor Morawetz.

\section{State of New Jersey, \\ County of Hudson, $\}$ ss.:}

Be it remembered that on this 23rd day of February, 1901, before the undersigned, personally appeared Charles C. Cluff, William J. Curtis and Charles MacVeagh, who, I am satisfied, are the persons named in and who executed the foregoing certificate; and I having first made known to them, and to each of them, the contents thereof, they did each acknowledge that they signed, sealed and delivered the same as their voluntary act and deed.

Geo. Holmes,

Master in Chancery of New Jersey.

10ct. Internal Revenue Stamp Cancelled.

Endorsed "Received in the Hudson Co. N. J. Clerk's Office Feb'y 25th A. D. 1901 and Recorded in Clerk's Record No on Page -

Maurice J. Stack, Clerk"

ENDoRsed "Filed Feb. 25, 1901

George Wurts,

Secretary of State." 


\title{
BY-LAWS OF UNITED STATES STEEL CORPORATION ${ }^{1}$
}

\author{
ARTICLE I \\ STOCKHOLDERS
}

\section{Section I.-Annual Meeting-Stockholders' Anndal Meeting-Date of Meeting}

The annual meeting of the stockholders of the Company shall be held annually at the principal office of the Company in the State of New Jersey, at twelve o'clock noon, on the third Monday in April in each year, if not a legal holiday, and if a legal holiday then on the next succeeding Monday not a legal holiday, for the purpose of electing directors, and for the transaction of such other business as may be brought before the meeting; and the terms of office of the directors of the several classes shall continue until the election of their successors at such meeting as provided in Article II hereof.

Advertising Notice of Meeting.-It shall be the duty of the Secretary to cause notice of each annual meeting to be published once in each of the four calendar weeks next preceding the meeting in at least one newspaper in each of the following places: Jersey City, N. J., New York, N. Y., Chicago, Ill., and Pittsburg, Pa. Nevertheless, a failure to publish such notice, or any irregularity in such notice, or in the publication thereof, shall not affect the validity of any annual meeting, or of any proceedings at any such meeting.

\section{Section 2.--Special Meetings}

Special Meetings.-Special meetings of the stockholders may be held at the principal office of the Company in the State of New Jersey, whenever called in writing, or by vote, by a majority of the Board of Directors.

Advertising Notice of Meetings.-Notice of each special meeting. indicating briefly the object or objects thereof, shall by the secretary be published once in each of the four calendar weeks preceding the meeting, in at least one newspaper in each of the following places: Jersey City, N. J., New York, N. Y., Chicago, Ill., and Pittsburg, $\mathrm{Pa}$. Nevertheless, if all the stockholders shall waive notice of a special meeting, no notice of such meeting shall be required; and whenever all the stockh-lders shall meet in person or by proxy, such meeting shall be valid for all purposes without call or notice, and at such meeting any corporate action may be taken.

1 As amended May 31, 1911. 


\section{Section 3.-Quorum}

Quorum.-At any meeting of the stockholders, one-third of all of the shares of the capital stock of the Company, present in person or represented by proxy, shall constitute a quorum of the stockholders for all purposes, unless the representation of a larger number shall be required by law, and, in that case, the representation of the number so required, shall constitute a quorum.

If the holders of the amount of stock necessary to constitute a quorum shall fail to attend in person or by proxy at the time and place fixed by these by-laws for an annual meeting, or fixed by notice as above provided for a special mecting called by the directors, a majority in interest of the stockholders present in person or by proxy may adjourn, from time to time, without notice other than by announcement at the meeting, until holders of the amount of stock requisite to constitute a quorum shall attend. At any such adjourned meeting at which a quorum shall be present, any business may be transacted which might have been transacted at the meeting as originally notified.

\section{Section 4.-Organization}

Chairman.-The chairman of the Board, and in his absence, the chairman of the Finance Committee, and in the absence of both, the president, shall call meetings of the stockholders to order, and shall act as chairman of such meetings. The Board of Directors or Finance Committee may appoint any stockholder to act as chairman of any meeting in the absence of the chairman of the Board and of the chairman of the Finance Committee and of the president.

Secretary. - The secretary of the Company shall act as secretary at all mectings of the stockholders; but in the absence of the secretary at any meeting of the stockholders the presiding officer may appoint any person to act as secretary of the meeting.

\section{Section 5.-Voting}

Voting.-At each mecting of the stockholders, every stockholder shall be entitled to vote in person, or by proxy appointed by instrument in writing, subseribed by such stockholder or by his duly authorized attorney, and delivered to the inspectors at the meeting; and he shall have one vote for each share of stock standing registered in his name at the time of the closing of the transfer books for said meeting The votes for directors, and, upon demand of any stockholder, the votes upon any question before the meeting, shall be by ballot. 
List of Stockholders.-At each meeting of the stockholders, a full, true and complete list, in alphabetical order, of all of the stockholders entitled to vote at such meeting, and indicating the number of shares by each, certified by the secretary or by the treasurer, shall be furnished. Only the persons in whose names shares of stock stand on the books of the Company at the time of the closing of the transfer books for such meeting, as evidenced by the list of stockholders so furnished, shall be entitled to vote in person or by proxy on the shares so standing in their names.

Prior to any meeting, but subsequent to the time of closing the transfer books for such meeting, any proxy may submit his powers of attorney to the secretary, or to the treasurer, for examination. The certificate of the secretary, or of the treasurer, as to the regularity of such powers of attorney, and as to the number of shares held by the persons who severally and respectively executed such powers of attorney, shall be received as prima facie evidence of the number of shares represented by the holder of such powers of attorney for the purpose of establishing the presence of a quorum at such meeting and of organizing the same, and for all other purposes.

\section{Section 6.-Inspectors}

Inspectors of Election.-At each meeting of the stockholders, the polls shall be opened and closed, the proxies and ballots shall be received and be taken in charge, and all questions touching the qualification of voters and the validity of proxies and the acceptance or rejection of votes, shall be decided by three inspectors. Such inspectors shall be appointed by the Board of Directors before or at the meeting, or, if no such appointment shall have been made, then by the presiding officer at the meeting. If for any reason any of the inspectors previously appointed shall fail to attend or refuse or be un. able to serve, inspectors in place of any so failing to attend or refusing or unable to attend, shall be appointed in like manner.

\section{ARTICLE II}

\section{BOARD OF DIRECTORS}

\section{Section 1.-Number, Classification and Term of Office}

Directors.-The business and the property of the Company shall be managed and controlled by the Board of Directors.

Classification.-As provided in the certificate of incorporation, the directors shall be classified in respect of the time for which they shall severally hold office, by dividing them into three classes, each class 
consisting of one-third of the whole number of the Board of Directors.

Terms of Each Class.-The directors of the first class shall be elected for a term of one year; the directors of the second class shall be elceted for a term of two years, and the directors of the third class shall be elected for a term of three years. At each annual election, the successors to the directors of the class whose term shall expire in that year, shall be elected to hold office for the term of three years, so that the term of office of one class of directors shall expire in each year.

Number of Directors.-The number of directors shall be twentyfour; but the number of directors may be altered from time to time by the alteration of these by-laws.

In case of any increase of the number of directors, the additional directors shall be elected by the directors then in office; one-third of such additional directors for the unexpired portion of the term of one year; one-third for the unexpired portion of the term of two years, and one-third for the unexpired portion of the term of three years, so that each class of directors shall be increased equally.

Directors Must be Stockholders.-Every director shall be a holder of at least, one share of the capital stock of the Company. Each director shall serve for the term for which he shall have been elected, and until his successor shall have been duly chosen.

Polls Open One Hour.-At all elections of the directors, the polls shall remain open for at least one hour, unless every registered owner of shares has sooner voted in person or by proxy, or in writing has waived the statutory provision.

\section{Section 2.-VACANCIES}

Vacancies in Board.--In case of any vacancy in the directors of any class through death, resignation, disqualification or other cause, the remaining directors, by affirmative vote of a majority thereof, may elect a successor to hold office for the unexpired portion of the term of the director whose place shall be vacant, and until the election of his successor.

Such vacancy shall be filled upon and after nominations shall have been made by the Finance Committee.

\section{Section 3.-Place of Meftina, Etc.}

Place of Meeting.-The directors may hold their meetings, and may have an office and kecp the books of the Company (except as otherwise may be provided for by law) in such place or places in the State of New Jersey or outside of the State of New Jersey, as the Board from time to time may determine. 


\section{Section 4.-Regular Meetings}

Regular Monthly Meetings.-Regular meetings of the Board of Directors shall be held.monthly on the last Tuesday of each month, if a legal holiday, then on the next succeeding Tuesday not a legal holiday. No notice shall be required for any such regular monthly meeting of the Board.

\section{Section 5.-Special Meetings}

Special Meetings.-Special meetings of the Board of Directors shall be held whenever called by direction of the chairman of the Board, or the chairman of the Finance Committee, or the president, or of one-third of the directors for the time being in office.

\section{NOTICE REQUIRED}

The secretary shall give notice of each special meeting by mailing the same at least two days before the meeting, or by telegraphing the same at least one day before the meeting, to each director; but such notice may be waived by any director. Unless otherwise indicated in the notice thereof, any and all business may be transacted at a special meeting. At any meeting at which every director shall be present, even though without any notice, any business may be transacted.

\section{Section 6.-QUORUM}

Quorum.-Ten directors shall constitute a quorum for the transaction of business; but if at any meeting of the Board there be less than a quorum present, a majority of those present may adjourn the meeting from time to time.

The affirmative vote of at least one-third of all the directors for the time being in office shall be necessary for the passage of any resolution.

\section{Section $\%$-ORder of Business}

Order of Business.-At meetings of the Board of Directors business shall be transacted in such order as, from time to time, the Board may determine by resolution.

Presiding Officer.-At all meetings of the Board of Directors, the chairman of the Board, or in his absence the chairman of the Finance 
Committee, or, in the absence of both of these officers, the president shall preside.

\section{Section 8.-Contracts}

Contracts.-Inasmuch as the directors of this Company are likely to be connected with other corporations with which from time to time this Company must have business dealings, no contract or other transaction between this Company and any other corporation shall be affected by the fact that directors of this Company are interested in, or are directors or officers of, such other corporation, if, at the meeting of the board, or of the committee of this Company, making, authorizing or confirming such contract or transaction, there shall be present a quorum of directors not so interested; and any director individually may be a party to, or may be interested in, any contract or transaction of this Company, provided that such contract or transaction shall be approved or be ratified by the affirmative vote of at least three directors not so interested.

Ratification by Stockholders of Acts of Contracts.-The Board of Directors in its discretion may submit any contract or act for approval or ratification at any annual meeting of the stockholders, or at any meeting of the stockholders called for the purpose of considering any such act or contract; and any contract or act that shall be approved or be ratified by the vote of the holders of a majority of the capital stock of the Company which is represented in person or by proxy at such meeting (provided that a lawful quorum of stockholders be there represented in person or by proxy) shall be valid and as binding upon the corporation and upon all the stockholders as though it had been approved or ratified by every stockholder of the corporation.

\section{Section 9.-Compensation of Directors}

Compensation of Directors.-For his attendance at any meeting of the Board of Directors, of any committee, every director shall receive an allowance of fifty dollars for attendance at each meeting.

\section{Section 10.-Election of Officers and Committees}

Election of Officers and Committees.-At the first regular meeting of the Board of Directors in each year (at which a quorum shall be present) held next after the annual meeting, the Board of Directors shall proceed to the election of the executive officers of the Company, and of the Finance Committee to be elected by the Board of Directors under the provisions of Article III. and Article IV. of the By-Laws. 


\section{ARTICLE III}

\section{Section 1.-Finance Committee}

Finance Committee.-The Board of Directors shall elect from the directors a Finance Committee, and shall designate for such committee a chairman, who shall continue to be chairman of the committee during the pleasure of the Board of Directors.

Vacancies, How Filled.-The Board of Directors shall fill vacancies in the Finance Committee by election from the directors; and at all times it shall be the duty of the Board of Directors to keep the membership of such committee full, with due regard to the qualifications for such membership indicated in this Article of the By-Laws.

Action of Committee to be Reported to Board.-All action by the Finance Committee shall be reported to the Board of Directors at its meeting next succeeding such action, and shall be subject to revision or alteration by the Board of Directors; provided, that no rights or acts of third parties shall be affected by any such revision or alteration.

Rules of Procedure.-The Finance Committee shall fix its own rules of proceeding, and shall meet where and as provided by such rules, or by resolution of the Board of Directors, but in every case the presence of at least four members shall be necessary to constitute a quorum.

In every case the affirmative vote of a majority of all of the members present at the meeting, shall be necessary to its adoption of any resolution.

\section{Section 2.-MeMbership}

Membership.-The Finance Committee shall consist of eight members, besides the chairman of the Board, who, by virtue of his office, shall be a member of the Finance Committee. So far as practicable each of the eight elected members of the Finance Committee shall be a person of experience in matters of finance. Unless otherwise ordered by the Board of Directors, each elected member of the Finance Committee shall continue to be a member thereof until the expiration of his term of office as a director.

Powers and Duties.-The Finance Committee shall have special charge and control of all financial affairs of the Company. The president, vice-presidents, the general counsel, the treasurer, the comptroller and the secretary, and their respective officers shall be under the direct control and supervision of the Finance Committee, and of its chairman when the Committee is not in session. 
During the intervals between the meetings of the Board of Directors, the Finance Committee shall possess, and may exercise, all the powers of the Board of Directors, in the management of all the affairs of the Company, including its purehase of property, and the exeeution of legal instruments with or without the corporate seal in such manner as said committee shall deen to be best for the interest of the Company, in all eases in which specific directions shall not have been given by the Board of Directors.

Powers of Chairman.-During the intervals between the meetings of the Finance Committee, and subject to its review, the chairman of the Board and the chairman of the Finance Committee together, shall possess, and may exercise any of the powers of the eommittee, except as from time to time shall be otherwise provided by resolution of the Board of Directors.

Salaries Fixed by Finance Committee.-Except as otherwise provided by the By-Laws, or by resolution of the Board of Directors, all salaries and compensation paid or payable by the Company shall be fixed by the Finance Committee.

No director not an executive officer shall become a salaried employee of the Company except by special vote of the Finance Committee.

\section{ARTICLE IV}

\section{OFFICERS}

\section{Section 1.-OfFicers}

Officers-Titles.-The executive officers of the Company shall be a chairman of the Board of Directors, a chairman of the Finance Committee, a president, a gencral counsel, a treasurer, a secretary and comptroller, all of whom shall be elected by the Board of Direetors.

Other Officers.-The Board of Directors may appoint such other officers as they shall deem necessary, who shall have sueh authority and shall perform such duties as from time to time nay be prescribed by the Board of Direetors.

One person may hold more than one office.

In its discretion, the Board of Directors by the vote of a majority thereof may leave unfilled for any such period as it may fix by resolution any office except those of president, treasurer, secretary and comptroller.

Term of Office.-All officers and agents shall be subject to removal at any time by the affirmative vote of a majority of the whole Board of Directors. All officers, agents and employees, other than officers 
appointed by the Board of Directors, shall hold office at the discretion of the committee or of the officer appointing them.

Each of the salaried officers of the corporation shall devote his entire time, skill and energy to the business of the corporation, unless the contrary is expressly consented to by the Board of Directors or the Finance Committee. No vacation shall be taken by any of such officers except by consent of the Board of Directors or the Finance Cornmittee.

Removal.-The Finance Committee shall have power to remove all officers, agents and employees of the Company, except officers elected or appointed by the Board of Directors.

\section{Section 2.-Powers and Duties of the Chatrman of the Board}

Chairman-Powers and Duties.-The chairman of the Board of Directors shall be the chief executive officer of the corporation and, subject to the Board of Directors and Finance Committee, shall be in general charge of the affairs of the corporation. He shall preside at all meetings of the stockholders and of the Board of Directors; and by virtue of his office shall be a member of the Finance Committee.

\section{Section 3.-Powers and Duties of the President}

President-Powers and Duties.-In the absence of the Chairman of the Board and the Chairman of the Finance Committee, the president shall preside at all meetings of the stockholders and of the Board of Directors. Subject to the Board of Directors and the Finance Committee, he shall have general charge of the business of the corporation relating to manufacturing, mining and transportation and general operation. He shall keep the Board of Directors and the Finance Committee and the Chairman of the Board and the Chairman of the Finance Committee fully informed, and shall freely consult them concerning the business of the corporation in his charge. He may sign and execute all authorized bonds, contracts, checks or other obligations in the name of the corporation, and with the treasurer or as an assistant treasurer may sign all certificates of the shares in the capital stock of the corporation. He shall do and perform such other duties as from time to time may be assigned to him by the Board of Directors.

\section{Section 4.-Vice-Presidents}

Vice-Presidents. - The Board of Directors may appoint a vice-president or more than one vice-president. Each vice-president shall have 
such powers, and shall perform such duties, as may be assigned to him by the Board of Directors or the Finance Committee.

\section{Sectiox 5.-The Gexeral Coussel}

General Counsel.- The general counsel shall be the chief consulting officer of the Company in all legal matters, and subject to the Board of Directors and the Finance Committee, shall have general control of all matters of legal import concerning the Company.

\section{Section 6.-Powers and Duties of tile Treasurer}

Treasurem-Powers and Duties.-The treasurer shall have custody of all the funds and securities of the Company which may have come into his hands; when necessary or proper he shall endorse on behalf of the Company, for collection, checks, notes and other obligations, and shall deposit the same to the credit of the Company in such bank or banks or depository as the Board of Directors or the Finance Committee shall designate; he shall sign all receipts and rouchers for paymients made to the Company; jointly with such other officer as may be designated by the Finance Committee, he shall sign all checks made by the Company, and shall pay out and dispose of the same under the direction of the Board or of the Finance Committee; he shall sign with the President, or such other person or persons as may be designated for the purpose by the Board of Directors or the Finance Committee, all bills of exchange and promissory notes of the Company; he may sign, with the president or a vice-president, all certificates of shares in the capital stock; whenever required by the Board of Directors or by the Finance Committce, he shall render a statement of his cash account; he shall enter regularly, in books of the Company to be kept by him for the purpose, full and accurate account of all moneys received and paid by him on account of the Company; he shall, at all reasonable times, exhibit his books and accounts to any director of the Company upon application at the office of the Company during business hours; and he shall perform all acts incident to the position of the treasurer, subject to the control of the Board of Directors or of the Finance Committee.

He shall give a bond for the faithful discharge of his duties in such sum as the Board of Directors or the Finance Committee may require.

\section{Section $\%-\Lambda$ ssistant Treasturfer}

Assistant Treasurers.-The Board of Directors or the Finance Committee may appoint an assistant treasurer or more than one assistant 
treasurer. Each assistant treasurer shall have such powers and shall perform such duties as may be assigned to him by the Board of Directors, or by the Finance Committee.

\section{Section 8.-Powers and Duties of Secretary}

Secretary-Powers and Duties. - The secretary shall keep the minutes of all meetings of the Board of Directors, and the minutes of all meetings of the stockholders, and also (unless otherwise directed by the Finance Committee) the minutes of all committees, in books provided for that purpose; he shall attend to the giving and serving of all notices of the Company; he may sign with the president in the name of the Company all contracts authorized by the Board of Directors or by the Finance Committee, and, when so ordered by the Board of Directors or the Finance Committee, he shall affix the seal of the Company thereto; he shall have charge of the certificate books, transfer books and stock ledgers and such other books and papers as the Board of Directors or the Finance Committee may direct, all of which shall, at all reasonable times, be open to the examination of any director, upon application at the office of the Company during business hours; and he shall in general perform all the duties incident to the office of secretary, subject to the control of the Board of Directors and of the Finance Committee. The offices of Secretary and of Treasurer may be held by one and the same person.

\section{Section 9.-Assistant Secretaries}

Assistant Secretaries.-The Board of Directors or the Finance Committee may appoint one assistant secretary or more than one assistant secretary. Each assistant secretary shall have such powers and shall perform such duties as may be assigned to him by the Board of Directors, or by the Finance Committee.

\section{SECTION 10.-CoMptroller}

Comptroller.-The Comptroller shall be the principal officer in charge of the accounts of the Company, and shall perform such duties as from time to time may be assigned to him by the Board of Directors, or by the Finance Committee.

\section{Section 11.-Voting Upon Stocks}

Voting Upon Stocks Owned in Other Companies.-Unless otherwise ordered by the Board of Directors or by the Finance Committee, the chairman of the Board or the chairman of the Finance Committee 
shall have full power and authority in behalf of the Company to attend and to act and to vote at any meetings of stockholders of any corporation in which the Company may hold stock, and at any such meeting shall possess and may exercise any and all the rights and powers incident to the ownership of such stoek, and which, as the owner thereof, the Company might have possessed and exercised if present. The Board of Directors or the Finanee Committee, by resolution, from time to time, may confer like powers upon any other person or fersons.

\section{ARTICLE V}

\section{CAPITAL STOCK-SEAL}

\section{Section 1.-Certificates of Shares}

Stock Certificates.-The certificates for shares of the capital stock of the Company shall be in such form, not inconsistent with the certificate of incorporation, as shall be prepared or be approved by the Board of Directors. The certificates shall be signed by the president or vice-president; and also by the treasurer or an assistant treasurer.

All certificates shall be consecutively numbered. The name of the person owning the shares represented thereby, with the number of such shares and the date of issue, shall be entered on the Company's books.

No certificate shall be valid unless it is signed by the president or a vice-president, and by the treasurer or an assistant treasurer.

All certificates surrendered to the Company shall be cancelled and no new certifieates shall be issued until the former certificate for the same number of shares of the same class shall have been surrendered and cancelled.

\section{Section 2.-Transfer of Silares}

Transfer of Shares.-Shares in the capital stock of the Company shall be transferred only on the books of the Company by the holder thereof in person, or by his attorney, upon surrender and cancellation of certificates for a like number of shares.

\section{Section 3.-Regulations}

Regulations.-The Board of Directors, and the Finance Committee, also, shall have power and authority to make all such rules and regulations as respectively they may deem expedient, concerning the is- 
sue, transfer and registration of certificates for shares of the capital stock of the Company.

Transfer Agent-Registrar.-The Board of Directors or the Finance Committee may appoint a transfer agent and a registrar of transfers, and may require all stock certificates to bear the signature of such transfer agent and of such registrar of transfers.

\section{Section 4.-Closing of Transfer Books}

Closing of Transfer Books.-The stock transfer books shall be closed for the meetings of the stockholders, and for the payment of dividends, during such periods as from time to time may be fixed by the Board of Directors, or by the Finance Committee, and during such periods no stock shall be transferable.

\section{Section 5.-Dividends}

Dividends. - The Board of Directors may declare dividends from the surplus or from the net profits of the Company.

Dates of Declaration.-The dates for the declaration of dividends upon the preferred stock and upon the common stock of the Company shall be the days by these By-Laws fixed for the regular monthly meetings of the Board of Directors in the months of April, July, October and January in each year, on which days, the Board of Directors in its discretion shall declare what, if any, dividends shall be declared upon the preferred stock and the common stock, or either of such stocks.

Preferred; When Payable.-The dividends upon the preferred stock, if declared, severally and respectively, shall be payable quarterly upon the day preceding the last day of May, of August, of November, and of February in each year.

Common; When Payable.-The dividends upon the common stock, if declared, severally and respectively, shall be payable quarterly on the day preceding the last day of June, of September, of December and of Marcil in each year.

If the date herein appointed for the payment of any dividend shall in any year fall upon a legal holiday, then the dividend payable on such date shall be paid on the next preceding day not a legal holiday.

\section{Section 6.-Working Capital}

Working Capital.-The directors shall not be required in January in each year, after reserving over and above its capital stock paid in. as a working capital for said corporation, such sum, if any, as shall 
have been fixed by the stockliolders, to declare a dividend among its stockholders of the whole of its accumulated profits exceeding the amount so reserved, and pay the same to such stockholders on demand; but the Board of Directors may fix a sum which may be set aside or reserved, over and above the Company's capital paid in, as a working capital for the Company, and from time to time they may increase, diminish and vary the same in their absolute judgment and discretion.

\section{SeCtion \%.-Corporate SeaL}

Corporate Seal.-The Board of Directors shall provide a suitable seal, containing the name of the Company, which seal shall be in charge of the secretary. If, and when so directed by the Board of Directors, or by the Finance Committee, a duplicate of the seal may be kept and be used by the treasurer or by any assistant secretary or assistant treasurer.

\section{ARTICLE VI}

\section{Section 1.-Amendments}

Amendments.-The Board of Directors shall have power to make, amend and repeal the By-Laws of the Company, by vote of a majority of all of the directors, at any regular or special meeting of the Board. provided that notice of intention to make, amend or repeal the By-Laws in whole or in part shall have been given at the next preceding meeting; or without any such notice, by a vote of two-thirds of all the directors. 


\section{FORM OF ORGANIZATION PAPERS OF A CORPORATION, INCLUDING MINUTES OF ORGANIZATION MEET- INGS:-}

First Meeting of the incorporators and subscribers of The HamILton Autonobile Compaxy of New York, held at the temporary office of the company, No. 1936 West 54th Street, in the Borough of Manhattan, City, County and State of New York, on the 16th day of April, 1908, at 10 o'clock in the forenoon.

Mr. Joseph Hall, one of the subscribers to the Certificate of Incorporation and to the capital stock of the corporation, called the meeting to order, and stated the object thereof.

On motion duly made, seconded and carried, Mr. Hall was nominated Chairman of the meeting, and a vote having been taken, was duly elested to occupy such position.

On motion, duly made, seconded and carried, Mr. James McKeon was nominated temporary Secretary thereof, and a rote having been taken, was duly elected to occupy such position.

Each accepted his respective office and discharged the duties thereof until the close of the meeting.

There were present the following subscribers to the capital stock of the corporation:

Names.

Post Office Address.

Joseph Hall..............1936 West 5th Street, New York dames McKeon............1936 West 54th Street, New York Andrew J. Cook............1325 West 83rd Street, New York

On motion, duly made, seconded and carried, the roll of incorporators and subscribers was called by the Secretary, and each of the above named incorporators and subscribers, personally representing the number of shares set opposite his name respectively, answered present, showing that 54 shares, being the whole number of shares subscribed for, were present in person.

At the close of the roll call, the Chairman declared that 54 shares of the capital stock were represented, which was the whole capital stock subscribed for, and that the meeting was completely organized and competent to proceed to the transaction of business.

The Secretary then presented and read a waiver of notice of the tinie and place of holding the present meeting, signed by all the incorporators and subscribers to the capital stock of the company.

1 Adapted from Commercial Law, by Charles W. Gerstenberg and Thomas W. Hughes. 
Upon motion, duly made, seconded and carried, the same was ordered filed, and the Secretary was requested to cause the same to be spread at length upon the minutes of the meeting.

\section{WAIVER OF NOTICE \\ $\rightarrow$ of the- \\ Meeting of the Incorporators and Subscribers \\ $\rightarrow$ of the- \\ HAMILTON AUTOMOBILE COMPANY}

WE, THE UNDERSIGNED, being all the incorporators named in the certificate of incorporation of the HAMILTON AUTOMOBILE COMPANY, and all the subscribers to the capital stock thereof, DO HEREBY WAIVE all notice whatsoever of the first meeting of the Incorporators and Subscribers to the capital stock of said Company, and do consent that the 16th day of April, 1908, at 10 o'clock in the forenoon be, and hereby is fixed as the time, and the temporary office of the company, at 1936 West 54th Street, in the Borough of Manhattan, City, County and State of New York, as the place of holding the same, and that all such business may be transacted thereat as may lawfully come before said meeting.

JosepH HALL.

JAMES MCKEON.

Dated New York, April 12th, 1908. ANDREW J. COOK.

The Secretary then presented and read to the meeting a copy of the Certificate of Incorporation of the Company, and reported that the same had been filed and recorded in the office of the Secretary of State of the State of New York, on the 10th day of April, 1908, and that the organization tax of one-twentieth of one per cent. on the authorized capital stock of the Company had been paid to the State Treasurer, to wit: the sum of Fifty dollars $(\$ 50.00)$; that a receipt therefor had been given by him on the 10th day of April, 1908, and that a duplicate original of said Certificate of Incorporation, together with receipt from the State Treasurer, had been filed in the office of the Clerk of the County of New York (the county in which the principal office and place of business of the company is to be located), on the 12th day of April, 1908, and that all the fees for filing and recording such Certificate and receipt had been duly paid before filing. Upon motion duly made, seconded and unanimously carried, it was

RESOLVED, that the said report be accepted as correct and the Secretary be requested to cause such Certificate and receipt to be spread at length upon the minutes of the meeting.

(Here follows the Certificate.)

Mr. Cook, one of the directors, on behalf of those named as directors in the certificate of incorporation, presented and read the subscription 
list to the capital stock of the corporation, and reported that fifty-four shares of said capital stock had been subscribed for, which are the shares only that were subscribed for by the incorporators, as appears by the certificate of incorporation.

On motion, duly made, seconded and carried, it was

RESOLVED, that said report be accepted as correct, and that this company accept such subscriptions, and notify said subscribers of the acceptance of their respective subsicriptions.

Upon motion, duly made, seconded and carried, Charles W. Gerstenberg, Esq., counselor-at-law, of the City of New York, was appointed a committee to prepare a set of by-laws for the regulation of the affairs of the Company, the management of its property, the transfer of its stock, and the calling of meetings of the shareholders and directors, and fixing what attendance and what amount of stock must be represented thereat to constitute a quorum, and such other matters as can properly be contained in such by-laws, and to report the same to the meeting at their earliest convenience.

Upon motion, duly made, seconded and carried, a recess was then taken until the Committee should be ready to report to the meeting.

The Chairman called the meeting to order, and announced that the Committee was ready to render its report, whereupon the Committee to whom had been entrusted the drawing of the by-laws, presented its report, with a proposed set of by-laws, which were taken up and read, clause by clause, and separately and carefully considered and discussed at length by the members, and

Upon motion, duly made, seconded and carried, the following wtre adopted as and for the By-laws of the Company, and the Committee discharged.

Upon motion, duly made, seconded and carried, the Secretary was instructed to cause the same to be spread at length upon the minutes.

\section{(Here Follow the By-Laws.)}

Upon motion, duly made, seconded and carried, the Board of Directors was requested, authorized and empowered to open books of subscriptions to the capital stock in such places and after giving such notice as they may deem expedient and to continue to receive subscriptions until the whole capital stock is subscribed; and to accept and receive payment for same, ten per cent. to be paid in cash at the time of each subscription by every subscriber, whose subscription is payable in money.

It was then communicated to the meeting by Joseph Hall, who attended the meeting for that purpose, that he was willing to sell this Company the patents, franchises, property, contracts, good will, and 
all other property of whatsoever kind or description belonging or relating to a certain patented automobile horn and to a certain patented wind-shield, for the sum of One Hundred Thousand $(\$ 100$,$000.00)$ Dollars, and to accept in payment therefor One Hundred Thousand $(\$ 100,000.00)$ Dollars of the capital stock of this Company at par value thereof, which is the whole capital stock of this Company. The question of accepting this offer was presented to the meeting, and all the incorporators and stockholders and Directors being present, it was,

On motion, duly made, seconded and carried,

RESOLVED, that this Company purchase of Joseph Hall the patents, franchises, property, contracts, good will, and all other of whatsoever kind or description belonging and relating to a certain automobile horn and a certain wind-shield, commonly known as the Surprise Horn, for the sum of One Hundred Thousand $(\$ 100,000.00)$ Dollars, to be paid for by shares of the capital stock of this Company at par value thereof, which is the total capital stock of this Company, and it is further,

RESOLVED, that the President and Secretary of this Company be, and they hereby are directed and authorized to issue to the said Joseph Hall all the stock of this Company unissued and unsubscribed for, and the President and Secretary procure to be transferred to said Joseph Hall, fifty-four (54) shares of the stock now subscribed for by the said Joseph Hall, James McKeon and Andrew T. Cook, and it is further,

RESOLVED, that the Company proceed to carry on the business for which it was incorporated.

It was duly moved, seconded and carried, that the principal office of the corporation be fixed at 1936 West 54th Street, in the Borough of Manhattan, City, County and State of New York.

On motion, duly made, seconded and carried, the foregoing minutes were then read and approved as and for the minutes of the meeting.

On motion, the meeting thereupon adjourned.

I, Joseph Hall, the Chairman of the foregoing meeting, and I, James McKeon, the Temporary Seeretary thereat, DO HEREBY CERTIFY that the foregoing is a true, full and accurate statement and record of all the acts and things done thereat.

Dated the 16th day of April, 1908.

JOSEPII HALL,

Chairman.

JAMES MCKEON, Sccretary.

\section{THE HAMILTON AUTOMOBILE CO.}

MINUTES OF THE FIRST MEETING OF THE BOARD OF DIRECTORS, held at the temporary office of the Company. 1936 
West 54th Street, in the Borough of Manhattan, City, County and State of New York, on the 15th day of April, 1908, at $11: 30$ o'clock in the forenoon.

Present: Messrs.

Joseph Hall,

James McKeon,

Andrew J. Cook,

being all the Directors named in the Certificate of Incorporation of the Hamilton Automobile Co.

Upon motion, duly made, seconded and carried, Mr. Cook was nominated and elected Temporary Chairman.

Mr. Cook accepted the position of Temporary Chairman, and acted as such until relieved by the President.

Upon motion, duly made, seconded and carried, Mr. McKeon was nominated and elected Temporary Secretary.

Mr. McKeon thereupon accepted the position of Temporary Secretary, and acted as such until relieved by the permanent Secretary.

The Chairman then requested the Secretary to read the list of Directors for the first year, as set forth in the Certificate of Incorporation, and the following was the list:

Joseph Mall,
James McKeon,
Andrew J. Cook.

The Secretary then presented and read to the meeting, a waiver of notice of the meeting, subscribed by all the Directors mentioned in the Certificate of Incorporation.

On motion, duly made, seconded and carried, it was,

RESOLVED, that the same be ordered on file, and the Secretary be requested to cause the same to be spread at length upon the minutes.

\section{WAIVER OF NOTICE}

$\multimap$ of the-

First Meeting of Directors

-of the-

HAMILTON AUTOMOBILE CO.

WE, the undersigned, being all the Directors of The Hamilton Automobile Co., DO HEREBX் WAIVE all notice whatsoever of the First Meeting of the Board of Directors of said Company, and do consent that the 16th day of April, 1908, at 11.30 o'clock in the forenoon, be, and hereby is fixed as the time, and the temporary office of the Company, at 1936 West 54th Straet, in the Borough of Manhattan. City, County and State of New York, 
as the place for holding the same, and that all such business be transacted thereat as may lawfully come before said meeting.

Dated the 12th day of April, 1008.

JOSEPH HALL.

JAMES MCKEON.

ANDREW J. COOK.

The Secretary then called the roll, and all the Directors of the Company were found to be present.

The Chairman thereupon stated that a quorum was present, as required by the By-laws.

On motion, duly made, seconded and carried, it was

RESOLVED, that the Board proceed to the business of the meeting.

The Secretary then presented and read to the meeting the minutes of the first meeting of the Incorporators and Stockholders, heid on the 16th day of April, 1908, at 10 o'clock in the forenoon, at the temporary office of the Company, 1936 West 54th Street, New York City.

Upon motion, duly made, seconded and carried, the same were in all respects ratified, approved and confirmed.

The Secretary then presented and read to the meeting the By-laws adopted at the said meeting of the Incorporators and Stockholders. The same were taken up clause by clausc, discussed, and upon motion, duly made, seconded and carried, the same were in all respects ratified, confirmed and approved as and for the By-laws of the Company.

The Chairman then stated that, in accordance with the By-laws, a President, Vice-President, Secretary and Treasurer of the Company were to be elected, and that nominations were in order.

Mr. Hall was nominated, his nomination was seconded and he was unanimously elected president.

The temporary chairman then withdrew from the chair and Mr. Hall thereafter acted as the chairman of the meeting.

The meeting thercupon proceeded to the election of a vice-president, a treasurer and a secretary. Nominations were duly made, seconded and ballots cast, the election resulting in the unanimous choice of the following officers:

Vice-President...............Andrew J. Cook

Treasurer.....................Andrew J. Cook

Secretary...................James McKeon

Upon motion, duly made, seconded and carried, it was

RESOLVED, that the first Tuesday of each month at $10 \mathrm{~A}$. M. be 
fixed as the day upon which the regular monthly meetings of the Board of Directors of this Company will be held during the ensuing year.

The following preamble and resolution for the purchase of property necessary for the business of this Company and for the issuance of the stock of this Company, fully paid, as a consideration therefor, were thereupon unanimously adopted:

WHEREAS, a resolution was passed, at a meeting of the Incorporators and Stockholders of this Company, held on the 16th day of April, 1908, accepting a proposition for the sale to this Company of the patents, franchises, property, contracts, good will, and all other property of whatsoever kind or description, belonging or relating to a certain patented automobile horn and a certain wind-shield, owned by Joseph Hall, and at said meeting the Directors were authorized and instructed to accept the aforesaid proposition and offer to purchase and acquire the aforesaid property, and to pay for the same the fair value of the property so transferred, as fixed by the aforesaid proposition, and to offer in payment the full paid stock of this Company, provided in the judgment of the Board of Directors the said price is a fair valuation thereof; and,

WHEREAS, in the judgment of the Board of Directors, after a careful examination and fair appraisement, this Board is unanimously convinced that the said property is necessary and advantageous for the business of this Company, and that the fair value thereof is the amount at par of stock proposed to be issued in payment thereof,

NOW, THEREFORE, BE IT RESOLVED, that in accordance with the provisions of the said resolution of the stockholders, and in accordance with the judgment of this Board of Directors this Company do accept the aforesaid proposition and offer and the President and Secretary of this Company are hereby authorized, empowered and instructed, upon delivery of said property, and the execution and delivery of the proper legal instruments necessary to convey and transfer said property, to issue and deliver, in accordance with this resolution, the full paid stock of this Company, to the full amount of the capital stock unsubscribed for and unissued, and to procure from the original incorporators and subscribers to the stock, a transfer of the shares held by them.

On motion, duly made, seconded and carried, it was

RESOLVED, that the certificates of the Capital Stock of the Company be in the following form: 
Incorporated under the laws of the State of New York.

Number 2.

\section{HAMILTON AUTOMOBILE CO. \\ Capital Stock, $\$ 100,000$.}

THIS CERTIFIES THAT _ _ - is the owner of - Shares of the Capital Stock of HAMILTON AUTOMOBILE CO., FULL PAID AND NONASSESSABLE, transferable only on the books of the Corporation by the holder hereof in person or by Attorney, upon surrender of this Certificate properly endorsed.

Is Wrtsess Whereor, the said Corporation has caused this Certificate to be signed by its duly authorized officers and to be sealed with the Seal of the Corporation this - day of - A. D. 19-

\section{Secretary.}

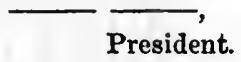

Shares, $\$ 100$ each.

Endorsed:

For Value Received, hereby sell, assign and trarsfer unto

Shares of the Capital Stock represented by the within Certificate, and do hereby irrevocably constitute and appoint —— to transfer the said Stock on the books of the within named Corporation, with full power of substitution in the premises.

Dated - - $19-$.

In presence of

NoTICE.-The signature of this assignment must correspond with the name as written upon the face of the certificate in every particular, without alteration or enlargement, or any change whatever.

The Secretary then read a resolution of the Incorporators and Subscribers, adopted at the meeting held on the 16th day of April, 1908, wherein and whereby the permanent office of the corporation was fixed at No. 1936 West 54th Street, in the Borough of Manhattan, City, County and State of New York. The said resolution was by motion, duly made, seconded and carried, affirmed and adopted.

On motion, duly made, seconded and carried, the meeting ADJOURNED.

THIS IS TO CERTIFY, that I, Andrew J. Cook, and I, Joseph Hall, Temporary Chairman and President, respectively, at the above meeting, and I, James McKeon, the Temporary Secretary and Permanent Secretary thereat, have read the foregoing minutes of said meeting, and the same are in all respects a full, true and accurate record of the proceedings thereat.

Dated the 10th day of April, 1908.

Axprew J. CoOK, Temporary Chairman. Josepil Hat,. President.

JAmes McKron, Secretary. 


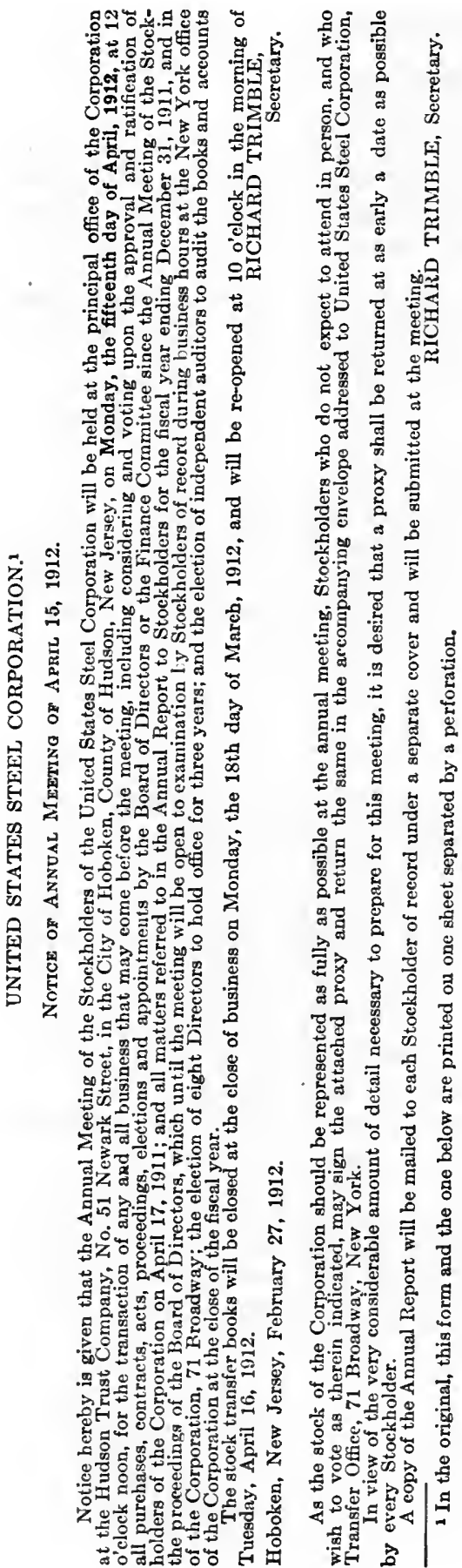

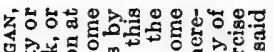

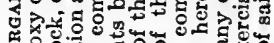

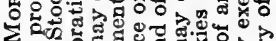
FT월 응

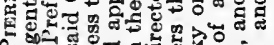
A

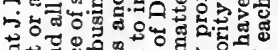

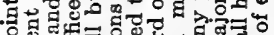

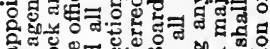

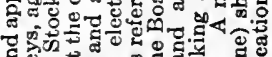

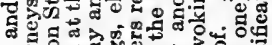
눌

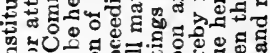
응

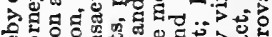

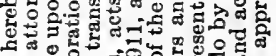

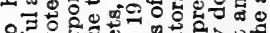

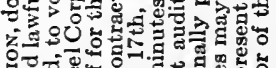
خ ㄱ. t5

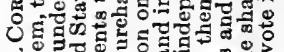

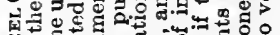

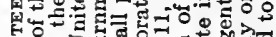
50.5

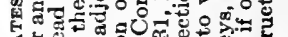

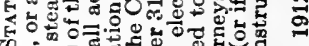
की

500 .

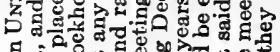

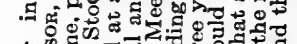

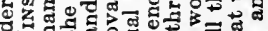
응 年

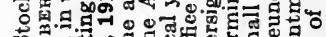

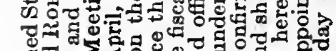
영 要

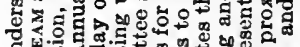

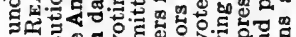
s.

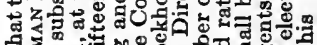

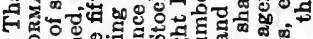
ํㅜㄴ.

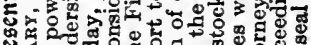

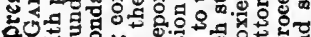
现 足

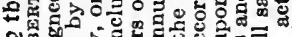
คำำ ᄃ⿶凵

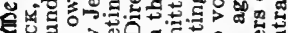

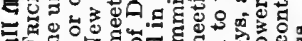

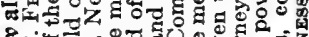
䛉定 至.

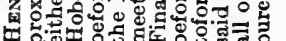




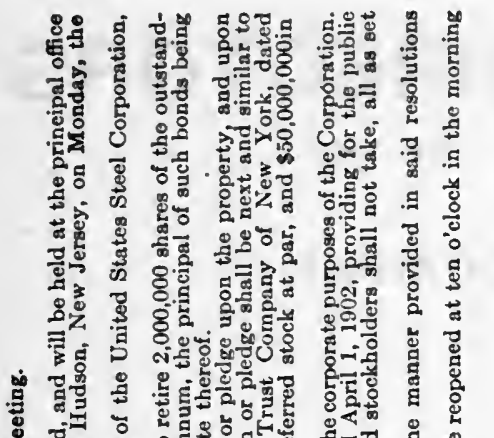

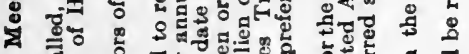

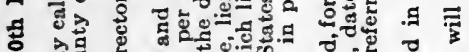

क्ष

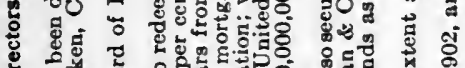

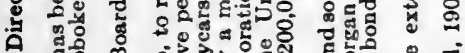

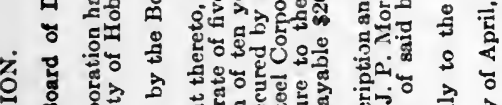

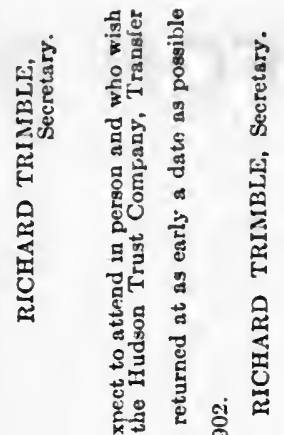

क्

\& 0 \%

\$ ब

क.

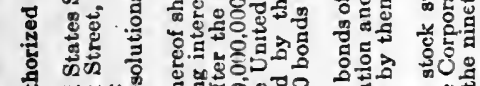

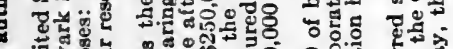

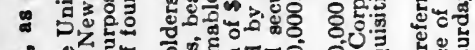

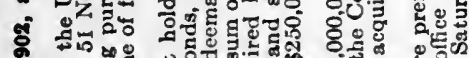

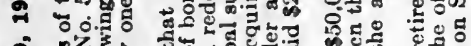

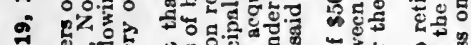

을 귱

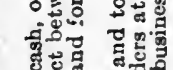

कن

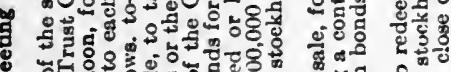

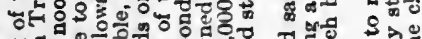

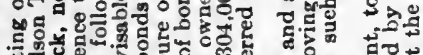

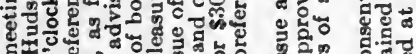

14:0

합훙

\&

뭉

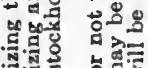

충형

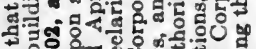

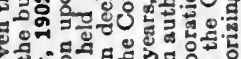

舟

눌

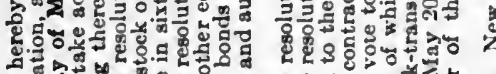

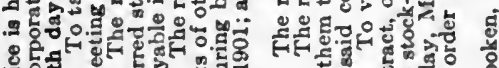
8 .

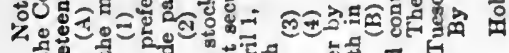

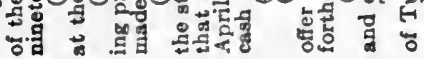

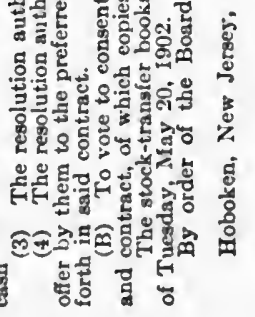

항

เ马 $=-$

용

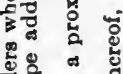

चु

要考

语

.

동

.

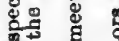

究留

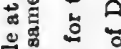

害骂

믐

$\rightarrow$ \&

鬲总

ट्टे है :

娄焉

홍

要

격

語

西

荧总

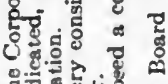

†. 땅

둥

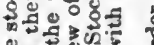

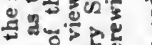

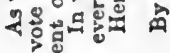

연 


\section{COMPANY}


VOTING TRUST AGREEMENT, INTERNATIONAL HARVESTER CO. BETWEEN WILLIAM G. LANE AND GEORGE W. PERKINS, CHARLES DEERING, AND CYRUS H MCCORMICK, VOTING TRUSTEES, DATED AUGUST 13, 1902. ${ }^{1}$

This agreement, made in the City of New York this thirteenth day of August, one thousand nine hundred and two, by and between William C. Lane, party of the first part, and George W. Perkins, Charles Deering and Cyrus H. McCormick (hereinafter called the "Voting Trustees"), parties of the second part,

Witnesseth as follows:

Whereas, the International Harvester Company (hercinafter called the "Company"), is a corporation organized under the laws of the State of New Jersey, with a capital stock of $\$ 120,000,000$, divided into $1,200,000$ shares, of the par value of $\$ 100$ each, all of which stock has been issued and is outstanding; and

Whereas, the party of the first part has caused to be delivered to the Voting Trustees certificates for fully paid shares of the capital stock of the Company to the amount of its entire capital stock (excepting such shares as are necessary to qualify directors); and said certificates, together with such other certificates for stock of the Company as hereafter, from time to time, may be delivered hereunder, are to be held and disposed of by the Voting Trustees under and pursuant to the terms and conditions hereof;

Now, therefore,

First. The Voting Trustees agree with the party of the first part, and with each and every holder of stock trust certificates issued as hereinafter provided, that, from time to time, upon request, they will cause to be issued to the party of the first part, or upon his order, in respect of said stock of the Company received from him, certificates in substantially the following form:

\section{InternationaL Harvester Company.}

No. Shares.

STOCK TRUST CERTIFICATE.

This certifies that, as hereinafter provided, will be entitled to receive a certificate or certificates for fully paid shares of one hundred dollars each, of the capital stock of the International Harvester Company, and, in the meantime, to receive payments equal to the dividends if any, collected by the Undersigned Voting Trustees upon a like number of such Co.

1 From Report of Bureau of Corporations, on The International Harvester 
shares standing in their names; such dividends, if received by the Voting Trustees in stock of said Company, to be payable in stock trust certificates. Until the actual delivery of such stock certificates, the Voting Trustees shall possess, in respect of any and all of such stock, and shall be entitled, in their discretion, to exercise, all rights and powers of absolute owners of said stock, including the right to vote for every purpose and to consent to any corporate act of said Company; it being expressly stipulated that no voting right passes by or under this certificate, or by or under any agreement expressed or implied.

This certificate is issued pursuant to, and the rights of the holder are subject to, and limited by, the terms and conditions of a certain agreement, dated the thirteenth day of August, 1902, by and between William C. Lane and the undersigned Voting Trustees.

Stock certificates shall be due and delivered in exchange for stock trust certificates on, but not before August 1, 1912, unless a majority of the Voting Trustees elect, as they may, to terminate said agreement after August 1, 190\%, upon not less than ninety days' notice.

This certificate is transferable only on the books of the Voting Trustees of the registered holder hereof, either in person or by attorney duly authorized, according to rules established for that purpose by the Voting Trustees, and on -surrender hereof; and, until so transferred, the Voting Trustees may treat the registered holder as owner hereof for all purposes whatsoever, except that they shall not be required to deliver stock certificates hereunder without surrender hereof.

This certificate is not valid unless duly signed on behalf of the undersigned Voting Trustees by —_ their agents, and also registered by ___

In witness whereof, the undersigned Voting Trustees have caused this certificate to be signed by their duly authorized agents, _- _ this _ - day of —_ one thousand nine hundred and

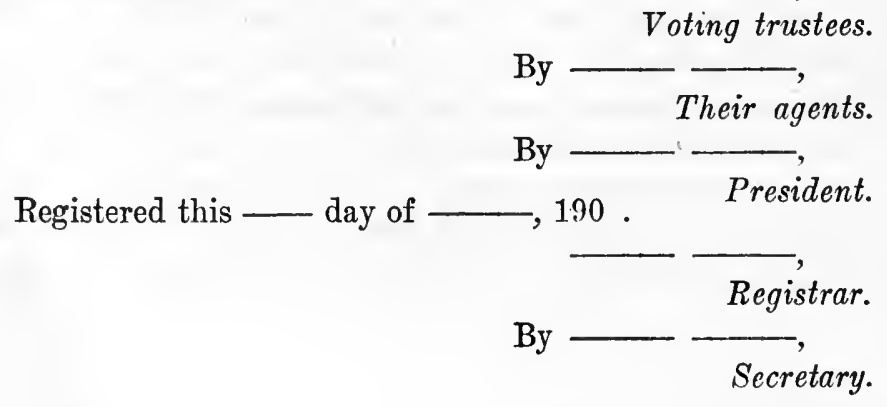


Second. At any time after August 1, 1907, if a majority of the Voting Trustees so decide, this agreement may be terminated; but at least ninety days' notice of an intention to terminate this agreement must be given by the Voting Trustees according to the provisions of Article Tenth hereof. This agreement shall in any event terminate on August 1, 1912, without notice by or action of the Voting Trustees. On August 1, 1912, or upon the earlier termination of this agreement, the Voting Trustees, in exchange for, or upon surrender of any stock trust certificate then outstanding, shall, in accordance with the terms hereof, deliver proper certificates of stock of the Company, and may require the holders of stock trust certificates to exchange them for certificates of capital stock

In case on or after the termination of said agreement-the Voting Trustees shall deposit with an incorporated bank or trust company of good standing, having an office in the City of New York, stock certificates properly endorsed for transfer in blank, representing stock of the Company to a par amount equal to the par amount of stock trust certificates outstanding, with authority in writing to such bank or trust company to deliver the same in exchange for stock trust certificates when and as surrendered for exchange as herein provided, then all further liability of said Trustees, or any of them, for the delivery of stock certificates in exchange for stock trust certificates shall cease and determine.

Third. The term Company, for the purpose of this agreement and for all rights thereunder, including the issue and delivery of stock, shall be taken to mean the said corporation organized under the laws of the State of New Jersey, or any successor corporation or corporations into which the same may be consolidated or merged.

Fourth. From time to time hereafter, the Voting Trustees may receive any additional fully paid shares of the capital stock of the Company, and in respect of all such shares so received, will issue and deliver certificates similar to those above mentioned, entitling the holders to the rights above specified. In case the Company shall hereafter have both common and preferred stock the Voting Trustees may receive, subject to the provisions hereof, certificates representing fully paid stock of each class, and the stock trust certificates shall indicate upon their face whether they represent common or preferred stock, and holders of stock trust certificates representing one class of stock shall have no interest in, or claim upon, stock of the other class. In any event the stock trust certificates outstanding shall be surrendered by the holders thereof in exchange for new certificates specifying the class of stock, whether preferred or common, represented thereby. In case the Voting Trustecs shall receive any stock 
of the Company issued by way of dividend upon stock held by them subject to said agreement, they shall hold such stock subject to the terms of said agreement, and shall issue stock trust certificates representing such stock to the respective registered holders of the then outstanding stock trust certificates entitled to such dividend.

Fufth. Any Voting Trustee may, at any time, resign by delivering to the other Trustees, in writing, his resignation, to take effect ten days thereafter. In case of the death or the resignation or inability of any Voting Trustee to act, the vacancy so occurring shall be filled by the appointment of a successor or successors, to be made as follows: Any successor in the line of succession to George W. Perkins shall by appointed by J. P. Morgan \& Co., as said firm now is or may hereafter be constituted. Any successor in the line of succession to Charles Deering shall be appointed by James Deering, or in the case of his failure to act, by Richard F. Howe, and in case of the failure of either to act, by the other two Voting Trustees. Any successor in the line of succession to Cyrus H. McCormick shall be appointed by Harold F. McCormick, or in case of his failure to act, by Stanley McCormick, and in case of the failure of either to act, by the other two Voting Trustees. The term Voting Trustees, as used herein and in said certificates, shall apply to the parties of the second part and their successors hereunder.

Sixth. The Voting Trustees may adopt their own rules of procedure. The action of a majority of the Voting Trustees expressed from time to time at a meeting or by writing with or without a meeting, shall, except as otherwise herein stated, constitute the action of the Voting Trustees and have the same effect as though assented to by all. Any Voting Trustee may rote in person or by proxy, and may act as a director or officer of the Company.

Seventh. In voting the stock held by them, the Voting Trustees will exercise their best judgment from time to time to secure suitable directors, to the end that the affairs of the Company shall be properly managed, and in roting and in acting on other matters which shall come before them as stockholders or at stockholders' meetings, will likewise exercise their best judgment, but they assume no responsibility in respect of such management or in respect of any action taken by them or taken in pursuance of their consent thereto as such stockholders, or in pursuance of their vote so cast, and no Voting Trustee shall incur any responsibility by reason of any error of law or of any matter or thing done or suffered or omitted to be done under this agreement, except for his own individual willful malfeasance.

Eighth. The Voting Trustees possess and shall be entitled in their 
discretion to exercise, until the actual delivery of stock certificates in exchange for stock trust certificates, all rights and powers of absolute owners of said stock, including the right to vote for every purpose and to consent to any corporate act of said Company, it being expressly stipulated that no voting right passes to others by or under said stock trust certificates or by or under this agreement, or by or under any agreement, expressed or implied; the Voting Trustees shall not, however, during the pendency of this agreement, vote in respect of the shares of the capital stock of the Company held by them, to authorize or consent to any mortgage or other lien upon the property of the Company, or (except as herein otherwise specifically provided) to authorize any increase or diminution in the amount of the authorized capital stock of said Company, except with the consent in each instance of the holders of stock trust certificates representing two-thirds in amount of each class of stock at the time deposited hereunder, given in writing, or by vote at a meeting called for that purpose; provided, however, that the Voting Trustees may, in their discretion, prior to July 1, 1903, without the consent of holders of any stock trust certificates, consent to and authorize the increase of the Company's capital stock to an amount not exceeding one hundred and eighty million dollars $(\$ 180,000,000)$.

Ninth. For the purposes of this agreement any consent in writing by the holders of stock trust certificates may be in any number of concurrent instruments of similar tenor, and may be executed by the certificate holders in person, or by agent or attorney appointed by an instrument in writing. Proof of the execution of any such consent, or of a writing appointing any such agent or attorney, or of the holding by any person of stock trust certificates issued hereunder, shall be sufficient for any purpose of this indenture, and shall be conclusive in favor of the Voting Trustees with regard to any action taken by them under such consent, if made in the following manner, viz.: (a) the fact and date of the execution by any person of any such consent may be proved by the certificate of any notary public or other officer authorized to take, either within or withont the State of New York, acknowledgements of dceds to be recorded in any State, certifying that the person signing such consent acknowledged to him the execution therof; or by the affidavit of a witness to such execution. (b) the amount of stock trust certificates held by any person executing any such consent and the issue of the same, may be proved by a certificate executed by any trust company, bank or other depositary (wheresocver situated) whose certificate shall be deemed by the Voting Trustees to be satisfactory, showing that at the date therein mentioned such person had on deposit with such depositary, or exhibited 
to it, the stock trust certificates numbered and described in such depositary's certificate.

Tenth. All notices to be given to the holders of stock trust certificates hereunder shall be given either by mail to the registered holders of stock trust certificates at the addresses furnished by such holders to the Voting Trustees or to the agents of the Voting Trustees, or by publication in two daily papers of general circulation in the City of New York and in two daily papers of general circulation in the City of Chicago, twice in each week for two successive weeks; and any call or notice whatsoever, when either mailed or published by the Voting Trustees as herein provided, shall be taken and considered as though personally served on all parties hereto, including the holders of said stock trust certificates, and such mailing or publication shall be the only notice required to be given under any provision of this agreement.

Eleventh. This agreement may be simultaneously executed in sereral counterparts, each of which so executed shall be deemed to be an original, and such counterparts shall together constitute but one and the same instrument.

In witness whereof, the several parties have hereunto set their hands and seals, in the City of New York, the day and year first hereinabove mentioned.

$$
\left.\begin{array}{ll}
\text { WM. C. Lane. } & \text { [L. s. }] \\
\text { G. W. Perkins. } & {[\text { L. s. }]} \\
\text { Charles Deering. } & \text { [L. s.] }] \\
\text { Cyrus H. MCCormick. [L. } & \text { s. }]
\end{array}\right\} \text { Voting trustees. }
$$

\section{State of New York,
County of New York, $\}$ ss.:}

On this thirteenth day of August, in the year nineteen hundred and two, before me personally came William C. Lane, to me known, and known to me to be the individual described in and who executed the foregoing instrument, and he acknowledged to me that he executed the same.

[SEAL.]

JoHN P. TuOMEY, Notary Public, Kings County. Certificate filed in N. Y. Co.

$\left.\begin{array}{l}\text { State of New York, } \\ \text { County of New York, }\end{array}\right\}$ ss.:

On this thirteenth day of August, in the year nineteen hundred and two, before me personally came George W. Perkins, Charles 
Deering and Cyrus H. McCormick, to me known, and known to me to be the individuals described in and who executed the foregoing instruments, and they severally acknowledged to me that they executed the same.

[SEAL.]

JoHN J. DALY,

Notary Public, Kings County.

Certificate filed in N. Y. Co. 


\section{GREAT NORTHERN IRON ORE PROPERTIES}

Trustees' Certificate of Beneficial Interest.

The undersigned, as Trustees under a certain Indenture entered into between them and the Lake Superior Company, Ltd., on the 7th day of December, A. D. one thousand nine hundred and six, do hereby certify that is the owner of shares of the beneficial interest therein specifically described. This certificate is transferable only upon the books of the Trustees in person or by attorney, and upon the surrender of this certificate. This certificate shall not be valid until countersigned by the Registrar of Transfers.

In Witness Whereof, the Trustees have signed this certificate this day of
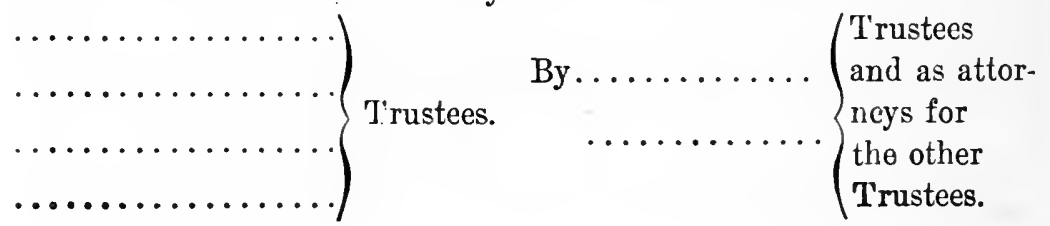
CORPORATE ACTS REQUIRING CONSENT OR VOTE OF STOCKHOLDERS UNDER THE NEW YORK STATUTE.

To alter or amend the Certificate of Incorporation a vote of the stockholders representing at least three-fifths of the capital stock at a meeting of the stockholders called for the purpose is required. (Stock Corporation Law, Sec. 18.)

The amount of the capital stock may be increased or reduced either by the unanimous consent of the stockholders expressed in writing and filed in the office of the Secretary of State and in the County Clerk's office, or by a vote of the stockholders owning at least a -majority of the stock of the corporation, taken at a meeting of the stockholders especially called for that purpose. (Stock Corporation Law, Secs. 62, 63.)

To increase or reduce the par value of shares into which the capital stock is divided a two-thirds vote of all the stock represented at a meeting held for the purpose is required. (Stock Corporation Law, Sec. 65.)

Every stock corporation may issue preferred stock, if the Certificate of Incorporation so provides, or if it obtains the consent of the holders of record of two-thirds of the capital stock at a special meeting called for the purpose. (Stock Corporation Law, Sec. 61.)

The vote of stockholders owning at least two-thirds of the capital stock of a corporation is necessary to effect a consolidation with another corporation. (Business Corporations Law, Secs. 7, 8.)

A stock corporation, excepting a railroad or a public service corporation, may sell its entire property with the consent of two-thirds of its stock. (Stock Corporation Law, Secs. 16, 1\%.)

The consent of not less than two-thirds of the capital stock is necessary effectually to execute a mortgage (except a purchase money mortgage) or to permit the authorization of the issue of bonds by a corporation. (Stock Corporation Law, Sec. 6.)

A corporation may guarantee the bonds or securities of any other domestic corporation engaged in the same general line of business in pursuance of a unanimous vote of the stockholders, voting at a special mecting called for the purpose. (Stock Corporation Law, Sec 8.)

Any stock corporation owning the entire capital stock of any other corporation engaged in the same general line of business may guarantee the bonds or securities of that corporation in pursuance of a two-thirds vote of its stockholders, roting at a special meeting called for that purpose. (Ibid.)

A corporation may voluntarily dissolve itself with the consent of 
the holders of two-thirds of the total capital stock of the corporation. (General Corporation Law, Sec. 221.)

The number of the directors of a corporation may be changed by the affirmative vote of holders of the majority of the stock cast at a meeting, or by unanimous consent without a meeting. (Stock Corporation Law, Sec. 26.)

A majority vote at the annual meeting or at a special meeting called for the purpose is necessary to make the by-laws provide for the closing of the transfer books prior to the meeting of stockholders. (General Corporation Law, Sec. 23.) 


\section{FROM THE ARTICLES OF INCORPORATION OF THE CALI- FORNIA PETROLEUM CORPORATION.}

The capital of the said Corporation shall be of a minimum par value of Ten Thousand Dollars $(\$ 10,000)$ and the maximum par value of Thirty-five Million Dollars $(\$ 35,000,000)$, divided into shares of the par value of One Hundred Dollars (\$100) each.

The minimum capital stock shall be common stock, with rights and privileges hereinafter stated.

Of the maximum capital stock, seventeen million five hundred thousand dollars $(\$ 17,500,000)$ par value, or a maximum of one hundred and seventy-five thousand $(175,000)$ shares of the par value of one hundred dollars $(\$ 100)$ each, shall be seven per cent. (7\%) cumulative preferred stock, participating as to dividend, and seventeen million five hundred thousand dollars $(\$ 17,500,000)$ par value thereof, or a maximum of one hundred and seventy-five thousand $(175,000)$ shares of the par value of one hundred dollars $(\$ 100)$ each, shall be common stock, which said preferred stock and common stock shall be issued upon the terms and conditions and with the rights and privileges following, that is to say:

A. Out of the surplus profits arising from the business of the Corporation :

FIRST. The holders of record of the preferred stock are entitled to receive dividends at the rate of seven per cent. (7\%) per annum, payable quarterly, before any dividends shall be declared, set aside or paid upon the common stock, and such dividends shall be cumulative from October 1, 1912.

SECOND. In January in the year 1915, and in January of each year thereafter, out of any remaining surplus profits of the preceding year, the Corporation shall set aside for the purchase or redemption of its preferred stock or of bonds of subsidiary companies (which term in this certificate of incorporation includes in every case every company in which the Corporation shall own a majority of the capital stock and every company in which any such subsidiary company shall own a majority of the capital stock) or both, an amount equal to five cents for each barrel of petroleum produced and sold by the Corporation during such preceding year; and, for each barrel produced and sold by any subsidiary company, an amount equal to five cents or such part thereof as shall be proportionate to the Corporation's stock interest, direct or indirect, in such subsidiary company. This obligntion is cumulative, so that if in any year said remaining surplus profits shall be insufficient to permit the full amount required as 
aforesaid to be set aside, or if for any other reason such full amount shall not be set aside, the deficiency shall be made good out of the surplus profits of the succeeding fiscal year or years before any dividend shall be declared or paid upon the common stock. All moneys at any time set aside pursuant to the provisions of this clause Second shall be applied as promptly as practicable and in any case before the next succeeding first day of July of each year, under suitable regulations to be established by the By-Laws or by resolution of the Board of Directors, either (a) to the purchase of bonds of subsidiary companies, or (b) to the purchase or, subject to the provision of section 13 of chapter 5 of said Act Concerning Corporations, the redemption of the preferred stock of the Corporation, at the election of the Board of Directors of the Corporation, provided that all such moneys shall be applied in the manner deemed most advantageous to the Corporation, and that the prices shall not exceed in the case of the preferred stock of the Corporation, one hundred and twenty dollars (\$120) per share and accrued dividends, or in case of the purchase of bonds of subsidiary companies, the redemption price thereof as fixed therein. The amounts set aside for the purposes of this clause Second shall not be required to be actually withdrawn from the business of the Corporation until the actual application thereof as herein provided; but such amounts shall not be made the basis of a stock or cash dividend or otherwise distributed among the holders of the common stock, nor shall the said amounts be depleted or used in any other way which would interfere with the application thereof as herein required. All bonds so purchased shall be kept alive, until paid or redeemed, unpledged in the treasury of the Corporation, unless and until the Corporation shall own all the capital stock of the subsidiary company or companies liable upon the same. Preferred stock redeemed or purchased shall not be reissued and no preferred stock shall be issued in lieu thereof or in exchange therefor. Surplus profits used to purchase or redeem, or growing out of the purchase, redemption or resulting reduction of preferred stock shall be and thereafter remain, so long as any of the preferred stock shall be outstanding, unavailable as a basis for dividends.

THIRD. Out of any surpus profits remaining after full cumulative dividends as aforesaid upon the preferred stock shall have been declared and paid or provided for, including all dividends accrued or in arrears and such dividend for the current quarterly dividend period, and after the Corporation shall have complied with the above clause Second in respect of any and all amounts then or theretofore due, but not otherwise, the holders of record of the common stock shall be entitled to receive non-cumulative dividends at the rate of 
seven per cent. per annum, before the payment or declaration of any dividends upon the preferred stock in excess of said cumulative preferential $7 \%$ dividends.

FOURTH. The holders of record of the preferred and of the common stock shall be entitled to participate ratably, share for share, and without preference of either class over the other, in all sums declared as dividends out of any surplus profits then remaining.

B. The preferred stock shall be preferred as to both earnings and assets, and in the erent of any liquidation or dissolution or winding up of the Corporation, the holders of record of the preferred stock shall be entitled, before any distribution shall be made to the holders of the common stock, to be paid in full the par amount of their shares, together with all dividends accrued or in arrears, and, if such liquidation or dissolution or winding up be voluntary, a further sum equal to twenty per cent. of such par amount; and the holders of record of the common stock shall be entitled, to the exclusion of the holders of record of the preferred stock, to share ratably in all assets of the Corporation then remaining. If upon any such liquidation, dissolution or winding up of the Corporation, the assets thus distributable among the holders of such preferred stock shall be insufficient to permit the payment to such preferred stocklsolders of the preferential amounts aforesaid, then the entire assets of the Corporation shall be distributed ratably among holders of said preferred stock. The term "dividends accrued or in arrears" whenever used in this certificate with reference to such preferred stock shall be deemed to mean that amount which shall be equal to seren per cent. ( $7 \%$ ) per annum upon the par value of said stock from October 1, 1912, the date of distribution or redemption as the case may be, less the aggregate amount of all regular seven per cent. preferred dividends paid upon said stock, plus any dividends deelared and unpaid under clause Fourth of subdivision A.

C. The Corporation may, subject to the provisions of section 13 of chapter 5 of said Act Concerning Corporations, redeen the whole or any part of the preferred stock at any time or from time to time by lot or pro rata at one hundred and twenty per cent. of the par value thereof plus dividends accrued or in arrears, upon forty days notice and by such method as shall be provided from' time to time hy the by-laws.

D. Without the affirmative vote or written consent of the holders of at least three-fourths in amount of the outstanding preferred stock, the Corporation shall not:

(1) Change either by increase, diminution or otherwise the voting power of either the preferred or common stock as fixed in this certificate; or 
(2) Sell, lease or otherwise dispose of the property, franchise and business of the Corporation in their entirety or any stock of any subsidiary company, or permit any subsidiary company to make such sale or other disposition of its property, except to the Corporation or some other subsidiary company; or

(3) Create or permit any subsidiary company to create any mort, gage or other lien to secure an issue of bonds or otherwise, or permit any subsidiary company to issue any additional bonds under any present mortgage; or

(4) Create any shares of stock having priority over or on a parity with the authorized preferred stock, or permit any subsidiary com. pany to issue any shares of stock without acquiring its proportionate part thereof; or

(5) Issue any of the authorized preferred stock in excess of $\$ 15$,000,000 in the aggregate except for the acquisition of additional income-producing oil properties; or

(6) After October 1, 1913, issue any of the authorized preferred stock, in excess of $\$ 12,500,000$ in the aggregate, unless the net earnings or profits of the Corporation available for dividends on the preferred stock for the last preceding fiscal year of twelve months shall have been at least equal to twice the annual dividends on the preferred stock outstanding and so to be issued.

E. The preferred stock shall have no voting power except as above stated, and except that in case the Corporation shall fail for four quarterly periods to declare and pay the full regular quarterly dividend on the preferred stock, then and so long as there shall be any arrears of dividends upon the preferred stock the holders of record of the preferred stock outstanding, voting as a class, shall be entitled to elect the remainder of the board. If, however, all such accrued instalments and arrearages shall be paid by the Corporation at any time, then and thereupon the power of the preferred stockholders to elect directors shall cease, subject, however, to being again revived upon any subsequent failure of the Corporation to comply with the conditions herein stated. 


\section{FROM THE ARTICLES OF ASSOCIATION OF THE CHICAGO, MILWAUKEE AND ST. PAUL RAILWAY CO.}

Third-Our capital stock shall not exceed, except as hereinafter provided, $\$ 1,200,000$ divided into 42,000 shares, which said shares shall be sub-divided as follows:

An amount not exceeding $\$ 3,450,000$, or 34,500 shares, shall be set apart and designated as "Preferred Stock," and the full sum of $\$ 100$ per share we hereby declare and acknowledge to be paid thereon, except on so much of this class as is hereinafter designated as "Scrip Preferred Stock"; and on this scrip stock we hereby declare and acknowledge the sum of one dollar per share to be paid.

The balance of said stock of $\$ 750,000$, or 7,500 shares, shall be designated as common stock; and we hereby declare and acknowledge the full sum of one hundred dollars per share to have been paid thereon.

Of the said $\$ 3,450,000$ preferred stock an amount not exceeding $\$ 2,200,000$ at par, or 22,000 shares, shall be set apart and designated as "scrip preferred stock"; the scrip preferred stock here named, or hereafter named, shall not at any time exceed the amount of outstanding mortgage bonds hereinafter named.

The scrip preferred stock shall not be subject to any assessment, and shall entitle the person in whose name it stands upon our books to all the rights and privileges of other stockholders, except that it shall not entitle the holder to any dividend or other profit or increase from the income or assets of this company.

It shall be issued in certificates of five and ten shares each, and shall accompany each mortgage bond of the company. The holder thereof shall have the right at any time within ten days after any dividend shall have been declared and become payable on the preferred stock, to make the scrip preferred stock attached to his bond full paid stock upon the surrender to the company of the mortgage bond named by its number in his scrip certificate, and, upon surrendering said scrip certificate and bond, he shall be entitled to receive therefor the same number of shares of preferred full paid stock and entitled to dividends.

The said preferred stock, except said scrip stock, shall be entitled to a dividend of seven per centum per annum from the net earnings of each current year after payment of interest on all the mortgage bonds, if the company earn so much during the current year, and before the payment of dividends to any other class of stockholders; but the company may reserve a reasonable working capital or surplus 
before the dividend shall be declared or paid on said preferred stock, while surplus shall not exceed at any time, the aggregate sum of $\$ 250,000$ over and above the floating or unfunded debt and the accrued interest on the mortgage bonds. If the net earnings of the company are not as much as seven per cent. in any one year then the said preferred stock shall receive, for that year, a dividend of whatever the said net earnings are after the payment of interest on the mortgage bonds and the reasonable reserve for a working capital as above described. Said preferred stock shall not have any claim upon the earnings of any other year for the non-payment of dividends of any preceding year. And whenever the company earns sufficient over and above the payment of interest on the bonds and the reserve above named to pay a greater sum than seven per cent. on said outstanding preferred stock and seven per cent. on the common stock, then the said preferred stock shall share pro rata with the common stock in such earnings. 


\section{FROM THE CERTIFICATE OF INCORPORATION OF THE MAY DEPARTMENT STORES COMPANY.}

(a) The number of shares of which the capital stock shall consist is Two Hundred Thirty-two Thousand Five Hundred $(232,500)$ of the par value of One Hundred $(\$ 100)$ Dollars each, of which Eightytwo Thousand Five Hundred $(82,500)$ shares shall be preferred stock and One Hundred Fifty Thousand $(150,000)$ shares shall be common stock. The amount of capital with which the corporation will begin business is Two Thousand Five Hundred $(\$ 2,500)$ Dollars.

(b) The holders of the preferred stock shall be entitled to receive, and the corporation shall be obligated to pay, but only out of the surplus or net profits of the corporation, dividends at the rate of seven per cent. per annum payable quarter-yearly on the first days of October, January, April and July in each year, the first quarteryearly dividends being payable on October 1, 1910; and said dividends upon said preferred stock shall be paid or set apart before any dividend shall be paid or set apart on the common stock. Said dividends on the preferred stock shall be cumulative, so that if the corporation shall fail on any dividend day to pay such dividends or any part thereof on all of the issued and outstanding preferred stock, such deficiency in the dividends shall be fully paid, but without interest, before any dividends shall be paid or set apart on the common stock. Subject to the foregoing provisions, said preferred stock shall not, however, be entitled to participate in any other or additional earnings or profits of the corporation.

(c) The whole of the preferred stock, or any part thereof, may be redeemed at any time at the option of the Board of Directors, upon three months' previous written or published notice to the holders of record of such stock given in such manner as may be prescribed by the by-laws, or by resolution of its Board of Directors, by paying therefor in cash the par value of said preferred stock, and in addition thereto all unpaid accrued dividends thereon at the date fixed for such redemption, and also a bonus of Twenty-five (\$25) dollars for each share of preferred stock so redeemed. If at any time less than the whole of the preferred stock then issued and outstanding shall be called for redemption, only such proportion of the said stock held by each preferred stockholder shall be redeemed as the total amount of stock then called for redemption shall bear to the total amount of preferred stock of the corporation then outstanding.

(d) Between the first day of July, 1910, and the first day of July, 1913, there shall be set apart in and for each year, ont of the surplus 
or net profits of the Company, after all accrued dividends upon all preferred stock then outstanding shall have been paid or set apart, a sum of money not less than One Hundred Fifty Thousand $(\$ 150,000)$ Dollars in a fund to be known as "Special Surplus Account." Between said first day of July, 1910, and said first day of July, 1913, said Special Surplus Account so set apart may, at the option of the Board of Directors of the corporation, be held by the corporation and added to its general surplus, or may be used at any time wholly or partially for the acquisition of preferred stock. After the first day of July, 1913, there shall be set apart in said Surplus Account in and for each year (so long as there shall be any preferred stock outstanding), out of the surplus or net profits of the Company, after all accrued dividends upon all preferred stock then outstanding shall have been paid, a sum sufficient to acquire at least three per cent. $(3 \%)$ of the largest amount in par value of said preferred stock that shall have been at any one time issued and outstanding.

In each year after the first day of July, 1913, the corporation shall acquire with the funds of said Special Surplus Account at least three per cent. (3\%) of the largest amount in par value of said preferred stock that shall have been at any one time issued and outstanding. Said preferred stock shall be acquired by redemption or purchase at the lowest prices at which the same may be obtainable by the Company, but in no event exceeding the par value thereof plus accrued and unpaid dividends and a bonus of twenty-five per cent. (25\%) upon the par value thereof, and shall be acquired in such manner as the Board of Directors may from time to time choose, either at public or private sale, and no preferred stock thus acquired shall be reissued by the Company. All preferred stock acquired for said Special Surplus Account, as hereinbefore provided, shall, as soon as acquired, be cancelled, and the capital stock of the corporation shall from time to time be accordingly reduced in accordance with requirements of the Stock Corporation Law. If in any year the amount actually set apart in said Special Surplus Account out of the net profits of the Company is less than the amount required to be so set apart, then such deficiency shall be made good out of the net profits of subsequent years before any dividends shall be declared or paid upon the common stock. If, in any year, the amount actually set apart in said Special Surplus Account is more than the amount required to be so set apart, then such excess may be credited to the amount required to be set apart in subsequent years.

(e) In no event shall any dividend be paid or declared on the common stock in or for any year (if prior to July 1, 1913) until the sum of $\$ 150,000$ shall have been set apart for such year in said Special 
Surplus Account, nor until (if subsequent to July 1, 1913) there shall have been first set apart for such year in said Special Surplus Account a sum sufficient to acquire, and there shall have been aequired, out of said Special Surplus Account an amount of preferred stock equal to three per cent. $(3 \%)$ of the largest amount in par value of said preferred stock that shall have been at any one time issued and outstanding, nor so long as there shall be any arrears in respect of said Special Surplus Account or in the acquisition of preferred stock therefor.

No dividend whatever shall be paid or declared upon the common stock until there shall have been first accumulated and set apart in said Special Surplus Account at least the sum of $\$ 250,000$ (such sum being either in the form of cash or its equivalent, or of preferred stock theretofore acquired and cancelled by the Company), nor shall any dividend be paid or declared upon the common stock which would reduce said Special Surplus Account below $\$ 250,000$. No dividend in excess of $4 \%$ per annum in and for any one year shall be paid or declared on the common stock until and unless there shall have been first accumulated and set apart in said Special Surplus Account at least the sum of $\$ 1,000,000$ (such sum being either in the form of cash or its equivalent, or of preferred stock theretofore acquired and cancelled by the Company), nor shall any dividend in excess of $4 \%$ per annum in and for any one year be paid or deelared on the common stock which would reduce said Special Surplus Account below $\$ 1,000,000$.

The Special Surplus Account may be used for the payment of dividends on the preferred stock, provided there are no other funds of the Company applicable for that purpose, and provided further that all encroachments upon or arrears in said fund shall be first made good before any dividend shall thereafter at any time be paid or declared on the common stock.

(f) Subject to the foregoing provisions, and not otherwise, dividends at such rate as may be determined by the Board of Directors, may be declared and paid on the common stock from time to time out of the remaining surplus or net profits of the Company.

(g) From time to time the preferred stock and the common stock may be increased aceording to law, and may be issued in such amounts and proportions as shall be determined by the Board of Directors, and as may be permitted by law, but the preferred stock by this certificate authorized shall not be increased unless such increase shall have been previously authorized by the consent of at least three-fourths in interest of the issued and outstanding stock of the Company of each class, preferred and eommon, given separately, in person or by proxy, 
at a meeting regularly called for that purpose, or by the unanimous consent of all the stockholders in writing.

(h) Upon any dissolution or liquidation of said corporation or in the event of its insolvency, or upon any distribution of capital, there shall be paid to the holders of the preferred stock the par value thereof and the amount of all unpaid accrucd dividends thereon, before any sum shall be paid, or any assets distributed, among the holders of the common stock; and after the payment to the holders of the preferred stock of its par value, and the unpaid accrued dividends thereon, the remaining assets and funds of the corporation shall be divided among and paid to the holders of the common stock according to their respective shares.

(i) The entire voting power for the election of directors shall be vested in the common stock, except as in this paragraph otherwise provided. The preferred stock shall have no voting power in the elections for directors, unless and until two quarterly dividends payable thereon shall be in default. Immediately upon the happening of such event and thereafter until such defaults, and all defaults subsequent thereto, shall have been made good, the common stock shall have no voting power of the corporation for directors, and the entire voting power in the elections for directors shall become and remain rested exclusively in the holders of the preferred stock.

At all stockholders' meetings, except as expressly otherwise provided in this certificate of incorporation, each share of stock of the corporation, both preferred and common, shall be entitled to one vote. 


\section{TRANSFERS OF CERTIFICATES AND SHARES OF STOCK.'}

$\S 162$. Hlow title to certificates and shares may be transferred. Title to a certificate and to the shares represented thereby can be transferred only,

(a) By delivery of the certificate indorsed either in blank or to a specified person by the person appearing by the certificate to be the owner of the shares represented thereby, or

(b) By delivery of the certificate and a separate document containing a written assignment of the certificate or a power of attorney to sell, assign or transfer the same or the shares represented thereby, signed by the person appearing by the certificate to be the owner of the shares represented thereby. Such assignment or power of attorney may be either in blank or to a specified person.

'The provisions of this section shall be applicable although the charter or articles of incorporation or code of regulations or by-laws of the corporation issuing the certificate and the certificate itself provide that the shares represented thereby shall be transferable only on the books of the corporation or shall be registered by a registrar or transferred by a transfer agent.

$\S 163$. Powers of those lacking full legal capacity and of fiduciaries not enlarged. Nothing in this article shall be construed as enlarging the powers of an infant or other person lacking full legal capacity, or of a trustce, executor or administrator, or other fiduciary, to make a valid indorsement, assignment or power of attorney.

$\S 164$. Corporation not forbidden to treat registered holder as ouner. Nothing in this article shall be construed as forbidding a corporation,

(a) To recognize the exclusive right of a person registered on its books as the owner of shares to receive dividends, and to vote as such owner, or

(b) To hold liable for calls and assessments a person registered on its books as the owner of shares.

$\S 165$. Title derived from certificatc extinguishes title derived from a separate document. The title of a transferee of a certificate under a power of attorney or assignment not written upon the certificate, and the title of any person claiming under such transferee, shall cease and determine if, at any time prior to the surrender of the certificate to the corporation issuing it, another person, for value

1 From the Personal Property Law of New York State as amended by Laws 1913. This is the uniform Stock Transfer Law, adopted in Massachusetts, Pennsylvanin and New York. 
in good faith, and without notice of the prior transfer, shall purchase and obtain delivery of such certificate with the indorsement of the person appearing by the certificate to be the owner thereof, or shall purchase and obtain delivery of such certificate and the written assignment or power of attorney of such person, though contained in a separate document.

$\S 166$. Who may deliver a certificate. The delivery of a certificate to transfer title in accordance with the provisions of section one hundred and sixty-two is effectual, except as provided in section one hundred and sixty-eight, though made by one having no right of possession and having no authority from the owner of the certificate or from the person purporting to transfer the title.

$\S 167$. Indorsement effectual in spite of fraud, duress, mistake, revocation, death, incapacity or lack of consideration or authority. The indorsement of a certificate by the person appearing by the certificate to be the owner of the shares represented thereby is effectual, except as provided in section one hundred and sixty-eight, though the indorser or transferor ${ }^{1}$

(a) Was induced by fraud, duress or mistake to make the indorsement or delivery, or

(b) Has revoked the delivery of the certificate, or the authority given by the indorsement or delivery of the certificate, or

(c) Has died or become legally incapacitated after the indorsement, whether before or after the delivery of the certificate, or

(d) Has received no consideration.

$\S 168$. Rescission of transfer. If the indorsement or delivery of a certificate,

(a) Was procured by fraud or duress, or

(b) Was made under such mistake as to make the indorsement or delivery inequitable; or

If the delivery of a certificate was made

(c) Without authority from the owner. or

(d) After the owner's death or legal incapacity, the possession of the certificate may be reclaimed and the transfer thereof rescinded, unless :

1. The certificate has been transferred to a purchaser for value in good faith without notice of any facts making the transfer wrongful, or

2. The injured person has elected to waive the injury, has been guilty of laches in endeavoring to enforce his rights.

Any court of appropriate jurisdiction may enforce specifically such right to reclaim the possession of the certificate or to rescind the

1 So in original. 
transfer thereof and, pending litigation, may enjoin the further transfer of the certificate or impound it.

$\S 169$. Rescission of transfer of certificate does not invalidate subsequent transfer by transferee in possession. Although the transfer of a certificate or of shares represented thereby has been rescinded or set aside, nevertheless, if the transferce has possession of the certificate or of a ncw certificate representing part or the whole of the same shares of stock, a subsequent transfer of such certificate by the transferee, mediately or immediately, to a purchaser for value in good faith, without notice of any facts making the transfer wrongful, shall give such purchaser an indefeasible right to the certificate and the shares represented thereby.

$\S 170$. Delivery of unindorsed certificate imposes obligation to indorse. The delivery of a certificate by the person appearing by the certificate to be the owner thereof without the indorsement requisite for the transfer of the certificate and the shares represented thereby, but with intent to transfer such certificate or shares, shall impose an obligation, in the absence of an agrecment to the contrary, upon the person so delivering, to complete the transfer by making the necessary indorsement. The transfer shall take effect as of the time when the indorsement is actually made. This obligation may be specially enforced.

$\S 171$. Ineffectual attempt to transfer amounts to a promise to transfer. An attempted transfer of title to a certificate or to the shares represented thereby without delivery of the certificate shall have the effect of a promise to transfer and the obligation, if any, imposed by such promise shall be determined by the law governing the formation and performance of contracts.

$\S 172$. Warranties on sale of certificate. A person who for value transfers a certificate, including one who assigns for valuc a claim secured by a certificate, unless a contrary intention appears, warrants:

(a) That the certificate is genuine,

(b) That he has a legal right to transfer it, and

(c) That he has no knowledge of any fact which would impair the validity of the certificate.

In the case of an assignment of a claim secured by a certificate, the liability of the assignor upon such warranty shall not exceed the amount of the claim.

$\S 173$. No warranty implied from accepting payment of a debt. A mortgagee, pledgee or other holder for security of a certificate who in good faith demands or receives payment of the debt for which such certificate is security, whether from a party to a draft drawn 
for such debt, or from any other person, shall not by so doing be deemed to represent or to warrant the genuineness of such certificate, or the value of the shares represented thereby.

$\S 174$. No attachment or levy upon shares unless certificate surrendered or transfer enjoined. No attachment or levy upon shares of stock for which a certificate is outstanding shall be valid until such certificate be actually seized by the officer making the attachment or levy, or be surrendered to the corporation which issued it, or its transfer by the holder be enjoined. Except where a certificate is lost or destroyed, such corporation shall not be compelled to issue a new certificate for the stock until the old certificate is surrendered to it.

$\S 175$. Creditor's remedies to reach Certificate. A creditor whose debtor is the owner of a certificate shall be entitled to such aid from courts of appropriate jurisdiction, by injunction and otherwise, in attaching such certificate or in satisfying the claim by means thereof as is allowed at law or in equity, in regard to property which cannot readily be attached or levied upon by ordinary legal process.

$\S 176$. There shall be no lien or restriction unless indicated on certificate. There shall be no lien in favor of a corporation upon the shares represented by a certificate issued by such corporation and there shall be no restriction upon the transfer of shares so represented by virtue of any by-law of such corporation, or otherwise, unless the right of the corporation to such lien or the restriction is stated upon the certificate.

$\S 17 \%$. Alteration of certificate does not divest title to shares. The alteration of a certificate, whether fraudulent or not and by whomsoever made, shall not deprive the owner of his title to the certificate and the shares originally represented thereby, and the transfer of such a certificate shall convey to the transferee a good title to such certificate and to the shares originally represented thereby.

$\S 178$. Lost or destroyed certificate. Where a certificate has been lost or destroyed, a court of competent jurisdiction may order the issue of a new certificate therefor on service of process upon the corporation and on reasonable notice by publication, and in any other way which the court may direct, to all persons interested, and upon satisfactory proof of such loss or destruction and upon the giving of a bond with sufficient surety to be approved by the court to protect the corporation or any person injured by the issue of a new certificate from any liability or expense, which it or they may incur by reason of the original certificate remaining outstanding. The court may also in its discretion order the payment of the corporation's reasonable costs and counsel fees. The issue of a new certificate under 
an order of the court as provided in this section shall not relieve the corporation from liability in damages to a person to whom the original certificate has been or shall be transferred for value without notice of the proceedings or of the issuance of the new certificate.

$\S 179$. Rule for cases not provided for by this act. In any case not provided for by this act, the rules of law and equity, including the law merchant, and in particular the rules relating to the law of principal and agent, executors, administrators and trustees, and to the effect of fraud, misrepresentation, duress or coercion, mistake, bankruptcy or other invalidating cause, shall govern.

$\S 180$. Interpretation shall give effect to purpose of uniformily. This act shall be so interpreted and construed as to effectuate its general purpose to make uniform the law of those states which enct it.

$\S 181$. Definition of indorsement. A certificate is indorsed when an assignment or a power of attorney to sell, assign or transfer the certificate or the shares represented thereby is written on the certificate and signed by the person appearing by the certificate to be the owner of the shares represented thereby, or when the signature of such person is written without more upon the back of the certificate. In any of such cases a certificate is indorsed though it has not been delivered.

$\S 182$. Definition of person appearing to be the owner of certificate. The person to whom a certificate was originally issued is the person appearing by the certificate to be the owner thereof, and of the shares represented thereby, until and unless he indorses the certificate to another specified person, and thereupon such other specified person is the person appearing by the certificate to be the owner thereof until and unless he also indorses the certificate to another specified person. Subsequent special indorsements may be made with like effect.

$\S 183$. Other definitions. 1. In this article, unless the context or subject-matter otherwise requires-

"Certificate" means a certificate of stock in a corporation organized under the laws of this state or of another state whose laws are consistent with this act.

"Delivery" means voluntary transfer of possession from one person to another.

"Person" includes a corporation or partnership or two or more persons having a joint or common interest.

To "purchase" includes to take as mortgagee or as pledgee.

"Purchaser" includes mortgagee and pledgee.

"Shares" means a share or shares of stock in a corporation organ- 
ized under the laws of this state or of another state whose laws are consistent with this act.

"State" includes state, territory, district and insular possession of the United States.

"Transfer" means transfer of legal title.

"Title" means legal title and does not include a merely equitable or beneficial ownership or interest.

"Value" is any consideration sufficient to support a simple contract. An antecedent or pre-existing obligation, whether for money or not, constitutes value where a certificate is taken either in satisfaction thereof or as security therefor.

2. A thing is done "in good faith" within the meaning of this act, when it is in fact done honestly, whether it be done negligently or not.

$\S 184$. Article does not apply to existing certificates. The provisions of this article apply only to certificates issued after the taking effect of this article.

$\S 185$. Inconsistent legislation repealed. All acts or parts of acts inconsistent with this article are hereby repealed. 


\section{STOCK TRANSFER TAX LAW OF NEW YORK.}

\section{§ 270. AMOUNT of Tax}

There is hereby imposed and shall immediately accrue and be collected a tax, as herein provided, on all sales, or agreements to sell, or memoranda of sales of stock, and upon any and all deliveries or transfers of shares or certificates of stock, in any domestic or foreign association, company or corporation, made after the first day of June, nineteen hundred and five, whether made upon or shown by the books of the association, company or corporation, or by any assignment in blank, or by any delivery, or by any paper or agreement or memorandum or other evidence of sale or transfer, whether intermediate or final, and whether investing the holder with the beneficial interest in or legal title to said stock, or merely with the possession or use thereof for any purpose, or to secure the future payment of money, or the future transfer of any stock, on each hundred dollars of face value or fraction thereof, two cents, except in cases where the shares or certificates of stock are issued without designated monetary value, in which cases the tax shall be at the rate of two cents for each and every share of such stock. It shall be the duty of the person or persons maling or effectuating the sale or transfer to procure, affix and cancel the stamps and pay the tax provided by this article. It is not intended by this act to impose a tax upon an agreement evidencing the deposit of stock certificates as collateral security for money loaned thereon, which stock certificates are not actually sold, nor upon such stock certificates so deposited, nor upon mere loans of stock or the return thereof. The payment of such tax shall be denoted by an adhesive stamp or stamps affixed as follows: In the case of a sale or transfer, where the evidence of the transaction is shown only by the books of the association, company or corporation, the stamp shall be placed upon such books, and it shall be the duty of the person making or effectuating such sale or transfer to procure and furnish to the association, company or corporation the requisite stamps, and of such association, company or corporation to affix and eancel the same. Where the transaction is effected by the delivery or transfer of a certificate, the stamp shall be placed upon the surrendered certificate and canceled; and in cases of an agreement to sell, or where the sale is effected by delivery of the certificate assigned in blank, there shall be made and delivered by the seller to the buyer, a bill or memorandum of such sale to which the stamp provided for by this article shall be affixed and canceled. Every such bill or memorandum of sale or agreement to sell shall show the date of the transaction which it evidences, the name of the seller, the 
stock to which it relates, and the number of shares thereof. All such bills or memoranda of sale shall bear a number upon the face thereof and no more than one such bill or memorandum of sale made by the seller on any given day shall bear the same number. The aforesaid identification number of the bill or memorandum of sale shall in all cases be entered and recorded in the book of account required to be kept by section two hundred and seventy-six of this chapter; and no further tax is hereby imposed upon the delivery of the certificate of stock, or upon the actual issue of a new certificate when the original certificate of stock is accompanied by the duly stamped memorandum of sale as herein provided. (Tax Law, Art. 12, §270; thus amended by L. 1913, chap. 779, in effect July 1, 1913.)

\section{§ 273. Canceling Stamps; Penalty for Failure}

In every case where an adhesive stamp shall be used to denote the payment of the tax provided by this article, the person using or affixing the same shall write or stamp thereupon the initials of his name and the date upon which the same shall be attached or used, and shall cut or perforate the stamp.in a substantial manner, so that such stamp cannot be again used; and if any person makes use of an adhesive stamp to denote the payment of the tax imposed by this article, without so effectually canceling the same, such person shall be deemed guilty of a misdemeanor, and upon conviction thereof shall pay a fine of not less than two hundred nor more than five hundred dollars or be imprisoned for not less than six months, or both, in the discretion of the court. (Thus amended by L. 1911, chap. 352, in effect June 15, 1911.)

\section{§ 275A. Registration; Penalty for Failure}

Every person, firm, company, association or corporation engaged in whole or in part in the making or negotiating of sales, agreements to sell, deliveries or transfers of shares or certificates of stock, or conducting or transacting a stock brokerage business, and every stock association, company or corporation which shall maintain a principal office or place of business within the state or which shall keep or cause to be kept within the state of New York a place for the sale, transfer or delivery of its stock, shall within ten days after the amendment to this section shall take effect if such certificate shall not have been theretofore filed, or if at the time this act shall take effect, not engaged in such business or maintaining such principal office or place of business or such a place for the sale or transfer of its stock, within ten days after engaging in such business or after establishing such principal office or place of business or such place for the sale or transfer 
of its stock as the case may be, file in the office of the comptroller a certificate setting forth the name under which such business is, or is to be, conducted or transacted, and the true or real full name or names of the person or persons conducting or transacting the same, with the post-office address or address of said person or persons, unless the party so certifying be a corporation, in which erent it shall set forth its said principal office or place of business and when and where incorporated. Said certificate shall be executed and duly acknowledged by the person or persons so conducting or intending to conduct said business or by the president or secretary of the corporation as the case may be.

In the event of a change in the persons composing such firm, company or association or of the address of any such person, firm, company, association or corporation, or termination of such business or relationship, a like certificate setting forth the facts with respect to such change or termination shall within ten days thereafter be filed in the office of the comptroller.

Any such person, firm, company, association or corporation who shall fail to comply with the provisions of this section shall be guilty of a misdemeanor, and upon conviction thereof shall pay a fine of not less than one hundred dollars nor more than five hundred dollars or be imprisoned for not more than six months or by both such fine and imprisonment, in the discretion of the court. (Thus amended by $L$. 1914, Chapter 206, in effect April \%, 1914.)

\section{$\S 276$. Books and Records to be Kept by Corporations and Others; Penalties; Powers of State Comptroller}

Every person, firm, company, association or corporation, engaged in whole or in part in the making or negotiating of sales, agreements to sell, deliveries or transfers of shares or certificates of stock, or conducting or transacting a brokerage business, shall keep or cause to be kept at some accessible place within the state of New York, a just and true book of account, in such form as may be prescribed by the comptroller, wherein shall be plainly and legibly recorded in separate columns, the date of making every sale, agreement to sell, delivery or transfer of shares or certificates of stock, the name of the stock and the number of shares thereof, the face value of the stock, the name of the seller or transferrer, the name of the purchaser or transferee and the number and face value of the adhesive stamps affixed and the identifying number of the bill or memorandum of sale as provided for by section two hundred and seventy of this chapter.

Every association, company, or corporation shall keep or cause to be kept at some accessible place within the state of New York, a stock 
certificate book and a just and true book of account, transfer ledger or register, in such form as may be prescribed by the comptroller, wherein shall be plainly and legibly recorded in separate columns the date of making every transfer of stock, the name of the stock and the number of shares thereof, the serial number of each surrendered certificate, the name of the party surrendering such certificate, the serial number of the certificate issued in exchange therefor, the number of shares covered by said certificate, the name of the party to whom said certificate was issued and evidence of the payment of the tax provided for by section two hundred and seventy of this chapter, which evidence, however, shall be provided in one of the following manners and not otherwise, to wit:

(a) By attaching to the stock certificate surrendered for transfer, the stamps required for such transfer, or

(b) If the stamps are not attached to the certificate, but are attached to the bill or memorandum of sale effecting or evidencing the transfer of such certificate, by attaching to said certificate the said bill or memorandum of sale with stamps attached, or

(c) If the stamps covering the transfer are attached to a bill or memorandum effecting a transfer of one or more certificates or to one or more certificates included in said transfer, a notation must be made upon such certificates, bill or memorandum, as the case may be, clearly specifying and identifying the certificate or certificates of stock to the sale or transfer of which the said stamps apply, or

(d) If the bill or memorandum bearing such stamps is not attached to the surrendered certificate or certificates to which it applies, a notation must be made upon such bill or memorandum stating the serial number or numbers of the certificates to which said bill or memorandum applies, as provided by section two hundred and seventy of this chapter. It shall also retain and keep all surrendered or canceled shares or certificates of its stock and all memoranda relating to the sale or transfer of any thereof. All such books of account, transfer ledgers, registers and stock certificate books, shall be retained and kept as aforesaid for a period of at least two years subsequent to the date of the last entry made therein as herein required; and all such surrendered or canceled shares or certificates of stock and memoranda relating to the sale or transfer of stock, shall be retained and kept for a period of at least two years from the date of the delivery thereof. For the purpose of ascertaining whether the tax imposed by this article has been paid, all such books of account, transfer ledgers, registers, stock certificate books, surrendered or canceled shares or certificates of stock and memoranda relating to the sale or transfer thereof, shall at all times between the hours of 
ten o'clock in the forenoon and three o'clock in the afternoon, except Saturdays, Sundays and legal holidays, be open to examination by the comptroller or his duly authorized representative.

The comptroller may enforce his right to examine such books of account and bills or memoranda of sale or transfer; and such transfer ledger, register and stock certificate books and surrendered or canceled shares or certificates of stock by mandamus. If the comptroller ascertains that the tax provided for in this article has not been paid, he shall bring an action in his name as such comptroller, in any court of competent jurisdiction for the recovery of such tax and for any penalty incurred by any person under the provisions of this artiele.

Every person, firm, company, association or eorporation who shall fail to keep such book of account or bills or memoranda of sale or transfer, or transfer ledger, register or stock eertificate book or surrendered or canceled shares or certificates of stock as herein required, or who alters, cancels, obliterates or destroys any part of said records or makes any false entry therein, or who shall refuse to permit the comptroller or any of his authorized representatives freely to examine any of said books, records or papers at any of the times herein provided, or who shall in any other respect violate any of the provisions of this section shall be deemed guilty of a misdemeanor and on conviction thereof shall for each and every such offense pay a fine of not less than five hundred dollars nor more than five thousand dollars, or be imprisoned not less than three months nor more than two years, or both, in the discretion of the court. (Thus amended by L. 1913, chap. 779 , in effect July 1, 1913.)

\section{\$278. Effect of Failure to Pay Tax.}

No transfer of stock made after June first, nineteen hundred and five, on which a tax is imposed by this article, and which tax is not paid at the time of such transfer, shall be made the basis of any action or legal proceedings, nor shall proof thereof be offered in evidence in any court in this state. 


\section{RULINGS OF THE STATE COMPTROLLER GOVERNING THE COLLECTION OF TAXES ON TRANSFERS OF STOCK.}

For the information of the public the Comptroller issues the following brief statement of the more general rules and regulations governing the imposition and collection of stock transfer taxes, prepared pursuant to the rulings made by the Attorney-General.

1. The application and scope of the Stock Transfer Tax Law has been considerably broadened by the amendments thereto, effected by chapter 352 of the Laws of 1911, chapter 292 of the Laws of 1912, chapter 779 of the Laws of 1913, and chapter 206 of the Laws of 1914, with the result that the rulings heretofore made asserting exemptions from the tax are not now as a rule controlling.

2. By the statute as amended, a tax is imposed upon all sales or agreements to sell and upon all deliveries or transfers of shares or certificates of stock of any and all associations, companies and corporations, whether domestic or foreign at the rate of two cents on each hundred dollars of face value or fraction thereof, except where shares or certificates of stock are issued without designated monetary value, in which case the tax shall be two cents for each and every share of such stock.

3. The statute does not apply to the original issue of stock; but all sales or transfers made subsequent thereto, whether intermediate or final, are taxable.

4. It is not necessary to render it taxable that the transaction involve a sale. By the statute, as amended, a tax is imposed upon all sales or transfers of shares or certificates of stock, whether operating to convey the beneficial interest in or merely the legal title to said stock, or possession thereof for any purpose. The only exceptions to this rule are those expressly provided for in section 270 of the law.

5. The transfer to and from roting trustees is taxable, also the transfer of voting trust certificates.

6. The mere surrender of a certificate of stock for reissue in smaller denominations is not taxable; but if reissued in part to the original owner and in part to a third party it is taxable to the extent of the transfer to the third party.

7. Likewise the mere surrender of a certificate of stock held by a deceased person for issuance in the name of his executor or administrator is not taxable; but all transfers made by the latter, whether to trustees, legatees or other persons, are taxable. 
8. The law applies to the stock of foreign as well as domestic corporations and to residents and non-residents alike.

9. While the law has not extra territorial operation, nevertheless, where it appears that the transfer of the stock on the corporate books within this State is essential to render the transfer effectual, it subjects it to a tax although in all other respects made without the State.

10. It is the duty of the person making or effectuating the sale or transfer to pay the required tax by procuring, affixing and canceling the stamps, except that where a sale or transfer is shown only by the books of the corporation, the person making the sale must secure, and the corporation affix and cancel the stamps to its books. (Sec. 270.)

11. Where the sale or transfer is effected by the delivery or transfer of a certificate the stamp must be placed upon the surrendered certificate. In case of an agreement to sell, or where the sale is effected by the delivery of the certificate assigned in blank, there must be made and delivered by the seller to the buyer a bill or memorandum of such sale, to which the stamps shall be affixed and canceled. This bill or memorandum with stamp attached must be affixed to the certificate, or properly identified as provided by section 276, when presented for transfer.

A strict compliance with these requirements will be insisted upon.

12. Every such bill or memorandum of sale, agreement to sell or sales ticket must show:

(a) The date of the transaction which it evidences.

(b) The name of the seller.

(c) The stock to which it relates and the number of shares thereof; and all such memoranda of sale or sales tickets as are not used for the purpose of transfer must be kept by the broker for two years from their respective dates.

(d) And an identifying number as provided by section 270 .

13. All persons liable for the payment of the tax and all persons acting as agents or brokers for any such persons or for the corporation whose stock is transferred, who in any manner assists in consummating a sale or transfer without payment of the required tax, are guilty of a misdemeanor.

14. Likewise corporations, and persons acting as transfer agents for corporations, are forbidden to transfer stock on the books of the corporation until the required tax has been paid; and for a failure to perform this duty they are guilty of a misdemeanor.

15. Every stamp used to denote the payment of the tax must be canceled by the user by writing or stamping thereon the initials of 
his name and the date upon which the stamp is attached or used. He must also cut or perforate the stamp in a substantial manner so that it cannot again be used. A failure so to do renders the party guilty of a misdemeanor.

16. Under no circumstances may a stamp erroneously attached to a certificate or memorandum be removed. An adequate remedy in such cases, in the nature of a refund, is provided by section 280 of the act.

17. Every broker is required to keep a just and true book of account in the form prescribed by the Comptroller wherein shall be plainly and legibly recorded in separate columns:

(a) The date of making every sale, agreement to sell, delivery or transfer of shares or certificates of stock.

(b) The name of the stock and the number of shares thereof.

(c) The face value thereof.

(d) The name of the seller or transferrer.

(e) The name of the purchaser or transferee.

(f) The identifying number of the bill or memorandum of sales as provided by section 270 .

These books must be kept for a period of at least two years subsequent to the date of such entry made therein and are subjected to examination by the Comptroller or his representative at all times between 10 A. M. and 3 P. M. (Saturdays, Sundays and legal holidays excepted.)

18. Every corporation or its transfer agent shall keep a just and true book of account in the form prescribed by the Comptroller wherein shall be plainly and legibly recorded in separate columns:

(a) The date of making every transfer of stock.

(b) The name of the stock and the number of shares thereof.

(c) The serial number of each surrendered certificate.

(d) The name of the party surrendering each certificate.

(e) The serial number of the certificate issued in exchange therefor.

(f) The number of shares represented by said certificate.

(g) The name of the party to whom said certificate was issued.

(h) The evidence of the payment of the tax as provided by section 276 .

It shall also keep and retain a stock certificate book and all surrendered or canceled shares of certificates of its stock and memoranda relating to the sale thereof for a period of two years from the date of the delivery thereof.

All such books and papers are subject to the examination by the Comptroller or his representative at any time between the hours of 
10 A. M. and 3 P. M. (Saturdays, Sundays and legal holidays excepted.)

19. It is imperative that these books, records and memoranda be kept and retained strictly in the form and manner provided by the statute and severe penalties are imposed for a failure so to do.

20. Severe penalties, civil and criminal, are also provided by the act for the illegal sale or use of stamps, for the removal or re-use thereof, for the failure to pay the tax imposed and for the violation of the other requirements of the statute. Furthermore, the failure to pay the tax constitutes an absolute defense to an action to recover the purchase price of the stock.

21. Every person, firm, company, association or corporation engaged in whole or in part in the making or negotiating of sales, agreements to sell, deliveries or transfers of shares or certificates of stock, or conducting or transacting a stock brokerage business, shall within ten days after July 1, 1913, or within ten days after engaging in such business, file with the State Comptroller, either in Albany or New York City, a certificate setting forth the name under which such business is or is to be conducted or transacted and the true and real full names of the person or persons conducting or transacting the same, with the post-office address or addresses of said persons, or in the event of a change in the persons conducting such business or change of address, like certificate setting forth the facts shall within ten days thereafter be filed. Such certificate shall be duly acknowledged. A failure to perform this duty is a misdemeanor.

22. Every stock association, company or corporation which shall maintain a principal office or place of business within the state or which shall keep or cause to be kept within the State of New York a place for the sale, transfer or delivery of its stock shall within ten days after April 7,1914 , if such certificate shall not have been theretofore filed, or within ten days after engaging in or maintaining a place for such business, file with the State Comptroller, either in Albany or New York City, a certificate setting forth the name of the company, the place of business and when and where incorporated, or in the event of a change in the persons or change of address like certificate setting forth the facts shall within ten days thereafter be filed. Such eertificates shall be duly acknowledged by the president or secretary of the corporation. A failure to perform this duty is a misdemeanor.

23. The Comptroller will be pleased at any time to advise interested parties as to the provisions and requirements of the law.

WILLIAM SOHMER, Comptroller, State of New York,

Mav 1. 1914. Albany, N. Y. 


\section{STOCK EXCHANGE BY-LAWS AND RULES 1}

Stock Exchange Rules for Transaction or Conduct of Business

\section{ARTicle XX}

\section{Hours of Business}

SEC. 1. The Exchange shall be opened for the entrance of members upon every business day at thirty minutes after nine o'clock A. M.

At ten o'clock the Chairman shall announce that the Exchange is open for the transaction of business, and it shall so remain until three o'clock P. M., when he shall announce it to be closed. On half-holidays the closing shall be at twelve o'clock, noon.

SEc. 2. The Exchange shall not be closed at any time between the hours named in the preceding section, except by order of the Governing Committee.

SEc. 3. Dealings upon the Exchange shall be limited to the interval between the hours above named; and a fine of fifty dollars for each offense shall be imposed by the Chairman, upon any member who shall make any bid, offer or transaction before or after those hours. Loans of money or securities may be made after the official closing of the Exchange.

SEC. 4. Dealing upon any other Exchange in the City of New York or publicly outside of the Exchange, either directly or indirectly, in securities listed or quoted on the Exchange, is forbidden; any violation of this rule shall be deemed to be an act detrimental to the interest or welfare of the Exchange.

\section{Article XXI}

\section{Calls}

The appointment and arrangement of Calls of Stocks or Bonds shall be under the control and direction of the Committee of Arrangements.

\section{Article XXII}

\section{Contracts Subject to the Rules of the Exchange}

All contracts of a member of the Exchange, or of a firm having a member of the Exchange as a general partner, with any other member of the Exchange, or with any other firm having a member of the Exchange as a general partner, for the purchase, sale, borrowing, loaning

1 Article $\mathrm{XX}$ of the Stock Exchange Constitution, By-Laws and Rules of the New York Stock Exchange. 
or hypothecation of securities, or for the borrowing, loaning, or payment of money, whether occurring upon the floor of the Exchange or elsewhere, are contracts subject to the rules of the Exchange.

\section{Article XXIII}

\section{Bids and Offers}

SEc. 1. All bids and offers made and accepted in accordance with these rules shall be binding.

SEC. 2. All offers to buy or sell securities shall be for 100 shares of stock or for $\$ 10,000$ par value of bonds, unless otherwise stated.

Offers to buy or sell specific amounts, other than as above stated, may be made at the same time and may be independently accepted.

SEc. 3. Bids and offers may be made only as follows:

(a) "Cash," i. e., for delivery upon the day of contract;

(b) "Regular Way," $i$. e., for delivery upon the business day following the contract;

(c) "At three days," $i$. e., for delivery upon the third day following the contract;

(d) "Buyer's" or "Seller's" options for not less than four days nor more than sixty days.

Bids and offers under each of these specifications may be made simultaneously, as being essentially different propositions, and may be separately accepted without precedence of one over another.

Bids and offers made without stated conditions shall be considered to be in the "Regular Way."

On transactions for more than three days written contracts shall be exchanged on the day following the transaction, and shall carry interest at the legal rate, unless otherwise agreed; on such contracts one day's notice shall be given, at or before $2: 15$ P. M., before the securities shall be delivered prior to the maturity of the contract.

On offers to buy "Seller's Option" or to sell "Buyer's Option," the longest option shall have precedence. On offers to buy "Buyer's Option" or to sell "Seller's Option," the shortest option shall have precedence.

SEc. 4. All contracts falling due on holidays or half-holidays observed by the Exchange shall be settled on the preceding business day, except that when two or more consecutive days are holidays or halfholidays, contracts falling due on other than the first of such days shall be settled on the next business day.

Loans of money or securities made on the day preceding a holiday or half-holiday observed by the Exchange shall mature on the succeeding business day, unless otherwise specified. 
SEC. 5. Bids or offers shall not be made at a less variation than one-eighth of one per cent.

SEC. 6. Bids and offers shall be made on the basis of a percentage of the par value of the securities dealt in, unless otherwise ordered by the Governing Committee.

Sec. 7. Any member violating any of the above provisions of this Article shall be fined by the Chairman in an amount not exceeding twenty dollars; for a repetition of the offense, he shall be liable to suspension for a period not exceeding ten days.

SEc. 8. Fictitious transactions are forbidden. Any member violating this rule shall be liable to suspension for a period not exceeding twelve months.

Sec. 9. No offers to buy or sell privileges to receive or deliver sech rities shall be made publicly at the Exchange, under penalty of a fine of twenty-five dollars for each offense.

\section{Article XXIV}

\section{Comparisons-Liability on Contracts}

SEc. 1. It shall be the duty of every member to report each of his transactions as promptly as possible at his office, where he shall furnish opportunity for prompt comparison.

SEc. 2. It shall be the duty of the seller to compare, or to endeavor to compare, each transaction at the office of the Buyer, not later than one hour after the closing of the Exchange. Nothing in this Article shall be construed to justify a refusal to compare before the closing of the Exchange.

SEc. 3. It shall be the duty of the BUYER to investigate, before 10 o'clock A. M. of the day after the purchase, each transaction which has not been compared by the Seller.

SEc. 4. Neglect of a member to comply with the provisions of Sec. tion 1 or 2 hereof shall render him liable to a fine not exceeding fifty dollars, to be imposed by the Committee of Arrangements.

SEC. 5. Comparison shall be made by an exchange of an original and a duplicate comparison ticket; the party to whom the comparison ticket is presented shall retain the original, if it be correct, and immediately return the duplicate duly signed.

An exchange of Clearing-House tickets shall constitute a comparison.

SEc. 6. Should a difference be discovered in an attempt to compare, the exact liability of the disputants shall be promptly established by purchase, sale or mutual agreement. 
SEC. \%. If an original party to a transaction gives up his principal, the latter shall have the same duties in the matter of comparison as the original party.

SEC. 8. No comparison or failure to compare, and no notification or acceptance of notification, shall have the effect of creating or of canceling a contract, or of changing the terms thereof, or of releasing the original parties from liability.

SEc. 9. No party to a contract shall be compelled to accept a substitute principal, unless the name proposed to be substituted shall be declared in making the offer and as a part thereof.

Orders for the receipt or delivery of securities, issued by the Clearing-House, shall, however, be binding and enforceable upon members or firms using the facilities of the Clearing-House.

SEc. 10. When written contracts shall have been exchanged the signers thereof only are liable.

\section{Article XXV}

\section{Payment and Delivery}

Sec. 1. In all deliveries of securitics, the party delivering shall have the right to require the purchase money to be paid upon delivery; if delivery is made by transfer, payment may be required at time and place of transfer.

SEc. 2. The Receiver of shares of stock shall have the option of requiring the delivery to be made either in certificates therefor or by transfer thereof; except that in cases where personal liability attaches to ownership, the Seller shall have the right to make delivery by transfer.

The right to require receipt or delivery by transfer shall not obtain while the transfer books are closed.

SEc. 3. Deliveries of securities on contracts subject to the rules of the Exchange shall in all cases conform to the requirements for regularity which may be made, from time to time, by the Committee on Securitics.

SEc. 4. The Buycr must, not later than two-fifteen o'clock P. M., accept and pay for all, or any portion of a stock contracted for which may be tendered in lots of one hundred shares or multiples thereof; and he may buy in "under the rule" the undelivered portion, in accordance with the provisions of Article XXVIII.

This rule shall also apply to contracts for bonds when tender is made in lots of ten thousand dollars or multiples thereof. 


\section{ARTICLE XXVI \\ Settlement of Contracts}

SEC. 1. All deliveries of securities must be made before quarter after two o'clock P. M., and when deliveries are not made by that time the contract may be closed "under the rule" in the manner provided in Article XXVIII of these Rules. In the absence of any notice or agreement the contract shall continue without interest until the following business day; but in every case of non-delivery of securities the party in default shall be liable for any damages which may accrue thereby; and all claims for such damages must be made before three o'clock P. M. on the business day following the default.

SEc. 2. The neglect or failure of a member or firm to exchange Clearing-House tickets on a contract, in conformity with the "Rules for Clearing," shall constitute a default; and such defaulted contract may be closed as provided in Article XXVIII; except that the limit of time for delivery of notice of intention to close such contract shall be ten-thirty o'clock A. M. of the following business day, and the time for closing shall not be before eleven o'clock A. M.

SEc. 3. Parties receiving securities shall not deduct, from the purchase price, any damages claimed for non-delivery, except by the consent of the party delivering the same.

SEC. 4. Notice for the return of loans of money, or of securities not admitted to the Clearing-House, must be given before one o'clock P. M. Notice for the return of loans of securities admitted to the Clearing-House must be given before three-thirty o'clock P. M., except on half-holidays observed by the Exchange, when such notice must be given before twelve-thirty o'clock P. M. All such notices shall be considered as in full force until delivery is made.

Sec. 5. On half-holidays observed by the Exchange, securities sold specifically for "Cash" must be delivered and received at or before eleven-thirty o'clock A. M. In case of default the contract may be closed after eleven-forty o'clock A. x. "under the rule," in manner provided in Article XXVIII.

\section{ARticle XXVII \\ Clearing-House}

SEc. 1. There shall be a Clearing-House for the purpose of acting as the common agent of the members of the Exchange in receiving and delivering such securities as may from time to time be designated by the Clearing-House Committee.

SEc. 2. Nothing in the conduct of the business of clearing shall 
attach any liability to the Exchange, or to any member of the Clearing-House Committee, and delays on the part of the Clearing-House shall not attach any liability to members who are clearing.

SEC. 3. The Clearing-House Committee shall designate from time to time the securities which shall be cleared, and, in all transactions in such securities, the deliveries shall be made through the ClearingHouse, unless otherwise specially stipulated in the bid or offer or otherwise agreed upon.

SEc. 4. The "Rules for Clearing" and the "Rules for Dealing" adopted by the Governing Committee, and all amendments thereto, shall be binding upon the members of the Exchange equally with the laws included in the Constitution.

Amendments to "Rules for Clearing" or to "Rules for Dealing" may be adopted by a vote of two-thirds of all the existing members of the Governing Committee and need not be submitted to the members of the Exchange for approval.

\section{Article XXVIII}

\section{Closing Contracts "Under the Rule"}

Sec. 1. When the insolvency of a member or firm is announced to the Exchange, members having contracts subject to the rules of the Exchange with the member or firm, shall without unnecessary delay proceed to close the same. If the contracts involve securities admitted to quotation upon the Exchange the closing must be in the Exchange, either officially by the Chairman, or by personal purchase or sale. If the contracts involve securities not dealt in on the Exchange, the purchase or sale of such securities must be promptly made in the best available market. Should a contract not be closed, as above provided, the price of settlement shall be fixed by the price current at the time when such contract should have been closed under this rule.

SEc. 2. A contract which has not been fulfilled according to the terms thereof may be officially closed "under the rule" by the Chairman, as hercin provided.

Notice of intention to make such closing of a contract must be delivered, at or before two-thirty o'clock P. M., at the registered office address of the member or firm in default. And the Chairman shall not close such contract before two thirty-five o'clock P. M.

SEc. 3. Every notice of intention to close a contract "under the rule," because of non-delivery, shall be in writing; and shall state the name of the member or firm by whom the order is given, also for whose acconnt-all of which shall be announced by the Chairman before closing the contract. 
The closing of a contract "under the rule," made in conformity with such notice, shall be also for the account and liability of each succeeding party in interest.

SEc. 4. Notice of intention to close a contract "under the rule" may be given upon the entire amount in default or upon any portion thereof, but in this latter case for not less than one hundred shares of stock or ten thousand dollars oî bonds.

SEc. 5. When notice that a contract will be closed "under the rule" is received too late for transmission to other members or firms interested in such contract, within the times stated therefor, the notified member or firm who is unable to so transmit said notice may, immediately after the official closing "under the rule," re-establish such contract by a new purchase or sale in the "regular way"; and any loss arising therefrom shall be a valid claim against the successive party or parties in interest.

SEc. 6. When a member has issued a notice of intention to close a contract "under the rule," for default in delivery, he must receive and pay for securities due upon such contract if tendered at his office within five minutes of the official time for closing; or thereafter, if tendered at the rostrum of the Exchange, before the Chairman has closed the contract.

SEC. 7. When a contract has been closed "under the rule," the member or firm who gave the order must give prompt notice of such closing to the member or firm in default.

Notification to successive parties in interest must be transmitted without delay, and claims for damages arising therefrom must be made prior to three o'clock P. Mr. of the business day following the closing of the contract.

SEc. 8. When a contract has been closed "under the rule" the Chairman shall endorse upon the order therefor the name of the purchaser or seller, the price and the hour at which such contract is closed, and deliver the order to the Secretary of the Exchange, who shall ascertain whether the money difference, if any, has been paid. If such difference shall not be paid within twenty-four hours after the closing of the contract, the Secretary shall report such default to the President.

SEc. 9. When a contract is closed "under the rule," any member or firm accepting the bid or offer, as made by the Chairman, and not complying promptly therewith, shall be liable for any damages resulting therefrom.

The member or firm, for whose account a contract is being closed "under the rule," shall not be permitted to accept the bid or offer made by the Chairman.

SEc. 10. When a loan of money is not paid at or before two-fifteen 
o'clock P. M. of the day upon which it becomes due, the borrower sliall be considered as in default, and the lender may sell "under the rule" the securities pledged therefor, or so much thereof as may be necessary to liquidate the loan, in the manner prescribed in the foregoing Sections of this Article.

\section{Article XXIX}

\section{Irregularity in Securities}

Reclamation for irregularity in a security, when such irregularity affects only its currency in the market, must be made within ten days from day of delivery of the security.

\section{Article XXX}

\section{Disagreement on Terms of Contract}

When a disagreement arising from a transaction in securities shall be discovered, the money difference shall forthwith be established by purchase or sale by the Chairman, or by mutual agreement.

\section{Article XXXI \\ Deposits on Contracts}

SEc. 1. Mutual cash deposits of not exceeding ten per cent. may be required at any time by either party to a contract. Whenever the margin of either party becomes reduced to five per cent. by reason of changes in the market value of the securities, further deposits may be called, from time to time, sufficient to restore the impaired margin.

SEc. 2. The holder of a due-bill issued for the dividend on stock contracted for may require the maker of the duc-bill to deposit the full amount due thereon, in a Trust Company, payable to the joint order of both parties.

SEc. 3. When deposits are called before two o'clock P. M., they must be made at or before two-thirty o'clock of the same day; if called after two o'clock $\mathbf{P}$. M. they must be made at or before ten-thirty o'elock A. M. of the following business day.

On half-holidays observed by the Exchange, deposits called before eleven o'clock A. M. must be made at or before eleven-thirty o'clock A. M. ; if called after eleven o'clock A. M. they must be made at or before ten-thirty o'clock A. M. of the next business day.

SEc. 4. Failure of either party to a contract to comply with a demand for a deposit shall constitute a default; and the other party to the contract may report such default to the Chairman, and instruct him to re-establish the contract forthwith, by a new purchase or sale 
"under the rule," and any difference arising therefrom shall be paid to the party entitled thereto.

Written notice of intention to re-establish the contract shall be sent to the office of the party in default.

SEC. 5. Unless otherwise mutually agreed, deposits on contracts shall be made in the New York Life Insurance and Trust Company.

\section{Article XXXII}

\section{Dividends-Interest_Premium}

SEc. 1. On the day of closing of the transfer books of a corporation for a dividend upon its shares all transactions therein for "Cash" shall be "dividend on" up to the time officially designated for the closing of transfers; all transactions on that day other than for "Cash" shall be "ex-dividend."

Should the closing of transfers occur upon a holiday or half-holiday, observed by the Exchange, transactions on the preceding business day, other than for "Cash" shall be "ex-dividend."

SEc. 2. The buyer shall be entitled to receive all interest, dividends, rights and privileges, except voting power, which may pertain to the securities contracted for, and for which the transfer books shall close during the pendency of the contract.

When such contract shall mature before the official date for payment of interest or dividend, the seller shall deliver a due-bill therefor signed or endorsed by him.

When a security is sold before the day of closing books for "Rights" (and is quoted "ex-Rights" on that day), and is delivered thereafter, the buyer shall on its delivery pay only the market price of the security "ex-Rights." He shall pay the balance due on the contract, when the seller delivers the "Rights," at any time on or before the day set by the Committee on Securities for settlement of contracts in "Rights."

When a security is loaned before the day of closing books for "Rights" (and is quoted "ex-Rights" on that day), and is returned thereafter, the lender shall on its return pay only the market price of the security "ex-Rights." He shall pay the balance due on the contract, when the borrower delivers the "Rights," at any time on or before the day set by the Committee on Securities for settlement of contracts in "Rights."

SEc. 3. A charge of one per cent. may be made for collecting diridends. For scrip or stock dividends the charge shall be computed upon the market value of such scrip or stock.

No charge shall be made for collecting dividends accruing on securities deliverable on a contract. 
SEc. 4. Offers to buy or sell dividends shall not be made publicly on the Exchange. The Chairman shall impose a fine of twenty-five dollars for each violation of this rule.

SEc. 5. When securities are borrowed or loaned the sum agreed upon, either as interest for carrying or as premium for use, shall be paid whether such securities are delivered or not.

SEc. 6. When money or securities are loaned at a premium said premium shall apply to the day for which the loan is made.

\section{Article XXXIII}

\section{Transfer and Registry}

SEc. 1. Corporations whose shares are admitted to dealings upon the Exchange will be required to maintain a Transfer Agency and a Registry office in the City of New York, Borough of Manhattan. Both the Transfer Agency and the Registrar must be acceptable to the Committee on Stock List, and the Registrar must file with the Secretary of the Exchange an agreement to comply with the requirements of the Exchange in regard to registration.

SEc. 2. When a corporation purposes to increase its authorized capital stock, thirty days' notice of such proposed increase must be officially given to the Exchange, before such increase may be admitted to dealings.

SEc. 3. When the capital stock of a corporation is increased through conversion of convertible bonds, already listed, the issuing corporation shall give immediate notice to the Exchange and the Committee on Stock List may, thereupon. authorize the registration of such shares and add them to the list.

SEc. 4. The Governing Committee may suspend dealings in the securities of any corporation previously admitted to quotation upon the Exchange, or it may summarily remove any securities from the list.

SEc. 5. After the admission of a security to dealings upon the Exchange no change in the form of certificate, or of the Transfer Agency or the Registrar of Shares, or of the Trustee of Bonds shall be made without the approval of the Committee on Stock List.

\section{Article XXXiv}

\section{Commissions}

SEc. 1. Commissions shall be charged and paid, under all circumstances, upon all purchases or sales of securities dealt in upon the Exchange; and shall be absolutely net, and free from all or any rebatement, return, discount or allowance in any shape or manner whatsoever, or by any method or arrangement, direct or indirect; and no 
bonus, nor any percentage or portion of the commission, shall be given, paid or allowed, directly or indirectly, or as a salary, or portion of a salary, to any clerk or person, for business sought or procured for any member of the Exchange.

SEc. 2. All commissions shall be calculated upon the par value of securities and the rates shall be as follows:

(a) On business for parties not members of the Exchange, including joint-account transactions in which a non-member is interested, transactions for partners not members of the Exchange, and for firms of which the Exchange member or members are special partners only, the commission shall be not less than one-eighth of one per cent.

(b) On business for members of the Exchange, the commission shall be not less than one-thirty-second of one per cent., except when a principal is given up, in which case the commission shall be not less than one-fiftieth of one per cent.

(c) On Mining Shares, Subscription Rights, and Notes of Corporations, such rates, to members and non-members, as may be determined, from time to time, by the Committee on Commissions with the approval of the Gorerning Committee.

(d) Government and Municipal Securities are exempted from the provisions of this Article.

SEC. 3. A firm having as a general partner a member of the Exchange shall be entitled to have its business transacted at the rates of commission hereinbefore prescribed for members. A member of the Exchange cannot confer this privilege upon more than one firm at any one time.

The privileges provided for under this Section can only be conferred upon a Branch House in this country when established under the same name as the parent firm and in which the partners and their respective interests are identical with those of the parent firm.

SEC. 4. A proposition for the transaction of business, at less than the minimum rates of commission herein provided, shall constitute a violation of this article.

SEc. 5. A member suspended by the Governing Committee shall not, during the time of his suspension, be entitled to have his business transacted at member's rates of commission.

A member who is in suspension by reason of insolvency may have his business transacted at member's rates.

SEc. 6. If the Governing Committee shall, by a majority vote of all its existing members, determine that a member of the Exchange has violated the provisions of this Article, it shall suspend such member, for the first offense, for such period not less than one year nor more than five years, as a majority of the members of said Committee 
present may determine. A member adjudged guilty of a second offense, by a majority vote of all the existing members of the Governing Committee, shall be expelled by a like vote.

\section{Article XXXV}

\section{Office Address-Partnerships-Branch Offices}

SEc. 1. Every member shall register with the Secretary an address, and subsequent changes thereof, where notices may be served. The registered address of every member transacting business upon the Exchange must be in its vicinity.

SEc. 2. When a member shall form a partnership he shall immediately register the same with the Secretary; official announcement thereof shall be made to the Exchange and notice posted upon the bulletin for ten days. Notice of dissolution of partnership must be given in like manner.

SEc. 3. No person shall be eligible to either general or special partnership in more than one registered firm at the same time.

This law shall not obtain, however, when a member of a registered firm forms a partnership in a foreign country under the same or different name from that of his firm in this country; provided, however, that the firm in said foreign country shall not derive any benefit from the privileges which attach to members of firms registered at the Stock Exchange.

SEC. 4. A member shall not form a partnership.with a suspended member of the Exchange, nor with any person who has been expelled therefrom; nor with any insolvent person, or with any person who may have previously been a member of the Exchange, and against whom any member holds a claim, arising out of transactions made during the time of such membership, and which has not been released, or settled in accordance with the laws of the Exchange.

A member, who is a special partner in a firm, does not thereby confer any of the privileges of the Exchange on such firm.

SEc. 5. A member of the Exchange who is a general partner in a firm represented thereon is liable to the same discipline and penalties for any act or omission of said firm as if the same were committed by him personally; but the Governing Committee may in its discretion by a vote of not less than thirty members relieve him from the penalty therefor.

SEc. 6. Members may, by the consent and approval of the Committee on Commissions, establish Branch Offices. Such offices must be in charge of either a partner, or of a manager or clerk acceptable to said Committee.

The member or firm establishing a Branch Office shall register it 
with the Secretary of the Exchange, and shall be directly responsible for the conduct of its business.

The managing clerk and all other employees must be paid fixea salaries, not varying with the business.

No agents for the solicitation of business, shall be employed on any other than the foregoing basis.

SEc. 7. Whenever it shall appear to the Governing Committee that a member has formed a partnership, or established a branch office, or is individually or through any member of his firm, interested in a partnership in a foreign country, whereby the interest or good repute of the Exchange may suffer, the Committee may require the dissolution of such partnership, the discontinuance of the interest in said foreign partnership, or of such branch office, as the case may be.

SEC. 8. Any member failing to comply with any requirement of this article, or with any requirement of the Governing Committee in regard thereto, shall be liable to suspension for a period not exceeding one year.

\section{ARticle XXXVI.}

\section{Disorderly Conduct.}

SEc. 1. Indecorous language, or an act subversive of good order and decorum, or serious interference with the personal comfort or safety of another. person is forbidden. Any member who shall violate this rule, within the limits of any department of the Exchange, may be fined by the Chairman, or by the Committee of Arrangements, in a sum not exceeding fifty dollars; or upon complaint made may be summoned before the Governing Committee and suspended for a period not exceeding sixty days.

SEC. 2. The Committee of Arrangements may make rules to govein the conduct of members upon the Exchange; it may impose a fine, not exceeding fifty dollars, for each violation thereof, or may report the delinquent to the Governing Committee, who may suspend him for a period not exceeding sixty days.

SEC. 3. Betting or offering to bet, upon the floor of the Exchange. is forbidden. A member violating this rule shall be subject to the penalties prescribed in the preceding Section of this Article.

\section{Article XXXVII.}

Minutes-Visitors-Communications.

SEc. 1. Members shall have access to the minutes of the Exchange.

SEC. 2. Visitors shall not be admitted to the floor of the Exchange 
except by permission of the President or the Committee of Arrangements.

SEc. 3. Communications shall not be read to the Exchange without the consent of the President or the Committee of Arrangements.

\section{ARTICLE XXXVIII.}

\section{Alterations of the Constitution.}

The Governing Committee may make additions, alterations or amendments to the Constitution by a majority rote of all its existing members. Every proposed addition, alteration or amendment must be presented, in writing, at a regular meeting of the Governing Committee, and referred to the Committee on Constitution, which shall report thereon at the next regular meeting of the Governing Committee, or at a special meeting called for the sole purpose of considering it. Action thereon may be postponed to a fixed date by a vote of two-thirds of the members of the Governing Committee present. Such alterations when adopted by the Governing Committee shall be submitted to the Exchange and shall stand as the law of the Exchange, if not disapproved within one week by a majority vote of the entire membership.

No alteration of Article XVIII shall ever be made which will impair, in any essential particular, the obligation of each member to contribute, as therein provided, to the provision for the families of deceased members.

\section{Resolutions Adopted by the Governing Committee.}

\section{Advertising.}

February 9, 1898.

"That in future the publication of an advertisement of other than a strictly legitimate business character, by a member of the Exchange, shall be deemed an act detrimental to the interest and welfare of the Exchange."

\section{Arbitrage Dealings.}

February 9, 1898.

"Whereas, The so-called Arbitrage business or trading between this Exchange and that of any other city in the United States, based upon quotations from the floor of this Exchange, has resulted in practically ignoring the commission law; therefore

"Resolved, That in the judgment of this Committee the sending of continuous quotations or quotations at frequent intervals by members of this Exchange, from the floor of the Exchange, is detrimental to the interest and welfare of the Exchange, and that any member engaging 
in such business or trading shall be proceeded against under Section 8 of Article XVII of the Constitution;

"Resolved, That the Committee of Arrangements be and they hereby are authorized and instructed to prevent the transaction of any such business or trading by any member of this Exchange, and to prefer charges against any member engaging therein."

\section{Foreign Arbitrage-Joint Accounts.}

(To take effect July 1, 1911.)

APril 20, 1911.

"Whereas, The so-called Arbitrage business by means of joint account trading between this Exchange and foreign cities, where each party interested charges a commission or allowance, has resulted in practically nullifying the Commission Law; therefore

"Resolved, That any business, domestic or foreign, for the joint account of a member of the Exchange and a non-member, where each party in interest charges a commission or allowance, is hereby prohibited.

"Resolved, That any business, domestic or foreign, conducted under an arrangement of accounts, not joint account in name, but designed to produce results similar to those of the above described joint account, is hereby prohibited."

\section{Bids and Offers.}

December 14, 1898.

"That where parties have orders to buy and orders to sell the same security, said parties must offer said security, whether it be stock or bonds, at one-eighth per cent. higher than their bid before making transactions with themselves."

\section{Rules Covering Bids and Offers.}

MaRCh 30, 1910.

(Amended May 12, 1911.)

1. That the recognized quotation on stocks shall be public bids and offers on lots of 100 shares.

2. All bids and offers on larger lots shall be considered to be for any part thereof in lots of 100 shares or of multiples thereof, whether so stated in the bid or offer or not.

3. If a bid is made for a larger lot of stock above the price at which smaller lots are offered, or if a transaction is made in a larger lot above the price at which smaller lots are offered, such bidder or buyer shall be compelled to buy any or all of the smaller lots which were publicly offered at the time, at the lower price, up to the amount of the bid for the larger lot. If the bid for the larger lot is accepted, and the 
buyer is unwilling to buy more, the seller must give up to the members who were publicly offering to sell at the lower price, such amounts as they were publicly offering to sell at the lower price, if such claim is made immediately.

4. If an offer is made to sell a larger lot of stock below the price which is bid for smaller lots, or if a transaction is made in a larger lot below the price which is bid for smaller lots, such member offering to sell, or the seller, shall be compelled to sell any or all of the smaller lots which were publicly bid for at the time, at the higher price, up to the amount of the offer of the larger lot. If the offer of the larger lot is accepted, and the seller is unwilling to sell more, the buyer must give up to the members who were publicly bidding the higher price, such amounts as they were publicly bidding for, at the higher price, if such claim is made immediately.

5. A member may sell on offer the largest amount bid for without regard to priority of bids. Should the offer be of an amount larger than the largest bid, the balance shall go to the next largest bidder in sequence; bids for equal amounts being on a par.

A member may buy on bids under the same rule.

6. Attention is directed to the resolution of the Governing Committee adopted October 26,1892 , which reads as follows:

"When a purchase or sale is claimed by a party who states that he had on the floor a prior or better bid or offer such claim shall not be sustained if the bid or offer was not made with the publicity and frequency necessary to make the existence of such bid or offer generally known at the time of the transaction."

7. Disputes arising from a questicn as to priority of bid or offer, if not settled by agreement between the members interested, shall be settled by vote of the members knowing of the transaction in question.

Disputes as to the application of rules relating to the transaction in question, if not settled by agreement between the members interested, shall be settled by any member of the Committee of Arrangements.

8. The above rules shall not apply to lots of less than 100 shares, nor to active openings when bids and offers are simultaneous.

\section{Members Dealing with Themselves - Specialists}

March 30, 1910.

(To take effect April 4, 1910.)

"Resolved, That any member of the Exchange who, while acting as a broker, either as a 'Specialist' or otherwise, shall buy or sell directly or indirectly for his own account, for account of a partner, or for any account in which he has an interest, the securities, the 
order for the purchase or sale of which has been accepted by him for execution, shall be deemed guilty of conduct or proceeding inconsistent with just and equitable principles of trade, and shall be subject to the penalties provided in Article XVII, Section 6, of the Constitution.

"The foregoing rule shall not apply to the act of a member who by reason of his neglect to execute an order is compelled to take or to supply on his own account the securities named in the order; in such case the member is not acting as a broker and shall not charge a commission.

"A member,' acting as a broker, is permitted to report to his principal a transaction as made with himself, only when he has orders both to buy and to sell and not to give up, and then he must add to his name on the report, 'On order,' or words to that effect."

\section{Bucket-shops}

MAY 19, 1909.

"That any member of this Exchange who is interested in, or associated in business with, or whose office is connected, directly or indirectly, by public or private wire or other method or contrivance with, or who transacts any business directly or indirectly with or for, any organization, firm or individual engaged in the business of dealing in differences or quotations (commonly called a bucketshop) shall, on conviction thereof, be deemed to have committed an act or acts detrimental to the interest and welfare of this Exchange."

\section{Clearing Charges}

NOVEMber 23, 1881 .

"That in transactions where orders are received from a nonmember, wherein the broker filling the order is directed to give up another broker or clearing-house, the responsibility of collecting the full commission of one-eight per cent. shall rest with the broker or clearing-house settling the transaction."

OCtober 24, 1894.

"That in transactions where orders are received from a member on which a clearing firm is given up by said member or by his order, the responsibility of collecting the full commission of one-thirtysecond of one per cent. shall rest with said clearing firm; and it shall be the duty of the broker who executes such orders to report the transactions to the clearing firm and render to them and collect his bill therefor at the rate of one-fiftieth of one per cent.; and also that where a broker executes an order for a member and clears the security himself, he must charge one-thirty-second of one per cent." 
December 28, 1911.

"That hereafter when a member of the Exchange receives and delivers securities for another member, the clearing charge for said service may be a matter of mutual agreement."

JANUARY 24, 1912.

"That the Governing Committee rules that in the matter of clearing charges between members of the Exchange, said charges shall be based upon a stipulated sum of money for each one hundred shares of stock or ten thousand dollars of bonds, or portions thereof."

"The payment of a certain sum of money for any period of time for said service, irrespective of the number of shares or amount of bonds cleared, is forbidden."

\section{Clerks in Nominal Positions.}

JANUARY 23, 1901.

"That the employment of a clerk or clerks in a nominal position because of the business obtained by such clerk or clerks for their employer, is a violation of the rules. Articles XXXIV and XXXV of the Constitution."

\section{Clerks, Speculative Transactions for.}

MaRch 30, 1910.

(To take effect April 4, 1910.)

"That the taking or carrying of a speculative account, or the making of a speculative transaction, in which a clerk of the Exchange, or of a member of the Exchange, or of a bank, trust company, banker or insurance company, is directly or indirectly interested, unless the written consent of the employer has been first obtained, shall be deemed an act detrimental to the interest and welfare of the Exchange."

\section{Responsibility for Accounts - Fictitious Names, etc.}

"That every member of the Exchange be required to use due diligence to learn the essential facts relating to every account accepted by himself or by his clerks or representatives, and also relating to the possible use of a name for the account other than that of the party interested."

\section{Commissions.}

Reciprocal Business.

Aprir 14, 1897.

"That transacting or offering to transact business in grain, produce, cotton or other commodities, without commission, or for a nominal 
commission, by any member of this Exchange or firm represented therein, for a customer dealing in securities dealt in at the Exchange, is a method or arrangement for rebatement of commissions, and is a violation of the commission law.

"That giving or offering to give reciprocal business in grain, produce, cotton or other commodities dependent upon the amount of Stock Exchange business received is a method or arrangement for rebatement of commissions and is a violation of the commission laws."

\section{Commission on Mining Shares.}

APRIL 13, 1910.

"That the rates of commission on mining shares shall. be based upon selling price, regardless of par value, and shall not be less than the following, for each one hundred shares:

\begin{tabular}{|c|c|c|c|}
\hline $\begin{array}{l}\text { Selling at } \\
\$ 10 \text { and above. }\end{array}$ & $\begin{array}{l}\text { For Non- } \\
\text { Members, } \\
\text {...\$12.50 }\end{array}$ & $\begin{array}{c}\text { For Members, } \\
\text { if cleared. } \\
\$ 3.121 \%\end{array}$ & $\begin{array}{c}\text { For Members, } \\
\text { if given up. } \\
\$ 2.00\end{array}$ \\
\hline Below $\$ 10 \ldots$ & .. 6.25 & $1.561 / 4$ & 1.00 \\
\hline
\end{tabular}

\section{Taking Over or Accepting Transactions.}

APRIL 12, 1911.

"Whenever a non-member of this Exchange shall cause to be executed in any market outside of the United States any order or orders for the purchase or sale of securities listed on this Exchange, other than Government, State or Municipal securities, and said purchase or sale shall be accepted by a member or a firm who are members of this Exchange, for the account of said non-member, oneeighth of one per cent. commission shall be charged said non-member in addition to any commission charged by the party or parties making the transaction."

\section{Commissions.}

\section{(Bunched Orders.)}

\section{JUNE 12, 1912.}

The Committee on Commissions reported to the Governing Committee that complaint had been made that a custom prevails upon the Floor of what is called "bunched" orders - that is, when one member has 300 shares of stock to sell, another 200 and another 500, they "bunch" the lots, one of said members offering the entire lot of 1,000 shares; if he succeeds in disposing of said lot, it is not the custom for him to charge his associates in the sale any commission.

The Committee on Commissions expressed the opinion that such an arrangement or custom is contrary to the commission law and 
should not be permitted, and asked the confirmation of said opinion by the Governing Committee.

On motion, said opinion was confirmed.

\section{Commission on Government Securities}

JUNE $12,190 \%$.

"That the Commission Law, in Subdivision $d$, Section 2, Article XXXIV, of the Constitution, which reads as follows:

"'Government and Municipal Securities are exempted from the provisions of this article,' refers only to securities of the United States, Porto Rico or the Philippine Islands, and of States and Municipalities therein."

\section{Comparisons.}

November 9, 1904.

"That when a mistake in comparison is made, either by a member in person or by his clerks, thereby causing a loss to another member, or when a failure to promptly fulfill the duties imposed by the comparison law causes a loss to another member, the member sustaining the loss may bring a suit before the Arbitration Committee, joining as defendants, if he so elects, any or all of the parties concerned, and the Arbitration Committee may render such verdict against any or all of the defendants as the facts in the case may warrant."

\section{Interest}

March 26, 1902.

"That any agreement or arrangement entered into between a member or his firm, and his or their customer, whereby special and unusual rates of interest are stipulated for, or money-advances upon unusual terms are made a condition, in connection with the conducting of an account, with intent thereby to give special or unusual advantages to such customer, for the purpose of securing his business, shall be deemed to be a violation of Article XXXIV of the Constitution, commonly known as the Commission Law."

\section{Money Loans-Interest.}

OCTOBER 25, 1899.

"When a member has contracted to borrow money on collateral, the simple payment of the interest by the borrower to the lender, after three o'clock P. M.., without actually effecting or properly endeavoring to effect a loan, shall be held to be an evasion of the contract and an act detrimental to the interest and welfare of the Exchange, and the offending member may be proceeded against under Section 8, Article XVII, of the Constitution." 


\section{Stamp Tax}

MaY 24, 1905.

"That in the judgment of the Governing Committee any member of the Exchange who, by agreement or otherwise, directly or indirectly, assumes or bears for his own account, or relieves his principal from any part of the Stamp Tax imposed by the Act of the Legislature of the State of New York, approved April 15, 1905, is guilty of a violation of Article XXXIV of the Constitution relating to commissions."

\section{Failure to Affix Stamps}

NoveMber 9, 1910.

"The Governing Committee calls the attention of members to the following resolution adopted on May 26, 1905:

'In order to constitute a good delivery after June 1, 1905, all deliveries on sales of stock, whether by Clearing-House delivery ticket or by certificate of stock, must be accompanied by a sales ticket stamped in accordance with the Act of the Legislature of the State of New York, adopted April 19, 1905, providing for a Tax on Transfers of Stock.'

"Any wilful failure on the part of a member to affix the stamps required by Article XII of the Tax Law relating to the Tax on Trans. fers of Sales of Stock, will be deemed by the Governing Committee an act detrimental to the interest and welfare of the Exchange."

\section{Telephones}

November 8, 1911.

"That the resolution adopted by the Governing Committee on March 28, 1900, be amended by striking out the words 'Sec. 8,' and inserting in lieu thereof the words 'Sec. 10,' so that said resolution as amended shall read as follows, viz.:

"Resolved, That the privilege of telephonic communication between the offices of members and the building of the New York Stock Exchange shall not be enjoyed as of right but shall rest in the discretion of the Committee of Arrangements or the Governing Committee, and that the Committee of Arrangements shall have power in their discretion, at any time, and from time to time, to withhold such privilege from any member, and to disconnect, or cause to be disconnected, any private telephone in the Stock Exchange building. Said Committee shall also have power in their discretion, at any time, and from time to time, to deprive any member of the privilege of using any public telephone in the Stock Exchange building; said 
Committee shall not be obliged to assign any reason or cause for any action taken by them under this resolution.

"Any member aggrieved by any decision of the Committee of Arrangements under this resolution shall have the right to appeal therefrom to the Governing Committee, and to appear in person before the Governing Committee to be heard upon such appeal.

"No such appeal shall suspend the operation of the decision appealed from.

"Every decision of the Committee of Arrangements by which the privilege of telephonic communication with the Stock Exchange building shall be withheld from any member, pursuant to this resolution, shall be immediately posted upon the bulletin board in the Exchange, and every member of the Exchange shall be deemed to have notice thereof. If after any such notice shall have been posted, any member of the Stock Exchange shall furnish to the member named therein, or to his partner or firm or office any facilities for communication between the office of such member and the Stock Exchange building, or between the office of the member named in such notice and the office of any other member of the Exchange by means of private wire, telephone or any electric or other device, contrivance or apparatus, he may be suspended by the Governing Committee for a period not exceeding two months, pursuant to the provisions of Sec. 10, Article XVII, of the Constitution of the Exchange."

\section{Telephone or Telegraph Connections.}

\section{(To take effect on June 1, 1900.)}

MAY $9,1900$.

"First.-That hereafter no member of the Stock Exchange and no firm of which such member is a partner, shall establish telephonic or telegraphic wire connection between the office of such member or firm and the office of any firm or individual not a member of the Stock Exchange transacting a banking or brokerage business, unless application therefor shall first be made to the Committee of Arrangements, and shall have been approved by them.

"Second. - Every such telephonic or telegraphic wire connection which shall be so authorized by the Committea of Arrangements, as well as all existing telephonic or telegraphic wire connections of the same character, shall be registered with the Committee of Arrangements, who shall make such regulations governing the matter as they shall deem necessary.

"Third. - That the Committec of Arrangements shall have power, at any time, in their discretion, to order any connection of the character described in these resolutions to be discontinued. 
"Fourth. - While members of the Stock Exchange may connect their offices by wire with the offices of non-members, in accordance with the provisions of these resolutions, and pay for such wire connection, nevertheless no such member shall directly or indirectly, by himself or through his firm, pay the cost of telegraph operators or any other expense pertaining to non-members' offices.

"Fifth. - No office in the City of New York of any member of the Stock Exchange, or of any firm of which such member is a partner, shall be connected by telegraphic or telephonic wire with any point outside of the City of New York unless such wire shall be furnished by a telegraph or telephone company approved by the Committee of Arrangements. Said Committee shall from time to time formulate a list of such approved companies.

"Sixth. - Any member violating any provision of these resolutions, or any regulation made by the Committee on Arrangements in pursuance thereof, shall be deemed guilty of an act detrimental to the interest and welfare of the Exchange."

\section{Privileges}

February 14, 1912.

"When securities are received or delivered on a privilege for a nonmember, one-eighth of one per cent. commission must be charged whether said securities are received or delivered upon the day of expiration of said privilege or prior thereto."

\section{Margins - Improper Use of Customers' Securities - Reckless and Unbusinesslike Dealing}

February 13, 1913.

"That the acceptance and carrying of an account for a customer, either a member or a non-member, without proper and adequate margin may constitute an act detrimental to the interest and welfare of the Exchange, and the offending member may be proceeded against under Section 8 of Article XVII of the Constitution.

"That the improper use of a customer's securities by a member or his firm, is an act not in accordance with just and equitable principles of trade, and the offending member shall be subject to the penalties provided in Section 6 of Article XVII of the Constitution.

"That reckless or unbusinesslike dealing is contrary to just and equitable principles of trade, and the offending member shall be subject to the penalties provided in Section 6 of Article XVII of the Constitution, in every case in which the offense does not come within the provisions of Section 5 of Article XVI thereof." 
Resolved, That no Stock Exchange member or member of a Stock Exchange firm shall give, or with knowledge execute, orders for the purchase or sale of securities which would involve no change of ownership.

The punishment for this offense shall be as prescribed in Section 8 of Article XXIII of the Constitution regarding fictitious transactions. 


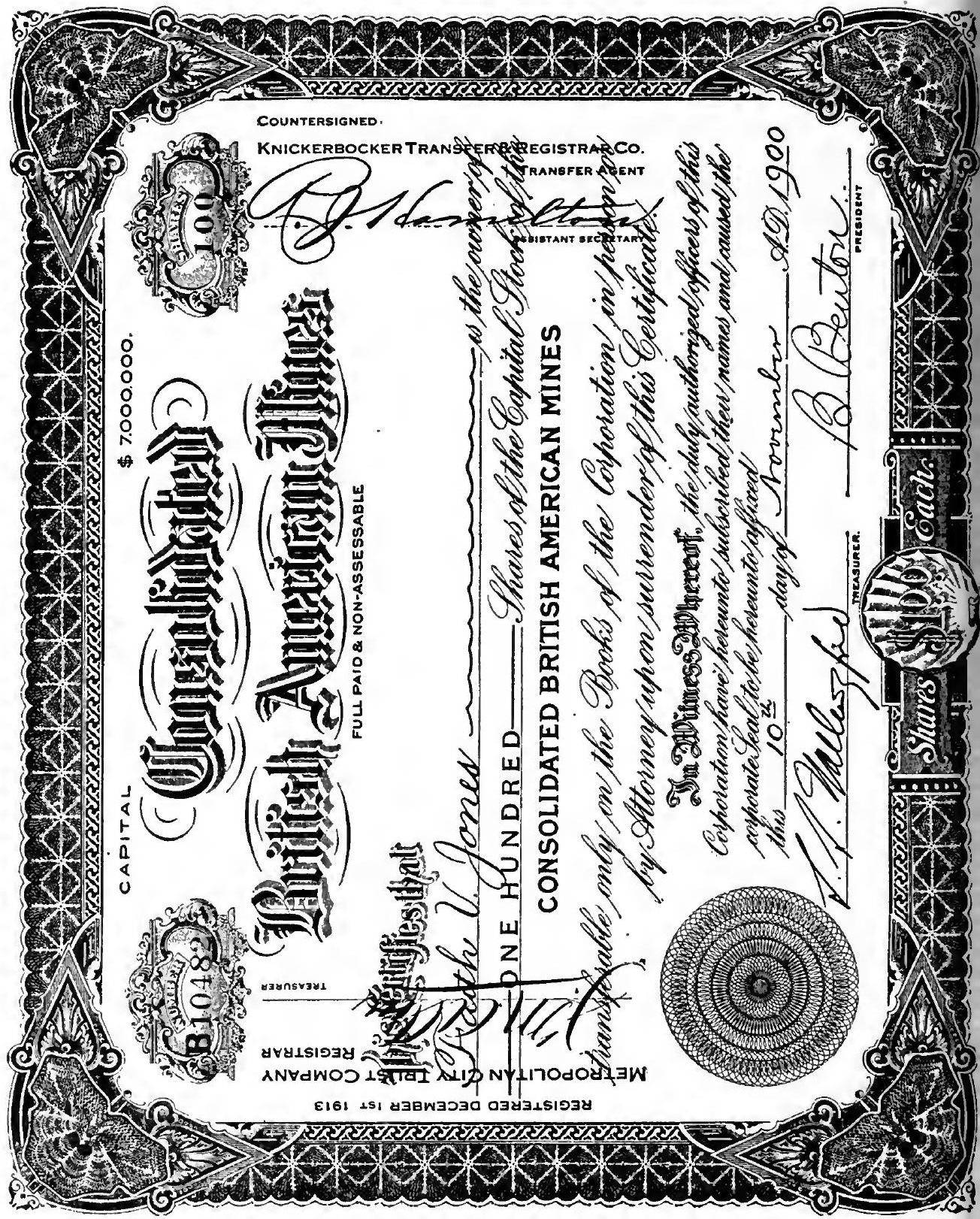




\section{RULES OF COMMITTEE ON STOCK LIST OF NEW YORK STOCK EXCHANGE.}

New York Stock Exchange.

JULY 1, 1912.

This Committee will meet on Mondays at $3: 30 \mathrm{P}$. M.

An application signed by an executive officer of a corporation must be filed with the Secretary of the Stock Exchange, and on notice six additional printed or typewritten copies must be filed on or before the Wednesday prior to date set for consideration.

Erery application must be accompanied by a check for Fifty Dollars for each $\$ 1,000,000$, or portion thereof, of the par value of each class of security. Checks should be drawn to the order of "Treasurer of the New York Stock Exchange."

\section{Requirements for Original Listings.}

RAILROAD CORPORATIONS.

Application for an original listing of the capital stock of railroad corporations shall recite the title of the corporation, date of organization and authority for same; special rights or privileges under charter; amount of capital stock authorized, issued, and applied for; par value; rate of dividend; voting power; whether capital stock is full paid and non-assessable; whether personal liability attaches to ownership; whether preferred stock is authorized, whether cumulative or non-cumulative; preference as to dividends and distribution of assets; location and route of road; description of property and total mileage in operation; contemplated extensions; total equipment; amount of mortgage lien, amount of other indebtedness or liability, jointly or severally, for leases, guarantees, rentals and car trusts, and terms of payment thereof; distribution of securities; application of proceeds; income account for onc year and balance shect of recent date; name and location of transfer agent and registrar; address of main office of corporation; list of officers and directors (classified); date and place of annual meeting; end of fiscal year.

Application for bonds shall recite in addition the full title; denominations; amount authorized, outstanding, applied for, with numbers, and authority for issue; date and maturity; rates of interest, when and where payable; distribution; names of trustees; redemption by sinking fund or otherwise; terms of exchange or convertibility into other securities; whether issued only in coupon form, registerable as to principal, or fully registered, or both, and if the latter, whether interchangeable; purposes of issue and application of procceds; terms 
of issue of additional amounts; trustees' obligation to declare principal and interest due and payable in event of default, and restrictions or limitations of unusual character; a tabulated list of properties owned, leased and operated, showing those covered by the mortgage or other indenture under which the bonds are issued; those covered by prior liens; indebtedness of leased companies or companies controlled by ownership of bonds and stocks, and the amount of such bonds and stocks owned, authorized, issued, assumed, guaranteed, or deposited as collateral.

If bonds are convertible into stock, file certified copy of the action of stockholders and directors authorizing issue and reservation of stock to be held specifically for such conversion.

When bonds are issued to replace other liens, the Committee will require evidence of the satisfaction of such liens, or a certificate of trustee that prior lien bonds are held under the terms of the mortgage or indenture.

A copy of the mortgage or indenture must be furnished, including a certificate from the County Clerk in each county in which the mortgaged property is located, that the mortgage or indenture has been recorded in such county. Should the laws of the State not require a record to be made in the several counties, a copy of certificate of the Secretary of the State, showing the legal record, shall be filed with the copy of mortgage or indenture. This copy must be certified by the Trustee to be a true copy.

When a mortgage or indenture provides that bonds may be issued interchangeably in coupon and registered form, each registered bond issued thereunder shall bear a legend reciting the number or numbers of the coupon bond or bonds reserved for exchange of such registered bond in substantially the following form:

The within bond is issued in lieu of or in exchange for (a) coupon bond (s), numbered ...... . for $\$ 1,000$ (each, none of) which bond (s) is (not) contemporaneously outstanding, and (a) coupon bond ( $\mathrm{s}$ ) bearing the said serial number(s) will be issued in exchange for this bond upon its surrender and cancellation.

A registered bond not interchangeable shall bear the following:

The within bond is issued in lieu of or in exchange for (a) coupon bond(s), numbered ....... for $\$ 1,000$ (each, none of) which bond(s) is (not) contemporaneously outstanding.

The Committee recommends that when fully registered bonds are to be issued, they shall be made interchangeable with coupon bonds.

When mortgages or indentures provide for the issuance of coupon bends of the denomination of 100 dollars, the Committee recom- 
mends that any ten such bonds be exchangeable into coupon bonds for 1,000 dollars each, and that each unit consisting of ten 100 dollar bonds bear a number together with an affixed letter (A to $J$ ) representing a 1,000 dollar bond reserved for exchange, and that each 100 dollar bond bear the following legend:

For this bond and nine other bonds of the same denomination and serial number, bearing affixed letters $A$ to $J$, a coupon bond for $\$ 1,000$ is held in reserve and is not contemporaneously outstanding, and on the surrender and cancellation of ten $\$ 100$ bonds of said series a coupon bond for $\$ 1,000$ will be issued in exchange therefor bearing the lowest serial number reserved for such purpose.

When bonds are to be denominated in foreign moneys, the Committee recommends that the standard of value in United States gold coin be stated, and that the text of all such bonds be in the English language with the foreign text in a parallel column. The English text shall govern the interpretation in all such issues.

(For papers and agreements to be filed, see pages 156 and 157.

\section{CORPORATIONS OTHER THAN RAILROADS}

Application for an original listing of securities of corporations other than railroads shall recite the title of the corporation, date of organization and authority for same; amount of capital stock authorized, issued and applied for; par value; rate of dividend; roting power; whether capital stock is full paid and non-assessable; whether personal liability attaches to ownership; whether preferred stock is authorized, whether cumulative or non-cumulative; preference as to dividends and distribution of assets, and redemption; whether an original organization or a consolidation of several previously existing firms or corporations; if a consolidation, a concise history of its organization, and the names and locations of constituent companies owned in entirety or otherwise, and amounts of authorized, issued and owned stocks of same; full description of the property, real, personal and leased; real estate owned in fee, acreage and location, and the character of buildings thereon; nature and character of product; business to be transacted; duration of charter and charters of subsidiary companies; special rights and privileges conveyed to the corporation under its charter, or to directors under by-laws; income account for one year and balance sheet of recent date; name and location of transfer agent and registrar; address of main office of corporation; list of officers and directors (classified); date and place of annual meeting; end of fiseal year.

For bond listings the requirements are substantially the same as for bonds of railroad corporations, page 156 .

(For papers and agreements to be filed, see pages 156 and 157. 


\section{MINING CORPORATIONS.}

Application to list securities of mining corporations shall recite details of original organization and authorized capitalization; amount of shares outstanding, amount applied for, amount of shares remaining unissued, and options or contracts on such shares; whether capital stock is full paid and non-assessable; par value; voting power; whether personal liability attaches to ownership; whether preferred stock is authorized, whether cumulative or non-cumulative; preference as to dividends and distribution of assets, and redemption; bonded indebtedness, if any, with date of issue, maturity and rate of interest; list and numbers of patented and unpatented claims; full description of mineral and other lands, leases and water rights, smelting and concentrating plants, timber and fuel supply, owned or controlled; a geological description of the country in which the mines are located showing the character of the ore produced, the proper method of treatment, a description of the ore bodies, average values, and probabilities on further exploration.

A history of the property giving prior workings of mine, results obtained and production each year, with statement of receipts and expenditures, and disposition of income; location of mines and proximity to railway or other common carrier; cost of mining, transportation, milling or smelting; balance sheet showing assets and liabilities; if a mining development and an income account not available, guarantee of an amount to complete development and afford working capital; statement of ore reserves compared with reserves of previous years and an estimate by a competent mining expert of the probable life of the mine; a balance sheet of all companies owned or controlled by stock ownership or otherwise; name and location of transfer agent and registrar; address of main office of corporation; list of officers and directors (classified); date and place of annual meeting; end of fiscal year.

For bond listings the requirements are substantially the same as for bonds of railroad corporations, page 156 .

(For papers and agreements to be filed, see pages 156 and 157 .

\section{REORGANIZED CORPORATIONS.}

Application to list securities of a corporation, which has been insolvent, or has been reorganized, shall recite a concise history of the corporation, and of its predecessor, with a statement of the reason for its reorganization; history of proceedings if property was sold under foreclosure; description and amount of all securities authorized, issued and applied for by the new corporation; tabulated statement 
of securities issued in lieu of, or exchanged for any of the preceding issues; purposes and terms in detail under which additional securities of the reorganized corporation may be issued; amount and description of the various securities which have been retired, canceled, deposited, or otherwise held, or are still outstanding; income account of the predecessor corporation for a period of at least one year prior to reorganization, and final balance sheet; also a balance sheet of the new corporation at date of reorganization; income account for one year and balance sheet of recent date; name and location of transfer agent and registrar; address of main office of corporation; list of officers and directors (classified); date and place of annual meeting; end of fiscal year.

(For papers and agreements to be filed, see pages 156 and 157.

\section{CERTIFICATES OF DEPOSIT IN TRUST.}

Institutions, firms, corporations, depositaries of securities under plans of reorganization, protective or associate action or voting trusts, are requested to accept on deposit only such securities as are a delivery on the Stock Exchange; provided, that in any case where said depositaries find it necessary to accept securities which are not a delivery, they shall issue therefor a distinctive certificate which will indicate the irregularity. Agreements for deposit of securities for protective or associate action must be limited to a specified time for continuance, within which a plan of reorganization or adjustment will be presented to the certificate holders for acceptance, or in default thereof such holders will be granted opportunity to withdraw the securities represented by their certificates, and terminate their agrecment. Penalty for dclay in depositing sccurities under any agreement should not be imposed until all holders of such securities have had reasonable opportunity for depositing, after the listing of the certificates of deposit.

Certificates of deposit will be considered as representing the deposit of coupon, registered, or interchangeable registered bonds. Certificates issued for deposit of non-interchangeable registered bonds or bonds not a delivery on the Stock Exchange must bear on their face evidence of such fact. Certificates of deposit for securities, whether for reorganization, protective or associate action, or for voting trusts, must bear the countersignature of some institution as registrar in same manner as certificates for stock.

(For papers and agreements to be filed, sce pages 150 and 157.

ADDITIONAL AMOUNTS OF LISTED SECURITIES

Application to list additional amounts of listed securities shall refer to previous applications by number; state character and amount 
of additional issues and amounts applied for; whether issued for cash, property, or otherwise; distribution; application of proceeds; amount, description and disposition of securities exchanged for new issues; additional property acquired and present physical condition; furnish income account and balance sheet of recent date; attested copy of resolutions of stockholders and action of directors as to issuance of the additional securities, and opinion of counsel as to validity of issue; trustee's certificate of issue of additional bonds under terms of the mortgage or indenture; certificate from the Secretary of State or other authority for increase in capitalization.

Thirty days' notice of any proposed increase in the authorized capital stock of a corporation shall be given to the Stock Exchange before such increase shall be eligible for listing.

The registrar shall not register any listed stock until authorized by this Committee.

When the capital stock of a corporation is increased through conversion of bonds, already listed, the issuing corporation shall give immediate notice to the Stock Exchange, and this Committee may thereupon add said stock to the list and authorize its registration.

(For papers and agreements to be filed, see below.)

\section{PAPERS TO BE FILED WITH APPLICATIONS}

For listing stocks:

Seven copies of the charter or articles of incorporation, one copy to be attested by the Secretary of State in which the corporation is incorporated.

Seven copies of by-laws, one copy to be attested by secretary of corporation.

Seven copies of leases and special agreements, one copy of each to be attested by the secretary of the corporation.

One copy of resolutions of stockholders authorizing issue and of the action of the directors thereunder, each attested by secretary of the corporation.

Opinion of counsel (not an officer or director of the corporation) as to legality of authorization and issue of securities.

Certificate of proper authority for issue.

Certificate of registrar as to amount of securities registered at date of application.

Report of a duly qualified engineer covering the actual physical condition of the property as of recent date.

Map of the property and contemplated extensions.

Specimens of all securities applied for.

In addition to the foregoing, for listing bonds:

Six additional copies of the mortgage or indenture.

Opinion of counsel shall cover-

$a$ as to organization,

$b$ as to validity of issue.

Trustees' certificate shall cover-

$a$ as to acceptance, 
b as to issuance under the terms of the mortgage or indenture with numbers and amount of bonds issued,

- as to securities held,

d as to cancellation or cremation or deposit of underlying securities, prior liens, etc.

Also, with applications for reorganized corporations:

Certified copies of legal proceedings and order of Court confirming sale, or other authority for reorganization.

Certified copy of plan of reorganization.

Opinion of counsel that the proceedings have been in conformity with legal requirements, that the title to the property is vested in the new corporation, and is free and clear from all liens and incumbrances, except as distinctly specified.

Certificate of cancellation, deposit, or holding of prior issues.

Certified copies of all mortgages or indentures.

\section{AGREEMENTS}

Every corporation applying to list securities must agree:

That it will not dispose of its interest in any constituent company, or allow any of said companies to dispose of its interests in other companies, except on direct authorization of stockholders of the holding company.

To publish at least once in each year and submit to the stockholders, at least fifteen days in advance of the annual meeting of the corporation, a detailed statement of its physical and financial condition, an income account covering the previous fiscal year, and a balance sheet showing assets and liabilities at the end of the year; also annually an income account and balance sheet of all subsidiary companies ;

To maintain a transfer office or agency in the Borough of Manhattan, City of New York, where all securities shall be directly transferable, and the principal of all securities with interest or dividends thereon shall be payable;

To give at least ten days' notice in advance of the closing of the books or the taking of a record of stockholders for any purpose. The Committee recommends that a date be fixed as record for dividends, allotment of rights and stockholders' meetings, without an extended closing of the transfer books.

To notify the Stock Exchange in the event of the issuance of any rights or subscriptions to or allotments of its securities and afford the holders of listed securities a proper period within which to record their interests, and that all rights, subscriptions or allotments shall be transferable, payable and deliverable in the Borough of Manhattan, City of New York. 
REMOVALS OR SUSPENSIONS IN DEALINGS OF LISTED SECURITIES

Whenever it shall appear that the outstanding amount of any security listed upon the Stock Exchange has become so reduced as to make inadvisable further dealings therein, this Committee may direct that such security be taken from the list and further dealings therein prohibited.

The Governing Committee may suspend dealings in the securities of any corporation previously admitted to quotation upon the Exchange, or may summarily remove any security from the list.

\section{TRUSTEES OF MORTGAGES}

The committee recommends that a trust company or other corporation be appointed trustee of each mortgage or indenture; but when a State law requires the appointment of a local individual as trustee, that a trust company or other corporation be appointed as co-trustee.

The Committee will not accept as trustee for securities an officer or director of the applying corporation, nor a corporation as a trustee in which an officer of the applying corporation is an executive officer.

The Committee will not accept the opinion of an officer or director of an applying corporation, nor of a firm in which the officer or director is a member, as counsel on any legal question affecting the corporation; nor will it accept the opinion of an officer or director of a guarantor corporation, on any legal question affecting the issuance of guaranteed securities.

Each mortgage, indenture or deed of trust made by a corporation or constituting a lien on property of the corporation should be represented by a separate trustee.

The trustee shall present a certificate accepting the trust, giving the numbers and amount of bonds executed, in accordance with the terms of the mortgage or indenture; and certifying that the lien has been recorded, that collateral has been deposited, and that prior obligations, if any, have been canceled, when required by the terms of the mortgage or indenture. The trustee holding securities for which listed certificates of deposit are issued must notify the Stock Exchange if the deposited securities are changed or removed for any reason. For additional issues of bonds, the trustee must certify that such increase has been made in conformity with the terms of the mortgage or indenture; that the lien has been recorded against any new property acquired, that the required additional collateral has been deposited, and that prior obligations, if any, have been canceled, when so required. The trustee shall notify the Stock Exchange of the holding, cancelation, or retirement, of bonds by redemption, or through the operation of the sinking fund, or by purchase. 
TRANSFER AND REGISTRY

Every corporation is required to maintain a transfer agency and a registry office in the Borough of Manhattan, City of New York. Both the transfer agency and the registrar must be acceptable to this Committee; the registrar must file with the Secretary of the Stock Exchange an agreement to comply with the requirements in regard to registration.

Certifications of registry must be dated and must bear the signature of a duly authorized officer of the corporation acting as registrar.

The registrar shall not register any listed stock until authorized by this Committee.

A trust company or other agency shall not at the same time act as transfer agent and registrar of a corporation.

When a company has its stock transferred at its own office, a transfer agent or transfer clerk shall be appointed by authority of the board of directors to countersign certificates, and shall be an individual other than an officer authorized by the by-laws of the company to sign certificates of stock.

The entire amount of the capital stock of a corporation listed upon the Stock Exchange must be directly transferable at the transfer office of the corporation in the Borough of Manhattan, City of New York.

When a corporation makes transfer of its shares in other cities, the certificates issued therefrom shall be interchangeable, and identical with the New York certificates, except as to the names of the transfer agent and the registrar, and the combined amounts of stocks registered in all cities shall not exceed the amount listed.

Interchangeable certificates must bear a legend indicating the right of transfer in New York and other cities.

A change in the form of certificate, of the transfer agency, of the registrar, or of the trustee of bonds, shall not be made without the approval of this Committee.

The Committee recommends that the text of bonds and certificates of stock shall provide for direct transfer without reference to the books of the corporation.

\section{ENGRAVED CERTIFICATES REQUIRED}

Evcry bond, coupon, or certificatc of stock must be printed from steel plates which have been engraved in the best manner and which have such varietics of work as will afford the greatest security against counterfeiting.

Certificates of depesit of trust companies, banks or firms for securi- 
ties deposited under reorganizations, voting trusts, or agreements for legal action, must be engraved and printed from steel plates with engraved border and engraved underlying tint.

For each bond, coupon, certificate of stock and certificate of deposit there must be at least two steel plates, viz.: A face plate containing the vignettes and lettering of the descriptive or promissory portion of the document which should be printed in black, or in black mixed with a color; and a tint plate from which should be made a printing in color underlying important portions of the face printing. The im. pressions from these two plates must be so made upon the paper that, the combined effect of the whole if photographed would be a confused mass of lines and forms, and so give as effectual security as possible against counterfeiting by any process.

The imprint of each denomination of bonds must be of such distinctive appearance and color as to make it readily distinguishable from other denominations and issues. It is required for each class of stock issued that there shall be a distinctively engraved plate for one hundred shares with said denomination engraved thereon in words and figures; for certificates issued for smaller amounts, there shall be a similar plate, distinctive in color, for each issue; there shall be engraved thereon some device whereby the exact written denomination of the certificate may be distinctly designated by perforation; also conspicuously the words, "Certificate for less than one hundred shares."

The terms of redemption by sinking fund or otherwise, and of conversion into other. forms of securities should be recited in the text of bonds.

Certificates of stock should recite ownership, par value, and whether shares are full paid and non-assessable; terms of redemption, preference as to dividends, voting power, or other privilege, including distribution of assets in the event of dissolution of the corporation; certificates for Common and Preferred Stock each shall recite preferences of the Preferred; also the following legend:

This certificate is not valid until countersigned by the transfer agent, and registered by the registrar.

A power of attorney upon the reverse of a certificate of stock must be irrevocable with a bill of sale and power of substitution. The following form is required:

For value received..$\ldots \ldots$ hereby sell, assign and transfer unto......... of the capital stock represented by the within certificate and do hereby irrev-

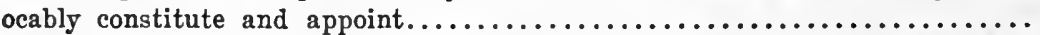


to transfer the said stock on the books of the within named company with full power of substitution in the premises.

Dated 19

In presence of

Notice: The signature to this assignment must correspond with the name as written upon the face of the certificate in every particular without altera. tion or enlargement, or any change whatever.

This Committee will object to any security upon which an impress is made by a hand stamp, except for a date or power of substitution.

No stock certificate or bond will be accepted unless it has been engraved by some engraving company whose work this Committee has been authorized by the Governing Committee to pass upon.

The name of the engraving company must appear upon the face of each bond and certificate of stock and upon the face of each coupon and the title panel of the bond.

Grorge W. Ely, Secretary. Wy. W. Heaton, Chairman. 


\section{APPLICATION FOR LISTING}

\section{A -4107}

COMMITTEE ON STOCK LIST, NEW YORK STOCK EXCHANGE

\section{PACIFIC LIGHT \& POWER COMPANY}

FIRST AND REFUNDING MORTGAGE TWENTY-YEAR FIVE PER CENT. BONDS

\section{(International Series)}

New YoRK, April 30, 1912.

Application is hereby made to list $\$ 5,295,000$ of an authorized issue of $\$ 30,000,000$ in aggregate principal amount of the Pacific Power \& Light Company First and Refunding Mortgage Twenty-year Five per cent. Gold Bonds, International Series, numbered from 1 to 5,295, inclusive, each for the sum of $\$ 1,000$ of the United States of America, and Registered Bonds for $\$ 5,000$ or multiples thereof, for which the same may be exchanged. Said bonds are also (at the options of the holders) payable in foreign countries in foreign currencies as follows: £205.4.2, sterling money of Great Britain, or 4,200 German marks, or 5,175 French francs, or 2,480 Dutch guilders.

The Coupon Bonds are subject to registry as to principal, and the Coupon and Registered Bonds are interchangeable. Registered Bonds are of the denomination of $\$ 5,000$ of the United States, or $£ 1,026.0 .10$, sterling money of Great Britain, or 21,000 German marks, or 25,875 French francs, or 12,400 Dutch guilders, or any multiple thereof.

These bonds are secured by a Mortgage or Deed of Trust from Pacific Power \& Light Company to United States Mortgage \& Trust Company, as Trustee, dated August 1, 1910.

The Coupon Bonds are dated August 1, 1910, and the Registered Bonds are dated as of the time of issue (except that if any Registered Bond is issued on August 1 or February 1, in any year, it shall be dated as of August 2 and February 2, respectively, in such year). Said bonds mature August 1, 1930, and bear interest at the rate of Five per Cent. per annum, payable semi-annually on the first days of February and August in each year, the principal being payable at the office or agency of the Company in the City of New York (the Company has no office in New York; its agency, however, for the payment of bonds is United States Mortgage \& Trust Company, 55 Cedar Street, New York, N. Y.), or at the holder's option! at the Company's office or agency in any of the following cities, to wit: Paris, France; London, England; Berlin, Germany; Amsterdam, Holland. 
The entire issue of said bonds is redeemable (but not, except in the case of redemption for the benefit of the improvement fund, in less part than all thereof) on any interest date at not more than One Hundred and Five per Cent. of the principal thereof and accrued interest if such redemption is effected not later than December 31, 1925. If such redemption is effected during the calendar year 1926 the redemption price will be One Hundred and Four per Cent. of principal and accrued interest. It will be One Hundred and Three per Cent. of principal and accrued interest during the year 1927, One Hundred and Two per Cent. during the year 1928, and One Hundred and One per Cent. during the year 1929, and during the period between January 1, 1930, and July 31, 1930, both inclusive. Notice of intention to redeem is required to be given by publication at least once a week for four successive weeks immediately preceding the date fixed for redemption in one newspaper of general circulation published in the City of New York and one newspaper of general circulation published in the City of Portland, Oregon.

Article III of the Mortgage establishes an improvement fund, whereby a cash fund is payable to the Trustee on August 1 of each year as follows: One per Cent. annually of the bonds outstanding, including underlying bonds and outstanding bonds of corporations whose Capital Stock at the time is owned by the Mortgagor and pledged under the Mortgage from 1915 to 1919 inclusive; Two per Cent. from 1920 to 1924 inclusive; Three per Cent. from 1925 to 1929 inclusive. The maximum payment remains at Two per Cent., however, when in any twelve months ending May 31 in any of the years from 1925 to 1929 inclusive the net earnings of the Company and its subsidiaries equal or exceed three times the annual interest charge on all bonds outstanding. Money in the improvement fund may be used for improvements and betterments to the property or as a sinking fund for the redemption of the First and Refunding Mortgage Twenty-year Gold Bonds on the same basis as provided in the Mortgage for the redemption of bonds.

Section 1 of Article VI of the Mortgage provides that if default in payment of interest or any payments to the improvement fund shall continue for ninety days, or any other default under said Mortgage, except in payment of principal, shall continue for ninety days, after notice from the Trustee or any bondholder, then, upon the election of the holders of a majority in interest of the bonds secured thereby and then outstanding, evidenced by an instrument or instruments in writing signed by them and delivered to the Trustee, the entire principal sum secured by said Mortgage and the interest accrued thereon shall become and be immediately due and payable, 
subject, however, to the right of a majority in interest of the holders of said bonds to annul such election and destroy its effect at any. time before sale under said Mortgage.

The total authorized amount of the Capital Stock of the Pacific Power \& Light Company is $\$ 3,500,000$ Preferred Stock, $\$ 2,500,000$ Second Preferred Stock and $\$ 6,000,000$ Common Stock. All of the Common Stock, $\$ 2,000,000$ of the Preferred Stock and $\$ 1,500,000$ of the Second Preferred Stock are outstanding.

The bonds covered by this application were issued for the following purposes, viz.:

For payment of unfunded debt of Pacific Power \& Light Company (Mtg., Art. I, Sec. 6, p. 67) ... \$3,200,000.00

For Refunding Underlying Bonds as follows:

Yakima Water, Light \& Power Company First Mortgage Five per Cent. Gold Bonds (Mtg., Art. I, Sec. 7, pp. 68-72) ..............

Northwest Light \& Water Company First Mortgage Five per Cent. Gold Bonds (Mtg., Art. I, Sec. 7 , pp. 68-72) ...................

Yakima Valley Power Company First Mortgage Five per Cent. Gold Bonds (Mtg., Art. I, Sec.

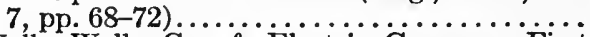

Walla Walla Gas \& Electric Company First Mortgage Six per Cent. Bonds (Mtg., Art. I, Sec. 7, pp. 68-72)...................

Northwestern Gas \& Electric Company First and Consolidated Mortgage Six per Cent. Sinking Fund Gold Bonds (Mtg., Art. I, Sec.

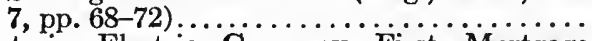

Astoria Electric Company First Mortgage Twenty-year Six per Cent. Gold Bonds (Mtg., Art. I, Sec. 7, pp. 68-72) .............

Walla Walla Valley Traction Company First Mortgage Five per Cent. Sinking Fund Gold Bonds (Mtg., Art. I, Sec. 7, pp. 68-72) ......

All of said underlying securities have been retired and cancelled, except in the case of the bonds of the Walla Walla Valley Traction Company. In that case $\$ 357,000$ of bonds and $\$ 6,000$ in cash have been pledged with the Trustee, and $\$ 363,000$ of bonds of Pacific Power \& Light Company have been issued therefor.

For permanent improvements and additions in accordance with the provisions of the Mortgage (Mtg., Art. I, Sec. 8, p. 72)............. 765,000.00

Total bonds issued and outstanding to date............

Balance, issuable as follows...................... 24,705,000.00

For an amount of principal equal to $80 \%$ (a) of the actual cost, reasonable worth and replacement value to the Company of any permanent improvements or additions to its plants or property other than shares of stock, bonds or other securities, or (b) of the actual cost to the Company of mortgage bonds or shares of stock (including First and Refunding Mortgage Five per Cent. Gold Bonds of

$133,000.00$

$63,000.00$

$14,000.00$

$81,000.00$

$526,000.00$

$150,000.00$

$363,000.00$

$\$ 5,295,000.00$ 
the Walla Walla Valley Railway Company) purchased and of the reasonable worth and replacement value of the property represented by such mortgage bonds or shares of stock, provided the net earnings of the Company and of underlying corporations for twelve months shall be not less than twice the interest charge upon outstanding bonds.

Such unissued balance may, in accordance with the terms of the Mortgage, be issued in the "International Series" in which the bonds already outstanding have been issued, or in any of the other series described in the Mortgage, viz.: The "American Series," payable in New York City only; the "French Series," payable in the City of Paris, France, only; the "English Series," payable in the City of London, England, only; the "German Series," payable in the City of Berlin, Germany, only; and the "Netherlands Series," payable in the City of Amsterdam, Holland, only; but in the construction of all bonds the English language shall prevail.

Pacific Power \& Light Company was incorporated on 'June 15, 1910 , under the laws of the State of Maine for the purpose of carrying on a general electrical and gas business with broad powers permitting it to engage (outside of the State of Maine) in electrical, gas, railway, steam, hot water, ice and water businesses. The period of its duration is unlimited. By deeds dated in July, 1910, it acquired electric lighting, power, gas and street railway properties in Washington, Oregon and Idaho, formerly owned by the Northwestern Corporation of Philadelphia, the Northwest Light \& Water Company, the Yakima Valley Power Company, the Astoria Electric Company and the Wasco Warehouse Milling Company.

All of the physical properties and assets so acquired are pledged under the Mortgage securing said First and Refunding Mortgage Twenty-year Gold Bonds, said Mortgage covering the business, franchises and real and personal properties of said Company situated in Washington, Oregon and Idaho, and any and all other property, real, personal and mixed, now owned or hereafter acquired by the Mortgagor and wheresoever situated, except such shares of stock, bonds, and other securities of other corporations as are not specifically mentioned in said Mortgage or acquired by the Company subsequent to the date of said Mortgage in whole or in part by the use of any of the bonds secured thereby or the proceeds thereof, or made the basis for the issuance of bonds secured thereby. At the time of the acquisition of said properties the Pacific Power \& Light Company purchased substantially all of the stock of the Wella Walla Valley Railway Company, operating an electric interurban railroad 
from Walla Walla, Washington to Freewater, Oregon, and pledged such stock under the Mortgage seeuring said First and Refunding Mortgage Twenty-year Gold Bonds. (All references in this application to interurban railroad lines are to those of said Walla Walla Valley Railway Company. The Pacific Power \& Light Company does not itself operate any interurban lines.) As of April 30, 1911, Pacific Power \& Light Company took over the properties formerly owned by the Husum Power Company operating a water power development on the White Salmon River, Washington, and supplying electrical energy to the towns of White Salmon and Bingen; Klickitat Light \& Power Company operating a water power development in Klickitat County, Washington and supplying electrical energy to Goldendale; Tucanon Power Company operating a water power development on the Tucanon River and supplying electrical energy to Pomeroy, Washington; Dayton Electric Company operating a water and steam plant on the Touchet River and supplying electrical energy to Dayton, Washington; Waitsburg Electric Light Company operating a water and steam plant on the Touchet River and supplying electrical energy to Waitsburg, Washington; Prosser Water Company and Prosser Power Company operating a combined hydraulic and steam plant on the Yakima River at Prosser, Washington, and supplying electrical energy and domestic water to the town of Prosser. These properties have been made subject to the lien of the Mortgage.

The Pacific Power \& Light Company furnishes electric light and power, street railway, gas and water service in many communities, as shown by the following list:

NAME

Astoria,

*Athena,

Bingen,

Dufur,

Freewater,

Milton,

Mosier,

Pendleton,

The Dalles,

*Weston,

*Attalia,

Benton City,

Beverly,

Centreville,

Clarkston,

Dayton,

Goldendale,

Grand View,

Granger,

Huntsville,

Husum,

Kennewick,

\section{Character of Service}

Oregon. Electric Light and Power. Gas. City cars.

W"

" $\begin{array}{lll} & \cdots & \text { " } \\ \text { " } & \cdots & \text { ". } \\ & \cdots & \text { " }\end{array}$

" "

Interurban cars (Walla Walla Vy. Ry. Co.).

“ . . Interurban Cars (Walla Walla Valley Railway Co.).

..Electric Light and Power.

.. " " " " " "

a a a a a

a d

" a

$\cdots$

. Electric Light and Power.

Gas.

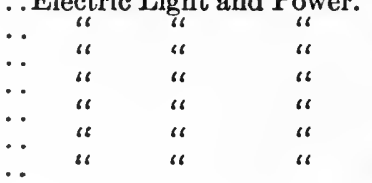

Water. 
NAME

Kiona,

Mabton,

Marengo,

North Yakıma,

Outlook,

Parker,

Pasco,

Pomeroy,

Prosser,

Richland,

Sunnyside,

Toppenish,

Waitsberg,

Walla Walla,

Wapato,

White Blufts,

White Salmon,

Zillah,

Lewiston,

* Wholesale only.

Cuaracter or Service

Wash. ...Electric Light and Power

"

It is expected that extension of transmission lines will soon provide light and power service at Prescott, Whitcomb, Lowden, Paterson, Plymouth, Mottinger, Wahluke, Dixie and Moxee City, Washington.

The total number of customers served by the Pacific Power \& Light Company as of December 31,1911, and the miles of gas mains and electric lines in use were as follows:

Gas customers................................... 4,022

Miles of gas mains in service................................... ${ }_{81}^{4}$

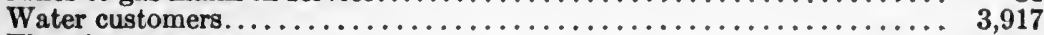

Electric customers......................................... 12,327

Miles of electric distributing lines in service.................... ${ }_{495}$

Miles of high voltage transmission lines in operation.............. 444

Miles of high voltage transmission lines under construction.............. 27

Miles of street railway and interurban railway lines (including Walla Walla

Valley Railway Company) in operation.....................

The Company has a total developed electric power capacity of approximately 20,735 horse-power, including 1,650 hydro-electric horse-power now under construction. Of the total amount of horsepower, 13,300 is generated by hydro-eleetric power plants.

With unimportant exceptions, the franchises of the Pacific Power \& Light Company are either unlimited as to time or run for a long period.

The electric light and power franchises in Astoria, Pendleton, The Dalles and Dufur are unlimited as to time, as is also the gas franchise in Astoria. The street railway franchise in Astoria expires in 1981. The electric light and power franchises at Granger and Freewater extend to 1960, and those at Attalia, Benton City, Centerville, Clarkston, Dixie, Dayton, Grandview, Iowden, Moxee City, Outlook, Parker, Presentt, Richland, Toppenish, Touchet, Underwood, Waits- 
burg, Wallula Junction, White Bluffs and Zillah extend to 1961. The electric light and power franchise in Hood River extends to 1952. All other grants extend to from 1930 to 1935, except the Sunnyside electric light, Lewiston gas and Prosser water franchises, which expire in 1929, and the Mabton and Wapato electric light franchises, which expire in 1924. The net receipts from these five towns last named for the past twelve months have been less than Five per Cent. of the total.

Statement of Income (Including Walla Walla Vallex Railway Company) Eighteen Months Ending December 31, 1911

Totals 18 Months Totals 6 Months Totals 12 Months

Gross Earnings..........
Operating expenses and

Ending 12-31-11 Ending 12-31-10 Ending 12-31-11

taxes............. $\$ 1,658,641.71$ $\$ 505,362.63$ $\$ 1,153,279.08$

Net earnings........

Interest on bonds......

Other interest.........

Net income after charges...........

Dividends paid.........

Surplus July 1, 1910...

$\begin{array}{r}898,721.10 \\ \hline \$ 759,920.61 \\ \hline \$ 361,560.32 \\ 79,013.61 \\ \hline \\ \$ 319,346.68 \\ 232,680.56 \\ \hline \$ 86,666.12 \\ 4,629.94 \\ \hline \$ 91,296.06\end{array}$

Surplus Dec. 31, 1911

\begin{tabular}{|c|c|}
\hline $266,743.32$ & $631,977.78$ \\
\hline$\$ 238,619.31$ & $\$ 521,301.30$ \\
\hline $\begin{array}{r}\$ 103,362.93 \\
1,611.59\end{array}$ & $\begin{array}{r}\$ 258,197.39 \\
77,402.02\end{array}$ \\
\hline$\$ 133,644.79$ & $\$ 185,701.89$ \\
\hline
\end{tabular}

Balance Sheet (Including Walla Walla Valley Railway Company), December 31, 1911

Assets

Securities of other corporations.

Current Assets:

Cash.

Accounts receivable:

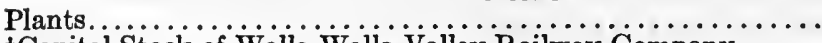

†Capital Stock of Walla Walla Valley Railway Company.......

$\$ 192,335.50$

Notes receivable................... $9,292.33$

Consumers...........\$140,560.52

American Power \& Light Co. $\quad 29,098.74$

Hanford Irrigation \& Power Co................ 75,406.50
Inventory

$245,065.76$ $267,437.70$

Total current assets

Contingent Assets:

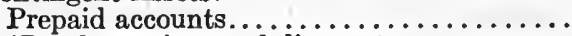

*Bond premium and discount.............

Trustee's bond sinking fund.

$\$ 13,295.95$

$231,596.47$ $26,025.76$
$\$ 14,225,510.09$ $499,500.00$ $5,000.00$

$714,131.29$

$270,918.18$

Total contingent assets

$\$ 15,715,059.56$

Total assets 
Capital Stock Outstanding:

Preferred.........................

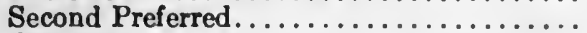

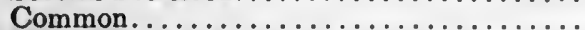

Walla Walla Valley Railway Company....

$\$ 2,000,000.00$

$1,500,000.00$

$6,000,000.00$

$500,000.00$

Total Capital Stock outstanding.......

Bonds Outstanding:

Pacific Power \& Light Co. First and Refund-

ing Mortgage Five per Cent............

$\$$ Nort hwestern Gas \& Electric Co. First and Consolidated Mortgage Six per Cent.

$\$$ Walla Walla Valley Traction Co. First

Mortgage Five per Cent.............

$\$ 10,000,000.00$

$4,791,000.00$

$473,000.00$

$31,000.00$

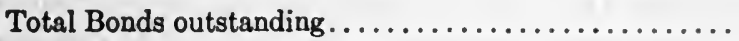

$5,295,000.00$

$\$ 54,330.85$

$17,409.58$

$151,030.90$

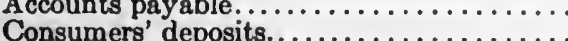

Accrued accounts.........................

Total current liabilities.

$222,771.33$

$105,992.17$

$91,296.06$

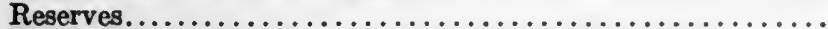

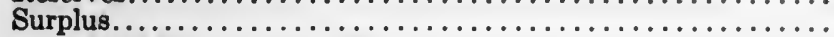

Totals.

$\$ 15,715,059.56$

tThe physical assets of Walla Walla Valley Railway Company are included in the item "Plants" and in this balance sheet accounts between Pacific Power \& Light Co. and Walla Walla Valley Railway Company have been eliminated.

* This account is being written off monthly during the life of the bonds.

$\$$ Since December 31,1911 , the Mortgage securing $\$ 473,000$. Northwestern Gas \& Electric Co. bonds has been released and bonds of the Pacific Power \& Light Co. have been issued in lieu thereof, and underlying bonds of the Walla Walla Valley Traction Co. (secured by a mortgage upon the properties of the Walla Walla Valley Railway Company) to the amount of $\$ 25,000$ and $\$ 6,000$ in cash have been exchanged for bonds of the Pacific Power \& Light Co.

The principal office of the Pacific Power \& Light Company is located at Augusta, Maine. Its principal office on the Pacific Coast is at Portland, Oregon, and its agency in the Borough of Manhattan is United States Mortgage \& Trust Company, which company also acts as Transfer Agent for the bonds.

The Company's fiscal year ends on December 31. The annual meeting is held on the third Tuesday in February in each year at the Company's office, 242 Water Street, Augusta, Maine.

The Directors of the Pacific Power \& Light Company are as follows: J. C. Ainsworth, Geo. F. Nevins, Edward Cookingham, F. I. Dame, Fred S. Fogg, S. S. Gordon, William Jones, John A. Laing, C. Hunt Lewis, H. C. Lucas, S. Z. Mitehell, Miles C. Moore, Josiah Richards, F. G. Sykes, Guy W. Talbot.

The Officers are as follows: S. Z. Mitchell, Chairman of the Board; Guy W. Talbot, President; F. G. Sykes, F. I. Dame, E. W. Hill, Edward Cookingham, A. S. Grenier, J. E. Davidson, Vice-Presidents; 
E. P. Summerson, Treasurer and Assistant Secretary; George F. Nevins, Secretary and Assistant Treasurer; M. H. Arning, Assistant Treasurer and Assistant Secretary.

The Pacific Power \& Light Company agrees to publish in pamphlet form at least once in each year and submit to the Stockholders at the annual meeting of the Company, a detailed statement of its physical and financial condition and income account covering previous fiscal year and a balance sheet showing assets and liabilities at the end of the year, and income account and balance sheet of all subsidiary companies; to maintain an agency in the Borough of Manhattan, City of New York, for the transfer and negotiation of its bonds; to notify the Stock Exchange in the event of the issuance of any rights or subscriptions to, or allotments of its listed securities, and to afford the holders thereof a reasonable period within which to exercise the privileges to which they may be entitled with respect to any such rights, subscriptions or allotments; and that all rights, subscriptions or allotments with respect to its listed securities shall be transferable, payable and deliverable in the Borough of Manhattan, City of New York.

\section{PACIFIC POWER \& LIGHT COMPANY,} By E. W. HrLL, Vice-President.

This Committee recommends that the above-described $\$ 5,295,000$ First and Refunding Mortgage Twenty-year Five per Cent. Bonds, International Series, due 1930, Nos. 1 to 5,295 inclusive, for $\$ 1,000$ each, be admitted to the list.

WM. W. HEATON, Chairman.

Adopted by the Governing Committee, May 8, 1912.

GEORGE W. ELY, Secretary. 


\section{REGULATIONS GOVERNING THE TRANSFER OF STOCKS $A N D B O N D S^{1}$}

In order to comply with the law and to safeguard the interests of the Company and its security holders, the following regulations in respect of the transfer of stocks and bonds are prescribed:

\section{I.-Registration}

1. In transferring stock or bonds to the name of an Individual or Firm, the full name should be given as it is usually signed, without prefix, suffix or title.

2. When a transfer is made to the name of a Woman, the prefix Miss or Mrs. should be omitted, and the security registered in her individual name. Thus, Jane Doe is preferable to Mrs. John Doe.

3. The titles of Corporations or Associations should be stated in full, including a prefix $T h e$ when applicable.

4. The name of a Trustee or Trustees should be followed by a brief description of the trust.

5. The name of an Executor or Administrator should be followed by a brief description of the will or estate.

6. Transfers to the Estate of John Doe are objectionable. Richard Roe, Executor (or Administrator) of the Estate of John Doe, is preferable.

7. Usually, Executors, Administrators or Trustees should not transfer to themselves as individuals. If necessarily done, the reason and justification therefor should be shown.

8. In all cases the addresses of transferees should be stated with particularity.

9. Persons or associations having securities transferred to themselves from time to time are requested to state the name uniformly, in order to avoid the opening of unnecessary accounts and the confusion and inconvenience consequent thereon.

If John Doe be a registered holder, the name should not be given as Jno. Doe or J. Doe at the time of subsequent transfers; and the name Richard Roe \& Co. should not afterwards be stated as Richard Roe \& Company or R. Roe \& Co.

10. A considerable number of stockholders have more than one account, some with different addresses. It is desirable that the entire holdings of a stockholder be combined into one account. To this end,

1 Circular issued by the Kansas City. Southern Railway Company, Ofrice of the Secretary and Transfer Agent, No. 25 Broad Street, New York, July 1, 1913. 
such certificates as necessary should be submitted for re-transfer, for which no charge will be made.

11. It is recommended that as far as readily practicable, transfers offered by persons unknown to the Transfer Agent should be transmitted through a broker having representation on the New York Stock Exchange, who will guarantee the signatures to assignments. In this way, the difficulties of identification, the resulting delay, or the expense of a Notarial certificate, will be avoided.

\section{II.-AssignMENT}

1. The assignment on the reverse side of a certificate or bond must be signed, witnessed and dated. The name of the person constituted as attorney to make the transfer upon the books of the Company, should be omitted.

2. Signatures to such assignments must be technically correct; that is, they must correspond in every particular with the name in which the security is issued, without abbreviation, enlargement or change.

(a) The assignment of a certificate or bond registered in the name of John Henry Smith, must not be executed in the name of John H. Smith, J. Henry Smith, or J. H. Smith.

(b) Titles, if any, must be prefixed or suffixed to signatures exactly as they appear on the face of the security. If the prefix Miss, Mrs., Rev., Dr., Capt., Baron, etc., constitutes a part of the name of the holder as registered, the signature must include such prefix.

(c) Brothers or Bros. must be written as it appears in the security.

3. When a security has been issued in a name incorrectly stated or wrongly spelled, the. assignment must be executed both in the name as registered and in the correct name.

4. The assignment of a security registered in the name of John Doe and Richard Roe must be executed by both.

5. The assignment of a security registered in the name of a woman subsequently changed by marriage must be executed Jane Doe, now. Jane Roe. Evidence of the marriage and of the holder's identity may be required.

6. A detached assignment must contain provision for the appointment irrevocable of a person (the name being left blank) as attorney to make the necessary transfer upon the books of the Company, and a full description of the security; that is, name of the Company, Issue, Certificate or Bond Number, and the face amount. 
(a) A separate assignment should accompany each certifcate or bond.

7. Any alteration in the wording of an assignment or appointment of an attorney should, whenever practicable, be attested by the signature of every person joining in the execution of the assignment as the assignor or as one of the assignors; and must in any event be attested by that of a person or persons thereunto authorized.

\section{III.-Assianments by Corporations or Associations}

1. When a transfer is to be made from the name of a Corporation or Association, the certificate or bond must (subject to paragraph 2 below) be accompanied by a copy of a resolution of the board of directors or trustees, authorizing its transfer and naming the officer delegated to execute the assignment.

(a) This copy must be certified by the secretary of the corporation as a true copy from the minutes.

(b) If such resolution is of continuing effect, the secretary of the corporation must certify that the resolution is in effect at the time of the intended transfer.

2. If a transfer is to be made on the authority of a by-law, the security must be accompanied by a copy of the by-law, certified by the secretary of the corporation as being in effect at the time of such intended transfer.

3. The corporate seal (if the corporation or association have one) must be impressed upon the assignment, whether on the security itself or detached, and likewise upon all attestations.

(a) If a corporation or association have no seal, attestations must be acknowledged before a Notary Public. See Section VI., paragraph 1, sub-paragraph (c).

\section{IV.-Assignments by Trustees}

1. When a certificate or bond is to be transferred from the name of a Trustee or Trustees, a certified copy of the instrument creating the trust must be submitted.

2. Evidence is requircd of the appointment of the trustee or trustees (if other than as stated in the creating instrument); of his or their acceptance of the trust, and retention of it at the time of the intended transfer.

3. Assignments by trustees require the signature of all living trustees. The signature of one alone is not sufficient to justify a transfer of stock or bonds. See Section V., paragraph 4. 
(a) The decease of a former co-trustee should be proved by a certificate of death when obtainable, or otherwise by credible affidarit, as a condition precedent to transfer.

\section{V.-Assignments by Executors and Administrators}

1. A certificate or bond offered for transfer from the estate of decedent intestate, must be accompanied by a certificate of the granting of Letters of Administration, and evidence of the retention of the trust by the Administrator or Administrators at the time of the intended transfer.

2. A security offered for transfer from the estate of a decedent testate, must be accompanied by the following:

(a) A certified copy of the Last Will and Testament of the deceased.

(b) A certificate of the appointment of an Executor or Executors, and evidence of his or their retention of the trust at the time of the intended transfer.

3. Presumptively, it is within the power of executors, or either of several executors alone, to sell and transfer the assets of a decedent. A will may, however, require joint action of all the executors.

4. If an assignment is proposed by executors more than eighteen months after the decedent's decease, a presumption arises that the executors have become trustees and must be so treated.

5. Evidence must be furnished of the payment of any inheritance or succession tax imposed by the laws of the State of New York, the State of Missouri, and the State wherein the corpus of the estate is located; or in lieu thereof, a waiver of notice issued by the Comptroller, Auditor, or other proper officer of such States.

(a) If the decedent was not a resident of the State of New York, and died subsequently to July 21, 1911, the Company is informed that a waiver by the Comptroller of that State will issue of right, upon application therefor with a proper presentment of the facts.

\section{VI.-Adthenticity of Assignments}

1. The signature to an assignment must either be-

(a) Known to the Transfer Agent; or

(b) Guaranteed by an establishment having representation on the New York Stock Exchange; by the signature (with official title affixed) of an officer of a state or national bank, or of a trust company; or

(c) If executed in this country, acknowledged before a No- 
tary Public; if exeeuted in a forcign country, acknowledged before a resident Consular Officer of the United States. A Notarial certificate executed without the State of New York must be duly attested by the Clerk of the local County or of a Court of Record.

Delay and mutual embarrassment are liable to occur if these requirements are not met.

\section{VII.-Charges for Registration and Transfer}

1. When a certificate of stock is surrendered and a greater number of certificates is issued in the same name, or in any one name, for a like aggregate number of shares, a charge of 25 cents each is made for the additional certificates. There is no other charge for the transfer of stock.

2. No charge is made for the registration of bonds, nor for the transfer of registered bonds. A charge of $\$ 1.00$ per bond is made to cover the actual cost of restoring registered bonds to coupon form, when such restoration is provided for by the mortgage securing such bonds.

\section{VIII.-Taxes on Registration and Transfer}

1. The State transfer tax on stock of the Company amounts to 2 cents per share. The duty to require payment in advance of making a transfer, is imposed upon the Company by law.

2. There is now no tax on the registration or transfer of bonds. See Section V., paragraph 5, as to inheritance taxes on decedents' estates.

\section{IX.-Meetings, Dividends, Closure of Books}

1. By provision of the By-Laws, the Annual Meeting of the Stockholders is held at Kansas City, Mo., the second Tuesday in May. The transfer books are closed for at least ten days next preceding that date, and are usually re-opened on Monday following the meeting.

2. Dividends on the Preferred Stock have usually been declared payable quarterly (July 15), to stockholders of record on the last business day of the month preceding. It is not now customary to close the transfer books for the payment of dividends.

$$
\text { G. C. HaND, }
$$

Secretary and Transfer Agent. 


\section{REAL ESTATE MORTGAGE}

This Indenture, made the tenth day of November in the year one thousand nine hundred and thirteen between A. C. Brown, Inc., party of the first part, hereinafter described and designated as the mortgagor, and John Doe, party of the second part, hereinafter described and designated as the mortgagee.

Whereas, the said A. C. Brown, Inc., by virtue of a certain bond or obligation bearing even date herewith; is justly indebted to the said mortgagee in the sum of Ten Thousand $(\$ 10,000)$ Dollars lawful money of the United States, secured to be paid on the tenth day of November, in the year nineteen hundred and fifteen, together with the interest thereon, to be computed from the tenth day of November, 1913, at the rate of six per centum per annum, and to be paid on the eleventh day of May next ensuing the date hereof and semiannually thereafter.

It being thereby expressly agreed, that the whole of the said principal sum shall become due after default in the payment of interest, taxes, assessments or water rates, as hereinafter provided or after any other default, anything herein contained to the contrary notwithstanding.

Now this Indenture Witnesseth, that the mortgagor, for the better securing the payment of the said sum of money mentioned in the said bond or obligation, with interest thereon, and also for and in consideration of the sum of ONE DOLLAR, to the mortgagor in hand paid by the mortgagee, the receipt whereof is hereby acknowledged, does hereby grant and release unto the mortgagee, and to his heirs and assigns forever, ALL that certain lot, piece, or parcel of land, with all buildings and improvements thereon made or erected, situate, lying and being in the Borough of Manhattan, City, County and State of New York, bounded and described as follows, to wit:-

Beginning at a certain point on the north side of Palmer Road, distant one hundred feet east of that point known as the northeast corner formed by the intersection of Bailey Avenue and Palmer Road, running thence (1) forty feet due east on a line with the said Palmer Road; thence (2) one hundred feet due north on a line parallel with said Bailey Avenue; thence (3) forty feet due west on a line parallel with said Palmer Road; then (4) one hundred feet due south on a line parallel with said Bailey Avenue to the place of beginning.

Together with all fixtures and articles attached to or used in connection with said premises, all of which are declared to be covered by this mortgage; together with the appurtenances, and all the estate and rights of the party of the first part in and to said premises: 
To have and to hold the above-granted premises unto the said mortgagee, his heirs and assigns forever.

Provided always that if the said mortgagor, or the heirs, executors, administrators or successors of the said mortgagor, shall pay unto the said mortgagee, or the personal representatives, successors or assigns of the said mortgagee, the said sum of money mentioned in the said bond or obligation, and the interest thereon, at the time in the manner mentioned in the said bond or obligation, then these presents and the estate hereby granted, shall cease, determine and be void.

And the said A. C. Brown, Inc., mortgagor covenants with the mortgagee as follows:

First-That the mortgagor will pay the indebtedness as hercinbefore provided, and, if default be made in the payment of any part thereof, the mortgagee shall have power to sell the premises herein described according to law. Said premises may be sold in one parcel, any provision of the law to the contrary notwithstanding.

Second-That the mortgagor will keep the buildings on the said premises insured against loss by fire for the benefit of the mortgagee. And should the mortgagee, by reason of any such insurance against loss by fire, as aforesaid, receive any sum or sums of money for any damage by fire to the said building or buildings, such amount may be retained and applied by said mortgagee toward payment of the amount hereby secured, or the same may be paid over either wholly or in part to the said mortgagor, or the heirs, successors or assigns of the mortgagor, to enable said mortgagor to repair said buildings or to erect new buildings in their place, or for any other purpose or object satisfactory to the said mortgagee, without affecting the lien of this mortgage for the full amount secured thereby before such damage by fire, or such payment ever took place.

Third-And it is hereby expressly agreed that the whole of said principal sum, or so much thereof as may remain unpaid, shall become due at the option of the mortgagee after default in the payment of any instalment of principal or in the payment of interest for thirty days, after default in the payment of any tax, assessment or water rate for sixty days after notice and demand, or in case of the actual or threatened demolition or removal of any building erected upon the said premises, anything herein contained to the contrary notwithstanding.

Fourth-That the mortgagor will execute any further necessary assurance of the title to said premises and will forever warrant said title.

Fifth-That if default shall be made in the payment of the principal sum mentioned in the said bond, or of any instalment thereof, 
or of the interest which shall accrue thereon, or of any part of either, at the respective times therein specified for the payment thereof, the mortgagee shall have the right forthwith, after any such default, to enter upon and take possession of the said mortgaged premises, and to let the said premises, and receive the rents, issues and profits thereof, and to apply the same after payment of all necessary charges and expenses, on account of the amount hereby secured, and said rents and profits are in the event of any such default hereby assigned to the mortgagee.

Sixth-And the mortgagee shall also be at liberty, immediately after any such default, upon proceedings being commenced for the foreclosure of this mortgage, to apply for the appointment of a receiver of the rents and profits of the said premises without notice, and the mortgagee shall be entitled to the appointment of such a receiver as a matter of right, without consideration of the value of the mortgaged premises as security for the amount due the mortgagee, or the solvency of any person or persons liable for the payment of such amounts.

Seventh-And the mortgagor does further covenant and agree that, in default of the payment of any taxes, charges and assessments which may be imposed by law upon the said mortgaged premises, or any part thereof, it shall and may be lawful for the said mortgagee, without notice to or demand from the mortgagor, to pay the amount of any such tax, charge or assessment, and any amount so paid the mortgagor covenants and agrees to repay to the mortgagee, with interest thereon, without notice or demand, and the same shall be a lien on the said premises, and be secured by the said bond and by these presents and the whole amount hereby secured, if not then due, shall thereupon, if the mortgagee so elect, become due and payable forthwith, anything herein contained to the contrary nothwithstanding.

Eighth-It is hereby further agreed by the parties hereto that, if at any time before said bond is paid, any law be enacted changing the law in relation to taxation so as to affect this mortgage or the debt thereby secured, or the owner or holder thereof, in respect thereto, then said bond and this mortgage shall become due and payable at the expiration of thirty days after written notice requiring the payment of the mortgage debt shall have been given to the owner of the mortgaged premises, anything herein contained to the contrary notwithstanding.

Ninth-The mortgagor, or any subsequent owner of the premises described herein, shall, upon request, made either personally or by registered mail, certify, in writing, to the mortgagee or any proposed 
assignee of this mortgage, the amount of principal and interest that may be due on this mortgage, and whether or not there are any offsets or defenses to the same, and upon the failure to furnish such certificate after the expiration of six days in case the request is made personally, or after the expiration of thirty days after the mailing of such request in case the request is made by mail, this mortgage shall become due at the option of the holder thereof, anything herein contained to the contrary notwithstanding.

Tenth-It is expressly understood and agreed that the whole of said principal sum and the interest shall become due at the option of the mortgagee, upon failure of any owner of the above-described premises to comply with any requirement of any department of the City of New York, within six months after notice in writing of such requirements shall have been given to the then owner of said premises by the mortgagee, anything herein contained to the contrary notwithstanding.

Eleventh-Every provision for notice and demand or request contained herein shall be deemed fulfilled by written notice and demand or request personally served on one or more of the persons who shall at the time hold the record title to the premises, or on their heirs or successors, or by registered mail directed to such person or persons or their heirs or successors, at his, their or its address to the mortgagee last known.

In Witness Whereof, the said mortgagor hath signed and sealed this instrument the day and year first above written.

Signed, sealed and delivered

A. C. Brown, Inc. (Seal)

in the presence of:

Richard Roe, President.

William Jones, (L. S.)

James Smith, (L. S.)

State of New York

County of $\}$ ss.

On this tenth day of November, in the year one thousand nine hundred and thirteen, before me personally came Richard Roe to me known, who, being wy me duly sworn, did depose and say, that he resides in the City of New York; that he is the president of the corporation described in, and which executed the foregoing instrument; that he knows the corporate seal of said corporation; that the seal affixed to said instrument is such corporate seal; that it was so affixed by "order of the Board of Directors of said corporation, and that he signed his name thereto by like order.

(Notary's official signature.) 


\section{BOND TO ACCOMPANY REAL ESTATE MORTGAGE}

Know All Men by These Presents,

That

\section{A. C. BROWN, Inc.}

hereinafter designated as the obligor, is held and firmly bound unto

\section{John Doe}

hereinafter designated as the obligee, in the sum of Ten Thousand $(\$ 10,000)$ Dollars, lawful money of the United States of America, to be paid to said obligee, his administrators, executors or assigns; For which Payment, well and truly to be made, it does bind itself firmly by these presents. SEALED with its seal, dated the tenth day of November, one thousand nine hundred and thirteen.

Whereas, A. C. BROWN, Inc.

has executed and delivered to John Doe certain bond or obligation, dated the tenth day of November, 1913, conditioned for the payment of the sum Ten thousand $(\$ 10,000)$ Dollars, on Wednesday the tenth day of November, one thousand nine hundred and fifteen, with interest thereon, to be computed from the tenth day of November, 1913, at and after the rate of six per centum per annum and to be paid semi-annually on the eleventh day of May and tenth day of November;

which said bond is secured by a certain mortgage, made by A. C. BROWN, Inc., to said obligee named in said bond, bearing even date with said bond, and covering certain premises fully described in said mortgage, situate in the Borough of Manhattan, in the City of New York, (description)

Whereas, to induce the said obligee to loan Ten thousand $(\$ 10,000)$ Dollars, the said obligor hath agreed to make, execute and deliver this bond as further and additional security for the payment of the said above-mentioned bond and mortgage.

Now therefore the condition of this obligation is such, that if the parties bound to pay the moneys secured by said bond and mortgage, or the above-bounden obligor, A. C. BROWN, Inc., shall well and truly pay, or cause to be paid, to the said obligee, his administrators, executors, or assigns, the just and full sum of Ten thousand $(\$ 10,000)$ 
Dollars, together with all interest thereon, as the same shall become due and payable according to the terms and conditions of the aforesaid bond and mortgage; and if the said obligor, A. C. BROWN, Inc., shall at all times hereafter, hold, indemnify and sare harmless the said obligee, John Doe, his administrators, executors and assigns, from and against all loss, damages, costs, expenses, suits, actions, claims and demands whatsoever, which he or they may or might otherwise, at any time hereafter, sustain, suffer, be liable to or oblige to pay under or by reason of and default in any of the terms, provisions, covenants or conditions of the aforesaid bond and mortgage, then this obligation to be void, otherwise to remain in full force and virtue.

A. C. BROWN, Inc.

Richard Roe, President.

Frank Herbert, Secretary.

Signed, sealed and delivered in the presence of $\left\{\begin{array}{l}\text { William Jones (L. S.) } \\ \text { James Smith (L. S.) }\end{array}\right.$

(Corporate Acknowledgment of President and Secretary.) 
CERTIFICATE BY PRESIDENT AND SECRETARY AS TO CONSENT OF STOCKHOLDERS TO MORTGAGE

A. C. BROWN, Inc., a corporation organized under the Laws of the State of New York, Richard Roe, President, and Frank Herbert, Secretary, of said corporation, Do Hereby Certify under the seal of said corporation, that the holders of not less than two-thirds in amount of the capital stock of said corporation have duly consented in writing to the execution and delivery by said corporation to John Doe or to any other person or corporation, of a mortgage for Ten thousand $(\$ 10,000)$ Dollars, upon that portion of the real estate owned by said corporation which is situated in the Borough of Manhattan, of the City of New York.

All that (description of property).

to secure payment of a bond of said corporation to be made to the lender of said sum, conditioned for the payment of the said principal sum of Ten thousand $(\$ 10,000)$ Dollars on the tenth day of November, Nineteen hundred and fifteen with interest to be computed from the tenth day of November, 1913, at the rate of six per centum per annum and to be paid on the eleventh day of May, next ensuing and semi-annually thereafter until the whole of said principal sum shall be fully paid and that said bond and mortgage be in such forms and contain such other terms, provisions, conditions, stipulations and agreements as shall be agreed upon by the proper officer of said corporation executing the same and such lender.

In Witness Whereof, said corporation has hereunto caused its corporate seal to be affixed and said Richard Roe, President, and Frank Herbert, Secretary, have hereunto subscribed their names, this eighth day of November, Nineteen hundred and thirteen.

A. C. BROWN, Inc. Richard Roe, President.

Frank Herbert, Secretary. (Corporate Acknowledgment of President and Secretary.) 


\section{CORPORATE MORTGAGE}

\section{Jones \& Ladahlin Steel Company}

TO

\section{First Trust and Savinga Bank and Emile K. Boisot, Trustees}

\section{RECITAL8:}

\section{TABLE OF CONTENTS.*}

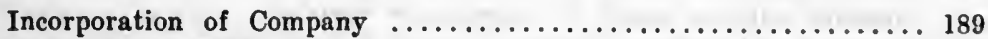

Authorization of bonds.............................. 189

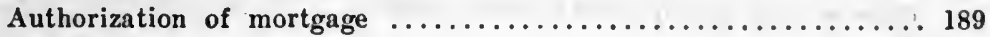

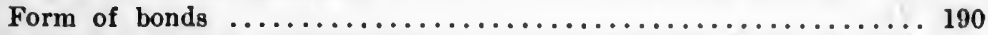

Form of coupons ................................. 191

Form of authentication of bonds...................... 192

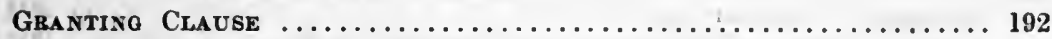

Description of plants and propertics in Pittsburgh District..... 193

District of Aliquippa plants and properties............... 193

Description of Chicago properties ..................... 193

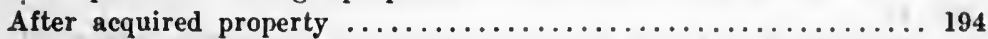

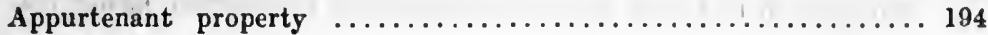

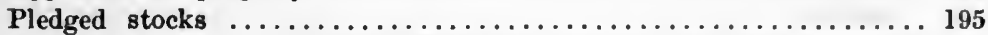

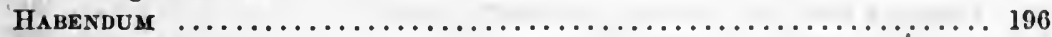

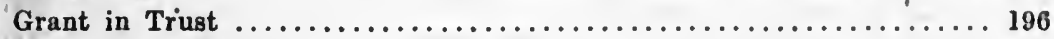

\section{ARTICLE ONE}

Execution, Authentication, Issue and Registration of Bonds

Sec. 1:

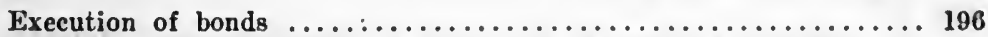

Total issue $\$ 30,000,000$ consecutively numbered............ 196

Sec. 2:

$\$ 2,069,000$ for exchanging old bonds..................... 196

$\$ 12,931,000$ to be delivered on resolutions of directors.......... 197

Sec. 3 :

$\$ 15,000,000$ to be delivered on or after January 1, 1911, on certificates 197

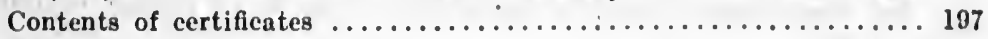

Sec. 4:

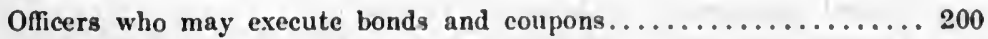

Authentication essential to validity of bonds............. 200

Matured coupons to be clipped before delivery............ 200

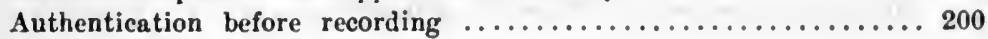

Sec. 5 :

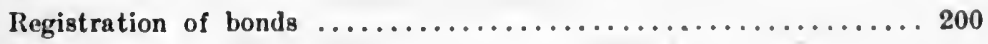

Sec. 6:

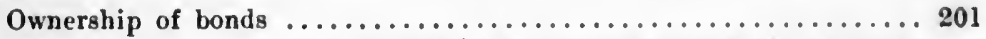

- The table of contents is not in the mortgage as executed and recorded. 
Sec. 7:

Replacing bonds mutilated, lost or destroyed

Sec. 8:

Temporary bonds

\section{ARTICLE TWO}

\section{Particulak Conenants of the Company}

Sec. 1:

Company to pay principal and interest without deduction for taxes.. 202

Interest payable only on surrender of coupons.............. 203

Company will not assent to extension of coupons............. 203

Company will maintain financial agency in New York.........2 203

Place of such agency until further notice............... 203

Sec. 2:

After acquired property subject to the mortgage........... 203

Company will maintain and extend the record of the mortgage.... 204

Covenant for further assurances ....................... 204

Sec. 3 :

Pledge of Ross and Woodlawn Land Company stocks........... 204

Old mortgage to be immediately cancelled................ 204

Sec. 4:

Mortgage to be kept a first lien subject only to purchase money obli-

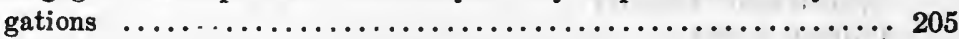

Company must pay taxes on mortgaged property............ 206

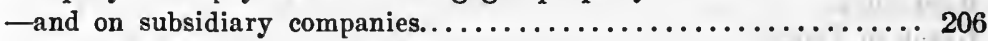

Company to maintain value of trust estate.............. 206

Sec. 5 :

Covenant to insure mortgaged premises................ 207

-and property of subsidiary companies................. 207

Sec. 6:

Sec. 7:

Trustee may perform above covenants and have lien for advances.... 207

No subsidiary company to issue stock or obligations unless pledgedexcept in certain specified cases.....................207

No sale or lease to be made by subsidiary company except as per-

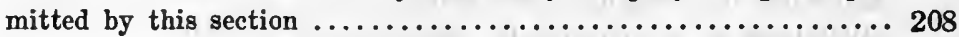

Sec. 8:

Quick assets must exceed liabilities as herein provided......... 210

Net assets must always be $\$ 25,000,000$ in excess of present capital

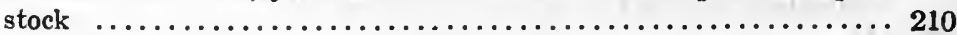

Annual statement to be furnished Trustees............... 210

Trustees may make examination...................... 210 Sec. 9:

On default, Company will disclose processes.............. 210

\section{ARTICLE , THREE}

Sec. 1:

\section{Control of Pledged Securities}

Delivery of pledged securities to Trustees................ 211

Trustees authorized to register and transfer securities.......... 211 
Sec. 2:

Trustees authorized to maintain corporate existence of companies...2 211

Company entitled to transfer of pledged stock to qualify directors... 212

Sec. 3:

Until default Company entitled to collect interest and dividends out

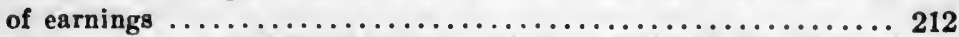

-but not interest and dividends paid otherwise than out of carnings. 213

Trustees to renew or extend maturing pledged obligations....... 213

Sec. 4:

Disposition of payments of principal and payments not made out of

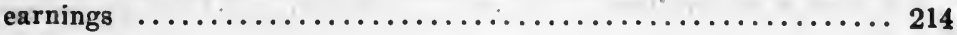

Sec. 5 :

Until default, Company to vote pledged stocks............. 214

Trustees to have rights of owners of pledged securities......... 214

Sec. 6:

Trustees entitled to enforce pledged securities............. 215

Trustees entitled to purchase property to protect pledged securlties.. 215

Trustees may join in plan of reorganization............... 216

Company to pay and Trustees to have lien for expenses under this

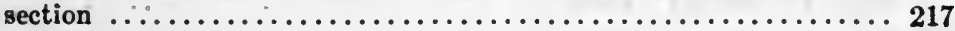

Sec. 7:

Merger or consolidation of subsidiary companies........... 217

Reduction of capital stock and dissolution of subsidiary companies... 219

\section{ARTICLE FOUR}

\section{Sinkina Fund and Redemption of Bonds}

Sec. 1:

Company to deposit interest moneys two days before May 1 and

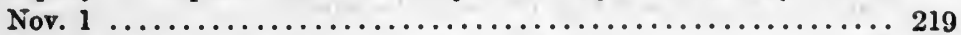

-and to make sinking fund payment on March $1 \ldots \ldots \ldots \ldots \ldots 219$

Sinking fund payment may be in bonds instead of cash........ 220

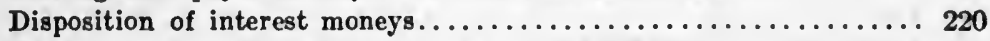

Disposition of sinking fund moneys prior to $1915 \ldots \ldots \ldots \ldots \ldots 220$

Disposition of sinking fund moneys after $1914 \ldots \ldots \ldots \ldots \ldots \ldots$

Sec. 2:

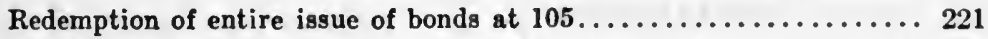

Sec. 3:

Satisfaction hereof on deposit of funds for redemption........... 222

Delivery and payment of bonds on redemption............ 222

Sec. 4:

Cancellation of bonds redeemed or acquired for sinking fund..... 223

\section{ARTICLE FIVE}

\section{Remedies of Trustees aNd BondHolders}

Bec. 1:

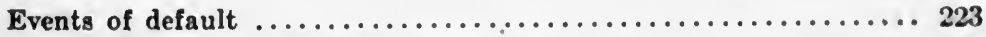

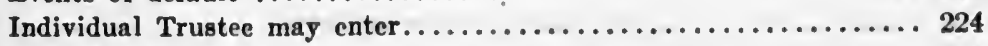

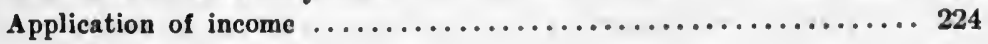


-if principal not due

-if principal due

Sec. 2:

Detached coupons deferred in payment.

Sec. 3 :

Upon default Trustees to control pledged securities.

Disposition of income and proceeds.

Sec. 4:

Declaration of maturity of bonds on default.............. 227

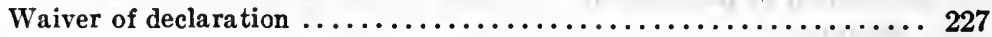

Sec. 5:

On default trust estate may be sold................... 227

Sec. 6:

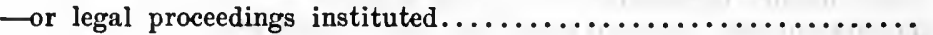

'Trustees' duty to act on request of bondholders............. 228

Sec. 7:

Majority of bondholders to control certain proceedings

Sale of mortgage premises to be as an entirety.

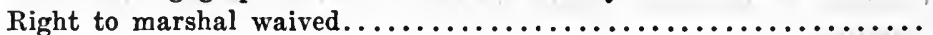

Sec. 8:

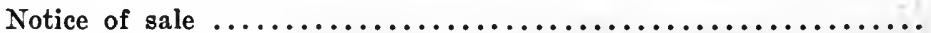

Sec. 9 :

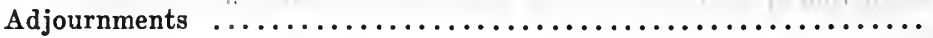

Sec. 10:

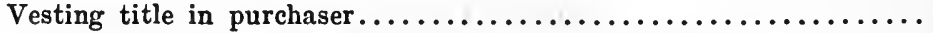

Corporate Trustee attorney to execute conveyances..............

Sale to divest all interest of Company......................

Personal property mortgaged to be deemed fixtures...............

Trustees' receipt sufficient discharge to purchaser.

Sec. 12:

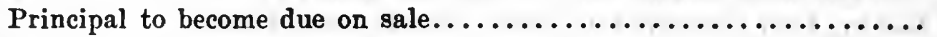

Sec. 13 :

Application of proceeds of sale.

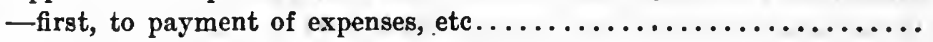

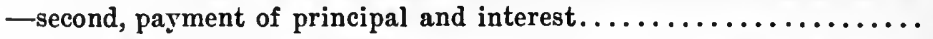

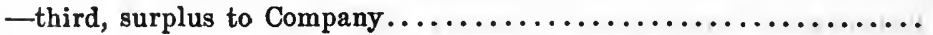

Sec. 14:

Purchaser permitted to apply bonds and matured coupons.........

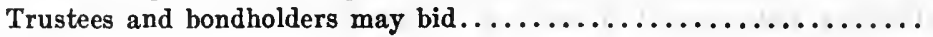

Sec. 15:

Company will pay to the Trustees whole amount due on bonds in case of default .................................... 231

Trustees may recover judgment although other proceedings pending.. 232

After sale Trustees entitled to collect deficiency............. 232

Recovery of judgment not to affect lien.................. 232

Application of moneys recovered...................... 232

Sec. 16:

Waiver of stay, extension and appraisement laws............ 233

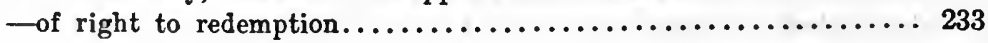


Sec. 17 :

PAGE

On instituting proceedings Trustees entitled to appointment of Re-

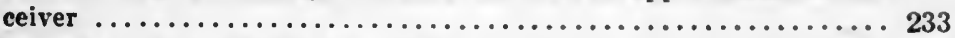

Sec. 18:

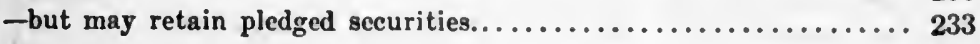

Bondholders not to sue until application made to Trustees....... 233

Sec. 19:

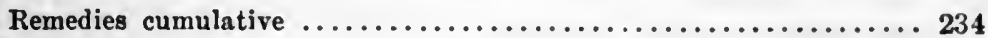

Sec. 20:

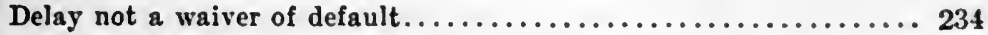

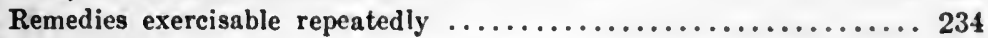

Sec. 21 :

Company and Trustees restored to former position on termination

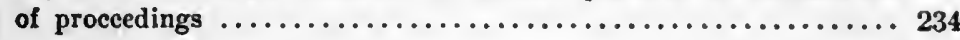

\section{ARTICLE SIX}

Immunity of Stockholders, Directors and Officers.......... 235

\section{ARTICLE SEVEN \\ Bondholders' Acts, Holdings and APparent AUthority}

Form and.proof of execution of instruments by bondholders....... 235

Proof of ownership of bonds and coupons......................... 236

ARTICLE EIGHT

Sec. 1: Releases of Mortgaged Property

Unnecessary property may be released on certain conditions...... 236

Disposition of proceeds of released property.............. 237

Evidence on which Trustees may act...........................

Sec. 2:

Sec. 3 :

Company may dispose of and replace tools and equipment.......238

Foregoing powers exercisable by receiver or Trustee in possession... 239 Sec. 4:

Releases may be executed by corporate Trustee alone........... 239

Purchaser not responsible for application of purchase money...... 239

\section{ARTICLE NINE}

Sec. 1:

\section{Possession Uxtil. Default-Defeasance Clause}

Until default Company entitled to possession and income.......239 Sec. 2:

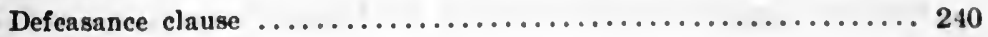

Sec. 3:

Moneys not claimed in six years to be repaid to Company........240

\section{ARTICLE TEN}

Sec. 1:

\section{Concersino tue Trustees}

Trustees may assume default not to exist until notified........ 240

-not required to incur expense without indemnity........... 241

-not required to take notice of default except on certain conditions.. 241 
-not responsible for validity of indenture or security........ 241

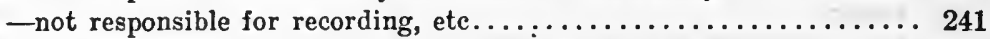

-not responsible for application of proceeds of bonds.......... 242

-not responsible for taxes or insurance................ 242

-entitled to compensation - the same to constitute a lien........ 242

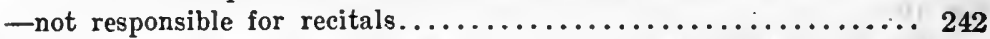

-protected by advice of counsel.................... 242

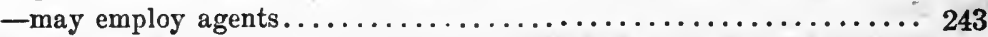

-responsible only for wilful misconduct or gross negligence...... 243

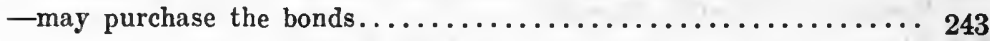

-may act on any instrument considered genuine............. 243

-may make independent investigation of certificates, etc....... 243

Evidence on which Trustees may act in cases otherwise unprovided

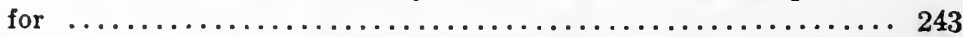

Effect of merger or consolidation of corporate Trustee......... 244

Successor corporate Trustee may authenticate the bonds......... 244

Delivery to corporate Trustee delivery to both Trustees........... 244

Individual Trustee may constitute corporate Trustee attorney...... 244

Moneys and securities to be deposited with corporate Trustee...... 244

No successor to be appointed to individual Trustee............ 244

Sec. 2:

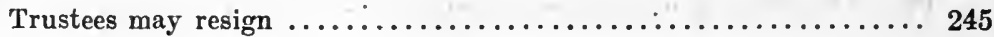

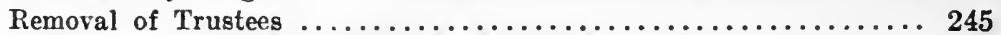

Appointment of new Trustees ......................... 245

Vesting mortgaged premises in successor................ 246

Appointment of additional or separate Trustees............ 247

Sec. 3:

Powers of individual Trustee....................... 247

\section{ARTICLE ELEVEN}

\section{Sundry Provisions}

Sec. 1:

Covenants to bind successors and assigns of Company......... 248 Sec. 2:

Lease of mortgaged premises by Company..................

Sec. 3:

Consolidation or merger of Company or sale of mortgaged premises. 248 Sec. 4:

Successor corporation substituted for the Company........... 249

Sec. 5 :

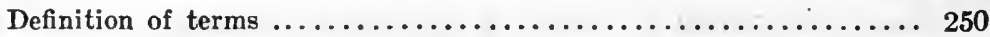

Meaning of "order of Company"..................... 250

Sec. 6:

Service of notices and demands..................... 250

Certification of directors' resolutions................... 250

Sec. 7:

Execution in counterparts $\ldots \ldots \ldots \ldots \ldots \ldots \ldots \ldots \ldots \ldots \ldots \ldots \ldots . \ldots \ldots$ 


\section{ARTICLE TWELVE}

Parties in INTerest

PAOE

Rights hereunder confined to parties and bondholders.......... 251

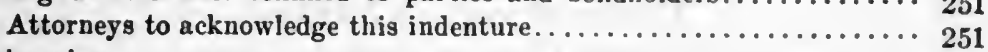

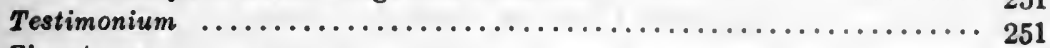

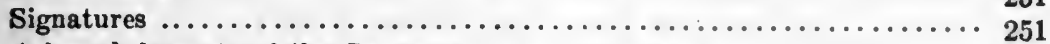

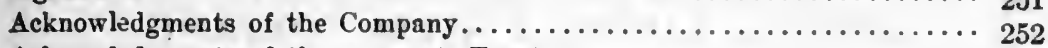

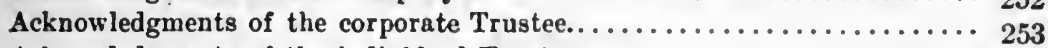

Acknowledgments of the individual Trustee.................. 254

THIS INDENTURE, dated the first day of May, one thousand nine hundred and nine, between the Jones \& Lavahuin Steel ComPANY, a corporation organized and existing under the laws of the State of Pennsylvania (hereinafter called the "Company"), party of the first part, First Trust and Savings Bank, a corporation organized and existing under the laws of the State of Illinois, herein called the "corporate Trustee," and EMILE K. BoIsot, herein called the "individual Trustee," parties of the second part, Witnesseth:

Whereas, the Company was duly incorporated by letters patent under the Great Seal of the Commonwealth of Pennsylvania on the second day of June, 1902, under the provisions of an Act of the General Assembly of said Commonwealth, approved the 29th day of April, 1874, and the supplements thereto, and has been duly organized and has a eapital stock of $\$ 30,000,000$ divided into 300,000 shares of the par value of $\$ 100$ each, all of which said stock is fully paid and nonassessable; and

Whereas, the Company, in order to accomplish and carry on and enlarge the business and purposes of the Company, has deemed it necessary to increase its indebtedness and for such purposes has by proper resolutions of its board of directors at meetings duly called and held for the purpose, with the consent of the holders of its entire capital stock given at a meeting duly called and held, determined to create the indebtedness hereinafter mentiond and to such extent to increase its indebtedness, and to ereate and issue the bonds of the Company to the par value of $\$ 30,000,000$; and

Whereas; the Company has duly approved the form of this mortgage and deed of trust of the property and franchises and of the pledge of the securities, hereinafter described, and has duly authorized the execution and delivery of the same and the pledging and delivering of said securities; and

Whereas, the form of the bonds so determined to be issued as aforesaid, and of the Trustee's authentication to be endorsed thereon, and of the coupons to be attached thereto severally and respectively, are substantially as follows, viz.: 
No.

\section{[FORM OF BOND.]}

\section{United States of America COMMONWEALTH OF PENNSYLVANIA \\ (American Iron and Steel Works) \\ JONES \& LAUGHLIN STEEL COMPANY Pittsburgh, $\mathrm{Pa}$.}

\section{First Mortgage Thirty Year Five Per Cent. Gold Bond}

Jones \& Laughlin Steel Company (hereinafter called the Company), for value received hereby promises to pay to the bearer, or if registered, to the registered holder of this bond, the sum of one thousand dollars $(\$ 1,000)$ in gold coin of the United States of America, of or equal to the present standard of weight and fineness, on the first day of May, 1939, at the agency of the Company in the Borough of Manhattan in the City of New York, and to pay interest thereon at the rate of five per cent. a year from May 1, 1909, payable semiannually at said agency, or at the office of First Trust and Savings Bank in the City of Chicago, as the coupon holder may elect, in like gold coin, on the first day of May and the first day of November in each year, but only upon presentation and surrender as they severally mature of the coupons therefor hereto annexed. Both the principal and interest of this bond are payable without deduction for any tax or taxes, assessments or other governmental charges which the Company may be required to pay thereon or to deduct or retain therefrom under any present or future law of the United States, or of any state, county, municipality or other taxing authority therein.

This bond is one of an issue of bonds of the Company, known as its First Mortgage Thirty Year Five Per Cent. Gold Bonds, limited to the principal amount of $\$ 30,000,000$ at any one time outstanding, all of like tenor, date, and amount, numbered from 1 consecutively upwards, and all issued and to be issued under and equally secured by a mortgage and deed of trust date May 1, 1909, executed by the Company to First Trust and Savings Bank and Emile K. Boisot as Trustees. For a description of the properties and franchises mortgaged and the securities pledged, the nature and extent of the security, the rights of the holders of the bonds and the terms and conditions upon which the bonds are, and are to be, issued and secured, reference is made to said mortgage and deed of trust, to all of the provisions of which the holder hereof, by the acceptance of this bond, assents.

After May 1, 1914, on interest payment dates as provided in said mortgage and deed of trust, after notice published at least thirty days 
in advance, all of said bonds may be called for redemption at 105 per cent. of their face value and accrued interest, and any of said bonds may upon like notice be called for the sinking fund at the same price. The principal of this bond may be declared due and payable in the manner and with the effect provided in said mortgage and deed of trust, in case default shall be made and shall continue as therein provided.

This bond shall pass by delivery, unless registered in the name of the owner on the books of the Company, such registry being noted on the bond by the Company, and after such registration, duly noted hereon, no transfer shall be valid unless made on said books by the registered owner in person or by his attorney, duly authorized, and similarly noted by the Company hereon, but the same may be discharged from registration by being in like manner transferred to bearer, and thereupon transferability by delivery shall be restored. The registration of this bond shall not affect the negotiability of the coupons, which shall continue to be transferable by delirery.

No recourse shall be had for the payment of the principal or the interest of this bond or for any part thereof or for any claim based thereon or otherwise in respect thereof, or of said mortgage and deed of trust, against any incorporator, stockholder, officer or director, past, present or future, of the Company, whether by virtue of any statute or by the enforcement of any assessment or penalty or otherwise, all such liability being, by the acceptance hereof, and as part of the consideration of the issue hereof, expressly released.

This bond shall not be valid or become obligatory for any purpose unless authenticated by the certficate hereon endorsed of the First Trust and Savings Bank, or its successor in the trust.

In Witness Whereor, the Jones \& Laughlin Steel Company has caused this bond to be signed in its corporate name by its President or one of its Vice-Presidents and its seal to be hereunto affixed, duly attested by its Secretary or Assistant Secretary and the coupons for said interest, with the engraved signature of its Treasurer to be attached hereto, this first day of May, 1909.

Jones \& Laughuin Steel Company,

Attest:

By....................

No. [FORM OF INTEREST COUPONS.]

$\$ 25.00$

On the first day of

, 19 , the Jones \& Laughlin Steel Company will pay to the bearer at the agency of the Company 
in the Borough of Manhattan in the City of New York, or at the office of First Trust and Savings Bank in the City of Chicago, as the bearer may elect, Twenty-five Dollars in United States Gold Coin, being six months' interest then to become due on its First Mortgage Thirty Year Five Per Cent. Gold Bond No.

, unless said bond shall have been called for previous redemption.

Treasurer.

\section{[FORM OF CERTIFICATE OF BONDS.]}

This bond is one of the bonds described in the within mentioned mortgage and deed of trust.

First Trust and Safings Bank,

By........................

Trust Officer.

AND Whereas all acts and things prescribed by law and by the by-laws and charter of the Company have been duly complied with, and the Company has executed this indenture and purposes to issue the bonds so determined to be executed and issued in the exercise of each and every legal right and power in it vested, and all things necessary to make said bonds, when authenticated by the corporate Trustee, the valid, binding and negotiable obligations of the Company, and to make this indenture a valid, binding and legal first mortgage and agreement for the security of said bonds, have been done and performed and the issue of said bonds as herein provided for has been in all respects duly authorized;

Now, Therefore, This Indenture Witnesseth:

That in order to secure the payment of the principal and interest of all of said bonds (which are hereinafter called the bonds) at any time issued and outstanding under this indenture, according to their tenor, purport and effect, as well the interest as the principal thereof, and to secure the performance and observance of all the covenants and conditions therein and herein contained and to declare the terms and conditions upon which the bonds are, and are to be, issued, received and held, the Company, party of the first part hereto, in consideration of the premises and of the purchase or acceptance of such bonds by the holders thereof, and of the sum of ten dollars (\$10) lawful money of the United States of America duly paid to it by the parties of the second part (herein called the Trustees) upon the ensealing and delivery of this indenture, the receipt whereof is hereby acknowledged, and for other valuable considerations, has 
bargained, granted, sold, aliened, remised, released, enfeoffed, conreyed, pledged, assigned, transferred and set over, and by these presents does bargain, grant, sell, alien, remise, release, enfeoff, convey, pledge, assign, transfer and set over, unto the Trustees, parties of the second part, and their successor or successors in the trust, the following described property, which is hereinafter referred to as the trust estate, viz. :

I.-All the following described real estate owned by the Company in the County of Allegheny, State of Pennsylvania, to wit:

[Here follows a description of plants and properties in Pittsburgh District and a deseription of Aliquippa plants and properties.]

All the real estate owned by the Company in the City of Chicago, County of Cook, State of Illinois, including the following more particularly described property, to wit:

Being the North Twenty-two (22) feet in width of the South Seventy-eight (78) feet of lots ten (10) to fourteen (14), both inclusive, and the West eight (8) feet of lot nine (9) of Block eight (8) of Union Park Second Addition to Chicago, being house and lot number Fifty-nine (59) Union Park Place; and

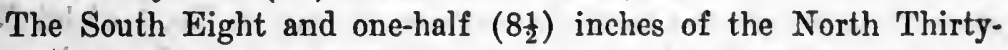
seven (37) feet of the West Eight (8) feet of lot nine (9) and the North Thirty-seven (37) feet of lots ten (10), eleven (11), twelve (12), thirteen (13) and fourteen (14), in Block eight (8) in Union Park Second Addition to Chicago, in Cook County, Illinois, hereby intending to convey a strip of land eight and one-half (81) inches in width along the South side of the lot owned by the Company and adjacent to the piece of property first above deseribed.

Lots three (3), four (4), five (5), twenty-four (24), twenty-fire (25), twenty-six (26), twenty-seven (27) and twenty-eight (28) in Daniel Gardner and Louisa Hall's Subdivision of Block one (1), in Carpenter's Addition to Chicago, in Chicago, Cook County, Illinois, according to the map of said Subdivision recorded in the Recorder's Office of Cook County, Illinois, on May 17th, 1852, in Book 49 of Maps at Page 12, said Addition being a subdivision of the Southeast quarter of Section eight (8) Township thirty-nine (39) North, Range fourteen (14) East of the Third Prineipal Meridian.

Said property above described is known as the Beam Yards and is situated between Green and Halsted Streets and near Kinzie Street, Chicago, Illinois.

Also all those certain lots numbered two (2) and three (3) in Block number twenty-two (22), in the original Town of Chicago, bounded and described as follows: 
Beginning at a point on the East line of Canal Street $801 / 10$ feet North of the Southwest corner of lot No. 6, in Block No. 22, aforementioned; running thence North along the East line of Canal Street aforementioned, 107 9/10 feet to a point where the East line of Canal Street is intersected by the West line of West Water Street; thence Southeasterly along the West line of West Water Street 138 8/100 feet to a point where the West line of West Water Street is intersected by the North line of lot No. 6 in Block No. 22 aforementioned; thence West along the North line of lot No. 6 aforesaid, 83.3/100 feet to the place of beginning. Meaning and intending hereby to convey what are known and described as Lots Nos. 2 and 3, in Block No. 22 in the Original Town of Chicago, lying between Canal and West Water Streets.

Also all that certain lot No. 6 in Block No. 22, in the Original Town of Chicago, bounded and described as follows:

Beginning at a point on the Southwest corner of said lot No. 6; running thence North along the East line of Canal Street 801/10 feet to the Northwest corner of said Lot No. 6; thence East along the North line of said Lot No. 6,83 3/100 feet of the West line of West Water Street; thence Southeasterly along the West line of West Water Street $10176 / 100$ feet to the North line of Sub-lot No. 1 of lot No. 7 in Block No. 22 aforesaid; thence West along the South line of said lot No. 6, $14467 / 100$ feet to the place of beginning. Meaning and intending hereby to convey all that part of lot No. 6 in Block No. 22, Original Town of Chicago, lying between Canal and West Water Streets.

Sub-lots one (1) to seven (7), both inclusive, of lot seven (7) in Block Twenty-two (22) in the Original Town of Chicago.

Upon the foregoing properties specifically described in Chicago are erected the warehouses of Jones \& Laughlin Steel Company.

All rights under and by virtue of the Homestead Exemption Laws of the State of Illinois are hereby released and waived.

All the interest of the Company in all property which may in any manner be hereafter acquired, either as additions to or improvements of any of the properties hereinbefore described in the foregoing clauses I, II and III, or hereinafter described in the following clause $\mathrm{V}$, and all property that shall be acquired, and all additions, improvements, alterations and repairs that shall be made, with the bonds or their proceeds.

Together with all and singular the buildings, improvements, railroads, rolling stock, streets, ways, alleys, passages, waters, water courses, easements, rights, liberties, privileges, hereditaments and appurtenances whatsoever unto any of the hereby granted and de- 
scribed premises and estates belonging and appertaining or to belong and appertain, and the reversions and remainders, rents, issues, profits and income thereof, and all the estate, right, title and interest, possession, claim and demand of every nature and kind whatsoever of the Company, as well at law as in equity of, in and to the same and every part and parcel thereof, including also all the engines, engine houses, furnaces, mills, steel works, foundries, machine shops, boilers, mills, factories, works, shops and structures now or hereafter to be erected thereon and all machines and machinery, tools and other implements used or hercafter to be used in and about the plants and property aforesaid.

The following shares of fully paid and non-assessable stock, which are hereby pledged with and delivered to the Trustees:

225 shares of the capital stock of the Blair Limestone Company, a corporation organized and existing under the laws of Pennsylvania;

4,800 shares of the capital stock of the Eastern Railroad Company, a corporation organized and existing under the laws of Pennsylvania; 10,962 shares of the eapital stock of the Interstate Iron Company, a corporation organized and existing under the laws of the State of Minnesota;

2,000 shares of the capital stock of the Jones and Laughlin Ore Company, a corporation organized and existing under the laws of the State of Michigan;

40,000 shares of the eapital stock of the Leetonia Mining Company, a corporation organized and existing under the laws of the State of Minnesota;

7,443 shares of the capital stoek of the Monongahela Connecting Railroad Company, a corporation organized and existing under the laws of Pennsylvania;

5,000 shares of the Capital Stock of the Vesta Coal Company, a corporation organized and existing under the laws of Pennsylvania;

1,500 shares of the capital stock of the Aliquippa and Southern Railroad Company, a corporation organized and existing under the laws of Pennsylvania;

2,769 shares of the capital stock of the Interstate Steamship Company, a corporation organized and existing under the laws of the State of West Virginia;

1,000 shares of the par value of $\$ 100$ each in the capital stock of the Harbor Land Company, a corporation organized and existing - under the laws of the State of Ohio, being the entire issued and outstanding capital stock of said Company.

All stocks, bonds and other property of any kind from time to time hereafter, by delivery or by writing of any kind for the pur- 
poses hereof, conveyed, mortgaged, pledged, assigned or transferred by the Company or by any one in its behalf to the Trustees or the corporate Trustee, who are hereby authorized to receive any property at any and all times as and for additional security, and also when and as hereinafter provided as substituted security, hereunder and to hold and apply any and all such property subject to the terms hereof.

To HAVE AND To Howd all and every the said premises, stock, rights, franchises and other property, real, personal or mixed, unto the Trustees and their successor or successors in the trust, forever.

But in Trust, Nevertheless, for the common and equal use, benefit and security of all and singular the person or persons, firm or firms, bodies politic or corporate, that shall from time to time be holders of any of the bonds or coupons, and without preference of any of the bonds over any of the others by reason of priority in the time of issue or negotiation thereof, or otherwise howsoever; subject to the terms, provisions and stipulations in the bonds and coupons contained, and for the uses and purposes, and upon and subject to the terms, conditions, provisions and agreements, in this indenture expressed and declared; and it is hereby covenanted that all such bonds, with the coupons for interest thereon, shall and will be issued, authenticated and delivered, and that the trust estate is to be held by the Trustees, subject to the further covenants, conditions, uses and trusts hereinafter set forth; and it is hereby covenanted and agreed between the parties hereto as follows, to wit:

\section{ARTicle ONe}

EXECUTION, AUTHENTICATION, ISSUE .AND REGISTRATION OF BONDS

Section 1.-The bonds to be issued under and secured by this indenture, together with the interest coupons appertaining thereto, shall be substantially of the tenor and purport above recited.

From time to time the bonds shall be executed by the Company and delivered to the corporate Trustee for authentication by it, and thereupon, as provided in Sections 2 and 3 of this Article, and not otherwise, the corporate Trụstee shall authenticate and deliver the same. The aggregate amount of all the bonds which may be issued and outstanding under and be secured by this indenture at any one time shall not in any event exceed the sum of thirty million dollars $(\$ 30,000,000)$ face amount of principal thereof. The bonds shall be consecutively numbered from one upwards.

Section 2.- $\$ 2,069,000$ face amount of bonds, being bonds numbered consecutively from 1 to 2,069, inclusive, shall, immediately upon the execution of this indenture and without any further action 
on the part of the Company be authenticated by the corporate Trustee and be delivered to the President or Treasurer of the Company to be used for the purpose of retiring and exchanging the present outstanding bonds of the Company to the amount of $\$ 2,069,000$, dated November 1, 1902, in accordance with the terms of an agreement with all the holders and owners of the same. The Trustees shall be under no obligation to see to the application of said bonds.

$\$ 12,931,000$ face amount of the bonds shall from time to time on and after the execution of this indenture be authenticated by the corporate Trustee and be delivered as the corporate Trustee shall be directed by resolution of the Board of Directors of the Company for the following uses and purposes and for no other, to wit: (a) for the purpose of acquiring property, either real or personal, for the uses and purposes of the corporation; (b) for the purpose of making additions, improvements, alterations and repairs to any part or portion of the property of the corporation; (c) for any legitimate and general purpose of the corporation which in the judgment of the Board of Directors of the Company shall be deemed for its best interest. A copy of any resolution of the Board of Directors of the Company setting forth the number of bonds required and the purpose or purposes for which said bonds are to be issued, duly certified under the corporate seal by the Secretary or any Assistant Secretary of the Company, shall be full and sufficient warrant to the corporate Trustee to authenticate and deliver the said bonds as it may be directed by said resolutions, and it shall not be necessary for any such resolutions to set forth specifically or in detail either the property to be purchased or the additions, improvements, alterations or repairs for which the bonds to be so authenticated and delivered are to be used, but it shall be sufficient for any such resolutions to state the uses and purposes in the general language of clauses (a), (b) or (c) above. The Trustees shall be under no duty to see to the application of said bonds or their proceeds.

Section 3.-The remaining $\$ 15,000,000$ face amount of the bonds shall from time to time be authenticated and delivered by the corporate Trustee in like manner as the $\$ 12,931,000$ face amount of the bonds above mentioned except that none of said $\$ 15,000,000$ face amount of the bonds shall be authenticated and delivered prior to January 1, 1911, and except that in each instance the corporate Trustee shall receive, before authenticating and. delivering said bonds or any of them, a certificate or certificates of the President or any Vice-President and of the Secretary or Treasurer or Auditor of the Company, stating as follows:

(a) That since May 1, 1909, property (other than stocks and 
bonds) has been acquired by the Company or by some company ninetyfive per cent. of the capital stock whereof shall at the time be pledged under this indenture (such a company being hereinafter referred to as a subsidiary company), or that betterments and improvements have been made upon the property of the Company or of some subsidiary company, or that such property has been so acquired and such betterments and improvements have been so made, costing not less, and of a present value not less, than the total par value of the amount of bonds previously authenticated and delivered by the corporate Trustee under the provisions of this section, if any, and of the amount of bonds called for by the resolution of the Board of Directors accompanying said certificate-designating in detail (except in the case of betterments and improvements or acquisitions specifically designated in previous certificates, with respect to which a reference to such previous certificates shall be sufficient) the particular property acquired or betterments and improvements made and the cost thereof and whether acquired for the Company or for a subsidiary company or companies, and if for the latter what company or companies and the location of all such property so acquired; the purpose being that out of the second $\$ 15,000,000$ of bonds the Company shall have the right from time to time, and at any time, after January 1, 1911, to receive from the corporate Trustee and the corporate Trustee shall deliver to the Company bonds for any legitimate purpose of the corporation to an amount face value that shall equal but not exceed the cost and value of property acquired by the Company or a subsidiary company or companies since May 1, 1909, and the cost and value of betterments and improvements made upon the property of the Company or a subsidiary company since May 1, 1909, whether the cost of such property acquired or betterments and improvements made has been paid out of the proceeds of the bonds or out of the surplus earnings of the Company or of any subsidiary company or companies.

(b) That all of said property stated to have been acquired by the Company and all betterments and improvements stated to have been made upon the property of the Company have become subject to this indenture as a first lien thereon and that the opinion of counsel of the Company is simultaneously delivered to the corporate Trustee stating either that said property and said betterments and improvements have been directly subjected to the lien of this indenture by an instrument or instruments therein referred to (which instrument or instruments shall be delivered to the corporate Trustee therewith) or that no instrument or instruments is necessary for such purpose. 
(c) That for all amounts stated to have been expended for betterments or improvements upon the property of any subsidiary company or companies, notes therefor of the company for whose benefit such betterments or improvements shall have been made have been assigned and delivered to the Trustees or are tendered and assigned and delivered to the Trustees simultaneously with the certificate, to be held by the corporate Trustee under this indenture as part of the trust estate, and that for all amounts stated to have been expended for the acquisition of property for any subsidiary company or companies, a purchase money bond and mortgage or purchase money bonds and mortgages, or bonds secured by a first mortgage or deed of trust, upon the property so acquired (or in case the property so acquired shall be acquired subject to any mortgage, lien or other charge, or in case the subsidiary company shall pay only a part of the purchase money for the property so acquired and shall give a mortgage for the unpaid part of the purchase price, then in any such event, a bond and mortgage or bonds secured by a mortgage or deed of trust, subjeet only to such prior mortgages, liens or other charges), of a face amount equal at least to the amount stated to have been so expended, have been taken and have been assigned and delivered to the Trustees or are tendered, assigned and delivered to the Trustees simultaneously with such certificate, to be held by the corporate Trustee under this indenture as part of the trust estate.

(d) That the prices paid for such betterments and improvements and for such property acquired were not in excess of the fair value of the work done or property aequired.

(e) That for all bonds reserved under the provisions of this Section 3 or the proceeds thereof in any way applied to or for the uses or purposes or benefit of any subsidiary company, notes or other obligations of such subsidiary company to at least the face value thereof have been taken by the Company and have been assigned and delivered to the Trustees, or are tendered, assigned, or delivered to the Trustees simultaneously with said certificate, to be held by the corporate Trustee under this indenture as part of the trust estate.

Upon receiving said certificate or certifieates and the certified resolution of the Board of Directors of the Company and the opinion of counsel above provided for and the instrument or instruments, if any, referred to in such opinion, and all the notes or other obligations stated in said certifieate to have been taken to represent the amounts expended for betterments or improvements upon, or the acquisition of property for, the subsidiary company or companies therein referred to, and all the notes or other obligations referred to in elause (e) of the certificate, the corporate Trustee shall authenticate and deliver 
the said bonds as above provided, but only to such extent that the amount of said bonds so authenticated and delivered when added to the amount of the bonds previously authenticated and delivered by the corporate Trustee under the provisions of this section will not exceed the cost and present value of the betterments and improvements made and property acquired since May 1, 1909, as stated in the certificate or certificates delivered to the corporate Trustee under this section. The corporate Trustee shall be absolutely protected in delivering the bonds in accordance with the foregoing provisions and the Trustees shall be under no duty to see to the application of said bonds or the proceeds thereof.

SECTron 4.-In case the officers who shall have signed and sealed any of the bonds shall cease to be such officers of the Company before the bonds so signed and sealed shall have been actually authenticated and delivered by the corporate Trustee, such bonds may nevertheless be adopted by the Company and be issued, authenticated and delivered as though the persons who signed or sealed such bonds had not ceased to be officers of the Company. The coupons to be attached to the bonds shall be authenticated by the engraved signature of the present Treasurer or any future Treasurer of the Company, and the Company may adopt and use for that purpose the engraved signature of any person who shall have been such Treasurer, notwithstanding the fact that he may have ceased to be such Treasurer at the time when such bonds shall be actually authenticated and delivered. Only such of the bonds as shall bear thereon endorsed an authentication substantially in the form hereinbefore recited, executed by the corporate Trustee, shall be secured by this indenture or entitled to any lien, right or benefit hereunder; and such authentication by the corporate Trustee upon any such bond shall be conclusive evidence, and the only evidence, that the bond so authenticated has been duly issued hereunder, and that the holder is entitled to the benefit of the trust hereby created. Before authenticating or delivering any bond all coupons then matured shall be cut off and cancelled, and on its written demand delivered to the Company. On request of the Company, but within the limitations herein prescribed, the bonds may be authenticated and delivered hereunder in advance of the registration, filing or recording of this indenture.

Section 5.-The Company will keep at an office or agency to be maintained by it in the Borough of Manhattan in the City of New York, or at some bank or trust company in said borough, a sufficient register or registers of the bonds, which shall at all reasonable times be open for inspection by the Trustees, and upon presentation for such purpose the Company will, under such reasonable regulations 
as it may prescribe, register therein any of the bonds. The holder of any bond may have the ownership thereof registered on said books, such registry being noted on the bond by the bond registrar of the Company, after which registration and notation thereof on the bond no transfer shall be valid unless made on said books by the registered holder in person or by his attorney duly authorized, such registration being duly noted on the bond by the bond registrar of the Company; but the same may be discharged from registry by being in like manner transferred to bearer, after which it shall be transferable by delivery. Such registration shall not affect the negotiability of the coupons belonging to any bond, but every such coupon shall continue to pass by delivery and shall remain payable to bearer as therein provided. For any transfer of bonds upon its register, the Company may require the payment of a sum sufficient to reimburse it for any stamp tax or other governmental charge connected therewith.

SECTION 6.-As to all bonds registered as to principal, the person in whose name the same shall be registered shall for all purposes of this indenture be deemed and regarded as the owner thereof, and payment of or on account of the principal of such bond, shall be made only to or upon the order of such registered holder thereof, but such registration may be changed as above provided. All such payments shall be valid and effectual to satisfy and discharge the liability upon such bonds to the extent of the sum or sums so paid. The Company and the Trustees may deem and treat the bearer of any bond which shall not at the time be registered as to principal, and the bearer of any coupon for interest on any bond, whether such bond shall be registered or not, as the absolute owner of such bond or coupon, for the purpose of receiving payment thereof, and for all other purposes whatsoever, whether such bond or coupon be overdue or not, and the Company and the Trustees shall not be affected by any notice to the contrary.

Section 7.-In case any bond, with the coupons thereto appertaining, shall be mutilated or destroyed or lost, the Company, in its discretion, may execute, and thereupon the corporate Trustee shall authenticate and deliver, a new bond of like tenor and date, bearing the same serial number, in exchange and substitution for, and upon cancellation of, the mutilated bond and its coupons, or in lieu of, and in substitution for, the bond and its coupons so destroyed or lost. The applicant for such substituted bond must furnish the Company and the corporate Trustee evidence satisfactory to the Company and to the corporate Trustee, respectively, in their discretion, of the destruction or loss of such bond and its coupons, so destroyed or lost, 
and said applicant must also furnish indemnity satisfactory to both of them in their discretion.

SECTION 8.-Until the bonds can be engraved and are ready for delivery, the Company may execute and the corporate Trustee shall authenticate and deliver, as provided in Sections 1,2 and 3 of this Article, in lieu of a like principal amount of definitive bonds, temporary printed bonds, either registered or negotiable by delivery, and substantially of the tenor of the bonds hereinbefore recited, except that no coupons shall be attached to any of said temporary bonds, and that such temporary bonds may be for the payment of $\$ 1,000$, or any multiple thereof, as the President or Board of Directors of the Company shall determine. Each of said temporary bonds shall bear upon its face the words: "Temporary First Mortgage Thirty Year Five Per Cent. Gold Bond, Exchangeable for Engraved Bond(s)," and said temporary bonds shall be exchangeable for a like principal amount or amounts of the engraved bonds, when the said engraved bonds are ready for delivery. Upon every exchange of temporary bonds for engraved bonds, the temporary bonds surrendered for exchange shall be forthwith cancelled by the corporate Trustee, and immediately delivered to the Company. The authentication by the corporate Trustee on the said temporary bonds shall be conclusive evidence and the only evidence that the temporary bond so authenticated has been duly issued hereunder and that the holder is entitled to the benefit of the trust hereby created. Until exchanged for engraved bonds, as provided herein, said temporary bonds so authenticated shall in all respects be entitled to the security of this indenture as bonds issued and authenticated hereunder, and interest when and as payable shall be paid, but only upon the endorsement of such payment upon the temporary bond. The Company agrees to have the engraved bonds prepared and executed with all convenient speed.

\section{Article Two}

\section{PARTICULAR COVENANTS OF THE COMPANY}

Section 1.-The Company covenants and agrees that it will duly and punctually pay or cause to be paid the principal and interest of every bond issued under this indenture at the times and places and in the manner mentioned in such bonds or in the coupons thereto belonging, according to the true intent and meaning thereof, without deduction from either principal or interest for any tax or taxes, assessments or other governmental charges which the Company may be required to pay thereon or to deduct or retain therefrom under any present or future law of the United States, or of any state, county; municipality or other taxing authority therein, the Company hereby 
agreeing to pay the same. The interest on the bonds shall be payable only upon presentation and surrender of the several coupons for such interest as they respectively mature, and when paid such coupons shall forthwith be cancelled and delivered to the Company.

In order to prevent any accumulation of coupons and claims for interest after maturity, the Company covenants that it will not, directly or indirectly, extend, or assent to the extension of, the time for the payment of any coupon or claim for interest on any of the bonds, and the Company will not, directly or indirectly, be a party to, or approve of, any such arrangement by purchasing said coupons or claims for interest, or in any other manner.

At all times until the satisfaction and discharge of this indenture the Company will designate a bank or bankers or trust company in the Borough of Manhattan in the City of New York as its financial agency for the payment of the bonds and the interest coupons and as a place where said bonds and coupons may be presented for payment and where notices or demands in respect thereof may be served and from time to time the Company will give due notice in writing to the corporate Trustee of the place of such agency. The Company hereby designates Messrs. Blair and Co., 2t Broad Street, New York, as the financial agency of the Company for said purpose in the City of New York and such agency shall continue the same until the Company shall designate a new agency and give notice thereof to the corporate Trustee as above provided. In case, however, at any time there shall be no such agency of the Company in the City of New York the corporate Trustee is hereby authorized to constitute any bank or bankers or trust company in the Borough of Manliattan in the City of New York that it may choose the agency of the Company for such purpose until such time as an appointment shall be made by the Company and written notice thereof duly furnished to the corporate Trustee as above provided.

Section 2.-All plants, lands, machinery, mines, franchises, notes, or other obligations, stocks and other property of every kind, real, personal, or mixed, hereby conveyed or pledged, or covenanted to be conreyed or pledged, to the Trustecs under this indenture, whether now owned or hereafter acquired by the Company, shall, immediately, or immediately upon the acquisition thereof by the Company, and without any further conreyance or assignment, become and be subject to the lien of this indenture as fully and completely as though now owned by the Company and specifically described in the granting clauses hereof, but at any and all times the Company will execute and deliver any and all such further assurances or conveyances or assignments thereof as the Trustees or either of them may reasonablv direet 
or require, for the purpose of expressly and specifically subjecting the same to the lien of this indenture. The Company agrees that it will forthwith cause this indenture to be duly recorded, and, as new property shall from time to time be acquired in places other than those places in which record shall originally be made, will cause this indenture to be there recorded, and will at all times cause this indenture to be kept recorded and filed as a mortgage both of real and of personal property in such manner and in such places, and do or cause to be done all such things, as may be required by law in order to fully preserve and protect the security of the bondholders and all rights of the Trustees. And also the Company will do, execute, acknowledge and deliver, or cause to be done, executed, acknowledged and delivered, all and every such further assurances in the law for the better assuring, conveying, assigning and confirming unto the Trustees or either of them all and singular the hereditaments and premises, estates and property hereby conveyed or assigned, or intended so to be, or which the Company may be, or hereafter become, bound to convey or assign to the Trustees or either of them, as the Trustees or either of them shall reasonably require.

The Company covenants and agrees that provided it obtains the consent of the holders of the entire capital stock of the Company it will assign to the Trustees as additional security to be held under the trusts of this indenture the following: The entire capital stock of the Ross Land Company, a corporation of the State of Pennsylvania, being 6,000 shares, of the par value of $\$ 50$ each, and the entire capital stock of the Woodlawn Land Company, a corporation of the State of Pennsylvania, the issued and outstanding capital stock of said company being 15,000 shares of the par value of $\$ 50$ each. Nothing contained in this indenture shall be construed to prevent the Ross Land Company, in case any shares of its capital stock shall be pledged under this indenture, from leasing offices in the office building owned by it, or from renewing or extending the bonds of said company now outstanding or the issuing of new bonds to a like amount for the purpose of refunding or paying the same or from carrying on its general business. Nothing in this indenture contained shall prevent the Woodlawn Land Company, in case any shares of capital stock thereof shall be pledged hereunder, from selling, exchanging or leasing, from time to time, free from the lien of this indenture, without the consent of either the corporate or the individual Trustee, its real estate or any part or parts thereof, and using the proceeds thereof for proper corporate purposes.

SECTION 3.-The Company covenants and agrees that coupon bonds Nos. 1 to 2,069, inclusive, shall be promptly used for the purpose of 
retiring and exchanging the present outstanding bonds of the Company to the amount of $\$ 2,069,000$, dated November 1,1902 , in accordance with the terms of an agreement with all the holders and owners of the same. The Company covenants and agrees that it will take all necessary steps and perform or eause to be performed all necessary acts in order to cause said outstanding bonds of the Company dated November 1, 1902, to be forthwith paid off and cancelled and the mortgage securing the same to be released and discharged of record and the Company hereby covenants and agrees that said bonds and mortgage will forthwith be cancelled, released and discharged of record. The Company covenants that the remainder of the bonds and their proceeds will be used only (a) for the purpose of aequiring property, either real or personal, for the uses and purposes of the corporation; (b) for the purpose of making additions, improvements, alterations and repairs to any part or portion of the property of the corporation; (c) for any legitimate and general purpose of the corporation which in the judgment of the Board of Directors of the Company shall be deemed for its best interest.

The Company covenants and agrees that for any of the $\$ 15,000,000$ face amount of bonds reserved under the provisions of Section 3 of Article One of this indenture or the proceeds thereof in any way applied for the uses, purposes or benefit of any subsidiary company, notes or bonds of such subsidiary company to at least the face value thereof will be taken by the Company and pledged with the Trustees hereunder, to be held by the corporate Trustee as part of the trust estate.

Section 4.-The Company covenants that this indenture is and will always be kept a first lien upon the premises and property described or mentioned in the granting clauses hereof, and upon renewals and replacements thereof, and will be kept a first lien on all after-acquired property, eovered by the granting elauses hereof, subject only to liens or deferred installments of the purchase price to which the said after-acquired property may be subject as and when acquired or purchase money mortgages thereon which the Company may give therefor. The Company will not voluntarily create or suffer to be created any lien or eharge which will be prior to the lien of this indenture upon the trust estate or any part thercof or upon the income thereof; and within three months after the same shall acerue it will pay or cause to be discharged, or will make adequate provision to satisfy and discharge, all lawful claims and demands of mechanics, laborers and others, which if unpaid may by law be given precedence over this indenture as a lien or charge upon the trust estate or any part thereof, or the income thereof, provided that nothing in this 
section shall require the Company to pay such debt, claim, lien or charge, so long as it shall in good faith contest the validity thereof.

The Company corenants and agrees that it will pay, when the same shall become due, all taxes and assessments levied or assessed upon it or upon the property now or hereafter covered hereby, or upon any part thereof, or upon any income therefrom or upon the lien or interest of the Trustee or of either of them in respect of such trust estate or income, and will duly preserve and conform to all valid requirements of any governmental authority relative to any of the property or rights at any time covered hereby, and all covenants, terms and conditions upon or under which any such property or rights are held, so that the interest and right of the Trustees or either of them hereunder and of the bondholders may be kept in all respects unimpaired and the security hereof maintained.

If any corporation, seventy-five per cent. of the outstanding shares of stock whereof shall at the time be subject to this inderture, shall fail to pay any taxes, assessments and charges lawfully imposed upon such corporation or its property or upon the income and profits thereof, when the same shall become due and payable, then the Company will itself pay and discharge the same unless the corporate Trustee shall state in writing that in its opinion it is not for the interest of the bondholders that such payment shall be made.

Nothing in this section shall require the Company to pay any tax, assessment or charge so long as it or the Company affected thereby shall in good faith contest the validity thereof.

The Company further covenants and agrees that it will keep or cause to be kept the mortgaged premises and the property of every corporation a majority in amount of the outstanding shares of stock whereof is or shall be subject to this indenture in good repair, working order and condition, and equipped with suitable machinery and appliances and will renew and replace the same or cause the same to be renewed and replaced as may be necessary to such an extent that the general efficiency of said properties as a whole shall not be impaired and shall at all times be at least equal to their present standard; but this provision shall not prevent the Company or any corporation the stock whereof is or shall be subject hereto from cutting timber, opening, mining and digging mines, and beds or veins of minerals, nor shall it prevent the removal, sale or use of minerals, ore, coal or other deposits taken therefrom, or the sale or use of such timber, in the ordinary conduct of business, nor require the operation or working of any mine, plant or works, to any greater extent than shall be deemed necessary by the Company in the ordinary conduct of business. 
Section 5.-The Company agrees that it will keep all buildings, structures, machinery and equipment at any time corered by this indenture of a character usually insured by companies similarly situated, insured against loss or damage by fire, to a reasonable amount, loss to be made payable to the Company and to the Trustees as interest may appear, and all other insurance which the Company shall elect to procure on any property covered hereby shall be made similarly payable. So long as the Company shall not be in default under this indenture, the proceeds of any insurance on any part of the trust estate shall be paid to the Company, and shall be kept by the Company in a separate fund, which said fund shall be in all respects subject to the lien of this indenture and be specially held for the benefit of the bondholders subject to the provisions hereof and shall be applied by the Company to restoring, repairing, replacing or acquiring or completing substitutes for the property injured or destroyed, or, if the Company so elect, and in all cases when such fund shall exceed $\$ 100,000$ in amount, such proceeds shall be deposited with the corporate Trustee and shall be thereafter held, used and applied as is hereinafter provided in Article Eight with reference to the proceeds of released property.

The Company further agrees that it will keep or cause to be kept all buildings, structures, machinery and equipment at any time belonging to any corporation a majority in amount of the outstanding capital stock whereof is or shall be subject to the lien hereof, which are of a character usually insured by companies similarly situated, insured against loss or damage by fire to a reasonable amount.

Section 6.-The Company covenants and agrees that if it shall fail to perform any of the covenants contained in Seetions 4 and 5 of this Article, the Trustees may, but shall not be obliged to, perform the same on behalf of the Company, making advances therefor; and the Company agrees that it will forthwith repay all sums so advanced, together with interest at five per cent. per annum until paid, and all sums so advanced by the Trustees or either of them or by any one on their behalf are hereby declared to be a lien upon the trust estate, in priority to the bonds and coupons. No such advances shall be deemed to relieve the Company from any default hereunder.

Section 7.-The Company will not sanction or permit any issue of additional shares of capital stoek of any company of whose outstanding capital stock a majority in amount is or shall be pledged or assigned hereunder, or the issue of any bonds or debentures by any such company or the creation of any mortgage or other lien upon the property of any such company (except purchase money bonds or notes in connection with the acquisition of additional property needed in 
its business which may be secured by a purchase money lien upon the property acquired) or any notes payable or indebtedness (except notes payable or other obligations issued or indebtedness incurred in the course of the ordinary conduct of its business) unless simultaneously there shall be made effective provision that such indebtedness and the evidences thereof and such bonds, debentures or notes issued and such mortgage or other lien and all such additional stock (or such part of such additional stock as shall be proportionate to the entire outstanding capital stock previously owned by the Company or pledged hereunder) forthwith upon the issue or creation thereof shall be delivered to and be pledged with the Trustees hereunder and be made subject to all the trusts of this indenture, and the Company agrees that all such additional stock shall be fully paid and non-assessable; provided, however, that nothing contained in this section or elsewhere in this indenture shall prevent the Eastern Railroad Company or the Monongahela Connecting Railroad Company or the Aliquippa and Southern Railroad Company or the Interstate Steamship Company or any company with which or into which they or any of them may be merged or consolidated or any company resulting from any such merger or consolidation or any railroad or steamship company any of the stock whereof shall at any time be pledged hereunder, from issuing shares of capital stock, incurring indebtedness and issuing bonds and securing the same by mortgage or other lien and disposing of the same for proper corporate purposes free from the lien of this indenture; and it is hereby expressly agreed that the Company may permit said companies to create, and said companies may create, such indebtedness and bonds or other obligations and mortgages or other liens, and may issue capital stock, and dispose of the same for proper corporate purposes, notwithstanding the foregoing provisions of this section.

Except as in Section 7 of Article Three or elsewhere in this indenture expressly permitted, the Company will not, unless with the consent of the corporate Trustee, sanction or permit the sale, conveyance, assignment, lease or other disposition by any company of whose outstanding capital stock sixty per cent. in amount or more shall at the time be subject hereto of any real property or plants or lease of mineral rights; except (a) a sale, exchange or conveyance to straighten lines or to facilitate, and lessen the cost of the mining of ores, coal or other minerals, and (b) a sale, lease or exchange of any such real property or plant or lease of mineral right, taken by any such company in satísfaction of a debt or upon enforcement of any security given for the payment of a debt, made within three years after such property is so taken.

Any company sixty per cent. in amount or more of the outstanding 
capital stock whereof shall at the time be subject hereto may make, in addition to any lease elsewhere herein expressly pernitted, any lease of any such real property or plant for any term of not to exceed three years, provided the corporate Trustee consents thereto; and the corporate Trustee may in its absolute discretion so consent.

Any such company may make any lease of any such real property or plant or lease of mineral rights for more than three years, or may make any sale thereof, or exchange thereof for other real estate or property, or, in case of leases of mineral rights, for other such leases, provided the corporate Trustee consents thereto. Such sale may be made entirely for cash or partly for cash and partly for other real estate or property or notes or other evidences of indebtedness reprezenting deferred payments secured by a purchase money mortgage, or a vendor's lien, or in some other way by a first lien upon the property sold. The corporate Trustee shall give such consent only upor: receiving a written request of the President or a Vice-President of the Company approved or authorized by resolution of its Board oi Directors, and upon receiving a certificate signed by a majority of the Board of Directors then in office including the President or a Vice-President, that such lease or assignment or sale or exchange is advisable and stating what the value of the property so leased, assigned, sold or exchanged is, that the consideration received or to be received is at least equal to the value of the property leased, assigned, sold or exchanged, and that any real estate forming part of the consideration has been, or simultaneously with such sale or exchange will be, conveyed to the company making such sale, assignment or exchange, or in case of leases of mineral rights, that the leases received in exchange therefor have been, or simultaneously with such assignment or exchange will be, assigned to or leased to the company making such sale, assignment or exchange, and that any cash forming part of the consideration has been, or simultaneously with such sale or exchange will be, delivered to such company, and that notes or other evidences of indebtedness representing deferred payments forming part of the consideration secured by a purchase money mortgage or vendor's lien, or in some other way as a first lien upon the property sold or exchanged, have been, or simultaneously with such sale or exchange will be, delivered to the company making such sale, assignment or exchange. The enrporate Trustee shall not, however, be required to give such consent except in its discretion.

Nothing contained in this indenture shall, however, prevent any railroad or steamship company stock whereof is or shall be pledged hereunder from leasing its railway or property to any other company. Nothing contained in this indenture shall prevent any railroad or 
steamship company any of the stock whereof is or shall be pledged hereunder from selling or otherwise disposing of its railroad or property for an adequate consideration.

SECTion 8.-The Company covenants and agrees that the surplus of quick assets over the liabilities of the Company other than the outstanding bonds issued under this indenture shall always equal at least $\$ 8,000,000$ so long as the said outstanding bonds shall equal or exceed $\$ 8,000,000$, and covenants and agrees that said surplus of quick assets over liabilities shall always equal the amount of bonds outstanding so long as the face amount of bonds outstanding shall be less than $\$ 8,000,000$. By the phrase "quick assets" is meant cash in banks, on hand and in transit, good accounts and short time bills and notes or similar securities received on the sale of products; raw material, material in the process of being manufactured, manufactured products and supplies (it being understood that all material, manufactures and supplies shall be figured at the market value thereof at the time of the valuation thereof hereunder). It is expressly understood and agreed that in the term "raw material" no ore, coal or limestone shall be included except such as has actually been mined or quarried and is then on the surface at the mines or at the quarries, available for shipment, or in transit, or at docks or at works, and in no case is raw material to be held to include unmined minerals. The Company further covenants and agrees that the net assets of the Company are and shall always be at least $\$ 25,000,000$ in excess of the par value of the present capital stock of the Company, such par value of the present capital stock of the Company being $\$ 30,000,000$.

The Company agrees to furnish to the Trustees on or before March 1, in each year, a detailed statement as of the thirty-first day of December then next preceding, of such assets and liabilities, signed by an executive officer of the Company, and certified by some public accountant or audit company approved by the corporate Trustee.

The Company covenants and agrees to permit the Trustees at all reasonable times to have access to the books and accounts of the Company and to permit the Trustees, if it shall be deemed by them or either of them advisable, to makc by their duly appointed agents, satisfactory to the Company, examinations frem time to time, but not oftener than once in twelve months, of the physical condition of the property of the Company, and upon request to pay the Trustees the reasonable expense of each such examination.

SECrion 9.-The Company covenants that, whenever there shall have occurred one or more of the events of default defined in Section 1 of Article Five of this indenture, it will, on request in writing from the Trustees, disclose or cause to be disclosed to the Trustees or 
to any person named by them for the benefit of the bondholders, all secret processes and formulæ and all other processes or methods of manufacture and formulæ owned or used by the Company in the conduct of its business and that it will furnish all information reasonably requested for using the same or for carrying on said business.

\section{Article Tirree}

\section{CONTROL OF PLEDAED SECURITIES}

Section 1.- When and as the certificates for any of the shares of stock which the Company has by this indenture assigned or transferred or agreed to assign and transfer to the Trustees or either of them, shall come into the possession of the Company or under its control, the Company shall forthwith deliver the same or cause the same to be delivered to the corporate Trustee, together with proper instruments of assignment and transfer thereof to the Trustees, or in blank, as the corporate Trustee may require.

The Trustees shall have the right and are hereby authorized to have any shares of stock registered in their names, or in the name of the corporate Trustee or any nominee of the corporate Trustee approved by the Company endorsed in blank or with a blank power of assignment or of attorney, or to receive and hold such stock or the certificates therefor in the name of the Company or in the names in which they may stand at the time they are delivered to the corporate Trustee endorsed in blank, or with a blank power of assignment or of attorney, provided that the company which issued the stock shall be notified of the pledge of such shares with the Trustees hereunder and directed to cause a note of such pledge to be placed upon its stock book. The Trustees or either of them may deliver any of said certificates of stock pledged hereunder to the Company, or to any agent or representative of, or person designated by the Company, for the purpose of having the same exchanged for certificates of different denominations, or certificates in the name of the corporate Trustee, or for such other purpose in furtherance of this trust as the Trustees or the corporate Trustee may deem advisable. The Company shall at all times have the right to inspect any certificates of stock or other securities pledged hereunder.

SECTION 2.-The Trustees or the corporate Trustee may do whatever may be necessary for the purpose of maintaining, preserving, renewing or extending the corporate existence of any company stock of which shall be subject to the lien herenf, and for such purpose from time to time may sell, assign, transfer and deliver so many of the 
shares of the stack of the several companies as may be necessary to qualify persons (to be named by the Company, in case it shall not at the time be in default hereunder) to act as directors of, or in any other official relation to, said companies. Whenever the Company, not being in default under this indenture, shall in writing so renuest, stating in such request that the Company has no shares for that purpose under its control other than shares held under this indenture, the Trustees or the corporate Trustee shall assign and transfer to persons designated by the Company a sufficient number of any shares then subject to the lien hereof to qualify any persons to act as directors of, or in any other official relation to the several companies which issued such shares, provided, however, that under this provision no transfer shall be made of the stock of any company the greater part in amount of the outstanding stock whereof shall be pledged or assigned hereunder which shall reduce the amount of stock in any such company held by the Trustees or the corporate Trustee so as to render it less than a majority in amount of such stock; and in every case the Trustees or the corporate Trustee may make such arrangements as they or it shall deem necessary for the protection of the trusts hereunder in respect of the shares so assigned.

Section 3.- Unless and until one or more of the events of default defined in Section 1 of Article Five hereof shall have happened, the Trustees shall not nor shall either of them (except with the assent of the Company or as otherwise authorized by this indenture) collect the interest on any of the notes or other obligations or indebtedness now or hereafter subject to this indenture and the Company shall be entitled to receive all interest paid in respect of such notes, obligations or indebtedness, and the dividends paid out of earnings, whether such earnings have been heretofore or shall be hereafter made, on all shares of stock, which shall be subject to this indenture, although the same may have been transferred to the Trustees or the corporate Trustee, and from time to time (subject to the covenants in respect thereof in this section contained) upon the request of the Company the Trustees or the corporate Trustee shall deliver to the Company any coupons for such interest then in the possession of the Trustees or the corporate Trustee in order that the Company may receive payments thereof for its own use or may cause the same to be cancelled, and the Trustee or the corporate Trustee shall deliver to the Company suitable orders in favor of the Company or its nominee for the payment of such interest and of such dividends, and the Company may collect such coupons, interest and dividends (but not by any proceeding which the Trustees or the corporate Trustee shall deem to be prejudicial to the trusts hereunder), and the Trustees or the corporate Trustee upon demand 
shall pay over to the Company any sueh interest and dividends which may be collected or be received by the Trustees or either of them or the nominee or nominees of them or either of them.

Provided, however, that exeept as in this indenture otherwise expressly provided (1) the Company shall not be entitled to receive and the Trustees shall not, nor shall either of them, pay over to the Company the principal of any of the notes, obligations or indebtedness subject to the lien hereof; or any interest on any of such notes, obligations or indebtedness which shall have been collected or paid otherwise than out of such earnings or other current income, or any dividends upon any shares of stock paid otherwise than out of such earnings or current income; it being the intention that the Oompany shall be entitled to receive only payments made out of earnings and rents, revenues, income or net proceeds of operation; and (2) until actually paid, released or discharged, every such coupon or right to interest or dividends shall remain subject to this indenture, and if any such coupons delivered to the Company shall not as aforesaid forthwith be paid and cancelled, the Company shall return the same to the corporate Trustee, and in case of the payment of any such coupon shall, upon demand of the corporate Trustee, furnish satisfactory evidence of the cancellation and extinguishment thereof. The Company hereby authorizes and directs all companies whose stocks and all persons and companies whose bonds, notes or other obligations or indebtedness are or shall be held hereunder to pay to the corporate Trustee hereunder any such dividends or interest or amounts not receivable by the Company as aforesaid.

The Trustees and each of them shall be entitled to assume that any interest received by them or either of them or by the Company on any note or other obligation or indebtedness, or any dividend received on any share of stock, is paid out of such rents, revenues, earnings, income or net proceeds of operation, unless the holders of at least ten per cént. in amount of the outstanding bonds shall in writing notify the corporate Trustee to the contrary, and it shall be conclusively presumed as between the Trustees and each of them and the bondholder that the Trustees and each of them in making any payments thereof to the Company acted in good faith.

In case any note or nther obligation or indebtedness now or hereafter subject to this indenture shall mature, the Trustees or the corporate Trustee shall, if there be at the time no continuing event of default such as is defined in Section 1 of Article Five of this indenture, and if so requested by the Company, continue to lold the same or extend the payment of the same or accept a new note or other obligation or other indebtedness of the same debtor or its successor 
of equal amount in place thereof, secured in the same manner and to the same extent as the note or other obligation or indebtedness so maturing. In case there shall be at the time of such maturity of any such note, obligation or indebtedness any such continuing event of default or in case the Company shall not so request and such note, obligation or indebtedness shall not forthwith be paid, the Trustees or the corporate Trustee shall take such steps as the corporate Trustee shall deem advisable in the best interest of the bondholders.

SEction 4.-In case any sum shall be paid on account of the principal of any notes or other obligations or indebtedness subject to this indenture or in case any sum shall be paid on account of the interest upon any such notes or other obligations or indebtedness otherwise than out of such earnings, rents, revenues, income, or net proceeds of operation, or in case any dividend shall be paid on any shares of stock pledged or assigned hereunder otherwise than out of such earnings, rents, revenues, income, or net proceeds of operation, or in case upon the liquidation or dissolution of any company any sum shall be paid upon any such notes, or other obligations, or indebtedness or shares of stock of such company pledged hereunder, then in every such case any such sum, unless applied on account of the purchase price of property purchased pursuant to Section 6 of this Article, shall be paid to and received by the corporate Trustee and shall be applied as hereinafter provided in Article Eight with respect to the proceeds of released property. Any note or other obligation which shall be fully paid shall be cancelled by the corporate Trustee and delivered to the maker or the Company.

Section 5.-Unless and until some one of the events of default defined in Section 1 of Article Five of this indenture shall have happened, the Company shall have the right to vote for all purposes not contrary to its covenants or agreements herein contained or otherwise inconsistent with the provisions or purposes of this indenture, and with the same force and effect as though such shares were not subject to this indenture, upon all shares of stock assigned or pledged hereunder, and from time to time upon demand of the Company the Trustees forthwith shall execute and deliver or shall cause to be executed and delivered to the Company, or to its nominee, powers of attorney or proxies to vote upon any shares of stock, which shall have been transferred to the Trustees or either of them or the nominee or nominees of them or either of them. The Company agrees that it will not vote or permit any proxy or proxies to vote on any of the shares of stock subject to the lien hereof,.contrary to the covenants and provisions in this indenture contained.

Subject only on the specific restrictions contained in this indenture, 
and to the actual exercise by the Company of rights in respect thereof conferred by this indenture, the Trustees or the corporate Trustee shall have and may exercise all the rights of an owner in respect of any stock or certificates of interest therein held by the Trustees or either of them under this indenture or in any manner whatsoever on the trusts hereof.

Secrion 6.-In case default shall be made in the payment of the principal of or interest upon any of the notes or other obligations which shall have been delivered to and shall be held by the Trustees or either of them hereunder, or any other notes, or obligations then secured by the same mortgage or deed of trust as notes or other obligations held by the Trustees or either of them, or in the due observance or performance of any covenant contained, or in case any other default or event of default mentioned in any of said notes or obligations or in the mortgage or other instrument securing the same shall occur, then in any such case, if the Trustees or either of them shall hold the greater part in amount of the entire issue of such notes or other obligations in default, upon the written request of the Company (the Company not being then in default under this indenture) and, upon receiving reasonable indemnity if required, the Trustees or the corporate Trustee shall, and otherwise in the absence of such indemnity but upon such written request, the Trustees or the corporate Trustee may, in their or its discretion, without prejudice to any right to claim a default under this indenture or to assert any right consequent upon such default, cause proper proceedings to be instituted and prosecuted in some court of competent jurisdiction to foreclose or enforce the mortgage or trust or charge by which such notes or obligations in default are secured and to collect such notes or obligations. In case any of the events of default hereinafter defined in Section 1 of Article Five shall have occurred, or in case the Trustees or either of them shall have entered or shall have elected to enter into possession of the trust estate, either under the power hereinafter conferred or by the voluntary action of the Company, then and in any such case, without such written request, the Trustees or the corporate Trustee in their or its discretion may, and upon the written request of the holders of ten per cent. of the bonds outstanding hereunder shall, institute such proceedings.

In case (1) at any time any company, shares of the capital stock of which shall be subject to this indenture, shall be dissolred or liquidated, or in case (2) all or any of the property of any such company shall be sold at any judicial or other sale, or in case (3) any of the property covered by any mortgage securing, or subject to any charge or trust for the payment of, any notes or other obligations subject to 
this indenture shall be sold upon foreclosure of such mortgage or by the enforcement of such charge or trust; then in any such event if the property of such dissolved or liquidated company or the property sold, or any of such property, can be acquired by crediting on the notes or other obligations or indebtedness or stock then held by the Trustees or either of them hereunder any sum accruing or to be received thereon out of the proceeds of such property and by paying not more than ten per cent. of the price of such property in cash (or more than ten per cent. if the holders of a majority in amount of the bonds outstanding hereunder shall so request) the Trustees or the corporate Trustee in their or its discretion may, and if requested in writing by the Company or the holders of a majority in amount of the bonds outstanding hereunder, and provided with the amount of cash necessary therefor (whether such amount be more or less than ten per cent. of the price of such property), shall, purchase or cause to be purchased such property either in the name or on behalf of the Trustees or of the corporate Trustee or of the Company, or of purchasing trustees, as the Trustees or the corporate Trustee may determine, and shall use, or permit the Company to use, such notes or other obligations or indebtedness or stock so far as may be to make payment for such property, and in case of any such purchase the Trustees or the corporate Trustee shall take such steps as they or it may deem proper to cause such property to be vested either in the Company subject to this indenture as a first lien thereon, or in some other corporation organized or to be organized with power to acquire and manage such property, provided that all the notes and other obligations and indebtedness (excepting notes, obligations or indebtedness, if any, subject to which said property shall have been sold to said corporation) and capital stock thereof (excepting the number of shares required to qualify directors) shall be received by the Trustees or corporate Trustee and shall be held for the benefit of the Company or its assigns subject to the primary lien of this indenture.

With the written consent of the Company the Trustees or corporate Trustee at any time may vote upon any shares of stock that shall be subject hereto, and may join in any plan of reorganization in respect of any notes or other obligations, or indebtedness or stock subject to the lien hereof and may accept or authorize the acceptance of new securities issued in exchange therefor under any such plan,.and may take such other action not in conflict with any express provision hereof, as in the discretion of the Trustees or corporate Trustee shall be deemed advisable to protect the interest of the Trustees and the interests of the bondholders hereunder in respect of any such notes, obligations or stock. In case of the happening of any of the events 
of default hereinafter defined in Section 1 of Article Five hereof, or in case the Trustees or either of them shall have entered or shall have elected to enter upon any part of the trust estate, either under the power herein conferred or by the voluntary action of the Company, the Trustees or the corporate Trustee shall be entitled to take such steps without the consent of the Company.

The Company covenants that on demand of the Trustees or either of them it forthwith will pay or will satisfactorily provide for all expenditures incurred by the Trustees or either of them under any of the provisions of this section, including all sums required to obtain and perfeet the ownership and title to any property which the Trustees or the corporate Trustee shall purchase or shall cause or authorize to be purchased pursuant to the provisions of this section; and in any case, without impairment of or prejudice to any of its rights hereunder by reason of any default of the Company, the Trustees or the corporate Trustee in their or its diseretion may advance all such expenses and such other moneys required, or may procure such advances to be made by others, and for such advances made by the Trustees or the corporate Trustee or by others at their or its request with interest thereon the Trustees or the corporate Trustee shall have a lien under this indenture in priority to the lien of the bonds issued hereunder upon all the stocks, obligations and indebtednesss in respect of which such advances shall have been made, and the proceeds thereof, and any property acquired by means thereof.

In case neither the Trustees nor the corporate Trustee nor the Company shall purchase or cause to be purehased the property sold at any such sale, and shall not join in a plan of reorganization as aforesaid in respect of such notes or other obligations or indebtedness or stocks, then the corporate Trustee shall receive any portion of the proceeds of the sale aceruing on the securities by it held hereunder, and such proceeds shall be applied as hereinafter provided in Article Eight with respect to the proceeds of released property.

Section 7.- Anything in this indenture to the contrary notwithstanding, any company, any of the shares of the capital stock whereof shall be subject to this indenture, may be merged or be consolidated with, or all or any of its property may be sold, leased, $t$ ansferred or conveyed to, the Company or any enmpany at least ni cety-five per cent. of the outstanding eapital stock wheren shall then be owned by the Company and pledged hereunder, and upon the property whereof there shall be no mortgage (or nther lien) other than one to securs notes or other obligations all of which shall be held by the Trustees or the corporate Trustee hereunder, and all the indebtedness of which to the Company shall be assigned to the Trustces hereunder, pro- 
vided, however, (1) that in case of a merger or consolidation with, or sale, lease, transfer or conveyance to, the Company, the property of such company, or the property sold, transferred or conveyed, shall, to the same extent it would if property of the Company described in the granting clause hereof become subject to the lien of this indenture, free from any prior lien or charge except a lien or liens to secure notes or other obligations, if any, then outstanding and permitted by the terms hereof; and (2) that in case of a merger or consolidation with, or sale, lease, transfer or conveyance to, any company other than the Company, at least ninety-five per cent. of the outstanding shares of the capital stock of such consolidated company or of the company into which such company shall have been merged, or of such company to which such sale, lease, transfer or conveyance shall have been made, shall continue to be held by the Trustees or the corporate Trustee, notwithstanding such merger, consolidation, sale, lease, transfer or conveyance, provided, however, that the Trustees or either of them may make any exchange, substitution, cancellation or surrender of shares of stock or other securities required for the purposes of, or in accomplishment of, any such merger or consolidation, and in the case of a sale, transfer or conveyance of all the property of any company to any other company or companies as above provided for, the Trustees or the corporate Trustee shall, upon the request of the Company, deliver all the shares of capital stock to the company making such sale, transfer or conveyance to the company to which such sale, transfer or conveyance shall be made, free from the lien and provisions of this indenture.

Anything in this indenture to the contrary notwithstanding, any railroad or steamship company any of the shares of the capital stock whereof are or shall be subject to this indenture may be merged or be consolidated with any other railroad or steamship company or companies any of the stock whereof shall at the time be pledged under this indenture or any other company or companies, none of the shares of stock whereof shall at the time be pledged hereunder, provided, however, that all of the shares of the capital stock or other securities of such consolidated company or the company into which any such company shall have been merged which shall be received in respect of the shar ss of the stock which shall at the time be pledged hereunder shall be deposited with the Trustees or the corporate Trustee and subject to the lien hereof; and nothing in this indenture contained shall prevent the merger of any company or companies none of the stock whereof is pledged hereunder into a railroad or steamship company any of the stock whereof shall at the time be pledged hereunder, provided that said pledged stock of such company shall continue to be held by the Trustees or the corporate Trustee not- 
withstanding such merger; and the Trustees or the corporate Trustee are hereby expressly authorized to make any exchange, substitution, cancellation or surrender of shares of stock or other securities required for the purposes of, or in accomplishment of, any such merger or consolidation. Upon the request or with the assent of the Company in case at the time there shall be no continuing event of default hereunder such as is defined in Section 1 of Article Fire hereof (and without such request or assent in case there shall at the time be any such continuing default) the capital stock of any company any of the shares whereof shall be subject hereto may be reduced and any such company may be dissolved; provided that in a case where at least half in amount of the outstanding capital stock is subject to the lien hereof, the Trustees or the corporate Trustee shall be of the opinion that such reduction of capital stock or such dissolution will not be injurious to the interests of the holders of the bonds; and provided that in every case of any such reduction there shall continue to be held subject to the lien hereof the same proportion of the reduced capital stock that was held of the capital stock previous to such reduction; and the Trustees or the corporate Trustee may make any exchange, substitution, cancellation or surrender of shares of stock for the purpose of such reduction or such dissolution. The Trustees or the corporate Trustee may receive the opinion of any counsel, approved by the Trustees or the corporate Trustee, whether counsel for the Company or not, as to the legal effect of any such merger, consolidation, reduction of capital, dissolution, sale, transfer or conveyance and as to the steps necessary to be taken to consummate the same, and as to any other matter under this section, and such opinion shall be full protection to the Trustees or the corporate Trustee for any action by them or it taken pursuant thereto.

\section{Article Four}

\section{SINKING FUND AND REDEMIPTION OF BONDS}

SEotion 1.-The Company shall and will on or hefore the 30th day of October, 1909, and on or before the 29th day of April and the 30th day of October in each year thereafter deposit with the corporate Trustee a sum in cash sufficient to pay the semi-annual interest due on the next succeeding interest date on all the bonds then outstanding; and for the purpose of creating a sinking fund for the extinguishment and payment of the bonds and the interest thereon the Company shall and will also deposit on or before the first day of March in each year, beginning with March 1, 1910, in case \$15,- 
000,000 in face amount of the bonds or less are issued an amount in cash (or in the bonds as hereinafter provided) equal to the difference between $\$ 1,000,000$ and the amounts required to pay the interest that fell due on the previous first day of November and that will fall due on the succeeding first day of May on all the bonds then outstanding, and, in case more than $\$ 15,000,000$ in face amount of the bonds are issued, to the difference between an amount equal to one-fifteenth of the face value of the total amount of the bonds which shall have been issued and the amount required to pay such interest, so long as the amount required to be paid hereunder for sinking fund purposes shall not exceed an amount sufficient to retire the bonds then outstanding, in which event only such amount shall be paid as will be sufficient to completely retire the bonds then outstanding. The Company may at its option deliver to the corporate Trustee in lieu of any part or all of the cash amount required to be deposited on or before the first day of March in each year for the purpose of a sinking fund as above provided, an equivalent amount of the bonds issued hereunder (taken at their par value), bearing all unmatured coupons, including the coupons which will mature on the succeeding first day of May.

For the purpose of determining the amount of the payments for interest and for the sinking fund above mentioned it shall be assumed that the amount of the bonds that will be outstanding on any first day of May will be the same as the amount that shall have been outstanding on the previous first day of November, except that in case additional bonds shall have been issued in the meantime the amount of said additional bonds shall be added.

The corporate Trustee shall, out of the sum in cash which shall be deposited by the Company with it for the payment of interest as aforesaid, on the next succeeding interest payment day pay such interest at the office of First Trust and Savings Bank in Chicago or at the agency of the Company in New York, as the coupon holder may elect. Any portion thereof not required for the payment of interest shall become part of the sinking fund. The corporate Trustee is hereby authorized to make such arrangements for the payment of coupons at said agency of the Company in New York as it shall deem proper.

Immediately upon the receipt of any deposit of money for the said sinking fund previous to the year 1915, the corporate Trustee shall, as it may be directed by the Company, expend the said sum in the purchase of as many of the bonds as can be acquired with said amount of money at any price not exceeding 105 per cent. of their face amount and accrued interests.

After the year 1914, all deposits of money for the sinking fund shall be applied by the corporate Trustee to the purchase of bonds in the 
open market at the then market price thereof, but not at any price exceeding 105 per cent. of their face amount and accrued interest, but if on the 28th day of March in any year after the year 1914, the corporate Trustee shall not have applied all deposits in its possession for the sinking fund to the purchase of bonds, all such amounts remaining in the hands of the corporate Trustee shall forthwith be applied by the corporate Trustee to the redemption of the bonds at a premium of five per cent. pursuant to call given as hereinafter provided. The bonds so to be redeemed shall be determined by lot, in any usual manner, in the presence of the President or Vice-President or other executive officer, for the time being, of the corporate Trustee, and of a notary public, and the corporate Trustee shall at the expense and cost and in the name of the Company cause a notice to be published in one daily newspaper in the City of New York, and one daily newspaper in the City of Chicago, once a week for four successive weeks, the first publication to be not less than thirty days prior to the first day of May, then next ensuing, stating the serial numbers of the bonds so drawn, and that interest on such bonds shall cease on the said first day of May and that on such date there will become and be due and payable on each of said bonds, at the financial agency of the Company, in the City of New York, the principal thereof, together with the premium as aforesaid, and accrued interest to such date, and requiring such bonds to be delivered for redemption for the sinking fund. $\Lambda$ similar notice shall be sent by the Company under the direction and at the request of the corporate Trustee, through the mails, postage prepaid, at least thirty days prior to such redemption day, to the registered holders of the bonds so drawn whose addresses shall appear from the transfer register. Upon such advertisement of notice the said bonds shall become due and be payable at the financial ageney of the Company in New York, on the interest payment day named in said notice, together with the said premium of five per cent. of the principal thereof and all interest which shall have then acerned and be unpaid, and the corporate Trustee shall deposit the said unexpended funds with the financial agency of the Company designated as set forth in Section 1 of Article Two hereof, with directions to apply the same to the payment of said bonds, together with the said premium in accordance with the provisions hereof.

Section 2.-After May 1, 1914, upon previous advertisement of notice as hereinafter in this section provided, the Company shall have the right to redeem and pay off on any interest day the entire issue of the bonds then outstanding (but not any part less than the entire outstanding amount thereof) by the payment of the principal thereof together with a premium of five per cent. thereon together with the 
interest accruing to the date of redemption specified in such notice. In case the Company shall desire to exercise such right to redeem and pay off such entire issue of bonds, it shall advertise in two daily newspapers of general circulation, one published in the Borough of Manhattan in the City of New York and one published in the City of Chicago, Illinois, at least once a week for four successive weeks (the first publication to be not less than thirty days and not more than forty days before the date of redemption specified in such notice), stating that the Company has elected to redeem and pay off all of the bonds and that on such interest payment date there will become and be due and payable upon each of said bonds at the financial agency of the Company in the Borough of Manhattan in the City of New York the principal thereof together with the premium as aforesaid and accrued interest to such date. A similar notice shall be sent by the Company through the mails postage prepaid at least thirty days prior to such redemption date to the registered holders of bonds whose addresses shall appear upon the transfer register. Upon such advertisement of such notice the entire issue of bonds shall become and be due and payable on the interest payment date designated as the day of redemption in said notice, together with the premium of five per cent. on the principal thereof and all interest which shall have then accrued and be unpaid.

On the deposit with the corporate Trustee of the amount necessary so to redeem all the outstanding bonds together with proof that said notice of redemption has been given by publication and by mail, as hereinbefore provided for, and on payment to the Trustees and each of them of all costs, charges and expenses, the Trustees shall cancel and satisfy this indenture and assign or cause to be assigned and shall deliver to the Company forthwith the stocks, notes, bonds, mortgages, and any and all other securities pledged hereunder. The said amount so deposited with the corporate Trustee shall be applied by said Trustee to the payment and redemption of the bonds and coupons in accordance with the provisions hereof.

SECrron 3.-The sum due for principal and premium on each bond called for redemption pursuant to the foregoing provisions shall be payable to the bearer of such bond unless it shall have been registered, and if it shall have been registered such payment shall be made to the registered holder of such bond, but in no case shall payment be required, except upon surrender of such bond and of all coupons for interest thereon not due at the date of redemption designated in such notice. The accrued interest represented by the coupons maturing on the date of redemption designated in any notice given pursuant to the provisions of any of the foregoing sections, and the interest rep- 
resented by coupons that shall have matured prior to such date, shall continue to be payable but without interest thereon, to the respective bearers of such coupons as therein provided. From and after the date of redemption designated in any such notice (unless default shall be made in payment upon demand on such date), no further interest shall accrue upon any of said bonds so called for redemption and, anything in said bonds or in such coupons or in this indenture to the contrary notwithstanding, any coupon appertaining to any such bond for interest maturing after such date shall become and be null and roid.

Section 4.-All bonds redeemed and paid hereunder, or delivered to the corporate Trustee for the sinking fund in lieu of cash as above provided, or acquired for the sinking fund under the provisions of this Article, shall, together with the coupons thereunto belonging, be forthwith cancelled and immediately surrendered to the Company, and no bonds shall be issued under the provisions of this indenture in substitution therefor.

\section{Article Five}

\section{REMEDIES OF TRUSTEES AND BONDHOLDERS}

SECTION 1.-If one or more of the following events, herein called the events of default, shall happen, that is to say:

(a) default shall be made in the payment of any instalment of interest on any of the bonds or any sinking fund payment when and as the same shall become payable as therein and herein expressed and such default shall continue for the space of 60 days, or default sliall be made in the payment of the prineipal of any of said bonds when the same shall become due and payable, either by the terms thereof, or otherwise as herein provided;

(b) default shall be made in the observance or performance of any other of the covenants, conditions and agreements on the part of the Company, its successors or assigns, in the bonds or in this indenture contained, and such default shall continue for the space of six months after written notice from the Trustees or either of them specifying such default and requiring the same to be remedied;

(c) an order shall be made for the appointment of a permanent receiver or receivers of the Company, or of the trust estate; 
(d) any judgment or decree for a sum of money shall be entered against the Company and shall remain unsatisfied and in force and unsecured by undertaking on appeal for thirty days after the entry thereof and the expiration of any stay of execution thereon;

then and in each and every such case the individual Trustee, if the corporate Trustee deem it advisable, personally, or by his agents or attorneys, may enter into and upon all or any part of the lands, property and premises, interests, rights and franchises hereby conveyed or intended so to be, and each and every part thereof, and may exclude the Company, its agents and servants wholly therefrom; and, having and holding the same, may use, operate, manage and control said property and premises, and conduct the business thereof, either personally or by his superintendents, managers, agents, servants and attorneys or receivers; and upon every such entry the individual Trustee, at the expense of the trust estate, from time to time, either by purchase, repairs or construction may maintain and restore and may insure or keep insured the buildings and structures, tools and machinery and other property and premises, whereof he shall become possessed, as aforesaid, in the same manner and to the same extent as is usual with companies of a character similar to the Company; and likewise from time to time, at the expense of the trust estate, may make all necessary or proper repairs, renewals and replacements, and useful alterations, additions, betterments and improvements thereto and thereon, as to him may seem judicious; and in such case the individual Trustee shall have the right to manage the mortgaged plants, lands and property, and to carry on the business and exercise all rights and powers of the Company, either in the name of the Company or otherwise, as he shall deem best; and he shall be entitled to collect and receive all earnings, income, rents, issues and profits of the same and every part thereof; and also the income from stocks and bonds and other obligations and indebtedness subject to this indenture; and after deducting the expenses of conducting the business thereof and of all maintenance, repairs, renewals, replacements, alterations, additions, betterments and improvements, and all payments which may be made for taxes, assessments, insurance, and prior or other proper charges upon the trust estate, or any part thereof, as well as just and reasonable compensation for the services of the Trustees and each of them and for all attorneys, counsel, agents, clerks, servants and other employees by them or either of them properly engaged and employed, the individual Trustee shall apply the moneys arising as aforesaid, as follows: 
(a) In case the principal of the bonds shall not have become due, to the payment of the interest in default, in the order of the maturity of the instalments of such interest, with interest on the overdue instalments at the rate of five per centum per annum, such payments to be made ratably to the persons entitled thereto, without discrimination or preference;

(b) In case the principal of the bonds shall have become due by declaration or otherwise, first to the payment of the accrued interest, with interest on the overdue instalments thereof at the rate of five per centum per annum, in the order of the maturity of the instalments, and next to the paymert of the principal of all the bonds, in every instance such payments to be made ratably to the persons entitled to such payments, without any discrimination or preference.

These provisions, however, are not intended in any case to modify the provisions of section 2 of this Article, but are subject thereto.

Upon the default or defaults then existing, and of which the corporate Trustee shall have had notice, being made good to the satisfaction of the Trustees, and the payment in full of whatever may have been due for principal or interest or be payable for other purposes, and after provision satisfactory to the corporate Trustee is made for the payment of the semi-annual instalment of interest upon the bonds and the sinking fund payment then next maturing, the premises shall, at the request of the Company, be returned to the Company, its sucsors or assigns.

Sectron 2.-Neither any coupon belonging to any bond, nor any claim for interest on any bond, which in any way at or after maturity shall have been transferred or pledged separate and apart from the bond to which it relates, shall, unless accompanied by such bond, be entitled, in case of the happening of an event of default, to any benefit of or from this indenture except after the prior payment in full of the principal of all the bonds and of all coupons and interest obligations not so transferred or pledged.

Section 3.-If one or more of the events of default shall happen, the Trustees or the corporate Trustee shall be entitled to revoke any proxies or powers of attorney which they or it may have given, and to vote, or cause sueh person as they or it may deem best to vote, on all shares of stock then subject to the lien of this indenture, and shall revoke any assignments or orders for the payment of interest, dividends or ineome which they or it may have given, and shall be entitled to collect and receive all dividends, interest and income payable on shares of stock and bonds or notes or other indebtedness sub- 
ject to this indenture, as well as the principal thereof; and, as holder of any such shares of stock and of any such bonds or obligations or other indebtedness, shall be entitled to perform any and all acts, and to make or execute any and all transfers, requests, requisitions or other instruments, for the purpose of carrying out the provisions of this section; and the Company hereby authorizes and directs all corporations whose stocks, bonds, notes or other indebtedness are held hereunder in such event to pay to the corporate Trustee hereunder all such dividends and sums payable as aforesaid; but in the event that a receiver shall have been appointed and shall be in possession of the mortgaged premises or a part thereof in the enforcement of this indenture, or pursuant to the provisions hereof, the Trustees or the corporate Trustee from time to time in their or its discretion may, and, if requested by the holders of three-fourths in amount of the outstanding bonds shall, turn over any part or all of the interest moneys and dividends so collected by them or it to such receiver, and may co-operate with such receiver in managing the entire property and business of the Company in such manner. as the corporate Trustee shall deem for the best interest of the holders of the bonds; provided, however, that if such default shall have been made good or shall have been waived, as herein provided, the right of the Company to vote upon any such shares and the obligation of the Trustees or corporate 'Trustee to execute proxies and powers of attorney as herein expressly provided for, shall revive and shall continue as though no such default had taken place, and the right of the Company to receive and collect such dividends on such stocks and such interest on such bonds, notes and other obligations, and the rights and duty of the Trustees with respect thereto shall be as though such default had not taken place, and after the payment in full of whatever may have been due hereunder for principal or interest, or be payable for other purposes, and after making provision satisfactory to the corporate Trustee for the payment of the instalment of interest and the sinking fund payment then next maturing, the Trustees or corporate Trustee shall return to the Company the amount, if any there be, of any such dividends, interest and income collected by them or it and then remaining unexpended in their hands which would have been receivable by the Company if there had been no default. The net receipts by the Trustees or the corporate Trustee, pursuant to the provisions of this section, for dividends, interest and income, may, and at the written request of the holders of a majority in amount of the bonds then outstanding shall be applied as provided in Section 1 of this Article; provided that, except in the discretion of the corporate Trustee, no distribution involving the part payment of any coupons shall be made. 
SEction 4.-If any one or more of the events of default shall happen, then and in every such case, the Trustees or the corporate Trustee, by notice in writing delivered to the Company or mailed to it postage prepaid at Pittsburgh, Pennsylvania, may, and upon the written request of the holders of a majority in amount of the bonds then outstanding shall, declare the principal of all the bonds then outstanding, if not already due, to be due and payable immediately, and upon any such declaration the same shall become and be immediately due and payable, anything in this indenture or in the bonds contained to the contrary notwithstanding. This provision, however, is subject to the condition that if, at any time after the principal of said bonds shall have been so declared due and payable, and before any sale of the trust estate shall have been made, all arrears of interest upon all the bonds, with interest on overdue instalments of interest at the rate of five per centum per annum, and all amounts in arrear payable for the sinking fund, together with all other amounts, except the principal of the bonds, including the reasonable charges and expenses of the Trustees and each of them, their and its agents and attorneys, and of any receiver or receivers theretofore appointed, shall either be paid by the Company or be collected out of the trust estate, then and in every such case the holders of a majority in amount of the bonds then outstanding by written notice to the Company and to the coroporate Trustee, may waive such default and its consequences but no such waiver shall extend to or affect any subsequent default or impair any right consequent thereon.

Secrion 5.-If one or more of the events of default shall happen, the Trustees, with or without entry, personally or by attorney, in the discretion of the corporate Trustee either $(a)$ may sell to the highest, and best bidder, all and singular the property and premises covered by this indenture, including stocks and bonds, rights, franchises, interests and appurtenances, and other real and personal property of every kind, and all right, title and interest, claim and demand therein, and right of redemption thereof; which sale or sales shall be made at public auction at such place in the Borough of Manhattan, City of New York, or at such other place, and at such time and upon such terms, as the Trustees may fix and briefly specify in the notice of sale to be given as herein provided, or as may be required by law; or $(b)$ may proceed to protect and enforce their rights and the rights of bondholders under this indenture, by a suit or suits in equity or at law, whether for the specfic performance of any covenant or agreement contained herein, or in aid of the execution of any power herein granted, or for any forcclosure hereunder, or for the enforcement of any other appropriate legal or equitable remedy, as the Trustees, 
being advised by counsel learned in the law, shall deem most effectual to protect and enforce any of its rights or duties hereunder.

SECTION 6.-Upon the written request of the holders of ten per cent. in amount of the bonds then outstanding, in case one or more of the events of default shall happen, it shall be the duty of the Trustees, upon being indemnified as hereinafter provided, to take all steps needful for the protection and enforcement of their rights and the rights of the holders of the bonds, and to exercise the power of entry or of sale herein conferred, or both, or to take appropriate judicial proceedings by action, suit or otherwise as the Trustees, being advised by counsel learned in the law, shall deem most expedient in the interest of the holders of the bonds; but anything in this indenture to the contrary notwithstanding, the holders of a majority in amount of the bonds then outstanding, from time to time, shall have the right to direct and to control the method and place of conducting any and all proceedings for, and the manner of, any sale of the premises and property subject to this indenture.

Section 7.-In the event of any sale, whether made under the power of sale herein granted or conferred, or under some judgment or decree of foreclosure and sale, or under or by virtue of any judicial proceedings, the whole of the property subject to this indenture shall be sold in one parcel and as an entirety, including all the rights, title, estates, lands, factories, equipment, franchises, leases, leasehold interests, contracts, stocks, bonds and other real and personal property of every name and nature, unless such sale as an entirety be impracticable by reason of some statute or other cause, or unless the holders of a majority in amount of the bonds then outstanding shall in writing request the Trustees to cause said property to be sold in parcels, in which case the sale shall be made in such parcels and in such order as may be required by law or be specified in such request or, in the absence of such request, as the corporate Trustee may determine. The Company, for itself and all persons and corporations hereafter claiming through or under it or who may at any time hereafter become holders of licns junior to the lien of this indenture, hereby expressly waives and releases all right to have the properties and estate comprised in the security intended to be created by this indenture marshalled upon any foreclosure or other enforcement hereof, and the Trustees, or any court in which the foreclosure of this mortgage or administration of the trusts hereby created is sought, shall have the right as aforesaid to sell the entire property of every description comprised in or subject to the trusts created by this indenture as a whole in a single lot. 
Section 8.-Notice of any sale pursuant to any provision of this indenture shall state the time and place when and where the same is to be made, and shall contain a brief general description of the property to be sold, and shall be sufficiently given if published once in each week for four successive weeks prior to such sale in three daily newspapers of general circulation, one published in the City of Chicago, Illinois, one published in the City of New York, and one published in the City of Pittsburgh, Pennsylvania.

Section 9.-The. Trustees may adjourn from time to time any sale by it to be made under the provisions of this indenture, by announcement at the time and place appointed for such sale, or for any adjourned sale or sales; and without further notice or publication, it may make such sale at the time and place to which the same shall be so adjourned.

Section 10.- Upon the completion of any sale or sales under this indenture, the Trustees shall execute and deliver to the accepted purchaser or purchasers a good and sufficient deed, or good and sufficient deeds, and other instruments conveying, assigning and transferring the properties, interests and franchises sold. The corporate Trustee and its successors are hereby appointed the true and lawful attorneys irrevocable of the Company and of the Trustees and of the individual Trustee in its or their name and stead to make all necessary conveyances, assignments and deliveries of property and all necessary transfers of shares of stock or bonds, or other obligations or indebtedness thus sold; and for that purpose it and its successors may execute all necessary deeds and instruments of assignment and transfer, and may substitute one or more persons with like power; the Company and the Trustees hereby ratifying and confirming all that its and their said attorney or attorneys or such substitute or substitutes shall lawfully do by virtue hereof.

Any such sale or sales made under or by virtue or this indenture, whether under the power of sale herein granted, or under or by virtue of judicial proceedings, shall operate to divest all right, title, interest, claim and demand whatsoever, whether at law, or in equity, of the Company, of, in and to the premises and property so sold, and shall be a perpetual bar both at law and in equity against the Company, its successors and assigns, and against any and all persons claiming or to claim the premises. and property sold, or any part thereof from, through or under the Company, its successors or assigns.

The personal property and chattels conveyed or intended to be conveyed by or pursuant to this indenture, other than stocks, bonds, notes and other securities and claims, shall be real estate for all the purposes of this indenture, and shall be held and taken to be fixtures and 
appurtenances of the real property conveyed and part thereof and are to be used and sold therewith and not separate therefrom, except as herein otherwise provided.

Section 11.-The receipt of the Trustees or of the corporate Trustee for the purchase money paid at any such sale shall be a sufficient discharge therefor to any purchaser of the property or any part thereof, sold as aforesaid; and no such purchaser or his representatives, grantees or assigns, after paying such purchase money and receiving such receipt, shall be bound to see to the application of such purchase money upon or for any trust or purpose of this indenture, or in any manner whatsoever be answerable for any loss, misapplication or non-application of any such purchase money or any part thereof, nor shall any such purchaser be bound to inquire as to the authorization, necessity, expediency or regularity of any such sale.

SEction 12.-In case of a sale under any of the foregoing provisions of this Article, whether made under the power of sale herein granted or pursuant to any judicial proceedings, the principal of the bonds, if not previously due, shall immediately thereupon become due and payable, anything in said bonds or in this indenture to the contrary notwithstanding.

Section 13.-The purchase money, proceeds or avails of any such sale, whether under the power of sale herein granted or pursuant to judicial proceedings, together with any other amounts which then may be held by the Trustees or either of them under any of the provisions of this indenture as part of the trust estate or the proceeds thereof, whethei under the provisions of Article Four or other. wise, shall be applied as follows:

First.-To the payment of the costs and expenses of such sale, including a reasonable compensation to the Trustees, their agents, attorneys and counsel, and of any judicial proceeding wherein the same may be made, and of all expenses, liabilities and advances made or incurred by the Trustees or either of them in the premises, and to the payment of all taxes, assessments or liens superior to the lien of this indenture, except the superior liens and any taxes, assessments or other charges, subject to which the property shall have been sold;

Second.-To the payment. of the whole amount then owing or unpaid upon the bonds for principal and interest, with interest on the overdue principal and instalments of interest at the rate of five per cent. a year; and in case such proceeds shall be insufficient to pay in full the whole amount so due and unpaid upon said bonds, then to the payment of the principal and in- 
terest of said bonds, without preference or priority of principal over interest, or of interest over principal, or of any instalment of interest orer any other instalment thereof, ratably to the aggregate of such principal and the accrued and unpaid interest, subject, however, to the provisions of Section 2 of this Article Five;

Third.-To the payment of the surplus, if any, to the Com: pany, its successors or assigns, or to whosoever may be lawfully entitled to receive the same, or as any court of competent jurisdiction may direct.

Sectios 14.-In case of any sale hereunder whether under the power of sale herein granted or pursuant to judicial proceedings, any purchaser, for or in settlement or payment of the purchase price of the property purchased, shall be entitled to use and apply any of the bonds, and any matured and unpaid coupons (subject, however, to the provisions of Section 2 of this Article), by presenting such bonds and coupons in order that there may be credited thereon the sums applicable to the payment thereof out of the net proceeds of such sale to the owner of such bonds and coupons as his ratable share of such net proceeds, after the deduction of all costs, expenses, compensations and other charges to be paid therefrom as herein prorided; and thereupon such purchaser shall be credited, on account of such price payable by him, with the portion of such net proceeds that shall be applicable to the payment of, and that shall have been credited upon, the bonds and coupons so presented; and at any such sale, the Trustees or either of them or any bondholders may bid for and purchase such property, and may make payment therefor as aforesaid, and upon compliance with the terms of sale, may hold, retain and dispose of such property without further accountability.

Section 15.-The Company covenants that (1) in case default shall be made in the payment of any interest on any of the bonds at any time outstanding, and such default slıall have continued for a period of 60 days, or (2) in case default shall be made in the payment of the principal of any such bonds when the same shall become payable, whether upon the maturity of said bonds or upon declaration as authorized by this indenture, or upon a sale as set forth in Section 12 of this Article, or otherwise, then upon demand of the corporate Trustee, the Company will pay to the Trustees for the benefit of the holders of the bonds and coupons then outstanding, the whole amount which then shall have become due and payable on all such bonds and coupons then outstanding, for interest or principal, or both, as the 
case may be, with interest upon the overdue principal and instalments of interest at the rate of five per cent. a year; and in case the Company shall fail to pay the same forthwith upon such demand, the Trustees in their own name and as trustees of an express trust, shall be entitled to recover judgment for the whole amount so due and unpaid.

The Trustees shall be entitled to recover judgment as aforesaid, either before or after or during the pendency of any proceedings for the enforcement of the lien of this indenture; and the rights of the Trustees to recover such judgment shall not be affected by any entry or sale hereunder, or by the exercise of any other right, power or remedy for the enforcement of the provisions of this indenture or the foreclosure of the lien thereof; and in case of a sale of the property subject to this indenture, and of the application of the proceeds of sale to the payment of the debt hereby secured, the Trustees, in their own name and as trustees of an express trust, shall be entitled to enforce payment of and to receive all amounts then remaining due and unpaid upon any and all of the bonds then outstanding for the benefit of the holders thereof, and shall be entitled to recover judgment for any portion of the debt remaining unpaid, with interest. No recovery of any such judgment by the Trustees, and no levy of any execution under any such judgment upon the property subject to this indenture, or upon any other property, shall in any manner or to any extent affect the lien of this indenture upon the property, or any part of the property, subject to this indenture, or any rights, powers or remedies of the Trustees or either of them hereunder, or any lien, rights, powers or remedies of the holders of the bonds, but such lien, rights, powers and remedies of the Trustees and of each of them and of the bondholders shall continue unimpaired as before.

Any moneys thus collected by the Trustees under this section shall be applied by the Trustees or the Trustee receiving the same, first, to the payment of the expenses, disbursements and compensation of the Trustees, their agents, servants and attorneys, and, second, towards rayment of the amounts then due and unpaid upon the bonds and interest in respect of which such moneys shall have been collected, ratably and without any preference or priority of any kind (except as provided in Section 2 of this Article), according to the amounts due and payable upon such bonds and coupons, respectively (with interest upon the overdue principal and instalments of interest at the rate of five per cent. a year), at the date fixed by the Trustees for the distribution of such moneys, upon presentation of the several bonds and coupons and the stamping thereon of such payment, if partly paid, and upon surrender thereof, if fully paid. 
Section 16.-The Company will not at any time insist upon or plead, or in any manner whatever claim, or take the benefit or advantage of, any stay or extension law, now or at any time hereafter in force; nor will it claim, take or insist upon any benefit or advantage from any law now or hereafter in force providing for the valuation or appraisement of the property, or any part of the property, subject to this indenture, prior to any sale or sales thereof to be made pursuant to any provisions herein contained, or to the decree, judgment or order of any court of competent jurisdiction; nor after any such sale or sales will it claim or exercise any right under any statute enacted by the United States or by any state or territory or otherwise to redeem the property so sold or any part thereof; and it hereby expressly waives all benefit and advantage of any and all such law or laws and it corenants that it will not hinder, delay or impede the execution of any power herein granted and delegated to the Trustees or either of them, but that it will suffer and permit the execution of every such power as though no such law or laws had been made or enacted.

Section 17.-Upon filing a bill in equity, or upon commencement of any other judicial proceedings, to enforce any right of the Trustees or either of them or of the bondholders under this indenture, the Trustees shall be entitled, as matter of right, to the appointment of a receiver of the premises and property subject to this indenture, and of the earnings, income, revenue, rents, issues and profits thereof, with such powers as the court making such appointment shall confer, which may comprise any or all of the powers which the individual Trustee is authorized to exercise by the provisions of Section 1 of this Article in case of entry upon the mortgaged premises; but notwitlstanding the appointment of any receiver, the Trustees or the corporate Trustee shall be entitled, as pledgee, to continue to retain possession and control of any stocks, notes, cash and other property pledged or to be pledged hereunder and to receive all dividends, interest and other sums payable thereon, subject, however, to the provisions of Section 3 of this Article.

Sectios 18.- No holder of any bond or coupon shall have any right to institute any suit, action or proceeding in equity or at law for the forcclosure of this indenture, or for the execution of any trust hereunder, or for the appointment of a receiver, or for any other remedy, hereunder, unless such holder previously shall have given to the corporate 'Trustee written notice of the Company's default and of the continuance thereof, nor unless also the holders of ten per cent. in amount of the bonds then outstanding shall lave made written request upon the 'Trustees and shall have afforded to them a reasonable 
opportunity, either to proceed to exercise the powers hereinbefore granted, or to institute such action, suit or proceedings in their own name; and shall have afforded to the Trustees adequate security and indemnity against the costs, expenses and liabilities to be incurred therein or thereby; and such notification, request and offer of indemnity are hereby declared in every such case, at the option of the corporate Trustee, to be conditions precedent to the execution of the powers and trusts of this indenture and to any action or cause of action for foreclosure or for the appointment of a receiver or for any other remedy hereunder; it being understood and intended that no one or more holders of the bonds and coupons shall have any right in any manner whatever by his or their action to affect, disturb or prejudice the lien of this indenture, or to enforce any right hereunder, except in the manner herein provided, and that all proceedings at law or in equity shall be instituted, had and maintained in the manner herein provided and for the equal benefit of all holders of the outstanding bonds and coupons.

Section 19.-Execept as herein expressly provided to the contrary, no remedy herein conferred upon or reserved to the Trustees or either of them or to the holders of the bonds is intended to be exclusive of any other remedy or remedies, and each and every such remedy shall be cumulative, and shall be in addition to every other remedy given hereunder or now or hereafter existing at law or in equity or by statute.

SECTION 20.-No delay or omission of the Trustees or either of them or of any holder of the bonds to exercise any right or power accruing upon any default continuing as aforesaid, shall impair any such right or power or shall be construed to be a waiver of any such default, or an acquiescence therein; and every power and remedy given by this Article to the Trustees or either of them and to the bondholders, respectively, may be exercised from time to time, and as often as may be deemed expedient by the Trustees or the corporate Trustee or by the bondholders, respectively.

Section 21.-In case the Trustees or either of them shall have proceeded to enforce any right under this indenture by foreclosure, entry or otherwise, and such proceedings shall hare been discontinued or abandoned because of waiver or for any other reason, or shall have been determined adversely to the Trustees, then, and in every such case, the Company and the Trustees and each of them shall severally and respectively be restored to their former position and rights hereunder in respect of the trust estate, and all rights, remedies and powers of the Trustees and each of them shall continue as though no such proceedings had been taken. 


\section{Article Six.}

\section{IMMUNITY OF STOCKHOLDERS, DIRECTORS AND OFFICERS.}

No recourse under or upon any obligation, covenant or agreement contained in this indenture, or in any of the bonds or coupons, or under or upon any indebtedness hereby secured, or because of the creation thereof, shall be had against any incorporator of the Company or any stockholder, director or officer, past, present or future, of the Company, or of any successor corporation, either directly or through the Company, by the enforcement of any assessment or by any legal or equitable proceedings by virtue of any statute, rule of law ${ }^{\circ}$ or otherwise; it being expressly agreed and understood that this indenture and the obligations hereby secured are solely corporate obligations, and that no personal liability whatever shall attach to or be, or be deemed to have been, incurred by the incorporators, stockholders, officers or directors of the Company, or of any successor or predecessor corporation, or any of them, because of the incurring of the indebtedness hereby authorized, or under or by reason of any of the obligations, covenants or agreements contained in this indenture, or in any of the bonds or coupons hereby secured, or implied therefrom; and that any and all personal liability of every name and nature, and any and all rights and claims against every such incorporator, stockholder, officer or director, past, present or future, whether arising at common law or in equity, or created by statute or constitution, are hereby expressly released and waived as a condition of, and as part of the consideration for, the execution of this inderture and the issue of the bonds and interest obligations hereby secured.

\section{Article Seven.}

\section{BONDHOLDER' ACTS, HOLDINGS AND APPARENT AUTHORITY.}

Any demand, request, notice, waiver, or other instrument required by this indenture to be signed and exccuted by bondholders may be in any number of concurrent writings of the same tenor and may be signed or executed by such bondholders in person or by agent appointed in writing. Proof of the execution of any such demand, request, notice, waiver or of the writing appointing any such agent, or other instrument, and of the ownership by any person of coupon bonds transferable by delivery or of coupons, shall be sufficient for any purpose of this indenture, and shall be conclusive in favor of the Trustees and each of them and of the Company with regard to due action taken by them or either of them under such instrument, if such proof be made in the following manner: 
The fact and date of the execution by any person of any such demand, request, or other instrument or writing may be proved by the certificate of any notary public or other officer of any jurisdiction authorized by the law thereof to take acknowledgments of deeds to be recorded therein that the person signing such request or other instrument acknowledged to him the execution thereof, or by any affidavit of a witness to such execution.

The fact of the holding by any bondholder of coupon bonds transferable by delivery or of coupons, and the amounts and issue numbers of such bonds and coupons, and the date of his holding the same, may be proved by a certificate executed by any trust company, bank, banker or other depositary (wherever situated), if such certificate shall be deemed by the corporate Trustee to be satisfactory, showing that at the date therein mentioned such bondholder had on deposit with such depository the bonds or coupons described in such certificate. For all purposes of this indenture and of any proceeding for the enforcement thereof such person shall be deemed to continue the holder of such bonds or coupons until the corporate Trustee shall have received notice in writing to the contrary, subject, however, to the provisions of Section 6 of Article One hereof. The ownership of bonds registered as to principal shall be proved by the registry of such bonds.

\section{Article Eight.}

\section{RELEASES OF MORTGAGED PROPERTY.}

SECTION 1.-If at any time any property of whatsoever kind and nature subject to the lien of this indenture, including stocks and other securities, cannot be advantageously used in the proper and judicious operation of the business of the Company, or, if the sale or disposition thereof has become necessary or advisable for any cause, the same or any interest therein may be sold or exchanged for other property, and, upon the request of the Company, approved by a resolution of the Board of Directors in favor of which at least a majority of such Board shall have voted, the. Trustees shall release the same from the lien and effect of this indenture upon the following provisions and conditions:

(a) Before any such property (unless the same in the judgment of a majority of the members of the Board of Directors shall be of a less value than $\$ 50,000$ ) shall be sold, the same shall be appraised by an appraiser or by more than one appraiser, who shall be selected by the corporate Trustee. 
(b) In case of any such sale of property or of any interest therein the price or proceeds of sale, not less than the value of such property or of such interest therein as appraised by such appraiser or appraisers (or not less than the value of such property as determined by a certificate or resolution of a majority of the members of the Board of Directors in ease of property deemed by them to be worth less than $\$ 50,000$ ) or a sum equal to such price or proceeds, shall be deposited with the corporate Trustee to be held for the further security of the bonds until paid over or applied as hereinafter provided.

(c) In case of an exchange the property received in exchange (which must be property free and clear of any liens and encumbrances and of a value at least equal to the value of the property given in exchange less any cash that may be received in exchange) shall be subjected to the lien and operation of this indenture and any cash received upon any such exchange shall be deposited as above provided in respect to the proceeds of any sale. The value of the property given in exchange and of the property reeeived in exchange shall be determined by an appraiser or appraisers selected by the corporate Trustee, or in case said property given in exchange or received in exehange shall, in the opinion of a majority of the members of the Board of Directors, be of a value less than $\$ 50,000$, shall be determined by a certificate or resolution of a majority of the members of the Board of Directors of the Company.

The moneys received by the Trustees or either of them upon any such sale and any moneys which it is elsewhere provided in this indenture shall be applied in the same way as the proceeds of released property, shall be applied as and when directed by the Company, as follows:

(1) To the purchase of real estate, coal or ore properties or leases of coal or ore properties, or the erection or acquisition of improvements, buildings, struetures, fixtures, machinery and apparatus necessary or useful for the business of the Company or otherwise for the benefit of the property of the Company upon which this indenture is a first lien, all of which real estate, coal or ore properties or leases of coal or ore properties, improvements, buildings, structures, fixtures, machinery and apparatus shall forthwith be or shall be made subject, to this indenture as a first lien thereon. 
(2) To the purchase of real estate, coal or ore properties or leases of coal or ore properties, for any company (other than a railroad or steamship company) at least 95 per cent. of the capital stock whereof shall at the time be pledged under this indenture, provided that for all amounts so expended a purchase money bond and mortgage or purchase money bonds and mortgages or bonds secured by a first mortgage or deed of trust upon the property so acquired (or in case the property so acquired shall be acquired subject to any mortgage, lien or other charge, or in case the subsidiary company shall pay only a part of the purchase money for the property so acquired and shall give a mortgage for the unpaid part of the purchase price, then and in any such event a bond and mortgage or bonds secured by a mortgage or deed of trust subject only to such prior mortgages, liens or other charges) of a face amount equal at least to the amounts so expended are taken by the Company and assigned and delivered to the Trustees to be held by the corporate Trustee under this indenture as part of the trust estate.

(3) At the option of the Company the Trustees or the corporate Trustee shall apply such proceeds or any part thereof in purchasing as they or it shall be directed by the Company bonds issued under this indenture then outstanding. All bonds so purchased shall forthwith upon the acquisition thereof be cancelled by the corporate Trustee and delivered to the Company and no bonds shall be issued hereunder in substitution thereof.

The Trustees and each of them accept as conclusive evidence as to the fact that any property cannot be advantageously used in the proper and judicious operation of the business of the Company, or that the sale or disposition of any property has become necessary or advisable for any cause, or as to the usefulness or necessity for the business of the Company, or as to the benefit otherwise to the mortgaged property, of any real estate, coal or ore properties or leases of coal or ore properties, improvements, buildings, structures, fixtures, machinery or apparatus, a certificate of a majority of the members of the Board of Directors of the Company then in office including the President or a Vice-President, and the Trustees and each of them shall be absolutely protected for all action taken by them or either of them in good faith thereon.

Section 2.- The Company from time to time while in possession of the mortgaged premises, and while not in default hereunder, shall have full power in its discretion to dispose of free from the lien hereof without release from the Trustees any portion of the machinery, equip- 
ment, tools and implements at any time subject to the lien hereof which may have become unserviceable or can no longer be advantageously used in the conduct of its business, the procecds being used to replace the same by new machinery, equipinent, tools or implements of equal value, which shall become subject to this indenture; or such proceeds being paid to the corporate Trustee to be applied by it as provided in Section 1 of this Article, with respect to proceeds of released property.

SECTION 3.-In case any of the property subject to this indenture shall be in the possession of a receiver lawfully appointed, the powers in and by this Article conferred upon the Company may be excrcised by such receiver with the approval of the corporate Trustee, and if the Trustees or either of them shall be in possession of any of such property under any provision of this indenture, then all the powers in this Article conferred upon the Company may be exercised by the Trustee or Trustees in possession in the discretion of the corporate Trustee.

Section 4.-Any release made under the powers in and by this Article conferred, may be executed by the corporate Trustee alone and whien so exccuted shall be as full and sufficient a release as if executed by the Trustees jointly; and in no event shall the purchaser or purchasers of any property disposed of under any provision of this Article be required to see to the application of the purchase money.

\section{Article Nine.}

\section{POSSESSION UNTIL DEFAULT-DEFEASANCE CLAUSE.}

Sectios 1.-Until some default shall have been made in the due and punctual payment of the interest or of the principal of the bonds at any time outstanding or of some part of such interest or principal, or until some default shall have been made in the due and punctual performance and observance of some covenant or condition hereof obligatory upon the Company, and any such default shall have continued beyond the period of grace, if any, herein provided in respect thereof, the Company, its suceessors and assigns, shall be suffered and permitted to retain actual possession of all the property, real, personal or mixed, corporcal or incorporeal rights and interests and everything else of every kind and nature now or hereafter subject to this indenture (other than the certificates of stock, and other securities pledged with and delivered, or to be pledged with and delivered, to the 'T'rustees or either of them as herein provided), and to manage, mine, operate and use the same and every part therenf, with the rights and franchises 
appertaining thereto, and to collect, receive, take, use, enjoy and distribute the earnings, income, rents, issues and profits thereof and of the business of the Company and of all subsidiary companies.

Section 2.-If, when the bonds shall have become due and payable, the Company shall well and truly pay, or cause to be paid, the whole amount of the principal and interest due upon all of the bonds and coupons then outstanding, or shall provide for the payment of such bonds and coupons by depositing with the corporate Trustee hereunder the entire amount due thereon for principal and interest, and also shall pay or cause to be paid, all other sums payable hereunder by the Company, and shall well and truly keep and perform all the things herein required to be kept and performed by it according to the true intent and meaning of this indenture, then and in that case all property, rights and interests hereby conveyed or assigned or pledged shall revert to the Company, and the estate, right, title and interest of the Trustees shall thereupon cease, determine and become void, and the Trustees in.such case, on demand of the Company, and at its cost and expense, shall enter satisfaction of this indenture upon the record; and shall re-assign, re-transfer and deliver the certificates for all shares of stock and all notes or other obligations and claims and the evidences thereof which are then on deposit with them or either of them hereunder to the Company, its successor or assigns, otherwise the same shall be, continue and remain in full force and virtue.

SeCtion 3.- If any of the bonds shall not, within six years after the date when the bonds shall have become due and payable, be presented to the corporate Trustee for payment, or the amount due thereon for principal and interest which shall have been deposited with the corporate Trustee for payment thereof, as hereinbefore provided, shall not be claimed by the owner or owners of such bonds, the corporate Trustee shall, upon demand, pay over to the Company any amount so deposited.

Article Ten.

\section{CONCERNING THE TRUSTEES}

Section 1.-The Trustees accept the trusts of this indenture and agree to execute them upon the following terms and conditions to which the parties and the holders of the bonds agree:

Unless and until the Trustees shall have received written notice to the contrary from the holders of not less than ten per cent. in amount of the bonds outstanding, the Trustees may, for all purposes, 
conclusirely assume that no default has been made in the payment of any of the bonds, or of the interest thereon, or in the observance or performance of any of the covenants contained in the bonds or in this indenture; and that no receiver has been appointed of the Company, or of any or its property or of the trust estate or any part thereof ; and they may so assume unless the said notice shall distinctly specify the default desired to be brought to the attention of the Trustees.

The Trustees shall not be under any obligation to take any action towards the execution or enforcement of the trusts hereby created which in their opinion shall be likely to involve them in expense or liability, unless one or more of the holders of the bonds shall, as often as requested by the Trustees or the corporate Trustee, furnish them reasonable security and indemnity against such expense or liability, anything herein contained to the contrary notwithstanding. The Trustees shall not be required to take notice of any default hereunder, unless notified in writing of such default by the holders of at least ten per cent. in amount of the bonds then outstanding, or to take any action in respect to any such default involving expense or liability, unless requested by an instrument in writing, signed by the holders of not less than ten per cent. in amount of the bonds then outstanding, unless tendered reasonable security and indemnity, as aforesaid, anything herein contained to the contrary notwithstanding; but neither any such notice or request, nor this provision therefor, shall affect any discretion herein elsewhere specially given to the Trustees or either of them to determine whether or not the Trustees or either of them shall take action with respect to such default or to take action without such request.

The Trustees shall incur no liability for or in respect of the validity or sufficiency of this indenture, or of the due execution thereof by the Company, or of the lien purported or intended to be hereby created, nor for or in respect of the title or value of the property or security hercinbefore or at any time hereafter conveyed or intended so to be. The Trustees shall not be responsible for the recording of this indenture or of any supplement hereto or of any conveyance or transfer of further assurance, and shall not be required to record or register the same nor to file or re-file the same as a chattel mortgage or otherwise. The Trustees shall not be under any obligation to give notice of the existence of the lien of this indenture nor to extend or supplement the lien sought to be created hereby, nor to do any act whatever, other than the accepptance of this indenture, for creating, effecting or continuing the lien of this indenture, but the Company covenants that it will, with all convenient speed, cause this indenture to be duly 
filed and recorded, and that it will do all other things requisite to create, effect and continue the lien hereof. The Trustees need not see to the application of the bonds or their proceeds, nor except as expressly required in Article One hereof, take any action to secure the conveyance, pledge or deposit to or with the Trustees or either of them, of after-acquired property of the Company, until requested in writing by the holders of ten per cent. in amount of the bonds then outstanding, as hereinbefore provided.

The Trustees shall be under no duty while not in possession of the mortgaged property to pay, nor to keep themselves informed as to the payment of, the rents, taxes or assessments thereupon, nor to effect insurance against fire or other damage to any portion of said property, nor to renew any policies of fire or other insurance thereon; nor shall the Trustees or either of them be liable or responsible for the collection or adjustment of any insurance in case of loss.

The Trustees shall be entitled to reasonable compensation for all services rendered by them or either of them in the execution of the trusts hereby created, and the Company agrees, from time to time, to pay such compensation and to reimburse them and each of them for all liabilities and expenses (with interest) which they or either of them may have incurred hereunder; and the charges and expenses of the Trustees and all liabilities by them incurred shall be secured by the lien of this indenture; and if the Company shall fail, neglect or delay to pay the same promptly, they shall be paid from and out of the trust estate and mortgaged property and premises prior to any payment therefrom of or on account of any of the bonds, coupons or claims for interest hereby secured.

The Trustees shall not be personally liable for any debt contracted by them or either of them or for damages to persons or property or for salaries or non-fulfilment of contracts during any period wherein the Trustees or either of them shall manage the trust property or premises upon entry or voluntary surrender as aforesaid, and the trust estate is hereby charged with a first lien in favor of the Trustees for their security and indemnification against any such liability.

All matters recited herein and in the bonds secured hereby (save only the corporate Trustee's certificates upon the bonds), shall be conclusively deemed to be the statements of the Company and not of the Trustees.

The Trustees may advise with legal counsel and the opinion of counsel shall be a full protection and justification to the Trustees for anything suffered or done by them or either of them in good faith and in accordance with such opinion. 
The Trustees may employ agents, accountants, appraisers, or attorneys in fact and shall not be answerable for the default or misconduct of any agent, accountant, appraiser, or attorney appointed by them or either of them in pursuance hereof, if such agent, accountant, appraiser, or attorney shall have been selected with reasonable care, nor shall any Trustee be liable for anything whatever in connection with this trust, except his or its own wilful misconduct or gross negligence after personal notice and distinct specification in writing from some person interested in the trust.

The Trustees or either of them may acquire or own bonds and coupons issued hereunder with the same rights which they would have if they were not Trustees.

The Trustees and each of them shall be protected and held harmless in acting upon any notice, demand, request, consent, waiver, certificate, bond or other instrument or paper provided for in this indenture and believed by such Trustee to be genuine and to have been signed or executed by the proper party. In any case where it is provided in this indenture that the Trustees or either of them may accept or act or shall act upon a certificate from the Company or from any of its officers or directors, or a resolution of the Board of Directors of the Company, or of its executive committee, concerning, or as conclusive proof of, any fact upon which the Trustees or either of them shall be required or permitted to take or refrain from taking action, the Trustees shall not be bound absolutely by such certificate or resolution, but may, in the discretion and at the option of the corporate Trustce make any independent investigation into the truth or accuracy of any such fact; and in case it shall, after such independent investigation, be satisficd that the said ccrtificate or resolution, or any statement of fact contained therein, is inaccurate, the Trustees or either of them may take or refuse to take or refrain from taking any action predicated or intended to be predicated upon such fact. Nothing in this section contained shall, however, take from the Trustees or either of them the absolute protection herein conferred upon them in case they shall accept, without further investigation, any certificate or resolution herein provided for.

As to any fact upon which the Trustees or either of them shall be required or permitted to take, or refrain from taking, action, in respect of which this indenture does not make specific provision for the evidence upon which the Trustecs or either of them may act, the Trustees or either of them may accept as conclusive the certificate of the president or a vice-president and secretary or treasurer of the Company. 
Any company into which the corporate Trustee may be merged or with which it may be consolidated or any company resulting from any merger or consolidation to which the corporate Trustee shall be a party, shall be the successor of the corporate Trustee hereunder without the execution or filing of any paper or any further act on the part of any of the parties hereto, anything herein to the contrary notwithstanding. In case any of the bonds hereunder shall have been authenticated but not delivered, any successor corporate Trustee may adopt the certificate of the First Trust and Savings Bank and deliver the same so authenticated; and in case any of said bonds shall not have been authenticated, any successor corporate Trustee may authenticate such bonds in the name of such successor corporate Trustee; and in all such cases such authentication shall have the full force which it is anywhere in said bonds or in this indenture provided that the authentication of the corporate Trustee shall have.

Any notice, request, or other writing by or on behalf of the bondholders delivered solely to the First Trust and Savings Bank or its successor in the trust shall be deemed to have been delivered to all the Trustees hereunder as effectually as if delivered to each of them. Said Emile K. Boisot and any of his successors in the trust and any additional Trustee may, so far as may be permitted by law, at any time by an instrument in writing constitute said First Trust and Savings Bank and its successors in the trust hereunder, his or its agent and attorney in fact with full power and authority to the full.extent which may be permitted by law, to do all acts and things and exercise all discretions hereunder for and in behalf and in the name of the Trustee or Trustees executing such instrument.

All cash collected by or payable to the Trustees shall be paid to and be deposited with, and all stocks, bonds and other securities be held by, the corporate Trustee. Any moneys at any time coming into the hands of any trustee other than the corporate Trustee shall be at once paid over to the corporate Trustee.

So long as any notes or other obligations or securities pledged hereunder shall remain so pledged any instrument to be executed or action taken under the mortgage or agreement securing the same by the noteholders or other security holders may be executed or taken by the corporate. Trustee hereunder.

All the assets, right, title and interest by this indenture conveyed or assigned or transferred to the Trustees are conveyed, assigned or transferred to them as joint tenants and not as tenants in common.

In case the said Emile K. Boisot, or any additional Trustee or a successor to either of them, shall die, become incapable of acting, resign or be removed, all the assets, property, rights, powers, trusts, 
duties and obligations of the Trustees hereunder shall vest in and be exercised by said First Trust and Savings Bank or its successor in the trust without the appointment of a new trustee as successor to said Emile K. Boisot or to any additional trustee shall be appointed unless such appointment shall be necessary for the full protection of the bondholders hereunder nor unless the First Trust and Savings Bank or its successor or the holders of a majority in amount of the bonds then outstanding shall deem such appointment expedient for any cause.

Secrion 2.-The Trustees or either of them or any successor or successors may resign and be discharged of the trusts created by this indenture, by executing an instrument in writing, resigning such trusts, specifying the date when such resignation shall take effect, and filing the same with the Company at its office or agency in the City of New York three months (or such shorter time as may be accepted by the Board of Directors of the Company as adequate) before such resignation shall take effect, and by giving notice of such resignation by publication at least once a week for two successive weeks in a daily newspaper of general circulation published in the City of New York, and a daily newspaper of general circulation published in the City of Chicago. Such resignation shall take effeet on the day specified in said writing and notice, unless previously a successor Trustee or Trustees shall be appointed as hereinafter provided, in which event such resignation shall take effect immediately upon the appointment of such successor Trustee or Trustees.

The Trustees or either of them or any successor or successors, with the written consent of the Company if at the time it be not in default hereunder, or without such consent if the Company shall then be in default hereunder, may be removed at any time by an instrument or concurrent instruments in writing executed in counterparts by the holders of two-thirds in amount of the bonds then outstanding appointing a successor to the trustee so removed, and filed with the Company, with the trustee so removed, and with the successor trustee so appointed, respectively; provided that there be filed at the same time with the Company and with the trustee so removed, respeetively, an instrument in writing executed in duplicate by the successor trustee so appointed accepting such appointment.

In case the 'Trustees or either of them or any successor or successors shall at any time resign or otherwise become ineapable of acting, a successor or successors may be appointed by the holders of a majority in amount of the bonds then outstanding, by an instrument or concurrent instruments exeeuted by such bondholders or their attorneys in fact duly authorized and filed with the Company and with the 
successor trustee so appointed and upon written notice thereof, and of the acceptance of such appointment, given by the successor trustee to the Company; but it shall be the duty of the Company, subject to the foregoing provisions hereof, by an instrument executed by order of its Board of Directors or the Executive Committee thereof, to appoint a trustee to fill a vacancy in the office of Trustee hereunder until a new trustee shall be appointed by the bondholders as herein authorizeã. The Company shall at once upon the making thereof publish notice of such appointment by it once a week for four successive weeks in a daily newspaper of general circulation published in the City of New York and a daily newspaper of general circulation published in the City of Chicago. Any new trustee so appointed by the Company shall immediately and without further act be superseded by a trustee appointed in the manner above provided by the holders of a majority in amount of the bonds then oustanding.

Every such trustee appointed in place of the corporate Trustee herein named, or its successor in the trust, shall always be a trust company in good standing authorized to accept such trusts and carrying on business in the Borough of Manhattan in the City of New York, or in the City of Chicago, Illinois, and having a capital, undivided profits and surplus aggregating at least $\$ 5,000,000$ if there be such a trust company willing and able to accept the trust upon reasonable or customary terms; and every Trustee appointed in place of the individual Trustee herein named or his successor in the trust shall always be a person satisfactory to and approved by the First Trust and Savings Bank or its successor in the trust and the Company. The Trustees and each of them and every successor trustee, shall be exempt from giving any bond or surety in respect of the execution of the trusts or powers herein provided for or otherwise in respect of the premises.

Any new trustee appointed hereunder shall execute, acknowledge and deliver to the trustee last in office, and also to the Company, an instrument accepting such appointment hereunder, and thereupon such new trustee shall without any further act, deed or conveyance, become rested with all the estates, properties, rights, powers, duties and trusts of its predecessor in the trust hereunder with like effect as if originally named as trustee herein; but the trustee retiring shall, nevertheless, on the written demand of the new trustee, and upon the filing with it of proof of the appointment of such new trustee, execute and deliver an instrument conveying and transferring to such new trustee, upon the trusts herein expressed, all the estates, properties, rights, powers and trusts of the trustees so retiring, and shall duly assign, transfer and deliver to the new trustee so appointed in 
its place all properties and moneys held by it under this indenture, subject, nevertheless, to the retiring trustee's first lien on all of the trust estate for its reasonable compensation and reimbursement of all its costs and expenses hereunder. Should any deed, conveyance or instrument in writing from the Company be required by any new trustee for more fully and certainly vesting in and confirming to such new trustee the said estates, properties, rights, powers, trusts and duties, then any and all such deeds, conveyances and instruments in writing shall, on request of such new trustee, be made, executed, acknowledged and delivered by the Company.

If at any time or times, in order to conform to any legal requirement, the Company shall so request or the Trustees shall deem it advisable, the Company shall, and the Trustees shall have power to, appoint, and the said parties shall unite in the execution, delivery and performance of all instruments and agreements necessary or proper to appoint, another trust company or one or more persons approved by the Trustees, either to act as co-trustee or co-trustees of all or any of the property subject to the lien hereof jointly with the Trustees originally named herein or their respective successor or successors, or to act as a separate trustee or trustees of any such property.

In case of the appointment of any new trustee under the provisions of this Article a copy of the instrument making such appointment, duly authenticated by the President or Vice-President or the Secretary of the Company (such officer having inspected and compared said copy with the original as a true copy), shall be filed with each corporation any of the stock or securities whereof shall then be subject to this indenture

Section 3.-Emile K. Boisot, one of the parties of the second part, has been joined as Trustee hereunder, so that if by any present or future law in any jurisdiction, in which it may be necessary to perform any act in the execution of the trusts herein created, the First Trust and Savings Bank, Trustec, or its successor or successors, may be incompetent or unqualified to act as sueh Trustee, then all of the acts required to be performed in such jurisdiction in the execution of the trusts hereby created, shall and will be performed by said Emile K. Boisot, as .Trustee, or his successor or successors, acting alone. Except as it may be deemed necessary for said Emile $K$. Boisot solely to execute the trusts hereby created, the First Trust and Savings Bank, Trustee, or its successor or successors, may solely have and execute the powers, and shall be solely charged with the performance of the duties hereinbefore declared on the part of the Trustees to be had and exercised, or to be performed. Any request in writing by the First Trust and Savings Bank Trustce or by any 
trust company appointed in succession to it to the individual Trustee hereunder or any Trustee appointed in succession to him. shall be sufficient warrant for the individual Trustee, or his successor, taking such action as may be so requested. Such individual Trustee, or any successor, may delegate to the First Trust and Savings Bank, or any trust company appointed in succession to it, the exercise of any power, discretionary or otherwise, conferred by any provisions of this indenture.

\section{Article Eleven}

\section{SUNDRY PROVISIONS}

Section 1.-All of the covenants, stipulations, promises and agreements in this indenture contained, by or in behalf of the Company, shall bind its successors and assigns, whether so expressed or not.

Section 2.- Nothing contained in this indenture, or in any of the bonds shall prevent any lease, subject to the continuing lien of this indenture and to all the provisions thereof, of all the property subject to this indenture, to a corporation at that time existing under and by virtue of the laws of any State or States of the United States, and empowered to take such a lease, provided, however, that such lease shall be made subject to termination by the corporate Trustee, in case of the happening of any event of default hereunder (even though the same shall not have continued for the time named with respect thereto in any provision of this indenture or for any special period), or by the purchaser at any sale of the trust estate, made in enforcement of this indenture.

Section 3.-Nothing contained in this indenture or in any of the bonds shall prevent the consolidation or merger of the Company with any other corporation, or prevent any consolidation or merger with the Company of any other corporation, or prevent any sale subject to the continuing lien of this indenture, and to all the provisions thereof, of all the property subject to this indenture, as an entirety. provided that such consolidation, merger or sale shall be on such terms as to preserve and not to impair the lien or security under this indenture, and the rights and powers of the Trustees and of the holders of the bonds, and that any successor corporation formed by such consolidation, or the corporation into which the Company shall be merged, shall, as part of such consolidation or merger, expressly assume the due and punctual payment of the principal and interest of all the bonds and the performance of all the covenants and conditions of this indenture, and provided that, as a condition of any such sale of the property of the Company as an entirety, the corporation 
to which such property shall be sold as an entirety, shall, as a part of the purchase price thereof, assume the due and punctual payment of the principal and interest of all the bonds and the performance of all the covenants and conditions of this indenture, and shall, simultaneously with the delivery to it of a transfer and conveyance thereof, execute and deliver a proper indenture to the Trustees, in form satisfactory to the Trustees, whereby such purchasing corporation shall so assume the due and punctual payment of the principal and interest of all of the bonds, and the performance of all of the covenants and conditions of this indenture, and charge therewith the property and franchises so taken over.

Section 4.- - In case any company shall be consolidated or merged with the Company as aforesaid, or in case the Company shall be so consolidated or merged with any other corporation, or in case of a sale of the property of the Company as an entirety, the corporation formed by such consolidation or into which the Company shall have been merged, or to which such sale shall have been made, upon executing and causing to be recorded an indenture with the Trustees, whereby such corporation shall assume the due and punetual payment of all the bonds and the performance of all the corenants and conditions of this indenture, and charge therewith the property and franchises so taken over, shall succeed to and be substituted for the Company, with the same effect as if it had been named herein as party of the first part hereto and such corporation may thereupon cause to be signed and may issue either in its own name or in the name of the Company any or all of the bonds which shall not theretofore have been signed by the Company and delivered to the corporate Trustee, and the corporate Trustee, upon the order of such corporation in lieu of the Company, and subject to all the terms, conditions and restrictions herein prescribed, shall authenticate any and all of the bonds which shall have been previously signed by the officers of the Company and delivered to the corporate Trustee for authentication, and any of the bonds which such corporation shall thereafter cause to be signed and delivered to the corporate Trustee for that purpose. All bonds so issued shall in all respects have the same legal rank and security as the bonds theretofore or thereafter issued in accordance with the terms of this indenture, as though all of said bonds had been actually issued by the Company as of the date of the execution hereof.

For every purpose of this indenture, including the execution, issue and use of any and all the bonds, the term Company includes and means not only the Jones \& Iaughlin Steel Company, hut also any such successor corporation. Every such successor corporation shall 
possess, and from time to time may exercise, each and every right and power hereunder of the Jones \& Laughlin Steel Company in its name or otherwise, and any act or proceeding by any provision of this indenture required to be done or performed by any board or officer of the Company may be done and performed with like force and effect by the like board or officer of any corporation that shall at the time be such lawful successor of the Company.

Section 5.-Except when otherwise indicated, the words "the Trustees" or any other equivalent term, as used in this indenture, shall be held and construed to mean the Trustees for the time being hereunder, whether original or successor; the words "corporate Trustee" mean the corporate trustee hereinbefore named, and each and every successor thereof; the words "Trustee," "bond," "bondholder," "holder," shall include the plural as well as the singular number, unless otherwise expressly indicated.

By "order of the Company," whenever those words are used in this indenture, is meant, unless otherwise expressly provided, a written order, signed by (1) the president or any vice-president, and (2) the comptroller, the auditor, the treasurer or the assistant treasurer of the Company, and whenever any moneys or bonds or securities are deliverable by the terms hereof to the Company, or upon the order of the Company, such delivery or payment shall be made only upon the receipt of such a written order.

Section 6.-Any written demand, request, notice, approval, waiver, designation, direction or nomination to be made by the Company under any of the provisions hereof, shall be deemed sufficiently made and executed if executed by the president or by a vice-president of the Company under the corporate seal of the Company, duly attested by its secretary or an assistant secretary. Any notice or demand in respect of the bonds and coupons or under this indenture may be served or presented, and such demand may be made, at the office in the City of Chicago, of the corporate Trustee, or, in the case of a notice or demand upon the Company, at the office of the Company in the City of Pittsburgh, Pennsylvania, or at the agency of the Company in the City of New York, and such presentation, service or demand hereunder upon the corporate Trustee or upon the Company, shall be sufficient. The Trustees or either of them may receive a certificate under the corporate seal of the Company, signed by the secretary or by an assistant secretary of the Company, as sufficient evidence of the passage of any resolution by the Board of Directors or by the Executive Committee of the Company.

SECTION 7.-In order to facilitate the record of this indenture, the same mav be simultaneously executed in several counterparts, each of 
which so executed shall be deemed to be an original, and such counterparts shall together constitute one and the same instrument.

\section{Article Twelve}

\section{PARTIES IN INTEREST}

Nothing in this indenture expressed or implied is intended or shall be construed, to confer upon, or to give to, any person or corporation, other than the parties hereto and the holders of the bonds, any right, remedy or claim, under or by reason of this indenture or any covenant, condition or stipulation hereof; and all the covenants, stipulations, promises and agreements in this indenture contained by or on behalf of the Company are and shall be held to be for the sole and exclusive benefit of the parties hereto and of the holders of the bonds.

The Board of Directors of Jones \& Laughlin Steel Company has by resolution duly adopted, authorized and appointed B. F. Jones, Jr., and the said Jones \& Laughlin Steel Company does hereby constitute and appoint said B. F. Jones, Jr., its attorney, for it and in its name and as and for its corporate act and deed, to acknowledge this indenture before any person or persons having authority by the laws of the Commonwealth of Pennsylvania to take such acknowledgment to the intent that the same may be duly recorded, and First Trust and Savings Bank does hereby constitute and appoint Emile K. Boisot to be its attorney, for it and in its name and as and for its corporate act and deed to acknowledge this indenture before any person having authority by the laws of the Commonwealth of Pennsylvania to take such acknowledgment to the intent that the same may be duly recorded.

In Witness Whereof, Jones \& Laughin Stefl Compaxi has caused its corporate seal to be hereunto affixed and this indenture to be signed in its corporate name by its president or vice-president and its secretary, and First Trust and Savings Bank, in token of its acceptance of this trust, has caused its corporate seal to be hereunto affixed and this indenture to be signed in its corporate name by its president or a vice-president and its secretary, and the said EMrLe $\mathrm{K}$. Borsor has hereunto set his hand and seal, all the day and year first above written. Exeeuted in five counterparts.

Jones \& Lauginlin Steel Company,

Attest:

By B. F. Jones, JR.,

Corporate

W. C. Moreland,

President.

Seal Secretary. 
Signed, sealed, executed and delivered

by Jones \& Laughlin Steel Company

in the rresence of us:

Geo. C. Wilson,

B. H. Inness Brown.

First Trust and Savings Bank, By EMile K. Boisot,

Corporate

Attest:

Vice-President.

Seal.

D. W. Webster,

Secretary.

Signed, sealed, executed and delivered

by First Trust and Savings Bank in

the presence of us:

O. A. Bestel,

J. R. Júlin,

Signed, sealed, executed and delivered

Emile K. Boisot. [SEaL.]

by Emile K. Boisot in the presence of us:

O. A. Bestel,

J. R. JuLIN,

Commonwealti of Pennsyluania,

County of Allegheny,

ss.:

I hereby certify that on this Fifth day of May, in the year of our Lord One thousand nine hundred and nine before me the subscriber, a Notary Public within and for said County and Commonwealth, personally appeared B. F. Jones, Jr., the attorney of Jones \& Laughlin Steel Company, named in the foregoing indenture and by virtue and in pursuance of the authority therein conferred upon him acknowledged the said indenture to be the act and deed of said Jones \& Laughlin Steel Company.

Witness my hand and Notarial seal the day and year aforesaid. My commission expires January 16, 1913.

Notarial

Seal.
S. W. ShaW, Notary Public in and for the County of Allegheny in the Commonwealth of Pennsylvania.

Commonwealth of Pennsyluania,

County of Allegheny, ss.:

I, S. W. SirAw, a Notary Public within and for the County and Commonwealth aforesaid, do hereby certify that B. F. Jones, Jr., 
President of the above-named Jones \& Laughlin Stcel Company, personally known to me to be the same person whose name is subscribed to the foregoing instrument as such President and to be such President, appeared before me this day in person and acknowledged that he signed sealed and delivered the said instrument as the free and voluntary act of said Jones \& Laughlin Stcel Company and as his own free and voluntary act as such President for the uses and purposes therein set forth.

Given under my hand and official seal this Fifth day of May, A. D. 1909. My commission expires January 16, 1913.

\section{Notarial}

Seal.
S. W. Shaw,

Notary Public in and for the County of Allegheny in the Commonwealth of Pennsylvania.

State of Illinois,

County of Cook, $\}$ ss.:

I hereby certify that on the 6th day of May, in the year of our Lord one thousand nine hundred and nine before me the subscriber, a Notary Public within and for said County and State, having a seal of office, personally appeared Emile $K$. Boisot, the attorney of First Trust and Savings Bank named in the foregoing indenture and by virtue and in pursuance of the authority therein conferred upon him acknowledge the said indenture to be the act and deed of the said First Trust and Savings Bank.

Witness my hand and official notarial seal the day and year aforesaid. My commission expires January 2, 1910.

Notarial

Seal.

\section{$\left.\begin{array}{l}\text { State of IllinoIs, } \\ \text { County of Cook, }\end{array}\right\}$ ss.:}

I; Ourver A. Bestes, a Notary Public in and for the County and State aforesaid, do hereby certify that Emile K. Boisot, Vice-President of the above named First Trust and Savings Bank, personally known to me to be the same person whose name is subscribed to the foregoing instrument as such Vice-President and to be such VicePresident appeared before me this day in person and acknowledged that he signed, sealed and delivered the said instrument as the free and voluntary act of said First Trust and Savings Bank and as his own free and voluntary act as such Viee-President for the uses and purposes therein set forth. 
Given under my hand and official seal this 6th day of May, A. D. 1909. My commission expires January 2, 1910.

Notarial

SeAL.
Oliver A. Bestel, Notary Public in and for the County of Cook and the State of Illinois.

$\left.\begin{array}{l}\text { State of IllinoIs, } \\ \text { County of Cook, }\end{array}\right\}$ ss.:

Be IT Remembered, that on the 6th day of May, 1909, before me, Oliver A. Bestel, a Notary Public in and for the County and State aforesaid, having a seal of office, personally came Emile $\mathrm{K}$. Boisot above named and acknowledged the foregoing indenture to be his act and deed and desired the same to be recorded as such.

Witsess my hand and official seal the day and year aforesaid. My commission expires January 2, 1910.

Notariat

SEAL.
Oliver A. Bestel, Notary Public in and for the County of Cook and the State of Illinois.

$\left.\begin{array}{l}\text { State of IllinoIs, } \\ \text { County of Cook, }\end{array}\right\}$ ss.:

I, Oriver A. Bestel, a Notary Public in and for the County and State aforesaid, do hereby certify that Emile K. Boisot, personally known to me to be the same person whose name is subscribed to the foregoing instrument appeared before me this day in person and acknowledged that he signed, sealed and delivered the said instrument as his free and voluntary act for the uses and purposes therein set forth.

Grven under my hand and official seal this 6th day of May, A. D. 1909. My commission expires January 2, 1910.

Notarial

SEal.
Oliver A. Bestel, Notary Public in and for the County of Cook and the State of Illinois. 
TRUST AGREEMENT-THE MORTGAGE BOND COMPANY OF NEW YORK WITH UNITED STATES TRUST COMPANY OF NEW YORK.

This Agreement, made the first day of October, Nineteen hundred and six, by and between the Mortgage-Bond Company of New York, a corporation duly created and existing by and under the laws of the State of New York, hereinafter termed "the Company," party of the first part, and the United States Trust Company of New York, a corporation duly created and existing by and under the laws of the State of New York, and having power to execute the trust hereby created and hereinafter termed "the Trustee," party of the second part;

[Whereas clauses stating purposes of agreement and acceptance of trust] ${ }^{1}$

Whereas, the said mortgage bonds, series 2 thereof, are to be issued in denominations of $\$ 100$, or $\$ 500$, or $\$ 1,000$ each, and the body of each bond is to be in the English, French, German and Dutch languages, arranged in four parallel columns, and said bonds are to be substantially in the following form, varying only as to amount, namely :

(Form of $\$ 1,000$ bond.)

THE MORTGAGE-BOND COMPANY OF NEW YORK.

United States of America, State of New York. $4 \%$ Gold Mortaage Bond.

No.............. Series 2

$\$ 1,000$

$$
\$ 1,000.00
$$

$$
\text { £205.15.2 Fs. } 5,180
$$

Mks. 4,200 D. R. W. Guilders 2,487.50

(Column 1)

For value received the Mortgage-Bond Company of New York (herein called the Company) promises to pay to the bearer hereof, not later than October 1,1966 , One Thousand Dollars $(\$ 1,000)$ in gold coin of the United States of America, of the present standard of weight and fineness, at the office of the company, or at the office of Ladenburg, Thalmann \& Co., in the City of New York, United States of America, or at the holder's option, 205 pounds, 15 sh., 2d., ster-

1 Statements included in brackets [ ] are digests of parts omitted. These parts, however, have been abbreviated because they are practically duplicated in the Corporate Mortgage of the Jones \& Laughlin Stecl Company, to which reference is made as follows: J. \& I. S. Co. Art. -, Sec. -, P.- 
ling, at the banking house of Coutts \& Co. in London, England, or 5,180 Francs at the Banque de l'Union Parisienne in Paris, France, or 4,200 Marks, D. R. W., at the office of L. Behrens und Söhne in Hamburg, Germany, or at the Bank für Handel und Industrie in Berlin, Germany, or 2,487.50 guilders, at Maatschappij tot Beheer van het Administratie kantoor van Amerkaansche Fondsen, opgerigt door Broes \& Gosman Ten Have en Van Essen en Jarman en Zoonen in Amsterdam, Holland, and to pay interest thereon in any of the cities in said respective currencies, at the rate of four per cent (4\%). per annum from October 1, 1906, semi-annually, on the first day of April and of October in each year, to the bearer of the annexed coupons, upon presentation and surrender thereof as they respectively mature.

This bond is one of a scries, known as Series 2, not exceeding five million dollars $(\$ 5,000,000)$ of principal payable in gold or its equivalent in foreign currencies, as stated, all of which are issued and to be issued, under a certain trust agreement between the Com. pany and the United States Trust Company of New York, dated October 1, 1906, assigning to said United States Trust Company of New York, as trustee, certain securities specified therein, to which agreement reference is hereby made for a description of the securities assigned, the nature and extent of the security, the rights and remedies of the holders of said bonds in relation thereto, and the terms and conditions upon which the said bonds are issued and secured. Said trust agreement expressly provides "if any question shall arise touching the meaning of the company's bonds, the English version shall prevail in the construction."

This bond shall not become obligatory until the certificate hereon shall have been signed by the said trustee, and is redeemable at the option of the company on and after October 1, 1916, upon any interest day, in the manner in said agreement provided.

The bonds of this series are entitled to the benefits of the amortization provisions contained in said agreement, and the drawings under said provisions are to be effected according to the table endorsed hereon.

\section{(Column 2)}

The Mortgage-Bond Company of New York (ci-après appelée la Compagnie) s'engage à payer au porteur le 1er Octobre 1966 au plus tard, pour valeur reçue: Mille Dollars en monnaie d'or des EtatsUnis d'Amérique, aux titre et poids actucls et ce, soit au Siège de la Compagnie, soit chez M.M. Ladenburg, Thalmann \& Co., à New York, ou, au choix du porteur: 205 Livres, 15 shillings, 2 pence 
sterling chez M.M. Coutts \& Co., Banquiers, à Londres (Angleterre), ou Fs. 5,180 à la Banque de l'Union Parisienne à Paris (France), ou Mks. 4,200 D. R. W. chez M.M.L. Behrens \& Söhne à Hambourg (Allemagne), ou à la Bank für Handel und Industrie à Berlin (Allemagne), ou 2,487.50 Florins à la Maatschappij tot Beheer van het Administratie Kantoor van Amerikaansche Fondsen, opgerigt door Broes \& Gosman, Ten Have en Van Essen en Jarman en Zoonen, à Amsterdam (Hollande) et à payer dans les dites villes en monnaie des dits pays, les intérêts au taux de quatre pour cent (4\%) l'an, à dater du 1er Octobre 1906, semestriellement, le premier Avril et lo premier Octobre, le dit paiement devant être effectué au porteur des coupons ci-attachés, contre présentation et remise de ces coupons au fur et à mesure de leur échéance.

La présente obligation fait partie d'une série d'obligations, désignée Série II, dont le montant total ne dépassera pas cinq millions de Dollars or $(\$ 5,000,000)$ ou leur équivalent en monnaies étrangères, comme ci-dessus indiqué, et qui sont ou seront émises conformément aux stipulations d'un contrat (trust agreement) intervenu entre la Compagnic et la United States Trust Company of New York en date du 1er Octobre 1906 et conférant à la dite United States Trust Company of New York, en sa qualité de tiers dépositaire, (trustee) certains gages spécifiés au dit contrat. La Compagnie se réfère par la présente à ce contrat pour tous détails relatifs aux gages conférés, à leur nature et leur montant, aux droits et privilèges des porteurs des obligations par rapport à ces gages, ainsi qu'aux termes et conditions dans lesquels les obligations sont émises et garanties. Le Trust Agreement déclare expressément: En cas de divergence dans l'interprétation du texte des obligations de la compagnie, le texte anglais prévaudra.

La présente obligation ne deviendra valable qu'après avoir été dûment revêtue de la signature du dit dépositaire; elle est remboursable au choix de la Compagnie, à partir du 1er Octobre 1916, à chaque échéance des coupons, aux termes prévus dans le sus-dit contrat.

Les obligations de la présente séric jouiront des stipulations du dit contrat relatives à l'amortissement, et les tirages prérus par ces stipulations devront être effectués conformément au tableau ci-annexé.

\section{(Column 3)}

The Mortgage-Bond Company of New York (hierin die Gesellsehaft genannt) verspricht für erhaltene Gegenleistung dem Inhaber Dieses nicht später als am 1. Oktober 1966, Ein Tausend Dollars 
$(\$ 1,000)$ in Goldmünzen der Vereinigten Staaten von Amerika von dem gegenwärtigen Gewicht und Feingehalt, bei der Kasse der Gesellschaft, oder bei den Herren Ladenburg, Thalmann \& Co. in New York, Vereinigte Staaten von Nord Amerika, zu zahlen, oder nach Wahl des Inhabers £205.15.2 sterling bei dem Bankhaus Coutts \& Co. in London, England, oder Frs. 5,180 bei der Banque de l'Union Parisienne in Paris, Frankreich, oder M.4,200 D. R. W. bei den Herren L. Behrens \& Söhne in Hamburg, Deutschland, oder der Bank für Handel und Industrie in Berlin, Deutschland, oder 2,48\%.50 Gulden bei der Maatschappij tot Beheer van het Administratie kantoor van Amerikaansche Fondsen, opgerigt door Broes \& Gosman, Ten Have en Van Essen en Jarman en Zoonen in Amsterdam, Holland, und Zinsen hierauf in irgend einer der genannten Städte in der diesbezüglichen Währung, zum Satz von vier Prozent (4\%) per Jahr, vom 1. Oktober, 1906, ab halbjährlich, am 1. April und Oktober jeden Jahres, dem Inhaber der beigefügten Coupons, gegen Vorzeigung und Ueberreichung des jeweilig fälligen Coupons zu zahlen.

Dieser Bond ist ein Bond aus einer Serie, genannt Serie II, von nicht mehr als Fünf Millionen Dollars $(\$ 5,000,000)$ Nominalbetrag in Gold, oder dessen Gegenwert in fremden Währungen, wie oben angegeben, und diese sämmtlichen Bonds sind und werden ausgegeben unter einem Trust Agreement zwischen der Geselleschaft und der United States Trust Company of New York, d. d. 1 Oktober, 1906, wodurch der genannten United States Trust Company of New York, als Treuhänder, bestimmte darin näher bezeichnete Sicherheiten übertragen werden. Für eine Beschreibung der übertragenen Sicherheiten, der Art und des Umfangs der Sicherheit, der Rechte und Befugnisse der Inhaber der Bonds, und der Vorschriften und Bedingungen, unter welchen die Bonds ausgegeben und sicher gestellt sind, wird auf das genannte Agreement Bezug genommen. Das Trust Agreement schreibt ausdrücklich vor: Falls irgend eine Frage hinsichtlich der Auslegung des Textes der Obligationen der Gesellschaft entstehen sollte, so soll der englische Text solcher Auslegung als entscheidend zu Grunde gelegt werden.

Dieser Bond verpflichtet die Gesellschaft nicht eher als bis das darauf befindliche Certifikat von dem genannten Treuhänder unterzeichnet ist. Die Gesellschaft hat das Recht diesen Bond an oder nach dem 1. Oktober, 1916, an irgend einem Zinszahlungstermine, in der in dem Trust Agreement vorgeschriebenen Art und Weise einzulösen.

Auf die Bonds dieser Serie finden die in dem Trust Agreement enthaltenen Vorschriften über die Amortisation Anwendung, und die 
Ziehungen gemäss jenen Vorschriften, müssen in Uebereinstimmung mit dem beigefügten Plan erfolgen.

\section{(Column 4)}

Voor ontvangen waarde verbindt The Mortgage-Bond Company of New York (hierin de Maatschappij genoemd) zich, den houder dezes, niet later dan 1 October 1966 , te betalen, duizend dollars $(\$ 1,000.00)$ in gouden munt van de Vereenigde Staten van Amerika, van den tegenwoordigen standaard van gewicht en gehalte, ten kantore der Maatschappij, of ten kantore van Ladenburg, Thalmann \& Co., in de stad New York, in de Vereenigde Staten van Amerika, of, ter keuze van den houder, 205 pond, 15 sh., 2 d. sterling, ten kantore van Coutts \& Co., te Londen, in Engeland, of 5,180 francs by de Banque de l'Union Parisienne te Parys in Frankryk, of 4,200 ryksmark, ten kantore van L. Behrens und Söhne te Hamburg, in Duitschland, of by de Bank für Handel und Industrie te Berlyn, in Duitsch. land, of 2,487.50 gulden by de Maatschappij tot Beheer van het Administratiekantoor van Amerikaansche Fondsen, opgerigt door Broes \& Gosmann, Ten Have en Van Essen en Jarman en Zoonen te Amsterdam, in Holland, en daarover, in eene dier steden, in genoemde respectieve muntsoorten, interest te betalen, à vier percent (4\%) 's jaars, van 1 October 1906 af, halfjaarlyks, op de eerste dagen van April en October van elk jaar, aan den houder van bygaande coupons, tegen aanbieding en overgave daarvan, naarmate ze vervallen.

Deze obligatie behoort tot eene serie, genaamd Serie II, niet te boven gaande een bedrag van Vyf Millioen Dollars $(\$ 5,000,000)$ nominaal in goud, of het equivalent daarvan in vreemde muntsoorten als boven gezegd, welke alle zyn of zullen worden uitgegeven volgens de bepalingen van zekere Trust overeenkomst tusschen de Maatschappij en de United States Trust Company of New York, gedateerd 1 October 1906, waarby aan genoemde United States Trust Company of New York, als Trustee, worden overgedragen zekere daarin omschreven onderpanden, en naar welke overeenkomst lierby wordt verwezen ter omschryving van de overgedragen onderpanden, den aard en omvang van het onderpand, de rechten en rechtsmiddelen van de houders der genoemde obligatien met betrekking daartoe, en de voorwaarden en conditien waarop genoemde obligatien zyn uitgegeven en verzekerd. Genoemde trustovereenkomst bepaalt uitdrukkelijk: "indien eenige questic zich mocht voordoen betreffende de bedoeling der obligatiën van de Maatschappij, zal in de opvatting volgens den Engelschen tekst worden geoordeeld." 
Deze obligatie zal niet geldig zijn voordat de daarop gestelde verklaring door genoemden trustee zal zyn geteekend. Deze obligatie is aflosbaar naar verkiezing der Maatschappij op en na 1 October 1916, op iederen vervaldag der rente op de wyze als in genoemde overeenkomst is geregeld.

De obligatien dezer hebben recht op aflossing volgens de regels in genoemde overeenkomst vervat, en de trekkingen overeenkomstig d'e regels moeten plaats hebben volgens den hier aangehechten staat.

(Testimonium Clause.)

In Witness Whereof, the Company has caused these presents to be signed by its President or Vice-President, and its corporate seal to be affixed hereto, attested by its treasurer or assistant treasurer, and has caused the coupons thereto annexed to bear the facsimile signature of its treasurer, as of the 1st day of October, 1906.

The Mortgage-Bond Company of New York,

By....................

[SEAL]

President.

Attest..............

Treasurer.

And Whereas, each of the coupons to be attached to said Morgage Bonds, Series 2, is to be in the following form, varying only as to amount namely

(Form of Coupon for $\$ 1,000$ Bond.)

THE MORTGAGE-BOND COMPANY OF NEW YORK. No.

\section{$\$ 20$ U. S. Gold}

£4.24 Fs. 103.60

Mks. 84 D. R. W. Guilders 49.75

The Mortgage-Bond Company of New York will pay to bearer in the City of New York, United States of America, twenty dollars (\$20) in gold, or in London, England, 4 pounds sterling, 2 sh. 4 d., or in Paris, France, 103.60 Franes, or in Hamburg, or Berlin, Germany, 84 Marks, D. R. W., or in Amsterdam, Holland, 49.75 guilders, on the first day of

, 19 , being the interest of the preceding six months on its Four Per Cent Gold Mortgage Bond Series 2, No........., unless said bond shall have been previously redeemed under the provisions of the Trust Agreement securing the same. 


\section{(BACK of Coupon.)}

No.

Payable in New York at the office of The Mortgage-Bond Company of New York, or at the office of Ladenburg, Thalmann \& Co.

Payable in London at the banking house of Coutts \& Co.

Payable à Paris ehez la Banque de l'Union Parisienne.

Zahlbar in Hamburg bei dem Bankhaus L. Behrens und Söhne. Zahlbar in Berlin bei der Bank für Handel und Industrie.

Betaalbaar in $\Lambda$ msterdam by het Administratiekantoor Broes \& Gosman c. s.

And Whereas, each of said mortgage bonds, series 2 thereof, is to bear the following endorsements, to-wit:

TABLE OF DRAWINGS FOR THE AMORTIZATION OF MORTGAGE BONDS SERIES 2 , OF

\section{The Mortanae-Bond Company of New York}

\begin{tabular}{|c|c|c|c|c|c|}
\hline \multicolumn{2}{|c|}{$\begin{array}{l}\text { DATE OF } \\
\text { PAYMENT }\end{array}$} & $\begin{array}{c}\text { Percentage of } \\
\text { Bonds Issued } \\
\text { to be drawn for } \\
\text { Payment }\end{array}$ & \multicolumn{2}{|c|}{$\begin{array}{l}\text { DATE OF } \\
\text { PAYMENT }\end{array}$} & $\begin{array}{l}\text { Percentage of } \\
\text { Bonds lssued } \\
\text { to be drawn for } \\
\text { Payment }\end{array}$ \\
\hline April & $1,1912 \ldots \ldots \ldots$ & .2 & April & $1,1940 \ldots \ldots \ldots$ & .8 \\
\hline October & $1,1912 \ldots \ldots \ldots$ & .2 & October & $1,1940 \ldots \ldots \ldots$ & .8 \\
\hline April & $1,1913 \ldots \ldots$ & .3 & April & $1,1941 \ldots \ldots$ & .8 \\
\hline Oetober & $1,1913 \ldots \ldots \ldots$ & .3 & October & $1,1941 \ldots \ldots$ & .8 \\
\hline April & $1,1914 \ldots \ldots \ldots$ & .3 & April & $1,1942 \ldots \ldots \ldots$ & .8 \\
\hline October & $1,1914 \ldots \ldots \ldots$ & .3 & October & $1,1942 \ldots \ldots \ldots$ & .9 \\
\hline April & $1,1915 \ldots \ldots \ldots$ & .3 & April & $1,1943 \ldots \ldots$ & .9 \\
\hline Oetober & $1,1915 \ldots \ldots \ldots$ & .3 & October & $1,1943 \ldots \ldots$ & .9 \\
\hline April & $1,1916 \ldots \ldots$. & .3 & April & $1,1 n 44 \ldots \ldots$ & .9 \\
\hline Oetober & $1,1916 \ldots \ldots$ & .3 & Oetober & $1,1944 \ldots \ldots \ldots$ & .9 \\
\hline April & $1,1917 \ldots \ldots \ldots$ & .3 & April & $1,1945 \ldots \ldots \ldots$ & .9 \\
\hline October & $1,1917 \ldots \ldots \ldots$ & .3 & Oetober & $1,1945 \ldots \ldots$ & 1. \\
\hline April & $1,1918 \ldots \ldots \ldots$ & .3 & April & $1,1946 \ldots \ldots$ & 1. \\
\hline October & $1,1918 \ldots \ldots \ldots$ & .3 & October & $1,1940 \ldots \ldots$ & 1. \\
\hline April & $1,1919 \ldots \ldots \ldots$ & .3 & April & $1,1947 \ldots \ldots \ldots$ & 1. \\
\hline Oetober & $1,1919 \ldots \ldots$ & .3 & October & $i, 1947 \ldots \ldots$ & 1.1 \\
\hline April & $1,1920 \ldots \ldots$ & .3 & April & $1,1948 \ldots \ldots$ & 1.1 \\
\hline October & $1,1920 \ldots \ldots \ldots$ & .4 & October & $1,1948 \ldots \ldots \ldots$ & 1.1 \\
\hline April & $1,1921 \ldots \ldots$ & .4 & April & $1,1949 \ldots \ldots$ & 1.1 \\
\hline October & $1,1921 \ldots \ldots \ldots$ & .4 & October & $1,1949 \ldots \ldots$ & 1.1 \\
\hline April & $1,1022 \ldots \ldots$ & .4 & April & $1,1950 \ldots \ldots$ & 1.1 \\
\hline October & $1,1922 \ldots \ldots \ldots$ & .4 & October & $1,1950 \ldots \ldots$ & 1.2 \\
\hline April & $1,1923 \ldots \ldots \ldots$ & .4 & April & $1,1951 \ldots \ldots$ & 1.2 \\
\hline October & $1,1923 . \ldots \ldots$ & .4 & October & $1,1951 \ldots \ldots$ & 1.2 \\
\hline April & $1,1924 \ldots \ldots$ & .4 & April & $1,1952 \ldots \ldots$ & 1.2 \\
\hline October & $1,1024 \ldots \ldots$ & .4 & Oetober & $1,1952 \ldots \ldots$ & 1.3 \\
\hline April & $1,1925 \ldots \ldots \ldots$ & .4 & April & $1,1953 \ldots \ldots$ & 1.3 \\
\hline
\end{tabular}




\begin{tabular}{|c|c|c|}
\hline \multicolumn{2}{|c|}{$\begin{array}{l}\text { DATE OF } \\
\text { PAYMENT }\end{array}$} & $\begin{array}{c}\text { Percentage } \\
\text { Bonds Issued } \\
\text { to be drawn for } \\
\text { Payment }\end{array}$ \\
\hline October & $1,1925 \ldots \ldots \ldots$ & .4 \\
\hline April & $1,1926 \ldots \ldots \ldots$ & .4 \\
\hline October & $1,1926 \ldots \ldots \ldots$ & .5 \\
\hline April & $1,1927 \ldots \ldots$ & .5 \\
\hline October. & $1,1927 \ldots \ldots \ldots$ & .5 \\
\hline April & $1,1928 \ldots \ldots \ldots$ & .5 \\
\hline October & $1,1928 \ldots \ldots \ldots$ & .5 \\
\hline April & $1,1929 \ldots \ldots \ldots$ & .5 \\
\hline October & $1,1929 \ldots \ldots \ldots$ & .5 \\
\hline April & $1,1930 \ldots \ldots \ldots$ & .5 \\
\hline October & $1,1930 \ldots \ldots \ldots$ & .5 \\
\hline April & $1,1931 \ldots \ldots \ldots$ & .5 \\
\hline October & $1,1931 \ldots \ldots \ldots$ & .6 \\
\hline April & $1,1932 \ldots \ldots \ldots$ & .6 \\
\hline October & $1,1932 \ldots \ldots$ & .6 \\
\hline April & $1,1933 \ldots \ldots \ldots$ & .6 \\
\hline October & $1,1933 \ldots \ldots \ldots$ & .6 \\
\hline April & $1,1934 \ldots \ldots \ldots$ & .6 \\
\hline October & $1,1934 \ldots \ldots \ldots$ & .6 \\
\hline April & $1,1935 \ldots \ldots \ldots$ & .6 \\
\hline October & $1,1935 \ldots \ldots \ldots$ & .6 \\
\hline April & $1,1936 \ldots \ldots \ldots$ & .7 \\
\hline October & $1,1936 \ldots \ldots$ & .7 \\
\hline April & $1,1937 \ldots \ldots \ldots$ & .7 \\
\hline October & $1,1937 \ldots \ldots \ldots$ & .7 \\
\hline April & $1,1938 \ldots \ldots \ldots$ & .7 \\
\hline October & $1,1938 \ldots \ldots \ldots$ & .7 \\
\hline April & $1,1939 \ldots \ldots$ & .8 \\
\hline October & $1,1939 \ldots \ldots$ & .8 \\
\hline
\end{tabular}

$\begin{array}{cc}\text { DATE OF } & \begin{array}{c}\text { Percentage of } \\ \text { Bonds Issued } \\ \text { to be drawn for } \\ \text { Payment }\end{array}\end{array}$

October $1,1953 \ldots \ldots \ldots 1.3$

April $1,1954 \ldots \ldots \ldots 1.3$

October $1,1954 \ldots \ldots \ldots 1.4$

April $1,1955 \ldots \ldots \ldots 1.4$

October $1,1955 \ldots \ldots \ldots 1.4$

April $\quad 1,1956 \ldots \ldots \ldots 1.5$

October $1,1956 \ldots \ldots \ldots 1.5$

April $1,1957 \ldots \ldots \ldots .1 .5$

October $1,1957 \ldots \ldots \ldots 1.6$

April $1,1958 \ldots \ldots \ldots 1.6$

October 1, 1958...... 1.6

April $1,1959 \ldots \ldots \ldots 1.6$

October $1,1959 \ldots \ldots \ldots 1.7$

April $1,1960 \ldots \ldots \ldots 1.7$

October $1,1960 \ldots \ldots \ldots 1.8$

April $\quad 1,1961 \ldots \ldots \ldots 1.8$

October $1,1961 \ldots \ldots \ldots 1.8$

April $1,1962 \ldots \ldots \ldots 1.8$

October $1,1962 \ldots \ldots \ldots 1.9$

April $1,1963 \ldots \ldots \ldots 1.9$

October $1,1963 \ldots \ldots \ldots 2$.

April $1,1964 \ldots \ldots \ldots 2$.

October $1,1964 \ldots \ldots \ldots 2$.

April 1, 1965......2.1

October $1,1965 \ldots \ldots 2.1$

April 1, 1966...... 2.2

October 1, 1966.....2.2

$100 \%$

Drawing of bonds at par as above provided will take place at the office of the Trustee twice a year, sixty days before the date fixed for payment, and bonds will be drawn as nearly as possible proportionately from the different denominations. Notice of the result of such drawings, containing the numbers of the bonds drawn, shall be published once a week for the four weeks subsequent to the date of drawing, in one daily newspaper in each of the cities New York, London, Paris, Hamburg, Berlin and Amsterdam, and interest shall cease upon the bonds so drawn from and after the day fixed for such payment. All as provided in said Trust Agreement.

\section{(To be Printed on the Back of Bonds)}

Extract from Article Seven of the Banking Law of the State of New YoRK

Section 199. General Powers.-In addition to the powers conferred by the general and stock corporation laws, a corporation organized as provided in the two preceding sections* shall have power to sell, offer for sale or negotiate bonds or notes secured by deed of trust or mortgages on real property situated in this State or outside of this State, or choses in action owned, issued, negotiated or guaranteed by it or may receive money or property 
either from its own stocklıolders or other persons in instalments or otherwise and may enter into any contract, engagement or undertaking with such persons for the withdrawal of such money or property, at any time, with any increase thereof, or for the payment to them or to any person of any sum of money at any time, either fixed or uncertain, excepting that said corporation can not do a general deposit business without complying with the provision of section fourteen of this chapter.

"[SEctioss 197-198 provide that a mortgage, loan or investment corporation may be formed with the authorization of the Superintendent of Banks, where the capital stock has been paid in cash and a deposit of $\$ 1,000$ made with him as a guaranty of compliance with the banking laws.]

\section{Extracts from Certificate of Ixcorporation of the Company.}

NAME OF COMPANY.-The name by which such corporation is to be known is Tine Mortgage-Bond Company of New York.

Head OFFICE.- The particular city where the operations are to be carried on is the City of New York in the State of New York, and it is to be established in the Borough of Manhattan in said City and in the County of New York.

Capital Stock.-The amount of its Capital Stock is Two Million Dollars, divided into twenty thousand shares of the par value of One Hundred Dollars each.

Lexgti of Francinse.-The date at which said corporation shall commence is the 27 th day of March, 1905, and it shall terminate on the 24th day of March, 2905.

Ixcrease of Capital Stock.-The Capital Stock of the Company may be increased from time to time in the manner provided by law at the time of such increase.

Extract from the By-Laws of the Company. Article One Section 1 a.

No such bonds shall be issued unless the same shall have been authorized by a vote of a majority of the Directors of this Company at a regular meeting thereof or at a special meeting duly called for that purpose. Before any issue of such bonds shall be authorized by the Board of Directors there shall be presented to the Board a certificate by a public accountant to be selected in advance by the Board for that purpose, showing the amount of the then outstanding obligations and indebtedness of the Company as the same appears from its books. No issue of such bonds shall be authorized at any time which, together witl the other obligations and indebtedness of the Company then outstanding, as shown by the said report of said accountant, shall be in excess of fifteen times the amount of its Capital Stock at the time of the issue of such obligation. This section shall not be amended or repenled cr. cept by the written consent duly acknowledged of every member of the Bon ril of Directors at the time being and of the holders of all of the bonds of the Company then outstanding issued as herein provided.

\section{Statement of the Company}

The Mortgage-Bond Company of New York was incorporated with the au. thorization of the Supcrintendent of Banks of the State of New York under date of April 18, 1905. The Company is subject to the supervision and exami. nation of the Superintendent of Banks in accordance with Section 201, Article 7, of the Banking Law of the State of New York. 
These Bonds are secured by first mortgages, equal in unpaid principal to the principal of the bonds outstanding, on improved real estate in cities of the United States of America of not less than forty thousand population. No mortgages can be used as security which are secured by farm property, unimproved property, an undivided interest in property, leaseholds, churches, factories, clubs or theatres. All mortgages used as securicy are limited to one-half of the value of the property mortgaged, except that in cities of three hundred thousand population and over they are limited to three-fifths of the value of the property, and in New York City to two-thirds of the value of the property. All as provided in the said Trust Agreement.

And Whereas, on each bond issued and to be issued hereunder there is to be endorsed a certificate of the United States Trust Company of New York, or its successor as trustee, that such bond is one of the bonds mentioned in the agreement therein referred to, and no bond shall be secured by this agreement or be obligatory for any purpose unless such certificate shall have been executed by said Trust Company or its successor as trustee hereunder; such certificate to be substantially of the following tenor:

\section{(Form of Certificate of Trustee.)}

It is hereby certified that this bond is one of the bonds mentioned in the trust agreement referred to within.

Dated, New York............

\section{United States Trust Company of New York,}

Trustee.

[Clause of due authorization.]

[Consideration clause.]

The Mortgage-Bond Company of New York, party of the first part, has granted, bargained, sold, assigned and set over, and by these presents does grant, bargain, sell, assign and set over unto the United States Trust Company of New York, party hereto of the second part, its successors and assigns forever, all the bonds and mortgages set forth and described in the schedule in the next paragraph hereof described, and also all other bonds and mortgages which the Company at any time hereafter shall deposit with and deliver to the Trustee under this Agreement, either concurrently with the authentication and issue of bonds hereunder or otherwise.

The schedule above referred to is to be identified by a certificate signed by the Company and the Trustee at the beginning thereof, in the following form, to-wit:

"Schedule of bonds and mortgages assigned by The MortgageBond Company of New York to and deposited with the United 
States Trust Company of New York, as Trustee, for the holders of The Mortgage-Bond Company's Mortgage Bonds, Series 2, and of all other of the said Company's Mortgage Bonds issued under and pursuant to the provisions of a certain Agreement or Deed of Trust bearing date the first day of October, 1906, between the said The Mortgage-Bond Company of New York and United States Trust Company of New York, as Trustee, and subject to and upon all the trusts, covenants and conditions in said Agreement contained and with all the powers conferred by said Agreement or Deed of Trust upon the Mortgage-Bond Company of New York and the United States Trust Company of New York, as Trustee, and the Bondholders respectively."

The particulars of each bond and mortgage and of the papers evidencing and relating to the same shall be set forth in other schedules or documents in such form as the Trustee shall devise, advise or approve. Such schedule when so certified by the signatures of the Company and Trustee shall be taken and deemed to be a part of this instrument.

The delivery to and deposit hereunder with the Trustee of bonds, mortgages or other securities, as herein provided, shall constitute an assignment and pledge under this Agreement of the securities so delivered and deposited, and of the income and interest due and to become due thereon.

The Trustee shall have and hold such bonds and mortgages upon the trusts hereby created for the equal pro rata benefit and security of the holders of bonds issued and to be issued under this agreement, without any preference or priority to any one bond over another, by reason of priority in the time of issue or negotiation thereof, or otherwise, and to secure the payment of each of the said bonds together with the interest thereon, and for all the other uses and purposes, and upon the terms and conditions herein declared and expressed.

1. The term "Company's Bonds" when used in this instrument shall be taken to mean all the Mortgage Bonds irrespective of series issued by the Company under this Agreement and authenticated by the Trustee as herein provided, and no others. The term "Bondholder" when used in this instrument shall be taken to mean the holder of any one of the "Company's Bonds." The term "Trust Fund" when used in this instrument shall be taken to mean and include all the property of what kind soever, which from time to time the Trustee shall hold as security for payment of the "Company's Bonds." The term "Bond and Mortgage" when used in thie 
instrument shall be taken to mean any obligation of whatsoever kind for the payment of money, and secured by an instrument corresponding to the requirements hereof with respect to instruments to secure obligations to be assigned to and deposited with the Trustee under this Agreement, together with such instrument. Whenever the plural is used in this instrument it shall be construed to include the singular and the singular the plural if the context so requires. If any question shall arise touching the meaning of the Company's Bonds, the English version shall prevail in the construction.

2. Inasmuch as at the time of the execution and delivery of these presents the Company may not desire to have all of the Company's Bonds, Series 2, authenticated by the Trustee, and to assign to and deposit with the Trustee bonds and mortgages to the full contemplated amount of Five Million Dollars $(\$ 5,000,000)$, it is agreed that from time to time hereafter the Company may have Bonds of Series 2 authenticated by the Trustee and delivered to the Company (subject to the provision of Article One of this Agreement touching the authentication of bonds) upon assigning to and depositing with the Trustee bonds and mortgages until the amount of Five Million Dollars $(\$ 5,000,000)$ of unpaid principal of such bonds and mortgages is made up, and that as the said bonds and mortgages are assigned to and deposited with the Trustee, they shall be entered in the schedule hereinbefore mentioned, and shall form a part of the Trust Fund hereby created, and shall in all respects be subject to the provisions of this Agreement with like force and effect as if they and the particulars thereof had been entered in the said Schedule hereinbefore mentioned at the time of the execution and delivery hereof, and as if such bonds and mortgages then had been assigned to and deposited with the Trustee.

3. The Company shall have the right to make further issues of bonds in addition to Series 2, to be issued under and secured by this Agreement, to an amount not to exceed, together with all other indebtedness of the Company then outstanding, secured and unsecured, fifteen times the Capital Stock of the Company outstanding at the time of any such issue. Such issues may be in one or more series, bearing different dates both as to issuance and maturity, different rates of interest, payable in different currencies, and at places and cities other than the places and cities mentioned in the bonds of Series 2 , and the bonds of the different series may in tenor and form vary from the form of the bonds of Series 2, and from the bonds of each of the other series. The Company may issue concurrently bonds of different series; but as long as any bonds issued or to bo 
issued under this Agreement are outstanding the Company shall make no further issues of bonds except under this Agreement; this shall not apply, however, to Series 1 of the Mortgage Bonds of the Company.

4. The bonds of any such additional series so issued may contain such provisions touching the redemption thereof, at the option of the Company, prior to maturity, as the Company may determine. And the Company may provide by provisions satisfactory to it for the creation and establishment of a Sinking Fund or for a Scheme of Amortization applicable to any such additional series, not necessarily identical with the Amortization provisions with respect to the bonds of Series 2 herein set forth. Any such Sinkirg Fund or Amortization Scheme or provisions touching the Redemption of any bonds of any such additional series shall be fully set forth in an instrument supplemental hereto, and such instrument when executed by the Company shall be attached to this Agreement and shall form a part hereof as far as the Series of Bonds to which it is applicable is concerned as fully to all intents and purposes as if it had formed a part of this Agreement; and the provisions of paragraph (c), Article Six, hereof, shall apply to such Sinking Fund or Amortization or Redemption provisions, and a failure on the part of the Company to comply with such provisions shall constitute and be an event of default within the meaning of paragraph (c) of Article Six of this instrument.

Each of the bonds of any such series so issued may contain suitable provision for its registration as to principal, or as to principal and interest, in which event the Company, by the corporate resolutions authorizing the issue of such series, shall provide for the maintenance of an office in the City of New York under suitable restrictions, where bonds of such series may be registered and when so registered may be transferred.

If at any time the Company shall desire to issue any such additional series of bonds, and shall be thereunto duly authorized by corporate action to that end duly had, it shall file with the Trustees a certified copy of the resolution of the Directors of the Company authorizing such issue, stating the aggregate principal amount of such series and prescribing the form of bonds which is to evidence the indebtedness included in such series, and a certified copy of such form of bonds shall be annexed to this Agreement by the Trustee with the same force and effect as though the same had been aftixed hereto at the time of the exceution hereof and constituted a part hereof. And the Trustee thereafter shall authenticate and deliver the bonds of each such series in the manner herein provided. 
The resolution of the Directors of the Company authorizing any such series may provide that, concurrently with the delivery of bonds of that series for authentication, and as a condition precedent to such authentication, the Company shall deposit with the Trustee such papers, documents, affidavits or certificates in addition to those required in Section 3 of Article One hereof, as the Company may approve.

Any and all bonds of any such additional series shall otherwise be subject to all the covenants, conditions and provisions of this Agreement, except such covenants, conditions and provisions as are by their terms expressly made applicable to Series 2 exclusively, and the Company and the Trustee from time to time will execute such supplemental instruments not inconsistent with the provisions of this Agreement as under the advice of counsel the Trustee may deem appropriate to accomplish such results and each such supplemental instrument when executed by the Company shall be attached to this Agreement and shall form a part hereof as fully to all intents and purposes as if it had formed a part of this Agreement.

Each bond secured hereby shall bear a Trustee's certificate in the form herein provided, and when and as soon as the Trustee shall authenticate any of said bonds, by the execution of such certificate, each such bond so authenticated shall be deemed to be issued and outstanding hereunder and to be entitled to the benefit of the security deposited hereunder and the trusts hereof, and until so authenticated by the Trustee no such bond shall be entitled to any benefit hereunder.

[Officers who may execute bonds. See J. \& L S. Co. Art. 1, Sec. 4, p. 200.]

Series 1 of the Mortgage Bonds of the Company are not. issued under nor affected by any of the provisions of this Agreement, and the holders thereof derive and possess no benefit or advantage herefrom or rights hereunder.

\section{ARTICLE ONE}

[All bonds equally secured.]

The Company's Bonds, Series 2, secured hereby, may be issued from time to time as herein provided and not otherwise, but the total amount thereof outstanding shall at no time exceed in the aggregate Five Million Dollars $(\$ 5,000,000)$ of principal, and the entire indebtedness of the Company, secured and unsecured, shall at no time exceed fifteen times the capital stock of the Company at such time issued and outstanding.

[Execution of bonds and coupons.] 
[Authentication essential to validity of bonds. See J. \& L. S. Co. Art. 1, Sec. 4, p. 200.]

[Redeemed bonds not to be reissued.]

[Matured coupons to be clipped before delivery. Sce J. \& L. S. Co. Art. 1, Sec. 4, p. 200.]

[Bearer of coupon bond or interest coupon treated as owner. See J. \& L. S. Co., Art. 1, Sec. 6, p. 201.]

Section 3.-At the time of the presentation of any of the Company's Bonds to the Trustee for authentication, there shall be delivered to the Trustee a copy of the resolution of the Board of Directors of the Company authorizing their issue, certified under the seal of the Company, and attested by its President and Secretary, or such other persons as the Directors of the Company may from time to time appoint for that purpose, together with such number of the bonds specified in said resolution as the Company may desire to have authenticated and concurrently therewith there shall be deposited with the Trustee, by it to be held under the trusts hereof, bonds and mortgages of an aggregate unpaid principal amount at least equal to the aggregate principal amount of the bonds so to be authenticated, together with properly executed instruments of assignment thereof to the Trustee, accompanied by an affidavit of the Treasurer, or an Assistant Treasurer, of the Company to the effect that each bond and mortgage so deposited is not in default with respect to the payment of interest due thereon, and that the principal indebtedness purporting to be secured by any such bond and mortgage has been actually advanced and is still unpaid thereon, except as stated thereon or in said affidavit, and that the same has been approved by the Executive Committee of the Company; and further stating the total amount of the indebtedness of the Company, secured and unsecured, then existing, and the amount of the capital stock of the Company issued and outstanding. And at the same time the Company shall deliver to the Trustee the policies of title insurance or certificates of title and policies of fire insurance required by Article Five hereof, with respect to each bond and mortgage so deposited. Upon the receipt thereof the Trustee shall permit the Company to enter the said bonds and mortgages in the Schedule as hereinbefore provided, and forthwith shall authenticate the bonds so presented to it for authentication and shall deliver the same to the Company or its order.

All assignments of bonds and mortgages executed by the Company to the Trustee to be held as part of the Trust Fund shall be made to the Trustee absolutely, and shall contain no reference to this Trust Agreement or any of the trusts hereby created, or to the fact that the 
said agreement is made to the Trustee as Trustee or upon any trust whatever, and the Trustee shall have the right, if it shall so desire and whenever authorized by this agreement so to do, to assign, satisfy or sue upon any of the said bonds and mortgages in its own name in the same manner as if the said bonds and mortgages had been its own property and not held upon any trust; provided, however, that the amount received by the Trustee from any of the said bonds and mortgages in any manner shall be held upon the trust herein created.

Sectiox 4.-No Company's Bonds, Series 2, shall at any time be authenticated by the Trustee, which shall cause the aggregate principal amount of the bonds outstanding at the time of such authentication to exceed the aggregate principal amount of such bonds which should be outstanding at that time according to the requirements of the Amortization Table set forth on said bonds; and in order to secure this result, if at any time subsequent to the first day of April, 1912, the Company shall request the Trustee to authenticate an instalment of bonds, the Trustee shall forthwith upon the tender of such instalment for authentication, cancel such a percentage thereof as shall equal the total percentage of all the Company's theretofore issued bonds required by the amortization clause to be drawn for payment on or prior to the date of such request (fractions being treated as provided in Article Sixteenth) and shall thereupon duly authenticate the balance of such instalment of bonds and shall deliver to the Company both the cancelled and the authenticated bonds. The bonds so cancelled shall be deemed to form part of the amount of bonds authorized to be issued hereunder and to be authenticated by the Trustee, to have been issued prior to April 1, 1912, to have been outstanding on that date, and to have been redeemed and cancelled under the Amortization provisions, and no such bonds so cancelled shall be reissued. For bonds so cancelled by the Trustee, without authentication, no bonds and mortgages need be assigned or deposited, and no money paid.

Section 5.-[Temporary bonds. See J. \& L. S. Co., Art. 1, Sec. 8, p. 202.]

SeCtion 6.-[Bonds lost, mutilated or destroyed. See J. \& L. S. Co., Art. 1, Sec. \%, p. 201.]

SeCtion 7.-[Clause reserving right for Company to appoint a new banking house in case of failure or refusal to act of any bank at which its securities by their terms are made payable.]

\section{Article Two.}

Section I.--The Trustce shall hold the Trust Fund in its possession, and as long as and at any time when the Trustee shall have in 
its possession bonds and mortgages assigned to it, the unpaid principal of which shall equal in the aggregate the principal of all the Company's Bonds then outstanding and secured hereby, and if no erent of default specified in Article Six shall then exist of which the Company has been notified in writing by the Trustee, the Trustee shall permit the Company to collect and retain the interest from time to time accruing upon the Trust Fund and to enforce for its own benefit, in the name of the Trustee or otherwise, any and all provision eontained in any of the said bonds and mortgages, and the Trustee at any such time upon the request of the Company and at its expense shall enforce any and all the provisions for the benefit of the mortgagee of the said bonds and mortgages therein contained which at such time may be enforceable.

Section 2.-If the Company shall be obligated for any reason to deliver to any mortgage debtor any document of mortgage, or other instrument forming a portion of the Trust Fund, forthwith upon demand of the Company the Trustee will deliver such documents to the mortgage debtor upon the assignment to and deposit with it by the Company of bonds and mortgages of an equal unpaid principal amount, or on receipt of cash equal to the unpaid principal amount of the mortgage so delivered, and shall accept, receive and hold any cash so paid as cash temporarily deposited with the Trustee as part of the Trust Fund.

SEcrion 3.-The Trustee from time to time, at the written request of the Company and at its expense, shall make, execute and deliver all asignments, satisfaction pieces or other instruments necessary or proper to enable the Company to exercise any and all of the rights conferred upon it or reserved to it by any provision of this Agreement.

\section{Article Three}

In case for any reason the Company shall deem it necessary to take any proceedings for the collection by foreclosure or otherwise of any bond and mortgage belonging to the Trust Fund, forthwith the Company shall substitute bonds and mortgages of an equal amount of unpaid principal, and shall assign the same to and deposit the same with the Trustee to be held as part of the Trust Fund, and shall thereupon be entitled to the delivery and assignment to it of the bond and mortgage so to be collected, and such bond and mortgage shall thereupon cease to form any part of the Trust Fund. In case the Trustee shall deem it necessary for the security of the Bondholders, that any bond and mortgage, the interest upon which has been delinquent for a period of not less than one year, or the taxes upon the property cov- 
ered by which have been delinquent for a period of not less than two years, shall be collected by foreclosure or otherwise, then, and in each and every such case, the Trustee shall give notice in writing to the Company requiring it to substitute and assign to and deposit with it for each such bond and mortgage, bonds and mortgages of an equal amount of unpaid principal, and in case the Company shall fail for twenty (20) days after the service upon it of such notice to make such substitution, assignment and deposit, then and in every such case it shall be the duty of the Trustee through its officers, agents or attorneys to proceed with the collection of the bond and mortgage so in default by foreclosure or otherwise. If upon or through the foreclosure or other collection of any such bond and mortgage the Trustee shall become the absolute owner of the property covered thereby, or any part thereof, free and clear of any right of redemption, it shall forthwith certify to the Company the amount necessary to reimburse it for its advances, and the Company within fifteen (15) days from the delivery to it of such certification notice shall assign to and deposit with the Trustee bonds and mortgages for an amount of unpaid principal equal to that of the mortgage foreclosed, and pay to the Trustee in cash an amount equal to its advances and expenses and upon making such payment and deposit the Company shall be entitled to receive a conveyance from the Trustee of the said property. If any cash shall be received by the Trustee with respect to any bond and mortgage liquidated by it, by or through a foreclosure sale or otherwise the Trustee shall retain an amount necessary to reimburse it for its advances and expenses with respect to the mortgage so liquidated and if no event of default specified in Article Six hereof shall then exist of which the Company has been notified in writing by the Trustee, on assignment to, and deposit with the Trustee of bonds and mortgages for an unpaid principal amount equal to the unpaid principal of the mortgage foreclosed or otherwise liquidated, it shall pay over the balance of such moneys so collected to the Company. Immediately on receiving any such cash, the Trustee shall notify the Company of the fact, and within fifteen (15) days from the date of delivery of such notice, the Company covenants that it will assign to and deposit with the Trustee bonds and mortgages of an amount of unpaid principal equal to the unpaid principal amount of the mortgage foreclosed or otherwise liquidated.

Nothing in this article shall be construed in any way to impair or abridge any right or power herein conferred upon the Trustee with respect to the Trust Fund and the bonds and mortgages constituting the same, in case, at any time, an event of default specified in Article Six hereof shall occur and exist. 


\section{Article Four}

The Company, if no event of default specified in Article Six hereof shall then exist of which it has been notified in writing by the Trustee, if it so elect may from time to time withdraw any of the bonds and mortgages belonging to the Trust Fund, provided that upon such withdrawal it shall assign to and deposit with the Trustee bonds and mortgages of an equal amount of unpaid principal.

In case of the withdrawal of any bond and mortgage under any of the provisions of this Agreement, the Trustee shall reassign the same to the Company and redeliver all accompanying papers, and the fact of such withdrawal shall be entered upon the Schedule hereinbefore mentioned and such other entries shall from time to time be made therein as may be required to the end that the said Schedule shall at all times show in what manner the Trust Fund is constituted.

In any case where the terms of this Agreement permit or require the Company to assign to and deposit with the Trustee bonds and mortgages, the Company may deposit temporarily with the Trustee, in place of - one or more such bonds and mortgages and as part of the Trust Fund an equal amount of prineipal either in eash, Government Bonds of the United States of America, or Bonds or Stock of the City of New York; any such bonds or stock so deposited shall be valued at five per cent. less than their market value.

In every case where pursuant to any provision of this instrument the Company shall assign to and deposit with the Trustee any bond and mortgage, concurrently with such assignment and deposit it shall deliver to the Trustee an affidavit of the treasurer or an assistant treasurer of the Company to the effect that each such bond and mortgage so assigned and deposited is not in default in respect to interest due thereon and that the principal indebtedness purporting to be secured thereby has been actually advanced and is still unpaid thereon except as stated thereon or in said affidavit, and that the same has been authorized by the Executive Committee of the Company, and the delivery of such an affidavit shall be a condition precedent to the exercise by the Company of any right accruing to it under any of the provisions of this agreement in respect to the deposit of any such bond and mortgage.

The Company may withdraw from the Trustec, and the Trustee shall transfer and deliver to the Company, on its demand, any cash or securities so deposited, on the assignment to and deposit with it of the bonds and mortgages for which such eash and securities were temporarily deposited. 


\section{Article Five}

All bonds and mortgages assigned to and deposited with the Trustee by the Company as herein provided shall be accompanied by a policy or policies of fire insurance to an amount sufficient in the opinion of the Company to protect the mortgage; and by a policy or policies satisfactory to the Company, issued by some corporation organized for the purpose of insuring the titles to real estate, guaranteeing, or by the certificate of the Company's local counsel certifying, that the said mortgages are valid first liens upon the premises covered thereby. But the existence of party wall agreements, restrictions as to the use of property, leases or other like incumbrances upon the title of the mortgaged property, not calling for the payment of money, stated as exceptions in the policies of title insurance or counsel's certificate of title, shall not be considered as rendering the lien of the mortgage not a first lien upon the property. The receipt of the proper recording officer of a Title Insurance Company may be deposited in place of a mortgage or assignment of mortgage while the latter is being recorded.

\section{ArTicle Six}

If at any time there shall occur on the part of the Company any case of default or failure in this Article specified, and herein termed "events of default," as follows, namely:

(a) In case default shall be made in the payment of any installment of interest upon any of the Company's Bonds when and as the same shall become payable, as therein and herein expressed, and such default shall continue for sixty days, whether demand for such payment be made at the time such interest becomes due or at any time thereafter; or

(b) In case the Company shall make default in the payment of the principal of any of said Company's Bonds, when the same shall become due and payable according to the terms thereof or hereof; or

(c) In case the Company shall make default in the payment of any bond drawn for payment under any Amortization or Redemption or Sinking Fund provision at the dates and in the manner provided herein or in any supplement hereof for such drawing and payment; or

(d) In case the entire indebtedness of the Company, secured and unsecured, at any time shall exceed fifteen times the capital stock of the Company at such time issued and outstanding; or

(e) In case the Company shall collect the principal of any bond and mortgage belonging to the Trust Fund, and within fifteen (15) days after written demand by the Trustee shall fail to pay over to the 
Trustee the proceeds of any such collection, or to assign to and deposit with the Trustee bonds and mortgages of an amount of unpaid principal equal to the amount of such collection; or

(f) In case the Company, upon notice from the Trustee, shall fail to comply with the provisions of Article Three or with the provisions of Section 2 of Article Nine hereof within the times therein specified; or

(g) In case an order shall be made for the appointment of a receiver of the Company or of its property, and shall remain in force for a period of ninety days or for the winding up and liquidation of the business and affairs of the Company, or in case corporate action shall be taken on the part of the Company for either of the purposes aforesaid; or

(h) In case the Company shall fail to comply with any final judgment, or decree of any court as specified in Article Fourteen of this Agreement, within thirty days from the service upon it of a copy of said judgment or decree and notice of entry of such final judgment or decree, as is provided in said Article Fourteen, unless the Company shall have duly and timely within the said thirty days taken an appeal from such judgment to a court having power to review the same; or

(i) In case at any time the Company shall fail or refuse within ninety days after written demand of the Trustee, to do and perform all such acts as may be required by the laws of any State in which any of the property covered by any mortgage forming portion of the Trust Fund is situated, to entitle the Company to transact business in such State to an extent necessary under the laws thereof to enable it to hold and give good title to such mortgage and to enforce the security thereof in case of default thereunder or in the bond accompanying the same, or to assign to and deposit with the Trustee, in lieu of any such bonds and mortgages, bonds and mortgages of an equal unpaid principal amount upon property situated in a State or States wherein the Company is authorized so to do business;

[Declaration of principal due on default. See J. \& I. S. Co., Art. 5, Sec. 4. p. 227.]

\section{Article Seven}

Section 1.-In erery case of the occurrence of any erent of default specified in Article Six of this Agreement, the Trustce, in its discretion, may, and upon a request in writing signed by the holder or holders of twenty-five per cent. (25\%) in amount of the Company's Bonds at the time outstanding, and upon proper indemnification for the cost and expenses to be incurred by it, the Trustee must and shall proceed to protect and enforce its rights and the rights of the holders 
of the Company's Bonds under this Agreement by a suit or suits in equity or at law, for the specific performance of any covenant or agreement contained herein, or in aid of the execution of any power herein granted, or it may proceed to realize so far as possible by the sale or foreclosure or other collection of the bonds and mortgages which shall then constitute the Trust Fund, the amounts secured thereby, and to apply the amounts so collected to the payment of the principal and interest then due upon the Company's Bonds in the manner provided in Section 7 of this Article.

Section 2.- If at any time there shall occur any event of default specified in Article Six hereof, in its discretion and regardless of the question as to whether the principal of the Company's Bonds be yet due or not, the Trustee, unless the company shall pay to it prior to sale the amount due for principal and interest on all the outstanding Company's Bonds and all moneys due for costs and the compensation and expenses of the Trustee, and any other payment directed by any decree of sale (the right to make which payment is hereby conferred upon the Company) shall be entitled to sell, and either personally or by its attorneys or agents may forthwith sell, at a single sale in a single block and as an entirety, or in separate parcels, at one sale or at successive sales, all the property at the time of such default constituting the Trust Fund. Any such sale or sales shall be made at public auction, and except as hereinafter provided, shall take place at such place in the Borough of Manhattan, City and County of New York as the Trustee may determine. Two weeks' notice of any sale by the Trustee at public auction, whether under or by virtue of the power of sale herein contained or of any judgment or decree of foreclosure and sale, or by virtue of judicial proceedings, shall be served upon the Company at its office in the city of New York and shall state the time when and the place where the sale is to be made, shall contain a brief general description of the property to be sold, and shall be published once in each week, commencing on any day of the week, for three successive weeks prior to such sale, in two daily newspapers published in the City of New York, and otherwise as may be required by law. In the case of any mortgage of real property or of any parcel of Real Estate which may form a portion of this Trust Fund, situate outside of the State of New York the Trustee may in its discretion sell the same at public auction in the city in which the mortgaged property is situated instead of in the City of New York. In such case the notice of sale above provided for shall state the place of sale and shall be published in the form and manner, and for the time above provided in respect to sales to take place in the City of New York, in a daily newspaper published in the city in which the sale shall take place, as well as in two 
daily newspapers published in the City of New York. The Trustee may adjourn any such sale, or cause the same to be adjourned, from time to time by announcement at the time and place appointed for such sale or of any adjourned sale or sales, and without further notice or publication such sale may be made at the time and place to which the same shall be so adjourned, but the provisions of this Article shall not apply to any sale of real property made by the Trustee pursuant to the terms of any mortgage securing any bends or other obligations forming a portion of the Trust Fund, nor be construed as in any way affecting any rights conferred upon the mortgagee by the terms of any such mortgage or by the laws of the State within which the mortgaged property therein described may be situated.

Section 3.-In case of any sale of the Trust Fund made by the Trustee, whether under any power by this article conferred, or under, or by virtue of judicial proceedings, the principal of all the Company's Bonds, if not previously due, shall beccme immediately due and payable, anything in said bonds or any of them or this Agreement contained to the contrary notwithstanding. Upon the completion of any such sale or sales, the Trustee shall deliver to the purchaser or purchasers thereat the property sold, with good and sufficient assignments or transfers thereof, and in such event the Company hereby appoints the Trustee and its successor or successors its true and lawful attorney or attorneys irrevocable to make any and all such assignments or transfers in its name and stead, and to execute in the name of the Company all necessary acts of assignment or transfer, and to substitute one or more persons or corporations with like power, the Company hereby ratifying and confirming all that its said attorney or attorneys or such substitute or substitutes shall lawfully do by virtue hereof. But the Company, if so requested by the Trustee, shall ratify and confirm any such sale by executing and delivering to the Trustee or to such purchaser or purchasers thereat, all such proper transfers and assignments as may be designated in such request.

Any sale or sales made hereunder, whether under any power of sale hereby granted and conferred or under and by virtue of any judicial proceeding, shall divest all right, title, interest, claim, estate or demand whatsoever, either at law or in equity, of the Company, of, in and to the property sold, and shall be a perpetual bar both in law and in equity against the Company, its successors and assigns, and against any and all persons claiming or to claim the property sold, or any part thereof from, through or under the Company its successors or assigns, and no purchaser or purchasers at any such sale or sales, or his or their representatives or assigns, shall be bound to see to the application of the purchase moneys upon or for any trust or purpose of this Agree- 
ment, or be answerable in any manner whatsoever for any loss, misapplication or nonapplication of any of such purchase money paid by him or any part thereof, or be bound to inquire as to the authorization, necessity, expediency or regularity of any such sale. In case of any sale of the Trust Fund made hereunder, whether by virtue of the power of sale herein conferred or pursuant to any order or decree of any Court, any purchaser thereat shall be entitled to apply any bonds and any matured and unpaid coupons hereby secured in settlement or payment for the property purchased to the extent of the sums payable out of the net proceeds of such sales, to the holder of such bonds and coupons, as such holder's ratable share of such net proceeds, and such purchaser shall be credited on account of the purchase price of the property purchased, with the sums so payable out of such net proceeds on the bonds and coupons so applied by such purchaser for such purpose; and at any such sale the Trustee or any Bondholder may bid for and purchase the property exposed for sale thereat, and may make payment therefor as aforesaid, and upon compliance with the terms of the sale, may hold, retain and dispose of such property without further accountability and free and clear of any trust in behalf of other Bondholders, and the receipt of the Trustee or of the Court Officer conducting such sale shall be a sufficient discharge for the purchase money or any part thereof.

Section 4.-Anything in this Agreement contained to the contrary notwithstanding, the holders of seventy-five per cent. (75\%) in amount of the Company's Bonds at the time outstanding, at any time prior to a sale of the whole or any part of the Trust Fund whether under any power of sale herein contained or under judicial proceedings, by written notice to the Company and to the Trustee may waive any default under this Agreement or under the said bonds, or the consequences of any such default, and in like manner may waive the exercise by the Trustee of any other power conferred on the Trustee under this Agreement, and may waive or annul the exercise by the Trustee of any power under this Agreement, and may dismiss any suit brought against the Company by the Trustee or by any holder of said bonds, upon or under this Agreement or on the said bonds, and may release and discharge any judgment or decree obtained thereunder on such terms as may be directed by said holders by the same or a subsequent instrument. Any such action or waiver by holders of no less than seventy-five per cent. ( $75 \%)$ in amount of said bonds at the time outstanding shall be binding on all holders of said bonds, provided that nothing in this section shall be construed as permitting a waiver or postponement of the payment of the principal of said bonds at the time and in the manner therein provided. Any such action on the part 
of the Trustee or the bondholders shall not prejudice or affect the powers or rights of the said Trustee or the bondholders in the event of any subsequent default.

Section 5.-All remedies conferred by this Agreement shall be deemed cumulative and not exclusive, and shall not be deemed to deprive the Trustee of any legal or equitable remedy by judicial proceedings appropriate to enforce the conditions, covenants and stipulations of this Agreement or otherwise, and on the occurrence of any event of default specified in Article Six hereof, the Trustee is authorized to exercise all the rights and remedies with respect to any bond and mortgage deposited hereunder, which, in its discretion, it may deem advisable and for the benefit of the Trust Fund, subject to the power reserved in Section 4 of this Article to the holders of seventy-five per cent. $(75 \%)$ in amount of the Company's Bonds issued and outstanding, as fully to all intents and purposes as legally it might or could do, if it were the legal owner of any such bond and the obligation given to secure the same.

If, for any reason, any security assigned and deposited hereunder should not correspond with the definition of a bond and mortgage hereinbefore giren, or should fail to comply with any of the requirements hereof, at its election the Trustee is fully authorized to treat such security as a security assigned and deposited under this Agreement, and as constituting a part of the Trust Fund, and to enforce all the rights and remedies herein conferred with respect to such security, as fully as though it complied with the definition given, but without prejudice to any right or cause of action which the Trustee may have, or which the Bondholders may have, by reason of the failure of such security to comply with the requirements of this Agreement.

Section 6.-In case of the occurrence of any event of default specified in Article Six hereof, the Trustee shall have power in its discretion, in case it shall be satisfied that the said default has been remedied, to waire the said default and discontinue all proceedings which it may have commenced with respect to such default unless otherwise directed by the holders of seventy-five per cent. ( $75 \%)$ of the then outstanding Company's Bonds. And in correction of any such default with respect to the payment of interest, it may apply all moneys collected by it during the continuance of such default as the income from the bonds and mortgages held by it as part of the Trust Funù. Any such discontinuance or waiver shall be without prejudice to the rights of the Trustee and the Bondholders in case of the subsequent occurrence of an event of default.

Sectron 7.-It is understood and agreed, subject to the provisions of Section 9 of this Article, that in case of any sale of the 
Trust Fund, whether under any power of sale hereby granted or pursuant to judicial proceedings, the purchase money proceeds and avails of any such sale or sales, or which shall otherwise be received by the Trustee, subsequent to the occurrence of and during the existence of an event of default specified in Article Six hereof of which the Company has been notified by the Trustee in writing, as the proceeds of any collection of any bonds and mortgages constituting the Trust Fund, together with any and all other sums which, according to the provisions of this Agreement, shall belong or appertain to the Trust Fund, and be applicable to the satisfaction, in whole or in part, of the indebtedness eridenced by the Company's Bonds then issued and outstanding, shall be applied as follows:-

Out of such moneys the reasonable and proper compensation, costs and expenses of all kinds of the Trustee in the administration of the trust, including all expenses of foreclosure and sale, and the recordation and registration of instruments, of courts, officers and receivers, including the reasonable counsel and attorney fees of the Trustee, shall first be paid, and the surplus shall be deroted first to the payment of the whole of the principal indebtedness of all the Company's bonds hereby secured then issued and outstanding, and interest thereon accrued at the rate specified therein to the time of such payment, including interest at the rate of six per cent. (6\%) per annum on each coupon or instalment of interest on registered bonds then due and in default from the date of the maturity thereof, pro rata, without priority of principal over interest or of one coupon over another coupon, save as herein otherwise provided, whether such principal and interest shall at the time have become due and payable according to the terms of the bonds and coupons or not, until the whole of said principal sum and accrued interest is paid, and if there should then remain any surplus, the same shall be paid over to the Company, its successors or assigns, or to whomsoever shall be entitled to receive the same.

If at any time it shall be necessary or proper for the Trustee, in order to fulfill any of its duties or to exercise any of its rights or powers under this Agreement, to qualify itself to do business in any state in which may be situated any real property belonging to the Trust Fund or covered by any bond and mortgage belonging to the Trust Fund, it shall be lawful for the Trustee at the expense of the Company to do all acts and things required by the laws of such state to be done in order to qualify the Trustee to do and transact business in such state to the extent necessary to enable it to fulfill such duties and exercise any of its rights and privileges in respect to such property. 
Section 8.-Any property or securities constituting part of the Trust Fund which may not have been sold, and which after payment in full as aforesaid of all the Company's Bonds, and the costs and expenses, and all other amounts due and payable under any of the provisions of this Agreement, shall remain in the hands of the Trustee, shall be assigned to and delivered by the Trustee to the Company, its successors or assigns, or to whomsoever may be lawfully entitled to receive the same. In making any sale of the bonds and mortgages which may constitute the Trust Fund, or any of them, the Trustee shall finally determine the order in which the deposited securities shall be sold.

Section 9.-In order to prevent any accumulation, after maturity, of coupons, or of claims for interest upon registered bonds, the Company agrees and covenants that it will not, directly or indirectly, extend or assent to the extension of the time for the payment of any coupon or claim for interest upon any bond secured hereby; and it will not, directly or indirectly, be a party to, or approve; any such arrangement by purchasing or funding such coupons or claims for interest upon registered bonds, or in any other manner. In case the time for payment of any such coupon or claim for interest shall be so extended, whether or not such extension be by or with the consent of the Company, such coupon or claim for interest shall not be entitled, in case of default hereunder, to the benefit or security of this Agreement, except subject to the prior payment in full of the principal of all bonds issued hereunder, then outstanding, and of all matured coupons and claims for interest on such bonds and interest accrued thereon, the payment of which has not been so extended.

Section 10.-The Company covenants that

(1) In case default shall be made in the payment of interest on any of the Company's Bonds when and as the same shall become payable as herein and therein expressed and such default shall have continued for sixty days, or

(2) In case default shall be made in the payment of the principal of any of the Company's Bonds when the same shall become payable, as herein and therein expressed

then upon demand of the Trustec, the Company will pay to the Trustee for the benefit of the holders of the Company's Bonds then outstanding and sccured by the Trust Fund, the whole amount due and payable on all such bonds and coupons for principal or interest or both, as the case may be, with interest at the rate of six per cent. $(6 \%)$ per annum upon the overdue instalments of interest from the date of maturity thereof and with interest on said priucipal sum at 
the rate of four per cent. (4\%) per annum from the maturity of the last coupon until paid; and, in case the Company shall fail to pay the same forthwith upon such demand, the Trustee, in its own name and as Trustee of an express trust, shall be entitled to recover judgment for the whole amount so due, and unpaid, interest to be cal. culated continuously at the aforesaid rates until the date of judgment. The Trustee shall be entitled to recover judgment as aforesaid either before or after or during the pendency of any proceedings for the enforcement of the lien of this Agreement upon the Trust Fund, and its right to recover such judgment shall not be affected by any sale hereunder, or by the exercise of any other right, power or remedy for the enforcement of the provisions of this agreement, or for the foreclosure of the lien hereof; and, in case of a sale of the Trust Fund and of the applications of the proceeds of sale to the payment of the indebtedness represented by the Company's Bonds and coupons, the Trustee in its own name and as Trustee of an express trust, shall be entitled to receive and to enforce payment of any deficiency or of any or all amounts then remaining due and unpaid upon any and all of the Company's Bonds then outstanding, for the benefit of the holders thereof, and shall be entitled to recover judgment for any portion of such indebtedness remaining unpaid, with interest as aforesaid. No recovery of any judgment by the Trustee, and no levy of any execution under any such judgment, upon the Trust Fund, or upon any other property, shall in any manner or to any extent affect or impair the lien of the Trustee upon the Trust Fund, or any part thereof, or any rights, powers or remedies of the Trustee hereunder, or any rights, powers or remedies of the holders of the Company's Bonds; but such lien, rights, powers or remedies shall continue unaffected and unimpaired as before, except as against the purchaser of any part of the Trust Fund at any sale made by the Trustee hereunder or under any judicial decree. Any moneys thus collected by the Trustee under this Section shall be applied by the Trustee in the manner provided in Section 7 of this Article.

\section{Article Eight}

SECTION 1.-[Termination of trust.]

SEction 2.-If no event of default, specified in Article Six hereof, shall then [discharge of the trust deed through payment of principal and interest] exist of which the Company has been notified in writing by the Trustee, payment to and deposit with the Trustee of the principal and interest to the dates upon which said bonds were payable, of 
any of the Company's Bonds which at the time of such payment are payable by the terms thereof (whether by reason of the provisions of any Amortization or Redemption clauses applicable to such bonds, or otherwise) and which shall not have been presented for payment, shall entitle the Company to withdraw from the Trust Fund bonds and mortgages for an unpaid principal sum equal to the amount of principal so deposited with the Trustee. Such deposit shall be made to the credit of each such bond, designating it by its series and number. Such deposit shall constitute full payment of each such bond and the interest thereon as between the Company and the holder thereof, and upon such deposit being made with the Trustee the holder of each such bond shall have no further rights in the Trust Fund and shall look for payment thereof only to the sums deposited with the Trustee to the credit of such bond and in no event to the Company. Such sum so deposited shall be held by the Trustee to the credit of and for the payment of such bonds and shall be paid by the Trustee to the holder thereof upon presentation and surrender to it or its agents of such bond with all outstanding coupons thereto belonging. The holder of such bond shall not be entitled to interest on the deposit in the hands of the Trustee. The moneys so deposited with the Trustee and not used for the payment of the Company's Bonds and Coupons presented for payment shall be returned by the Trustce to the Company at the expiration of three years from the date of such deposit. In that event the rights of the bondholder shall revive against the Company to the extent of the amounts so repaid by the Trustee to the Company but without interest thereon, but not his rights under this Agreement, nor to the security of the Trust Fund.

Section 3.-At any time when all the Company's Bonds which have bcen authenticated by the Trustees shall be paid, or being at any time due shall have been provided for by the payment to and deposit with the Trustee as provided hereinbefore or hereinafter, or by any supplemental agreement applying to any series of bonds issucd hereunder, and all the Trust Fund has been conveyed, assigned and delivered to the Company by the Trustee, this Agreement ipso facto shall cease and come to an end except as to the amounts so deposited with the Trustee in payment of bonds and coupons not presented for payment.

SECrion 4.-It is further agreed that if the Company's Bonds shall be placed upon the market by the Company at a price less than the face value thereof, the Company is authorized to carry in its assets an amount equal to nine-tenths of the discount; from the amount thus carried in its assets at least one-ninth must be written off annually. 


\section{ARTicle Nine}

Section 1.-The Trust Fund at all times shall consist of bonds and mortgages of an aggregate principal sum unpaid thereon which together with the cash and other securities, if any, belonging to the Trust Fund as herein provided shall be equal to the aggregate principal amount of all the Company's Bonds then outstanding, and secured by the Trust Fund, and if at any time for any reason the aggregate principal sum unpaid on all the bonds and mortgages then constituting the Trust Fund shall exceed the aggregate principal sum of all the Company's Bonds then outstanding and secured thereby, the Company shall have the right to demand and to receive from the Trustee (if no event of default specified in Article Six hereof shall then exist of which the Company has been notified in writing by the Trustee) the assignment and delivery to it of bonds and mortgages belonging to the Trust Fund, for an unpaid principal sum equal to such excess.

Secrion 2.- If at any time for any reason the Trust Fund shall be less than the amount herein provided, the Company shall within ten days after service upon it by the Trustee of a demand in writing so to do assign to and deposit with the Trustee bonds and mortgages of an unpaid principal amount equal to the amount of such deficiency.

\section{ARTICLE TEN}

[Terms of acceptance of Trust.

(1) Full discretion in instituting proceedings.

(2) Under no obligation to record this instrument or assignments of Trust Fund prior to default.

(3) Immunity of Trustee.

(4) Liable only for authentication of bonds and its misconduct and negligence.

Entitled to reasonable compensation. See J. \& L. S. Co. Art. 10, Sec. 1, p. 240.]

\section{Article Eleven}

[Resignation of Trustee. Removal of Trustee. Appointment of successor. See J. \& L. S. Co., Art. 10, Sec. 2, pp. 245-247.]

\section{Article Twelve}

[Covenants of the Company:

(1) To pay principal and interest. 
(2) To keep an office in New York City.

(3) To obtain authority to do business in various states. See J. \& L. S. Co., Art. 2, Sec. 1, pp. 202-3.]

\section{Article Thirteen}

Exclusively for the benefit of the Trustee and the holders of the Company's Bonds the Company further covenants and agrees with the Trustee and its successor or successors that it will observe the following rules with respect to the conduct of its business touching the bonds and mortgages assigned to and deposited with the Trustee from time to time under this Agreement:

(1) That each and every mortgage which it shall at any time assign to and deposit with the Trustee under this Agreement, shall be (subject to the provisions of Article Fire hereof) a first lien upon improved real estate in a city situated in the United States of America having a population of not less than forty thousand, for an amount not exceeding one-half of the value of the mortgaged property as appraised for the Company, except that in cities having a population of not less than three hundred thousand such mortgage may be for an amount not exceeding three-fifths of the value of the mortgaged property as appraised for the Company, and that within the political boundaries of New York City such mortgage may be for an amount. not exceeding two-thirds of the value of the mortgaged property as appraised for the Company. The term "city" is used throughout this instrument in the economic sense to designate an urban community, and without reference to its political boundaries.

(2) That it will not assign to and deposit with the Trustee under this Agreement any mortgage on a single building which shall exceed an amount equal to $\$ 2.00$ for each inhabitant of the city in which the property is located.

(3) That the aggregate unpaid principal amount of all mortgages forming portion of the Trust Fund upon property in any one city will not exceed in amount $\$ 2.00$ for each inhabitant of such city per $\$ 1,000,000$ of the Company's Bonds issued and outstanding and secured by this agreement.

(4) That the aggregate unpaid principal amount of all mortgages forming portion of the Trust Fund upon property in any one city shall not exceed in amount twenty per cent. of the total amount of the Company's Bonds issucd and outstanding, unless such mortgages are upon property situated within the political boundaries of New York City. 
(5) That the aggregate unpaid principal amount of all mortgages forming portion of the Trust Fund upon property in any city of from 40,000 to 70,000 inhabitants shall not exceed a total of $\$ 40$ per inhabitant, and in cities of from 70,000 to 100,000 inhabitants shall not exceed a total of $\$ 50$ per inhabitant.

(6) That no single bond and mortgage shall be assigned to and deposited with the Trustee under this Agreement which shall exceed in principal amount ten per cent. of the capital and surplus of the Company then outstanding.

(7) That the appraised value taken as a basis for the mortgage loans is not to exceed the selling value determined by the Company by careful investigation. In arriving at this value only the established utility of the property and the earning power under systematic management will be considered.

(8) That such appraised value of properties securing bonds and mortgages assigned to and deposited with the Trustee under this Agreement shall be in all cases based on two appraisals, one of which shall be made by the Company's appraiser in the city where the property is located, and the cther shall be made by a representative of the Company in the home office, who shall have personal knowledge of values in all the cities in which he makes appraisals. From time to time the Board of Directors shall issue instructions to the appraisers touching the methods to be employed in fixing the value of properties on which loans are to be made. No mortgage shall be assigned to and deposited with the Trustee unless it has been approved by the Executive Committee of the Company. In case any mortgage amounts to $\$ 100,000$ or over, a third appraisal shall be obtained, made by an additional appraiser selected by the Company.

(9) That the bonds and mortgages which it shall assign to and deposit with the Trustee under this Agreement shall in no case be secured by farm property, unimproved property, undivided interests in property representing less than the entire ownership of the property, leaseholds, or by churches, factories, clubs or theatres.

(10) That mortgages on new buildings which are not completed and productive must not form more than one-tenth of the total of mortgages assigned to and deposited with the Trustee under this Agreement. No building loans shall be made in New York City without a guarantee either of the completion of the building or of the repurchase of the mortgage by a corporation in good standing competent to make such a contract, nor in other cities without retaining at all times from the moneys to be advanced upon the mortgage an amount which the Company shall deem sufficient to entirely complete the building according to the plans and specifications. 
(11) That no real estate shall be acquired except to avoid losses under foreclosure, or to provide offices for the Company's own use. All real estate acquired under foreclosure shall be promptly sold.

(12) That fire insurance policies to an amount which the Company shall deem sufficient to protect the mortgage in Fire Insurance Companies in good standing shall be obtained by the Company and deposited with the Trustee.

(13) That the time within which an action hereunder or upon any of the coupons or bonds of the Company may be commenced shall be that now established by the laws of the State of New York, namely, twenty years from accrual of such right of action.

(14) That so long as any of the Company's Bonds shall be outstanding, the Company agrees that it shall have an annual audit of its books by independent auditors or chartered accountants to be designated from time to time by the Executive Committee of the Company.

(15) That it will from time to time duly pay and discharge all taxes, assessments and governmental charges lawfully imposed upon the Trust Fund, or upon any part thereof, and all taxes, assessments and governmental charges lawfully imposed upon the interest of the Trustee therein; provided, however, that the Company shall not be required to pay any such tax, assessment or governmental charge so long as it shall in good faith, by appropriate legal proceedings, contest the validity thereof.

(16) That it will do, execute, acknowledge and deliver, or cause to be done, executed, acknowledged and delivered, all and every such further acts, deeds, transfers and assurances for the better assuring, assigning and confirming unto the Trustee each and every bond and mortgage which shall at any time be assigned to and deposited with the Trustee or intended so to be, as portion of the Trust Fund, as the Trustee shall reasonably require for better accomplishing the provisions and purposes of this Agreement, and for better securing the payment of the principal and interest of the bonds issued and outstanding hereunder.

(17) That it will not do or perform nor voluntarily permit to be done or performed, any act or thing by which the security of this Agreement and the assignment and deposit of the bonds and mortgages which shall from time to time form portion of the Trust Fund can be in any way or manner impeached or impaired.

(18) That it will well and truly at all times fully inform the Trustee in writing with respect to all payments of principal receired by the Company from or with respect to any bond and mortgage assigned and deposited hereunder and will give the Trustee such addi- 
tional information touching any of such bonds and mortgages, or the property covered thereby, as the Trustee may reasonably require from time to time.

\section{Article Foorteen}

[Action for specific performance or damages when one or more of covenants in Article Thirteen violated.]

\section{Article Fifteen}

[Assignment by Company of interest in Trust Fund. See. J. \& L. S. Co., Art 11, Sec. 4, p. 249.]

\section{Article Sixteen}

On the first day of April, 1912, and on the first days of October and April in each and every year thereafter, until the payment of all the Company's Bonds, Series 2, the Company will pay or cause to be paid, in gold coin of the United States, of the present standard of weight and fineness, the principal and interest of such of the Company's Bonds, Series 2, as shall be drawn for payment according to the Table of Drawings for Amortization, endorsed upon the back of said bonds, in the manner herein provided.

The numbers of the bonds at any time drawn for payment under such Amortization provisions shall be determined by the Trustee by drawing by lot from the entire number of bonds, Series 2, issued and outstanding, and secured by the Trust Fund, in the manner provided in Section 2 of Article Seventeen of this Agreement, for the determination of the Company's Bonds, Series 2, to be redeemed and discharged, in the event that the Company shall elect to redeem only a part of the entire number thereof; subject, nevertheless, to the fol. lowing provisions:

The bonds shall be drawn as nearly as possible proportionately from the different denominations of the Company's Bonds, Series 2, issued and outstanding and secured by the Trust Fund at the time of such drawing, but the decision of the Trustee in this matter shall be final.

In the event that the requisite percentage of bonds issued and outstanding at the time of any drawing should equal an amount of principal not divisible by 100 , any balance shall be carried over to the next drawing and shall be added to the percentage of bonds to be drawn at the next drawing. 
Notice of the result of such drawing shall be published as provided in Article Serenteen, Section 2 hereof.

Upon publication by the Company of such notice in the manner aforesaid, and upon filing proof of such publication with the Trustee, interest shall cease to accrue upon the bonds so drawn for payment, from their respective dates of payment as specified in the said notice, provided the Company shall make in respect to such bonds a deposit of money with the Trustee as specified in Section 3 of Article Seventeen hereof.

All bonds so drawn for payment shall, when paid, be cancelled by the Trustee, together with all coupons belonging thereto. The Trustee shall enter the Serial numbers of all bonds which it shall be required to cancel under any provision hereof in a book or books to be kept for that purpose, so that there shall be at all times a com. plete and accurate record of the Company's Bonds, Series 2, issued and outstanding under this Agreement.

After such cancellation and the entry of the numbers of said bonds by the Trustee, as aforesaid, the same are to be returned to the custody and control of the Company.

\section{Article Seventeen}

[Redemption of Bonds, Series 2:

SEction 1.-Right of redemption October 16, 1916, at par. Redeemed bonds cancelled.

Section 2.-Numbers of bonds ascertained by lot. Publication of Notice. Interest to cease on bonds drawn.

Section 3.-Deposit to pay bonds not presented. After three years deposit returned to Company.]

\section{Article Eighteen}

[Section 1.-Right limited to parties and bondholders. See J. \& L. S. Co., Art. 12, p. 251.]

Section 2.-Bondholders requests:

(1) Proof of fact and date of execution.

(2) Proof of ownership of bonds.

(3) Proof of ownership of registered bonds. See J. \& L. S. Co., Art. 7, pp. 235-6.]

Section 3.-Actions by Trustee.

SECTION 4.-Provisions for publishing notices in foreign countries.]

\section{Article Nineteen}

[Waiver of personal liability. See J. \& I. S. Co., Art. 6, p. 235.] 


\section{ArTicle Twenty}

[Bondholders' right to sue:

SEction 1.-Prerequisites to action by bondholder.

Section 2.-Omission of Trustee or bondholder not a waiver.

Section 3.-Direction by seventy-five per cent. bondholders.

Section 4.-Waiver by Company.

SECTION 5.-Consolidation permitted.

SeCTION 6.-Company's rights not limited.]

\section{Article Twenty-one}

[Trustee accepts trust.]

[Testimonium. See J. \& L. S. Co., Art. 12, p. 251.]

[Acknowledgments of Company and Trustee. See J. \& L. S. Co., Art. 12, pp. 252-4.] 


\section{AGREEMENT SECURING SHORT TERM NOTES}

Agreement made this first day of August, 1911, between American Power \& Light CoMpany, a corporation of the State of Maine (hereinafter called the "Company"), party of the first part, and Guaranty Trust CoMpany of New York, a corporation of the State of New York (hereinafter called the "Trustee"), party of the second part.

Whereas, the Company has resolved to execute and issue a series of notes to be known as 'Ten-Year Six Per Cent. Gold Notes for the principal sum in the aggregate of two million two hundred thousand dollars $(\$ 2,200,000)$ each for the principal sum of $\$ 1,000$ or $\$ 500$ or $\$ 100$, with interest payable semi-annually at the rate of six per centum per annum, evidenced by interest coupons attached thereto, said notes to be duly authenticated by the certificate of the Trustee hereunder; and

Whereas, said $\$ 1,000$ notes and the interest coupons and Trustee's certificate therein provided for are to be in substantially the following form, suitable changes being made therein for the $\$ 500$ and $\$ 100$ notes:

United States of America

State of Maine

AMERICAN POWER \& LIGH'T COMPANY

Ten-Year Six Per Cent. Gold Note No........

For value received, American Power \& Light Company promises to pay to bearer, or in case this note is registered, to the registered holder hereof, one thousand dollars in gold coin of the United States of America of the present standard of weight and fineness, at the office or agency of the obligor company in the City of New York on August 1, 1921, and to pay interest thereon in like gold coin at the rate of six per centum per annum from August 1, 1911, on presentation and surrender, at the office of Guaranty Trust Company of New York, in the City of New York, of the annexed coupons as they severally become due, on the first days of February and August in each year until such principal shall be paid, without deduction from principal or interest on account of any tax or taxes, which the obligor company may be required to pay or retain therefrom by virtue of any present or future law or requirement. 
This note is one of a series of notes for the aggregate principal sum of two million two hundred thousand dollars $(\$ 2,200,000)$, entitled to the benefits and subject to the provisions of an agreement, dated August 1, 1911, between American Power \& Light Company and Guaranty Trust Company of New York, as Trustee, to which reference is made for a complete statement of the terms and conditions under which said notes are issued, received and held.

The principal of said notes may become due in case of default under said agreement, as provided in said agreement.

This note shall be subject to redemption at 102 and accrued interest upon any interest date upon notice as provided in said agreement.

Upon the exercise of the right of the holders of the option warrants referred to in said agreement to purchase at par common stock of the obligor company, this note, when presented to the obligor company (with all unmatured coupons attached) by the holder of an option warrant for ten (10) shares of said common stock, shall entitle such holder to receive a certificate for such ten (10) shares of stock or, at the option of the obligor company, voting trust certificates therefor, and also to receive in cash the amount of interest accrued on this note from the last coupon date to date of such presentation, as provided in said agreement.

This note may be registered on the books of the obligor company kept at the office of the Trustee under said agreement and the registration noted hereon, after which no valid transfer hereof can be made except on said books until after registered transfer to bearer, but registration shall not restrain negotiability of the coupons, which shall continue to be transferable by delivery merely.

No recourse shall be had for the payment of the principal or interest of this note against any present or future stockholder, officer or director of the obligor company.

In witness whereof, American Power \& Light Company has caused its corporate seal to be affixed hereto, attested by its Secretary or Assistant Secretary, and these presents to be signed by its President or a Vice-President, this first day of August, 1911.

American Power \& Light Company,

$$
\text { By................... }
$$


Attest:

Secretary.

$\$ 30.00$

[COUPON]

On the first day of

No........ CoMpany will pay the bearer Thirty Dollars $(\$ 30)$ in gold coin of the United States, at the office of Guaranty Trust Company of New York, in the City of New York, being six months' interest then due upon its Ten-Year Six Per Cent. Gold Note No.......

Not due if note redeemed or called for previous redemption.

Treasurer.

\section{[TRUSTEE'S CERTIFICATE]}

This note is one of the series of notes described in the agreement in this note referred to.

Guaranty Trust Company of New York,

Trustee.

and

By..................

Whereas, the option warrants referred to in said note and in this agreement are to be in substantially the following form:

United States of America

State of Maine

American Power \& Light Company

OPTION WARRANT

No

$\$ \ldots \ldots$

For value received, Amerionn Power \& Liamt Company promises to issue to

for

shares of the par value of

a certificate

(\$) of its full-paid common stock (or, at its option, to deliver voting trust certificates therefor), at the office of Guaranty Trust Company of New York, at any time before August 1, 1921, upon the surrender hereof and upon payment in cash for said stock at par, or, in lieu of such cash payment, the delivery of a note or notes (with all unmatured coupons attached) issued under an agreement between American Power \& Light Company and Guaranty Trust Company of New York, as Trustee, dated August 1, 1911, for a principal amount equal to the par value of said stock to which the holder of this warrant shall be en- 
titled. Provided, however, that if any such note or notes shall have been called for redemption the right to deliver such note or notes hereunder shall cease at the close of business upon the date for redemption specified in such call. Holders of notes so delivered in payment for stock shall be entitled to receive in cash the amount of interest accrued on such notes from the last coupon date to date of such delivery.

The rights represented hereby are transferable only on the books of American Power \& Light Company at the office of Guaranty Trust Company of New York by said holder or by attorney, upon surrender of this certificate properly endorsed.

\section{American Power \& Light Compant,}

By..................,

President.

Attest:

\section{Secretary. \\ [ENDORSEMENT]}

For value received, the undersigned hereby assigns to

all the rights and interest represented by the within option warrant and hereby irrevocably constitutes and appoints attorney to transfer the same on the books of American Power \& Light Company with full power of substitution in the premises.

Dated, Witness :

and

Whereas, the execution and delivery of this agreement have been duly authorized by the Board of Directors of the Company at a meeting duly called for that purpose;

Now, therefore, this agreement witnesseth: That, in order to secure the payment of said notes and the interest thereon and to declare the terms and conditions on which said notes are to be issued, received and held, the Company, in consideration of the premises and of one dollar to it paid, receipt whereof is hereby acknowledged, hereby agrees and provides as follows:

\section{Article I}

Notes for the aggregate principal amount of two million two hundred thousand dollars $(\$ 2,200,000)$ shall be certified by the Trustee 
upon the request of the Company at once or at any time or times hereafter and delivered in accordance with the order or orders of the Company evidenced by a writing or writings signed by its President or a Vice-President and its Treasurer or Assistant Treasurer.

[Temporary Notes. See J. \& L. S. Co., Art. 1, Sec. 8, p. 202.] ${ }^{2}$

[Officers who may execute bonds. See J. \& L. S. Co., Art. 1, Sec. 4, p. 200.]

[Bonds lost, mutilated, or destroyed. See J. \& L. S. Co., Art 1, Sec. 7, p. 201.]

\section{Article II}

[Corenants of Company :

(1) To pay principal and interest

(2) To keep an office or agency in New York City. See J. \& L.

S. Co., Art. 2, Sec. 1, pp. 202-3.]

\section{Article III}

As provided in the option warrants above referred to the Company for value received will issue on or before August 1, 1921, to the holders thereof full-paid common stock of the Company (or, at the option of the Company, will deliver voting trust certificates therefor) for the number of shares specified in such warrants, such stock to be delivered to the holders of option warrants upon the surrender of such warrants and upon payment of the sum of one hundred dollars $(\$ 100)$ for each share of stock so delivered, or, in lieu of said cash payment, the delivery of notes secured hereby (with all unmatured coupons attached) for an amount of principal equal to the aggregate par value of such shares. Holders of notes so presented shall be entitled to receive in cash the amount of interest acerued on such notes from the last coupon date to date of such presentation.

The Company covenants that it will pay or cause to be paid to the Trustee hereunder all sums of money received by it from time to time in payment for common stock of the Company, as provided in said option warrants. Such sums of money shall be held by the Trustee, such interest being allowed on the money as the Trustee shall allow on other deposits of similar character. Such sums of money shall be applied as rapidly as shall be reasonably practicable from time to time for the purchase of notes issued hereunder and secured hereby at not more than accrued interest and 101 per cent. of

1 Note-Statements enclosed in brackets [] are digests of parts omitted. These parts, however, have been abbreviated because they are practically duplieated in the Corporate Mortgage of the Jones \& Inughlin Steel Company to which reference is made as follows: J. \& L. S. Co., Axt. - , Sec.,- p. - 
the principal thereof. The purchase of notes as aforesaid may be made by the Trustee without notice, provided notes shall be offered to it or shall be purchasable in the market at a price in its judgment fair and reasonable within the above limit. The Trustee may also at any time call for offers of said notes within said limit as to price by advertisement in one or more daily newspapers published in the City of New York. The expense of such advertisement shall be paid by the Company. The Trustee shall be under no duty to advertise as aforesaid unless requested so to do by holders of $20 \%$ of the notes issued and outstanding hereunder, and unless indemnified to its satisfaction against the cost of such advertising. All of such notes purchased by the Trustee shall forthwith be canceled and the Trustee shall note on one of the originals hereof the fact of such cancellation and thereupon deliver the notes so canceled to the Company.

Whenever there shall have remained on deposit with the Trustee as much as five thousand dollars $(\$ 5,000)$ for sixty (60) successive days, notwithstanding efforts to purchase notes therewith, as hereinbefore provided, such fund shall be paid out by the Trustee from time to time upon the direction of the Company expressed by resolution of its Board of Directors or Executive Committee and upon delivery to the Trustee of (1) a copy of such resolution certified by the Secretary or Assistant Secretary of the Company under its corporate seal, and (2) a certificate signed and verified by the President or Vico-President and the Treasurer or Assistant Treasurer of the Company, stating in substance:

(a) That the Company has acquired stocks, bonds, notes or other securities of corporations, at least fifty-one per cent. of whose stock is owned by the Company, describing the same with reasonable detail and stating the actual cash cost of each item; and

(b) That the sum directed to be paid out does not exceed the fair value and does not exceed the actual cash cost to the Company of said stocks, bonds, notes or other securities. Prior to any payment by the Trustee, there shall be delivered to it any shares of stock or any mortgage bonds, notes or other securities of corporations made the basis of such payment.

The certified copy of resolution and the certificate above provided for shall be full protection to the Trustee in making any payment hereunder.

[Such stocks, bonds, notes, or other securities of corporations deposited with the Trustee hereunder shall be held by it as further security for the payment of the notes secured hereby and so long as there shall be no default, the Company shall be entitled (1) to receive 
all interest paid or dividends declared on such securities and (2) to vote upon all shares of stock deposited with the Trustee hereunder. See J. \& I. S. Co., Art. 3, Sec. 5, p. 214.]

[The purchase price of any stocks, bonds, etc., delivered by the Trustee to the Company by resolution of its Board of Directors or Executive Committee shall be paid in cash to the Trustee.]

[Trustee entitled to expenses and reasonable compensation. See J. \& L. S. Co., Art. 10, Sec. 1, pp. 241-2]

\section{ARTICLE IV}

[All notes, but not less than all, redeemable at 102 and accrued interest. See J. \& L. S. Co., Art. 4, Sec. 2, p. 221.]

\section{Artiole V}

Sectron 1. [Principal and accrued interest due on default. See J. \& L. S. Co., Art. 5, Sec. 4, p. 22\%.]

Section 2. [In case of default in interest payment for 90 days the Trustee may demand that the principal then due and any accrued interest be paid with $6 \%$ interest; also expenses of collection and reasonable compensation.]

In case the Company shall fail forthwith to pay said amounts upon such demand, the Trustee may sell and dispose of for cash either all, or from time to time any part, of the stocks, bonds, notes or other securities of other corporations held in pledge hereunder, if any, which sale or sales, if deemed best by the Trustee, may be made privately, but otherwise shall be made in the City of New York, State of New York, either at the New York Stock Exchange, according to the rules and customs thereof, or at public auction at such other place or places, and at such time or times, and upon such terms as the Trustee may fix, and notice or notices of the time and place of sale shall be sufficient if given by publication thereof in at least two newspapers published in the City of New York, for five days in the week next preceding such sale or sales.

[If proceeds of sale are insufficient, then proceedings may be instituted at law or in equity to secure the deficiency. See J. \& L. S. Co., Art. 5, Sec. 15, p. 232.]

[Rights of action enforceable by Trustee without the possession of any of the notes or coupons.]

[No noteholder or noteholders shall have right of action until written notice of default of Company has been given to Trustee. See J. \& L. S. Co., Art. 5, Sec. 18, p. 233.] 


\section{SeCtion 3.}

[Application of proceeds of sale:

(1) To payment of expenses, etc.

(2) Payment of principal and interest.

(3) Surplus to Company. See J. \& L. S. Co., Art. 5, Sec. 13, pp. 230-1.]

\section{Section 4.}

[Trustee and noteholder may bid. Purchaser permitted to apply notes and matured coupons. See J. \& L. S. Co., Art. 5, Sec. 14, p. 231.]

\section{ARTicle VI}

[Form and proof of execution of instruments by noteholders. Proof of ownership of notes and coupons. See J. \& L. S. Co., Art. 7, pp. 235-6.]

\section{ARTicle VII}

[Waiver of personal liability. See J. \& L. S. Co., Art. 6, p. 235.]

\section{ARTICLE VIII}

[Trustee may assume default not to exist until notified, Trustee not required to incur expense without indemnity, Trustee not responsible for validity of indenture or security, Trustee not responsible for recitals, Trustee may employ agents or lawyers, Trustee entitled to compensation-same to constitute a lien, Trustee not responsible for recording, etc. See J. \& L. S. Co., Art. 10, Sec. 1, pp. 240-3.]

[Testimonium. See J. \& L. S. Co., Art. 12, p. 251.]

[Acknowledgments. See J. \& L. S. Co., Art. 12, pp. 252-4.] 


\section{CONDITIONAL SALE AGREEMENT}

This Agreement, made at the City of New York, in the State of New York, on the first day of October, 190\%, by and between American Car and Foundry Company, a corporation organized under the laws of the State of New Jersey, hereinafter called the Car Company, party of the first part; Columbia Trust Company as Trustee, a corporation organized under the laws of the State of New York, hereinafter called the Trustee, party of the second part; and Erie Railroad Company, a corporation organized under the laws of the State of New York, and having its chief office and place of business in the City of New York, State of New York, hereinafter called the Railroad, party of the third part; Witnesseth:

[Whereas clause stating purpose of agreement and acceptance of trust. ${ }^{1}$

[Consideration clause.]

First.-The Car Company agrees to manufacture for and to deliver to the Trustee during the months of October, November and December, 1907 (all deliveries to be completed not later than January 31,1908 ), and in the lots hereinafter specified, three thousand forty-ton, steel-underframe box cars lettered "Erie" and numbered 109500 to 112499 inclusive (comprising the "trust equipment" in this instrument mentioned), which said cars are to be built in accordance with the Car Company's specifications No. 809 and subject to inspection and approval by the representatives of the Railroad. Two thousand of said cars shall be delivered on tracks at the Car Company's works at Berwick, $\mathrm{Pa}$, and one thousand on tracks at its works at Detroit, Mich.

The Car Company agrees to accept as full payment for said cars the principal sum of Three million, four hundred and eighty thou. sand, seven hundred Dollars $(\$ 3,480,700)$, of which sum Four hundred and forty thousand, seven hundred Dollars $(\$ 140,700)$ shall be in cash or in materials for use in the construction of said trust equipment, and the remaining Three million and forty thousand Dollars $(\$ 3,040,000)$ of said principal sum shall be in the "equipment notes" (hereinafter described) of the Railroad to be issued and delivered as hereinafter provided for.

Second.-The Trustee agrees to, and does hereby, lease unto the Railroad, and the Railroad does hereby hire and lease from the Trus-

1 Note-Statements enclosed in brackets [] are digests of parts omitted. These parts, however, have been abbreviated because they are practically duplicated in the Corporate Mortgage of the Jones \& Laughlin Steel Company to which reference is made as follows: J. \& L. S. Co., Art. - Sec. - , p. - 
tee, all and singular the said trust equipment constructed as aforesaid, from the dates of the respective deliveries thereof and until October 1, 1917 (or the earlier termination of this lease as hereinafter provided for), at the rental and upon and subject to the terms and conditions hereinafter stated, which said cars shall be delivered to the Railroad as they shall from time to time be received by the Trustee from the Car Company.

Third.-The Railroad agrees to receive and accept, upon and subject to all the terms and conditions of this agreement, said trust equipment, built as herein provided, as and when the same shall be ready for delivery at the places and within the times herein specified; and to pay as rental therefor the amount in the manner and at the times as hereinafter set forth.

And it is distinctly and specially stipulated, covenanted and agreed that the delivery to and the acceptance of the trust equipment, or of any part thereof, by the Railroad shall not vest any right or interest therein or title thereto in the Railroad other than as defined in this indenture; and that until payment by the Railroad of all the equipment notes by this agreement provided for and of the coupons belonging thereto, and until all the obligations of the Railroad hereunder shall have been fully complied with and performed, the title to the trust equipment or to any part thereof shall not pass to or vest in the Railroad, but shall remain in the Trustee on the Trust to perform and enforce this agreement for the equal benefit of the holders of the equipment notes herein mentioned, notwithstanding the delivery of the trust equipment to and its possession and use by the Railroad.

And it is further covenanted and agreed by and between the parties:

I.-The Railroad agrees, as a consideration for the leasing tn it of the trust equipment, to faithfully observe and comply with all and every the terms, provisions and conditions of this agreement by it to be observed and complied with; and agrees to pay the Trustee, to and for the account of the Car Company, as part payment for the trust equipment to be manufactured by the Car Company, the sum of Four Hundred and Forty Thousand, Seven Hundred Dollars $(\$ 440,700)$, in cash or in materials for use in the construction of said trust equipment. The Railroad agrees also to pay as rental for said trust equipment:

(a) The entire principal of the equipment notes issued in accordance with the provisions hereof, according to their tenor, as the same 
severally mature, together with interest at the rate of five per cent. per annum upon the principal of said notes, according to the tenor of the coupons thereto attached-all such payments both of principal and interest to be in gold coin of the United States of the present standard of weight and fineness, or its equivalent; and

(b) Any and all taxes which may be assessed or levied upon the trust equipment, or any part thereof, and any and all taxes which may be assessed or levied upon the equipment notes issued hereunder and the interest coupons thereon, and which the Railroad may be required to pay thereon or deduct therefrom.

II.-The Railroad agrees to forthwith execute and deliver to the Trustee its notes (herein designated "equipment notes") aggregating in principal amount Three Million and Forty Thousand Dollars $(\$ 3,040,000)$. Such notes shall be designated as "Erie Railroad Equipment Notes; Series N," shall be for the principal sum of One Thousand Dollars each; shall be dated and bear interest (to be evidenced by interest coupons attached) from October 1, 190\%, at the rate of five per cent. per annum, payable semi-annually on the first days of April and October in each year; shall be numbered consecutively from one to three thousand and forty, both inclusive; shall have endorsed thereon a certificate of the Trustee as hereinafter specified; and shall mature at the rate of $\$ 152,000$ face amount thereof on the first day of April and the first day of October in each year, beginning April 1, 1908, and ending October 1, $191 \%$.

Said notes shall be in substantially the following form:

$$
\text { (Form of Note.) }
$$

Number

$\$ 1,000$.

N.

\section{Erie Railroad Company}

\section{Equipuent Note, Serifs $\mathrm{N}$,}

Total Issue Limited to $\$ 3,040,000$.

For value received Erie Railroad Company promises to pay to bearer on the first day of 19 , without grace, the sum of One Thousand Dollars $(\$ 1,000)$, in gold coin of the United States of America, of the present standard of weight and fineness, or its equivalent, at the office of First National Bank of New York, in the Borough of Manhattan, City of New York, with interest thereon from October 1, 1907, until paid, at the rate of five per cent. per annum, payable semi-annually in like gold coin at the office of said First National Bank of New York on the first days of. April and 
October in each year on the presentation and surrender of the respective coupons for such interest (hereto attached) as they severally mature. All payments upon this note, both of principal and of interest, shall be made without deduction for any tax or taxes which the Railroad Company may be required to pay thereon or retain therefrom under any present or future law of the United States or of any State, County or Municipality thereof.

This note is one of a series of notes designated as "Erie Railroad Company Equipment Notes, Series N," numbered consecutively from $\mathrm{N} 1$ to N3,040 both inclusive, aggregating in par value the principal sum of Three Million and Forty Thousand Dollars $(\$ 3,040,000)$, all of like date, amount and tenor except as to the date of maturity, of which said notes

\begin{tabular}{|c|c|c|c|c|c|c|c|}
\hline imbers & N1 & to & N152 & inclusive & mature & April & 1,1908 , \\
\hline “ & N153 & $\because 6$ & N304 & 6 & " & Oct. & 1, 1908, \\
\hline “ & N305 & “ & N456 & $"$ & “ & Apr. & 1,1909 , \\
\hline "s & $\mathrm{N} 457$ & “ & N608 & " & “ & Oct. & 1,1909 , \\
\hline " & N609 & “ & N760 & 6 & “ & Apr. & 1, 1910, \\
\hline “6 & N761 & “" & N912 & “ & “ & Oct. & 1,1910 \\
\hline “ & N913 & $"$ & N1064 & " & “ & Apr. & 1,1911 \\
\hline “ & N1065 & $"$ & N1216 & “ & “ & Oct. & 1,191 \\
\hline “" & N1217 & $"$ & N1368 & “ & “ & Apr. & 1,191 \\
\hline "6 & N1369 & $"$ & N1520 & “ & “ & Oct. & 1,191 \\
\hline “ & N152I & 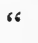 & $\mathrm{N} 1672$ & " & “ & Apr. & 1,191 \\
\hline " & N1673 & 6 & N1824 & " & “ & Oct. & 1,191 \\
\hline$" 6$ & N1825 & "6 & N1976 & $"$ & “ & Apr. & 1,191 \\
\hline “ & N1977 & $"$ & N2128 & “ & “ & Oct. & 1,191 \\
\hline “6 & N2129 & “ & N2280 & “ & “ & Apr. & 1,191 \\
\hline “ & N2281 & $" 6$ & N2432 & $"$ & “ & Oct. & 1,191 \\
\hline " & $\mathrm{N} 2433$ & $" 6$ & N2584 & “ & $"$ & Apr. & 1,191 \\
\hline$"$ & N2585 & $" 6$ & N2736 & “ & $"$ & Oct. & 1,191 \\
\hline$" 6$ & N2737 & “6 & N2888 & “ & “ & Apr. & 1,191 \\
\hline “ & N2889 & $" 6$ & N3040 & " & 6 & Oct. & 1,191 \\
\hline
\end{tabular}

Said notes represent the obligation of Erie Railroad Company to pay the purchase price of certain equipment and are issued under and all equally secured by, the provisions of the certain indenture of lease and conditional sale agreement dated First day of October, 1907, made between Erie Railroad Company, Columbia Trust Company, as Trustee, and American Car and Foundry Company, in which said equipment is fully described and by the terms of which the title to all of said equipment is retained and held by Columbia Trust Company as Trustee for the equal benefit of the holders of said equipment notes and until full payment of all thereof, and of the interest thereon.

For the further terms and conditions of the said indenture of lease and conditional sale agreement, and the rights and obligations of the 
said parties thereto and the rights of the several note holders, reference is hereby made to the said agreement.

This note shall not become or be valid or obligatory for any purpose until the certificate endorsed hereon has been duly signed by Columbia Trust Company, 'Trustee under said agreement.

In witness whereof, Erie Railroad Company has caused its corporate name to be hereunto subscribed by its Vice-President and its corporate seal to be hereunto affixed and attested by its Secretary, and coupons for interest, bearing the engraved or lithographed fac-simile of the signature of its Treasurer, to be hereto attached, as of the first day of October, 1907.

\section{Erie Railroad Company}

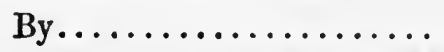

Vice-President.

Attest:

\section{Secretary}

Each of the said coupons appertaining to said notes shall represent interest for a period of six months and shall be in substantially the following form:
No. N
(Form of Coupon.)

$\$ 25.00$

On the first day of $\ldots \ldots \ldots \ldots \ldots \ldots \ldots \ldots \ldots \ldots$

\section{Erie Railroad Company}

Will pay to bearer, at the office of First National Bank of New York, in. Manhattan Borough, New York City, Twenty-five Dollars in gold coin of the United States, of the present standard of weight and fineness, or its equivalent-being interest then due on its equipment note, Series N, No.

subject to all the conditions stated in the said note and in the indenture of lease and conditional sale agreement dated October 1,1907 , therein referred to.

Treasurer.

The Certificate of the Trustee to be endorsed on each of said notes shall be in substantially the following form: 


\section{(Form of Trustee's Certificate.)}

This note is one of the series of notes specified in and issued under the provisions of the indenture of lease and conditional sale agreement therein referred to, bearing date October 1, $190 \%$.

Columbia Trust Company,

Trustee.

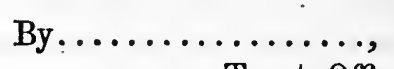

Trust Officer.

[Officers who may execute the notes. See J. \& L. S. Co., Art. 1, Sec. 4, p. 200.]

[Attached coupons must contain fac-simile signature of present or future treasurer. See J. \& L. S. Co., Art. 1, Sec. 4, p. 200.]

All interest on each and every of said notes shall cease after the principal thereof shall have become due unless the Railroad shall, after demand, fail to pay the principal thereof, together with interest in full to date of maturity of principal.

The Railroad shall not execute nor shall the Trustee certify and deliver equipment notes issued hereunder in excess of the aggregate principal sum of Three Million and Forty Thousand Dollars (\$3,040,000) at any one time outstanding.

Only such of said notes as shall bear thereon a certificate substantially in the form hereinbefore recited, duly executed by the Trustee, shall be entitled to any benefit or right hereunder.

\section{[Temporary bonds. See J. \& L. S. Co., Art. 1, Sec. 8, p. 202.]}

[Bonds lost, mutilated, or destroyed. See J. \& L. S. Co., Art. 1, Sec. 7, p. 201.]

III.-The Car Company agrees to make deliveries of the trust equipment in lots (as near as may be) of one hundred (100) cars each, beginning in October, $190 \%$, and continuing in like manner until the entire trust equipment shall have been delivered (which shall not be later than January 31, 1908) - the Car Company's obligation with respect to deliveries, however, being made expressly subject to delays caused by accidents, strikes, fires or other cause or causes beyond the control of itself or of its sub-contractors. 
The Car Company agrees also that from October 1, 1907, and until the dates of actual deliveries of the trust equipment, it will pay to the Railroad a sum equivalent to the interest on such of the equipment notes as shall represent the unpaid part of the purchase price of the equipment not theretofore delivered-such payment to be made on the adjustment provided for in paragraph $\mathrm{V}$ hereof.

IV.-The Railroad agrees that it will keep an inspector at the several works of the Car Company in which the trust equipment shall be constructed, for the purpose of inspecting the construction thereof, which said inspector shall, as and when the cars comprising the trust equipment are from time to time completed in accordance with the specifications and the provisions of this agreement, sign and deliver to the Car Company a certificate that the same have been inspected and accepted by him-which said certificate shall be taken at all times and in all places as final and conclusive evidence that the cars covered by the said certificates are constructed in accordance with the provisions of the specifications and of this agreement relating thereto. And no cars shall be accepted by the Trustee under this agreement until such cars shall have been so inspected and accepted by the inspector of the Railroad.

V.-The Railroad agrees that upon delivery of each one hundred (100) cars of the trust equipment, and from time to time as the same are delivered, it will execute and deliver to the Car Company a certificate showing the number (in every case 100 or a multiple thereof) of the cars so delivered and the road numbers thereof.

Such certificate shall be taken and acted on by the Trustee as conclusive evidence of its right to certify and issue the equipment notes of the Railroad provided for by this agreement; and upon presentation of any such certificate or certificates to the Trustee, it shall thereupon certify and deliver to the Car Company in respect to each lot of one hundred (100) cars the equipment notes of the Railroad of the face value of One Hundred and One Thousand Dollars $(\$ 101,000)$.

Any balance of the equipment notes not theretofore paid or delivered shall be adjusted upon the delivery to the Trustee of the certificate of the Railrond respecting the last lot of cars delivered hereunder. And as soon as may be after such last delivery the Railroad and the Car Company shall account together respecting the allowance of interest that may be due from the Car Company to the Railroad under the provisions of paragraph III hereof.

VI.-[All parties agree that Railroad is entitled to use and possession of equipment.] 
Prior to or upon the delivery of the trust equipment to the Railroad a metal plate bearing the words "Columbia Trust Company, Trustee, owner," in plain letters shall be permanently and securely placed and fastened upon each side of every of the cars comprising the trust equipment, in such manner as to render such plates readily visible and so as to indicate plainly the ownership of said equipment. In case any of such plates shall at any time be removed, defaced or destroyed, the Railroad shall and will immediately restore and replace the same, so that each and every of the cars comprising the trust equipment, and each and every of the cars replacing the same, shall always be marked as above provided on both sides thereof with the name Columbia Trust Company, Trustee, owner; and the Railroad shall and will do all such other things as shall be reasonably necessary and expedient for the full protection of the Trustee as the owner of the trust equipment and for the full and complete protection of the holders of the equipment notes.

The Railroad Company shall not during the life of this agreement allow the name of any person, association or corporation to be placed upon any of said trust equipment as a designation which might be interpreted as a claim of ownership by the Railroad, or by any one other than the Trustee, provided, however, that the Railroad may cause the cars comprising the trust equipment and each of them to be lettered "Erie," for convenience of identification of its lessee interest therein and its right to the use thereof.

VII.-The Railroad agrees that it shall and will at all times keep all of said trust equipment, and any equipment that may be used to replace any part thereof, in proper order and complete repair, and at all times in good working condition; all repairs and maintenance to be done to the satisfaction of the Trustee by and at the expense of the Railroad. The Railroad shall and will renew and replace from time to time such of the trust equipment as may be worn out, lost or destroyed, so that the number, character and capacity thereof shall always be maintained, the title to all new equipment procured for such renewing and replacing to be taken in the name of the Trustee-provided, however, that the Railroad may at its option; instead of replacing any of said cars which may be worn out, lost or destroyed, pay to the Trustee the sum of One Thousand Thirteen and 33/100 Dollars $(\$ 1,013.33)$ for each car so worn out, lost or destroyed-all such money to be paid within a reasonable time after such wearing out, loss or destruction, and to be held by the Trustee until all the payments provided for hereunder have been made by the Railroad after default or otherwise. Thereupon all such money and the interest 
thereon shall be turned over to the Railroad and the Trustee agrees to pay the Railroad interest thereon at a reasonable rate, not less than the highest rate paid general depositors of the Trustee-said interest to be retained by the Trustee, its successors or assigns, until all the payments provided for herein have been made by the railroad. All such new equipment shall be immediately subject to all the terms and conditions of this Indenture in all respects as though it had been part of the original equipment hereby leased, so that the equipment aforesaid shall at all times, during the life of this Indenture, be undiminished in amount and value, except so far as the same may be affected by the natural use and wear thereof. All new equipment purchased or procured to replace equipment worn out, lost or destroyed, shall be of substantially the same quality and character as the original trust equipment, or of such quality or character as the Trustee may approve, and shall bear the same numbers and be lettered as the equipment thereby replaced, or by altered lettering and numbers if consented to by the Car Company and the Trustce. The Railroad shall, if required by the Trustec, once in every year during the term of this Indenture, furnish a full and complete statement of the trust equipment covered hereby and its whereabouts as near as may be, and of the number and description of the cars comprising the trust equipment as may have been destroyed and replaced by others, the number of those repaired during the preceding year and the number of those at the date of such statement undergoing repair or in the shops for repair, and shall annually, if requested by the Trustee, allow its agents to make full inspection of the same, and shall furnish all reasonable facilities to the agents of the Trustee for making such inspection.

If the Railroad shall receive from, or if there shall be paid by, foreign lines of railroad or other persons or corporations moneys on account of the loss or destruction of, or damage suffered by, any of the trust equipment, the same shall be forthwith applied by the Railroad to the replacement or repair of the trust equipment so lost, damaged or destroyed.

VIII.-The Railroad agrees that it will not assign or transfer this Indenture, or transfer or sublet the trust equipment, or any part thereof, without the written consent of the Trustce first had and obtained, and the Railroad shall not without such written consent part with the possession of, or suffer or allow any of such trust cquipment to pass out of its possession or control except in the ordinary and usual interchange of traffic. In the event of the appointment of a Receiver of the property of the Railroad, and provided the Railroad shall have 
fully complied with and observed each and every of the terms, conditions and provisions of this agreement by it to be complied with and observed and shall not be in default in the performance of any of its. obligations hereunder, such Receiver shall have the right to retain. possession of the trust equipment so long as he shall comply in the place and stead of the Railroad with the provisions of this agreement, and he shall during such time be entitled to the benefit thereof.

The Railroad shall, during the term of this Indenture, pay promptly as and when due all taxes, licenses, assessments and charges of every kind that may be assessed, rated, levied, charged or made upon any of the trust equipment, or against any person, as owner thereof, while such equipment is in the possession and control of the Railroad, provided, however, that the Railroad shall have the right to contest by legal proceedings any such tax assessment or charge, and pending such contest may delay payment thereof provided it shall, if requested, indemnify the Trustee to its (the Trustee's) satisfaction with respect thereto. In case the Railroad shall neglect to pay such licenses, taxes, assessments or charges, the Trustee may pay the same, but shall not be required to do so; and the Trustee shall, upon the Railroad's request and upon being indemnified to its satisfaction in connection therewith, refrain from making any such payment. In the event and so often as the Trustee shall make such payments the Railroad shall and will repay any and all amounts so paid, with interest at six per cent. per annum from the time of payment; and until such repayment, which is hereby expressly made one of the obligations to be performed before title to the trust equipment shall vest in the Railroad; the title to the trust equipment shall remain in the Trustee, notwithstanding the payment of all the equipment notes and other payments to be made by the Railroad hereunder.

The Trustee shall, in addition to all other rights hereunder, have the right to recover from the Railroad, with interest as aforesaid, any and all amounts paid by the Trustee under this or the preceding paragraph hereof.

The Railroad shall not sell, assign, transfer, sublet, pledge or encumber, unless subject to this indenture, the trust equipment or any part thereof, but may pledge or otherwise dispose of its equity therein.

IX.-The Railroad agrees with regard to the trust equipment to comply in all respects with all Acts of Congress, and with the laws of the United States and of the States of New York, Pennsylvania, New Jersey, Ohio, Indiana and Illinois, and of all other States and Territories in which the trust equipment may be operated in the ordinary 
course of business, and with the lawful rules of the Interstate Commerce Commission, and with all lawful acts, rules, regulations and directions of any municipal assembly, council or other legislative, executive, administrative or judicial body or officer, exercising any power, regulation or supervision over any part of the trust equipment, including all laws and rules relating to automatic coupling devices or attachments, air brakes and other appliances as may be provided by Act of Congress or any legal body or officer of competent jurisdiction in the premises; or failing such compliance shall indemnify the trustee to its (the trustee's) satisfaction and save it (the trustee) harmless from any and all damage and expense that may accrue to or be incurred by the trustee because of such failure of compliance by the railroad. The Railroad may, in good faith, contest the application of any such law, regulation or order to or upon the trust equipment as aforesaid, or any part thereof, in any reasonable manner which shall not affect the title of the Trustee in and to said equipment.

X.- [The Car Company agrees to protect the Trustee against all claims for infringement of patents.]

XI.- [Notes and coupons shall be paid at maturity and cancelled.]

XII.-The Railroad covenants and agrees to make, execute and deliver from time to time all such further or supplemental agreements, deeds or other instruments as may by the Car Company or the Trustee, or their respective counsel, be deemed advisable, necessary or expedient, to effectually protect and enforce the Trustee's rights hereunder and to protect its title to said equipment or to such equipment as may be at any time hereafter procured to replace any of the equipment which may become worn out, lost or destroyed. In case the Railroad shall wish to change any of the serial numbers of the cars composing such equipment, or in case the Railroad shall wish a change in the quality, quantity, character or serial numbers of any of the cars used to replace any of such equipment worn out, lost or destroyed, and the Car Company and the Trustee shall consent thereto in writing as hereinabove provided for, the Railroad, if requested thereunto by the Car Company and the Trustee (both or either), and if the same be feasible, will at its own expense endorse upon, annex to or file with the record, counterpart or copy of this Agreement in every place or office in which the same has been recorded, registered or filed pursuant to law, a statement or other instrument concerning such change in form satisfactory to the Car Company and the Trustee. If the change is in the serial numbers of the cars composing the original equipment delivered hereunder, the statement or other 
instrument shall set forth the old and the new numbers of those whereof a change in serial numbers has been effected; or if the change is in respect of equipment procured to replace any of the original equipment delivered hereunder, the statement or other instrument shall describe the quality, character and numbers of such new equipment, and also of the equipment which is replaced thereby, and shall set forth that said new equipment is delivered, and that title thereto is held by the Trustee in all respects and for all purposes, as if said new equipment had been part of the original equipment delivered hereunder; and the Railroad will make, execute and deliver any and all other instruments, and will do any and all other things deemed necessary, proper or expedient by the Car Company and the Trustee in respect of the premises.

And it is further covenanted and agreed by and between the parties:

XIII.-That upon payment by the Railroad of all of the equipment. notes in full, together with the interest thereon, in the manner and form herein and therein provided, and upon performance by the Railroad of all the covenants, obligations and agreements herein contained and by it to be performed, the title to the trust equipment shall pass to and vest in the Railroad; and the Trustee will thereupon execute, at the expense of the Railroad, any bill of sale or other instrument which may be reasonably required by the Railroad, as evidence of its title to said equipment and of its compliance with the terms of this agreement and as evidence that the absolute ownership of said trust equipment is vested in the Railroad, its successors and assigns. Until payment in full, however, of all said equipment notes and interest thereon, and the performance of all the obligations and covenants on the part of the Railroad hereunder, all and singular the trust equipment shall remain the absolute property of, and the title thereto shall continue to be vested in, the Trustee, as owner thereof, to all intents and purposes whatsoever, but subject to the Railroad's lessee interest therein under this agreement.

XIV.-The Railroad shall be entitled to the possession of the trust equipment at all times during the life of this agreement so long as it shall observe the conditions and obligations hereof; but (1) in case default shall be made by the Railroad in the payment of the principal of any of the equipment notes issued hereunder, or of any interest coupon, as and when the same may be due and payable, and upon such default continuing for a period of thirty days; or (2) in case default shall be made in the due observance or performance of any other of the terms, provisions, covenants, conditions or 
obligations of this agreement, and upon such default continuing for thirty days after notice in writing by the Trustee requiring the Railroad to comply therewith (which notice the Trustee shall serve at the request of the holders of at least one-fourth in amount of the equipment notes outstanding), the Trustee shall be entitled to and may, at its option, retake the trust equipment and every part thereof, retaining all payments which up to that time may have been made on account of such equipment (principal and interest); and for the purpose of taking such possession, the Trustee shall be entitled to enter upon and take and remove all said equipment (including all substitutions therein and additions thereto) from the premises of the Railroad or wherever the same may be found; and the Railroad will afford the Trustee every possible facility and means of assistance to such end. And the Railroad agrees that in the event of any default continuing as aforesaid, it will upon written demand by the Trustee and as promptly as possible, deliver to the Trustee, without cost or charge, each and every piece of said trust equipment, at such place or places upon the lines of the Railroad as the Trustee shall require. The Trustee shall, upon application to any court of equity having jurisdiction in the premises, be entitled to a decree against the Railroad, requiring specific performance hereof.

Upon such notice by the Trustee requiring redelivery to it of the trust equipment, and within thirty days after the receipt of such notice, the Railroad shall have the right (but without impairment of, or delay to, the Trustee's right to retake possession of the trust equipment) upon payment by it of all outstanding notes and of the acerued interest thereon to date of such payment, and of all other sums which it is obligated to pay hereunder, to have redelivered to it (at its expense) such of the trust equipment as may, at the time of such payment, have been retaken by the Trustec under the preceding provisions hereof; and thereupon the title to the trust equipment shall pass to and vest in the Railroad; and the Trustee will thereupon execute, at the Railroad's expense, any bill of sale or other instrument that may be reasonably required by the Railroad as evidence of its title to such trust equipment, and shall return to the Railroad the sum deposited by the Railroad with the Trustee on account of the cars lost, worn out or destroyed, together with any interest thereon.

[Upon such election by the Trustee to retake the trust equipment, the then outstanding notes and accrued interest may by the Trustee be declared due and payable upon a written request of the majority of the noteholders.] 
[Upon such election, the Trustee may, upon ten days' notice to the Railroad, sell the trust equipment and use the proceeds to liquidate expenses, notes and interest. If there is deficiency the Railroad agrees to pay it; if surplus it will be returned to the Railroad.]

[Detached coupons deferred in payment. See J. \& L. S. Co., Art. 5, Sec. 2, p. 225.]

[Trustee may institute legal proceedings. See J. \& L. S. Co., Art. 5, Sec. 5, p. 22\%.]

[Remedies cumulative. See J. \& L. S. Co., Art. 5, Sec. 19, p. 234.]

[Waiver of stay, appraisement, extension, and redemption law. See J. \& L. S. Co., Art. 5, Sec. 16, p. 233.]

[Seventy-five per cent. of noteholders to control certain proceedings. See J. \& L. S. Co., Art. 5, Sec. 6, p. 228.]

[Trustee and noteholders may bid. Purchaser permitted to apply notes and matured coupons. See J. \& L. S. Co., Art. 5, Sec. 14, p. 231.]

[Principal to become due on sale. See J. \& L. S. Co., Art. 5, Sec. 12, p. 230.]

XV.- - T Trustee not responsible for delay in delivery of equipment, not responsible for any defects or damage to equipment, responsible only for its own negligence, misconduct or bad faith, not responsible for recording, filing, etc., entitled to reasonable expenses, not responsible for recitals, may act on any instrument considered genuine. See J. \& L. S. Co., Art. 10, Sec. 1, pp. 240-3.]

XVI.-[Notices must be made to the Railroad in registered letters.]

XVII.-[Trustee may resign. Appointment of new trustee. See J. \& L. S. Co., Art. 10, Sec. 2, p. 245.]

XVIII.- [Bearer of note and interest coupon treated as owner. See J. \& L. S. Co., Art. 1, Sec. 6, p. 201.]

XIX.-[Definition of terms. See J. \& L. S. Co., Art. 11, Sec. 5, p. 250.]

XX.- [The agreement shall exist until all obligations thereunder are fulfilled.]

XXI.-[Execution in counterparts. See J. \& L. S. Co., Art. 11, Sec. 7, p. 250.]

[Testimonium. See J. \& L. S. Co., Art. 12, p. 251.]

[Acknowledg ments. See J. \& L. S. Co., Art. 12, pp. 252-4.] 


\section{AGREEMENT BETWEEN STANDARD STEEL CAR COM- PANY AND BANKERS TRUST COMPANY AND ERIE RAILROAD}

This agreement, made in triplicate this first day of July, One Thousand Nine Hundred and Seven, between the Standard Steel Car Company, of the first part, Bankers Trust Company, a corporation of the State of New York, hereinafter called the Trustee, of the second part, and the Erie Railroad Company, hereinafter called the Railroad Company, of the third part.

\section{WITNESSETH :}

Whereas, by Indenture of Lease ${ }^{1}$ bearing date the first day of July, 1907, the said Standard Steel Car Company did lease to the Erie Railroad Company certain railroad cars therein particularly described for a certain term and upon rental in said Indenture of Lease particularly described, and,

Whereas, the Standard Steel Car Company has secured subseriptions to the amount of Two Million One Hundred and Forty Thousand Dollars to a fund to be known as the "Erie Railroad Equipment Trust, Series "L," which said fund is to be applied by the Standard Steel Car Company to the payment of the purchase price of the railroad cars particularly mentioned in said Indenture of Lease; and

Whereas, the said Standard Steel Car Company proposes to secure to the parties subscribing to said fund of Two Million One Hundred and Forty Thousand Dollars the repayment thereof in twenty installments, to wit: In twenty semi-annual payments of One Hundred and Seven Thousand Dollars each, beginning January first, 1908, and the final payment on the first day of July, 1917, with interest meanwhile at the rate of five per cent. per annum from July first, 1907, payable semi-annually on the first days of January and July in each year, payments of such principal and interest to be made in equal half-yearly installments, and to evidence the rights of the subscribers to said fund by the delivery of certificates in the form hereinafter set forth, Now, This Aareement Witnessetr :

First.-That the said Standard Steel Car Company hereby assigns and sets over to the Bankers Trust Company, as Trustee, for the hold-

1 The Leaso referred to is almost identieal in terms with the Conditional Sale Agreement between the American Car and Foundry Company, The Columbia Trust Company and the Erie Railroad (pp. 200-312), and for that reason is not annexed hereto. 
ers of the certificates hereinafter set forth, all the right, title and interest of the said Standard Steel Car Company in and to said railroad cars leased, as aforesaid, unto the said Railroad Company and as well all the claims, demands and remedies of the said Standard Steel Car Company accruing or to accrue under the lease aforesaid.

The Car Company also hereby assigns and sets over to Bankers Trust Company, as Trustee, for the holders of the bonds hereinafter set forth, all the right, title and interest of said Car Company in and to the above described lease and the provision thereof with respect:

(a) To the repayment of money deposited in lieu of the replacement of cars lost, worn out or destroyed, and payment of interest thereon; and

(b) To the delivery of a bill of sale by the Lessor on the termination of said lease and on the delivery to the Lessor of all bonds and coupons issued thereunder, or on the delivery of satisfactory proof that the same have been paid and cancelled, the Trustee agrees to perform, it being understcod and agreed, however, that the Trustee neither incurs nor assumes any responsibility for the delivery of railroad cars by the Car Company, as in said lease provided.

Second.-The said Trustee covenants and agrees that it will certify and deliver to the Standard Steel Car Company, for distribution to the several subscribers to the said fund, Two Thousand One Hundred and Forty certificates, to be furnished to said Trustee for that purpose, in the following form, and in the amounts of One Hundred and Seven Thousand Dollars $(\$ 10 \%, 000.00)$ of bonds for each one hundred (100) cars delivered, at the times corresponding to the times of delivery of the various lots of said railroad cars by the said Standard Steel Car Company to the said Erie Railroad Company; such delivery of certificates to be made by the Trustee upon the delivery by the Car Company of certificate signed by an authorized inspector of the Erie Railroad Company giving the numbers of the cars contained in that delivery and certifying to the inspection and acceptance thereof, and approved by the President or a Vice-President of the Railroad Company and accompanied by the proper bonds or certificates to be certi.fied as aforesaid, and also a bill of sale to the Trustee of the cars so delivered, said bills of sale to be subject, however, to all the provisions of this agreement and the Indenture of Lease herein referred to; and the Standard Steel Car Company covenants that all of said certificates when and as issued shall be entitled to the security of all such railroad cars previously and subsequently delivered by said Standard Steel Car 
Company to the said Railroad Company under the terms of said Indenture of Lease of even date herewith; and said certificates and coupons to be in form substantially as follows:

\section{UNITED STATES OF AMERICA \\ STATE OF NEW YoRK ERIE RAILROAD COMPANY.}

$\$ 1,000$.

(No...........)

$\$ 1,000$.

Five Per Cent. Gold Car Trust.

Series "L."

Total Issue $\$ 2,140,000.00$.

The Erie Railroad Company hereby acknowledges itself to be indebted to the holder hereof, in the sum of One Thousand Dollars, in gold coin of the United States of America, which the said Railroad Company promises to pay to the holder hereof, at the office of the said Railroad Company, in the City of New York, State of New York, on the first day of ................, A. D. 19..., with interest thereon at the rate of five per centum per annum, payable semi-annually' in like gold coin, on the first days of January and of July in each year, as the same shall become due and payable, at the office of the said Railroad Company, upon delivery of the proper coupon therefor.

This certificate is one of a series of Two Thousand One Hundred and Forty for One Thousand Dollars each, numbered from 1 to 2140, both inclusive, each of like date, tenor and effect, except as to the due date thereof, issued under the terms of a lease bearing date the first day of July, 1907, between the Standard Steel Car Company of the one part and the Erie Railroad Company of the other part.

The obligation hereof shall only become effective when the certificate of the Bankers Trust Company, of New York, Trustee, is hereon endorsed.

Is Witness Whereor, the Erie Railroad Company has caused its corporate seal to be hereunto attached, duly attested, this first day of July, 1907.

Erie Railroad Company, By.....................

Attest:

President. 


\section{(TRUSTEE'S CERTIFICATE.)}

Bankers Trust Company, Trustee, hereby certifies that the within certificate is one of an issue of two thousand one hundred and forty certificates of One Thousand Dollars each, known as the Erie Car Trust, Series "L," referred to in the within mentioned lease bearing date the first day of July, 1907, made by Standard Steel Car Company to the Erie Railroad Company.

Bankers Trust Company, Trustee,

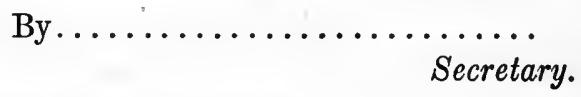

\section{(FORM OF COUPON.)}

The Erie Railroad Company will pay to the bearer, on the first day of.............., at its office in the City of New York, twenty-five dollars in gold coin, being six months interest on Certificate No.......... of the Erie Car Trust, Series "L."

\section{Treasurer.}

The signature of the present or any future Treasurer of the Erie Railroad Company lithographed or engraved upon said coupons shall be regarded and treated in all respects as equivalent to his manual signature thereon.

The said certificate shall be numbered consecutively from No. 1 to No. 2140, inclusive, and by the terms thereof the principal shall be payable as follows:

[The numbers of the certificates and their dates of maturity followed here. See Conditional Sale Agreement, p. 302.]

All dividends on the said certificates shall cease after the principal thereof shall have become due.

Third.-As all of the bonds to be executed by the Railroad Company and secured by said Indenture of Lease will bear date the first day of July, 190\%, and the interest thereon, represented by the coupons attached thereto, will date from the first day of July, 1907, the Car Company agrees to pay to the Railroad Company, in cash, such sums as may represent the interest which may accumulate on the said bonds from July 1, 1907, to the average date the cars referred to in the Indenture of Lease are delivered; said payment of interest by the Car Company to the Railroad Company to become due and payable immediately following the delivery of the last of the said cars. 
Fourth.-The Trustee, as assignee of the said Standard Steel Car Company, Lessor, further covenants to perform and, so far as possible, to enforce the performance of all and singular the terms, conditions and covenants of the said lease, and to apply and distribute the rentals thereunder when and as the same shall be received, for the following purposes, to wit:

(a) To the payment of any taxes upon the railroad cars leased which it may be required to pay.

(b) To the payment of the dividend warrants attached to the said certificates when and as the same shall become payable.

(c) To the payment and redemption of the principal of the said certificates when and as the same shall become payable. The said coupons and certificates to be cancelled upon payment thereof. Provided, however, that the Railroad covenants and agrees to pay bonds or certificates and coupons issued under said lease at its office in accordance with the terms and provisions of said bonds and coupons and of this instrument and of said lease, and such payments shall to the extent thereof be satisfaction of the rental reserved in said lease and a discharge of the Trustee from all obligation to require the payment of rentals to that extent and to apply and distribute the same.

It being distinctly understood that neither the said Trustee nor any successor in the trust shall be liable or responsible for any matter or thing connected with the trust intended to be hereby created except for its own or their own willful and intentional breach thereof.

Fifth.-The Erie Railroad Company becomes a party hereto in order to express its assent to the assignment of the said lease by the said Standard Steel Car Company to the said Bankers Trust Company, as Trustee, for the benefit of the subscribers to said "Erio Railroad Equipment Trust, Series "L," and does hereby accept all the terms of this assignment, including the obligation to make payment of all taxes hereinabove mentioned, for which the Trustce may be liable.

Sixth.-It is further herein agreed and provided that in case the Railroad Company (a) shall at any time make default in the payment of any part in the rental in said lease reserved for more than thirty days after the same shall have become payable, or in case (b) the Railroad Company shall fail to keep the said cars in good and serviceable condition or to perform all other obligations and covenants in said lease contained to be performed, on its part, and such last mentioned default or defaults shall have continued for a 
period of thirty days after written notice thereof from the Trustee, then and in each and every case of default as aforesaid, the Trustee shall have the right, as assignee of said Car Company, to enforce all the terms and stipulations of said lease subject to the right of the Railroad Company to exercise its option of purchase as therein set out, and in case the said Trustee shall re-take possession of the said cars, it may either hold or lease, or dispose of said cars or so many thereof as it may deem necessary in such manner at public or private sale, for cash or upon credit, as the Trustee may deem most beneficial, and the proceeds of said lease or sale, together with all moneys in the hands of the Trustee in lieu of lost, worn out or destroyed cars, and any unpaid interest thereon, shall be applied by the Trustee to the payment, after deducting all taxes which the Trustee may by law be required to pay in respect to the railroad cars covered by the said lease.

(1) of the dividend warrants then due.

(2) of the principal of all of the said outstanding certificates whether the same shall then have matured by their terms or not, in full, if such proceeds shall be sufficient, and if not, then pro rata.

And such re-taking possession of the said railroad cars by the said Trustee shall not be a bar to the recovery by the Trustee from the Railroad Company for future accruing rent until such sum is realized as, with the proceeds of the sale of said cars, is sufficient for the payment in full of all taxes aforesaid, together with all accrued interest warrants and the principal of all of the said certificates.

The Trustee assumes no liability, however, saving for its own willful or gross neglect; for the neglect of its agents it assumes no such liability. It shall undertake no active duty, however, in the way of taking care of, or taking possession of, equipment, until fully secured from all liability. No duty of insurance or of recording or of taking care of any of the Trust property is encumbent upon it.

Seventh.-[Temporary bonds. See Jones and Laughlin Steel Company Corporate Mortgage, Art. 1, Sec. 8, p. 202; this mortgage is hereinafter referred to thus: J. \& L. S. Co., Art. -, Sec. - p.-]

Eighth.-[Trustee entitled to reasonable compensation and protection from liability. See J. \& L. S. Co., Art. 10, Sec. 1, pp. 240-3.]

Ninth.-[The Car Company agrees to protect the Trustee against all claims for infringement of patents.] 
Tenth.-[Execution in counterparts. See J. \& L. S. Co., Art. 11, Sec. 7, p. 250.]

The parties hereto hereby respectively constitute and appoint the person set opposite their names to be their respective attorneys for and in their names and as and for their corporate acts and deeds to acknowledge this agreement before any person having authority by the laws of the Commonwealth of Pennsylvania to take such acknowledgments to the intent that the same may be duly recorded, to wit:

The Car Company appoints J. M. Hansen.

The Trustee appoints J. F. Thompson.

The Railroad Company appoints G. A. Richardson.

[Testimonium. See J. \& L. S. Co., Art. 12, p. 251.] 


\section{JLLUSTRATION OF -THE METHOD OF REFUNDING WITH THE AID OF A BANKER ${ }^{1}$}

TO THE HOLDERS OF

\section{TOLEDO TRACTION COMPANY}

Consolidated First Mortgage Bonds, Due January 1, 1912

Toledo Consolidated Street Railway Company

Consolidated First Mortgage Bonds, Due January 1, 1912

Toledo Electric Street Ratlway Company

First Mortgage Bonds, Due February 1, 1912

The Toledo Railways and Light Company has arranged with Blair $\& C$. for an extension of the time of payment of the above mentioned bonds of the Toledo Traction Company to January 1, 1913, with interest at the rate of six per cent. per annum, payable semi-annually, subject to redemption at the option of this company on July 1, 1912, on thirty days' notice. Holders of the said bonds desiring to avail themselves of the privilege of so extending their bonds, must present same (ex-coupon due January 1, 1912), at the office of Blair \& Co. on or before December 28, 1911, for the purpose of having affixed thereto the Extension Certificate.

The Company has also arranged for an exchange of the bonds of the Toledo Consolidated Street Railway Company and the Toledo Electric Street Railway Company for extended bonds of the Toledo Traction Company. Holders of bonds of the Toledo Consolidated Street Railway Company desiring to avail themselves of the privilege of exchanging their bonds for such extended bonds of the Toledo Traction Company must present same (ex-coupon due January 1, 1912), for such purpose at the office of Blair \& $\mathrm{Co}$. on or before December 28, 1911. Holders of the said bonds of the Toledo Electric Street Railway, desiring to avail themselves of the privilege of exchanging their bonds for such extended bonds of the Toledo Traction Company, must present the same (with coupon due February 1, 1912), for such purpose at the office of Blair \& Co. on or before January 28, 1912, interest to be adjusted to date of exchange.

Holders of the said bonds of the Toledo Consolidated Street Railway Company and of the Toledo Traction Company who do not desire to avail themselves of the above privileges will receive par for their bonds upon delivery of the same on or after January 1, 1912, to said Blair \& Co.

${ }^{1}$ Advertisement in New York Times. 
Holders of the said bonds of the Toledo Electric Street Railway Company who do not desire to avail themselves of the above privileges will receive par for their bonds upon delivery of the same on or after February 1, 1912, to said Blair \& Co.

Copies of the Extension Agreement, stating the terms of the extension and other details, may be obtained at the Company's office or from Blair \& Co.

Dated Toledo, Ohio, December 15, 1911.

\section{THE TOLEDO RAILWAYS AND LIGHT COMPANY,} By Frank R. Coats, President.

Referring to the foregoing Notice, we are now prepared to receive deposits of the aforesaid bonds for exchange and extension. Holders of such bonds desiring to avail themselves of the privilege should deposit the same promptly at our office. Depositing Bondholders will receive receipts, exchangeable for extended bonds, as soon as the Extension. Certificate and Coupons ean be attached thereto. The privileges as to the bonds of the Toledo Consolidated Street Railway Company and the Toledo Traction Company will terminate on December 28, 1911. The privileges as to the bonds of the Toledo Electric Street Railway Company will terminate on January 28, 1912. All bonds of the Toledo Consolidated Street Railway Company and all bonds of the Toledo Traction Company, the holders of which do not wish to avail themselves of the above-mentioned privileges, will be purchased by us at par, on or after January 1, 1912. All bonds of the Toledo Electric Street Railway Company, the holders of which do not wish to avail themselves of the above-mentioned privileges, will be purchased by us, at par, on or after February 1, 1912.

BLAIR \& CO., 24 Broad Street, New York 


\section{CONVERSION OF BONDS INTO STOCK 1}

Section 1. Any of the bonds issued hereunder may be converted at the option of the bearer or registered holder thereof at any time after the first day of November, 1913, until, but not including, the date of maturity of such bond, or if such bond is called for redemption, until, but not including the date fixed for redemption, into shares of the par value of $\$ 100$ each of the full-paid common capital stock of the Company as its authorized capital stock shall be constituted at the time of such conversion at the rate of $\$ 100$ principal amount of bonds for one share of stock; and on presentation and surrender to it at its office or agency in the City of New York, of such bond with all unmatured coupons thereto appertaining for conversion, the Company will deliver in exchange therefor certificates for said shares of the common capital stock of the Company at the rate aforesaid.

The Company shall not be required to convert any bonds into stock while its stock transfer books are closed for any meeting of stockholders, or for the payment of dividends, or for any other purpose, and the right of conversion shall be suspended during such periods, provided, however, that the right of conversion shall not at any one time be so suspended for a longer period than twenty days.

All bonds surrendered for conversion as aforesaid, and all unmatured coupons appertaining to any of said bonds, shall at once become null and void and shall be cancelled and deposited with the Trustee.

SEc. 2. The Company covenants and agrees that at all times there shall be reserved unissued, exclusively for the conversion of said bonds, Five Million Dollars $(\$ 5,000,000)$ par value of the common capital stock of the Company or such part thereof as may be necessary for the conversion of all said bonds as herein provided, which are then outstanding, or may thereafter be issued hereunder, and that said stock shall not be issued or used for any other purpose.

SEC. 3. Nothing herein contained shall prevent the Company from increasing from time to time its present authorized or outstanding stock or from issuing preferred stock or different classes of stock.

1 From Mortgage of Atlantic Fruit and Steamship Company to Knickerbocker Trust Company, Trustee. Dated November 1, 1911. 
SEc. 4. In case any corporation duly becomes the sole successor of the Company, in accordance with the provisions of Article Fourteen of this indenture, all references contained in this Article to the common capital stock of the Company shall be deemed to refer to the common capital stock of such successor corporation, and evcry other reference contained in this Article to the Company shall be deemed to refer to such successor corporation. This provision shall not be construed to limit in any manner the application of Section 3 of Article Fourteen to all of the provisions of this indenture. 
Spencer Trask \& Co. Bankers

William and Pine Sts. New York

CONVERTIBLE BONDS (FOURTH EDITION)
CABLE ADDREBS, "TRABI".

JUNE 11, 1907

Convertible bonds are usually secured by a direct lien, at a fixed rate of interest, upon the property of the issuing company, and in addition, holders of such bonds have the right to convert them into stock, in accordance with the terms of conversion, at such time as they may elect. When it is considered that the prices for stocks reflect to a greater extent than other security issues the increase and growth of the business of corporations, the strong probability of holders of convertible bonds realizing substantial profits becomes readily apparent.

The very heavy declines which have taken place in the security markets are largely responsible for the study being given properly selected convertible bonds by well-informed investors. In order to aid in selecting such investments, we describe herein practically all of the convertible bonds now upon the market, although, of course, we do not recommend the purchase of all of the issues as suitable for conservative buyers.

One of the strongest features in connection with convertible bonds is aptly illustrated by existing conditions in the stock market; that is, when, as now, stocks have declined considerably below the conversion figures, convertible bonds, other things being equal, decline only to approximately the same level as other junior fixed liens of the issuing company. The reason for this is that convertible bonds, viewed from the standpoint of security, are usually just as valuable as any of the other junior liens of the issuing company. Therefore, at the present time, convertible bonds are being purchased upon the basis of their security value, the conversion privilege being ignored as of remote advantage. There may, therefore, be considered a certain level below which convertible bonds will not decline. When, however, the market for stocks begins to advance, convertible bonds advance also. If the right to convert actually exists, it is obvious that the prices of convertible bonds will practically coincide with the quotation for the stock of the same issuing company. But, even if the date of conversion is not immediately at hand, when the stock advances to figures above the conversion prices, it is usually the case that convertible bonds also move with the stock, and sell at considerably higher prices than the junior liens or the prior liens of the same company, there being practically no limit to the figures to which they may advance.

A study of the history of convertible bonds will show that investors have often made as large a profit at $50 \%$ or more. Therefore, during 
such abnormal times as these, when prices are so low, it seems reasonable to believe that in some cases the extraordinary results may be repeated. In our judgment, where the management, general conditions and prospects of a corporation are good, its convertible bonds may be bought with safety, and also with the probability of greater profits being realized than from any other form of corporate obligations.

(1) THE ATCHISON, TOPEKA \& SANTA FE RAILWAY COMPANY.

Fifty Year Four Per Cent. Convertible Bonds.

Dated February 9, 1905. Due June' 1, 1955. Interest payable June and December 1st. In coupon form, $\$ 1,000$ each. In registered form $\$ 1,000$, $\$ 5,000$, or any multiple thereof. The Morton Trust Company, New York, Trustee. Authorized issue, $\$ 50,000,000$. Outstanding, $\$ 48,952,000$. Convertible after June 1, 1906, but prior to June 1, 1918, into common stock at (par value, $\$ 100$ ) and subject to redemption at 110 and interest, but if called for payment prior to June 1, 1918, may be converted into stock.

The proceeds from sale of these bonds are to be used to complete lines under construction, build additional branehes, second tracks, reduction of grades on main line, additional equipment, etc. The indenture stipulates that no new mortgage on lines owned January 1, 1905, shall be made without securing the convertible bonds thereunder.

For the fiscal year ending June 30,1906 , the Company reports a total net income of $\$ 28,335,393$, out of which there was paid for fixed charges, ineluding interest on adjustment bonds, $\$ 10,622,184$, leaving a surplus of $\$ 17,733,209$. The $\$ 114,173,7305 \%$ preferred stock receives regular dividends. The $\$ 102,759,000$ common stock outstanding reeeives div. idends at the rate of $6 \%$ per annum. On January 30,1907 , the stockholders approved the proposition to increase the authorized common stock from $\$ 152,000,000$ to $\$ 200,000,000$; also to authorize an issue, in lieu of eommon stock, of bonds convertible into common stock at the option of the holder during a term of ten ycars.

(2) THE ATCHISON, TOPEKA \& SANTA FE RAILWAY COMPANY.

Ten Year Five Per Cent. Convertible Gold Bonds.

Dated May 9, 1907. Due June 1, 1917. Interest payable June and December 1st. In coupon form $\$ 1,000$ each. In registered form $\$ 1,000$, $\$ 5,000$, or any multiple thereof. Coupon bonds may be exehanged for registered bonds and registered bonds for eoupon bonds. Redeemable on any interest date at 110 and interest. Convertible into common stock prior to June 1, 1913, at the option of the holder, on the basis of ten shares of common stock (par value $\$ 100$ ) for each $\$ 1,000$ bond. If called for. redemption prior to expiration of conversion period, holders may convert in licu of taking cash. Authorized issue, $\$ 35,000,000$. Present issue, about $\$ 26,000,000$. (See carnings given above.)

(3) THE BROOKLYN RAPID TRANSIT SYSTEM.

First Refunding Mortgage Four Per Cent. Oonvertible Gold Bonds.

Dated July 1, 1902. Due July 1, 2002. Interest payable January and July 1st. Redeemable at 110 and interest before July 1, 2000. In 
coupon form, $\$ 1,000$ each, with privilege of registration. Authorized issue, $\$ 150,000,000$. Outstanding, $\$ 25,835,000$. Convertible into capital stock at any time after July 1, 1904, and before July 1, 1915, on the basis of ten shares (par value $\$ 100$ ) for each $\$ 1,000$ bond.

These bonds will retire all of the existing bonds of the system, and provide for improvements, additions, etc., as needed from time to time. For the fiscal year ending June 30, 1906, the net earnings of the system are reported as $\$ 7,473,024$, with fixed charges (net) $\$ 4,730,072$, special appropriation and miscellaneous items $\$ 580,343$, balance $\$ 2,162,609$. The outstanding capital stock is $\$ 45,000,000$, all common.

(4) THE DELAWARE AND HUDSON COMPANY.

Ten Year Debenture Four Per Cent. Convertible Gold Bonds.

Dated June 15, 1906. Due June 15, 1916. Interest payable June and December 15th. In coupon form, $\$ 1,000$ each, with privilege of registration. Issue, $\$ 14,000,000$. Convertible into the capital stock of the Company from June 15, 1907, to June 15, 1912, on the basis of five shares of stock ( $p a r$ value $\$ 100$ ) for each $\$ 1,000$ bond.

On February 19, 1906, the stockholders of the Company were given the right to take at par $\$ 1,000$ debenture bond for every 30 shares of stock. The proceeds enabled the Company to pay for additional equipment, the cost of electric railway lines in Albany, Schenectady, Rensselaer and Saratoga Counties, and of making certain extensions thereof, and of providing the means for making needed improvements upon the railways operated by it in Pennsylvania.

The outstanding stock of the Delaware and Hudson Company is \$41,493,500 , and the dividend record since 1883 is as follows: $1884,7 \%$; $1885,6 \%$; 1886 and $1887,5 \% ; 1888,6 \%$; 1889 to 1896 , inclusive, $7 \%$; 1897 to 1900 , inclusive, $5 \%$; 1901 to 1906 , inclusive, $7 \%$; dividends for 1907 are fixed at 9\%, payable quarterly March 15th.

\section{(5) THE ALBANY AND SUSQUEHANNA RAILROAD COMPANY.}

Forty Year Convertible Three and One-Half Per Cent. Gold Bonds.

Dated April 1, 1906. Due April 1, 1946. Guaranteed both as to principal and interest by the Delaware and Hudson Company by endorsement. Interest payable April and October 1st. In coupon form, $\$ 1,000$ each, with privilege of registration. Issue, $\$ 10,000,000$. Convertible into the capital stock of the Delaware and Hudson Company at any time prior to April 1, 1916, on the basis of five shares of stock (par value $\$ 100$ ) for each $\$ 1,000$ bond.

On May 29, 1905, the stockholders of the Delaware and Hudson Com. pany were given the right to take at par $\$ 1,000$ forty year convertible $31 / 2 \%$ bond for every 45 shares of stock. The proceeds retired $\$ 10,000$,000 consolidated mortgage $7 \%$ and $6 \%$ bonds of the Albany and Susquehanna Railroad Company, due April 1, 1906. The road extends from Binghamton to Albany, N. Y., about 142 miles, and the Company operates the line from Cobleskill to Cherry Valley, about 21 miles. The Delaware and Hudson Company owns $\$ 450,000$ of the $\$ 3,500,000$ stock, and guarantees dividends at the rate of $9 \%$ per annum upon the entire $\$ 3,500,000$ stock.

(See dividend record of $D$. \& H., given above.) 
(6) THE ERIE RAILROAD COMPANY.

Four Per Cent. Convertible Fifty Year Gold Bonds.

Series A, $\$ 10,000,000$ dated April 1, 1903. Series B, $\$ 12,000,000$ dated April 1, 1905. Due April 1, 1953. Interest payable April and October 1st. In coupon form, $\$ 1,000$ each. In registered form, $\$ 500, \$ 1,000$ or multiples thereof. The Standard Trust Company, of New York, Trustee. Authorized issue, $\$ 50,000,000$. Series $A$ convertible at par into common stock at $\$ 50$ per share from April 1, 1905, to April 1, 1915. Series B convertible at par into common stock at $\$ 60$ per share from October 1 , 1907, to October 1, 1917.

These bonds are secured by a mortgage upon all of the property of the Company, subject to underlying liens. The $\$ 22,000,000$ bonds outstanding were issued to provide funds for improvements and new equipment.

For the fiscal year ending June 30, 1906, the Company reports a total net income of $\$ 14,667,098$, out of which there was paid for interest, rentals, etc., $\$ 9,650,454$, and for additions and improvements $\$ 1,915,696$, leaving a surplus of $\$ 3,100,948$. Dividends at rate of $4 \%$ per annum are paid upon $\$ 47,892,400$ first preferred and $\$ 16,000,000$ second preferred stock. The amount of common stock outstanding is $\$ 112,378,000$.

(7) THE NEW YORK, NEW HAVEN AND HARTFORD RAILROAD COMPANY.

Convertible Three and One-Half Per Cent. Gold Bonds.

Dated January 1, 1906. Due January 1, 1956. Interest payable January and July lst. In coupon form, $\$ 100, \$ 500$ and $\$ 1,000$ each, with privilege of registration. Issue, $\$ 30,000,000$. Convertible into the capital stock of the Company between January 1, 1911, and January 1, 1916 , or within thirty days thercafter on the basis of one share (par value $\$ 100$ ) for each $\$ 150$ in bonds.

The Company has an authorized issue of $\$ 100,000,000$ stock, of which $\$ 80,000,000$ is outstanding. From 1873 to 1893 the dividend rate was $10 \%$ per annum, $9 \%$ in 1894 , and from 1895 to 1906 , inclusive, $8 \%$ per annum.

(8) THE NORTHWESTERN ELEVATED RAILROAD COMPANY.

First and Refunding Mortgage Four Per Cent. Convertible Gold Bonds.

Dated 1901. Due September 1, 1911. Interest payable March and September 1st. In coupon form, $\$ 1,000$ each, with privilege of registration as to principal and interest. Redecmable at the option of the Company at $102 \frac{1}{2}$ and interest on or after September 1, 1906. Authorized issue, $\$ 25,000,000$. Outstanding, $\$ 18,000,000$. Convertible at the option of the holder into $5 \%$ preferred stock on the basis of ten shares (par value $\$ 100)$ for each $\$ 1,000$ bond. If called for redemption the holders vill have the right to take preferred stock in licu of cash. Authorized issue of $5 \%$ non-eumulative preferred stock, $\$ 25,000,000$; outstanding, $\$ 5$,000,000 .

The Northwestern Elevated extends through the "North Side" of the City of Chicago, which has a population of about 600,000 . The above bonds are secured by a first mortgage on the Northwestern Elevated 
Railroad and are a lien also on the "Union Loop," now owned by the Northwestern Elevated Railroad Company. By virtue of its ownership of the "Union Loop" the Northwestern shares the increased earnings of all other elevated roads in Chicago. The company is operating under a fifty-year franchise, granted in 1894, and, with the exception of about one mile, the entire right of way is owned in fee. Total net income for fiscal year ending June 30, 1906, \$1,243,154; fixed charge6, $\$ 962,656$; surplus, $\$ 280,498$.

\section{(9) THE PENNSYLVANIA RAILROAD COMPANY.}

Three and One-Half Per Cent. Ten Year Convertible Gold Bonds.

Dated November 1, 1902. Due November 1, 1912. Interest payable May and November lst. In coupon form, $\$ 500$ and $\$ 1,000$ each. In registered form, $\$ 500, \$ 1,000, \$ 10,000$ or multiples thereof. The Girard Trust Company, of Philadelphia, Pa., Trustee. Authorized issue, \$50,000,000. Outstanding, $\$ 20,000,500$. Redeemable after May 1, 1904, at $102 \frac{1}{2}$ and accrued interest. Convertible on May 1, 1904, or any halfyearly interest date thereafter prior to maturity on thirty days' notice, into stock of the Railroad Company at rate of $\$ 70$ per share (par value $\$ 50)$, but may be converted if called for payment.

These bonds were issued for corporate purposes, and of the authorized issue $\$ 29,999,500$ were converted into stock up to December 31, 1906. For the year ending December 31, 1906, the Railroad Company reports a total net income of $\$ 51,917,601$, out of which there was paid for interest, taxes, rentals, etc., $\$ 16,243,300$, for sinking funds and miscellaneous items $\$ 357,126$, for payments on account of principal of car trusts $\$ 4,246,039$, for extraordinary expenditures $\$ 8,701,475$, transferred to extraordinary expenditure fund $\$ 2,500,000$, and for dividends upon capital stock $\$ 19,869,660$. The outstanding capital stock is $\$ 305,951,350$, upon which dividends at the rate of $7 \%$ per annum are paid.

\section{(10) THE' PENNSYLVANIA RAILROAD COMPANY.}

Ten Year Three and One-Half Per Cent. Convertible Gold Bonds.

Dated October 2, 1905. Due October 1, 1915. Interest payable June and December 1st, except that two months' interest to December 1st, 1905, shall be payable on that date and four months' interest from June lst to October 1st, 1915, shall be payable on the latter date. In coupon form, $\$ 500$ and $\$ 1,000$ each. In registered form, $\$ 1,000$ and $\$ 5,000$ each, with such larger denominations as may be authorized. The Girard Trust Company, of Philadelphia, Pa., Trustee. Authorized issue, $\$ 100,000,000$. Outstanding, $\$ 99,624,500$. Redeemable at the option of the Company on and after December 1, 1910, on 90 days' notice, at par and accrued interest. Convertible after December 1, 1905, and prior to maturity, into capital stock of the Railroad Company, at the rate of $\$ 75$ per share (par value $\$ 50$ ). If the bonds are called for redemption the right to convert into stock will be had up to thirty days prior to the date named for redemption.

These bonds were issued for corporate purposes. A part of the proceeds was used to retire $\$ 27,480,0006 \%$ bonds maturing in June and July, 1905, and the balance for improvements. (See earnings given above.) 


\section{(11) THE UNION PACIFIC RAILROAD COMPANY.}

Twenty Year Four Per Cent. Convertible Gold Bonds.

Dated July 1, 1907. Due July 1, 1927. Interest payable January and July lst. In coupon form $\$ 500$ and $\$ 1,000$ each, with privilege of registration as to principal and exchangeable for registered bonds without coupons. Registered bonds exchangeable for coupon bonds. Entire issue, but not any part thercof, redeemable on and after July 1, 1912, on ninety days' notice, at $1021 / 2$ and interest. Convertible at the option of the holder at any time prior to July 1, 1917, into common stock on the basis of $\$ 175$ per share. If called for payment during the conversion period, bonds may be converted up to 30 days prior to the date named in the redemption notice. Issue, $\$ 75,000,000$.

The Union Pacific Railroad pays regular $4 \%$ dividends upon \$99,544,100 preferred stock, and dividends at the rate of $10 \%$ per annum upon $\$ 195,446,900$ common stock.

\section{(12) WESTERN MARYLAND RAILROAD COMPANY.}

General Lien and Convertible Four Per Cent. Gold Bonds.

Dated October 1, 1002. Due October 1, 1952. Interest payable April and October 1st. In coupon form, $\$ 1,000$ each. Principal may be regis. tered. The Bowling Green Trust Company, of New York, Trustee. Authorized and outstanding, $\$ 10,000,000$. Convertible at the option of the holder at any time into common stock at par (par value $\$ 50$ ) at the rate of 20 shares for each $\$ 1,000$ bond.

The Western Maryland Railroad Company comprises about 534 miles of road extending from extensive terminals in the city of Baltimore and on Baltimore Harbor to Elkins and Durbin, W. Va., at which latter point connection is had with the Chesapeake and Ohio Railway Company. These bonds are a mortgage (either directly or through the ownership of practically all of the capital stocks of various proprietary Companies) upon about 515 miles, subject to underlying liens, including an authorized issue of $\$ 50,000,000$ first mortgage $4 \mathrm{~s}$, due 1050 , of which $\$ 39,576,000$ are outstanding. For the year ending December 31, 1906 , the total net income is reported as $\$ 2,498,527$; fixed charges, $\$ 2$,247,018 ; surplus, $\$ 251,509$. The outstanding common stock is $\$ 15$,685,400 .

\section{(13) AMERICAN TELEPHONE AND TELEGRAPH COMPANY.}

Convertible Four Per Cent. Gold Bonds.

Dated March 1, 1906. Due March 1, 1936. Interest nayable March and September 1st. Redeemable on and after March 1, 1914, at 105 and accrued interest, on twelve wceks' noticc. In coupon form, $\$ 1,000$ each, with privilege of registration. Authorized issue, $\$ 150,000,000$. Outstanding, $\$ 40,000,000$. Convertible at par into capital stock at $\$ 140$ per share (unless additional stock be issucd or sold at less than $\$ 140$ per share, in which case bondholders will have the bencfit of a reduced conversion price) aftcr March 1, 1909, and before March 1, 1918, and in the mcantime up to thirty days prior to date of redemption, if called for payment.

The Company also has outstanding $\$ 53,000,000$ collateral trust $4 \%$ bonds, due 1929, $\$ 20,000,000$ collateral trust 5\% notes, due May 1, 1907 
(secured by deposit of $\$ 25,000,000$ collateral trust mortgage $4 \%$ bonds) and $\$ 25,000,0005 \%$ notes, due January 1,1910 . The authorized amount of capital stock is $\$ 250,000,000$, all common, of which $\$ 131,551,400$ is outstanding, excluding $\$ 27,110,400$ held by the American Bell Telephone Co. and virtually unissued. The stock has received dividends from April, 1900, to April, 1906, at the rate of $71 / 2 \%$ per annum, since which time the distribution has been at the rate of $8 \%$ per annum. Its predecessor, the American Bell Telephone Company, has paid dividends at an equivalent of $71 / 2 \%$ or more each year from 1884 to 1900 .

\section{(14) THE BROOKLYN UNION GAS COMPANY.}

\section{Convertible Debenture Six Per Cent. Gold Bonds.}

Dated 1904. Due March 1, 1909. Interest payable March and September lst. In coupon form, $\$ 500$ and $\$ 1,000$ each. Issue, $\$ 3,000,000$. Convertible at the option of the holder on and after March 1, 1907, on any interest date, into capital stock, on the basis of ten shares (par value $\$ 100$ ) for each $\$ 1,000$ bond.

The Company has outstanding $\$ 14,647,000$ first consolidated mortgage $5 \%$ bonds, and an authorized capital stock issue of $\$ 20,000,000$, of which there is outstanding $\$ 15,000,000$. Following is the annual dividend record: 1896 to $1900,6 \% ; 1901$ to $1903,8 \% ; 1904,9 \frac{1}{2} \% ; 1905$, $81 / 2 \% ; 1906,3 \%$. On July, 1906, dividend payments were discontinued.

\section{(15) THE' CONSOLIDATED GAS COMPANY OF NEW YORK.}

\section{Six Per Cent. Convertible Debenture Gold Bonds.}

Dated July 1, 1904. Due July 1, 1909. Interest payable January and July 1st. In coupon form, $\$ 1,000$ each, with privilege of registration. Authorized and outstanding, $\$ 20,000,000$. Convertible into capital stock on and after July 1, 1907, and on any subsequent interest date prior to July 1, 1909, on the basis of 10 shares (par value $\$ 100$ ) for each $\$ 1,000$ bond.

The Company controls the gas and electric lighting business in the Boroughs of Manhattan and the Bronx of Greater New York. The authorized capital stock of the Company is $\$ 100,000,000$, of which $\$ 80$,000,000 is outstanding. The dividend record is as follows: $1892,6 \%$; $1893,7 \%$; 1894 to 1898 , inclusive, $8 \% ; 1899,51 / 2 \% ; 1900,6 \% ; 1901$ to 1903 , inclusive, $8 \% ; 1904$ and $1905,81 / 2 \% ; 1906,5 \%$. Present dividends are at the rate of $4 \%$ per annum.

\section{(16) THE DETROIT EDISON COMPANY.}

Five Year Six Per Cent. Convertible Gold Debenture Bonds.

Dated September 1, 1906. Due September 1, 1911. In coupon form, $\$ 1,000$ each. Interest payable March and September 1st. Subject to redemption at the option of the Company after September 1, 1910, at par and accrued interest. Convertible after September 1, 1908, into full paid stock of the Company at par at option of the holder. Authorized issue, $\$ 1,000,000$. Outstanding, $\$ 660,000$.

There are also outstanding $\$ 6,600,000$ (authorized issue $\$ 10,000,000$ ) first mortgage $5 \%$ bonds, due January 1, 1933, secured upon the entire property and franchise of the Company. The Company does all of the 
commercial lighting and industrial power business in the city of Detroit, with a population in excess of 300,000 . A new central steam turbine station-one of the most highly equipped and eflicient ever con. structed, with an immediate installation of machinery of 20,000 rated horse-power capacity-is now in operation and produces the company's entire output of current, which is distributed economically through nine modern substations. This station is favorably situated on a large tract of land on the Detroit River, and is accessible to four railroads and to the river channel. The property on which it is built is suffciently large to admit of the construction of additional stations from time to time, as required to meet the growing demands of the conpany. A. well-developed system of underground distribution is in use in the commercial district, and owing to the rapid growth of the city a large amount of new business is being connected to the company's circuits.

For the year ending December 31, 1906, the Company reports gross income, $\$ 1,126,316$, operating expenses, taxes, etc., $\$ 655,688$, bond interest, $\$ 299,857$, surplus, $\$ 170,771$. The authorized capital stock is $\$ 6,000,000$, of which $\$ 5,000,000$ is outstanding.

\section{(17) THE DISTILLERS' SECURITIES CORPORATION.}

\section{First Mortgage Five Per Cent. Convertible Gold Bonds.}

Dated April 1, 1902. Due April 1, 1927. Interest payable April and October lst. In coupon form, $\$ 1,000$ each, with privilege of registration. Redecmable on any intercst day on and after Oetober 1, 1908, at 105 and interest. The Mercantile Trust Company, New York City, Trustee. Convertible into the capital stock of the Corporation, on any interest date on or at any time prior to October 1, 1912, at the rate of ten shares of stock (par value $\$ 100$ ) for each $\$ 1,000$ bond. Authorized issue, $\$ 16,000,000$. Outstanding $\$ 13,763,998$.

These bonds are secured by pledge with the Trustee of $\$ 28,860,000$, par value, of the preferred stock (over $90 \%$ of the total issue), and $\$ 44,125,000$, par value, of the common stock (over $92 \%$ of total issue) of the Distilling Company of America; also by pledge of $\$ 11,000$ first mortgage $6 \%$ bonds of the American Spirits Manufacturing Company.

Of the unissued balance of the first mortgage $5 \%$ bonds of the Distillers Securities Corporation, $\$ 1,510,000$ are reserved to retire a like amount of first mortgage $6 \%$ bonds of the American Spirits Manufac. turing Company, due September 1,1915 , and a sufficient amount is also reserved to retire about $\$ 637,299$ unassented stoek of the Distilling Company of America.

The companies controlled by the Distilling Company of America manufacture, distribute and sell spirits, alcohol, Kentucky or Bourbon whiskey, rye whiskey, and compound and blend the same. The operating companies are the American Spirits Manufacturing Company, the Kentucky Distilleries and Warehouse Company and the Iannis Dis. tilling Company. The Standard Distilling and Distributing Company was dissolved in 1905 , resulting, it is oflicially stated, in a material saving in taxes, office expenses, etc.

For the fiseal year ending June 30, 1906, the Distillers Securities Corporation reports total net profits of $\$ 2,847,070$, out of which there was paid for interest $\$ 750,006$ and $4 \%$ dividends upon the cnpital stock 
$\$ 1,327,036$, leaving a surplus of $\$ 797,028$. The corporation has outstanding $\$ 30,435,943$ capital stock, all one class.

(18) THE INTERNATIONAL PAPER COMPANY.

First Consolidated Mortgage Six Per Cent. Sinking Fund Convertible Gold Bonds.

Dated 1898. Due February 1, 1918. Interest payable February and August 1st. In coupon form, $\$ 1,000$ each, with privilege of registration. Redeemable on and after February 1, 1908, at 105 and interest, and an annual sinking fund of $\$ 150,000$ became operative February 1, 1905. Bonds may be draun by lot at 105 and interest for the account of sinking fund, if not offered by holders. Authorized issue, $\$ 10,000,000$. Outstanding, $\$ 9,771,000$. Convertible on any interest day on or before August 1,1910 , into preferred stock, on the basis of 10 shares (par value $\$ 100$ ) for each $\$ 1,000$ bond.

The Company has an authorized issue of $\$ 25,000,0006 \%$ cumulative preferred stock, of which $\$ 22,406,700$ is outstanding. The authorized amount of common stock is $\$ 20,000,000$, of which $\$ 17,442,800$ is outstanding. Dividends at the rate of $6 \%$ per annum have been paid upon the preferred stock since July, 1898. On December 31, 1898, 1\% was paid on the common stock, and $2 \%$ on December 31,1899 . For the fiscal year ending June 30, 1906, the Company reports net earnings of $\$ 3,158,519$, taxes, insurance and interest, $\$ 1,172,978$, dividends on preferred stock, $\$ 1,344,402$, surplus, $\$ 641,139$.

\section{(19) THE INTERNATIONAL PAPER COMPANY.}

Consolidated Mortgage Five Per Cent. Sinking Fund Convertible Gold Bonds.

Dated January 3, 1905. Due January 1, 1935. Interest payable January and July 1st. In coupon form, $\$ 1,000$ each, with privilege of registration. A sinking fund of $2 \%$ of all bonds ever issued is pay. able yearly, beginning with January 1, 1908, for which bonds are subject to call at 105 and interest beginning with January 1, 1910. Bonds may be drawn by lot at 105 and interest for the account of sinking fund, if not offered by holders. Authorized issue, $\$ 10,000,000$. Outstanding, $\$ 6,000,000$. Convertible into preferred stock on any interest. day beginning July 1, 1907, and before 1917, on the basis of 10 shares (par value $\$ 100$ ) for each $\$ 1,000$ bond.

The outstanding bonds were sold to reimburse the treasury for surplus earnings used for improvements, and to provide working capital. The remaining $\$ 4,000,000$ bonds are reserved for the future uses of the Company. (See earnings and dividend record given above.)

\section{(20) THE INTERNATIONAL STEAM PUMP COMPANY.}

Six Per Cent. Convertible Debenture Gold Bonds.

Dated January 1, 1903. Due January 1, 1913. Interest payable January and July Ist. In coupon form, $\$ 1,000$ each, with privilege of registration. The Colonial Trust Company, of New York City, Trustee. Authorized and issued, $\$ 3,500,000$. Redeemable on or after Jan- 
wary 1, 1908, at 105 and accrued interest. Convertible into common stock at any time before redemption or maturity on the basis of ten shares (par value $\$ 100$ ) for each $\$ 1,000$ bond.

The indenture stipulates that the Company will not mortgage any of its property, so long as any of the debenture bonds are outstanding, without including in such mortgage and subjecting to the lien thereof, all the debentures of this issue then outstanding, nor without securing said debentures pari passu with all other debts and obligations that may be secured by such mortgage.

The Company is estimated to do $90 \%$ of the stcam pump business of the country, exclusive of high duty engines.

For the fiscal year ending March 31, 1906, the Company reports net profits of $\$ 1,849,744$, with interest charges of $\$ 392,149$. There is outstanding $\$ 17,262,500$ preferred stock and $\$ 11,250,000$ common stock. Dividends at rate of $6 \%$ per annum have been paid on the preferred stock since 1899. From July, 1901, to 1904, inclusive, the common stock received 1\% quarterly; October, 1904, 1/2\%; January and April, $1905,1 / 2 \%$.

\section{(21) THE LACKAWANNA STEEL COMPANY.}

\section{First Mortgage Convertible Five Per Cent. Gold Bonds.}

Dated April 1, 1903. Due April 1, 1923. Interest payable April and October 1st. In coupon form, $\$ 1,000 \mathrm{each}$, with privilege of registration. The Farmers' Loan and Trust Company, of New York City, Trustee. Issue limited to $\$ 15,000,000$, all outstanding. Redeemable at the option of the Company at 1071/2 and interest to April 1, 1906, on 60 days' notice. Convertible into common stock, after April 1, 1906, and up to A pril 1, 1915, on the basis of ten shares (par value $\$ 100$ ) for each $\$ 1,000$ bond, if not redeemed A pril 1, 1906.

These bonds are a first mortgage upon the manufacturing plant and appurtenances of the Company in Hamburg and West Seneca, N. Y., and also upon the stocks of other corporations owned. In addition, the Company owns ore properties in Michigan, Minnesota, Wisconsin, and New York; coal lands and rights in Pennsylvania, and blast furnaces and coke ovens at and near Lebanon, $\mathrm{Pa}$. The cost of the property as of December 31, 1903, was stated as $\$ 34,319,071$.

The Company also has an authorized issue of $\$ 30,000,000$ first consolidated 5s, due March 1, 1935, of which $\$ 15,000,000$ are reserved for the redemption of the first mortgage $5 \mathrm{~s}, \$ 12,500,000$ being the collateral to secure $\$ 10,000,0005 \%$ notes, due March 1, 1910 (all of the notes are outstanding) and $\$ 2,500,000$ being available for the proper corporate purposes of the Company. There are also outstanding $\$ 1,775$, 000 first mortgage $5 \mathrm{~s}$ of the Lackawanna Iron and Steel Company, due February 1, 1926. The authorized issuc of capital stock is $\$ 60,000,000$. all common, of which there is outstanding $\$ 34,071,400$.

\section{(22) THE UNITED FRUIT COMPANY.}

Ten Year Debenture Five Per Cent. Gold Bonds.

Due September 1, 1911. Interest payable March and September 1st. In coupon form, $\$ 1,000$ each. Redcemable at 110 and interest. Out- 
standing, $\$ 1,820,000$. Convertible into capital stock at the option of the holder on the basis of ten shares (par value $\$ 100$ ) for each $\$ 1,000$ bond.

The Company has an authorized stock issue of $\$ 20,000,000$, of which there is outstanding $\$ 17,961,000$. Following is the annual dividend record: October, I899, 21/2\%; 1900, 10\%; 1901, 8\%; 1902 to 1906, inclusive, $7 \%$. For the fiscal year ending September 30, 1906, the Company reports a total net income of $\$ 3,900,887$, interest on bonds, $\$ 114,354$, dividends on preferred stock, $\$ 1,235,745$, surplus, $\$ 2,550,788$.

(23) THE UNITED STATES REALTY AND IMPROVEMENT COMPANY.

\section{Convertible Debenture Five Per Cent. Gold Bonds.}

Dated July 1, 1904. Due July 1, 1924. Interest payable January and July Ist. Redeemable at 105 and interest. In coupon form, $\$ 1,000$ each, with privilege of registration. Authorized issue, $\$ 13,506,000$. Outstanding, $\$ 13,284,000$. Convertible into capital stock up to July 1 , 1908, on 90 days' prior notice in uriting, on the basis of ten shares (par value $\$ 100$ ) for each $\$ 1,000$ bond. At the time of giving notice of conversion bondholders must deposit bonds with the New York Trust Company.

Capital stock authorized, $\$ 30,000,000$; outstanding, $\$ 16,162,800$. There is also outstanding $\$ \$ 76,900$ stock of subsidiary companies. For the fiscal year ending April 30, 1906, the Company reports net income, $\$ 1,445,935$, interest and dividends on stock of subsidiary companies, $\$ 680,789$, surplus, $\$ 765,146$.

\section{(24) THE WESTERN UNION TELEGRAPH COMPANY.}

\section{Convertible Four per Cent. Gold Bonds.}

Dated January 2, 1907. Due November 1, 1936. Interest payable May and November lst, but the first payment for interest will be for four months only, from January 2, 1907, to May 1, 1907. Redeemable at 105 and interest on and after May 1, 1912. In coupon form, $\$ 1,000$ each. Registered bonds without coupons, $\$ 1,000, \$ 5,000$ and $\$ 10,000$ each. Authorized issue, $\$ 25,000,000$. Outstanding, $\$ 10,000,000$. Convertible at the option of holders, or registered owners, into the capital stock of the Company after January 2, 1909, and before January 2, 1919, on the basis of ten shares of stock (par value $\$ 100$ ) for each $\$ 1,000$ bond. If called for payment, bonds may be converted within said period up to thirty days prior to redemption date.

These bonds are secured by pledge of collateral, the total bonds outstanding at any time not to exceed $85 \%$ of the appraised value of the collateral. The authorized capital stock of the Company has been increased from $\$ 100,000,000$ to $\$ 125,000,000$ to provide for conversion of the bonds. The outstanding bonds provide for construction of new lines and wires and purchase of new property.

For the fiscal year ending June 30, 1906, the Company reports net revenue $\$ 7,070,582$, interest $\$ 1,327,975$, dividends on outstanding stock $\$ 4,868,088$, surplus $\$ \$ 74,519$. Following is the dividend record since $1886: 1887,2 \% ; 1888$ and $1889,5 \% ; 1890,53 / 4 \% ; 1891,5 \% ; 1892$, $5 \%$ and $10 \%$ in stock; since which date the distribution has been at the rate of $5 \%$ per annum. 


\section{(25) THE WESTINGHOUSE ELFCTRIC AND MANUFACTURING COM-} PANY.

\section{Convertible Five Per Cent. Sinking Fund Gold Bonds.}

Dated January 1, 1906. Due January 1, 1931. Interest payable January and July 1 st. In coupon form, $\$ 1,000$ each, with privilege of registration. Beginning with December 31, 1907, an annual sinking fund of $\$ 500,000$ must be made for the purchase of bonds at not to exceed 105 and interest, or on and after January 1, 1912, for the redemption thereof. Authorized issue, $\$ 20,000,000$. Outstanding, $\$ 15,000$,000. Convertible into "assenting" stock after January 1, 1910, and up to 30 days prior to any date of redemption, on the basis of $\$ 500$ par value "assenting" stock for each $\$ 1,000$ bond. (The term "assenting" means that all but $\$ 3,650$ of the common stock agreed to participate in the plan for reorganizing the Company.) There is $\$ 20,966,350$ "assenting" stock outstanding. There is also $\$ 3,998,7007 \%$ cumulative preferred stock outstanding, which has preference as to assets and dividends. The preferred stock has the right to share equally with the "assenting" stock after the latter reeeives $7 \%$.

The outstanding bonds will provide for all the indebtedness of the Company, except $\$ 2,500,0005 \%$ gold debenture certificates and $\$ 6,000$, 000 collateral notes, due August 1, 1907. The $5 \%$ gold debentures will be provided for at maturity by reservation of $\$ 2,500,000$ convertible $5 \mathrm{~s}$; while it is expected that the $5 \%$ notes will be paid from a part of the collateral pledged as sccurity.

The indenture stipulates that the properties securing these bonds are free from mortgage, that no mortgage shall be placed thereon and that no additional notes or other bills payable shall be issued at any time. unless the average of the annual net earnings for the threc calendar years next preceding shall be at least double the amount of the annual interest upon the entire indebtedness of the Company at the date of such issue, including the bonds, collateral notes or other bills payable so to be issued; also that the Company will not issue any stock entitled to preference or priority over the "assenting" stock, and that none of its capital stock shall be distributed by way of stock dividends or issued at a price more than ten per cent. below the market price of the "assenting" stock at the time such stock is offered for subscription or sale.

Dividends at the rate of $10 \%$ per annum are paid upon $\$ 3,998,700$ preferred stock and $\$ 20,996,350$ assenting stock. For the five months ending August 31, 1906, net earnings, $\$ 2,002,258$, interest, adjustment, depreciation, etc., $\$ 576,265$, dividends $\$ 1,041,494$, surplus, $\$ 384,499$.

All statements made in this circular are obtained from reliable sources, and although we cannot guarantee their accuracy, we believe them to be correct.

SPENCER TRASK \& CO.,

State and James Streets,

Albany, N. Y.
William and Pine Streets,

New York. 
SPECIMEN OF OFFER TO PURCHASE BONDS WHERE THE MORTGAGE GIVES TRUSTEES THE RIGHT TO INVEST SINKING FUNDS IN BONDS. BONDS ARE NOT REDEEMABLE.

\section{Pennsylfania Coal \& Coke Company. ${ }^{1}$}

First Mortgage 5\% Bonds, Series "A" Sinking Fund.

Notice is hereby given that pursuant to the Sinking Fund provision of the above mortgage, dated July 1, 1902, proposals will be received at the office of the Commercial Trust Company, Trustee, 20 South Broad Street, Philadelphia, for the sale to the Trustee, of a sufficient number of bonds to consume the sum of $\$ 28,851.45$ now in the Sinking Fund, at a price not to exceed 105 per cent. and accrued interest. The right is reserved to reject any or all proposals in whole or in part.

Proposals should be sealed and marked "Proposals for the Sale of Pennsylvania Coal and Coke Company Series 'A' Bonds," and be presented to the undersigned before 12 o'clock noon on Tuesday, the 19th of December, 1911.

Commercial Trust Company, Trustee, W. А. ОвDYке, Treasurer.

Philadelphia, December 1, 1911.

\section{Louisville \& Nashville Railroad Company. ${ }^{2}$}

71 Broadway, New York.

November 27th, 1911.

Pensacola \& Atlantic R. R. Company 6\% Mortgage.

In accordance with the terms of the mortgage of the Pensacola \& Atlantic Railroad Company, the following eighty-seven (87) bonds have this day been drawn by the Trustees for the Sinking Fund, viz.:

\begin{tabular}{|c|c|c|c|c|c|c|c|}
\hline 26 & 280 & 540 & 885 & 1177 & 1408 & 1945 & 2236 \\
\hline 107 & 292 & 544 & 886 & 1190 & 1435 & 1960 & 2245 \\
\hline 157 & 332 & 557 & 904 & 1203 & 1469 & 1975 & 2264 \\
\hline 177 & 338 & 566 & 923 & 1232 & 1640 & 1990 & 2304 \\
\hline 213 & 357 & 579 & 935 & 1245 & 1672 & 1995 & 2308 \\
\hline 227 & 363 & 664 & 965 & 1248 & 1695 & 2077 & 2332 \\
\hline 230 & 432 & 671 & 982 & 1297 & 1799 & 2159 & 2334 \\
\hline 232 & 434 & 675 & 1033 & 1312 & 1816 & 2197 & 2399 \\
\hline 238 & 464 & 726 & 1052 & 1322 & 1822 & 2220 & 2436 \\
\hline 240 & 487 & 787 & 1058 & 1329 & 1852 & 2222 & 2465 \\
\hline 263 & 496 & 863 & 1151 & 1342 & 1912 & 2226 & \\
\hline
\end{tabular}

The interest on the same will cease February 1, 1912, and the principal of the bonds, plus ten per cent. premium, will be redeemed at this office on and after that date.

E. L. Smithers, Assistant Treasurer.

1 Notice advertised in New York Times of December 1, 1911.

2 Notice advertised in New York Times of December 11, 1912. 


\section{PUBLIC UTILITIES COMMISSION ACT OF NEW JERSEY.}

As Act concerning public utilities; to create a Board of Public Utility Commissioners and to prescribe its duties and powers.

BE IT ENAOTED by the Senate and General Assembly of the State of New Jersey:

1. There shall be a commission vested with the powers and duties hereinafter specified, which shall consist of three persons, citizens of this State, not under thirty years of age, who shall be appointed by the Governor, by and with the advice and consent of the Senate, and who shall constitute and be designated and known as the Board of Public Utility Commissioners.

2. The Board of Public Utility Commissioners, as heretofore constituted, shall be the Board of Public Utility Commissioners under this act until the expiration of the term of office of each of said commissioners respectively, and at the expiration of their respective terms a successor shall be appointed for the term of six years from the date of such expiration. All vacancies, except through expiration of term, shall be filled for the unexpired term only. The Governor may remove any commissioner for neglect of duty or misconduct in office, giving to him a copy of the charges against him and an opportunity of being publicly heard in person or by counsel in his own defense upon not less than ten days' notice.

3. The members of said board shall each receive an annual compensation of seven thousand five hundred dollars, to be paid in equal monthly payments by the Treasurer or the State.

4. The commissioners and secretary and other employes of said board shall be entitled to receive from the State of New Jersey their necessary traveling expenses while traveling on the business of said board, which shall be paid on proper voucher therefor, approved by the president of said board.

5. The board shall organize annually by the election of a president; it shall appoint a secretary, counsel and such other employes as it may deem necessary, fix their duties, compensation and terms of service.

6. The secretary shall keep full and correct minutes of all of the transactions and proceedings of the board; perform such othe: duties as may be required of him, and shall be the official reporter of the proceedings of the board.

7. The board shall furnish its secretary such of its findings and 
decisions as, in its judgment, may be of general public interest; the secretary shall compile the same for the purpose of publication in a series of volumes to be designated "Reports of the Board of Public Utility Commissioners of the State of New Jersey," which shall be published in such form and manner as may be best adapted for public information and use, and such authorized publications shall be competent evidence of the reports and decisions of the commission therein contained without any further proof or authentication thereof. The contents of said reports shall not be under the supervision or control of the official State editor.

8. The board shall purchase such materials, apparatus and standard measuring instruments as it may deem necessary.

9. No member or employe of said board shall have any official or professional relation or connection with, or hold any stock or securities in, any public utility as herein defined, operating within the State of New Jersey, nor hold any other office of profit or trust under the government of this State or of the United States.

10. The board shall have an office in the State House, and in such other place or places as it may designate, and shall meet at such times and places within this State as it may provide by rule or otherwise, and shall be provided with all necessary furniture, stationery, maps, supplies and office appliances.

11. The board shall have the power to make all needful rules for its government and other proceedings not inconsistent with this act, and shall have and adopt a common seal.

12. The total expenses of the board, including salaries, shall not exceed one hundred thousand dollars per annum.

13. The members of the board are hereby empowered to sit singly for the purpose of taking testimony in any proceeding. A majority vote of the board shall be necessary to the making of any order.

14. The board shall report annually, on or before the first day of January, to the Governor, making such recommendations as it may. deem proper, which report shall be laid before the next succeeding Legislature.

15. The board shall have general supervision and regulation of, jurisdiction and control over, all public utilities, and also over their property, property rights, equipment, facilities and franchises so far as may be necessary for the purpose of carrying out the provisions of this act. The term "public utility" is hereby defined to include every individual, co-partnership, association, corporation or joint stock company, their lessees, trustees or receivers appointed by any court whatsoever, that now or hereafter may own, operate, manage or control within the State of New Jersey any steam railroad, street railway, trac- 
tion railway, canal, express, subway, pipe line, gas, electric light, heat, power, water, oil, sewer, telephone, telegraph system plant or equipment for public use, under privileges granted or hereafter to be granted by the State of New Jersey or by any political subdivision thereof.

\section{II}

16. The board shall have power:

(a) To investigate, upon its own initiative, or upon complaint in writing, any matter concerning any public utility as herein defined.

(b) From time to time to appraise and value the property of any public utility as herein defined, whenever in the judgment of said board it shall be necessary so to do, for the purpose of carrying out any of the provisions of this act, and in making such valuation the board may have access to and use any books, documents or records in the possession of any department or.board of the State or any political subdivision thereof.

(c) After hearing, upon notice, by order in writing, to fix just and reasonable individual rates, joint rates, tolls, charges or schedules thereof, as well as commutation, mileage and other special rates which shall be imposed, observed and followed thereafter by any public utility as herein defined, whenever the board shall determine any existing individual rate, joint rate, toll, charge or schedule thereof or commutation, mileage, or other special rate to be unjust, unreasonable, insufficient or unjustly discriminatory or preferential.

(d) To require every public utility as herein defined to file with it complete schedules of every classification employed and of every individual or joint rate, toll, fare or charge made, charged or exacted by it for any product supplied or service rendered within this State, as specified in such requirement.

(e) After hearing, by order in writing, to fix just and reasonable standards, classifications, regulations, practices, measurements or service to be furnished, imposed, observed, and followed thereafter by any public utility as herein defined.

(f) After hearing, by order in writing, to ascertain and fix adequate and serviceable standards for the measurement of quantity, quality, pressure, initial voltage or other condition pertaining to the supply of the product or service rendered by any public utility as herein defined, and to prescribe reasonable regulations for examination and test of such product or service and for the measurement thereof.

Ec (g) After hearing, by order in writing, to establish reasonable rules, regulations, specifications and standards, to secure the accuracy of all meters and appliances for measurements. 
(h) To provide for the examination any test of any and all appliances used for the measuring of any product or service of a public utility as herein defined.

(i) By its agents, experts or examiners, to enter upon any premises occupied by any public utility as herein defined, for the purpose of making the examinations and tests provided for in this act and to set up and use on such premises any apparatus and appliances necessary therefor.

(j) To fix the fees to be paid by any consumer or user of any product or service of a public utility as herein defined, who may apply to said board for such examination or test to be made, and any consumer or user may have any such appliance tested upon the payment of the fees fixed by the board, which fees shall be repaid to the consumer or user if the appliance be found defective or incorrect to the disadvantage of the consumer or user, and in that event, paid by the public utility.

(k) After hearing, upon notice, by order in writing, to direct any railroad or street railway company to establish and maintain at any junction or point of connection or intersection with any other line of said road, or with any line or any other railroad, street railway, or traction company, such just and reasonable connections as shall be necessary to promote the convenience of shippers of property, or of passengers and in like manner to direct any railroad, street railway or traction company engaged in carrying merchandise to construct, maintain and operate, upon reasonable terms, a switch connection with any private side-track, which may be constructed by any shipper to connect with the railroad or street railway where, in the judgment of the board, such connection is reasonable and practicable, and can be put in with safety, and will furnish sufficient business to justify the construction and maintenance of the same.

(1) To permit any street railway or traction company to change its existing gauge to standard steam railroad gauge, upon such terms and conditions as said board shall prescribe.

17. The board shall have power, after hearing, upon notice, by order in writing, to require every public utility as herein defined:

(a) To comply with the laws of this State and any municipal ordinance relating thereto and to conform to the duties imposed upon it thereby or by the provisions of its own charter, whether obtained under any general or special law of this State.

(b) To furnish safe, adequate and proper service and to keep and maintain its property and equipment in such condition as to enable it to do so. 
(c) To establish, construct, maintain and operate any reasonable extension of its existing facilities, where, in the judgment of said board such extension is reasonable and practicable and will furnish sufficient business to justify the construction and maintenance of the same, and when the financial condition of the said public utility reasonably warrants the original expenditure required in making and operating such extension.

(d) To keep its books, records and accounts so as to afford an intelligent understanding of the conduct of its business and to that end to require every such public utility of the same class to adopt a uniform system of accounting. Such system shall conform, in so far as in the judgment of the board is practicable, to any system adopted or approved by the inter-state commerce commission of the United States of America.

(e) To furnish annually a detailed report of finances and operations, in such form and containing such matters as the board may from time to time by order prescribe.

(f) To carry, whenever in the judgment of the board it may reasonably be required, for the protection of stockholders, bondholders or creditors, a proper and adequate depreciation account in accordance with such rules, regulations and forms of account as the board may prescribe. The board shall from time to time ascertain and determine, and by order in writing after hearing fix proper and adequate rates of depreciation of the property of each public utility, in accordance with such regulations or classifications, which rates shall be suffcient to provide the amounts required over and above the expense of maintenance to keep such property in a state of efficiency corresponding to the progress of the industry. Each public utility shall conform its depreciation accounts to the rates so ascertained, determined and fixed, and shall set aside the moneys so provided for out of earnings and carry the same in a depreciation fund. The income from investments of moneys in such fund shall likewise be carried in such fund. This fund shall not be extended otherwise than for depreciation, improvements, new constructions, extensions or additions to the property of such public utility.

(g) To give such notice to the board as the board may by rulc require of any and all accidents which may occur within this State upon the property of any public utility as herein defined or directly or indirectly arising from or connected with its maintenance or operation, and to investigate any such accident and to make such order or recommendation with respect thereto as in its judgment may be just and reasonable. 
(h) When any public utility as herein defined shall increase any existing individual rates, joint rates, tolls, charges or schedules thereof, as well as commutation, mileage and other special rates, or change or alter any existing classification, the board shall have power either upon written complaint or upon its own initiative to hear and determine whether the said increase, change or alteration is just and reasonable. The burden of proof to show that the said increase, change or alteration is just and reasonable shall be upon the public utility making the same. The board shall have power pending such hearing and determination to order the suspension of the said increase, change or alteration until the said board shall have approved said increase, change or alteration, not exceeding three months. It shall be the duty of the said board to approve any such increase, change or alteration upon being satisfied that the same is just and reasonable.

\section{III}

18. No public utility as herein defined shall:

(a) Make, impose or exact any unjust or unreasonable, unjustly discriminatory or unduly preferential individual or joint rate, commutation rate, mileage and other special rate, toll, fare, charge or schedule for any product or service supplied or rendered by it within this State.

(b) Adopt or impose any unjust or unreasonable classification in the making or as the basis of any individual or joint rate, toll, fare, charge or schedule for any product or service rendered by it within this State.

(c) Adopt, maintain or enforce any regulation, practice or measurement which shall be unjust, unreasonable, unduly preferential, arbitrarily or unjustly discriminatory or otherwise in violation of law; nor shall any public utility as herein defined provide or maintain any service that is unsafe, improper or inadequate, or withhold or refuse any service which can reasonably be demanded and furnished when ordered by said board.

(d) Make or give, directly or indirectly, any undue or unreasonable preference or advantage to any person or corporation or to any locality or to any particular description of traffic in any respect whatsoever, or subject any particular person or corporation or locality or any particular description of traffic to any prejudice or disadvantage in any respect whatsoever.

(e) Hereafter issue any stocks, stock certificates, bonds or other evidences of indebtedness payable in more than one year from the date thereof until it shall have first obtained authority from the board for 
such proposed issue. It shall be the duty of the board, after hearing, to approve of any such proposed issue maturing in more than one year from the date thereof, when satisfied that the same is to be made in accordance with law and the purpose of such issue be approved by said board.

(f) Capitalize any franchise to be a corporation; capitalize any franchise in excess of the amount (exclusive of any tax or annual charge) actually paid to the State or any political subdivision thereof as the consideration of such franchise; capitalize any contract for consolidation, merger or lease; issue any bonds or other evidence of indebtedness against or as a lien upon any contract for consolidation, merger or lease; provided, however, that the provisions of this section shall not prevent the issuance of stock, bonds or other evidence of indebtedness subject to the approval of said board by any lawfully merged or consolidated public utilities not in contravention of the provisions of this section.

(g) Hereafter give, grant or bestow upon any local, municipal or county official any discrimination, gratuity or free service whatsoever, but nothing herein contained shall prevent the entry into any public conveyance or in or upon the property of any such public utility as herein defined of any such official in the pursuit of his public duties in connection with the particular conveyance or property so entered by him, upon exhibiting his authority so to do.

(h) Without the approval of the board sell, lease, mortgage, or otherwise dispose of or encumber its property, franchises, privileges or rights, or any part thereof; nor merge or consolidate its property, franchises, privileges or rights, or an part thereof, with that of any other public utility as herein defined. Every sale, lease, mortgage, disposition, encumbrance, merger or consolidation made in violation of any of the provisions hereof shall be void and of no effect. Nothing herein contained shall be construed in any wise to prevent the sale, lease or other disposition by any public utility as herein defined of any of its property in the ordinary course of its business.

19. No public utility as herein defined incorporated under the laws of this State shall sell, nor shall any such public utility make or permit to be made upon its books any transfer of any share or shares of its capital stock, to any other public utility as herein defined, unless authorized to do so by the board. Nor shall any public utility as herein defined incorporated under the laws of this State sell any share or shares of its capital stock or make or permit any transfer thereof to be made upon its books, to any corporation, domestic or foreign, result of which sale or transfer in itsclf or in connection with other previous sales or transfers shall be to vest in such corporation a ma- 
jority in interest of the outstanding capital stock of such public utility corporation unless authorized to do so by the board. Every assignment, transfer, contract or agreement for assignment or transfer by or through any person or corporation to any corporation in violation of any of the provisions hereof shall be void and of no effect, and no such transfer shall be made on the books of any public utility corporation. Nothing herein contained shall be construed to prevent the holding of stock heretofore lawfully acquired.

20. No railroad company shall, without first obtaining the approval of the board, abandon any railroad station or stop the sale of passenger tickets, or cease to maintain an agent to receive and discharge freight at any station now or hereafter established in this State, at which passenger tickets are now or may hereafter be regularly sold, or at which such agent is now or may hereafter be maintained.

21. No highway shall be constructed across the tracks of any railroad company at grade, nor shall the tracks of any railroad company, street railway or traction company be laid across any highway, so as to make a new crossing at grade, nor shall the tracks of any railroad or street railway or traction company be laid across the tracks of any other railroad or street railway or traction company without first obtaining therefor permission from the board; provided, however, that this section shall not apply to the replacement of lawfully existing tracks.

22. Whenever it appears to the board that a public highway and a railroad cross one another, or that a public highway and a street railway cross one another, or that a railroad and a street railway cross one another at the same level, and that conditions at such grade crossing make it necessary for the protection of the traveling public at such grade crossing that gates be erected or that some other reasonable provision for the protection of the traveling public at such grade crossing should be adopted, the board may order and direct such railroad company or such street railway company, or either or both of them, to install such protective device or devices or adopt such other reasonable provision for the protection of the traveling public at such crossing as in the discretion of the board shall be necessary.

23. Said board shall have power to require every public utility as herein defined to file with the board a statement in writing, verified by the oaths of the president and secretary thereof, respectively, setting forth the name, title of office or position and post-office address, and the authority, power and duties of every officer, member of the board of directors, trustees, executive committee, superintendent, chief or head of construction and operation, or department, division or line of construction and operation thereof, in such form as to disclose the 
source and origin of each administrative act, rule, decision, order or other action of the corporation, and shall, within ten days after any change is made in the title of, or authority, powers or duties appertaining to any such office or position, or the person holding the same, file with the board a like statement, verified in like manner, setting forth such change.

24. No privilege or franchise hereafter granted to any public utility as herein defined, by any political sub-division of this State, shall be valid until approved by said board, such approval to be given when, after hearing, said board determines that such privilege or franchise is necessary and proper for the public convenience and properly conserves the public interests, and the board shall have power in so approving to impose such conditions as to construction, equipment, maintenance, service or operation as the public convenience and interests may reasonably require.

25. Every municipality operating any form of public utility service shall keep the accounts thereof in the manner prescribed by the board for the accounting of similar public utilities, and shall file with said board such statements thereof as it may be directed so to do by said board.

\section{IV}

26. All hearings and investigations before the board or any member thereof shall be governed by rules adopted by the board, and in the conduct thereof neither the board nor such member shall be bound by the technical rules of legal evidence.

27. The board shall have power to compel the attendance of witnesses and the production of tariffs, contracts, papers, books, accounts and all other documents, and any member of the board shall have power to administer oaths to all witnesses who may be called before the board or any member thereof. Subpœnas issued by the board shall be signed by one of the members thereof and by the secretary and may be served by any person of full age. The foes of witnesses required to attend before the board shall be one dollar for each day's attendance and three cents for every mile of travel, by the nearest generally traveled route, in going to and from the place where the attendance of the witness is required, such fees to be paid when the witness is excused from further attendance, and the disbursements made in payment of such fees shall be audited and paid in the same manner provided for the payment of expenses of the board; provided, however, that no witness subpœnaed at the instance of parties other than the board shall be entitled to compensation from the State for attendance or travel, unless the board shall certify that his testimony was material to the matter investigated. If a person subpœnaed to 
attend before the board, or a member thereof, fails to obey the command of such subpœna without reasonable cause, or if a person in attendance before the board, or a member thereof, refuses, without lawful cause, to be examined or to answer a legal or pertinent question, or to produce a book or paper, when ordered so to do by the board, or any member thereof, the board or such member thereof may apply to the Supreme Court or any justice thereof, who shall have the power of the court for that purpose, upon proof, by affidavit of the facts, for an order returnable in not less than two nor more than ten days, directing such persons to show cause before the court, or the justice thereof who made the order, or to any other justice, why he should not comply with the subpœna or order of the board; upon the return of such order the court or justice before whom the matter shall come on for hearing, shall examine under oath such person whose testimony may be relevant, and such person shall be given an opportunity to be heard, and if the court or justice shall determine that such person refused without legal excuse to obey the command of such subpœna, or to be examined, or to answer a legal or pertinent question, or to produce a book or a paper which he was ordered to produce, said court or justice may order said person to comply forthwith with the subpœna or order of the board, and any failure to obey such order of the court or justice may be punished by said court or justice as a contempt of said Supreme Court.

28. The board may, in any investigation or hearing, by its order in writing, cause the depositions of witnesses residing within or without the State to be taken in such manner as it may, by rule, prescribe.

29. No person shall be excused from testifying or from producing any book, document or paper in any investigation or inquiry by or upon the hearing before said board or any member thereof, when ordered so to do by the board or any member thereof, upon the ground that the testimony or evidence, book, document or paper required of him may tend to incriminate him or subject him to penalty or forfeiture, but no person shall be prosecuted, punished or subjected to any penalty or forfeiture for or on account of any act, transaction, matter or thing concerning which he shall, under oath, have testified or produced documentary evidence; provided, however, that no person so testifying shall be exempt from prosecution or punishment for any perjury committed by him in his testimony. Nothing herein contained is intended to give, or shall be construed in any manner giving, to any corporation immunity of any kind. No member or employe of the board shall be required to give testimony in any civil suit to which the board is not a party, with regard to information obtained by him in the discharge of his official duty. 
30. Copies of all official documents and orders filed or deposited in the office of the board, certified by a member of the board, or by the secretary to be true copies of the originals, under the official seal of the board, shall be evidence in like manner as the originals in all courts of this State, and the board may charge and collect for such copies ten cents for each folio; the fees so collected shall be paid into the treasury of the State.

31. The board, at any time, may order a re-hearing and extend, revoke or modify any order made by it.

32. Every order made by the board shall be served upon the person or public utility, as herein defined, affected thereby, within ten days from the time said order is filed, by personally delivering or by mailing a certified copy thereof, in a sealed package, with postage prepaid, to the person to be affected thereby, or in case of a public utility, to any officer or agent thereof, upon whom a summons may be served in accordance with the provisions of the law of this State. All orders of the board to continue service or rates in effect at the time said order is made shall be immediately operative; all other orders shall become effective upon the date specified therein, which shall be at least twenty days after the date of said order.

33. In default of compliance with any order of the board when the same shall become effective the person or public utility affected thereby shall be subject to a penalty of one hundred dollars per day for every day during which such default continues, to be recovered in an action of debt in the name of the State, and observance of the orders of the board may be enforced by mandamus or injunction in appropriate cases, or by suit in equity to compel the specific performance of the order or orders so made, or of the duties imposed by law upon such public utility.

34. Any person who shall knowingly and willfully perform, commit or do, or participate in performing, committing or doing, or who shall knowingly and willfully cause, participate or join with others in causing any public utility corporation or company to do, perform or commit, or who shall advise, solicit, persuade, or knowingly and willfully instruct, direct or order any officer, agent or employe of any public utility corporation or company to perform, commit or do any act or thing forbidden or prohibited by this act, shall be guilty of a misdemeanor.

35. Any person who shall knowingly and willfully neglect, fail or omit to do or perform, or who shall knowingly and willfully cause or join or participate with others in causing any public utility corporation or company to neglect, fail or omit to do or perform, or who shal) advise, solicit or persuade, or knowingly and willfully instruct, direct 
or order any officer, agent or employe of any public utility corporation or company to neglect, fail or omit to do any act or thing required to be done by this act shall be guilty of a misdemeanor.

36. Any public utility corporation which shall perform, commit or do any act or thing hereby prohibited or forbidden, or which shall neglect, fail or omit to do or perform any act or thing hereby required to be done or performed by it, shall be guilty of a misdemeanor.

37. This act shall not have the effect to release or waive any right of action by the board or by any person for any right, penalty or forfeiture which may have arisen or which may arise, under any of the laws of this State, and any penalty or forfeiture enforceable under this act shall not be a bar to or effect a recovery for a right, or affect or bar any indictment against any public utility as herein defined, or person or persons operating such public utility, its officers, directors, agents or employes.

38. Any order made by the board may be reviewed on the application of any person or public utility affected thereby, by certiorari in appropriate cases, or by petition, to the Supreme Court of the State of New Jersey, within thirty days from the date upon which such order becomes effective, as herein provided; said petition shall be filed with the clerk of the Supreme Court and a copy thereof served upon the secretary of the board either personally or by leaving same at the office of said board in the city of Trenton. The Supreme Court is hereby given jurisdiction to review said order of the board, and to set aside such order when it clearly appears that there was no evidence before the board to support reasonably such order, or that the same was without the jurisdiction of the board. The evidence presented to the board, together with the finding of the board and any order issued thereon shall be certified by the board to the Supreme Court. The procedure for review, except as herein provided, shall be prescribed by rules of the Supreme Court.

39. The allowance of a writ of certiorari or the institution of any proceeding to review any order of the board by the Supreme Court as aforesaid, shall in no case supersede or stay the order of the board, unless the Supreme Court, or a justice thereof, shall so direct, and the appellant may be required by the Supreme Court or a justice thereof, to give bond in such form and of such amount as the Supreme Court, or the justice thereof allowing the stay, shall require.

40. Any proceeding in any court of this State directly affecting an order of the board or to which the board is a party, shall have preference over all other civil proceedings pending in such court.

41. Nothing in this act shall be construed to prevent the issue by any steam railroad, street railway, traction, canal, express, telephone 
or telegraph companies or other common carriers, of free passes or franks to their employes, officers, agents, surgeons, physicians, attorneys at law, and their families, and the interchange between said public utilities and common carriers, of passes or franks for their employes, officers, agents, surgeons, physicians, attorneys at law, and their families.

42. If, for any reason, any section or provision of this act shall be questioned in any court, and shall be held to be unconstitutional or invalid, no other section or provision of this act shall be affected thereby.

43. All acts or parts of acts inconsistent herewith are hereby repealed, and this act shall take effect on the first day of May, Anno Domini one thousand nine hundred and eleren.

Approved April 21, 1911. 


\section{APPROVAL OF ISSUES OF STOCKS, BONDS AND OTHER FORMS OF INDEBTEDNESS. ${ }^{1}$}

A common carrier, railroad corporation or street railroad corporation organized or existing, or hereafter incorporated, under or by virtue of the laws of the State of New York, may issue stocks, bonds, notes or other evidence of indebtedness payable at periods of more than twelve months after the date thereof, when necessary for the acquisition of property, the construction, completion, extension or improvement of its facilities, or for the improvement or maintenance of its service or for the discharge of lawful refunding of its obligations or for the reimbursement of moneys actually expended from income, or from any other moneys in the treasury of the corporation not secured by or obtained from the issue of stocks, bonds, notes or other evidence of indebtedness of such corporation, within five years next prior to the filing of an application with the proper commission for the required authorization, for any of the aforesaid purposes except maintenance of service and except replacements in cases where the applicant shall have kept its accounts and vouchers of such expenditure in such manner as to enable the commission to ascertain the amount of moneys so expended and the purposes for which such expenditure was made; provided and not otherwise that there shall have been secured from the proper commission an order authorizing such issue, and the amount thereof and stating the purposes to which the issue or proceeds thereof are to be applied, and that, in the opinion of the commission, the money, property or labor to be procured or paid for by the issue of such stock, bonds, notes or other evidence of indebtedness is or has been reasonably required for the purposes specified in the order, and that except as otherwise permitted in the order in the case of bonds, notes, and other evidence of indebtedness, such purposes are not, in whole or in part, reasonably chargeable to operating expenses or to income.

1 The Public Service Commissions Law of New York, Section 55. 


\section{INTERPRETATION OF SECURITY RESTRICTIONS.}

General Principles Regulating Action by the Board of Public Utility

Commissioners Upon Petitions Asking Approval of Proposed Issues of Securities. ${ }^{3}$

The law at present casts upon this board the responsibility of determining what security issues may be made by public utilities in New Jersey (Chapter 195, III, 18(e), Laws of 1911). The board after due hearing is required to approve proposed security issues, provided the board approve the purpose of said proposed issues.

Conspicuous among the legal requirements to be met by proposed issues are those embodied in Chapter 331 of the Laws of 1906. This Act, inter alia, forbids the issue, sale or delivery of bonds, notes or obligations of any character by public untilities, except for cash or property of an actual cash value of at least 80 per cent. of the face value of the securities. The Act also forbids the issue, sale or delivery of public untilities of capital stock except for cash or property of actual cash value at least equal to the par value of the stock.

So far as the board's approval of the purpose of a proposed security issue is concerned, the board is already on record to the following effect:

"The term 'purpose,' in the opinion of the Board, cannot and ought not narrowly to be confined merely to the corporation's intention to procure or pay for property, materials and services with the proceeds of the securities intended to be issued. The powers and responsibilities of the Board in this respect are no less ample than may fairly be inferred from the spacious term 'purpose' advisedly incorporated in the statute." (Memorandum dated July 7, 1911. In the Matter of the Application of the Riverside Traction Company for Leave to Issue, Sell and Deliver Bonds, etc.)

Various cases involving the approval of proposed security issues have been acted upon by the board under the law. $\Lambda$ n analysis of many of these cases discloses certain general principles upon which these applications should be determined. These general principles will control unless and until good reason can be shown for departing therefrom. For the information of public utilities petitioning or intending to petition for the approval of security issues, certain of these general principles are set forth as follows:

1. The two conditions first named above must, in all cases, be met: These are that a proposed issue must be in accordance with

1 Conference Order No. 7 and Conference Ruling No. 13 of the New Jersey Board. 
the law, and that the purpose of a proposed issue must be approved by the board.

2. The purpose of a proposed issue is not commendable and will not carry the board's approval where the issue, if approved, would result in an invasion of mandatory statutory provisions governing the issue, sale and delivery of securities. Thus, where bonds have been used by the issuing public utility as collateral security for loans to an amount of less than 80 per cent. of the face value of the bonds, and where such a condition still holds, the board has decided ad. versely to subsequent security issues prayed for by such public utilities. Such refusal is based on the ground that such subsequent approval would be to connive at an attempt to circumvent the provision and intent of Chapter 331 of the Laws of 1906. (See memorandum dated July \%, 1911. In the Matter of the Application of the Riverside Traction Company for Leave to Issue, Sell and Deliver Bonds, etc.)

The "purpose" of an intended security issue is held to be vitiated, if a result of said issue, if approved, would enable the company to evade mandatory legal provisions. Thus, in the case of the Riverside Traction Company cited immediately supra, the purpose of a proposed bond issue was held vitiated by the fact that said bond issue, if approved, would defer for a time, or indefinitely postpone, an assessment for an unpaid percentage of the face value of the stock issued and outstanding.

3. Where approval of security issues is asked, and statement is made of the use to which proposed securities are to be put, the board endeavors through its inspectors to determine that the proceeds of the securities whose issue is asked shall be reasonably commensurate with the property or services to be purchased therewith. Where the property whose acquisition is sought can be inventoried and appraised, such a course is followed with as much care and in such detail as under all the circumstances is possible. Where the property or services to be acquired cannot be physically inventoried, because not yet existent, such estimate is made on the basis of unit prices and otherwise, with such care and in such detail as is possible under all the circumstances.

The board has already called public attention to what is implied by its approval of proposed security' issues. This it did by a statement dated May 26, 1911, entitled "In the Matter of Certain Published Statements Made in Connection with the Offering for Sale of Public Utility Securities Issued Under the Laws of This State." In this statement it is said: "Nor does such approval by this board of such proposed issue of securities carry or imply any confirmation of the 
business or financial standing of the issuing corporation as a whole." It must be recognized that no care exercised in the way of approval by the board at the time securities are issued can preclude the subsequent chance of poor management, dishonesty or ill-fortune, by which the assets of a public utility may be lessened or impaired. The intent of the statute and the board's action thereunder seek to preclude reckless and irresponsible promotion or subsequent inflated issues. No statute and no administrative process, however, can relieve the investor of the obligations of prudence and vigilance. At best they can but aid him in furnishing some grounds for the exercise of intelligent judgment.

4. Where petition is made for the approval of the issue of bonds or notes, where said bonds or notes are to be sold at a discount, the board has adopted the general policy of approving such issues only upon the companies undertaking to authorize the bond discount in accordance with certain stipulations inserted in the board's certificate of approval. Where, for example, a 5 per cent. bond is sold at 80 per cent. of its face value, the result of the sale of a thousanddollar bond is as follows: First, an increase of the company's liabilities to the amount of $\$ 1,000$; second, an increase of the company's assets to the amount of cash realized of $\$ 800$. The difference is commonly entered as an asset of $\$ 200$ termed bond discount. This asset is practically a dummy asset. If the company is to make its real assets equal to its added liabilities, it must add to its property an amount equal to $\$ 200$. The most effectual way would seem to be to lay aside from earnings a small amount annually. The setting aside of this amount annually must be done before the company is entitled to declare or make any dividend. It is true that the process implies that the consumer must contribute in rates more than he would be required to pay if no amount were needed annually for this amortization. On the other hand, if the bond has been sold at par, a higher rate than the assumed 5 per cent. would have been exacted by the lender to the company, and this higher rate of interest would have been included in the annual fixed charges. The higher fixed charges would have imposed a greater annual payment upon consumers. Practically, therefore the burden which amortization imposes on the consumer is simply the necessary outcome of the process of issuing bonds at less than par. It would not disappear, but only change its form, if the bond were sold at par, and the real rate of interest thereon were not disguised.

It has been progressively acknowledged that bond discount is not properly chargeable to capital account, but should be amortized within the life of the obligation. In certain authorizations of bond issues 
by this board, request has been made by the issuing corporation that a specific sum shall be named by the board, to be set aside annually for this purpose. It may be taken, therefore, as the rule that the board's approval of bond issues will be contingent upon the petitioner's acceptance of a proper amortization provision where necessary. But the provision may vary in different cases, according to the life of the bond, the desire of the company to expedite the process and the varying of different utilities to provide expeditiously for proper amortization.

5. Where a petition for the board's approval of a bond issue contains a clause providing for calling the bonds at a premium before maturity, the board has commonly insisted that such clause be eliminated. This has been insisted upon to avoid the possibility of an indirect evasion of Chapter 331 of the Laws of 1906. If, for example, a bond has been isued at 80 per cent. of its face value, and thereafter a petition is made to authorize a new issue of bonds (also at 80 ) to refund the first issued bonds, dollar for dollar, the following might result. For the original bond issue of the face value of $\$ 100,000$, the company secured real assets worth $\$ 80,000$. If the bonds are redeemable at 110 before maturity, and a new issue is made also at $80, \$ 137,500$ in bonds of the refunding issue would be required to take up the earlier issue. But as against the issue of $\$ 13 \%, 500$ there would be real assets of only $\$ 80,000$ as against $\$ 110,000$ in real assets required if $\$ 137,500$ of bonds were originally issued.

On the other hand, it is realized that in certain instances, refunding of bonds at a premium before maturity might effect such a reduction of fixed charges as to be advantageous both to the company and the consumers. Accordingly, the board in approying bond issues will not sanction bond redemption before maturity at a premium at the company's sole option; should the issuing company, however, reserve such right of redemption at a fixed premium before maturity subject to future approval by this board after due hearing, the board will consider in any case the inclusion of such provision in its formal certificate of approval.

6. In acting upon petitions for the approval of proposed issues of bonds or notes, the board will insist on adequate evidence of the probability that the fixed charges can be regularly met, and that the principal sum can be repaid at maturity. Where such securities are to be issued by a public utility now operating, the past, and current earnings of the public utility will be a relevant consideration. Also worthy of consideration will be such probable changes in earnings as properly may be expected to result from the property to be acquired by the proposed issue. 
Where the company is newly projected and where past experience is not available to indicate the probable return in revenue to the company, bond issues or note issues, if they are to be approved, must carry a reasonable probability that, with average good management, fixed charges may be regularly met, and ultimate payment of the principal sum may be provided.

Where approval of proposed stock issues is requested, the board will endeavor to be assured that the stock issues will secure for the public utility additional property commensurate with the par value of the stock issue proposed. The investor in stock knowingly takes a chance of return, however, which the investor in bonds commutes for' a specified return of fixed amount. For this reason the board does not feel obliged to be assured of the probability of returns upon stock as it does in the case of proposed bond issues.

7. Certain special cases of proposed security issues may arise under certain circumstances, some of which are set forth hereafter. In these special cases the general principles outlined above will be applied so far as seems equitable, and exceptions made only where the general principles enunciated supra would work inequitably. Among the special cases may be mentioned the following: First, where a bond issue has previously been sanctioned, under a mortgage or deed of trust providing that all bonds issued thereunder shall be identical in tenor, and where some part of the authorized bonds has not been actually issued, in such cases the board does not feel that it can impose as a condition of authorizing a remaining and unissued part of the total issue authorized, requirements against redemption at a premium prior to maturity. Second, where petitions are made for authority to make sccurity issues for refunding outstanding securities, the new securities to issue must conform to such requirements as would be imposed, if the refunding securities were an original issue. The refunding bonds and stock must be backed respectively by such proportionate amounts of cash or property of actual eash value as is required under Chapter 331 of the Laws of 1906. The refunding bonds must afford the same likelihood of meeting their fixed charges and payment of the principal sum at maturity as is indicated in the sixth paragraph supra. Nor will agrcements or contracts providing for refunding of security issues where such agreements or contracts were made prior to the enactment of Chapter 195 of the Laws of 1911 be regarded by this board as invalidating or overriding the authority over sccurity issues rested in this hoard by said Act. The power conferred upon this board to disapprove security issues not in accordance with law or whose purpose is not approved by the board is expressly conferred by the $\Lambda$ ct of $\Lambda$ pril 
21, 1911 (Chapter 195, Laws of 1911), and this power is not restricted by any other provision of the law governing public utilities, or corporations generally. All such agreements or contracts, however binding upon the individual parties thereto they might have been, in default of the Legislature's subsequently vesting power over proposed security issues in this board, are not controlling so as to. delimit the board's action upon proposed security issues. For such outstanding securities as may legally have come into existence prior to the passage of the Act of April 21, 1911, this board has no responsibility. But its authority is not delimited by expectations or contracts between private parties made prior to the enactment of the statute in question. Where the provisions of such agreements can be carried out comformably to the general principles regulating the approval of proposed security issues by this board, no obstacle will be interposed by the board to such authorization. But the carrying out of such provisions of agreements or contracts as involve issue of new securities must be submitted to the board.

8. The declaration of stock dividends by public utilities is permissible only in such cases as this board after hearing may authorize. To declare such a stock dividend without first obtaining the approval of the board is a misdemeanor, and all such securities issued without the board's approval are illegal.

In general, the board will approve of the issue of stock dividends by public untilities only after hearing and investigation and after being satisfied that as the outcome of such issues the net assets and property of the company over and above other liabilities resting thereon shall be equal to the par value of the total stock outstanding after such stock dividends have been made. Adequate depreciation reserves and surplus must also be provided by a public utility petitioning to issue a stock dividend, and a careful inquiry will be made by the board into the methods by which the additional stock dividend is to be justified. Full publicity of approval of all petitions for stock dividends will be deemed essential.

9. For the information of all public utilities intending to petition this board for the approval of proposed security issues, reference should be made to Conference Order No. 7 and Conference Ruling No. 13 of the board. The requirements of this order and ruling as to the form and content of petitions should be carefully observed. Petitions should be filed sufficiently in advance of the time at which approval of securities is desired to insure the board reasonable time to make the inquiries relevant. The larger the proposed issue, and the more complex the conditions surrounding it, the earlier should the application be filed with the secretary of the board. 
The petitions will be acted upon hereafter in order of their filing as indicated by the dating stamp of the secretary's office. Applications essentially defective in form or content will not be listed for consideration until properly amended. Where such applications involve the necessity of inventoring property or checking accounts, the public utility applying for such authorization is requested to give such assistance as is within its power by putting its engineers, managers and accountants in touch with the board's inspector.

Where the annual reports required of public utilities have not been promptly filed as required by the rules of this board, or where such accounts when filed, disclose failure upon the part of the public utility to comply with the requirements of law or with the terms upon which previous security issue of said utilities has been approved by this board, any subsequent petition for the approval of securities by a public utility shown to be in default may be postponed until the requisite and legal compliance with the law and the lawful rules of this board has been made by said public utility.

Adopted July 8, 1912. 


\section{STOCKHOLDERS' RIGHTS}

The New York, New Haven and Hartford Railroad Company ${ }^{2}$ New Haven, Conn., October 15, 1913.

To the stockholders of The New York, New Haven and Hartford Railroad Company, and to holders of its $3 \mathrm{~T} / 2 \%$ Convertible Debenture Certificates convertible between January 1, 1911, and January 1, 1916, and to holders of its 6\% Convertible Debentures convertible between January 15, 1923, and January 15, 1948:

Pursuant to resolutions of this Company's stockholders and directors, this Company hereby offers for subscription its Convertible Debentures of 1913, of the aggregate principal amount of Sixty-seven Million Five Hundred and Fifty-two Thousand Dollars $(\$ 67,552$,000), all to be dated October 1, 1913, to be payable October 1, 1933, to bear interest at the rate of six per cent. per annum, to be convertible after October 1, 1918, and not later than October 1, 1928, into shares of the Company's capital stock, par for par, with an adjustment of interest and dividend, and to be issued under and in pursuance of an indenture between this Company and a trustee, to all the provisions of which said debentures and the rights of the holders thereof will be subject.

These debentures will in substance provide, so far as lawfully may be, that the holders thereof shall enjoy, until October 1, 1928, a right of subscription to any future issue of capital stock of the Railroad Company to the same extent as if holders at the time of such issue of the shares of the capital stock of the Company to the future delivery of which they are entitled.

These debentures will also provide, so far as lawfully may be, that if this Company shall hereafter create any mortgage upon its now existing main line of railroad between Woodlawn in the City and State of New York and Springfield in the Commonwealth of Massachusetts, or its now existing main line of railroad between New Haven in the State of Connecticut and Providence in the State of Rhode Island, such debentures shall without further act be entitled to share in the security of such mortgage pro rata with any other obligations that may be secured thereby, and that any such mortgage shall expressly so provide.

The right to subscribe for these Convertible Debentures of 1913, on or before November 15, 1913, but not thereafter, is offered as follows:

1 Notice advertised in New Tork Times, November 1, 1913. 
To the holders of stock of this Company (not held in its treasury) of record at the close of business September 9, 1913, a right of subseription at the rate of One Hundred Dollars of principal amount of such debentures for every three shares of this Company's stock held by them respectively.

To all holders at the close of business September 9, 1913, of this Company's $31 / 2 \%$ Convertible Debenture Certificates convertible into stock between January 1, 1911, and January 1, 1916, which are registered as to principal and interest, a right of subscription at the same rate as if the holders of such contracts were holders of the stock of the future delivery of which they are entitled under the terms of said contracts, to wit, at the rate of One Hundred Dollars of principal amount of such debentures for each Four Hundred and Fifty Dollars of principal amount of such $31 / 2 \%$ Convertible Debenture Certificates held by them respectively.

To all holders at the close of business September 9, 1913, of this Company's $6 \%$ Convertible Debentures convertible into stock between January 15, 1923, and January 15, 1948, which are registered as to principal and interest, a right of subscription at the same rate as if the holders of such contracts were holders of the stock to the future delivery of which they are entitled under the terms of said contracts, to wit, at the rate of One Hundred Dollars of principal amount of such debentures for each Three Hundred Dollars of principal amount of such $6 \%$ Convertible Debentures held by them respectively.

To all holders of such $3 \frac{1}{2} \%$ Convertible Debenture Certificates or such $6 \%$ Convertible Debentures laving coupous attached, whether registered as to principal or not, a similar right of subseription at the same rate as if the holders of such contracts were holders of the stock to the future delivery of which they are entitled: provided, however, that such holders shall present such debentures on or before November 15, 1913, to either

The Treasurer of the Company, New Haven, Conn.,

Treasurer's Agent, Grand Central Terminal, New York City,

Treasurer's Agent, South Station, Boston, Mass.,

Bankers Trust Company, New York City,

Old Colony Trust Company, Boston, Mass.,

Rhode Island Hospital Trust Company, Providence, R. I.,

Hartford Trust Company, Hartford, Conn.,

Union Trust Company, Springfield, Mass.,

Morgan, Grenfell \& Company, Jondon, England, or

Morgan, Harjes \& Company, Paris, France, to be stamped substantially as follows: 
"Right to subscribe for Convertible Debentures of 1913 exercised by holder hereof without affecting the within contract."

All subscriptions must be for debentures of the principal amount of One Hundred Dollars or multiples thereof. Fractional rights of subscription must be so combined by purchase or sale thereof as to entitle the holders to subscribe for debentures of the principal amount of One Hundred Dollars or multiples thereof. The Company can neither buy nor sell rights.

Under the subscriptions to be made in accordance herewith, the subscribers will be obliged to make payments in one of the following ways :

1. In one payment on or before November 15, 1913, of an amount equal to the principal amount of the debentures subscribed for, with interest thereon at the rate of $6 \%$ per annum from October 1, 1913, to November 15, 1913.

2. In two payments, the first on or before November 15, 1913, of an amount of money equal to sixty-five per cent. of the principal amount of the debentures subscribed for, with interest at the rate of $6 \%$ per annum on the amount paid, from October 1, 1913, to November 15, 1913, and the second on or before January 15, 1914, of the unpaid balance of the principal amount of the debentures subscribed for, with interest at the rate of $6 \%$ per annum on the amount then paid from October 1, 1913, to January 15, 1914.

Payments may be made either directly to the Treasurer of the Company at New Haven, Connecticut, or through any of the above-named agencies.

Failure to make payment upon a subscription in accordance with the above provisions will operate as an abandonment of all rights as a subscriber.

No subscription or assignment of any right to subscribe will be recognized unless made on the forms of the Company and upon the terms and in the manner prescribed by the Company.

Subscription warrants specifying the amount of debentures for which under this circular stockholders and registered holders of Convertible Debenture Certificates and Convertible Debentures are entitled to subscribe, will be mailed to them as soon as is practicable. Such warrants will be issued to the holders of such Convertible Debenture Certificates and Convertible Debentures having coupons attached after the holders thereof have presented them to be stamped.

The warrants to be issued will be of two kinds: warrants certifying a right of subscription for debentures of an aggregate principal amount of One Hundred Dollars or multiples thereof, and warrants 
for fractional rights of subscription, expressed in ninths, for a Debenture of the principal amount of One Hundred Dollars.

For illustration: The holder of four shares of stock will receive a warrant entitling him or his assigns to subscribe for a Convertible Debenture of 1913 of the principal amount of One Hundred Dollars and a fractional warrant for three-ninths of a right to subscribe for such a Debenture; the holder of eight shares of stock will receive a warrant entitling him or his assigns to subscribe to Convertible Debentures of 1913 of the principal amount of Two Hundred Dollars and a fractional warrant for six-ninths of a right to subscribe for a Convertible Debenture of One Hundred Dollars; the holder of a $31 / 2 \%$ Convertible Debenture Certificate of the face value of One Thousand Dollars will receive a warrant entitling him or his assigns to subscribe for Convertible Debentures of 1913 of the principal amount of Two Hundred Dollars and a fractional warrant for two-ninths of a right to subscribe for a Convertible Debenture of One Hundred Dollars; the holder of a $3 \mathrm{r} / 2 \%$ Convertible Debenture Certificate of the face value of Five Thousand Dollars will receive a warrant entitling him or his assigns to subscribe for Convertible Debentures of 1913 of the principal amount of One Thousand One Hundred Dollars and a fractional warrant for one-ninth of a right to subscribe for a Convertible Debenture of One Hundred Dollars; the holder of a $6 \%$ Convertible Debenture of the principal amount of One Hundred Dollars will receive a fractional warrant for three-ninths of a right to subscribe for a Convertible Debenture of 1913 of the principal amount of One Hundred Dollars; the holder of a $6 \%$ Convertible Debenture of the face value of One Thousand Dollars will receive a warrant entitling him or his assigns to subscribe for Convertible Debentures of 1913 of the principal amount of Three Hundred Dollars and a fractional warrant for three-ninths of a right to subscribe for a Convertible Debenture of One Hundred Dollars.

The fractional warrants will be transferable by delivery; the other warrants will be transferable by execution of the blank form of assignment on the back thereof.

Holders of these warrants other than fractional warrants who may wish to subscribe for a portion of the debentures covered by the warrant and to dispose of the remainder of their rights, or to dispose of a portion of their rights to one person and of the remainder to another, should return these warrants to the Treasurer of the Company at New Haven, Connecticut, or through one of the agencies ahove specified, to be exchanged for other warrants of the same aggregate principal amount, specifying the number of warrants desired in 
exchange, the amount of debenture to be covered by each, and the names of those to whom they are to be issued respectively.

Warrants will be void and of no value unless surrendered to the Treasurer of the Company at his office or through one of the abovenamed agencies on or before November 15, 1913, accompanied by 2 subscription duly made in pursuance of the terms of the warrants and by the payment of either the first instalment or of the full amount payable upon such subscription.

Upon payment of subscriptions in full or in part, non-negotiable receipts will be issued, certifying the amount that has been paid. Such receipts may be exchanged for negotiable receipts when desired.

Full paid receipts will be exchangeable for debentures as soon as these are prepared.

Coupon debentures will be issued in the denomination of One Thousand Dollars, and may be registered as to principal in the owner's name, and at his election be discharged from registration in the manner prescribed in the indenture under which they are issued. Registered debentures will be issued in denominations of One. Hundred Dollars, One Thousand Dollars, and Ten Thousand Dollars.

Coupon debentures may be exchanged for registered debentures and registered debentures for coupon debentures, in the manner provided in said indenture.

All the debentures are to be payable at the option of the holder in London, England, in sterling money of Great Britain, as set forth in said indenture.

Application will be made to have the said debentures listed on the New York Stock Exchange.

All correspondence relating to the foregoing should be addressed to the Treasurer of the Company at New Haven, Connecticut.

By Order of the Direstors:

A. E. Clark, Secretary: 


\section{STOCKHOLDERS” RIGHTS}

To Stockholders (Common and Preferred) of the

\section{UNION PACIFIC RAILROAD COMPANY' and}

Stockholders of the

\section{SOUTHERN PACIFIC COMPANY:}

With the approval of the Attorney-General of the United States, the Union Pacific Railroad Company has adopted a plan, which has also been assented to by the Southern Pacific Company in so far as action on its part is required, for complying with the terms of the decree to be entered in the Government suit in accordance with the recent decision of the United States Supreme Court, which plan includes the following: The Southern Pacific Company has agreed to sell to the Union Pacific Railroad Company the entire capital stock of the Central Pacific Company, and to cancel or assign the existing lease of the railroad and other property of the Central Pacific Company, thus transferring to the Union Pacific Railroad Company the beneficial ownership of the railroads and other property of the Central Pacific Company, subject to certain leases, reciprocal contracts for the joint use of railroads and terminals, and other arrangements intended for the mutual protection of the two companies. It had been expected that the Union Pacific Railroad Company would pay for the Central Pacific property by surrendering or transferring $\$ 84,675,500$, par value, of the stock of the Southern Pacific Company now held by the Oregon Short Line Railroad Company, by the cancellation and surrender of $\$ 5,449,000$, face value, of the Four Per Cent. Central Pacific Stock Collateral Bonds of the Southern Pacific Company now owned by the Union Pacific Railroad Company, and by the payment of $\$ 14,065,441$ in cash. But there being doubt as to the right of the Southern Pacific Company to acquire its own stock, it has been decided to sell the Oregon Short Line Railroad Company's entire holdings of stock in the Southern Pacific Company, aggregating $\$ 126,650,000$, par value, and it has been agreed that the net proceeds of the sale of $\$ 84,675,500$, par value, of said stock, shall be paid to the Southern Pacifie Company in lieu of such contemplated surrender to it of said amount of stock. Accordingly the privilege is.offered to stockholders, registered on the books of the Union Pacific Railroad Company and the Southern Pacific Company (excluding, however, the Oregon Short Line Railroad Company

1 Notice advertised in New York Times, February 12, 1913. 
and its nominees), respectively, at the close of business on February 28,1913 , to subscribe on or before March 21, 1913, for such stock of the Southern Pacific Company in the proportion of one share of Southern Pacific stock for each four shares of Union Pacific stock, preferred or common, and of one share of Southern Pacific stock for each three shares of Southern Pacific stock held by others than the Oregon Short Line Railroad Company and its nominees.

The price of subscription is $\$ 100$ for each share of $\$ 100$ par value (equivalent as of the date of subscription to 98.67 per cent. and accrued dividend) payable either in full on March 21, 1913, or in four instalments of $\$ 25$ each on March 21, July 1 and October 1, 1913, and January 2, 1914.

A check for the dividend payable on April 1, 1913, will be mailed by the depositary hereinafter mentioned, as and when received by it, to registered subscribers, having paid either in full or the first instalment. Interest will be charged from March 21, 1913, on deferred payments at the accruing rate of dividends. Dividends payable after April 1, 1913, when received by the Depositary, will be so far as needed applied in payment of such interest and a check for the balance will upon payment of the instalments be mailed to holders of part-paid receipts. Holders of part-paid receipts may anticipate payment at any time by paying interest as above stated to the date of full payment. Until and except to the extent that stock is paid for in full by the subscribers and certificates therefor delivered to them, the shares subscribed for are to be transferred of record to the National City Bank of New York, as Depositary, or its nominee, which is to vote the same in accordance with the written directions of the registered subscription receipt-holders and hold the same for them as owners, but subject to the payment of the unpaid portion of the subscription price.

Warrants signed by the Treasurer or an Assistant Treasurer of the Union Pacific Railroad Company will be issued to each stockholder (the Southern Pacific to furnish the Union Pacific Railroad Company a list of its stockholders for the purpose) as soon as possible after the closing of the books on February 28, 1913, specifying the amount of stock for which the stockholder is entitled to subscribe. Warrants will be mailed to stockholders at addresses to which their dividends are sent. If dividends are collected by bankers or others on powers of attorney, or other authority, warrants will be sent to such authorized parties, unless other instructions are received. Warrants not so provided for may be obtained at this office not later than March 18, 1913. "Subscription Warrants" entitling the holder to subscribe will be isued for amounts of $\$ 100$, or multiples thereof, 
and "Fractional Warrants" for fractions of $\$ 100$. "Fractional Warrants" will not entitle the holder to subscribe, but will be exchangeable in amounts aggregating at least $\$ 100$ on or before March 18, 1913, for "Subscription Warrants," and if the surrendered "Fractional Warrants" include a fraction in excess of $\$ 100$ a new "Fractional Warrant" will be issued for such fraction. "Fractional Warrants" desired by stockholders to complete full shares or "Fractional Warrants" which the stockholders desire to dispose of must be bought or sold in the market, as the Company will not sell or purchase such fractions. After March 18, 1913, all "Fractional Warrants" will be void and of no effect. On the back of the warrants will be two forms. In case it is desired to subscribe, the first form is to be filled out and signed by the stockholders or by their assignees, but in case it is desired to dispose of the subscription privilege, the second form, which is an assignment, is to be filled out and signed by the stockholders. Where a warrant authorizes a subscription to two or more shares, stockholders who may wish to subscribe for a portion of the shares covered by the warrant and dispose of the balance, or who may wish to dispose of a portion of the shares covered by the warrant to one person and the balance to another, should return the warrants to this office on or before March 18,1913, to be exchanged for other warrants, specifying in writing the number of warrants desired in exchange and the number of shares to be covered by each. In no case, however, on such exchange will a fractional warrant be issued. The subscription warrants must be surrendered at the office of the National City Bank of New York, or at the office of Baring Brothers \& Co. Ltd., 8 Bishopsgate Within, London, E. C., England, by the stockholders or by the persons to whom assigned, on or before March 21, 1913, accompanied by the payment of the first instalment or the full amount payable, and all warrants not so surrendered with such payment on or before said date shall be void and of no value. Failure to pay any instalment when and as payable will operate as a forfeiture of all rights in respect of the subscription and the instalments previously paid. Said Bank, directly or through said Baring Brothers \& Co, Ltd., as its agents in Iondon, will, on surrender of the warrants and on payment of the first instalment, or full payment, as the ease may be, issue receipts which shall be transferable by assignment, and which must, unless previously paid in full, be returned on or before July 1, and on or before October 1, 1913, and on or before January 2, 1914, accompanied by the payment of the second, third and final instalments, respectively, or, at the option of the holder, accompanied by the payment of the full amount remaining payable, for endorsement thereon, as the case may be, of the payment of the said instalments or full payment. Certificates of stock registered 
in the name of or as directed by receipt-holders will be delivered in exchange for full-paid receipts. No subscription or assignment of this privilege will be recognized unless made on the forms approved by the Union Pacific Railroad Company. No holder of the stock of either the Union Pacific Railroad Company or the Southern Pacific Company shall be entitled to any of the above mentioned shares unless the terms of subscription herein specified are fully complied with. The subscription and respective instalment payments must be made at the dates and in accordance with the provisions stated above. Checks or drafts in payment of subscriptions must be drawn in favor of the National City Bank of New York in New York funds or in favor of Baring Brothers \& Co., Ltd., in London funds, as the case may be, and for the exact amounts covering the respective instalments.

The plan and the agreements embodying the same will not become effective unless and until approved by the District Court of the United States for the District of Utah in the suit of the United States of America vs Union Pacific Railroad Company et al., now pending therein, upon the mandate of the Supreme Court of the United States, nor unless and until the Railroad Commission of the State of California shall approve the provisions of said plan in respect of which in the opinion of the Company's counsel the approval of said Commission may be necessary or advisable to give the same validity.

By order of the Board of Directors.

FREDERIC V. S. CROSBY, Treasurer,

Union Pacific Railroad Company,

165 Broadway, New York.

New York, February 10, 1913. 


$$
\$ 10,000,000^{1}
$$

Seven Per Cent. Cumulative Preferred Stock.

(Preferred as to Both Dividends and Principal)

$$
\text { of }
$$

\section{UNITED DRY GOODS COMPANIES}

Dividends Payable Quarterly at the Rate of Seven Per Cent. Per Annum from June 1st, 1909. Shares $\$ 100$ each.

$$
\text { Office of J. P. Morgan \& Co., }
$$

23 Wall St., New York,

$$
\text { May 27th, } 1909 .
$$

\section{UNITED DRY GOODS COMPANIES}

(A Corporation Under the Laws of Delaware.)

Has Preferred Stock authorized .........\$16,000,000 of which $\$ 10,000,000$ is now issued;

and Common Stock authorized $\ldots \ldots \ldots \ldots \ldots \ldots 35,000,000$ of which $\$ 10,000,000$ is now issued.

Having sold a large portion of the above Preferred Stock, we offer, subject to prior sale and change in price, the balance of the $\$ 10,000,000$ Seven Per Cent. Cumulative Preferred Stock of the United Dry Goods Companies at $\$ 110$ per share.

Attention is called to the letter received from John Claflin, Esq., printed below; and also to the report of Messrs. Haskins \& Sells, Certified Public Accountants.

Provision has been made either in the certificate of incorporation or in the by-laws to the following effect:

(1) That from time to time by vote of the Board of Directors additional authorized Common Stock to the amount of $\$ 25,000,000$ may be issued and disposed of for the following purposes:

(a) To be sold for cash at not less than par.

(b) T'o be exchanged for the various classes of stock of The Associated Merchants Company on equitable terms.

(2) That from time to time by vote of the Directors additional authorized Preferred Stock to the amount of $\$ 6,000,000$ may be issued and disposed of for the following purposes:

1 Three-quarter page advertisement in Wall Strect Journal of May 28, 1909. 
(a) To be sold for cash at not less than 120, excepting that $\$ 1,000,000$ thereof (reserved for the exclusive benefit of the employees of the Companies) may be allotted from time to time by the Directors of the United Dry Goods Companies at a price not less than par on such terms and conditions as shall encourage and enable the employees to participate in the profits of the business.

(b) To be exchanged for the Preferred Stocks of The Associated Merchants Company on equitable terms.

No stock other than that above mentioned can be authorized without consent of stockholders, as provided in the certificate of incorporation or by-laws, and no bonds can be issued except upon the written consent of three-fourths of the holders of each class of the company's stock, or by a vote of the stockholders holding at least three-fourths of the amount of each class of the capital stock of the corporation represented at a meeting specially called for that purpose or an annual meeting.

Temporary certificates will be issued pending the delivery of the definitive stock.

Application will be made to list the stock on the New York Stock Exchange.

We offer and recommend this Preferred Stock as a mercantile investment of the highest class.

J. P. MoRgaN \& Co.

224 Church Street, New York, N. Y., May 25, 1909.

Messris. J. P. Morgan \& Co.:

Dear Sirs-The United Dry Goods Companies, incorporated under the laws of the State of Delaware, has issued at par $\$ 20,000,000$ Capital Stock, divided into $\$ 10,000,000$ Common Stock and $\$ 10,000,000$ Seven per cent. cumulative Preferred Stock, having a preference as to both principal and dividends. It has acquired from me in exchange for $\$ 8,650,000$ of its Common Stock $\$ 8,650,000$ of the Capital Stock of The Associated Merchants Company out of a total issued Capital Stock of $\$ 17,250,000$. This gives the United Dry Goods Companies control of The Associated Merchants Company, which has control of the following companies:

Wholesale: The H. B. Clafin Company.

Retail: James McCreery \& Company, 34th Street, New York. James McCreery \& Company, 23d Street, New York. O'Neill-Adams Company, two blocks on Sixth Avenue, 20 th to 22d Streets, New York. 
Stewart \& Company, of Baltimore.

J. N. Adam \& Company, of Buffalo, and Four-fifths of the Common Stock of

C. G. Gunther's Sons (furs), New York.

The market value of The Associated Merchants Company's stock is more than par, and the dividends on the $\$ 8,650,000$ of its stocks at current rates exceed the dividend requirements on the $\$ 10,000,000$ Preferred Stock of the United Dry Goods Companies.

The United Dry Goods Companies has bought outright from me four large stores, to wit:

Hahne \& Company, of Newark,

Powers Mercantile Company, of Minneapolis, The William Hengerer Company, of Buffalo, and Stewart Dry Goods Company, of Louisville.

The available income of these four stores alone, disregarding all other sources of income, exceeds the dividend requirements on the $\$ 10,000,000$ Preferred Stock of the United Dry Goods Companies.

In the acquisition of the entire Capital Stock of these stores the United Dry Goods Companies has paid current market values for their tangible assets as appraised by independent experts, without any allowance for their exceedingly valuable good-will.

The merchandise has been taken at figures somewhat below wholesale prices.

Upon the opening of its books the balance sheet of the United Dry Goods Companies will stand in substance approximately, thus:

$\$ 8,650,000$ Capital Stock of The Associated Common Stock. $\$ 10,000,000$ Merchants' Company ......... Preferred Stock. 10,000,000

10,000,000 Tangible Assets of Hahne \& Company, Powers Mercantile Company, The William Hengerer Company and the Stewart Dry

1,350,000 Cash. Goods Company.

$\$ 20,000,000$

$\$ 20,000,000$

In the tangible assets is included the cntire capital stock of Hahne Realty Company. This stock represents the store property of Hahne \& Company, and is appraised subject to a mortgage of $\$ 1,250,000$ on said property. It is taken over by the United Dry Goods Companies at the net value so determined. This mortgage can be paid in 1911, two years hence, should the company so desire. 
There is no net indebtedness whatsoever against any other of the tangible assets aforesaid, an amount of cash exactly equal to the indebtedness of each company conveyed being left in the treasury of each company to cancel its indebtedness. This cash is additional to the tangible assets of $\$ 10,000,000$, and is also additional to the $\$ 1,350,000$ cash in the treasury of the United Dry Goods Companies.

The fact that the United Dry Goods Companies has no net indebtedness, has assets at market value more than double in amount the face value of its Preferred Stock, and has from various and separate sources an income which in bad times would be more than double its preferred dividend requirements, renders its Preferred Stock exceptionally safe as to principal and as to dividends.

In this relation it is interesting to note the dividend record of The H. B. Claflin Company, which was incorporated in 1890, and that of The Associated Merchants Company, incorporated in 1901.

The H. B. Claflin Company has paid dividends on all classes of its stock from organization to date, covering the three panic periods of 1892-1894, 1903-1904 and 190\%-1908, always full fixed dividends on its Preferred Stock and dividends at a rate never less than six per cent. on its Common Stock. The total dividends on its Common Stock amount to 139 per cent. The present dividend rate of eight per cent. has not been changed in ten years.

The Associated Merchants Company has paid regular dividends on its Preferred Stocks from organization to date, and numerous additional dividends beyond those provided for in the organization of the Company. After accumulating a safe surplus during the first year and a half of its corporate existence, it began dividends on its Common Stock December, 1902, at the rate of Seven per cent. per annum. It has maintained this rate to date, and has paid frequent extra dividends. Its average distribution for the last six years has been more than Eight per cent. per annum. In an experience covering more than eighteen years in one case and eight years in the other, neither company has ever needed to modify in the least the statements or promises made in its prospectus.

No change is proposed in the management of the affiliated companies. The active heads of the various companies will continue their customary work. I will continue to be President of The H. B. Claflin Company and of The Associated Merchants Company and of the United Dry Goods Companies if the stockholders so wish.

I enclose copies of the Certificate of Incorporation and of the By-Laws of the United Dry Goods Companies.

John Claflin. 


\section{Haskins \& Selis}

Certified Public Accountants

30 Broad Street, New York, May 24, 1909.

\section{Messrs. J. P. Morgan \& Company,}

3 Broad Street, New York City.

Gentlemen-In accordance with our arrangement with you we have made an examination of the books, records, and accounts of the following named companies:

Hahne \& Company, Newark, N. J.

The Wm. Hengerer Company, Buffalo, N. Y.

The Stewart Dry Goods Company, Louisville, Ky.

Powers Mercantile Company, Minneapolis, Minn.

The general purpose of our examination was to determine the value as of April 30,1909, of the assets of these companies in respect to real estate, buildings, store fixtures, delivery equipment, and merchandise on hand, and to study and report on the organization.

From our examination of the various properties and of the books and records relating thereto, and from the appraisals and estimates which have been furnished us by competent real estate dealers and engineers, we are of the opinion that the value of the real estate and buildings is conservatively stated. We are also of the opinion that the store fixtures and delivery equipment are conservatively valued.

Regarding the merchandise, from the tests made by us in several departments at each of the stores we estimate that the trading stock is undervalued below wholesale cost from $2 \%$ to $4 \%$, and that $3 \%$ is a conservative estimate of such undervaluations of the stock as a whole.

It was noted that while two of the companies carry certain of their miscellaneous store supplies as assets, as a general rule all purchases of this nature, including fuel and feed, and in some cases insurance premiums and interest paid in advance, were charged to expenses as incurred. We are of the opinion that a detailed andit of the accounts of each of the companies would show assets of this nature on hand which are not reflected in the statement attached hereto, amounting in the aggregate to $\$ 75,000$ or more. This amount, in connection with the excess of the cost of the merchandise on hand over the book cost heretofore referred to, makes total additional assets of approximately $\$ 200,000$, which, in our opinion, might reasonably be added to the total of the assets shown by our statement to determine the real value of such assets. 
All of the companies have a very large good-will value which is not included in the statement of the assets.

The loss from uncollectible accounts has been very low, averaging only a small fraction of one per cent. of the amount of the total sales.

A uniform system of periodical reports is maintained in all of the department stores controlled by Mr. Claflin. These reports show the result of operation in each department of each store by days, weeks, months, seasons, etc., and its aid to the executives and consequent effect on the results of operation can scarcely be overestimated. Such a system enables comparisons to be made which are of the highest value in determining and locating specifically the primary sources of any variation in profit or loss.

A system of reports is also maintained in each store which shows at once the nature and amount in detail of all slow-moving stock in each department. It appeared to us that these reports were receiving consideration and attention by the executives, and only about $3 \%$ of slow-moving stock existed in the stores examined.

The management and organization of the business throughout impressed us as being capable and efficient, with a spirit of : earnest co-operation existing between the general officers; the store managers and all other employees. We were particularly impressed with the interest taken by the managers of the different stores, in the success of the business as a whole, and the prosperity of their own store in particular.

In the various companies controlled by $\mathrm{Mr}$. Claflin, the general supervising organization consists of Mr. Claflin, at its head, Mr. Louis Stewart, his principal associate and adviser, Mr. John C. Eames; Vice-President of The H. B. Claflin Company, and about a dozen of the most able executives among the store managers. These gentlemen comprise a board of council which considers and decides upon all important questions involving policy, management and operation of the various stores controlled. Few organizations possess so capable a managing force or give so great attention to the training of their employees, with a view to their future usefulness. This policy assures in large measure the continuance of successful operation of the business.

The system of checks and reports maintained throughout is thorough and complete, and the reports are advantageously used in the administration of the business. The results of each store and each department therein are compared with the results of the other stores and the same departments in such stores. The employees who show themselves most efficient are moved forward from department to de- 
partment, and from store to store, and the inefficient are relieved. The organization is strengthened by this system and a spirit of interest among the employees is developed.

The men charged with the administration in the various stores impress us as being broad-minded business men, capable of successfully assuming larger responsibilities.

Yours truly,

Haskins \& Sells, Certified Public Accountants. 
$\$ 10,000,000$

JONES \& LAUGHLIN STEEL COMPANY

FIRST MORTGAGE THIRTY-YEAR SINKING FUND

$5 \%$ GOLD BONDS ${ }^{1}$

Dated May 1, 1909. Due May 1, 1939. Authorized issue $\$ 30,000,000$. Issued $\$ 25,000,000$.

Interest payable May 1st and November 1st at First Trust and Savings Bank, Chicago, or the agency of the Company in New York.

Coupon Bonds, or may be registered as to principal.

Redeemable after May 1, 1914, at 105 and interest.

First Trust and Savings Bank, Chicago, Trustee.

A letter from the President of the Company on file at our office emphasizes the following statements :

1. Secured by an absolute first mortgage on all the property now owned by the Company and additional property acquired by these bonds.

2. The property consists of real estate, furnaces, steel mills, including the new modern plant of the Company at Aliquippa, which is recognized as one of the most modern, convenient and economical plants to be found in the country.

3. Through its subsidiary companies, whose stocks are pledged to secure these bonds, it controls ore lands, coal lands and limestone property sufficient to supply the Company many years beyond the term of the bonds.

4. During the last two years the Company has invested twenty million dollars in the new plant and additions and betterments to its former property.

5. The Company is required to keep net quick assets of eight million dollars as long as a like amount of bonds remain outstanding.

6. A sinking fund is provided which will approximately retire the bonds at maturity.

7. The average yearly earnings for the last ten years were more than four times the interest payment on the outstanding bonds.

1 Bond house circular, issued by Blair \& Co.. announcing the Jones \& Laughlin Steel Co. Bonds. See Jones \& Laughlin Steel Co. Mortgage, pp. 183 et seq. 
Having sold a large part of these bonds, the undersigned offer the . remainder at $102 \frac{1}{2}$ and accrued interest.

We regard these bonds a desirable investment.

\section{FIRST TRUST \& SAVINGS BANK} Chicago
BLAIR \& CO. New York

\section{THE JONES \& LAUGHLIN STEEL COMPANY}

Gextlemen:

Pittsburgh, June 16, 1911

Referring to the $\$ 10,000,000.00,5 \%$ First Mortgage Bonds of this Company recently purchased by you, these bonds are part of an authorized issue of $\$ 30$,$000,000.00$, dated May 1, 1909, of whieh $\$ 25,000,000.00$ has been issued, and $\$ 24,487,000.00$ are outstanding, the balance having been retired by the operation of the sinking fund.

They are secured by an absolute first mortgage on all the property of the Company now owned, and on additional property which may hereafter be acquired by the proceeds of these bonds. They are further secured by the pledge of bonds and stocks of subsidiary companies, whose property consists of coal mines, ore lands and railways; all used in connection with this business in a general way.

The security behind these bonds is:

First: The real estate, furnaces, steel mills, finishing mills, plants of various kinds, located largely in the City of Pittsburgh, and the new and modern plant of the Company at Aliquippa, twenty miles from Pittsburgh, which plant has been constructed by the Company during the last three years. and is recognized as one of the most complete, modern, convenient and econom. ical plants to be found in this country.

Second: Through its subsidiary companies it controls ore lands, coal lands and limestone properties in fee or under lease, containing sufficient ore, coal and limestone to supply the Company's furnaces, at their present capacity, for . many years beyond the term of these bonds.

During the last two years the Company has invested, approximately, twenty million dollars in new plants or additions or betterments to its former pronerty, and the proceeds of the ten million dollars of bonds sold you will be largely used to reimburse the Company for such expenditures, and when their proceeds are absorbed, will leave the Company practically free of debt other than these first mortgage bonds.

Among the covenants of this trust deed, I might mention that the Company is required to, at all times while an equal amount of their bonds is outstanding, have net quick assets to the amount of eight million dollars, and further, a sinking fund is provided, equal yearly to one-fifteenth of the amount of bonds outstanding, which sinking fund is applied to the payment of interest on the outstanding bonds and to the retirement of principal. The sinking fund, it is figured, will approximately retire the bonds at their maturity.

The Audit Company of New York, before the investment of the twenty million dollars above referred to, made a careful examination of the property, from which it is safe to say that the net value of our property is over three times the bonded debt. It has been the policy of the Company, for many 


\section{MATERIALS OF CORPORATION FINANCE}

years, to return to the property large sums for additions and improvements, besides making a liberal allowance for depreciation.

The average yearly earnings, for the last ten years, have been more than sufficient to pay four times the interest on the present outstanding bonds.

Yours truly,

(Signed) B. F. Jones, JR., President. 


\section{PROSPECTUS 1}

\section{MR. WILLIAM LAWRENCE GREEN ORGANIZES A BIG EXPLORATION COMPANY}

\section{a Remarkable Opportunity for Money Making Offered to Readers of "Van Norden Magazine"}

By E. C. Rowe

A fortunate opportunity for extraordinary profits from a $\$ 200$ expenditure is open to Van Norden readers exclusively. This opportunity arises from the recent formation of an exploration company by a number of prominent and wealthy Eastern business men, well known to the publishers, who agree to permit the readers of Van Norden Magazine to obtain an interest in their company upon the most fair and equitable terms.

You may secure a $\$ 1,000$ interest in the new exploration company for a total expenditure of $\$ 200$. Or you make a smaller investment, obtaining the same proportionate interest; $\$ 50$ secures an interest equivalent to a $\$ 250$ investment at par, and so on. The extraordinary value of this opportunity is apparent when I tell you that the active head and president of this company is William Lawrence Green, vicepresident and treasurer of Banks \& Company (Inc.), the great law publishers, booksellers and importers, of Albany, New York. Banks \& Company, as a copartnership firm, was established in Albany 105 years ago by the grandfather of the present head of the firm, Hon. A. Bleecker Banks, who is associated with Mr. Green in the Exploration Company. Mr. A Bleecker Banks has served in the State Senate and as Mayor of Albany.

The other men forming the directorate are prominent and have been attracted to exploration work because of the amazing profits accruing to those engaged in the business, and because they were able to secure ownership for the corporation to 1,200 acres of some of the richest mineralized land in the entire Southwest. This land was brought to the attention of Mr. Green and his associates by Senator Stephen E. Barron, of California, who has mined in the Colorado River Desert for upward of forty years. Mr. Barron has been many years in collecting these properties, perfecting their titles, doing assessment work and proving their richness, and it was not until he had fully determined their value that he sought the aid of Eastern people. These properties are in three different States, Nevada, California and Arizona, and the 
Green-Banks-Barron Company is officially known as the Tri-State Development Company.

The Tri-State Development Company has been organized for the working and development of over sixty claims, representing about 1,200 acres located in the choicest section of Death Valley, and at the conjunction of that vast mineral deposit that lies partly in the States of California and Nevada and the Territory of Arizona. This section marks the center of the famous mineral zone and group of mines that has brought to the world new life and twice saved the credit of the nation by yielding millions of gold which turned into coin as a redeemer of all obligations. It is that portion of our hemisphere and new zone of wealth that makes any traveler look with awe at the gold and copper mining giants contained within its borders.

Two miles west from the Tri-State Mines are the Copper Butte Mines. One mile east is the Pioneer, four miles northeast the Klinefelter, ten miles south the Gold Bend, fifteen miles east the Colorado River with its many celebrated mineral veins on both sides, in Nevada, California and Arizona. Just north of the Gold Knob group, owned by the Tri-State, is the famous Turtle Dove, and a little further north comes the wonder of all mines in the district near Von Trigger, and known as Cram's Mines, celebrated for their uniform values and richness in both gold and copper.

This is a property that we don't read much about, but which has produced gold for some fourteen years and is a really wonderful property. At 250-foot depth it has an 80-foot body of copper; at about the same depth it has an immense gold ore vein running as high as $\$ 140$ to the ton. The property is now erecting smelter works and pip ing water many miles for its operations. It is under bond for $\$ 2,500$,000. The Patsy Pat group of claims is in precisely the same belt as the great Cram's Mine.

A feature of the properties here in these districts is uniformity of values, and without exception they are both gold and copper. The Cram's Mines are perhaps the best illustration of this because they have been well developed and there are millions in both metals in this one property.

Several other mines of great value in the Crazy Basin and on York Mountain form the connecting link between the Tri-State Mines and the well-known Quartette Group of mines in the Searchlight District, and the Duplex Mines which have struck ore extraordinarily rich in the lower level of their workings.

The Tri-State claims, known as the Copper Vault Group, are located just east of Death Valley, on the Nevada side of the State line, 
and between the great Potosi and Copper Chief Mines south from Goldfields and Bullfrog Districts with connecting claims the entire distance.

Another group of fire claims belonging to the Tri-State is situated about ten miles north from Kingman, Arizona, in Mojave County, near Stockton Hills, where the great producers, known as the Banner and Treasure Hills Mines, are located, and are connected by adjoining claims that promise just as satisfactory results as their better developed neighbors.

Between the Tri-State group of claims on the west side of the Colorado River and their group on the east side of Stockton Hills is tho most celebrated group of the district, the Gold Roads Mines, which are producing and shipping $\$ 50,000$ per month regularly. It was gold from this wonderfully rich property that set the visitors in Los Angeles wild during the Shriners' visit a few months ago.

Just east the United Verde at Jerome, Arizona, offers an example of the value of a mine in this mineral zone when fully developed. It is doubtful if $\$ 500,000,000$ would be accepted for this one property.

Other claims of great promise and value in these districts are the Gold Cone, Moonlight, Delaip and Gold Basin, south of Goffs, California, where the Tri-State has nine claims, two miles south of the farfamed Turtle Dove group of gold claims, are linked together by the Keyes and Banta Mines. Properties of the Tri-State being centrally located in the midst of this great mineral zone and bound on all sides for miles with rich producers are located among the best properties in the entire country.

A very important feature of the plans of the Tri-State Development Company will be the locating, the partial development and sale of properties. This is essentially the work of exploration companies, and the sale of a single claim often affords profit enough to reimburse the shareholders in one dividend, all they expended originally for their shares.

The properties of the Tri-State Development Company are in one of the richest mineralized sections on the globe. Within sight of the TriState property, known as the Patsy Pat group, is the Tom Reed Mine, which recently sold for $\$ 2,000,000$ to interests represented by John Hays Hammond.

Shrewd, successful merchants do not embark in mining ventures nowadays until they have assured themselves by expert advice beyond any doubt that their ventures shall he profitable, hence before $\mathrm{Mr}$. Green and his associates paid over their money for the properties owned by the Tri-State Company they sent Mr. George C. Harrison, of New York, to visit the properties and make report thereon. Mr. 
Harrison discovered 26 veins of exceedingly rich free milling ore, much of it assaying $\$ 30$ in gold and from 10 per cent. to 35 per cent. copper. The extent of this vein matter is fully revealed in Mr. Harrison's report to the directors.

The opportunity for extraordinary profits is offered exclusively to the readers of this magazine. Fifty dollars may be invested in the shares of this company. This opportunity comes at a time when mining investment is once more engaging the attention of the better class of the speculative masses by virtue of the steady outpouring of profits from American mines. The following figures are significant:

The Mining World says: "One hundred and nine American mines during the first ten months of the year paid their shareholders $\$ 52$,850,110 . Of this amount the Amalgamated disbursed $\$ 3,077,75 \%$." These figures are eloquent facts. There is absolutely no other industry, no other investment that rivals the possibility of mining when conducted with a proper regard for clean and honest methods and when in the hands of capable men who shall apply industrial economics in winning the metal from the ore deposits they own.

When a mining and exploration company is organized by men of the type of Mr. William Lawrence Green and Mr. A. Bleecker Banks, there is every evidence of sincerity and ultimate success attending their operations, and all those who are permitted to join in such an enterprise have more than an average chance of making an amount of profit out of all proportion to the amount invested.

Mr. Green and his associates in the Tri-State Development Company permit you to join them upon the exceedingly liberal terms they. mention to test the writer's theory that the readers of this magazine are financially able, and indeed eager to purchase all the treasury shares of the new company, first at 20 cents, then at 35 cents, and then at par. I believed that Mr. Banks could thus widely distribute the shares of his company without publicly advertising, and I told him so, and my proposition was accepted after it had been passed upon by the Board of Directors.

But Mr. Green's offer must be accepted quickly, else the opportunity to secure $\$ 1.00$ shares for 20 cents will be canceled. You should notify. Mr. Green to-day that you will accept his offer, provided, of course, you desire to. Address your letter to Mr. Wm. Lawrence Green, President, Tri-State Development Company, 32 Broadway, New York City. You need not limit your investment to $\$ 200$. Mr. Green will permit you to secure a $\$ 300$ or a $\$ 500$ investment in his enterprise, but not more than $\$ 500$ will be accepted from any one reader of this magazine, as it is Mr. Green's desire to have the shares of his company very widely distributed. 
Remember this, even a $\$ 100$ investment in mining shares possesses great possibilities for profit; such a renture may make you rich. Such things are numerous in mining history. One hundred dollars invested a few years ago in gold coin stock at 20 cents increased to $\$ 7,500$ and paid 4,800 per cent. in profits. Home Mining Company paid $\$ 10,000$ in profits for every $\$ 100$ investment, and every $\$ 100$ invested in Copper Queen has earned over $\$ 3,000$ in dividends, and the company pays millions in profits every year. The Bonanza Mine of East Oregon was sold in 1896 for $\$ 100$. In 1902 a 60 per cent. interest in this same property was sold by the exploration company who had bought it for $\$ 2,000,000$ cash. The Independence Mine of Cripple Creek, a mere prospect in 1891 , has paid about $\$ 30,000$ in profits for every $\$ 100$ originally invested in the shares when they were selling at 20 cents. The original shareholders of the Camp Bird Mine realized $\$ 8,500$ for every $\$ 100$ they expended. And so the long list goes on and on.

Of course every one who reads of wealth quickly made by this or that man by fortunate investment.in some mining or exploration company, wishes that some such opportunity would present itself to him. He perhaps sees offered to the public the shares of mining companies actively traded in on the New York Curb. He halts between his desire for quick gain and profits and his doubts about the prudence of speculating in mines, and finally resolving to take a flyer, he buys the stock that seems to be the most active, or the one backed by the most extravagant promises, either of which is likely to be the most worthless of all. He is probably perfectly unfamiliar with mining and the tricks of promoters and curb brokers, and simply goes it blind. And when his speculation proves disastrous he wrongly thinks he has lost money in mining.

Still real mining or the selling of partially developed mines is the most profitable industry in America to-day, and for capital invested it pays a far greater percentage of returns than any other industry. The time to invest in mining is when a company is in its infancy. Then the investor obtains all the benefit of the rise in the prices of the shares that generally occurs when a mine is managed by competent and responsible men.

Now again. Two hundred dollars obtains a $\$ 1,000$ interest in the Tri-State Development Company. Suppose you hold your investment for two or three years? Suppose the Tri-State Company mects with ordinary success and has distributed profits to the shareholders aggregating $\$ 1,000$ for every $\$ 200$ invested? Would such earnings on your investment be satisfactory? I take it that they would. Still such percentage of profit is not only usual in well conducted mining com- 
panies, but it would be unusual if this amount should not be distributed within two or three years after the formation of a company officered and protected by such men as form the directorate of the TriState Development Company.

But, you say, even acknowledging that Mr. Green and his associates are earnest, responsible, pushing business men, how do I know that my isvestment will turn our satisfactorily? Frankly, you do not know. But given a fair field for operations, a proven property and an able management by men of large affairs in other pursuits, and who have amply endowed their enterprise with their own funds-an interest in such a company is more than likely to succeed and to pay in profits an amount far outclassing any expenditure made at the initial stage.

Tell Mr. Green to reserve for you as much of an interest in his company as you may afford to take, or you may ask him to send you Mr. Harrison's report and a prospectus of the Tri-State Development Company. Although a very busy man, Mr. Green will find time to answer your letter personally if you desire to ask him questions, or prefer to pay for shares by remittances covering a space of six or twelve months. If it is possible for you to visit Mr. Green by appointment at his office, you will find doubtless such a visit profitable and instructive, for Mr. Green, aside from being a business man and merchant, has large interests in the mining world, and converses with rare intelligence with his visitors upon mining topics. 
Cable "Stebentere New Yore" Code Ubed: A BC (5tr edition) Tel. 2280 Stutvebant

\section{STERLING DEBENTURE CORPORATION}

BANK AND TRUST COMPANY STOCKS-INVESTMENT SECURITIES

TO ATOID POBAIBLE DELAT8

ALL COMMUNICATIONB

BEOULD BE ADDREABED TO

TBE CORPORATION, NOT

TO INDIVIDUAL MEMBERS.

133 EAST 16th ST., NEW YORK

February 19, 1912.

Mr. JoHN

New York, N. Y.

Dear Sir :

The enclosed Referendum is being mailed to every shareholder of the Bartica Company, and is practically sure to result in the withdrawal of the Company's present offer of shares with Convertibles.

As all whose subscriptions are registered before the present offer is withdrawn will receive Convertibles with their shares, and will also be entitled to a vote in this referendum and the right of first call on a pro rata portion of each yearly bond issue, we are sending the enclosed documents to those of our clients who, in our judgment, will be glad to take this opportunity to claim the special benefits vouchsafed to the original shareholders in this remarkable plantation enterprise.

Attached to the Referendum Form is a special blank for your convenience in applying for shares. This application when registered entitles you to vote in the Referendum. We suggest, therefore, that you fill out the Referendum Form at the same time and forward [it] to us so that your vote may be recorded simultaneously with your application.

Whatever opinion one may hold regarding political Referendums there can be no doubt that in the relationship between a Company and its shareholders the idea is as commendable as it is unusual. It is a practical recognition of the intimate relations which should exist between shareholders and Directors in all corporate bodies. It is an example of what should be, and a forerunner of what soon will be the basis of all corporations whose officers recognize their true obligations to the investing public.

Whichever way the vote may go, every shareholder has cause for congratulation on the fact that the Bartica Company has passed through, with such credit to its management, the difficulties that always confront a new enterprise of this nature, and is now entering on a new era in full possession of the excellent results which have been wrought out by that management-a record that cannot be surpassed 
in thorough scientific efficiency by any other rubber plantation on the Globe.

The proceeds of the proposed bond issue will provide for putting at least 1,000 additional acres under rubber cultivation during the next twelve months in addition to installing the fibre factory and providing ample funds for the continued care of the fields already planted and approaching maturity. As the successive rubber plantings come into bearing you will receive larger profits than could be hoped for from any other agricultural enterprise.

Your application for such shares as you may desire will have our prompt attention.

Yours very truly,

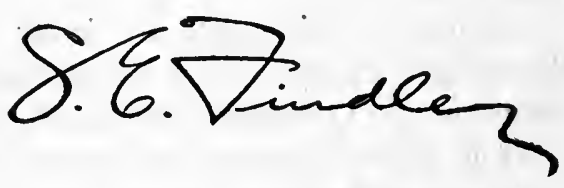

Vice-President.

Cable "Stebenture New York" Code Ubed A B C (5th edition) Tel. 5750 Mad. SQ.'

\section{STERLING DEBENTURE CORPORATION}

BANK AND TRUST COMPANY STOCḰ-INVESTMENT SECURITIES

BRUNSWICK BLDG., MADISON SQUARE, NEW YORK

F. W. Shumaker, Chatrman

G. H. MIDDLEBROOKK, PRESIDENT

C. B. SEABURY, 1 ST VICE-PRES.
S. E. FINDLEY, 2ND VICE-PRES.

E. A. BARRON, SECRETART

W. S. EDWARDS, TREASURER

H. H. PLATT, Asgt. Treasurer

Mr. E.

September 19, 1918.

New York, N. Y.

Dear Sir :

Because of its advance information this is the most important letter we have ever addressed to you.

When we recently mailed to you a pamphlet on the Bartica Company it was to tell you of a place admirably adapted to the culture of rubber and which it was proposed to plant with Para rubber trees. The plans for the development of the immense estate were then well under way. On the basis of tapping the trees now under cultivation. or being set out, the rubber estate would return very large earnings, to the stockholders. But extensive explorations on the property have. 
resulted in remarkable discoreries, and a cablegram from Manager Withers now confirms the news to an extent which raises the value of Bartica shares to several times their par value.

When Mr. Henry C. Pearson, the foremost rubber expert of America, went to British Guiana, in behalf of the Sterling Debenture Corporation, to investigate the conditions and prospects of the Bartica Estates, he made the unexpected discovery that wild rubber trees were already growing on the plantation and expressed the opinion that the find indicated the possibility of an extensive growth of rubber on the Estate and advised careful examination of the forests before further clearing was done.

The management at once proceeded to act on the advice, but as the Company's property comprises fifteen thousand acres, being considerably larger than the Island of Manhattan (New York City), and is covered with tropical forest, it was cf course slow work to inspect it carefully and get any clear idea of the number of rubber trees. Under instructions from the Governing Director, Manager Withers has been carrying his investigations into the forest all over the concession. Recent letters from him reported the finding of Hevea growing in great profusion as well as quantities of Sapium, a tree producing rubber almost equal in value to Para. Some of these trees have been tapped and the rubber has come on to New York for examination and analysis. Although hastily cured, without proper facilities, all the experts who have seen it pronounce it of excellent quality.

Mr. Withers' work has been pushed steadily on, and his latest cablegram, rounding out his earlier information, states that further exploration indicates an average of twenty rubber trees to the acre throughout the entire tract. These trees, he states, range from 20 to 90 inches in circumference.

You will see at once the importance to the Bartica Company of this discovery. On Mr. Withers' estimate there are approximately 280,000 trees now ready for tapping which on the most conservative basis will yield five pounds of rubber per tree in the first year. At the present price of rubber (or even at only half the present price) you can readily figure out that this means an enormous income each year. There will now be no waiting for the trees to grow. All that is necessary is to clear paths to the rubber trees, tap and collect the latex. 'As rapidly as this work is pushed will the income increase. It may take a year to fully cover and open up the whole tract, but every day's progress, will add to the earnings.

This work of gathering and handling the rubber can all be done with only a fraction of the capital which would have been required to 
plant and develop the Estate along the original plan. The gathering of rubber from the wild trees discovered will not, however, interfere with the development of the estate along the lines originally planned. It means additional income, enough to pay large dividends, while the planted Para trees are growing to the producing stage. Splendid possibilities are in sight for those who secure shares at the original price.

The sudden development which so greatly increases the value of this investment will require immediate changes in the Company's plans. Mr. E. A. Hackett, Secretary of the Bartica Company, is well experienced in matters pertaining to the handling and marketing of crude rubber, and he has already sailed for the Estates. He will supplement Mr. Withers' work to the end of quickly starting the Company's income, and his early advice will help in the decision of the Company, whether to withdraw their stock entirely from the market or to reopen the subscription lists at a price commensurate with its present value. In the meantime the Bartica Company instructed us to close the stock subscription, accepting no further orders under our original offer of $\$ 10$ a share.

In addition to the subscriptions already accepted, we had in good faith extended the offer at $\$ 10$ to a number of our correspondents, and we insisted that in such cases we be permitted to give due notice of the withdrawal of the offer. The justice of this demand was conceded, and you being one to whom the offer had already been made, are entitled to receive this notice.

It is to our interest always to protect our customers, giving them the lowest price on every security offered. We would prefer to secure for you to-day at $\$ 10$ as many Bartica shares as you can afford to carry, rather than to sell you a lesser number next month or next year. at $\$ 30$ or $\$ 40$ or $\$ 50$ per share. That is why we give you this advance notice of the withdrawal of our previous offer; but in the nature of the case we cannot continue, beyond the receipt of this notice, your privilege of accepting our offer at $\$ 10$ a share. It is advisable that a telegram be used in making application for this stock, but telegraphic reservations should be confirmed immediately by mail.

\section{Yours very truly,}

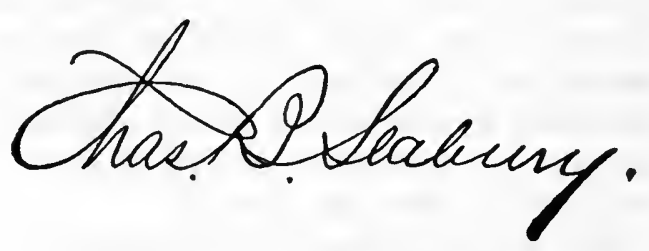

First Vice-President 
BARTICA COMPANY ANNUAL REPORTS, JANUARY, 1912

\section{Report of the President}

\section{To the Shareholders of the Bartica Company:}

To comply with the laws of British Guiana the plantation is held by the Bartica Agricultural Estates, Ltd., a British Guiana corporation owned by the Bartica Company.

The Board of Directors of the Bartica Company and the Bartica Agricultural Estates are identical, and the business, both here and in British Guiana, is transacted through this Board. Funds as received are remitted, less necessary office and administration expenses here, to the Bartica Agricultural Estates in British Guiana, through which corporation the business is carried on in that country. Neither the Bartica Company nor the Bartica Agricultural Estates has any indebtedness. At no time has there been any debt except for current expenses during the month.

The Bartica Company has a contract with the Sterling Debenture Corporation to sell its treasury stock, making payments according to the requirements of the Company, which are stipulated in the contract and will enable us to plant and carry to full bearing six thousand acres of rubber without using any portion of our profits for plantation purposes.

\section{PLANTINGS OF 1911}

To provide for our first planting the company ordered through the Agricultural Department of British Guiana 170,000 rubber seeds. These were received and planted in the nursery. It was expected that they would yield 125,000 plants, but because of defective packing in Ceylon, we got a very small percentage of germination, securing only about 5,000 plants. In consequence of this loss and because of its desire to encourage worthy enterprise in its territory, the Government subsequently refunded the purchase price.

We were able to secure from the Government Agricultural Station about 15,000 seedlings, so that from our secds and the seedlings we had 20,000 trees in the nursery available for planting.

In addition to this, we purchased from Ceylon 70,000 stumps, and Messrs. P. W. Woolley \& Company, through whom the purchase was made, sent a surplus of about 5 per cent. to cover possible losses. We were extremely fortunate with this shipment, as our superintendent reports that about 70,000 of the stumps developed, and are either planted permanently in the ficlds or are in the nursery ready for planting out as fast as the ground is prepared for them. 
Besides caring for and keeping in order the two hundred and fifty acres planted in sisal, the Company has planted 50,000 Para rubber trees raised in the nursery on four hundred and fifty acres and has remaining 40,000 trees in the nursery, giving us a total of 90,000 trees.

An additional one hundred and fifty acres have been felled and 20,000 trees will be transplanted from the nursery to this ground between now and the 15th of April.

\section{PLANTINGS FOR 1912}

To provide for the current year's planting we purchased and have received 200,000 seeds through P. W. Woolley \& Company, and Mr. Withers reports that we are getting very excellent results in germination.

\section{EXCEPTIONALLY FAVORABLE CONDITIONS}

The trees planted are all showing results beyond our anticipation. The reason for this is found in the showing made by meteorological records which have been kept on the plantation for the past three years. The noon sun temperature is 145 to 148 degrees. Our maximum shade temperature has been 92 degrees, the minimum 70 degrees, with an average of about 80 degrees. A great factor is the unusual percentage of sunshine. In May, one of our months of greatest rainfall, with a record of 12.88 inches, we had an average of ten hours a day of sunshine out of a possible twelve. The rainfall has been as follows:

\begin{tabular}{|c|c|c|c|}
\hline & 08 to 1909 & 1909 to 1910 & 1910 to 1911 \\
\hline Rainfall & Inches & Inches & Inches \\
\hline September & 6.44 & 3.73 & 7.04 \\
\hline October $\ldots \ldots \ldots \ldots \ldots \ldots \ldots$ & 6.51 & 10.14 & 5.37 \\
\hline November $\ldots \ldots \ldots \ldots \ldots \ldots$ & 10.23 & 4.59 & 8.03 \\
\hline December $\ldots \ldots \ldots \ldots \ldots \ldots$ & 15.14 & 10.52 & 3.83 \\
\hline January $\ldots \ldots \ldots \ldots \ldots \ldots$ & 5.13 & 11.50 & 10.70 \\
\hline February $\ldots \ldots \ldots \ldots \ldots \ldots$ & 12.37 & 8.81 & 10.12 \\
\hline March $\ldots \ldots \ldots \ldots \ldots \ldots \ldots$ & 7.23 & 10.72 & 8.93 \\
\hline April $\ldots \ldots \ldots \ldots \ldots \ldots \ldots$ & 5.95 & 8.10 & 12.99 \\
\hline May $\ldots \ldots \ldots \ldots \ldots \ldots \ldots \ldots$ & 13.57 & 8.82 & 12.88 \\
\hline$\ldots \ldots \ldots \ldots \ldots \ldots$ & 11.68 & 15.42 & 12.78 \\
\hline July $\ldots \ldots \ldots \ldots \ldots \ldots \ldots$ & 8.71 & 12.92 & 10.14 \\
\hline August $\ldots \ldots \ldots \ldots \ldots \ldots$ & 7.32 & 5.79 & 7.73 \\
\hline Totals $\ldots \ldots \ldots \ldots \ldots$ & 110.28 & 111.06 & 110.54 \\
\hline
\end{tabular}

Our longest times without rain for the three years have been once ten days, twice nine days, once eight days, once seven days; so that only five times in three years have we had a week at a time without 
rain, and the rainfall for each of the three years is practically the same, as shown above. During the three years we have had $296 \mathrm{dry}$ days and 799 days with rain.

I do not believe that any rubber plantation in the world can show such farorable conditions for growing Para rubber. Our trees, one year old, show an average of 4 inches in girth 3 feet from the ground, and those two and one-half years old, $8 \mathrm{z}$ inches, with the best 11 inches. Our trees over two years old have been showing a growth of substantially one-half inch per month in circumference.

\section{FREEDOM FROM DISEASE AND PESTS}

The plantation has been absolutely free from either disease (fomes or fungus growth) or ants (termites), the two serious plagues of the East. From the conditions surrounding the plantation, we do not anticipate any trouble from either of these causes. In the first place, the Government has strict regulations prohibiting the bringing in of stumps carrying any soil from any of the rubber-growing countries lest the fungus disease be imported. In the next place, the plantation has thorough natural drainage by reason of its hilly formation and there is no possibility of a development of disease from excessive moisture and bad drainage, a common cause in the East. As our plantation lies on a broad river and there are no other rubber plantations in the neighborhood, there is no chance for the spread of infection such as occurs in the thickly planted portion of the Malay Peninsula.

\section{GOVERNMENT INSPECTION}

In May the Government, through Professor Harrison, head of the Department of Agriculture, and Mr. Ward, agricultural instructor, made a thorough examination of the plantation to see that our cultivation is in accord with Government requirements. Unfortunately, the policy of the Government does not permit the publication of the reports of this examination, but the Demerara "Argosy" published the following notice:

"On Tuesday the party went to 'The Hills' estate, which is under the management of Mr. Withers, and inspected the cultivation of sisal and rubber. 'We were astonished with the progress made since our last visit,' said Professor Harrison, 'and very much struck with the potentialities of Para rubber cultivation in the Bartica district.'”

We have every reason to believe that not only is our cultivation fully up to Government requirements, but that it is equal to any in the East. 


\section{BUILDINGS}

During the year the company purchased a large building known as Kalicoon House, which would have cost us from $\$ 5,000$ to $\$ 6,000$ to build. It is to be used as quarters of the overseer and as our rubber curing house. In addition, we have made a considerable investment in building permanent laborers' quarters, so that we now have sufficient to house properly all the laborers needed to plant one hundred acres per month and care for the existing plants.

\section{ROADS, BRIDGES, ETC.}

As the land is cleared it is laid out in regular fields with roads and substantial bridges where required, all being kept in good order. It is the policy of the Company to leave standing a belt of forest trees from fifty to one hundred feet in width surrounding each five hundred-acre field to act as a wind brake. I would state here, however, that we have no high winds and have never lost a tree from such cause.

\section{AMPLE PROVISIONS FOR DEVELOPMENT}

The Bartica Company has a capital of $\$ 2,000,000$ to provide the necessary working funds for planting and carrying to maturity 6,000 acres. When we have 6,000 acres, producing one hundred pounds per acre, which they will do when the trees are four years old, we will have 600,000 pounds of rubber per year; and when they are producing 600 pounds per acre, which they will do when the trees are nine years old, we shall have $3,600,000$ pounds of rubber. The cost of this rubber laid down in New York City will not.exceed 25 cents per pound, and our net profit will be the difference between this cost and the selling price of rubber. Even on the basis of a gross selling price of 75 cents per pound and a net profit of only 50 cents, the sale of 600,000 pounds of rubber will give us a net profit of $\$ 300,000$, or 15 per cent. on our capital stock, and when we are producing $3,600,000$ pounds will give us a profit of $\$ 1,800,000$, or 90 per cent. per annum on our capital stock.

\section{SUPPLY AND DEMAND}

The average price for rubber during 1911 has been over \$1.44, and both the present price and the indication of the rubber trade are that the price will remain substantially above this estimate during the present year and in the future. The best posted men in the rubber trade do not anticipate purchasing rubber at an average annual price of less than $\$ 1.00$ per pound for a good many years. An examination of the sources of rubber supply for the past year shows 
that there is a steady decrease in wild rubber. The total world's production has been as follows:

$\begin{array}{cccccc} & & \begin{array}{c}\text { Plantation } \\ \text { Para }\end{array} & \begin{array}{c}\text { Wild } \\ \text { Para }\end{array} & \begin{array}{c}\text { All Other } \\ \text { Wild Rubber }\end{array} & \begin{array}{c}\text { Total } \\ \text { in Tons }\end{array} \\ 1905 & \ldots \ldots \ldots \ldots \ldots & 179 & 27,905 & 37,423 & 65,507 \\ 1910 \ldots \ldots \ldots \ldots \ldots \ldots & 3,700 & 31,150 & 34,522 & 69,372 \\ 1911 & \ldots \ldots \ldots \ldots \ldots & 8,500 & 31,500 & 36,553 & 76,553 \\ 15,000 & 31,612 & 32,683 & 79,305\end{array}$

A very considerable portion of the trade has been supplied by Guayule, a low-grade rubber extracted from a shrub in Mexico and the United States. This rubber is secured by pulling the shrub up by its root, macerating it and extracting the rubber by a mechanical and chemical process. This, of course, means the destruction of the plant. The production of Guayule rose from a few hundred tons in 1905 to something over 14,000 tons in 1910. The production for 1911 was about 8,500 tons, for 1912 it will not exceed 4,000 tons: and by 1915 will be less than 1,000 tons a year, or a negligible quantity in the market.

Another process for extracting a low grade rubber was that undertaken at Goebilt, in Borneo, by the United Malaysian Company, a large proposition financed principally by the Vanderbilts and Goelets. This company was organized to collect jelutong, a gum which sells in the market for about four to five cents a pound and carries a small per cent. of rubber. They have a process by which the gum is purified, and it was expected that the resin which was extracted in this purification would pay the total cost, leaving a very large profit. The latest reports, however, are that in this there has been a serious disappointment, and not only has the company paid no dividends, but it is not in good financial condition.

\section{A DECREASING WILD RUBBER SUPPLY}

The same is true of the other wild rubbers. There will be a decrease in wild rubber, due, first, to the exhaustion of the supply, and second, to the fact that at an average price of $\$ 1.00$ for up-river fine Para and a proportionate low price for the poorer grades of rubber, there is a very small profit in collecting. The average cost of gathering and delivering wild Para rubber to the New York market exclusive of the export tax exacted by Brazil, is admitted to be about 75 cents per pound. As the Government at present collects an export duty of about 20 per cent. on the value of the rubber, it will be readily seen that with rubber selling at a dollar a pound the margin of profit on wild rubber is entirely too small to compensate for the risks of the industry. 
Should Para rubber reach a permanent level of $\$ 1.00$ per pound, the only possible profit sufficient to continue the wild rubber industry must arise from the decrease by Brazil in its export royalties. With this royalty totally removed, some rubber would still be shipped, unless the price drops below 75 cents per pound.

Two points are to be remembered: The first is that the quotation for Para rubber means up-river fine Para; that only about 50 per cent. of the wild rubber gathered is of this grade, the balance selling for from 60 per cent. to 80 per cent. of the price of up-river fine. With up-river fine selling at 75 cents, the rubber gatherer would probably only receive 60 cents to 65 cents for the average of the total crop gathered. A drop therefore to 75 cents per pound for up-river fine Para would mean practically the stopping of the production of wild rubber. The second point is that plantation Para rubber, such as we are growing, on account of its preparation and lack of moisture, commands in the market from 8 cents to 12 cents per pound more than up-river fine Para.

\section{CROP SHORTAGES INEVITABLE}

The total rubber supply of the world has increased between 5 and 10 per cent. per annum, due entirely to the increase in the plantation production. This, however, is not sufficient to balance the increased demand for rubber in the arts. Not only has there been a general increase in the demand for rubber, but it is especially strong in the department of automobile tires. This increase has been so great as to overshadow the other demands. It now accounts for at least 60 per cent. of the total rubber consumption of the world. A statement was recently published from one of the leading tire manufacturers of the United States to the effect that there are in use in the United States about 600,000 automobiles and that for all of these there will be made an average of six tires each a year, making a total of 3,$600 ; 000$ tires, and that three-quarters of the regular tire is rubber.

The weight of a $4 \times 32$ automobile tire, which is about the average size, is 27 pounds, and, on the above statement, 20 pounds of this is rubber. This would make, for tires in the United States alone, $72,000,000$ pounds, or 36,000 tons, of rubber. If the rest of the world manufactures an equal number of tires, this would account for 72,000 tons of rubber. While there is an annually increasing quantity of rubber used in pneumatic automobile tires, we are now entering upon a new field for rubber which will probably require even a larger quantity than that taken by the pneumatic tire. This use is the solid rubber tire for trucks. A prominent tire maker has 
estimated that the trucks within three years from to-day will consume as much rubber as the automobiles.

In his analysis of Eastern plantations, Mr. Parry, who is probably the best authority, estimates that the total plantation production of rubber in 1916 will be 80,000 tons. It is not likely, from present indications, that the total production, other than plantation rubber, will be more than 20,000 to 30,000 tons, giving a total of 100,000 to 110,000 tons of rubber for 1916 .

\section{GOOD PRICES ASSURED}

Under all these conditions I believe that we are safe in estimating that the arerage annual price of rubber will not fall below $\$ 1.00$ for the next five years, and that ten years will probably not see rubber as low as 75 cents per pound.

That these facts are appreciated by the large users of rubber is shown by the fact that the United States Rubber Corporation invested $\$ 15,000,000$ in Eastern plantations and that a very large proportion of the manufacturers are acquiring an interest in rubber plantations to ensure them at least a portion of their necessary supply.

I do not believe that any other industry shows as bright a future or as great a certainty of continued prosperity.

In the Bartica Estates we believe we have a plantation which will rank among the best and most profitable of the rubber estates of the world.

$$
\text { Respectfully submitted, }
$$

$$
\text { JAMES C. BAYLES, }
$$

President.

Jersey City, New Jersey, Jan. 9, 1912.

\section{Report of the Treasurer}

To the Shareholders of the Bartica Company:

The financial statement shows simply the financial condition of the Company, but equally important is the executive organization and the management. The Directors of your Company realize the importance of these matters and keep in perfect touch with the work on the plantation. They receive twice a month detailed reports of the work on the plantation, which is checked off on a copy of a survey map, and once each month they receive a statement from Fitzpatrick, Graham, Greenwood \& Co., chartered accountants in Georgetown, certifying the expenditures in British Guiana. The superintendent sends each month a copy of the daily meteorological reports, showing tem- 
perature and rainfall conditions. In addition we have the benefit of the regular inspection by the Department of Agriculture of British Guiana, three such examinations having been made during the past year.

The Governing Director has had some twenty years' experience in the tropics and is thoroughly familiar with agricultural work, the labor conditions, and the management of estates, and has been at all times in readiness to take up the work should the General Manager be incapacitated for any reason. The property is frequently visited and inspected by the officers and agents of the Company from New York.

\section{Financial Statement of the Bartica Company} ASSETS AND DISBURSEMENTS

Cash and receivables .............\$ $5,921.56$

Bartica Agricultural Estates, Ltd. See note 1. . 600,000.00

Plantation work, organization, and all expenses

and payments since the organization of the

Company. See note 2............ 229,597.94

Furniture and fixtures in the United States... $\quad 150.50$

Treasury shares. See note 3.......... 1,164,330.00.

$$
\$ 2,000,000.00
$$

\section{LIABILITIES}

Capital stock authorized (no debts or other liabilities) $\ldots \ldots \ldots \ldots \ldots \ldots \ldots \ldots \ldots \ldots \ldots, 000,000.00$

Note 1. The item, "Bartica Agricultural Estates, Ltd.," represents the 30 per cent. paid to the vendors for the 15,000 acres under a 99 years lease, and the further assumption by the vendors of the payment of $\$ 60,000$ to the Government for a deed to the property; and all development work done on the plantation previous to its purchase by the Bartica Company. It further includes stock to the amount of $\$ 100,000$ paid to Mr. Withers for his contract to manage the Estates for five years. These payments were made entirely in Treasury Stock of Series E (carrying no convertibles) and the total amount is trusteed by the vendors, and is not to be released until the completion of the financing of the Bartica Company.

Note 2. The item "Plantation work, etc.," represents the total expenditures by the Company since it took over the property, including all development and organization work, and cost of financing the enterprise. 
Against this expenditure the Company shows rubber plantings which by the conservative British standards of valuation represent a sale value, at the present stage of growth, of $\$ 135,000.00$, which, with the 150 acres cleared and to be planted with stumps now in the nursery, will have a sale value in December, 1912 , of $\$ 292,200.00$; in December, 1913, $\$ 448,200.00$; in December, $1914, \$ 633,600.00$, and so on continuously until the trees have reached their maximum productiveness.

The 1,000 additional acres to be planted to rubber this year will have by the British standards a sale value of $\$ 300,000.00$ in December, $1912 ; \$ 487,000.00$ in December, $1913 ; \$ 737,000.00$ in December, 1914, etc. And each succeeding year's development will give an added sale value to the Estates at the same rapid rate of increase.

The sisal acreage has now reached a stage where it will, after paying all costs of labor and upkeep, yield a net profit of 7 per cent. on $\$ 85,000.00$ to $\$ 115,000.00$ this year, and will increase rapidly until it reaches its maximum productiveness two years hence, after which time it will continue to produce at the maximum rate.

Note 8 . The Company's treasury stock provides amply for the complete development of the first 6,000 acres by 1917 , which will give the developed portion of the Estates a sale value at that time of $\$ 6,348,200.00$ by the British standards, and in addition the Company will hold full title to 9,000 acres yet to be developed. The Estates will then, by the most conservative estimates, be yielding annual net profits sufficient to pay very large dividends, after providing for the redemption of convertibles and setting aside enough to continue the development of the remaining 9,000 acres of the Estates at the rate of 1,500 acres per year.

In view of the fact that the sisal plantings have now reached a productive stage, I have attached to this report a recommendation to the Board of Directors which, if adopted will, in my judgment, prove decidedly advantageous to the Company and its shareholders.

Respectfully submitted,

LINDLEY VINTON,

Secretary and Treasurer.

Jersey City, N. J., Jan 9, 1912.

\section{A Recommendation by the Treasurer}

To the Board of Directors of the Bartica Company:

Recognizing that the early investor is entitled to ample returns upon his investment to compensate him for the use of his money dur. 
ing the unproductive period, we gave to our early shareholders Convertible Certificates, each certificate representing a 50 per cent. extra dividend on the amount of his investment.

As the Company is now in a position to earn interest on a reasonable amount of bonds, I suggest that the Directors consider the advantage that will come to the Company from the saving of interest through the lower rate which would be made possible by a bond issue.

To provide for the present year's plantings the Bartica Company could issue at par ten-year exchangeable bonds paying 7 per cent. interest, payable semi-annually, this bond to be redeemable in cash on call, at any interest period at 110 per cent. and accrued interest; the holder to have the right at any time before maturity of the bond to exchange this bond for shares at par; should the bond be called before maturity, the holder to have the privilege for sixty days after call to exercise his option of exchanging his bond for shares.

Two hundred and fifty acres of sisal on the company's property have now reached the productive stage. The sisal will return within the first year a net profit of about eight thousand dollars and the monthly yield will increase each month for two years, by which time the first rubber field will come into bearing. This enables the Company to offer a security which gives an income of 7 per cent. per annum until the rubber production enables the Company to pay dividends in excess of 7 per cent. And when the bonds are exchanged for shares, this income will be increased from year to year, until it exceeds 50 per cent. per annum on the investment.

The proposed issue of bonds would find a ready market, for investors have come to realize that no agricultural investment is so secure or offers such large profits as rubber planting.

As an instance of the Company's advantage in the proposed plan, I would call your attention to the experience of the Malacca rubber plantations, which, in November, 1909, out of a total authorized issue of $£ 400,000(\$ 2,000,000.00)$ in $£ 1(\$ 5.00)$ shares, issued:

Seven and one-half cumulative par-

ticipating preference shares...... $£ 115,000 \quad(\$ 575,000)$

Ordinary shares $\ldots \ldots \ldots \ldots \ldots \ldots £ 185,000 \quad(\$ 925,000)$

They then issued $£ 500,000(\$ 2,500,000.00)$ in 6 per cent. bonds in November, 1909, giving holders the right to the 30th of November, 1914 , of exchanging each $£ 10(\$ 50)$ bond for one ordinary share of $£ 1(\$ 5.00)$ par value. These bonds are selling at par and the ordinary shares of the Malacca Company are selling $£ 11(\$ 55.00)$ bid and $£ 111 / 2$ (\$5\%.50) asked, showing that the stock has already reached conversion value. 
It will be obvious to all that in the case of the Bartica Estates, with its exceptional advantages in climatic and soil conditions, the rate of increase in share values will be such that when the subsequent yearly bond issues are made, the exchangeable value of shares will be in a rapidly ascending ratio. Therefore it would not be advisable, in my opinion, to make the succeeding years' bond issues exchangeable for shares at par, though it would be well to reward the subscribers for the first issue in this liberal manner.

Should the Board of Directors favor the bonding plan, I recommend that the present shareholders of the Bartica Company be given first call on the bond issue for such succeeding year.

Respectfully submitted,

LindLEY Vinton,

Secretary and Treasurer. 


\title{
EXAMPLE OF MINING PROSPECTUS PERSUASION
}

\section{SAFE BANKING SYSTEM}

\author{
Mining Recorder
}

\section{THE ONLY RELIABLE BANKER}

Old Mother Nature is the only reliable banker, and a good mine is her bank. Crops may fail, drouth may wither the prospects of the farmer, scourge and devastation may visit the stock man and the rancher, the factory, the foundry and every other species of industry may fail, but nothing can disturb the splendid equilibrium of a mine. The property is there. It cannot decay, it cannot be stolen; therefore, it constitutes Nature's unfailing banker.

That bank may not be blessed with an august surplus, but this much is sure, the cashier never absconds, the paying teller is always at his post with ample funds. That bank never has to close. It never petitions the commissioner in bankruptcy.

True, it requires judgment and experience of a fine order to calculate the contents of its vaults and extract it when located.

It requires brains and muscle to open its combination. But it never accepts deposits and never dishonors a check. The greater the run you make on that bank, the bigger the surplus after the teller has handed you your shining share. When the report of that bank shows that one dollar has been added to the aggregate wealth of the world by production and not by manipulation, that dollar has been made, not simply exchanged. Not precipitated from a father's perspiration or a mother's tears, not in the form of residuum in the bottom of the washer-woman's tub, the weary sighs of the factory girl or the grime of overworked childhood; BUT, a dollar gathered from dear old Nature's breast, thrown out into the world by her fair hand, a shining token of her love, a tribute to honest toil and brains consisting of an article in which values are inherent and intrinsic to sustain the unfailing stability of the industrial world and incidentally to contribute to everything that is dear, precious and patriotic.

Pin your faith to the mines, Nature's banking system. They are the only trust companies that can be trusted; their issue needs no redemption. Gold, silver and copper are their own redeemers

Never hesitate to take all the stock you can get in Nature's Barking SySTEM, the mines.

The Surest Way to Get Some of the Big Dividends That Nature's Banking System Pays Is to Invest in the Stock of the Mexamerican Company, owner of the Great 


\section{OFFER OF STOCK CONVERTIBLE INTO FUNERAL}

Mr.

New York City,

\section{DEAR Sir:}

I have incorporated my business and offer for sale to the Public $\$ 300,000$ worth of $7 \%$ Preferred Stock at $\$ 10$ per share.

$\$ 300,000$ worth of $7 \%$ Preferred Stock will be sold to the Public in shares of $\$ 10$ each.

\section{INCORPORATED FOR $\$ 1,000,000$}

Net Profit from operations in 1912 as shown by the report issued by the Audit Co. $-\$ 72,331.14$, which is over $7 \%$ on $\$ 1,000,000$.

Established 1895. Incorporated 1914 under the laws of the State of New Jersey.

Gross amount of business for $1912-\$ 425,000$.

Gross amount of business for $1913-\$ 500,000$.

Total number of funerals conducted during January, February and March, 1914-1,542.

Total amount of business done during January, February and March, 1914-\$172,400.00.

Total number of funerals conducted since established-21,123. Gross amount of business done- $\$ 2,22 \%, 990.00$.

The above statement shows you how this business has grown and the confidence the Public has placed in me when I could build up an undertaking business to the amount of $\$ 2,227,990$.

The history of the business is too well known without making a lengthy explanation. To-day it is the largest in the world.

In February, 1895, I started in business without a dollar. During the first year I conducted 46 funerals under the old system of a few funerals a year and exorbitant prices for funeral supplies. I shortly woke up to the fact that I was overcharging my friends and was actually acting the part of a hypocrite. I immediately broke away from the old custom, started to fight the Undertakers' Association and the exorbitant prices charged for funeral supplies. The wonderful success I had in this new method can be better explained by reading the statement on page 4 of this letter (p. 402 below) as to how this establishment grew. During the year 1913, I conducted 4,820 funerals at a total amount of a half million dollars. During the months of January, February and March, 1914, I conducted 1,542 funerals, at a gross amount of $\$ 172,740$.

On January 1st, 1913, I engaged the Audit Co., of 165 Broadway, New York, at an expense of $\$ 1,200$, to take an inventory, make an ap- 
praisal, audit my books and issue a report on the gross amount of business done during 1912, and the profit I made thereon. The report is on file in my office and open for inspection to prospective stock buyers and shows a gross amount of business of $\$ 425,000$, with a net profit from operations of $\$ 72,331.14$.

During the year of $1913 \mathrm{I}$ increased my business to a half million dollars, opened a great many branch offices, increased my equipment to almost double the amount of 1912, added another seven-story building to the already large plant, and I am to-day equipped to handle 10,000 funerals yearly. I also spent about $\$ 15,000$ during the year of 1913 in preparing a staff to handle 10,000 funerals a year, and still have a very substantial profit, which is shown by the report made by the Audit Co. of New York, and is also on file in my office and open for inspection to prospective stock buyers.

I feel safe to say that the gross amount of business during 1914 will be about $\$ 690,960$ or more.

I have to-day the largest and best equipped undertaking establishment in the world, facing on Main Street 150 feet and running through 200 feet to Liberty Street, seven stories, all new and up-todate construction, where I have my factory, garage, varnish room, paint shop, woodworking department, cloth-covering department, sewing rooms and my own crematory and florist department. My garage is equipped with over forty automobiles and the livery department with over one hundred horses. This will prove to you that I am able to handle 10,000 funerals a year without any difficulty.

I have started this business without a dollar, made a fortune and have spent another fortune in advertising it and putting it on the footing it is to-day, and assure those who invest money in this proposition that it is just as safe as though it were in their own hands.

For the benefit of those who wish to purchase stock and share my profits with me, I will state that I would be pleased to have them call personally, go through the plant, examine the books and see the report issued by the Audit Co., or if they would make an appointment, I would make it my business to call at their homes personally and go over the matter more fully.

Ten dollars will give you a start in life which might be the making of you. You can rest assured it is earning $7 \%$ from the moment it is invested. This stock will not be handled by brokers, and I hold the right to reject any application. You are dealing with me personally and can receive stock from absolutely nobody but William Necker.

Why allow your money to lay in a savings account in some bank at $3 \%$ and earn big profits for already millionaires, when you can get into 
a commercial business as sound as this one and buy $7 \%$ Preferred Stock at $\$ 10$ per share?

There is no doubt in my mind that you are familiar with the Henry Ford Motor Proposition, also the Douglas Shoe Company. I claim our proposition is second to none if properly financed and handled. As to my ability of handling this proposition, I will leave that to the Public.

To further increase the profits of this business, I intend to take one entire floor in the main building and equip in it a monumental and mausoleum department. On another floor a mourning goods department will be installed, where clothing of all descriptions can be had, including millinery. I also intend to establish a great many more branch offices within a radius of 100 miles, and possibly later on, all over the country, all of which will add large profits to the business which will be a benefit to every stockholder. The extent this business might grow to is unknown and cannot be predicted by anyone.

If you have $\$ 10$ or more to invest, don't hesitate when you can get into a commercial business established for 19 years, knocked from pillar to post by the Undertakers' Association, better known as the Trust, survived all storms and to-day stands out as the largest undertaking establishment in the world. Come in and go through the plant and visit the various branches, examine the books and reports if you will, and be convinced for yourself.

In our certificate of incorporation we have the privilege of manufacturing coffins, caskets and monuments, building vaults, controlling cemeteries, manufacturing mourning goods, automobiles and furniture, or everything else pertaining to woodwork. This will be very beneficial in enabling us to produce for our own use and for the purpose of sale to other dealers, all things usually used by any undertaker.

I also have connected with my establishment one of the largest florist departments that has ever been controlled by any undertaker in the world, doing close to $\$ 25,000$ worth of business yearly, which also can be increased to double the amount.

We have also built, in the home office, at the rear of the main chapel, which has a seating capacity of 400 , one of the most up-to-date crematories, built by the F. B. Branklin Co., of New York. After we have received our permit from the State to operate same, we will positively be able to handle the cremating for the City of New York and surrounding territories, as we will be able to do the cremating at probably one-quarter the cost charged by the cremation companics.

Through my incorporating and having associated myself with thousands of families who will purchase this $7 \%$ Preferred Stock at $\$ 10$ per 
share, I will have a Fort established that the Undertakers' Association could never break into.

The stocks will be transferable on the books of the Company at any time.

One of the greatest and most important things in my Incorporation that should interest thousands and thousands of people, especially those who cannot receive life insurance and others who do not believe in it:

You can purchase five shares of my $7 \%$ Preferred Stock for $\$ 50$, or you can purchase ten shares of my $7 \%$ Preferred Stock for $\$ 100$, and I feel safe to say, receive your $7 \%$ dividend during your lifetime, and if you have no life insurance or any money at the time of death, the five shares can be paid into the Company for a $\$ 50$ funeral, which is as good as ever furnished by any other undertaker for $\$ 100$, or the ten shares can be paid into the Company for a $\$ 100$ funeral, including a new grave, which is equal to any funeral furnished by any other undertaker for $\$ 200$. This $\$ 100$ funeral that I offer in this proposition, including a new grave, is positively only to stockholders.

My business is established for the past 19 years. I started without a dollar, and have positively to-day the largest undertaking establishment in the world, and to more fully convince you as to how well my. business is established, and on how good a paying condition it is, look up my certificate, filed with the Income Tax Bureau of the State of New Jersey, and see the amount of taxes I am forced to pay as a positive net income, and you can bet your life there isn't anybody padding his income tax report.

You should not hesitate. Sit right down and send in your application for five shares of the $7 \%$ Preferred Stock or ten shares if you choose, and take advantage of the above offer.

\section{HOW THIS ESTABLISHMENT GREW}

During 1895 I conducted 46 funerals. During 1896 I conducted 93 funerals. During 1897 I conducted 102 funerals. During 1898 I conducted 137 funerals. During 1899 I conducted 162 funerals. During $1900 \mathrm{I}$ conducted 243 funerals. During $1901 \mathrm{I}$ conducted 207 funerals. During 1902 I conducted 216 funerals. During 1903 I conducted 297 funerals. During 1904 I conducted 427 funerals. During 1905 I conducted 415 funerals. During 1906 I conducted 392 funerals. During 1907 I conducted 636 funerals. During 1908 I conducted 940 funerals. During 1909 I conducted 1,278 funerals. During 1910 I conducted 1,904 funerals. During 1911 I conducted 8,146 funerals. During 1912 I conducted 4,118 funerals. During 1913 I conducted 4,820 funerals. 
Total number of funerals conducted since established, 21,123.

Gross amount of business done since established, $\$ 2,227,990.00$.

Total number of funerals conducted in January, February and March, 1914, 1,542.

Gross amount of business done in January, February and March, $1914, \$ 172,740$.

\section{Yours truly,}

WM. NECKER.

\section{OFFICERS}

William Necker, Pres. and Treasurer.

Thomas McClelland (Banker), Vice-President.

Chas. Singer, Jr. (Real Estate), Secretary.

\section{BOARD OF Directors}

Edw. W. Berger (Banker),

Georae Limouze (Retired),

Thomas Henry (Building Supplies and Banker),

Chas. Nielson (Contractor),

Chas. Singer, Jr. (Real Estate),

Thomas McClelland (Banker),

William Necker.

Executive Committee

William Necker

Chas. Singer, Jr.

Geo. Limouze

Thomas McClelland. 


\section{BOND HOUSE LETTER}

N. W. Halsey \& Co.

New York, Philadelphia, 49 Wall Street

San Francisco,

Chicago.

New York, Sept. 28, 1912.

Pacific Gas \& Electric Co. General \& Refunding 5s, 1942

We ask careful consideration of the enclosed circular because we believe these bonds are unusually safe and some of the reasons are as follows:

First.-The market equity is more than $\$ 29,000,000$.

Second.-During the last seven years over $\$ 11,500,000$ has been put into the property from earnings.

Third.-Net earnings for three years have been about double interest charges.

Fourth.-The Company is paying dividends as follows:

$6 \%$ on $\$ 10,000,000$ Preferred Stock.

$5 \%$ on $\$ 31,998,750$ Common Stock.

Contrast these facts with the present price of $91 \frac{1}{2}$ and interest at which the bonds yield about $5.60 \%$. The price certainly looks very, very cheap, and it is cheap.

The Company is now making application to list on the New York Stock Exchange.

We recommend that you telephone or telegraph us to reserve a certain amount of these bonds for you pending investigation, for the preliminary sales have been large, and the price is strictly subject to advance.

Yours very truly,

JSA :S

N. W. HALSEY \& CO. 


\title{
UNDERWRITING SYNDICATE AGREEMENT 2
}

\author{
REPUBLIC OF CUBA \\ FIVE PER CENT BONDS OF 1904
}

SYNDICATE AGREEMENT

Dated February 16, 1904

\author{
SPEYER \& CO., \\ New York, \\ Syndicate Managers.
}

\section{PARTIES}

Agreement made this 16th day of February, 1904, by and between Speyer \& Co., of the City of New York, hereinafter called the "Syndicate Managers," parties of the first part, and the subseribers hereto, severally, each of whom is hereinafter termed a "Subscriber," and all of whom, taken together with the said parties of the first part, are termed the "Syndicate," parties of the second part.

\section{DESCRIPTION OF BONDS}

Whereas the Republic of Cuba acting under the law of February 27 th, 1903, as amended by the law of January 25th, 1904, proposes to issue Thirty-five Million Dollars $(\$ 35,000,000)$ five per cent gold bonds, to be known as "Republic of Cuba five per cent. Gold Bonds of 1904," which said bonds are to be coupon bonds of denominations to be hereafter determined, with the privilege of registration, to be dated March 1, 1904, and to be payable March 1, 1944, except so far as previously retired by the Sinking Fund, and to bear interest at the rate of five per cent. per annum, payable semi-annually on the first days of March and September in each year, both principal and interest being payable in the City of New York in United States gold coin of the present standard of weight and fineness, and in sueh European cities and in such foreign moneys as may be designated, and are to be exempt from all kinds of Cuban taxes that now exist or may be imposed hereafter; and

1 Exhibit No. 52 in connection with testimony taken before the Legislative Insurance Investigating Committee of Now York. 


\section{RELATION OF MANAGERS TO THE ISSUE}

Whereas, Speyer \& Co. (having heretofore purchased from the Government of Cuba all said $\$ 35,000,000$ Bonds) have agreed to sell to a syndicate, of which they are to be the managers and in which the subscribers desire to join, Twenty Million Dollars $(\$ 20,000,000)$ face value of the said bonds at ninety-one per cent. (91 per cent.) and accrued interest with the option to the Syndicate until September 1,1904 , to buy all or any part of the remaining Fifteen Million Dollars $(\$ 15,000 ; 000)$ face value of bonds at ninety-two and one-half per cent (921/2 per cent.) and accrued interest.

Now, This Agreement Witnesseth, That in consideration of the premises and the mutual promises herein contained, the subscribers hereto severally agree with each other and with the Syndicate Managers as follows:

\section{LIABIIITY OF UNDERWRITERS}

Finst. Each subscriber hereby agrees to purchase the amount of said Republic of Cuba five per cent. Gold Bonds of 1904 (or of temporary certificates issued by Speyer \& Co., representing the same) which is set opposite his signature hereto, and to pay for the same ninety-one per cent. (91 per cent.) of the face value thereof and accrued interest as herein provided, and also to purchase at any time, or from time to time, at ninety-two and one-half per cent. (921/2 per cent.) of the face value thereof and accrued interest, a further portion or portions of the Fifteen Million Dollars $(\$ 15,000,000)$ of said bonds, which are subject to the option of purchase above mentioned (or of the part or parts thereof which the Syndicate Managers shall under said option at any time, or from time to time, elect to purchase), which shall bear the same ratio to the whole amount which the Syndicate Managers shall so elect to purchase as the amount of bonds set opposite his signature hereto bears to the amount of Twenty Million Dollars of such bonds purchased firm as aforesaid.

\section{MANAGERS AS UNDERWRITERS}

The Syndicate Managers, parties hereto of the first part, may be subscribers to the Syndicate and to the extent of their subscription shall be liable hereunder for and entitled to receive their ratable proportion of the said bonds or temporary certificates or of the net proceeds of the sales thereof, in the same manner as other subscribers. 


\section{PAYAENTS TO BE MADE WHEN CALLED}

Second. The subscribers will at any time, and from time to time (but not before June 1, 1904), make cash payments on account of their respective subscriptions hereunder, as called for by the Syndicate Managers. At least five days' previous notice in writing shall be given by the Syndicate Managers in the manner herein provided, of the amount and date when each payment is to be made, and each subscriber will promptly pay when and as required by such notices.

\section{RECEIPTS FOR PAYMENTS}

Trinrd. All subscriptions shall be payable to the Syndicate Managers at their office in the City of New York, and on making the first payment each subscriber shall be entitled to receive a Participation Certificate certifying that the subscriber or his assigns, so long as he or they shall not be in default hereunder, is or are entitled to participate pro rata in the benefits of the Syndicate formed hereunder and to receive his ratable proportion of said bonds or temporary certificates when the Syndicate Managers shall deliver the same, or of the net proceeds thereof if and so far as sold. The said Participation Certificates shall be of such tenor and form as the Syndicate Managers may determine, and all subsequent payments shall be receipted for or endorsed thereon.

SYNDICATE MANAGER'' RIGHT TO HOLD BONDS.AND DEAL IN THEM FOR SYNDICATE

Fodrth. The Syndicate Managers may retain all of the bonds or temporary certificates for the bonds purchased by the Syndicates either from or under the said option for such period as in their discretion they may deem expedient, not exceeding twelve months from the first day of March, 1904, and from time to time during said period, and at any time before final distribution hereunder, they may for account of the Syndicate deal in and buy and sell all or any of such bonds or temporary certificates at public or private sale at such prices as they may deem fit, and in their discretion they may repurchase and resell the same for account of the Syndicate at such prices as they may deem proper and advisable.

\section{RIGITT OF UNDERWRITERS TO WITHDRAW}

Within such period or periods as the Syndicate Managers may prescribe, and, with their written consent any subscriber may, on pay- 
ment of one per cent. on the face value of bonds withdrawn (as being his pro rata share of the estimated expense of the Syndicate and the commission on sales), withdraw from sale, at the respective prices for firm and option bonds herein specified, his pro rata share of the unsold bonds or temporary certificates included in the firm purchase or the option above mentioned. Each such withdrawing subscriber must simultaneously with such withdrawal agree that he will not, without the written consent of the Syndicate Managers, sell or offer for sale any such withdrawn bonds or temporary certificates before the termination of the Syndicate Agreement.

\section{COMPENSATION OF MANAGERS AND DIVISION OF PROFITS}

FrfrH. The Syndicate Managers will make no charge to subscribers for their services in managing the Syndicate, but in respect of bonds or temporary certificates sold by them shall be entitled to receive the commission of one-half of one per cent. upon the face value of the bonds or temporary certificates sold, which may be allowed by them to issuing houses. The Syndicate Managers shall determine the profits and losses of the Syndicate and such determination thereof shall be final. All profits and losses of the Syndicate shall be divided and borne by the subscribers pro rata.

\section{MANAGERS' RIGHT TO INCUR EXPENSES}

Sixtr. The Syndicate Managers shall have authority, so long as this agreement is in force, to incur such expenses, including cost of engraving, preparation and execution of bonds and temporary certificates, counsel fees, advertising, commissions and brokerages paid on purchases or sales of bonds and outlays of any other character, as they may deem proper and in the interest of the Syndicate; and all such expenses shall be a charge against the Syndicate.

\section{LIABILITY OF UNDERWRITERS NOT THAT OF PARTNERS}

SEventh. Nothing herein contained or otherwise shall constitute the parties hereto partners or shall render any one of the subscribers liable to contribute more than his several and proportionate amount as herein provided or shall prevent any of the parties from contracting with each other with reference to any of their respective interests.

Each subscriber signing this agreement or any counterpart thereof shall set opposite his name the amount of his subscription to the 
$\$ 20,000,000$ face value of the said bonds purchased firm, and each subscriber shall be called upon to pay and be liable for only such portion or portions of said $\$ 20,000,000$ of firm bonds, and of the amount or amounts of said $\$ 15,000,000$ of option bonds, in respect of which the options shall be exercised as aforesaid, as the amount set opposite his signature hereto shall bear to the sum of $\$ 20,000,000$.

\section{DURATION OF SYNDICATE}

EIGHTH. The Syndicate shall continue until March 1, 1905; but the Syndicate Managers shall be the sole and final judges as to whether at any time it is to the interest of the Syndicate to proceed further under this agreement, and they may at any time prior to said date by notice in writing to the subscribers, terminate this agreement, in which event any or all bonds or temporary certificates then held for account of the Syndicate, and the proceeds of such bonds or certificates as may have been sold, shall remain charged with the payment of all expenses and liabilities by them incurred hereunder, and shall be applied and dealt with as above provided. The Syndicate Managers may also terminate this agreement in case of the failure of the Government of Cuba to deliver to Speyer \& Company all of said $\$ 35,000,000$ of said bonds purchased by Speyer \& Company as aforesaid, or if Speyer \& Company under advice of counsel, decline to accept same.

\section{POWERS OF MANAGERS}

Nintrr. The Syndicate Managers may sell any bonds or temporary certificates held hereunder to any subscriber and any such subscriber may make any purchase of bonds or temporary certificates from the Syndicate Managers. The Syndicate Managers shall have absolute control over the disposition of all bonds and temporary certificates held by them hereunder, subject to the provisions hereof. They shall have sole direction and management and entire control of the Syndicate, and shall have exclusive power to determine whether and to what amount or amounts and at what time or times the option of purchase above mentioned shall be exercised. They shall be sole judges, in behalf of the Syndicate, as to the form and terms of the said bonds. The enumeration of particular or specific powers in this agreement shall not be considered as in any way limiting or abridging each power and discretion intended to be conferred upon and reserved to the Syndicate Managers, in order to authorize them to do any and all things proper, necessary or expedient in their discretion to carry out 
the purposes of this agreement. The Syndicate Managers shall not be liable for any error of judgment nor for any mistake of law or fact nor for anything except gross negligence or bad faith. Each subscriber nominates and appoints the Syndicate Managers his agents and attorneys irrevocably until the termination of this agreement to enter into or execute any and all arrangements or agreements deemed by the Syndicate Managers expedient or necessary tc carry out and perform said agreement for the purchase of said bonds by the Syndicate and the issue of the temporary certificates herein referred to, and to accomplish the objects and purposes of the Syndicate, and each subscriber hereby ratifies and assents to any action of the Syndicate Managers taken under this agreement, and agrees to perform his undertakings herein from time to time promptly on the call of the Syndicate Managers, to the full extent of his proportion of the entire Syndicate liability.

\section{BREACH OF CONTRACT BY UNDERWRITERS}

Tenth. The failure of any subscriber to perform any of his undertakings hereunder shall not affect or release any other subscriber. In case of any and every such failure the Syndicate Managers may, at their sole and exclusive option, exclude such failing subscriber from further interest and participation in the Syndicate and forfeit all payments theretofore made by him hereunder and hold the failing subscriber liable for any damages that may have been caused by such failure.

\section{RELEASE OF UNDERWRITER BY MANAGER}

The Syndicate Managers may in their discretion release any subscriber, either absolutely or upon such terms as the Syndicate Managers may prescribe, and, in case of failure to perform on the part of any subscriber, or a release of any subscriber by the Syndicate Managers, other subscribers may be received by the Syndicate Managers to take the place of the subscribers so failing to perform or so released.

\section{DEFINITION OF MANAGER}

Eueventh. The term "Syndicate Managers" as herein used shall be deemed to apply to the firm of Speyer \& Company, as the same is at present constituted and as it may hereafter at any time be constituted. 


\section{NOTICE TO SUBSCRIBERS}

TweLfTr. Each subscriber shall set opposite his subscription. hereunder written an address to which notices or other communications may be sent, and any such notice or communication addressed to any subseriber at the address so given, and either left at such address or deposited in a post office, enelosed in a post-paid wrapper addressed to such subseriber at such address, shall be deemed actually given to such subscriber on the date of so leaving or depositing the same, and shall be sufficient for all the purposes of this agreement. If any subscriber shall fail so to furnish his address to the Syndicate Managers he shall not be entitled to any notice or other communieation, and he shall be deemed to assent to any action of the Syndicate Managers.

\section{AGREEMENT, HOW MADE UP}

Thirteenth. An original copy shall be signed by the Syndicate Managers and retained by them, and one or more counterparts may be signed by the subscriber, but all together shall be taken and deemed to be but one original instrument.

\section{OBLIGATION TO BIND LEGAL SUCCESSORS OF SUBSCRIBERS}

Fourteentr. This agreement shall bind the subscribers respectively, their respective personal representatives, suceessors and assigns.

In Wrtness Whereof the Syndicate Managers, parties of the first part hereto, have subscribed an original hereof, and the subscribers, parties of the second part hereto, have subseribed said original or a counterpart thereof, as of the day and year first above written.

SPEYER \& Co.

Firm bonds

(face value)

Name of subscribers.

Address. subseribed for

The Mutual Life Insurance 32 Nassau Strect

Company of New York

$\$ 2,500,000$

Signed : 


\section{THE KANSAS CITY, MEXICO AND ORIENT RAILWAY COMPANY ${ }^{1}$}

A. E. STILWELL, PRESIDENT

SINGER BUILDING, NEW YORK

February 6, 1912.

To the Secretaries of Boards of Trade and

Members of New York, Boston and Chicago Stock Exchanges.

Dear Sirs: I have started out on a campaign to help free American business from the inquisition of the money power.

I understand full well the magnitude of this fight, but after sixteen years of unrelenting persecution while building two important railroads of the United States, I have made up my mind that it would be un-American longer to stand such treatment without protest; that it would be better to fight for clean business methods and go down if need be than to work longer against unbearable conditions.

Sixteen years ago a leading New York banker wanted me to exploit my stockholders to enrich him and myself. I refused, and he forthwith proceeded by every device to make my work most difficult. Eleven years ago a second New York banker of prominence made me a similar proposition. I again refused, and more obstacles were put in my way. I made up my mind then and there to look directly to the business men of the country rather than to the money power for fair and honest backing. This plan I have adhered to, but the persecution keeps up; and $I$ am now in the frame of mind of the people of Boston when they threw the tea overboard.

I am convinced that if other deals are engineered like the two offered to me, it is a menace to our civilization and to the business of the United States; and it is easy to see how unscrupulous men may amass colossal fortunes in a few years' time.

This land is developing fast. All men are entitled to a fair field and no favor. The money of our land, which under existing conditions drifts to the reserve banks in large cities, ought not to be used simply to make billionaires of a few. There is no reason why the people that own it shall realize only $2 \%$ and the people that use it realize from $10 \%$ to $25 \%$. This is to serve favorites and ruin industry.

Wall Street ought to be a help to enterprise, not a hindrance;

1 Letter of A. E. Stillwell as promoter of Kansas City, Mexico and Orient Railway Co. 
but ask the experience of many great industries that have been forced to go there for the last five or six years. They will tell you that they have seen their competitors helped in every way if they happened to have a friend who was on one of the interlocking bank directorates.

There is no way on earth for the egregious fortunes that are made in this district to be made honestly and so quickly. It is only because of the enormous toll that is exacted from American business and industry. The whole nation pays these men tribute. They toil not, neither do they spin, but Solomon in all his glory is not arrayed like one of these.

Mr. Reynolds, president of the second largest bank in the United States, says that the money power is in the hands of twelve menand that he is one of them. Vanity here spoke truly!

So American industry is chained to a Hydra with twelve headstwelve sharp, shrewd heads, thinking, working only for self! It is a monstrous power of which the Chicago banker was led to brag!

The remedy for all this is not so difficult. The members of the New York, Boston and Chicago stock exchanges are as honorable, high-minded men as can be found. Let all contracts for financing be passed on by them. Let all contracts for commissions and purchase of a business be endorsed by them as fair. Let no bond prospectus of any offer of bonds be issued unless it has their $0 . K$.; and then robbery would stop. The money deals would not be handled by a few. Any man could float a company on fair terms, as the "hallmarking" of the Exchange would be for any house of bankers or brokers that did honest business. Let any man who deems himself to have been treated unjustly appear before a committee of the Exchange, state his grievance, and if the committee finds his statement true, let it from that time on refuse to pass any flotation by the house that adopts crooked methods. Give the New York, Boston and Chicago Exchanges the right of "hall-marking" deals and prospectuses and at once American finance will be on a rock foundation, and every enterprise have a fair chance to succed on its merits.

This would make the Stock Exchanges of New York, Boston and Chicago take the place, in a measure, of Somerset House in England; the terms of underwriting would be stated, also the commission paid and the list of underwriters; and this would end the three levels ("friends, good friends, and very good friends") that now exist. It would bring the sunlight into business deals, and things now done in the dark would not be done. England solved this problem in 1900 , after the Baring failure, by requiring the visé of Somerset House on all financial deals of consequence. 


\section{MATERIALS OF CORPORATION FINANCE}

My suggestion is merely that the function assumed by Mr. Reynolds and his confrères, who are partial and self-seeking, be transferred to the Stock Exchanges, whose members are impartial men, interested only to have business naturally developed and honestly conducted.

Very truly yours,

A. E. Stilwell,

President. 


\section{AMERICAN WOLVES ${ }^{1}$}

Every few years the commerce and prosperity of our country have been forced to pay tribute to the financial raiders.

Pirates of the North African coast, in the fifties, demanded from the United States a tribute so small, as compared to the demands and exactions of these bear leaders, that it makes the African pirates of old seem meek as Sunday-school teachers. In each bear attack we see some leading man mangled on the financial rack. While the victim's fingers are not pulled out, as was the method of the Spanish inquisition, and while the torture chamber is not now in some dark dungeon, but in beautifully equipped and furnished offices, the torture is just as great.

A man may have a fair financial standing. He perhaps thinks he has the confidence and respect of leading interests. He imagines he may escape the cough-up-quick methods of the street. No doubt he is a director of banks or trust companies. He has been requested to carry his account in this or that bank or trust company; he has been given unlimited credit at the broker's; but the day comes when the bears-or, in truth, wolves- "need his money"; these wolves may have been associated with him and he thinks they will play fair. Like Russian wolves, financial raiders do not discriminate while picking their victims.

The time comes for the victim to disgorge a million or two beeause he believed in his wolfish chums. These wolves have friends in many banks and can find out just where his loans are, nearly all being "on demand." In twenty-four hours they size up what pressure he can stand; they know his assets, almost to a cent.

The play begins. They sell short, three or four thousand shares of his favorite stock. The banks eall for more collateral and he complies. Next, three or four thousand shares more are dumped on the market and the man they are after is the principal supporter of these stocks; he is now on the run! Therefore, the market is not protected in these stocks. Gossip is started that Mr. Vietim is in a tight place. This stops all buying of his stocks, since a greater slump is feared because he is reported weak. Suddenly more shares are sold at a five point drop. More collateral is demanded, which he cannot now give, and this is known at once at the seat of war. His bank loans are called; cash and collateral gone-excepting a package of "cats and dogs" that the bankers will not accept. One

1 Circular of A. E. Stillwell as promoter of Kansas City, Mexico and Orient Railway Co. 
more raid on prices; a little more bear talk, and the victim, recognizing the pursuers, disgorges to the wolf-pack anywhere from a quarter to half of his life savings. Then the market rebounds and the papers mention how the day was saved. The curtain falls!

\section{From "Confidence or National Suicide"}

BY ARTHUR E. STILWELL, PRESIDENT KANSAS CITY, MEXICO AND ORIENT RAILWAY

It was a put-up job from start to finish. If he had been a big fish, a panic might have resulted affecting all interests. Confidence is shaken! Millions of dollars are lost; our people are made to suffer; business is retarded; and we are damned in the eyes of the world.

Why is it that a man, on the slightest provocation, will whoop it up for the Stars and Stripes, singing:- "My country, 'tis of thee," will fight in the Spanish War, and allow his son to join the Society for the Prevention of Cruelty to Animals; will contribute to the Ice Fund and other charities; will do all in his power (as he thinks) for humanity's sake; will weep great tears over the Armenian massacres; and then, forsaking all good prompting, will perversely degenerate to engineer a financial raid? Raiders are willing to attack a great American, and ruin an enterprise which probably represented years of suffering and labor in the building. The money wolves may bring down in the wreck a bank or trust company just for a little gold. And while doing this wrecking, he dares to think he is a patriot, and considers himself a Christian or an orthodox Jew, yet feels no more compunction when shooting holes in the ten commandments than he experiences while smashing clay pigeons.

What is the good of money secured in this way and who can be sodden enough to want it?

A man once prominent in business and whose name was daily in the papers, a few years ago made the remark to me: "I am out for the stuff and I will get it in some way-any way; people know that is my game, but I am the smarter and will win."

I have watched that man and it is true that he has won money, but he has no friendly associates. It is true that he has a brilliant mind, yet he has not won a respected position in the business world. He can secure all that money can buy; he can weigh out his gold for land, pictures, houses and automobiles, but he cannot purchase desirable friends; he cannot buy respectable standing in the business world. If his name were now connected with any great business enterprise it would damn it from the start. 
I wonder if he realizes, as the shadows of the great unknown sweep over him, that he cannot push them back; that he will soon be swept into the great hereafter, for which he cared so little in the years gone by. When he is alone in the twilight of his earthly life, and sees the night approaching, will all his millions take the vile taste from his mouth, when he thinks of the nasty tricks which won the gold? Then, surely, he would gladly give half of all his possessions in exchange for his sacrificed character and manhood. 


\title{
STILLWELL'S ROAD IS IN RECEIVER'S HANDS 1
}

\section{ENGLISH BONDHOLDERS ACT OWING TO DIFFICULTY OF FINANCING MEXICAN LINE ABROAD}

\section{NO AID FROM WALL STREET}

\author{
KANSAS CITY CAPITALISTS INVESTED $\$ 2,000,000$ AND FOREIGN \\ INTERESTS MORE THAN $\$ 5,000,000$
}

\section{Special to The New York Times}

Kansas City, Mo., March 7.-Edward Dickinson, Vice-President of the Kansas City; Mexico \& Orient Railway Company, was appointed receiver for that railroad in the Federal Court in Kansas City, Kan., this afternoon at 5:15 o'clock. Another receiver will be appointed in a few days.

Three corporations, all construction companies, appeared in court in company with the United States and Mexican Trust Company, Trustees in mortgages representing $\$ 25,000,000$.

The construction companies are the International Construction Company of Delaware, which had claims for $\$ 1,300,000$; the Union Construction Company of Delaware, which had a claim for $\$ 146,000$, and the Western Tie and Timber Company of Arkansas, with a claim of $\$ 18,000$. Each of the claims was allowed, including the claims on the $\$ 25,000,000$ of bonds represented by the United States and Mexican Trust Company.

The hearing was held in chambers and lasted abogut an hour. The attorneys would not talk of the suit further than to say that construction work on the road would continue, and that the line would be rushed to completion under the receivership.

Twelve years of building along the projected 1,629 miles of the Kansas City, Mexico \& Orient Railway have brought the system to this date with 988 miles of finished track, in actual operation. Of that mileage a single great stretch of 642 miles lies within the United States, from Wichita, Kan., to Granada, Texas. In Mexico two separated stretches, aggregating 342 miles, are operating; the longer $28 \%$ miles, stretching northeast and southwest from Chihuahua, playing between Sanchez and Marquez, in Northern Mexico, and the other 150 miles in length reaching from Topolobampo, the Pacific Coast terminus, 105 miles to the mountains at La Junta.

1 From New York Times of March 8, 1912. 
The Kansas City, Mexico \& Orient Railroad was conceived by A. E. Stillwell twelve years ago. The project has numerous unique features. It was to be "the shortest route to the Orient." It was to go through a a district in Mexico rich in minerals and timber, but supposed to be inaccessible for railroads.

Mr. Stillwell announced at the outset that he proposed to build the road without the aid of Wall Street, and he has been hard at work for twelve years raising money wherever he could obtain it and building the road as fast as he could get funds. He announced in 1900 that he proposed to have the road completed and trains running into Kansas City within three years.

A former official of the company said to-day that Kansas City investments in the project probably exceeded $\$ 2,000,000$.

No statement ever has been published showing the amount of money actually expended in the construction of the road. The last annual report of the company, for June 30,1911 , showed outstanding $\$ 12$,500,000 of common stock, $\$ 12,500,000$ of preferred stock, $\$ 21,000$,000 of funded debt, $\$ 8,500,000$ of other liabilities.

The receivership for the Kansas City, Mexico \& Orient was applied for at the instance of a committee of English bondholders, according to Frederick Hurdle of London, England, who, with Lord Munson, another member of the committee, arrived in this city a few days ago as representatives of the English interests.

Mr. Hurdle attributed the predicament of the company largely to difficulties in financing. He said the efforts to place additional issues of bonds abroad had recently failed. It was proposed to reorganize the company, he said, but at the present time no definite plans in this direction had been decided upon. Upward of $\$ 5,000,000$ of the bonds were sold to English capitalists about two years ago, after President Stillwell had conducted a party of them over the road on a special train.

The International and Union Construction Companies were organized by President Stillwell to construct the road, and are holders of some of the company's bonds. The United States and Mexican Trust Company, of which Mr. Stillwell is President, is trustee of the bonds.

Mr. Stillwell's methods of financing his road were not looked upon with confidence among men of experience in money matters, and when he began a campaign of publicity last month both by letters to public bodies and in costly advertisements assailing the "money trust," there was many who predicted that developments would not be far behind and that the "Money Trust" would be a convenient scapegoat.

It was in connection with an offering of $\$ 10,000,0005$ per cent. first mortgage collateral trust bonds to stockholders of his rond at par, that 
President Stillwell first lauched into an attack on the money trust. $\mathrm{He}$ said that the Directors wanted him to advise stockholders and the public of obstacles encountered and of the "artificial barriers created by those who through sheer patriotism, should have been our friends and helpers." He told of bankers, without naming them, who had been told that their business would be ruined if they attempted to help, but concluded "the people will subscribe for this issue not only because it is a splendid investment, but because they believe in a square deal."

In later letters some of them addressed to stock brokers all over the country as well as to Legislators, he attacked the "Money Trust" in picturesque language.

Last Fall in explaining to stockholders the many reasons why the road was costing more than planned and why its completion had been so long delayed, he offered as a reward of patience a share in a telephone patent in which he had become interested. The railway stockholders were to receive 49 per cent. interest in the company which was to be formed to exploit the company in England and British possessions and a like share in companies to be formed in other foreign countries.

Mr. Stillwell is the author of several unique books which have brought him considerable publicity. One published in 1910 called "Confidence or National Suicide" was written largely to justify higher railroad rates. 


\section{WALL STREET WAYS ${ }^{1}$}

\section{A General Exposition of Stock Market Trading}

\section{INTRODUCTION}

In the following pages we have endeavored to give a lucid explana. tion of the manner of transacting business in stocks, touching upon points which we have found to be often misunderstood not only by the uninitiated but by the more experienced traders. We will, of course, always be pleased to furnish any further information which may be desired either along these lines or regarding any specific securities in which you may be interested.

\section{PURCHASING}

There are two methods of buying or selling stocks through members of the New York Stock Exchange, viz: buying or selling outright for cash and buying or selling on margin.

When purchasing stock outright, or what is commonly termed "for cash," a person pays the entire cost of the stock plus commission, $\frac{1}{8}$ of $1 \%$, (or $12 \frac{1}{2}$ cents per share). For instance, if one purchased 100 shares of United States Steel at 70 he would pay $\$ 7,000$ plus commission, $\$ 12.50$, total $\$ 7,012.50$, and certificate for the 100 shares would be delivered. When stocks are purchased outright it is customary to have them transferred to the name of the buyer, especially if the stock is one upon which dividends are paid, same being paid to the party in whose name certificate is made out. At times, however, the purchaser desires to leave the stock with the broker in order to facilitate sale of same when desired, and the certificate is placed in an envelope marked as property of the owner to be delivered when called for. In this case the stock is often left in the broker's name and the customer is credited with the dividend when payable or check for that amount is forwarded to him. Thus the buyer receives the dividend but does not have the trouble of endorsing the certificate and sending it to the broker when he desires to sell. Non-dividend paying stocks when purchased outright are also often left in the original "street name," as a certificate endorsed by a stock exchange house is a good delivery at any time he may wish to sell and he has no trouble about endorsing, witnessing, etc.

When purchasing on margin the broker buys the stock, paying for same in full, but loans the customer a certain amount, holding the certificates as collateral and charging interest on this debit balance.

1 Pamphlet issued by J. F. Pierson \& Co., members of the New York Stock Exchange. 
The difference between the amount loaned and the purchase price is deposited by the customer, being what is commonly termed "margin." The customer may at any time pay off this loan, together with any interest which may have accrued since the purchase, and take up the stock. Ten points, that is, $\$ 10$ per share, is the usual amount required on a majority of stocks, and the broker will carry same as long as the market price is sufficient to protect him. This does not mean that he will carry the stock until a sale is made at the exact limit of the margin, however, as he might not be able to obtain that amount if he attempted to sell. For instance, if U. S. Steel were purchased at 70 on a 10 point margin the broker would call for additional margin when the market price was say, approximately 65 , and if no further additional margin was fortheoming after notification he would hold same to within from one to two points of the limit or until whatever time he might deem it necessary to sell for his own protection. The round commission of $\frac{1}{4} \%$ must be figured out of the ten points, together with whatever interest may have accrued on the money loaned. Many figure that stock is held to the exact limit of the margin, but it must be remembered that while there might still be a margin of a fraction or even a point at the close of the day, the market might open off more than that the next morning and the broker be unable to close out the commitment except at a loss to himself. Many of the inactive stocks also have wide quotations and sales might be one, two, three or more points apart, thus affording no opportunity to sell at the desired figure. The distance which a stock will be carried depends to a great extent upon the condition of the market and the character of the stock. Eren active stocks which in ordinary times would be carried to within from one to two points of exhaustion could not be carried over night on such a small margin in panicky times when there is a chance that they might open off several points the following morning. A customer is, of course, always given every opportunity to deposit additional margin, which should always be done when it has been reduced to approximately five points whether a margin call is received or not, it being assumed that a person either long or short of stock is suffciently interested to keep track of market movements. There is no limit to the length of time stocks may be carried on margin as long as the amount of margin is sufficient to protect the broker.

We have endeavored to point out the features of marginal trading which ofttimes lead to discussion and annoyance to both broker and customer, but if a customer understands marginal requirements fully it is often the most convenient and profitable manner of trading if conservatism is observed. For instance, one may believe that a cer- 
tain stock is due for an adrance and have only sufficient funds to purchase say 50 shares, but is enabled to take 100 shares by borrowing the difference from the broker. When the stock advances he may procure just double the profits he would have if the stock were purchased outright. He thus has a $50 \%$ margin, which should be a very conservative amount on a stable stock, and is in the same position as a man who purchases a house and secures a mortgage thereon.

We require ten points ( $\$ 10$ per share) margin on a majority of stocks, but will accept fire points on some low priced issues having a ready market for purchase or sale, although even more than ten points is often necessary on some of the very high priced or other stocks which have a very wide market, that is, in cases where the bid and asked prices are far apart and fluctuations apt to be abnormal. If only this minimum amount be provided for one may obtain profits many times as great as if purchasing the stock outright, but we always endeavor to impress upon our customers the advantage of a heavier margin. The greater the number of points with which a customer fortifies his account the greater his protection is against possible adverse market movements.

\section{SELLING}

In selling stock held outright in a customer's name, customer must endorse the certificate, spelling the name exactly as it is spelled on the face, and have same witnessed, but should fill in none of the other blank spaces on the back of the certificate. The commission for selling is the same as for buying, $\frac{1}{8}$ of $1 \%$, with a minimum charge of $\$ 1$ on any transaction, and in addition the seller pays a tax of 2c. per every $\$ 100$ par value, which is levied by the State of New York.

When selling stock held on margin the customer simply gives the order to the broker, who sells the stock, delivers the certificate and credits the customer's account with the proceeds, less commission and State tax.

In selling stock short the broker sells the stock, borrows it and delivers same on regular delivery day. The margin required is the same as when purchasing stock but is a protection against a rise in the market instead of a decline. If the market reacts the customer may repurchase the stock at a lower figure, his profits being the difference between the sale price and the purchase pricn, and if the market advances and he buys in, or "covers," at a higher figur his loss is also the difference between the salc price and the purchase price. This is simply the reverse of purchasing stock and then selling, the sale being made first and the purchase later on. When the stock is covered the broker returns same to the party from whom he origi- 
nally borrowed it. No interest is charged a customer on thestransaction, except when the stock is loaning at a premium because of a great scarcity; that is, when he is forced to pay a certain amount for the privilege of borrowing the stock. This, however, is a very rare occurrence.

\section{DELIVERIES}

When stock is bought or sold the certificate is not delivered until the following day, at which time the purchasing broker pays the selling broker the amount due. Stocks or bonds purchased on Friday or Saturday are not deliverable until Monday, as Saturday is a nondelivery day. It is customary for the broker to receive from a customer at least a deposit against the purchase of the stock before the stock is bought, as he obligates himself to take the stock from the other broker on the regular delivery day, and if any unforeseen accident occurs to the customer over night preventing him from paying for the stock, the broker would have to take it himself and stand any loss which might be incurred by a possible decline in the market price. When stock is sold payment is not received until the next day, when it is delivered. It is customary, however, for the broker to have the stock in his possession before selling, unless it is a short transaction.

\section{TRANSFERRING STOCK}

When stock is to be transferred to a customer's name the certificate received by the broker is sent to the transfer office of the company and a new certificate made out, which may take two or three days after the regular delivery. Stock cannot be transferred while the books of the company are closed for dividends or any other reason. Stock must be paid for in full before the broker will have same transferred to the customer's name, as after the stock is deposited at the transfer office it is useless to him until the customer has endorsed the new certificate issued in place of the old. Therefore, if any unforeseen accident prevented the purchaser from endorsing the certificate the broker would be left without security for the amount loaned.

\section{STOP LOSS ORDERS}

Stop loss orders are used by a great many traders to limit the amount of possible loss on any transaction and ofttimes save one from losing his entire margin. A stop loss order for the purchase or. sale of a stock means that the purchase or sale, as the case may be, is to be made "at the market" when a certain price is reached. For instance, if U. S. Steel is selling at 70, and an order is placed to sell 100 shares at 68 stop, it means that when a sale of 100 shares or more is made on the Stock Exchange at 68 or less 100 shares are to 
be sold "at the market," that is, at the best price obtainable. At times, however, it might close above 68 on one day and open below 68 the next morning, or even during the day might break from a price above to below 68 without a sale at that figure, in which case the stop loss order would be executed as soon as a sale was made under 68. Conversely, if an order is given to buy 100 shares at say 72 stop, it means that 100 shares are to be purchased "at the.market" when a sale of 100 shares or more is made at 72 or higher.

This method has often proved itself of inestimable value to traders. Purchases may be made at a certain figure in the belief that the market is about to advance but something occurs to change the course of the market and it starts to break. 'If a stop loss order is in, however, the loss is confined to approximately the difference between this figure and the price at which the stock is purchased, and if it breaks ten points further one has becn saved just that amount. The use of this protection is also valuable when. a profit is shown on a transaction, yet one believes it will run still further. He may then place a stop loss order below the market if he is long or above the market if he is short, but at a figure where a profit is assured. In this way the transaction may be allowed to run with risk eliminated. For a person trading on a medium sized margin this method appeals strongly, especially to those who make up their minds to take a certain amount of profit or a certain amount of loss.

\section{COMMISSION CHARGES}

Our commission charges for transactions on the Stock Exchange are $\frac{1}{8} \%$ for buying and $\frac{1}{8} \%$ for selling, which is equal to $12 \frac{1}{2}$ cents per share, except in the case of mining shares selling below $\$ 10$ upon which the charge is $1-16 \%$, but the minimum charge upon any transaction is $\$ 1$. The commission on outside securities varics according to the selling price.

\section{INTEREST}

Interest is charged on any unpaid balances, the rate being governed by the prevailing money rates, the size and activity of the account, the amount of margin maintained and the character of the stock in question, having ranged from $3 \%$ to $6 \%$ during the past year. We can, of course, make more favorable rates upon stocks which we can readily place in loans with a bank than on those upon which we cannot borrow money and must, therefore, lie idle in our safe deposit vault.

Interest is credited on daily balances according to prevailing money rates and the amount involved, and we furnish check books as a convenience to customers who may wish to draw upon their account. 
Aside from the fact that we require a deposit on all orders, many find it both convenient and profitable to leave their funds on deposit with us pending stock or bond transactions inasmuch as they receive interest on daily balances, whereas at times they lose interest when they have to withdraw their funds from a savings bank where interest is allowed only on money left until a certain date.

\section{STATEMENTS}

Many people are puzzled by statements received from a broker, and in the following we have endeavored to give a lucid explanation of same.

\section{TRADING ON THE LONG SIDE FOR A RISE}

Suppose John Brown, believing that U. S. Steel would adrance from 75 to 80 , sent us a check for $\$ 1,000$ with instructions to buy one hundred shares of U. S. Steel at the market, and to sell same at five points profit or stop at five points loss. We would buy for his account one hundred U. S. Steel at tho prevailing market price, say at 75 . The following day the broker from whom we made the purchase would deliver to us the certificate for one hundred shares of U. S. Steel, and we would pay him $\$ 7,500$, using the $\$ 1,000$ the customer had deposited and $\$ 6,500$ which we would loan to the customer, charging interest on same for the length of time we carried the stock.

Suppose the market adranced to 80 fifteen days after the purchase. We would then sell one hundred shares of steel at 80 , and at the end of the month a statement would be rendered as per example below.

\section{John Brown}

In Account with J. F. Pierson, Jr., \& Co., 74 Broadway, N. Y.

Debit.

\begin{tabular}{|c|c|c|c|c|c|}
\hline . & & & & Days. & Int. \\
\hline \multirow{4}{*}{$\begin{array}{c}\text { March 5th } \\
\text { “ 31st }\end{array}$} & \multirow{4}{*}{$\begin{array}{l}100 \text { U. S. Steel @ } \\
\text { Interest........... } \\
\text { Balance.......... }\end{array}$} & \multirow{4}{*}{$\begin{array}{l}75 \\
4 \%\end{array}$} & $\$ 7,512.50$ & 26 & $\$ 32.55$ \\
\hline & & & 9.06 & .. & \\
\hline & & & $1,463.94$ & $\ldots$ & \\
\hline & & & $\$ 8,985.50$ & $\ldots$ & $\$ 32.55$ \\
\hline
\end{tabular}


Credit.

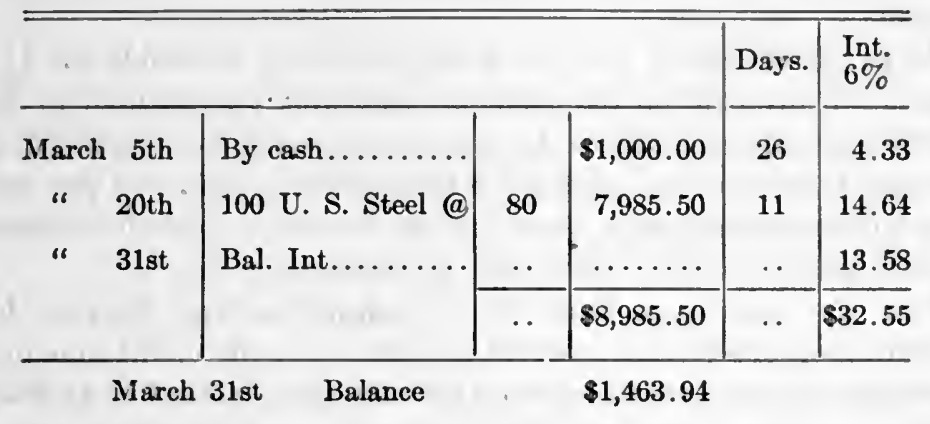

Commission for buying is added to the purchase debit, and commission for selling, together with the State stamp tax (2c. per $\$ 100$ par value of stock sold), are deducted from the selling credit.

Many are puzzled by the interest items appearing on the statement, but this method has been found to be the simplest and is used by practically all brokers allowing interest on daily balances. Interest on each item is figured from the date of the transaction until the day to which the statement is made out. Taking the above mentioned statement for example, when 100 shares of U. S. Steel were purchased on the 5 th inst. $\$ 7,512.50$ was paid out of the account. The account was made up to March 31st, and the interest was, therefore, charged for the twenty-six intervening days and appeared in the debit interest column figured at $6 \%, \$ 32.55$. On the credit side $\$ 1,000$ was received on the 5 th inst. and interest for the intervening twenty-six days was figured at the same rate, $6 \%$, appearing in the credit interest column as $\$ 4.33$. When 100 shares of steel were sold at 80 on the 20th inst. $\$ 7,985.50$ was taken into the account and interest was figured up to the 31 st inst., or for eleven days, at $6 \%$, appearing in the credit column $\$ 14.64$. Thus interest being charged on money paid out and being allowed on all money coming in from respective dates until the day the balance is struck, the balance shows interest charged on excess debit over credit for the exact time, or, if there is a credit balance shows interest allowed on the excess credit for the exact number of days. In this case the debit balance of interest at $6 \%$ was $\$ 13.58$. These interest columns are used merely as a convenience to figure the interest at $6 \%$ and are not considered in the final general balance, as the interest rates may vary monthly. In this case we have figured at a $4 \%$ rate and, therefore, the final debit balance of interest on March 31st has been brought over at 4\%, or $\$ 9.06$. The credit balance of $\$ 1,463.94$ as of March 31 st, would draw interest 
from that date until John Brown drew it out or again used it as margin.

At any time during the life of the trade any dividends the U. S. Steel Company paid on the common stock would be credited to John Brown's account the same as though he owned the stock outright, and he could at any time, by paying the balance due, $(\$ 6,512.50$ plus whatever interest might have accrued), order the delivery of the certificate to him, which would be forwarded by registered mail.

Had the price gone down to 70 before reaching 80 and John Brown's stop order been executed at that price, the credit amount of $\$ 6,985.50$ for sale would appear on the statement instead of $\$ 7,985.50$, and the interest items and final balance would have been changed accordingly.

TRADING ON THE SHORT SIDE FOR A DECLINE

Supposing John Brown, believing that U. S. Steel would have a downward movement from 80 to $\% 5$, sent us $\$ 1,000$, instructing us to sell one hundred shares U. S. Steel at the market and to buy a five points profit or to stop at five points loss. We would then sell one hundred shares of U. S. Steel at the prevailing market price, say 80 . The next day we would have to deliver certificate for 100 shares U. S. Steel to the broker to whom we had made the sale. We would borrow the stock in order to make the delivery, charging John Brown nothing for this borrowing transaction, (except interest in very rare instances when there is such a large short interest in the market that stocks are loaning at a premium).

Suppose the price reached 75 fifteen days after the sale was made. We would buy one hundred shares U. S. Steel at 75 and at the end of the month would render a statement as per example below.

\section{John Brown}

In Account with J. F. Pierson, JR., \& Co., 74 Broadway, N.Y.

Debit.

\begin{tabular}{|c|c|c|c|c|c|}
\hline & & & & Days. & $\begin{array}{l}\text { Int. } \\
6 \%\end{array}$ \\
\hline \multirow{2}{*}{$\underset{*}{\text { March 20th }} \underset{\text { 31st }}{2 \text { st }}$} & \multirow{2}{*}{$\begin{array}{l}100 \text { U. S. Stee: @ } \\
\text { Balance........... }\end{array}$} & \multirow[t]{2}{*}{75} & $\$ 7,512.50$ & . & 4.33 \\
\hline & & & $\$ 8,988.39$ & & 4.33 \\
\hline
\end{tabular}


Credit.

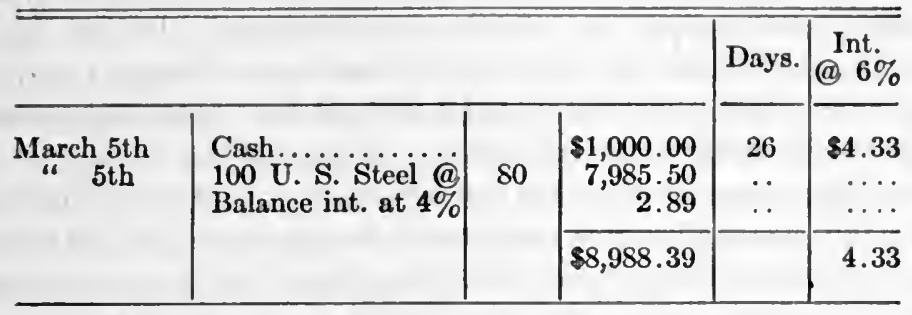

March 31st Baiance

$\$ 1,475.89$

Commission for buying is added to purchase debit, and commission for selling and State tax (2c. per $\$ 100$ par value of stock sold) are deducted from selling credit. No interest is charged on short sales and, therefore, the only interest item to be considered in this statement would be the allowance of interest on the cash deposit of $\$ 1,000$. The statement being made up as of March 31st, this $\$ 1,000$ would have been in the account for twenty-six days, which, figured at $6 \%$, would amount to $\$ 4.33$. Reducing this to $4 \%$, the final interest credit would amount to $\$ 2.89$. The credit balance of $\$ 1,475.89$ as of March 31st, would draw interest until John Brown withdrew it or again used it as margin. If, however, this "short" transaction were carried on to another statement or further "short" transactions made, and the market price advanced, thus reducing the amount of margin, interest would be figured upon the amount of deposit remaining according to the existing market price of the stock.

At any time during the life of the short trade any dividends the U. S. Steel Company paid on the common stock would be charged to John Brown's account, and he could at any time deliver to us one hundred shares of this stock, for which we would pay him $\$ 8,985.50$ plus interest on his deposit, regardless of the price prevailing at the time of delivery.

Had the price gone to 85 before reaching 75 and the stop loss order been executed at that figure the debit amount $\$ 8,512.50$ would appear on the statement instead of $\$ 7,512.50$ and all other items would appear the same except the credit balance, which would be $\$ 1,475.89$.

\section{ADVANTAGES OF FRACTIONAL LOT TRADING}

No one who is at all familiar with the stock market can doubt that since we conceived the idea of specializing in "Fractional Lots," (less than 100 shares), in 1907 this class of trading has become an important factor in the business transacted on the New York Stock Exchange. $\mathrm{A}$ few years ago a person of limited means desiring to invest in a small amount of stock felt under obligations to a New York 
Stock Exchange house that would execute the order, and then have to pay a premium upon the price for round amounts. But all this has been changed during the last few years and the advantages and convenience of dealing in "Fractional Lots" are now becoming generally realized by investors and speculators throughout the country. Any amount from one share upward can be bought or sold on the quotation of the 100 share unit. For instance, if the quotation for 100 or more shares of United States Steel is 78 bid, offered at $781 / 8$, one share or more can be sold at the same bid of 78 or purchased at the same offered price, $78 \mathrm{r} / 8$. It will thus be seen that if 100 shares are sold on the bid price, 78 , the seller has absolutely no advantage over the one who sells 10 shares, and the purchaser of 10 shares at the offered price fares as well as the one who takes 100 as offered.

Thus the opportunity to enter the stock market is brought within the reach of nearly everyone, with the knowledge that the size of the. commitment will not militate against the chances of securing profits.

To the investor who purchases stocks with an idea of obtaining a greater return upon his money than the interest received in the savings banks, and who is not subject to the "get rich quick" mania, it opens an avenue for the exercising of still greater conservatism. While he may have sufficient funds to purchase a full hundred or more shares, he might ofttimes feel that it would not be politic to "place all his eggs in one basket" and he could, therefore, purchase ten, twenty or thirty shares of several stocks. In this way he would be in a much stronger position to guard against loss in case of adverse developments in any one company.

But to the man who trades from a more speculative standpoint does this method especially appeal. Many a man who has been carrying one hundred, two hundred or more shares on what appeared to be a comparatively safe margin has seen prices suddenly melt away ten or twenty points in a short while, and been forced to close out with all his capital gone. Only then has he realized that had he been content to buy ten, twenty or fifty shares at the higher figure, he would have been in a position to take on another small amount every few points down, thus averaging his cost price. It is seldom indeed that a sharp rally does not succeed such a recession, and on this rally he would be in a position to sell out with a profit instead of being forced to close out his commitment at the bottom of the decline, losing his entire capital. True, if the market goes with him he would have consider. ably greater profits on the larger amount of stock, but is it not far better to take smaller profits and risk less, than to risk all on one venture?

But the advantagee of fractional lot trading are not confined to the 
buying of stocks. When the market has had a considerable advance during the few years following a period of general depression declines are apt to become continually more severe and often. At such times conservatism must be observed more strictly and even the investor should begin to realize that there are two sides to the market, and that there will surely be a time when it will prove advantageous to take profits and await recessions upon which to repurchase. In fact, by selling on bulges and repurchasing on recessions, it should be possible to make far more than the dividend return. Say a stock pays a dividend of 5 per cent. per annum. If sold on a rise and repurchased five points cheaper the entire year's dividend could be made on one transaction, which operation might be repeated several times during the year.

At times, however, one might feel that while the market had had a good rise it might go still further, and, therefore, hesitate to sell all his stock. He could, however, compromise by selling a small lot, and, if the advance continued, sell more every few points up. In this way when a break did come he would be sure to have part of his stock sold near the top, and be in a position to repurchase at a profit every few points down.

\section{HINTS TO TRADERS}

In order to observe conservatism, therefore, it might appear to be a good plan for a man of moderate means to use some such system in trading as the following.

Suppose he is in a position to carry 100 shares of stock. Instead of buying 100 shares of Union Pacific at 180, buy 20 shares and on each decline of three points take 20 shares more. Should the price adrance instead of recede, he will be sure of his profit on the 20 shares. If, on the other hand, an extensive decline sets in he will be continually adding to his holdings at lower figures, and when the market has reacted 12 points to 168 he will have his 100 shares at an average price of 174. instead of 180. It is seldom that such a decline is not followed by a sharp rally, and as the price again rises he can take his profits on the various 20 share lots as they appear, and thus be in a position to repurchase should the decline again be resumed.

of course the amounts and points away on each purchase can be changed to suit the means of the investor. A man with a fifty share limit could purchase 10 shares at a time, or each purchase could be made at a two, four, five or any other number of points recession, thus regulating the extent of decline provided for. Should no decline come, the profits would not, of course, be so great on a small as large amount, but profits are surer, and more could be bought as they accu. mulated. 
This method is of especial advantage to out of town customers who are not in constant touch with the market. Orders may be placed for purchase of a certain amount of stock every few points down and profits taken on each lot at a certain advance. Likewise orders may be placed for the sale of stock at certain points above the market and for repurchasing on designated declines.

Do not be obstinate. Be willing to change your position with conditions. Ofttimes a man who is bullish on the market is right in his position for some time but sudden adverse developments naturally change conditions, and if he is not willing to change his position he will in all probability lose not only his profits but considerably more in addition. In the same way a person who is bearish in a declining market and refuses to turn to the long side when conditions change for the better will also be the loser thereby.

The market always looks good when high and bad when low. The stock market anticipates and discounts good and bad conditions. In prosperous times when business is in full swing people are naturally bullish and willing to pay high prices for stocks. This is usually the time when the "big interests" are unloading. When business conditions are poor the public is down in the mouth and anxious to dispose of their securities. It is always darkest just before dawn, however, and when the public is most anxious to sell the insiders are usually buying in stocks.

Nine times out of ten when favorable news, such as an increase in dividend, is announced the stock in question has already advanced sufficiently to discount same and insiders who purchased much lower in anticipation take advantage of the opportunity to secure profits and under this selling the price soon recedes, even though but temporarily. Conversely, when a cut in dividend or other "bad" news on some stock is announced same has been discounted and stock sold previously at higher prices is purchased from frightened holders to whom the news is a surprise. Of course, this rule would not apply in the event of adverse developments unexpectedly by even the controlling interests.

When a few days of wild trading come after a continual rise or decline a turn is usually imminent. After a rally from the low point or decline from the high point prices usually react again to the low or high as the case may be. After a material advance stocks usually react about midway to the previous low and same holds good conversely in case of an extensive decline.

As a general thing do not buy stocks after an advance. Wait for a reasonable reaction even though it comes from a somewhat higher figure. Likewise under general conditions it is not well to sell after a decline. Wait for a reasonable rally. 
Undoubtedly the most dangerous pitfall in the path of the speculator is the tendency to overtrade. A man who purchases a conservative amount of stock and makes a profit is very apt to feel disappointed because he did not buy a larger amount on a smaller margin and make just that much greater profit. This would be all right when the market went his way, but if a break came his smaller margin might be wiped out, whereas he could easily have carried the lighter load until the price again advanced. Furthermore, when a man becomes nervous and begins to worry over his commitments he is practically lost. A cool head is necessary for success in this as in any business and when an adverse market movement finds one overloaded he is very apt to sell out just before the turn comes in order to save a portion of his funds.

It has been truly said that " $a$ bull can make money in Wall Street and a bear can make money in Wall Street, but a hog never can." The top and bottom prices of a movement are caught by only one or a very few persons out of a multitude interested in the stock, and the man who keeps looking for the final fraction will in nearly every case find that he has lost his market and ultimately take a loss or be glad to get out about even. Be satisfied to take a reasonable profit; let someone else have what may be left and remember that the risk constantly becomes greater as the movement continues.

\section{OPENING AN ACCOUNT}

In opening an account deposit should be made in New York funds (draft, money order or check) or, if the depositor resides outside of New York, money may be deposited to our credit with his local bank, and upon receipt of telegram to that effect from the cashier of the bank we will accept orders against same.

\section{ORDERS}

We consider all orders sent by mail or telegraph as "good until countermanded" unless otherwise instructed. Orders to buy or sell may be cancelled at any time before execution and new orders entered.

Some stocks traded in on the New York Exchange, such as Reading, Lehigh Valley, Pennsylvania and Westinghouse, are of only $\$ 50$ par value and known as "half stock." The quotations, however, are for $\$ 100$ par value. Thus a quotation of 167 for Reading means $\$ 167$ for $\$ 100$ par value, or two shares. Therefore, an order to buy $\$ 100$ par value, or $\$ 167$ worth, would be for two shares. An order to buy 100 shares of these stocks would mean 50 full shares of $\$ 100$ each.

Great care should be taken in making orders explicit, as we simply follow instructions as received and never accept discretionary accounts. 
Many times we are asked to use our own judgment in making a selection of stocks to be bought or sold, and also as to price, but we cannot use our discretion in this as such a proceeding is very apt to result in misunderstanding and ill feeling at one time or another.

\section{REPORTS AND STATEMENTS}

Reports of purchases and sales are mailed on the evening of the day on which the transaction is made and statements of accounts are rendered monthly where there has been any change, or as often as the customer may desire.

All of the details of transactions are looked after by the broker. These include borrowing and loaning the stock and borrowing and loaning money to carry on the transaction. All that is required of the customer is to deposit the necessary funds and give orders to buy or sell.

While we do not confine our business to "fractional lot" trading, we will be pleased to accept orders for the purchase or sale of stocks for cash in any amount from one share upward and will carry on margin stocks traded in on the New York Stock Exchange in lots of five shares or more. 


\section{BUYING AND SELLING TO SUPPORT THE MARKET'}

\section{"EXHIBIT No. $132 \frac{1}{2} "$}

During the course of the Pujo investigation at Washington last December, testimony was submitted showing the stock market operations of the syndicate that was formed to sell $\$ 5,000,000$ California Petroleum stock, which had been received as a bonus. The following figures were taken from the exhibit, showing the number of shares of California.Petroleum traded in by the syndicate managers between October 5 , 1912, and October 31, the buying orders being placed to support the market in weak spots until the 50,000 shares were unloaded:

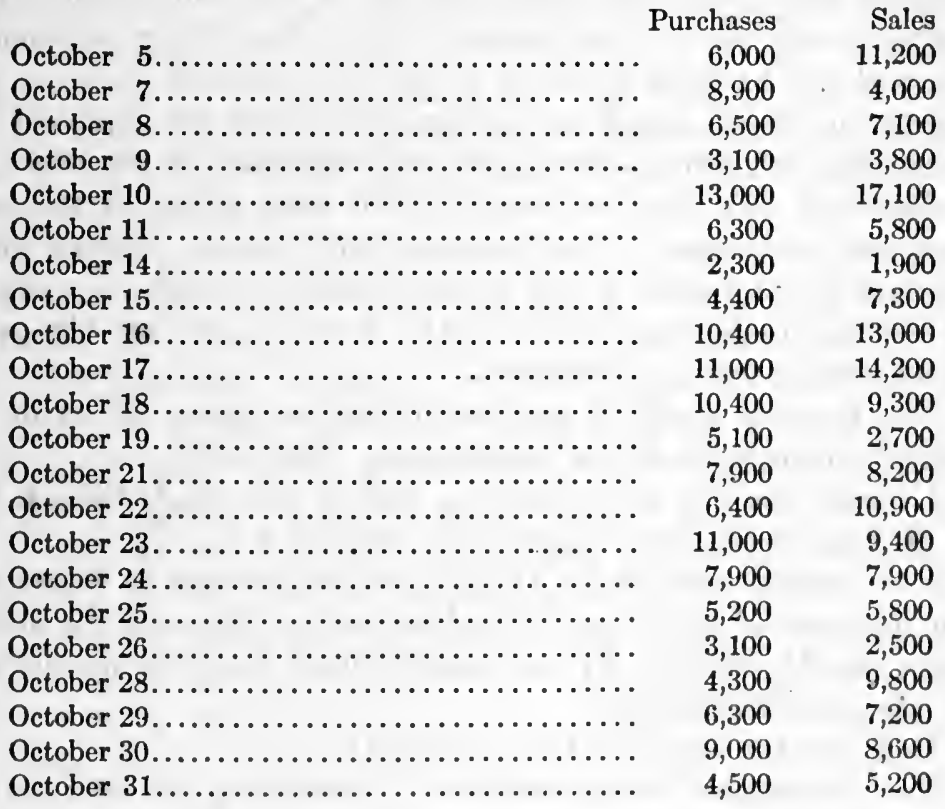

1 From New York Evening Post of February 8, 1913. 


\section{STOCK-POOLING AGREEMENT}

Commenting on this stock-pooling agreement, the New York Evening World (issue of January 24, 1910), from which this agreement is printed, says: "The Evening World herewith presents for consideration by the State Legislature the brokers' agreement in the Hocking Valley pool which ended in three failures, carrying liabilities of upward of $\$ 7,000,000$. For eleven months this pool continued under the eyes of the Stock Exchange governors, who saw a stock which has not paid three per cent. of dividend in its whole corporate existence inflated from $\$ 20$ to $\$ 91.25$ a share. How much further the inflation would have been carried had one of the gamblers not played traitor to his pals it is impossible to say. That the expectation of the pool was to jump the stock to par is not denied . . . The number of shares stated in the agreement does not represent the actual total of shares accumulated and controlled by the pool. As a matter of fact, the pool bought 5,000 more shares of the stock than had been issued. The agreement calls for the termination of the pool on September 1, but it was extended through an exchange of mutual pledges until March next. The time for the big public melon cutting had not yet arrived.

The Evening World is enabled to give the names of six of the dozen or more firms in the combination. They are:

Lathrop, Haskins \& Co., Roberts, Hall \& Cris, A. J. Elias \& Co., J. M. Fiske \& Co., Day, Adams \& Co., Rollins \& Co.

The common stock of the Hocking Valley amounts to $\$ 6,981,100$. On the basis of 20 , when the pool came into existence, the market value was $\$ 1,396,220$. By pool manipulation the value was inflated to more than $\$ 5,000,000$.

Here are the terms of the agreement:

The undersigned being desirous of purchasing at least 20,000 shares of the common stock of the Columbus and Hocking Coal and Iron Company, do hereby agree to purchase the same, or so much thereof as in the opinion of the hereinafter appointed managers may be deemed advisable in the proportion set opposite the respective names of the said subscribers, and we hereby appoint........... our agent and manager to make such purchases at such time or times before the first day of September, 1909, unless sooner dissolved by the majority of the stock subscribed, in such manner and amount and at such prices as in his judgment shall be to our mutual advantage. 
Each one signing this agreement to pay on demand for so much of said purchases as his subscription (as near as may be practicable) bears to the whole amount subscribed, as such agent or manager may require. Also to return the same amount of certificates or part thereof at any time when called for before the first day of September, 1909, on receiving from the manager the amount paid therefor, with interest at 5 per cent. per annum. We further agree on any call from said manager to deliver to the said manager the same certificates theretofore delivered to us by him.

Further we hereby authorize the said agent and manager to sell at his discretion the whole or any part of the certificates purchased and again buy, so buying and selling at his discretion.

It is further agreed that any profits or losses incurred through the purchase and sale of said certificates shall be divided in proportion to the amount subscribed for by each one signing this agreement. No one signing this agreement shall have the right to call for a statement of accounts growing out of transactions herein authorized except on the request in writing of 60 per cent. in amount of certificates subscribed.

We hereby agree to reimburse the said agent and manager for any commissions paid by him to such brokers as he may deem advisable to employ in the execution of the herein authorized purchases and sales and such other expenses as he may incur and which to him may seem for the best interests of all parties to this agrcement.

This agreement is not to be binding on the undersigned until certificates for 20,000 shares are subscribed, and thereupon this agreement shall become operative. Subscriptions beyond this amount may be received by the agent and manager up to 30,000 shares.

The original hereof shall be signed by the manager. Counterparts hereof may be signed by subscribers and all shall be taken together and deemed to be one original instrument, and upon the agreement becoming operative the manager shall notify the subscribers.

In witness thereof the parties have signed this agreement as of March 1, 1909.

Manager.

Subscriber.

Address.

No. of Shares. 


\section{PUTS AND CALLS 1}

\section{DeAr Sirs:}

We are writing this letter with a view to strongly recommending the purchase at this time of options (either the "Call" or the "Put") on the various American stock dealt in on the London Stock Exchange, which option orders we are prepared to execute through the London Stock Exchange firm of which we are the American representatives.

Broadly speaking, our two chief reasons for making this recommendation are: firstly, that we believe that the present time is an exceptionally propitious one for the purchase of options, and of which advantage should now be taken; and second, that the prices of options as now quoted are relatively lower than they have been for a long time past.

Judging from our past experience, we find it very generally the case-excepting certain important and shrewd operators, who are experienced in the matter-that the general option buying public, in its eager desire not to buy an option until what it believes is the very eve of a market move, generally misses its best opportunity and does not buy until the market quietly slips away and has already recorded a very substantial advance or decline. Then the relative prices of options are considerably dearer than they were when the market was in a quieter condition, because very naturally the seller of an option is largely governed in the prices he makes for the same by the degree of activity of the stock on which the option is sold.

As a striking example of this situation, we would merely cite the instance that during our entire experience in Wall Street, by far our greatest activity in the purchase of "Calls" on behalf of clients was in U. S. Stcel Common, and occurred in the last weeks of the year 1909, when the stock was quoted above 90 , and when the "cream" was naturally already off the rise, and at the same time the prices paid for these options were much higher than they had been quoted shortly before the big rise in Steel had even started. Naturally what we say here refers to the general option buying public and not to several important operators who were far seeing enough to buy their options before the rise was under real headway and who made very large profits from the same.

Equally true is the reverse of that situation, for we have generally found that when the public have most desired to buy "Puts," instead of doing so when the market was at a comparatively high level and not unduly excited, they generally refused the opportunity, but have

1 Circular Letter issued by W. \& E. Rosenbaum, May 8, 1912. 
been clamorous for the same after the market had already suffered a very great decline, or was even in a panic.

While it is not our purpose to express our opinion as to which option, a "Put" or a "Call," may be more desirable at the moment to buy, this being naturally left to one's individual opinion as to the future course of the market, still we do feel confident that the present opportunity, whether one may feel bullish or bearish is an especially favorable one to take the subject under serious consideration.

It appears to us that the remaining eight months of the year 1912 should be full of very important stock market influences. Naturally, the two dominant factors will be the political situation and the crop situation, and these taken in conjunction with the future course of the money market, the labor situation, and other conditions, should give plenty of room for market activity in the near future.

It hardly calls for argument that it is at just such a time as this, when one faces an outlook as uncertain as at present, that the purchase of options is most desirable, and may be the means not only of making from the options themselves large profits, but also be the means of insuring against large stock market losses.

For the information of those who are not entirely acquainted with the general theory of options and the method of dealing against the same, we are reprinting on another page of this letter an extract from an article published by us on the subject some time ago.

It is enough here merely to point out that these London options, entitling the holder to either "call" or "put" a certain amount of stock at some future time, have in recent years found very great favor on this side, and many of the most important and largest operators are frequently purchasing them with the purpose in view, either of making a large profit out of the "Call" or "Put" itself, or of using them as a protection against their long or short position in the market, as the case may be.

While naturally options can be bought in London on any of the other active international stocks, and extending over any reasonable period of time, still for a concrete example, and in order to point out its especial reasonableness, we would mention a Call on, say, U. S. Stecl Common, which could be bought at the present time.

Through the London firm whom we represent, we could, on the basis of the present option price as quoted, buy for you at the market price, interest and commission, a "Call" on U. S. Steel Common stock in any reasonable amount, for the end of June settlement, for about $2 \frac{1}{2} \%$.

This Call, if exercised at its maturity, would carry with it the dividend of $1 \frac{11}{4} \%$ which comes off during the month of June, and which, 
offsetting by say $\frac{7}{8} \%$ the interest charges of about $\frac{3}{8} \%$, would really give you a Call standing in net about $15 \%$ over the current market price of the stock at the time when the option was bought, and everything above this figure would be clear profit.

Thus, if U. S. Steel Common at the time of the purchase of the option were quoted here at say 67 , you would have a Call which would figure out, including everything at about 685, and all above this price would be clear profit.

In view of the fact that this option would include the period corered by the National Conventions, and the probable attendant activity of the market, it would seem to us that it is extremely reasonable, and may offer opportunities for large profits, and we strongly recommend to the consideration of our clients the purchase of the same.

We are enclosing herewith a general list of the most recent option prices quoted by cable to us by our London correspondents. They are naturally subject from time to time to change.

The only charge to our clients for executing option orders in London is $6 \mathrm{~d}$. ( $\left.\frac{1}{8}\right)$ per share, which is payable to the London brokers whom we represent. Should you wish to trade against your options in the London market, we have through our London offices every facility at hand for doing the same, and our London correspondents will be pleased to execute your orders for the regular commission of $6 \mathrm{~d}$. $\left(\frac{1}{8}\right)$ per share.

We shall be very pleased to have you avail yourselves of our services, and with the assurance that your orders will receive our best attention, we remain,

Yours very truly,

W. \& E. Rosenbaum. 
(Extract from an article previously published by W. \& E. Rosenbaum.) OPTIONS

The options generally dealt in are Calls and Puts. There is also the double option termed the Straddle which is a combination of a Call and a Put.

The price paid for an option is termed the Premium.

A Call is an option giving its purchaser the right to call from the seller of the same a certain amount of stock at a fixed time and at a stated price. For this right he pays a stipulated price (premium) which, of course, is governed by and varies in accordance with the character of the stock, the state of the market and the time for which the option has to run.

In the absence of an order with a fixed limit, an order to purchase a Call would be executed based on the current market price of the stock at the time in London and for the current premium.

The call price is arrived at by taking the market price of the stock in London and adding thereto interest at a fair rate for the time the option has to run.

For example, if an order is given to buy a Call on a stock for a period covering four months, and the stock at the time in London is say 34 , the eall price of the option would be about $34 \frac{1}{2}$ ( 34 plus $\frac{1}{2} \%$, which would be the amount of interest on a stock selling at 34 for four months at about $5 \%$ per annum).

A Put is just the reverse of a Call-in other words, it gives the purchaser the right to put (deliver) to the seller of the Put a certain amount of stock at a certain fixed time and at a certain fixed price, in consideration of which the purchaser of the same pays a certain price (premium). In the case of a Put, interest will be allowed to the purchaser in the same manner at a fair rate.

All option contracts are subject to the rules of the London Stock Exchange, and an option bought for the settlement at the end of a certain month is understood to mature and must be declared on the day preceding the Contango or Making Up Day of the settlement for that month and which usually comes from three to six days before the last day of the month, this being arranged by the London Stock Exchange.

In the case of a Call, the holder thereof is entitled to all dividends and rights which become due during its pendeney, while on the other hand, in the case of a Put he must allow them.

There are many arguments in favor of the purchase of options. and it is now very generally appreciated by the largest operators over 
here that at certain times and under certain conditions it is very advantageous to buy options in preference to dealing firm (buying or selling) in stocks.

-With the purchase of an option, the buyer knows exactly where he stands, and his possible loss is in any event, irrespective of the future course of the market, absolutely limited to the amount which he pays for his option, while on the other hand his profits on the same may be very much greater than he had formed any estimate of or anticipated.

Thus, for an approximate example, if a Call is purchased, we will say, on 1,000 shares of a stock for four months at $34 \frac{1}{2}$ for $3 \%$, the total cost and liability for this option is limited to the $\$ 3 ; 000$ (or to be exact $£ 600$ ), which is paid for the same, and it makes no difference what the course of the market may be during the next ensuing four months, the owner of the option has at its maturity the right to call the stock at $34 \frac{1}{2}$. The stock in the meantime may have suffered a very severe temporary decline, but his liability would not at any time or in any way have been increased beyond the original cost of his option.

On the other hand, should the stock at any time before the expiration of the Call sell at so high a figure as to make the owner believe that he is then justified in securing his profit, he may sell the stock firm against his Call and remain short of the same until the expiration of his Call, and then call the stock if the same is above his call price, and deliver the same, thereby covering his short sale; or if the market price of the stock should at the expiration of his Call be below the call price, he would naturally buy the stock in the market and thus cover his short sale, and merely abandon his option.

Very often the owner of an option has several opportunities during the term of his outstanding option to take advantage of the fluctuations in the market to make several turns, always with his option standing behind him as a protection.

Should he not desire to sell against his Call before its expiration, he may stand on the same until its maturity and he then has any one if three courses open to him if the stock at the time is above the call price: (1) He may exercise his option by calling the stock, and then sell the same out in London at the market, thus securing his profit; or (2) He may call the stock and remain long of the same in London; or (3) He may call the stock and have the same shipped to him over here.

Of course in the case of a Put just the reverse of all of the above illustrations would apply. 
Then again with the fact in view, that the purchase price of an option absolutely measures its owner's liability, options are very often purchased, one might say, as a sort of insurance, using a Put as a protection when one is bullish on the market and has, or intends taking, a long position, and a Call to protect one when he is bearish on the market and has, or intends taking, a short position.

Thus, for example, if one is short, we will say, 1,000 Southern Pacific, he may buy a Call on 1,000 shares of Southern Pacific at the existing market price and he can thus feel secure that his loss on the short side of the market will be at the most limited, as long as his Call runs, to the amount (the premium), which he paid for the same. The reverse also applies, namely, if he is bullish on say Southern Pacific and is carrying say 1,000 shares, he may purchase a Put on 1,000 shares against his long position, and his loss on the long side of the market is limited, as long as his Put runs, to the premium which he pays for the same.

There is also another phase to be considered: very often one may have been bullish on the market, and have secured a large profit in his operations on the long side, and, while he feels that the market may go still higher and would not wish to part with his stock and thereby maybe lose his market, still quite possibly he may not wisb to run the chance of a severe reaction in the market and thus lose his profits already made.

Under such circumstances it is very advantagcous to buy a Put covering a specific future time, and the premium paid for this protection is seldom begrudged, as it enables him to still remain long for a further period, without having to part with his stock. Or if he wishes, even though he may see a further rise ahead, he could sell out his long stock and buy a Call and thus feel that even if his ideas of a further rise should not materialize, still it has at the most but cost him the price paid for his Call, while on the other hand, if his ideas turn out to be correct and the stock still further advances, his Call will enable him to secure the additional profit.

Naturally in the case of one being bearish on the market the reverse of the above proposition would equally apply.

To the operator who has strong reason to believe that a certain stock is within a certain time going to have a large move, and wishes to take advantage of this belief or information to make a very large profit, there is a special advantage in the purchase of options.

It is quite possible that he may not be in a position or may not desire to carry or sell short an unusually large line of stock with the attendant risk that if his ideas are not realized and the market should go against him, he would suffer a very serious or even perhaps a dis- 
astrous loss. If, however, he purchases a Call or a Put as the case may be, on a block of stock, he knows that he can rest assured that if he is wrong his greatest possible loss, as before pointed out, is absolutely limited to the amount which he has paid for his option, while if he is right, his profits, less the price paid for his option, will be the same as if he had taken a firm position in the market.

The foregoing are probably the chief advantages which recommend the purchase of options, and the more that people over here in recent years have become educated and accustomed to dealing in them, the more it is generally acknowledged that the arguments in their favor are sound and that by means of their use a very much safer way is found to speculate in the market.

\section{PUTS AND CALLS ${ }^{1}$}

Thirty-six-Year-Old “Call” by Jay Gould-Wall Street Memories Revived

"Put” Sold by Daniel Drew in 18r4 Also Unearthed, Recalling Early Trading Days

Reminiscences of Wall Street's "good old days" were revived yesterday with the unearthing of two "privileges," one sold by Jay Gould and the other by Daniel Drew. The New York American was handed these interesting documents for reproduction.

Puts and calls often play a prominent part in campaigns in stocks. 18,1874 , and expired in sixty days, which was January 17, 18\%5. The same stock was traded in at 144 yesterday, a rise of more than

The privilege sold by Jay Gould was a "call" on 200 shares of Western Union Telegraph Company stock at 74 . It was dated February 21, 1876, and expired at 1:45 P.M. March 22. Last night Western Union closed at $83 \frac{1}{4}$. 100 points.

The other privilege was a "put" sold by Daniel Drew on 100 shares of Chicago \& Northwestern stock at $40 \frac{1}{4}$. It was dated November

1 From New York American, April 5, 1912. 
Russell Sage made millions out of the sale of these privileges. It is the general belief in Wall Street that Jay Gould carried on his campaigns in the Gould shares without the use of puts and calls, but the call on Western Union shows that he sold them at times.

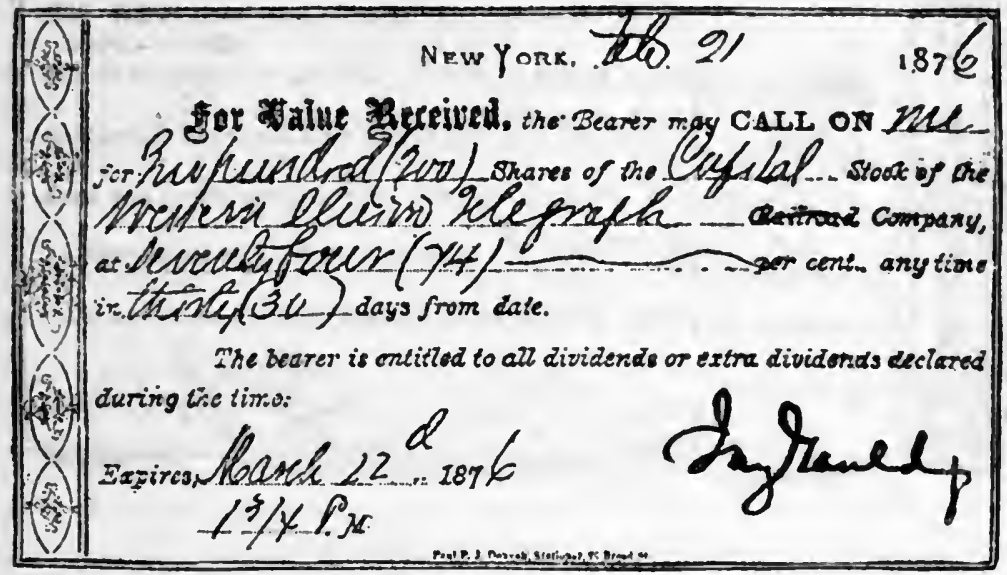

GOULD USED TO "MAKE" MARKET

One of the oldest market operators in the Strcet, upon being shown the privileges here photographed, said:

"Mr. Gould very rarely did anything in puts and calls exeept as part of a campaign in the stock market. When he was condueting his campaign in Union Pacific he sold probably the largest number of puts that were ever sold on any stock in Wall Strcet. He did this to eneourage trading in the shares, and at one time the number of puts he had outstanding was estimated to equal the total amount of the capital stock of the company.

"During his campaign in Union Pacifie he sold so many puts that the number of people trading in the issue inereased materially. These puts insured possible buyers of Union Pacific against heavy losses, and because of this resulted in the greatest market Union Pacifie ever had. It also caused a very big rise in the price of the stock."

Jay Gould at one time bought Union Pacific as low as 14 cents on the dollar. The Union Pacifie puts were issued after Gould had consolidated the road with others and began the boom in its securities, which increased his wealth by many millions.

The call on Western Union is believed to have been issued shortly after Gould aequired that company and was making a market for its securities. The amount of privileges sold by Gould on Western Union 
is said to have been very small compared with the volume put out on Union Pacific.

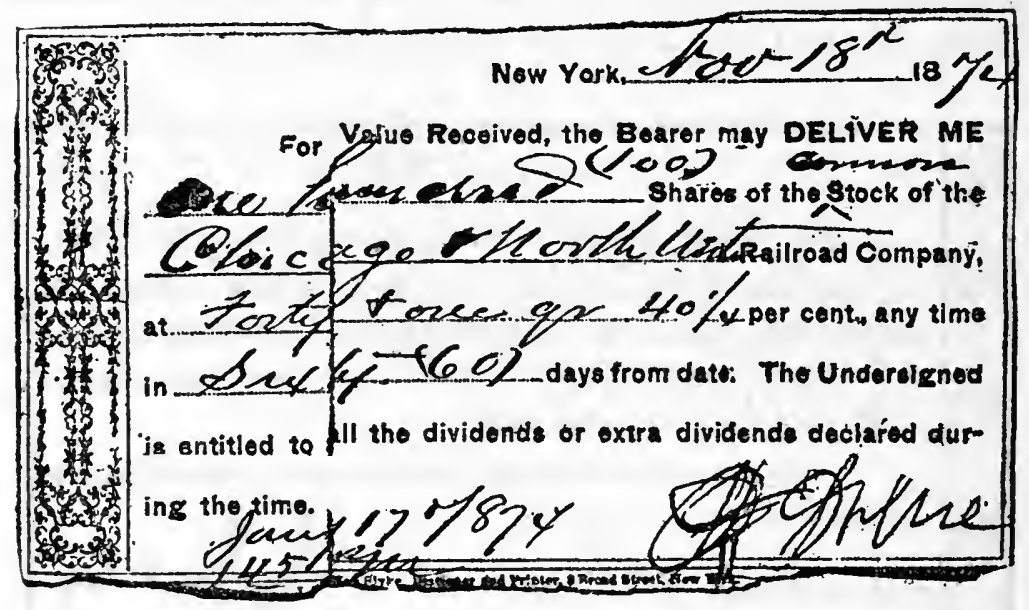

DREW AND ERIE MANIPULATION

The put issued by Daniel Drew on Chicago \& Northwestern is believed to have been sold by him at the time he received a bad "squeezing" in the stock. The actual signature of Drew also caused the followers of the tape to remember him as an example of how a man can succeed with practically no education. Drew was considered one of the shrewdest stock market operators in Wall Street, and at one time was estimated to be worth about $\$ 13,000,000$. He was known as "Uncle Daniel," and made most of his money out of his manipulation of Erie stock.

Just about the time Jay Gould began climbing the ladder of fame Daniel Drew began descending, and kept going down until he died ruined and broken hearted.

Russell Sage was the largest seller of puts and calls that Wall Street has ever known. He made his fortune out of these privileges, and since his death no one has taken his place.

Conditions existing in Wall Street when Jay Gould and Daniel Drew were breaking stock markets are fully described in Henry Clews's book, "Fifty Years in Wall Street." 


\section{LEGAL INVESTMENTS FOR TRUSTEES ${ }^{1}$}

A trustee or other person holding trust funds for investment may invest the same in the same kind of securities as those in which savings banks of this State are by law authorized to invest the money deposited therein, and the income derived therefrom, and in bonds and mortgages on unencumbered real property in this State worth fifty per centum more than the amount loaned thereon. A trustee or other person holding trust fundi may require such personal bonds or guaranties of payment to accompany investments as may seem prudent, and all premiums paid on such guaranties may be charged to or paid out of income, providing that such charge or payment be not more than at the rate of one-half of one per centum per annum on the par value of such investments. But no trustee shall purchase sccurities hereunder from himself.

Investment of Trust Funds. ${ }^{2}$-All investments of money received by any such corporation, and by any trust company chartered by special act, prior to May 18, 1892, as executor, administrator, guardian, personal or testamentary trustee, rcceiver, committee or depositary, shall be absolutely liable, unless the investments are such as are proper when made by an individual acting as trustee, executor, administrator, guardian, receiver, committee, depositary, or such as are permitted in and by the instrument or words creating or defining the trust.

Interest.-On all sums of money not less than one hundred dollars, which shall be collected and received by a trust company acting as executor, administrator, guardian, trustee, receiver or committee under the appointment of any court or officer, or in any fiduciary capacity under such appointment, or as a depositary of moncys paid into court, interest shall be allowed by such trust company at not less than the rate of two per centum per annum until the moneys so received shall be duly expended or distributed. If such interest moneys, or any part thereof, shall not annually be expended or distributed pursuant to the terms or provisions of the trust under which such moneys are held, the amount thereof not so expended or distributed shall be accumulated by such trust company for the benefit of the parties interested in such trust fund, and shall be added to the principal to constitute a new principal upon which interest shall thereafter be computed.

1 From the New York Personal Property Law, Section 21.

2 From the New York Banking Law of 1914. 


\section{SAVINGS BANKS ${ }^{1}$}

Since all trustees may invest in securities which are legal for sav. ings banks, it is necessary to set forth the provisions. of the new banking law relating to investment by such banks.

Investments of Deposits and Guaranty Funds and Restrictions Thereon.-A savings bank may invest the moneys deposited therein, the sums credited to the guaranty fund thereof and the income derived therefrom, subject to the following restrictions:

1. The stocks or bonds or interest-bearing notes or obligations of the United States, or those for which the faith of the United States is pledged to provide for the payment of the interest and principal, including the bonds of the District of Columbia.

2. The stocks or bonds or interest-bearing obligations of this state, issued pursuant to the authority of any law of the state.

3. The stocks, bonds or interest-bearing obligations of any state of the United States, upon which there is no default and upon which there has been no default for more than ninety days; provided that within ten years immediately preceding the investment such state has not been in default for more than ninety days in the payment of any part of prineipal or interest of any debt duly authorized by the legislature of such state to be contracted by such state since the first day of January, eighteen hundred and seventy-eight.

4. The stocks, bonds, interest-bearing obligations, or revenue notes sold at a discount, of any city, county, town, village, school district, union free school district or poor district in this state, provided that they were issued pursuant to law and that the faith and credit of the municipality or district that issued them are pledged for their payment.

5. The stocks or bonds of any incorporated city situated in one of the states of the United States which was admitted to statehood prior to January first, eighteen hundred and ninety-six, and which since January first, eighteen hundred and sixty-one, has not repudiated or defaulted in the payment of any part of the principal or interest of any debt authorized by the legislature of any such state to be contracted, provided said city has a population, as shown by the federal census next preceding said investment, of not less than forty-five thousand inhabifants, and was incorporated as a city at least twenty-five years prior to the making of said investment, and has not, since January first, eighteen hundred seventy-eight, defaulted for more than ninety days in the payment of any part either of principal or interest, of any bond, note or other evidence of indebtedness,

1 Quoted from New York Banking Law by Frank C. McKinney in his Legal Investments for Trust Fuṇds 
or effected any compromise of any kind with the holders thereof. But if, after such default on the part of any such state or city, the debt or security, in the payment of the principal or interest of which such default occurred, has been fully paid, refunded or comprised, by the issue of new securities, then the date of the first failure to pay principal or interest, when due, upon such debt or security, shall be taken to be the date of such default, within the provisions of this subdivision, and subsequent failures to pay installments of principal or interest, upon such debt or security, prior to the refunding or final payment of the same, shall not be held to continue said default or to fix the time thereof, within the meaning of this subdivision, at a date later than the date of said first failure in payment. If at any time the indebtedness of any such city, together with the indebtedness of any district or other municipal corporation or subdivision except a county, which is wholly or in part included within the bounds or limits of said city, less its water debt and sinking fund, shall exceed seven per centum of the valuation of said city for purposes of taxation, its bonds and stocks shall thereafter, and until such indebtedness shall be reduced to seven per centum of the valuation for the purposes of taxation, cease to be an authorized investment for the money of savings banks.

6. Bonds and mortgages on unincumbered real property situated in this state, to the extent of sixty-five per centum of the appraised value thereof. Not more than sixty-five per centum of the whole amount of deposits and guaranty fund shall be so loaned or invested. If the loan is on unimproved and unproductive real property, the amount loaned thereon shall not be more than forty per centum of its appraised value. No investment in any bonds and mortgages shall be made by any savings bank except upon the report of a committee of its trustees charged with the duty of investigating the same, who shall certify to the value of the premises mortgaged or to be mortgaged, according to their judgment, and such report shall be filed and preserved among the records of the corporation.

7. The following bonds of railroad corporations:

(a) The first mortgage bonds of any railroad corporation of this state, the principal part of whose railroad is located within this state, or of any railroad corporation of this or any other state or states connecting with and controlled and operated as a part of the system of any such railroad corporation of this state, and of which connecting railroad at least a majority of its capital stock is owned by such a railroad corporation of this state or in the mortgage bonds of any such railroad corporation of an issue to retire all prior mortgage debt of such railroad companies respectively; provided that at 
no time within five years next preceding the date of any such investment, such railroad corporation of this state or such connecting railroad corporation respectively shall have failed regularly and punctually to pay the matured principal and interest of all its mortgage indebtedness, and in addition thereto regularly and punctually to have paid in dividends to its stockholders during each of said five years an amount at least equal to four per centum upon all its outstanding capital stock; and provided further, that at the date of every such dividend the outstanding capital stock of such railroad corporation or such connecting railroad company respectively shall have been equal to at least one-third of the total mortgage indebtedness of such railroad corporations respectively, including all bonds issued or to be issued under any mortgage securing any bonds in which such investment shall be made.

(b) The mortgage bonds of the following railroad corporations: The Chicago \& Northwestern Railroad Company, Chicago, Burlington \& Quincy Railroad Company, Michigan Central Railroad Company, Illinois Central Railroad Company, Pennsylvania Railroad Company, Delaware \& Hudson Company, Delaware, Lackawanna \& Western Railroad Company, New York, New Haven \& Hartford Railroad Company, Boston \& Maine Railroad Company, Maine Central Railroad Company, the Chicago \& Alton Railroad Company, Morris \& Essex Railroad Company, Central Railroad of New Jersey, United New Jersey Railroad \& Canal Company, also in the mortgage bonds of railroad companies whose lines are leased or operated or controlled by any railroad company specified in this paragraph if said bonds be. guaranteed both as to principal and interest by the railroad company to which said lines are leased or by which they are operated or controlled. Provided that at the time of making investments authorized by this paragraph the said railroad corporations issuing such bonds shall have earned and paid regular dividends of not less than four per centum per annum in cash on all their issues of capital stock for the ten years next preceding such investment, and provided the capital stock of any said railroad corporations shall equal or exceed in amount one-third of the par value of all its bonded indebtedness; and further provided that all bonds authorized for investment by this paragraph shall be secured by a mortgage which is a first mortgage property of the company issuing such bonds, or that such bonds shall be mortgage bonds of an issue to retire all prior mortgage debts of such railroad company; provided, further, that the mortgage which secures the bonds authorized by this paragraph is dated, executed and recorded prior to January first, nineteen hundred and five. 
(c) The mortgage bonds of the Chicago, Milwaukee \& Saint Paul Railroad Company and the Chicago, Rock Island \& Pacific Railroad Company, so long as they shall continue to earn and pay at least four per centum dividends per annum on their outstanding capital stock, and provided their capital stock shall equal or exceed in amount one-third of the par value of all their bonded indebtedness, and further provided that all bonds of either of said companies hereby authorized mortgage on either the whole or some part of the railroad or railroad property actually in the possession of and operated by said company, or that such bonds shall be mortgage bonds of an issue to retire all prior debts of said railroad company; provided, further, that the mortgage which secures the bonds authorized by this paragraph is dated, executed and recorded prior to January first, nineteen hundred and five.

(d) The first mortgage bonds of the Fonda, Johnstown \& Gloversville Railroad Company, or in the mortgage bonds of said railroad company of an issue to retire all prior mortgage debts of said railroad company shall equal or exceed in amount one-third of the par value of all its bonded indebtedness, and provided also that such railroad be the standard gauge of four feet eight and one-half inches, and in the mortgage bonds of the Buffalo Creek Railroad Company of an issue to retire all prior mortgage debts of said railroad company, provided that the bonds authorized by this paragraph are secured by a mortgage dated, executed and recorded prior to January first, nineteen hundred and five.

(e) The mortgage bonds of any railroad corporation incorporated under the laws of the United States, which actually owns in fee not less than five hundred miles of standard gauge railway exclusive of siding, within the United States, provided that at no time within five years next preceding the date of any such investment such railroad corporation shall have failed regularly and punctually to have paid in dividends to its stockholders during each of said fire years an amount at least equal to four per centum upon all its outstanding capital stock, and provided further that during said five years the gross earnings, the amount received directly or indirectly by said company from the sale of coal from mines owned or controlled by it, shall not have been less in amount than five times the amount necessary to pay the interest payable during that year upon its entire outstanding indebtedness, and the rentals for said year of all leased lines, and further provided that all bonds authorized for investment by this paragraph shall be secured by a mortgage which is at the time of making said investment or at the date of the execution of said mortgage (1) a first mortgage upon not less than seventy-five per 
centum of the railway owned in fee by the company issuing said bonds exclusive of sidings at the date of said mortgage or (2) a refunding mortgage issued to retire all prior lien mortgage debts of said company outstanding at the time of said mortgage investment and covering at least seventy-five per centum of the railway owned in fee by said company at the date of said mortgage. But no one of the bonds so secured shall be legal investment in case the mortgage securing the same shall authorize a total issue of bonds which together with all outstanding prior debts of said company, after deducting therefrom in case of a refunding mortgage, the bonds reserved under the provisions of said mortgage to retire prior debts at maturity, shall exceed three times the outstanding capital stock of said company at the time of making said investment. And no mortgage is to be regarded as a refunding mortgage, under the provisions of this paragraph, unless the bonds which it secures mature at a later date than any bond which it is given to refund, nor unless it covers a mileage at least twenty-five per centum greater than is covered by any one of the prior mortgages so to be refunded.

(f) Any railway mortgage bonds which would be a legal investment under the provisions of paragraph (e) of this subdivision, except for the fact that the railroad corporation issuing said bonds actually owns in fee less than five hundred miles of road, provided that during five years next preceding the date of any such investment the gross earnings in each year from the operations of said corporation, including the gross earnings of all lines leased and operated or controlled and operated by it, shall not have been less than ten million dollars.

(g) The mortgage bonds of a railroad corporation described in the foregoing paragraph (e) or (f) or the mortgage bond of a railroad owned by such corporation, assumed or guaranteed by it by endorsement or said bonds, provided said bonds are prior to and are to be refunded by a general mortgage of said corporation the bonds secured by which are made a legal investment under the provisions of said paragraph (e) or (f) ; and provided, further, that said general mortgage covers all the real property upon which the mortgage securing said underlying bonds is a lien.

(h) Any railway mortgage bonds which would be a legal investment under the provisions of paragraph (e) or (g) of this subdivision except for the fact that the railroad corporation issuing said bonds actually owns in fee less than five hundred miles of road, provided the payment of principal and interest of said bonds is guaranteed by endorsement thereon by, or provided said bonds have been assumed by a corporation whose first mortgage is, or refunding mortgage bonds are, a legal investment under the provisions of paragraph (e) or (f) 
of this subdirision. But no one of the bonds so guaranteed or assumed shall be a legal investment in case the mortgage securing the same shall authorize a total issue of bonds which, together with all the outstanding prior debts of the corporation making said guarantee or so assuming said bonds, including therein the authorized amount of all previously guaranteed or assumed bond issues, shall exceed three times the capital stock of said corporation, at the time of making said investment.

(i) The first mortgage bonds of a railroad the entire capital stock of which, except shares necessary to qualify directors, is owned by, and which is operated by a railroad whose last issued refunding bonds are a legal investment under the provisions of paragraph (a), (e), or (f) of this subdivision, provided the payment of principal and interest of said bonds is guaranteed by endorsement thereon by the company so owning and operating said road, and further provided the mortgage securing said bonds does not authorize an issue of more than twenty-thousand dollars in bonds for each mile of road covered thereby. But no one of the bonds so guaranteed shall be a legal investment in case the mortgage securing the same shall authorize a total issue of bonds which together with all the outstanding prior debts of the company making said guarantee, including therein the authorized amount of all previously guaranteed bond issues, shall exceed three times the capital stock of said company, at the time of making said investment.

Bonds which have been or shall become legal investments for savings banks under any of the provisions of this section shall not be rendered illegal as investments, though the property upon which they are secured has been or shall be conveyed to another corporation, and though the railroad corporation which issued or assumed said bond has been or shall be consolidated with another railroad corporation, if the consolidated or purchasing corporation shall assume the payment of said bonds and shall continue to pay regularly interest or dividend or both upon the securities issued against, in exchange for or to acquire the stoek of the company consolidated or the property purchased or upon securities subsequently issued in exchange or substitution therefor to an amount at least equal to four per centum per annum upon the capital stock outstanding at the time of such consolidation or purchase of said corporation which has issued or assumed such bonds.

Not more than twenty-five per centum of the assets of any savings bank shall be loaned or invested in railroad bonds, and not more than ten per centum of the assets of any savings bank shall be invested in the bonds of any one railroad corporation described in paragraph (a) of this subdivision, and not more than five per centum of such assets 
in the bonds of any other railroad corporation. In determining the amount of the assets of any savings bank under the provisions of this subdivision its securities shall be estimated in the manner prescribed for determining the per centum of par value surplus by section (257) of this article.

Street railroad corporations shall not be considered railroad corporations within the meaning of this subdivision.

8. Promissory notes payable to the order of the savings bank upon demand, secured by the pledge and assignment, if necessary, of the stocks or bonds or any of them enumerated in subdivision one, two, three, four and five of this section or by the railroad bonds or any of them mentioned and described in subdivision seven of this section, but no such loan shall exceed ninety per centum of the cash market value of such securities so pledged. Should any of the securities so held in pledge depreciate in value after the making of such loan, the savings bank shall require an immediate payment of such loan or of a part thereof or additional security therefor, so that the amount loaned thereon shall at no time exceed ninety per centum of the market value of the securities so pledged for such loan.

9. Real estate as follows:

(a) A plot whereon there is or may be erected a building or buildings suitable for the convenient transaction of the business of the savings bank, from the portions of which not required for its own use a revenue may be derived.

(b) Such as shall be conveyed to it in satisfaction of debts previously contracted in the course of its business.

(c) Such as it shall purchase at sales under judgments, decrees or mortgages held by it.

The trustees of a savings bank shall not be held liable for investing in state or municipal bonds named in the last list furnished by the Superintendent of Banks pursuant to section (52) of article two of this chapter, or in any railroad bonds mentioned in such list, which have been legally issued and properly executed, unless such savings bank shall have been notified by the Superintendent of Banks that, in his judgment, such bonds do not conform or have ceased to conform to the provisions of this section. 


\section{ELEMENTS OF THE COST AND VALUE OF A GAS PLANT'}

The cost of a gas plant and of acquiring its business may be subdivided as follows :

1. Preliminary development, which includes:

a. Investigation of the project;

b. Assembling of parties who may be willing to participate;

c. Preliminary engineering and legal advice on the proposition;

d. Canvass of territory to ascertain if sufficient business can be obtained;

e. Estimate of cost of plant and probable income;

f. Incorporation of the company; and

g. Securing the franchise.

2. Real Estate,

3. Labor, materials and sub-contracts,

4. General contractor's profit,

5. Engineering,

6. Expense of company organization during eonstruction,

7. Interest during construction,

8. Taxes and insurance during construction,

9. Stores, supplies and working capital,

10. Acquiring or establishing the business, which includes:

a. Expenses of canvassing for business;

b. Advertising;

c. Setting meters free of charge;

d. Interest on cost of plant in excess of income until business becomes self-supporting; and

e. Taxes and insurance during that time.

11. Legal expenses;

12. Financing, including banker's commission, discount on bonds and promoter's profits.

Many of these items are overlooked by those who have had no experience in the actual establishment of such a business, and that, no doubt, is the reason why the cost of such a plant and establishing such a business almost always largely exceeds the anticipated outlay.

The value of a gas property and business, however, exceeds the sum of the items I have mentioned, if the property is well located, and the property now in question is favorably located. (Case, pp. 446-453; also pp. 1278 and 1279.) If such a plant were not worth more than it cost

1 From Brief for the Prosecutor, Public Service Gas Company, Proseculor, vs. Board of Public Utility Commissioners, et als., Defendants, New Jersey Supreme Court. 
it would be unwise to construct it. And if it were known that the value of such a plant would be cut down for rate making to its actual cost less depreciation, capital could not be found to build it.

Actual disbursements in money for the construction of a gas plant must be made:

1. For preliminary development prior to beginning the actual work of construction,

2. For real estate,

3. For material and labor.

These expenses are sometimes called structural cost. After construction of the plant additional disbursements must be made.

4. For the development of the business.

These four elements of value of a gas plant are actual disbursements of money. There are also other outlays which are commonly called overhead charges, to which reference will be made hereafter. Such charges are really a part of structural cost. Besides, there are other elements of value of such a property, the principal of which are:

1. The value created by an organization of pieces of physical property into an income producing unit. This value was recognized and stated in the case of Newark v. State Board of Taxation, 37 Vr., 466; and has been repeatedly recognized and asserted by the courts. Adams Express Co. v. Ohio, 165 U. S., 194, and 166 U. S., 185.

2. The value created by uniting two or more plants or properties engaged in public service, whereby greater efficiency and reduced operating expenses produce better results at less cost; Cleveland Ry. Co. . Backus, 154 U. S. at p. 444.

3. The rights or special franchises which confer the easement in or right of way through lands, indispensable to the construction and operation of the plant, and which also confer vitality and earning power on physical property. 


\section{ENGINEER'S PRELIMINARY REPORT ${ }^{1}$}

Contents

\section{INDEX TO CONTENTS}

General Proposition

Page

Principal Features

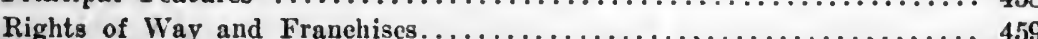

Description of Route.

Schedule of Alignment ........................461

Schedule of Grades ............................. 461

Plan of Construetion ............................... 462

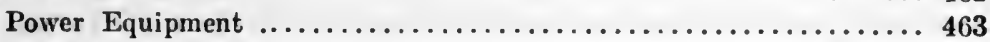

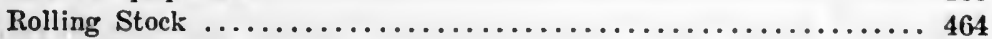

Cost of Construction................................. 464

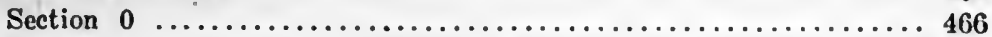

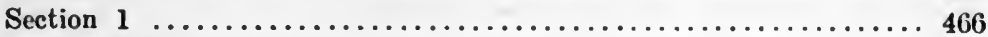

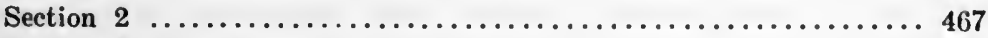

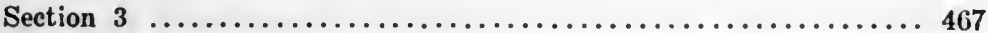

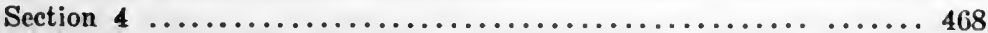

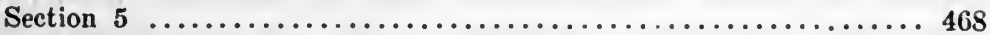

Line Construction .............................469

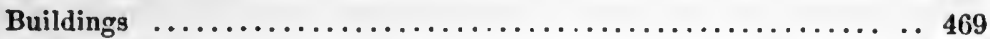

Power Plant ................................ 469

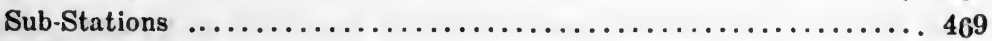

Rolling Stock ................................ 469

Summary of Costs ..........................470

Character and Importance of Trade.................... 470

Lima ......................................470

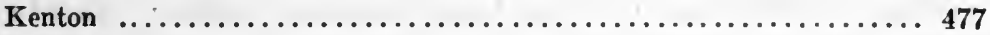

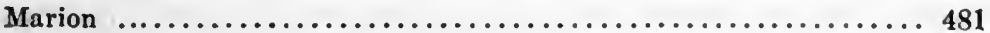

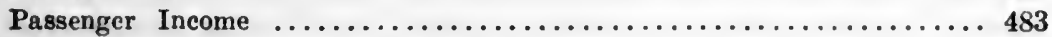

Table Showing Population Directly on Line................. 484

Table Showing Population Tributary to Line................. 485

Summary of Tributary Population ................. 486

Revenues-

United States Mail .............................486

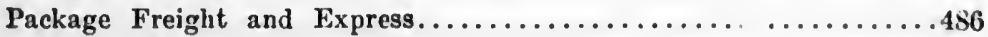

Dairy Products ................................ 487

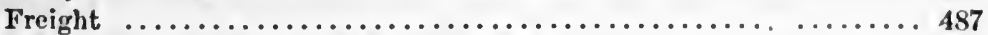

Statement of Revenue and Operating Expense................ 489

\section{GENERAL PROPOSITION}

The Lima Eastern Railway Company was incorporated ander the Laws of the State of Ohio in nineteen hundred and five for the purpose of constructing an electric railroad from Lima, Ohio, to Marion, Ohio, a distance of fifty-five miles.

1 Prospectus of the Lima-Eastern Railway, proposed electric road connecting Lima-Kenton-Marion, Ohio. The F. A. Pease Engineering Company, engineers, Cleveland, July, 1906. 
The various electric lines contemplated and constructed to the north, west and south from Lima have been shown to be profitable financial enterprises, and the patronage of roads in operation has been fully up to expectations. The lines in operation extend south to Springfield, Dayton, Xenia and Cincinnati; west to Fort Wayne, Muncie, and Indianapolis, and north to Findlay, Fostoria, Fremont, Tiffin and Toledo. The projected lines extend to Ottawa on the north and Bellefontaine on the south.

At Marion, the eastern terminus of proposed road, lines are in operation to Delaware, Columbus, Newark, Zanesville, Lancaster and Chillicothe, while other lines are projected north to Tiffin with Toledo and Sandusky connections; northeasterly to Bucyrus, and east to Galion, which will connect with Mansfield and, by the lines now under construction, with Ashland, Creston and Cleveland.

With the transportation facilities, with which each of the terminal cities is provided for traffic in other directions, there is no present connection between them except the Erie Railroad which, while having four through trains in each direction daily, has but one train which stops at all local stations. It is therefore impossible, under present conditions of transportation, for the residents of local towns along the line to go to and return from either of the cities at terminii during the same day.

\section{PRINCIPAL FEATURES}

The construction of The Lima Eastern Railway would connect three prosperous cities, the county seat of Allen, Hardin and Marion counties, and provide transportation facilities for an extensive and prosperous territory. The western part of this territory is at present inadequately served by a steam road; the eastern part, although paralleling the steam road, is remote from railroad at such a distance as to give the proposed electric line practically all the local traffic. While the Erie Railroad passes through the three principal cities along proposed electric line, in every case the station is at such a distance, remote from the business center, that it becomes necessary for the traveling public to use the city cars or other conveyance. The electric road would accommodate passengers at the most advantageous points, thereby providing accommodations to the public which should secure practically all the through passenger traffic as well as local.

The cities of Lima and Marion are among the most prosperous in the State of Ohio, both being noted for their extensive manufacturing and commercial enterprises. Allen and Marion counties, which are traversed by proposed road and in which are located the above-named cities, show an increase in population of eighteen and sixteen per cent. 
respectively for the decennial period, eighteen hundred and nintey to nineteen hundred. This is a record for growth that is equaled by but twelve out of the eighty-eight counties in the State.

\section{RIGHTS OF WAY AND FRANCHISES}

The Lima Eastern Railway Company has secured a private right of way of sufficient width to construct double track the entire length of line. At terminals and in municipalities along the route franchises have been secured in the streets for the necessary tracks, switches and turnouts. These grants are particularly valuable at Marion and Kenton where the road fulfils the requirements of a city line, giving local transportation to the more densely populated territory in addition to the through service.

\section{DESCRIPTION OF ROUTE}

The Lima Eastern Railway cars are calculated to leave Lima over the present city tracks at the Public Square, then out Market Street and Bellefontaine Arenue to the Allen County Fairgrounds, the present limits of city line. Extending southeasterly, from Fairgrounds to north line of Erie Railroad Company's right of way, three and fourtenths miles from Public Square in Marion, the line deflects from highway and parallels the steam road.

Numerous oil wells and pumping stations are located along the line, but in such locations that it is not necessary to alter track alignment to aroid them. At a point one and one-tenth miles east of deflection from Bellefontaine Avenue, a cemetery is located adjacent to Erie right of way which necessitates a deflection to the north in passing; this, however, is accomplished by means of two one-degree and a four-degree curve, after which the line again parallels the Erie.

At Westminster station another deflection is made to overcome an offset in the north line of stcam road and to avoid the railroad station and other buildings. At Harrods, ten miles out of Lima, the location was made for a distance of sixteen hundred feet in Second Street, parallel with and adjoining the railroad property.

Near the western limits of Hardin County, thirteen miles from Lima, a large county drainage ditch, on north line of Erie right of way, necessitates offsetting the Lima Eastern to the north, and a mile further along again deflecting to pass through Alger on Lee Street. The route parallel with and adjoining steam road is again taken up after leaving Alger and continued easterly a distance of six miles through McGuffy and Foraker.

At a distance of twenty and one-half miles from Lima, a slight deflection is made to pass along north side of highway paralleling. the 
Erie. The location continues easterly, parallel with highway, to Station 1,151, then parallel with Erie Railroad until at crossing of Sciota River, a course is taken, which, extended, passed along Franklin Street through Kenton, passing the station and crossing the tracks of Toledo \& Ohio Central and of the Big Four at Grade, in the west part of city.

Traversing the main business thoroughfare of Kenton its entire length, easterly to Grove Cemetery, a private right of way is followed along south side of highway a distance of thirteen miles which is practically all tangent, there being but six hundred fifty feet of one degree curve in the above distance.

At station 2185 the line crosses to north side by a two degree reversed curve and continues east two and one-half miles in a straight line through Scottown. From a point one mile east of Scottown to Big Island, the alignment is somewhat irregular by reason of following line of highway; it has been possible, however, to limit curvature to six degrees, which will not materially decrease the running time.

From Big Island to North Main Street in Marion, the line is run with very little curvature. The Hocking Valley Railroad is constructed upon an embankment of sufficient height above general level of ground to permit an under crossing. The Pennsylvania Railroad is built at such an elevation that a grade crossing is necessary. As this is a single track branch road, there would be less objection to a grade crossing than to the expense of and conditions created by an overhead crossing. The route along North Main Street is straight south in centre of highway to Court House, the eastern terminus of line.

Throughout its entire length the locations conforms as nearly as possible to a direct line. The grade shown on profile is equal to any that could be secured throughout the territory traversed. The line, as located, passes through all cities and villages along the route by traversing the main thoroughfares, thus making conditions most advantageous for passenger traffic.

By following line of Erie Railroad a most economical construction can be secured and the shortest possible distance obtained between Lima and Kenton. East of Kenton the location passes through a more densely populated territory than exists to the south along line of steam road. When the Erie Railroad was projected through Ohio, the original location was made through Scottown, covering practically the same territory as traversed by proposed electric line; aiter grading for roadbed, however, the line was altered to present location.

The following schedules show data relative to alignment and curvature for the entire distance between terminals: 


\begin{tabular}{|c|c|c|c|c|c|c|c|}
\hline 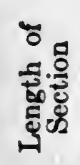 & $\begin{array}{l}0 \\
0 \\
= \\
=\end{array}$ & 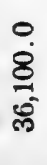 & $\mid \begin{array}{c}0 \\
8 \\
8 \\
0 \\
010\end{array}$ & 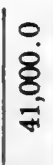 & $\begin{array}{l}0 \\
8 \\
8 \\
0 \\
0 \\
1\end{array}$ & में & 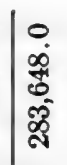 \\
\hline 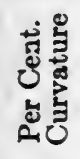 & $\begin{array}{l}{ }^{L} \\
\text { \% } \\
0\end{array}$ & $\underset{\text { శ్ }}{\stackrel{\text { m. }}{\circ}}$ & $\stackrel{\mathscr{0}}{0}$ & $\begin{array}{l}\not \\
0 \\
0 \\
0\end{array}$ & $\begin{array}{l}0 \\
0 \\
0\end{array}$ & $\stackrel{9}{3}$ & $\begin{array}{l}\stackrel{12}{0} \\
0 \\
0\end{array}$ \\
\hline 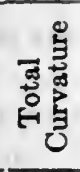 & $\begin{array}{l}0 \\
\dot{q} \\
\dot{q}\end{array}$ & $\stackrel{+}{\stackrel{4}{\leftarrow}}$ & \begin{tabular}{l}
0 \\
\multirow{+}{*}{} \\
$i 5^{-1}$
\end{tabular} & 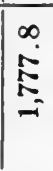 & בְ & 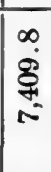 & 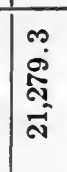 \\
\hline $\begin{array}{l}\mathbf{8} \\
1 \\
0\end{array}$ & & $\vdots$ & 苛 & |c & & $\mid$\begin{tabular}{l}
$\infty$ \\
$\dot{8}$ \\
\multirow{+}{*}{} \\
$\infty$
\end{tabular} & 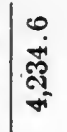 \\
\hline
\end{tabular}

\begin{tabular}{|c|c|c|c|c|c|c|c|}
\hline 递苟 & $\begin{array}{l}\stackrel{8}{\circ} \\
\stackrel{9}{\circ} \\
0 \\
0\end{array}$ & 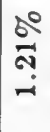 & $\begin{array}{l}8^{\circ} \\
0 \\
10 \\
0\end{array}$ & $\begin{array}{l}\stackrel{0}{0} \\
\stackrel{5}{\circ} \\
\text { ci }\end{array}$ & $\begin{array}{l}80 \\
0 \\
0 \\
:\end{array}$ & 苍 & 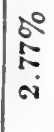 \\
\hline 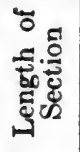 & $\begin{array}{l}0 \\
0 \\
= \\
=\end{array}$ & 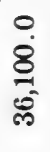 & $\begin{array}{l}0 \\
\text { 8̊ } \\
8 \\
\text { : }\end{array}$ & $\begin{array}{l}0 \\
\dot{8} \\
=-1\end{array}$ & $\begin{array}{l}0 \\
\dot{8} \\
0 \\
\infty\end{array}$ & 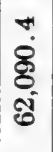 & 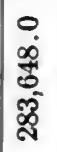 \\
\hline 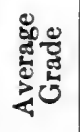 & 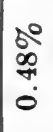 & \begin{tabular}{l}
$\frac{50}{5}$ \\
\multirow{0}{*}{}
\end{tabular} & $\begin{array}{l}\stackrel{20}{7} \\
\stackrel{0}{0}\end{array}$ & $\begin{array}{l}\stackrel{\circ}{0} \\
\stackrel{+}{*} \\
0\end{array}$ & $\begin{array}{l}\stackrel{\circ}{0} \\
\text { 営 } \\
0\end{array}$ & $\begin{array}{l}\stackrel{0}{0} \\
\stackrel{10}{0} \\
0 \\
0\end{array}$ & 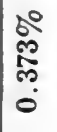 \\
\hline $\begin{array}{l}\stackrel{8}{1} \\
\stackrel{5}{5} \\
i \\
i \\
0 \\
i\end{array}$ & $\vdots$ & $\begin{array}{l}\vdots \\
\vdots \\
\vdots\end{array}$ & $\begin{array}{l}\vdots \\
\vdots \\
\vdots\end{array}$ & 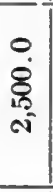 & $\begin{array}{l}\vdots \\
\vdots \\
\vdots\end{array}$ & & \begin{tabular}{l}
0 \\
$\dot{8}$ \\
\multirow{3}{0}{} \\
s.
\end{tabular} \\
\hline $\begin{array}{l}\stackrel{\circ}{0} \\
0 \\
i \\
i \\
-i\end{array}$ & : & $\begin{array}{l}\vdots \\
\vdots \\
\vdots\end{array}$ & $\begin{array}{l}\vdots \\
\vdots \\
\vdots\end{array}$ & $\begin{array}{l}0 \\
\dot{8} \\
- \\
-\end{array}$ & $\begin{array}{l}0 \\
\dot{0} \\
0 \\
-\end{array}$ & $\begin{array}{c}\vdots \\
\vdots \\
\vdots\end{array}$ & $\begin{array}{l}0 \\
\dot{8} \\
\stackrel{1}{0} \\
\infty\end{array}$ \\
\hline 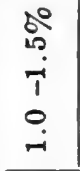 & & $\begin{array}{l}0 \\
\dot{8} \\
\dot{0} \\
\text { o }\end{array}$ & $\begin{array}{l}\vdots \\
\vdots \\
\vdots\end{array}$ & $\begin{array}{l}0 \\
\dot{8} \\
\stackrel{6}{-1}\end{array}$ & $\begin{array}{l}0 \\
\dot{8} \\
0 \\
0 \\
0 \\
0\end{array}$ & $\begin{array}{l}0 \\
\dot{8} \\
6 \\
\text { ஸे }\end{array}$ & \begin{tabular}{l}
0 \\
$\dot{8}$ \\
\multirow{2}{*}{}
\end{tabular} \\
\hline $\begin{array}{l}\stackrel{0}{0} \\
\text { - } \\
1 \\
0 \\
0 \\
0\end{array}$ & 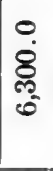 & $\begin{array}{l}0 \\
\dot{8} \\
\text { के }\end{array}$ & 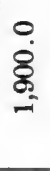 & $\begin{array}{l}0 \\
\dot{8} \\
8 \\
10\end{array}$ & $\begin{array}{l}0 \\
\dot{8} \\
\dot{0}\end{array}$ & 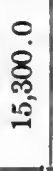 & 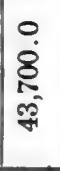 \\
\hline $\begin{array}{l}00 \\
10 \\
0 \\
0 \\
0\end{array}$ & 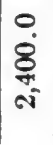 & 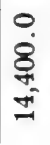 & 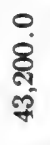 & $\begin{array}{l}0 \\
\dot{8} \\
8 \\
\dot{8}\end{array}$ & 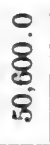 & 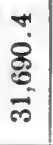 & 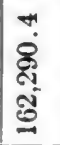 \\
\hline 离 & $\begin{array}{l}0 \\
\stackrel{0}{\circ} \\
\text { oi }\end{array}$ & 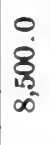 & 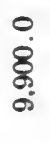 & $\begin{array}{l}0 \\
\dot{8} \\
8 \\
0\end{array}$ & 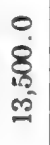 & 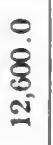 & 苟 \\
\hline 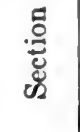 & 0 & - & N & $\infty$ & * & 10 & 蛋 \\
\hline
\end{tabular}


PLAN FOR CONSTRUCTION.

The Lima Eastern is contemplated as a single track line with suffcient turnouts and sidings to permit running on fifteen-minute schedule. While it is improbable that such running time would be immediately required, such conditions as unforeseen delays on sidings, due to a car off schedule or a work train on the line, would be more readily overcome and traffic more speedily restored to normal equilibrium by having siding not more than two and one-half miles apart.

The details of construction, upon which estimates are based, are set forth as follows:

Roadbed to be graded to lines shown on profiles; all changes in grade to be made by means of long vertical curves. In single track work, width of roadbed to be 14 feet on fills and 18 feet in cuts.

Ties to be $6^{\prime \prime} \times 8^{\prime \prime}$ spaced 24 inches on centres with four spikes to the tie.

Rail, along private right of way, to be 70 pound standard tee rail, joined with four bolt splice bars. Through village streets it is intended to use 9 inch $95 \mathrm{lb}$. girder rail.

No. 10 spring frogs and 15 foot split switches are contemplated for turnouts to enable cars making sidings at a high rate of speed. The length of turnouts is estimated at 500 feet, point to point, except where passing along streets at points of heavy passenger traffic, where they are extended to meet the requirements.

The ballast to be broken stone or gravel to a depth of 6 inches under ties and crowned up to the center.

The construction of concrete arches is planned at such points as will afford the necessary clearance; over low ground, however, concrete abutments are planned, having a clear span of "I" beam construction. Plate girders are contemplated where the spans are in excess of limits of "I" beam construction. The principal structures are over the Scioto and Little Rivers and under the Hocking Valley Railroad.

Spans of plate girders and trusses are as follows:

Section 0:

Station $754 \ldots \ldots \ldots \ldots \ldots \ldots \ldots \ldots \ldots \ldots \ldots \ldots \ldots \ldots$ feet

SECTION 2:

Station $692 \ldots \ldots \ldots \ldots \ldots \ldots \ldots \ldots \ldots \ldots \ldots$ feet

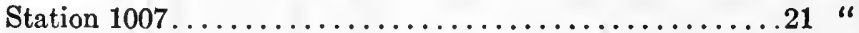

Cottonwood ditch............................66 "

Scioto River..............................66 "

Section 3:

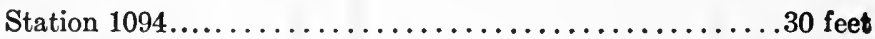

Scioto River...............................90 "

Section 4:

Scottown..........................6 feet 


\section{Section 5:}

Station $2431 . \ldots \ldots \ldots \ldots \ldots \ldots \ldots \ldots \ldots \ldots \ldots$ feet

Station 2480................................... "

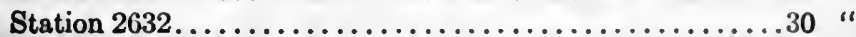

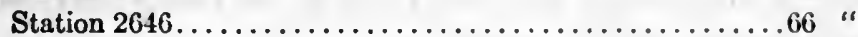

Station $2670 \ldots \ldots \ldots \ldots \ldots \ldots \ldots \ldots \ldots \ldots \ldots$.

Subway at Hocking Valley Railroad.

For line work, 35 foot cedar or chestnut poles are contemplated, spaced one hundred feet on tangent, the trolley wire being carried on brackets, with cross-arms for high tension and feeder wires, and for telephone line. In streets and on passing switches, double pole line and cross suspension is estimated.

\section{POWER FQUIPMENT.}

After a careful examination of the route, consideration for traffic, and a comparison of the steam roads crossed, it is found that the proper location for power house is at Kenton, along the Toledo \& Ohio Central Railroad.

It would be possible to secure an abundant supply of water at this place, and by reason of the Toledo \& Ohio Central being a coal road, a fuel supply at the lowest possible cost.

This point is as near the centre for distribution as it is practical to locate; the eastern terminus is 28.4 miles distant from power house, and the western end, connecting with city line, is 24.3 miles.

The power house is estimated as concrete block construction in walls with steel trusses and gravel roof.

The boiler room is calculated as $48^{\prime} \times 72^{\prime}$, being 26 feet from floor to roof trusses; the engine room as $48^{\prime} x^{\prime} 72^{\prime}$, being in the same building and separated from boiler room by a 12 inch fire wall.

For boiler equipment there is required $5300 \mathrm{H}$. P. water tube boilers connected in battery so that any four might carry maximum load, leaving one in reserve.

Two electrical generator sets of $750 \mathrm{~K}$. W. each, are necessary for operation of line. During light traffic on one hour schedule, one of the units will carry the load, the other being held in reserve for heavy traffic, accidents, or conditions that may require its use.

The units are alternating-current generators of three-phase, 25 ycle direct connected type, developing a current of 600 volts, and being driven by stcam turbines, condensing being done by means of a jet condenser connected with each engine.

The exciter sets are $50 \mathrm{~K}$. W. each, direct conneeted and working in independent units.

A rotary converter, located at power house, feeds direct current a distance of about $51 / 4$ miles in each direction. For transmission to 
the rotary converters on line, the current is raised to 20,000 volts by means of $3-400 \mathrm{~K}$. W. step-up transformers.

Each sub-station is equipped with $3-100 \mathrm{~K}$. W. transformers for reducing to line voltage, and with a $300 \mathrm{~K}$. W. rotary converter with necessary starters, switch panels, etc.

The sub-station buildings are designed as $30^{\prime} \times 40^{\prime}$, the walls being constructed of concrete blocks with steel trusses and gravel roof.

The car house and repair shop are of similar construction, the car house being $190^{\prime} \times 46^{\prime}$ and repair shop $140^{\prime} \times 24^{\prime}$.

As it would only be necessary to hold but one or two cars over night at either terminal, it would be economy to shelter them in barns of city railway companies.

\section{ROLLING STOCK.}

The rolling stock cost is based upon eight standard passenger cars, two combination passenger and express cars, and two package freight cars, each having a $200 \mathrm{H}$. P. motor equipment.

A 30 ton locomotive, having $300 \mathrm{H}$. P. motor equipment for hauling work trains and freight cars, and ten flat cars, are included in estimate.

\section{COST OF CONSTRUCTION.}

In the following estimates the quantities and costs are based as follows under the various heads:

(a) Clearing and Grubbing: All cutting of trees and underbrush, and removing of stumps along right of way.

(b) Excavation and Embankments: All earth work to subgrade.

(c) Bridges: All plate girders, steel trusses, and wooden trestles.

(d) Concrete: All masonry in wall or arch for culverts and abutments for steel spans.

(e) Ballast: All cost of material, loading, transportation and placing.

(f) Rails: All "T" and girder rails and special work in main track, sidings and switches.

(g) Spikes: All used in main track, sidings and switches.

(h) Splices and Bolts: All used in main track, sidings and switches.

(i) Ties: All used in main track, sidings and switches.

(j) Track Laying and Bonding: All labor connected with this part of construction.

(k) Fencing: All cost of one line on private right of way paralleling roads; two lines where passing through a property.

(1) Highway Crossing: All cost for planking, cattle guards and fencing.

(m) Culvert Pipe: All cost of cast iron pipe in place.

(n) Bonds and Cross-bonds: All cost of 0000 copper bonds in place under splice bar and cross-bonds every 500 feet.

(o) Platforms and Shelter Houses: All costs for stations along line.

(p) Repaving: All cost for taking up and relaying pavement in Kenton and Marion. 


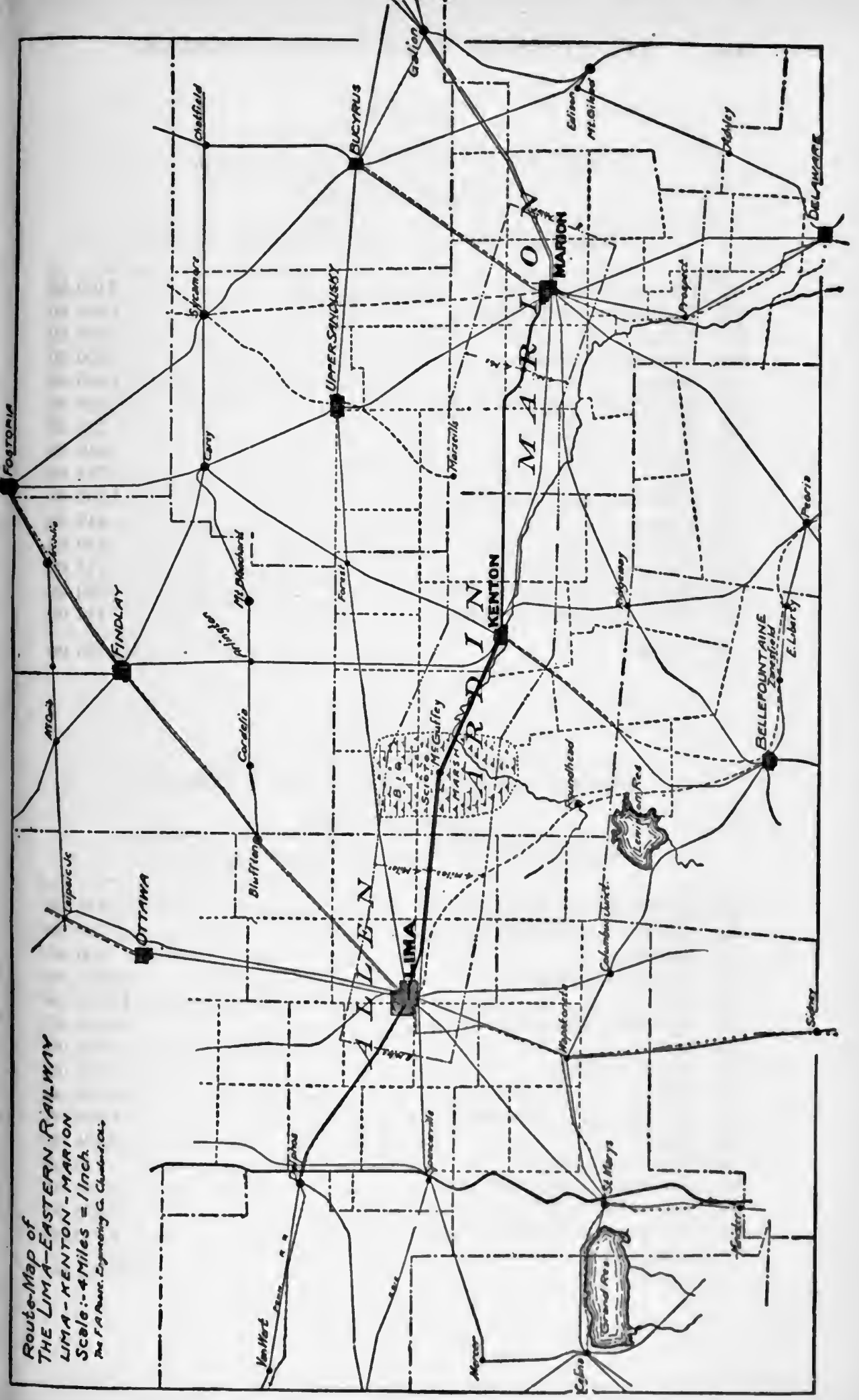




\title{
SECTION 0
}

\section{From End of City Line to Erie Railroad}

Distance-2.17 Miles

\author{
Average Grade $-0.48 \% \quad$ Maximum Grade $-0.95 \%$
}

(a) Clearing and Grubbing......................... $\$ 100.00$

(b) Excavation and Embankment..................... 2,035.00

(c) Bridges................................ $\quad 500.00$

(d) Concrete in Culverts......................... $\quad 3,300.00$

(e) Ballast................................ $3,630.00$

(f) Steel Rails and Special Work.................. $\quad 7,638.00$

(g) Spikes................................. $\quad 238.00$

(h) Splices and Bolts........................... $\quad 840.00$

(i) Ties................................... $3,724.00$

(j) Track Laying and Bonding................... 1,302.00

(k) Fencing................................. $\quad \mathbf{6 1 8 . 0 0}$

(l) Highway Crossings............................ 120.00

(m) Cast Iron Culvert Pipe.......................... $\quad \mathbf{2 1 5 . 0 0}$

(n) Copper Bonds and Cross Bonds.................... $: 320.00$

(o) Platforms and Shelter Houses.................... $\quad \mathbf{1 5 0 . 0 0}$

Total................................... $\overline{\$ 24,730.00}$

\section{SECTION 1}

Bellefontaine Avenue to East Line of Harrods Distance-6.83 Miles

Average Grade- $0.47 \% \quad$ Maximum Grade $-1.21 \%$

(a) Clearing and Grubbing........................ $\$ \$ 75.00$

(b) Excavation and Embankments..................... $\quad \mathbf{7 , 7 2 0 . 0 0}$

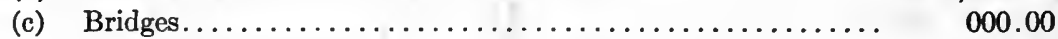

(d) Concrete in Culverts........................... $2,325.00$

(e) Ballast...................................

(f) Steel Rails and Special Work.................. 26,530.00

(g) Spikes.................................. $\quad \mathbf{7 8 2 . 0 0}$

(h) Splices and Bolts........................... $2,783.00$

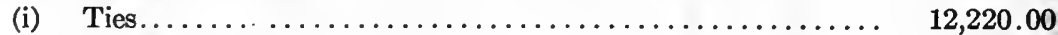

(j) Track Laying and Bonding.................... $4,266.00$

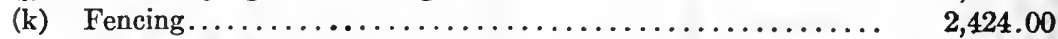

(l) Highway Crossings.............................. $\quad \mathbf{2 4 0} .00$

(m) Cast Iron Culvert Pipe............................ $\quad 390.00$

(n) Copper Bonds and Cross Bonds................. 1,035.00

(o) Platforms and Shelter Houses................. $\quad 1,200.00$

Total. 


\section{SECTION 2}

East line of Harrods to East line of Foraker

Distance-10.41 Miles

Average Grade $-0.13 \% \quad$ Maximum Grade $-0.78 \%$

(a) Clearing and Grubbing $\ldots \ldots \ldots \ldots \ldots \ldots \ldots \ldots \ldots \ldots \ldots$

(b) Excavation and Embankments.................. $8,868.00$

(c) Bridges.................. $10,700.00$

(d) Concrete in Culverts.........................., $\mathbf{7 , 9 5 0 . 0 0}$

(e) Ballast................... 17,147.00

(f). Steel Rails and Special Work................... $\quad \mathbf{3 9 , 1 3 0 . 0 0}$

(g) Spikes.................................. $\quad \mathbf{1 , 1 7 5 . 0 0}$

(h) Splices and Bolts........................... $\quad \mathbf{4 1 5 . 0 0}$

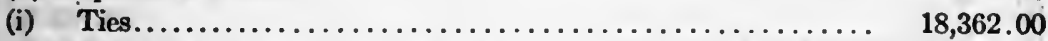

(j) Track Laying and Bonding..................... $6,414.00$

(k) Fencing $\ldots \ldots \ldots \ldots \ldots \ldots \ldots \ldots \ldots \ldots \ldots \ldots \ldots \ldots \ldots \ldots, \quad \mathbf{3 , 1 6 4 . 0 0}$

(l) Highway Crossings............................ $\quad 300.00$

(m) Cast Iron Culvert Pipe......................... $\quad \mathbf{4 5 5 . 0 0}$

(n) Copper Bonds and Cross Bonds.................. 1,555.00

(o) Platforms and Shelter Houses................... 1,100.00

Total................................ $\frac{1,100.00}{\$ 117,035.00}$

\section{SECTION 3}

East Line of Foraker to East Line of Kenton Distance-7.76 Miles

Average Grade- $0.46 \% \quad$ Maximum Grade-2.77\%

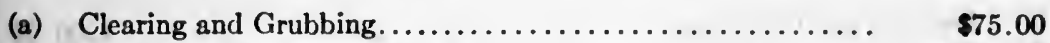

(b) Excavation and Embankments................... $\quad \mathbf{6 , 9 6 8 . 0 0}$

(c) Bridges............................... 10,000.00

(d) Concrete in Culverts........................... 16,500.00

(e) Ballast................................. 13,922.00

(f) Steel Rails and Special Work..................... $\mathbf{3 5 , 4 2 8 . 0 0}$

(g) Spikes....................................... $\mathbf{8 8 8 . 0 0}$

(h) Splices and Bolts.................................... $3,230.00$

(i) Ties.................................. 13,845.00

(j) Track Laying and Bonding....................., $4,842.00$

(k) Fencing......................... $\quad \mathbf{1 , 9 4 0 . 0 0}$

(l) Highway Crossings.......................... 225.00

(m) Cast Iron Culvert Pipe......................... $\quad 270.00$

(n) Copper Bonds and Cross Bonds................... 1,145.00

(o) Platforms and Shelter Houses................... 1,250.00

(p) Repaving $\ldots \ldots \ldots \ldots \ldots \ldots \ldots \ldots \ldots \ldots \ldots \ldots \ldots \ldots, \quad \mathbf{6 , 8 4 0 . 0 0}$

Total............................... \$117,368.00 


\title{
SECTION 4
}

\section{East Line of Kenton to Scotrown}

\author{
Distance-14.77 Miles \\ Average Grade $-0.35 \% \quad$ Maximum Grade-1.68\%
}

(a) Clearing and Grubbing...

$\$ 200.00$

(b) Excavation and Embankments.

$17,265.00$

(c) Bridges

$4,200.00$

(d) Concrete in Culverts.

$16,500.0 \mathrm{C}$

(e) Ballast

$24,460.00$

(f) Steel Rails and Special Work.

$56,145.00$

(g) Spikes

$1,676.00$

(h) Splices and Bolts.

$5,900.00$

(i) Ties

$26,162.00$

(j) Track Laying and Bonding.

$9,144.00$

(k) Fencing

$4,776.00$

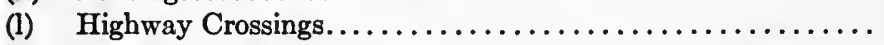

$1,200.00$

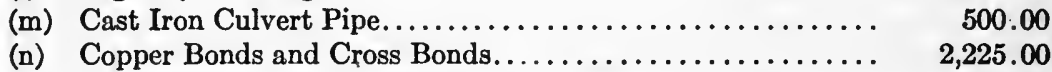

(o) Platforms and Shelter Houses.................. 1,350.00

Total.................................. \$171,703.00

\section{SECTION 5}

\section{Scottown to Center Street in Marion}

Distance-11.76 Miles
Average Grade- $0.35 \% \quad$ Maximum Grade- $1.50 \%$

(a) Clearing and Grubbing

$\$ 200.00$

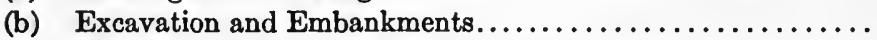

$12,933.00$

(c) Bridges.

$26,370.00$

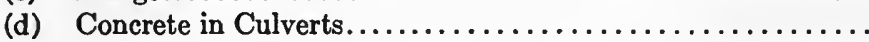

$10,500.00$

(e) Ballast

$20,728.00$

(f) Steel Rails and Special Work......................

$51,524.00$

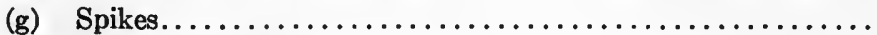

$1,335.00$

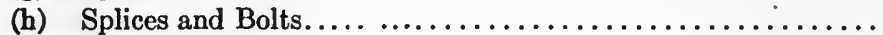

$4,875.00$

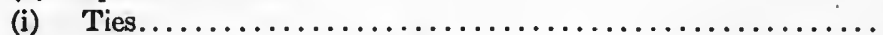

$20,830.00$

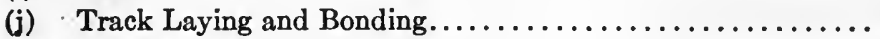

$7,284.00$

$2,960.00$

675.00

540.00

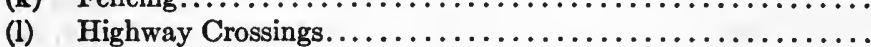

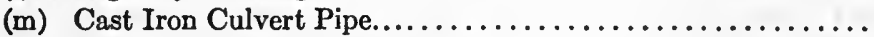

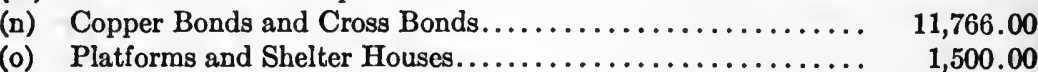

(p) Repaving $\ldots \ldots \ldots \ldots \ldots \ldots \ldots \ldots \ldots \ldots \ldots \ldots \ldots \ldots, \quad 6,480.00$

Total................................... $\overline{\$ 170,505.00}$ 


\section{Line Construction}

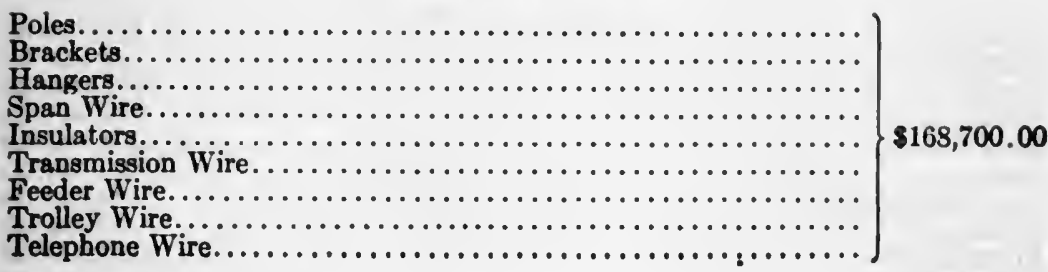

\section{Bulldings}

The estimate for buildings includes necessary tracks and special work, and mechanical devices not listed under power plant.

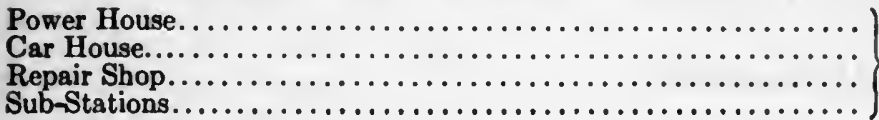

\section{Power Plant}

Mechanical Equipment:

5300 H.P. Water Tube Boilers

210 ft. x 8 ft. x 12 ft. Feed Pumps

Well and Intake for Water Supply...

Steam Pipe and Fittings.

Jet Condensers.

$847,400.00$

Boiler Settings.

Heaters.

Stack.

Electrical Equipment:

$2750 \mathrm{~K}$.W. Turbo Alternators.

250 K.W. Exciter Sets.

$3400 \mathrm{~K}$.W. Step-up Transformers

$\$ 85,200.00$

6 Panel Switchboards.

Foundations.

\section{Sub-Stations}

$6300-K . W$. Rotary Converters (4 in sub-stations, 1 in power house and 1 portable).

15 100-K.W. Step-down Transformers.

6 Rotary

6 Rotary Switchboard Panels.

$\$ 62,400,00$

Foundations.

Car for Portable Sub-station.

\section{Rollina STock}

8 Standard Passenger Cars.

2 Combination Cars. .

2 Package Freight Cars. .

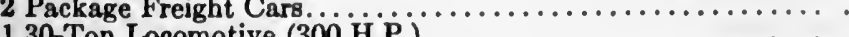

130 -Ton Locomotive (300 H.P.)

10 Flat Cars. 


\section{Summary of Costs}

Section 0

$\$ 24,730.00$

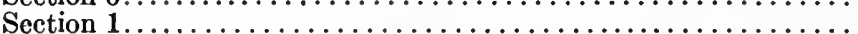

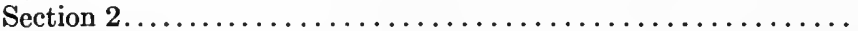

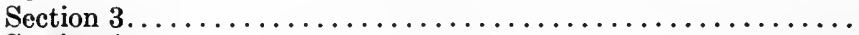

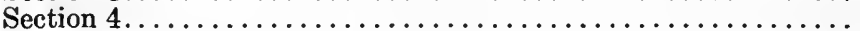

Section $5 \ldots \ldots \ldots \ldots \ldots \ldots \ldots \ldots \ldots \ldots \ldots \ldots \ldots \ldots$

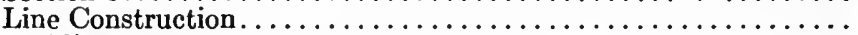

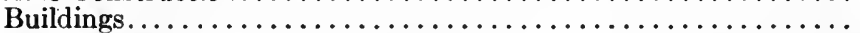

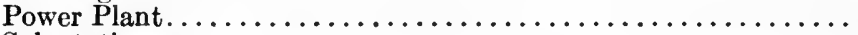

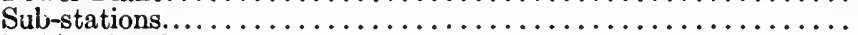

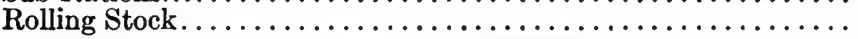

Total........................... $\$ 1,198,626.00$

Seven Per Cent. of Total Cost for Supervision of Construction, Engineering, Contingencies, and First Year's Carrying

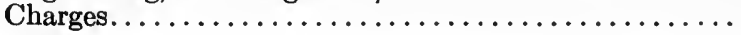

Total Estimated Cost

$\$ 1,282,530.00$

\section{CHARACTER AND IMPORTANCE OF TRADE.}

Lima, the county seat of Allen County, is a city noted as being the largest center for oil production in the United States and for railroad and manufacturing interests. It is situated on the Ottawa River, ninety-five miles northwest from Columbus, and has an elevation of two hundred feet above Lake Erie.

The city is modern in every respect, ranking with the foremost in Ohio in municipal improvements, street railways, lighting, business blocks, hotels and public parks. The Allen County Court House is an exceptionally fine building, having been constructed from sandstone and granite at a cost of three hundred and fifty thousand dollars.

The city is a leading railroad center for steam and electric lines, having six steam and three electric interurban lines.

For the past twenty-five years the Lima field has produced more oil than has any other field in the world, the veins being struck at depths ranging from twelve to fifteen hundred feet. The productiveness of the territory has created an industry for Lima of vast commercial value.

The numerous enterprises of the city are listed as follows:

\section{MUNICIPAL:}

180 Miles City Streets.

21 Miles Electric Street Railways.

57 Miles Sewers.

Water Works.

3 Fire Department Stations.

3 Gas Companies.

4 Parks-having an area of 105 acres.

2 Cemeteries. 
STEAM RAILROADS:

Cincinnati, Hamilton \& Dayton (Shops).

Lake Erie \& Western (Shops).

Erie.

Pennsylvania.

Detroit Southern.

Columbus \& Lake Michigan.

\section{ELECTRIC RAILROADS:}

Western Ohio.

Lima, Findlay \& Toledo.

Fort Wayne, Van Wert \& Lima.

Sandusky \& Southwestern (under construction).

\section{MANUFACTURING :}

3 Gas Engine Works.

1 Gas .Well Supply Company.

1 Cement Company.

2 Brick Manufacturing Companies.

3 Cornice Manufacturing Companies.

2 Railway Shops.

5 Iron Works and Machine Shops.

1 Lock and Machine Company.

8 Carriage and Wagon Works.

1 Brass Foundry.

1 Marble Works.

1 Ice Company.

3 Breweries.

7 Cigar Companies.

2 Cloak and Suit Manufacturing Companies.

1 Mattress Manufacturing Company.

1 Tannery.

3 Carpet Weavers.

5 Harness Makers.

8 Blacksmiths.

2 Book Binderies.

The various industries listed above employ a total of more than six thousand men.

\section{FINANCIAL:}

7 Banks.

4 Building and Loan Associations.

5 Trust Companies.

4 Brokers.

2 Bonding Ageneies.

3 Bonding Companies.

3 Foreign Exchange Agencies.

\section{EDUCATIONAL:}

2 Iibraries.

13 Public Schools.

3 Private Schools.

2 Business Colleges. 


\section{COMMERCIAL:}

4 Builders' Supply Companies.

11 Coal.Dealers.

4 Commission Merchants.

2 Gas and Electric Fixtures Companies.

Branch of National Cash Register Company.

26 Hotels.

2 Tclephone Companies.

3 Telegraph Companies.

40 Oil Producing Companies.

4 Pipe Line Companies.

3 Ice Companies.

29 Cigar Stores.

7 Express Companies.

3 General Merchandise Stores.

3 Bottling Works.

3 Stationery Stores.

40 Barber Shops.

14 Druggists.

11 Bakery and Confectionery Stores.

8 Florists.

2 Fish and Game Stores.

11 Jewelers.

10 Printing Establishments.

2 Carpet Cleaning Works.

6 Bicycle Repair Shops.

4 Garages.

18 Livery Stables.

4 Opticians.

9 Plumbers.

5 Laundries.

2 Gunsmiths.

5 Hardware Stores.

13 Milliners.

10 Shoe Stores.

5 Clothes Cleaning Companies.

2 Funeral Directors.

12 Furniture Dealers.

17 Dry Goods Stores.

11 Flour and Feed Stores.

26 Meat Markets.

83 Saloons and Liquor Stores.

5 Dairy Companies.

1 Department Store.

10 Clothing Stores.

Swift \& Company-Meat Dealers.

1 Five and Ten Cent Store.

87 Groceries.

32 Restaurants. 


\section{AMUSEMENTS:}

\section{Theaters.}

Race Track and Fair Grounds.

2 Bowling Alleys.

9 Billiard and Pool Rooms.

RELIGIOUS AND CHARITABLE:

35 Churches.

1 Y. M. C. A.

2 Hospitals.

53 Secret Societies.

The train schedules show fifty-nine passenger trains, twenty-five local, and one hundred and fifty freight irains out of Lima every twenty-four hours.

Forty-six of the eighty-eight counties in the State can be reached from Lima without change of cars.

There is hourly passenger service on all interurban lines entering the city.

The Western Ohio Railway Company's report shows that forty-one thousand six hundred and eight passengers were carried in and out of Lima during May, nineteen hundred and six; this is an average month for the year.

The Allen County Fair attendance is from twenty-five to thirty thousand.

Moore Brothers \& Company, wholesale grocers transact business with towns as far east as Kenton to the amoun' of two thousand dollars per month. They also have incoming stock, from their house to Columbus, to an amount of twenty-five hundred dollars per month. They state that it will be to their advantage to give the handling of all the above freight to The Lima Eastern Railway.

Sealts \& Company, producers, have a trade amounting to fifty thousand dollars per year with the towns and farmers between Lima and Kenton. They guarantee the handling of all their freight to this line.

Altschul Brothers, wholesale commission merchants, state that their Company transacts a business of ten thousand dollars per month between Lima and Kenton. The proposed electric railway would secure all their freight business.

Traffic east out of Lima, for the month of May, 1906, over the Erie Railroad, shows as follows:

312 Return Tickets Sold to Marion.

503 Return Tickets Sold to Kenton

200 Return Tickets Sold to Other Points.

143 Milcage Passengers to Other Points.

The above statement may be taken as an arerage month of the year. The passenger traffic to Lima from outside points is shown in the following list of villages : 
WESTMINSTER is a village of three hundred population, located southeast one and one-quarter miles, by highway, from Westminster Station, on the Erie Railroad.

All merchandise and supplies brought into this village come via the Erie Railroad to Westminster Station and are freighted from there by wagon.

There are two general stores doing a business of ten thousand dollars annually, and supplying the country within a radius of four miles on the north, west and south and two miles east.

The hotel accommodates about fifty transients per week.

The enterprises of Westminster are as follows:
1 Drug Store.
1 Hotel.
2 General Stores.
1 Restaurant.

1 Blacksmith Shop.

The village also has :
A Post Offlee.
1 Town Hall.
1 Gradéd School.
3 Churches.

The Erie Railroad is rarely used by persons going to Lima; as the trains are now operated, it is impossible to make a round trip of seven miles in one day.

Westminster Station is shown at "Mile 6" on the right of way map.

HARRODS is an incorporated village having a population of five hundred, is located on the Erie Railroad, and shown at "Mile 10" on the right of way map.

The leading general store has a trade aggregating fifteen thousand dollars annually, and the other ten stores ten thousand dollars annually.

The hardware store does an annual business of fifteen thousand dollars and has freight bills to the amount of four hundred dollars.

The leading bakery has a trade of seven thousand dollars annually and freight bills amounting to two hundred dollars.

The meat market does a wholesale and retail business, shipping meat to Lima.

The business places of Harrods are shown as follows:
1 Grist Mill.
2 General Stores.
2 Gr.cery Stores.
2 Hotels.
1 Hardware Store.
2 Blacksmith Shops.

1 Handle and Stave Factory.

1 Lumber Yard and Planing Mill.

1 Livery.

2 Bakeries.

1 Meat Market.

1 Furniture Store.

1 Barber Shop:

There is also in the village three churches and a first class graded school. 
The village is progressire, maintaining roads in excellent condition and having cement walks on all the principal streets.

The present travel by rail and team is reported as fifteen to Lima and west, and the same number to Kenton, Marion and east daily.

The hotels of Harrods have two hundred and fifty transients per week.

A round trip from this point to Kenton or east, cannot be made in one day on the Erie Railroad, and west only by returning at midnight.

ALGER is an incorporated village having a population of nine hundred, located on the Erie Railroad, and at "Mile 14" on right of wáy map.

The general store has a trade aggregating twenty-six thousand dollars annually. The hardware store has trade amounting to twelve thousand dollars annually.

The leading hotel accommodates two hundred and fifty transients per week, and the other about one hundred and fifty.

The village has cement sidewalks on all its principal streets.

Traffic is estimated at twenty per day each way by rail and team. The business enterprises of Alger are as follows:

1 Saw Mill.

2 Hotels.

4 General Stores.

2 Billiard Halls.

2 Meat Markets.

1 Blacksmith Shop.

1 Drug Store.

Telephone Exchange.
1 Brick and Tile Plant.

1 Hardware Store

3 Restaurants.

2 Liveries.

2 Barber Shops.

1. Elevator.

I Lumber Yard and Planing Mill. Onion Storage House.

1 Jewelry Store.

The village also contains two churches and a graded school.

A round trip to Kenton or east, via. Erie Railroad, cannot be made in one day, and west only by returning about midnight.

SCIOTO MARSH is a tract of comparatively low land containing eighteen thousand acres lying between Alger and Foraker on the Erie Railroad and extending about equal distance north and south.

The marsh, so-called, was originally a shallow lake fed by the Scioto River from the south and numerous creeks from the surrounding higher land. The outlet was the Scioto River to the north. By extensive dredging the outlet was deepened enough to entirely drain the lake, and numerous tributary reclamation ditches were excavated, which, at the present time, make possible the cultivation of the entire eighteen thousand acres. Only about half of this is under cultivation, due entirely to inadequate transportation. The soil is a 
comparatively light black muck and well adapted to the raising of farm and garden products.

During the season 1903, a good year for the crops, one thousand one hundred cars of onions shipped out through the towns of Alger, McGuffey and Foraker; seven hundred cars in 1904 and seven hundred in 1905 , the last two being poor years.

The average shipment of potatoes is from five to six hundred cars; corn seven hundred to eight hundred cars, and miscellaneous products three hundred to three hundred and fifty per year. These shipments would be practically doubled by a spur line into the center of the marsh.

The development of the remainder of this tract of land will be possible only by the construction of a railroad which will give the required outlet for its products. It is now entirely dependent upon the Erie Railroad, which road has never, in the past, been able to furnish a sufficient number of cars for the territory developed.

The passenger traffic into the marsh is worthy of consideration, as labor for the cultivation and harvesting of crops comes principally from Lima, Kenton, and other surrounding towns.

McGUFFEY is an incorporated village of six hundred, present. population, is located on the Erie Railroad at "Mile 17.4" on right of way map. It lies in about the center of Scioto Marsh.

A fair proportion of the products of this locality are shipped over the Erie Railroad from McGuffey.

The four general stores are each doing a business of from five to seven thousand dollars annually.

The Edwards and Stanbaugh Company own and cultivate twentyfive hundred acres of the Scioto Marsh lying adjacent to the south line of the town and do all their shipping from that point. Their principal products are onions and potatoes.

The business of the village is shown by the following statement:

2 Meat Markets.

1 Barber Shop.

1 Saloon.

1 Livery.

1 Coal Yard.

Telephone Exchange.
2 Restaurants.

4 General Stores.

1 Hotel.

1 Elevator.

11 Onion Storage Houses.

3 Churches.

Cement sidewalks are laid on all the main streets.

Traffic is estimated at nine per day each way.

The same conditions prevail here, relative to return trips east or west, as at Alger and Harrods.

FORAKER is practically divided into East and West Foraker; both are located on the Erie Railroad. West Foraker is at "Mile 20" 
and East Foraker at "Mile 20.5" on the right of way map. Population is one hundred and fifty.

This village lies on the east edge of the Scioto Marsh and has about the same percentage of products from the Marsh, shipped from its station, as has Alger.

The Erie Railroad station and sidings are located at West Foraker. The business of the west section is as follows:

\section{General Store. \\ 1 Coal Yard.}

2 Elevators

1 Storage House.

East Foraker is more properly the center of the village when considered as a whole, the stores surpassing the [western?] section, as well as being the religious and educational center.

The business is listed as follows:
2 General Stores.
1 Blacksmith Shop.
I School House.
2 Churches.

Traffic each way is estimated at five per day.

The conditions here for return trips by the Erie Railroad are similar to those at the stations west.

KENTON, the county seat of Hardin County, is fifty-six miles northwest of Columbus and screnty miles from Toledo. It is an enterprising commercial and manufacturing city and is an important railroad center, being located on the main line of the Erie Railroad and traversed north and south by the Toledo and Ohio Central and Big Four Railroads. The Toledo and Ohio Central shops are located in this city.

The streets of the city are well paved, and excellent turnpiked roads radiate into the surrounding country.

The Kenton and Southern Railway Company has constructed about two miles of track on the line to Bellefontaine.

The city has a present population of nine tlousand two hundred and seventy.

The various industries are listed as follows:

\section{MUNICIPAL:}

Fire Department.

Water Works.

Sewer System.

Electric Light Plant.

Natural Gas.

STEAM AND ELECTRIC RAILROADS:

Erie Railroad.

Big Four Railroad.

Toledo \& Ohio Central Railroad.

Kenton and Southern Railway (under construction). 


\section{MANUFACTURING :}

Toledo and Ohio Central Railway Shops.

3 Iron and Machine Works.

3 Planing Mills.

3 Gas Engine Manufacturing Companies.

3 Carriage Manufacturing Companies.

1 Cigar Manufacturing Company.

1 Drain Tile Manufacturing Company.

I Ice and Cold Storage Company.

8 Blacksmith Shops.

1 Rubber Works.

1 Tannery.

1 Cement Block and Tile Roofing Company.

1 Brewery.

1 Handle Factory.

1 Cracker Factory.

2 Flour Mills.

1 Dye Works.

\section{FINANCIAL:}

4 Banks.

1 Building and Loan Association.

EDUCATIONAL:

1 Library.

5 Public Schools.

\section{COMMERCIAL:}

7 Farming Implement Stores.

3 Electric Companies.

4 Elevators.

Western Union Telegraph Company.

2 Telephone Companies.

2 Daily Newspapers.

5 Weekly Newspapers.

7 Hardware Stores.

7 Coal Yards.

1 Bottling Works.

2 Draying Companies.

2 Dining Halls.

7 Drug Stores.

4 Dry Goods Stores.

5 Hotels.

2 Hack and Transfer Lines.

8 Liveries.

5 Clothing Stores.

14 Confectioneries.

24 Grocers.

3 Cafes.

17 Cigar Stores.

4 Wagon Shops.

7 Feed Stores. 
5 Gent's Furnishing Stores.

3 Furniture Stores.

1 Gunsmith.

3 Laundries.

8 Meat Markets.

9 Merchant Tailors.

7 Millinery Stores.

3 Music Stores.

15 Barber Shops.

2 Five and Ten Cent Stores.

8 Cleaning and Pressing Stores.

2 Creameries.

9 Restaurants.

32 Saloons and Liquor Stores.

3 Second Hand Stores.

2 Undertakers.

4 Bakeries.

7 Bicycle Stores.

3 Cloak and Suit Companies.

3 Jewelry Stores.

3 Book Stores.

2 Florists.

AMUSEMENTS:

Opera House.

1 Skating Rink.

1 Bowling Alley.

10 Billiard Parlors.

Race Track and Fair Grounds.

RELIGIOUS AND CHARITABLE:

1 Hospital.

15 Churches.

20 Secret Societies.

The various manufacturing enterprises in Kenton give employment to over twelve hundred men.

People living in the country and west of Kenton, on the Erie Railroad, cannot go to Kenton and return the same day on this railroad. This city has no interurban or eity car lines.

HEPBURN is located on the Erie Railroad one and one-quarter miles south of "Mile 33.3" on the right of way map.

The town of Hepburn proper has a population of one hundred and fifty, but the principal feature is the park lying adjacent to the Scioto River and a lake fed by springs.

This is the only park in this locality and is greatly patronized by residents of Kenton, Marion and the surrounding towns. Excursionists are brought to this lake over the Erie Railroad, from places at a great distance. Private parties, to the number of twenty or thirty individuals, drive to the park from Kenton on an average of 
two or three per week during the season. It is customary for the churches to hold their annual picnics in this park.

The park is equipped with customary amusements, and affords boating, bathing, and fishing in the river to the patrons.

A large number of campers are located at the lake during the season, and upon the grounds may be purchased all supplies needed. The total attendance is from fifteen to eighteen thousand annually.

A branch line from the Lima-Eastern could be built to this park. developing it to a greater extent and making it a feature of the road and a source of great revenue.

MARSEILLES is on incorporated village lying three and onehalf miles north of "Mile 35.3" on the right of way map. Its present peprlation is four hundred.

This village is entirely isolated from railway facilities, the Erie Railroad lying seven miles to the south and the Pennsylvania Railroad eight miles to the north. All merchandise and supplies are freighted by wagon from Kenton, Marion and DeCliff.

A freight station built at "Mile 35.3." would provide storage for freight that went into the products that came from Marseilles, and the Road derive a revenue from all the business done in the Village.

The one general store carries a full line of merchandise and transacts business to the amount of twenty thousand dollars annually. They would doubtless exceed this amount with better transportation facilities. The surrounding district is supplied from this village.

The business enterprises of this village are as follows:

1 General Store.

1 Meat Market.

1 Hotel.
1 Barber Shop.

1 Furniture Store.

1 Hardware Store.

I Stave Factory.

The village also contains two churches, one graded school, one post office.

SCOTTOWN is located at "Mile 43.4," has a population of two hundred, and its nearest railroad is about four miles south of the village. All merchandise and supplies are freighted by wagon from Marion or DeCliff. Over two hundred and fifty tons of coal were brought to the village in this manner last year for individual use.

The transfer of cars from the Toledo and Ohio Central at Kenton, or the Columbus, Hocking Valley and Toledo at Marion could readily be accomplished on the electric road, the reduced cost for hauling in the coal making this fuel in greater demand.

The three general stores handle over twenty-five thousand dollars 
worth of merchandise per annum, all of which would be freighted over the Lima-Eastern.

The town is very prosperous, lying, as it does, in the center of an excellent agricultural district.

Following is a list of the business enterprises of this village:

3 General Stores.

1 Barber Shop.
1 Hotel.

2 Blacksmith Shops.

There is also in the village a church, graded school, and a post office.

BIG ISLAND is a town having a population of about fifty. There are no railroads, whatever, running through this village. It is shown at "Mile 48.8" on the right of way map. All supplies are freighted by wagon from Marion. It contains one general store, a blacksmith shop, one church and a school.

The proposed line passes through the center of the settlement.

MARION, the county seat of Marion County is a thriving railroad and manufacturing city located forty-four miles north of Columbus.

The Columbus, Delaware and Marion Railway is in operation south to Columbus, and a line is now under construction north to Bucyrus. This line gives excellent passenger and freight service, having an hourly schedule from six A.M. to nine P.M. to Columbus, and ten and eleven P.M. to Stratford. Cars arrive from Stratford at six, seven, and eight A.M., and from nine A.M. to eleven P.M. from Columbus. The running time from Marion to Columbus is two hours and twentyfive minutes, and from Marion to Delaware one hour, making connections at Prospect for Richwood and at Delaware for Magnetic Springs. The fare from Marion to Columbus is seventy-five cents, round trip one dollar forty-five cents; from Marion to Delaware forty cents, round trip seventy-five cents.

Four railroads pass through Marion-the Big Four, Erie, The Columbus, Hocking Valley and Toledo, and the Columbus and Sandusky branch of the Pennsylvania.

The Erie Railroad freight tonnage at Marion for last year was eight hundred fifty thousand tons; the passenger earnings at Marion Station were eighty-five thousand dollars. This covers out-going business in both directions.

The principal manufacturies are steam shovels, contractors' tools and harvesting machinery. The limestone quarries have an enormous output of crushed rock, building stone, and lime.

The growth of Marion in recent years has been phenomenal-the population in 1890 was 8,327 , in 190011,862 , and at present it is estimated at 17,000 . 
The value of property, according to tax duplicates is six million seven hundred thousand dollars; actual real estate values eighteen million two hundred fifty thousand dollars.

The industries of the city are carried on by about fifty manufacturing companies giving employment to more than five thousand persons with an annual pay roll in excess of three million dollars.

The numerous enterprises of the city are listed as follows:

\section{MUNICIPAL:}

18 Miles of Paved Streets.

Water Works.

Sewer System.

Garbage Disposal Plant.

4 Parks.

3 Fire Departments.

1 Patrol Station.

STEÀM RAILROADS:

The Big Four.

The Erie.

Columbus, Hocking Valley \& Toledo.

Columbus \& Sandusky.

ELECTRIC RAILROADS:

Columbus, Delaware \& Marion Railway.

Marion Railway Light and Power Plant.

MANUFACTURING :

Marion Steam Shovel Company.

Huber Manufacturing Company.

2 Brick Manufacturing Companies.

2 Planing Mills.

2 Ice Companies.

3 Stone Quarries.

1 Brewery.

I Silk Manufacturing Company.

3 Cigar Manufacturing Companies.

1 Monumental Works.

3 Wagon Manufacturing Companies.

8 Blacksmiths.

\section{FINANCIAL:}

5 Banks.

3 Building and Loan Associations.

- COMMERCIAL:

1 Bottling Works.

5 Piano Stores.

9 Hardware Stores.

10 Hotels.

10 Liveries.

6 Jewelers.

44 Saloon and Liquor Stores. 
52 Groceries.

11 Dry Goods Stores.

11 Druggists.

3 Express Companies.

2 Telegraph Companies.

2 Telephone Companies.

5 Dairies.

8 Clothiers.

9 Wood and Coal Yards.

2 Furniture Stores.

5 Feed Stores.

19 Meat Markets.

4 Restaurants.

2 Wholesale Grocers.

20 Barber Shops.

2 Daily Newspapers.

2 Semi-weekly Newspapers.

4 Weekly Newspapers.

22 Shoe Dealers.

8 Confectioners.

8 Millinery Stores.

5 Cigar Stores.

2 Florists.

2 Laundries.

3 Undertakers.

\section{EDUCATIONAL:}

10 Public Schooıs.

1 Public Library.

\section{AMUSEMENTS:}

\section{Opera House.}

Fair Grounds.

1 Skating Rink.

\section{CHARITABLE AND RELIGIOUS:}

\section{Hospitals.}

Young Men's Christian Assoeiation.

23 Churches.

40 Seeret Societies.

pASSENGer inCOME.

The location of proposed line, and claracter of territory occupied, makes the possibilities for passenger traffic particularly attractive.

The proposed road runs through three prosperous counties, whose aggregate population is one hundred and eighteen thousand, and connects by a direct line the three county seats. In each city, the existing east and west steam road has its station remote from the business 
center, while the Lima-Eastern traverses the principal streets and reaches the center of each city.

The three principal cities on the line are traversed north and south by steam roads, and the terminal cities by electric roads, creating transportation facilities for an east and west line.

A comparison of the United States census reports for the decennial periods of 1890 and 1900 shows a rapid increase in the population of Lima, Kenton and Marion. This rate has been exceeded in recent years, and according to the most accurate information available, the present population of Lima is thirty thousand; Kenton, nine thousand, and Marion, seventeen thousand. Local estimates place the figures considerably above those given herein.

In estimating passenger income, the total population has been taken four miles from located line for direct traffic.

For tributary passenger income, an estimate has been made of the population along steam and electric roads out of Lima, Kenton and Marion to the principal city or village at a distance not exceeding fif. teen miles from the Lima-Eastern Railway.

Table Showing Population Directly on Line

\begin{tabular}{|c|c|c|c|c|}
\hline & Township & $\begin{array}{l}\text { Census } \\
1900\end{array}$ & $\begin{array}{l}\text { Percentage } \\
\text { Covered }\end{array}$ & $\begin{array}{l}\text { Popiu- } \\
\text { lation }\end{array}$ \\
\hline Allen County.... & 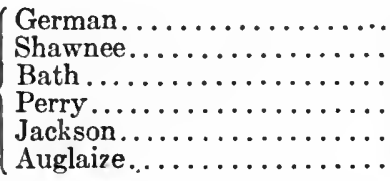 & $\begin{array}{l}1,511 \\
1,493 \\
1,517 \\
1,467 \\
1,931 \\
1,909\end{array}$ & $\begin{array}{l}50 \\
30 \\
60 \\
70 \\
50 \\
80\end{array}$ & $\begin{array}{r}755 \\
448 \\
910 \\
1,027 \\
965 \\
1,528\end{array}$ \\
\hline Hardin County.. & 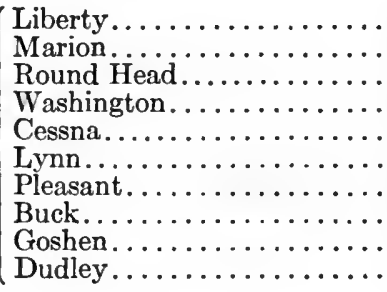 & $\begin{array}{r}1,410 \\
1,098 \\
1,331 \\
1,334 \\
804 \\
1,127 \\
1,418 \\
1,070 \\
953 \\
1,320\end{array}$ & $\begin{array}{l}40 \\
90 \\
10 \\
10 \\
90 \\
60 \\
75 \\
80 \\
80 \\
75\end{array}$ & $\begin{array}{r}564 \\
988 \\
133 \\
133 \\
724 \\
676 \\
1,065 \\
856 \\
762 \\
990\end{array}$ \\
\hline Wyandot...... : & Marseilles............... & 997 & 25 & 219 \\
\hline Marion County.. & 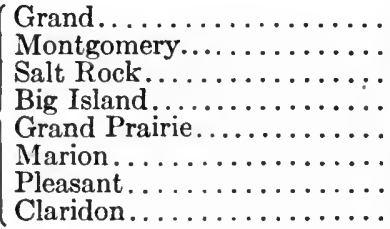 & $\begin{array}{r}499 \\
1,325 \\
619 \\
1,342 \\
502 \\
1,360 \\
1,109 \\
1,070\end{array}$ & $\begin{array}{r}100 \\
80 \\
80 \\
90 \\
40 \\
100 \\
25 \\
25\end{array}$ & $\begin{array}{r}499 \\
1,060 \\
495 \\
1,208 \\
201 \\
1,360 \\
277 \\
267\end{array}$ \\
\hline & & & & 18,140 \\
\hline
\end{tabular}


Cities and Villages

Lima.

Harrod

Alger..................

McGuffey

Kenton.

Scottown.

Marseilles.

Marion.
Census

\begin{tabular}{r}
1890 \\
15,981 \\
269 \\
$\ldots \ldots$ \\
\hdashline$\ddot{5} \dot{5} 7$ \\
$\ddot{2} \ddot{1} \dot{1}$ \\
8,327
\end{tabular}

Estimated

1906

30,000

500

900

600

9,000

200

400

$17,000 \quad 58,600$

Total for Line

76,740

Total population directly on line, per mile, 1,395.

Table Showina Popdlation Tributary to Proposed Line Along Steam and Electric Roads Crossjng or at Termunals of Lima-Eastern

Lima.

Cities, Villages and Townships

Columbus Grove Village.

Pleasant Township......... 1,466

West Cario Village.......... 338

Monroe Township........... 1,537

Bath Township.......... 1,517

Sugar Creek Township....... 1,416

Sugar Creek Township....... 1,038

German Township......... 1,511

Delphos City............ 4,517

Marion Township.......... 2,284

Jennings Township........ 1,338

Speneerville............. 1,874

Spencer Township......... 1,142

Amanda Township......... 1,384

Shawnee Township......... 1,493

Moulton Township.......... 1,286

Logan Township........... 1,473

Cridersville.............. 581

Wapakoneta Village......... 3,915

Duchouquet Township....... 1,636

Union Township ........... 1,666

Clay.................., 1,647

Perry Township............. 1,467

Beaver Dam Village......... 477

Bluffton Village............ 1,783

Richland................ 1,839

Percentage PopuCovered lation $100 \quad 1,935$

25
100

$100 \quad 338$

$50 \quad 767$

$40 \quad 607$

$50 \quad 708$

$50 \quad 518$

$50 \quad 755$

$100 \quad 4,517$

$50 \quad 1,142$

$25 \quad 334$

$100 \quad 1,874$

$50 \quad 571$

$50 \quad 692$

$70 \quad 1,045$

$50 \quad 643$

$25 \quad 368$

$100 \quad 581$

$100 \quad 3,915$

$50 \quad 818$

$25 \quad 416$

$25-412$

$30 \quad 440$

$100 \quad 477$

$100 \quad 1,873$

$50 \quad 918$

Total West Terminal............................ $\overline{26,940}$

\begin{tabular}{|c|c|c|c|c|}
\hline \multirow{8}{*}{ Kenton.. } & (Dunkirk-Village..... & 1,222 & 100 & 1,222 \\
\hline & Blanehard Township.. & 804 & 25 & 200 \\
\hline & Pleasant Township... & & 25 & 354 \\
\hline & Forest Village...... & 1,155 & 100 & 1,155 \\
\hline & Patterson Village..... & 219 & 100 & 219 \\
\hline & Jaekson Township... & 822 & 50 & 411 \\
\hline & Lynn Township.......... & 1,127 & 40 & 450 \\
\hline & Taylor Creek Township.... & 864 & 50 & 432 \\
\hline & Belle Center Village....... & 962 & $\begin{array}{r}100 \\
50\end{array}$ & 962 \\
\hline & MeDonald Township...... & 1,947 & 25 & 485 \\
\hline & Buek Township........... & 1,070 & 20 & 214 \\
\hline t. & Ridgeway Village......... & 447 & 100 & 447 \\
\hline & 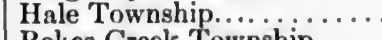 & 859 & 25 & 214 \\
\hline & Bokes Creck Township..... & 901 & 50 & \\
\hline
\end{tabular}


Marion

\begin{tabular}{|c|c|c|c|}
\hline $\begin{array}{c}\text { Cities, Villages and } \\
\text { Townships }\end{array}$ & $\begin{array}{l}\text { Census } \\
1900\end{array}$ & $\begin{array}{l}\text { Percentage } \\
\text { Covered }\end{array}$ & $\begin{array}{l}\text { Popu- } \\
\text { lation }\end{array}$ \\
\hline Little Sandusky Village..... & 181 & 100 & 181 \\
\hline Pitt Township............. & 992 & 50 & 496 \\
\hline Salt Rock Township..... & 619 & 20 & 124 \\
\hline Grand Prairie Township.... & 502 & 60 & 301 \\
\hline Scott Township............ & 549 & 25 & 137 \\
\hline Dallas Township............... & 465 & 25 & 116 \\
\hline Caledonia Village........... & 682 & 100 & 682 \\
\hline Claridon Township......... & 1,070 & 25 & 267 \\
\hline Tully Township.... & 877 & 50 & 438 \\
\hline Pleasant Township... & 1,109 & 75 & 832 \\
\hline Waldo Village....... & 278 & 100 & 278 \\
\hline Waldo Township. & 644 & 50 & 322 \\
\hline Prospect Village... & 983 & 100 & 983 \\
\hline Prospect Township.. & 850 & 50 & 425 \\
\hline Marlboro Township........ & 397 & 50 & 198 \\
\hline Radnor Township......... & 1,133 & 50 & 566 \\
\hline Green Camp Village...... & 369 & 100 & 369 \\
\hline Green Camp Township.... & 962 & 25 & 240 \\
\hline & & & \\
\hline
\end{tabular}

\section{Summary of Trjbutary Popdlatjon}

Lima-West Terminal............................ 26,940

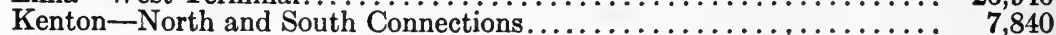

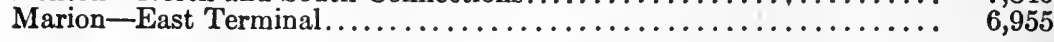

Total......................... 41,735

Total tributary population per mile, 759 .

\section{UNITED STATES MAIL.}

Under conditions of business and transportation, similar to those shown on proposed line, the mail business has been almost invariably secured by electric roads. This is due, in a great measure, to frequency of cars, more rapid handling of mail, and to the fact that electric cars are run through village streets, making the transfer from railway to post office more convenient and rapid.

With two round trips per day, for three hundred and ten days, the mail cars will cover sixty-eight thousand two hundred car miles during the year.

This service will give a revenue of not less than seven thousand five hundred dollars per annum.

\section{PACKAGE FREIGHT AND EXPRESS.}

As heretofore shown, there is a large business of this character between the farms and villages and the principal cities.

One express car can cover the route both ways in one day, handling the bulk of shipments; the combination cars can carry small consignments at two hour intervals. 
It is estimated that five tons per day of miscellaneous merchandise can readily be secured, which, carried at an average price of thirty cents per hundred, would be thirty dollars per day or nine thousand three hundred dollars for three hundred and ten days.

\section{DAIRY PRODUCTS.}

While Allen, Hardin and Marion counties do not take a prominent lead in dairy products, there is, of course, a possibility of handling the milk trade to terminal cities. The present condition, as previously set forth, relative to present transportation facilities, make dairy farming unattractive.

The altered conditions, brought about by the construction of a highspeed interurban road, would result in this industry being followed more extensively, giving, within a few years, an cxcellent source of revenue.

The following estimate, however, is based upon trade that could be derived at this time:

800 gal. milk per day-288,000 per yr. (a) 2c............. \$5,760

Butter, eggs, etc., per yr.......................... 1,000

\section{FREIGHT.}

The territory between Lima and Kenton is served by the Erie Railroad, but on account of infrequency of trains, lack of cars for summer and autumn shipments, and the fact that a large part of the consignments are transferred to other roads, it will be possible for an electric line to sccure a fair portion of this transportation.

Outside the cities of Lima, Kenton and Marion the supply of coal could be more economically handled by the Lima-Eastern than by the Erie Railroad, as the rate would be lower, more prompt service assured, and in the majority of cases, particularly at Big Island, Scottown and Marseilles, the advantage would be more than doubled.

Farm products are extensively shipped by car lots or teamed to the nearest city.

The region, known as the Scioto Marsh, shows the greatest industry in car shipments, but a large business could be developed for consignments to north and south roads, and even for transfer to the Erie Railroad, from points east of Kenton.

Large quantities of lumber, shingles, brick, cement, lime, and other building materials are constantly being brought into the territory, and in many instances the charges for teaming are from four to five times the cost of hauling by electric line.

Such necessitics as harvesting machinery, wire fencing, fertilizers, and other farm implements are also transported by team, all of which would go toward making up an extensive traction business. 
The income from freight; which may be derived from the territory traversed, is estimated as follows:

Coal, 125 cars-3,750 tons, @ $\$ 0.40 \ldots \ldots \ldots \ldots \ldots \ldots \ldots \ldots . \$ 1,500$

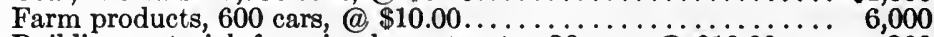

Building material, farm implements, etc., 20 cars, @ $\$ 10.00 \ldots .200$

\section{Revende and Operating Expense.}

Annual Revenue

1. Passenger Traffic:

(a) Directly on line, 76,740 @ $\$ 2.25$.

(b) Tributary to line, $41,735 @ \$ 0.221 / 2 \ldots \ldots .$. (1-10 of above rate)

(c) Transfer of passengers from distant points on roads, from and between steam and electric railroads, in Lima, Kenton and Marion....................... $\quad 2,500.00$

2. United States Mail.

$\$ 172,665.00$

$9,390.00$

$\$ 184,555.00$

. Package Freight and Expres

4. Dairy Products:

(a) Milk ............................ \$5,760.00

(b) Butter, eggs, etc.................... $\quad$\begin{tabular}{l}
$1,000.00$ \\
\hline
\end{tabular}

$7,500.00$

$9,300.00$

$6,760.00$

5. Freight:

(a) Coal

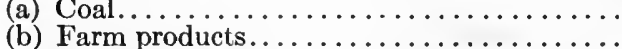

(c) Miscellaneous

$\$ 1,500.00$

$6,000.00$

200.00

Total Estimated Revenue.

Operating Expense

Per Car-Mile:

Maintenance........................... \$0.025

Power Plant Operation......................... $\quad 0.030$

Operation of Cars................................

Miscellaneous............................ 0.020

Car-Miles:

Per Car-Mile........................... \$0.130

Passenger Service.................... 743,200

Express, Freight, Work Trains, etc............ 137,600

Total Car-Miles........................ 880,800

880,800 Car-miles.............................@ $\$ 0.13$

Gross Income, Less Operating Expenses............ \$101,310.00

ESTIMATED INCOME FROM FIRST YEAR'S OPERATION.

Total estimated cost of construction. . . . . . $\$ 1,282,530$

Capitalization-Bonds placed at $90 \ldots \ldots \ldots \ldots 1,425,000$

Gross earnings less operating expenses........ \$101,310

Fixed charges-Interest at 5 per cent........ $\quad \mathbf{7 1 , 2 5 0}$

Net income 


\section{PROMOTION}

\section{Amended Bill as Furtier Amended}

(Filed February 10, 1908.)

\section{IN CHANCERY OF NEW JERSEY'}

To the Honorable Mahlon Pitney, Chancellor of the State of New Jersey:

Complaining shows unto your honor, your orator, Harry C. Haskins, of Seabright, in the State of New Jersey:

I. That during the year eighteen hundred and ninety-eight, eighteen hundred and ninety-nine, nineteen hundred and nineteen hundred and one, your orator devoted a large part of his time to the study of the industrial conditions concerning the output of pig lead in the United States, and the manufacture and production of white lead and other products obtained from lead; that previous to that time he had been somewhat interested in, and had had some knowledge of the production of white lead, and was to some extent familiar with the trade conditions, competition and rivalry in production of the same; that during the years above mentioned, he had made a diligent study of these matters and had spent much time and many thousands of dollars in visiting different plants in various parts of the country where white lead was manufactured and had conceived the plan of uniting the outstanding lead interests and enterprises that had not already become a part of the National Lead Company into one company, for the purpose of either competing successfully with the National Lead Company, or ultimately forming a combination therewith, so that thereby the consumer might acquire white lead and other similar products at reduced prices, and by combination greatly lessen the expense of production, and to that end had, from time to time, procured options on a large part of such outstanding lead interests. Among the properties that he had either thus acquired an option on, or opened negotiations for their purchase, were those of the Wetherill White Lead Company of Philadelphia; IV. W. Lawrence and Bailey \& Farrell of Pittsburg; Eagle White Lead Co., of Cincinnati; Gerhart White Lead Co., of Dayton; Hoyt Metal Co., and American Shot and Lead Co., of St. Louis; the Carter White Iead Co., of Omaha; Raymond Lead Co., of Chicago; E. W. Blatchford, of Chicago; the McDougall Lead Co., of Buffalo; the Chadwick Isad Co., and Boston Lead $\mathrm{Co}$, of Boston; Sterling White Iead Co., of Pitts-

1 See Haskins vs. Ryan, 75 New Jersey Equity Reports, 330. 
burg; Harrison Bros. \& Co., of Philadelphia; Pitcher Lead Co., of Joplin. In addition to this he, at great expense, had obtained renewals of options and made investigations into the affairs and properties of other lead producers and estimates of their value and the probable expense and power to purchase or acquire the same in fulfilment of his plans and scheme of combination.

II. 'The results of the foregoing efforts of your orator was such that in the spring of nineteen hundred and one, he had crystallized and formulated a complete plan for the combination of the white lead interests in the United States, that were not already in the $\mathrm{Na}$ tional Lead Company. While your orator was possessed of some means, his fortune was not sufficient to undertake the enterprise alone, and he became, therefore, desirous of interesting other capital to join with him in the promotion and advancement of his said scheme. With this in mind, your orator had a number of conferences with the then president of the American Smelting \& Refining Company, Edward W. Nash, a personal friend of your orator, and whose position as such president was of a character to add weight to your orator's proposition, and through his intervention, procured a letter of introduction from Daniel Guggenheim, chairman of the executive committee of the American Smelting \& Refining Company, to Thomas F. Ryan, the defendant herein, who then was, and now is, vice-president of the Morton Trust Company, a large and influential banking institution of the city of New York, and was himself a prominent financier, interested in many large corporations and a man of large means, for the purpose of laying your orator's plans before him, and to seek his co-operation, influence and financial assistance in the furtherance of your orator's plan. As a result of such letter of introduction, your orator, in May, 1901, procured an audience, and had a long conference, with the said Thomas F. Ryan, and laid before him the plan your orator had conceived, and sought his cooperation and aid, and proposed to contribute his perfected plans, scheme of combination, options, contracts of sale, renewals of options, estimates and data, which he then owned and possessed and which related to the corporations, firms and individuals set forth in the first paragraph of this bill of complaint, and if necessary, as much as two hundred thousand dollars to the said project, if the said Ryan would join him therein and also contribute enough to carry the enterprise through. Said Ryan became very much interested in the project as the same was laid bare by your orator before him, and agreed to join your orator therein, provided an examination of your orator's plans and papers by the attorneys of the said Ryan confirmed the statements your orator made to him. Your orator was 
then referred by the said Ryan for the purpose of such examination to William H. Page, Jr., Esquire, the attorney of said Ryan, to whom your orator submitted a written, formulated, alternative plan and scheme of merger and combination, and options or contracts of sale on the properties mentioned in paragraph $\mathrm{I}$. herein, which were received by the attorney of the said Ryan with evident interest, and with the promise on his part to examine carefully and report to your orator as soon thereafter as possible. That said Page did examine said plan, options and papers and confirmed to said Ryan the statements made by your orator. And your orator further shows and charges that in compliance with said agreement with said Ryan in pursuance thereof, and only because of the desire of the said Ryan that his attorney should have opportunity to examine them, your orator turned over and submitted to Ryan's said attorney, a large part of his said options, contracts of sale, data, estimates, renewals of options, and other documeuts and papers and similarly offered to submit all the same which your orator then possessed, and the same were subsequently wrongfully used and appropriated by said Ryan.

III. That after reasonable time had elapsed for the examinations of said papers, your orator again called several times upon the attorney of said Ryan, and was told by him that he had submitted your orator's plans, options and papers to the said Ryan, and confirmed your orator's statements, touching said plan, to said Ryan, and had endorsed the matter as comprehensive, feasible, and attractive, but that the said Ryan had not yet had time to take up the matter with him.

IV. That during a period of several months from the time of the submission to said Ryan and his counsel of his plans, options, estimates and material, and while your orator was waiting to hear from said Ryan, he heard rumors that one Grant Hugh Browne, who was and is connected both with the said Morton Trust Company and said Ryan, and who your orator charges is frequently used by said Ryan for similar purposes, was, in connection with Edward Lauterbach, a prominent attorney of the eity of New York, who was also one of the attorneys of said Ryan, engaged in obtaining options on the plants of all the Lead Companies, individuals and firms from whom your orator had obtained options, most of said options having then expired, and some of which would soon thereafter expire, and from others with whom your orator had opened negotiations for such purchase, all of which together with complete details as to their rights, properties, interests and prices, were named in the report your orator had left with the attorney of said Ryan, and all of the details of which had been by your orator revealed to the said Ryan and his said attorney, 
at the several interviews had with them or either of them pursuant to the agreement of said Ryan as aforesaid. Your orator immediately apprised William H. Page, Jr., the attorney of said Ryan, to whom your orator had submitted said plans and property, of the fact that such rumors were current, and late in the fall of 1901, was told by him that said Ryan had evidently dropped him, the said Page, out of the matter, and secured the services of other attorneys, and that he, the said Page, knew nothing further about the matter.

$V$. Your orator is informed and verily believes and charges that through the efforts of the said Browne, as the agent of the said Ryan, or of his attorney, Edward Lauterbach, Esquire, or both, options, contracts of sale, and renewals of options formerly held by your orator and turned over to Ryan as heretofore alleged, have been obtained in the interests of said Ryan, upon most, if not all, of the plants and properties upon which your orator had options as before stated of which the said Ryan was so as aforesaid apprised by your orator, in pursuance of and in accordance with the plan and scheme of your orator, disclosed and presented in detail to said Ryan and his attorney in manner hereinabove set out and which was the first information the said Ryan had thereof; that subsequent to the obtaining of said options by or on behalf of said Ryan, and on or about the twentieth day of January, nineteen hundred and three, the United Lead Company was organized as a corporation under the laws of the State of New Jersey, and under the direction and control of said Thomas F. Ryan and said Grant Hugh Browne, his agent, and proceeded to acquire, and now owns the interests in nearly all, if not all, of the companies, firms and individuals named by your orator in said statements, and from whom your orator held options, or with whom he had opened negotiations. Said United Lead Company is capitalized with a capital stock of fifteen million dollars and has issued bonds for seventeen million dollars. Its president is Barton Sewell, then vicepresident of the American Smelting \& Refining Company, and one of its vice-presidents is Grant Hugh Browne, and said Ryan is and has been for several years a director of said United Lead Company, and your orator shows and charges that in the formation and exploitation of the said United Lead Company, the said Thomas F. Ryan had made an enormous profit, both as promoter and otherwise by the sale of your orator's property, not as a mere promoter's profit, but in compensation and payment of your orator's plans, scheme of combination, options, contracts, writing, documents, information, data and other property, turned over to said Ryan and his agent by your orator, and held in trust by said Ryan in compliance with and as part of your orator's contribution on account of the agreement between 
your orator and said Ryan aforesaid. That most of said profits were secret profits, the amount of which is unknown to your orator, and although your orator had made an effort to ascertain the same, the said Ryan and his attorneys have constantly declined to disclose the same. All efforts that your orator has made to discover the exact connection of said Thomas F. Ryan with said United Lead Company, and whether or not the said Grant Hugh Browne represents him therein, or how much the said Grant Hugh Browne on account of said Ryan, or the said Ryan himself, has made in and by the promotion and successful exploitation of the combination of interests have been, up to this time, utterly futile; that a combination or merger substantially as planned and proposed by your orator to said Ryan has taken place, or is about to take place, with the result of great profits to said Ryan. That by the holding, appropriation and using of the property of your orator turned over by him in trust to said Ryan and solely in compliance with the agreement aforesaid, the wrongful use of the same and the many months of delay which elapsed before your orator was aware of said breach of trust and wrongful acts of said Ryan, your orator was wholly prevented from joining with other capitalists in the promotion and carrying out of the plans and scheme of combination aforesaid.

That the amount of stock, money or other property receired by said Ryan in payment or compensation for the property of your orator held in trust by said Ryan or by him wrongfully turned over to and utilized for the United Lead Company, as aforesaid, is unknown to your orator, and your orator, before the commencement of this suit, endeavored to obtain from said Ryan information upon these points, which information was denied by said Ryan.

That said Ryan is and was a man of great wealth and did not need or call upon your orator for any part of the two hundred thousand dollars agreed to be contributed by your orator in addition to the property contributed by him. Said Ryan did need and did use said plans, contracts, options, renewals of options, schemes of combination, documents in formation, data and other property contributed by your orator solely in compliance with said agreement and which was wrongfully used by said Ryan as aforesaid, and for which he received in payment large amounts of stock, bonds and valuable property, which stocks and bonds were and still are selling in the markets of the city of New York and elsewhere at high prices. That the plan formulated by your orator and disclosed to said Ryan as aforesaid did not require nor contemplate that either of the parties should contribute a very large amount of money for the purpose of promoting and orgunizing a new company, in fact only a few hundred thousand dollars. Under 
your orator's plan appropriated by said Ryan as aforesaid, the capital stock of the new company would be represented by and part of it given in payment for the property, good-will and cash assets of the firms, corporations and individuals which should make up the new company and on whose plants options had been obtained by your orator, and appropriated by said Ryan as aforesaid. This plan was carried out by said Ryan and his agents.

VI. Your orator charges and shows that the acts and doings of said Thomas F. Ryan in this regard, in availing himself of the information, options, materials, knowledge, plans, schemes, propositions and property which your orator, after years of labor, and great expenditure of money, had collected together, and had only disclosed to said Ryan and delivered to him in trust and upon agreement and understanding on the part of said Ryan that he would join your orator in the said scheme and share with him in the profits arising therefrom, are contrary to equity and good conscience, and that the said Ryan should account to your orator for your orator's share of any and all profits that have been reaped by him from or in connection with the promotion and exploitation of the said United Lead Company, and should be directed to pay over to your orator, your orator's share thereof.

To the end therefore that the said Thomas F. Ryan may, without oath, (an answer under oath being hereby waived), full, true and perfect answer make to all and singular the matters and things hereinbefore stated, and more particularly that he may discover and specifically set forth whether it is not true that he did, after listening to your orator's description of his said plan and proposition, refer your orator to William H. Page, Jr., in order that a thorough examination might be made of the project and whether or not the said Page did not bring to his attention a statement or plan handed to him by your orator, and whether or not the said Ryan did not, through the intervention of the said Grant Hugh Browne, or the said Edward Lauterbach, Esquire, or other agents or attorneys, enter into negotiations with and procure options upon the properties of the companies, or business interests hereinabove named, and others unknown to your orator, for the purpose of uniting them into a combination of lead interests subsequently known as the United Lead Company, and whether the United Lead Company was not formed at his inspiration, and under his direction, and what interest, if any, the said Thomas F. Ryan has in the stock or securities of the said United Lead Company, and how much he paid for the same, and how much the same are worth in the market, and that the said Thomas F. Ryan may specifically discover and set forth how much profit, secret and other- 
wise, he has made by his connection with the enterprise known as the United Lead Company, and more particularly from the promotion and exploitation thereof, and that an accounting may be had, and that the said Thomas F. Ryan may be decreed to pay over to your orator, your orator's share of such profits as joint adventures and through the wrongful use and sale of your orator's property as aforesaid, and that your orator may have such other relief as to your honor shall seem meet and shall be agrecable to equity and good conscience:

May it please your honor, the premises considered, to grant unto your orator, the state's writ or writs of subpoena, issuing out of and under the seal of this honorable court, to be directed to the said Thomas F. Ryan, commanding him, by a certain day and under a certain penalty therein to be expressed, to be and appear before your honor in this honorable court, then and there to answer all and singular the said premises, and to stand to, abide by, and perform such order and decree therein as to your honor shall seem meet, and shall be agreeable to equity and good conscience.

And your orator, as in duty bound, will ever pray, etc.

McCARTER \& ENGLISH, Solicitors for and of Counsel with Complainant.

John C. F. Gardner,

Robert H. McCarter, of Counsel. 


\section{STEEL RAIL POOL ${ }^{1}$}

The Steel-Rail Pool.-By far the most important pool organization in the steel industry at this time was that in steel rails. This pool was formed on August 2, 1887, and, while it was dissolved in 1893, it was speedily renewed and continued in existence until the early part of $189 \%$. The general nature of this pool may perhaps best be indicated by reproducing the following copy of the memorandum of agreement:

Memorandum of agreement, entered into August 2, 1887, by and between the North Chicago Rolling Mill Company, the Cambria Iron Company, the Pennsylvania Steel Company, the Union Steel Company, the Lackawanna Iron \& Coal Company, the Joliet Steel Company, the Western Steel Company, the Cleveland Rolling Mill Company, Carnegie, Phipps \& Co., Limited; the Bethlehem Iron Company, the Scranton Steel Company, the Troy Steel \& Iron Company, the Worcester Steel Works and the Springfield Iron Company.

We, the before-named companies and corporations, manufacturers of steel rails, hereby mutually agree one with the other, that we will restrict our sales and the product of steel rails to 50 pounds to the yard and upward, applying to orders taken by us and to be delivered by us or from our respective works during the year 1888, as hereinafter allotted and limited; and we respectively bind ourselves not to sell in excess of our current allotments, without first obtaining the consent of the Board of Control thereto-that is to say :

It is agreed there shall now be made an allotment of 800,000 tons of rails, which shall be divided and apportioned to and among the several parties hereto to be sold by them during the year 1888, upon the following basis of percentages, to wit: North Chicago Rolling Mill Company, 121/2 per cent; Pennsylvania Steel Company, 9 8/10 per cent; Bethlehem Iron Company, 9 per cent; Carnegie Bros. \& Co., Limited, and Carnegie, Phipps \& Co., Limited (jointly), 13 5/10 per cent; Joliet Steel Company, 8 per cent; Lackawanna Iron \& Coal Company, 8 per cent; Cambria Iron Company, 8 per cent; Scranton Steel Company, 8 per cent; the Union Steel Company, 8 per cent; Cleveland Rolling Mill Company, 48/10 per cent; Troy Steel \& Iron Company, 45/10 per cent; Western Steel Company, 45/10 per cent; Worcester Steel Works, $14 / 10$ per cent.

And in addition to the said allotment of 800,000 tons of rails

1 Report of Commissioner of Corporations on the Steel Industry, Washington, 1911, Part I. pp. 68-71. 
above allotted, an additional allotment of 250,000 tons is hereby made and allotted to the Board of Control, to be reallotted and reapportioned by it, as and to whom it may deem equitable, in the adjustment of any differences that may arise. It being also further agreed that all subsequent allotments of rails hereafter made, to be sold, divided and apportioned to the several parties hereto in the same ratio of percentages as said apportionment of 800,000 tons is herein divided and apportioned.

It is further agreed, that the Board of Control shall, from time to time, make such further allotments as shall be necessary to at all times keep the unsold allotments at least 200,000 tons in excess of the total current sales, as shown by the monthly reports of sales. This is to be in addition to the then unappropriated part of the 250,000 tons hereinbefore allotted to the Board of Control to adjust differences.

It is further agreed, on the first day of April, July and October the Board of Control are authorized and directed to cancel such part of the unmade allotments of the respective parties hereto as they the said Board of Control shall determine such party unable to make in due time, and all allotments so canceled the Board of Control shall have the right to reallot to any of the other parties hereto; it being understood that all such cancellations shall apply only to allotments standing to the credit of the respective parties hereto on the dates above named, but no reallotment as aforesaid shall be made by the Board of Control to any of the parties hereto for the purpose of enabling them, or any of them, to make and sell rails from foreign made blooms.

It is further agreed, that all transfers of parts of allotments from one party to another shall be made by the Board of Control.

It is further agreed, that there shall be made by the Board of Control, consisting of three members, namely, Orrin W. Potter, Luther S. Bent and W. W. Thurston, who shall have power to employ a paid secretary and treasurer.

It is further agreed, that the Board of Control, upon the written consent of 75 per cent of the percentages as hereinbefore named, shall increase the allotments for the year 1888, and such increase shall be allotted to the parties hereto as hereinbefore provided.

It is further agreed, that each party whose name is hereunto annexed shall and will make monthly returns to the Board of Control of all contracts for delivery of rails of 50 pounds to the yard and upward during the year 1888, and also of all shipments of such rails made by them during the said year; a copy of such returns shall be furnished to each party hereto. 
It is further agreed, that all the parties hereto shall and will, on or before January 15, 1888, make a written return to the Board of Control of all rails of 50 pounds to the yard and upward (designating the weight), whether the same are sold, and if sold, on what order they apply.

It is further agreed, that the Board of Control shall have the right whenever they deem it expedient to convene a meeting of the parties hereto, and they shall give at least ten days' previous notice of all meetings, and any business transacted at such meetings, and receiving 75 per cent of the votes present thereat, either in person or by proxy, shall be binding on all the parties hereto, excepting as to a change in percentages as aforesaid.

The Board of Control shall be required to call a meeting of the parties hereto when requested so to do in writing, signed by any three of the contracting parties, but such request and such notice shall state the object for which such meeting is called.

It shall be the duty of the Board of Control to have a proper record kept of all the returns made to it, with power from time to time to change the form of return as they may deem expedient.

The Board of Control shall have authority to levy an assessment, pro rata to the allotted tonnage, to defray the actual expenses made necessary to carry out this agreement.

It is further agreed, that we will, respectively, immediately make return to the Board of Control of all rails of 50 pounds to the yard and upward which we are now under contract to deliver during the year 1888 , said return to state to whom such rails are sold and when they are to be delivered.

North Chicago Rolling Mill Company, by 0. W. Potter, president; Cambria Iron Company, by E. Y. Townsend, president; Pennsylvania Steel Company, by Luther S. Bent, vice-president; the Union Steel Company, by H. A. Gray, secretary and treasurer; Lackawanna Iron \& Coal Company, by B. G. Clarke, vice-president; Joliet Steel Company, by W. R. Stirling, treasurer; Western Steel Company, by A. M. Wilcox, president; Cleveland Rolling Mill Company, by Wm. Chisholm, president; Carnegie Bros., Limited, by D. A. Stewart, V. C.; Carnegie, Phipps \& Co., Limited, by John Walker, chairman; the Bethlehem Iron Company, by Wm. W. Thurston, vice-president; the Scranton Steel Company, by W. W. Scranton, president; Troy Steel \& Iron Company, Selden E. Marvin, secretary; Worcester Steel Works, by Samuel D. Nye, manager; the Springfield Iron Company, by Charles Ridgely, president. 


\section{AGREEMENT BETWEEN DEERING HARVESTER CO. AND WILLIAM C. LANE, JULY 28, 1902}

An agreement, made and entered into this 28th day of July, nineteen hundred and two, by and between the Deering Harvister CosrPANY, a copartnership consisting of Charles Deering, James Deering and Richard F. Howe (hereinafter called the "Vendor"), party of the first part, and William C. Lane (hereinafter called the "Purchaser"), party of the second part.

Whereas, the Vendor owns certain manufacturing properties located at Chicago, Illinois, and in Canada, and employed in the maufacture of harvesting machinery and other properties intended for use in conneetion therewith; and,

Whereas, the Purchaser desires to acquire said properties and intends, upon the acquisition of said properties, to sell, convey and transfer the same to a corpora ion now existing or hereafter to be organized under the laws of the state of Illinois or other state (hereinafter called the "Purchasing Company"), with capital stock as hereinafter provided:

Now, this agreement witnesseth, that the parties hereto have agreed and covenanted as follows:

First. The Vendor agrees, for the considerations and upon the terms hereinafter stated, to sell, assign, transfer, convey and deliver unto the Purchaser, his nominee or assign, by good and indefeasible title free and clear of incumbrances, indebtedness and liabilities, except as herein stated, and the Purchaser agrees to purehase, all and singular the real estate, factories, plants, buildings, improvements, machinery, patterns, tools, apparatus, fixtures and appliances of the Vendor and all the patents, inventions, devices, patent rights, lieenses, trade-marks, trade-names and good-will of all and singular said property as a going concern, and also all of the products manufactured and in process of manufacture, materials, supplies and mercliandise on hand at the time of closing said sale and all and singular its then pending contracts for the purchase of property or materials or the sale of product; also all other property of the Vendor appertaining to the Vendor's business aforesaid. There shall also be sold and purchased with said properties $\$ 16,000,000$ (at face value and accrued interest) of bills and accounts receivable representing sales made by the Vendor. Such bills and accounts receivable are to mature prior to March 1, 1905, and are to be guaranteed as hereinafter

From Report of Bureau of Corporations on the International Iarvester Company. 
provided. Cash may be substituted for the whole or any part of such accounts and bills receivable at the option of the Vendor.

Second. The Vendor agrees that, as soon as practicable after the execution of this instrument, it will duly execute and acknowledge, and cause to be forthwith deposited with J. P. Morgan \& $\mathrm{Co}$., or a trust company designated by them, as depositary, proper deeds and other instruments of conveyance and sale for the granting, conveying and transferring as aforesaid unto the Purchaser and his assigns, all the property hereinbefore recited. Such depositary shall hold the said deeds and other instruments in escrow and deliver the same to the Purchaser or upon his order only upon receiving for account of the Vendor the consideration hereinafter provided, and upon the performance by the Purchaser of the provisions hereof.

Third. The Vendor agrees to deliver to said depositary as soon as practicable full statements in respect of its property and its assets and liabilities, its contracts for the purchase of materials and other property and for the sale of its manufactured products and otherwise relating to its property and business. The Vendor agrees that, pending the performance of and while this contract is in force, it will not, without the written consent of the Purchaser, or of said Purchasing Company, enter into any new contracts or assume any new obligations or make any purchases or sales except such as are necessary and customary in the ordinary conduct of its regular business or to maintain it as a going concern and except such as may be necessary for the performance of agreements already entered into; nor make payments in advance of their maturity on pending contracts. The Vendor further agrees that during and while this contract is in force, no new capital shall be employed in its business and no bonds issued, and that no mortgage, lease or conveyance shall be made upon or in respect of its real estate or plant without the written consent of the Purchaser; and also that in case of any difference of opinion between the Vendor and the Purchaser in relation to the conduct of the business of the Vendor, such difference shall be decided by J. P. Morgan or George W. Perkins, whose decision shall be final. All service contracts of the Vendor taken over by the Purchasing Company shall be terminable on sixty days' notice unless in specific cases otherwise determined by said Purchasing Company; and the Vendor shall indemnify the Purchasing Company against any claims under profit sharing contracts. In the case of any property delivered to the Purchaser by the Vendor which is subject to incumbrance, the amount of the incumbrance shall be deducted in determining the value thereof.

Fourth. The Purchaser and said Purchasing Company and his or its nominees, the appraisers, accountants and counsel shall have the 
right to examine the deeds and other instruments of conveyance and transfer so to be deposited by the Vendor with the depositary as aforesaid, and shall, if the Purchaser shall so require, be furnished with abstracts of title, title deeds and surveys which may facilitate the examination of the title to the property to be conveyed or transferred, and shall have free access to all the deeds, contracts, books and records of the Vendor for the purpose of examining and verifying the statements made with respect to its property, business, assets, liabilities and status.

Fifth. The purchase price to be paid by the Purchaser to the Vendor for all and singular said property shall be the aggregate of the several appraisals and valuations hereinafter provided for and of said accounts and bills receivable and cash, if any, and shall be payable in full paid and non-assessable shares of the capital stock of the said Purchasing Company taken at par.

In order to make such appraisals and fix and determine such valuations, the property of the Vendor shall be classified as follows:

(1) Real estate, buildings, factories, warehouses, fixtures, machinery, tools, patterns, drawings, moulds and all other personal property used in connection with or appertaining to the Vendor's business and which is not intended for sale in the ordinary course of business or to form part of or to be consumed in the manufacture of the Vendor's products, and including pending contracts for purchase of real property and for construction of buildings or fixtures, but not including the property and contracts otherwise elassified. The assets of this class are hereinafter collectively designated as "Plant."

(2) All materials on hand, manufactured, unmanufactured or in process of manufacture, including any and all articles intended to form part of or to be used in manufacturing the Vendor's product. The assets of this class are hereinafter collectively designated as "Materials on hand."

(3) Unexecuted contracts or orders for the sale of the Vendor's manufactured products, but not including contracts or orders for deliveries after the year 1902, for which latter contracts and orders (although to be transferred) no allowance shall be made. No allowance shall be made for contracts or orders for delivery prior to January 1,1903 , unless the material necessary for the completion of the machines or other manufactured products shall be in the possession of the Vendor and upon its plant at the time of the appraisal. Such contracts are hereinafter collectively designated as "Pending Sales."

(4) All contracts heretofore entered into by the Vendor for the purchase of materials to be used in the manufacture of its product. 
Such contracts are hereinafter collectively designated as "Material Contracts."

(5) The coal, iron and steel properties of the Vendor, including its coal and iron lands, steel plant and blast furnaces, such property being hereinafter referred to as the "Deering Iron, Coal and Steel Properties."

(6) Patents, patent rights, devices, inventions, licenses, trademarks, trade-names and good-will, including the value of the established business, name, standing in the trade, stability of business, organization, trade and custom as a going concern. Such assets are hereinafter collectively designated as "Patents, Good-Will," etc.

The value of the plant, as above defined, shall be ascertained and determined by three appraisers, who shall fix the present value of such plant as a going concern. One of such appraisers shall be nominated and appointed by the Vendor, and the other two by J. P. Morgan \& Co.

The present value to a going concern of said materials on hand, of the said pending sales, and of the said material contracts, as above defined, shall similarly be determined by three appraisers, one to be nominated and appointed by the Vendor and two by J. P. Morgan $\&$ Co. Such appraisers shall make allowance in their judgment for unprofitable contracts.

The value of the Deering Iron, Coal and Steel properties to a going concern, as above defined, shall be determined by J. P. Morgan or George W. Perkins.

The value of the patents and good-will shall, for the purposes of this contract, be a sum equal to the net profits of the Vendor during the two years ending November 30,1902, as ascertained in the manner hereinafter provided, plus ten per cent. thereof; and to such amount shall be added the value of the name, standing in the trade, stability of business, organization, trade, custom, etc., of the Vendor as a going concern, which value shall be fixed by J. P. Morgan or George W. Perkins in his sole discretion.

The profits for said two years shall be ascertained and reported to J. P. Morgan \& Co. by three accountants, one of whom shall be nominated by the Vendor and the other two by J. P. Morgan \& Co. In calculating the net profits of the business, there shall be excluded all allowance for interest on bills and accounts receivable as well as the cost of collecting bills and accounts receivable, and all interest paid or payable on moneys used by the Vendor but belonging to any of the members of the Vendor or William Deering \& Co. or William Deering or any member of his family. Said accountants, in calculating the net profits for said two years, shall make allowance for de- 
preciation or loss, if any, on bills and accounts receivable, for depreciation or loss, if any, on materials on hand, and for depreciation, if any, of the said plant from wear and tear or otherwise. In each case hereinbefore enumerated the decision, appraisal or report of a majority of the appraisers or accountants or the decision of J.P. Morgan or George W. Perkins (if sole arbitrator or appraiser), as the case may be, shall be binding and conclusive upon the parties hereto.

Sixth. Payment of the amount of all contracts or orders for sales of manufactured products included as assets of the Vendor as aforesaid and transferred under this contract, shall be guaranteed to the satisfaction of J. P. Morgan \& Co. by the Vendor and the net value thereof shall be appraised on that basis. Any and all accounts and bills receivable transferred by the Vendor hereunder shall be taken at their face value and accrued interest to date of transfer, but the Vendor shall guarantee and hereby does guarantee that the Purchaser or the Purchasing Company shall realize thereon such face value and interest accrued and to accrue and that said principal and interest shall all be received on or prior to the first day of March, 1905. The collections shall be made by the Purchasing Company, but the expenses of collections shall be borne by the Vendor. Pending such collections, the Vendor agrees to advance and pay to the Purehasing Company on demand, from time to time, on aecount of such guaranty such amounts as the board of directors of the Purchasing Company may determine to be necessary or convenient for the conduct of its business, but not in excess of such amounts as J. P. Morgan \& Co. may from time to time approve. If such advance payments be made by the Vendor, then the Purchasing Company shall transfer to the Vendor or their nominees an equal amount in principal and accrued interest of uncollected accounts or bills receivable of the earliest maturities. The Purchasing Company may take such measures as to it may seem wise, for the collection of the accounts and bills receivable and grant extensions and indulgences to debtors by whom the same are payable without release of or prejudice to such guaranty or extension or change of the obligation of the Vendor to make payments as aforesaid. The Purchasing Company shall from time to time, on demand, furnish the Vendor a full statement showing what accounts and bills receivable remain unpaid, and what, if any disposition has been made in regard thereto or steps taken to enforce the collection therenf.

The Vendor shall secure the guaranties in this article provided, by collateral or otherwise, to the satisfaction of J. P. Morgan \& Co. in their discretion. 
Seventh. The Purchasing Company shall have such corporate title, capital stock, organization, by-laws, directors and committees as may be approved by J. P. Morgan \& Co. and shall have, in addition. to materials on hand and inventories, a working capital of $\$ 60,000,000$ to be represented by cash or bills and accounts receivable guaranteed as aforesaid.

Eighth. The amount and the classes (if there be more than one class) of the capital stock of the Purchasing Company shall be determined after the ascertainment of the aggregate value of all its assets and properties, but such amount and such classes shall severally be satisfactory to J. P. Morgan \& Co. If, however, there be only one class of stock, the capital stock shall not exceed $\$ 120,000,000$ par value, even though the aggregate value of the assets and properties of the Purchasing Company be in excess thereof. If there be both preferred stock and common stock, the preferred stock shall not exceed $\$ 120,000,000$ par value and shall entitle the holders to cumulative preferential dividends at the rate. of but not to exceed six per cent. per annum, with preference as to principal and accumulated dividends on dissolution or liquidation; and the common stock shall not exceed the remaining value of the corporate assets and properties as so determined, which value may be ascertained and determined irrespective of the special appraisals which are to be made under this agreement.

If there shall be two classes of stock, then and in that event the Vendor shall be entitled to receive as additional purchase price under this agreement common stock to an amount that shall bear to the total issue thereof the same proportion that the preferred stock to be received by the Vendor under this agreement shall bear to the total issue of preferred stock.

Ninth. The purchase provided for in this contract shall take effect as of such day in September, 1902, as shall be designated by the Purchaser with the approval of J. P. Morgan \& Co.; the appraisals shall be made as of such date as nearly as practicable, and the performance of the contract shall be completed prior to January 1, 1903.

Tenth. The charter or certificate of incorporation or organization of the Purchasing Company shall provide, among other things, that the capital stock of the corporation shall not be increased or diminished except upon the affirmative vote or consent of the holders of at least two-thirds of each class of the outstanding capital stock of the company. Said charter or certificate may also provide that the stockholders may enter into a voting trust of their stock for a limited period. The charter or certificate shall likewise provide that no mortgage or lien upon the real property, plants, tools or machinery 
of the Purchasing Company shall be created without the affirmative vote or the written consent of the holders of at least two-thirds of each class of the outstanding capital stock.

Eleventh. The Vendor undertakes and agrees that it or the holders of the stock of the Purchasing Company so to be issued in payment for the property to be transferred and conveyed under this agreement, shall deposit their stock with J. P. Morgan \& Co. or a trust company to be designated by them, as depositary, upon a voting trust, which shall provide, among other things, for the appointment of three voting trustees, one of whom shall be J. P. Morgan or George W. Perkins and the other two shall be persons appointed by J. P. Morgan \& Co. The voting trust agreement shall be for the period of ten years with provision, however, that it may be terminated at any time after the expiration of five years upon ninety days' notice, if a majority of the voting trustees shall so decide. The capital stock of the Purchasing Company shall be transferred to such voting trustees, who shall issue transferable certificates of beneficial interest entitling the holder to any dividends, distribution of profits and subscription rights which may accrue in respect of the stock so held by the voting trustees, and upon the termination of the voting trust entitling the holder to a porportionate amount of the stock so transferred to the voting trustees. The form, terms and provisions of the voting trust agreement shall be subject to the approval of J. P Morgan \& Co. The voting trust agreement shall contain adequate restrictions upon the voting power of the voting trustees in respect of an increase or diminution of capital stock, or the creation of any mortgage as aforesaid, so that any vote or consent by .the voting trustees for any such increase or diminution, or mortgage, shall be given only upon the affirmative vote or written consent of the owners of a corresponding amount of the voting trust certificates of interest outstanding.

The Vendor shall further agree with J. P. Morgan \& Co. that during the first year after the issue of such stock or voting trust certificates, the Vendor shall own, and shall refrain from selling or otherwise disposing of at least eighty per cent. of the original holdings acquired under this agreement or otherwise; during the second year at least sixty per cent. of such original holdings; during the third year at least forty per cent. of such original holdings; and thereafter, and during the existence of the voting trust, at least one-third of such original holdings; provided, however, that Vendor may at any time after the expiration of the fourth year withdraw from the custody of J. P. Morgan \& Co. and sell or otherwise dispose of the remaining one-third of said original holdings, or any part thereof, but in such 
case any voting trustee representing such holdings shall immediately resign as trustee if desired by the two remaining trustees. A successor shall thereupon be appointed by the other two trustees.

As guaranty for the performance of the foregoing covenant not to sell or otherwise dispose of stock or voting trust certificates, the Vendor shall severally pledge with J. P. Morgan \& Co. an amount of stock or voting trust certificates equal to the proportion which they have agreed to continue to own, which stock shall be released and delivered to them or upon their order from time to time as they may become entitled to sell; but, except as herein otherwise provided, onethird of the total original holdings as aforesaid shall remain pledged with J. P. Morgan \& Co. during the existence of the voting trust.

In case during the first year after the issue of said stock by the Purchasing Company the Vendor shall desire to sell any of the stock or voting trust certificates which it is free to sell under the provisions hereof, it shall offer the stock to J. P. Morgan \& Co. by notice in writing, specifying the amount of the stock and the price at which the same is offered, and the Vendor shall be entitled to sell such stock to others only in case J. P. Morgan \& Co. shall not within twenty days thereafter purchase said stock at the price named in the notice or at a price satisfactory to the Vendor.

Twelfth. This contract, or any part thereof, may be transferred by the Purchaser to the Purchasing Company, and such Purchasing Company may thereupon enforce all and singular its terms and conditions as fully to all intents and purposes as if it were a party thereto. The place of performance of this contract shall be at the office of the Hudson Trust Company, Hoboken, New Jersey.

Thirteenth. The individual members of the Vendor shall jointly and sererally guarantee the performance of this contract.

Fourteenth. The Purchaser undertakes to duly secure by contract the appointment of J. P. Morgan \& Co. as the fiscal agents of the Purchasing Company and their acceptance of such appointment, in crder that the Purchasing Company may secure and have the benefit and advantage of the advice of said firm in the management of its financial affairs.

If any dispute should arise under this contract as to its true intent or meaning, or in respect of the performance of any part thereof, whether between the parties hereto or between the Vendor and the Purchasing Company, the matter in dispute in each and every case shall be left to J. P. Morgan or George W. Perkins as sole arbitrator, and the decision of such arbitrator shall be binding and conclusive upon the parties.

Fifteenth. In case any appraiser, arbitrator, accountant or voting 
trustee shall for any reason fail or cease to serve, then and in said event another or a successor shall be nominated and appointed in his place by the Vendor or by J. P. Morgan \& Co. respectively as the case may be, subject, however, in the case of voting trustees to the provisions of the voting trust agreement.

Reference in this agreement to J. P. Morgan \& Co. shall apply to that firm as now or hereafter constituted.

In witness virereof, the party of the first part and the party of the second part have hereunto set their hands and seals the day and year first above written.

Deering Harvester Company,

Charles Defring, [seal.]

James Deering, [Seal.]

By Charles Deering,

Attorney-in-fact.

JAMES DeERING,

Richard F. Howe, [Seal.]

WM. C. Lane.

[SEAL.] 
SUPPLEMENTAL AGREEMENT BETWEEN DEERING HARVESTER CO. AND WILLIAM C. LANE, AUGUST 11, 1902.

Supplemental agreement, made and entered into this 11th day of August, 1902, by and between the Denring Harvester Company (hereinafter called the "Vendor"), party of the first part, and William C. Lane (hereinafter called the "Purchaser"), party of the second part.

The parties hereto have entered into an agreement, dated July 28, 1902, (hereinafter called the "Original Agreement"), providing for the sale by the Vendor to the Purchaser of the property of the Vendor as therein described. The parties hereto have agreed that said property shall be conveyed and transferred by the Vendor to the Purchaser forthwith and in advance of the determination of the exact purchase price of said property as in said Original Agreement provided.

Now, in consideration of the premises, the parties hereto have agreed and covenanted as follows:

First. The Vendor shall forthwith convey and transfer to the Purchaser all of the property described in the Original Agreement by instruments of conveyance which shall contain covenants of warranty and further assurance. The Vendor shall also forthwith assign and transfer to the Purchaser all of its accounts and bills receivable, and the same shall be subject to the provisions of the Original Agreement respecting the accounts and bills receivable to be transferred by the Vendor to the Purchaser as therein provided, but the Vendor shall be entitled to substitute cash in place of any such accounts and bills receivable.

Second. The Purchaser shall cause to be prepared, as soon as practicable, a statement of the accounts and bills receivable assigned by the Vendor as herein provided, including such as may be received prior to the date in September which shall be fixed by the Purchaser with the approval of $J$ P. Morgan \& Co. for the adjustment of the purchase price payable to the Vendor. If the aggregate of such accounts and bills receivable, at their face value and accrued interest, shall exceed the sum of sixteen million dollars $(\$ 16,000,000)$, then the excess shall be held for the account of the Vendor, and shall be available to be applied by the Vendor towards any other payments that may be due by the Vendor to the Purchaser, or in such other manner as the Vendor shall direct.

Third. The capital stock of the purchasing company provided for in said contract shall be one hundred and twenty million dollars 
$(\$ 120,000,000)$, but, prior to January 1,1903 , capital stock shall not

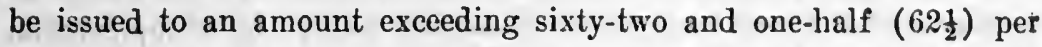
cent. of the aggregate amount of the money and cash assets acquired by said company and of the value of the other property acquired by said company, as such value shall be ascertained and fixed by the board of directors of the company at the time of the acquisition of such property.

Fourth. Forthwith upon the conveyance of said property by the Vendor to the Purchaser, the Purchaser shall deliver to J. P. MIorgan \& Co. stock trust certificates for such an amount of the capital stock of the purchasing company as shall, in the opinion of J. P. Morgan \& Co., be required to provide the amount of stock trust certificates necessary for ultimate delivery to the Vendor in payment for the property, accounts and bills receivable and cash to be transferred and paid by it as herein and'in the Original Agreement provided. J. P. Morgan \& Co. are hereby authorized to deliver to the Vendor, from time to time, such amounts of the stock trust certificates so delivered as, in their opinion, it is proper to deliver to the Vendor. If after the final ascertainment of the amount of stock trust certifi. cates to be delivered to the Vendor, as herein and in the Original Agreement provided, and after the delivery to the Vendor of such stock trust certificates, any of said deposited stock trust certificates shall remain on deposit with J. P. Morgan \& Co., the same shall be returned to the Purchaser, but if the stock trust certificates on deposit with J. P. Morgan \& Co. shall not be sufficient for the purpose of such delivery, then the deficiency shall be forthwith supplied by the Purchaser.

Fifth. The purchase price to be paid by the Purchaser to the Vendor for said property shall be ascertained as provided in the Original Agreement, and notwithstanding the immediate transfer and delivery of the property of the Vendor, the purchase shall, so far as the adjustment of the purchase price is concerned, be considered as taking effect as of such day in September, 1902, as shall be designated by the Purchaser, with the approval of J. P. Morgan \& Co.; and, for the purposes of this contract and of the Original Agrcement, the profits of the Vendor for the two years ending November 30,1902, shall be ascertained in accordance with the provisions of the Original Agreement. The Purchaser shall cause separate accounts of the business of the Vendor, when transferred to the purchasing company, to be kept so long as may be necessary for the purpose of ascertaining the profits thereof for the year ending November 30, 1902, and for the purpose of determining and apportioning the profits in accordance with the Original Agreement. 
Sixth. The Original Agreement shall continue in force except as herein modified, and any questions arising under this Supplemental Agreement shall be determined by J. P. Morgan \& Co. as sole arbitrators.

In witness whereof the Vendor has caused this agreement to be duly signed in the name of said firm, and the Purchaser has signed his name and affixed his seal hereto the day and year first above written.

In presence of:

Joseph P. CotToN, Temple Bowdoin.

WM C. Lane.

Deering Harvester Company, Charles Deering, James Deering, By Charles Deering, Richard F. Howe, By Charles Deering, Attorney-in-fact. James Deerina. 


\section{AGREEMENT PRELIMINARY TO THE FORMATION OF THE AMERICAN SNUFF COMPANY.}

Memorandum of agreement made this 15th day of February, 1900, between George B. Wilson, Henry D. Moore and John W. Woodside, of the first part; James B. Duke of the second part, and John B. Cobb of the third part:

The parties of the first, second and third parts agree to and with each other, to forthwith organize a corporation under the laws of the State of New Jersey, by the name of the American Snuff Company, or other name to be agreed on by the parties hereto, with an authorized capital stock of twenty-five million dollars $(\$ 25,000,000)$, of which twelve million five hundred thousand dollars $(\$ 12,500,000)$, shall be six per cent. non-cumulative preferred stock, and twelve million five hundred thousand dollars $(\$ 12,500,000)$ shall be common stock.

There shall be a provision in the charter that no mortgages, or incumbrances of any kind, shall be placed upon any of the property of such proposed corporation as a prior lien to such preferred stock, and any profits realized by such corporation to the extent of six per cent. upon such preferred stock, or any part thereof, as may be earned in any year, shall be first applicable to such preferred stock. If any profits are realized by the corporation in any one year beyond the sum necessary to pay six per cent. dividends, such profits shall be applicable to the common stock only.

The said parties of the first part agree to undertake to deliver to said proposed corporation, in such manner as counsel may advise, all of the issued stock of the Atlantic Snuff Company, a corporation organized under the laws of the State of New Jersey, with an authorized capital stock of ten million dollars, of which one million eight hundred and thirty-six thousand five hundred dollars is preferred, and seven million five hundred thousand two hundred dollars, common stock, or all the property real and personal (and the property of all corporations owned or controlled by it), together with its or their good-will, business and trade-marks. The party of the second part agrees to undertake to deliver and have conveyed to said proposed corporation, in such manner as counsel may advise, the snuff business and good-will of The American Tobacco Company and Continental Tobacco Company, together with all of the real and personal property of said The American Tobacco Company and Continental To-

1 From Report of the Commissioner of Corporations on the Tobacco Industry. 
bacco Company, used by them or either of them, and pertaining to the snuff business of them or either of them, and the good-will and trade-marks of the snuff business of said companies.

The party of the third part agrees to undertake and have conveyed to said proposed corporation, in such manner as counsel may advise, the snuff business and good-will of P. Lorillard Company, together with all of the real and personal property of said P. Lorillard Company, used by it, and pertaining to the snuff business of it, and the good-will and trade-marks of the snuff business of said corporation.

The consideration of such conveyance to such proposed corporation as above set forth by said parties of the first part shall be seven million five hundred thousand dollars $(\$ 7,500,000)$, of the preferred stock of said proposed corporation, and two million five hundred thousand dollars $(\$ 2,500,000)$, of the common stock of said proposed corporation applied pro rata to the total present issue of preferred and common stock of the Atlantic Snuff Company.

The consideration of such conveyance to such proposed corporation as above set forth by the said parties of the second and third parts shall be two million five hundred thousand dollars $(\$ 2,500,000)$ of said preferred stock of said proposed corporation and seven million five hundred thousand dollars of the common stock of said proposed corporation to be issued to The American Tobacco Company, Continental Tobacco Company and P. Lorillard Company, in such proportions as the parties of the second and third parts hereto shall hereafter notify said proposed corporation.

It is agreed that the parties of the first part shall deliver and convey to said proposed corporation all of the assets of the Atlantic Snuff Company, which (exclusive of good-will and trade-marks) shall be of the fair value of at least one million eight hundred and thirtysix thousand five hundred dollars $(\$ 1,836,500)$, all of which shall be good, useful and available, and free of debts, liens and liabilities. All real estate and machinery, tobacco, raw, wrought and in process, supplies and materials are to be taken at book value, not exceeding cost. The book accounts included in such assets are to be satisfactorily guaranteed.

It is agreed that the parties of the second and third parts shall deliver and convey to such proposed corporation all of the assets of The American Tobacco Company, Continental Tobacco Company and P. Lorillard Company, pertaining to the snuff business of said companies respectively, which said assets, exclusive of good-will and trade-marks, shall in the aggregate be of the fair value of at least one million five hundred thousand dollars $(\$ 1,500,000)$, all of which shall be good, useful and available, and free of debts, liens and lia- 
bilities. All real estate and machinery, tobacco, raw, wrought and in process, supplies and materials, are to be taken at book value not exceeding cost. The book accounts included in such assets are to be satisfactorily guaranteed.

The deliveries and conveyances herein contemplated shall be as of March 1st, 1900. Said proposed corporation shall accept and assume such contracts of the Atlantic Snuff Company, The American Tobacco Company, Continental Tobacco Company and P. Lorillard Company, as Messrs. Henry D. Moore, George B. Wilson, James B. Duke and John B. Cobb shall agree that it is advisable for said proposed corporation to accept and assume.

If said proposed corporation shall pay any money, or deliver any article or thing on account of any obligation, by way of rebate or otherwise issued or undertaken by the Atlantic Snuff Company, or The American Tobacco Company, or Continental Tobacco Company or P. Lorillard Company, prior to March 1st, 1900, the amount so paid by said proposed corporation, or the value of the article or thing so delivered by said proposed corporation, in performance of such obligation, shall be refunded to said proposed corporation by the corporation, or party, whose obligation was thus performed by said proposed corporation; though this shall not be construed as binding on said proposed corporation to pay any such obligation unless it elects to do so; if any manufactured goods sold by the Atlantic Snuff Company, The American Tobaceo Company, Continental Tobacco Company or P. Lorillard Company have to be taken or transferred by said proposed corporation, the amount of loss or injury sustained by said proposed corporation by such taking or transfer shall be paid to it by the corporation or party who sold such goods.

There shall be a committee of four to determine the available assets, exclusive of real estate and machinery, of the Atlantic Snuff Company, The American Tobacco Company, P. Lorillard Company and Continental Tobaceo Company. Two members of this committee shall be appointed by Henry D. Moore and two by James B. Duke. If the decision of such committee as to the availability of any such assets shall not be satisfactory to its owner, and cannot be made satisfactory within three days after the report of the committee thereon, the difference of opinion shall be settled by an arbitrator selected by said committee, whose decision shall be final and conclusive and shall be made within five days after the time of his selection.

One-half of the expenses of organization of said proposed corporation, which have to be paid in advance of said organization, shall be advanced by the parties of the first part and the other half by the parties of the second and third parts. and all such advances shall, im- 
mediately after its organization, be refunded by said proposed corporation.

Said proposed corporation shall be organized by and under the advice of the firm of Jones, Carson \& Beeber and W. W. Fuller, none of whom shall make any charge to said proposed corporation for any services rendered by them; the said firm of Jones, Carson \& Beeber to look for their compensation solely to the parties of the first part, and the said W. W. Fuller to look for his compensation solely to the parties of the second and third parts. It is understood, however, that the new corporation shall pay a fee to Jones, Carson \& Beeber, in the event of its securing, through their advice, the acquisition, upon satisfactory terms, of Geo. W. Helme Company, it being understood that such compensation shall be twenty-five thousand dollars $(\$ 25,000)$ if said Geo. W. Helme Company agrees to sell to such proposed corporation, upon satisfactory terms to it, within 60 days hereafter; or, only twelve thousand five hundred dollars $(\$ 12,500)$ if after 60 days, and within four months of this date, and if not agreeing so to sell within at least four months, then no fee to be paid to the said Jones, Carson \& Beeber.

The parties of the first, second and third parts hereto, respectively undertake to have made known and imparted to the designated agents of said proposed corporation, the processes, formulæ and recipes for the preparation and manufacture of snuff, employed by the Atlantic Snuff Company, The American Tobacco Company, Continental Tobacco Company and P. Lorillard Company.

The parties of the first part agree that each of the directors of the Atlantic Snuff Company shall enter into contracts with the proposed corporation not to go into the business of manufacturing snuff, in the United States, for a period of ten years, either directly or indirectly, or to take any interest in manufacturing snuff in said country, during the said time, without the written consent of the said proposed corporation; and that similar contracts shall be entered into by The American Tobacco Company, Continental Tobacco Company and P. Lorillard Company.

It is agreed that the property and business of the corporation shall be managed by a board of fifteen directors divided into classes as the committee above named shall agree. Shares of preferred and common stock shall have equal powers of voting.

The by-laws shall provide that the President, as such, shall, receive a salary not exceeding fifteen thousand dollars a year; that the VieePresident shall receive a salary not exceeding five thousand dollars a year; that the Treasurer shall receive a salary not exceeding five 
thousand dollars a year, and that the Secretary shall receive a salary not exceeding five thousand dollars a year.

The by-laws shall not be amended except by at least two-thirds of the whole Board of Directors. A quorum of said board shall consist of five directors.

The by-laws shall provide that the stock shall forthwith be listed on the New York Stock Exchange.

The charter shall provide, if counsel conclude that such provision can be legally introduced into the same, that the preferred stock shall not be increased beyond the amount of twelre million five hundred thousand dollars $(\$ 12,500,000)$ without the assent of, at least, seventy per cent. of the preferred stock.

The details of organizing said proposed corporation, and the carrying out of this agreement, shall be determined by a committee composed of Henry D. Moore, George B. Wilson, Chas. E. Halliwell and John B. Cobb. They shall proceed forthwith to earry into effect the same, and to prepare by-laws to be submitted for adoption, and any question that may arise between the contracting partics hereto, in the formation of the proposed corporation, and the conveying of any property the settlement for which is not provided for herein, shall be determined by the decision of three-fourths of such committee after the consideration of such disputed question.

To the performance of the agreements hereinbefore made, the parties hereto each pledges his earnest, bona fide efforts, but it is to be understood that no signer hereto incurs any personal liability for non-performance of any part of this agrecment.

Witness our hands and seals, at the City of New York, this 15th day of February, 1900.

Geo. B. Wilson.

[SEAL.]

Henry D. Moore. [seal.]

JohN W. Woodside. [sEal.]

J. B. DuKE.

[SEAL.]

J. В. СОВB.

[SEAL.]

Witness all signatures

Geo. M. Gales. 


\section{AGREEMENT PRELIMINARY TO THE FORMATION OF} THE AMERICAN CIGAR COMPANY.

This agreement, made and entered into this $3 \mathrm{~d}$ day of January, 1901, by and between-

George J. Smith, of Kingston, N. Y., and Harry J. Luce, of New York City, N. Y., partners, doing business under the name and style of Powell, Smith \& Company (hereinafter called "Partners") parties of the first part; and

The American Tobacco Company, a corporation organized and existing under and by virtue of the laws of the State of New Jersey( hereinafter called "American Company") party of the second part; and

Continental Tobacco Company, a corporation organized and existing under and by virtue of the laws of the State of New Jersey (hereinafter called "Continental Company") party of the third part:

Witnesseth :

That partners, as an inducement to the American Company and Continental Company, to enter into this contract, represent and warrant to them :

1st. That, as partners in the business of manufacturing and selling cigars under various brands, they have for the past three years done a business, as follows:

\section{In the year 1898}

Number of cigars sold.

$52,199,257$

Amount received for cigars sold

$\$ 1,732,441.95$

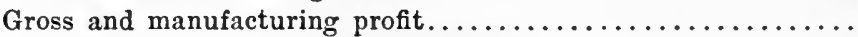

$419,412.72$

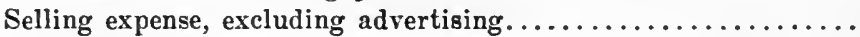

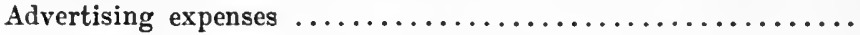

Net profit

$164,190.18$

$57,747.42$

$\$ 197,475.12$

In the year 1899

Number of cigars sold $\ldots \ldots \ldots \ldots \ldots \ldots \ldots \ldots \ldots \ldots$

Amount received for cigars sold.

$61,036,256$

Gross or manufacturing profit.

$\$ 2,014,242.73$

$455,301.93$

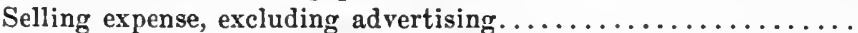

$169,488.79$

Advertising expenses

$100,642.37$

Net profit

$\$ 185,170.77$

In the year 1900

Number of cigars sold

$70,046,663$

Amount received for cigars sold

$\$ 2,189,919.44$

2nd. That Partners own and have used without interference or adverse claim the trade-mark used by them, and that they will be

1 From the Report of the Commissioner of Corporations on the Tobacco Industry. 
able to make the conveyance or conveyances hereinafter set out and hereafter contemplated, and that said conveyance when so made will convey to the purchaser all of their property and good-will needful and useful in the carrying on of the business free from any debts or liabilities, and with full power and right in the purchaser to make use of the brands and trade-marks conveyed, as well as the tangible property and the trade-name "Powell, Smith \& Company."

It is agreed that the American Company and the Continental Company may send their expert accountants and agents to examine the books, papers, property and business of Partners, in order to verify the representations above made, and that Partners will afford such experts and agents full and unrestricted opportunity to make such examination.

And it is further agreed that if upon the completion of such examination such experts and agents of the American Company and the Continental Company shall agree and report that the representations of Partners above made are substantially true then and in that case a corporation shall be formed under the laws of the State of New Jersey, with power to engage in the business of manufacturing and selling cigars, cheroots and little cigars, and with such other powers as the said the American Company and the Continental Coinpany shall desire or be advised are desirable, with an authorized capital stock of ten million dollars $(\$ 10,000,000)$.

Said new corporation shall be organized, and the examinations hereinbefore provided for and hereinafter provided for shall be made as expeditiously as possible, so that on or as soon as practicable after January 16, 1901, (conveyances and inventories to be as of that date) Partners shall convey to said new corporation their entire cigar business, including name, good-will, trade-marks, trade-names, symbols, patents and copy-rights and rights analagous thereto, recipes of manufacture, and including also stock on hand, whether manufactured, in process of manufacture, or fully manufactured, labels, wrapping materials, advertising matter, and supplies, machines and appliances suitable and useful in the manufacture of cigars, and such as have been used by Partners in their manufacture of cigars, real estate in Kingston, N. $\dot{Y}$., and in Poughkeepsie, N. Y., suitable for the business of said new corporation, and all the property, whether herein specially mentioned or not, owned by Partners, useful and arailable in the business of cigar manufacturing (except cash on hand, bills receivable, accounts receivable and contracts not hereinafter scheduled belonging to said Partners, which cash, bills and accounts receivable and contracts not hereinafter scheduled are hereby expressly excluded from the contemplated conveyance); the 
said conveyance is to be of the exclusive right to the use of the name of the co-partners "Powell, Smith \& Company," as well as the name or names of either of the partners, and any name which Partners or the co-partnership has a right to use on its labels or advertisements.

Said conveyance is to contain warranties by Partners, jointly and severally, that the business and property conveyed are free from any lien, debt, liability, incumbrance or assessment of any kind, legal or equitable, including all taxes of whatever sort for the year 1900, and that the trade-marks conveyed are valid trade-marks, which Partners have the right to convey; and that they will jointly and severally warrant and defend the title made to said new corporation against all claims whatsoever and all persons whomsoever.

At the time of said conveyance, and in the same instrument, Partners shall and will covenant and agree each for himself that he will not, for a term of twenty years from the date of said conveyance directly or indirectly engage in the manufacture of tobacco into cigars, or into any other of its forms, or distributing the same, or own stock in any corporation other than said new corporation, and The American Tobacco Company and Continental Tobacco Company, so engaged in such manufacture or distribution within the several States, colonies or dependencies of the United States, or the several countries or nations of Europe (except the State of Utah and the Territory of Alaska) except for or with the written consent of said new corporation, authorized by a majority vote of all its Directors, and that they will not permit the use of their names, or the name of either of them whether in connection with each other or separately, or with or without other names or initials within said time hereinbefore mentioned, to wit, twenty years.

At the time of said conveyance, and in the same instrument, Partners shall each for himself agree to enter into and devote his whole time and best efforts to the service of said new corporation, and, if the new corporation desires so long to retain him, to remain in said business for five years, at the following salaries, respectively, all payable in equal monthly installments, to wit, George J. Smith ten thousand dollars $(\$ 10,000)$ per year; and Harry J. Luce ten thousand dollars $(\$ 10,000)$ per year. Said contract of employment shall not, however, require said new corporation to retain the service of either of Partners beyond a year after the said conveyance, and after said first year term the new corporation may at any time dispense with the services of either of said Partners without liability to him for any part of the unexpired term of five years.

At the time of said conveyance, and in the same instrument, Partners shall further, each for himself, agree to at any time thereafter 
instruct the designated agents of said new corporation as to any of the formulæ, process or recipes for the treatment or cure of tobacco and manufacture of cigars used by or known to him, and further instruct such designated agents in the use of such formulæ, recipes or processes, and that he will not make known to any other than such designated agents, or make use of any such formulx, processes or recipes.

In consideration of the conveyances, covenants and agreements by Partners as aforesaid, said new corporation is to pay to Partners the sum of One Million two hundred and fifty thousand dollars $(\$ 1,250$,000) in cash, which said amount shall be in full payment for the trade-names, good-will, trade-marks, symbols, recipes, copyrights, patents and rights analogous thereto and all other intangible assets belonging to said Partners of whatsoever kind, and in any way useful or available in the cigar business, except book accounts, bills receivable and contracts not scheduled, and a further sum for the tangible assets useful and available in the cigar business, to be arrived at as follows: The real estate, buildings, unmanufactured stock, stock in process of manufacture, and that fully manufactured, at the cost thereof to Partners as shown by the books of Partners, if the same have been accurately kept. In arriving at the cost of any such property no amount is to be allowed for interest on the investment made by Partners, but in the case of stock of tobacco the actual cost of earriage, storage and insurance is to be considered. Machinery and fixtures, such as are useful and available in the cigar business is to be taken at its actual and agreed value, and in no case exeeeding cost. Wrapping material, labels and supplies other than leaf and manufactured stock are to be taken just as leaf and manufactured stock, provided, however, that none shall be taken by said new corporation except such as will be useful and available to it in its business. Such leaseholds as the said Partners have useful to said new corporation in its business shall be turned over to said new corporation without premium. If Partners have made advances on contracts for purchase of leaf, and additional amounts are due to the vendors thereof, the said new corporation will upon receipt of such leaf if said contract is taken by said new corporation pay for the same by returning to Partners the amount advanced by them without interest, and settling with the vendor for the balance due him. No contract of whaterer sort not set out in Schedule $\mathrm{A}$ hereto attached shall be taken by said new corporation unless the same is agreed to by W. R. Harris who is the agent appointed hereby for both the American Company and the Continental Company to pass on such contract.

It is agreed that said new corporation shall be organized under the 
direction of the legal advisers of the American Company and the Continental Company and there shall be no charge to said new corporation for legal advice and services in its organization. The expense of such organization other than legal advice and service shall be borne by it, the said new corporation. The stock of said new corporation shall be issued for cash as par, and it shall be issued and paid for in the proportion of seven per cent. to Partners or their nominees, forty-six and one-half per cent. to the American Company or its nominees, and forty-six and one-half per cent. to the Continental Company or its nominees, and each of the parties shall meet any call made by the directors for cash in this way; seven per cent. of the amount so called to be paid by Partners, or their nominees; forty-six and one-half per cent. by the American Company or its nominees, and forty-six and one-half per cent. by the Continental Company or its nominees. Stock shall issue to the amount that payments are made, and at the time such payments instead of being credited to the subscribers paying the same on their respective stock subscriptions. In case the directors of said new corporation decide to purchase any other property or business and to pay for the same in stock and not in cash the stock necessary and used in such purchase shall be deducted equally from the amount that under this agreement would be coming to the American Company and the Continental Company and the payments required by them shall be likewise abated.

The said new corporation shall be organized with a paid-up capital stock of ten thousand dollars, of which the nominees of the American Company and the nominees of the Continental Company shall hold $\$ 9,300$ and Partners and their nominees shall hold $\$ 700$, and these first stockholders shall organize and elect a board of directors and thereafter such board of directors shall control the operation of said new corporation, controlling only by the provisions of this agreement. The said nominees of said the American Company and the Continental Company shall select a name for said new corporation and fix the number of the directors.

In witness whereof, and of all the foregoing, the said Partners have caused this instrument to be signed in their partnership name "Powell Smith \& Company" by George J. Smith, one of its active partners, and they have individually set their hands and seals hereto; and the said party of the second part has caused this instrument to be signed in its corporate name by its President, and its corporate seal to be fixed, attested by its Secretary; and said party of the third part has caused this instrument to be signed in its corporate name by 
its 1st Vice-President, and its corporate seal to be affixed, attested by its Secretary.

All done in triplicate, the day and year first above written.

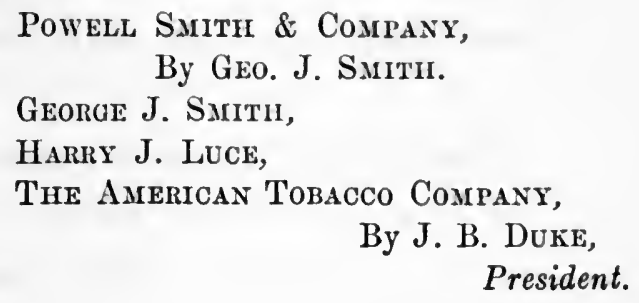

Powell Saith \& Company, By Geo. J. S.mitir.

Georae J. Smith, HARRY J. LUCE, The american Tobacco Company, By J. B. Duke, President.

[SEAL.]

Attest:

R. L. Patterson,

Secretary.

Continental Tobacco Company,

By Cilas. E. Halliweld,

1st Vice-President.

[SEAL.]

Attest:

W. H. McAlister,

Secretary. 


\section{CONSOLIDATION BY SALE OF ASSETS}

Iowa Central Railway Company

The Minneapolis \& St. Liouis Railroad Company

Total Mileage Owned and Operated, 1,585 Miles.

NEw YoRK, December 13, 1911.

To the Stockholders of

\section{Iowa Central Railifay Company and}

The Minneapolis \& St. Louis Railroad Company:

The Boards of Directors of the Iowa Central Railway Company and of The Minneapolis \& St. Louis Railroad Company have agreed, subject to the approval of the stockholders of said Companies, at meetings to be held, for the Iowa Central Railway Company, on December 19th next, and for The Minneapolis \& St. Louis Railroad Company on December 18th next, for the sale and conveyance by the Iowa Central Railway Company of all its railroad and property, subject to its debts and liabilities, to The Minneapolis \& St. Louis Railroad Company and for the payment by the Iowa Central Railway Company to The Minneapolis \& St. Louis Railroad Company of the sum of $\$ 2,500,000$, in consideration for the issue and delivery by The Minneapolis \& St. Louis Railroad Company of 19,175 shares of its preferred stock, 93,702 shares of its common stock and $\$ 2,500,000$ of an issue about to be made by it of Refunding and Extension Mortgage Five Per Cent. Fifty-Year Gold Bonds.

Said bonds will be dated January 1, 1912, and will bear interest from February 1, 1912, at the rate of 5 per cent. per annum, payable quarterly on the first days of February, May, August and November in each year, and will be redeemable at 105 at any interest period. Said bonds will be part of an authorized issue of $\$ 75,000,000$ of bonds secured by mortgage upon the railroads and properties now owned by The Minneapolis \& St. Louis Railroad Company and the Iowa Central Railway Company, subject to existing liens thereon, and said mortgage, through the retirement of the outstanding $\$ 6,250,000$ of bonds of the Minnesota, Dakota \& Pacific Railway Company, will also be a first lien upon the railroad and property of said Minnesota, Da- 
kota \& Pacific Railway Company constituting the recent extension to the Missouri River, 229.6 miles. Said mortgage will also be a first lien upon the contemplated extensions of the property of The Minneapolis \& St. Louis Railroad Company. 'The issue of the $\$ 2,500,000$ of bonds above referred to will not increase the aggregate indebtedness of the Companies as the proceeds are to be used to take up maturing obligations.

It is proposed that the securities to be received by the Iowa Central Railway Company will be distributed upon the following basis :

One share of the preferred stock and nine shares of the common stock of The Minneapolis \& St. Louis Railroad Company will be exchanged for each ten shares of the preferred stock of the Iowa Central Railway Company; and one share of the common stock of The Minneapolis \& St. Louis Railroad Company will be exchanged for two shares of the common stock of the Iowa Central Railway Company.

By an arrangement between the two companies, and under an agreement between the Iowa Central Railway Company and Messrs. J. S. Bache \& Co., Bankers, of New York City, the Iowa Central Railway Company has agreed, subject to the approval of its stockholders and of the stockholders of The Minneapolis \& St. Louis Company, that the $\$ 2,500,000$ of Refunding and Extension Mortgage Bonds above referred to, shall be offered by the Iowa Central Railway Company for subscription to stockholders of the two companies as the same appear of record on the books of said companies at the close of business December 26, 1911, pro rata, to the extent of 10 per cent. of the par value of the shares of the stock held by them respectively, together with $\$ 1,250,000$ of the preferred stock of The Minneapolis \& St. Louis Railroad Company, at a price of $\$ 1,000$ for each $\$ 1,000$ Refunding and Extension Mortgage bond, with preferred stock of the par value of $\$ 500$. The entire amount of subscriptions will be payable on or before January 25, 1912. A syndicate has been formed by Messrs. J. S. Bache \& Co. for the purpose of purchasing so much of said $\$ 2$,500,000 of bonds and $\$ 1,250,000$ of preferred stock as shall not be subscribed and paid for on or before January 25, 1912, by the stockholders of the two companies.

The money received from the proceeds of this transaction will enable the properties to discharge obligations maturing February 1, 1912 , aggregating $\$ 2,100,000$ and release underlying bonds aggregating $\$ 1,850,000$.

2. The capitalization of The Minneapolis \& St. Ionis Railroad Company, after the acquisition by it of the properties of the Iowa Central Railway Company, will be less than the aggregate capitalization of 
the two separate companies. The outstanding preferred stock of The Minneapolis \& St. Louis Railroad Company will be increased to $\$ 5$,917,500 , being about $\$ 4,100$ per mile, while the outstanding common stock will be at an average of about $\$ 10,000$ per mile.

The Iowa Central Railway Company has considerable value as a feeder to the Minneapolis \& St. Louis Railroad and logically. should be a part of a through line from the Missouri River to the Canadian border. While the records of the two companies show that without the tonnage concentrated upon its lines from The Minneapolis \& St. Louis Railroad Company, the Iowa Central Railway Company would be unable properly to sustain itself, its value to The Minneapolis \& St. Louis Railroad Company as a link in the connection which it is contemplated will be made with railroads at the Canadian border makes it desirable that they should be united.

The importance of the proposed extensions in the development of the properties can hardly be over-estimated. They should establish the property as one of the most important in the middle west, giving to independent Canadian roads a direct connection with Minneapolis and St. Paul, forming a through direct line from Canada and the Canadian northwest to the Gulf. The managers of the respective companies have the greatest confidence in the earning power and success of the properties with these plans executed. The Minneapolis \& St. Louis Railroad Company earned and paid dividends consecutively for fifteen years until January 1, 1910, when it was met with a crop failure in South Dakota which was repeated and aggravated in the present year. The conditions in that State, so far as it is possible to judge at this time, point to a good crop, as the earth, for the first time in three years, is thoroughly water-soaked.

Under the arrangement between the two companies and the agreement between the Iowa Central Railway Company and Messrs. J. S. Bache \& Co. above referred to, the right to subscribe for $\$ 2,500,000$ of Refunding and Extension Mortgage Bonds and $\$ 1,250,000$ of preferred stock of The Minneapolis \& St. Louis Railroad Company has been reserved to the stockholders of the two companies, as indicated above. In the event that the approval of the stockholders of the two companies to the foregoing plan is given at the special meetings to be held on December 18th and 19th next, subscription certificates will be mailed to stockholders on or about December 26th. Stockholders who desire to subscribe for more than their ratable proportion of these bonds and shares of preferred stock may indicate their wishes in a communication addressed to Mr. A. C. Doan, the secretary of the Iowa Central Railway Company at his office No. 25 Broad Street, New York City, and if any of these securities remain unsubscribed for, 
their wishes will receive consideration by Messrs. J. S. Bache \& Co., the bankers who have formed a syndicate to underwrite the entire issue.

Respectfully yours,

IOWA CENTRAL RAILIVAY COMPANY,

By Newman Erb,

President.

THE MINNEAPOLIS \& ST. LOUIS RAILROAD CO., By EDwin Hawlex, Chairman of the Board. 


\section{Confidential.}

\section{PLAN FOR THE CONSOLIDATION OF THE ELECTRIC} RAILWAY COMPANIES, THE GAS AND ELECTRIC LIGHT COMPANIES OF THE CITY OF NEW ORLEANS, LA., UNDER THE CONTROL OF THE NEW ORLEANS RAILWAYS COMPANY, A CORPORATION ORGANIZED UNDER THE LAWS OF THE STATE OF NEW JERSEY.

It is proposed to recapitalize the present New Orleans Railways Company on the basis of an authorized issue of fifty-year four and one-half per cent. gold sinking fund mortgage bonds to an amount of $\$ 40,000,000$, of which amount there will be held in the treasury for existing bonds.................. $\$ 12,846,000$ For future extensions and improvements........ $7,154,000$ To be issued now for the purchase of the securities of the present companies................. 20,000,000

Four per cent. cumulative preferred stock....... $\$ 10,000,000$ Common stock.................... $30,000,000$

It is proposed by the New Orleans Railways Company to take over by exchanging its securities the New Orleans Gas Light Company.

New Orleans Lighting Company.

Edison Electric Company.

Merchants' Electric Company.

New Orleans City Railroad Company......... about 115 miles. New Orleans and Carrollton Railroad, Light and

Power Company ...................... " 35 "

Orleans Railroad Company.............. " " 10 "

St. Charles Street Railroad Company......... " " 18 "

\section{Total} about 178 miles.

The Electric Light Companies are owned by the New Orleans and Carrollton Railroad, Light and Power Company, and the Gas Plant is owned by the New Orleans Gas Light Company, which is leased to and operated by the New Orleans Lighting Company, right to the control of all of which Companies, with the exception of the St. 
Charles Street Railroad Company, has been obtained in the interest of the New Orleans Railways Company.

The outstanding mortgage bonds of these Companies which cannot be retired are as follows:

New Orleans Gas Light Company.............

New Orleans City Railroad Company.............

New Orleans and Carrollton Railroad, Light and Power

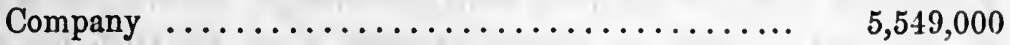

St. Charles Street Railroad Company........... $\quad 300,000$

Orleans Railroad Company................ $\quad 400,000$

$\$ 76,000$

$6,521,000$

$\$ 12,846,000$

It is believed, howerer, that a considerable amount of these bonds can be exchanged for the bonds of the New Orleans Railways Company to be issued under this Plan.

The bonds and stocks of the various companies to be controlled by the New Orleans Railways Company under this plan are as follows, and at least a majority of the stocks of each Company (except the St. Charles Street Railroad Company), as well as all the bonds of the New Orleans Lighting Company and the New Orleans Railways Company, are controlled by optional feature or otherwise for the purposes of this plan.

Bonds Pfd. Stock Com. Stock Total

New Orleans City R. R. Co....\$6,521,000 \$2,500,000 \$5,000,000 $\$ 14,021,000$

New Orleans \& Carrollton $R$.

$$
\text { R., L. \& P. C........ 5,549,000 }
$$

New Orleans Gas Light Co... 76,000

New Orleans Lighting Co.... 1,500,000

Orleans Railroad Co...... 400,000

New Orleans Railways Co.... 2,000,000

St. Charles Street Railroad Co. 300,000

\begin{tabular}{rrr}
$4,600,000$ & $2,500,000$ & $12,649,000$ \\
& $3,750,000$ & $3,826,000$ \\
$2,000,000$ & $3,500,000$ \\
300,000 & 700,000 \\
$5,000,000$ & $7,000,000$ \\
$1,000,000$ & $1,300,000$ \\
\hline
\end{tabular}

$\$ 42,996,000$

As the New Orleans Gas Iight Company has but $\$ 76,000$ bonds outstanding, of which $\$ 46,000$ can be retired April, 1903, and $\$ 30$,000 April, 1908, the new bonds will be practically a first lien on the property of that Company when all of its stock is secured.

The stocks and bonds now controlled or that may be acquired for the purposes of this plan are to be deposited under the mortgage given to secure the new Fifty-Year Four and One-half Per Cent. Sinking Fund Gold Bonds, and unless at least a majority of the 
stock of the St. Charles Street Railroad Company can be secured it will not be included in this plan.

For the year 1901 the receipts of the various companies were approximately $\$ 3,900,000$ gross, $\$ 1,500,000$ net.

The increase in gross receipts should be not less than 10 per cent. per annum, based upon what the properties have done in the past.

Operating expenses can be reduced by a consolidation of the power houses and shops; reduction in dead car mileage; substitution of oil as fuel, and reduction in general expenses about $\$ 265,000$ per annum.

The first year of operation under consolidation, based on the report of our engineers, Messrs. Sanderson \& Porter, of New York, whose letter is attached hereto, and corroborated by the above figures, should be :

Gross Earnings ................... \$4,234,000

Operating Expenses and Taxes............. 2,117,000

Net earnings $\ldots \ldots \ldots \ldots \ldots \ldots \ldots \ldots \ldots \ldots \quad \$ 2,117,000$ Interest Charges:

Existing Bonds ............. $\$ 630,855$

New Bonds .............. 900,000

Total ................... \$1,530,855

Surplus $\ldots \ldots \ldots \ldots \ldots \ldots \ldots \ldots \ldots \ldots$

Four per cent. on $\$ 10,000,000$ Cumulative Preferred Stock ................. 400,000

Surplus for Common Stock............ $\$ 186,145$

For the calendar year 1908, Surplus.......... $\$ 719,143$

Four per cent. on the Cumulative Preferred Stock 400,000

Surplus for Common Stock............. \$319,145

The receipts for 1901 as stated above cannot be taken as a basis of what the properties will do in 1902, as the St. Charles Railroad has added about 60 per cent. to its track mileage, while the Gas Company and the Electric Light Company are improving and extending their plants by the expenditure of $\$ 1,000,000$, which should result in a large increase of business over and above the natural increase from year to year. 
In order that the management for five years may be controlled it is intended that the scope of the present roting trust of the New Orleans Railways Company shall be so extended as to cover the intended new issue of stock, whereby the stock will all be represented by roting trust certificates, which certificates will be delivered to subscribers, covering the amount of stock to which they may be entitled.

Subscribers are to receive a commission of 5 per cent. in cash and 10 per cent. in the Common Stock of the New Orleans Railways Company, one-fifth of each to be retained by the Manager as compensation for managing the Syndicate.

The owners of the existing securities of the companies proposed to be acquired hereunder are to be given the privilege of accepting the following securities of the New Orleans Railways Company in lieu of each $\$ 1,000$ in cash to which they might be entitled:

Four and One-half Per Cent. Bonds at par..........\$769 23

Four Per Cent. Cumulative Preferred Stock at par...... 38461

Common Stock at par.................... 76923

Estimating the value of the Four and One-half Per Cent. Bonds at 100 Estimating the value of the Cumulative Preferred Stock at....: 60 Estimating the value of the Common Stock at........... 15

Holders exchanging will receive about

77 per cent. of the option price of their holdings in $4 \frac{1}{2}$ Per Cent. Bonds;

23 per cent. of the option price of their holdings in 4 Per Cent. Cum. Pfd. Stock;

11 per cent. of the option price of their holdings in Com. Stock;

\section{Total,}

showing present holders about $\$ 1,110$ in value of new securities in lieu of $\$ 1,000$ cash value.

Subscribers are entitled to receive for the cash advanced certificates of the New York Security and Trust Company, exchangeable as provided for the above securities in like proportion, in addition to the above-named commission. The securities which are taken by the Syndicate as above may be held by the Manager as agent of the Syndicate for twelve months from June 1, 1902, and may be sold by the Manager for the benefit and account of the Syndicate at not less than the following prices:

Four and One-half Per Cent. Bonds........ 100 and interest

Four Per Cent. Cumulative Preferred Stock..... 60

Common Stock ................... 15 
The Syndicate may, however, be dissolved at an earlier date and the securities delivered to the Subscribers if the Managers so determine.

Twenty-five per cent. of the subscriptions will be payable on June 1, 1902, and the balance when called for by the Manager. No further single call will be made for more than 25 per cent. of the subscription, and thirty days' notice of any call shall be given to Subscribers.

\section{NEW YORK SECURITY AND TRUST COMPANY,} Manager.

By Charles S. Fairchild, President.

Agreement, made the fifth day of May, 1902, by and between the New York Security and Trust Company, of the City of New York, Manager, party of the first part, and the subseribers hereto (hereinafter called severally the "Subscribers" and collectively the "Syndicate"), severally parties of the second part.

Whereas, the New York Security and Trust Company has itself and in connection with certain other parties for whom it acts as agent, secured the right to the control of certain properties in the City of New Orleans, Louisiana; and

Whereas, the parties hereto desire to form a Syndicate to underwrite the securities to be issued under a certain Plan for the consolidation of the Electric Railways, the Gas and Electric Light Companies of the City of New Orleans, Louisiana:

Now, Therefore, in consideration of the premises and of the mutual promises herein contained, the New York Security and Trust Company (which is to be Manager of the Syndicate) and the Syndicate mutually have agreed, and do agree as follows:

First. That the control of securities acquired by the said "Manager" as agent, shall be vested in the New Orleans Railways Company either by the purchase or through exchange of the securities of the constituent companies for the new securities of the New Orleans Railways Company, said corporation to be capitalized as stated in the plan hereto annexed, which is to be taken as a part of this agreement.

Second. The "Subscribers" covenant and agree to pay the "Manager" the amounts set opposite their respective names or the amount allotted to them by the "Manager" as follows: On June 1, 1902, 25 per cent. of the allotment; the remainder whenever called upon by the "Manager," it being understood that no single call shall be made for more than 25 per cent. of the entire allotment, and that in each case thirty days' notice shall be given of any such call. 
Third. It is understood that the "Manager" is to offer, either directly or through the officers of the New Orleans Railways Company, to the present holders of the securities of the constituent companies, the right to accept the new securities on the following basis for each $\$ 1,000$ of purchase price:

In par value Four and One-half Per Cent. Gold Sinking

Fund Bonds ........................\$769 23

In par value Four Per Cent. Cumulative Preferred Stock. . 38461

In par value Common Stock................ 76923

All the securities not taken as above by the holders of the securities of the constituent companies are to be held in escrow for a period of twelve months from June 1, 1902, during which time the "Manager" shall have the right to sell any or all of the securities so held at not less than the following prices:

Four and One-half Per Cent. Bonds at 100 and interest;

Four Per Cent. Cumulative Preferred Stock at 60 ;

Common Stock at 15.

Only such securities belonging to the Syndicate shall be issued as are needed to secure stocks and bonds of the constituent companies, and such securities so acquired shall be deposited with the Trustee under the mortgage of the New Orleans Railways Company.

Until June 1, 1903, or until the final distribution hereunder, the New York Security and Trust Company, in such manner, at such prices, on such terms and in such amounts as they may deem expedient, shall have power, for account of the Syndicate, to make purchases not to exceed 10 per cent. of the total amount of Syndicate, of the Four and One-half Per Cent. Gold Bonds and of the Preferred and Common stocks or subscriptions of the New Orleans Railways Company, and they may resell any such bonds, stocks or subscriptions which they may have purchased; and, in their discretion, they may make any further undertakings of any kind with any persons concerning any such bonds and stocks. They may apply towards any such purchases any sums realized from any sales of bonds, stocks or subscriptions of the New Orleans Railways Company under any provision of this agreement; and they may make advances, or may procure loans, and may secure the same to such amounts and in such manner as from time to time they may deem expedient for any of the purposes of this agreement.

The "Subscribers" are to receive a cash commission of 5 per cent. and a stock commission of 10 per cent. in the Common Stock of the New Orleans Railways Company on the face value of their allotments, less one-fifth thereof which is to go to the "Manager" for its services. 
Fourth. The Manager agrees to issue to the "Subscribers" upon payment of their subscriptions herein, negotiable subscription receipts substantially in the form as follows:

No............

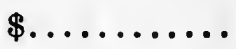

\section{PARTICIPATION RECEIPT}

\section{NEW ORLEANS RAILWAYS COMPANY SYNDICATE}

New York Security and Trust Company hereby acknowledges receipt from , of the sum of dollars being payment of per cent. upon the subscription of dollars to the Syndicate for underwriting the purchase and exchange of the stock and bonds of certain Electric Railway Companies the Gas and Electric Light Companies of the City of New Orleans, under a certain plan and agreement thereto attached bearing date the Fifth day of May, 1902, in accordance with the terms and conditions of which plan and agreement, (they) (he) ha been allotted a participation, and to all terms and conditions of said plan and agreement the holder hereof fully consents.

When the bonds and stocks, or the proceeds of said bonds if sold, are ready for delivery by us, the holder hereof to be entitled upon surrender of this certificate to receive in full.liquidation of his right to participation such of said bonds and stock, or the proceeds of said bonds, as have been allotted (them) (him.).

This receipt is transferable only on the books kept for the purpose at the office of the New York Security and Trust Company.

No assignment or transfer of any interest hereunder shall release the original subscribers from (their) (his) full liability on (their) (his) subscriptions, which shall remain binding until paid in full. All payments must be evidenced by endorsements hereon.

Dated New York, , 1902.

NEW YORK SECURITY AND TRUST COMPANY, Syndicate MaNager,

By

Vice-President.

Secretary.

Fifth. In case of the failure of any Subscriber to perform any of his undertakings hereunder, as and when called for by them, the Manager on behalf of itself and the Syndicate shall have, and at its sole and exclusive option it may exercise, the right to exclude such Subscriber from all interest in the Syndicate; and in its discretion, with- 
out any proceedings at law or in equity, and in such manner as it may see fit, it may sell at public or private sale the participation of such Subscriber, and all his rights and interest under this agreement and in or to any bonds, stocks or moneys that shall be received hereunder. At any such sale the Manager or any party hereto, or any person, may become purchasers, without any accountability; but notwithstanding any sale, whether public or private, such defaulting Subscriber shall be responsible to the Manager and to the Syndicate for all damages caused by any failure on his part.

Sixth. The "Manager" is to retain possession of all bonds, preferred and common stocks, received by it hereunder for account of the holders and "Subscribers" herein until they have been sold, or twelve months from the date hereof, and is hereby constituted agent and attorney in fact for "Subscribers" to vote said shares or to cause the same to be voted upon at all corporate meetings of said companies as may be necessary, requisite or advantageous for the carrying of such plan into full execution.

Seventh. Each and every "Subscriber" shall be taken as agreeing that the enumeration and expression of the powers hereinbefore expressly conferred upon the "Manager" shall not be construed as excluding or limiting the exercise by the "Manager" of powers not expressed herein and each of them is to be taken as hereby constituting and appointing the "Manager" their attorney irrevocably and with full power of substitution in the premises to do all such other and additional matters and things as in the sole judgment of the "Manager" may be wise and to the interest of said "Subscribers," including such alterations, changes or modifications of the terms and conditions of the Plan of Purchase and the amount and character of securities to be allotted thereunder as the "Manager" may from time to time deem advisable, or to abandon the undertaking, anything hereinbefore or in said Plan of Purchase expressed, implied or to be inferred therefrom to the contrary notwithstanding.

Eighth. For convenience of parties, signatures of "Subscribers" may be taken upon a copy or copies of this Agreement with like effect as if one of the duplicate originals were signed by them, and it is expressly agreed and understood that each and every taker or holder of the Participation Receipt hereunder, whether original or an assignee thereof, shall be deemed and taken to have subscribed to this Agreement and to be subject in all respects to each and every of the terms and provisions thereof.

In evidence whereof this Agreement is executed in duplicate and the New York Security and Trust Company has caused its corporate seal to be hereto attached, attested by its Secretary and the Partici- 
pants have affixed their signatures hereto the day and year first above written, each for the amount set opposite his or their respective names.

NEW YORK SECURITY \& TRUST COMPANY,

By Charles S. Fairchild,

President.

Attest:

L. Carroll Root,

Secretary.

[COPY]

\begin{tabular}{|c|c|c|}
\hline Name. & Address. & Amount \\
\hline $\begin{array}{l}\text { SANDERson \& PorTer, } \\
\text { Engineers and Contractors. } \\
\text { Edwin N. Sanderson, } \\
\text { H. Hobart Porter, Jr. } \\
\text { Francis Blossom, } \\
\text { Richmond Talbot. }\end{array}$ & $\begin{array}{c}\text { Telephone, } 2721 \text { Cortlandt. } \\
\text { BANK of commerce BuILdING, } \\
31 \text { Nassau Street. } \\
\text { New York, May 1, 1902. }\end{array}$ & \\
\hline
\end{tabular}

New York Security and Trust Company,

46 Wall Street, New York.

Gentlemen: Referring to the proposed consolidation of the Electric Railway Companies, the Gas and Electric Light Companies of New Orleans, Louisiana, we beg to say that from the examination which we made of these properties, and from the reports submitted to us, we believe that the total receipts of the various companies, for the year 1902 , based on the earnings already shown, will be. . $\$ 4,234,000$ and the operating expenses and taxes, under the present

conditions .......................... 2,255,550

Leaving an income from operation of about........ 1,978,450

When these companies are consolidated and operated as a unit, and the proposed extensions and improvements completed, a considerable increase in the gross revenue will result, and a substantial decrease in the operating expenses be assured.

In our opinion the united property should be operated for

50 per cent. of the gross receipts, which would show

a net income at the current rate of gross earnings. . $\$ 2,117,000$

for the first full year after consolidation. 
Should this consolidation and the improvements contemplated be effected immediately, we believe that for the calendar year 1903 the Company will show gross receipts ....................... $4,500,000$ Operating and Taxes $\ldots \ldots \ldots \ldots \ldots \ldots \ldots \ldots \ldots$ 2,250,000

Net Income

Yours very truly,

(Signed) Sanderson \& Porter. 


\section{BASIS OF CONSOLIDATION ${ }^{1}$}

A corporation to be formed under the laws of the State of Michigan, with a paid-up capital of ten million dollars, to be apportioned into 6 per cent. preferred stock and common stock, as the parties interested may hereafter determine.

This corporation to purchase all the assets, property, good-will, etc., of all the four companies and to pay therefor in preferred and common stock and by an assumption of the indebtedness of each company.

The amount of preferred and common stock, to be paid to each company, to be determined by the value of the net tangible assets and the valuation placed upon the earning power of each company.

In placing a value upon the tangible assets, same to be reached as follows :

(1) The land, buildings, machinery, tools, and patterns, to be determined by appraisers, to be chosen by a majority of a committee made up of one appointed by each of the companies; on failure of this committee to agree on appraisers the selection to be left to the committee who present these suggestions.

(2) Inventories of raw materials, work in progress and manufactured stock to be taken, and valuations placed thereon by the individual companies, and this to be done under the supervision of a disinterested party, to be named by the committee.

The inventories are to be made as of the same date, and to be taken at substantially the same time.

When completed the inventories are to be passed and agreed upon by a committee consisting of a representative of each of the companies and one to be named by the committee. The decision of these five to be binding.

(3) In reaching the value of the earning power of the several companies, consideration is to be given to the following details:

(a) That profits are incidental to the business and have not been anticipated.

(b) To the charging to operating expenses of items, exceptional or unusual, and which have had the effect of reducing profits below normal.

(c) The effect upon the earnings of the money paid out as interest upon borrowed capital, in case it be found that the borrowings (loans) made by the several companies are disproportionate to each other.

(d) That all charges to operating expenses are proper charges

1 Quoted by W. H. Lough in his Corporation Finance from an article in the Journal of Accountancy by F. H. McPherson, F.C.A. (November, 1908). 
against the business and that they are made for and during the proper period.

(e) That proper and reasonable allowances have been made for repairs and renewals and that these have been charged against earnings.

(f) That charges against earnings for depreciation are adjusted upon an equitable basis.

(g) Such other matters as appear from an examination of the accounts and which would prejudicially affect the earnings of any of the companies, either advantageously or disadvantageously.

(h) The value of the earning power to be determined by a consideration of the business done by each of the several companies for the three years, 1903, 1904 and 1905.

(i) Accountants to be selected by the committee and questions which may arise as to treatment of various matters and about which there is difference of opinion, to be determined by the committee.

(j) All costs and expenses incurred in making appraisals, examination of accounts, or of performing the other duties in connection with the formation of the proposed new company to be charged to and borne by the new company; should the new company not be formed, then such costs, expenses, and disbursements to be borne by the four individual companies in proportion to the number of men employed by each. 


\section{AGREEMENT TO CONSOLIDATE.}

Each vendor executing this agreement also executes and delivers a schedule of the entire property, which it sells to said purchaser, setting forth briefiy the various classes of property, with the sufficient description of the several items of real estate, plant and movables to identify the same, which schedule sets forth the value of the entire property so sold, the tangible and intangible property in separate items, the tangible property being valued as prescribed by subdivisions $a$ and $b$ in the Method of Appraisal hereinafter set forth, and the value of its intangible property ascertained and certified by one or more responsible public accountants, as prescribed by subdivision $c$ of said Method of Appraisal, together with a statement of any additional facts, and of the valuations based thereon, which, in the vendor's judgment, may aid the Appraisal Committee in exercising the discretion conferred upon it by subdivision $b$ of said Method of Appraisal. The valuations of the tangible and intangible properties so made by each vendor shall be considered as prima facie evidence of the true value of said vendor's property for the purposes of sale, but shall in no case be controlling upon the Appraisal or Executive Committee hereinafter appointed, such valuations or prices being subject in all cases to any investigation and modification which the said committee or committees may deem that justice requires; the total of such valuations as verified or modified according to the terms of this agreement, to be the purchase price which said vendor is to receive for its entire property so sold.

\section{PURCHASE PRICE}

The purchase price to be paid to such vendor for the property sold by it to the purchaser shall be the total value of its tangible and intangible property and shall be paid in stock of the purchaser at par, as follows:

1. Tangible property paid for in preferred, etc.

Each vendor whose net earnings for the six months ending July 1st, 1898, amount to 4 per cent.-that is, at the rate of 8 per cent. per annum-on the value of its land and plant, ascertained as above, shall receive preferred stock for the full value of all its tangible property.

Any vendor whose net earnings for the said period of six months shall amount to less than at the rate of 8 per cent. per annum on the

1 Quoted by W. H. Lough in his Corporation Finance as an "actual agreement where several fair-sized manufacturing corporations and partnerships were to be consolidated." 
value of its land and plant, shall receive preferred stock to the amount of twenty-five times its net earnings for said six months; and the balance of the value of said tangible property it shall receive in common stock.

Each vendor has upon its schedule set forth a statement of its net earnings for said period, which is subject to modification by said committee under the above rules applicable thereto.

\section{Intangible property paid for in common stock.}

The entire value of the intangible property, ascertained as per this agreement, shall be paid by the purchaser in its common stock at par.

Simultaneous with the sale and transfer of its properties each vendor shall receive from the purchaser in stock, or if permanent certificates are not ready, then script for the same, one-half of the purchase price to which it claims to be entitled by its schedule, less an amount of preferred stock equal to 125 per cent. of its mortgage indebtedness, if any, and the remainder of said stock shall be withheld by the purchaser until the exact amount of the purehase price shall have been finally determined as herein provided, whereupon the vendor shall become entitled to the remainder of the purchase price, but the purchaser may out of such remaining stock retain an amount thereof sufficient to secure it against any defective title and against any indebtedness which is not otherwise sufficiently provided for.

\section{APPRAISAL, ETC.}

Each vendor expressly covenants and agrees that the property set forth by it in its schedule has been fairly and honestly valued in accordance with the following rules and methods, which shall be the rules and methods to govern the Appraisal and Executive Committees in their verification or modification of the same.

\section{METHOD OF APPRAISAL}

(1) Tangible Property.

(a) Land:

Land shall be separately appraised at its actual value without reference to plants thereon, and consideration shall be given to special adaptability or want of adaptability to the business.

Plants shall be appraised apart from the bare land at their value to-day to a going concern for the purpose for which used, based upon present cost of construction at the same places respectively. No vendor shall set forth in its schedule any unimproved land or other property belonging to it which is neither a part of the plant of such vendor nor essential in the operation of the same, nor shall the same be purchased by the second party. 
(b) Materials, Supplies and Manufactured Product.

These shall be appraised at what it would cost to replace the same at the place and date of the transfer of the same to the purchaser.

(2) Intangible Property.

(c) Intangible property shall be appraised by multiplying by ten the average yearly earnings during the past five and one-half years, which shall be ascertained as follows:

In order to arrive at the earnings of the property sold by each vendor and to determine on a uniform basis fair for all, the earning power of the property so sold, each vendor shall add to its net profits such of the following items as have been theretofore deducted by said vendor in ascertaining its net profits during said period.

1. Interest on indebtedness.

2. Insurance of any description.

3. Arbitrary items of depreciation or wear and tear not paid out or actually incurred as a debt, and all items of new construction.

4. Also salaries and compensation paid to officers, directors, partners, trustees, superintendents of departments or works, general managers, auditors, cashiers and chief accountants, but all wages, salaries and compensation paid to laborers, servants, foremen, clerks and employees in subordinate positions shall remain charged against earnings.

5. The accountants must ascertain the amounts expended by each of said vendors for repairs, renewals and maintenance of plant which have been deducted from earnings during said period of five and onehalf years, and the said amounts so ascertained are set forth on the schedules of said vendors.

In order to place said vendors on a uniform basis as to the amounts expended, or which ought to have been expended, for repairs, renewals and maintenance of plant and charged against or deducted from the earnings during said five and one-half years or other period, each vendor shall add to said earnings any amount actually expended by it for repairs, renewals and maintenance of plant which it has heretofore charged against and deducted from said earnings, and there shall then be charged against and deducted from said earnings of each vendor ascertained as aforesaid, annually a sum equal to 3 per cent. of the schedule value of the plant of said vendor completed prior to the last date of the five and one-half years or other period applicable to said vendor.

In the case of those vendors, if any, which shall not have kept a separate repair account the amounts expended by them for repairs, as required by this subdivision shall be ascertained as nearly as possible 
by the accountants and the committee of appraisal from the books of such vendors and from the condition of their plants and otherwise, and in default of information to the contrary it shall be assumed that they have expended in repairs a sum equal to 3 per cent. of the value of their respective plants.

Having by the foregoing methods, ascertained the earnings, there shall thereupon be deducted from the arerage annual earnings of each vendor for said period, a sum equal to 5 per cent. $(5 \%)$ of the value of the land and plant sold and completed prior to the last date of the five and one-half years or other period applicable to such vendor, and the balance of said average annual earnings so ascertained shall be deemed for the purposes of this agreement the net profits of the respective vendors to be severally multiplied by ten as aforesaid.

Provided, however, that in case it shall be found that the aforesaid multiplier of ten will produce a grand aggregate of common stock greater in amount than the grand aggregate of preferred stock, the Executive Committee shall choose such lower multiplier as will limit the grand aggregate of common stock.

Provided, further, that in the event that the grand aggregate of the average annual net earnings of the vendors, ascertained as aforesaid, shall be found to exceed 12 per cent. of the total value of the tangible property, then said Executive Committee in its discretion may choose such multiplier as will fix the volume of common stock as closely as may be at an amount upon which such past net earnings would show 6 per cent. applicable to dividends upon such common stock after providing for the dividend on the preferred stock.

And thereupon such newly chosen multiplier (whatever the same may be) shall be the multiplier to be used in the case of each vendor. 


\title{
THE NEW YORK CENTRAL AND HUDSON RIVER RAILROAD COMPANY.
}

\author{
GRAND CENTRAL TERMINAL
}

New YoRk, December 15, 1911.

To the Holders of The New York Central and Hudson River Railroad Company's Three and One-half Per Cent. Gold Bonds, Michigan Central Collateral:

Under the indenture, dated April 13, 1898, executed by The New York Central and Hudson River Railroad Company and the Guaranty Trust Company of New York, as Trustee, pursuant to which the above-mentioned bonds were issued, the Michigan Central Railroad Company may be consolidated with the New. York Central, or any other company may be consolidated with the Michigan Central, upon such terms as may be approved by the holders of three-quarters of said bonds; but in case of any such consolidation, these bonds and certain other bonds of the New York Central of a similar issue not exceeding in amount $\$ 100,000,000$ (the latter being the three and onehalf per cent. gold bonds of this Company for which stock of the Lake Shore \& Michigan Southern Railway Company is pledged as collateral) shall be secured by a mortgage upon the railroad of the New York Central, as provided in the Section 5 of Article Two of the indenture, next in rank and second only to its existing general mortgage, dated June 1, 1897, securing an authorized issue of $\$ 100,000,000$ of bonds; and, in connection with any such consolidation of the Michigan Central and the New York Central, no lien or charge shall be created or incurred except in subordination and subjection to the prior claim, lien and charge of the Michigan Central collateral bonds. There are similar provisions as to the Lake Shore in the indenture under which The New York Central and Hudson River Railroad Company's Three and One-Half Per Cent. Gold Bonds, Lake Shore collateral, were issued.

The New York Central owns more than 90 per cent. of the stock of the Lake Shore, and it is thought that it may be desirable to consolidate the two companies, and to include in such consolidation certain others of the New York Central Lines.

It is not intended at the present time to consolidate the Michigan Central with the New York Central or with the Lake Shore, but (the necessary consents being obtained) the Michigan Central collateral bonds will be secured by a mortgage on the railroad of the New York Central when any two of those companies are consolidated 
In that connection and in order to facilitate such Michigan Central consolidation as may hereafter be decided on, the holders of the Michigan Central collateral bonds are asked to give their consent to the consolidation of the Michigan Central with the New York Central, or its successors, or with any other railroad company or companies now or hereafter of the New York Central System, which consolidation may be made presently or at any future time.

Such consent being given, before making use of it, the New York Central will secure these bonds and also the Lake Shore collateral bonds above referred to by executing a mortgage upon the railroad now owned by it, second only to its existing general mortgage, and in that connection will pay the mortgage tax, which will entitlo your bonds to the exemption provided for in the existing mortgage tax laws of the State of New York.

The indenture by which your bonds are secured provides that the amount and numbers of coupon bonds held by any person executing any request of other instrument as a bondholder and the date of holding the same may be proved by the certificate of any trust company bank, bankers or other depositary, if such certificate shall be deemed by the Trustee to be satisfactory, showing therein that at the date therein mentioned such person had on deposit with such depositary the bonds described in such certificate. The holding of registered bonds of course is shown by the registry. The holders of coupon bonds are, therefore, requested to furnish the certificate of a depositary, as provided in the indenture, a form of which certificate is herewith enclosed. The deposit of bonds required for the purpose of procuring such certificate need be only a temporary one.

Herewith you will find a form of consent, which we should be pleased to have you execute and return at your convenience, first having acknowledged its exccution before a notary public.

By order of the Board of Directors.

The New York Central and Hudgon River Railroad Company,

W. C. Brown, President.

Dwight W. Pardee,

Secretary.

Extra copies of the form of consent will be sent to you on application. 
THE NEW YORK CENTRAL AND HUDSON RIVER RAILROAD COMPANY

\section{GRAND CENTRAL TERMINAL}

New YoRK, December 15, 1911.

To the Holders of The New York Central und Hudson River Railroad Company's Three and One-half Per Cent. Gold Bonds, Lake Shore Collateral:

Under the indenture, dated February 4, 1898, executed by The New York Central and Hudson River Railroad Company and the Guaranty Trust Company of New York, as Trustee, pursuant to which the above-mentioned bonds were issued, the Lake Șhore \& Michigan Southern Railway Company may be consolidated with the New York Central, or any other company may be consolidated with the Lake Shore, upon such terms as may be approved by the holders of threequarters of said bonds; but in case of any such consolidation, these bonds and certain other bonds of the New York Central of a similar issue not exceeding in amount $\$ 21,550,000$ (the latter being the three and one-half per cent. gold bonds of this company for which stock of the Michigan Central Railroad Company is pledged as collateral) shall be secured by a mortgage upon the railroad of the New York Central, as provided in Section 5 of Article Two of the indenture, next in rank and second only to its existing general mortgage, dated June 1,1897 , securing an authorized issue of $\$ 100,000,000$ of bonds, and in connection with any such consolidation of the Lake Shore and the New York Central, no lien or charge shall be created or incurred except in subordination and subjection to the prior claim, lien and charge of the Lake Shore collateral bonds.

The New York Central owns more than 90 per cent. of the stock of the Lake Shore, and it is thought that it may be desirable to consolidate the two companies, and to include in such consolidation certain others of the New York Central Lines.

As a preliminary step, your consent is requested pursuant to the provisions of the indenture securing your bonds.

Such consent being given, before making use of it, the New York Central will secure these bonds and also the Michigan Central collateral bonds above referred to by executing a mortgage upon the railroad now owned by it, second only to its existing general mortgage, and in that connection will pay the mortgage tax, which will entitle your bonds to the exemption provided for in the existing mortgage tax laws of the State of New York. 
The indenture by which your bonds are secured provides that the amount and numbers of coupon bonds held by any person executing any request or other instrument as a bondholder and the date of holding the same may be proved by the certificate of any trust company, bank, bankers or other depositary, if such certificate shall be deemed by the Trustee to be satisfactory, showing therein that at the date therein mentioned such person had on deposit with such depositary the bonds described in such certificate. The holding of registered bonds of course is shown by the registry. The holders of coupon bonds are, therefore, requested to furnish the certificate of a depositary, as provided in the indenture, a form of which certificate is herewith enclosed. The deposit of bonds required for the purpose of procuring such certificate need be only a temporary one.

Herewith you will find a form of consent, which we should be pleased to have you execute and return at your convenience, first having acknowledged its execution before a notary public.

By order of the Board of Directors.

The New York Central and Hudson River Railroad Company

W. C. Brown, President.

Dwight W. Pardee, Secretary.

Extra copies of the form of consent will be sent to you on application. FORM ACCOMPANYING PRECEDING NOTICES.

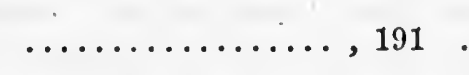

The undersigned, being the owner and holder of The New York Central and Hudson River Railroad Company's Three and One-iralf Per Cent. Registered (Coupon) Gold Bonds, Michigan Central Collateral, under an indenture dated April 13, 1898, to Guaranty Trust Company of New York as Trustee, of the aggregate par value of $\$$

, numbered as follows:

on his (her, its) own behalf and on behalf of his (her, its) successors in the ownership of such bonds, hereby consents to and approves of the consolidation of The Michigan Central Railroad Company with The New York Central and Hudson River Railroad Company, or its successors, together with any other railroad companies, now or here- 
after of the New York Central System, which the Board of Directors of The New York Central and Hudson River Railroad Company, or. its successors, may determine to include in such consolidation with it, and also hereby consents to and approves of the consolidation of The Michigan Central Railroad Company with any other railroad company or companies now or hereafter of the New York Central System, such consolidation or consolidations being made upon such terms and conditions as the Boards of Directors and the stockholders of said companies, acting pursuant to law, may fix, and the particular terms and conditions hereinafter mentioned; this consent being applicable either to a single consolidation or to successive consolidations which may be effected by consolidation proceedings or by merger under present or future laws, or by purchase or otherwise.

The consent and approval hereby given are, however, on the particular terms and conditions that, prior to any such consolidation, The New York Central and Hudson River Railroad Company's Three and One-Half Per cent. Gold Bonds, Michigan Central Collateral, and The New York Central and Hudson River Railroad Company's Three and One-Half Per Cent. Gold Bonds, Lake Shore Collateral, shall have been secured by a mortgage to be executed by The New York Central and Hudson River Railroad Company upon the railroad owned by it at the date hereof, which mortgage shall be next in rank and second only to the existing general mortgage of The New York Central and Hudson River Railroad Company, dated June 1, 1897, securing an authorized issue of $\$ 100,000,000$ of bonds; and that the Railroad Company shall have paid the tax on the Michigan Central collateral bonds under the present mortgage tax law of the State of New York; and that in connection with any consolidation with the New York Central no lien or charge upon the property of The Michigan Central Railroad Company shall be created or incurred except in subordination and subjection to the prior claim, lien and charge of the Michigan Central collateral bonds.

L.S.

State of

County of

On this

day of

scriber, personally came

\} ss.:

, 191 , before me, the sub-

to me known

and known to me to be the same person described in and who executed the foregoing instrument, and he duly acknowledged to me that he executed the same. 
CONSOLIDATION OF NEW YORK CENTRAL LINES 547

State of

County of

\} ss.:

On the day of

came

duly sworn, did depose and say: that he resided

that he was

of

the corporation

which executed the foregoing instrument; that he knew the seal of said corporation; that the seal affixed to said instrument was such corporate seal; that it was so affixed by order of the Board of of said corporation, and that he signed his name thereto

as such by like order.

Notary Public,

The undersigned hereby certifies that, at the date hereof, had on deposit with it of ThE New York Central and Hudson River Railroad Company's Three and One-half Per Cent. Coupon Gold Bonds, Michigan Central Collateral, dated April 13, 1898, each of the par value of $\$ 1,000$, numbered 


\section{PURPOSE AND METHOD OF CONSOLIDATION.}

\section{Report of the Commission to the Senate of the United States.}

\section{By the Commission:}

The Interstate Commerce Commission has the honor to report the result of its investigation, conducted pursuant to the resolution of the Senate of July 10, 1913, reading as follows:

Resolved, That the Interstate Commerce Commission be instructed to in. vestigate, if it has not the information now in hand, and report to the Senate, all the facts and circumstances connected with the proposed issue by the New York Central \& Hudson River Railway, of 4 per cent. mortgage bonds for $\$ 167,102,400$, for the purpose of taking up outstanding $3 \frac{1}{2}$ per cent. bonds now existing against said railroad and the stock of the Lake Shore and Michigan Central Railways.

That the Commission be instructed to furnish the Senate with the date and amount of all said $3 \frac{1}{2}$ per cent. mortgage bonds, the reason for their issue, when they mature, whether the issuing of the said 4 per cent. bonds for the said $3 \frac{1}{2}$ per cent. bonds will not be an unwarranted and illegal capitalization of said railroads, whether the proposed consolidation of said railroads involved in the aaid proposed issue of 4 per cent. bonds would not be unwarranted and unlawful, and whether the increase of the rate of interest thus proposed by the issuing of said 4 per cent. bonds is necessary, even though the consolidation of said railroads is unobjectionable.

The New York Central \& Hudson River Railroad Company will be referred to in this report as the New York Central, the Lake Shore \& Michigan Southern Railway Company as the Lake Shore, and the Michigan Central Railway Company as the Michigan Central.

The $\$ 167,102,400$ of bonds referred to in the Senate resolution constitute the total of the New York Central's Lake Shore collateral bonds for $\$ 90,578,400$, issued in 1898 , to mature in 100 years, in payment for about 90 per cent. of the stock of the Lake Shore at $\$ 200$ a share; its Michigan Central collateral bonds for $\$ 19,336,000$, issued in 1898, to mature in 100 years, in payment for about 90 per cent. of the stock of the Michigan Central at $\$ 114$ a share; its debenture bonds for $\$ 48,000,000$, issued in 1904 , to mature in 30 years; and its debenture bonds for $\$ 9,188,000$, issued in 1912 , to mature in 30 years.

1 Interstate Commerce Commission. No. 5960. In the matter of a proposed Bond Issue by the New York Central \& Hudson River Railroad Company. April 13, 1914. By direction of Senate resolution the Commission reports to the Senate the facts, and its opinions on certain questions raised thereby, in connection with the New York Central \& Hudson River Railroad Company's proposal to consolidate with that company the Lake Shore \& Michigan Southern Railway Company and certain of its owned or controlled lines, and to refund $\$ 90.578,400$ of the New York Central Company's Lake Shore collateral $31 / 2$ per cent bonds with the consolidated company's 4 per cent mortgage bonds in consideration for the consent of these bondholders to the consolidation. 
The Lake Shore and Michigan Central collateral bonds bear interest at $3 \frac{1}{2}$ per cent., the debenture bonds at 4 per cent. The par value of the stock purchased as above shown is $\$ 100$ a share. The Lake Shore collateral bonds are secured by pledge of the Lake Shore stock, and the Michigan Central collateral bonds by pledge of the Michigan Central stock, for which they were issued in payment. None of the bonds mentioned, collateral or debenture, is secured by mortgage, but as to all of them the New York Central is bound by corenant contained in the respective indentures under which they were issued to secure them in any future mortgage which it may place upon its property. The New York Central is also bound by the further covenants not to consolidate the Lake Shore with the New York Central without first obtaining the written consent thereto from the holders of threefourths of the Lake Shore collateral bonds, and not to vote the stock of the Lake Shore in favor of any increase in the Lake Shore's capital stock, which is $\$ 50,000,000$. Similar covenants in the two respects last noted are contained in the indenture under which the New York Central's Michigan Central collateral bonds were issued.

The New York Central extends from New York to Buffalo and the Lake Shore from Buffalo to Chicago. The New York Central now desires to consolidate the Lake Shore with the New York Central, wot only in the interest of the through traffic of the two companies between New York and Chicago, but more particularly in the interest of simplicity and strength in the financing of the two companies. The Lake Shore owns all of the stock of the Toledo \& Ohio Central Railway Company; of the Chicago, Indiana \& Southern Railroad Company; and of the Jamestown, Franklin \& Clearfield Railroad Company; and a trifle more than 50 per cent. of the stock of the Pittsburgh \& Lake Erie Railroad Company, and of the New York, Chicago \& St. Louis Railroad Company. The New York Central intends to include all of these companies so owned or controlled by the Lake Shore, together with certain of their subsidiaries, in the consolidation, except the New York, Chicago \& St. Louis Railroad Company. The capital stock and bonded debt of the principal companies which the New York Central proposes to consolidate are as follows:

\begin{tabular}{|c|c|c|}
\hline Company & Stock & Bonds \\
\hline 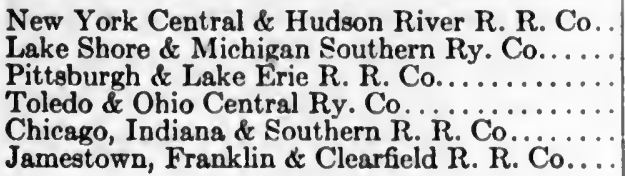 & $\begin{array}{r}\$ 225,581,100 \\
50,000,000 \\
29,988,000 \\
10,208,000 \\
20,000,000 \\
3,000,000\end{array}$ & $\begin{array}{r}\$ 291,211,400 \\
150,000,000 \\
4,000,000 \\
8,500,000 \\
20,000,000 \\
11,000,000\end{array}$ \\
\hline
\end{tabular}


Included in the $\$ 291,211,400$ of the New York Central's bonds shown in the above table are the $\$ 167,102,400$ of bonds referred to in the Senate resolution.

The New York Central states that the proportion of bonds to stock of the Lake Shore approaches closely the limit of separate and economic financing of that property, and that the situation as to the Lake Shore is further complicated by the restriction mentioned with respect to any future increase in its capital stock. The New York Central proposes to provide for the issuance, following the consolidation of bonds secured by mortgage on the combined properties, to be available for refunding the present bonded debt of the two companies and for additional future capital needs of the consolidated company so far as those needs are to be met by the sale of bonds. It represents that such a simplified series of bonds, each of equal lien, would find readier confidence with the investing public than would the separate issues of the two companies, each subject to previous issues of prior lien, and that they would soon become established in the market as the consolidated company's standard bonds.

The issue of $\$ 167,102,400$ of bonds referred to in the Senate resolution is but a step in this general plan of future financing of the two properties. The New York Central proposes to secure those bonds by mortgage on the property of the New York Central, and, following the consolidation, by mortgage on the property also of the Lake Shore, under what the New York Central designates its consolidation mortgage. It has been explained that the New York Central is bound by corenant of indenture to secure by mortgage its Lake Shore collateral bonds, its Michigan Central collateral bonds, and its debenture bonds of 1904 and of 1912 before it may place other mortgages on its property, and it is to carry out this promise that it proposes to execute the consolidation mortgage. This mortgage restricts the issuance of bonds thereunder to the exact amount of these collateral and debenture bonds; that is, to the total of the $\$ 167,102,400$ referred to in the Senate resolution, and provides that the New York Central may, following the consolidation, issue 4 per cent. bonds thereunder in exchange for all or any part of those bonds. The final bond which the New York Central contemplates as its standard consolidated company security it proposes to authorize and secure by another mortgage, which it terms its general refunding and improvement mortgage. This mortgage authorizes the issuance of bonds sufficient in amount to refund all prior indebtedness of the consolidated company, including the consolidation mortgage bonds, and to provide for such future bonds as may from time to time be required for the consolidated system. Its only restriction is that there shall at no time be out- 
standing thereunder bonds exceeding in amount three times the capital stock of the consolidated company, and that additional bonds beyond $\$ 500,000,000$ may be sold only to the extent of 80 per cent. of the cost of needed improvements. The New York Central estimates that the consolidated company will require within the next 10 years $\$ 350,000,000$ of new money for addition and improvement purposes, a sum which would increase the present bonded debt of the consolidated company to more than $\$ 800,000,000$. Unless increased in the meantime, there would be then outstanding against the consolidated company $\$ 275,581,100$ of capital stock. The consolidation would have the effect of removing the present restriction with respect to the increase of the Lake Shore's capital stock. It is therefore problematical what the stock and bond capitalization of the consolidated company under the proposed plan would eventually be.

We have explained that this general plan of future financing of the two companies is dependent upon the consolidation taking place, and that the consolidation is contingent upon the New York Central obtaining the written consent thereto from the holders of threefourths of the Lake Shore collateral bonds. In December, 1911, the New York Central in order to procure that consent offered to secure these bonds by mortgage on the property of the New York Central, and, following the consolidation, on the property also of the Lake Shore, in conformity with the covenant mentioned, and to provide for the payment of certain taxes on these bonds under the New York law. In response to this proposal consents representing only $\$ 20,000,000$ of the required $\$ 67,933,800$ were received. In May, 1913, the New York Central offered, in addition to the mortgage security of the first offer, to extend to these bondholders the opportunity, following consolidation, of exchanging their $3 \mathrm{t} / 2$ per cent. collateral bonds for 4 per cent. consolidation mortgage bonds. As the collateral bonds have 84 years yet to run, the exchange would have the effect of adding annually to the fixed charges of the consolidated company for that period $\$ 452,892$ if the entire issue should be exchanged, and $\$ 339,669$ if the offer should be withdrawn after securing consents only of the necessary three-fourths. The New York Central proposes this increase in interest rate to be effective under its present plan only as to the $\$ 90,578,400$ of the $\$ 167,102,400$ mentioned in the Senate resolution which represents its Lake Shore collateral bonds. While the New York Central concedes that it reserves the right under the consolidation mortgage to make the same offer of exchange to holders of its Michigan Central collateral bonds and of its debenture bonds of 1904 and of 1912 , also secured under that mortgage, it declares that it has ne present intention of including the Michigan Central in the 
consolidation, and therefore no present intention of offering the opportunity of exchange to the holders of those bonds. Its debenture bonds of 1904 and of 1912 now bear interest at 4 per cent.

We have stated that the New York Central states its main object in consolidating to be not so much to effect economy in operation of the two companies as to afford a broader basis for their future financing. Nevertheless, it represents to us that by the consolidation substantial savings can be made. It estimates that perhaps $\$ 325,000$ a year can be saved by unification and simplification of accounting, by the elimination of interline records, reports, printing, etc., incident to the consolidation. It also represents that perhaps $\$ 200,000$ annually can be saved under the federal income tax law; for example, the present triplicate taxation under that law of the 50 per cent. of Pittsburgh \& Lake Erie Railroad Company's dividends that pass first to the Lake Shore and finally, to the extent they enter into 90 per cent. of the Lake Shore's dividends, to the New York Central, will be stopped, and only the one tax thereon as part of the aarnings of the consolidated company be required. Finally, it expresses the opinion that by reason of greater public confidence in a bond of the consolidated company over separate bonds of the two companies the saving to it in iterest charges in connection with the sale of new bonds under the refunding and improvement mortgage will more than offset the annual increase of $\$ 452,892$ in interest charges which it proposes to pay as a maximum to the Lake Shore collateral bondholders for their consent to the consolidation.

It seems probable that by the consolidation a substantial saving can be effected, possibly a sum equal to that last above stated.

We think that from the standpoint of economy in operation and facility in the future financing of the two companies the consolidation is warranted. Neither the consolidation itself nor the exchange of bonds on the basis of increased interest rate indicated, incident thereto, would, so far as we are advised, offend any federal statute. The question whether the exchange of the Lake Shore collateral bonds on that basis is warranted will be answered by our reply to the Senate resolution's further question, whether the exchange as proposed is necessary even though the consolidation of the two companies be found unobjectionable. We have stated that, in response to the New York Central's first offer to the holders of its Lake Shore collateral bonds of a mortgage security for their bonds in consideration for their consent to the consolidation, consents representing only about $\$ 20,500,000$ of the required $\$ 67,933,800$ were received. On the date the taking of testimony before us was concluded most of the required consents had been secured under the New York Central's second offer of an increased 
interest rate in addition to that security. We have been since advised by the New York Central, by letter, that the necessary con. sents have been received. We think that as a practical matter the exchange of the $31 / 2$ per cent. Lake Shore collateral bonds for 4 per cent. consolidation mortgage bonds is, under the cireumstances disclosed, a necessary step in the carrying out of the proposed consolidation plan as outlined to us by the New York Central.

What we here say is aside from any question as to the necessity or advisability of federal control of the issuance by railroads of their securities or, in lieu of that control, of a requirement for full measure of publicity with respect thereto. Whether one or the other of these measures or some other provision looking to the same purpose should be enacted into law is a question we deem it unnecessary to discuss in this report. We have under existing law no jurisdiction or control over such matters. We have expressed our views on the sub. ject in previous reports.

The execution of the mortgages referred to herein, and the issuance of bonds thereunder, are subject to the approval of the Public Service Commission of the State of New York (Second District) and of the Board of Public Utility Commissioners of the State of New Jersey. They have approved the execution of both mortgages. This approval does not extend, however, to the issuance of bonds thereunder or to the consolidation itself. Separate applications must be made for those purposes, and the application to consolidate cannot be made unless and until the necessary consent of stockholders has been secured. Since the taking of testimony before us has been concluded an application made by the New York Central to the New York and New Jersey authorities for leave to issue $\$ 70,000,000$ of bonds under the refunding and improvement mortgage to refund certain short-term notes that mature in 1914 has been granted.

Certain New York Central stockholders have objected to the proposed consolidation, not only on the ground that the increase in interest rate on the Lake Shore collateral bonds is unwarranted and, as they state, in violation of statutes of the State of New York in certain respects, but also because, as they allege, the consolidation will violate the Sherman Anti-trust act unless prior thereto the New York Central disposes of its stock in the Michigan Central and in certain lake lines between Buffalo and Chicago, and Buffalo and Detroit, and unless also the Lake Shore first disposes of its stock in the New York, Chicago \& St. Louis Railroad. These stockholders state that the Michigan Central, the New York, Chieago \& St. Touis Railroad and these lake lines are competing routes with the Iake Shore. We think this question is one more properly to be passed 
upon by the Department of Justice, and as to it we therefore express no opinion. However, it would seem that if this ownership of stock in parallel lines by the New York Central and Lake Shore violates the Anti-trust law, the offence is as complete now as it would be after the consolidation. The New York Central's relation to lake lines will be considered in connection with cases before us under the Panama Canal act.

By the Commission.

[SEAL]

George B. McGintr, Secretary. 


\section{LEASE 1}

\section{-West End Street Railway Co. Boston Elevated Railway Co.}

\section{THIS INDENTURE, made in duplicate, this} day of

, A. D. 1897, by and between the WEST END STREET RAILWAY COMPANY, a corporation existing under and by virtue of the laws of the Commonwealth of Massachusetts, party of the first part, and hereinafter denominated the "Lessor," and the BOSTON ELEVATED RAILWAY COMPANY, a corporation existing under and by virtue of the laws of the said Commonwealth, party of the second part, and hereinafter denominated the "Lessee,"

WITNesseTH, That the said parties, each for itself, its successor and assigns, and each in consideration of the grants, covenants and engagements herein made by the other, have granted, covenanted and agreed, and do hereby grant, covenant and agree, each to and with the other, and its successor and assigns, as follows, to wit:

\section{I.}

The Lessor doth grant, assign, transfer, demise and lease unto the Lessee, its successors and assigns, subject to all legal obligation and encumbrances thereon, its railway and property of every description; including therein its railway, branches, tracks, sidetracks, road-beds, lands, stations and station grounds, viaducts, shops, car-houses, powerhouses, buildings, fixtures, cars, horses, rolling stock, machinery, tools, furniture, patents, licenses, telegraphic and electrical apparatus, poles, wires, conduits, equipment, material and supplies and cash on hand at the inception of this lease, and all accounts and notes receivable, whether secured by mortgage or otherwise, and all rights, franchises, easements, privileges and appurtenances thereto belonging, together with the right to demand and receive all tolls, rent, revenue, income and profits of the demised premises; including therein, subject to all the duties, obligations and undertakings thereby imposed, all the rights, privileges and powers granted and conveyed to the Lessor by a certain contract between it and the City of Boston, acting by the Boston Transit Commission, dated December 7th, A. D. 1896; and also including therein, subject to all legal obligations and encumbrances thereon, all the right, title and interest of the Iessor in and to any and all street railways operated by it, directly or indirectly,

1 Described by E. S. Meade as "one of the most carefully drawn leases ever executed." Corporation Finance, p. 380. 
under lease or operating contract or through ownership of stock or otherwise, and in and to any stock of other street railway companies, all dividends thereon, and its right of voting thereon, and in and to any bonds, obligations and contracts of or with other corporations or individuals and all income or other advantages and benefits to be derived therefrom.

To HAVE AND то HoLD all and singular the demised premises to the Lessee, its successors and assigns, for and during the term of twenty-four years eight months and nine days from and after the first day of October A. D. 189\%, the said Lessee keeping and performing the covenants herein contained on its part to be kept and performed and yielding and paying rent for the said premises to the amount and in the manner following, to wit:

1. The Lessee shall pay all operating expenses of the Lessor and of all railways of which it shall come into possession under and by virtue of this instrument, there being included therein, as part thereof, all repairs and, subject to the provisions of Article VI., all renewals; all expenditures arising out of any contract, obligation, business, negligence or misfeasance, or however otherwise arising, and whether the liability for the same now exist or be hereafter created, in any way connected with the use and operation of the demised premises, except the scheduled indebtedness hereinafter mentioned, and including damages to persons or property, insurance, taxes of every description, federal, state or municipal, levied upon the Lessor's property, income, business, franchises or capital stock, or by law required to be deducted from any amounts payable upon the Lessor's stock; all expenses consequent upon or incidental to the renewal or refunding of the Lessor's indebtedness, or that of any company for which it is responsible; all necessary legal expenses of the Lessor; all expenses incidental to the transfer and registration of the Lessor's stock and bonds, provided that the Lessee shall have the right to designate from time to time the registration and transfer agents, and if at any time the Lessor is dissatisfied with the responsibility of any transfer or registration agent so designated another agent shall be designated unless the Arbitral Board hereinafter mentioned shall approve of the continuance of the first agent; any expenditures hereinafter declared to be operating expenses; and the expenses of maintaining the organization of the Lessor, for which expenses, in addition to sufficient and suitable offices in Boston, with appropriate furniture and fittings to be supplied by the Lessee, there shall be paid to the Lessor at the end of each successive six months during the term of this lease, the sum of Three Thousand Seven Hundred and Fifty $(\$ 3,750)$ Dollars; provided, however, that the Lessor shall, from the proceeds of 
bonds heretofore issued or authorized, or of stock or bonds, or both, hereafter to be issued and authorized, as provided in Article IV., from time to time repay to the Lessec all sums which the Lessee shall pay on account of any indebtedness existing at the date hereof which has been incurred for permanent additions or improvements to the demised property, or which it may be obliged to pay under any existing contract for like purposes, or which it may be obliged to pay for the purpose of completing any work in the nature of such permanent additions or improvements already in part or in whole contracted for by the Lessor; and provided further that the Lessor shall at the expiration or earlier termination of this lease reimburse the Lessee for all sums which it, the Lessee, may be obliged to pay on account of any indebtedness or liability of the Lessor existing or incurred prior to the inception of this lease other than for permanent additions or improvements, and also for such proportional part of all rentals, taxes, interest and dividend charges on preferred and common stock, as shall have accrued prior to the date hereof and shall be paid by the Lessee.

2. The Lessee, during the continuance of this lease, shall pay, as the same may from time to time become due, the rental of any railway of which it shall come into possession, by virtue of this lease; shall pay to the holders thereof the interest on the existing indebtedness of the Lessor and on the existing indebtedness of any street railway company whose indebtedness the Lessor is under obligation to pay, a schedule whereof is hereto annexed, and the interest upon any future indebtedness created in the manner hereinafter provided. The Lessee shall assume and pay the current expenses and indebtedness upon open account of the Lessor outstanding at the inception of this lease, and the same shall be accounted for and reimbursed to the Lessee from the proceeds of stock or bonds as hereinbefore provided so far as the indebtedness is for permanent additions or improvements, and at the expiration or earlier termination of this lease so far as the indebtedness is not for permanent additions and improvements.

The Lessor shall turn over to the Lessee all cash on hand, all bills, notes and accounts receivable outstanding at the inception of this lease, and all sums received thereon and all cash on hand shall be accounted for and paid over to the Lessor without interest at the expiration or earlier termination of this lease, together with a sum equal to all then accrued and unpaid rentals, taxes, interest and dividend charges on preferred and common stock; provided, howerer, that so far as proceeds of bonds heretofore issued under authority of the Railroad Commissioners or authorized by them are received by the Iessee under this Indenture, such proceeds shall be applied by tho Lessee to the specific purposes for which said bonds were authorized, 
and the Lessee shall not be obliged to account therefor except by showing that such proceeds have been so applied.

3. The Lessee shall on the first day of April, 1898, and thereafter on the first days of October and April in each year during the continuance of this lease, pay to each holder of record of common stock of the Lessor a sum equal to one dollar and seventy-five cents for each and every share of common stock so held by him, and shall, on the first days of January and July in each year, during the continuance of this lease, pay to each holder of record of the preferred stock of the Lessor a sum equal to two dollars per share for each and every share of preferred stock so held by him; it being the intent hereof that the holders of common stock of the Lessor shall receive three and one-half (3 $\left.3 \frac{1}{2}\right)$ per cent. semi-annually, net, and the holders of preferred stock four (4) per cent. semi-annually, net, during each and every year this lease continues in force. The Treasurer of the Lessor shall, at least five days before each date of payment, furnish the Lessee with a certificate list of holders of record of the common or preferred stock of the Lessor entitled to dividends on such date.

\section{II}

The Lessee, as assignee hereunder of the contract of the Lessor with the City of Boston for the use of the subway, dated December 7th, 1896, hereby assumes all liabilities of the Lessor under said contract, shall punctually pay to the City of Boston the compensation therein stipulated at the times and in the manner therein set forth, and shall fulfil every obligation, express or implied, therein devolved upon the Lessor in the same manner and with the same effect as if said contract had been made with the Lessee.

Such alterations of said subway and its approaches as may be necessary to connect the same with the Lessee's road and to adapt the same to the use of the Lessee's road, shall, if made by the Lessee, with the approval of the Transit Commission, be borne exclusively by the Lessee; if, however, said alterations are made by the Transit Commission upon request of the Lessee, pursuant to the provisions of section 12 of chapter 500 of the Acts of 1897 , nothing herein shall be construed as requiring the Lessor to make or join in any agreement respecting the same; provided, however, that at the expiration or earlier termination of this lease, said subway, if it shall then be in the control of the Lessee, shall be delivered to the Lessor in as good order and repair as the same shall be in when the use thereof shall be begun under said contract, and so that the same shall be equally well fitted for the independent use and operation thereof by the Lessor. 
Any failure to comply with the terms of said subway contract by the Lessec shall be deemed a violation of the covenants of this lease, giving the Lessor the rights and remedies herein provided in case of violation, including a right of entry and repossession if such failure shall have continued for sixty days; provided, however, that if the Lessor shall at any time deem it necessary for its own protection, it may itself make any payment required by said subway contract and may fulfill any other provision thereof, and in every such case, while retaining unimpaired all its rights and remedies against the Lessee shall have the right to require the Lessee to indemnify it for all money thus expended and for all loss thus sustained.

The Lessee, in anticipation of the expiration of said subway contract, shall use its best endeavors to agree with the City of Boston upon a new contract for a renewal or extension of the same upon the most farorable terms practicable, in which said new contract shall be embodied stipulations satisfactory to the Lessor, providing for the use and control of said subway by the Lessor upon the expiration or earlier termination of this lease.

All of the provisions of this leasc applicable to said existing subway contract shall apply to any contract renewing or extending the same in the same manner and with the same effect as if said new contract had been in existence at the inception of this lease.

Extensions of said subway under the existing contract shall not be requested nor promoted by the Lessee except with the consent of the Lessor first had and obtained. In the event of any extension thereof under any other contract, or of the construction of any new subway, the use and control thereof if. acquired by the Lessce shall be so acquired that upon the expiration or earlier termination of this lease, if such extension or new subway constitutes an essential part of the Lessor's surface system, the same shall belong to the Iessor; that if such extension or new subway constitute an essential part of the Lessee's system, the same shall belong to the Lessce; that if such extension or new subway be capable of concurrent use by both systems, provision shall be made for such concurrent use by both Lessor and Lessee; and that if such extension or new subway constitute an essential part of both systems, but be incapable of concurrent use by both, the Arbitral Board provided for by Article XII., shall determine, in view of all the equities of the case and of all the private and public considerations involved, to which of said systems the use and control of said new extension or new subway shall belong.

Provided, however, that the right of said Arbitral Board to assign the use and control of said new extension or new subway to the Isessee shall not affect or impair, nor be affected or impaired by, the obliga- 
tion hereinafter imposed upon the Lessee to return the Lessor's road without break of continuity or connection.

\section{III}

The Lessee shall assume all traffic balances due from the Lessor to other companies; shall assume and have the benefit of all contracts of the Lessor for equipment, supplies and material and all other contracts and liabilities of the Lessor to and with individuals or corporations express or implied (its contracts with the holders of its indebtedness as scheduled excepted); shall assume and defend all suits against the Lessor arising out of or in any way connected with the past or future use or operation of the railways demised or directly or indirectly operated by the Lessee under and by virtue of this instrument, and shall pay all judgments obtained thereon against the Lessor or which the Lessor is under obligation to assume; and shall assume and discharge all liabilities of the Lessor except as herein otherwise provided.

\section{IV}

The Lessee shall pay the interest upon any portion of the indebtedness of the Lessor or of any Company for whose indebtedness the Lessor is responsible that shall be renewed or extended during the term of this lease in like manner as upon the same indebtedness before renewal or extension.

In case it shall become necessary under the provisions of this lease for the Lessor to make payment for permanent additions, alterations or improvements to the demised premises, or to pay or refund any portion of the indebtedness mentioned in the annexed schedule, or any indebtedness hereafter incurred and scheduled, or to pay or fund any indebtedness contracted for permanent additions and improvements prior to the inception hereof, or to make any repayments to the Lessee for expenditures made by it for the foregoing purposes, the Lessor shall, from time to time at the request of the Lessee, issue additional stock or bonds, or both, to an amount sufficient for the purpose so far as it may legally have or can obtain the right so to do. In such cases the Lessor shall, at the expense and under the direction of the Lessee, do all such acts and things as may be necessary or proper to obtain the requisite authority for the issue desired from the Board of Railroad Commissioners or from any other board having jurisdiction in the premises or from the Legislature. Said stock and bonds so issued shall, except so far as other provision is made by law, be sold under the direction of the Lessee. In so far as the proceeds of any issue of stock or bonds exceed the amount to obtain which the issue has been authorized. the excess shall be paid over to the Lessee 
to be invested by it in permanent additions, alterations or improvements to the demised property, under the provisions of Article VI.

The Lessee shall in all cases have authority as between the parties to decide whether stock or bonds, or both, and what amount thereof, shall from time to time be issued, and shall also have the right to determine the rate of interest upon all interest-bearing obligations, - and the time for which they shall run, whether the same are issued for the purpose of refunding or paying indebtedness or for the purpose of paying for permanent additions, alterations or improvements to or upon the demised property; provided, howerer, that no bonds shall be issued in excess of the outstanding capital stock of the Lessor; that no bonds shall be issued to become payable after the expiration of this lease without the consent of the Lessor; that all bonds shall be payable in lawful money of the United States, unless, in the case of bonds issued to refund gold bonds of the Lessor already outstanding, the parties shall otherwise agree; that no such bonds shall be sold at less than par; and that the benefit of all reductions in interest shall accrue to the Lessee. All stock issued as provided in this article shall from the time of such issue be deemed part of the Lessor's capital stock within the provisions of Clause 3 of Article I. of this Indenture, and all bonds so issued shall be scheduled and the interest paid as part of the Lessor's indebtedness under and pursuant to Clause 2 of Article I.

$\mathrm{V}$

The Lessee shall have the right of voting on all stock owned by the Lessor in other eorporations, and said stock shall not be sold or otherwise disposed of except with the assent of both the Lessor and the Lessee.

\section{VI}

The Lessee shall have the right at its own expense to alter the tracks of the demised railway and to build such sidings and branches as may be necessary to connect the demised railway with the stations or railroad of the Iessee.

The Lessee may from time to time make such additions to, alterations and improvements in the demised railway, its rolling stock, tracks, equipment, power-houses, car-houses, stations, structures and appurtenances, as it may deem necessary for the purpose of making better provisions for the due and safe transportation of the public, or for the purpose of eomplying with any requirement of law or public or municipal authority, or for the purpose of reducing the operating expenses of the demised railway.

The Lessor shall from time to time. either from moneys received 
by the Lessee under Article VII: or from the proceeds of stock and bonds lawfully authorized, and in no other manner, repay to the Lessee the cost of such permanent additions, alterations and improvements made by the Lessee, as the Lessor may consent to, or, if such consent be refused, as the Arbitral Board provided for in Article XII. shall determine that the Directors of the Lessor, if actually operating the Lessor's road, would be justified in making in the interest of the Lessor.

Permanent additions, alterations and improvements for which the Lessor may be called upon to pay under the provisions of this lease shall consist of,-

(1) The abolition of grade crossings.

(2) Additional rolling stock and its equipment.

(3) Additional track mileage and its equipment.

(4) Additional real estate.

(5) Additional stations, additional power-houses with their equipments, and additional car-houses with their equipments.

(6) Additional bridges, buildings and other structures.

(7) Renewals of or substitutions for stations, bridges, buildings and other structures, tracks and equipment, rolling stock and equipment, power-houses and equipment and car-houses and equipment, so far as the cost of such renewals or substitutions exceeds the cost, when new, of the things renewed or the things replaced.

Provided, however, that the road of the Lessor shall so far as practicable continue unimpaired in length and value; that no part of the same shall be voluntarily discontinued except with the consent of the Lessor; that road discontinued by compulsion of law in consequence of the result of the construction and operation of the Lessee's elevated road, shall, within a reasonable time, be made good to the Lessor by other road of equal value constructed by the Lessee at its own expense, or otherwise shall be paid for at its value in money to be applied as in the case of the proceeds of real estate under Article VII.; and that new track mileage shall be deemed a permanent addition or improvement hereunder only when increasing the mileage of the Lessor's road as existing at the inception of this lease, or when exceeding in cost the cost of road previously discontinued, and then only to the extent of such increase or such excess of cost. Track mileage discontinued or removed from Tremont Street in Boston between Boylston Street and Scollay Square and from Boylston Street between Park Square and Tremont Street under the provisions of section 35, chapter 548, Acts of 1894, and all track mileage discontinued under compulsion of law which has been paid for by the Lessee as above provided, shall, for the purpose of computing addi- 
tional mileage to be paid for by the Lessor, be deducted from the aggregate mileage of the Lessor's road existing at the inception of this lease.

Any moneys from time to time in the possession of the Lessee which are by the terms of this Indenture applicable to such purpose shall first be applied to the repayment to the Lessee of the cost of permanent additions, alterations and improvements, and only the balance remaining unpaid shall be paid from the proceeds of stock or bonds or both to be issued by the Lessor as provided in Article IV.

The Lessee shall have the right to apply for the necessary consent of the Lessor or for the necessary certification or determination of said Arbitral Board either before said additions, alterations and improvements are made or within one year thereafter.

The Lessee shall not directly or indirectly locate or construct, or through any agency or device promote or aid in the location or construction of any surface street railway paralleling or in any way competing with any surface street railway, or any portion thereof, demised to or directly or indirectly operated by the Lessee by virtue of this lease.

\section{VII}

Real estate of the Lessor in the judgment of the Lessee not required by the Lessee for the conduct of its business may be sublet by the Lessee for a period not longer than the expiration or other earlier termination of this lease.

Such real estate may also be sold with the consent of the Lessor to be given upon the reasonable request of the Lessee, and the proceeds of said sale shall be received by the Lessee and applied either to purchasing and retiring the outstanding indebtedness of the Lessor as scheduled or to making permanent additions, alterations or improvements upon the property demised or operated by virtue of this lease,-as the parties hereto may agree. If such proceeds are applied to retire outstanding indebtedness, the annual rental to be paid by the Lessee under Clause 2 of Article I. hereof shall be reduced by the amount of the saving in interest charges thereby effected.

If the parties are unable to agree as to whether a sale of said real estate is reasonable or upon the terms thereof or upon the application of the proceeds, the matters in difference shall be determined by the arbitrators provided for in Article XII. hereof.

If the City of Boston, upon the expiration or any earlier termination of said Subway contract, shall take over and become the owner of the tracks, wires, appliances, fixtures, machinery and other equipment of said Subway, any money paid for the same, so far as such 
money shall represent Subway equipment supplied by the Lessor, shall be applied or disposed of in the manner in this Article prescribed respecting the proceeds of sale of real estate.

The Lessee shall also receive any money paid by the City of Boston on account of Subway equipment, also all money not yet received to which the Lessor may be or become entitled for land or property taken by public authority, either before or after the date hereof, or for injury or damage to the same and apply the same as hereinabove provided with respect to the proceeds of real estate.

\section{VIII}

The Lessee shall, subject to the special provisions of this Indenture, at its own expense maintain and keep the demised premises and all the property and fixtures of every description which it shall receive or operate under this lease in as good order and condition as the same now are or shall be when received by the Lessee, so that there shall be no depreciation as to quality or quantity in the same or any part thereof, and, at the expiration or earlier termination of this lease, shall, subject to the special provisions of this Indenture return the same to the Lessor in the same good order and condition, and put the Lessor in possession of all the railways and property at said time demised to the Lessee under this Indenture. The Lessee shall use and operate said railways and properties so demised and operated in accordance with all laws of the Commonwealth of Massachusetts, all municipal ordinances, and all orders of the Railroad Commissioners or of any public authority that may be applicable thereto; shall, subject to the provisions of Article VI., furnish all horse or electric or other power, all engines, rolling stock and equipment of every description required, in addition to the like property hereby demised, for the due operation of the railways operated under and by virtue of this Indenture; shall not diminish the facilities for travel upon the Lessor's railway as they exist at the inception of this lease, except so far as substantially equal facilities may be furnished in substitution therefor either by the Lessee's elevated railway or otherwise; shall observe and perform all the provisions of contracts of the Lessor with companies whose railways now are or hereafter may be operated under this Indenture; shall keep the demised premises reasonably insured and shall apply the proceeds of any insurance to restoring or replacing the property destroyed or to making permanent improvements, not in the nature of ordinary repairs, upon the demised premises; shall apply the proceeds of the rolling stock, equipment and other personal property herein demised, which it may deem advisable to sell and which it is hereby authorized to sell at its dis- 
cretion so as to substitute therefor like property of equal value; shall replace buildings or structures on the demised premises taken down or removed, and which the Lessee is hereby authorized to take down or remove at its discretion, with other buildings, structures or permanent improvements upon the demised premises of equal value and equally convenient for the use of the Lessor at the expiration or earlier termination of this lease, or shall apply a sum of money equal to the value thereof in the same manner as the proceeds of real estate are to be applied under Article VII.; shall permit the demised premises to be inspected annually by the Lessor's Directors and by some competent person appointed by the Lessor who shall report to the Lessor the condition of said premises and shall, for the purpose of such inspection, be furnished with free transportation over the railways operated under and by virtue of this Indenture and shall receive a reasonable compensation for his services to be paid by the Lessee; shall make all returns required by law and shall iurnish the Lessor with such abstracts of accounts as shall enable it to make all returns required of the Lessor; shall not assign this lease nor underlet the premises or any part thereof without the written assent of the Lessor first had and obtained, except as provided in Article VII. hereof and except that nothing herein shall be construed to impair the right and power of the Lessee to mortgage or pledge the interests acquired under and by virtue of this lease in accordance with the authority conferred by chapter 500 of the Acts of 1897 ; and at the end of the term of this lease, or at any earlier termination thereof from any cause whatever, shall surrender the real and personal estate demised under and by virtue of this Indenture, to be ascertained and determined according to the inventory hereinafter provided for, in the like good order and condition in which they are at the inception of this lease, or when received by the Lessee or may be put during the term, with all improvements thereon or additions thereto, the amount of money, materials and supplies to be surrendered or accounted for to the Lessor to be equivalent in value to the amount on hand at the inception of this lease, as shown by said inventory, and all stocks, bonds and securities, or any bonds, stocks or securities substituted therefor under the provisions of this Indenture to be returned at the expiration or other earlier termination of this lease.

Provided, however, that the continuity of the Iessor's road, whenever returned to the Lessor, and the connection between its several parts shall be such that said Iessor's road will be as well fitted for independent use and operation by the Lessor as at the inception of this lease, - any compensation for mileage previously discontinued 
and paid for but restored or made good, under this provision, to be accounted for and reimbursed to the Lessee.

\section{IX}

That the property herein demised, and to be accounted for at the expiration or earlier termination of this lease, may be accurately determined, there shall be made, as of the day when this lease takes effect, a full, complete and particular inventory and description of all estate and property, real or personal, belonging to the Lessor, and coming into the possession of the Lessee by virtue of this lease, and to this, from time to time, shall be added such other estate and property as shall come into the possession of the Lessee under the terms of this lease. Such inventory and description, with the additions thereto from time to time, shall be made by two competent persons, one selected by each party; in case of their disagreement, they shall refer the matter in difference to some third person, whose decision shall be final. Such inventory and description shall be made in duplicate, and an original furnished to each party, and shall be evidence of the nature and condition of the property demised at the inception of this lease, or at the time of the additions thereto in all cases in which any questions of the nature, condition or value may arise. The reasonable compensation for services and expenses of the persons making such inventory shall be paid by the Lessee.

\section{$\mathrm{X}$}

The Lessor shall maintain its existence and organization as a corporation, and to that end shall comply with all the requirements and forms of law; shall do all acts and things, and execute all legal instruments necessary and proper to put and secure the Lessee in the full enjoyment of all the property, rights, franchises and interests herein demised, and to carry into effect the true intent and meaning of this Lease; and shall not increase its capital stock as now existing and issued nor its indebtedness except as provided in this Lease. To further secure the Lessee in the beneficial enjoyment of the property, franchises, rights and privileges herein demised and specified, the Lessor constitutes the Lessee its attorney irrevocable with full right and power, at the Lessee's expense, to use the name of the Lessor in all legal proceedings and in all cases needful for obtaining, holding and enjoying the premises herein demised and specified, and for all purposes consistent with the true scope and intent of this instrument.

The Lessor further covenants that it will at the expense of the Lessee comply with all requirements of law and with the ordinances of all cities and towns in which the demised property is located, in 
so far as the Lessee cannot act in its stead, and that it will, at the request of the Lessee, itself make applications for extensions or alterations of tracks and locations where the Lessee cannot act in its stead, and with at all times, when it cannot aet by the Lessee as attorncy, itself do such acts and execute such papers as may be necessary or proper to carry out the true intent of these presents. Any locations, rights or property so acquired by the Lessor after the date hereof shall be made subject to the provisions of this Indenture. The Lessor also constitutes and appoints the Lessee its attorney in fact with full power to collect and receive all moneys due to the Lessor, and to compromise or refer to arbitration all claims by or against the Lessor or its property.

XI

This lease is upon the condition that, if the Lessee shall at any time fail to punctually pay to the holders of the Lessor's indebtedness and each of them the interest on the Lessor's indebtedness as scheduled as the same shall become due and payable, or shall fail to make any payment as stipulated for in Clause 3 of Article I. hereof, then, and in such case, at any time after the expiration of thirty days from the time when written notice of such default has been served on the Lessee, the Lessor may, if such default still continues, enter upon the demised premises, and upon any part thereof, as and for the whole, and expel the Lessee, and determine the estate hereby granted, and shall thereupon become seized and possessed of the demised premises, and of all premises then in possession of the Lessee or the Lessor under this Indenture, and of every part thereof in its original right, and as if this lease had never been made; and upon the further condition that, if the Lessee shall fail to perform any other of the covenants and agreements in this case contained, and such failure shall continue for six months after written notice of such failure from the Directors of the Lessor, the Lessor shall have the like right to enter and expel the Lessee, and vest in itself its former estate in the demised premises, and all premises then in possession of the Lessee or the Lessor under this Indenture, and every part thereof; provided, however, that such entry by the Lessor for breach of condition shall in no wise prejudice or impair any remedies to which it might otherwise be entitled for arrears of rent or preceding breach of covenant, or any other rights secured by this lease in case of its termination before the expiration of the time thereof.

\section{XII}

In case of any disagrecment between the parties hereto as to the true intent and meaning of this lease or any part thereof, or as to 
anything done under and by virtue of it, or growing out of it, the matter in controversy shall be determined by arbitrators to be chosen in the manner following: One shall be chosen by each of the parties hereto, or if either shall unreasonably fail or neglect to appoint an arbitrator when requested by the other, the Board of Railroad Commissioners or the Chief Justice of the Superior Court may, after due notice to the party so failing or neglecting to appoint an arbitrator. The third shall be selected by the two so chosen, or in case of their failure to choose a third, by the Board of Railroad Commissioners or the Chief Justice of the Superior Court. The arbitrators shall hear the parties, after due notice to each of them, and if either party fail to attend after such notice, may proceed ex parte. The award in writing of said arbitrators, or a majority of them, being duly notified to the parties, shall be final and conclusive upon them. The expenses and reasonable compensation of said arbitrators shall be paid by the Lessee.

\section{XIII}

This lease shall take effect as of the first day of October, 1897, and all accounts between the parties shall be made up as of that date; provided, however, that on or before January 15, 1898, at least five million $(\$ 5,000,000)$ dollars in cash shall have been paid in upon the Lessee's capital stock, and that until such payment the Lessor shall remain in possession and operation of the demised propertythe Lessor accounting to the Lessee for all income in the interval; and provided further than this lease shall not be valid until the terms thereof, as respects the rental or compensation to be paid and the due and safe transportation of the public shall have been approved by the Board of Railroad Commissioners.

In Witness Whereof, the said parties, by their respective Presidents and Treasurers, thereunto duly authorized, have caused their corporate seals to be hereto affixed, and these presents to be executed the day and year first above written. 
SCHEDULE OF INDEBTEDNESS REFERRED TO IN THE WITHIN LEASE

\section{West End Street Railway Company}

\section{FUNDED DEBT}

Bonds Highland St. Ry. due Jan. 1, 1898, 6\%......... \$100,000.0n

Bonds Highland St. Ry. due May 1, 1902, $5 \% \ldots \ldots \ldots \ldots \ldots \ldots \quad 300,000.00$

Bonds West End St. Ry. due Nov. 1, 1902, 5\%......... 3,000,000.00

Bonds Cambridge R. R. due April 1, 1903, 5\%.......... 480,000.00

Bonds Metropolitan R. R. due Dec. 15, 1903, 5\%......... 500,000.00

Bonds Chas. River St. Ry. due April 1, 1904, 5\%......... 150,000.00

Bonds Middlesex R. R. due July 1, 1904, $5 \% \ldots \ldots \ldots \ldots \ldots \ldots \quad 200,000.00$

Bonds So. Boston H. Ry. due May 1, 1905, 5\%.......... 200,000.00

Bonds Boston Con. St. Ry. due June 1, 1907, 5\%......... 500,000.00

Bonds West End St. Ry. due March 1, 1914, 41/2\%....... 2,000,000.00

Bonds West End St. Ry. due May 1, 1916, 4\%......... $815,000.00$

Bonds West End St. Ry. due Feb. 1, 1917, $4 \% \ldots \ldots \ldots \ldots \ldots, 2,700,000.00$ 


\section{HOLDING COMPANIES IN THE PUBLIC UTILITY FIELD ${ }^{1}$}

For the convenience of the committee there has been printed an appendix, which is herein submitted, containing quotations from the opinions of courts, public service commissions, and experts on the benefits of the combination of publc utilities. There is also a reference to various State statutes permitting their combination.

Before the Interstate Commerce Committee of the United States Senate.

In the matter of Senate bill 4160 , entitled a bill "To create an Interstate trade commission, to define its powers and duties, and for other purposes."

\section{Brief on Behalf of Public Utility Holding Companies.}

We having heretofore filed with the Judiciary Committee of the House of Representatives a brief asking that public utility or public service corporation be specifically exempted from the provisions of House Bill No. 1565\%, known as the Clayton antitrust bill, we desire to respectfully renew our request before your committee and suggest that there be added at the conclusion of section 13 of the bill, on page 18, the following:

These sections shall not apply to corporations acquiring or holding the stock of, or engaged in the business of conducting a public utility which is subject to State regulation, other than common carriers as defined in the act to regulate commerce approved February 4, 188\%, and the amendments thereto.

Our objection to section 10 as it now appears in the bill is that the large public utility holding companies as now organized and operated might be held to be engaged in interstate commerce, particularly in view of the recent decision in the Sixth United States Circuit, in the case of Alabama \& N. O. Transp. Co. v. Doyle (210 Fed. Rep., 173), wherein it was held "that stocks and bonds are now the subject of interstate commerce, and that shipments and sales of them between the States are interstate commerce." That the Supreme Court will uphold this view is indicated by their decision in the Lottery cases (188 U. S., 321). As one of the useful features of these holding companies as indicated in our point III is the widespread sale of their stocks and bonds in order to finance the subsidiary corporations. the probability of such a decision is increased.

1 Brief submitted on behalf of Public Utility Holding Companies to the Interstate Commerce Committee of the United States Senate, in the matter of Senate Bill No. 4160. 
The effect of this section if the holding company is thus engaged in interstate commerce may be to prevent such a company from acquiring or holding the controlling interest in the gas and electric plants of a particular locality, even though the State commission permits it as in the case in New York and many States. And the same is true of street railroads on different streets in the same town.

Furthermore, many public utility holding companies actually transmit power from State to State, such as the Appalachian Power Co., which operates in Virginia and West Virginia and has acquired the control of the local plants in many towns through which its lines run. Such a company would be absolutely crippled by this section, though under the strictest control of the public service commission of the States in which it operates such utilities.

The exception of public utility companies is urged because we real: ize that Congress is only desirous of enacting legislation which will eradicate the evil and does not wish to injure or prohibit such holding companies as serve a useful purpose and do not lessen or prevent competition between corporations which are or should be competitive.

In presenting our argument for the exception of such companies we should like to bring to the attention of the committee:

I. The magnitude of the interests involved and the large amount of capital invested in such companies.

II. The great economical advantages of combining public utilities serving different communities through the means of a holding company.

III. The indispensable service rendered by the holding company as a means of financing public utilities and in securing the necessary capital for their extension and development.

IV. The fact that the objections to intercoporate stockholding do not apply to public-service corporations, for they are natural monopolies and are subject to State regulation.

\section{I}

THE Magnitude of the interests involved aNd the large AMOUNT OF CAPITAL INVESTED IN SUCH COMPANIES

The total capital employed in electric, gas, street, and interurban railway companies, commonly called public-utility corporations, in this country to-day is estimated to exceed eight billion dollars. of this capital nearly five and a half billion dollars are controlled by holding companies and their subsidiary companies. Of the approximately $89,000,000$ people served by electric light and power and gas companies over $62,000,000$ (approximately 70 per cent) are served by holding company systems. 
Electric light and power.-The electric light and power companies represent approximately two billion dollars of capital, of which approximately 76 per cent is controlled by the holding company form of organization. These utilities serve over $50,000,000$ people, approximately $38,000,000$ of which are served by holding companies. Of 577 cities of 10,000 or more population served, 428 are served by holding company systems. Of the $\mathbf{1 1 4}$ cities in the United States of a population in excess of $50,000,103$ are served by holding companies. Of the 54 cities in this country having in excess of 100,000 population, 49 are served by the holding company.

Gas.-Artificial gas companies represent a capital of approximately one and one-third billion dollars. Of that capital, approximately two-thirds is controlled by holding companies. The gas utilities of the country serve approximately thirty-eight and one-half million people. Of this number nearly twenty-five million are served by holding companies or their subsidiaries.

Street railways.-Street and interurban railway companies represent a total capital of approximately five billion dollars. Of this sum it is estimated that not less than two-thirds is controlled by holding companies. In the 28 cities of the United States having a population in excess of 200,000 , the mileage of track controlled by holding companies is in excess of 61 per cent. Here, again, it is of interest to note that only four of these cities have more than one principal operat. ing company and only two of these cities have companies that are really independently and separately owned.

\section{II}

THE GREAT ECONOMIICAL ADVANTAgES OF COMBINING PUBLIC UTILITIES, SERVING DIFPERENT COMMUNITIES, THROUGH THE MEANS OF A HOLDING COMPANY

It is almost self-evident that, in the realm of public utilities, the large holding company possesses great economic advantages over the independent small local company.

Disadvantages of independent companies.-In small towns and in sparsely settled districts the independent company is, as a rule, unable to supply good service at reasonable cost. The business is too small to warrant the employment of the high-grade but expensive staff needed to insure efficiency in construction, administration, maintenance and operation. Then, owing to the limited output, the unit cost of production and distribution is necessarily high. Again, ,because of its limited local character, the entire business is likely to be completely paralyzed by some calamity and the company so seriously 
embarrassed as to be unable for a protracted period, or perhaps permanently, to continue its service to the community.

Advantages of holding companies to investor.-Many of these causes for the lack of success of the independent local companies have been eliminated by the device of the holding company which unites under one control and management the public utilities of several communities. The increased volume of business so obtained enables the holding companies to make the expenditure necessary to secure a thoroughly competent executive, engineering, and operating staff, whose services are available to all of its subsidiaries. Thus, along with the resulting increase in efficiency, the expenses of each subsidiary are materially reduced. Expenses are further reduced by the standardization of materials and supplies, and by the purchasing of such sup. plies by skilled purchasing agents in large quantities in a far wider market and upon much better terms of credit than could possibly be secured by the separate local companies acting independently. The centralized expert management effects further economies in the cost of production by the standardization of operating and accounting methods. Plants are combined and construction work is standardized, so that equipment outgrown by one community can be utilized by transfer to another smaller community, instead of being discarded as useless; in this way the enterprise is run with a minimum amount of capital, and depreciation charges are materially lessened. The distribution of the business over an enlarged territory "averages the risk" and secures the holding company against irreparable damage from purely local causes. All of these improved conditions operate to increase the attractiveness of the enterprise to the investor, and, consequently, to bring about the very great economy of decreased cost of capital and the resultant fixed carrying charges.

From the point of view of salability, the securities of the large holding company and of its subsidiaries are so greatly superior to those of the small independent company that the two are scarcely comparable. The safety and stability due to the large volume and diversified character and location of the business, the reduced expenses, and the increased efficiency of the management climinate one of the greatest obstacles to the successful financing of public utility companies. And the risk of the investor is further reduced by the ability of the holding company to carry the losses of its subsidiaries during the accumulation of business and through periods of stress, to provide working capital for their temporary needs, and to protect them against prolonged or permanent curtailment or suspension of operations by furnishing immediate financial and enginecring assistance in case of accident or calamity. The securities of subsidiary companies con- 
trolled by holding companies are valuable in a broader market, at a higher price, and with a more ready demand on the part of investors by reason of the fact that these securities are advertised as securities having priority over the securities of a well-known and established holding company.

Advantages of holding company to public.-In a large measure the economic advantages of the public utility holding company inure to the benefit of the general public. The community enjoys more efficient and more extended service at the same or lower cost. It is protected against any crippling, interruption, or discontinuance of that service, due to local causes. Where individual consumers are served, as in the case of light, heat, and power companies, there is a direct and distinct saving to the community and to the taxpayer; one set of house connections takes the place of several, thereby reducing the costly and inconvenient interference with traffic and injury to pavements caused by the necessary openings in the streets.

The actual record of the public utility holding companies affords ample proof of their great economic advantages. That the securities of these companies offer an investment astonishingly free from risk appears from the steady gain in earnings over a period of years. In 10 years the gross earnings of gas and electric light and power companies in the United States increased 110 per cent, and those of electric railways 75 per cent, the net earnings for the same period being 100 per cent and 60 per cent, respectively—a far better record than that of railroads and industrials, the two other large classes of securities. And this increase has been steady, and almost free from fluctuation, showing remarkable independence of the effects of general business depression.

The receivership risk of the public utility holding companies over a period of years is only 37 cents for $\$ 100$ of capital invested. This is but little in excess of that of national banks actually closed for insolvency, and only one-fifth of that of steam railroads and twoelevenths of that of industrials. The safety of the investment has appealed to the general investor, has brought the securities of the public utility holding companies through the experimental stage, and has resulted in opening up a market for them throughout the United States and abroad, where they are now competing on equal terms with the older classes of securities.

That there has, in general, been a great improvement in the character of the service since the development of the public utility holding company is patent to almost everyone. In the electrical field alone, in 14 years the efficiency of the electric lamp has been increased 268 per cent, while the cost of current has been reduced 61.5 per 
cent. The lowered cost of public utility service has been practically the only reduction in the cost of living in recent years.

The advantage to the public of the public utility holding companies has been generally recognized by the public service commissions which now exist in most of the States. They are practically unanimous in lolding that public utilities are best supplied to the community by a single large company subject to State regulation and control. Indeed, the general objections to intercorporate stockholding are eliminated in case of State-regulated corporations by the supervision and control of the public service commissions. These commissions prevent overcapitalization and the manipulation of the securities of subsidiaries by their control over the issuance of securities. They prevent overcharge to the public for service by their power to fix the legal rates upon which that service shall be furnished. They also have power to compel adequate and efficient service.

Disastrous effect of prohibiting public utility holding companies.A refusal to permit the continued existence of holding companies in the public utility field would be a widespread public calamity. Such action would retard the development of many small communities whose immediate needs and resources are not sufficient to attract capital. This loss can not readily be measured, but is reflected in the universal desire of local boards of improvement and trade to secure for their localities such favorable conditions for industrial plants and such public conveniences as will render them profitable locations for business enterprises and attractive for residence purposes. The supply of light and power through a large central station and transmission lines is the only means of reaching the farmer and the dweller in the small village. As the result of the development of the public utility holding company, the farmer can to-day in many districts pump his water, operate his farm machinery, and light his house by electricity, and give his wife electric power for laundry and other houschold purposes. He enjoys the tremendous advantages of having electricity brought to his very door to the same extent and at practically the same cost as does the dweller in the largest city. Such a state of affairs could never have existed were each small community compelled to pay the cost of a local independent service or do without.

The prohibition of the combination of public utilities by means of the holding company would deprive the small communities of the sure reduction in the cost of living due to the decreased cost of such modern necessities as power, heat, light, and transportation facilities. It would result in a direct tax on the consumer (the general public) to the extent of the reduction in cost securable through the larger 
enterprise. Charges for operation, financing, etc., are essential elements in the cost of production; they are properly considered by the public utility companies in fixing their rates for service; they must be, and are, considered by the public service commissions in confirming or changing those rates. Any increase, therefore, in these charges is sure to be shifted to the consumer and not borne to any degree by the stockholder. It is clear, therefore, that legislation depriving a community of the economic advantages of a large holding company will operate to impose an increased financial burden on that community, even if it be sufficiently large to secure the public utility. service at any price.

\section{III}

THE INDISPENSABLE SERVICE RENDERED BY THE HOLDING COMPANY AS A MEANS OF FINANCING PUBLIC UTILITIES AND IN SECURING THE NECESSARY CAPITAL FOR THEIR EXTENSION AND DEVELOPMENT.

Constant need for new capital.- The total capital employed in electric light and power, gas, street, and interurban railroad companies in this country to-day is approximately $\$ 8,000,000,000$. New capital at the rate of approximately $\$ 400,000,000$ per year- $\$ 8,000$,000 per week-will be required for several years to come if the present rate of progress is to be maintained. Figures and experience prove that for every dollar of new annual revenue to an electric utility a capital expenditure of $\$ 5$ must be made. The public, as it has a legitimate right to do, demands up-to-date service, and is impatient of any delay in securing it. This natural growth and development of existing plants and the requirements of new fields of service make so great demand for new capital that the entire revenue derived from the operation of all existing utilities in the country; without the deduction of one cent for the payment of interest or dividends, if devoted to this purpose, would be utterly inadequate to supply the necessary new capital for these extensions and developments.

A consideration of the above facts makes it obvious that the public utility companies must continually enlist new capital in order to finance their business and shows how vital both to the utility and to the public is the ability on the part of these companies to secure the necessary funds. This ever present necessity, in fair and stormy financial weather, of new financing, presents, possibly, the most serious and difficult problem faced by American public utilities companies. It was to meet this situation and to facilitate this necessary financing that the holding company was first used in the field and it has proved to be indispensable. 
Reasons for indispensability of holding company.-Any analysis of the reasons why may not include all the causes, but among the very apparent advantages of this form of organization may be enumerated the following:

1. The holding company combines in one concrete, responsible, and convenient business-doing form of ownership all the resources and advantages, tangible and intangible, of all the utilities owned or controlled by it. The combined credit of the former separate and comparatively small properties can now be readily pledged to any given project and the necessary business details satisfactorily and expeditiously performed. The total resources of the various properties when combined make an impressive total and secure for the holding company recognition by and credit with the large metropolitan banking and bonding houses, with which it is quite impossible for the separate and small constituent companies to establish connections and secure for themselves the advantages of the services rendered by such establishments.

As a practical matter, it is impossible to secure these very real advantages resulting from the combination of small and separate utilities except through the organizations of a holding company. The ownership of any large number of separate plants by one corporation is impossible for the reason that, generally speaking, the laws of each State require that the utilities within their limits must be owned and operated by domestic corporations. Furthermore, the State laws establishing public utilities commissions vary greatly and provide different requirements relative to accounting, issuance of securities, etc., so that it is fairly a legal necessity that the utilities in each State shall be owned and operated by a corporation organized under the laws of the particular State.

2. The securities of the holding company, owning and controlling a large number of separate utilities located in wide and separate areas, present a greater element of security and stability due to the fact that the risk is prorated and averaged over a large number of physically entirely separate plants located in many different localities. As a result, if any one or more plants, due to any local condition or to any casuality or any other cause, fails to prosper, the remaining and comparatively large number of plants, free from the misfortune of the particular plants, are able to make good the securities issued by the holding company. Where the earnings of one plant or company are low, those of a corresponding company are high, and so the average earnings of all the plants operated by the holding company are maintained at a satisfactory rate. From the investor's point of view, this is simply an application of the homely but time- 
honored adage with reference to putting all your eggs in one basket.

3 . The borrowing power of the holding company is much greater than that of the separate constituent companies, for it can seek the capital in large financial centers. The credit with local banks, where local companies operate, is still retained. This enables the holding company to meet emergency demands and to provide funds pending the marketing of securities.

4. The facilities of the holding company for the sale and distribution of its securities are greatly enlarged by reason of its connections with large bond houses. An efficient organization is indispensable in the marketing of securities. This advantage the separate companies are unable to secure because of the small and local character of the issues of their securities.

5. The holding company is in a position to finance temporarily with its own funds the emergency requirements of any of its subsidiary companies. This was illustrated in the instance of certain Indiana companies during the severe floods of a year ago. Certain local companies suffered severe and extensive losses and would have been unable to finance successfully the necessary replacements. The holding company, however, advanced these funds at once and enabled the local companies to continue their service with the least possible interruption.

6. The holding company system of organization presents greater elasticity in that it makes possible additional forms of financing to meet any particular condition of the money market. When it is impossible to dispose of bonds of subsidiary companies, the holding company can issue short-term notes or debentures secured by the bonds of subsidiary companies. These notes and debentures with the diversified security back of them can ordinarily be disposed of to provide funds temporarily and until conditions permit of the marketing of other long-time securities.

\%. Another advantage in financing enjoyed by the holding company is the feeling among those who purchase securities that the properties operated and controlled under the supervision of a holding company are, as a rule, more successfully operated than the independent plants.

\section{IV.}

THE OBJECTTONS TO INTERCORPORATE STOCKHOLDING DO NOT APPLY TO PUBLIC-SERTICE CORPORATIONS, FOR THEY ARE NATURAL MONOPOLIES AND ARE SUBJECT TO STATE REGULATION.

The particular objections against which the bill is directed, namely, that the devices of intercorporate stockholding and holding companies 
may lead to unlawful restraints of trade or monopolies, are not applicable to public-service corporations, because it is now universally recognized that such corporations can be economically and successfully operated only as monopolies, and that competition in this field is an evil which should be eliminated whererer possible.

The interests of the public are best subserved by protecting monopoly in such corporations, and supervising and regulating them in the public interest. Competition is wasteful and expensive. It is bad for the public and the investor alike.

Many of the States have recognized this principle and require certificates of public convenience and necessity as a prerequisite for a competing company.

Public utilities are natural monopolies.-The principle that a monopoly regulated by governmental authority is a sounder economic principle than unrestricted competition is the basis of the widespread State legislation creating public service commissions. Including Colorado and Maine, whose utility laws are in referendum and will be voted on in the fall in 1914, 30 States and the District of Columbia intrust their commissions with more or less complete powers to regulate utilities.

Actual experience is the foundation for this principle. It was experience of the evils of uncontrolled competition among railroads that led to the creation of the railroad commissions now acting in 45 States. It was experience of the actual workings of competition that has led 19 jurisdictions to give their commissions power to restrict competition among utilities, to a greater or less degree.

Striking conclusions may be drawn if attention is focused on the States of largest population, where presumably the best facilities lare been offered to judge of the advantages and disadvantages of competition: Cf the 13 States which in 1910 had more than two and onequarter million inhabitants, namely, in order of population, New York, Pennsylvania, Illinois, Ohio, Texas, Massachusetts, Missouri, Michigan, Indiana, Georgia, New Jersey, California, and Wisconsin, no less than 11 have given their commissions power to restrict competition in the utility field.

A fair sample of these provisions is that in the very recent Illinois Public Utilities Commission law (effective Jan. 1, 1914):

"Sec. 55. Certificate of Convenience and Necessitr.-No public utility shall begin the construction of any new plant, equipment, property, or facility which is not in substitution of any existing plant, equipment, property or facilities, or in extension thereof or in addition thereto, unless and until it shall have obtained from the conn- 
mission a certificate that public convenience and necessity require such construction.

"No public utility not owning any city or village franchise nor engaged in performing any public service or in furnishing any product or commodity within this State at the time this act goes into effect shall transact any business in this State until it shall have obtained a certificate from the commission that public convenience and neces.: sity require the transaction of such business."

In addition to providing against competition by new construction, etc., a number of States exempt public utility companies from the operation of the local antitrust acts by permitting the merger of competing utilities with the approval of the State commission. As a rule, these provisions permit utilities to purchase each other's stock as well as to purchase each other's franchises and property, always, of course, assuming that the consent of the commission is obtained.

Nature and extent of State regulation.-It is of interest here to note the extremely broad powers of supervision and regulation with which the commissions have been intrusted. In general these commissions have been empowered to insure safe and adequate service at fair and reasonable rates in respect to both consumers and producers, without discrimination or favoritism among the former

Of these powers, the first and foremost is that to regulate rates and see that no utility earns more than a fair compensation for the service rendered. Allied to this is the power to prevent discrimination or favoritism. Then comes the power to require safe service, involving therein adequate security and protection, not only to the users of the service, but to the employees of the company furnishing the service. The numerous regulations made for the protection, comfort, and convenience of motormen and conductors, the installation of safety devices in electric generating stations, etc., are samples of the exercise of this power. The power to compel adequate service involves the duty of seeing that plants are kept in good repair and not allowed to fall into poor condition for the sake of showing increased profits. The commissions also can require the establishment of depreciation funds and thus insure that no disaster shall befall through failure to provide for the renewal of machinery, etc., after it is worn out. In addition to this the commissions may regulate systems of utilities, classify expenditures, and determine what shall be charged against capital and what must be charged against income. Furthermore, the commissions regulate the stocks, bonds, and other securities issued by the utilities, they pass upon the amount that shall be issued, the type of security that shall be issued, the price at which the securities shall be sold, the persons to whom they shall be offered for sale, and, 
in addition, they specify the way in which the funds secured shall be spent, and have power to follow the funds in the course of their expenditure and see that they are actually applied to the purposes enumerated. The commissions even prescribe how the bond discount shall be handled-that is, whether it shall be amortized out of earnings or may be provided for by the sale of new securities.

As a result of these elaborate and detailed powers the commission have such control over the utilities within their jurisdiction that it is practically impossible for the owners of public utility plants to operate them except for the good of the public, or, in fact, do anything but render service in return for a fair profit.

\section{CONCLUSION}

It would seem from the foregoing argument that your committee must reach the conclusion that intercorporate stock-holding companies have an unquestioned economic value in the public utility field, and that through them the great development of our public utilities in this country has been made possible. To check this development by Federal legislation, which might conflict with State regulation, would work a great hardship on both the public and the companies as well. The exception asked for is in the interest of all, and if inserted in the bill will remove all doubt as to the policy of Congress and will further the great progress which has been made in this field in the interest of those necessities of the twentieth century-light, heat, power, and traction.

Dated May 11, 1914.

Respectfully submitted.

\section{Barber, Watson \& Gibboney,}

165 Broaduay, New York.

Stuart G. Gibboney, of Counsel.

Representing Bertrom, Griscom \& Co., of New York and Philadelphia, interested in the United Gas \& Electric Corporation, operating public utilities in the following States: Connecticut, Pennsylvania, Indiana, Texas, Louisiana, New York, Kansas, Illinois, and Colorado.

Also interested in the American Cities Co., operating public utilities in Alabama, Louisiana, 'Tennessee, Arkansas, and Texas.

Birnard Fidexer, Raliph D. Strevenson, 112 West Adams Street, Chicago, Ill.

Representing Middle West Utilities Co., which operates in 315 cities in Illinois, Indiana, Kentucky, Oklahoma, Missouri, Michigan. 
New York, Vermont, New Hampshire, Maine, Wisconsin, and Nebraska.

$$
\begin{aligned}
& \text { H. Alexander Suith, } \\
& \text { Daniel W. Knowlton, } \\
& \text { George B. Hatch, } \\
& \text { Colorado Springs, Colo. }
\end{aligned}
$$

Representing Wm. P. Bonbright \& Co. (Inc.), New York, interested in public utilities operating in the following States: Alabama, Arizona, Arkansas, California, Colorado, Connecticut, Georgia, Idaho, Illinois, Indiana, Iowa, Kansas, Kentucky, Louisiana, Maine, Michigan, Minnesota, Missouri, Montana, New Hampshire, New York, North Dakota, Ohio, Oklahoma, Oregon, Pennsylvania, Tennessee, Texas, Utah, Vermont, Virginia, Washington, West Virginia and Wisconsin. 


\section{PARTNERSHIP BETWEEN MUNICIPALITY AND PUBLIC UTILITY CORPORATION ${ }^{1}$}

The ordinance adopted by the City Council of Kansas City, Mo., signed by the Mayor, accepted by the company, and on July 7 roted by the people, forms a pamphlet of about 60 pages. Some of the leading provisions we have condensed as follows:

- Merger.-The company (duly organized for the purpose) will acquire all the property, franchises and privileges in Missouri owned by the Metropolitan St. Ry. Co., Central Electric Ry. Co. and the Kansas City Elevated Ry. Co., and all the property of said Kansas City \& Westport Belt Ry. Co., free and clear of all liens except judgments for injuries. At the same time all contracts between the city and said other companies and all claims thereunder, except as herein otherwise expressly stated, are annulled.

Term of Franchise.-Thirty years from vote on ordinance by the people.

Organization.-The aggregate amount of outstanding mortgage indebtedness and capital stock of the company shall at no time exceed the value of its property, wherever situated, exclusive of franchise value under this ordinance. The company shall upon demand deliver to the city one share of stock to qualify each person designated by the city as its representative on the board. The stock of such company shall, pending the acquisition of the title as aforesaid, be deposited with U. S. Judge William C. Hook, to be held for the benefit of the parties entitled thereto under a plan of reorganization to be hereafter prepared or in ease reorganization cannot be effected. then for the benefit of those who pay for the stock. Such plan of reorganization must be in harmony with this ordinance and must be approved by Judge Hook or his successor in office. Of the eleven direetors, Kansas City, Mo., shall select five, who at the outset will be William T. Kemper, John H. Wiles, Davis M. Pinkerton, Frank C. Niles and John W. Wagner, to serve for five, four, three, two and one years respectively. The city may by agreement with Kansas City, Kan., give to the latter the right to name not more than two of said five city directors.

Books. - The City Comptroller, or accountants authorized by him, under the direction of the Mayor or of the city directors, shall have the right at all reasonable times to examine all the books, vouchers, etc., and there shall also be an annual audit for the year ending May

'From The Commercial and Financial Chronicle, July 18, 1914. 
31 and a formal written report by public accountants selected by company and City Comptroller.

Board of Control.-Will consist at outset of P. J. Kealy for the company and Robert P. Woods for the city, with salaries of not less than $\$ 6,000$ nor over $\$ 10,000$; any difference between to be determined by an arbiter to be selected by the judges of the Kansas City Court of Appeals. Said board of control shall, with the aid of ingineers, clerks, etc., (1) supervise the routing, stopping and schedules of cars; (2) require the operation of sufficient cars; (3) supervise construction, reconstruction, equipment, etc.; (4) properly classify and charge all expenditures; (5) supervise the bookkeeping; (6) file semi-annually complete statement of all receipts and disbursements, and of the condition of the capital and other accounts, etc.

Fares.-The fares, until and unless reduced as in this ordinance provided, shall be five cents for each passenger over twelve years of age and two and one-half cents for each passenger of eight to twelve years, over the entire system within the city. Universal transfers free over all parts of the city, and also over all parts of the system in Kansas within the limits of Rosedale and Kansas City, Kan., and intermediate points, so long as the company shall operate therein.

Rehabilitation-Immediate Extensions and Additions.-As soon as the 12th Street viaduct is completed, the company shall electrify all parts of the system not then electrified. The company shall proceed immediately to put its entire street railway and equipment in firstclass condition and complete the work within three years, expending $\$ 1,500,000$ or so much thereof as may be necessary, adding also for each of the three years twenty-five new cars and five miles of track as extensions (shown in the ordinance).

The city shall own and be charged with the cost of the following named portions of said lines, viz.: Broadway from Southwest Boulevard to 24th Street, and thence across the Union Station Plaza or along 24th Street to Main Street and along Main Street to 19th Street.

Also a further $\$ 250,000$ shall be used at once to build such other extensions as the board of control may determine.

Future Extensions. - The city at any time after. three years may require the company to construct extensions as follows: (a) any four miles of track a year not manifestly unneeded; (b) such additional extensions, reasonably necessary, that will pay not less than six per cent. per annum over and above the expense of operating and maintaining.

Rights to Other Companies. - The city shall have the right to authorize one or more street railway companies to use the tracks of the company for six consecutive blocks or less, also over the Main and 
Delaware, 10th Street, 3d Street and Cherry Street loops and the Allen Avenue viaduct.

The company shall pay to each existing interurban line for the use of interurban cars while on the company's tracks, a sum equaling 15 per cent. of the amount received by it from each through passenger at its regular eity rate.

Express Matter.-The company may carry U. S. mail and also light packages or parcels.

Paving.-Company must pave for eighteen inches beyond each outer rail—on parkways for thirty inches.

Street Cleaning, etc.-The company shall sweep, keep clean and free from snow and ice and sprinkle or oil that portion of the streets which it is required to pave and keep in repair, the city to furnish the water free.

Capital Value.-The eapital value of all of the property in Missouri is hereby fixed at $\$ 25,648,806$, plus the cost of all additions, extensions and betterments made after May 31, 1913, properly chargeable to capital account. The amount named takes into consideration the value of all existing property in Missouri on May 31, 1913, together with the value of the earnings for the fixed period of existing contracts with the city, as well as the total moneys expended in building up said properties, said sum being a compromise between company and city of their respective calculations.

The company agrees to procure such new money as, together with such portions of the surplus as by this ordinance may be used to pay for extensions and additions to property in Missouri, will provide the following sums of money with which to pay for additions and extensions to be made in accordance with this ordinance, to wit, yearly:

$\begin{array}{cccccc}1914-1918 & 1919-1923 & 1924-1928 & 1929-1933 & 1934-1938 & 1939-1943 \\ \$ 650,000 & \$ 725,000 & \$ 775,000 & \$ 825,000 & \$ 875,000 & \$ 925,000\end{array}$

Such new money shall be added to and beeome a part of the capital value, and if the net earnings, in the aggregate, exceed or are less than 35 per cent. of the gross receipts in any year, then the amount so to be annually expended shall be correspondingly increased or diminished.

There has been filed in the City Clerk's office a reconcilement dated September 6, 1913, of the appraisals of Bion J. Arnold and L. R. Ash (V. 66, p. 553), wherein it is agreed that the depreciated physical value of all property in Missouri and Kansas, May 31, 1912, was $\$ 22,500,000,84$ per eent. thereof being in Missouri and 16 per cent. in Kansas. There has also been filed a statement showing that between May 31, 1912, and May 31, 1913, the receivers added to prop- 
erty value in Missouri $\$ 600,000$, making the total depreciated value, exclusive of other elements of value, of the physical property in Missouri $\$ 19,500,000$ as of May 31,1913 . The board of control shall within ninety days adjust said appraisal inventories in detail without increasing or decreasing the totals as stated in this paragraph.

Disposition of Earnings.-Out of each year's gross earnings in Missouri there shall be paid in this order: (1) All expenses of management, operation and maintenance, and all taxes, license fees and special assessments. (2) To the company six per cent. per annum, cumulative, upon the capital value from time to time determined. (3) All liabilities for personal injuries and damages to property. (4) The remaining surplus income shall be credited to the city from time to time and shall be used by the company to pay for extensions and additions to the property until the sum of $\$ 6,300,000$ is so used. No part of said sum and no part of the value of any additions or extensions acquired by the use thereof shall be added to or become a part of capital value or be considered as a payment in reduction thereof.

When said $\$ 6,300,000$ shall have been so used, then and thereafter the surplus income shall be paid two-thirds to the city and one-third to the company. The two-thirds belonging to the city shall be credited to it until the city otherwise ordains and be used either (a) to reduce capital value, or (b) for additions and extensions approved by the city's directors.

The city expressly reserves the right at any time after said sum of $\$ 6,300,000$ shall have been paid, first, by ordinance, to reduce fares and thereby diminish the amount of its share of surplus income, but not so as materially to reduce the company's share below what it would be if the fare had not been reduced; and, second, by ordinance approved by vote of the people to direct that its surplus income be used for any other public purpose.

When and as said surplus is used either to reduce capital value or to pay for additions or extensions, it shall be deemed and taken to be an investment by the city of so much money in the property towards the acquisition of title to the property as hereinafter provided, and to that extent the city shall become and be an owner of an equitable interest in the property, subject to the company's right to capital value, the return thereon and participation as defined in this ordinance.

When and as capital value is reduced, the six per cent. return thereon shall abate and cease pro tanto. The rights and interests of the company, shareholders, bondholders, mortgagees and all persons claiming any interest in the property under or through the company 
shall be restricted and confined to and be no greater than the right to be paid the capital value of the property from time to time.

All the covenants in this contract shall run with the property in whatsoever manner the same may be mortgaged, sold, transferred or conveyed.

Maintenance, etc.-Each year the board of control shall determine what percentages of the gross earnings shall be used during that year for (a) maintenance, repairs, renewals and depreciation, and (b) for damage claims, such percentages to be not less than 16 per cent. and four per cent., respectively.

Right of City to Acquire.-The company agrees that the city shall have the right (when legally empowered so to do) to become the owner of the property in Jackson County, Mo., as follows:

(a) Whenever, by application of the city's share of the surplus, the capital value shall be reduced to an amount not in excess of 50 per cent. of the combined capital value and cost of extensions and additions, then the city shall at once become the owner of all of the property in Jackson County, subject only to a lien securing the payment of the balance unpaid of the capital value in Missouri and any mortgage securing same.

(b) Whenever, by the application of the city's interest in the surplus income to the reduction of such capital value and to the payment for extensions and additions to property and by payment, by the city to the company, of cash, the capital value shall be so reduced, or the actual value so increased, that the unpaid portion of the capital value shall not exceed 50 per cent. of the sum mentioned, then if the city shall also pay to the company in cash the value of the remainder of its right to participation and the cost, if any, of redeeming before maturity such mortgage bonds of the company as it may be necessary to redeem in order to accomplish the purpose aforesaid at not exceeding a premium of three per cent. on the bonds so redeemed, the city shall thereupon become the owner of all said property in Missouri, subject to a lien to secure the payment of the unpaid portion of the capital value and any mortgage securing same or any part thereof.

Whenever such capital value shall be reduced by any of the methods aforesaid to 50 per cent. of the sum aforesaid then the company's right to participation in the surplus shall cease and entire surplus shall belong to the city.

(c) The city may at any time pay for the entire capital value, but prior to the time such capital value shall have been, reduced to one-half of the sum aforesaid, it shall pay also for the value of the remainder of the company's right to participation in the surplus income, and also the cost of redeeming, before maturity, mortgage 
bonds in order to accomplish said purpose, not exceeding a premium of three per cent. on bonds so redeemed.

If, however, before the company's right to participation in the surplus income begins, the city should pay in cash the entire capital value and also all sums due as a return thereon, as well as the said sums necessary to redeem bonds, then there shall be no payment on account of the value of the said right of participation, but in such event the city shall take the property only for municipal operation and ownership, and shall continue to own and operate the property for a period of five years thereafter, or it may sell said property, or to grant the right to operate the same, to another than the company within said period on giving six months' notice and paying to the company the full value of the company's right of participation in the surplus income.

Mortgages.-Any and every mortgage shall conform to the provisions of this ordinance, and may cover the whole or any part of the property at any time owned, but not any line or extension built by the city. It may include all property in Missouri and Kansas, but that portion which in Missouri shall not stand as security for so much, if any, of the obligations at any time outstanding as are in excess of the then capital value of the part of the property in Missouri, and it shall be released as to such property when such capital value and the return thereon has been paid. If, however, it includes only the property in Missouri, then the aggregate amount of bonds at any time issued and outstanding under all mortgages which are liens upon such property shall never exceed the then capital value as herein defined. Whenever the city acquires the property all such mortgages, so far as they are liens upon the property acquired, shall be closed and the principal indebtedness thereby secured shall not be increased.

In the event mortgage bonds theretofore issued by the company shall be in excess of the amount subject to which the property is to be conveyed to the city under this ordinance, then the city shall have the right to designate which of said bonds up to the amount subject to which the property is to be conveyed to the city shall continue to be secured by the lien of such mortgage on property then acquired.

In aid of the present contemplated plan of reorganization and the refunding of the present existing bonded and mortgage debt, the company is authorized to execute a mortgage, as above provided, and issue thereunder bonds of an amount not in excess of the then capital value, as herein defined. Thereafter, the company shall, before making any increase of its stock or bonded indebtedness, notify the city's directors of such proposed increase. No such increase shall be made 
so as to make the total outstanding stock and bonds in excess of the limitations provided for above.

Every receiver, trustee, purchaser and successor of or to the interest and rights of the company shall be bound by this contract.

Employees.-Company shall not discriminate either in favor of or against any person because of his or her affiliation with any labor organization.

Endorsement on Stock.-All stock certificates issued by the company shall bear this endorsement: "The holder hereof has taken this certificate upon condition that it shall always be voted for the election of city directors, as provided in any franchise contract with Kansas City, Mo. Without power of revocation, the Mayor of said city is constituted attorney in fact, to that extent, so to rote the stock. No stockholder shall receive any dividend upon or vote any share of stock unless he holds a certificate so endorsed."

Forfeiture.-If the company shall willfully do any act or thing by this ordinance prohibited, or willfully neglect to do any act or thing required by its terms, it shall forfeit all rights conferred by this ordinance, but such forfeiture shall not affect the right of mortgagees and those claiming under the company to capital value and return thereon, as herein provided.

Expiration of Grant.-At the expiration of this franchise the city shall have the right either to take over the property on payment of the unpaid portion of the capital value, or to transfer this right to any person or corporation, such new company to pay therefor in cash the anpaid portion of the capital value and, if the city so require, an additional price.

The expiration of this franchise shall not have the effect of terminating the mortgage indebtedness existing against the property with the approval of the city, but the same shall continue as a lien against the property, and every person, including the city, who shall come into possession of the same. At the expiration of this franchise, the city may, if it desires so to do, require the company to continue to operate under this contract, pending such purchase or other arrangement, and if no such purchase or other arrangement shall be made, the company's rights shall hereunder cease and terminate and then the city through its trustees shall take over the property subject. to the unpaid portion of capital value and operate it under the terms hereof, but shall apply all surplus income to the payment of capital value and return thereon until its entire payment shall have been made.-V. 99, p. 119. 


\section{THE SHERMAN ANTI-TRUST LAW'}

AN ACT To protect trade and commerce against unlawful restraints and monopolies.

Be it enacted by the Senate and House of Representatives of the United States of America in Congress assembled,

SEc. 1. Every contract, combination in the form of trust or otherwise, or conspiracy, in restraint of trade or commerce among the several States, or with foreign nations, is hereby declared to be illegal. Everv person who shall make any such rontract or engage in any such combination or conspiracy, shall be deemed guilty of a misdemeanor, and, on conviction thereof, shall be punished by fine not exceeding five thousand dollars, or by imprisonment not exceeding one year, or both said punishments, in the discretion of the court.

SEc. 2. Every person who shall monopolize, or attempt to monopolize, or combine or conspire with any other person or persons, to monopolize any part of the trade or commerce among the several States, or with foreign nations shall be deemed guilty of a misdemeanor, and, on conviction thereof, shall be punished by fine not exceeding five thousand dollars, or by imprisonment not exceeding one year, or by both said punishments, in the discretion of the court.

SEC. 3. Every contract, combination in form of trust or otherwise, or conspiracy, in restraint of trade or commerce in any Territory of the United States or of the District of Columbia, or in restraint of trade or commerce between any such Territory and another, or between any such Territory or Territories, and any State or States or the District of Columbia, or with foreign nations, or between the District of Columbia and any State or States or foreign nations, is hereby declared illegal. Every person who shall make any such contract or engage in any such combination or conspiracy, shall be deemed guilty of a misdemeanor, and, on conviction thereof, shall be punished by fine not exceeding five thousand dollars, or by imprisonment not exceeding one year, or by both said punishments, in the discretion of the court.

SEc. 4. The several circuit courts of the United States are hereby invested with jurisdiction to prevent and restrain violations of this act; and it shall be the duty of the several district attorneys of the United States, in their respective districts, under the direction of the Attorney General, to institute proceedings in equity to prevent and restrain such violations. Such proceedings may be by way of petition setting forth the case and praying that such violation shall be enjoined or otherwise prohibited. When the parties complained of shall have been

1 Act of July 2, 1890 (26 Stat., 209). 
duly notified of such petition the court shall proceed, as soon as may be, to the hearing and determination of the case; and pending such petition and before final decree, the court may at any time make such temporary restraining order or prohibition as shall be deemed just in the premises.

SEc. 5. Whenever it shall appear to the court before which any proceeding under section four of this act may be pending, that the ends of justice require that other parties should be brought before the court, the court may cause them to be summoned, whether they reside in the district in which the court is held or not; and subpœnas to that end may be served in any district by the marshal thereof.

SEc. 6. Any property owned under any contract or by any combibination, or purusant to any conspiracy (and being the subject thereof) mentioned in section one of this act, and being in the course of transportation from one State to another, or to a foreign country, shall be forfeited to the United States, and may be seized and condemned by like proceedings as those provided by law for the forfeiture, seizure, and condemnation of property imported into the United States contrary to law.

SEc. \%. Any person who shall be injured in his business or property by any other person or corporation by reason of anything forbidden or declared to be unlawful by this act, may sue therefor in any circuit court of the United States in the district in which the defendant resides or is found, without respect to the amount in controversy, and shall recover threefold the damages by him sustained, and the eosts of suit, including a reasonable attorney's fee.

SEc. 8. That the word "person," or "persons," wherever used in this act shall be deemed to include corporations and associations existing under 'or authorized by the laws of either the United States, or the law of any of the Territories, the laws of any State, or the laws of any foreign country.

ANTI-TRUST AMENDMENTS TO TIIE WILSON TARIFF ACT OF AUGUST 27,1894 - SF.CTIONS 73-74

[28 Stat., 570]

SEC. 73. That every combination, conspiracy, trust, agreement, or contract is hereby declared to be contrary to public policy, illegal, and void, when the same is made by or between two or more persons or corporations either of whom is engaged in importing any article from any foreign country into the United Stales, and when such combination, conspiracy, trust, agreement, or contract, is intended to operate in restraint of lawful trade, or free competition in lawful trade or com- 
merce, or to increase the market price in any part of the United States of any article or articles imported or intended to be imported into the United States, or of any manufacture into which such imported article enters or is intended to enter. Every person who is or shall hereafter be engaged in the importation of goods or any commodity from any foreign country in violation of this section of this act, or who shall combine or conspire with another to violate the same, is guilty of a misdemeanor, and, on conviction thereof in any court of the United States, such person shall be fined in a sum not less than one hundred dollars and not exceeding five thousand dollars, and shall be further punished by imprisonment, in the discretion of the court, for a term not less than three months nor exceeding twelve months.

SEc. 74. That the several circuit courts of the United States are hereby invested with jurisdiction to prevent and restrain violations of section seventy-three of this act; and it shall be the duty of the several district attorneys of the United States, in their respective districts, under the direction of the Attorney General, to institute proceedings in equity to prevent and restrain such violations. Such proceedings may be by way of petitions setting forth the case and praying that such violations shall be enjoined or otherwise prohibited. When the parties complained of shall have been duly notified of such petition the court shall proceed, as soon as may be, to the hearing and determination of the case; and pending such petition and before the final decree, the court may at any time make such temporary restraining order or prohibition as shall be deemed just in the premises.

Sec. 75. That whenever it shall appear to the court before which any proceeding under the seventy-fourth section of this act may be pending that the ends of justice require that other parties should be brought before the court, the court may cause them to be summoned, whether they reside in the district in which the court is held or not; and subpœnas to that end may be served in any district by the marshal thereof.

SEc. 76. That any property owned under any contract or by any combination, or pursuant to any conspiracy (and being the subject thereof) mentioned in section seventy-three of this act, and being in the course of transportation from one State to another, or to or from a Territory or the District of Columbia, shall be forfeited to the United States, and may be seized and condemned by like proceedings as those provided by law for the forfeiture, seizure, and condemnation of property imported into the United States contrary to law.

SEc. 7\%. That any person who shall be injured in his business or property by any other person or corporation by reason of anything forbidden or declared to be unlawful by this act may sue therefor in any 
circuit court of the United States in the district in which the defendant resides or is found, without respect to the amount in controversy, and shall recover threefold the damages by him sustained and the costs of suit, including a reasonable attorney's fee.

[The foregoing sections were expressly preserved in the Dingley Act of 1897. Section 34 of that act (30 Stat., 213) concludes as follows:]

And further provided, That nothing in this act shall be construed to repeal or in any manner affect the sections numbered seventy-three, seventy-four, seventy-five, seventy-six, and seventy-seven of an act entitled "And act to reduce taxation, to provide revenue for the Government, and for other purposes," which became a law on the twenty-eighth day of August, eighteen hundred and ninety-four.

\section{[32 Stat., 823]}

AN ACT To expedite the hearing and determination of suits in equity pending or lereafter brought under an act of July second, eighteen hundred and ninety, entitled "An act to protect trade and commerce against unlawful restraints and monopolies," "An act to regulate commerce," approved February fourth, eighteen hundred and eighty-seven, or any other acts having a like purpose that may be hereafter enacted.

Be it enacted by the Senate and House of Representatives of the United States of America in Congress assembled, That in any suit in equity pending or hereafter brought in any circuit court of the United States under the act entitled "An act to protect trade and commerce against unlawful restraints and monopolies," approved July second, eighteen hundred and ninety, "An act to regulate commerce," approved February fourth, eighteen hundred and eighty-seven, or any other acts having a like purpose that hereafter may be enacted, wherein the United States is complainant, the Attorney General may file with the clerk of such court a certificate that, in his opinion, the case is of general public importance, a copy of which shall be immediately furnished by such clerk to each of the circuit judges of the circuit in which the case is pending. Thereupon such case shall be given precedence over others and in every way expedited, and be assigned for hearing at the earliest practicable day, before not less than three of the circuit judges of said circuit, if there be three or more; and if there be not more than two circuit judges, then before them and such district judge as they may select. In the event the judges sitting in such case shall be divided in opinion the case shall be certified to the Supreme Court for review in like manner as if taken there by appenl as hereinafter provided.

SEc. 2. That in every suit in equity pending or hereafter brought in 
any circuit court of the United States under any of said acts wherein the United States is complainant, including cases submitted but not yet decided, an appeal from the final decree of the circuit court will lie only to the Supreme Court and must be taken within sixty days from the entry thereof: Provided, That in any case where an appeal may have been taken from the final decree of a circuit court to the circuit court of appeals before this act takes effect, the case shall proceed,to a final decree therein, and an appeal may be taken from such decree to the Supreme Court in the manner now provided by law.

Approved, February 11, 1903. 


\section{CLAYTON LAW SUPPLEMENTARY TO SHERMAN ANTI-TRUST ACT.'}

An Act To supplement existing laws against unlawful restraints and monopolies, and for other purposes.

Be it enacted by the Senate and House of Representatives of the United States of America in Congress assembled, That "anti-trust laws," as used herein, includes the Act entitled "An Act to protect trade and commerce against unlawful restraints and monopolies," approved July second, eighteen hundred and ninety; sections seventythree to seventy-seven, inclusive, of an Act entitled "An Act to reduce taxation, to provide revenue for the Government, and for other purposes," of August twenty-seventh, eighteen hundred and ninetyfour; an Act entitled "An Act to amend sections seventy-three and seventy-six of the Act of August twenty-seventh, eighteen hundred and ninety-four, entitled 'An Act to reduce taxation, to provide revenue for the Government, and for other purposes," approved February twelfth, nineteen hundred and thirteen; and also this Act.

"Commerce," as used herein, means trade or commerce among the several States and with foreign nations, or between the District of Columbia or any Territory of the United States and any State, Territory; or foreign nation, or between any insular possessions or other places under the jurisdiction of the United States, or between any such possession or place and any State or Territory of the United States or the District of Columbia or any foreign nation, or within the District of Columbia or any Territory or any insular possession or other place under the jurisdiction of the United States: Provided, That nothing in this Act contained shall apply to the Philippine Islands.

The word "person" or "persons" wherever used in this Act shall be deemed to include corporations and associations existing under or authorized by the laws of either the United States, the laws of any of the Territories, the laws of any State, or the laws of any forcign country.

SEc. 2. That it shall be unlawful for any person engaged in commerce, in the course of such commerce, either directly or indirectly to discriminate in price between different purchasers of commodities, which commodities are sold for use, consumption, or resale within the United States or any Territory thereof or the District of Columbia or any insular possession or other place under the jurisdiction of the United States, where the effect of such discrimination may be to

1 Public-No. 212-63d Congress. H. R. 15657. 
substantially lessen competition or tend to create a monopoly in any line of commerce: Provided, That nothing herein contained shall prevent discrimination in price between purchasers of commodities on account of differences in the grade, quality, or quantity of the commodity sold, or that makes only due allowance for difference in the cost of selling or transportation or discrimination in price in the same or different communities made in good faith to meet competition: And provided further, That nothing herein contained shall prevent persons engaged in selling goods, wares, or merchandise in commerce from selecting their own customers in bona fide transactions and not in restraint of trade.

SEC. 3. That it shall be unlawful for any person engaged in commerce, in the course of such commerce, to lease or make a sale or contract for sale of goods, wares, merchandise, machinery, supplies or other commodities, whether patented or unpatented, for use, consumption or resale within the United States or any Territory thereof or the District of Columbia or any insular possession or other place under the jurisdiction of the United States, or fix a price charged therefor, or discount from, or rebate upon, such price, on the condition; agreement or understanding that the lessee or purchaser thereof shall not use or deal in the goods, wares, merchandise, machinery, supplies or other commodities of a competitor or competitors of the lessor or seller, where the effect of such lease, sale, or contract for sale or such condition, agreement or understanding may be to substantially lessen competition or tend to create a monopoly in any line of commerce.

Sec. 4. That any person who shall be injured in his business or property by reason of anything forbidden in the anti-trust laws may sue therefor in any district court of the United States in the district in which the defendant resides or is found or has an agent, without respect to the amount in controversy, and shall recover threefold the damages by him sustained, and the cost of suit, including a reasonable attorney's fee.

SEC. 5. That a final judgment or decree hereafter rendered in any criminal prosecution or in any suit or proceeding in equity brought by or on behalf of the United States under the antitrust laws to the effect that a defendant has violated said laws shall be prima facie evidence against such defendant in any suit or proceeding brought by any other party against such defendant under said laws as to all matters respecting which said judgment or decree would be an estoppel as between the parties thereto: Provided, This section shall not apply to consent judgments or decrees entered before any testimony has been taken: Provided further, This section shall not apply to consent 
judgments or decrees rendered in criminal proceedings or suits in equity, now pending, in which the taking of testimony has been commenced but has not been concluded, provided such judgments or decrees are rendered before any further testimony is taken.

Whenever any suit or proceeding in equity or criminal prosecution is instituted by the United States to prevent, restrain or punish violations of any of the anti-trust laws, the running of the statute of limitations in respect of each and every private right of action arising under said laws and based in whole or in part on any matter complained of in said suit or proceeding shall be suspended during the pendency thereof.

SEC. 6. That the labor of a human being is not a commodity or article of commerce. Nothing contained in the anti-trust laws shall be construed to forbid the existence and operation of labor, agricultural, or horticultural organizations, instituted for the purposes of mutual help, and not having capital stock or conducted for profit, or to forbid or restrain individual members of such organizations from lawfully carrying out the legitimate objects thereof; nor shall such organizations, or the members thereof, be held or construed to be illegal combinations or conspiracies in restraint of trade, under the antitrust laws.

SEc. 7. That no corporation engaged in commerce shall acquire, directly or indirectly, the whole or any part of the stock or other share capital of another corporation engaged also in commerce, where the effect of such acquisition may be to substantially lessen competition between the corporation whose stock is so acquired and the corporation making the acquisition, or to restrain such commerce in any section or community, or tend to create a monopoly of any line of commerce.

No corporation shall acquire, directly or indirectly, the whole or any part of the stock or other share capital of two or more corporations engaged in commerce where the effect of such acquisition, or the use of such stock by the voting or granting of proxies or otherwise, may be to substantially lessen competition between such corporations, or any of them, whose stock or other share capital is so acquired, or to restrain such commerce in any section or community, or tend to create a monopoly of any line of commerce.

This section shall not apply to corporations purchasing such stock solely for investment and not using the same by roting or otherwise to bring about, or in attempting to bring about, the substantial lessening of competition. Nor shall anything contained in this section prevent a corporation engaged in commerce from causing the formation of subsidiary corporations for the actual carrying on of their 
immediate lawful business, or the natural and legitimate branches or extensions thereof, or from owning and holding all or a part of the stock of such subsidiary corporations, when the effect of such formation is not to substantially lessen competition.

Nor shall anything herein contained be construed to prohibit any common carrier subject to the laws to regulate commerce from aiding in the construction of branches or short lines so located as to become feeders to the main line of the company so aiding in such construction or from acquiring or owning all or any part of the stock of such branch lines, nor to prevent any such common carrier from acquiring and owning all or any part of the stock of a branch or short line constructed by an independent company where there is no substantial competition between the company owning the branch line so constructed and the company owning the main line acquiring the property or an interest therein, nor to prevent such common carrier from extending any of its lines through the medium of the acquisition of stock or otherwise of any other such common carrier where there is no substantial competition between the company extending its lines and the company whose stock, property, or an interest therein is so acquired.

Nothing contained in this section shall be held to affect or impair any right heretofore legally acquired: Provided, That nothing in this section shall be held or construed to authorize or make lawful anything heretofore prohibited or made illegal by the anti-trust laws, nor to exempt any person from the penal provisions thereof or the civil remedies therein provided.

SEc. 8. That from and after two years from the date of the approval of this Act no person shall at the same time be a director or other offcer or employee of more than one bank, banking association or trust company, organized or operating under the laws of the United States, either of which has deposits, capital, surplus, and undivided profits aggregating more than $\$ 5,000,000$; and no private banker or person who is a director in any bank or trust company, organized and operating under the laws of a State, having deposits, capital, surplus, and undivided profits aggregating more than $\$ 5,000,000$, shall be eligible to be a director in any bank or banking association organized or operating under the laws of the United States. The eligibility of a director, officer, or employee under the foregoing provisions shall be determined by the average amount of deposits, capital, surplus, and undivided profits as shown in the official statements of such bank, banking association, or trust company filed as provided by law during the fiscal year next preceding the date set for the annual election of directors, and when a director, officer, or employee has been elected 
or selected in accordance with the provisions of this Act it shall be lawful for him to continue as such for one year thereafter under said election or employment.

No bank, banking association or trust company, organized or operating under the laws of the United States, in any city or incorporated town or village of more than two hundred thousand inhabitants, as shown by the last preceding decennial census of the United States, shall have as a director or other officer or employee any private banker or any director or other officer or employee of any other bank, banking association or trust company located in the same place: Provided, That nothing in this section shall apply to mutual saving 3 banks not having a capital stock represented by shares: Provided further, That a director or other officer or employee of such bank, banking association, or trust company may be a director or other officer or employee of not more than one other bank or trust company organized under the laws of the United States or any State where the entire capital stock of one is owned by stockholders in the other: And provided further, That nothing contained in this section shall forbid a director of class $\mathrm{A}$ of a Federal reserve bank, as defined in the Federal Reserve Act from being an officer or director or both an officer and director in one member bank.

That from and after two years from the date of the approval of this Act no person at the same time shall be a director in any two or more corporations, any one of which has capital, surplus, and undivided profits aggregating more than $\$ 1,000,000$, engaged in whole or in part in commerce, other than banks, banking associations, trust companies and common carriers subject to the Act to regulate commerce, approved February fourth, eighteen hundred and eighty-seven, if such corporations are or shall have been theretofore, by virtue of their business and location of operation, competitors, so that the elimination of competition by agreement between them would constitute a violation of any of the provisions of any of the anti-trust laws. The eligibility of a director under the foregoing provision shall be determined by the aggregate amount of the capital, surplus, and undivided profits, exclusive of dividends declared but not paid to stockholders, at the end of the fiscal year of said corporation next preceding the election of directors, and when a director has been elected in accordance with the provisions of this Act it shall be lawful for him to continue as such for one year thereafter.

When any person elected or chosen as a director or officer or selected as an employee of any bank or other corporation subject to the provisions of this Act is eligible at the time of his election or selection to act for such bank or other corporation in such capacity his eligibility 
to act in such capacity shall not be affected and he shall not become or be deemed amenable to any of the provisions hereof by reason of any change in the affairs of such bank or other corporation from whatsoever cause, whether specifically excepted by any of the provisions hereof or not, until the expiration of one year from the date of his election or employment.

SEc. 9. Every president, director, officer or manager of any firm, association or corporation engaged in commerce as a common carrier, who embezzles, steals, abstracts or willfully misapplies, or willfully permits to be misapplied, any of the moneys, funds, credits, securities, property or assets of such firm, association or corporation, arising or accruing from, or used in, such commerce, in whole or in part, or willfully or knowingly converts the same to his own use or to the use of another, shall be deemed guilty of a felony and upon conviction shall be fined not less than $\$ 500$ or confined in the penitentiary not less than one year nor more than ten years, or both, in the discretion of the court.

Prosecutions hereunder may be in the district court of the United States for the district wherein the offense may have been committed.

That nothing in this section shall be held to take away or impair the jurisdiction of the courts of the several States under the laws thereof; and a judgment of conviction or acquittal on the merits under the laws of any State shall be a bar to any prosecution hereunder for the same act or acts.

Sec. 10. That after two years from the approval of this Act no common carrier engaged in commerce shall have any dealings in securities, supplies or other articles of commerce, or shall make or have any contracts for construction or maintenance of any kind, to the amount of more than $\$ 50,000$, in the aggregate, in any one year, with another corporation, firm, partnership or association when the said common carrier shall have upon its board of directors or as its president, manager or as its purchasing or selling officer, or agent in the particular transaction, any person who is at the same time a director, manager, or purchasing or selling officer of, or who has any substantial interest in, such other corporation, firm, partnership or association, unless and except such purchases shall be made from, or such dealings shall be with, the bidder whose bid is the most favorable to such common carrier, to be ascertained by competitive bidding under regulations to be prescribed by rule or otherwise by the Interstate Commerce Commission. No bid shall be received unless the name and address of the bidder or the names and addresses of the officers, directors and general managers thereof, if the bidder be a corporation, or of the members, if it be a partnership or firm, be given with the bid. 
Any person who shall, directly or indirectly, do or attempt to do anything to prevent anyone from bidding or shall do any act to prevent free and fair competition among the bidders or those desiring to bid shall be punished as prescribed in this section in the case of an officer or director.

Every such common carrier having any such transactions or making any such purchases shall within thirty days after making the same file with the Interstate Commerce Commission a full and detailed statement of the transaction showing the manner of the competitive bidding, who were the bidders, and the names and addresses of the directors and officers of the corporations and the members of the firm or partnership bidding; and whenever the said commission shall, after investigation or hearing, have reason to believe that the law has been violated in and about the said purchases or transactions it shall transmit all papers and documents and its own views or findings regarding the transaction to the Attorney General.

If any common carrier shall violate this section it shall be fined not exceeding $\$ 25,000$; and every such director, agent, manager or officer thereof who shall have knowingly roted for or direeted the act constituting such violation or who shall have aided or abetted in such violation shall be deemed guilty of a misdemeanor and shall be fined not exceeding $\$ 5,000$, or confined in jail not exceeding one year, or both, in the discretion of the court.

SEc. 11. That authority to enforce compliance with sections two, three, seven and eight of this Act by the persons respectively subject thereto is hereby vested: in the Interstate Commerce Commission where applicable to common carriers, in the Federal Reserve Board where applicable to banks, banking associations and trust companies, and in the Federal Trade Commission where applicable to all other character of commerce, to be exereised as follows:

Whenever the commission or board vested with jurisdiction therenf shall have reason to believe that any person is violating or has riolated any of the provisions of sections two, three, seven and eight of this Act, it shall issue and serve upon such person a complaint stating its charges in that respect, and containing a notice of a hearing upon a day and at a place therein fixed at least thirty days after the service of said complaint. The person so complained of shall have the right to appear at the place and time so fixed and show cause why an order should not be entered by the commission or board requiring such person to cease and desist from the violation of the law so charged in said complaint. Any person may make application, and upon good cause shown may be allowed by the commission or board, to intervene and appear in said proceeding by counsel or in person. The testi- 
mony in any such proceeding shall be reduced to writing and filed in the office of the commission or board. If upon such hearing the commission or board, as the case may be, shall be of the opinion that any of the provisions of said sections have been or are being violated, it shall make a report in writing in which it shall state its findings as to the facts, and shall issue and cause to be served on such person an order requiring such person to cease and desist from such violations, and divest itself of the stock held or rid itself of the directors chosen contrary to the provisions of sections seven and eight of this Act, if any there be, in the manner and within the time fixed by said order. Until a transcript of the record in such hearing shall have been filed in a circuit court of appeals of the United States, as hereinafter provided, the commission or board may at any time, upon such notice and in such manner as it shall deem proper, modify or set aside, in whole or in part, any report or any order made or issued by it under this section.

If such person fails or neglects to obey such order of the commission or board while the same is in effect, the commission or board may apply to the circuit court of appeals of the United States, within any circuit where the violation complained of was or is being committeed or where such person resides or carries on business, for the enforcement of its order, and shall certify and file with its application a transcript of the entire record in the proceeding, including all the testimony taken and the report and order of the commission or board. Upon such filing of the application and transcript the court shall cause notice thereof to be served upon such person and thereupon shall have jurisdiction of the proceeding and of the question determined therein, and shall have power to make and enter upon the pleadings, testimony, and proceedings set forth in such transcript a decree affirming, modifying, or setting aside the order of the commission or board. The findings of the commission or board as to the facts, if supported by testimony, shall be conclusive. If either party shall apply to the court for leave to adduce additional evidence, and shall show to the satisfaction of the court that such additional evidence is material and that there were reasonable grounds for the failure to adduce such evidence in the proceedings before the commission or board, the court may order such additional evidence to be taken before the commission or board and to be adduced upon the hearing in such manner and upon such terms and conditions as to the court may seem proper. The commission or board may modify its findings as to the facts, or make new findings, by reason of the additional evidence so taken, and it shall file such modified or new findings, which, if supported by testimony, shall be conclusive, and 
its recommendation, if any, for the modification or setting aside of its original order, with the return of such additional evidence. The judgment and deeree of the court shall be final, except that the same shall be subject to review by the Supreme Court upon certiorari as provided in section two hundred and forty of the Judicial Code.

Any party required by such order of the commission or board to cease and desist from a violation charged may obtain a review of such order in said circuit court of appeals by filing in the court a written petition praying that the order of the commission or board be set aside. A copy of such petition shall be forthwith served upon the commission or board, and thereupon the commission or board forthwith shall certify and file in the court a transeript of the record as hereinbefore provided. Upon the filing of the transcript the court shall have the same jurisdiction to affirm, set aside, or modify the order of the commission or board as in the case of an application by the commission or board for the enforcement of its order, and the findings of the commission or board as to the facts, if supported by testimony, shall in like manner be conclusive.

The jurisdiction of the circuit court of appeals of the United States to enforce, set aside, or modify orders of the commission or board shall be exclusive.

Such proceedings in the circuit court of appeals shall be given precedence over other cases pending therein, and shall be in every way expedited. No order of the commission or board or the judgment of the court to enforce the same shall in any wise relieve or absolve any person from any liability under the anti-trust Acts.

Complaints, orders, and other processes of the commission or board under this section may be served by anyone duly authorized by the commission or board, either (a) by delivering a copy thereof to the person to be served, or to a member of the partnership to be served, or to the president, seeretary, or other executive officer or a director of the corporation to be served; or (b) by leaving a copy therenf at the principal office or place of business of such person; or (c) by registering and mailing a copy thereof addressed to such person at his principal office or place of business. The verified return by the person so serving said complaint, order, or other process setting forth the manner of said service shall be proof of the same, and the return post-office receipt for said complaint, order, or other process registered and mailed as aforesaid shall be proof of the service of the same.

Sec. 12. That any suit, action, or proceedings under the anti-t rust laws against a corporation may be brought not only in the judicial district whereof it is an inhabitant, but also in any district wherein it may be found or transacts business; and all process in such cases may 
be served in the district of which it is an inhabitant, or wherever it may be found.

SEc. 13. That in any suit, action, or proceeding brought by or on behalf of the United States subpœnas for witnesses who are required to attend a court of the United States in any judicial district in any case, civil or criminal, arising under the anti-trust laws may run into any other district: Provided, That in civil cases no writ of subpœna shall issue for witnesses living out of the district in which the court is held at a greater distance than one hundred iniles from the place of holding the same without the permission of the trial court being first had upon proper application and cause shown.

SEC. 14. That whenever a corporation shall violate any of the penal provisions of the anti-trust laws, such violation shall be deemed to be also that of the individual directors, officers, or agents of such corporation who shall have authorized, ordered, or done any of the acts constituting in whole or in part such violation, and such violation shall be deemed a misdemeanor, and upon conviction therefor of any such director, officer, or agent he shall be punished by a fine of not exceeding $\$ 5,000$ or by imprisonment for not exceeding one year, or by both, in the discretion of the court.

SEC. 15. That the several district courts of the United States are hereby invested with jurisdiction to prevent and restrain violations of this Act, and it shall be the duty of the several district attorneys of the United States, in their respective districts, under the direction of the Attorney General, to institute proceedings in equity to prevent and restrain such violations. Such proceedings may be by way of petition setting forth the case and praying that such violation shall be enjoined or otherwise prohibited. When the parties complained of shall have been duly notified of such petition, the court shall proceed, as soon as may be, to the hearing and determination of the case; and pending such petition, and before final decree, the court may at any time make such temporary restraining order or prohibition as shall be deemed just in the premises. Whenever it shall appear to the court before which any such proceeding may be pending that the ends of justice require that other parties should be brought before the court, the court may cause them to be summoned whether they reside in the district in which the court is held or not, and subpœnas to that end may be served in any district by the marshal thereof.

SEc. 16. That any person, firm, corporation, or association shall be entitled to sue for and have injunctive relief, in any court of the United States having jurisdiction over the parties, against threatened loss or damage by a violation of the anti-trust laws, including 
sections two, three, seren and eight of this Act, when and under the same conditions and principles as injunctive relief against threatened conduct that will cause loss or damage is granted by courts of equity, under the rules governing such proceedings, and upon the execution of proper bond against damages for an injunction improvidently granted and a showing that the danger of irreparable loss or damage is immediate, a preliminary injunction may issue: Provided, That nothing herein contained shall be construed to entitle any person, firm, corporation, or association, except the United States, to bring suit in equity for injunctive relief against any common carrier subject to the provisions of the Act to regulate commerce, approved February fourth, eighteen hundred and eighty-seven, in respect of any matter subject to the regulation, supervision, or other jurisdiction of the Interstate Commerce Commission.

Sec. 17. That no preliminary injunction shall be issued without notice to the opposite party.

No temporary restraining order shall be granted without notice to the opposite party unless it shall clearly appear from specific facts shown by affidavit or by the verified bill that immediate and irreparable injury, loss, or damage will result to the applicant before notice can be served and a hearing had thereon. Every such temporary restraining order shall be indorsed with the date and hour of issuance, shall be forthwith filed in the clerk's office and entered of record, shall define the injury and state why it is irreparable and why the order was granted without notice, and shall by its terms expire within such time after entry, not to exceed ten days, as the court or judge may fix, unless within the time so fixed the order is extended for a like period for good cause shown, and the reasons for such extension shall be entered of record. In case a temporary restraining order shall be granted without notice in the contingency specified, the matter of the issuance of a preliminary injunction shall be set down for a hearing at the earliest possible time and shall take precedence of all matters except older matters of the same character; and when the same comes up for hearing the party obtaining the temporary restraining order shall proceed with the application for a preliminary injunction, and if he does not do so the court shall dissolve the temporary restraining order. Upon two days' notice to the party obtaining such temporary restraining order the opposite party may appear and move the dissolution or modification of the order, and in that event the court or judge shall proceed to hear and determine the motion as expeditiously as the ends of justice may require.

Section two hundred and sixty-three of an Act entitled "An Act to sodify, revise, and amend the laws relating to the judiciary," ap- 
proved March third, nineteen hundred and eleven, is hereby repealed.

Nothing in this section contained shall be deemed to alter, repeal, or amend section two hundred and sixty-six of an Act entitled "An Act to codify, revise, and amend the laws relating to the judiciary," approved March third, nineteen hundred and eleven.

SEc. 18. That, except as otherwise provided in section 16 of this Act, no restraining order or interlocutory order of injunction shall issue, except upon the giving of security by the applicant in such sum as the court or judge may deem proper, conditioned upon the payment of such costs and damages as may be incurred or suffered by any party who may be found to have been wrongfully enjoined or restrained thereby.

SEc. 19. That every order of injunction or restraining order shall set forth the reasons for the issuance of the same, shall be specific in terms, and shall describe in reasonable detail, and not by reference to the bill of complaint or other document, the act or acts sought to be restrained, and shall be binding only upon the parties to the suit, their officers, agents, servants, employees, and attorneys, or those in active concert or participating with them, and who shall, by personal service or otherwise, have received actual notice of the same.

SEc. 20. That no restraining order or injunction shall be granted by any court of the United States, or a judge or the judges thereof, in any case between an employer and employees, or between employers and employees, or between employees, or between persons employed and persons seeking employment, involving, or growing out of, a dispute concerning terms or conditions of employment, unless necessary to prevent irreparable injury to property, or to a property right, of the party making the application, for which injury there is no adequate remedy at law, and such property or property right must be described with particularity in the application, which must be in writing and sworn to by the applicant or by his agent or attorney.

And no such restraining order or injunction shall prohibit any person or persons, whether singly or in concert, from terminating any relation of employment, or from ceasing to perform any work or labor, or from recommending, advising, or persuading others by peaceful means so to do; or from attending at any place where any such person or persons may lawfully be, for the purpose of peacefully obtaining or communicating information, or from peacefully persuading any person to work or to abstain from working; or from ceasing to patronize or to employ any party to such dispute, or from recommending, advising, or persuading others by peaceful and lawful means so to do; or from paying or giving to, or withholding from, any person engaged in such dispute, any strike benefits or other moneys or things of value; 
or from peaceably assembling in a lawful manner, and for lawful purposes; or from doing any act or thing which might lawfully be done in the absence of such dispute by any party thereto; nor shall any of the acts specified in this paragraph be considered or held to be violations of any law of the United States.

Sec. 21. That any person who shall willfully disobey any lawful writ, process, order, rule, decree, or command of any district court of the United States or any court of the District of Columbia by doing any act or thing therein, or thereby forbidden to be done by him, if the act or thing so done by him be of such character as to constitute also a eriminal offense under any statute of the United States, or under the laws of any State in which the act was committed, shall be procceded against for his said contempt as hereinafter provided.

SEc. 22. That whenever it shall be made to appear to any district court or judge thereof, or to any judge therein sitting, by the return of a proper officer on lawful process, or upon the affidavit of some credible person, or by information filed by any district attorney, that there is reasonable ground to believe that any person has been guilty of such contempt, the court or judge thereof, or any judge therein sitting, may issue a rule requiring the said person so charged to show cause upon a day certain why he should not be punished therefor, which rule, together with a copy of the affidavit or information, shall be served upon the person elarged, with sufficient promptness to enable him to prepare for and make return to the order at the time fixed therein. If upon or by such return, in the judgment of the court, the alleged contempt be not sufficiently purged, a trial shall be directed at a time and place fixed by the court: Provided, however. That if the accused, being a natural person, fail or refuse to make return to the rule to slow eause, an attachment may issue against his person to compel an answer, and in case of his continued failure or refusal, or if for any reason it be impracticable to dispose of the matter on the return day, he may be required to give reasonable bail for his attendance at the trial and his submission to the final judgment of the court. Where the aceused is a body corporate, an attachment for the sequestration of its property may be issued upon like refusal or failure to answer.

In all cases within the purview of this Act such trial may be by the court, or, upon demand of the accused, by a jury; in which latter event the court may impanel a jury from the jurors then in attendance, or the court or the judge thereof in chambers may cause a sufficient number of jurors to be selected and summoned, as provided by law, to attend at the time and place of trial, at which time a jury shall be selected and impaneled as upon a trial for misdemeanor; 
and such trial shall conform, as near as may be, to the practice in criminal cases prosecuted by indictment or upon information.

If the accused be found guilty, judgment shall be entered accordingly, prescribing the punishment, either by fine or imprisonment, or both, in the discretion of the court. Such fine shall be paid to the United States or to the complainant or other party injured by the act constituting the contempt, or may, where more than one is so damaged, be divided or apportioned among them as the court may direct, but in no case shall the fine to be paid to the United States exceed, in case the accused is a natural person, the sum of $\$ 1,000$, nor shall such imprisonment exceed the term of six months: Provided, That in any case the court or a judge thereof may, for good cause shown, by affidavit or proof taken in open court or before such judge and filed with the papers in the case, dispense with the rule to show cause, and may issue an attachment for the arrest of the person charged with contempt; in which event such person, when arrested, shall be brought before such court or a judge thereof without unnecessary delay and shall be admitted to bail in a reasonable penalty for his appearance to answer to the charge or for trial for the contempt; and thereafter the proceedings shall be the same as provided herein in case the rule had issued in the first instance.

SEc. 23. That the evidence taken upon the trial of any persons so accused may be preserved by bill of exceptions, and any judgment of conviction may be reviewed upon writ of error in all respects as now provided by law in criminal cases, and may be affirmed, reversed, or modified as justice may require. Upon the granting of such writ of error, execution of judgment shall be stayed, and the accused, if thereby sentenced to imprisonment, shall be admitted to bail in such reasonable sum as may be required by the court, or by any justice, or any judge of any district court of the United States or any court of the District of Columbia.

SEc. 24. That nothing herein contained shall be construed to relate to contempts committed in the presence of the court, or so near thereto as to obstruct the administration of justice, nor to contempts committed in disobedience of any lawful writ, process, order, rule, decree, or command entered in any suit or action brought or prosecuted in the name of, or on behalf of, the United States, but the same, and all other cases of contempt not specifically embraced within section twenty-one of this Act, may be punished in conformity to the usages at law and in equity now prevailing.

SEc. 25. That no proceeding for contempt shall be instituted against any person unless begun within one year from the date of the act complained of; nor shall any such proceeding be a bar to any 
criminal prosecution for the same act or acts; but nothing herein contained shall affect any proceedings in contempt pending at the time of the passage of this Act.

SEc. 26. If any clause, sentence, paragraph, or part of this Act shall, for any reason, be adjudged by any court of competent jurisdiction to be invalid, such judgment shall not affect, impair, or invalidate the remainder thereof, but shall be confined in its operation to the clause, sentence, paragraph, or part thereof directly involved in the controversy in which such judgment shall have been rendered.

Approved, October 15, 1914. 


\section{FEDERAL TRADE COMMISSION LAW.'}

An Act To create a Federal Trade Commission, to define its powers and duties, and for other purposes.

$B e$ it enacted by the Senate and House of Representatives of the United States of America in Congress assembled, That a commission is hereby created and established, to be known as the Federal Trade Commission (hereinafter referred to as the commission), which shall be composed of five commissioners, who shall be appointed by the President, by and with the advice and consent of the Senate. Not more than three of the commissioners shall be members of the same political party. The first commissioners appointed shall continue in office for terms of three, four, five, six, and seven years, respectively, from the date of the taking effect of this Act, the term of each to be designated by the President, but their successors shall be appointed for terms of seven years, except that any person chosen to fill a vacancy shall be appointed only for the unexpired term of the commissioner whom he shall succeed. The commission shall choose a chairman from its own membership. No commissioner shall engage in any other business, vocation, or employment. Any commissioner may be removed by the President for inefficiency, neglect of duty, or malfeasance in office. A vacancy in the commission shall not impair the right of the remaining commissioners to exercise all the powers of the commission.

The commission shall have an official seal, which shall be judicially noticed.

SEc. 2. That each commissioner shall receive a salary of $\$ 10,000$ a year, payable in the same manner as the salaries of the judges of the courts of the United States. The commission shall appoint a secretary, who shall receive a salary of $\$ 5,000$ a year, payable in like manner, and it shall have authority to employ and fix the compensation of such attorneys, special experts, examiners, clerks, and other employees as it may from time to time find necessary for the proper performance of its duties and as may be from time to time appropriated for by Congress.

With the exception of the secretary, a clerk to each commissioner, the attorneys, and such special experts and examiners as the commission may from time to time find necessary for the conduct of its work, all employees of the commission shall be a part of the classified civil service, and shall enter the service under such rules and regula-

1 Public-No. 203-63d Congress. H. R. 15613. 
tions as may be prescribed by the commission and by the Civil Service Commission.

All of the expenses of the commission, including all necessary expenses for transportation incurred by the commissioners or by their employees under their orders, in making any investigation, or upon official business in any other places than in the city of Washington, shall be allowed and paid on the presentation of itemized vouchers therefor approved by the commission.

Until otherwise provided by law, the commission may rent suitable offices for its use.

The Auditor for the State and Other Departments shall receive and examine all accounts of expenditures of the commission.

SEc. 3. That upon the organization of the commission and election of its chairman, the Bureau of Corporations and the offices of Commissioner and Deputy Commissioner of Corporations shall cease to exist; and all pending investigations and proceedings of the Bureau of Corporations shall be continued by the commission.

All clerks and employees of the said bureau shall be transferred to and become clerks and employees of the commission at their present grades and salaries. All records, papers, and property of the said bureau shall become records, papers, and property of the commission, and all unexpended funds and appropriations for the use and maintenance of the said bureau, including any allotment already made to it by the Secretary of Commerce from the contingent appropriation for the Department of Commerce for the fiscal year nineteen hundred and fifteen, or from the departmental printing fund for the fiscal year nineteen hundred and fifteen, shall become funds and appropriations available to be expended by the commission in the exercise of the powers, authority, and duties conferred on it by this Act.

The principal office of the commission shall be in the city of Washington, but it may meet and exercise all its powers at any other place. The commission may, by one or more of its members, or by such examiners as it may designate, prosecute any inquiry necessary to its duties in any part of the United States.

SEo. 4. That the words defined in this section shall have the folloiwng meaning when found in this $\Lambda$ ct, to wit:

"Commerce" means commerce among the several States or with foreign nations, or in any Territory of the United States or in the District of Columbia, or between any such Territory and another, or between any such Territory and any State or foreign nation, or between the District of Colummbia and any State or Territory or foreign nation. 
"Corporation" means any company or association incorporated or unincorporated, which is organized to carry on business for profit and has shares of capital or capital stock, and any company or association, incorporated or unincorporated, without shares of capital or capital stock, except partnerships, which is organized to carry on business for its own profit or that of its members.

"Documentary evidence" means all documents, papers, and correspondence in existence at and after the passage of this Act.

"Acts to regulate commerce" means the Act entitled "An Ast to regulate commerce," approved February fourteenth, eighteen hundred and eighty-seven, and all Acts amendatory thereof and supplementary thereto.

"Anti-trust acts" means the Act entitled "An Act to protect trade and commerce against unlawful restraints and monopolies," approved July second, eighteen hundred and ninety; also the sections seventythree to seventy-seven, inclusive, of an Act entitled "An Act to reduce taxation, to provide revenue for the Government, and for other purposes," approved August twenty-seventh, eighteen hundred and ninety-four; and also the Act entitled "An Act to amend sections serenty-three and seventy-six of the Act of August twenty-seventh, eighteen hundred and ninety-four, entitled 'An Act to reduce taxation, to provide revenue for the Government, and for other purposes," approved February twelfth, nineteen hundred and thirteen.

SEc. 5. That unfair methods of competition in commerce are hereby declared unlawful.

The commission is hereby empowered and directed to prevent persons, partnerships, or corporations, except banks, and common carriers subject to the Acts to regulate commerce, from using unfair methods of competition in commerce.

Whenever the commission shall have reason to believe that any such person, partnership, or corporation has been or is using any unfair method of competition in commerce, and if it shall appear to the commission that a proceeding by it in respect thereof would be to the interest of the public, it shall issue and serve upon such person, partnership, or corporation a complaint stating its charges in that respect, and containing a notice of a hearing upon a day and at a place therein fixed at least thirty days after the service of said complaint. The person, partnership, or corporation so complained of shall have the right to appear at the place and time so fixed and show cause why an order should not be entered by the commission requiring such person, partnership, or corporation to cease and desist from the violation of the law so charged in said complaint. Any person, partnership, or corporation may make application, and upon good 
cause shown may be allowed by the commission, to intervene and appear in said proceeding by counsel or in person. The testimony in any such proceeding shall be reduced to writing and filed in the office of the commission. If upon such hearing the commission shall be of the opinion that the method of competition in question is prohibited by this Act, it shall make a report in writing in which it shall state its findings as to the facts, and shall issue and cause to be served on such person, partnership, or corporation an order requiring such person, partnership, or corporation to cease and desist fom using such method of competition. Until a transcript of the record in such hearing shall have been filed in a circuit court of appeals of the United States, as hereinafter provided, the commission may at any time, upon such notice and in such manner as it shall deem proper, modify or set aside, in whole or in part, any report or any order made or issued by it under this section.

If such person, partnership, or corporation fails or neglects to obey such order of the commission while the same is in effect, the commission may apply to the circuit court of appeals of the United States, within any circuit where the method of competition in question was used or where such person, partnership, or corporation resides or carries on business, for the enforcement of its order, and shall certify and file with its application a transcript of the entire record in the proceeding, including all the testimony taken and the report and order of the commission. Upon such filing of the application and transcript the court shall cause notice thereof to be served upon such person, partnership, or corporation and thereupon shall have jurisdiction of the proceeding and of the question determined therein, and shall have power to make and enter upon the pleadings, testimony, and proceedings set forth in such transcript a decree affirming, modifying, or setting aside the order of the commission. The findings of the commission as to the facts, if supported by testimony, shall be conclusive. If either party shall apply to the court for leave to adduce additional evidence, and shall show to the satisfaction of the court that such additional evidence is material and that there were reasonable grounds for the failure to adduce such evidence in the proceeding before the commission, the court may order such additional evidence to be taken before the commission and to be adduced upon the hearing in such manner and upon such terms and conditions as to the court may seem proper. The commission may modify its findings as to the facts, or make new findings, by reason of the additional evidence so taken, and it shall file such modified or new findings, which, if supported by testimony, shall be conclusire, and its recommendation, if any, for the modification or setting aside of its original order, 
with the return of such additional evidence. The judgment and decree of the court shall be final, except that the same shall be subject to review by the Supreme Court upon certiorari as provided in section two hundred and forty of the Judicial Code.

Any party required by such order of the commission to cease and desist from using such method of competition may obtain a review of such order in said circuit court of appeals by filing in the court a written petition praying that the order of the commission be set aside. A copy of such petition shall be forthwith served upon the commission, and thereupon the commission forthwith shall certify and file in the court a transcript of the record as hereinbefore provided. Upon the filing of the transcript the court shall have the same jurisdiction to affirm, set aside, or modify the order of the commission as in the case of an application by the commission for the enforcement of its order, and the findings of the commission as to the facts. if supported by testimony, shall in like manner be conclusive.

The jurisdiction of the circuit court of appeals of the United States to enforce, set aside, or modify orders of the commission shall be exclusive.

Such proceedings in the circuit court of appeals shall be given precedence over other cases pending therein, and shall be in every way expedited. No order of the commission or judgment of the court to enforce the same shall in any wise relieve or absolve any person, partnership, or corporation from any liability under the antitrust acts.

Complaints, orders, and other processes of the commission under this section may be served by anyone duly authorized by the commission, either (a) by delivering a copy thereof to the person to be served, or to a member of the partnership to be served, or to the president, secretary, or other executive officer or a director of the corporation to be served; or (b) by leaving a copy thereof at the principal office or place of business of such person, partnership, or corporation; or (c) by registering and mailing a copy thereof ad: dressed to such person, partnership, or corporation at his or its principal office or place of business. The verified return by the person so serving said complaint, order, or other process setting forth the manner of said service shall be proof of the same, and the return postoffice receipt for said complaint, order, or other process registered and mailed as aforesaid shall be proof of the service of the same.

SEc. 6. That the commission shall also have power-

(a) To gather and compile information concerning, and to investigate from time to time the organization, business, conduct, practices, and management of any corporation engaged in commerce, excepting 
banks and common carriers subject to the Act to regulate commerce, and its relation to other corporations and to individuals, associations, and partnerships.

(b) To require, by general or special orders, corporations engaged in commerce, excepting banks, and common carriers subject to the Act to regulate commerce, or any class of them, or any of them, respectively, to file with the commission in such form as the commission may prescribe annual or special, or both annual and special, reports or answers in writing to specific questions, furnishing to the commission such information as it may require as to the organization, business, conduct, practices, management, and relation to other corporations, partnerships, and individuals of the respective corporations filing such reports or answers in writing. Such reports and answers shall be made under oath, or otherwise, as the commission may prescribe, and shall be filed with the commission within such reasonable period as the commission may prescribe, unless additional time be granted in any case by the commission.

(c) Whenever a final decree has been entered against any defendant corporation in any suit brought by the United States to prevent and restrain any violation of the anti-trust Acts, to make investigation upon its own initiative, of the manner in which the decree has been or is being carried cut, and upon the application of the Attorney General it shall be its duty to make such investigation. It shall transmit to the Attorney General a report embodying its findings and recommendations as a result of any such investigation, and the report shall be made public in the discretion of the commission.

(d) Upon the direction of the President or either House of Congress to investigate and report the facts relating to any alleged violations of the anti-trust Acts by any corporation.

(e) Upon the application of the Attorney General to investigate and make recommendations for the readjustment of the business of any corporation alleged to be violating the antitrust Acts in order that the corporation may thereafter maintain its organization, management, and conduct of business in aceordance with law.

(f) To make public from time to time such portions of the information obtained by it hereunder, except trade secrets and names of customers, as it shall deem expedient in the public interest; and to make annual and special reports to the Congress and to subinit therewith recommendations for additional legislation; and to provide for the publication of its reports and decisions in such form and manner as may be best adapted for public information and use.

(g) From time to time to classify corporations and to make rules and regulations for the purpose of carrying out the provisions of this Act 
(h) To investigate, from time to time, trade conditions in and with foreign countries where associations, combinations, or practices of manufacturers, merchants, or traders, or other conditions, may affect the foreign trade of the United States, and to report to Congress thereon, with such recommendations as it deems advisable.

SEc. 7. That in any suit in equity brought by or under the direction of the Attorney General as provided in the anti-trust Acts, the court may, upon the conclusion of the testimony therein, if it shall be then of opinion that the complainant is entitled to relief, refer said suit to the commission, as a master in chancery, to ascertain and report an appropriate form of decree therein. The commission shall proceed upon such notice to the parties and under such rules of procedure as the court may prescribe, and upon the coming in of such report such exceptions may be filed and such proceedings had in relation thereto as upon the report of a master in other equity causes, but the court may adopt or reject such report, in whole or in part, and enter such decree as the nature of the case may in its judgment require.

SEc. 8. That the several departments and bureaus of the Government when directed by the President shall furnish the commission, upon its request, all records, papers, and information in their possession relating to any corporation subject to any of the provisions of this Act, and shall detail from time to time such officials and employees to the commission as he may direct.

SEc. 9. That for the purposes of this Act the commission, or its duly authorized agent or agents, shall at all reasonable times have access to, for the purpose of examination, and the right to copy any documentary evidence of any corporation being investigated or proceeded against; and the commission shall have power to require by subpœna the attendance and testimony of witnesses and the production of all such documentary evidence relating to any matter under investigation. Any member of the commission may sign subpœnas; and members and examiners of the commission may administer oaths and affirmations, examine witnesses, and receive evidence.

Such attendance of witnesses, and the production of such documentary evidence, may be required from any place in the United States, at any designated place of hearing. And in case of disobedience to a subpœna the commission may invoke the aid of any court of the United States in requiring the attendance and testimony of witnesses and the production of documentary evidence.

Any of the district courts of the United States within the jurisdiction of which such inquiry is carried on may, in case of contumacy or refusal to obey a subpœna issued to any corporation or other person, issue an order requiring such corporation or other person to appear 
before the commission, or to produce documentary evidence if so ordered, or to give evidence touching the matter in question; and any failure to obey such order of the court may be punished by such court as a contempt thercof.

Upon the application of the Attorney General of the United States, at the request of the commission, the district courts of the United States shall have jurisdiction to issue writs of mandamus commanding any person or corporation to comply with the provisions of this Act or any order of the commission made in pursuance thereof.

The commission may order testimony to be taken by deposition in any proceeding or investigation pending under this Act at any stage of such proceeding or investigation. Such depositions may be taken before any person designated by the commission and having power to administer oaths. Such testimony shall be reduced to writing by the person taking the deposition, or under his direction, and shall then be subscribed by the deponent. Any person may be compelled to appear and depose and to produce documentary evidence in the same manner as witnesses may be compelled to appear and testify and produce documentary evidence before the commission as hereinbefore provided.

Witnesses summoned before the commission shall be paid the same fees and mileage that are paid witnesses in the courts of the United States, and witnesses whose depositions are taken and the persons taking the same shall severally be entitled to the same fees as are paid for like services in the courts of the United States.

No person shall be excused from attending and testifying or from producing documentary evidence before the commission or in obedience to the subpena of the commission on the ground or for the reason that the testimony or evidence, documentary or otherwise, required of him may tend to criminate him or subject him to a penalty or forfeiture. But no natural person shall be prosecuted or subjected to any penalty or forfeiture for or on account of any transaction, matter, or thing concerning which he may testify, or produce evidence, documentary or otherwise, before the commission in obedience to a subpona issued by it: Proviled, That no natural person so testifying shall be exempt from prosecution and punishınent for perjury committed in so testifying.

SEC. 10. That any person who shall neglect or refuse to attend and testify, or to answer any lawful inçuiry, or to produce documentary evidence, if in his power to do so, in obedience to the subpona or lawful requirement of the commission, shall be guilty of an offense and upon conviction thereof by a court of competent jurisdiction shall be punished by a fine of not less than $\$ 1,000$ nor more than $\$ 5,000$, or 
by imprisonment for not more than one year, or by both such fine and imprisonment.

Any person who shall willfully make, or cause to be made, any false entry or statement of fact in any report required to be made under this Act, or who shall willfully make, or cause to be made, any false entry in any account, record, or memorandum kept by any corporation subject to this Act, or who shall willfully neglect or fail to make, or to cause to be made, full, true, and correct entries in such accounts, records, or memoranda of all facts and transactions appertaining to the business of such corporation, or who shall willfully remove out of the jurisdiction of the United States, or willfully mutilate, alter, or by any other means falsify any documentary evidence of such corporation, or who shall willfully refuse to submit to the commission or to any of its authorized agents, for the purpose of inspection and taking copies, any documentary evidence of such corporation in his possession or within his control, shall be deemed guilty of an offense against the United States, and shall be subject, upon conviction in any court of the United States of competent jurisdiction, to a fine of not less than $\$ 1,000$ nor more than $\$ 5,000$, or to imprisonment for a term of not more than three years, or both such fine and imprisonment.

If any corporation required by this Act to file any annual or special report shall fail so to do within the time fixed by the commission for filing the same, and such failure shall continue for thirty days after notice of such default, the corporation shall forfeit to the United States the sum of $\$ 100$ for each and every day of the continuance of such failure, which forfeiture shall be payable into the Treasury of the United States, and shall be recoverable in a civil suit in the name of the United States brought in the district where the corporation has its principal office or in any district in which it shall do business. It shall be the duty of the various district attorneys, under the direction of the Attorney General of the United States, to prosecute for the recovery of forfeitures. The costs and expenses of such prosecution shall be paid out of the appropriation for the expenses of the courts of the United States.

Any officer or employee of the commission who shall make public any information obtained by the commission without its authority, unless directed by a court, shall be deemed guilty of a misdemeanor, and, upon conviction thereof, shall be punished by a fine not exceeding $\$ 5,000$, or by imprisonment not exceeding one year, or by fine and imprisonment, in the discretion of the court.

SEc. 11. Nothing contained in this Act shall be construed to prevent or interfere with the enforcement of the provisions of the ant1- 
trust Acts or the Acts to regulate commerce, nor shall anything contained in the Act be construcd to alter, modify, or repeal the said anti-trust Acts or the Acts to regulate commerce or any part or parts thereof.

Approved, September 26, 1914. 
WHAT AN INVESTOR SHOULD KNOW REGARDING A PUBLIC UTILITY. ${ }^{1}$

\section{TERRITORY :}

Location of property.

Natural resources of surrounding territory.

Transportation facilities.

Chances for competition.

Whether the industries established in the territory are stable or speculative.

Growth in population.

OPERATION :

Gross earnings, operating expenses, net earnings, taxes, interest charges for a period of years.

If a holding company, such earnings should be a consolidated statement, as well as a detailed statement of earnings of all the subsidiaries.

\section{CAPITALIZATION :}

Balance sheet showing liabilities and assets, and, in the case of holding companies, a consolidated balance sheet to show especially the assets and liabilities of subsidiaries.

\section{BONDS :}

In the case of bonds, the usual fundamental terms of the mortgage, showing property secured, sinking or improvement funds, rate of interest, provisions as to income tax, market value of securities junior to the bonds.

Terms under which additional bonds can be issued.

\section{DIVIDENDS PAID:}

Record of rates over a series of years.

RANGE OF PRICES OF SECURITIES:

Record of fluctuations over a series of years.

LEGAL FEATURES :

General legality of the issue of all securities by reputable lawyers.

Length of franchise and terms thereof.

\section{MANAGEMENT:}

How is the management of the company handled?

1 From Special Public Utilities Number of The Evening Post of New York, March 20, 1914. 


\section{GENERAL:}

With the above information in hand, it is possible to make a careful analysis to show, let us say, the percentage of increase in population, gross earnings, and net earnings, and the ratio per dollar of gross earnings of the combined capitalization, bonded debt, preferred stock, and common stock.

Such an analysis has the advantage of showing, if obtained for a series of years, to what extent the company is developing. 
FORTY-SIXTH REPORT of the NIPPON YUSEN KAISHA (Japan Mail Steamship Company, Limited.)

Presented to the Shareholders at the HALF-YEARLY ORDINARY GENERAL MEETING, held at Tokio, on Wednesday, 28th May, 1913.

Capital Paid-up.

..Yen 22,000,000

Reserve Fund, Insurance and Structural Repair Fund, etc......Yen 30,807,224

Reserve for Equalization of Dividends................ 3 en $3,300,000$

\section{Board of Directors}

Baron Rempei Kondo, Managing Director. Masayoshi Kato, Esq., Managing Director. Toshinobu Suda, Esq., Managing Director.

Toru Hori, Esq., Managing Director.

Tamio Hayashi, Esq., Managing Director.

Kirrosuke Harada, Esq. Tamotsu Yatsui, Esq.

Renjiro Nogishi, Esq.

President.

Baron Rempei Kondo.

Vice-President.

Masayoshi Kato, Esq.

To the Shareholders

Gentlemen :

The Directors submit to you the annexed Statement of the Liabilities and Assets of the Company, and the Profit and Loss Account for the Half-Year, ended March 31st, 1913:

The Gross Profits of the Company for the past Half-Year amount to $Y$ en $5,277,890.452$, out of which there has been paid:

Depreciation of the Company's fleet and property.........Yen 1,036,594.492 Insurance Fund............................ $618,863.070$ Ships' Structural Repair Fund.................... $\quad 632,751 .{ }^{330}$

Yen $\overline{2,288,209.702}$

leaving a balance of $Y$ en $3,803,404 .^{650}$, including $Y$ en $813,723 . .^{990}$ brought forward from the last Account.

The Directors now propose that this surplus be appropriated as follows:

Addition to Reserve Fund . .................... Yen

Addition to Reserve for the Annual Reduction of Subsidies...Y Yen Addition to Fund for the Extension of Services and Improvement

of the Fleet............................... Yen

Reserve for Construction and Repairs of Building..........Yen

Special Reserve..............................Yen

$149,484.030$

$98,474 .{ }^{\text {s60 }}$

$700,000.000$ $500,000.000$ $300,000.00$ 
ANNUAL REPORT, JAPAN MAIL S. S. CO. 623

From the remaining balance $Y$ en $2,055,446 .{ }^{000}$ the Directors further propose that $Y$ en $73,555 .^{000}$ be allowed as Directors' and Auditors' fees, and recommend a dividend at the rate of ten per cent. per annum, which will absorb $Y$ en, $1,100,000{ }^{.00}$, leaving a balance of $Y$ en 881,$891 .{ }^{060}$ to be carried forward to the next Account.

REMPEI KoNDo,

Head Office, Tokio, 28th May, 1913.

Chairman. 


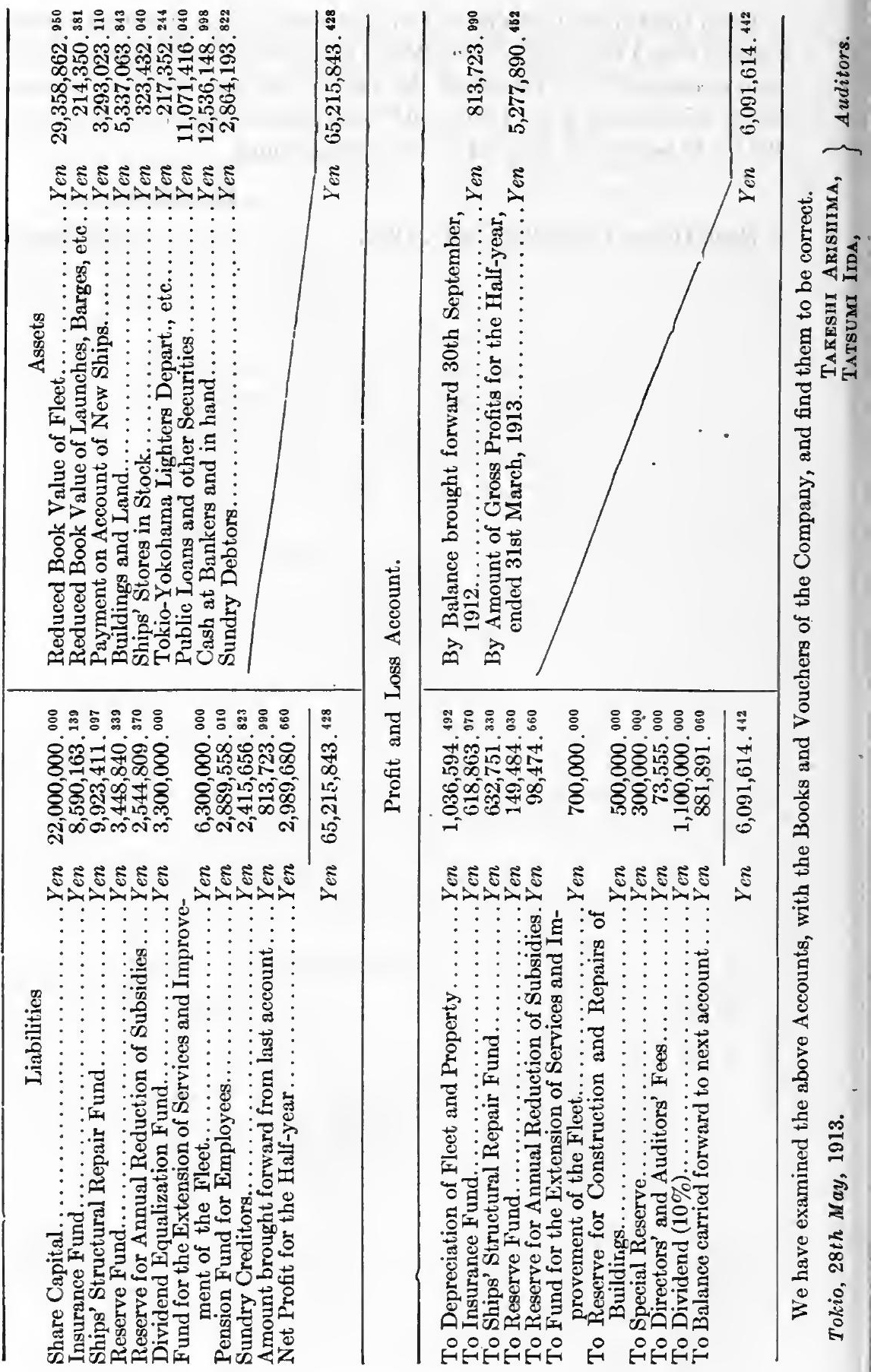


INCOME STATEMENT (B. \& O., 1908)

\begin{tabular}{|c|c|c|c|c|c|c|c|c|c|c|c|}
\hline 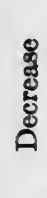 & 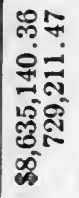 & 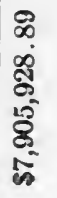 & & 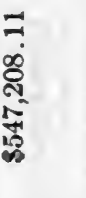 & & 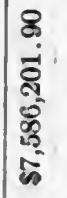 & 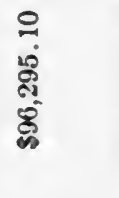 & ? & 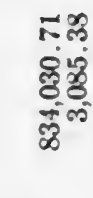 & 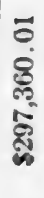 & 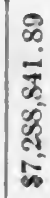 \\
\hline 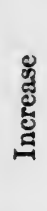 & & $\begin{array}{l}\vdots \\
\vdots \\
\vdots\end{array}$ & 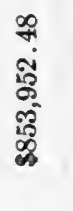 & 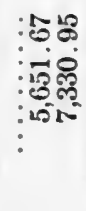 & 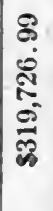 & $\vdots$ & 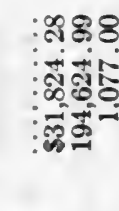 & 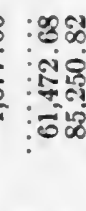 & & & \\
\hline 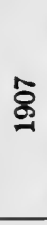 & 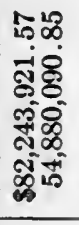 & 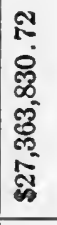 & 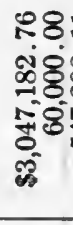 & 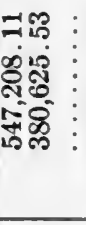 & 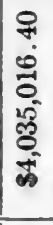 & 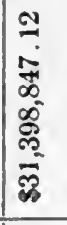 & 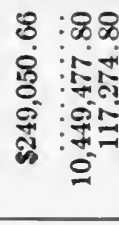 & 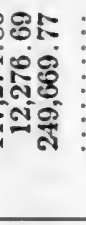 & 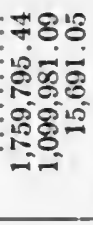 & 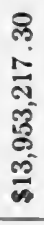 & 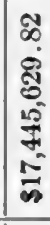 \\
\hline \& & 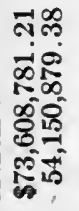 & 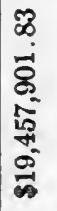 & 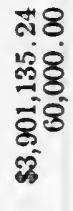 & 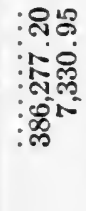 & 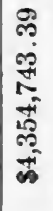 & 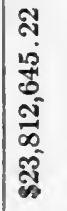 & 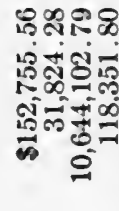 & 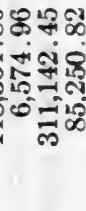 & 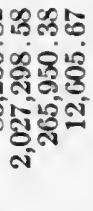 & 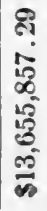 & 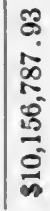 \\
\hline
\end{tabular}

题
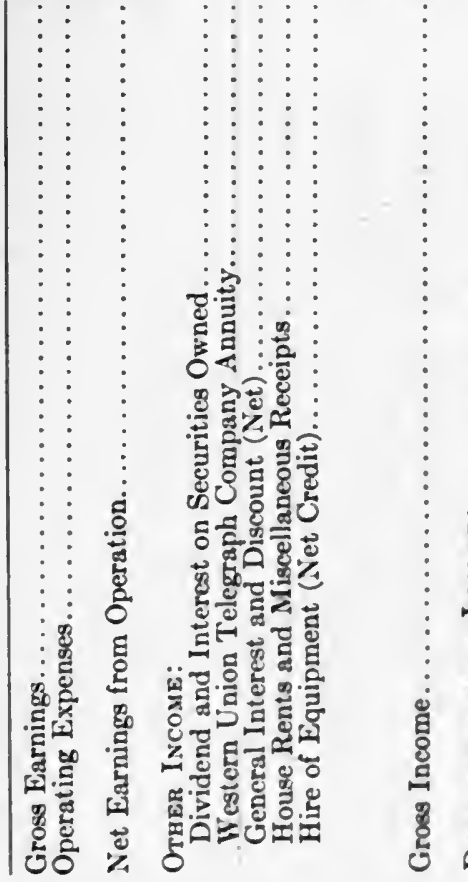

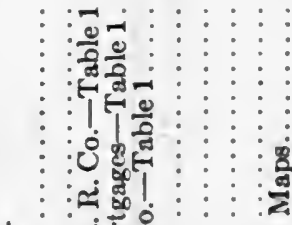

$1 \vdots: \vdots 0$

范 : :

. : : :

E: : : : : :

:

ह :

: :

क

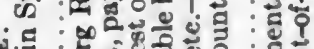

त्रे

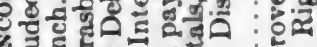

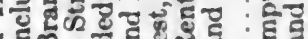

ㄱ.ㄹ.

을

일

.

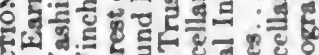

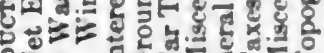

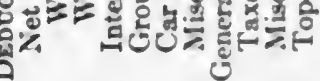

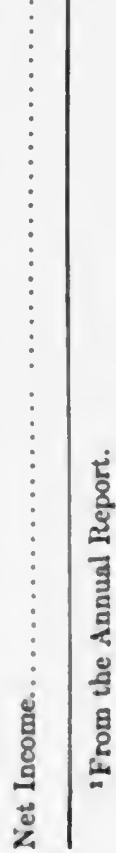




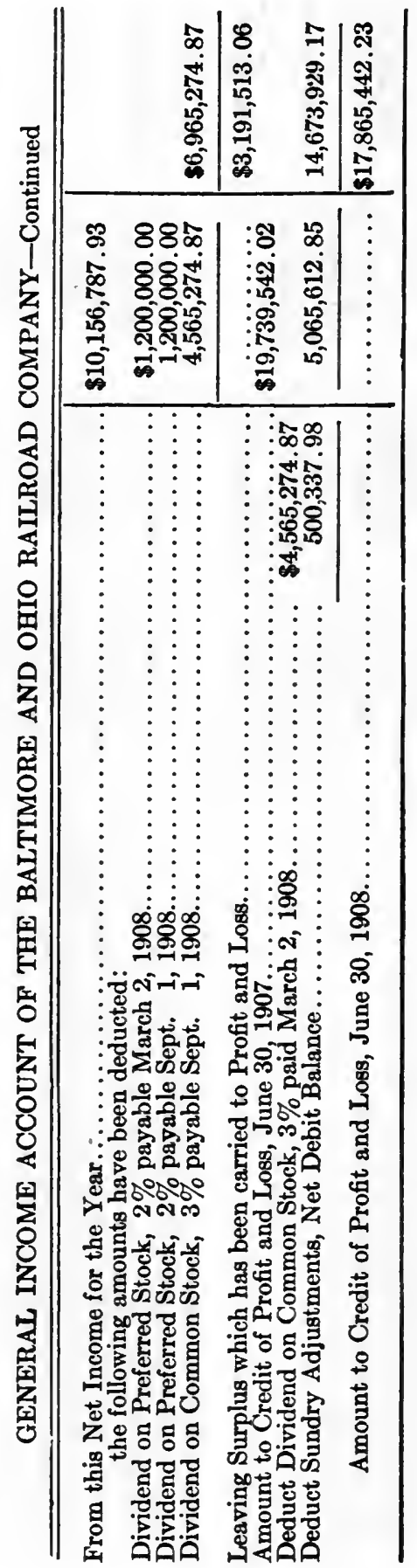




\section{ANNUAL REPORT WESTINGHOUSE ELECTRIC AND MANUFACTURING COMPANY, MARCH 31, 1911.}

BOARD OF DIRECTORS.

Term Expiring 4th Wednesday of July, 1911.

Charles F. Brooker, President, American Brass Co., Ansonia, Conn.

James S. Kuhn, Chairman of Board, First National Bank, Pittsburg, $\mathrm{Pa}$.

Edwin F. Atkins, of E. Atkins \& Co., Boston, Mass.

E. M. Herr, First Vice-President, Westinghouse Electric \& Mfg. Co.

Term Expiring 4th Wednesday of July, 1912.

Geo. Westinghouse, Pittsburg, Pa.

Robert Mather, Chairman of Board, Westinghouse Electric \& Mfg Co.

Joseph W. Marsh, President, Standard Underground Cable Co., Pittsburg, Pa.

Albert H. Wiggin, President, Chase National Bank, New York, N. Y.

Term Expiring 4th Wednesday of July, 1913.

Richard Delafield, President, National Park Bank, New York, N. Y.

T. W. Lamont, of J. P. Morgan \& Co., New York, N. Y.

Anthony N. Brady, Capitalist, New York, N. Y.

J. D. Callery, Vice-President, Philadelphia Company, Pittsburg, Pa.

Term Expiring 4th Wednesday of July, 1914.

A. G. Becker, President, A. G. Becker \& Co., Chicago, Ill.

Geo. M. Verity, President, The American Rolling Mill Co., Middletown, Ohio.

William McConway, President, The McConway \& Torley Co., Pittsburg, $\mathrm{Pa}$.

Charles A Moore, President, Manning, Maxwell \& Moore, Inc., New York, N. Y.

\section{EXECUTIVE COMMITTEE.}

Edwin F. Atkins,

James S. Kuhn,

T. W. Lamont,
Joseph W. Marsh, Robert Mather, Geo. M. Verity,

Albert H. Wiggin.

1 Of this report Dr. Dewing says in his Corporate Promotions and Reorgan. izations, (p. 211:) "The annual report of March 31, 1911, is worthy of perma. nent preservation for its fulness, frankness, and the willingness of Mr. Mather to express opinions of the 'worth' of inventoried investments. It was his lant report and shows clearly the foundation of a policy, the good romults of which were just beginning to bear fruit. In its detailed completeness the present writer knows not its equal among corporation reports." 


\section{PROXY COMMITTEE.}

Chas. Francis Adams, James N. Jarvie,
F. W. Roebling,

Jacob H. Schiff,

Robert S. Smith.

STOCK TRANSFER AGENTS.

Bankers Trust Co., 7 Wall St., New York, N. Y.

Union Trust Co., Pittsburg, Pa.

New England Trust Co., Boston, Mass.

REGISTRARS OF STOCK.

The Mercantile Trust Co., 120 Broadway, New York, N. Y. Fidelity Title \& Trust Co., Pittsburg, Pa.

Boston Safe Deposit \& Trust Co., Boston, Mass.

OFFICERS AND DEPARTMENTS.

Officers.

Robert Mather, Chairman of Board, New York.

Edwin F. Atkins, President, New York.

E. M. Herr, First Vice-President, Pittsburg.

L. A. Osborne, Second Vice-President, Pittsburg.

Charles A. Terry, Third Vice-President, New York.

G. W. Hebard, Acting Vice-President, New York.

H. D. Shute, Acting Vice-President, Pittsburg.

James C. Bennett, Comptroller and Secretary, New York.

Warren H. Jones, Assistant Secretary, New York.

T. W. Siemon, Treasurer and Assistant Secretary, Pittsburg.

H. F. Baetz, Assistant Treasurer, Pittsburg.

S. H. Anderson, Acting Assistant Treasurer, Pittsburg.

F. E. Craig, Auditor, Pittsburg.

W. B. Covil, Jr., Assistant Auditor, Pittsburg.

Manufacturing Department.

Tracy Lyon, Assistant to First Vice-President.

Alexander Taylor, Manager of Works.

C. B. Auel, Assistant Manager of Works.

J. McA. Duncan, Assistant Manager of Works.

C. W. Johnson, Assistant Manager of Works.

E. R. Norris, Assistant Manager of Works.

E. F. Harder, Superintendent of Newark Works.

Erecting Department.

W. K. Dunlap, Assistant to First Vice-President.

G. W. Canney, Superintendent of Erecting. 


\section{Engineering Department.}

H. P. Davis, Assistant to First Vice-President and Manager of Engineering.

B. G. Lamme, Chief Engineer.

Chas. F. Scott, Consulting Engineer.

S. L. Nicholson, Sales Manager.

\section{Sales Department.}

C. S. Cook, Manager, Railway and Lighting Department.

Charles Robbins, Manager, Industrial and Power Department.

G. Brewer Griffin, Manager, Detail and Supply Department.

Maurice Coster, Manager, Export Department.

WESTINGHODSE ELECTRIC \& MANUFACTURING COMPANY.

Operating plants at East Pittsburg, Pa.; Newark, N. J.; Pittsburg, Pa.; Cleveland, Ohio. Main offices, East Pittsburg, Pa.; New York offices, 165 Broadway.

\section{SUBSIDIARY MANUFACTURING COMPANIES.}

Westinghouse Lamp Company.-Walter Cary, General Manager. Operating plants at Bloomfield, N. J.; New York City. Main offices, Bloomfield, N. J.

The Bryant Electric Company-The Perkins Electric Switch Manufacturing Company.-W. C. Bryant, President, Treasurer and General Manager. Operating plants at Bridgeport, Conn. Main offices, Bridgeport, Conn.

R. D. Nuttall Company.-F. A. Estep, President and Treasures. Operating plant at Pittsburg, Pa. Main offices, Pittsburg, Pa. Pittsborg, Pa., Jonr 5, 1911.

To the Stockholders of the Westinghouse Electric \& Manufacturing Company:

The Directors respectfully present herewith their report of the operations of your Company and of its subsidiary Companies for the fiseal year ended March 31, 1911. The Income Account for the year, which includes the operations of all the subsidiary Companies-sales between Companies, however, being eliminated-is as follows:

Gross Earnings:

Shipments Billed..................

$\$ 38,119,312.01$

Cost of Shipments:

Factory Costs, including all Fixpenditures for Patterns, Dies, New Sinall 'Tools and Other Betterments and Extensions; also Inventory Adjustments and all Selling, Adminiatration, General and Development

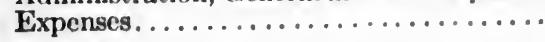


OTHER Income:

Interest and Discount...............

Dividends and Interest on Sundry Stocks and Bonds Owned...................

Miscellaneous-Royalties, etc...............

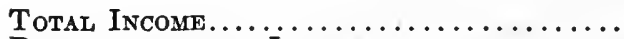

Deductions From INCOME:

Interest on Bonds and Debentures........

Interest on Collateral Notes................

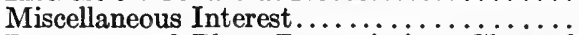

Property and Plant Depreciations Charged

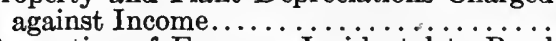

Proportion of Expenses Incidental to Bond and Note Issues.................

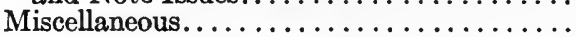

$\$ 272,055.28$

$615,299.40$

$628,177.13$

$\$ 1,076,553.71$

$416,000.00$

$92,933.04$

$371,668.19$

$76,666.66$

$209,369.37$
$1,515,531.81$

$\overline{\$ 7,124,296.95}$

$2,243,190.97$

$\overline{\$ 4,881,105.98}$

Net Income-SURplus for the Year.......

The year's business, both in gross earnings and net income, was the largest in the history of the Company. The gross earnings exceeded those of the preceding fiscal year by $\$ 8,870,630$ and were greater by $\$ 5,093,072$ than the earnings of the best previous year in the Company's existence. A condensed comparative statement of gross earnings and net profits for the past six years, adjusted to the basis of the foregoing statement of income, follows:

\begin{tabular}{|c|c|c|c|c|c|c|}
\hline \multirow[t]{2}{*}{. } & \multicolumn{6}{|c|}{ Year Ended March 31} \\
\hline & 1906 & 1907 & 1908 & 1909 & 1910 & 1911 \\
\hline $\begin{array}{l}\text { Gross Earnings-Ship- } \\
\text { ments Billed........... } \\
\text { Cost of Shipments-In- } \\
\text { cludes all Selling, Ad- } \\
\text { ministration and Gen- } \\
\text { eral Expenses.......... }\end{array}$ & $\begin{array}{l}\$ 24,081,601 \\
21,390,059\end{array}$ & $\$ 33,026,240$ & $\$ 32,844,829$ & $\$ 20,606,592$ & $\$ 29,248,682$ & $\begin{array}{r}\$ 38,119,312 \\
32,510,547\end{array}$ \\
\hline $\begin{array}{l}\text { Net Manufacturing Prof- } \\
\text { its....................... } \\
\text { Other Income... }\end{array}$ & $\begin{array}{r}\$ 2,691,542 \\
959,786\end{array}$ & $\begin{array}{r}\$ 4,179,575 \\
1,256,335\end{array}$ & \begin{tabular}{r|r}
$\$ 2,543,682$ \\
$1,555,697$
\end{tabular} & $\begin{array}{r}\$ 650,784 \\
986,293\end{array}$ & \begin{tabular}{r|r}
$\$ 3,552,978$ \\
$1,616,56 \mathrm{i}$
\end{tabular} & $\begin{array}{r}\$ 5,608,765 \\
1,515,531\end{array}$ \\
\hline $\begin{array}{l}\text { Total Income.......... } \\
\text { Less-Inventory Adjust- } \\
\text { ments, Inactive Appa- } \\
\text { ratus and M a t e rial } \\
\text { Scrapped, Bad Ac- } \\
\text { counts and Extraordi- } \\
\text { nary Items of Expense } \\
\text { charged to Income.... }\end{array}$ & $\begin{array}{r}\$ 3,651,328 \\
\\
493,081\end{array}$ & $\$ 5,435,910$ & $\$ 4,099,379$ & $\$ 1,637,077$ & $\$ 5,169,539$ & $\$ 7,124,296$ \\
\hline $\begin{array}{c}\text { Net Income Applicable } \\
\text { to Interest and other } \\
\text { charges.............. }\end{array}$ & $\$ 3,158,247$ & \& $, 365,527$ & $\$ 3,011,926$ & $\$ 795,756$ & $\$ 4,749,847$ & $\$ 6,466,592$ \\
\hline Interest Charges........ & $\$ 1,137,592$ & $\$ 1,592,353$ & $\$ 2,061,091$ & $\$ 2,200,771$ & $\$ 1,689,183$ & $\$ 1,585,487$ \\
\hline $\begin{array}{l}\text { Net Income-Surplus for } \\
\text { the Year............. }\end{array}$ & $\$ 2,020,6=5$ & $\$ 2,773,174$ & $\$ 950,835$ & $\underset{\text { (Deficit) }}{\$ 1,405,015}$ & $\$ 3,060,664$ & $\$ 4,881,105$ \\
\hline
\end{tabular}

Your Directors feel that the satisfactory results of the past year, reached as they were during a period of somewhat less than normal activity in other lines of industry, afford sound basis for continued hope in the future of the electrical manufacturing industry and in the 
maintenance by your Company of its position in that field. It is, on the other hand, a fact that the volume of business now offering is on a diminishing scale, and the results of the last year, therefore, are no certain indication of a continuance for the future of gross earnings and net profits such as the past twelve months have produced. The business taken by the Company during February and March, 1911the last two months of the fiscal year covered by this report-was somewhat less than that taken during the same months of 1910, and the value of the orders booked since the close of the fiscal year does not compare farorably with that of the corresponding period a year ago.

The value of unfilled orders as of March 31,1910 , was $\$ 11,256$,196 ; as of March 31, 1911, this value stood at $\$ 7,616,058$.

Certain other conditions affect the estimate for the immediate future of the earning power of your Company. On March 31, 1896, your Company entered into an agreement with the General Electric Company whereby for a period of fifteen years thereafter each Company licensed the other under the patents controlled by it during the term of the agreement, with provision for the payment of royalties by each on the basis of its use of the patents of the other. For the past few years under the operation of this agreement your Company has received substantial sums by way of royalties. This agreement expired by limitation of time on April 30, 1911. No renewal of it is contemplated. This source of revenue, therefore, cannot now be counted upon.

Other patent license agreements with manufacturers of mining loco. motives, small motors, fuses, switches and sockets, under which your Company has been working for some years, hare recently been cancelled on the suggestion that they might be questioned as being in violation of the Federal anti-trust laws, notwithstanding they were originally made and have been maintained under advice of counsel that assured your Company of their validity.

Your Directors have had steadily in mind the purpose of strengthening your Company's position in every possible direction. To that end they have authorized considerable increase in the expenditures of the selling organization, for increasing the number of salesmen in the field, for remuneration to its representatives adequate to secure the best effort on their part, for the extension of advertising, and to provide for proper warehouse facilities for carrying stocks at distributing points. This has added considerably to the aggregate selling expense, but the results, we believe, have been justified in the increased volume of business obtained. It is a matter of simple computation, on the basis of the operations of the past two years, to ascertain the point at 
which the volume of gross business fails to provide a surplus over operating expenses and fixed charges. It is vital that your business should not drop to that point.

With the same purpose in view fairly large expenditures have been authorized for the work of new development and for improvement in current types of apparatus. This work has been particularly marked with respect to the redesigning of direct current motors, alternating current and direct current mill and crane motors, small power motors, high speed turbo-generators, circuit breakers, railway equipment and. heating and cooking apparatus. Your Directors feel that this is an item of expenditure which, owing to the position of your Company, it would be unwise at any time to curtail. It must be borne in mind that your Company must keep pace in technical skill and inventive ingenuity with its competitors even though their combined capital and manufacturing facilities are greatly in excess of yours. The cost of all new development and redesigning is charged monthly as a part of the current costs.

During the past year additional real estate adjoining the Newark plant has been acquired, so that your Company now owns substantially all of the city square on which the factory is located. Upon part of this additional real estate an extension to the plant is in course of construction upon a plan which contemplates ultimately occupying all the newly acquired area with an harmonious structure. The extension now being built will increase the manufacturing floor space of this plan about 30 per cent.

The New York City plant is now in full operation by the Westinghouse Lamp Company in the production of Tungsten lamps, the equipment of the building for that purpose, referred to in the last report, having been fully completed.

The additions to the Bridgeport, Conn., plant under way at the end of the previous fiscal year have also been carried to completion.

During the year the R. D. Nuttall Company, which has heretofore occupied rented premises in Pittsburg, completed negotiations for the purchase of an existing manufacturing plant on Fifty-fourth Street, in Pittsburg, Pa., comprising approximately five acres. This plant, with some additions to its equipment now in progress, will furnish the Nuttall Company with ample facilities for many years to care for its growing business. This transaction will be taken on the books of the Company during April, 1911.

Your Company operates an iron foundry at Pittsburg, Pa., on leased premises. In anticipation of the termination of its lease, and because the plant is poorly adapted to the Company's needs, plans have been 
completed during the year for the erection of a new foundry at Trafford City, about six miles east of the main factory of your Company at East Pittsburg. Approximately sixty-three acres of land have been acquired for this and other possible purposes, at a total cost of $\$ 184,500$. Your Company has further acquired, for the purpose of insuring communication between tre proposed new foundry and its plant at East Pittsburg, sixty per cent. of the capital stock of the Interworks Railway Company, owning and operating a line of railway between East Pittsburg and Trafford City. Plans have been prepared for the erection of foundry and pattern buildings at Trafford City, at an aggregate cost of approximately $\$ 1,250,000$.

Your Company was made party defendant, together with the General Electric Company, the National Lamp Company and a number of other lamp manufacturers, to a bill in equity recently filed by the United States under the provisions of the Sherman anti-trust law. This bill proceeds on the theory that certain agreements and acts of the lamp manufacturers, defendants in the suit, constitute a combination in restraint of trade. While it would not be proper to discuss in this report the matters involved in this proceeding, your Directors feel justified in saying that your Company's operations have been such that the outcome of the suit is not likely to seriously affect the conduct of its lamp business.

The surplus as of March 31, 1910, was $\$ 5,668,948.23$. This has been increased during the year by various items of profit detailed in the statement of Profit and Loss, to $\$ 6,349,255.92$. Adding the net income for the year, $\$ 4,881,105.98$, there resulted a surplus with which your Directors had to deal as of the end of the fiscal year, of $\$ 11,230,361.90$.

Against this surplus have been charged dividends on the Preferred Stock, for the year at the rate of 7 per cent. per annum and a balance of $83 / 4$ per cent. accumulated but unpaid in previous years, together aggregating $\$ 629,795.25$. In the adjustment of the account Property and Plant (hereinafter referred to) and in establishing a direct liability for bonds of the Walker Company guaranteed by your Company (hereinafter explained), there resulted charges against Surplus aggregating $\$ 1,193,297.79$, the items comprising which are shown separately in the statement of Profit and Loss. Charges against Surplus in connection with reserves for notes and accounts receivable were made during the year, aggregating \$589,77.4.05. Miscellaneous charges against Profit and Loss amounted to $\$ 355.00$. The total of the charges enumerated is $\$ 2,413,222.09$. 'There were also written off as depreciations of investments, the following: 
STOcks :

Westinghouse Electric Company, Ltd., London......\$500,000.00 Societe Anonyme Westinghouse (French Company) .. 218,974.00 The Westinghouse Machine Company........... 93,538.60

Bonds :

Lackawanna \& Wyoming Valley Rapid Transit Co.... 2,000,000.00 Miscellaneous Stocks and Bonds......... 40,302.31

Total .. $\$ 2,852,914.91$

As a result of these depreciations the Surplus as of March 31, 1911, shown in the Balance Sheet, is $\$ 5,964,224.90$.

The Consolidated Balance Sheet as of March 31, 1911, follows:

Property and Planti:

\section{ASSETS}

Factory Plants, including Real Estate, Machinery, Equipment, etc.............

Sinking Fund:

With Trustee for Redemption of Convertible Sinking Fund, 5\%, Gold Bonds.........

INVESTMENTS:

Stocks, Bonds, Debentures, Collateral Trust

Notes, etc., including those of Affiliated

European and Canadian Westinghouse

Companies.......................

Current Assets:

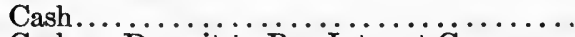

Cash on Deposit to Pay Interest Coupons..

Cash on Deposit to Pay Dividends on Preferred Stock.

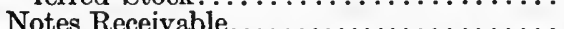

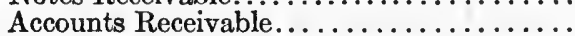

Due from Subscribers to Capital Stock....

Total Current Assets............

Working and Trading Assets:

Raw Materials and Supplies, Finished Parts and Machines, Work in Progress, Goods on Consignment and Apparatus with Cus-

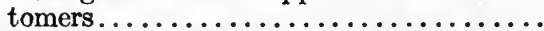

OTher Assets:

Patents, Charters and Franchises............

Insurance, Taxes, etc., Paid in Advance....

Deferred Charge-Expenses Incidental to

Issue of Bonds and Notes..............

Total Other Assets..............

Total Assets. ................

$\$ 17,692,145.61$

445.48

$24,034,635.99$

$\begin{array}{r}\$ 6,634,677.07 \\ 27,340.00 \\ \\ 940.62 \\ 2,946,551.46 \\ 9,494,731.06 \\ 53,928.77 \\ \hline\end{array}$

$19,158,168.98$

$14,321,474.01$

$\begin{array}{r}\$ 6,074,985.17 \\ 120,321.78 \\ 993,333.34 \\ \hline\end{array}$

$7,188,640.29$ $\$ 82,395,610.36$

Capital Stock:

LIABILITIES

Preferred...................\$3,998,700.00

Assenting-In Hands of

Puolic......\$35, 187,587.50

In Treasury.... 1,607,000.00 $\quad 36,694,587.50$

Total Capital Stock............ 


\title{
Fonded Debt:
}

Convertible Sinking Fund, 5\%, Gold Bonds, due January 1,1931

In Hands of Public......\$19,691,000.00

Iu Treasury .......... 266,000.00

Debenture Certificates, $5 \%$, due July 1, 1913.

Bonds-Walker Company, due January 1, 1916, Guaranteed by W. E. \& M. Co.....

\author{
$\$ 19,957,000.00$
}

$1,500,000,00$

$850,000.00$

Total Funded Debt

$22,607,000.00$

Collateral Notes:

Six Per Cent Collateral Notes, due August 1, 1913 . . . . . . . . . . . . . . . . . . . . .

Five Per Cent Collateral Notes, due October

$1,1917 \ldots \ldots \ldots \ldots \ldots \ldots \ldots \ldots \ldots \ldots$

Total Collateral Notes...........

LoNa TerM Notes:

Four Year 5\% Notes, due January 1, 1913.

Five Year 5\% Notes, due January 1, 1914.

Six Year $5 \%$ Notes, due January 1, 1915...

Fifteen Year 5\% Notes, due January 1, 1924.

Total Long Term Notes...........

Real Estate Mortgages Assumed in Pü-

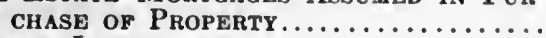

Current Liabilities:

Accounts Payable....................

Interest, Taxes, Wages, Rebates, etc., Ac-

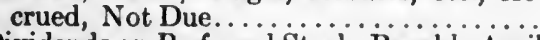

Dividends on Preferred Stock, Payable April $15,1911 \ldots \ldots \ldots \ldots \ldots \ldots \ldots \ldots \ldots$

Unpaid Dividends on Preferred Stock......

Reserve:

Total Current Liabilities..........

\section{S $4,000,000.00$}

$2,720,000.00$

$6,720,000.00$

$\begin{array}{r}429,900.00 \\ 429,500.00 \\ 425,500.00 \\ 98,750.00 \\ \hline\end{array}$

$1,383,650.00$

$228,200.00$

\& $2,454,674.83$

$572,803.75$

$139,954.50$

940.62

For Adjustments of Inventories, Notes and Accounts Receivable, etc............. Profit and Loss:

Surplus.

$3,168,373.70$

$1,630,774.26$

$5,964,224.90$

Total Liabilities

$\$ \$ 2,395,510.36$

Note-There is a Contingent Liability for Notes Receivable discounted by Subsidiary Companies amounting to $\$ 16,703.87$.

Your Directors present the following explanation of important items in the Balance Sheet, with the view of informing the Stockholders as fully as possible, without entering into unnecessary details, as to the character and value of the Company's assets and the extent and nature of its liabilities. This information is given both in recognition of the duty of corporate directors to give their stockholders the fullest practicable publicity as to the corporation's affairs and for the purpose of enabling the stockholders to form for themselves an intelligeut judgment as to the advisability of distributing the Company's current earnings by way of dividends on the assenting stock. 


\section{ASSETS}

\section{I-Property and Plant- $\$ 17,692,145.61$}

This item represents the present value of the real estate, buildings, machinery and equipment comprising your manufacturing plants at East Pittsburg, Pa., Newark, N. J., Pittsburg, Pa., Cleveland, Ohio, Bloomfield, N. J., New York, N. Y., and Bridgeport, Conn.; also storage and warehouse properties at distributing points throughout the country.

During the past year your Directors caused to be made by the American Appraisal Company of Milwaukee, Wis., a complete inventory and appraisal of the buildings, machinery and equipment of all your plants. A like appraisal of the real estate was made through local agencies. The appraisal of the buildings, machinery and equipment was made to ascertain, first, the cost as of the date of appraisal of reproducing the buildings, machinery and equipment, new; and second, the present sound values, after 'charging against the reproductive cost all depreciations in buildings, machinery and equipment as determined by the judgment and estimate of the Appraisal Company.' These sound values thus ascertained by the Appraisal Company, are the figures appearing in thi 3alance Sheet.

The aggregate of the item Property and Plant in the Balance Sheet as of March 31, 1910, was $\$ 14,974,629.20$. There is an increase in this item of $\$ 2,717,516.41$. This increase is chiefly due to the following: Your plants at Newark, New York City and Cleveland have heretofore appeared in the Balance Sheet, not under "Property and Plant," but under "Investments," for the reason that your Company's control of these properties was represented by the ownership of securities of other corporations that held title to them. Title to the Newark plant was held by The United States Electric Lighting Company, all of whose stock is now owned by your Company, to the New York plant by The Consolidated Electric Light Company, substantially all of whose stock is likewise owned, and to the Cleveland plant by the Walker Foundry Company, all of whose stock your Company also owns. The Cleveland plant is subject to the lien of a mortgage securing $\$ 850,000$ of bonds of the Walker Company, a former owner of the plant. These bonds, though guaranteed as to principal and interest by the Westinghouse Electric \& Manufacturing Company, have never appeared as a direct obligation of your Company, though reference has been made in former reports to this guaranty as a contingent liability. During the past year title has been taken by the Westinghouse Electric \& Manufacturing Company to the Cleveland plant, subject to the $\$ 850$,000 bonds. Steps are in progress to convey to the Westinghouse Elec- 
tric \& Manufacturing Company the Newark plant and it is intended that similar action shall be taken with reference to the New York City plant. In view of this situation it was determined to write into the account "Property and Plant," the appraised value of the buildings, machinery and equipment comprising each of these plants, eliminating from investments the items heretofore representing your stock control of these properties, and taking upon the books of the Westinghouse Electric \& Manufacturing Company as its direct obligation, its guaranty of the Walker Company bonds. This difference between former book values and present appraised values, aggregating $\$ 1,193$,297.79, has been charged against Surplus, partly as depreciation of Investments, and partly as an adjustment due to establishing on the books as a direct liability the guaranty of the bonds of the Walker Company.

Your Directors have determined that for the current fiscal year depreciation charges to provide for obsolescence of buildings shall be made monthly at the annual rate of two per cent. of the reproductive cost thereof, providing for all other depreciations of Property and Plant by charging monthly to operating expenses the cost of all renewals, replacements and maintenance of both buildings and machinery and equipment. As to the former, this is a new policy. As to the latter, this determination is but a continuance of past practices, as a result of the application of which to the operations of the past year, $\$ 2,271,471.41$ were charged out of earnings, as part of current operating expenses, on account of depreciation of buildings, machinery and equipment.

\section{II-Sinking Fund- $\$ 145.48$}

This item represents the balance uninvested of sinking fund payments made to the Trustee, in accordance with the requirements of the indenture controlling the Company's issue of Convertible Sinking Fund Five Per Cent. Gold Bonds.

\section{III-I NVESTMENTS- $\$ 24,034,635.99$}

A-Securities of Westinghouse Electric \& Manufacturing Co.

There are included in this account securities of Westinghouse Electric \& Manufacturing Company carried at their face values as follows:

Capital stock-assenting $\ldots \ldots \ldots \$ 1,50 \%, 048.00$

Convertible sinking fund bonds .. $266,000.00$

Bond scrip ............ $1,150.50$

Total .................... \$1,774,198.50

The assenting capital stock was acenired partly by the several subsidiary Companies in settlenent of accounts lue them by the Westing- 
house Electric \& Manufacturing Company at the time of the receivership, and partly in settlement of disputed relations existing at and after the receivership between the Westinghouse Electric \& Manufacturing Company and Security Investment Company. The stock is carried as an investment with the intent that at a favorable time it shall be resold.

The convertible sinking fund bonds have been acquired and are held in anticipation of sinking fund requirements. The bond scrip represents scrip purchased to be exchanged for bonds, also to be held for sinking fund purposes.

\section{B-Securities of Subsidiary Companies}

The following are known as the "Subsidiary Companies" of Westinghouse Electric \& Manufacturing Company:

Westinghouse Lamp Company;

The Bryant Electric Company (The Perkins Electric Switch Manufacturing Co.);

R. D. Nuttall Company;

Westinghouse Electric \& Manufacturing Company of Texas.

None of these Companies has any funded debt. All the shares of stock of each of them is owned by Westinghouse Electric \& Manufacturing Company, but none of these stocks appear as investments in the consolidated balance sheet herewith presented. Instead, the assets and liabilities of each of the subsidiary companies are included under their several appropriate headings in the consolidated balance sheet.

The ownership by The Bryant Electric Company of all the capital stock $(\$ 125,000)$ of The Perkins Electric Switch Manufacturing Company, is carried on the books of The Bryant Electric Company at $\$ 2,000,000$. This item is included in "Investments" in the consolidated balance sheet, after deducting the par amount of the outstanding capltal stock, at . . . . . . . . . . . . . . . . . $\$ 1,875,000.00$ This item can be considered as having value only as goodwill.

\section{C-Foreign Companies}

Since 1889 your Company has from time to time invested large amounts of its capital in establishing and maintaining companies for the manufacture and sale of Westinghouse electrical apparatus in foreign countries. Since no detailed report of these efforts and of their results has heretofore been made to the stockholders, your Directors deem this an opportune time to inform the stockholders concerning them, and also as to the values at which the resulting investments now stand upon the books. 
The first foreign Company, organized July 11, 1889, was Westinghouse Electric Company, Limited (a corporation of Great Britain)

Its issued capital consists of :

$$
\begin{aligned}
& \text { Preference shares } \ldots \ldots \ldots \ldots \ldots \ldots £ 189,550 \quad(\$ 919,317.50) \\
& \text { Ordinary shares } \ldots \ldots \ldots \ldots \ldots £ 275,000 \quad(\$ 1,333,750.00)
\end{aligned}
$$

The entire issued eapital of this company was eventually acquired by Westinghouse Electric \& Manufaeturing Company, and as of March 31, 1909 , was earried as an investment on your books at an aggregate book value of $\$ 1,773,084.05$. This book value represented expenses ineurred from 1889 to 1906 in the efforts to establish the manufacture and sale of your Company's apparatus in foreign countries. This expense included the cost of taking out and maintaining patents in foreign countries on the inventions and improvements of the home company. From time to time the patents issued by the various foreign countries in which manufacturing companies were organized, as hereinafter described, were transferred to such companies. As of March 31,1910, the assets of Westinghouse Electric Company, Ltd., consisted (aside from some small holdings of shares in other companies, of little or no value) of the patents owned by it in Germany, Austria, Hungary, Norway, Sweden and Denmark, and in certain licenses granted by it under some of these patents. The income of the ecmpany is and has long been insufficient to pay the expenses of its operations and the upkeep of its patents. During the fiscal year ended March 31, 1910, your Directors deemed it wise to write off from the book value of this item $\$ 7 \% 3$,084.05 and during the fiseal year just ended there has been written off an additional $\$ 500,000.00$ making a total depreciation of this item of $\$ 1,273,084.05$, leaving the book value of this investment as of March $31,1911 \ldots \ldots \ldots \ldots \ldots \ldots \ldots \ldots \ldots \ldots \ldots \ldots \ldots 00,000.00$ Further depreciation of this item must be contemplated.

The next foreign company, organized July 10, 1599, was

The British Westinghouse Electric \& Manufacturing Co., Ltd.

(a corporation of Great Britain)

This company by 1903 had completed the construction and equipment of immense works for the manufacture of electrical apparatus, steam turbines and gas engines. The buildings comprise machine shops, an iron foundry, a steel foundry and forge, a brass foundry, a malleable iron foundry and office buildings, at Traftord Park, near Manchester, England. The company's buildings occupy a total floor area of 27 acres. Its real estate holdings comprise 133 acres which it holds under an annual rent charge of $£ 7,740 \quad(\$ 37,539)$, to be increased on January 1, 1915, in perpetuity, to $£ 8,845$ (\$12,898.25). 
The company's original capital, issued from time to time from 1900 tc 1906 , consisted of

Ordinary shares $\ldots \ldots \ldots \ldots \ldots £ 750,000(\$ 3,637,500)$

Preference shares .......... £2,500,000 (\$12,125,000)

$4 \%$ Mortgage debenture stock.. £1,241,353 (\$6,020,562)

$$
\text { Total........... } 14,491,353(\$ 21,783,062)
$$

The ordinary shares were issued in payment for patents, manufacturing information and territorial rights. The preference shares and the mortgage debenture stock were sold for cash at substantially par, and the aggregate of their face value, $£ 3,741,353 \quad(\$ 18,1.45,562)$, represents approximately the amount of money spent in producing the facilities of the British Company and in paying the losses incurred in its operations prior to 190\%. In January, 1907, because of losses thus far incurred, the capital of the company was reduced by $£ 1,375$,$000(\$ 6,668, \% 50)$. In 1908 there was a further authorized issue of $£ 300,000(\$ 1,455,000)$ of $6 \%$ prior lien debentures, of which $£ 250,000(\$ 1,212,500)$ were issued. Of this issue $£ 16,400 \quad(\$ 79,540)$ have been retired under sinking fund provisions, leaving outstanding $£ 233,600(\$ 1,132,960)$ as of December 31, 1910.

The present capitalization is :

Preference shares ......... £1,500,000 (\$7,275,000)

Ordinary shares $\ldots \ldots \ldots \ldots \ldots \ldots £ 375,000 \quad(\$ 1,818,750)$

$4 \%$ Mortgage debenture stock. . $£ 1,241,353$ (\$ 6,020,562)

$6 \%$ Prior lien debentures ...... £ 233,600 (\$1,132,960)

$$
\text { Total............ }
$$

The operations of the British Company have been quite uniformly unprofitable, as is shown by the table of gross earnings and net in-

\begin{tabular}{|c|c|c|c|c|c|c|c|}
\hline \multirow[b]{3}{*}{$\begin{array}{c}\text { Gross } \text { Earn- } \\
\text { ings- Ship- } \\
\text { ments Bil'd }\end{array}$} & \multicolumn{7}{|c|}{ Year Ended December 31} \\
\hline & 1904 & 1905 & 1906 & 1907 & 1908 & 1909 & 1910 \\
\hline & $£ 1,464,695$ & $£ 1,334,815$ & $£ 1,054,189$ & $£ 1,121,432$ & $£ 1,068,559$ & $£ 984,709$ & $£ 1,206,366$ \\
\hline $\begin{array}{l}\text { Net Profit } \\
\text { from Oper- } \\
\text { ations..... } \\
\text { Other Income }\end{array}$ & $\begin{array}{l}4,289 \\
2,813\end{array}$ & $\begin{array}{c}126,784 \\
(\text { loss }) \\
3,228\end{array}$ & $\begin{array}{c}310,524 \\
(\text { loss) } \\
1,231\end{array}$ & $\begin{array}{r}17,836 \\
(\text { loss }) \\
1,668\end{array}$ & $\begin{array}{r}12,626 \\
2,760\end{array}$ & $\begin{array}{l}51,623 \\
17,435\end{array}$ & 62,372 \\
\hline $\begin{array}{l}\text { Total Income } \\
\text { Interest } \\
\text { Charges.... }\end{array}$ & 37,298 & $\begin{array}{c}123,556 \\
(\mathrm{loss}) \\
43,476\end{array}$ & $\begin{array}{c}309,293 \\
(\text { loss }) \\
56,764\end{array}$ & $\begin{array}{c}\begin{array}{c}16,168 \\
(103 s) \\
64,033\end{array} \\
\end{array}$ & $\begin{array}{l}15,386 \\
62,607\end{array}$ & $\begin{array}{l}69,058 \\
64,556\end{array}$ & $\begin{array}{l}82,263 \\
64,184\end{array}$ \\
\hline $\begin{array}{l}\text { Net Surplus } \\
\text { for the Year }\end{array}$ & $\begin{array}{c}£ 30,196 \\
\text { (loss) } \\
\text { (\$146,450 }\end{array}$ & $\begin{array}{c}£ 167,032 \\
(\text { loss) } \\
(\$ 810,105)\end{array}$ & $\begin{array}{c}£ 366,057 \\
\text { (loss) } \\
(\$ 1,775,376\end{array}$ & $\begin{array}{c}f 80,201 \\
(1088) \\
(\$ 388,974)\end{array}$ & $\begin{array}{c}£ 47,221 \\
(\text { (los8) } \\
(\$ 229,021)\end{array}$ & $\begin{array}{r}£ 4,502 \\
(\$ 21,834)\end{array}$ & $\begin{array}{r}\boldsymbol{E} 18,079 \\
(\$ 87,683)\end{array}$ \\
\hline
\end{tabular}
come, which follows: 
A further reduction of the British Company's capital seems to be forecasted by the necessity for providing for payment of an award against it aggregating with costs substantially more than $£ 100,000$ $(\$ \$ 85,000)$, in an arbitration proceeding, recently decided, between the British Company and the London Underground Railway.

The Income Account for the year ended December 31, 1910, follows:

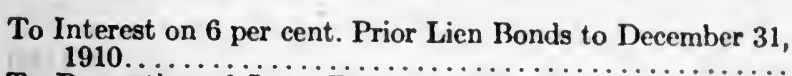

To Proportion of Issue Expenses of 6 per cent. Prior Lien

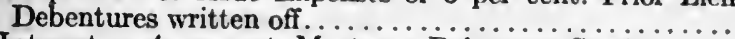

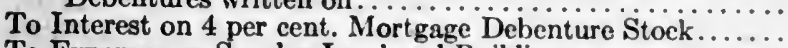

To Expenses on Surplus Land and Buildings.............

To Amount Written off Works, Machinery,

Plant, etc................... $9,423 \quad 116$

To Additional Sum Reserved for General

Depreciation.................. 15,000 00

To Profit for Year, Including Prior Lien Redemption Ac-

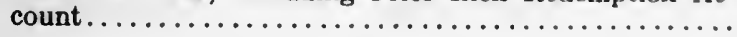

By Profit for Year, Including Estimated Profit Accrued to

$\begin{array}{rrr}£ & \text { 8. } & \text { d. } \\ 14,358 & 0 & 0 \\ 660 & 0 & 0 \\ 49,654 & 2 & 4 \\ 5,364 & 13 & 5\end{array}$

\begin{tabular}{ccc}
24,423 & 11 & 6 \\
18,078 & 12 & 8 \\
\hline$£ 112,538$ & 19 & 11 \\
$£$ & 8. & d.
\end{tabular}

Date on Contracts in Progress, Interest Received, etc., after Providing for the Expenses of Management, Directors' Fees, for Bad and Doubtful Debts, Maintenanee of Buildings, Machinery, etc., and all other Working Charges By Interest on Deposits and Loans...................

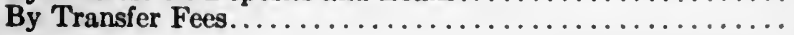

$\begin{array}{rrr}110,133 & 17 & 8 \\ 2,370 & 7 & 3 \\ 34 & 15 & 0\end{array}$

$£ 112,538 \quad 19 \quad 11$

The improved situation and prospects of the British Company reflected by the results of its operations for the past year, seem to assure the ability of the company to meet its fixed charges represented by the interest on its two classes of debentures, but do not give promise of an early return on either its preference or ordinary shares. The balance sheet of the company as of December 31, last, follows:

Property and Plant:

\section{ASSETS}

Buildings, Fixtures and Land ..................

Machinery, Plant and Furniture, Tools and Dies, Patterns, Draw-

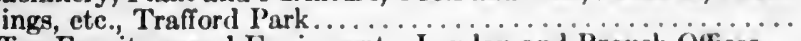

Office Furniture and Equipment-Iondon and Branch Offices...

Tотац.......................... $£ 1,691,639$

INVESTMENTS:

Clyde Valley Electrical Power Company, I.td.-Shares........

Traction \& Power Securities Company, Ltd.-Shares...........

\& 200,790

56,950

Misccllaneous Shares and Debentures.............. 25,674

Total........................... 256,414 
Corrent Assets:

Cash at Bankers and on Loan.................... £ 92,792

Cash with Cashiers, Agents and others.................. 21,744

Notes Receivable........................... $\quad 6,753$

Accounts Receivable....................... 559,628

Total

Working and Trading Assets:

Materials and Supplies, Finished Product, Work in Progress, etc. $£ \quad 516,100$

OTher Assets:

Patents and Good-will.......................... £ 375,000

Insurance, Taxes and Royalties Paid in Advance................

Suspense Account-Prior Lien Debenture Issue Expenses.......

Development of Rateau Turbines.

TOTAL

£ 408,910

Total Assets

$£ 3,583,980$

\section{LIABILITIES}

Capital:

Share Capital:

Preference Shares................................

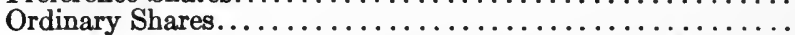

Tотац................................ $£ £ 1,875,000$

Debentures:

$6 \%$ Prior Lien............................. £ 233,600

$4 \%$ Mortgage Stock ................................

Total................................. $\quad \mathfrak{£ 1 , 4 7 4 , 9 5 3}$

Current Liabilities:

Current Accounts................................. \& 130,615

Taxes and Rents, Royalties, etc..................... $\quad 17,585$

Advances Received on Contracts in Progress................. $\quad 2,009$

Interest Accrued............................... 28,331

Total................................ £ 178,540

ReServe Accounts and Surplus................... £ 55,487

Total Liabilities........................... £3,583,980

Of the outstanding capital of the British Company the Westinghouse Electric \& Manufacturing Company owns the following:

Preference shares ........... £536,112 $(\$ 2,600,143)$

Ordinary shares $\ldots \ldots \ldots \ldots \ldots \ldots £ 190,230(\$ 922,615)$

$4 \%$ Mortgage debenture stock..... $£ 675,000 \quad(\$ 3,273,750)$

Of these, the ordinary shares do not appear on your books as an investment of any value. The preference shares, having a par value 
(after the reduction of capital in 1907) of $\$ 2,600,143$ were carried on your books as an investment until 1910 at a book value, representing the original cost of acquisition, of $\$ 4,458,083$. As of March 31, 1910 , your Directors wrote off for depreciation of this item the sum of $\$ 3,564,563$. Its book value as of March 31,1911 , is $\$ 893,520.00$. The shares have a present market value on the London Stock Exchange of 21 shillings per share of the par value of $£ 3$ each, which makes the present aggregate market value of this item approximately the book value.

The $4 \%$ Debenture stock, having a par value of $\$ 3,273,750$, is carried on the books as an investment at the cost of acquisition, $\$ 3,137,104.84$. It yields a return of $4 \%$ on par. Recent sales on the London Stock Exchange have been at the price of $62 \%$ of par.

On November 28, 1901, there was organized under French law Societe Anonyme Westinghouse, of Paris

(French Company).

Its outstanding capital is:

Preference shares ........ Frs. 10,000,000 $(\$ 1,930,000)$

Ordinary shares ......... Frs. $10,000,000 \quad(\$ 1,930,000)$

$5 \%$ Debentures .......... Frs. 7,500,000 $(\$ 1,447,500)$

The French Company operates a factory at Havre, France, where it manufactures a general line of electrical apparatus and certain condensing apparatus for steam engines and turbines. It also has a factory at Freinville, near Paris, where it manufactures Westinghouse air brakes. Its territory includes France, Belgium, Holland, Switzerland, Spain and Portugal. The operations of the company have been steadily unprofitable; and, while it earns and pays the interest on its debentures, only once, for the year 1908, has it paid a dividend on its preference shares. It underwent one reduction of capital in 1907, whereby its ordinary shares were reduced from Frs. $20,000,000(\$ 3,860,000)$ to Frs. $10,000,000(\$ 1,930,000)$. In 1909 it increased its issue of preference shares by Frs. $5,000,000(\$ 965,000)$. Since January 1, 1911, it has increased its $5 \%$ debenture issue from Frs. $7,500,000(\$ 1,447,500)$ to Frs. $10,000,000(\$ 1,930,000)$. It proposes at its annual general meeting in June, 1911, again to reduce its capital by a reduction of the ordinary shares from Frs. $10,000,000(\$ 1,930,000)$ to Frs. $4,000,000(\$ 7 \gamma 2,000)$. Statement of its gross and net earnings for the years 1906 to 1910, inclusive, follows: 


\begin{tabular}{|c|c|c|c|c|c|}
\hline \multirow{3}{*}{ Gross Earnings-Shipments Billed... } & \multicolumn{5}{|c|}{ Year Ended December 31} \\
\hline & 1906 & 1907 & 1908 & 1909 & 1910 \\
\hline & $\underset{9,864,092}{\text { Francs }}$ & $\begin{array}{c}\text { Francs } \\
10,350,733\end{array}$ & $\begin{array}{c}\text { Francs } \\
15,184,819\end{array}$ & $\begin{array}{c}\text { Francs } \\
13,207,311\end{array}$ & $\underset{14,031,636}{\text { Franc8 }}$ \\
\hline $\begin{array}{l}\text { Net Profit from Operations......... } \\
\text { Other Income................. }\end{array}$ & $\begin{array}{r}730,021 \\
(1088) \\
83,581 \\
\end{array}$ & $\begin{array}{r}1,183,941 \\
(10 s s) \\
183,163\end{array}$ & $\begin{array}{l}670,785 \\
211,629\end{array}$ & $\begin{array}{r}288,125 \\
(1098) \\
726,120 \\
\end{array}$ & $\begin{array}{r}23,243 \\
(\text { (lcss) } \\
412,205\end{array}$ \\
\hline $\begin{array}{c}\text { Total Income............... } \\
\text { Interest Charges................ }\end{array}$ & $\begin{array}{r}646,440 \\
(\text { loss) } \\
29,825\end{array}$ & $\begin{array}{r}1,000,778 \\
(108 s) \\
351,644\end{array}$ & $\begin{array}{l}882,414 \\
604,881\end{array}$ & $\begin{array}{l}437,995 \\
513,327\end{array}$ & 388,862 \\
\hline Net Surplus for the Year......... & $\begin{array}{r}676,265 \\
(\text { loss }) \\
(\$ 130,519)\end{array}$ & $\begin{array}{r}1,352,422 \\
\text { (loss) } \\
(\$ 261,017)\end{array}$ & $\begin{array}{r}277,533 \\
(\$ 53,563)\end{array}$ & $\begin{array}{r}75,332 \\
(\text { loss }) \\
(\$ 14,539)\end{array}$ & $\begin{array}{r}8,397 * \\
(\text { loss }) \\
(\$ 1,620)\end{array}$ \\
\hline
\end{tabular}

*Preliminary-final reports not yet received.

A condensed preliminary balance sheet of the French Company as of December 31, 1910, which does not take into account the increase in its debenture issue, or the proposed reduction of share capital, follows :

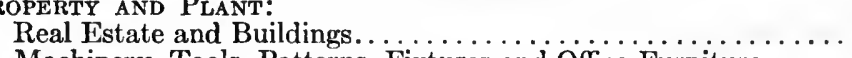

Machinery, Tools, Patterns, Fixtures and Office Furniture......

Patents

Francs

$3,621,769$

$4,537,979$

$3,985,000$

Total.

$12,144,748$

INVESTMENTS:

Italian Company $\ldots \ldots \ldots \ldots \ldots \ldots \ldots \ldots \ldots \ldots$

Miscellaneous.

${ }^{*} 2,969,694$

748,949

Total

$3,718,643$

Current Assets:

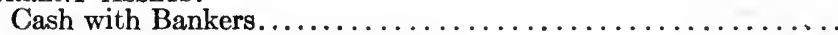

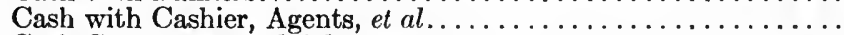

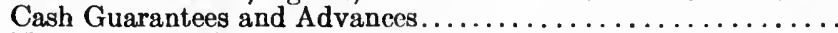

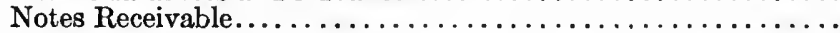

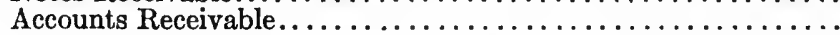

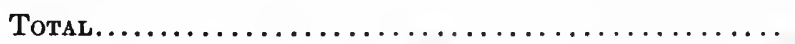

157,258

84,559

224,287

36,250

$8,466,677$

$8,969,031$

Working and Trading Assets:

Raw Materials and Supplies, Finished Product, Work in Progress,

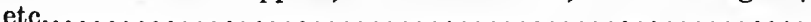

Deferred Charges.............................

$7,842,535$

178,501

Total Assets

$32,853,458$

\section{LIABILITIES}

Capital Stock:

Francs

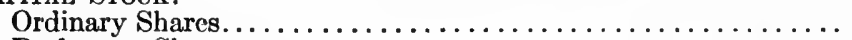

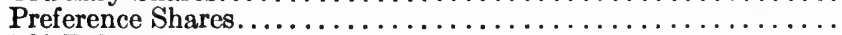

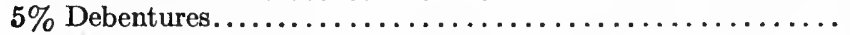

$10,000,000$

$10,000,000$

$7,500,000$

Total Capital and Funded Debt............ 27,500,000 
Current Liabilities:

Notes Payable.

473,091

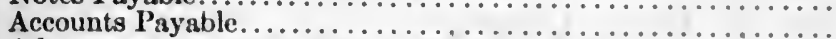

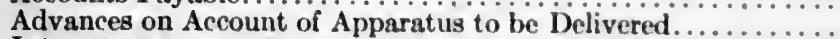

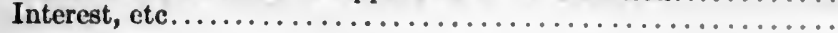

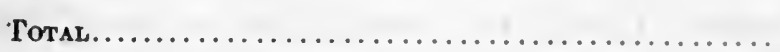

Reserves, Proftt and Loss, Erc.

Total Liabilities.

*1,000 Shares (par value Lire 250,000) deposited with Bankera as security for guarantees on contracts undertaken.

Note-As of December 31, 1910, the French Company had a contingent lisbility for guar antees and endorsements made for account of the Italian Company to the amount of Frs. 1,570,014

Of the outstanding capital of the French Company, the Westinghouse Electric \& Manufacturing Company owns:

Preference shares $\ldots \ldots \ldots \ldots$ Frs. $4,628,750(\$ 893,348)$
Ordinary shares $\ldots \ldots \ldots \ldots$ Frs. $2,883,750 \quad(\$ 556,563)$
$5 \%$ Debentures $\ldots \ldots \ldots \ldots$ Frs. $7,500,000 \quad(\$ 1,447,500)$

With the exception of Frs. $3,478,750 \quad(\$ 671,398)$ of preference shares, these were all acquired prior to $190 \%$. During the Receivership of your Company (1907-1908) the Court authorized the Receivers to advance $\$ 1,300,000$ to the French Company. These advances were not actually made during the Receivership, but in 1909 your Company took at par Frs. $3,478,750(\$ 671,398)$ of the preference shares issued that year.

The debentures are carried on your books as an in-

vestment at cost ................\$1,430,730.37

The preference shares are likewise carried among

investments at cost ............... 896,536.51

Prior to March 31, 1910, the ordinary shares were carried as an investment at cost, $\$ 494,032.21$. During the year ended March 31, 1910 , there was written off as depreciation of this item $\$ 275,05 \% .21$. During the last fiscal year there was written off a further sum of $\$ 218,974.00$, leaving the book value of the ordinary shares as of

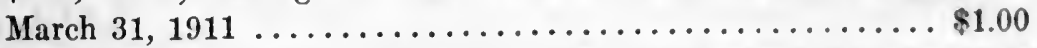

Your Directors hope that with carcful management the debentures and the preference shares of the French Company may be made worth their face values. There is no market quotation for any of these securities.

On March 11, 1907, there was organized under Italian law, as a subsidiary of the French Company,

\section{Societa Italiana Westinghouse}

(Italian Company).

The outstanding capital of this company consists of: 
Ordinary shares $\ldots \ldots \ldots \ldots$ Lire $4,000,000 \quad(\$ 772,000)$

Of these the French Company

owns approximately ...... Lire $3,000,000 \quad(\$ 579,000)$

For the purpose of capitalizing certain advances recently made to it by the French Company and the Westinghouse Electric \& Manufacturing Company, the Italian Company is about to create an issue of Lire $4,000,000(\$ 772,000)$ of $5 \%$ debentures. Of this issue approximately Lire $1,500,000(\$ 289,500)$ will be received by the French Company and Lire 2,500,000 $(\$ 482,500)$ by the Westinghouse Electric \& Manufacturing Company. These debentures will in next year's balance sheet of your Company appear among Investments; meanwhile the amounts advanced as of March 31, 1911, appear in the balance sheet under the items Notes and Accounts Receivable at $\$ 289,746.12$.

The Italian Company in 1907-8 constructed a factory at Vado, Ligure, Italy, for the primary purpose of executing important contracts for the electrification of certain of the Italian State Railways. Delays by the Italian Government in carrying out its program for the improvement of its railway lines has temporarily disappointed the expectations with which this company was organized and its plant created, so that it is now looking to the general market for orders for electrical apparatus to keep its works in operation.

Statement of its earnings and profits and its balance sheet as of December 31, 1910, follows:

\begin{tabular}{|c|c|c|c|}
\hline \multicolumn{4}{|c|}{ Year Ended December 31} \\
\hline Gross Earnings_-Shipments Billed.. & $\begin{array}{c}1908 \\
\text { Lire } \\
2,325,678\end{array}$ & $\begin{array}{c}1909 \\
\text { Lire } \\
2,899,718\end{array}$ & $\begin{array}{c}1910 \\
\text { Lire } \\
3,688,241\end{array}$ \\
\hline 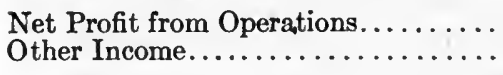 & $\begin{array}{l}104,611 \\
141,210\end{array}$ & $\begin{array}{l}318,786 \\
173,653\end{array}$ & (loss) $\begin{array}{r}121,590 \\
469,033\end{array}$ \\
\hline TотаL Inсомe... & 245,821 & 492,439 & 347,443 \\
\hline $\begin{array}{l}\text { Deductions from Income-Interest } \\
\text { and Other Charges.............. }\end{array}$ & 75,077 & 255,225 & 518,121 \\
\hline Net Surplus for the Year. & 170,7 & $\begin{array}{r}237,214 \\
(\$ 45,782\end{array}$ & (loss) 170 \\
\hline
\end{tabular}

ASSETS

Property and Plant:

Lire

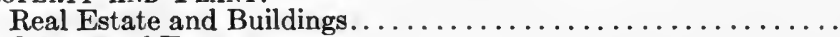

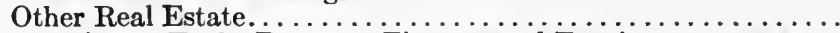

Machinery, Tools, Patterns, Fixtures and Furniture...........

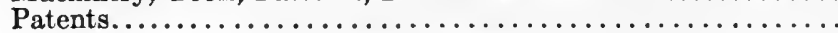

329,626

665,148

$2,466,522$

$1,049,917$

Total...........................

$5,511,213$ 
Current and Working Assets:

Cash with Cashier and Banks....................... 22,174

Cash with Agents, etc........................... 110,319

Cash Guarantees, etc................................. $\quad \mathbf{3}_{\mathbf{3}} \mathbf{1 0 7 3 1}$

Accounts and Notes Receivable.......................... $\quad 2,995,850$

Inventories...................................

Total............................. $\frac{1,642,178}{4,6 \ldots \ldots}$

Deferred Charges............................ 61,765

Total Assets........................ 10,215,156

Capital Stock:

LIABILITIES

Ordinary Shares............................. $\quad \begin{aligned} & \text { Lire } \\ & 4,000,000\end{aligned}$

Current Liabilities:

Notes Payable:

Issued for Cash........................ 3,091,014 (1)

Miscellaneous............................... ${ }_{36,579}$

Accounts Payable................................. 2,563,643 (2)

Bank Overdraft ............................. ${ }_{93,191}^{2,6}$

Miscellaneous-Including Interest...................... $\quad 50,155$

Total.............................

Legat Reserve and Proftt and Loss..............

Total Liabilities....................... $\overline{10,215,156}$

(1) Includes notes for L. 1,500,000 held by American Co. far cash advanced. The balance is held almost exclusively by Italian banks and in part is secured by guarante of the French $\mathrm{Ca}$.

(2) Includes account due the French Co. amounting to approximately L. 1,250,000.

In July, 1906, there was organized under the laws of France

Societe Electrique Westinghouse de Russie

(Russian Company).

The outstanding capital of this company is:

Cash shares ............. Frs. 7,000,000 $(\$ 1,351,000)$

Apport shares ............ Frs. 13,000,000 $(\$ 2,509,000)$

$5 \%$ Debentures ........... Frs. 14,000,000 (\$2,702,000)

This company was organized primarily to execute a contract amounting to over Rs. $10,000,000(\$ 5,150,000)$ for the electrification of the St. Petersburg tramways. For the purpose of this work the Russian Company acquired the electric manufacturing plant in Moscow of the Compagnie Centrale d'Electricite of Paris. Part of the purchase price was deferred and secured by a mortgage on the plant, of which there is still due approximately Firs. $750,000 \quad(\$ 144,750)$ maturing in three nearly equal instalments on July 25, 1911, January 25,1912 , and July 25, 1912. Upon the organization of the Russian Company the Westinghouse Electric \& Manufacturing Company advanced to it sums aggregating $\$ 895,888.12$, of which there remains 
due to this Company $\$ 290,000.00$. The Westinghouse Electric \& Manufacturing Company purchased from the Russian Company its issue of Frs. 14,000,000 (\$2,702,000) of $5 \%$ debentures at $83 \%$ of par, the cost aggregating $\$ 2,243,243.24$. It also subscribed for Frs. 3,600,000 $(\$ 694,800)$ cash shares of the Russian Company at par, the payment for this subscription aggregating $\$ 696,322.35$. The apport shares of which your company owns Frs. 1,240,000 (\$239,320) par value, cost $\$ 198,962.05$. The Russian Company owes the Westinghouse Electric \& Manufacturing Company on open account for materials $\$ 32,355.81$. There remains unpaid also the interest on the debentures from October 1, 1908, to April 1, 1911, aggregating $\$ 324,324.30$. The total investment in and accounts due by the Russian Company at the close of the last fiscal year therefore aggregate $\$ 3,785,207.75$. Of this, prior to March 31,1910 , there were carried on your books as Investments:

Cash shares at cost $\ldots \ldots \ldots \ldots \ldots . \$ 696,322.35$

Apport shares ............. 198,962.05

$5 \%$ Debentures at cost ........ 2,243,243.24

As of March 31, 1910, the investment in the cash and apport shares was written off to $\$ 1.00$ for each class of shares, leaving as of March 31,1911 , the book value of this investment.......\$2,243,245.24 lurther depreciation of this investment may be required.

Other items are carried against the Russian Company in other accounts as follows:

Accounts Receivable .......... $\$ 32,355.81$

Notes Receivable ............290,000.00

The unpaid interest on the debentures has not been entered on the books of your Company.

The execution of the St Petersburg contract resulted in a loss of approximately Rs. $2,000,000(\$ 1,030,000)$. In its other operations the losses of the Russian Company have aggregated Rs. 1,584,425 $(\$ 815,978)$. The aggregate losses in the operations of the Russian Company to date therefore are in excess of $\$ 1,800,000$. There are other losses not yet definitely ascertained, due to the differences between the actual value of the Moscow plant and the price paid for it, and to depreciations occurring since the property was acquired not yet entered on the books.

The City of St. Petersburg is withholding from the amount due by it to the Russian Company an aggregate of over Rs. 700,000 (\$360,500 ) by way of fines imposed for alleged delays in the performance of the contract and the company is urging a large claim for extras. There 
is reason to hope that the fines may be substantially remitted. Until these disputes are adjusted and payment made, it is obviously impossible to predict how much of our investment in the Russian Company can be realized. The maintenance of the company as a going concern is necessary pending the negotiations with the Municipality of St. Petersburg, and for this purpose your Directors have found it necessary to provide it with funds. These advances, approximating $\$ 110,322$ to March 31,1911 , are secured by mortgage. During the past year, improvement in the operations and increase of the business of the Moscow plant encourage the hope that it may at least earn its operating expenses.

On September 6, 1906, there was organized under Austrian laws

Westinghouse Metallfaden-Gluhlampen-Fabrik Gesell-

$$
\text { schaft, m.b.H (Austrian Company) }
$$

The outstanding capital stock of this company is Kronen $1,600,000$ $(\$ 324,800)$. Of this Kronen $1,230,000(\$ 249,690)$ are owned by the Westinghouse Electric \& Manufacturing Company and Westinghouse Lamp Company and are carried among investments at the cost of acquisition aggregating $\ldots \ldots \ldots \ldots \ldots \ldots \ldots \ldots \ldots 250,626.75$ The Austrian Company operates a factory for the manufacture of tungsten lamps at Atzgersdorf near Vienna. Its operations have so far been measurably profitable, and the shares owned by your Company may safely be considered worth their book value.

The balance sheet of the Austrian Company as of February 28, 1911, follows:

Property and Plant:

ASSETS

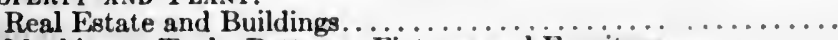

Machinery, Tools, Patterns, Fixtures and Furniture...........

Patents.

Kronen

503,137

827,634

Total.

$1,330,772$

Current and Working Assets:

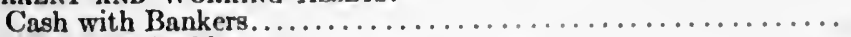

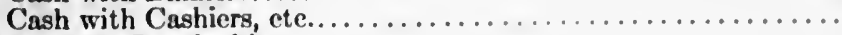

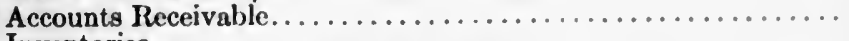

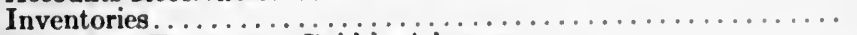

Insurance, Taxes, ete., Paid in Advance.

Total Curnent and Working Assets.

$1,911,128$

Toral Assets

$3,241,900$

Capteal:

Capital Stock 
Current Liabilities:

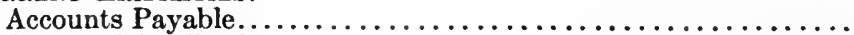

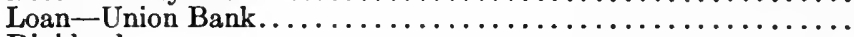

Dividend.

TotaL............................ 1,106,836

Reserve Accounts, Profit and Loss, Etc............... $\overline{535,064}$

Total Liabilities.......................... $\overline{\mathbf{3 , 2 4 1 , 9 0 0}}$

At the time of the organization of the Austrian Lamp Company, there was organized The Westinghouse Metal

Filament Lamp Company, Ltd. (London Lamp Company)

with a capitalization of $£ 10,000(\$ 48,500)$ of which $80 \%$ is owned by the Westinghouse Lamp Company, one of your subsidiary companies, and is carried on the books of that company at cost..... $\$ 38,800.00$

The London Lamp Company was organized to control the patents covering the tungsten lamp manufacturing processes for the territory outside of that of the Austrian Lamp Company. It is believed that the book value of this investment will be realized.

At various times from 1903 to 1908 the Westinghouse Electric \& Manufacturing Company acquired shares in

Canadian Westinghouse Company, Limited (organized under the laws of Canada)

$$
\begin{aligned}
& \text { Capital-Authorized } \ldots \ldots \ldots \ldots \ldots \$ 5,000,000.00 \\
& \text { Capital-Issued } \ldots \ldots \ldots \ldots \ldots .4,376,600.00
\end{aligned}
$$

Of the latter the Westinghouse Electric \& Manufacturing Company owns $\$ 1,710,000$, of which $\$ 500,000$ was acquired in consideration of the transfer of patent rights and manufacturing information for Canada. The balance, $\$ 1,210,000$, has been acquired from time to time at par for cash. The shares are carried on your books as an investment at par ...................\$1,710.000.00

Canadian Westinghouse Company, Ltd., operates a manufacturing plant at Hamilton, Ontario, Canada. It manufactures a general line of electrical apparatus and in addition the Westinghouse air brake. It has been uniformly and increasingly successful and has paid dividends regularly since 1903 at the rate of $6 \%$ per annum, with an extra $1 \%$ paid for 1910 . The shares may safely be considered worth in excess of their book value. The general balance sheet and statement of profit and loss both as of December 31, 1910, follow: 


\section{GENERAL BALANCE SHEET}

\section{ASSETS}

Cash

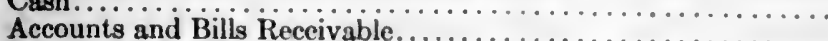

Phoperty and Plant:

\& $376,565.29$

$1,276,527.14$

(Includes Air Brake and Electric Properties, Real Estate,

General Office Building, Equipment, Sundries and Patents,

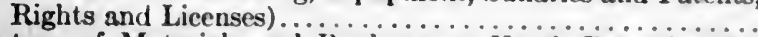

Inventory of Materials and Products on 1 Hand,

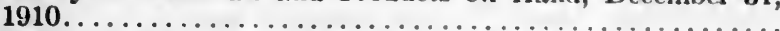

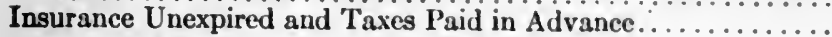

Total Assets

$2,764,403.05$

$1,626,884.31$

$10,679.94$

$\$ 6,055,059.73$

\section{LIABILITIES}

Capital Stock

$\$ 4,376,600.00$

$501,846.51$

$400,000.00$

$50,000.00$

$726,613.22$

Reserve for Depreciation of Property and Plant.............

Reserve for Inventory Adjustment.....................

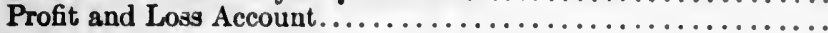

Total Liabilities.

$\$ 6,055,059.73$

\section{PROFIT AND LOSS ACCOUNT}

Balance Brought Forward January 1, 1910.

Net Earnings, Fiscal Year Ended December 31,1910

Less:

Dividends 1910

Reserve for Gencral Depreciation of Property and Plant..........

Reserve for Inventory Adjustment

Written off Property and Plant...

$\$ 306,362.00$

$\$ 697,393.56$

$\$ 536,103.83$

Balance Carried Forward January 1,1911

\section{D-Other Manufacturing Companies.}

The Westinghouse Machine Company.

On February 28, 1910 the Westinghouse Electric \& Manufacturing Company acquired $\$ 250,000$ par value, of the capital stock of The Westinghouse Machine Company, as part consideration of the adjustment of relations heretofore referred to between your Company and the Security Investment Company. These shares were taken on the books at the time of acquisition at a value of $\$ 218,538.60$. As of March 31, 1911 your Directors wrote off for depreciation of this item $\$ 93,538.60$, leaving the book value of these shares in investments at $. \$ 125,000.00$

\section{Nernst Iamp Company.}

On October 28, 1909 the Westinghouse Electric \& Manufacturing Company acquired $\$ 500,000$ of Nernst Isamp Company $5 \%$ first inortgage bonds at par. These were taken in pursuance of the terms of an adjustment by the Nernst Iamp Company with all of its creditors, by virtue of which it was discharged from the hands of receivers. The claim thus adjusted represented in part moneys advanced and mate- 
rials furnished to the Nernst Lamp Company, and in part an unpaid balance on the sale in 1907 by the Westinghouse Electric \& Manufacturing Company to the Nernst Lamp Company of the property known as the Garrison Alley factory in Pittsburgh, $\mathrm{Pa}$. These bonds are carried on your books at par . . . . . . . . . $\$ 500,000.00$

The Nernst Lamp Company is a subsidiary of The Westinghouse Machine Company, which owns all of its capital stock.

\section{E-The Traction \& Power Securities Company, Ltd.}

The Receivers of the Westinghouse Electric \& Manufacturing Company on December 31,1907 , acquired at par $£ 169,150$ (\$820,377), of the capital stock of The Traction \& Power Securities Company, Ltd., from The British Westinghouse Electric \& Manufacturing Company, Ltd., in payment of certain notes, open account and interest.

The Traction \& Power Securities Company, Ltd., was organized in 1901 under the laws of Great Britain as a securities holding company. Its issued and outstanding capital is

$$
\text { Ordinary shares ........£854,100 (\$4,142,385) }
$$

The assets of The Traction \& Power Securities Company Ltd., consist almost wholly of:

(a) $£ 620,000(\$ 3,00 \%, 000)$ face value $4 \%$ prior lien debentures of the Mersey Railway, an electrically operated railway extending through the tunnel under the Mersey River, from Liverpool to Birkenhead The Mersey Railway earns a small surplus over and above the interèst on these debentures. Market sales of the debentures have recently been made in small lots at about 81 .

(b) $£ 344,470(\$ 1,670,679)$ par value, ordinary shares of The Clyde Valley Electrical Power Company. The latter company owns and operates two power plants, one at Motherwell and the other at Yoker, on the Clyde River near Glasgow, Scotland. For additions to its plant the Clyde Valley Company has recently incurred indebtedness, secured by mortgage to The Traction \& Power Securities Company, of over $£ 140,000(\$ 679,000)$ which will probably be increased before the work is completed, to $£ 200,000(\$ 970,000)$. Some adjustment of its capital to provide for the funding of this temporary loan will be necessary before the Clyde Valley Company can pay dividends, although it is now earning substantial profits above its operating expenses and fixed charges. There is no present market for the shares and no exact basis on which to estimate their value.

It is obvious that the value of The Traction \& Power Securities Company's shares owned by your Company depends upon the future of the Mersey Railway and The Clyde Valley Electrical Power Company. Until there can be established a market value for the debentures of the former and the shares of the latter, the value of The Trac- 
tion \& Power Securities Company shares is undeterminable. It is believed, that eventually they may be made worth substantially par, but there is at present no market for them. These shares are carried on the books of your Company as of March 31, 1911 at.....\$820,135.00

$$
\text { F-Power Companies. }
$$

Niagara, Lockport \& Ontario Power Company.

Your Company owns $\$ 912,000$, par value, of the First Mortgage 5\% bonds, and $\$ 1,000,000$, par value, of the five year 5\% coupon notes of Niagara, Lockport \& Ontario Power Company, and owns or controls substantially $55 \%$ of the outstanding capital stock of that company. These securities are carried on your books as investments, the

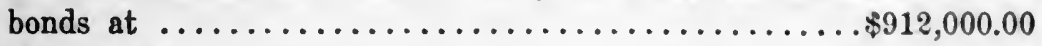

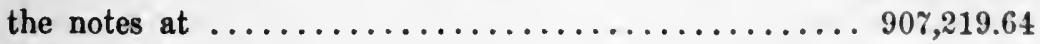

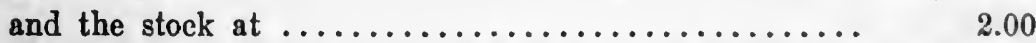

These bonds, notes, and stock were acquired, chiefly in exchange for collateral notes of the Iroquois Construction Company bought by your Company in October, 190\%, and partly in payment of advances made prior to and during the receivership of your company to finance the construction of the transmission line of the Niagara, Lockport \& Ontario Power Company, extending from Niagara Falls to Syracuse and intermediate points. This company is engaged in the transmission and sale of electric power generated at Niagara Falls by the Ontario Power Company, in which your company has no interest. The Niagara, Lockport \& Ontario Power Company is earning and paying the interest on both its notes and bonds and its business shows a continuous growth. It would seem that the book valucs of these inrestments should eventually be realized. Following is a comparative statement of the operations and earnings of the company during the three and one-half years ended December 31, 1910.

\begin{tabular}{|c|c|c|c|}
\hline & $\begin{array}{c}\text { Total } \\
\text { Reccipts }\end{array}$ & $\begin{array}{c}\text { Gross } \\
\text { Income }\end{array}$ & $\begin{array}{c}\text { Net } \\
\text { Income }\end{array}$ \\
\hline $\begin{array}{l}\text { ix month ended December } 31 \text {, } \\
1907 \ldots \ldots \ldots \ldots \ldots \ldots \ldots \ldots \ldots \ldots\end{array}$ & $196,226.63$ & \& $7,676.63^{\circ}$ & $\$ 67,811.51^{\bullet}$ \\
\hline $\begin{array}{l}\text { Year ended December } 31,1908 \ldots \\
\text { Year ended December } 31,1909 \ldots\end{array}$ & $\begin{array}{r}592,103.10 \\
863,773.80 \\
1,051,521.50\end{array}$ & $\begin{array}{l}216,525.87 \\
448,513.31 \\
555,631.12\end{array}$ & $\begin{array}{r}42,876 \cdot 39 \\
251,956.47 \\
351,521.10\end{array}$ \\
\hline
\end{tabular}

Atlanta Water \& Electric Power Company.

On Oetober 1, 190\%, the Westinghouse Electric \& Manufacturing Company acquired at par $\$ 400,000$ of the cupital stock of the Atlanta Water \& Electric Power Company, being part of an issue of $\$ 1,500,000$ outstanding. These shares are carried on your books at cost $\$ 400,000$. This book value should eventually be approximately renlized but there is no present market for the shares. 
This company operates an hydraulic electric power plant near Atlanta, Ga. Its power is sold on long term contracts to the company operating the local traction lines and the light and power company in Atlanta. It earns regularly a surplus over and above the $4 \%$ dividend paid on its stock. A statement of its earnings for six years ended December 31, 1910, follows :

\begin{tabular}{|c|c|c|c|c|c|c|}
\hline \multirow[b]{2}{*}{$\begin{array}{l}\text { Gross Earnings... } \\
\text { Operating expense } \\
\text { and Taxes }\end{array}$} & \multicolumn{6}{|c|}{ Year Ended December 31} \\
\hline & \begin{tabular}{|c|}
1905 \\
$\$ 134,609.28$ \\
$28,024.94$
\end{tabular} & \begin{tabular}{|c|}
1906 \\
$\$ 177,994.89$ \\
$35,900.37$
\end{tabular} & \begin{tabular}{|c|}
1907 \\
$\$ 170,265.03$ \\
$30,756.99$
\end{tabular} & \begin{tabular}{|c|}
1908 \\
$\$ 176,908.02$ \\
$34,633.91$
\end{tabular} & \begin{tabular}{|c|}
1909 \\
$\$ 183,981.03$ \\
$39,423.52$ \\
\end{tabular} & $\begin{array}{r}1910 \\
\$ 181,783.58 \\
33,917.06\end{array}$ \\
\hline $\begin{array}{l}\text { Net Earnings..... } \\
\text { Other Income... }\end{array}$ & $\begin{array}{l}\$ 106,584.34 \\
\ldots \ldots \ldots \ldots\end{array}$ & $\begin{array}{r}\$ 142,094.52 \\
1,339.97\end{array}$ & $\begin{array}{r}\$ 139,508.04 \\
2,388.04\end{array}$ & $\mid \begin{array}{r}\$ 142,274.11 \\
2,832.12\end{array}$ & $\begin{array}{r}\$ 144,557.51 \\
2,569.02\end{array}$ & $\begin{array}{r}\$ 147,866.52 \\
6,578.07\end{array}$ \\
\hline Total Income.. & $\$ 106,584.34$ & $\$ 143,434.49$ & $\$ 141,896.08$ & $\$ 145,106.23$ & $\$ 147,126.53$ & $\$ 154,444.59$ \\
\hline $\begin{array}{c}\text { Interest }(5 \% \text { on } \\
\$ 1,350,000 \text { bonds }) \\
\text { Reserve for De- } \\
\text { preciation....... } \\
\text { Other Income } \\
\text { Charges........ }\end{array}$ & $\begin{array}{l}\cdots \cdots \cdots \\
1,500.00\end{array}$ & $\$ 67,500.00$ & $\begin{array}{r}\$ 67,500.00 \\
25,000.00 \\
176.00\end{array}$ & $\begin{array}{r}\$ 67,500.00 \\
25,000.00 \\
72.07\end{array}$ & $\begin{array}{r}\$ 67,500.00 \\
15,000.00 \\
748.20\end{array}$ & $\begin{array}{r}\$ 67,500.00 \\
15,000.00 \\
79.87\end{array}$ \\
\hline $\begin{array}{c}\text { Total Income } \\
\text { Charges..... }\end{array}$ & $\$ 69,000.00$ & $\$ 68,125.00$ & $\$ 92,676.00$ & $\$ 92,572.07$ & $\$ 83,248.20$ & $\$ 82,579.87$ \\
\hline $\begin{array}{l}\text { Surplus for the } \\
\text { Year.......... }\end{array}$ & $\$ 37,584.34$ & $\$ 75,309.49$ & $\$ 49,220.08$ & $\$ 52,534.16$ & $\$ 63,878.33$ & $\$ 71,864.72$ \\
\hline
\end{tabular}

Your company owns and carries as investments the following securities of other power companies:

Par Value Book Value

Catskill Illuminating \& Power Co. stock $\$ 25,350.00 \$ 25,223.24$

Sierra Power Co. stock ........... $\quad 9,000.00 \quad 8,100.00$

Telluride Power Co stock $\cdots \cdots \cdots \cdots, \quad 5,000.00 \quad 1,250.00$

Cascade (1906) Power Co. stock ...... 45,607.44 2,000.00

Idaho-Oregon Light \& Power Co. bonds. $\quad 30,000.00 \quad 21,000.00$

Idaho-Oregon Light \& Power Co. stock. $\quad \mathbf{2 , 5 0 0 . 0 0} \quad 500.00$

Central Georgia Power Co. bonds...... $180,500.00 \quad 153,424.00$

Central Georgia Power Co. stock..... 90,250.00 1.00

Total book value................

$\$ 211,498.24$

These bonds and stocks were practically all acquired in payment for apparatus sold. It is expected that the book values will be realized in time.

The ownership of the securities of power companies above described constitutes the sole foundation in fact for the statements from time to time appearing in current periodicals and Government reports of the connection of your company with a so-called "water power trust."

\section{G-Traction Companies}

Lackawannȧ \& Wyoming Valley Rapid Transit Company

On various dates in 1904 and 1908 the Westinghouse Electric \& Manufacturing Company acquired at par $5 \%$ bonds of the Lacka- 
wanna \& Wyoming Valley Rapid Transit Company to an aggregate face value of $\$ 6,174,000.00$. Until March 31,1911 , these bonds were carried in Investments at cost, $\$ 6,147,042.0 \%$, but on that date your Directors authorized that there be written off this item for depreciation the sum of $\$ 2,000,000.00$ making the book value in the present balance sheet $\ldots \ldots \ldots \ldots \ldots \ldots \ldots \ldots \ldots \ldots \ldots+1,147,042.07$ At this value it is hoped that this investment may eventually be liquidated.

Your company also owns $\$ 4,885,600$ (out of a total issue of $\$ 6,000$,000) of the capital stock of the Lackawanna \& Wyoming Valley Rapid Transit Company, carried on the books at............. \$1.00

The Lackawanna \& Wyoming Valley Rapid Transit Company owns all the securities of five subsidiary companies, which in turn own a line of double track, electrically operated railway extending from WilkesBarre to Scranton, Pa., a total distance of operated double track of 22.63 miles. The cost of constructing and equipping this property was $\$ 7,097,091$. There are two issues of $5 \%$ bonds outstanding against the property. Of the first issue, secured by a prior lien upon most of the property, there are $\$ 888,000$ outstanding, of which $\$ 100$,000 are included in the $\$ 6,174,000$ stated above as owned by your company, and the others are owned by outside interests. The company's net earnings have never been sufficient to pay the entire interest on its outstanding bonds. A consolidated statement of the operations of its subsidiary companies follows:

\begin{tabular}{|c|c|c|c|c|c|}
\hline \multirow[b]{2}{*}{ ' } & \multicolumn{5}{|c|}{ Year Faded January 31} \\
\hline & 1907 & 1908 & 1900 & 1910 & 1911 \\
\hline $\begin{array}{l}\text { Gross Earnings........... } \\
\text { Operating Expenses and } \\
\text { Taxes............... }\end{array}$ & $\begin{array}{r}\$ 457,174.10 \\
253.416 .87\end{array}$ & $\begin{array}{r}8511,491.31 \\
270,443.73\end{array}$ & $\begin{array}{r}\$ 543,122.55 \\
333,006.47\end{array}$ & $\begin{array}{r}\$ 561,900.35 \\
344,108.44 \\
\end{array}$ & $\begin{array}{r}\$ 590,959.46 \\
3.50 .278 .85 \\
\end{array}$ \\
\hline Net Earnings............ & $\$ 203,757.29$ & $\$ 241,047.58$ & $\$ 212,116.11$ & $\$ 217,881.98$ & $\$ 240,050,61$ \\
\hline
\end{tabular}

Your company owns also the following securities of other traction and miscellaneous companies, the final realization of which it is believed will approximate the book values:

\section{Name}

Grand Rapids, Grand Haven \& Murkeqnn Rail.

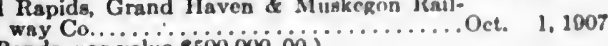
(Bonds, par value $\$ 500,000,00$ )

Indianapolis \& Cincinnati Traction Co .........Jan. 23, 1911

(Bonds, par value $\$ 104,000)$
Pitteburg \& Weat moreland St. Rail way Co........ Mny 25, 1010 (Stock, par value $\$ 100$ )

Rock Island Southern Inilway Co..............Mar. 31, 1911

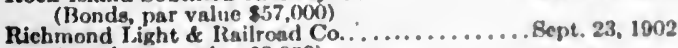
(1)onds, par value $\mathbf{3 3 , 0 0 0 )}$

Bpokane \& Inland Frnpire Railway Co......... 1000 \& 1907 (Stock, par value $\$ 150,000$ )

$\begin{array}{rr}\begin{array}{c}\text { Book Value } \\ \text { af Date } \\ \text { Acjuired }\end{array} & \begin{array}{c}\text { Book Value } \\ \text { Mlareh } 31 . \\ 1011\end{array} \\ \$ 500,000.00 & \$ 500,000.00 \\ 139,400.00 & 139,400,00 \\ 100.00 & 100.00 \\ 82,100.00 & \$ 2,100.00 \\ 2,400.00 & 2,490.00 \\ 100,000.00 & 85,000 \mathrm{~m}\end{array}$




\section{Migcellaneous Companies \\ Name \\ Date}

Consumers Electric Co

(Bonds, par value $\$ 7,000$

Cutter Electrical \& Manufacturing Co............ Oct. 29, 1909 (Stock, par value \$57,300)

H-O Company, The..............

(Bonds, par value $\$ 24,700$ )

Lau rentide Mica Co., Ltd., The ............... Dec. 31, 1904 (Stock, par value \$25,000)

Lehigh Valley Transit Co..................... 17, 1906 (Stock, par value $\$ 1,224.09$ )

Montgomery County Rapid Transit Co...........May 9, 1910 (Bonds, par value $\$ 13,600$ )

Portales Irrigation Co...

Prescott Company, The.

(Stock, par value \$190)

Sing Sing Electric Lighting Co.

(Bonds, par value $\$ 25,000$ )

2, 1909

(Bonds, par value \$ 870.56 )

(Stock, par value $1,305.85$ )

Titan Steel Casting Co...................June 14, 1910 (Stock, par value $\$ 292,200$ )

Toledo \& Indiana Railway Co...............Feb. 24, 1910 (Bonds, par value \$2,500)

United Water, Gag \& Electric Co...............Jan. 17, 1910 (Stock, par value \$135.87)

Walker Electric Co.......................... 29, 1909 (Stock, par value \$28,700)

Whitewater Electrie Light Co................June 30, 1901 (Stock, par value $\$ 4,000$ )

Miscellaneoua Companies-Bonds and Stocks at $\$ 1.00$ each, total $\begin{array}{cc}\text { Book Value } & \text { Book Value } \\ \text { at Date } & \text { March 31, } \\ \text { Acquired } & 1911\end{array}$

$3,990.00$

$3,990.00$

$59,865.00$

$59,865.00$

$24,700.00$

$24,700.00$

$25,000.00$

$1,224.09$

$25,000.00$

300.00

100.00

100.00

$126,167.60$

$126,167.50$

190.00

100.00

$25,000.00$

$25,000.00$

871.56

$41,801.00$

$41,801.00$

$1,722.49$

$1,722.49$

135.87

25.00

$28,665.00$

$28,665,00$

$4,000,00$

$1,600.00$

14.00

\section{Miscellaneots Invegtments}

East Pittsburg Club and Casino properties, East Pittsburg, Pa............

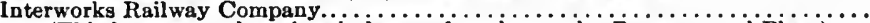
(This investment bas already been referred to under Property and Plant)

Total Book Value of All Investments.

$\$ 24,034,635.99$

\section{IV-CURRENT Assets- $\$ 19,158,168.98$}

Little comment seems required upon this item of the balance sheet. It is the established practice of your company to create monthly on a fixed basis a reserve for notes and accounts receivable. During the year the amount credited to this reserve in excess of bad debts charged off was $\$ 89,774.05$. As of March 31, 1911, your Directors created an additional reserve for notes and accounts receivable of $\$ 500,000$ making the aggregate of this reserve at the end of the fiscal year $\$ 589,774.05$. It is believed that this adequately provides for all probable shrinkage in the book value of notes and accounts receivable, except, possibly, in respect of a note of Security Investment Company carried at a book value approximating $\$ 600,000$, which may call for further consideration when the affairs of that company become more definitely adjusted.

\section{V-Working and Trading Assets- $\$ 14,321,474.01$}

These figures represent actual present values at cost or less, based on an actual inventory carefully taken as of December 31, 1910. 


\section{VI-OTHer Assets- $\$ 7,188,640.29$}

Of this total $\$ 6,074,985.17$ is the cost of patents, charters and franchises. Considering the important relation which the Company's patents in the aggregate bear to its business, your Directors are now disposed to recommend a reduction of their book value.

The deferred charges, representing discount and other expenses incidental to the issuance of your convertible bonds and collateral notes, are being written off in stated monthly amounts adequate to amortize the account during the life time of the respective issues.

\section{LIABILITIES}

The only item on the liabilities side of the balance sheet that calls for any comment is that of Collateral Notes. The $\$ 6,000,000$ six per cent. notes outstanding a year ago were reduced to $\$ 4,000,000$ by the payment of $\$ 2,000,000$ on August 1, 1910 .

The collateral securing the six per cent. notes maturing August 1, 1913 , is as follows:

$\$ 6,000,000$ face value $5 \%$ first lien and consolidated mortgage gold bonds of the Lackawanna \& Wyoming Valley Rapid Transit Company.

$\$ 950,000$ par value assenting capital stock of the Westinghouse Electric \& Manufacturing Company.

$\mathbf{£ 6 7 5 , 0 0 0}$ face value $4 \%$ mortgage debenture stock of The British Westinghouse Electric \& Manufacturing Company, Ltd.

$\mathfrak{\$ 2 3 6 , 1 0 0}$ par value preference shares of The British Westinghouse Electric \& Manufacturing Company, Itd.

$\$ 500,000$ face value $5 \%$ first mortgage bonds of the Grand Rapids, Grand Haven \& Muskegon Railway.

$\$ 160,000$ par value capital stock of the Canadian Westinghouse Company, Ltd.

The collateral securing the $\$ 2,720,000$ five per cent. notes maturing October 1, 1917, is as follows:

Frs. 10,500,000 face value 5\% debentures Societe Electrique Westinghouse de Russie (Russian Company).

Frs. 7,395,000 face value $5 \%$ debentures Societe Anonyme Westinghouse, of Paris (French Company).

$\$ 322,000$ par value capital stock of the Canadian Westinghouse Company, Itd.

$\$ 21,000$ face value $5 \%$ convertible bonds of the Westinghouse Electric \& Manufacturing Company.

$\$ 699.45$ cash.

The Long Term Notes aggregating $\$ 1,283,650$ are unsecured. 
By reference to the foregoing description of the securities comprising the collateral for the six per cent. and five per cent. collateral notes it will be seen that, with the possible exception of the shares of assenting capital stock of the Westinghouse Electric \& Manufacturing Company, the collateral securing these notes is not readily saleable. Your company must therefore contemplate the necessity, as these notes mature, either of extending them with the same collateral, or of providing other means of meeting them than through the sale of the collateral. There can, in the nature of things, be but two such other sources: first, through the issuance of additional capital securities either by way of bonds, securities or stock; or, second, through the use of the company's earnings.

This is a question seriously to be considered before the earnings of your company, gratifying as they have been for the last year and satisfactory as they were for the preceding year, are applied to the payment of dividends on the assenting stock.

After a careful consideration of all of the circumstances, having due regard for the true condition of our balance sheet, hereinbefore minutely described to you, the elements of uncertainty as to the immediate future of your company's business, the need for cash for new foundry facilities, for extension of the Newark plant and other factory improvements, and the necessity of making wise provision for shortly maturing obligations, your Directors have felt that it is not wise at the present time to weaken your company's position by diverting its surplus earnings, even in part, to the payment of dividends on the assenting stock. Whenever a change in conditions shall lead your Directors to feel that a different attitude can safely be assumed, the question will be reconsidered and determined in the light of such change; meanwhile your Directors trust that, with the aid of the very intimate information which this report gives as to the situation and affairs of their company, the stockholders in general will be led to the same conclusion.

The books and accounts of the company and of its subsidiary companies have been audited by Messrs. Haskins \& Sells, Certified Public Accountants, and their certificate is made a part of this report.

The thanks of the Board are extended to officers and employes for the loyal and enthusiastic service that has made the results of the year possible.

By order of the Board of Directors.

Robert Mather,

Chairman. 


\author{
HASKINS \& SELLS \\ CERTIFIED PUBLIC ACCOUNTANTS \\ NEW YORK \\ 30 BROAD STREET \\ LONDON, E. C. \\ 30 Coleman Street
}

CHICAGO

ST. LOUIS

CLEVELAND

Harris Trust Building. Third National Bank Building. Williamson Building.
PITTSBURGH
BALTIMORE
Farmers Bank Building. Equitable Building.

Cable Address "HASEELLs"

New York, May 22, 1911.

To the Board of Directors, Westinghouse Electric \& Manufacturing Co., New York.

We have made an audit, for the year ended March 31, 1911, of the books and accounts of the Westinghouse Electric \& Manufacturing Company and the following subsidiary companies, viz.: Westinghouse Lamp Company, The Bryant Electric Company, The Perkins Electric Switch Manufacturing Company, the R. D. Nuttall Company and the Westinghouse Electric \& Manufacturing Company of Texas.

We have rerified the Cash, the Notes Receivable and the Stocks and Bonds owned, by count or by proper certificates from the depositaries. We have also verified, from the companies' records, the Accounts Receivable.

The investments are stated at the book value, which is considerably less than their aggregate cost.

The inventories of Raw Materials and Supplies, Finished Parts and Completed Apparatus, and Work in Progress were accurately and properly taken at cost, and

We Hereby Certify that, on the basis stated, the accompanying Consolidated General Balance Sheet of March 31, 1911, of the Westinghouse Electric \& Manufacturing Company and subsidiary companies named above, properly represents the financial condition on that date, that the accompanying statement of Income and Profit and Loss for the year ended March 31,1911, correctly states the result of operations for that period, and that the books of the companies are in agreement with these statements.

(Signed) Haskixs \& Selis,

Certified Public Accountants. 
WESTINGHOUSE ELECTRIC \& MANUFACTURING COMPANY AND SUBSIDIARY COMPANIES IN THE UNITED STATES

Consolidated General Balance Sheet, March 31, 1911

\section{ASSETS}

\section{Property and Plant:}

Factory Plants, including Real Estate, Machinery Equipment, etc...............

Sinking FUNd:

With Trustee for Redemption of Convertible Sinking Fund, 5\%, Gold Bonds..........

INVESTMENTS:

Stocks, Bonds, Debentures, Collateral Trust Notes, etc., including those of Affiliated European and Canadian Westinghouse Companies.....................

Corrent Assets:

Cash.

Cash on Deposit to Pay Interest Coupons...

Cash on Deposit to Pay Dividends on Preferred Stock...................... Notes Receivable.

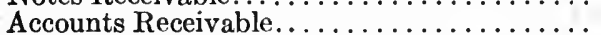

Due from Subscribers to Capital Stock......

Total Current Assets...........
$\$ 6,634,677.07$

$27,340.00$

940.62

$2,946,551.46$

$9,494,731.06$

$53,928.77$

$19,158,168.98$

Working and Traning Assets:

Raw Materials and Supplies, Finished Parts and Machines, Work in Progress, Goods on Consignment and Apparatus with Customers..........................

OTHER AsSETS:

Patents, Charters and Franchises..........

Insurance, Taxes, etc., Paid in Advance.....

Deferred Charge-Expenses Incidental to Issue of Bonds and Notes..............

$\$ 6,074,985.17$ $120,321.78$

$993,333.34$

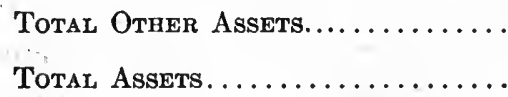

LIABILITIES

Capital Stock:

Preferred.

Assenting - In Hands of Public.......... $\$ 35,187,587.50$

In Treasury........ $1,507,000.00 \quad 36,694,587.50$

Total Capital Stock........... 
WESTINGHOUSE ELEC. \& MFG. CO. REPORT 661

\section{Fonded Debt:}

Convertible Sinking Fund, 5\%, Gold Bonds, due January 1, 1931:

In Hands of Public. ....\$19,691,000.00

In Treasury.......... 266,000.00 \$19,957,000.00

Debenture Certificates, 5\%, due July 1, 1913. 1,800,000.00

Bonds-Walker Company, due January 1, 1916; Guranteed by W. E. \& M. Co...... $850,000.00$

Total Funded Debt..............

$22,607,000.00$

Collateral Notes:

Six Per Cent. Collateral Notes, due August 1,

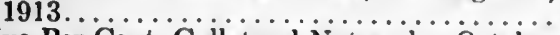

Five Per Cent. Collateral Notes, due October $1,1917 \ldots \ldots \ldots \ldots \ldots \ldots \ldots \ldots \ldots \ldots$

$4,000,000.00$

$2,720,000.00$

Total Collateral Notes.

$6,720,000.00$

LoNa TerM Notes:

Four Year 5\% Notes die January 1, 1913 . . \$ 429,900.00

Five Year $5 \%$ Notes due January $1,1914 \ldots \quad 429,500.00$

Six Year 5\% Notes due January 1, 1915... $\quad 425,500.00$

Fifteen Year 5\% Notes due - January 1, 1924. 98,750.00

Total LoNa Term Notes..........

$1,383,650.00$

$228,200.00$

Real Estate Mortanges Assumed in Pur-

chase of Property..................

Current Liabilities:

Accounts Payable................ \$ 2,454,674.83

Interest, Taxes, Wages, Rebates, etc., Ac-

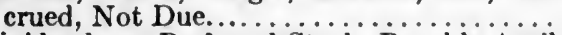

Dividends on Preferred Stock, Payable April $15,1911 \ldots \ldots \ldots \ldots \ldots \ldots \ldots \ldots$

Unpaid Dividends on Preferred Stock......

$572,803.75$

$139,954.50$

940.62

Total Current Liabilities........

$3,168,373.70$

RESERVE:

For Adjustments of Inventories, Notes and

Accounts Receivable, ete............

$1,630,774.26$

Profit and Loss:

Surplus...........................

$5,964,224.90$

Total Liabilities............ \$\$2,395,510.36

Note-There is a Contingent Liability for Notce Receivable discounted by Subaidiary Com. pavies amounting to $\$ 16,703.87$ 


\section{WESTINGHOUSE ELECTRIC \& MANUFACTURING COMPANY AND SUBSIDIARY COMPANIES IN THE UNITED STATES}

Consolidated Statement of Income and Profit and Loss for the Year ENDed March 31, 1911

Gross Earnings:

Shipments Billed.................

Cost of Shipments:

Factory Costs, Including all Expenditures for

Patterns, Dies, New Small Tools and Other

Betterments and Extensions; also Inventory Adjustments and all Selling, Administration, General and Development Ex-

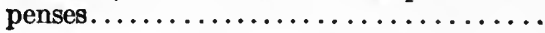

Net Mandfacturing Profits...............

\section{OTHER INCOME:}

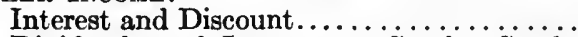

Dividends and Interest on Sundry Stocks

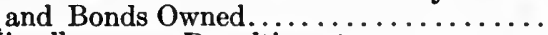

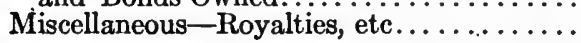

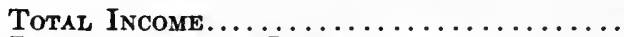

Deductions From Income:

Interest on Bonds and Debentures.........

Interest on Collateral Notes..............

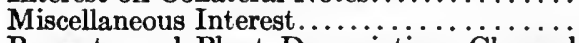

Property and Plant Depreciations Charged

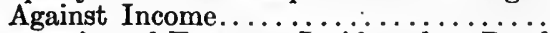

Proportion of Expenses Incidental to Bond and Note Issues...................

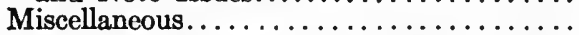

Net Income-SURPLUS For the Year...... Profit and Loss Credits:

Profit and Loss-Surplus, March 31, 1910..

Profit on Bonds and Debenture Certificates Purchased......................

Adjustment of Property and Plant Accounts to Appraised Values..................

Collection of Accounts Receivable Previously Written off.....................

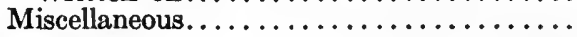

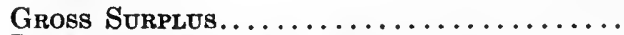

Profit and Loss Charges:

Dividends on Preferred Capital Stock:

For the Current Year............... Accumulated Prior to the Current Year. .

Depreciation of Securities:

The United States Electric Lighting Company-Stock..........\$431,091.61

The Consolidated Eiectric

Light Company-Stocks

and Bonds........... 307,121.27

Difference Between Direct Liability established for Walker Company Bonds and Appraised, Sound Value of Property

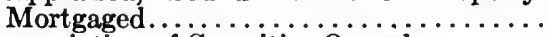

Depreciation of Securities Owned..........

Reserved for Notes and Accounts Receivable

Miscellaneous......................

Surplus, March 31, 1911, per Balance Sheet

$32,510,546.87$

$\$ 38,119,312.01$

$\overline{\$ 5,608,765.14}$

$\$ 272,055.28$

$615,299.40$

$628,177.13$

$1,515,531.81$

$\overline{7,124,296.95}$

$\$ 1,076,553.71$

$416,000.00$

92,933.04

$371,668.19$

$76,666.66$

$209,369.37$

$2,243,190.97$

$\$ 4,881,105.98$

$\$ 5,668,948.23$

$5,200.43$

$459,399.10$

$172,335.75$

$43,372.41$

$6,349,255.92$

$\$ 11,230,361.90$

$\$ 279,909.00$

$349,886.25$

$738,212.88$

$455,084.91$

$2,852,914.91$

$589,774.05$

355.00

$5,266,137.00$

$\overline{\$, 964,224,90}$ 
Forty-third Year

GENERAL STATEAENT

OF TIIE AFFAIRS OF

\section{THE NEW YORK, NEW HAVEN AND HARTFORD RAIL- ROAD COMPANY}

For the Year Ending June 30, 1914

\section{Contents}

Berkshire Street Ry. Co., Income Account and Balance Sheet...........

Central New England Ry. Co., Income Account and Balance Sheet....

The Connecticut Co., Income Account and Balance Sheet............

Directors.

The Hartford and New York Transportation Co. Income Account and Balance Sheet.

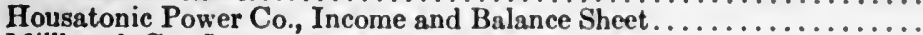

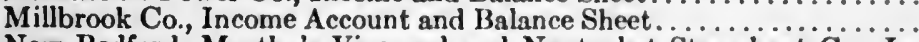

New Bedford, Martha's Vineyard and Nantucket Steamboat Co... In-

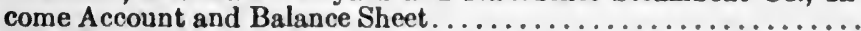

The New England Navigation Co., Income Account, Balance Sheet, and

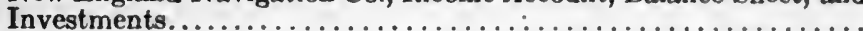

The New England Steamship Co., Income Account, Balance Sheet, and

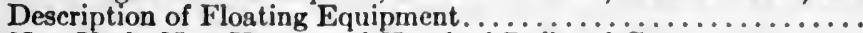

The New York, New Haven and Hartford Railroad Co.:

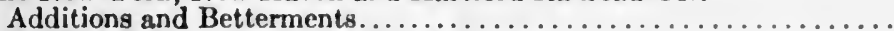

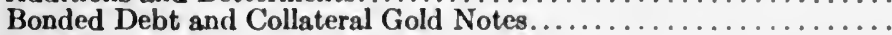

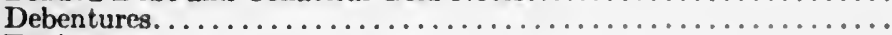

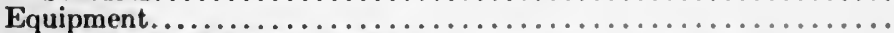

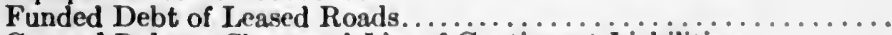

General Balance Sheet and List of Contingent Liabilities...........

General Information Regarding the Various Properties.............

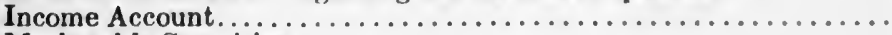

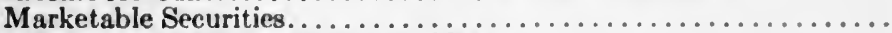

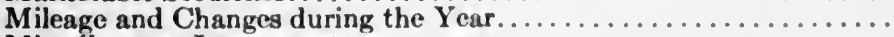

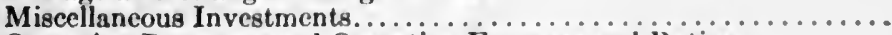

Operating Revenues and Operating Expenses and Ratios............

Profit and Loss Account. . . . . . . . . . . . . . . . . . .

Rentals of Ieased Lines. . . . . . . . . . . . . . . . . . . .

Securities of Proprietary, Affiliated and Controlled Companies........

Securities Issued or Assumed . . . . . . . . . . . . . . . . . . .

Statistice (Various) . . . . . . . . . . . . . . . . . . . . . . .

New York and Stamford Ry. Co., Income Account and Balance Sheet.

New York, Westchester and Boston Ry. Co., Income Account and

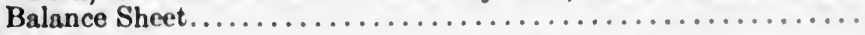

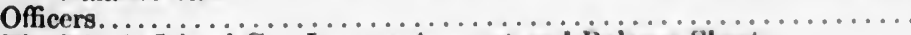

The Rhode Island Co., Income Account and Balance Sheet. ........

Waterbury Gas Light Co., Income Account and Balance Sheet.......

Watertown Gas Co., Income Arcount and Balance Shert Be............

Westport Water Co., Incoine Account and Balance Sheet........... 


\title{
THE NEW YORK, NEW HAVEN AND HARTFORD RAIL- ROAD COMPANY
}

\section{DIRECTORS}

\author{
Sept. 29, 1914.
}

William Skinner,

D. Newton Barney,

Robert W. Taft,

James S. Hemingway,

A. Heaton Robertson,

Frederick F. Brewster,

Henry K. McHarg,

T. DeWitt Cuyler,

Edward Milligan,

Francis T. Maxwell

Samuel Rea,

Morton F. Plant,

John T. Pratt,

Howard Elliott,

W. Murray Crane,

Arthur T. Hadley,

James L. Richards,

Augustus S. May,

Arthur E. Clark,

J. Korace Harding,

\section{THE NEW YORK, NEW HAVEN AND HARTFORD RAIL-} ROAD COMPANY

General Offices of the Company are maintained at Boston in the South Station; at New Haven in the Company's Office Building; and at New York in the Grand Central Terminal Building.

\section{OFFICERS}

Sept. 29th, 1914

Howard Elliott, Chairman of the Board,

Howard Elliott, President,

E. G. Buckland, Vice-President and General Counsel,

Benjamin Campbell, Vice-President,

A. R. Whaley, Vice-President,

A. E. Clark, Secretary,

C. H. Hempstead, Assistant Secretary,

A. S. May, Treasurer,

T. F. Paradise, Assistant Treasurer,

A. W. Bowman, Assistant Treasurer,

J. M. Tomlinson, General Auditor,

A. Mackrille, Assistant General Auditor,

J. C. Sweeney, General Attorney,

B. I. Spock, Counsel,

F. A. Farnham, Counsel,

N. W. Smith, Counsel,

C. M. Sheafe, Jr., Counsel,

A. A. Maxwell, Commissioner, Real Estate Right of $\dot{W}$ ay and

Taxes,

A. B. Smith, General Passenger Agent,

F. C. Coley, First Assistant General Passenger Agent,

A. H. Seaver, Assistant General Passenger Agent,
Holyoke, Mass.

Farmington, Conn.

Providence, R. I.

New Haven, Conn.

New Haven, Conn.

New Haven, Conn.

Stamford, Conn.

Philadelphia, $\mathrm{Pa}$.

Hartford, Conn.

Rockville, Conn.

Philadelphia, $\mathrm{Pa}$.

Groton, Conn.

New York, N. Y.

Boston, Mass.

Dalton, Mass.

New Haven, Conn.

Boston, Mass.

New Haven, Conn.

New Haven, Conn.

New York, N. Y. 
E. I. Wilson, Assistant General Passenger Agent,

G. A. Morton, General Baggage Agent,

L. H. Kentfield, General Freight Agent,

G. M. Wood, Assistant General Freight Agent,

H. H. Benedict, Assistant General Freight Agent,

H. A. Fahian, Manager of Purchases and Supplies,

E. Gagel, Chief Engineer,

W. S. Murray, Consulting Electrical Engineer,

C. L. Bardo, General Manager,

C. N. Woodward, General Superintendent,

J. A. Dinege, General Superintendent,

G. W. Wildin, Mechanical Superintendent,

W. J. Backes, Engineer, Maintenance of Way,

E. G. Riggs, Executive Assistant,

A. G. Webb, Superintendent Dining Cars,
Boston, Mass.

New Haven, Conn.

New Haven, Conn.

Boston, Mass.

New York, N. Y.

Boston, Mass.

- New Haven, Conn. New Haven, Conn. New Haven, Conn. Boston, Mass.

New Haven, Conn. New Haven, Conn. New Haven, Conn. New York N. Y. New York, N. Y.

\section{THE NEW YORK, NEW HAVEN AND HARTFORD RAIL- ROAD COMPANY}

General Offices

New Havex, Conn., September 29, 1914.

To the Stockholders of the New York, New Haven and Hartford Railroad Company:

The Board of Directors herewith submits its report for the fiscal year ending June 30,1914 , with such data relating to the railway and other corporations embraced in the System or in which it has an interest as will show the results of operations for the year and of their financial condition at the close of the year. 


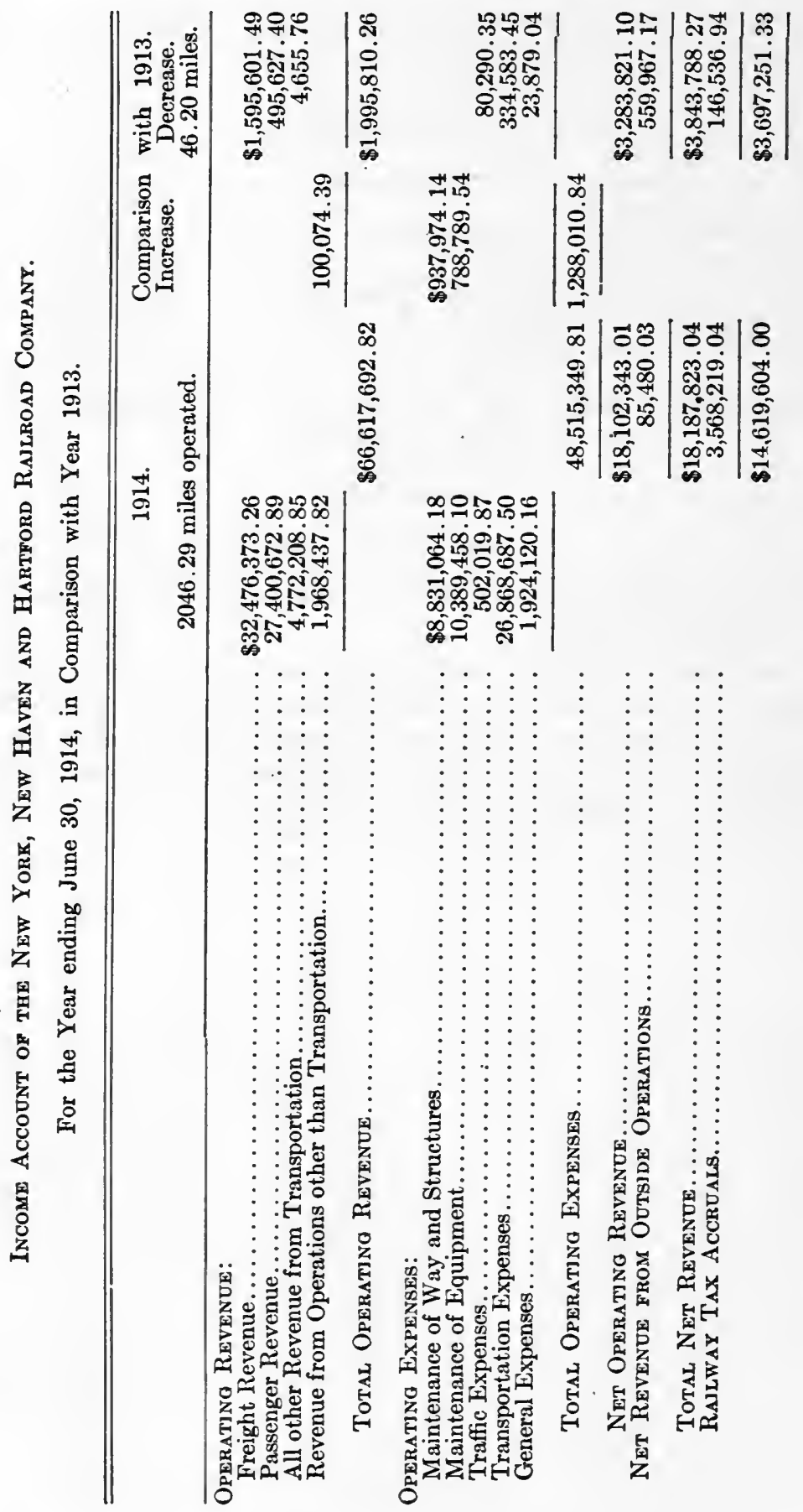


N. Y., N. H. \& H. RR. CO. REPORT, 1914667

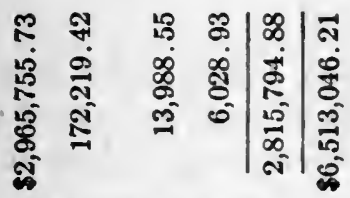

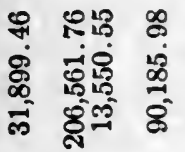

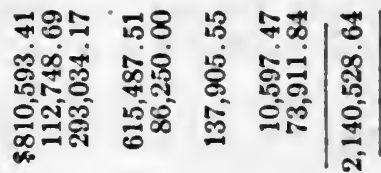

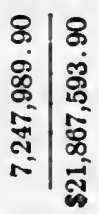

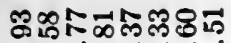

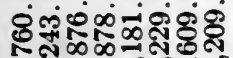
ที่

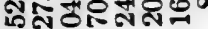

है
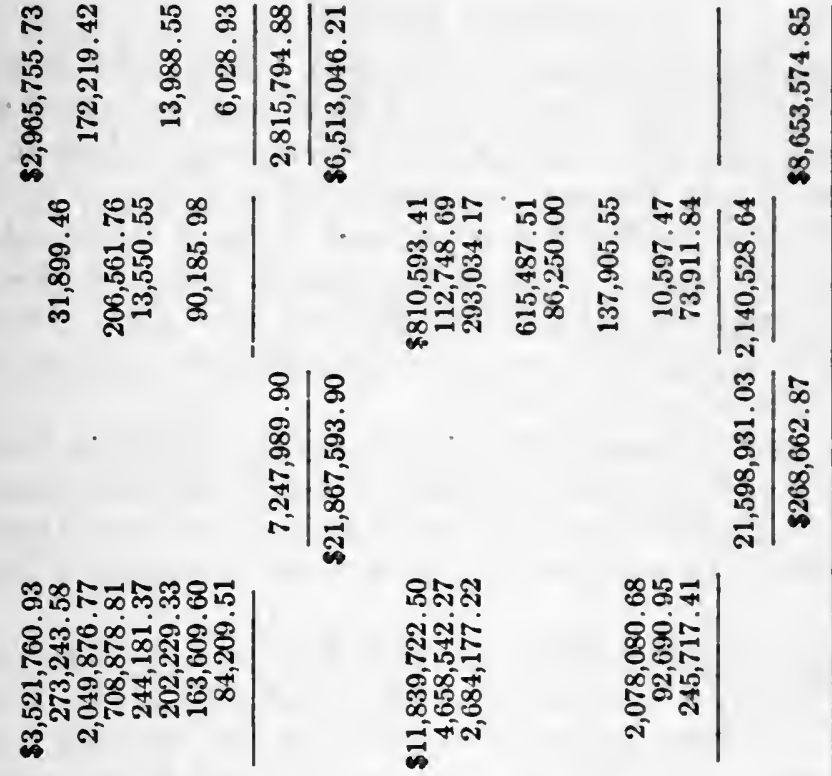

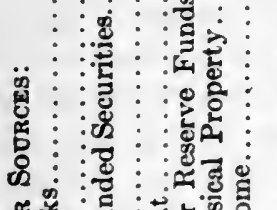

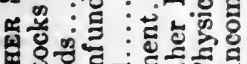

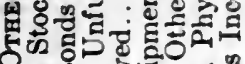
뎡ํำ

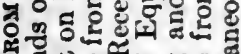

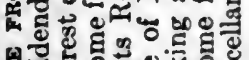

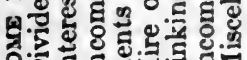

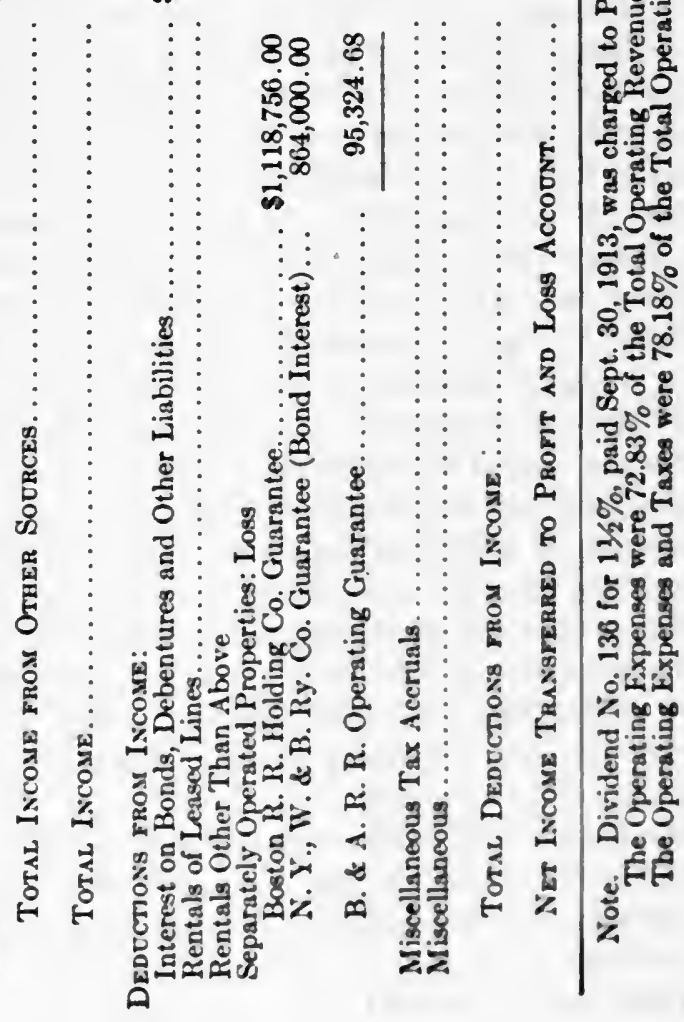

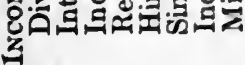




\section{Operating Results}

Miles Operated.-There was a decrease in average miles of road operated of 46.20 miles. The average miles of track maintained was 4,397.75 compared with 4,452.55 the previous year, a decrease of 54.80 miles. These decreases were mainly due to giving up certain trackage rights on the Boston \& Albany and Boston \& Maine and to the Central New England assuming the operation of the line between Danbury, Connecticut, and Hopewell Junction, New York. Details of changes in mileage as of June 30, 1914, compared with June 30, 1913, will be found on page 731 .

Revenues and Expenses.-The general business depression during the greater part of the fiscal year caused a decrease in the operating revenue of $\$ 1,995,810.26$, while operating expenses increased $\$ 1,288$,010.84 , resulting in a decrease in net operating revenue of $\$ 3,283$,821.10 .

Freight revenue decreased $\$ 1,595,601.49,4.7 \%$, and passenger revenue $\$ 495,627.40,1.8 \%$. Express revenue fell off $\$ 307,378.75,9.7 \%$, due partly to reduced express rates ordered by the Interstate Commerce Commission, effective February 1st, 1914, and to the increase in shipments by Parcel Post, for which no adequate compensation has as yet been received. There was an increase of $\$ 198,17 \% .34$ in other passenger train revenue, mainly due to the inclusion of a full year's receipts from the Pullman Company and extra fares on Limited trains, the previous year's accounts having been credited with only six months' proportion, as the Pullman contract became effective January 1st, 1913. Net revenue from outside operations decreased $\$ 559,967.17$, largely because the Pullman Company operated equipment formerly operated by the railroad. Revenues from operations other than transportation, after deducting decrease of about $\$ 100$,000.00 account of falling off in revenue from discharging, wharfage, hoisting and car service, shows a net increase of $\$ 100,074.39$, largely on account of additional rentals at Grand Central Terminal. In this connection, however, it should be noted that the net payment for entrance to and use of the passenger terminal at New York for the year ending June 30 th, 1914, amounted to $\$ 3,150,947$, as compared with $\$ 2,983,969$, for 1913 . The net charge against the Company during 1914 was equivalent to about 31 cents for each passenger into and out of the terminal.

Maintenance of Way and Structures.-This account increased $\$ 937,974.14$, caused in part by higher wages and in part by the larger amount of renewals required because of work that was deferred in previous years.

There were 2,060,485 ties laid in renewals as compared with 1,814,- 
190 in the previous year, an increase of $14 \%$. This includes 157,907 creosoted ties with screw spikes and tie plates put in between New Haven and Woodlawn and on the Harlem River Branch, compared with 123,672 last year, an increase of $28 \%$. There were 25,783 tons of new rail laid, an increase over the previous year of 3,173 tons, or $14 \%$.

Removal of snow and ice cost $\$ 108,378.90$ more than in the previous year, and the maintenance of the electric power transmission system cost $\$ 154,969.00$ more. Much work was done on signals and interlocking plants.

The track, bridges and structures of the company are in safe and serviceable condition, but expenses for maintenance of way must be liberal because of the heavy equipment and the great number and speed of trains.

Maintenance of Equipment.-This account increased $\$ 788,789.54$, due to some increase in wages, work on electric locomotives deferred in 1912 , increase in repairs to freight cars of $\$ 351,985.82$, and an increase in the charges for depreciation of $\$ 476,738.67$.

Since July 1st, 1913, charges to depreciation have been made as required by the Interstate Commerce Commission, based on the original cost of equipment, as follows:

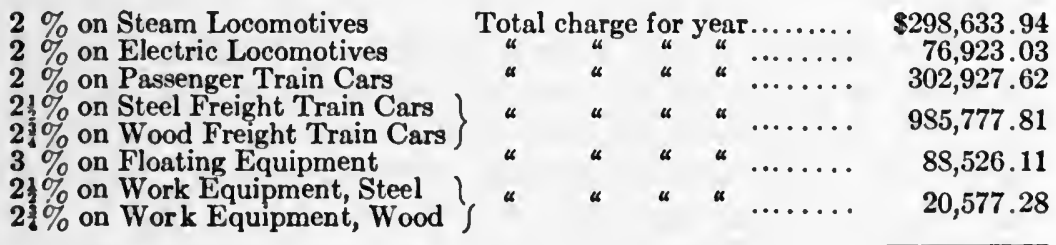

Toras.................................... \$1,773,365.79

The equipment of the Company, other than the freight cars, is in good condition. In 1906-07-08 a large number of new freight cars were purchased, about 20,000 , and heavy repairs are now needed on these cars and charges for this class of work will be heavy for several years to come. Because of the decreased volume of business this class of work was deferred and there are about 2,500 more bad order freight cars on the road than should be the case under normal conditions. Repairs are now being made more rapidly and the number of bad order cars is decreasing.

Traffic Expenses.-This account decreased $\$ 80,290.35$.

Transportation Expenses.-This account decreased $\$ 334,583.45$. The miles run by trains of all classes were $25,254,718$, a decrease of $1,559,166$. The cost per revenue train mile for transportation expenses was $\$ 1.12$, compared with $\$ 1.07$ for last year, an increase of 5 cents, or $4.7 \%$. The average number of passengers per train was 96 , 
an increase of 1 , and the average number of tons of revenue freight per revenue train mile was 303.96 , an increase of 13.01 tons, or $4.5 \%$. There was an increase in wages, the greater part of which was the result of awards under Federal Arbitration Acts, and increases in forces at engine terminals so as to take better care of power and insure greater regularity of service.

The cost of fuel decreased $\$ 356,045.96$.

Injuries to persons required the large sum of $\$ 1,181,735.59$, an increase of $\$ 37,966.92$, due to the settlements for the sad and disastrous accidents in $1912-1913$. Of the $\$ 1,181,735.59, \$ 318,324.93$ was charged to the Accident and Casualty Operating Reserve, and the balance, $\$ 863,410.66$ to Operating Expenses. There remains in the Accident and Casualty Operating Reserve $\$ 1,042,59 \% .1 \%$, which will be used to take care of the unadjusted personal injury claims prior to the current fiscal year, so that the charges to Operating Expenses account personal injuries for the current fiscal year will probably be materially less than for the past fiscal year.

Loss and Damage accounts of all kinds amounted to $\$ 1,966,492.64$, or 8 cents per train mile.

Very earnest efforts have been made during the year to reduce accidents and damage and to improve the practice in the consumption of fuel.

General Expenses.-This account decreased $\$ 23,879.04$, although the Company had to sustain unusual burdens, the result of negotiations with the Federal Government and investigations by the Public Service Commission of Massachusetts, the Department of Justice of the United States and the Interstate Commerce Commission.

The Federal Act requiring valuation of railways increased expenses $\$ 24,176.77$, and this expense will be more during the coming year. The Commissioners advise that they will begin to value the property of the Company April 1st, 1915, and by that date the Company expects to have completed the resurvey of 1,000 miles of road.

\section{Financial}

Capital Stock.-Of the total authorized outstanding capital stock of 1,800,170 shares, 228,991 shares are in the treasury and 1,479 shares are owned by The Rhode Island Company. During the past fiscal year there has been no increase in the capital stock. A dividend of $1 \frac{1}{2} \%$ was paid Sept. 30, 1913, and charged to Profit and Loss Account.

Temporary Financing.-In 1913 the Company had a large floating debt, because of the Massachusetts law prohibiting any funded debt exceeding in amount the paid in capital of the Company. This law 
was changed in July, 1913, so as to permit the issue of bonds to an amount equal to twice the amount of the capital stock.

In order to fund the floating debt under this new law and to provide for the purchase of steel passenger cars and for other improvements the Directors in July, 1913, arranged for an issue of six per cent. convertible debentures to the amount of $\$ 67,552,000$, to be offered to the holders of the stock and the outstanding convertible debentures of the Company. General financial conditions at that time were not favorable, and to make certain that the Company would have its money when needed the Directors caused this proposed issue of debentures to be underwritten. The stockholders approved this arrangement at a meeting August 22, 1913.

The issue of these debentures though opposed before the Public Service Commission of Massachusetts, was on October 14th, 1913, finally approved by that Commission. An appeal was taken from this decision to the Supreme Court of Massachusetts, which on January 9 th, 1914, decided that the proposed issue was not lawful.

There were $\$ 40,000,000$ of notes maturing on December 1st, 1913, and $\$ 5,000,000$ of bonds maturing February 1st, 1914. Therefore, it became necessary pending the decision on the application for the issue of the proposed six per cent. convertible debentures to borrow on November 18th, $1913, \$ 45,000,000$ to retire the notes maturing on December 1st, 1913, and the bonds maturing on February 1st, 1914. Later other amounts were borrowed to pay for new equipment and for improvements which could not be stopped or postponed, the whole amount to be provided aggregating nearly $\$ 54,000,000$, all payable prior to July 26th, 1914. The decision of the Massachusetts Supreme Court made necessary an alternative plan of immediate financing, to take care of the maturing short term notes and to meet capital requirements until 1915.

With the assistance of Messrs. J. P. Morgan \& Co., the First National Bank and the National City Bank of New York, and Messrs. Kidder, Peabody \& Co., Lee, Higginson Co., of Boston, there were sold $\$ 50,000,000$ of Notes dated May 1st, 1914, as follows:

$\$ 20,000,000$. - The New York, New Haven and Hartford Railroad Company One Year 5\% Collateral Gold Notes, callable at $100 \frac{1}{2} \%$.

$\$ 10,000,000$. - The Harlem River and Port Chester Railroad Company One Year 5\% Gold Notes, Scries " $\Lambda$," guaranteed by The New York, New Haven and Hartford Railroad Company as to principal and interest, callable at $100 \frac{1}{2} \%$.

$\$ 20,000,000$. - The New England Navigation Company Three Year $6 \%$ Collateral Gold Notes, callable at $101 \frac{1}{2} \%$, all dated May 1st, 1914. 
The Bankers further agreeing to take within six months' time, at their option, $\$ 10,000,000$ of One Year $6 \%$ Notes of The New York, New Haven and Hartford Railroad Company without collateral. The collateral pledged under the New Haven and Navigation Company notes, mentioned above, consisted of some of the securities in the treasuries of the companies.

It.was expected to market some of the collateral and to retire the notes in part. From the proceeds of collateral sold, notes to the amount of $\$ 435,000$ have been cancelled; but the war and general financial conditions made further sales of securities impossible.

Your directors have had in mind the urgent necessity for a broad plan for permanent financing, but the laws are conflicting and circumstances and conditions have not been favorable.

Increase in Debt.-The outstanding indebtedness of the Company and its leased lines in the hands of the public (not including that held in the treasuries of subsidiary companies) has been increased during the year by the amount of $\$ 4,522,250.00$, as follows:

\section{INCREASES}

Five per cent. Collateral Gold Notes...........\$19,927,000.00

Providence Securities Company 4\% gold debentures assumed as a direct instead of an indirect liability, (heretofore on obligation of

The New England Navigation Co.) .........

Six per cent. six months notes dated Nov. 18 , 1913 (balance matured but notes not presented by holders)......................

Six per cent.three:months note dated April 13,1914 Five per cent. six months notes dated January 14,

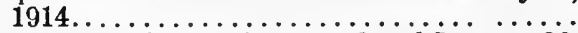

Five per cent. six months notes dated January 26 ,

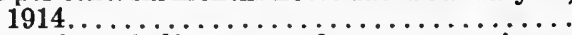

Four and one-half per cent. five year promissory notes dated May 7, 1914 ..............

Five per cent. six months notes dated June 26,1914

Five per cent,four months note dated June 26,1914

The Harlem River \& Port Chester R. R. Co. one year $5 \%$ gold notes, guaranteed by The New New York, New Haven \& Hartford Railroad Company..............................

\section{Decreases}

New Haven St. Ry. $5 \%$ first mortgage bonds, paid in August, $1913 \ldots \ldots \ldots \ldots \ldots \ldots \ldots \ldots$.

Four per cent. non-convertible debentures, paid Feb. 1. 1914.....................

New Haven St. Ry. $5 \%$ convertible mortgage bonds, paid in June, $1914 \ldots \ldots \ldots \ldots \ldots$.

Four and onc-half per cent. notes, paid in July,

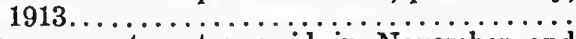

Five per cent, notes, paid in November and December, $1913 \ldots \ldots \ldots \ldots \ldots \ldots \ldots \ldots$. . . .

Note in favor of City of New Haven, paid September 16, 1913...................

$19,180,000.00$

$40,000.00$ $400,000.00$

$2,000,000.00$

$250,000.00$

$222,000.00$

$550,000.00$

$375,000.00$

$10,000,000.00$ $\$ 52,944,000.00$

$\$ 599,000.00$

$5,000,000.00$

$229,000.00$

$2,575,000.00$

$39,995,000.00$

$23,750.00$

$48,421,750.00$

$\$ 4,522,250.00$

Total Increase...$\ldots \ldots \ldots \ldots \ldots \ldots$ 
Maturing Debt.-There will mature between October 1st, 1914, and June 30 th, 1915, the following obligations for which your Company is responsible:

October 26th, 1914, Five per cent. four months note......... December 1st, 1914, Middletown Horse R. R. 5\% 1st Mortgage

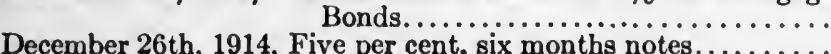
January 14th, 1915, Five per cent. six months notes............. January 27 th, 1915, Five per cent. six months notes.............. May 1st, 1915, Five per cent. one year Collateral Gold $\$ 375,000.00$ $150,000.00$ $550,000.00$ $1,000,000.00$ $200,000.06$

May 1st, 1915, Total issue......... \$20,000,000.00 Less, paid off..... $\quad 435,000.00$

The Harlem River \& Port Chester Railroad Co. Five per cent. one year Gold Notes, Series "A".................. 10,000,000.00

Total $\$ 31,840,000.00$

A statement of your Company's Contingent Liabilities in the hands of the public is shown in this report. All of the companies therein mentioned were able to meet their obligations for interest and dividends without recourse to your Company's guaranty except the Boston Railroad Holding Company and the New York, Westchester and Boston Railway Company.

Insurance Funds.-As no appropriations have been made by the New Haven Company to the Fire Insurance and Coal Insurance Funds since June 30, 1911, the current losses being charged to Operating Expenses, it was thought unnecessary to continue these Funds, and they were cancelled and contracts for insurance placed; the securities and assets of the various Funds turned into the treasury of the New Haven Company, and the reserve in those funds credited to the Profit and Loss Account of the New Haven Company.

No appropriation has becen made to the Accident and Casualty Fund since June 30, 1911, and it was cancelled. For the 1913 fiscal year there was charged to the Accident and Casualty Reserve \$337,744.21, for the 1914 fiscal years $\$ 318,324.93$, leaving $\$ 1,042,597.17$, which has been set up as a reserve to take care of unadjusted personal injury claims prior to July 1, 1914.

The New England Steamship Company Marine Insurance Fund was cancelled and contracts for insurance placed, the securities and assets turned into the treasury of the Steamship Company and the reserve in the Fund credited to the Profit and Loss Account of the Steamship Company. The securities were subsequently sold to the New Haven Company.

Merchants and Miners Transportation Company.-Because of the attitude of the Federal authorities and the very serious financial con- 
dition of this Company, the securities of the Merchants and Miners Transportation Company were sold in April, 1914. Additional Capital was needed to finance the Merchants and Miners Transportation Company which the New Haven Company was unable to furnish. On account of unfavorable conditions the sale resulted in a loss of $\$ 3,594,500.00$.

These securities were held by The New England Navigation Company and their cost was reflected in the capital stock of that company. 'The capital stock of The New England Navigation Company was reduced by 35,945 shares, the New Haven Company's investment in the Navigation Company was reduced a like amount, and the amount of the reduction in value of the New Haven Company's investment in the Navigation Company was charged to the Profit and Loss Account of the New Haven Company.

Profit and Loss.-The Profit and Loss surplus of $\$ 7,916,55 \% .24$ as of June 30th, 1913, has been reduced by transactions shown on page 712 , to $\$ 1,822,246.14$ as of June 30 th, 1914.

Equipment Trust.-Under date of April 1st, 1914, an arrangement was made with the Farmers' Loan \& Trust Company for an Equipment Trust, under which the Company is to make semi-annual payments for fifteen years, when the title to the equipment will be vested in the Company.

\section{NEGOTIATIONS WITH THE DEPARTMENT OF JUSTICE OF THE} UNITED STATES

On April 11th, 1914, a pamphlet was mailed to each stockholder giving some account of the negotiations with the Department of Justice for a peaceful solution of the so-called "New England Railoard Situation."

At a meeting of the stockholders on April 21st, 1914, the Directors were authorized to complete negotiations and to arrange for the segregation of the various properties that were under dispute. Since then there have been prolonged conferences with the Department of Justice.

The Department filed its petition in the District Court of the United States, Southern District of New York, on July 23, 1914, and the Company filed its answer on September 17, 1914.

An agreed decree is to be entered which produces the following results :

First. The New Haven Company transfers to Frank P. Carpenter, of Manchester, New Hampshire, Henry B. Day, of Newton, James L. Doherty, of Springfield, Charles P. Hall, of Newton, and Marcus P. Knowlton, of Springfield, all in Massachusetts, as trustees, 31,065 shares of the common stock and 244,939 shares of the preferred stock 
(being all of the common and all but 28,000 shares of the preferred stock) of the Boston Railroad Holding Company, the latter being the holder of 6,543 shares of the preferred and 219,189 shares of the common stock (a majority of all outstanding stock) of the Boston \& Maine Railroad, in trust to sell the Boston and Maine shares under the order of the Court.

The trustees shall hold the shares and exercise all the powers the owners of the shares of the Holding Company are entitled to exercise, excepting the right to sell or dispose of them until otherwise ordered.

No order directing the sale of any of the shares of the Holding Company shall be made by the Court until after July 1st, 1915, unless the New Haven Company shall in writing consent thereto. If no sale is made before July 1st, 1915, the Court, on application of any party, and after a hearing at which the Commonwealth of Massachusetts shall be invited to appear, shall determine when a sale shall be made and fix the terms and conditions thereof.

The trustees shall also use their best efforts to complete the sale of the shares of the Boston \& Maine Railroad before January 1st, $191 \%$.

Second. The New Haven Company transfers to the same trustees, the following shares of corporations, the railroad lines of which are leased to the Boston \& Maine Central Railroad Company:

922 shares of capital stock of the Northern Railroad (of New Hampshire). 1,015 shares of capital stock of the Connecticut River Railroad Company.

63 shares of capital stock of the Manchester \& Lawrence Railroad.

246 shares of capital stock of the Hereford Railway Company.

2,469 shares of capital stock of the Concord \& Montreal Railroad.

184 shares of capital stock of the Vermont \& Massachusetts Railroad Company.

193 shares of capital stock of the Lowell \& Andover Railroad Company.

412 shares of capital stock of the Boston \& Lowell Railroad Corporation.

710 shares of capital stock of the Pemigewasset Valley Railroad.

1,464 shares of capital stock of the Connecticut \& Passumpsic Rivers Railroad Company.

73 shares of capital stock of the Upper Coos Railroad.

18 shares of capital stock of the Concord \& Portsmouth Railroad.

98 shares of capital stock of the Wilton Railroad Company.

86 shares of capital stock of the Peterborough Railroad.

84 shares of capital stock of the Nashua \& Lowell Railroad Corporation. 354 shares of capital stock of the Massawippi Valley Railway Company.

The trustees shall hold these shares and exercise all the powers in the management of the corporations which the owners of the shares are entitled to exercise. They shall sell the shares, whenever in their judgment such sale or sales can be made to the best advantage, so long as they remain subject to sale and upon such terms as the New Haven Company shall request in a writing sigued by its President or Cliair- 
man of the Board of Directors and approved at a meeting by said Board.

The trustees shall exercise their best efforts to complete the sale of said shares before January 1st, $191 \%$.

Third. The New England Navigation Company transfers to Lyman B. Brainerd, of Hartford, Charles Cheney, of South Manchester, George E. Hill of Bridgeport, William W. Hyde, of Hartford, and Walter C. Noyes, of New London, all in Connecticut, as trustees, 400,000 shares being all of the capital stock of The Connecticut Company.

The trustees shall hold these shares and exercise all the powers in the management of The Connecticut Company which the owners of the shares therein are entitled to exercise.

The trustees shall sell said shares for such prices and upon such terms as shall be named by the New Haven Company and the Navigation Company in a writing signed by their respective President or Chairman of their Boards of Directors and approved at a meeting by their Boards.

The trustees shall exercise their best efforts to complete the sale of said shares before July 1st, 1919.

Fourth. The New Haven Company transfers to John 0 Ames, John P. Farnsworth, Rathbone Gardner, Theodore Francis Green and Charles. C. Mumford, all of Providence, Rhode Island, as trustees, 96,855 shares, being all of the capital stock of The Rhode Island Company, and The New England Navigation Company transfers to the same trustees 9,132 shares in the capital stock of the Providence \& Danielson Railway Company, bonds of said company to the par value of $\$ 600,000,7,000$ shares in the capital stock of the Sea View Railroad Company, and bonds of said company to the par value of $\$ 600,000$.

The trustees shall hold said shares and bonds and exercise all the powers in the management of these trolley companies which the owners of shares therein are entitled to exercise.

The trustees shall sell said shares and bonds at such time or times as shall be named by the New Haven Company in a writing signed by its President or the Chairman of its Board of Directors and approved at a meeting by said Board.

The trustees shall exercise their best efforts to complete the sale of the said shares and bonds before July 1st, 1919.

Fifth. The 53,981 shares of the capital stock of the Berkshire Street Railway Company and the 6,500 shares of capital stock of The Vermont Company owned by the New Haven Company, shall be sold before July 1st, 1919; provided, however, such sale shall not be proceeded with until action shall have been taken by the Commonwealth of Massachusetts authorizing a sale of the shares of the Berkshire 
Street Railway Company or until the Court, on the application of any party, and after a hearing at which the Commonwealth of Massachusetts shall be invited to appear, shall by further order so direct.

Sixth. The New England Navigation Company shall sell on or before July 1st, 1917, the 15,000 shares of preferred and 20,000 shares of common stock in the Eastern Steamship Corporation and bonds of said corporation to the par value of $\$ 2,500,000$., held by it, and pending such sale the New Haven Company and the Navigation Company are enjoined from voting upon the capital stock of said Eastern Steamship Corporation.

Seventh. The New Haven Company shall sell on or before July 1st, 1919, 5,000 shares of the capital stock of the New York \& Stamford Railway Company and bonds of the said company to the par value of $\$ 678,000$, also the rights to the capital stock and other securities of the Westchester Street Railroad Company now owned by il, and the Navigation Company shall sell on or before July 1, 1919, the rights to the capital stock and other securities of the Shore Line Electric Railroad, a corporation of New York, when the same may be issued, and the gold notes of the New England Investment \& Security Company, a voluntary association, to the par value of $\$ 13,709,000$, now owned by it.

Eighth. The times within which the sales heretofore ordered shall be made may be extended in each case by the Court for good cause shown upon the application of any party or any body of liquidators or trustees, and if they are not sold by the Trustees 60 days before the last date fixed for the sale they shall be sold at public auction.

Ninth. None of the shares or other securities hereinbefore ordered sold shall be offered to the stockholders of the New Haven Company as a class either in proportion to their stockholdings or otherwise, or be sold to the New Haven Company or to any person or persons, corporation or corporations, to be held in its interests, directly or indirectly, or so as to re-establish in any manner the combination and control which it is the purpose of the decree to terminate.

There is now pending before the Interstate Commerce Commission an application of the New Haven Company, under Act of Congress approved March 24th, 1912, known as the Panama Canal Act, for authority to retain stocks and other securities and continue control of its steamship lines including The New England Steamship Company and The Hartford \& New York Transportation Company. Similar applications are required by law from all railroad companies having an ownership in steamship lines.

The contract between the New York Central \& Hudson River Railroad Company and the New Haven Company for sharing in the finan- 
cial results of the operation of the Boston \& Albany Railroad, has already been cancelled, and the Company has also disposed of its interest in the Merchants \& Miners Transportation Company.

The final papers giving effect to the agreement with the United States Government are now being drawn up by the Counsel of the Company and the Attorney General of the United States, and it is expected that the agreed decree will become effective in the near future.

In view of the present conditions and the policy of the Federal Government and its various departments, the Directors have felt that it was wise to agree with the Department of Justice and to divest itself of ownership in these various properties, and therefore, with the authority of the stockholders it made every reasonable concession toward a peaceful adjustment, but with the hope that the arrangement will not ruthlessly and unnecessarily sacrifice values and impair the service that the various properties can give to the public.

It is believed that in the time allowed the Company, if there is a return to prosperity to the country with a more reasonable attitude on the part of the public toward railroad corporations, many of these properties will show a value much in excess of the estimates to-day, and that losses in carrying these properties will be reduced if patience is exercised and fair treatment accorded.

The report of the Interstate Commerce Commission of June 20th, 1913, said about these properties:

"They are for the most part of substantial value and in many instances are a kind of property the value of which should improve."

That is true, and within the past year each of the properties within the control of the New Haven Company has been improved physically, and in its organization and ability to serve the public.

A summary of the properties covered by the decree, and the book value thereof, including stock, bonds, notes and advances, as shown on the books of the New Haren Company and the Navigation Company is as follows:

Boston Railroad Holding Co................

Boston \& Maine R. R. subsidiary lines.........

The Connecticut Company..................

The Rhode Island Company................

Berkshire Street Rilway Company............

The Vermont Company.....................

Eastern Steamship Co....................

New York \& Stamford Railway..............

The Westchester Street Railroad ..............

Shore Line Electric Railroad....................

New England Investment and Security Company.

\begin{tabular}{|c|c|}
\hline \multicolumn{2}{|c|}{ As carried on books of } \\
\hline New Haven & Navigation \\
\hline & Company. \\
\hline \multirow{5}{*}{$\begin{array}{r}\$ 29,371,165.97 \\
1,417,216.95 \\
2,125,000.00 \\
27,852,336.41 \\
9,809,395.58 \\
1,477,164.31\end{array}$} & \\
\hline & $\$ 40$. \\
\hline & $\begin{array}{r}1,266,379.37 \\
1,300,0\end{array}$ \\
\hline & \\
\hline & $4,200,000.00$ \\
\hline \multirow{2}{*}{$\begin{array}{l}1,395.523 .40 \\
1,152,150.84\end{array}$} & \\
\hline & $\begin{array}{r}117,000.00 \\
13,631,750.00\end{array}$ \\
\hline
\end{tabular}

$\$ 74,599,953.46 \$ 59,215,129.37$

\section{As carried on books of \\ New Haven Navigation}

$99,371,165.97$

$1,417,216.95$

$1,395.523 .40$

$117,000.00$ 
From time to time it has been intimated that the present financial condition of the New Haven Company is due to these and similar inrestments. It is fair, however, to point out certain conditions which are national in their effect on railroad net income, conditions over which neither the New Haven Company, nor any other company, has any effective control.

Some of these conditions are:

1. Increase in rates of interest.

2. Increases in rates of pay.

3. Increase cost due to changes of working hours and working conditions.

4. The so-called Full Crew Law, which makes necessary the employment of extra and unnecessary men.

5. The federal valuation of railroads.

6. The great increase in accounting and special reports to numerous public authorities.

7. The increase in taxes.

8. The increased demands for luxurious passenger facilities, both train and station.

9. Stationary or falling rates.

10. Inadequate pay for mail and parcels post.

Increase in rates of pay and rates of interest as compared with 1903 shows an increased annual charge of more than $\$ 8,000,000$. The various governmental requirements mean a charge of at least $\$ 300,000$ a year. The taxes in 1914 were $\$ 1,182,829.52$ more than in 1903 . The underpay for carriage of mail matter represents more than $\$ 700,000$ a year in gross earnings. Much passenger train service is furnished far below any fair estimate of the cost for the particular service rendered. Without allowing for this loss on non-remunerative passenger trains, the foregoing additional burdens compared with 1903 , represent a net loss of at least $\$ 10,000,000$ a year; a loss greater than the annual interest on the cost of all outside properties acquired.

The same general causes reduce the income received by your Company from the transportation companies in which it is interested.

The attention of stockholders is called to what Mr. Commissioner Daniels, of the Interstate Commerce Commission, said in his dissenting opinion of July 29, 1914, in the "Eastern Railroads Advance Rate Case," as follows:

"The world-wide phenomenon of rising prices is by this time no novelty. Since 1906 the average rise in the world's price level is estimated by competent statisticians at from 30 to 50 per cent. It has mirrored itself in the rising cost of living; it has evoked, and most properly, advances in wages and salaries; it has coincided with 
an increase in the nominal rate of interest where part of the interest so-called is but compensation for the anticipated depreciation of the capital sum later to be repaid. This rise in the price level must eventually be reckoned with in railroading. For a time its effects may be masked by adventitious increases in the volume of traffic, but this temporary relief in its very nature is uncertain, and sooner or later the difficulty is sure to reappear. For a time it may be circumvented by extraordinary economies, but in its nature it is inexorable. It must be faced, not trifled with. It is hardly an adequate remedy to accord to carriers relief only when their returns have reached the well-nigh desperate level now shown in Central Freight Association territory. Even before this inadequate return is evidenced, higher rates are warranted. Such a solution of the present case would have done no less than justice to the carriers and would have promoted the welfare of the community they serve.

"A living wage is as necessary for a railroad as for an individual. A carrier without a sufficient return to cover costs and obtain in addition a margin of profit large enough to attract new capital for extensions and improvements cannot permanently render service commensurate with the needs of the public."

\section{SPECIAL INVESTIGATIONS}

By the Company.-During the year, for the purpose of checking the methods and operations of the Company, special investigations of some of its affairs were made by order of the Chairman of the Board as follows:

(1) An expert in the purchase and handling of supplies made a critical examination of the methods of the Company in purchasing, storing and issuing of material. Hus report is being used by the officers of the Company as a basis for introducing such improvements and economies as are reasonable and practicable in this part of the Company's affairs.

(2) A committee of signal experts, one from the Pennsylvania Railroad, two from the New York Central and one from the Delaware, Lackawanna \& Western Railroad, made a crifical examination and report on the signals and signal practice of the Company. Their investigations, report and suggestions are being used as a basis for improving the New Haven's signal system and practice as rapidly as the financial conditions permit.

(3) The Stone \& Webster Corporation, of Boston, made a critical examination of the financial condition, organization and methods of management of the various trolley properties, and an elaborate report 
which has been of considerable use to the Company in perfecting the details of its organization and in adopting the most advanced methods of trolley management.

(4) The firm of Price, Waterhouse \& Company, Accountants, assigned one of its principals who has been engaged since January 1, in a critical examination of the past history of the financial transactions of the Company. His work is not completed, but soon will be and his reports will be used during the current fiscal years as a basis for further simplification and improvement of the Company's corporate organization. All his reports were transmitted promptly to the Interstate Commerce Commission.

(5) In order to obtain a complete and thorough history of the charters, mortgages, leases and the character of each security, of the Company, a thorough investigation was made of all these papers by a competent lawyer detailed from the Company's law department for that purpose. He has made the most complete history of this part of the New Haven system that has ever been prepared, which will be used during the coming year as a basis for drawing up a financial plan that will permit the refunding of the Company's floating debt if the necessary legislation can be obtained.

By the Public Service Commission of Massachusetts.-On December 17, 1913, the Public Service Commission of Massachusetts began an investigation of the expenditures of the New Haven Company classified under the head of "Other Expenses." Certain sums of money have been spent in former years for advertising, legislative and miscellaneous expenses which it was thought should not have been spent. Prior to this investigation all expenditures of the character complained of had been stopped.

By the Interstate Commerce Commission.-In response to a resolution of the United States of February 3, 1914, a prolonged investigation was made by the Interstate Commerce Commission of the financial transactions of the New Haven Company since 1903. Their report was published on July 11, 1914. While statements to the contrary have been circulated, it is proper to point out that the Company co-operated to the fullest extent in furnishing information to the Commission, and no books, papers or documents in the possession of or within the control or jurisdiction of the Company were burned or destroyed, either before, during or since the investigation The records of the Company have been preserved carefully and the general orders of the Commission applicable to the preservation of all records have been complied with. Explieit instruetions were given and obeyed that the files of the Company should remain open at all times to the most complete investigation and inspection by the 
representatives of the Commission. The custodians of the records of the Company assisted the Commission's examiners, and the latter were granted every facility within the power and control of the Company to aid them in their investigations.

For nearly two years prior to this investigation in Washington, examiners and representatives of the Commission have been almost continuously at the offices of the Company,-at one time as many as sixteen. They have examined the books, documents and files of the Company, and no information has been kept from them and all information obtainable having a bearing on the subjects under investigation was furnished promptly and fully by the officers and employees of the Company.

The following is an illustration of the action taken to respond to requests for information:

Within a period of forty-eight hours, from Friday afternoon until Sunday afternoon, 504 clerks were taken from their regular duties and worked 6,220 hours, equivalent to 777 clerks for one day, at a cost of $\$ 1,400$, in order to segregate certain records, which were then sent in a special car to Washington so as to be there Monday morning.

All of the suggestions made in the report of the Commission which are of a helpful nature and which will in any way aid the Company in sustaining itself under the present condtions, which are so adverse to all railroads, and particularly to those in New England, are now being made use of and steps are being taken to give effect to the various suggestions and recommendations.

Special counsel were assigned last Spring to an investigation of the affairs of the Billard Company as far as they affect the New Haven Company. Requests for information having proved ineffectual, orders have been given to institute judicial proceedings to compel an accounting.

Counsel are also carefully considering whether, in the testimony obtained by the Commission or elsewhere, evidence can be found that will enable the Company to bring an effective suit against any other parties to recover funds alleged to have been improperly diverted from the Company's treasury.

\section{ADDITIONS AND BETTERMENTS}

As shown in table on page $726, \$ 3,290,549.97$ was spent for additions and betterments and charged to Capital Account.

Harlem River Branch.-Re-arrangement of the New Haven Company's tracks between Casanova and 132nd street to permit construction of the New York Connecting Railroad. This work will probably 
be completed during the year 1914, and will provide track connections between the two railroads.

Pelham Bay Trestle is being filled to the bulkhead line established by the City of New York and United States Government. A portion of the trestle is now filled, affording a permanent road. bed. The work will be finished in 1914 .

City of New York, East River Piers Nos. 37, 42 and 43.-A much needed improvement providing additional facilities for handling package freight for New York City, resulting in the increase and improvement of pier properties now held by the railroad company under leases extending over a period of thirty years. The work consists of the removal of a city dumping platform on Pier No. 37, remodelling, widening and construction of pier and bulkhead sheds at Pier No. 37; the removal of old Pier No. 49 to increase the facilities for handling car floats, and to permit the full utilization of the bulkhead shed being constructed between Piers No. 37 and No. 38. The city's dumping platform was removed from Pier No. 37 to Pier No. 43, and construction of new pier and bulkhead sheds at Pier No. 42 has been completed. Every effort is being made to complete the work before the end of the calendar year.

Woodlawn, N. Y.-The renewal of the steel bridge carrying the New Haven westbound track over the tracks of the New York Central at Woodlawn Junction, which bridge was designed and constructed twenty years ago, has become necessary, as the bridge is insufficient for the present heavy trains. A new investigation of the entire matter was made and a plan adopted which will permit of operation of the heavier power, and so arranged as to become a part of the entire scheme when it becomes necessary to complete the fourtrack connection in future, but postponing for the present the large expense of the four-track bridge.

Mount Vernon, N. Y.-By order of the Public Service Commission, a new steel bridge to carry the extension of North Fifth arenue over the railroad company's main line tracks has been completed and placed in service.

Berkshire Junction to New Milford Double-Tracking and Elimination of Grade Crossings.-The elimination of seren grade crossings, improvement of alignment and grades, new railroad bridge at Still River, new station at Brookfield and remodelling and relocation of present Still River station. Double tracks are in service and highway traffic at the location of the grade crossings hus been diverted over the new bridges. Still River station changes are completed and new station at Brookfield will be completed this Fall. 
New Haven.-The work of lowering tracks in the west cut approaching New Haven to provide sufficient overhead clearance for electrification, including the underpinning of retaining wall foundations and bridge piers, as well as construction of new steel highway bridges at Cedar, Lamberton, DeWitt streets and Howard avenue, has been completed.

Burning of Hartford Station.-On February 21, 1914, the passenger station at Hartford, Conn. was damaged by fire, causing a serious loss, a part of which loss was recovered from the insurance companies. Temporary arrangements were made promptly to provide accommodutions so that business could be transacted, although with some inconvenience to the public and the Company. Contract has been let for the rebuilding and improvement of the station at an estimated cost of about $\$ 261,500$ and the work is being pushed.

Air Line Improvement.- The filling of the viaducts on the Air Line, known as Lyman and Rapallo viaducts, has been completed, as well as the strengthening of several small bridges. The viaducts were of iron, constructed in $18 \% 0$.

The greatest depth of the Lyman viaduct was 128 feet; the greatest depth at Rapallo viaduct was 60 feet, requiring at Lyman viaduct 710,000 cubic yards of filling, and 339,000 cubic yards at Rapallo viaduct. The work was carried out in a very satisfactory manner by the Company's construction forces, which resulted in a large saving over what it would have cost if done under contract.

New London, Conn.- Surveys and soundings to determine the most desirable and economical location for the proposed new bridge over the Thames River, as well as surveys for improving the alignment over Winthrop Cove, have been completed. Detailed plans for the work are now in course of preparation. The improvement across Winthrop Cove will consist of a solid embankment, eliminating the present timber trestle, as well as such grade crossings as will be permitted by the Public Utilities Commission. Hearings on the entire matter of elimination of grade crossings and approval of the relocation of the line are now under way.

Olneyville, R. I.-Elimination of Hartford Avenue and Plainfield Street Grade Crossing.-This work is being done under an agreement with the City of Providence, and will eliminate two very actively used grade crossings by carrying the tracks over the streets, including the construction of an additional crossing under the railroad tracks to meet the requirments of the city. The work is progressing and will be completed in 1914 .

In connection with the raising of the tracks it becomes necessary to abandon the bulk delivery facilities at Olneyville, as well as the 
freight house, and modern and larger facilities are being provided to replace the facilities abandoned. This portion of the work is under way, and should be completed during the fiscal year.

Providence, $R$. I.-Filling of the approach timber trestles to the Seekonk River bridge has been completed, utilizing for this purpose material excavated in connection with other construction work. This will permit a reduction of maintenance charges.

Pawtucket-Central Falls, R. I.-This work consists of the elimination of five grade crossings, improving alignment and grades, construction of two additional tracks, joint passenger station, reconstruction of freight yards, eight overhead highway bridges and one foot bridge, etc. Contract for the steel work for the passenger station has been awarded, and the entire work should be completed during 1915 . Satisfactory progress on the grading has been made, and the tracks can probalsly be used prior to completion of the passenger station, eliminating the very busy grade crossings now existing.

Readville, Mass.-Extension of locomotive shop has been completed and put in service during the year.

Clinton, Mass.-Under decree of the Court four highway crossings and one railroad crossing are being eliminated. Owing to certain delays, due to the very severe winter and other causes, the work has not yet been completed as hoped, but will probably be completed during the coming autumn.

The number of grade crossings eliminated during the year for the greater safety of the public was:

State of Connecticut, Highway...................... 12

State of Rhode Island, Highway....................... 2

State of Massachusetts, Highway...................... 4

Total, Highway $\ldots \ldots \ldots \ldots \ldots \ldots \ldots \ldots \ldots \ldots \ldots, \overline{18}$

State of Massachusetts (Clinton, B. \& M. R. R.) Railroad....... 1

Passenger Stations.-Five new passenger stations have been constructed, and improved passenger station facilities have been provided at fifty-five other points. Work on five more new passenger stations and improved facilities at three other points is under way and will be completed during the ensuing year.

Freight Stations. - Seven new freight stations have been constructed during the year, and improved freight house facilities at thirty-seven other points. One more new freight house is under way, and improved freight facilities are being provided at five other points, which work will be completed during the ensuing year.

Signals and Interlocking.-Automatic signals between Cedar Hill and Springfield have been completed. Improved and additional signalling or interlocking has been provided at thirteen other points. 
One hundred and fourteen derails connected to main line switches have been installed on sidetracks. Four-track automatic signal system between Stamford and New Haven has been authorized, also new interlocking plants or signal towers at seven other points.

The rules for the proper spacing and blocking of trains were revised during the year. Under the new rules and with the automatic signals now on the road there are 1744.1 miles of road protected by block signals as against 803.1 on January 1, 1914.

Bridges.-Important bridge work has been done during the year at forty-four various points. The capacity of the following lines has been increased on account of strengthening or rebuilding bridges during the year, permitting the operation of increased rolling loads to the extent mentioned:

\begin{tabular}{|c|c|c|}
\hline & From & To \\
\hline East Hartford to East Longmeadow.... & $100,000 \mathrm{lbs}$. & $156,000 \mathrm{lbs}$. \\
\hline East Meriden to Meriden............. & 95,000 & 145,000 \\
\hline Hamlet Branch $\ldots \ldots \ldots \ldots \ldots \ldots \ldots$ & 130,000 & 156,000 \\
\hline Judd's Bridge to Litchfield...... & 90,000 & 95,000 \\
\hline Plainfield to Worcester .............. & 156,000 & 200,000 \\
\hline Portland to Willimantic ............ & 120,000 & 200,000 \\
\hline Saybrook Junction to Fenwick....... & 130,000 & 156,000 \\
\hline Valley Falls to Worcester............. & 130,000 & 156,000 \\
\hline Vernon-Rockville-Melrose $\ldots \ldots \ldots \ldots \ldots$ & 100,000 & 156,000 \\
\hline Webster to Southbridge $\ldots \ldots \ldots \ldots \ldots$ & 115,000 & 156,000 \\
\hline
\end{tabular}

Passing Sidings and Commercial Sidetracks.-Five passing sidings have been installed or extended to accommodate longer trains.

Ninety-one sidetracks to serve industries along the Company's lines have been installed during the year.

New Equipment. - Under the new Equipment Trust (Farmers' Loan \& Trust Co., Trustee) there have been added during the year:

72 Steel Coaches.

28 " Smokers.

15 " Postal Cars.

12 " Multiple Unit Motors.

24 " " " Trailers.

and in addition:

New Equipment.-(Not under the Equipment Trust.)

3 Electric locomotives,

34 Steel coaches,

1 Steel smoker,

20 Milk cars,

6 Steel postal cars,
1 Steam crane,

1 Rail unloader,

1 Transformer,

3 Steel car floats. 
For this equipment, the conversion of certain cars from one class to another, providing safety appliances, also superheaters, pumps, flash boilers, etc., on locomotives, the Company paid $\$ 1,054,659.07$, the entire amount of which was charged to the equipment account. There are also due on 1913 orders, ten steel smoking cars and four multiple unit cars and on 1914 orders fifty steel baggage cars, thirty steel passenger coaches and twenty steel combination cars.

At the present time, with the exception of baggage cars and four dining ears, all of the regular express passenger train service is handled with all-steel or steel underframe cars between New York and Boston via the three routes, Shore Line, Springfield and Hartford-Willimantic. The same is also true of the New York-Springfielı, New York-Winsted, New York-Pittsfield, New York-New Haven and, with the exception of two trains, New Haven-Boston \& Maine service.

As stated above, equipment is under order, the early receipt of which is expected; these cars and reinforcement of four dining cars now under way will complete the above trains with all-steel or steel underframe equipment.

Abandonment of New Work.-All construction and betterment work has been stopped except that which is so far advanced that its completion is required and that which the Company is compelled under legal orders to complete. This policy must of necessity continue until the Company can obtain money from increased earnings and through some plan that will permit financing its floating debt at lower rates of interst than are now current.

Therefore, many improvements cannot now be undertaken that would add to the comfort and convenience of the public and eventually produce economies in the operation of the railroad.

\section{ELECTRICAL DEPARTMENT}

Between New York and New Haven, including all yards and sidings, and the Cedar Hill yard at the latter point, your Company has 518 miles of track equipped for electrical operation, excluding that part of the New York Central Company between Woodlawn and Grand Central Terminal used under lease but maintained by that Company. The volume of passenger and freight business moving between New Haven and New York is very heavy and the necessity for the most effective organization is very essential.

The investment in the electrification between New York and Cedar Hill in power, locomotive, transmission lines, distributing system, 
electrical shops, when all the business is handled electrically, will be about $\$ 20,000,000$.

For the purpose of supervising closely and making the most effective use of these large investments and because the operation and maintenance of this extensive electrical installation is very technical, an Electrical Department was organized on March 18th, 1914, consisting of a Consulting Electrical Engineer, with necessary assistants, having advisory jurisdiction over matter pertaining to the engineering, construction and operation of the electrical system and equipment. Better results are being gradually obtained by having this new department acting in co-operation with the divisional operating officers.

Electrification of Freight Yards and Sidings Between Stamford and New York.-The electrification of Harlem River and Van Nest yards, including all freight sidings west of Stamford, has been completed and electric switching, including freight service, inaugurated in these yards.

Building of Electrical Shops at Van Nest.-The installation of machinery in these shops was completed and the transfer of the heavy repair work on electrical equipment from Stamford to Van Nest was made in September, 1913. The increased facilities offered by these shops has resulted in a marked improvement in the maintenance of electric equipment, and should effect a decrease in costs.

Extension of Electrification from Stamford to New Haven.-The electrification of main line tracks, the freight yards at South Norwalk and Bridgeport, and the sidings at intermediate points, has been completed and placed in operation, commercial passenger service having been inaugurated on June 22nd, 1914. At present forty passenger trains are being operated electrically between New Haven and New York and approximately sixteen freight trains are being hauled daily by electric locomotives between Harlem River, Bridgeport and New Haven. This includes approximately 50\% of the passenger train service between Stamford and New Haven on week days and on Sundays the entire passenger train service.

The present eastern terminus of the Electric Zone is at New Haven. The extension to Cedar Hill will be completed and put into service some time in October when the transfer from steam to electric motive power will be made at Cedar Hill.

The electric haulage of freight trains should result in increasing the capacity of this part of the road, and giving better service to the public.

Elimination of Electro-Magnetic Induction on Foreign Wires in the Electric Zone.-The new system of electric power distribution was 
inaugurated in January, 1914, resulting in the practical elimination of disturbances in the circuits of the Telephone and Telegraph Companies paralleling the electric zone and in improved conditions of operation in the railway circuits.

Power and Equipment.-That part of the electric zone east of Woodlawn and including the Harlem River Branch, in other words the New Haven Road's electrification, is operated by alternating current. The New York Central line between Woodlawn and Grand Central Terminal, over which our passenger trains are run, is operated by direct current, the New Haven engines and cars being equipped both for alternating and direct current. For the operation of the zone between Woodlawn and Grand Central Terminal, at present, all power is provided by the New York Central.

Power for operation in the New Haven's electrification zone is provided from the Company's Cos Cob power station. The capacity of the Cos Cob power station has been increased from 15,000 kilowatts to 35,000 kilowatts, this work having been completed during the year. Steps are now being taken to increase the output at Cos Cob, and to purchase power from the New York Edison Company on such terms as will justify your Company in deferring the outlay of capital for that purpose. With this additional power the maximum use of the electrical installation can be made with the electric locomotives now owned by the Company.

\section{AFFILIATED COMPANIES}

Boston \& Maine Railroad.-By reason of the continued unfavorable business conditions, and the increased cost of operation, no dividends were paid on the stock of the Boston and Maine Railroad held by the Boston Railroad Holding Company, consequently your company received no dividends on its holdings of the Boston Railroad Holding Company preferred or common stock, but was obliged under the guaranty to charge its Income with $\$ 112,000.00$, representing the dividend on the preferred stock in the hands of the public, and $\$ 27,000.00$ covering taxes, organization expenses, etc., of the Boston Railroad Holding Company.

A condensed statement of Income of the Boston and Maine Railroad for the year ending June 30th, 1914, is given hereunder, in comparison with the year 1913 : 
Total Revenue from Transportation $\$ 46,615,094.58$

Compared with 1913

1914

Increase

Decrease

Total Operations other than Trans-

$\$ 1,086,276.12$ portation, including Outside

Operations.................

985,050.79

Total Operating Revenue........ 47,600,145.37

Total Operating Expenses....... 38,296,678.73 \$ 195,254.11

Total Net Revenue.......... $9,9,303,466.64$

Railway Tax Accruals............ $2,059,016.83$

Total Operating Income....... $\overline{7,244,449.81}$

Other Income............. 1,516,009.82

Gross Corporate Income....... $\frac{1,5,760,459.63}{8}$

Deductions from Income:

Rentals of Leased Lines, Hire of

Equipment, Interest, etc..... $\quad 10,805,201.64 \quad 924,302.61$

Deficit................ $\overline{\$ 2,044,742.01} \$ \overline{2,094,438.83}$

Boston \& Albany Railroad.-Because of the demands of the Department of Justice the agreement with the New York Central and Hudson River Railroad Company to share equally in the net results of the operation of the Boston and Albany Railroad was terminated as of January 31st, 1914. In the final settlement there will be certain increased charges on account of depreciation adjustment on equipment.

Your Company has also withdrawn so far as it legally may from the agreement made with the New York Central and Hudson River Railroad Company for the acquisition of a one-half interest in certain equipment provided by the Central Company for use on the Boston and Albany Railroad under "Boston and Albany Equipment Trust of 1912."

Central New England Railway Company.-The results on the Central New England Railway Company during the past year justified the declaration by that Company of a dividend of $\$ 4.00$ per share upon the preferred stock; the amount paid to the New York, New Haven and Hartford Railroad Company, $\$ 149,480.00$, has been credited to the Income of the year.

The funded debt of the Central New England Railway Company has been increased by the issue of $\$ 2,632,000.00$ additional First Mortgage 4\% Gold bonds due January 1st, 1961, which are held in the treasury of the Central New England Railway Company.

The operating expenses of the Central New England Railway Company increased $\$ 550,160.35$, or $28 \%$, principally due to taking over the operation of the line between Danbury, Connecticut, and Hopewell Junction, New York, 33.56 miles of double track, effective September 1st, 1913. There was also some increase in transportation expenses on account of increased wages and New York State Full 
Crew Bill. The total revenue train mileage increased 372,159 , or $31 \%$.

New York Connecting Railroad.-Construction work on the New York Connecting Railroad, owned jointly by your Company and the Pennsylvania Railroad Company, which has been fully described in previous annual reports, is progressing between the tracks of the New Haven, in the Borough of the Bronx to the tracks of the Pennsylvania in the Borough of Queens, New York City. This section constitutes the most difficult and expensive portion of the railroad, as it includes the large bridges over the East River, Little Hell Gate, and the Bronx Kills, with the long viaduct approaches.

During the past year the Public Service Commission of New York for the First District, approved of the First Mortgage of the New York Connecting Railroad Company and the issue and sale thereunder of $\$ 16,000,000.00$ of bonds dated August 1st, 1913, and maturing August 1st, 1953, bearing interest at the rate of four and onehalf per cent. per annum, and guaranteed as to principal and interest by your Company and the Pennsylvania Railroad Company. The proceeds from the sale of these bonds were used to retire its $\$ 7,000$,000.00 of Three Months' Five per cent. Notes maturing November 21st, 1913, issued to pay for real estate and construction, and the balance is being used for construction purposes.

New York, Ontario and Western Railway Company.-The results on the New York, Ontario and Western Railway during the past fiscal year did not justify the declaration by that Company of a dividend, consequently your Company received no income on its 291,600 shares of common stock of this Company for the past year.

A condensed statement of income of the New York, Ontario and Western Railway for the year ending June 30th, 1914, is given hereunder:

Total Revenue from Transportation.... \$8,915,691.24

Comparison with 1913

Total Operations other than Transpor-

tation, including Outside Operations. .

Total Operating Revenue........... $\overline{9,013,344.96}$

Total Operating Expenses.......... 6,692,923.58

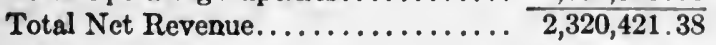

Increase Decrease

$\$ 409,786.66$

Railway Tax Accruals............ $\frac{238,561.69}{2,081,859.69}$

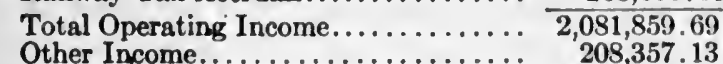

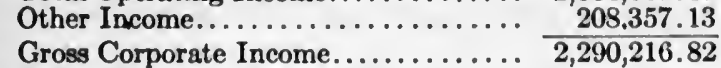

Deductions from Income:

Rentals of Leased Lines, Hire of

Equipment, Interest, etc......... 1,626,524.76

Net Corporate Income. . . . . . . . . \$ $663,692.06$

$\frac{\$ 1,101.41}{193,883.11} \frac{}{408,685.25}$

$7,469.56$

$\overline{610,037.92}$

$4,428.20$

$\overline{614,466.12}$

$66,525.17$

$\overleftarrow{\$ 547,940.95}$ 
New York, Westchester and Boston Railway Company.-The gross operating revenue of the New York, Westchester and Boston Railway Company during the past fiscal year increased $39 \%$; operating expenses decreased $8 \%$. 3,062,985 passengers were handled during the fiscal year, an increase of $31 \%$.

The deficit from operation for the fiscal year was $\$ 30,154.34$, a reduction, and consequently a gain of $\$ 149,759.99$ over the previous year, or $83 \%$. Since the beginning of April, 1914, the revenues of the Company have been sufficient to pay the operating expenses and leave a surplus applicable to taxes. It is estimated that the earnings for the present fiscal year will be sufficient to pay the operating expenses and the taxes of the Company.

The construction of the extension of the Lenox Avenue Branch of the New York City Subway to the Westchester Station at 180th Street, New York, has been commenced and the work should be completed within a year, also the work of third tracking the Third Avenue Elevated Railroad is under way, as well as on the Lexington Avenue Subway and its extension through the eastern section of the Bronx, from all of which the Westchester Company should derive increased business.

The charge to the income account of the New York, New Haven and Hartford Railroad Company for the fiscal year by reason of its guaranty of the interest on the bonds of the Westchester Company was $\$ 864,000.00$; there was also a further sum of $\$ 434,396.50$ representing interest on bonds and notes held by the New Haven Company and on advances made by it, which on account of the inability of the Westchester Company to pay has not been credited to the income account of the New Haven Company; nor has any credit been taken therein for accrued interest amounting to $\$ 176,803.13$ on notes of the Millbrook Company held by the New Haven Company. The Millbrook Company is the owner of a large amount of real estate purchased originally for proposed locations of the route of the Westchester line; such of this real estate as was not required for actual right of way is in the market for sale and as fast as sold the proceeds will be available for application to payment of note for $\$ 3,536,062.56$ held by the New Haven Company and to interest thereon which to June 30,1914, amounted to $\$ 500,942.20$. The results of the operations of the Westchester and Millbrook Companies will be found in the income accounts of subsidiary companies appended hereto.

THE TROLLEY COMPANIES

During the past year a change has been made in the method by which the electric traction properties are operated. Heretofore the 
details of management have been largely centralized in the general offices of the New York, New Haven \& Hartford Railroad Company in New Haven; but now the principal units have been given independent organizations separated from the New Haven, thus giving to the electric properties a complete staff of officials, all of whom give their entire time and attention thereto. It is expected that greater efficiency will be obtained by this change.

During the year the same high standard of maintenance of these properties has been continued and they are in better physical condition now than at any time since their purchase. In common with all transportation companies throughout the eastern part of the United States, the electric properties have not maintained the customary growth in gross revenue, and, coupled with very extensive requirements by the municipalities served by the various lines for improved street conditions and new parement, the expense for operation has increased in much greater ratio than the gross revenue.

Large undertakings for improvements and betterments of the properties which were well under way at the beginning of the year have been carried to completion, so that these lines are now in very much better position to take care of any increase in business which may come to the transportation companies with a revival in general business and industrial conditions in the territory served.

Berkshire Street Railway Company.-This Company operates through ownership or lease $\mathbf{1 4 4 . 8 6}$ miles of track in western Massachusetts and Southwestern Vermont.

The New York, New Haven \& Hartford Railroad Company holds all the capital stock of the Company at a cost of $\$ 6,371,395.58$, and all the stock of The Vermont Company at a cost of $\$ 571,164.31$, a total of $\$ 6,942,559.89$. It also holds bonds of the Berkshire and Vermont Companies and notes of the Berkshire Company amounting to $\$ 4,344,000.00$.

During the year there was spent $\$ 681,823.89$ for additions to the property, the principal item being for completion of an extension from Lee through East Lee to Huntington to a connection with the street railroad lines running westward from the eity of Springfield, this line not as yet being in operation. In addition to this there were expenditures for track improvements necessitated by state highway construction and city road betterments.

During the year the net revenue of the Company was sufficient to provide interest on all underlying bonds and rentals of leased lines; but not sufficient to pay the total amount of interest due the New Haven Road, the deficit being $\$ 72,507.17$. 
The Connecticut Company.-This Company operates through ownership, lease and trackage agreement 705 miles of track, all in the western half of Connecticut; in addition to which it owns 88.1 miles of track under lease to The Shore Line Electric Railway Company in New London, Norwich, Willimantic, Danielson and Putnam.

The New England Navigation Company owns all of the capital stock of the Company, at a cost of $\$ 40,000,000.00$. The New Haven Company also holds the $6 \%$ demand notes of this company amounting to $\$ 2,125,000.00$ all of which have been issued to provide funds for additions and betterments.

During the past year there was spent for additions to the property the sum of $\$ 1,214,535.70$, by far the greater part of which was for track betterment and paving to meet the requirements of the various municipalities served by the company, other large expenditures having been made to improve power conditions at a number of points.

During the past year the Company earned sufficient to pay all operating expenses, taxes and interest and returned to the Navigation Company $\$ 1,500,000.00$ as dividend and showed a surplus of $\$ 1,072.42$. The following table shows the results of the operations of the company for the past four years: 
N. Y., N. H. \& H. RR. CO. REPORT, 1914695

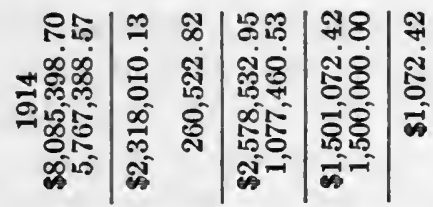

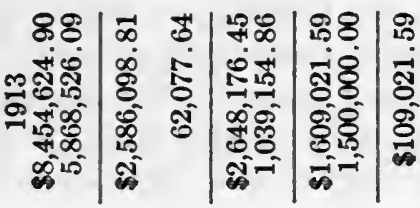

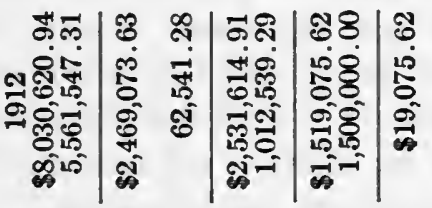

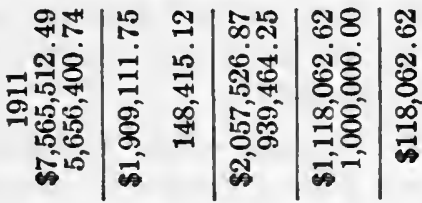


New York \& Stamford Railway Company.-This Company operates through ownership or lease 37.51 miles of track in Westchester.

The New York, New Haven \& Hartford Railroad Company owns all the capital stock of the Company at a cost of $\$ 610,643.40$. It also owns property between the Mianus River and the State line between New York and Connecticut, which is leased to the New York \& Stamford Railway Company at an annual rental of $\$ 20,000.00$. The New Haven Company also owns first mortgage bonds of the New York \& Stamford Railway Company carried at a cost of $\$ 599,880.00$, and also holds $6 \%$ demand notes of the New York \& Stamford Railway Company in the amount of $\$ 185,000.00$, the notes all having been issued for additions and betterments, chiefly for double tracking a large portion of this line to care for the large distribution of commuting travel between New York and the various suburban points.

The amount spent for additions and betterments during the cyrrent year was $\$ 58,184.89$, for new double tracking.

During the year the Company did not earn an amount sufficient to pay operating expenses, taxes and interest on the outstanding bonds, the deficit being $\$ 5,824.1 \%$.

The Rhode Island Company.-This Company operates through ownership or lease 345.3 miles of electric railroad track, and 8.43 miles of steam operated trackage of the Narragansett Pier Railroad Company, all in the State of Rhode Island. This includes all of the electric railroad in the cities of Providence, Pawtucket and Woonsocket and the large industrial communities adjacent.

The New York, New Haven \& Hartford Railroad Company owns the entire capital stock of the Company at a cost of $\$ 24,352,336.41$, in addition to which it now holds $6 \%$ demand notes of the Company in the sum of $\$ 3,500,000.00$, all issued to provide funds for expenditures for betterments and improvements of the property. The Rhode Island Company has also outstanding $\$ 1,000,000.00$ in notes for moneys borrowed from outside sources.

During the current year the Company has spent $\$ 1,568,914.21$. for betterments and improvements, consisting of the following:

A tunnel under the hill to connect the business and residential portions of the city of Providence has been completed and put in operation, eliminating an expensive and cumbersome operation by gravity plane. A very large amount has also been spent for additions to the power house to meet the requirements of the Company for a number of years. An extension of 10 miles from Centerdale to Chepachet was built to provide transportation facilities for territory heretofore without direct connection with the city of Providence. 
N. Y., N. H. \& H. RR. CO. REPORT, 1914697

The earnings of the Company were sufficient to take care of the operations and pay all interest, rentals and taxes, and leave a sur-plus of $\$ 347,642.94$.

The Company leases the property of the Sea View Railroad Company and the Providence \& Danielson Railway Company, owned by The New England Navigation Company and representing a total investment for stock and bonds of $\$ 1,266,379.37$, on which The Rhode Island Company pays rental of $\$ 83,132.00$ annually.

The following table shows the operating results for the past four years: 

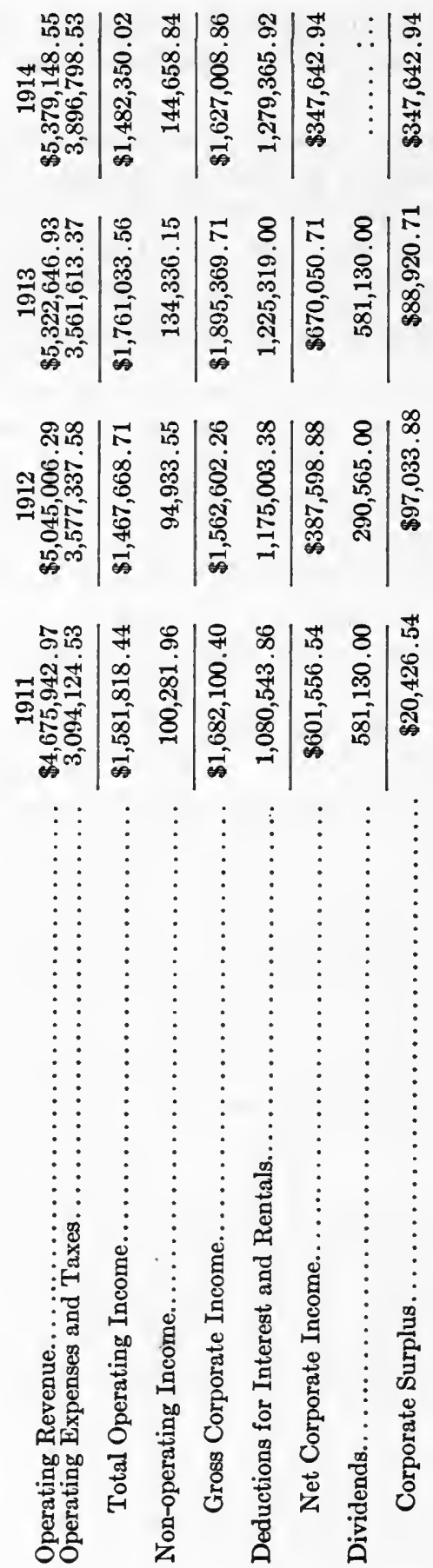
The Westchester Street Railroad Company.-This Company operates through ownership or lease 30.67 miles of track in Westchester County, New York.

During this year the Public Service Commission for the $2 \mathrm{~d}$ District of New York authorized the Company to issue 7,000 shares of stock to represent the cost of the property to the New Haven Road. This is carried at a cost of $\$ 896,379.63$, in addition to which the New Haven holds notes of the Westchester Company to the amount of $\$ 255,771.21$ issued for capital improvements of the Company's property since acquisition.

The amount spent for additions and betterments during the current year was $\$ 56,625.54$, for improvements of and additions to the track and line construction.

During the year the Company earned an amount sufficient to pay the interest on outstanding notes; but paid no dividends, the surplus from operations amounting to $\$ 4,883.99$.

\section{WATER Lines}

The causes that adversely affected the results on the steam and trolley lines had a somewhat similar effect on the various water lines owned and controlled by your Company.

The Hartford and New York Transportation Company.-The gross earnings of The Hartford \& New York Transportation Company were $\$ 1,096,499.16$ as compared with $\$ 1,157,337.82$ for the previous year; but by careful operation the expenses were reduced so that the net income of this Company for the fiscal year just passed was $\$ 85,965.42$ as compared with $\$ 64,285.70$ for the previous year.

This Company reduced its equipment by one barge which had become obsolete, but on account of the depression in business did not replace it.

The property of this Company is in good condition.

New Bedford, Martha's Vineyard \& Nantucket Steamship Company. - On account of considerable activity in Martha's Vineyard and Nantucket the earnings of the New Bedford, Martha's Vineyard and Nantucket Steamboat Company increased from $\$ 209,469.82$ to $\$ 232$,704.45 ; by careful operation the expenses were reduced somewhat, so that the net income of this Company for the year just past was $\$ 62,708.25$ as compared with $\$ 25,630.17$ for the previous year.

Just as soon as financial conditions permit this Company should add to its equipment a modern steamer to care for the growing business between the mainland and the two islands.

The New England Steamship Company.-The gross earnings of The New England Steamship Company were $\$ 4,697,211.94$, a de- 
crease of $\$ 219,512.25$. In spite of this decrease in gross earnings, by careful operation and rearrangement of work on some of the piers in New York, the deficit in meeting the fixed charges of this Company of $\$ 355,070.50$ for the year ending June 30th, 1913, was reduced to a deficit for this year of $\$ 77,802.62$.

One steamer, the "City of Bridgeport," which was not needed, was sold for $\$ 100,000$. in cash, and one transfer tug was dismantled and put out of service.

During the investigation of the Company's affairs by the Interstate Commerce Commission, some criticism was made upon the character of the steamships and the operation thereof. As a result, the Secretary of Commerce caused a very thorough investigation to be made by the Supervising Inspectors of New York and Boston. The United States Steamboat Inspection Service has prepared a very complete report on this steamship property and it is now a matter of record with the United States Government, open to the inspection of all interested parties. Space does not permit the publishing of this report but the following extract summing up the Government's report will be of interest:

"This office is therefore of the opinion in view of the nature of the safeguards placed upon these vessels and the excellent discipline that prevails, that danger from fire is a minimum, and that a menace to the lives of the patrons of this line does not exist."

\section{Real Estate}

Grand Central Terminal.-To utilize the real estate and "aerial rights" adjacent to the Grand Central Terminal in New York, the following buildings have been constructed: Biltmore Hotel, Merchants and Manufacturers Exchange, Adams Express Company and United Cigar Stores. The New Haven Company being a joint user of the Terminal and its approaching tracks joined with the New York Central in advancing money for the development of the property not required for railroad use.

The total amount advanced by your Company during the past fiscal year was $\$ 1,628,190.35$, and its aggregate advances to June 30 th, 1914, for these purposes, $\$ 4,153,161.75$.

All of the advances made yield a satisfactory interest rate and the lessees of the buildings pay ground rents and taxes, which reduce the expenses of the Grand Central Terminal, and in addition the lessees pay annual sinking fund payments, which, together with accretions to the fund, will in about twenty-seven years return to the owning Companies the sums advanced. 
The following buildings are now under construction:

Todd Building, for which the Company must advance. .\$325,000.00*

Yale Club, for which the Company must advance..... 250,000.00

$* \$ 40,000$. of this amount has been paid since June 30,1914 .

Other buildings are projected, work upon which will begin in the near future, as follows:

Postoffice Building, between East 45th and East 46th Streets

Apartment House, 50th Street and Park Avenue.

Apartment House, 51st Street and Park Arenue.

As to these the Company is under no present obligation to advance money but retains an option to participate at any time within two years.

The New Haven Company has also advanced $\$ 1,310,000.00$, onehalf of the cost of the office building located at the Grand Central Terminal, which amount is to be repaid with interest in annual installments extending over a period of twenty-five years and of which amount $\$ 104,800.00$ has been repaid, leaving $\$ 1,205,200.00$ to be repaid.

Increased Efficiency and Safety.-Last year's report referred to the effort of officers and employees to raise the railroad and service to a higher standard of efficiency, safety, discipline and economy. The North Haven accident of September 2d, 1913, following as it did other serious accidents, made it imperative that the rules and regulations of the Company be of such a character as to safeguard to the greatest extent possible the lives of the public and the employees.

For some time previous to this accident negotiations had been conducted with committees representing the engineers and firemen to revise rules which were not in accordance with modern railroad practice. The new management felt that it owed a duty to the public as well as to the employees to put the new rules into effect at once. The engineers and firemen felt aggrieved at this position of the Company and roted to strike. On October 18th, 1913, however, the matter was adjusted amicably with the employees, and rules containing the principles for the management contended remained in effect.

These negotiations, in the judgment of your officers, tended to establish a better understanding and improved relations between the employees and the management, and have assisted materially in restoring confidence throughout the service. Every effort is being made by officers and men to promote a spirit of helpful co-operation, so necessary to maintain and operate the properties efficiently, safely and economically. and to give good service to the public. 
Safety and Efficiency Bureau.-At the present time the Company has fully organized safety and efficiency bureaus as follows:

1 Central Committee,

7 Divisional Committees,

13 Shop, Engine House and Terminal Committees,

1 Telegraph Department Committee,

1 Electrical Department Committee.

Regular meetings are held and considerable has been accomplished in the way of removing obstructions, securing better clearances, eliminating unsafe practices, improving view at grade crossings, etc.

New Haven Railroad Club.-The New Haven Railroad Club was organized on February 26th, 1914, and is composed of officers, assistants, chief clerks, bureau foremen, or other employees of The New York, New Haven \& Hartford Railroad Company, or affiliated companies, holding co-ordinate positions.

The object of the Club is to promote knowledge on all matters relative to the maintenance, operation and general administration of railroads, and to encourage social relations and a common understanding between departments.

Monthly meetings are held (except in June, July and August) in the Railroad Y. M. C. A. building at New Haven, preceded by a dinner at a nominal cost.

The average attendance at these meetings has been about one hundred and sixteen. There is much interest taken in the Club and its object, and good results are already being accomplished.

Rates.-During the year the passenger rate between Boston and New York, 229.15 miles, was increased from $\$ 4.75$ to $\$ 5.00$ with corresponding increases at intermediate points.

Tariffs have been filed increasing the rates for mileage books from 2c. to $2 \frac{1}{4}$ c. a mile. Tariffs are now being prepared adjusting local passenger rates, outside of the commutation zones, to $2 \frac{1}{2}$ c. a mile. A new tariff adjusting the merchandise and class rates is being prepared, and one adjusting the commodity rates. These tariffs are very complicated and in preparing the new schedules every effort has been made to eliminate discrimination and remove inequalities. Some rates in the new tariffs will be reduced and some will be advanced. The result as a whole will be a much more scientific and logical set of rates and a slightly higher basis. The freight tariffs will be filed with the proper Commissions between now and January 1st, and it is hoped that they will be approved.

Service.-Every effort has been made to give regular and safe service, both freight and passenger, and to economize, some of the non-remunerative passenger trains have been discontinued with the 
result that 284,897 miles less were run by passenger trains this fiscal year than last.

Approximately $32 \%$ of all passenger trains operated by the Company earn less than 50c. and approximately $30 \%$ earn $50 \mathrm{c}$. and less than $\$ 1.00$ a mile, or $62 \%$ earn less than $\$ 1.00$ per mile. The average cost of running all trains (passenger and freight) on the New Haven road for the last fiscal year for transportation expenses, maintenance of equipment and taxes, and not including anything for maintenance of way or administration expenses, or interest on the investment, was $\$ 1.69$ per mile.

These figures emphasize the fact that the road is performing a large amount of service for the public at a loss and justify some increases in the passenger rates and some decreases in service.

\section{STOCKHOLDERS}

The following statement of stockholders of the New Haven Company, and their location and holdings is of interest:

Classification of Capital Stock JUNe 30

Shares Held Is: $1914 \quad 1913 \quad 1912$

Massachusetts.

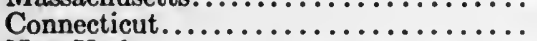

New York.......................

Rhode Island...................

Miscellaneous

\begin{tabular}{|c|c|}
\hline $\begin{array}{r}570,166 \\
264,491 \\
529,167 \\
40,463 \\
166,892\end{array}$ & $\begin{array}{l}-36 \% \\
-17 \% \\
-331 / 2 \% \\
-11 \% \\
-11 \%\end{array}$ \\
\hline & 00 \\
\hline
\end{tabular}

$35 \%$ $19 \%$ $34 \%$ $\mathbf{3 \%}$

Treasury 228,991

NUMBer of Stockholders IN:

$$
\overline{1,800,170}
$$

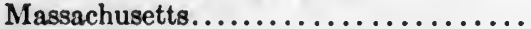

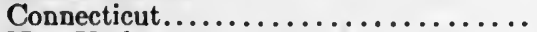

New York.

Rhode Island.

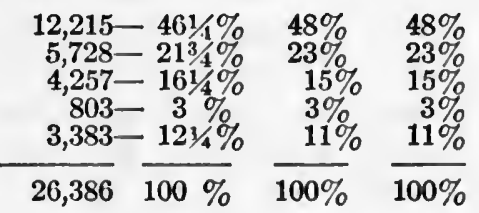

Distribution of Holdinas:

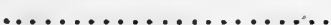

Miscellaneous.

12,127

1 to 10 shares inc..............

11 " 50 " " $\ldots \ldots \ldots \ldots \ldots \ldots$

51 " 100 " $\quad$ " $\ldots \ldots \ldots \ldots \ldots \ldots \ldots$

$101 " 500$ " " $\quad \ldots \ldots \ldots \ldots \ldots \ldots$.

501 " 1,000 " " $\quad \ldots \ldots \ldots \ldots \ldots . .$.

1,001 and over.....................

Individual and Corporate Stockholders:

Males.........................

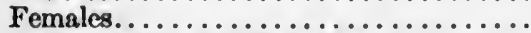

Trustees and Guardianships............

Insurance Co's and other Corporations..

$\mathbf{9}, 651$

9,314

8,685

2,348

1,891

207

147

26,386

1,995

228

146

8,698

8,626

2,295

2,101

216

170

11,113

10,920

3.551

802

$\overline{22,716}$

22,106

$\overline{26,386}$

8,185

10,102

3,666

8,079

9,710

3,584

763

733

59.5

$\overline{22,716}$

22,106

Average Suares per Stockholder......

69.06


The Company is pre-eminently one that is owned and controlled by stockholders living along the line of the road. There are only $\mathbf{7 7}$ stockholders living in Europe. There are 147 stockholders owning more than 1,000 shares with total holdings of 507,916 shares, and there are 26,239 stockholders owning 1,063,263 shares.

Stockholders are urged most earnestly to inform themselves about the situation of the Company, to explain the difficulties in their respective communities and to use their active influence to help the management in its efforts to reduce expenses and to increase rates slightly, and to obtain favorable consideration for the Company at this time, when the help of everyone interested in the welfare of New England is needed in order to maintain efficiently the transportation system that is so closely interwoven with the industrial, financial and social life of this part of the country.

\section{ORgANIZATION}

The following changes in the Board of Directors occurred from July 25th, 1913, to September 29th, 1914:

Mr. Howard Elliott, of Boston, Mass., elected July 25, 1913. Mr. De Ver H. Warner, of Bridgeport, Conn., resigned August 22, 1913. Mr. W. Murray Crane, of Dalton, Mass., elected August 22nd, 1913. Mr. Arthur T. Hadley, of New Haven, Conn., elected September 18th; 1913. Mr. Sidney W. Winslow, of Boston, Mass., resigned September 18th, 1913. Mr. James H. Hustis, of New Haven, Conn., elected September 18th, 1913, resigned August 15th, 1914. Mr. Theodore N. Vail, of Boston, Mass., resigned October 16th, 1913. Mr. Alexander Cochrane, of Boston, Mass., resigned October 16th, 1913. Mr. James L. Richards, of Boston, Mass., elected October 22d, 1913. Mr. Galen L. Stone, of Boston, Mass., elected October 22d, 1913, resigned January 15th, 1914. Mr. Edwin Milner, of Moosup, Conn., resigned January 15th, 1914. Mr. J. P. Morgan, of New York, N. Y., resigned January 15th, 1914. Mr. Lawrence Minot, of Boston, Mass., resigned February 19th, 1914. Mr. John L. Billard, of Meriden, Conn., resigned August 11th, 1914. Mr. A. S. May, of Bridgeport, Conn., elected August 11th, 1914. Mr. A. E. Clark, of Wallingford, Conn., elected September 1st, 1914. Mr. William Rockefeller, of New York, N. Y., resigned September 29th, 1914. Mr. Charles F. Brooker, of Ansonia, Conn., resigned September 29th, 1914. Mr. James S. Elton, of Waterbury, Conn., resigned September 29th, 1914. Mr. George F. Baker, of New York, N. Y., resigned September 29th, 1914. Mr. J. Horace Harding, of New York, N. Y., elected September 29th, 1914 . 
On September 1st, 1913, Mr. Charles S. Mellen retired as President of the Company and Mr. Howard Elliott was elected President and Mr. James H. Hustis, Vice-President. On October 22d, 1913, Mr Elliott became Chairman of the Board and Mr. Hustis, President.

On April 2d, 1914, Mr. H. M. Kochersperger resigned as VicePresident in charge of the Accounting and Treasury Departments. It was deemed better practice to have these two departments entirely independent of each other, and Mr. J. M. Tomlinson, General Auditor, in charge of the Accounting Department, continued in that position, and Mr. A. S. May continued as Treasurer, both reporting to the President.

Because of the various questions regarding the ownership and management of the Boston \& Maine Railroad, it was deemed best for the New Haven Company to withdraw from any direction of the affairs of that property.

On January 24th Mr. Elliott resigned as a Director and Chairman of that Company. Later in the calendar year 1914, the question of a President for the Boston \& Maine was taken up by the Directors of that Company, because of the wish of Mr. McDonald to resign from the Boston \& Maine and devote his whole attention to the Maine Central, the Boston \& Maine having sold its Maine Central Stock on April 1, 1914. The Directors of the Boston \& Maine felt that Mr. Hustis could help the situation and asked him to accept the presidency. Finally it was agreed that he should do so, and he was elected a Director and President of the Boston \& Maine Railroad on August 15th, 1914, being succeeded as President of the New Haven by Mr Elliott, who also fills the position of Chairman of the Board.

On October 22nd, 1913, Mr. Timothy E. Byrnes' term of office as Vice-President of the Company, expired, and this position was not filled.

On September 17th, 1914, Mr. E. D. Robbins, General Counsel of the Board of Directors, tendered his resignation to take effect October 1st, and this position will not be filled at present.

On September 18, 1913, Mr. Elliott was elected Chairman of the Board and Mr. John B. Kerr, President of the New York, Ontario and Western Railway Company.

For the purpose of closer and more independent managements of the various trolley properties, Mr. I. S. Storrs, a Vice-President of the New Haven Company, gave up that position on October 22, 1913, and was elected President of The Connecticut Company on December 
24, 1913, President of the Housatonic Power Company on January 15th, 1914, and continued to act as Vice-President of the Berkshire, New York \& Stamford and Westchester Street Railway Companies.

Mr. A. E. Potter, on December 27th, 1913, was elected President of The Rhode Island Company, Mr. Elliott serving as Chairman of the Board of The Connecticut Company and The Rhode Island Company and President of the Berkshire, Stamford and Westchester Companies.

Mr. Elliott was also elected President of The New England Steamship Company and of The Hartford \& New York Transportation Company, Mr. J. Howland Gardner continuing as Vice-President of the Steamship Company and Mr. C. C. Goodrich as Vice-President of the Transportation Company.

Under this plan there has been created during the calendar year managements for the various affiliated companies practically independent of the New Haven Company.

In order to obtain closer supervision of operation the New Haven was sub-divided on October 15th, 1913, into two Operating Divisions, one is in charge of General Superintendent C. N. Woodward, with headquarters at Boston, who has 1,091.44 miles of railroad in charge, the other in charge of General Superintendent J. A. Droege, with headquarters at New Haven, with 860.58 miles of railroad.

The past year has been a most trying one for the Company, the owners of its securities, employees, officers and directors. That the Company has been able to sustain itself under the very disturbed conditions is evidence of its inherent strength. It has had to meet great loss in revenues, large increases in expenses; it has been the subject of exhaustive investigations and of much hostile criticism, of which no complaint is now made, but instead an appeal for fair treatment and constructive aid.

Among the conditions necessary for the success of the Company are :

First.-Freedom from disturbance and the opportunity for constructive work.

"There is much truth," said the Interstate Commerce Commission in its report of June 20,1913, on the New England situation, "in the claim of the carriers that they have been so occupied with investigations and so criticized by the public that no fair opportunity has been given for the operation of their railroad properties."

Second.-The removal of restrictions and conflicts in the laws and policies of the various New England States which prevent the Com- 
pany from adopting a comprehensive financial plan enabling it to meet its obligations by mortgage bonds.

Third.-A readiness on the part of Commissions, both State and National, to permit a readjustment and increase in freight and passenger rates; and an increase in the pay received for the carriage of mail and parcels post.

Fourth.-Adequate time for the Company to dispose of its investments in other companies. The Directors, as trustees for the stockholders, as well as in a large measure for the community served by the lines, should, for the protection of the property, its owners and the business of the New England States, not be forced to sacrifice these investments and at a time when values have been depressed by adverse criticism, controversy and generally poor business conditions.

The Directors and Officers are endeavoring most earnestly to conduct the affairs of the Company in a lawful, prudent and efficient manner, and are continuing to compact, improve, maintain and preserve the property in order to meet adequately the public demands and to benefit the stockholders. They will continue to strengthen its working organization, fully realizing that only with public confidence and support, and especially the co-operation of the various Commissions and governmental authorities, can the success of the Company be assured.

Your attention is directed to the tables hereto attached giving additional information about each of the properties in which your Company is interested.

The year opened with the staff of officers and the employees seriously disturbed and somewhat demoralized and discouraged because of the conditions and obstacles to be met and overcome. The efforts of the officers and employees have been directed to bringing about a better feeling towards the Company from the communities served, as well as to improving the operation of the various properties. The thanks of the owners of the property are due to the many loyal officers and employees who have rendered faithful service during the year under the most serious and most unusual conditions and obstacles.

Respectfully submitted by order of the Board of Directors.

Howard Elliott,

Chairman of the Board and

President of the Company. 


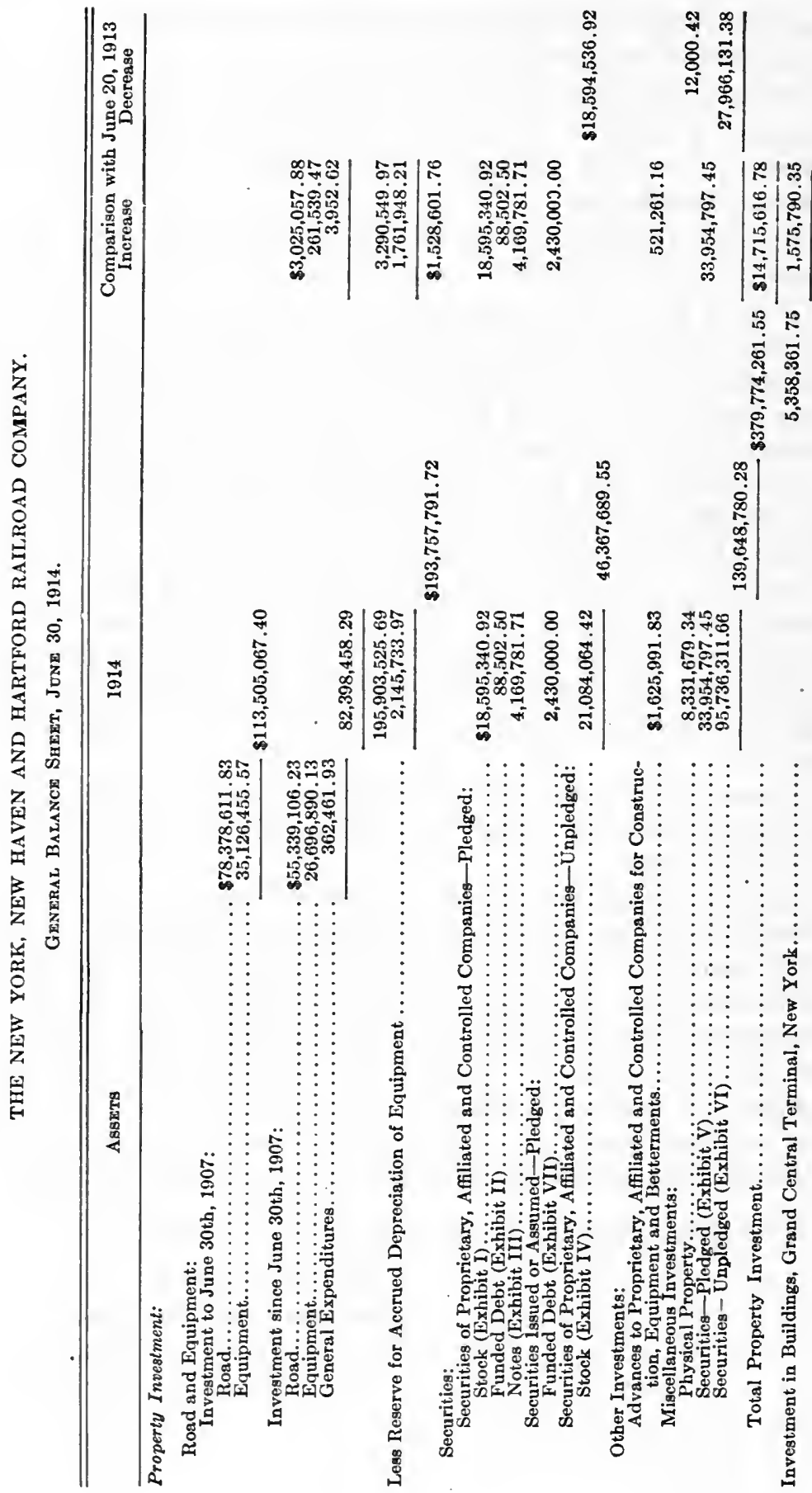


N. Y., N. H. \& H. RR. CO. REPORT, 1914709

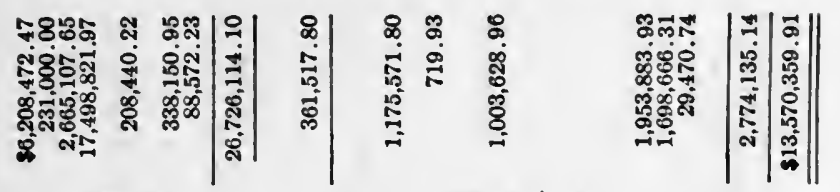

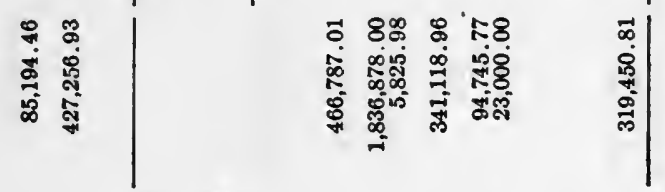

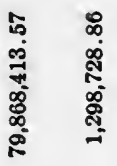

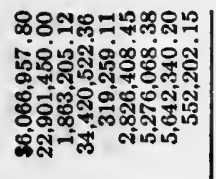

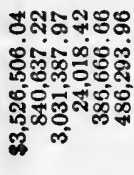

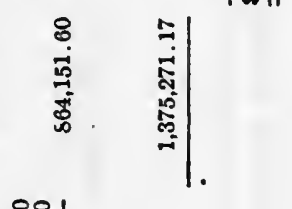

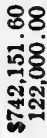

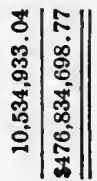

紫

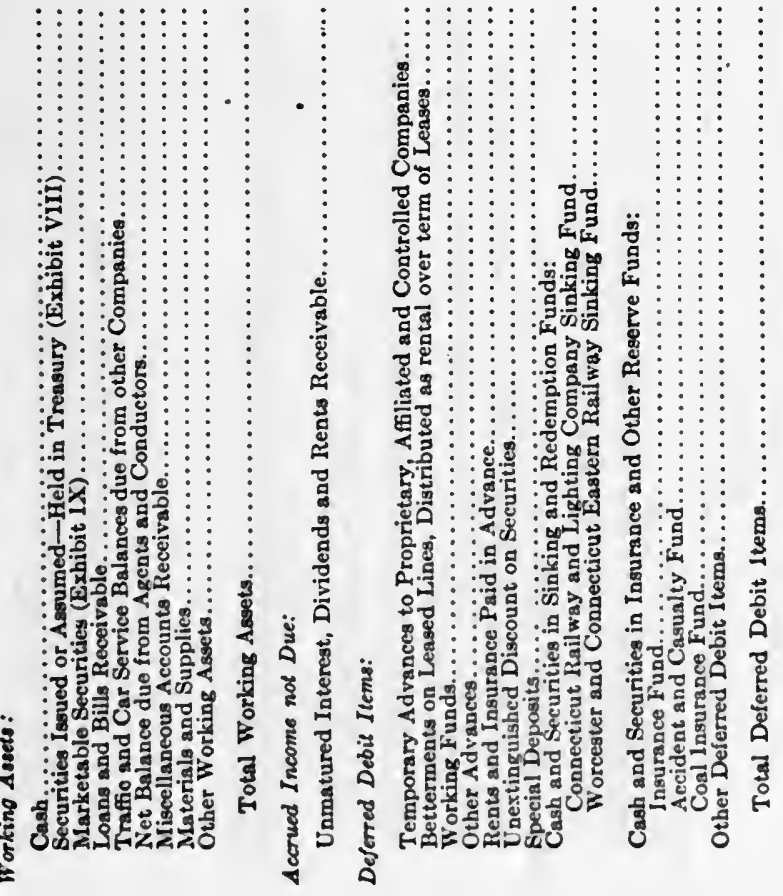




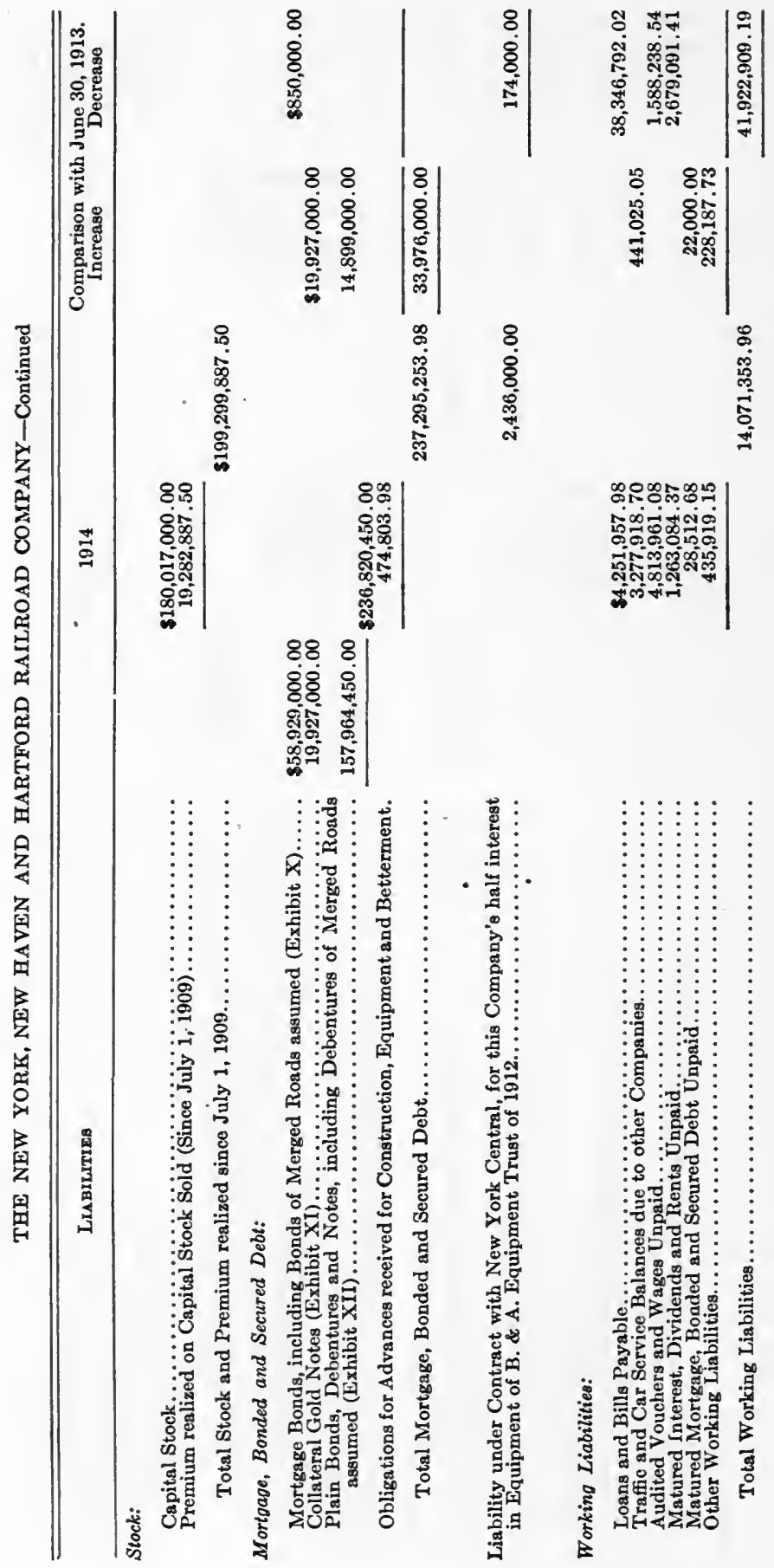


N. Y., N. H. \& H. RR. CO. REPORT, 1914711
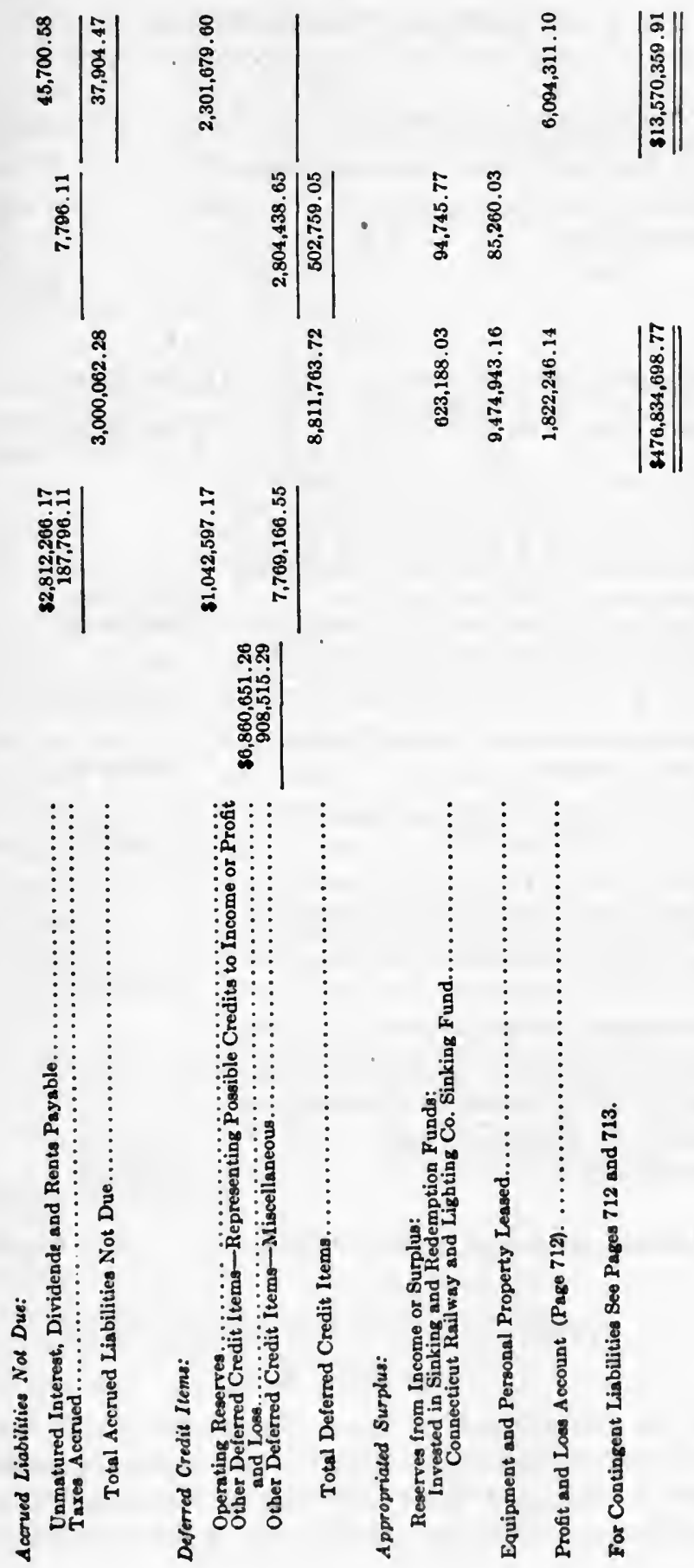


\section{PROFIT AND LOSS ACCOUNT}

\section{Credit}

Balance brought forward from June 30th, 1913 . . .

Credit balance of net income for the year........

Balance in Insurance Funds transferred to this

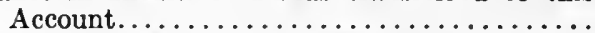

Adjustment of securities to par value..........

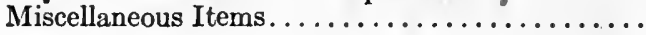

$\$ 7,916,557.24$

$268,662.87$

$1,983,354.67$

$123,720.53$

$25,863.55$

$\$ 10,318,158.86$

\section{DEBIT}

Dividend paid September 30th, 1913.

Loss resulting from the sale of securities of the chants \& Miners Transportation Co.........

$\$ 2,356,768.50$

$3,594,500.00$

Unamortized loss on the New York, Westchester \& Boston Ry. Co. bonds, which bonds were received in payment for advances to the New York, Westchester \& Boston Ry. Co. and the bonds sold to the public by the New Haven Company prior to the past fical year........

Loss on Treasury securities sold or reduced to par. Depreciation on equipment assigned to the Boston \& Albany R. R. prior to July 1st, 1913, under "Boston \& Albany Equipment Trust of 1912"

Depreciation prior to July 1st, 1913 on equipment

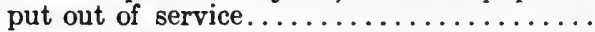

Franchise and other taxes at Grand Central Terminal proir to July 1st, $1913 . \ldots \ldots \ldots \ldots \ldots$.

$111,592.57$

Rental, Grand Central Palace, N. Y., for station facilities during construction of permanent station buildings, charges accruing prior to July 1st, 1913, the amount not determined until recently....................

$50 \%$ of net charges to Profit and Loss made by the Boston \& Albany R. R., assumed by the New Haven Company under agreement to share equally in the net results of the operation of the Boston \& Albany, which agreement was cancelled as of January 31st, 1914. . . . . . .

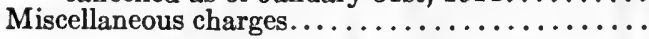

Balance June 30th, 1914, as per balance sheet... .

\section{STATEMENT OF CONTINGENT LIABILITIES}

$$
\text { June 30th, } 1914 .
$$

Under the provisions of Section 4, Chapter 519, of the Acts of the General Court of the Commonwealth of Massachusetts, passed at its 1909 session, The New York, New Haven and Hartford Railroad Company promises when they shall be sold, to guarantee the principal 
of, and the dividends and interest upon the capital stock, bonds, notes and other evidences of indebtedness of Boston Railroad Holding Company acquired by it. On June 15th, 1910, the General Court of the Commonwealth of Massachusetts passed an act authorizing the issue of preferred stock (without voting power) of Boston Railroad Holding Company, in exchange for its four per cent. fifty-year Debentures dated November 1st, 1909; and on January 10th, 1911, the $\$ 20$,012,000 Debentures owned by The New York, New Haren and Hartford Railroad Company were exchanged for preferred stock. On June 30 th, 1914, there were held by the public 28,000 shares of preferred stock of Boston Railroad Holding Company, on which the guaranty had been executed; and on the same date The New York, New Haven and Hartford Railroad Company held the following stock :

31,065 shares of Common Stock of Par Value. .\$3,106,500.00 244,939 shares of Preferred Stock of Par value. . 24,493,900.00

\section{THE NEW YORK, NEW HAVEN AND HARTFORD RAILROAD COMPANY}

Is liable jointly with other roads for any deficiency on foreclosure of bonds of the Boston Terminal Company.

Is liable by endorsement on $\$ 200,000$ six per cent. demand notes dated May 1st, 1914, of the Central New England Railway Company deposited as Collateral under Indenture dated May 1st, 1914, securing $\$ 20,000,000$ one year $5 \%$ Collateral Gold Notes of The New York, New Haven and Hartford Railroad Company.

Guarantees the payment of principal and interest of the four per cent. First Mortgage Gold Bonds of the Central New England Railway Company of the issue of January 1st, 1911, to the amount of $\$ 12,012,000$.

Is liable by endorsement on $\$ 1,325,000$ six per cent. demand notes dated May 1st, 1914, of The Connecticut Company deposited as Collateral under Indenture dated May 1st, 1914, securing $\$ 20,000,000$ one year 5\% Collateral Gold Notes of The New York, New Haven and Hartford Railroad Company.

Is liable by endorsement on $\$ 3,000,000$ six per cent. demand notes, Series "E," dated May 1, 1914, of The Harlem River and Port Chester Railroad Company deposited as Collateral under Indenture dated May 1st, 1914, securing $\$ 20,000,000$ one year $5 \%$ Collateral Gold Notes of The New York, New Haven and Hartford Railroad Company.

Guarantees the payment of principal and interest of The Harlem River and Port Chester Railroad Company one year 5\% Gold Notes, Series "A," dated May 1st, 1914, to the amount of $\$ 10,000,000$. 
Is liable by endorsement on $\$ 819,781.71$ five per cent. demand note dated September 22nd, 1911, of the Hartford and Connecticut Western Railroad Company (previously endorsed by the Central New England Railway Co.) deposited as Collateral under Indenture dated May 1st, 1914, securing $\$ 20,000,000$ one year 5\% Collateral Gold Notes of The New York, New Haven and Hartford Railroad Company.

Is liable by endorsement on $\$ 1,150,000$ six per cent. demand notes dated May 1st, 1914, of Housatonic Power Company deposited as Collateral under Indenture dated May 1st, 1914, securing $\$ 20,000,000$ one year $5 \%$ Collateral Gold Notes of The New York, New Haven and Hartford Railroad Company.

Guarantees the payment of principal of $\$ 300,000$ and interest on the $6 \%$ one year Notes of the Housatonic Power Company dated March 31st, 1914.

Guarantees four per cent. dividends on preferred stock of the New England Investment and Security Company, $\$ 4,000,000$, and payment of principal at one hundred five per cent. on liquidation; also guarantees the payment of principal, $\$ 5,000,000$ and interest of the New England Investment and Security Company fifteen-year Funding Gold Notes dated April 1st, 1909.

Guarantees the payment of principal and interest of the Gold Debenture of The New England Navigation Company in case of termination of lease of the Old Colony Railroad Company, $\$ 3,600,000$.

The New York, New Haven and Hartford Railroad Company and the Pennsylvania Railroad Company, jointly and severally, guarantee the payment of the principal and interest of the outstanding $\$ 16$,000,000.00 First Mortgage four and one-half per cent. Gold Bonds dated August 1st, 1913, due August 1st, 1953, of the New York Connecting Railroad Company.

Guarantees the payment of principal and interest of the four per cent. fifty-year First and Refunding Mortgage Gold Bonds of the New York and Stamford Railway Company, of the issue of November 1st, 1908 , to the amount of $\$ 925,000$.

Is liable by endorsement on $\$ 185,000$ six per cent. demand notes dated May 1st, 1914, of New York and Stamford Railway Company deposited as Collateral under Indenture dated May 1st, 1914, securing $\$ 20,000,000$ one year 5\% Collateral Gold Notes of The New York, New Haven and Hartford Railroad Company.

Guarantees the payment of principal and interest of the four and one-half per cent. First Mortgage Gold Bonds of The New York, Westchester and Boston Railway Company of the issue of July 1st, 1911 , to the amount of $\$ 21,200,000$. 
N. Y., N. H. \& H. RR. CO. REPORT, $1914 \quad 715$

Is liable by endorsement on $\$ 1,725,000$ six per cent. demand notes dated May 1st, 1914, of The Rhode Island Company deposited as Collateral under Indenture dated May 1st, 1914, securing $\$ 20,000,000$ one year 5\% Collateral Gold Notes of The New York, New Haven and Hartford Railroad Company.

Is liable by endorsement on $\$ 150,000$ five per cent. demand note dated May 1st, 1914, of Rutland Railroad Company deposited as Collateral under Indenture dated May 1st, 1914, securing $\$ 20,000,000$ one year $5 \%$ Collateral Gold Notes of The New York, New Haven and Hartford Railroad Company.

Guarantees four per cent. dividends on preferred stock of the Springfield Railway Companies, $\$ 3,387,900$, and payment of principal at one hundred five per cent. on liquidation. 


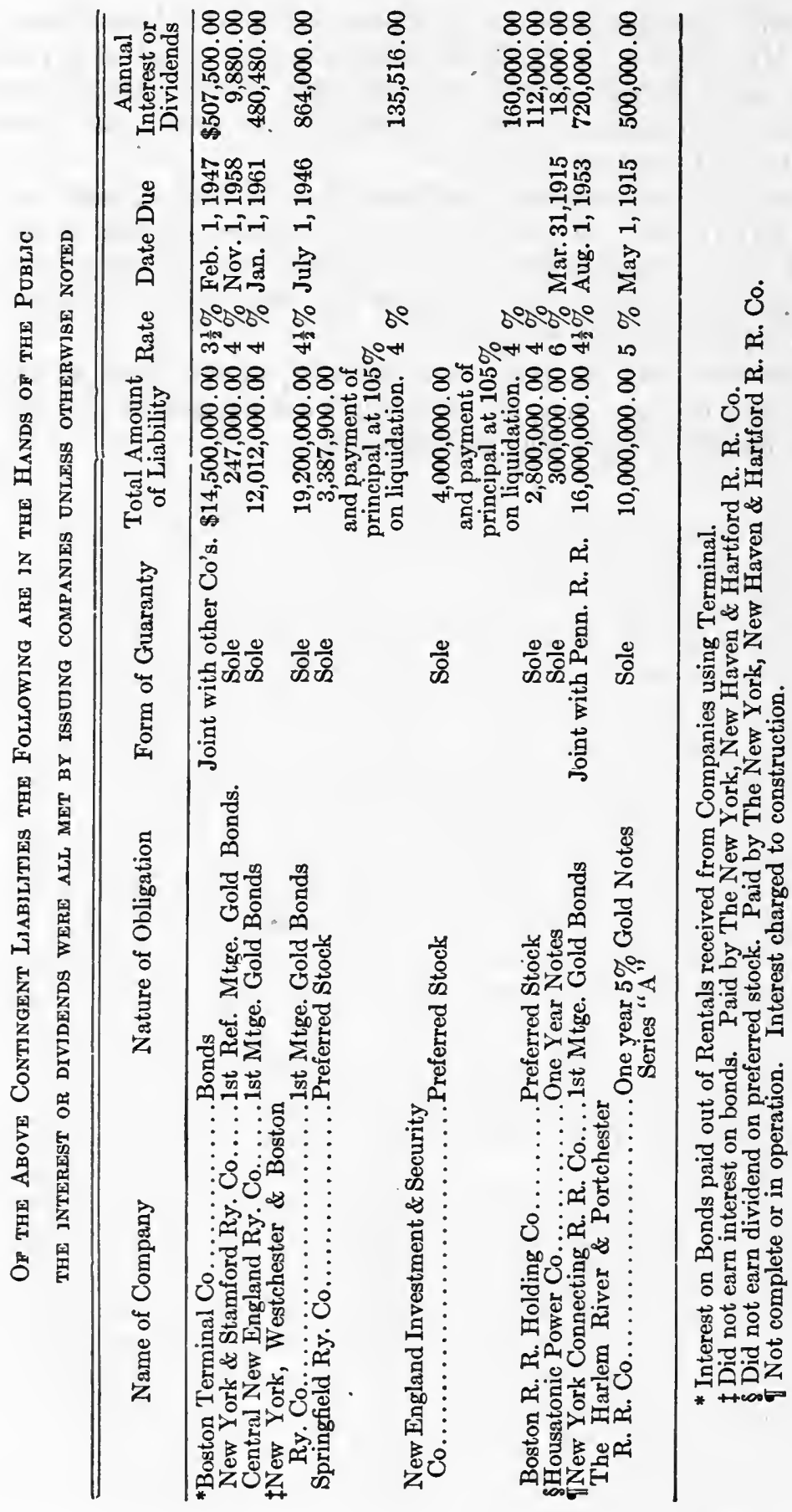


PLEDGED

SECURITIES OF PROPRIETARY, AFFILIATED AND CONTROLLED COMPANIES

\section{EXHIBIT I}

Number
of
Shares Book Value

\section{Stocks.}

Central New England Railway Co. Common Stock...............

Central New England Railway Co.

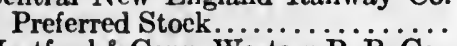

Hartford \& Conn. Western $\ddot{R} . \ddot{\mathrm{R}} . \ddot{\mathrm{Co}}$. New York, Ontario \& Western Ry.

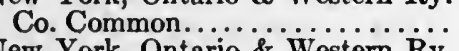
New York, Ontario \& Western Ry. Co. Preferred................

Rutland Railroad Co..............

Total....................

\begin{tabular}{rr}
47,920 & $868,566.55$ \\
37,360 & $1,052,335.91$ \\
17,482 & $1,201,063.69$ \\
291,600 & $13,105,185.62$ \\
22 & $3,212.00$ \\
$23,520 \frac{1}{2}$ & $2,364,977.15$ \\
\hline
\end{tabular}

$\$ 18,595,340.92$

\section{EXHIBIT II}

Par Value Book Value

\section{Funded Debt:}

Central New England Railway Co.

$4 \%$ First Mortgage Gold Bonds........ \$ \$85,000.00 \$\$8,502.50

\section{EXHIBIT III}

Rate of Interest Book Value

Notes:

Central New England Railway Co............

The Harlem River \& Port Chester R. R. Co... Hartford \& Conn. Western R. R. Co.......... Rutland Railroad Co.................... dated May 1st, 1914, securing 5\% Collateral Gold Notes. 


\section{EXHIBIT IV}

\section{SECURITIES OF PROPRIETARY, AFFILIATED AND CONTROLLED COMPANIES-UNPLEDGED}

\begin{tabular}{|c|c|c|c|}
\hline & $\begin{array}{l}\text { Number } \\
\text { of Shares }\end{array}$ & Book Value & \\
\hline \multicolumn{4}{|l|}{ STOCKS: } \\
\hline Boston \& Providence R. R. Corpora- & & & \\
\hline tion............ & $\begin{array}{l}5,246 \\
2,000\end{array}$ & $\begin{array}{r}\$ 1,582,443.18 \\
200,000.00\end{array}$ & \\
\hline Central New England Ry. Co. & & & \\
\hline Common Stock and Scrip........ & 30 & 543.90 & \\
\hline Central New England Ry. Co. & & & \\
\hline Preferred Stock and Scrip........ & 10 & 281.60 & \\
\hline $\begin{array}{l}\text { The Harlem River \& Port Chester } \\
\text { R. R. Co.............. }\end{array}$ & 10,000 & $1,000,000.00$ & \\
\hline Holyoke \& Westfield R. R. Co..... & 200 & $20,000.00$ & \\
\hline The New York Connecting R. R. Co. & 15,000 & $1,527,204.33$ & \\
\hline Norwich \& Worcester R. R. Co.... & 971 & $219,038.19$ & \\
\hline Old Colony R. R. Co.............. & 98,132 & $13,065,341.80$ & \\
\hline $\begin{array}{l}\text { Providence, Warren \& Bristol R. R. } \\
\text { Co. Common. . . . . . . . . }\end{array}$ & 4,867 & $730,212.67$ & \\
\hline $\begin{array}{l}\text { Providence, Warren \& Bristol R. R. } \\
\text { Co. Preferred. }\end{array}$ & 1 & 220.00 & \\
\hline Providence \& Worcester R. R. Co... & 9,551 & $2,738,762.75$ & \\
\hline Roxbury Central Wharf Co....... & 7 & 7.00 & \\
\hline South Bay Wharf \& Terminal Co... & 9 & 9.00 & \\
\hline TotaL.......... & & & $\$ 21,084,064.42$ \\
\hline
\end{tabular}

\section{EXHIBIT V}

MISCELLANEOUS INVESTMENTS-PLEDGED

\begin{tabular}{|c|c|c|}
\hline & $\begin{array}{c}\text { Number of } \\
\text { Shares }\end{array}$ & $\begin{array}{l}\text { Book } \\
\text { Value }\end{array}$ \\
\hline \multicolumn{3}{|l|}{ Sтоскs: } \\
\hline American Telephone \& Telegraph Co... & 314 & $\$ 37,782.56$ \\
\hline Concord \& Montreal R. R.............. & 2,469 & $395,765.70$ \\
\hline Connecticut \& Passumpsic Rivers R. R. Co... & 1,464 & $208,162.44$ \\
\hline Northern R. R. (of New Hampshire)......... & 922 & $130,750.27$ \\
\hline Pennsylvania Railroad Co.............. & 1,168 & $71,907.64$ \\
\hline The Rhode Island Co. . . . . . . . . . . & 96,855 & $24,352,336.41$ \\
\hline 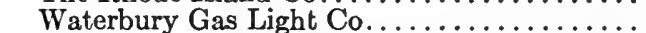 & 8,374 & $847,971.88$ \\
\hline
\end{tabular}

Bonds:

American Telephone \& Telegraph Co.

$4 \frac{1}{2} \%$ Gold Bonds due $1933 \ldots \ldots \ldots \ldots \ldots . \$ \$ 6,300.00$

$\$ 6,290.55$

Chicago, Burlington \& Quincy R. R. Co. (Ill. Div.)

$3 \frac{1}{2} \%$ Bonds due $1949 \ldots \ldots \ldots \ldots \ldots \ldots \ldots . \quad 10,000.00$

$9,150.00$

Chicago \& Eastern Illinois R. R. Co.

$5 \%$ Bonds due $1937 \ldots \ldots \ldots \ldots \ldots \ldots \ldots$.

Chicago, Rock Island \& Pacific R. R. Co. $4 \%$ General Mortgage Bonds due 1988.... .

New York, Westchester \& Boston Ry. Co. $4 \frac{1}{2} \%$ First Mortgage Gold Bonds due 1946 .

New York and Stamford Railway Co. $4 \%$ First and Refunding Mortgage Gold

Bonds due 1958.

The Vermont Company.

$$
22,000.00
$$

$25,300.00$

$38,000.00$

$38,000.00$

$2,000,000.00$

$2,000,000.00$

$5 \%$ First Mortgage Gold Bonds due 1931.. .

$678,000.00$

$599,880.00$

$846,000.00$

$846,500.00$ 
NoTES:

Housatonic Power Co...................

New York and Stamford Railway Co.........

The Connecticut Co......................

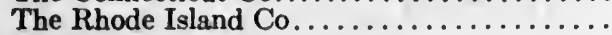

Total.

These securities comprise part of the Collateral Pledged under the Indenture dated May 1st, 1914, securing 5\% Collateral Gold Notes. \begin{tabular}{cr} 
Rate of Interest & \multicolumn{1}{c}{ Par Value } \\
$6 \%$ & $1,150,000.00$ \\
6 & $185,000.00$ \\
6 & $1,325,000.00$ \\
6 & $1,725,000.00$ \\
\hline & $\$ 33,954,797.45$
\end{tabular}

\section{EXHIBIT VI}

MISCELLANEOUS INVESTMENTS-UNPLEDGED

\begin{tabular}{c}
$\begin{array}{c}\text { Number } \\
\text { of } \\
\text { Shares }\end{array}$ Book Value \\
\hline
\end{tabular}

\section{STOCKs:}

Berkshire Street Railway Co.......

Boston Railroad Holding Co.

Preferred..... Ho. Holding Co... Common................. 31,065

Millbrook Co................... $\quad 1,000$

The New England Navigation Co.... 494,055

New York \& Stamford Railway Co..

New York, Westchester\& Boston Ry. Co. Stock and Scrip.............

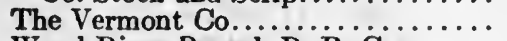

Wood River Branch R. R. Co......

The Westchester Street R. R. Co....

TotaL..................

$\begin{array}{rr}53,981 & \$ 6,371,395.58 \\ 244,939 & 24,493,900.00 \\ 31,065 & 3,106,500.00 \\ 1,000 & 100,000.00 \\ 494,055 & 53,322,899.48 \\ 5,000 & 610,643.40 \\ & \\ 49.249 & 6,241,951.76 \\ 6,500 & 571,164.31 \\ 336 & 21,477.50 \\ 7,000 & 896,379.63\end{array}$

$\$ 95,736,311.66$

\section{EXHIBIT VII}

\section{SECURITIES ISSUED OR ASSUMED-PLEDGED}

Par Value Book Value

\section{Fonden Debt:}

New York, Providence \& Boston R. R. Co. $4 \%$ General Mortgage Bonds, due April 1, 1942.......

The New York, New Haven \& Hartford R. R. Co. $6 \%$ Convertible Debenture Certificates, due January $15,1948 \ldots \ldots \ldots \ldots \ldots \ldots$ $31 / 2 \%$ Non-Convertible Debenture Certificates, due April 1, 1954. . $31 / 2 \%$ Convertible Debenture Certificates due, January 1, 1956. . $31 / 2 \%$ Non-Convertible Debenture Certificates, due March 1, 1947. Providence Seeurities Co. 4\% Fifty Year Gold Debentures, due May $1,1957 \ldots \ldots \ldots \ldots \ldots \ldots \ldots$.

Total..................

\author{
$\$ 247,000.00 \$ 247,000.00$
}

$$
\begin{array}{rr}
600,800.00 & 600,800.00 \\
2,100.00 & 2,100.00 \\
852,100.00 & 852,100.00 \\
9,000.00 & 9,000.00
\end{array}
$$

$719,000.00 \quad 719,000.00$

$\$ 2,430,000.00$

These securities comprise part of the Collateral Pledged under the Indenture dated May 1, 1914, securing 5\% Collateral Gold Notes. 
EXHIBIT VIII

SECURITIES ISSUED OR ASSUMED, HELD IN TREASURYUNPLEDGED

Number of Book Value

Shares

STOCKs:

The New York, New Haven \& Hart-

ford R. R. Co...............

$228,991 \$ 22,899,100.00 \$ 22,899,100.00$

Funded Debt:

The Consolidated Ry. Co. 3, 31/2 and

$4 \%$ Debentures and Scrip........

Par Value Book Value

$\$ 2,350.00 \$ 2,350.00$

$2,350.00$

Total.................

$\$ 22,901,450.00$

\section{EXHIBIT IX}

MARKETABLE SECURITIES

ב.

STOCKs:

Boston \& Lowell R. R. Corporation.

City National Bank, Holyoke.......

Connecticut River R. R. Co.........

Concord \& Portsmouth R. R. Co...

Hereford Railway Co..............

Iron Works Aqueduct \& Water Co...

Lowell \& Andover R. R. Co........

Manchester \& Lawrence R. R. Co...

Massawippi Valley Railway Co......

Nashua \& Lowell R. R. Co........

Pemigewasset Valley R. R. Co......

Peterborough R. R. Co............

Pittsfield \& North Adams R. R. Corp.

Quincy Quarries Co..............

Upper Coos R. R. Co................

Vermont \& Massachusetts R. R. Co..

Village Water Co., New Hartford . . . .

Westinghouse Air Brake Co.........

Wilton R. R. Co................

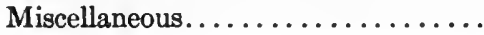

Funded Debt:

Berkshire Street Ry. Co. 5\% 20 year Gold Debentures..............

Central New England Ry. Co. $\ddot{5} \%$

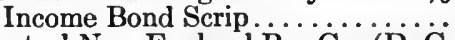

Central New England Ry. Co. (D. C. R. R.) $41 / 2 \%$ First Mortgage Gold Bonds.......................

Park Square Theatre Co., Inc., $\mathbf{5} \%$ Second Mortgage Notes. .........

Wood River Branch R. R. Co. $5 \frac{1}{2} \% \%$ First Mortgage Bonds...........

Pawtuxet Valley Electric Street $\mathrm{Ry}$.

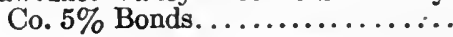

Par Value

$412 \$ 88,775.13$

$100 \quad 11,500.00$

$1,015 \quad 276,220.04$

$18 \quad 3,285.00$

$246 \quad 21,928.77$

12 Interest 100.00

$193 \quad 41,919.26$

$63 \quad 14,081.66$

$354 \quad 46,020.00$

$84 \quad 20,170.51$

$710 \quad 99,676.51$

$86 \quad 8,390.00$

$50 \quad 6,965.26$

$38 \quad 2,110.00$

$73 \quad 10,242.75$

$184 \quad 30,439.77$

$2 \quad 24.00$

967.00

$98 \quad 21,389.14$

$2,500.00$

$\$ 200,000.00 \$ 200,000.00$

$608.50 \quad 608.50$

$5,000.00 \quad 5,230.00$

$320,000.00 \quad 320,000.00$

$56,500.00 \quad 28,250.00$

$38,000.00 \quad 39,900.00$

\section{$\$ 706,704.80$}


N. Y., N. H. \& H. RR. CO. REPORT, 1914721

Norms: Rate of Interest Par Value

City Lumber and Coal Co......... $\quad 5 \% \quad \$ 15,000.00$

P. C. Larkin ................ $5 \quad 5 \quad 63,894.05$

Providence, Warren \& Bristol $\stackrel{R}{R}$. R.

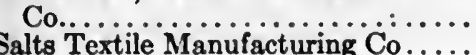

Shearer Realty Trust Co............

Rutland Railroad Co................

Trustees of the Massachusetts Automobile Club Trust ...............

Waterbury Lumber \& Coal Co......

Ida V. Whitney ..................

$6 \quad 38,617.77$

$575,000.00$

$5 \quad 200,000.00$

$5 \quad 50,000.00$

$5 \quad 90,000.00$

$5 \quad 5,000.00$

$41 / 2 \quad 25,000.00$

$\$ 562,511.82$

ToraL..................

$\$ 1,863,205.12$ 


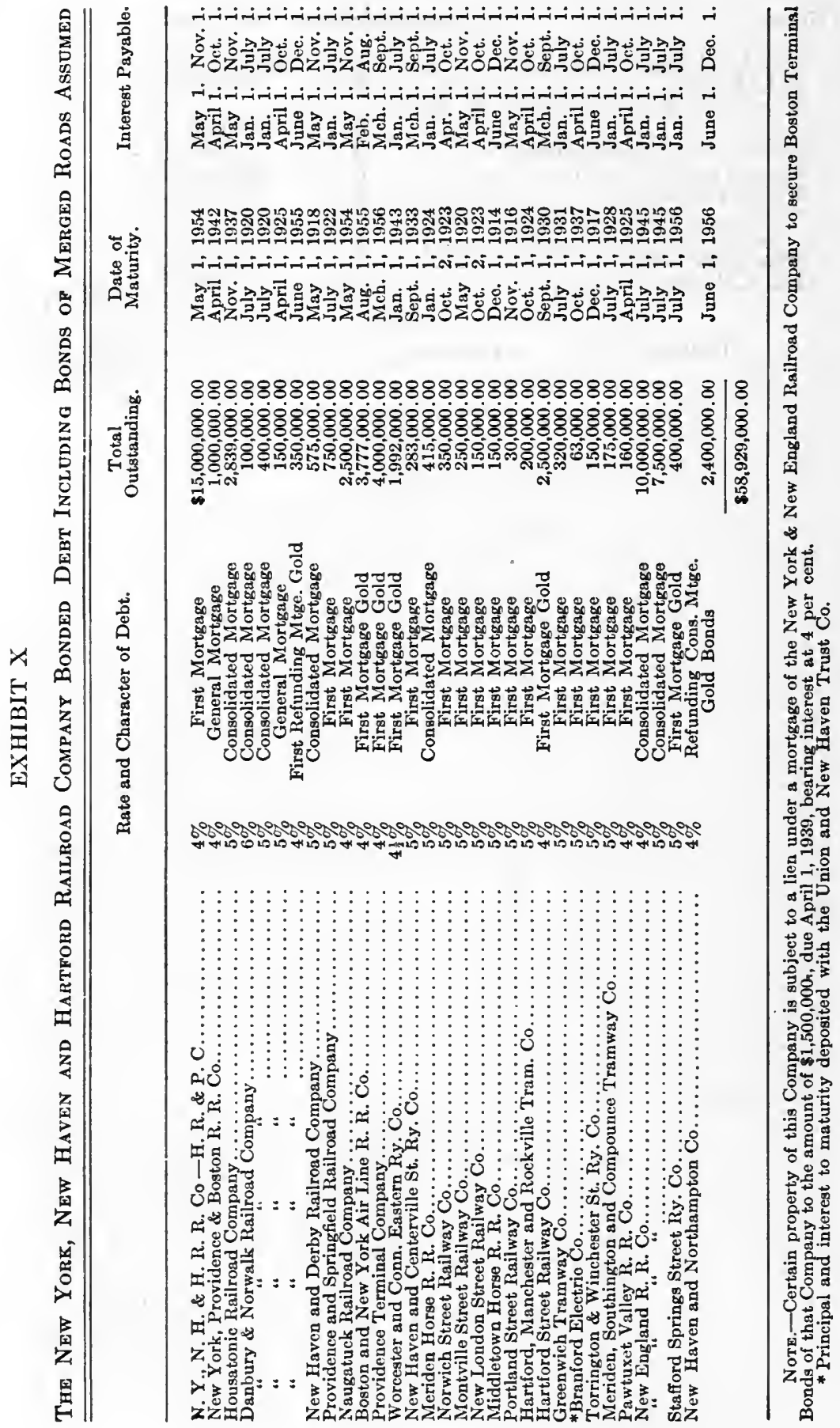




\section{EXHIBIT XI}

Tue New York, New Haven and Hartyord Railroad Company Collateral Gold Notes

5\% Collateral Gold Notes dated May 1st, 1914, due May 1st, 1915. Total Outstanding, $\$ 19,927,000.00$.

Interest payable May 1st and November 1st. For list of collateral pledged as security see pages 717-719. Exhibits 1, 2, 3, 5, 7 .

\section{EXHIBIT XII}

New York, New Haven \& Hartford Railroad Company Debentures Including Debentures of Merged Roads Assumed

\begin{tabular}{|c|c|c|c|}
\hline & $\begin{array}{c}\text { Total } \\
\text { Outstanding }\end{array}$ & $\begin{array}{l}\text { Date of } \\
\text { Maturity }\end{array}$ & Interest Payable \\
\hline 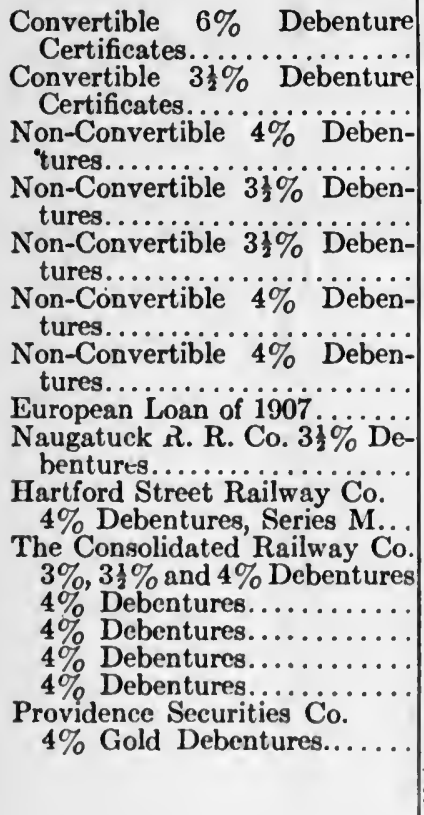 & $\begin{array}{r}\$ 39,029,000.00 \\
9,765,450.00 \\
5,000,000.00 \\
5,000,000.00 \\
10,000,000.00 \\
15,000,000.00 \\
15,000,000.00 \\
27,985,000.00 \\
234,000.00 \\
165,000.00 \\
972,000.00 \\
4,255,000.00 \\
2,309,000.00 \\
1,340,000.00 \\
2,011,000.00 \\
19,899,000.00\end{array}$ & $\begin{array}{lr}\text { Jan. } & 15,1948 \\
\text { Jan. } & 1,1956 \\
\text { Mch. } & 1,1947 \\
\text { Mch. } & 1,1947 \\
\text { April } & 1,1954 \\
\text { July } & 1,1955 \\
\text { May } & 1,1956 \\
\text { April } & 1,1922 \\
\text { Oct. } & 1,1930 \\
\text { Jan. } & 1,1930 \\
\text { Feb. } & 1,1930 \\
\text { July } & 1,1954 \\
\text { Jan. } & 1,1955 \\
\text { April } & 1,1955 \\
\text { Jan. } & 1,1956 \\
\text { May } & 1,1957\end{array}$ & $\begin{array}{llll}\text { Jan. } & 15 . & \text { July } & 15 \\
\text { Jan. } & 1 . & \text { July } & 1 \\
\text { Mch. } & 1 . & \text { Sept. } & 1 \\
\text { Mch. } & 1 . & \text { Sept. } & 1 \\
\text { April } & 1 . & \text { Oct } & 1 \\
\text { Jan. } & 1 . & \text { July } & 1 \\
\text { May } & 1 . & \text { Nov. } & 1 \\
\text { April } & 1 . & \text { Oct. } & 1 \\
\text { April } & 1 . & \text { Oct. } & 1 \\
\text { Jan. } & 15 . & \text { July } & 15 \\
\text { Feb. } & 1 . & \text { Aug. } & 1 \\
\text { Jan. } & 1 . & \text { July } & 1 \\
\text { Jan. } & 1 . & \text { July } & 1 \\
\text { April } & 1 . & \text { Oct. } & 1 \\
\text { Jan. } & 1 . & \text { July } & 1 \\
\text { May } & 1 . & \text { Nov. } & 1\end{array}$ \\
\hline
\end{tabular}


724 MATERIALS OF CORPORATION FINANCE

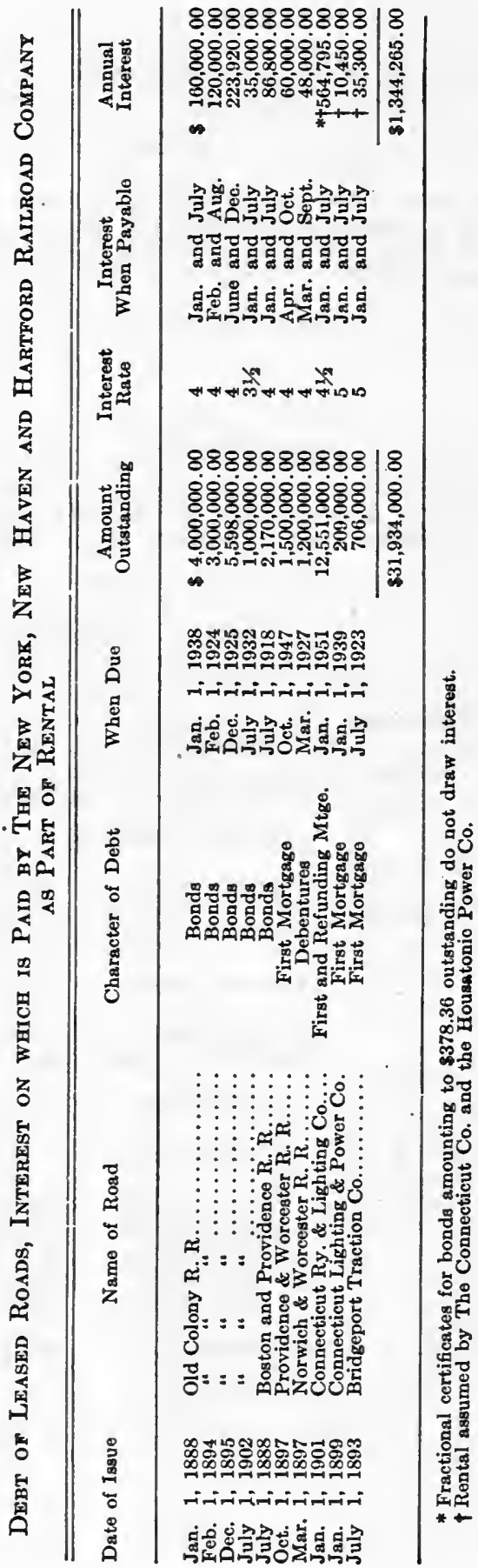


Rentals of Leased Lines

For the Year Ending June 30, 1914, in Comparison with Year 1913

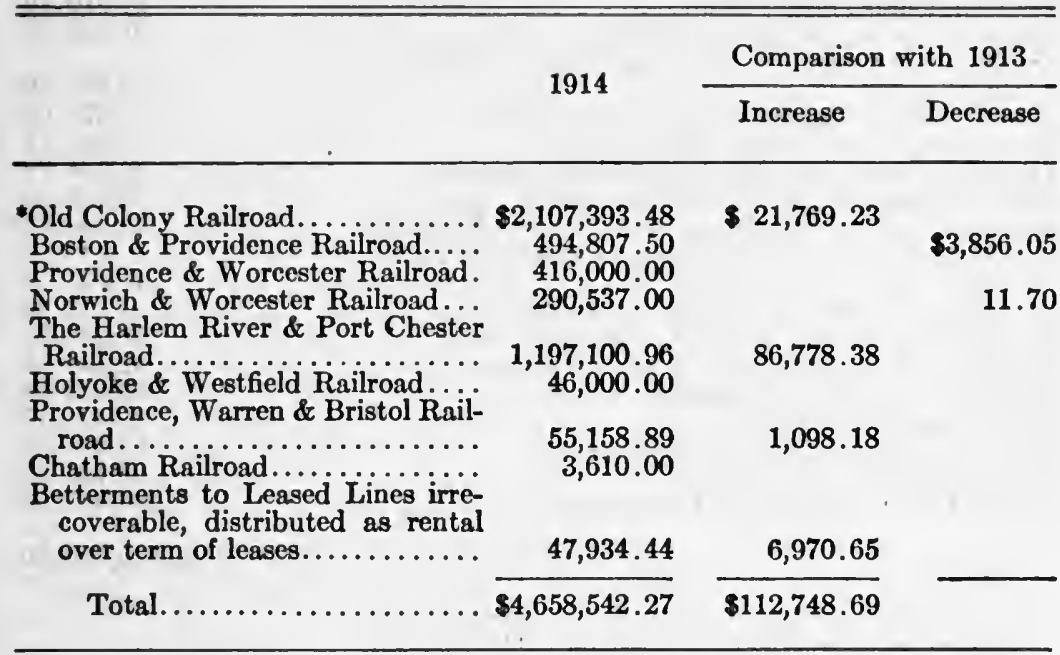

* There has been no increase in the Capital Stock of the Old Colony Railroad Company during the past fiscal year.

\section{ADDITIONS AND BETTERMENTS}

Year Ending June 30, 1914

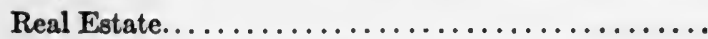

New or Improved Bridges:

New London, Conn

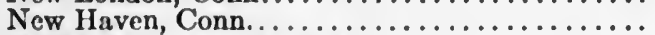

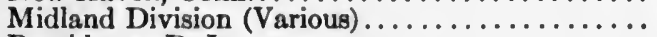

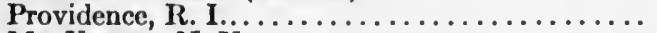

Mt. Vernon, N. Y . . . . . . . . . . .

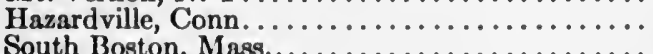

$24,548.52$

$16,136.95$

$13,452.91$

$8,348.48$

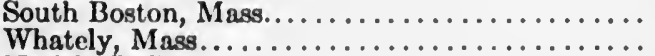

Natick, $\mathbf{R}$. I . . . . . . . . . . . . . . . .

$6,257.76$

$5,490.50$

$5,000.03$

Sundry Places.

$15,157.97$ 
Brought forward.

Glenbrook, Conn. - New Haven, Conn., Electrifica-

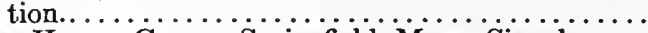

New Haven, Conn. - Springfield, Mass., Signals .....

Stamford, Conn.-New Haven, Conn., Signals.......

Berkshire Jct., Conn.-New Milford, Conn., Dcuble Tracking.

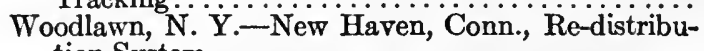

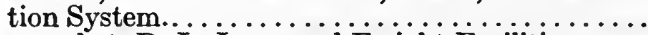

Woonsocket, R. I., Improved Freight Facilities.......

Cos Cob, Conn., Power Plant..................

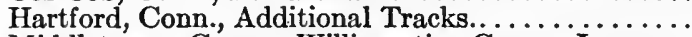

Middletown, Conn.-Willimantic, Conn... Improve-

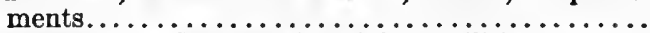

Bradford, R. I., Improved Freight Facilities..........

Stonington, Conn., Track Improvements.............

Torrington, Conn. Freight House Improvements......

New Rochelle Jct., N. Y., Revision Track Layout...

Stamford, Conn.-Woodlawn, N. Y., Circuit Breakers

New Haven, Conn., Re-arrangement Telephone Facil-

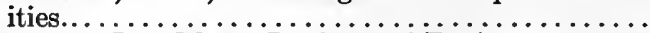

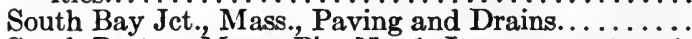

South Boston, Mass., Pier No. 1, Improvements...

Olneyville, R. I., Temporary Freight Facilities . . . . . .

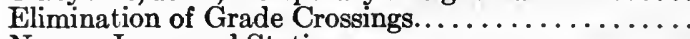

New or Improved Stations.. . . . . . . . . . . . . .

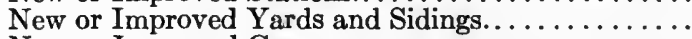

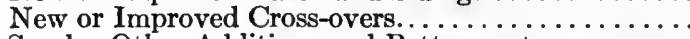

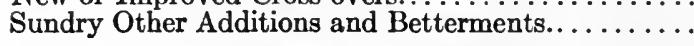

$\$ 186,681.21$

$955,610.47$

$216,660.36$

$192,369.61$

$153,094.76$

$124,251.06$

$67,839.99$

$51,910.10$

$31,061.79$

$24,902.19$

$22,878.05$

$22,603.71$

$19,954.78$

$19,759.02$

$18,946.15$

$16,977.78$

$14,718.34$

$13,984.35$

$12,534.68$

233,913.84

$16,571.17$

$64,831.51$

$24,105.58$

248,663.65

$\$ 3,029,010.50$

New Equipment, consisting of 3 electric locomotives, 34 steel coaches, 6 steel postal cars, 1 steel smoker, 20 milk cars, 3 steel floats, 1 steam locomotive crane, 1 transformer, 1 rail unloader, 20 passenger and freight cars converted to freight train cars and 262 passenger and freight train cars converted into work cars and tool cars................

Less:

$\$ 4,083,669.57$

Equipment put out of Service and Equipment transferred to Equipment Trust..................

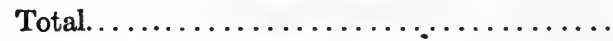

$793,119.60$

$\$ 3,290,549.97$

These expenditures were disposed of as under:

Charged to Cost of Road..................

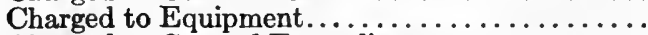

Charged to General Expenditures...............

$\$ 3,025,057.88$

$261,539.47$

$3,952.62$

$\$ 3,290,549.97$ 
ร ๑๐్

ค :

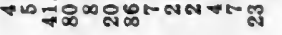

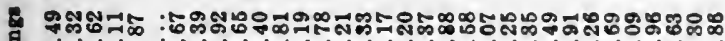

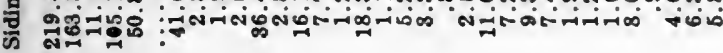

:ஐํำ-

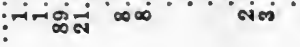

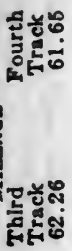

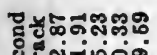

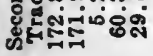

$:$ : :

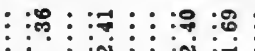

$: \begin{gathered}\infty \\ \vdots \\ \vdots \\ \vdots \\ \vdots\end{gathered}$

๑

:문으 :

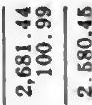

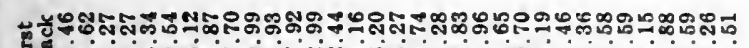

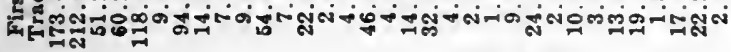

ลิ ลิ

안

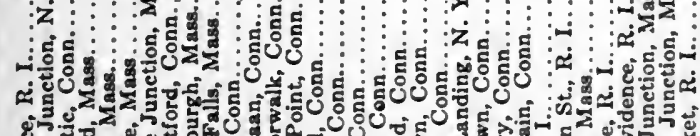

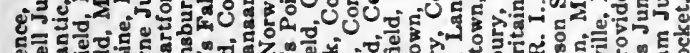

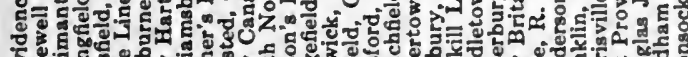

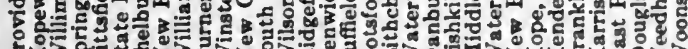

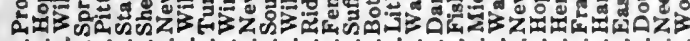

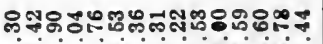

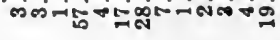

E

$\vdots: \vdots:$

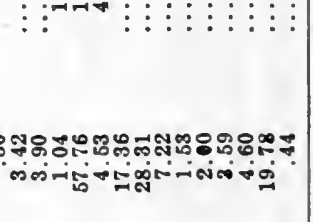

:

-iंs

:

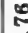

6

ธุ

ชัช

옹

กำ

$z$
$z$
$z$

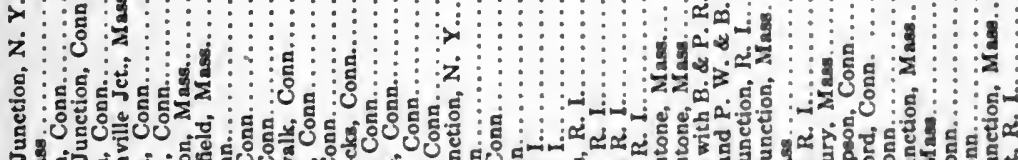
5 . EN 7. 定

:

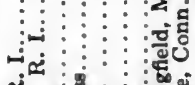

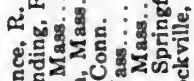

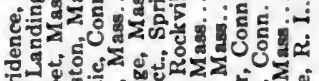

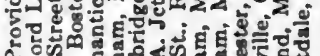
مै

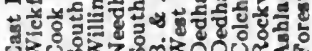
\&

نه

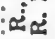

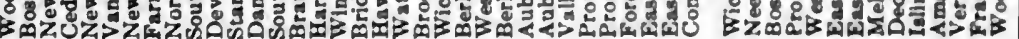




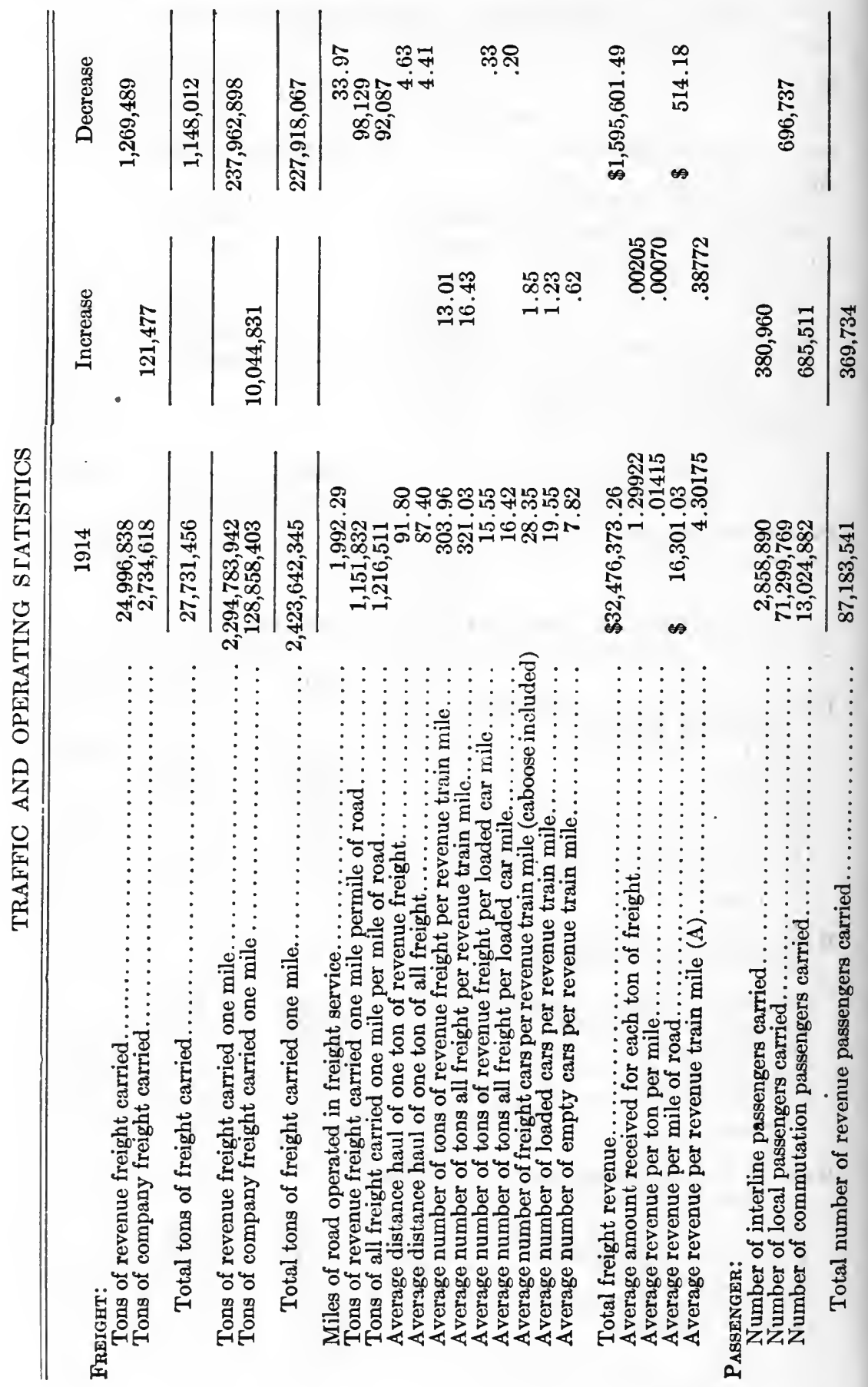


730 MATERIALS OF CORPORATION FINANCE

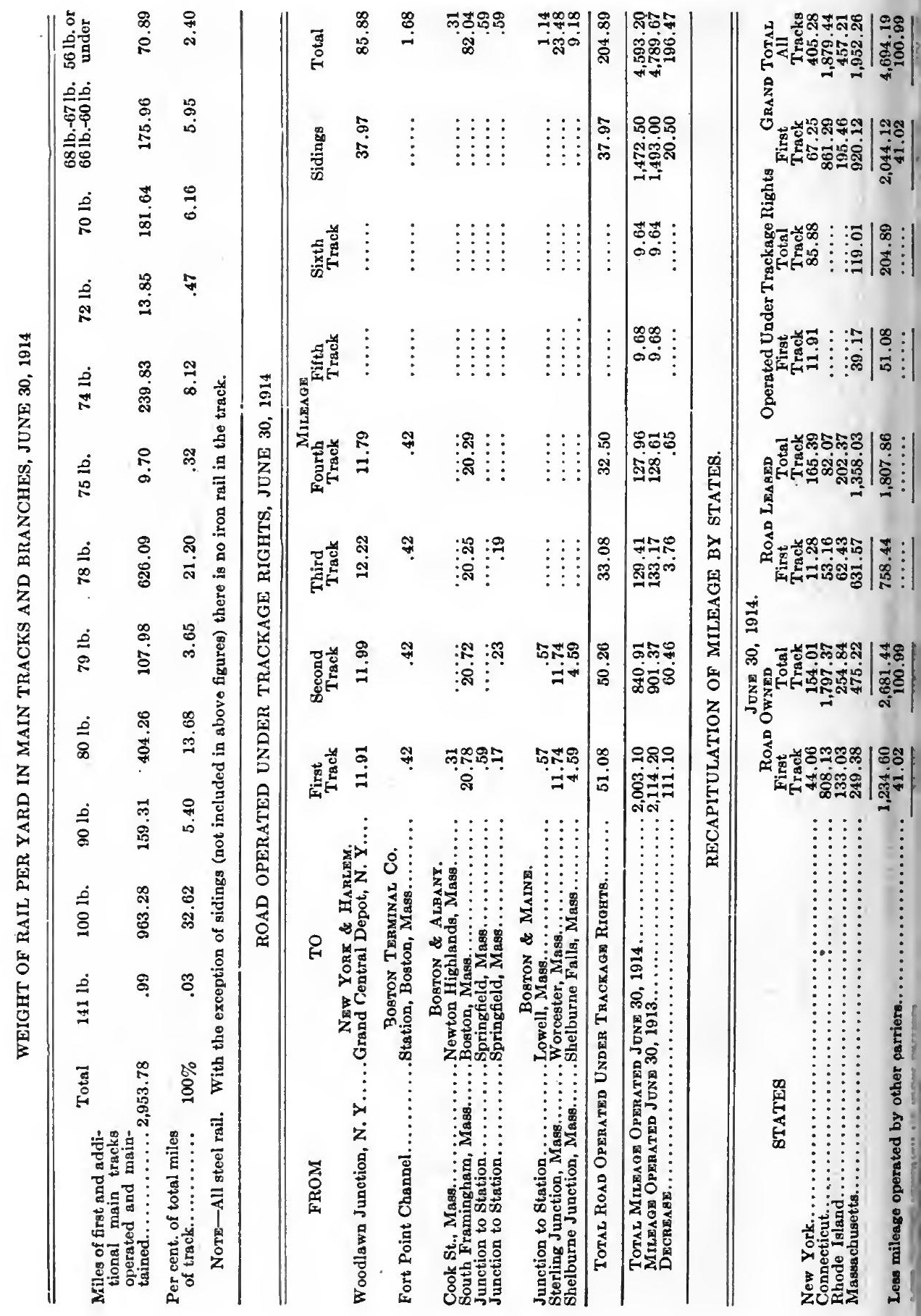


N. Y., N. H. \& H. RR. CO. REPORT, 1914731

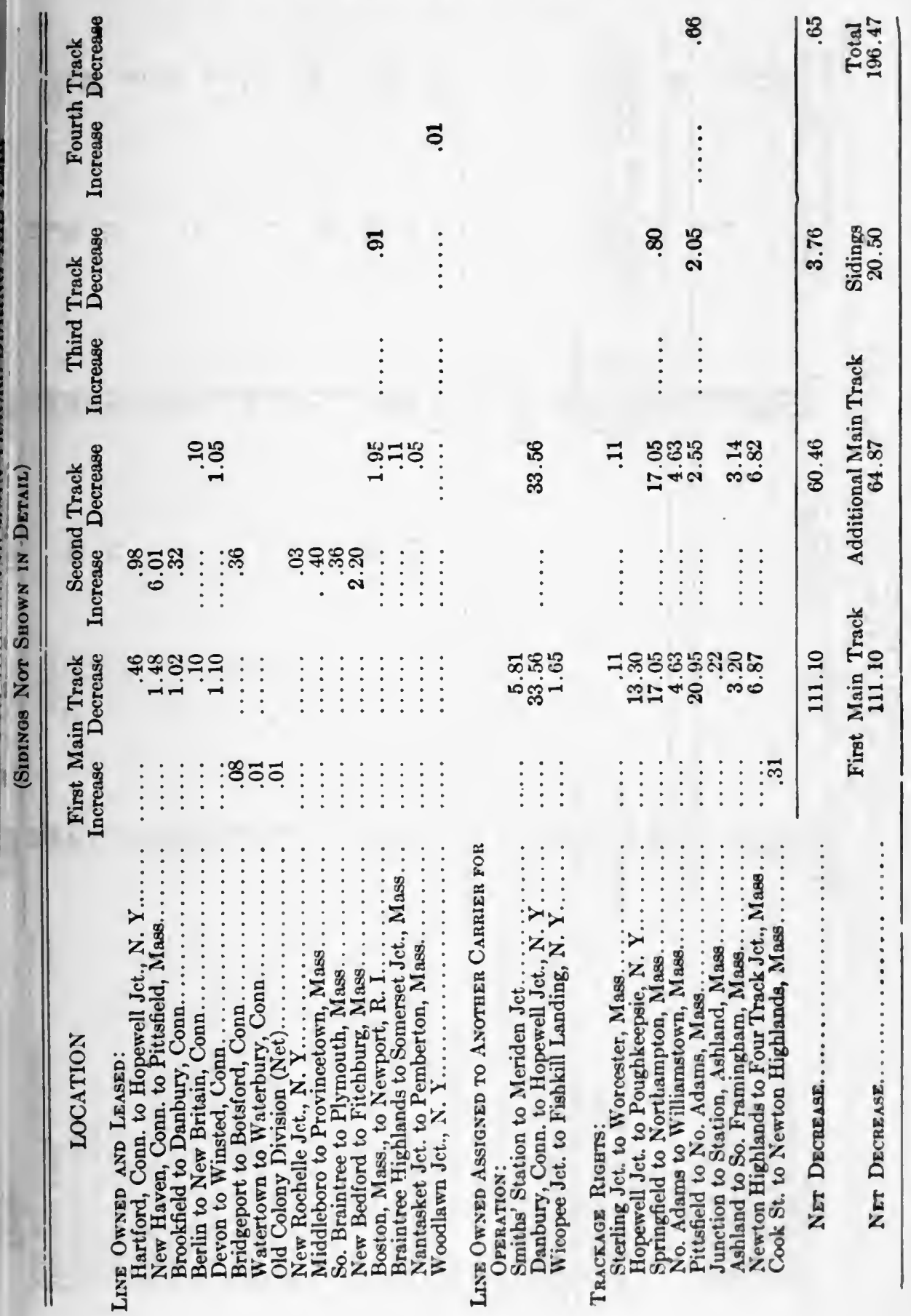




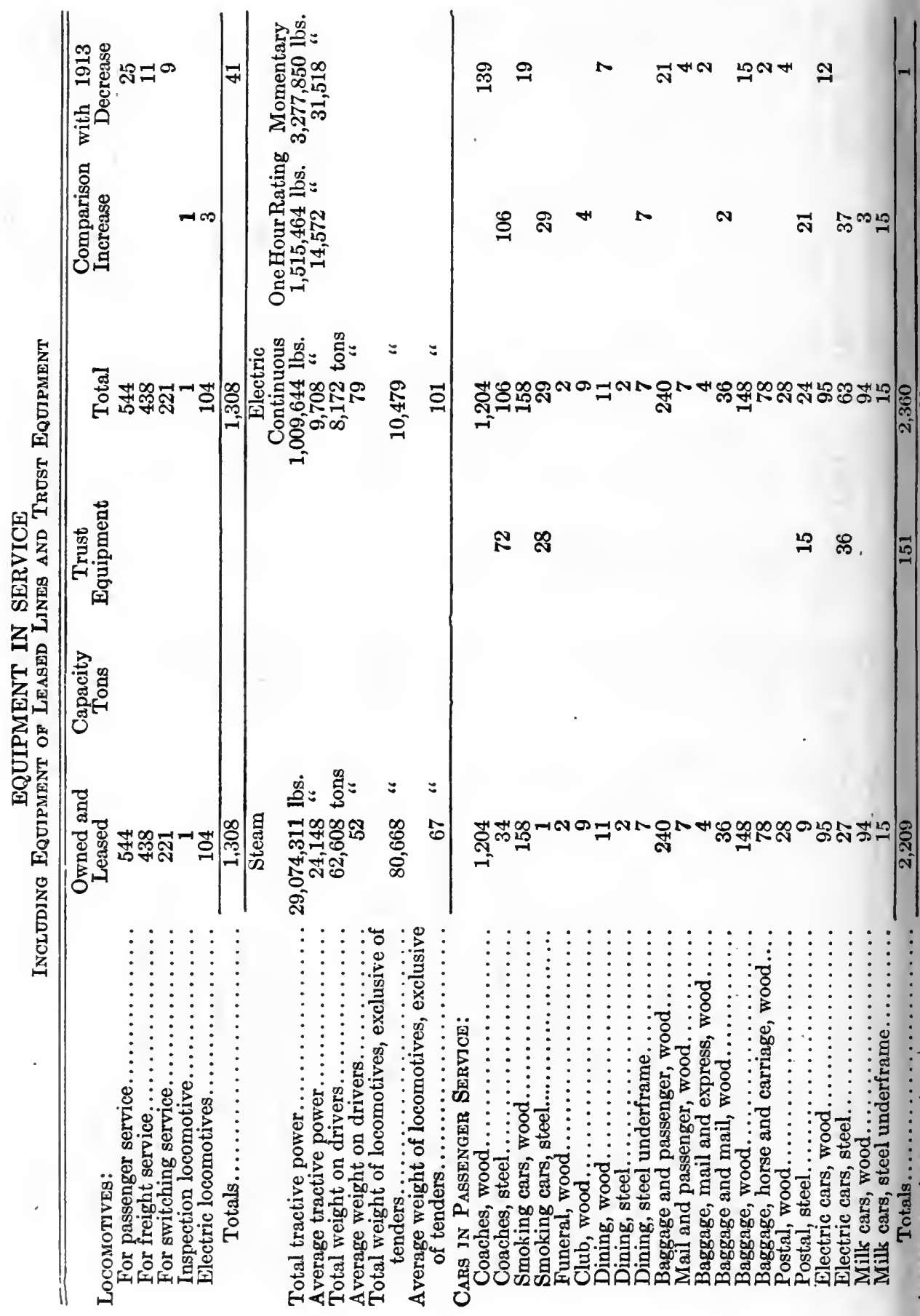


N. Y., N. H. \& H. RR. CO. REPORT, 1914733

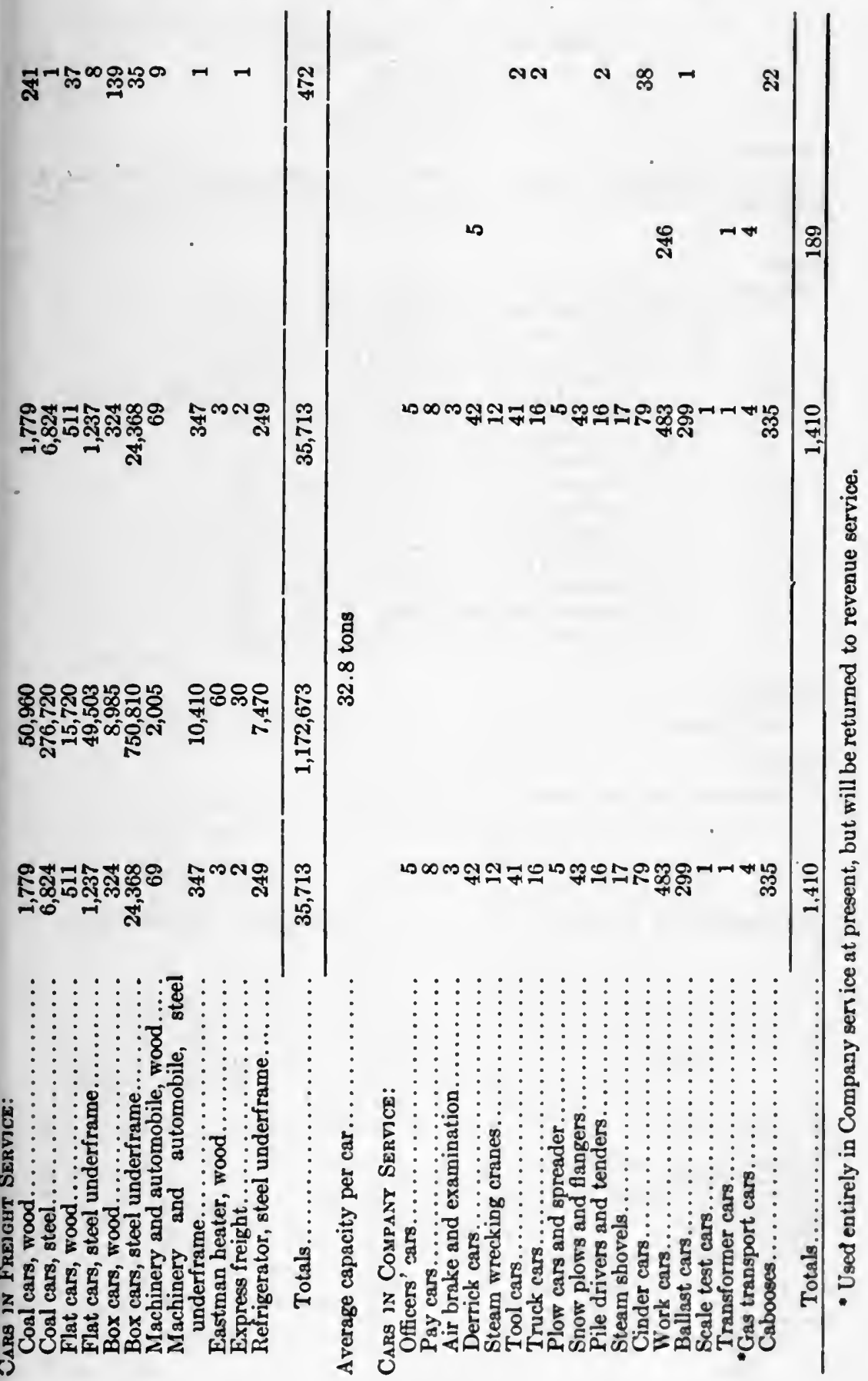




\title{
EQUIPMENT IN SERVICE
}

\author{
$\therefore$ (Continued)
}

\section{Steamer:}

\section{FLOATING STOCK}

Ferryboat Fairhaven, length over all, 94 feet; breadth over guards, 26 feet, 2 inches; depth 10 feet; vertical beam engine, cylinder 30 inches diameter, stroke 6 feet.

\section{Tugs:}

Transfer No. 2, simple engine, cylinder $26^{\prime \prime} \times 30^{\prime \prime}$.
" "5, compound engine, cylinders $22^{\prime \prime}-40^{\prime \prime} \times 26^{\prime \prime}$.
“ $" 6$, compound engine, cylinders $22^{\prime \prime}-40^{\prime \prime} \times 26^{\prime \prime}$.
" "7, compound engine, cylinders $20^{\prime \prime}-40^{\prime \prime} \times 28^{\prime \prime}$.
" " 8, compound engine, cylinders $20^{\prime \prime}-40 " \times 20^{\prime \prime}$.
“ "9, (Steam Lighter), compound engine, cylinders $20^{\prime \prime}-40^{\prime \prime} \times 28^{\prime \prime}$.
“ " 10 , compound engine, cylinders 22 " -40 " $\times 26^{\prime \prime}$.
“ “ 11 , compound engine, cylinders $20^{\prime \prime}-40^{\prime \prime} \times 28^{\prime \prime}$.
" " 12 , compound engine, cylinders $20 "-40 " \times 20^{\prime \prime}$.
" "14, compound engine, cylinders $22^{\prime \prime}-48^{\prime \prime} \times 36^{\prime \prime}$.
“ " 15 , compound engine, cylinders $22^{\prime \prime}-48^{\prime \prime} \times 36^{\prime \prime}$.
" " 16, compound engine, cylinders $20^{\prime \prime}-44^{\prime \prime} \times 30^{\prime \prime}$.
" " 17 , compound engine, cylinders $20^{\prime \prime}-44^{\prime \prime} \times 30^{\prime \prime}$.
" " 18, compound engine, cylinders $20^{\prime \prime}-44^{\prime \prime} \times 30^{\prime \prime}$.
" " 19 , compound engine, cylinders $20^{\prime \prime}-44^{\prime \prime} \times 30^{\prime \prime}$.
" " 20 , compound engine, cylinders $20 "-44 "$ × $30 "$.
" " 21 , compound engine, cylinders $20^{\prime \prime}-44^{\prime \prime} \times 30^{\circ}$.
“ " 22 , compound engine, cylinders $20^{\prime \prime}-44^{\prime \prime} \times 30^{\prime \prime}$.

\section{Car Floats:}

8-car, 9; 10-car, 8; 12-car, 8; 14-car, 2; 20-car, 10; 22-car, 17; T'otal, 54.

\section{DERrick:}

"Americus," hoisting capacity 20 tons.

STATEMENT OF EARNINGS AND OPERATING EXPENSES OF THE STEAM

\section{RAILROAD IN DETAIL}

For the Year Endino June 30, 1914, in Comparison with the Year 1913

\begin{tabular}{|c|c|c|c|c|}
\hline REVENUE & \multicolumn{2}{|c|}{$\begin{array}{c}1914 \\
2,046.29 \text { miles operated }\end{array}$} & \multicolumn{2}{|c|}{$\begin{array}{l}\text { Comparison with } 1913 \\
\text { Inc ease Decrease } \\
46.20 \text { miles }\end{array}$} \\
\hline Freight Revende............ & . & $\$ 32,476,373.26$ & & $\$ 1,595,601.49$ \\
\hline 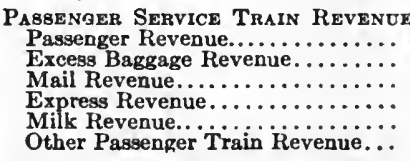 & $\begin{array}{r}\$ 27,400,672.89 \\
142,685.17 \\
724,309.91 \\
2,849,652.42 \\
103,997.74 \\
586,899.66\end{array}$ & & $\begin{array}{r}80,455.68 \\
436.13 \\
198,177.34\end{array}$ & $\begin{array}{r}495,627.40 \\
1,233.36 \\
307,378.75\end{array}$ \\
\hline 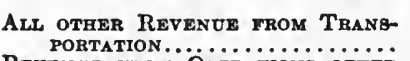 & & $364,663.95$ & $24,887.20$ & \\
\hline $\begin{array}{l}\text { REVENCE FROM OPERATIONB OTHER } \\
\text { THAN TRANBPORTATION......... }\end{array}$ & & $1,968,437.82$ & $100,074.39$ & \\
\hline Tотад............... & & $\$ 66,617,692.82$ & & $\$ 1,995,810.26$ \\
\hline
\end{tabular}




\section{OPERATING EXPENSES}

Maintenance or Wat and StrucTURE8:

Superintendence..............

Ballast......................

Ties.........................

Rails.............................

Other Track Material..............

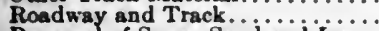

Removal of Snow, Sand and Ice...

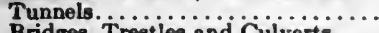

Bridges, Trestles and Culverts.....

Over and Under Grade Crossings...

Grade Crossings, Fences, Cattlo

Guards and Signa.............

Snow, Sand Fences and Snow Sheds

Signal and Interlocking Plants....

Telegraph and Telephone Lines....

Electrie Power Transmission......

Buildings, Fixtures and Grounds...

Docka and Wharvea..............

Roadway Toola and Supplies......

Injuries to Persons...............

Stationery and Printing..............

Other Expenses..........................

Maintaining Join: Tracks, Yards, Maintaining Joint Tracks..... Yards,

- $369,252.08$ $16,177.03$

$1,460,049.94$ $501,273.96$ 383,099.51

$2,406,202.63$

$164,580.45$

$1,168.00$

$382,579.82$

$144,317.88$

$131,071.63$

26.45

$679,249.40$

$53,007.51$

$307,123.73$

$879,681.01$

$110,502.97$

$71,052.51$

$73,836.71$

$8,260.94$

6.774 .70

$696,721.85$

$14,946.53$
S $64,209.93$

$233,937.83$

204,243.97

$6,103.23$

$4,000.52$

$108,378.90$

34.80

$24,000.80$

$57,699.53$

$5,522.65$

271.15

$57,368.85$

$16,595.65$

$154,969.00$

$56,901.45$

$28,352.27$

4,662.82

$13,086.72$

942.17

$5,748.55$

$33,942.94$

$7,144.46$

Total Marntenance or Way AND STRUCTURE8........

Amount carried forward. .

$\varepsilon, 831,064.18 \quad 937,974.14$

$\$ 8,831,064.18 \$ 937,974.14$

BTATEMENT OF EARNINGS AND OPERATING EXPENSES OF THE STEAM RAILROAD IN DETAIL-Continued

1914

Comparison with 1913

Increase

Decrease

Amount brought forward.

$\$ 8,831,064.18 \$ 937,974.14$

Mantenance or Equipment:

Superintendence.................

Steam Iocomotives- Repairs.........

Steam Locomotives-Renewals....

Steam Locomotives-Depreciation.

Electric Locomotives-Repairs.....

Electrio Locomotiver - Deprecia-

tion....................

Passenger Train Carg-Repairs....

Passenger Train Cars-Renewals..

Passenger Train Cars-Depreciation

Freight Train Carg-Repairs......

Freight Train Cars-Renewals....

Freight Train Cars-Depreciation.

Electric Equipment of Cars-Re-

Electrio Equipment of Cara-Rö-

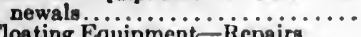

Floating Equipment-Repairs....

Floating Equipment-Renewals...

Floating Equipment-Depreciation

Work Equipment-Repairs.......

Work Equipment-Renewals......

Work Equipment-Depreciation...

Shop Machinery and Tools........

Power Plant Equipment............

Injuries to Persons...............

Stationery and Printing...........

Other Expenses.................

Maintaining Joint Equipment at Terminals............... Dr.

Maintaining Joint Equipment at

Terminals.................

$277,433.59$ $2,998,378.75$

$25,582.61$

$298,633.94$

$332,442.07$

76.923 .03

$1,316,722.35$

$4,517.99$

$302,927.62$

$2,549,357.37$

47,576. 12

$985,777.81$

$95,750.58$

295,853.56

$88,526.11$

$61,978.23$

$10,010.80$

$20,577.28$

$259,371.74$

84.775 .31

$39,290.82$

$6,160.69$

6.32

$11,754.98$

853.03
$55,170.40$

$123,268.72$

$19,018.31$

$242,903.99$

$207,992.94$

$76,923.03$

57.687 .73

$351,985.82$

$103,407.75$

0,222.95

484. 32

$16,233.67$

805,60

$15,856.58$

$5,355.80$

5.720 .60

$\$, 537.32$

$2,127.04$

$104,164.58$

$4,015,0 \mathrm{OC}$

$19,304.92$ $26,911.25$

$20,040,41$

$817,600.59$

$276,511.63$

Total Maintenance of Equip-

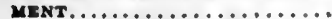

1.220 .78 
Traffic Expenses:

Superintendence............\& 208,204.54

Outside Agencies............... $\quad \mathbf{7 2 , 6 5 0 . 8 7}$

Advertising. ............... 167,229.07

Traffic Associations..............

Industrial and Immigration Bur-

raus.......................

Stationery and Printing............

Other Expenses................

$3,057.33$

1.057 .33

$5,692.93$

$45,185,13$

Total Tramptc Expenses

Amount carried forward....

$36,573.34$

$2,442.68$

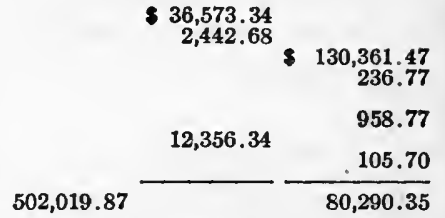

$\$ 19,722,542.15 \$ 1,646,473.33$

STATEMENT OF EARNINGS AND OPERATING EXPENSES OF THE STEAM RAILROAD IN DETAIL-Continued

1914 $\quad \begin{gathered}\text { Comparison with } 1913 \\ \text { Increase Decrease }\end{gathered}$

Amount brought forward...

Transportation Expenses:

Superintendence...............

Dispatching Trains.............

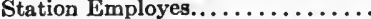

Weighing and Car Service Associs-

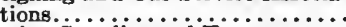

Station Supplies and Expenses.....

Yard Masters and their Clerks....

Yard Conductors and Brakemen...

Yard Switch and Signal Tenders. .

Yard Supplies and Expenses.......

Yard Enginemen..............

Enginehouse Expenses-Y. Yard......

Fuel for Yard Locomotives.........

Water for Yard Locomotives.......

Lubricants for Yard Locomotives..

Other Supplies for Yard Loco-

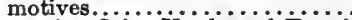

Operating Joint Yards and Terminals...................... Operating Joint Yards and Termi-

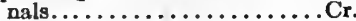

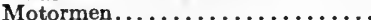

Road Enginemen.............

Enginehouse Expenses - Road.....

Fuel for Road Locomotives........

Water for Road Locomotives.......

Lubricants for Road Locomotives.

Other Supplies for Road Loco-

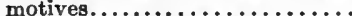

Operating Power Plants. ..........

Purchased Power..................

Road Trainmen................

Train Supplies and Expenses......

Interlockers, Block and Other Signals-Operation..............

Crossing Flagmen and Gatemen...

Drawbridge Operation............

Clearing Wrecks.................

Telegraph and Telephone-Opera-

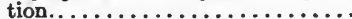

Operating Floating Equipment....

Stationery and Printing...........

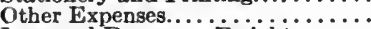

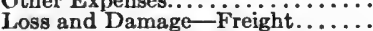

Loss and Damage-Baggage........

Damage to Property ...............

Damage to Stock on Right of Way.

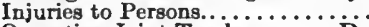

Operating Joint Tracks......... Dr.

Operating Joint Tracks...........

Total Transportation Expenses..................

Amount carried forward....
$\$ 19,722,542.15 \$ 1,646,473.33$

$18,102.74$

$15,097.87$

$182,721.56$

$4,857,766.24$

$2,987.95$

$411,692.33$

$433,571.96$

$1,033,842.87$

$270,129.70$

$34,588,44$

$579,912.98$

$157,390.58$

$705,600.15$

$46,296.02$

$10,658.55$

$16,970.00$

$1,108,842.91$

$64,270.18$

$220,184.47$

$2,290,808.74$

$781,541.35$

$4,541,441.70$

$256,258.70$

$72,344.80$

$113,251.82$

$225,669.75$

$168,915.83$

$3,094,478.12$

$778,617.68$

$700,598.45$

$398,650.03$

$73,924.46$

$57,975.24$

$2,754.46$

$11,265.61$

$6,187.20$

$22,214.52$

$7,228.15$

$1,257.65$

27,219.42

$25,392.45$

$4,710.28$

$17,944.00$

$2,404.46$

$2,283.17$

$63,081.70$

$24,541.92$

$11,329.02$

$142,706.09$

$622,564.92$

$311,638.62$

$28,118.29$

$557,977.71$

$6,098.54$

$161,123,10$

$1,582.46$

$750,283.13$

$250,256.06$

$7,365.06$
$68,267.00$

$169,708.16$

$338,101.96$

$40,483.95$

6,018.32

398.92

$55,526.19$

$7,591.87$

$70,399.30$

$23,256.71$

$10,906.94$

$2,438.83$

707.17

$22,694.06$

9,594.40

$16,886.93$

$26,121.03$ $31,618.01$

10.89

$8,356.84$

495.81

$64,917.12$

2,513.32

$2,826.17$ 
STATEMENT OF EARNINGS AND OPERATING EXPENSES OF THE STEAM RAILROAD IN DETAIL-Concluded

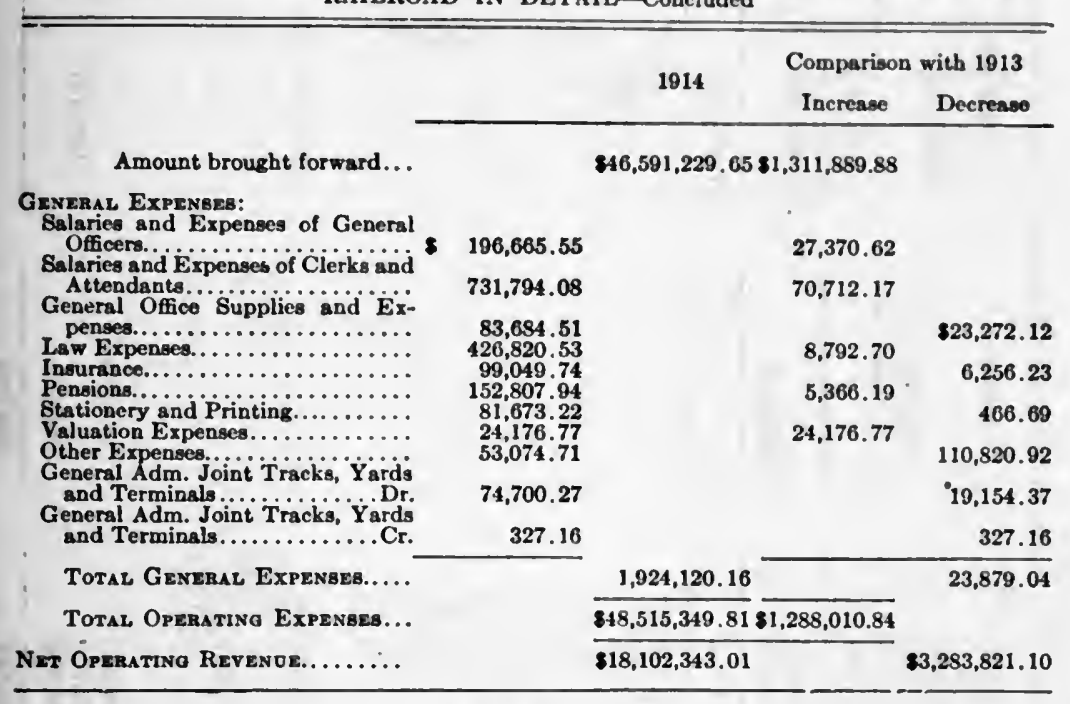

RATIOS

Year Ending June 30, 1914, Compared with Previous Year

Ratio of Each Class of Revenue to Total 1914 Increase Decrease Operating Revenue:

Freight.

Passenger...................................

Mail.................................

Express..............................

Miscellaneous......................

Operations other than Transportation.......

Total.

1914 Increase Decrease

\begin{tabular}{c}
$48.75 \%$ \\
41.13 \\
1.09 \\
4.28 \\
1.80 \\
2.95 \\
\hline $100 \%$
\end{tabular}

$.47 \%$

$.15 \%$

Ratio of Each Class of Expenses to Total Operatino Expenses:

Maintenance of Way and Structures.......

Maintenance of Equipment................

Traffic Expenses .....................

Transportation Expenses.................

General Expenses...................

$\begin{array}{ll}18.20 \% & 1.49 \% \\ 21.42 & 1.09\end{array}$

Total.

1.03

55.38

3.97

$.91 \%$

$100 \%$

Ratio of Each Class of Expenses to Total Operating Revenue:

Maintenance of Way and Structures.......

Maintenance of Equipment................

Traffic Expenses.......................

Transportation Expenses....................

General Expenses......................

Total.

\begin{tabular}{|c|c|c|}
\hline $\begin{array}{l}13.26 \% \\
15.60\end{array}$ & $\begin{array}{l}1.76 \% \\
1.61\end{array}$ & \\
\hline $\begin{array}{r}40.75 \\
2.83\end{array}$ & $\begin{array}{l}.08 \\
.05\end{array}$ & $.10 \%$ \\
\hline $72.83 \%$ & $4 \%$ & \\
\hline
\end{tabular}




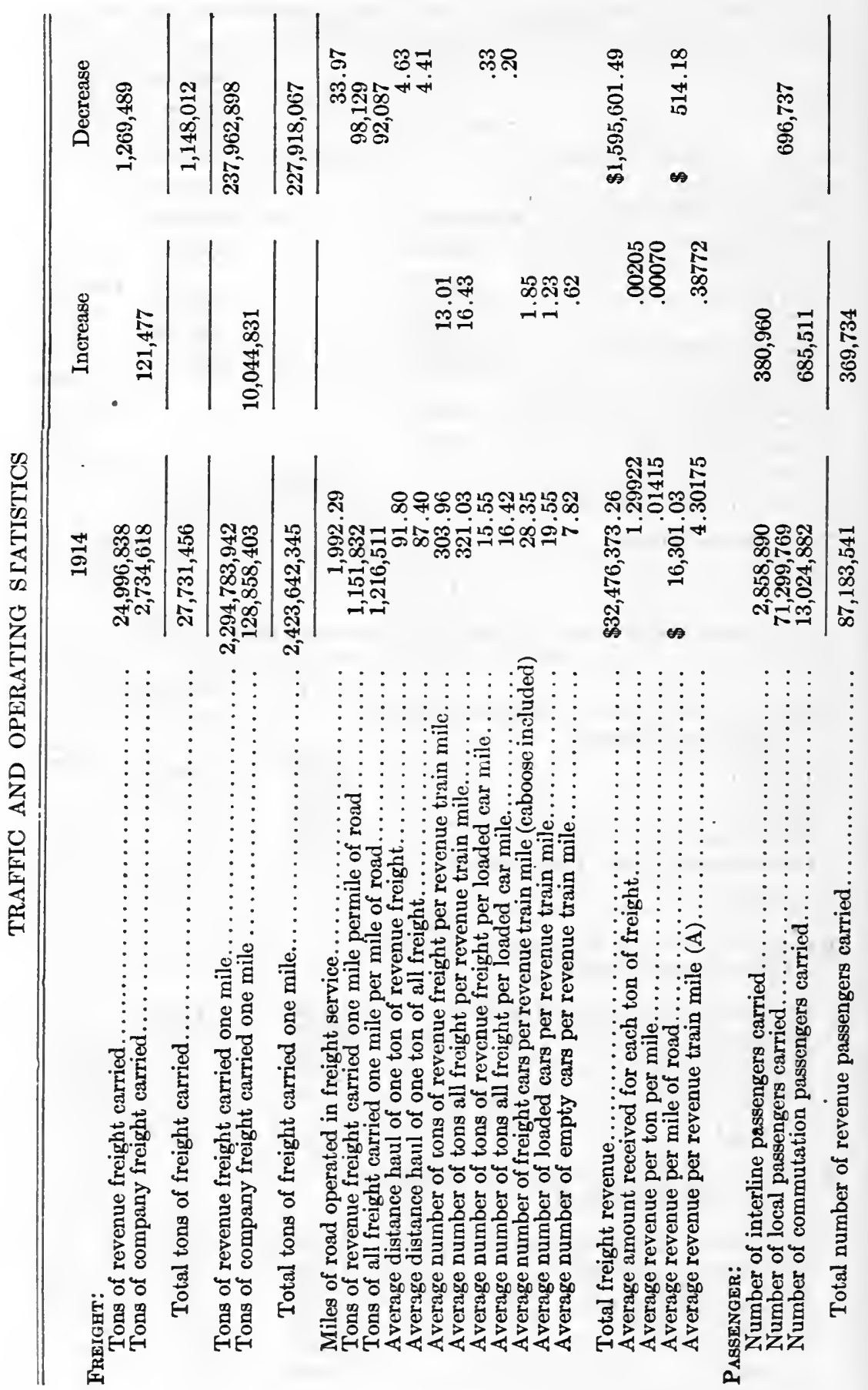


N. Y., N. H. \& H. RR. CO. REPORT, $1914 \quad 739$

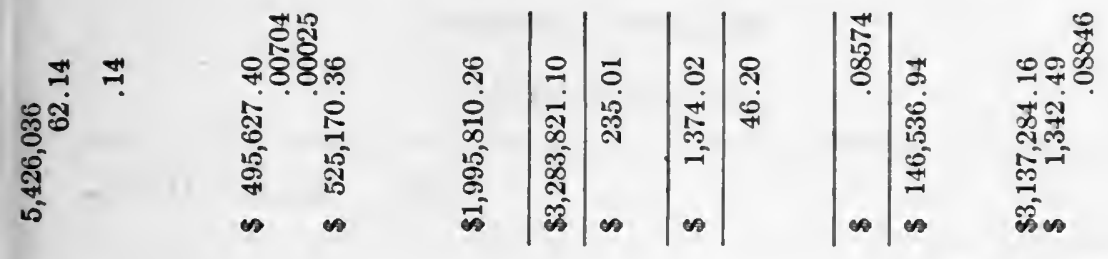

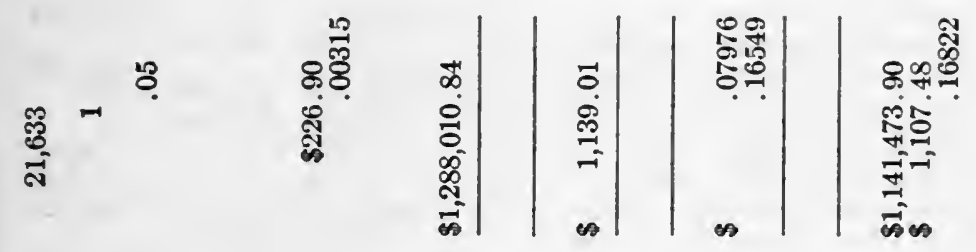

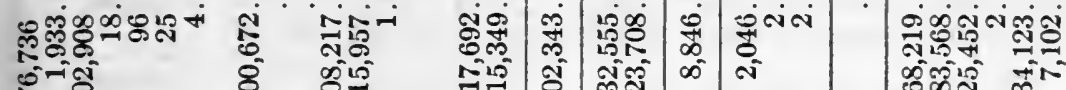
है

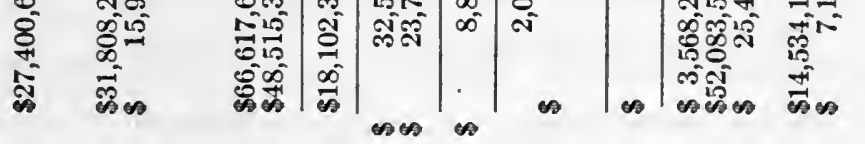

$\vdots: \frac{0}{\vdots} \vdots \vdots \vdots: \frac{0}{0}$

药 : 的

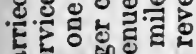

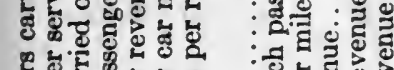

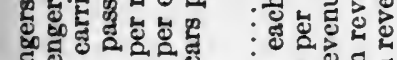
政 等

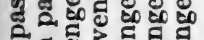

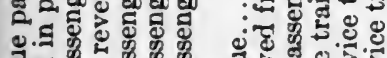

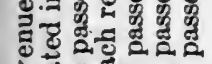
of

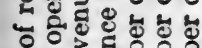
年

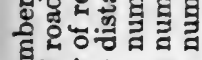

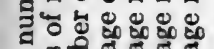
든

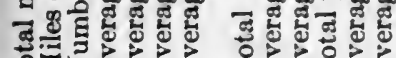

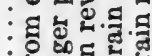
果呵 a.

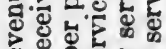

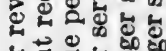

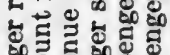

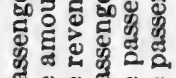
a 就 霓 的的

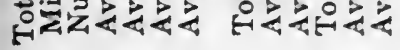




\section{MILEAGE STATISTICS}

\section{Locomotive Mileage}

1914 Increase Decrease

Revenue Service:

Freight locomotive-miles-steam.........

Freight locomotive-miles-electric........

Passenger locomotive-miles-steam........

Passenger locomotive-miles-electric.......

Mixed locomotive-miles-steam..........

Special locomotive-miles-steam.........

Special locomotive-miles-electric.........

Switching locomotive-miles - steam........

Switching locomotive-miles-electric.......

Total revenue locomotive-miles-steam..

Total revenue locomotive-miles-electric.

Non-revenue locomotive-miles-steam......

Non-revenue locomotive-miles-electric.....

Total locomotive-miles-steam..........

$7,944,956$

47,184

$14,045,794$

$2,350,367$

149,833

44,117

2,178

$4,684,910$

513,231

$26,869,610$

$2,912,960$

$1,113,217$

41,403

$27,982,827$

Total locomotive-miles-electric....... 2,954,363

Total locomotive-miles.

$30,937,190$

177,516

334,936

3,666

8,243

313

467,522

276,585

478,801

$2,061,079$

197,962

31,707

$2,259,041$

510,508

$1,748,533$

\section{Train Mileage}

Revenue Service:

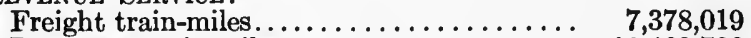

Passenger train-miles........... 16,468,726

Mixed train-miles....................

Special train-miles.................. 48,354

Total revenue train-miles........... $\overline{24,066,656}$

Non-revenue train-miles............. $1,188,062$

Total train-miles.

$25,254,718$

\section{Car Mileage}

Revenue Service:

Freight car-miles:

Loaded.................... 147,591,291

Empty....................... 59,056,063

Caboose.................

Total freight car-miles.......... 214,020,529

$11,922,731$

$3,628,241$

$1,142,634$

$16,693,606$

Passenger car-miles:

*Passenger...................... 50,249,383

*Sleeping, parlor and observation........ 13,791,315

Other passenger-train cars........... 17,061,716

Total passenger car-miles.......... 81,102,414 


\section{MILEAGE STATISTICS}

Car MiLeage-Continued.

1914 Increase Decreec

\begin{tabular}{|c|c|c|c|}
\hline \multicolumn{4}{|l|}{ Special car-miles: } \\
\hline Freight-loaded. . & 112,984 & & 54,709 \\
\hline Freight-empty.. & 1,427 & & 7,933 \\
\hline Caboose........ & 10,809 & & 905 \\
\hline Passenger........... & 194,415 & & 127,326 \\
\hline * Sleeping, parlor and observation......... & 46,376 & & 1,405 \\
\hline Other passenger-train cars........... & 5,300 & 5,300 & \\
\hline Total special car-miles.............. & 371,311 & & 186,978 \\
\hline $\begin{array}{l}\text { Total revenue car-miles.. } \\
\text { Non-revenue car-miles....... }\end{array}$ & $\begin{array}{r}295,494,254 \\
3,021,232\end{array}$ & 631,749 & $17,527,791$ \\
\hline Total car-miles. & $298,515,486$ & & $16,896,042$ \\
\hline
\end{tabular}

* 1913 figures revised for purposes of comparison.

COMPARISON OF VARIOUS AVERAGES PER MILE OF ROAD OPERATED AND OPERATING RATIOS

\begin{tabular}{|c|c|c|c|c|c|c|}
\hline $\begin{array}{c}\text { Year } \\
\text { ending } \\
\text { June } 30\end{array}$ & $\begin{array}{c}\text { Average } \\
\text { Mileage } \\
\text { Operated }\end{array}$ & $\begin{array}{c}\text { Total } \\
\text { Operating } \\
\text { Revenue }\end{array}$ & $\begin{array}{c}\text { Operating } \\
\text { Expenses } \\
\text { and Taxes }\end{array}$ & $\begin{array}{c}\text { Ratios } \\
\text { Operating Expenses } \\
\text { to Revenue } \\
\text { (Taxes not included) }\end{array}$ & $\begin{array}{c}\text { Net } \\
\text { Operating } \\
\text { Revenue } \\
\text { (Less Taxes) }\end{array}$ & $\begin{array}{c}\text { Net } \\
\text { Income }\end{array}$ \\
\hline $\begin{array}{l}1903 \\
1904 \\
1905 \\
1906 \\
1907 \\
1908 \\
1909 \\
1910 \\
1911 \\
1912 \\
1913 \\
1914\end{array}$ & $\begin{array}{l}2,027 \cdot 34 \\
2,031 \cdot 58 \\
2,075.45 \\
2,062.06 \\
2,060 \cdot 17 \\
2,047 \cdot 16 \\
2,042.59 \\
2,042.89 \\
2,040.75 \\
2,091 \cdot 31 \\
2,092 \cdot 49 \\
2,046.29\end{array}$ & $\begin{array}{r}\mathbf{2 3}, 329 \\
23,766 \\
24,082 \\
25,695 \\
26,989 \\
25,914 \\
26,607 \\
29,716 \\
30,456 \\
31,049 \\
32,790 \\
32,555\end{array}$ & $\begin{array}{r}\mathbf{1 1 8 , 4 1 8} \\
18,515 \\
18,546 \\
18,444 \\
19,807 \\
20,297 \\
19,351 \\
20,889 \\
21,794 \\
21,946 \\
24,345 \\
25,452\end{array}$ & $\begin{array}{l}73.91 \\
72.82 \\
71.69 \\
68.48 \\
68.07 \\
72.03 \\
66.39 \\
63.74 \\
65.80 \\
64.84 \\
68.83 \\
72.83\end{array}$ & $\begin{array}{r}\mathbf{4}, 911 \\
5,251 \\
5,536 \\
7,251 \\
7,182 \\
5,617 \\
7,256 \\
8,821 \\
8,662 \\
9,103 \\
8,445 \\
7,103\end{array}$ & $\begin{array}{r}82,381 \\
3,000 \\
3,232 \\
4,939 \\
4,702 \\
2,315 \\
3,638 \\
5,285 \\
5,482 \\
6,401 \\
4,264 \\
131\end{array}$ \\
\hline
\end{tabular}




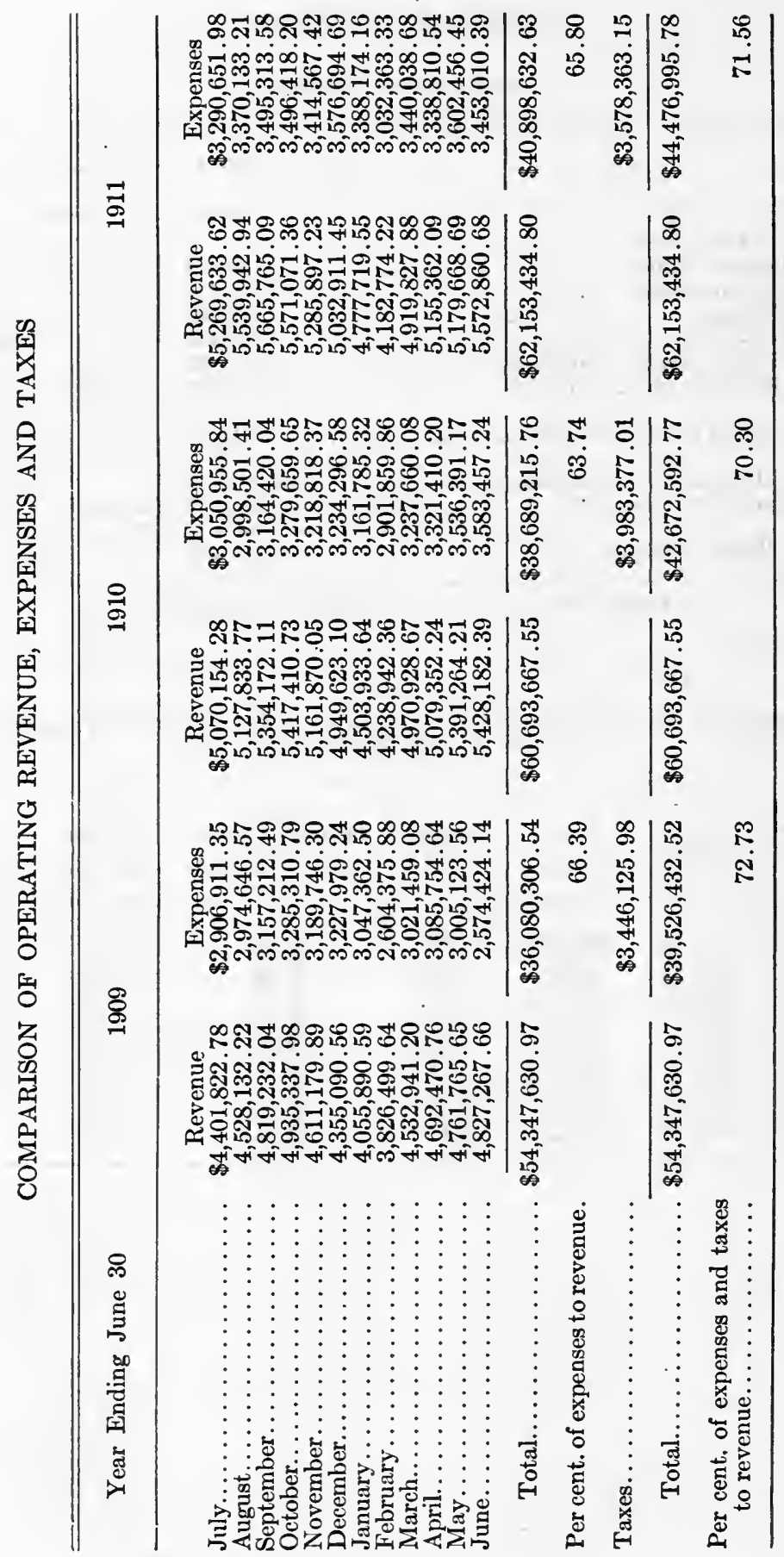




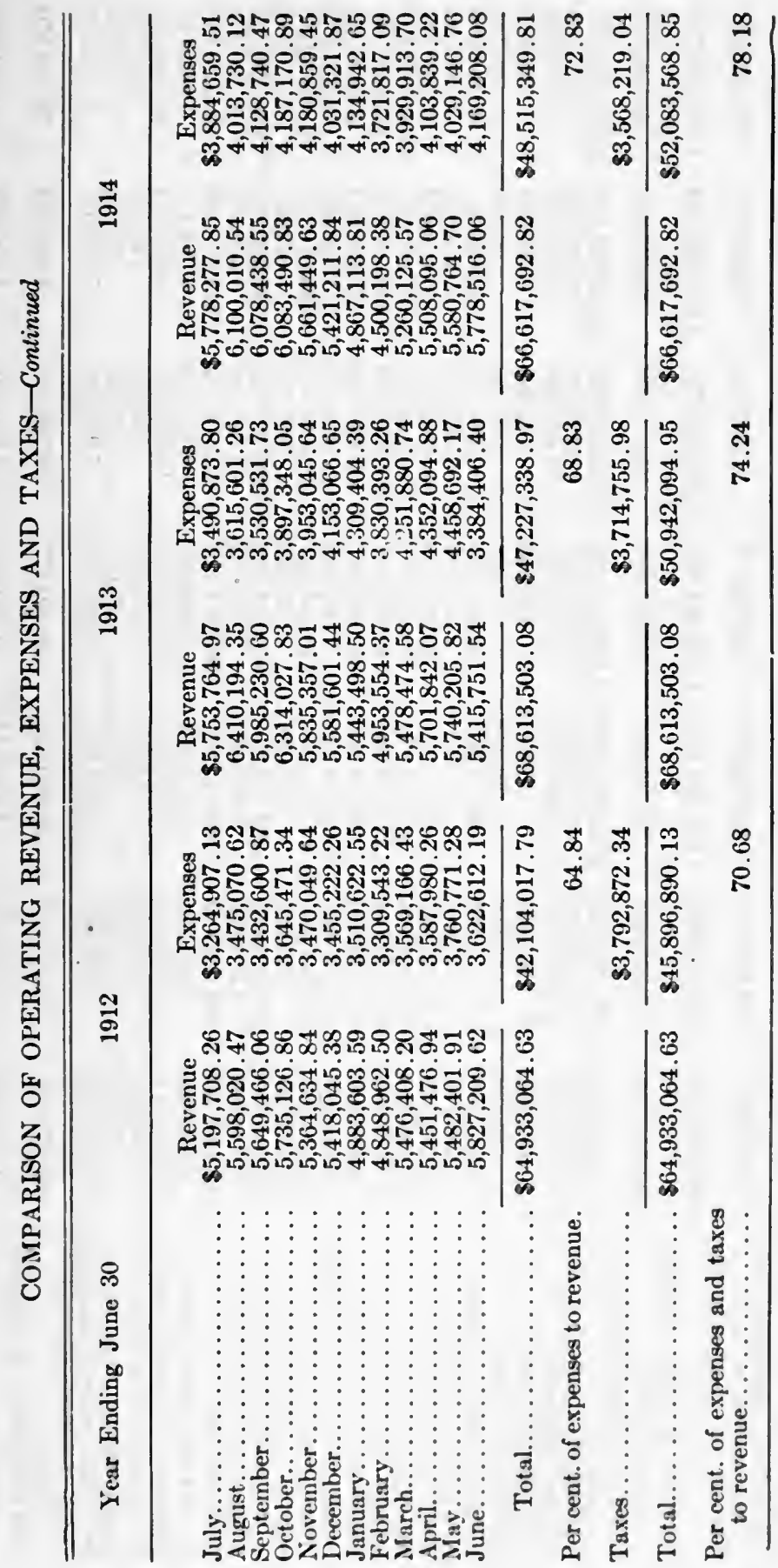




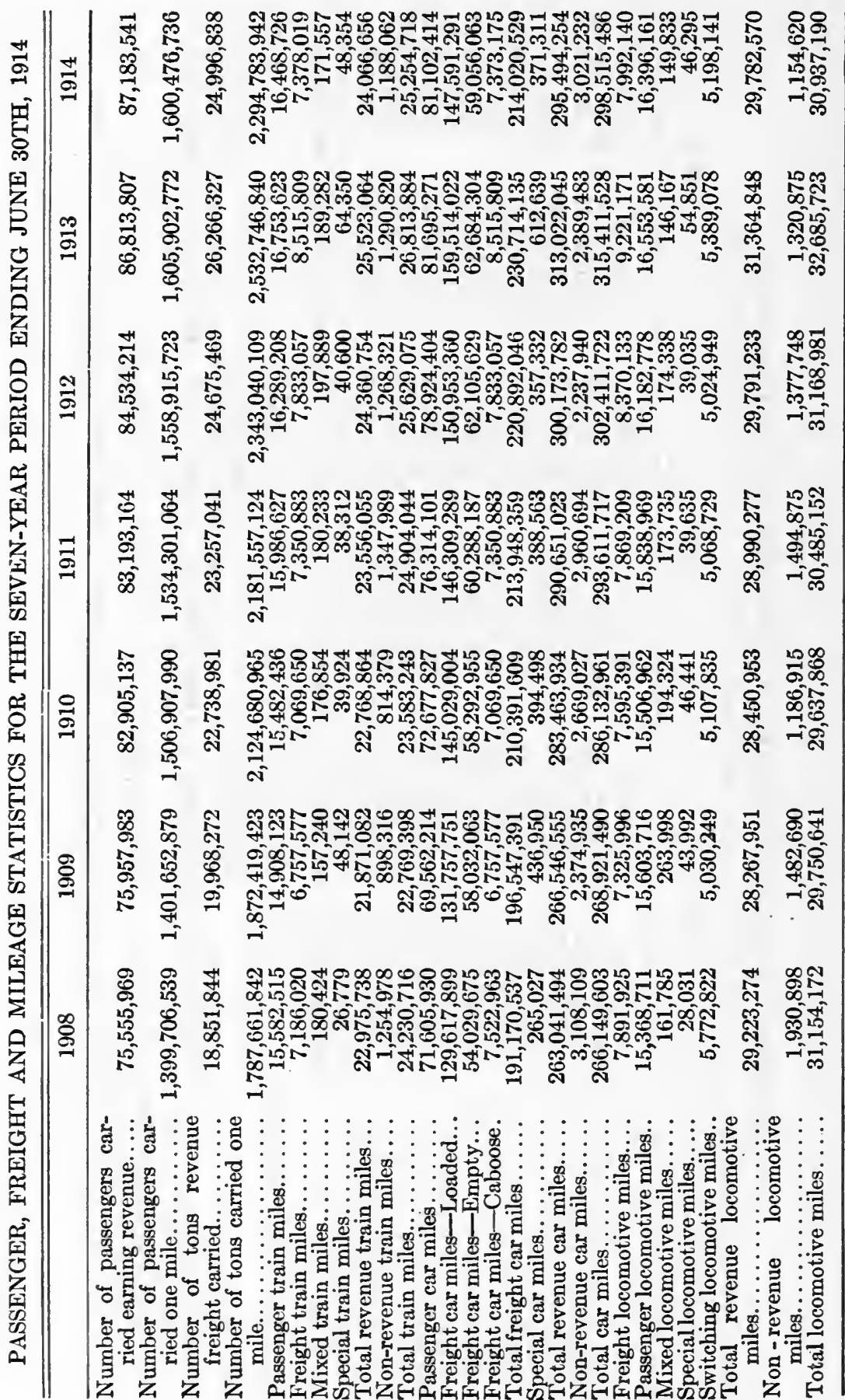


N. Y., N. H. \& H. RR. CO. REPORT, 1914745

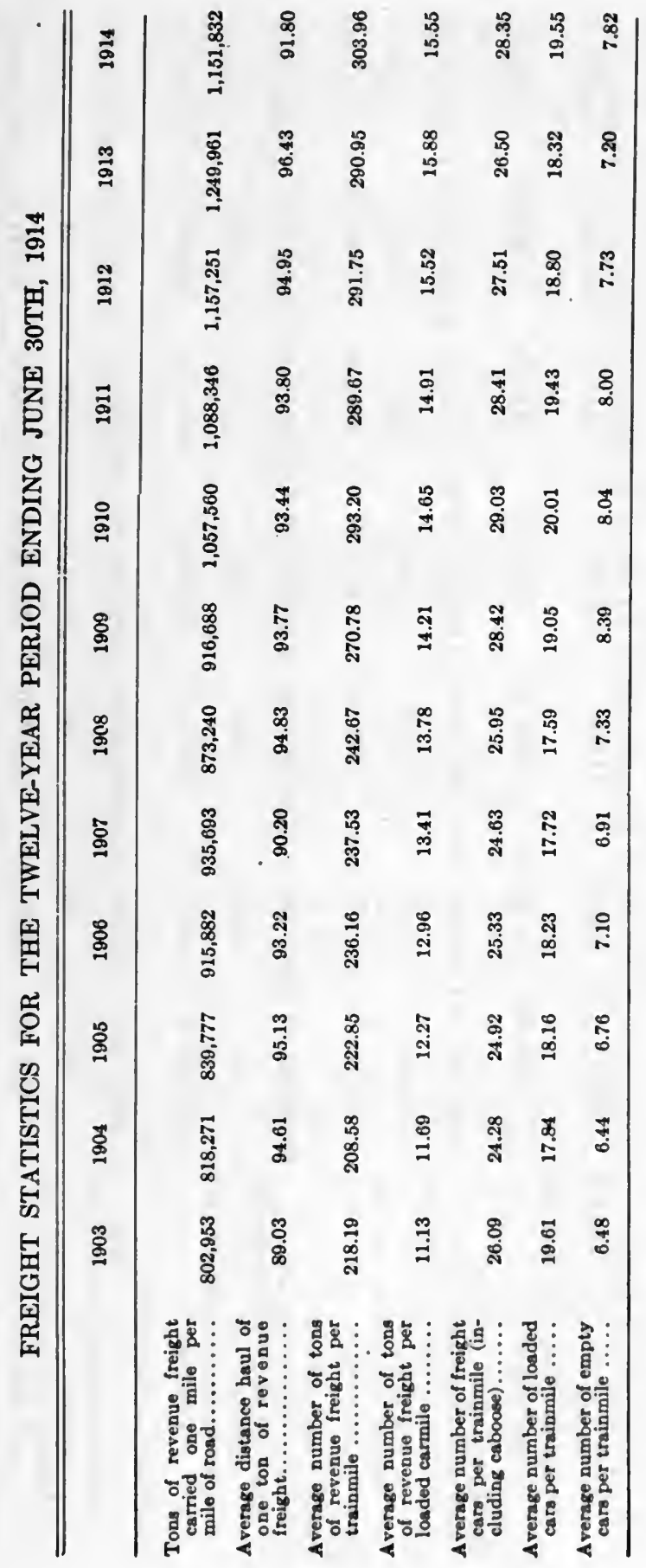




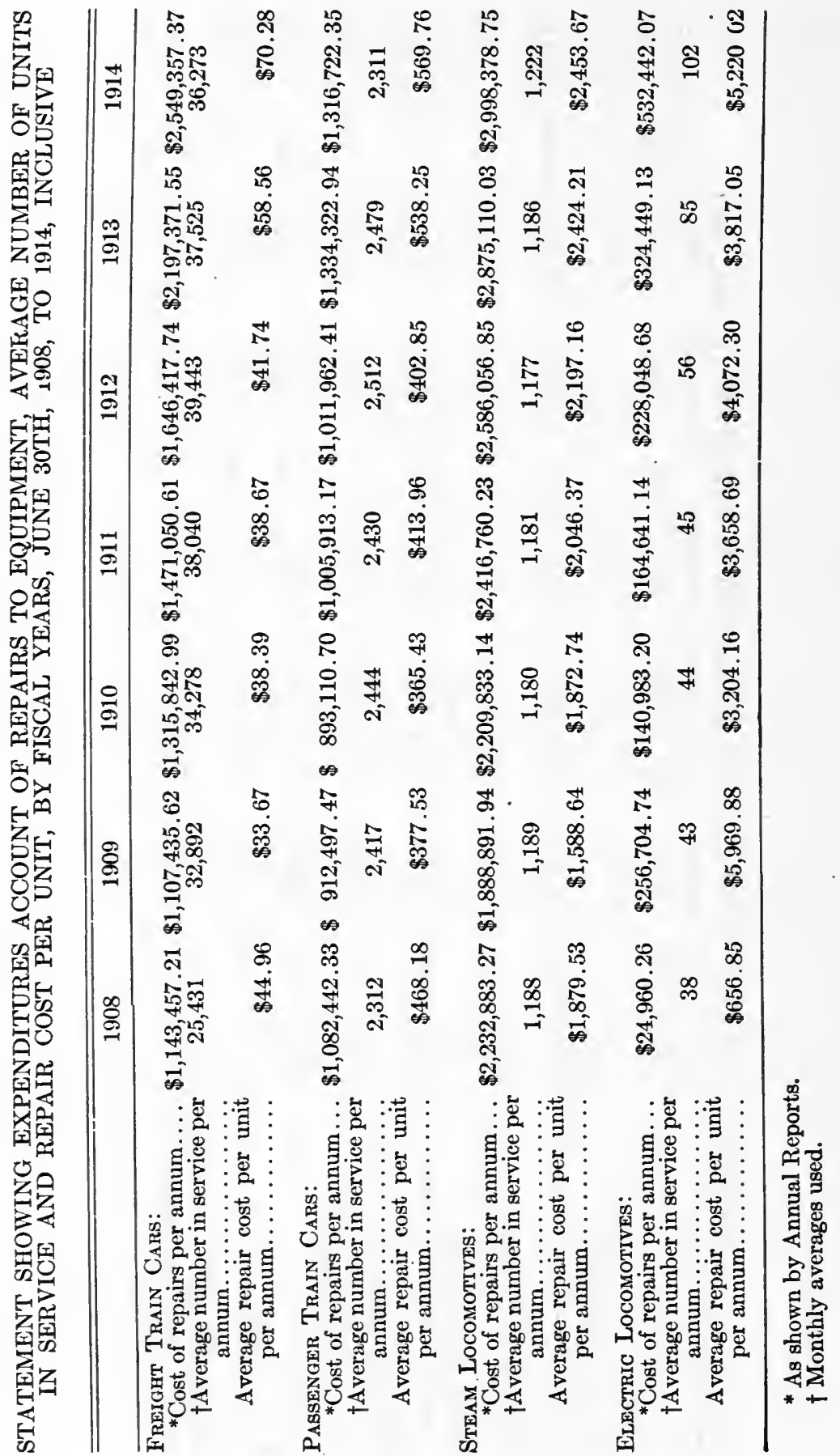


N. Y., N. H. \& H. RR. CO. REPORT, 1914747

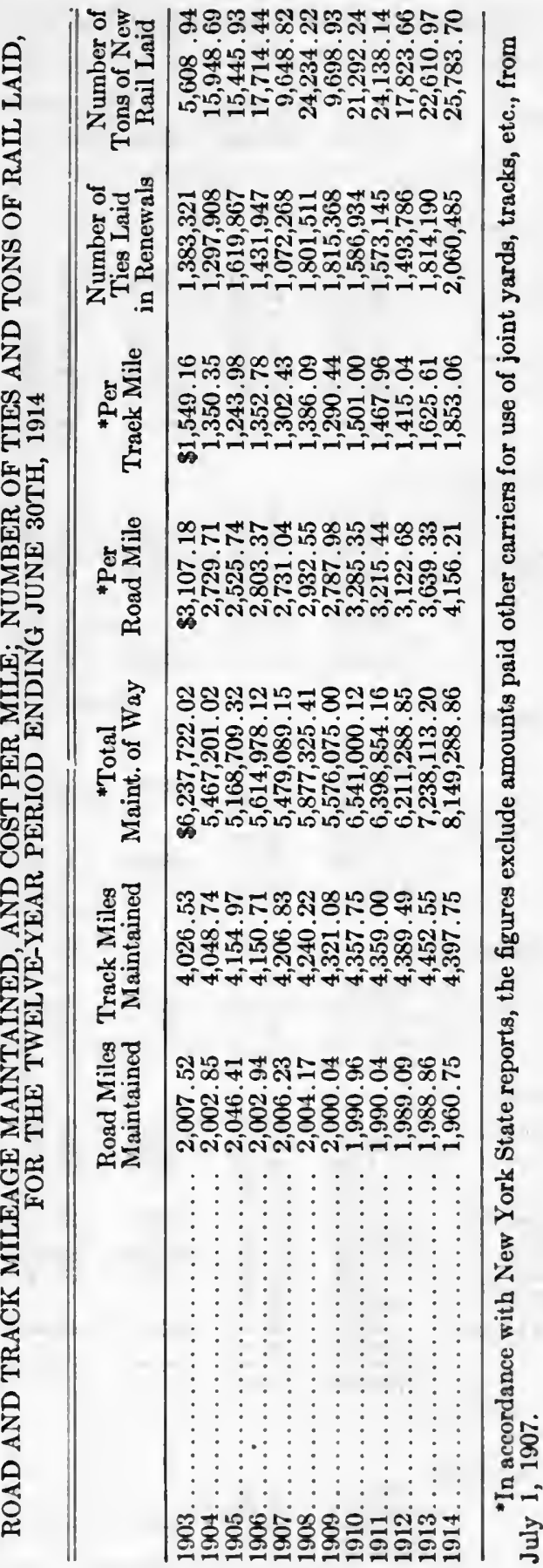




\section{DESCRIPTION OF REVENUE FREIGHT MOVED}

\begin{tabular}{|c|c|c|c|c|}
\hline \multirow{2}{*}{ Commodities } & \multirow{2}{*}{\multicolumn{2}{|c|}{ 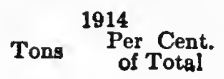 }} & \multicolumn{2}{|c|}{ Comparison with Year 1913} \\
\hline & & & Tons $\quad \stackrel{\text { Increase }}{\text { Per Cent. }}$ & $\begin{array}{c}\text { Decrease } \\
\text { Tons Per Cent. }\end{array}$ \\
\hline
\end{tabular}

\section{Prodocts of Aariculture}

Grain

Grain .....................

Other mill products.................

Hay.......................

Tobacco........................

Cotton ...........................

594,516
251,055
154,403
260,022
20,714
340,069
489,292
217,169

02.38

01.00

00.62

01.04

00.08

01.36

Other articles. ...................

217,169

Total.

$2,327,240$

01.96

00.87

$\overline{09.31}$

\begin{tabular}{rr}
17,092 & 07.31 \\
3,735 & 22.00 \\
77,677 & 29.60 \\
23,085 & 04.95 \\
145,534 & 203.16 \\
\hline 198,745 & 09.34
\end{tabular}

24,479

03.95

41,182

2,717

21.06

\section{Prodocts of Animals}

Live Stock............. 54,073

Dressed meats.............. 156,821

Other packing house products.. $\quad 23,464$

Poultry, game and fish....... $\quad 52,979$

Wool................... $\quad 99,120$

Hides and leather............ 119,379

Other articles. ............. 187,539

Total.

693,375

00.21

00.09

00.21

00.40

00.48

00.75

34,322

2,593

1,833

28.02

4,465

07.63

$\overline{02.77}$

12.42

03.58

13,923

9,932

12.32

07.68

00.04

\section{Prodects of Mines}

Anthracite Coal. . . . . . . . . 2,422,153

Bituminous coal............ 4,135,725

Coke................... 123,295

Ores.................... 15,280

Stone, sand and other like

articles................ 947,566

Other articles............... 163,422

Total.

$7,807,441$

09.69
16.55
00.49

00.06

03.79

00.65

$\overline{31.23}$

$\overline{10,357}$

01.52

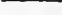

\section{Products of Forests}

Lumber................... . 1,038,042

Other articles...............

04.15

00.93

90,190

35,566

143,928

05.61

75,773

01.80

39,282

72.00

48,869

47,883

04.81

222,431

$\overline{02.77}$

Total.

$1,268,924$

05.08

101,834

08.93

11,644

00.91

\section{Manufacturers}

Petroleum and other oils...... $\quad 400,857$

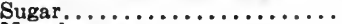

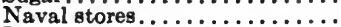

64,201

Iron: pig and bloom.......... 314,059

Iron and steel rails ............ $\quad \mathbf{7 6 , 7 7 4}$

Other castings and machinery.. $\quad 382,866$

Bar and sheet metal.......... 342,815

Cement, brick and lime........ $\quad 949,918$

Agricultural implements........ $\quad 6,288$

Wagons, carriages, tools, etc... 21,812

Wines, liquors and beers. .... 146,145

Household goods and furniture. $\quad \mathbf{4 6 , 4 7 9}$

Other articles.............. 2,288,854

Total.............. $5,045,234$

$\begin{array}{rrr}01.60 & 5,619 & 01.42 \\ 00.26 & 13,947 & 27.75 \\ 00.02 & 2,785 & 201.67\end{array}$

00.02

01.26

01.53

01.37

03.80

00.02

00.09

00.58

00.18

09.16

41,367

201.67

79,311

20.16

$41,367 \quad 12.11$

713

31,979

03.48

55,876

14.01

3,108

97.74

3,479

13.76

14,411

44.94

20,991

12.56

20.18

101,236

04.24

265,390

05.00

\section{Mrsceluaneods}

Commodities not previously

mentioned............. $3,784,678$

Merchandise.............. $4,069,946$

Grand Total ......... $24,996,838$ 


\section{THE HARTFORD AND NEW YORI TRANSPORTATION COMPANY}

\section{Ofricers}

Howard Eli.jott, President

C. C. Goopricn, Vice-President

R. J. Noble, General Manager

Owns 6 steamers, 7 tugs and 33 barges, operating lines between New York and Bridgeport, New York and Hartford and intermediate points on the Connecticut River; and New York and Providence.

Income Account for the Year Ending June 30tr, 1914

\section{Operatina Revenue:}

Freight Revenue

Passenger Reve....................

Pll Onger Revenue........................

All Other Revenue from Transportation......

Revenue from Operations other than Transportation............................

Total Operating Revenue............... Operating Expenses........................

Net Operating Revenue...............

Taxes..................................

Income from Other Sources...............

Total Income.....................

DEDUCTIONS From INCOME:

Interest on Bonds and Other Liabilities.......

Miscellaneous Rents...................

Miscellaneous.

Total Deductions from Income...........

Net Income.........................

Dividends..........................

Surplus.

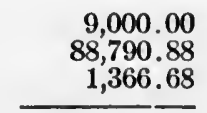

$720,011.73$
$317,890.32$
$33,398.67$
$25,198.44$

$\$ 1,096,499.16$ $942,020.54$

$\$ 154,478.62$ $16,206.44$

$\$ 138,272.18$ $46,850.80$

$185,122.98$

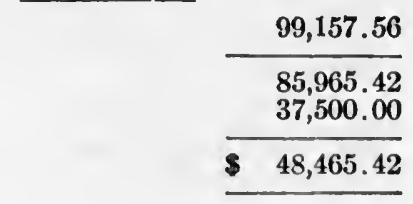

The Operating Expenses and Tazes were 87.39 per cent. of the Total Operating Revenue. 


\title{
THE HARTFORD AND NEW YORK TRANSPORTATION COMPANY
}

\section{General Balance Sheet, June 30, 1914}

\author{
As8ET8
}

Permanent and Lono Term Istegtments:

Real Property and Equipment:

Floating Equipment and Terminal Prop-

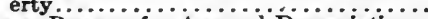

Less, Reserve for Accrued Depreciation..

Other Investments:

Miscellaneous Investments.

Less, Reserve for Accrued Depreciation...

Intangible Assets.

\section{$\$ 1,469,412.99$} $117,503.77$

$35,195.81$ $5,174.93$

$830,020.88$ $891,247.20$

Total Permanent and Long Term Investments Workiva Asset8:

Cash.

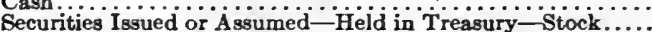

Traffic Balances due from Other Companies................

Net Balance due from Agents, Pursers and Stewards. .......

Insurance Claims against Underuriters.................

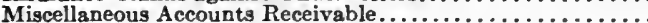

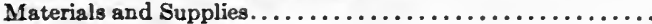

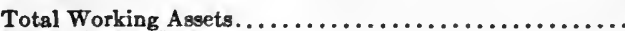
Deferred Debit ITEMS:

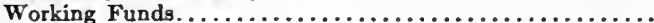

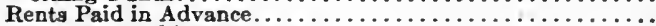

Other Deferred Debit Items. . . . . . . . . . . . . . . . . .

Insurance Paid in Advance.

Total Deferred Debit Items.

LIABILITIE:

STock:

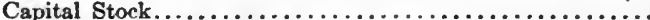

Mortgage, Bonded and Secured Debt:

Mortgage Bonds....

WorkiNg LIABILITIEs:

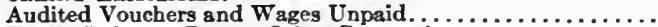

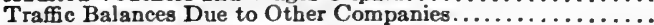

Miscellaneous Accounts Payable.

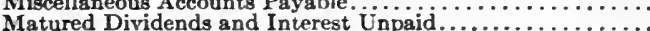

Matured Renta Unpaid.

Total Working Liabilities.......................

Deferred CRedTt IteMs:

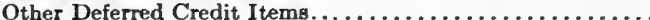

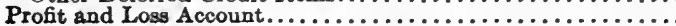

$55,143.05$

$\$ 7,743,745.75$

$\$ 3,073,177.30$

$\$ 90,084.24$ $4,203,000.00$

357.51

39.701 .65

$21,057.70$

$250,938.55$

$10,285.75$

$4,615,425.40$

\$ 26,335.00

$7,323.38$

$3,317.05$

$18,167.62$

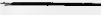

$36,703,000.00$

$200,000.00$

\& $\quad 81,765.02$

$2,533.05$

169.90

$1,545.00$

173. 34

$86,186.31$

$2,193.35$

$752,366.09$

$\$ 7,743,745.75$

Out of a total 67,030 Shares of Capital Stock, The New England Navigation Company owns 25,000 Shares, the remaining 42,030 Shares being held in the Treasury of this Company. 
N. Y., N. H. \& H. RR. CO. REPORT, 1914

\section{NEW YORK, WESTCHESTER AND BOSTON RAILWAY COMPANY}

\section{OFFICERS}

L. S. MrLen, President

Howard Ezuotr, Vice-President

The line of the New York. Westchester and Boston Railway commences at Harlem River Station of The New York. New Haven and Hartford Railrond Company in the City of New York, running thence northerly for 1.66 miles on the four-track line of the New Haven Railroad to 149 th Street and continuing on the New Haven six-track line from that point 2.06 miles to 174 th Sireet Junction (the Westchester Company having a trackage contract covering these tracks), at which point the New York, Weatchester and Boeton Railway diverges from the New Haven and on its own four tracks extends 4.9 miles to the nortberly line of the City of New York; all the foregoing described lines being in the East Bronx.

From the northerly line of the City of New York the line continues as a four-track road 1.93 miles through the City of Mount Vernon to Columbus Avenue Junction at which point the line diverges into two double-track lines.

One line extends easterly through Mount Vernon. Pelham and New Rochelle to Larchmont Junction, about midway between New Rochelle and Larchmont Manor, being a distance of 2.16 miles from Columbus Avenue Junction. This line it is expected will eventually be extended to Port Chester, N. Y.

The other line extends northerly 9.04 miles from Columbus Avenue Junction to White Plains, passing through Mcunt Vernon, Eastchester, New Rochelle, Scsrsdale and White Plains.

The total mileage operated as above is 21.75 miles.

\section{INCOME ACCOUNT fOR The YeAR ENDINO JUNe 30Th, 1914}

\section{Operatino Revenoe:}

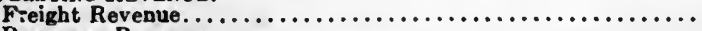

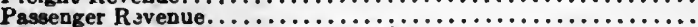
All other Revenue from Transportation................

Revenue from Operations other than Transportation..........

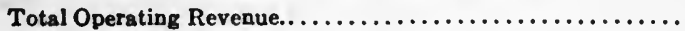

\section{Operatino Expenges:}

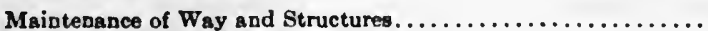

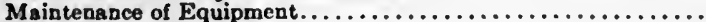

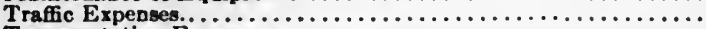

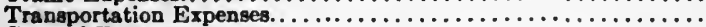

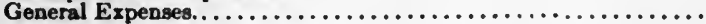

Total Operating Expenses......................

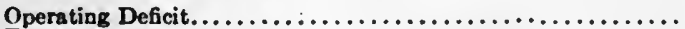

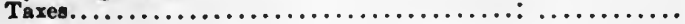

Deficit.

Income from other Source.
$\$ 13,035.12$

352.971 .17

15.803 .60

$18,870.02$

\section{$\$ 400,679.91$}

$85,175.29$

\section{Deductong moM INCOME:}

Interest on Bonds and other Liabilities. . . . . . . . . . . 1,297.785.33

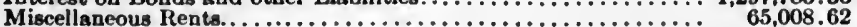

Amortixation of Discount on Securities........ $4,664,40$

Other Contractural Deductions from Income................

Totsl Deductions from income.....................

Deficit.

Passenger Train Mileage in Revenue Service............. 1.150.277

Freight Train Mileage in Revenue Service. . . . . . $2, \ldots \ldots \ldots, \mathbf{2 0 , 4 0 6}$

Mixed or other Train Mileage in Revenue Service.......... 38,076

Total Revenue Train Mileage............... $\overline{1,208,759}$

1913 Increase

$1,127,162 \quad 23,115$

$4,420 \quad 15,988$

$17,102 \quad 20,974$

$1.148,6 8 4 \longdiv { 6 0 , 0 7 5 }$

Number of Passengers carried earning revenue.......... 3,062,985 Number of Tons of freight carried earning revenue......... 31,882 Number of Tons of freight carried sne mile............, 472,276 


\section{NEW YORK, WESTCHESTER AND BOSTON RAILWAY COMPANY General Balance Sheet, June 30th, 1914}

Assets

\section{Fixed Capital:}

Main Line.

White Plains Branch

Westchester Northern $\ldots \ldots \ldots \ldots \ldots \ldots \ldots \ldots \ldots \ldots \ldots$

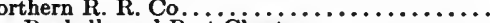

Main Line, New Rochelle and Port Chester............

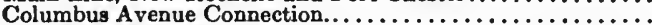

Intangible Capital.

\section{$\$ 17,062,150.27$ $5,540,026.32$ \\ $15,148.19$ \\ $84,532.55$ \\ $143,589.26$ $8,193,390.96$}

$\$ 31,038,837.55$

\section{Floatina Capital:}

Cash.

Materiaj . .

Bills Receivable.

Accounts Receivable

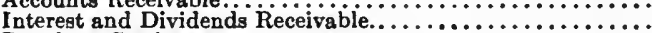

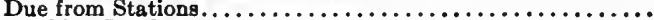

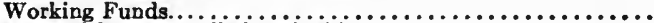

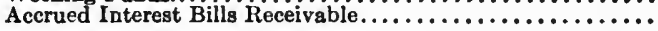

$\begin{array}{r}\$ 87,978.83 \\ 222,732.76 \\ 335,086.05 \\ 102,750.75 \\ 140.00 \\ 405.97 \\ 2,435.00 \\ 24,561.66 \\ \hline\end{array}$

$776,091.02$

\section{INVEETMENTE:}

The City and County Contract Co. Stock..............

\section{Spectal Deposits:}

Comptroller, City of New York

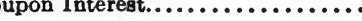

Insurance Paid in Advance........................

Suspense Accounts:

Unamortized Debt Discount and Expense..............

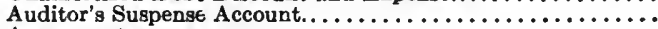

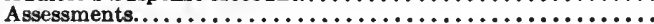

Corporate Deficit.

$\$ 44,668.12$

$480,667.50$

$\$ 150,259.85$

927.15

$35,661.59$

$186,848.59$ $2,805,664.87$

$\$ 35,333,403.80$

LIABILITIES

\section{STock:}

Capital Stock

$\$ 4,945,250.00$

\section{Funded Debt:}

First Mortgage Bonds.

$21,200,000.00$

\section{UNFUNDED DeBt:}

Accrued Taxes and Rentals.

Accrued Interest on Bonds...

terest on Bills Payable....................

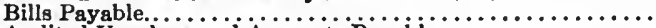

Audited Vouchers and Accounts Payable.

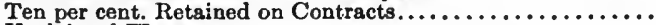

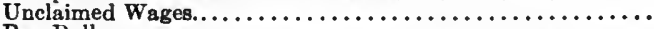

The Rew York, New Haven \& Hartford $\dot{R}$ R. Co. Advances.

\section{REserves:}

$9,152,492.21$

$35,661.59$

$\longdiv { \$ 3 5 , 3 3 3 , 4 0 3 . 8 0 }$

Assessment Account 180th Street.................

$\$ 4,230.56$ $480,667.50$ $684,549.70$ $5,842,423.48$ $327,032.52$

$6,619.50$

370.30

98.65

$1,806,500.00$

Out of $49,4521 / 2$ Shares of the Capital Stock of this Company, The New York, New. Haven and Hartford Railroad Company owns 49,249 Shares and $\$ 37.50$ Scrip, the remainder being held by the public. 
COMPARATIVE INCOME ACCOUNT

Years ENDEd JUNe 30

\begin{tabular}{lcllllll}
\hline & 1915 & 1914 & 1913 & 1912 & 1911 & 1910 & 1909 \\
Average mileage oper..... & $10,052.58$ & $\mathbf{9 , 6 8 3 . 9 5}$ & $\mathbf{9 , 6 1 2 . 8 2}$ & $\mathbf{7 , 5 1 1 . 4 1}$ & $\mathbf{7 , 5 1 1 . 5 6}$ & $\mathbf{7 , 5 1 1 . 5 6}$ & $\mathbf{7 , 5 1 1 . 7 3}$
\end{tabular}

Operating Reventes:

Other transp. revenue.... 8, $8,193,891$

Non-transp. revenue...... 1,335,256

Total oper. rev's...... $\overline{91,435,374}$

\section{$\$$}

$65,266,420$

$18,961,225$

$\begin{array}{r}6,755,606 \\ 799,440 \\ \hline\end{array}$

$\overline{91,782,691}$ \begin{tabular}{lll} 
Passenger revenue......... & $63,953,799$ \\
\hline $7,952,428$
\end{tabular}

\section{8}

$67,964,161$

$18,457,136$
$6,919,686$

$\begin{array}{r}743,072 \\ \hline\end{array}$

$\overline{94,084,055}$

\section{8}

$42,815,573$

$13,936,963$

$5,751,668$

618,539

$\overline{63,122,743}$

\section{s}

$44,776,454$ $14,077,757$ $5,516,822$ 604,962

$\overline{64,975,995}$

\section{Operating Expexges:}

Maint. way and struct... 10,377,184

Maint. of equipment...., 13,737,53

Traffic expenses........... $\quad 1,756,800$

Transp. expenses......... $\quad 35,697,961$

General expenses. . ...... 2,585,576

Transp. for invest......... cr. 2,183,355

Total oper. expenses... $\overline{61,971,701}$

Per cent. of exp. to gross.. (67.78\%)

Net oper. rev........... 29,463,673

Net from outside oper....

, $9,463,673$

Total net revenue.... $\overline{29,463,673}$

Taxes accrued.......... 4,746,721

Operating income..... $24,716,952$

$\begin{array}{ll}10,704.519 & 10,648,785\end{array}$

$13,112,978 \quad 13,871,985$

$1,799,610 \quad 1,894,343$

$33,960,581 \quad 35,065,842$

$1,752,373 \quad 1,403,012$

….

$61,330,061$

$1,403,012$

62,883,968

$66.82 \%) \quad(66.84 \%)$

\begin{tabular}{rr}
$30,452,630$ & $31,200,087$ \\
260,483 & 174,748 \\
\hline
\end{tabular}

$\overline{30,713,113} \overline{31,374,835}$

$4,106,557 \quad 3,823,832$

$\overline{26,606,555} \overline{27,551,003}$

$8,812,314$

$9,681,271$

$1,266,136$

$26,842,051$

$1,141,384$

......

$47,743,156$

$(75.63 \%)$

$15,379,587$

21,468

$15,401,055$

$2,868,710 \quad 2,662,700$

$\overline{12,532,345} \quad \overline{15,455,245}$

$8,864,401$

$8,839,384$

$1,264,272$

$1,118,709$

7,053,719

$(72.42 \%)$

$17,922,276$

195,669

$44,790,997$ $(69.07 \%)$

$\overline{20,263,517} \overline{21,345,907}$ $2,529,373 \quad 2,428,675$

$17,734,144 \quad \overline{18,917,232}$

Other INcome:

Div'ds on stocks owned.

Interest on bonds owned.

Other interest............

Rents received.

Miscellaneous credits....

515,191

342,257

$1,974,565$

487,988

329,712

Total other income.....

$3,649,713$

Gross income.

$28,360,665$
51,143

234,842

$2,065,328$

402,547

721,241

$3,475,101$

$30,081,656$
58,107

154,814

$1,886,818$

363,008

$1,509,792$

$3,972,539$

$31,523,542$
31,825

$5,283,516$

$1,575,206$

701,402

$7,591,948$

$\overline{20,124,293}$
$5,065,115$

$4,730,978$

$1,628,436$

804,880

$6,059,495$

$2,589,175$

.......

$\overline{9,453,550} \overline{1,090,245}$

$11,879,786$

$27,335,031$

$27,187,6 9 4 \longdiv { 2 0 , 0 0 7 , 4 7 7 }$

\section{Fixed Charges:}

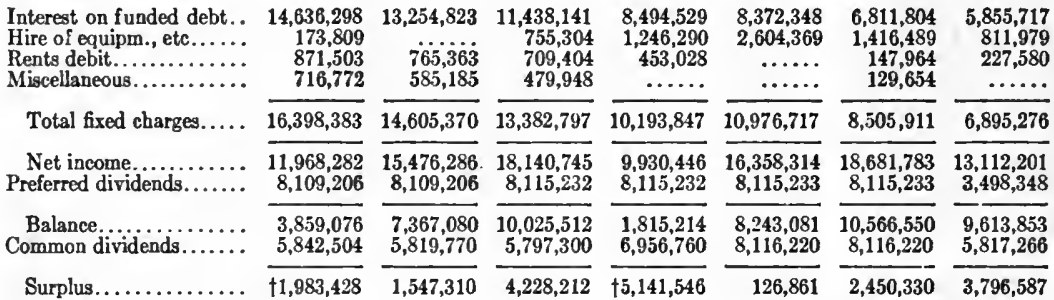

INDICATED EARNINGS:

$\begin{array}{llllllll}\text { On preferred stock..... } & 10.29 \% & 13.36 \% & 15.64 \% & 8.43 \% & 14.11 \% & 16.11 \% & 26.24 \%\end{array}$

- Figures for 1915, 1914 and 1913 inelude the operations of the Chicago, Milwaukee \& Puget Sound Ry.; for prior years, the revenue from that source is included in "Other Income.

$\uparrow$ Deficit.

\section{Capitalization Outstanding:}

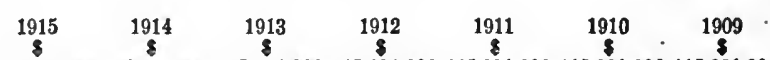

Preferred.............. 116,274,900 116,274,900 115,931,900 115,931,900 115,931,900 115,931,900 115,931,900 Common............... 117,361,400 116,855,400 115,946,000 115,946,000 115,946,000 115,946,000 115,946,000 Bonds.............. 356,146,655 333,308,655 299,554,754 227,599,155 192,860,655 147,809,500 115,765,500

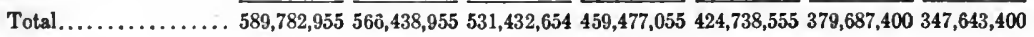




\section{COMBINED GENERAL BALANCE SHEET-WORKING CAPITAL.} (As OF JUNE 30.)

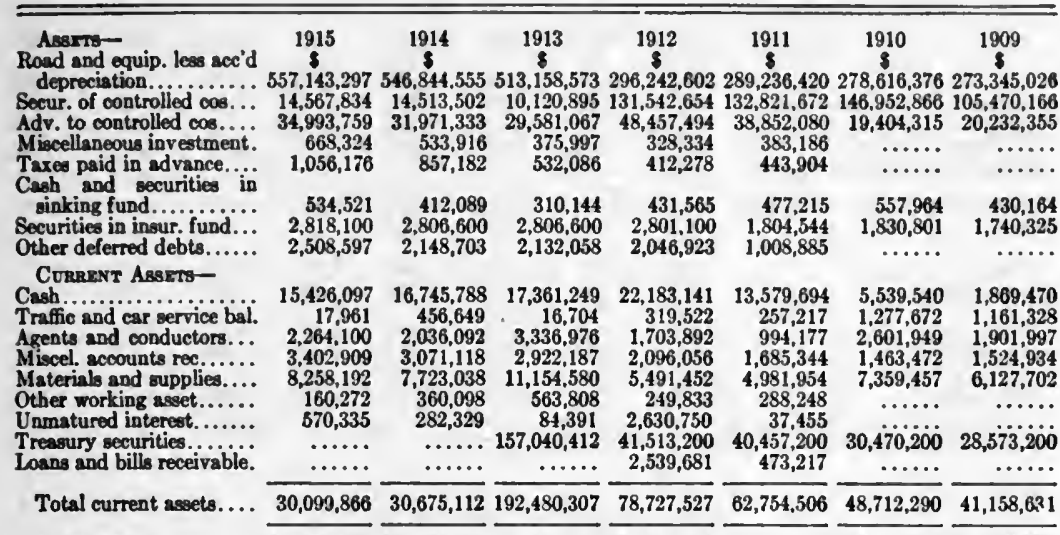

Total aseets.

$644,390,474630,762,992751,497,727 \quad 560,990,474 \quad \frac{527,782,412}{496,074,612} 442,376,667$

Lunartues-

Common stock

$117,361,400116,855,400116,348,200 \quad 116,348,200 \quad 116,348,200 \quad 116,348,200 \quad 116,348,200$

Preferred stock........... 116,274,900 116,274,900 116,274,900 116,274,900 116,274,900 116,274,900 116,274,900

Premium realized on capi-

tal stock............ $36,184,36,184$

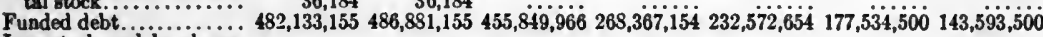

Less stock and bonds un-

sold; held by company.. $124,236,800 \quad 153,915,500$

Total capital liabilities. . $591,568,839$

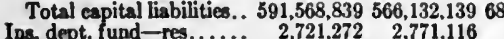

Other deferred credits.....

Renewals and improvem't

scoount...............

Appropriated surplus.....

Corrent Iabmirus-

Bills payable..............

Traffic and car service bal.

Pay rolls and vouchers...

Matured interest.........

Matured interest.........

Other working liabilities.

Interest accrued on funded

debt...................

French government tax...

550,730

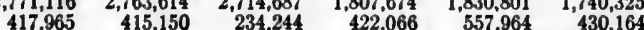

$688,473,066 \overline{500,990,254}$

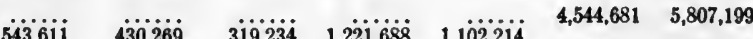

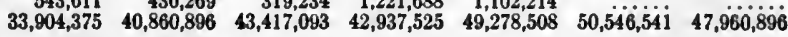

\begin{tabular}{|c|c|c|c|c|c|c|}
\hline $\begin{array}{r}30,280 \\
554,624\end{array}$ & $\begin{array}{r}5,030,280 \\
516,327\end{array}$ & 140.285 & 1121008 & 052027 & $4,090,000$ & 5749 \\
\hline $7,393,080$ & $\begin{array}{r}7,592,103 \\
\end{array}$ & $8,857,116$ & $6,534,394$ & $\begin{array}{r}4,001,529 \\
\end{array}$ & $\begin{array}{l}1,201,042 \\
4,945,276\end{array}$ & $5,488,823$ \\
\hline 389,248 & 340,974 & 457,832 & 150,647 & 98,764 & 393,268 & $1,450,927$ \\
\hline 171,110 & 120,410 & 95,081 & 32,055 & 41,452 & 47,470 & 58,786 \\
\hline 5,400 & 5,000 & 10.000 & 10,000 & 36,000 & ..... & \\
\hline 266,502 & 615,955 & 729,666 & 455,423 & 502,690 & & \\
\hline $5,459,273$ & $5,001,099$ & $4,495,241$ & $3,233,498$ & $3,110,290$ & $3,193,838$ & $2,648,0$ \\
\hline 832,130 & 928,459 & $1,308,399$ & $1,308,399$ & $1,308,399$ & $14,655,631$ & \\
\hline & …... & 6,950 & 42,594 & 23,135 & $\cdots \cdot \cdot$ & \\
\hline $5,101,647$ & 0150.607 & 6.109 .570 & $12,898,076$ & $9,976,196$ & $28,437,025$ & 10.221 \\
\hline
\end{tabular}

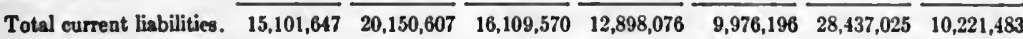

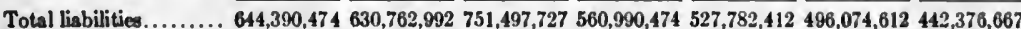

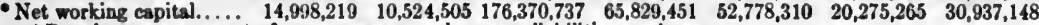

- Based upon statement of current assets and current liabilities as above.

Distribution of Gross Income.

\begin{tabular}{|c|c|c|c|c|c|c|}
\hline \multirow{3}{*}{$\begin{array}{l}\text { Per cent. of groes op. rev. to groes income.... } \\
\text { Per cent. of other income to gross income... }\end{array}$} & 1915 & 1914 & 1913 & 1912 & 1911 & 5-Yr. \\
\hline & $\begin{array}{r}96.1 \\
3.9\end{array}$ & $\begin{array}{r}96.1 \\
3.9\end{array}$ & $\begin{array}{r}95.6 \\
4.4\end{array}$ & $\begin{array}{l}89.2 \\
10.8\end{array}$ & $\begin{array}{l}84.3 \\
15.7\end{array}$ & $\begin{array}{r}02.2 \\
7.8\end{array}$ \\
\hline & 100.0 & 100.0 & 100.0 & 100.0 & 100.0 & 100.0 \\
\hline 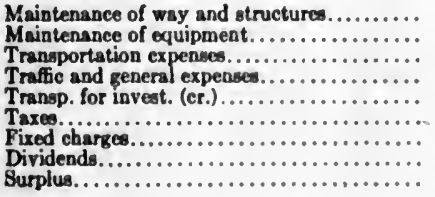 & $\begin{array}{r}10.9 \\
14.3 \\
37.6 \\
4.6 \\
2.2 \\
5.0 \\
17.1 \\
14.7 \\
\text { def. } 2.0\end{array}$ & $\begin{array}{r}11.3 \\
13.7 \\
35.5 \\
3.7\end{array}$ & $\begin{array}{r}10.8 \\
14.2 \\
35.7 \\
3.3\end{array}$ & $\begin{array}{r}4.1 \\
14.4 \\
21.2 \\
\text { def. } 7.2\end{array}$ & $\begin{array}{r}\dddot{3} .4 \\
11.2 \\
21.2 \\
0.2\end{array}$ & $\begin{array}{r}4.2 \\
14.9 \\
17.2 \\
\text { def. } 0.6\end{array}$ \\
\hline & 100.0 & 100.0 & 100.0 & 100.0 & 100.0 & 100. \\
\hline
\end{tabular}


Per Mile Statistics.

(Average Mileage Operated.)

\begin{tabular}{|c|c|c|c|c|c|c|c|c|}
\hline $\begin{array}{l}\text { Gross earnings............... } \\
\text { Maintenance way and structure } \\
\text { Maintenance of equipment..... } \\
\text { Cond. transp. and gen. exp..... } \\
\text { Transp. for invest. (cr.)........ }\end{array}$ & $\begin{array}{r}{ }^{*} 1915 \\
8 \\
9,096 \\
1,032 \\
1,367 \\
3,983 \\
217\end{array}$ & $\begin{array}{l}* 1914 \\
\$ \\
9,478 \\
1,105 \\
1,354 \\
3,874\end{array}$ & $\begin{array}{l}* 1913 \\
8 \\
9,787 \\
1,108 \\
1,443 \\
3,990\end{array}$ & $\begin{array}{l}1912 \\
8 \\
8,404 \\
1,173 \\
1,289 \\
3,894\end{array}$ & $\begin{array}{l}1911 \\
\$ \\
8,649 \\
1,047 \\
1,177 \\
4,040\end{array}$ & $\begin{array}{c}1910 \\
\$ \\
8,634 \\
1,128 \\
1,029 \\
3,807 \\
\ldots \ldots\end{array}$ & $\begin{array}{r}1909 \\
8 \\
7,974 \\
970 \\
969 \\
3,218\end{array}$ & $\begin{array}{r}1908 \\
8 \\
7,592 \\
886 \\
939 \\
3,131\end{array}$ \\
\hline 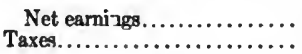 & $\begin{array}{r}2,931 \\
472\end{array}$ & $\begin{array}{r}3,145 \\
424\end{array}$ & $\begin{array}{r}3,246 \\
398\end{array}$ & $\begin{array}{r}2,048 \\
382\end{array}$ & $\begin{array}{r}2,385 \\
354\end{array}$ & $\begin{array}{r}2,670 \\
336\end{array}$ & $\begin{array}{r}2,818 \\
323\end{array}$ & $\begin{array}{r}2,636 \\
308\end{array}$ \\
\hline 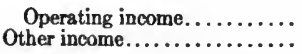 & $\begin{array}{r}2,459 \\
363\end{array}$ & $\begin{array}{r}2,721 \\
386\end{array}$ & $\begin{array}{r}2,848 \\
431\end{array}$ & $\begin{array}{l}1,666 \\
1,014\end{array}$ & $\begin{array}{l}2,031 \\
1,607\end{array}$ & $\begin{array}{l}2,334 \\
1,060\end{array}$ & $\begin{array}{r}2,495 \\
199\end{array}$ & $\begin{array}{r}2,328 \\
229\end{array}$ \\
\hline 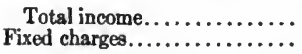 & $\begin{array}{l}2,822 \\
1,632\end{array}$ & $\begin{array}{l}3,107 \\
1,508\end{array}$ & $\begin{array}{l}3,279 \\
1,392\end{array}$ & $\begin{array}{l}2,680 \\
1,357\end{array}$ & $\begin{array}{l}3,638 \\
1,461\end{array}$ & $\begin{array}{r}3,394 \\
907\end{array}$ & $\begin{array}{r}2,694 \\
949\end{array}$ & $\begin{array}{r}2,557 \\
882\end{array}$ \\
\hline Net income................ & 1,190 & 1,599 & 1,887 & 1,323 & 2,177 & 2,487 & 1,745 & 1,675 \\
\hline
\end{tabular}

* Figures for 1915, 1914 and 1913 include the operations of the Chicago, M. P. Sound Ry.; for prior years, the revenue from that source is included in "Other Income."

\section{Capitalization per Mile.}

\begin{tabular}{|c|c|c|c|c|c|c|c|}
\hline 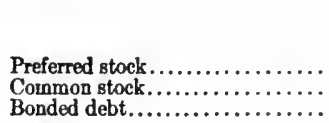 & $\begin{array}{r}1915 \\
8 \\
8,409 \\
8,488 \\
25,757\end{array}$ & $\begin{array}{r}1914 \\
\$ \\
8,508 \\
84,550 \\
24,390\end{array}$ & $\begin{array}{c}1913 \\
8 \\
8,873 \\
8,874 \\
22,926\end{array}$ & $\begin{array}{c}1912 \\
\mathbf{8} \\
11,293 \\
11,294 \\
22,170\end{array}$ & $\begin{array}{c}1911 \\
\text { \$ } \\
11,438 \\
11,439 \\
19,027\end{array}$ & $\begin{array}{c}1910 \\
\$ \\
11,543 \\
11,544 \\
14,717\end{array}$ & $\begin{array}{c}1909 \\
\$ \\
11,571 \\
11,572 \\
11,554\end{array}$ \\
\hline Total $\ldots \ldots \ldots \ldots \ldots \ldots \ldots \ldots$ & 42,654 & 41,448 & 40,873 & 44,757 & 41,904 & 37,804 & 34,697 \\
\hline
\end{tabular}

Notz. - The above figures, representing capitalization per mile, are based upon total main tracks and sidings owned and operated in the various years, as follows:

\begin{tabular}{|c|c|c|c|c|c|c|c|}
\hline & 1915 & 1914 & 1913 & 1912 & 1911 & 1910 & 1909 \\
\hline Main track, miles. & $9,617.22$ & $9,578.48$ & $9,321.99$ & $7,265.93$ & $7,265.93$ & $7,266.09$ & $7,266.09$ \\
\hline $\begin{array}{l}\text { Second track, miles } \\
\text { Third track, miles. }\end{array}$ & $\begin{array}{l}1,023.50 \\
21.72\end{array}$ & $\begin{array}{r}924.95 \\
21.72\end{array}$ & $\begin{array}{r}606.05 \\
22.27\end{array}$ & $\begin{array}{r}593.44 \\
11.89\end{array}$ & $\begin{array}{r}572.86 \\
11.89\end{array}$ & $\begin{array}{r}485.09 \\
9.39\end{array}$ & $\begin{array}{r}480.69 \\
9.39\end{array}$ \\
\hline Fourth track, miles.... & 13.11 & 13.11 & 13.11 & 2.63 & 2.63 & 2.63 & 2.63 \\
\hline Connecting track, miles. & $\begin{array}{r}46.98 \\
\end{array}$ & 45.13 & $\begin{array}{r}44.42 \\
2\end{array}$ & $\begin{array}{r}40.69 \\
0\end{array}$ & $\begin{array}{r}40.31 \\
20.10\end{array}$ & 39.48 & 39.13 \\
\hline Yard track, etce., miles.. & $3,104.48$ & $3,083.07$ & $2,998.63$ & $2,351.07$ & $2,242.19$ & $2,240.06$ & $2,216.61$ \\
\hline Total mileage... & $13,827.01$ & $13,666.46$ & $13,066.47$ & $10,265.62$ & $10,135.81$ & $10,043.34$ & $10,019.54$ \\
\hline
\end{tabular}

\section{Commodity Statistics.}

Products of -

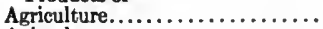

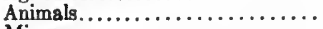

Mines.

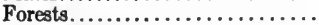

Manufactures.................

Miscellaneous.................

Total.

\begin{tabular}{ccc}
1915 & 1914 & 1913 \\
$\%$ & \multicolumn{1}{c}{$\%$} & $\%$ \\
23.49 & 21.70 & 20.95 \\
6.08 & 5.45 & 5.19 \\
26.77 & 25.03 & 26.07 \\
16.66 & 18.29 & 17.77 \\
16.30 & 17.50 & 18.72 \\
10.70 & 12.03 & 11.30 \\
\hline 100.00 & 100.00 & $\frac{100.00}{}$
\end{tabular}

$\begin{array}{r}1912 \\ \% \\ 19.00 \\ 6.56 \\ 27.43 \\ 15.92 \\ 18.34 \\ 12.75 \\ \hline 100.00\end{array}$

\begin{tabular}{ccc}
1911 & 1910 & 1909 \\
$\%$ & $\begin{array}{c}190 \\
\%\end{array}$ & $\%$ \\
21.42 & 18.74 & 21.34 \\
6.45 & 5.36 & 6.41 \\
26.82 & 31.87 & 28.90 \\
13.52 & 12.55 & 13.50 \\
18.55 & 19.73 & 17.81 \\
13.24 & 11.75 & 12.04 \\
\hline 100.00 & 100.00 & 100.00
\end{tabular}

\section{Traffic Statistics.}

Freight Trafric-

Revenue freight carried (tons).

- Freight traffic density

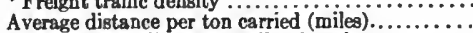

Freight train mileage per mile of road.

Average revenue train load (tons)...

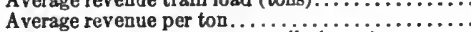

Average revenue per ton per mile (cents) .............

Freight revenue per train mile................

Car Loading and Movement-

Average revenue freight per loaded car (tons)....

Average loaded cars per train (No.)...............

Average empty cars per train (No.)..............

Per cent. of loaded to total car mileage...............
$1915 \quad 1914$

$\begin{array}{rrr}32,959,392 & 33,007,277 & 34,805,491 \\ 814,364 & 834,338 & 891,507 \\ 248.37 & 244.79 & 246.23 \\ 2,086 & 2,479 & 2,213 \\ 390.21 & 379.78 & 356.95 \\ \$ 1.9404 & \$ 1.9773 & \$ 1.9527 \\ .7813 & .8078 & .7930 \\ \$ 3.0486 & \$ 3.0678 & \$ 2.8308 \\ & & \\ 16.835 & 16.498 & 16.776 \\ 23.179 & 23.019 & 21.277 \\ 10.138 & 9.318 & 7.462 \\ 69.5 \% & 71.2 \% & 74.0 \%\end{array}$

1912

1911

$29,286,115 \quad 26,793,647$.

679,799 - $\quad 708,671$

$224.55 \quad 198.68$

$2,232 \quad 2,581$

$\begin{array}{ll}307.82 & 274.58\end{array}$

$\$ 1.9052 \quad \$ 1.6712$

$.8485 \quad .8411$

$\$ 2.6117 \quad \$ 2.3095$

$15.355 \quad 14.968$

$20.046 \quad 18.345$

$\begin{array}{ll}7.136 & 7.319\end{array}$

$73.7 \% \quad 71.5 \%$

* Representing the tonnage of freight and the number of passengers carried one mile, per mile of road operated. 
Traffic Statistics (Cont.)

Pasgenger Trame-

$\begin{array}{lllll}1915 & 1914 & 1913 & 1912 & 1911\end{array}$

Passengen Trumc-
Passengers carried (No.)

$\begin{array}{lllll}16,065,456 & 16,426,016 & 16,123,475 & 14,859,937 & 14,395,918\end{array}$

- Passenger traffic density........................ $\quad 85,401$

Average distance per passenger carried (milea)......

Passenger train mileage, per mile of road..........

Average passengers per train mile (No.)...............

Average revenue per passenger...................

Passenger revenue per train mile................

$\begin{array}{rrrrr}53.43 & 55.54 & 53.48 & 53.13 & 47.05 \\ 1.854 & 1.077 & 1.089 & 1.914 & 1.947\end{array}$

94,215

88,694

$91,055 \quad 100,917$

$\begin{array}{lllll}46.05 & 47.66 & 45.10 & 43.20 & 46.31\end{array}$

$\$ 1.1175 \quad \$ 1.1543 \quad \$ 1.1447 \quad \$ 1.1128 \quad 80.9781$

$\begin{array}{lllll}2,091 & 2,078 & 2,141 & 2,094 & 2,079\end{array}$

$\begin{array}{lllll}\$ 0.9629 & \$ 0.9905 & \$ 0.9654 & \$ 0.9047 & \$ 0.9628\end{array}$

- Representing the tonnage of freight and the number of passengers carried one mile, per mile of road operatea.

Gross Earnings by Months.

\begin{tabular}{|c|c|c|c|c|c|c|c|}
\hline 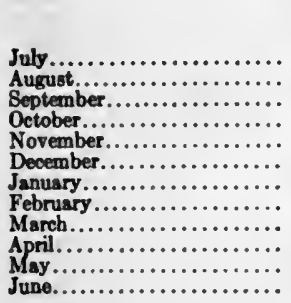 & $\begin{array}{c}\dagger 1914-15 \\
8 \\
7,824,986 \\
8,189,201 \\
9,240,207 \\
8,873,521 \\
7,379,909 \\
7,289,244 \\
6,696,116 \\
6,472,696 \\
7,544,390 \\
6,877,038 \\
7,244,196 \\
7,810,870\end{array}$ & $\begin{array}{r}\dagger 1913-14 \\
\$ \\
7,740,518 \\
7,870,612 \\
8,675,621 \\
9,246,434 \\
8,161,618 \\
7,652,902 \\
6,912,067 \\
6,144,423 \\
7,630,103 \\
7,106,116 \\
6,970,871 \\
7,671,406\end{array}$ & $\begin{array}{c}11912-13 \\
8 \\
7,393,547 \\
8,111,277 \\
8,604,270 \\
9,410,077 \\
8,670,292 \\
8,313,293 \\
7,283,152 \\
6,564,392 \\
7,596,900 \\
7,166,906 \\
7,338,031 \\
7,631,916\end{array}$ & $\begin{array}{c}1911-12 \\
5 \\
5,044,537 \\
5,495,460 \\
5,062,267 \\
6,141,524 \\
5,402,186 \\
5,298,578 \\
4,256,348 \\
4,903,318 \\
5,300,658 \\
5,054,242 \\
4,936,862 \\
5,326,758\end{array}$ & $\begin{array}{c}1910-11 \\
5 \\
5,341,535 \\
5,998,306 \\
6,504,202 \\
6,508,260 \\
5,762,846 \\
5,407,237 \\
4,736,623 \\
4,483,669 \\
5,238,606 \\
\mathbf{4}, 771,762 \\
5,040,679 \\
\mathbf{5 , 1 8 2 , 2 6 2}\end{array}$ & $\begin{array}{r}5 \text { Yr. Av. } \\
\mathbf{5} \\
6,660,024 \\
7,132,971 \\
7,797,313 \\
8,035,963 \\
7,075,370 \\
6,790,848 \\
5,976,862 \\
5,713,699 \\
6,662,131 \\
6,195,223 \\
6,306,127 \\
6,724,642\end{array}$ & $\begin{array}{c}\text { \%o of } \\
\text { Total } \\
8.22 \\
8.80 \\
0.61 \\
9.91 \\
8.73 \\
8.38 \\
7.37 \\
7.05 \\
8.22 \\
7.64 \\
7.78 \\
8.20\end{array}$ \\
\hline 3 & & & & & &, 173 & 00.00 \\
\hline
\end{tabular}

* Operating Income by Months.

\begin{tabular}{|c|c|c|c|c|c|c|c|}
\hline 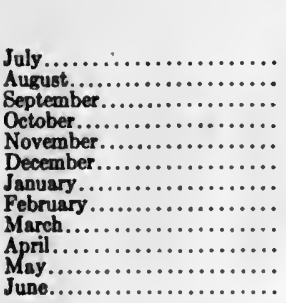 & $\begin{array}{l}\uparrow 1914-15 \\
8 \\
2,383,898 \\
2,157,688 \\
3,208,945 \\
2,683,710 \\
1,646,072 \\
1,826,485 \\
1,349,513 \\
907,492 \\
2,479,908 \\
1,556,038 \\
1,694,466 \\
2,822,737\end{array}$ & $\begin{array}{l}+1913-14 \\
8 \\
2,230,314 \\
1,903,603 \\
2,614,282 \\
3,273,231 \\
2,434,792 \\
2,641,871 \\
1,882,303 \\
974,536 \\
2,783,166 \\
1,784,275 \\
1,830,218 \\
2,253,964\end{array}$ & $\begin{array}{r}\dagger 1012-13 \\
8 \\
2,393,643 \\
2,949,242 \\
3,067,856 \\
3,665,528 \\
2,830,147 \\
2,533,809 \\
1,734,941 \\
857,483 \\
2,130,510 \\
1,470,995 \\
1,804,898 \\
2,061,940\end{array}$ & $\begin{array}{r}1911-12 \\
8 \\
1,126,827 \\
1,085,200 \\
1,274,061 \\
1,711,479 \\
1,276,886 \\
1,447,571 \\
249,565 \\
651,265 \\
1,241,369 \\
580,358 \\
618,806 \\
1,268,950\end{array}$ & $\begin{array}{r}1910-11 \\
5 \\
1,375,831 \\
1,545,183 \\
1,898,177 \\
1,902,095 \\
1,124,430 \\
989,400 \\
332,821 \\
546,502 \\
1,550,298 \\
1,058,696 \\
1,415,881 \\
1,715,924\end{array}$ & $\begin{array}{r}5 \text { Yr. Av. } \\
\$ \\
1,902,103 \\
1,929,183 \\
2,412,664 \\
2,647,209 \\
1,862,466 \\
1,897,827 \\
1,109,829 \\
787,456 \\
2,037,050 \\
1,290,073 \\
1,472,854 \\
2,024,703\end{array}$ & $\begin{array}{r}\% \text { of } \\
\text { Total } \\
8.90 \\
9.02 \\
11.20 \\
12.39 \\
8.71 \\
8.88 \\
5.19 \\
3.60 \\
9.53 \\
6.04 \\
6.89 \\
9.47\end{array}$ \\
\hline Tota & & & & 344 & & 417 & 0.00 \\
\hline
\end{tabular}

- After deduction of "outside operations" and taxes.

f Figures for 1914-15, 1913-14 and 1912-13 include the operations of the Chicago, Milwaukce \& Puget Sound Railway.

\section{HISTORY AND PROPERTY}

History.--Incorporated on May 5, 1863, in Wisconsin, as the Milwaukee \& St. Paul Ry.; name was changed to present title on Feb. 14, 1874. During the development of the system the following lines have been added either by acquisition of control or by construction:

Western Union R. R. (in 1874).

Milwaukce \& Northern R. R. (Oct. 1, 1890).

Wisconsin Western R. R. (in 1903).

Duluth, St. Cloud, Glencoe

Mankato Ry. (in April, 1906).
Chicago Milwaukce \& Puget Sound Ry. (construetion completed 1012).

Idaho \& Western Ry. (Dec. 6, 1912).

Idaho \& Washington Northern R. R. (acquired Dec., 1913).

Great Falls Terminal Railway (sequired Nov. 5, 1914).

Note. - I. \& W. N. R. R. was acquired by exchange of that company'a bonda and notes for C., M. \& St. P. Ry. $4 \%$ Debentures, due 1934, par for par. On June 30,1914 , the company had acquired $83 \%$ of the copital atock and all the bonds and notes except $\$ 60,000$ first mortgago bonds.

Property,-Owns lines from Chicago to Milwaukee, Minnerpolis, Kansas City, Omaha, St. Paul, Duluth, Des Moines, Sioux Falls, Butte, Spokane, Seattle, Tacoma, and a large number of other important cities and towns in 
Mlinois, Wisconsin, Michigan, Missouri, Iowa, Minnesota, North and South Dakota, Montana, Idaho and Washington. Total main line mileage directly owned, 9,617.22 miles; owned jointly with other companies, 103.45 miles; used under contracts, 354.94 miles; total mileage operated, including second track, sidings, etc., $14,554.28$ miles.

Mileage Summary.

June 30, 1915.

Main track, miles.....................

Second track, miles

Third track miles

Fourth track, miles.

Connection track, miles.......................

Yard track, etc., miles.

Total miles.

\begin{tabular}{cc}
$\begin{array}{c}\text { Owned solely } \\
\text { by this }\end{array}$ & $\begin{array}{c}\text { Owned jointly } \\
\text { with other }\end{array}$ \\
company & companies \\
$9,617.22$ & 103.45 \\
$1,023.50$ & 6.14 \\
21.72 & 1.94 \\
13.11 & 1.93 \\
46.98 & 5.92 \\
$3,104.48$ & 175.34 \\
\hline $13,827.01$ & \\
& 294.72
\end{tabular}

\begin{tabular}{cr}
$\begin{array}{c}\text { Used under } \\
\text { contracts }\end{array}$ & \multicolumn{1}{c}{ Total } \\
& \multicolumn{1}{c}{} \\
354.94 & $10,075.61$ \\
76.47 & $1,106.11$ \\
1.14 & 24.80 \\
$\cdots \cdots$. & 15.04 \\
$\cdots \cdots$ & 52.90 \\
$\cdots \cdots$ & $3,279.82$ \\
\hline 432.55 & 14.554 .28
\end{tabular}

\section{Mileage by States.}

(Main track owned solely and jointly.)
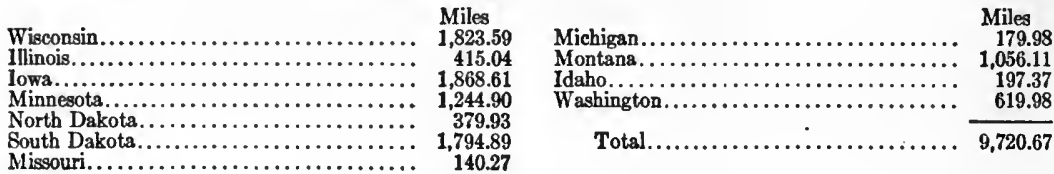

\section{Equipment.}

\begin{tabular}{|c|c|c|c|c|c|}
\hline Loer & $\begin{array}{r}\dagger 1915 \\
1,983\end{array}$ & $\begin{array}{l}\dagger 1914 \\
1,976\end{array}$ & $\begin{array}{c}+1913 \\
1,959\end{array}$ & $\begin{array}{c}\dagger 1912 \\
1,812\end{array}$ & $\dagger 1911$ \\
\hline I tractive power (lb & $\ldots \ldots$ : & $\ldots \ldots$ & $6,614,053$ & $47,797,795$ & $1,720,558$ \\
\hline rage $T . P$ & & & 28,490 & & \\
\hline t cars, No............ & 65,466 & 66,897 & 65,7 & & \\
\hline ht cars, total capacity (tons)... & $\cdots$ & $\cdots \cdot$ & $2,198,4$ & $1,952,491$ & 1,86 \\
\hline reight cars, average capacity (tons)........ & & & 34.00 & 32.9 & \\
\hline Passenger cars (No.).......................... & 1,606 & 1,563 & & 1,479 & \\
\hline ervice cars (No.) $\ldots \ldots \ldots \ldots \ldots \ldots$ & 1,704 & 1,730 & & & \\
\hline
\end{tabular}

* Including sleeping cars, dining cars, parlor cars, baggage cars, etc.

$\uparrow$ Figures include Chicago, Milwakkee \& Puget Sound Ry.

\section{Officers AND Directors.}

Officers-A. J. Earling, Pres.; H. R. Williams, J. H. Hiland, E. S. Keeley, E. D. Sewall, D. I. Bush, H. B. Earling, Vice-Pres.; E. W. Adams, Sec'y; F. G. Ranney, Treas.; P. C. Hart, Gen. Mgr.

Executive Commitree-A. J. Earling, C. W. Harkness, P. A. Rockefeller, Wm. Rockefeller' J. A. Stewart, H. R. Williams.

Directors-(1917) W. P. Bliss, C. W. Harkness, J. D. Ryan, Samuel McRoberts, New York; A. J. Earling, Chicago; (1915) D. G. Geddes, Wm. Rockefeller, J. A. Stewart, H. R. Williams, New York; (1916) P. A. Rockefeller, New York; J. Ogden Armour, Stanley Field, Chicago; L. J. Petit, Milwaukee. 


\section{COMPARATIVE CONSOLIDATED INCOME ACCOUNT, YEARS ENDED DECEMBER 31}

Net earn. of smelt. \& refin. plta \& indus dependent plta. \& indus, dependent

Net earb. from mining properties............ $\quad 935,193 \quad 1,185,154 \quad 3,113,105 \quad 2,000,187 \quad 105,619 \quad 331,334 \quad \ldots$ Total net earnings..... $\overline{\$ 11,603,015} \overline{\$ 12,111,408} \overline{\$ 15,081,940} \overline{\$ 14,100,948} \overline{\$ 6,913,964} \overline{\$ 7,069,555} \ldots$ Ormar Ixcour -

Inter, rents, divds. rec'd, etc. $\ldots \ldots \ldots \ldots \ldots \ldots \ldots \ldots, 1,222,514 \quad 1,318,525 \quad 1,077,560 \quad 1,011,177 \quad 072,741 \quad 823,116 \quad \ldots$ Groes income. $\underset{\$ 12,825,530}{\$ 13,429,933} \overline{\$ 16,759,500} \underset{\$ 15,112,125}{\$ \$ 7,886,705} \underset{\$ 7,892,971}{\$ \$, 349,314}$ Dendcrions-

Adminic. expenses.........

Research \& exam. exp.....

Corporate taxes...........

Deben. bond inter.........

Discount on bonds........

Depreciation.............

Total deductions.

\begin{tabular}{|c|c|c|c|c|c|c|}
\hline \multirow{4}{*}{$\begin{array}{r}\$ 924,683 \\
55,008 \\
175,859 \\
808,064 \\
50,000 \\
1,540,350\end{array}$} & \multirow{4}{*}{$\begin{array}{r}\mathbf{8 9 6 , 6 3 9} \\
90,538 \\
210,698 \\
900,000 \\
\mathbf{5 0 , 0 0 0} \\
\mathbf{1 , 5 2 5 , 5 1 8}\end{array}$} & \multirow{4}{*}{$\begin{array}{r}\$ 758,177 \\
159,619 \\
123,917 \\
900,000 \\
50,000 \\
3,013,543\end{array}$} & $\$ 767,982$ & $\$ 368,358$ & $\$ 375,077$ & $\begin{array}{r}-8637,335 \\
\ldots \ldots\end{array}$ \\
\hline & & & 114,198 & $102,23 i$ & $\ddot{0} 977$ & …...... \\
\hline & & & & & & \\
\hline & & & $\begin{array}{r}45 \\
1,887\end{array}$ & 750,000 & $\ddot{4} 101,638$ & 321,234 \\
\hline & & $\$ 5,005,256$ & & 020.5 & 28609 & 2058 \\
\hline & & & & & & \\
\hline
\end{tabular}

Net income.

1914

1919

1911 $+1911$

1910

$\$ 1909$

Div'ds on Prd. Stocks:

Amer. Smelt. \& Refining Co....................

Amer. Smelt. Secur. Co. Pref. "A" $A$...........

Pref. "B"............

Total pref. div'ds......

Avail. for com. stock div-

idends................ Refin. Co..............

Surplus for year.

$\begin{array}{lllll}\$ 3,500,000 & \$ 3,500,000 \quad \$ 3,500,000 \quad \$ 3,500,000 & \$ 3,500,000 \quad \$ 3,500,000 \quad \$ 3,500,000\end{array}$

$1,017,450 \quad 1,020,000 \quad 1,020,000 \quad 1,020,000 \quad \ldots \ldots \ldots$

$1,500,000 \quad 1,500,000 \quad 1,500,000 \quad 1,500,000 \quad \ldots \ldots$.

$\$ 6,017,450 \frac{\$ 6,020,000}{\$ 6,020,000} \overline{\$ 6,020,000} \overline{\$ 3,500,000} \frac{\$ 3,500,000}{\$ 3,500,000}$

$\$ 3,254,115 \quad \$ 3,736,540 \quad \$ 5,734,244 \quad \$ 5,451,713 \quad \$ 3,166,116 \quad \$ 3,546,279 \quad \$ 3,890,745$

$\begin{array}{lllllll}2,000,000 & 2,000,000 & 2,000,000 & 2,000,000 & 2,000,000 & 2,000,000 & 2,000,000\end{array}$

$\$ 1,254,115 \$ 1,736,540 \$ \$ 3,734,244 \frac{\$ 3,451,713}{\$ 1,166,116} \stackrel{\$ 1,546,279}{\$ 1,890,745}$ $\begin{array}{lllllll}18,405,943 & 16,759,402 & 13,699,726 & 11,148,223 & 16,797,547 & 15,251,268 & 13,408,219\end{array}$

Previous surplus.

Apprais. val. of Amer. Smelt. Sec. Co. com. stock...................

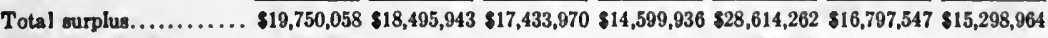

Misc. P. \& L. chgs.......

Deprec. in value of in vestments..............

Approp. to empl. bonuser

Trans. to prop. acct.......

P. \& L. surplus.

\begin{tabular}{|c|c|c|c|c|c|c|}
\hline 240,000 & $\ldots \cdots$ & ...... & ...... & 20,572 & ...... & ..... \\
\hline ...... & ....... & 367,823 & ....... & 300,572 & ...... & \\
\hline$\ldots \ldots$ & $\ldots \ldots$ & $\begin{array}{r}306,745 \\
\ldots \ldots \ldots\end{array}$ & $\begin{array}{c}900,210 \\
\ldots . .\end{array}$ & $15,24 \overline{4}, 30 \dot{5}$ & $\ldots \ldots$ & $\begin{array}{l}\$ 7,695 \\
\ldots \ldots\end{array}$ \\
\hline …… & …… & …… & …… & & $\cdots \cdots$ & \\
\hline
\end{tabular}

INDICATED EARNINGS:

On $\$ 50,000,000$ Proferred Stock..........

On $\$ 50,000,000$ common stock ...............

$\begin{array}{crrrrrr}1914 & 1913 & 1912 & 1911 & +1911 & +1910 & +1909 \\ 18.54 \% & 19.51 \% & 23.51 \% & 22.94 \% & 13.33 \% & 14.09 \% & 14.78 \% \\ 6.51 \% & 7.47 \% & 11.47 \% & 10.90 \% & 6.33 \% & 7.09 \% & 7.78 \%\end{array}$

† Years ended April 30, including transactions of the American Smelting \& Refining Co. only.

- Includes taxes. 
CONSOLIDATED GENERAL BALANCE SHEET-WORKING CAPITAL.

(As of December 31)

\begin{tabular}{|c|c|c|c|c|c|c|c|}
\hline $\begin{array}{l}\text { Assets- } \\
\text { Property account........ } \\
\text { Investm. in secur. of other }\end{array}$ & $\begin{array}{c}1914 \\
\$ \\
\$\end{array}$ & $\begin{array}{c}1913 \\
\$ \\
140,906,799\end{array}$ & 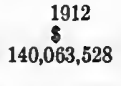 & $\stackrel{1}{\$}_{139,963,733}$ & $\begin{array}{c}\text { *1910 } \\
86,845,671\end{array}$ & $\begin{array}{c}* 1909 \\
8 \times \\
86,845,671\end{array}$ & $\begin{array}{c}{ }^{*} 1908 \\
86,845,671\end{array}$ \\
\hline 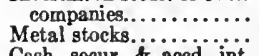 & $\begin{array}{r}1,204,502 \\
24,660,943\end{array}$ & $\begin{array}{r}1,183,653 \\
26,481,003\end{array}$ & $\begin{array}{r}1,010,538 \\
29,661,019\end{array}$ & $\begin{array}{r}1,585,670 \\
26,492,980\end{array}$ & $\begin{array}{r}2,058,388 \\
15,547,541\end{array}$ & $\begin{array}{r}3,949,958 \\
15,537,487\end{array}$ & $\begin{array}{r}3,950,088 \\
15,451,158\end{array}$ \\
\hline $\begin{array}{l}\text { Cash. secur. \& aced. int. } \\
\text { in funds............. } \\
\text { Unextin. disc. on bds..... } \\
\text { Prep. tax., insur., etc..... } \\
\text { Adv. to affl. cos.......... }\end{array}$ & $\begin{array}{l}594,700 \\
554,167 \\
426,512 \\
282,228\end{array}$ & $\begin{array}{l}479,637 \\
604,167 \\
569,751 \\
180,425\end{array}$ & $\begin{array}{l}229,601 \\
654,167 \\
327,185 \\
349,744\end{array}$ & $\begin{array}{l}232,555 \\
704,167 \\
400,149 \\
333,705\end{array}$ & $\begin{array}{l}\cdots \cdots \\
\cdots \cdots \\
\cdots \cdots\end{array}$ & $\begin{array}{l}\cdots \cdots \\
\cdots \cdots \\
\cdots \cdots\end{array}$ & $\begin{array}{l}\cdots \cdots \\
\cdots \cdots \cdots \\
\cdots \cdots\end{array}$ \\
\hline Currankt Assets- & & & & & & & \\
\hline $\begin{array}{l}\text { Materials and supplies. } \\
\text { Cash on hand and in }\end{array}$ & $2,785,636$ & $3,017,682$ & $2,783,113$ & $2,566,872$ & $1,278,098$ & $1,330,774$ & $1,380,742$ \\
\hline $\begin{array}{l}\text { transit. } \\
\text { Foreign bills of exch. and } \\
\text { temp. invests.......... }\end{array}$ & $8,034,778$ & $4,043,666$ & $3,809,374$ & $5,890,708$ & $\cdots \cdots$ & $\cdots \cdots$ & - $\ldots \ldots$ \\
\hline $\begin{array}{l}\text { Demand loans secured..... } \\
\text { Accts. and notes receiv... }\end{array}$ & $\begin{array}{l}4,533,945 \\
4,857,605\end{array}$ & $\begin{array}{l}5,068,167 \\
5,851,433\end{array}$ & $\begin{array}{l}5,935,873 \\
4,387,563\end{array}$ & $\begin{array}{l}3,192,050 \\
4,236,519\end{array}$ & 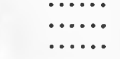 & & \\
\hline $\begin{array}{l}\text { Net current assets....... } \\
\text { Cash and demand loans.. }\end{array}$ & $\cdots \cdots$ & $\cdots \cdots$ & $\cdots \cdots$ & $\cdots \cdots$ & $\uparrow 11, \ddot{620,000}$ & $\begin{array}{r}465,140 \\
7,359,239\end{array}$ & $\begin{array}{r}500,526 \\
5,629,034\end{array}$ \\
\hline Total current assets..... & $\$ 20,211,964$ & $19,438,348$ & $16,915,923$ & $15,886,149$ & $12,898,498$ & $9,155,153$ & $7,510,302$ \\
\hline
\end{tabular}

Total assets. . $\$ 188,577,2 3 7 \vec { 1 8 9 , 8 4 3 , 7 8 3 } \vec { 1 8 9 , 2 1 1 , 7 0 5 } \vec { 1 8 5 , 5 9 9 , 1 0 8 } \vec { 1 1 7 , 3 5 0 , 0 9 8 } \vec { 1 1 5 , 4 8 8 , 2 6 9 } \longdiv { 1 1 3 , 7 5 7 , 2 1 9 }$

\section{LUBחuTIEs-}

Pfd. stock outstand...... Com. stock outstand......

Deb. bonds outstand......

Reserve and susp. cred.

accounts...............

P. \& I. surplus.

$96,830,000 \quad 97,000,000 \quad 97,000,000$

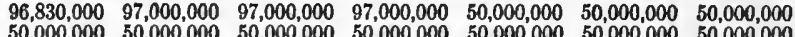
$\begin{array}{lllllll}50,000,000 & 50,000,000 & 50,000,000 & 50,000,000 & 50,000,000 & 50,000,000 & 50,000,000\end{array}$ $\begin{array}{lllll}1,322,192 & 1,307,788 & 1,169,216 & 1,089,272 & \ldots\end{array}$ $\overline{\$ 19,510,058} \overline{18,495,943} \overline{16,759,402} \overline{13,699,726} \overline{16,797,547} \overline{15,251,269} \overline{13,408,219}$

Corrent Lubitites-

Accounts, drafts and wages payable.................
Defd. paym. on min. properties................ Int. on deb, bds.unDivds. unclaimed and pay-

able.................

Accd. taxes not due.......

Emp. sav. deposits.......

\begin{tabular}{|c|c|c|c|c|c|}
\hline $4,710,388$ & $6,427,881$ & $6,773,296$ & $5,598,661$ & ...... & ...... \\
\hline 215,500 & 330,000 & 440,000 & ...... & & \\
\hline 389,910 & 380,100 & 412,605 & 379,125 & & .... \\
\hline $\begin{array}{r}1,924,314 \\
323,875\end{array}$ & $\begin{array}{r}2,045,897 \\
321,674\end{array}$ & $\begin{array}{r}1,917,377 \\
244,809\end{array}$ & $\begin{array}{r}2,517,427 \\
198,493\end{array}$ & …... & ….... \\
\hline …..... & $\cdots \cdots \cdot$ & ........ & $\begin{array}{c}116,404 \\
\ldots \ldots\end{array}$ & $431, \overline{5} 51$ & $\ldots \ldots$ \\
\hline$\$ 7,563,987$ & $\mathbf{9 , 5 0 5 , 5 5 2}$ & $9,788,087$ & $8,810,110$ & 431,551 & \\
\hline
\end{tabular}

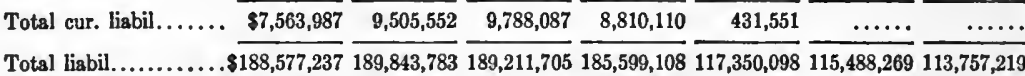

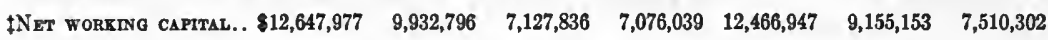

* The fiscal year ended April 30 represents assets and liabilities of the American Smelting \& Refining Co. After the fiscal year April 30, 1910, the Balance Sheets of the American Smelting \& Refining Co. and American Smelting Security Co. were consolidated.

$\dagger$ Demand loans cover advances to affiliated companies.

$\ddagger$ Based on current assets and current liabilities as indicated above. 


\section{BETHLEHEM STEEL CORPORATION.?}

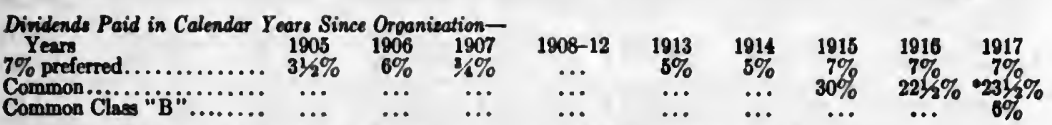

-Also a dividend of $200 \%$, payable February 17, 1917, in Class "B" common stock at par.

For any dividends paid during current calendar year, sce Daily Dividend Sheet.

IOYEAR ANALYSIS OF INCOME ACCOUNT.

Years Ended December 31.

\begin{tabular}{|c|c|c|c|c|c|c|c|}
\hline 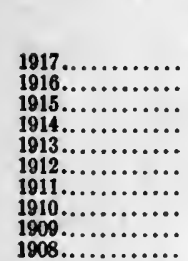 & $\begin{array}{c}\text { Net Manufac- } \\
\text { turing Profits } \\
\$ 51,002,772 \\
60,092,551 \\
23,782,784 \\
9,378,385 \\
8,530,708 \\
4,846,814 \\
\mathbf{4 . 6 0 5 , 4 1 0} \\
\mathbf{4 , 3 8 6 , 4 3 9} \\
2,811,400 \\
2,024,025\end{array}$ & $\begin{array}{c}\text { Other } \\
\text { Income } \\
\mathbf{\$ 2 , 9 7 6 , 5 8 8} \\
1,624,758 \\
1,038,624 \\
271,282 \\
221,963 \\
267,626 \\
187,303 \\
127,702 \\
182,136 \\
172,147\end{array}$ & $\begin{array}{c}\text { Total } \\
\text { Income } \\
853,979,360 \\
61,717,310 \\
24,821,408 \\
9,649,668 \\
8,752,671 \\
5,114,440 \\
4,792,713 \\
4,524,141 \\
2,993,536 \\
2,196,172\end{array}$ & $\begin{array}{r}\text { Deprec. \& } \\
\text { Depletion } \\
\$ 17,911,641 \\
\dagger 14,350,786 \\
+4,716,000 \\
1,847,273 \\
11,528,785 \\
+1,046,884 \\
+888,148 \\
\$ 850,279 \\
+656,944 \\
\$+387,817\end{array}$ & $\begin{array}{c}\text { for Interest } \\
\text { Charges } \\
\mathbf{2}, 067,719 \\
\mathbf{4 7 , 3 6 6 , 5 2 4} \\
20,105,408 \\
\mathbf{7 , 8 0 2 , 3 9 5} \\
\mathbf{7 , 2 2 3 , 8 8 6} \\
\mathbf{4 , 0 6 7 , 5 5 6} \\
\mathbf{3 , 9 0 4 , 5 6 5} \\
\mathbf{3 , 6 7 3 , 8 6 2} \\
\mathbf{2 , 3 3 6 , 5 9 2} \\
1,808,355\end{array}$ & $\begin{array}{c}\text { Interest } \\
\text { Charges } \\
\mathbf{8 8 , 7 4 6 , 9 8 2} \\
3,772,556 \\
2,342,595 \\
2,212,374 \\
2,101,183 \\
2,003,915 \\
1,865,586 \\
1,672,250 \\
1,635,781 \\
1,441,491\end{array}$ & $\begin{array}{r}\text { Times } \\
\text { Earned } \\
4.12 \\
12.56 \\
8.58 \\
3.63 \\
3.44 \\
2.03 \\
2.09 \\
2.19 \\
1.52 \\
1.25\end{array}$ \\
\hline
\end{tabular}

†Provision for extinguishment of mining investments, amortisstion of patents and depreciation of other properties.

fInchides excess of book value over amounts realized on sale of investments in subsidiary companies amounting to $\$ 98,959$ in 1907 and $\$ 14,000$ in 1908 .

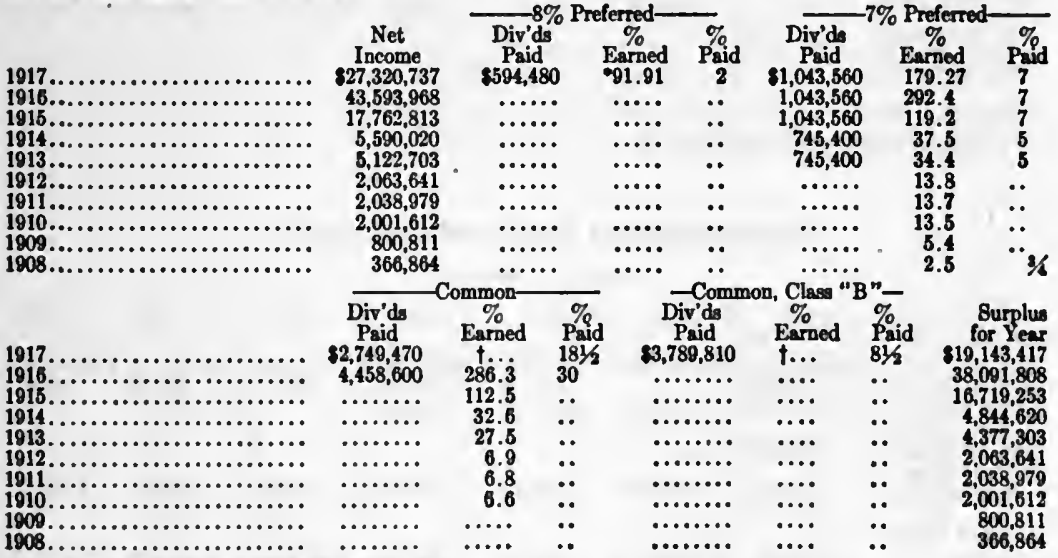

Baved on amount outstanding December 31.

tIn the year ended December 31, 1917, $43.20 \%$ was earned on common otock and common, clase "B" stock combined.

COMPARATIVE INCOMB ACCOUNT, YEARS ENDED DEC. SI.

\begin{tabular}{|c|c|c|c|c|c|c|c|}
\hline $\begin{array}{l}\text { Groes sales \& earo- } \\
\text { ings........... } \\
\text { Manu'fg cost \& } \\
\text { oper. exp., includ } \\
\text { adminis., selling } \\
\text { and general exp. } \\
\text { Taxes.............. }\end{array}$ & $\begin{array}{r}8298,029,531 \\
234,437,465 \\
13,489,294\end{array}$ & $\begin{array}{r}151,278,302 \\
4,913,703\end{array}$ & $\bullet \ldots \ldots \ldots$ & 1914 & $\begin{array}{c}1913 \\
\bullet \ldots \ldots \ldots\end{array}$ & $\begin{array}{c}1012 \\
\bullet \ldots \ldots .\end{array}$ & $\begin{array}{c}1911 \\
\bullet \ldots \ldots . .\end{array}$ \\
\hline $\begin{array}{l}\text { Net manufacturing } \\
\text { profits.......... } \\
\text { Other income..... }\end{array}$ & $\begin{array}{r}851,002,772 \\
2,976,588\end{array}$ & $\begin{array}{r}800,092,551 \\
1,624,758\end{array}$ & $\begin{array}{r}823,782,784 \\
1,038,624\end{array}$ & $\begin{array}{r}89,378,385 \\
271,282\end{array}$ & $\begin{array}{r}88,530,708 \\
221,963\end{array}$ & $\begin{array}{r}4,846,814 \\
267,626\end{array}$ & $\begin{array}{r}4,605,410 \\
187,303\end{array}$ \\
\hline Total incomc..... & $\$ 53,979,360$ & $861,717,310$ & $\$ 624,821,408$ & $\$ 9,649,667$ & $88,752,671$ & $\$ 5,114,440$ & U,792,713 \\
\hline
\end{tabular}

IFrom Standand Corporation Reconds. Copyright 1918 by Standand Statiatic Co., Ino., 17-10 Weat St. N. Y. This information, while not guaranteod, is believed to be correct. 


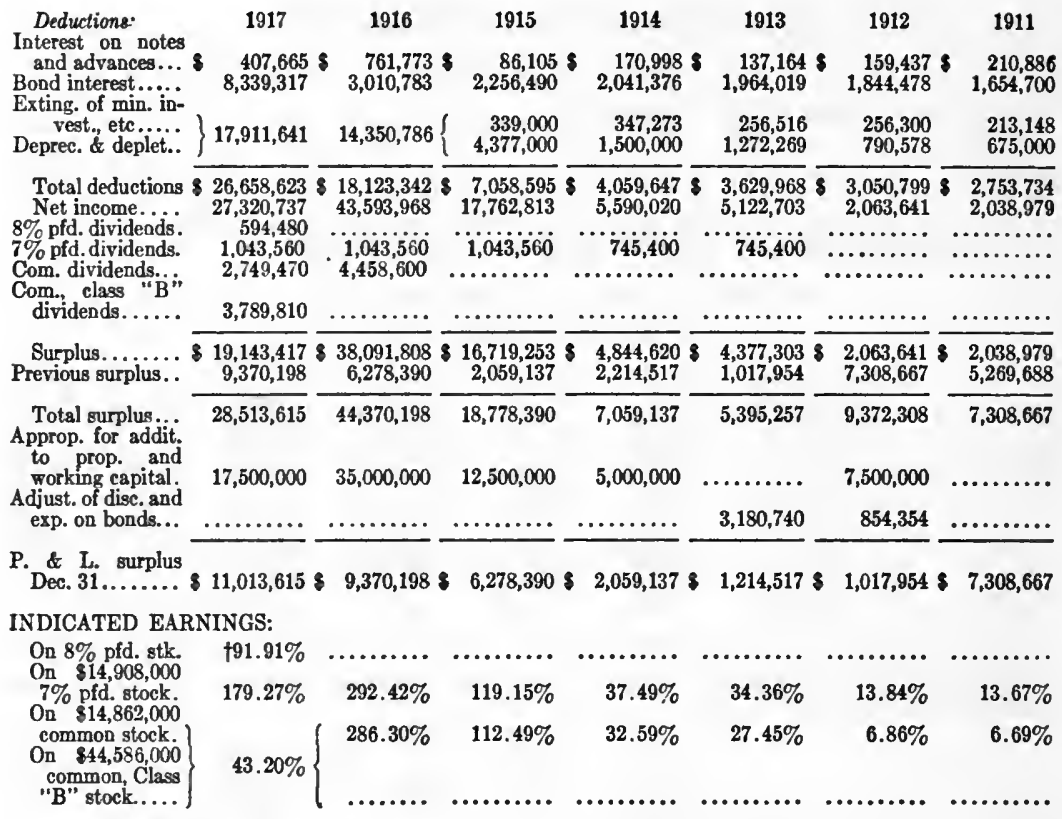

*Not reported.

†Based on amount outstanding Dec. 31.

\section{GENERAL BALANCE SHEET-WORKING CAPITAL.}

(A\& of Dec. S1.)

Asset:-

Property ..........

Trustees' account.

Funded assets....

Contingent \& dep-

rec. fund assets.

Deferred charges to operations.......

Current Assets-

Inventories........

Accts. \& notes rec.

Miscel. investm'ts

U. S. Gov't ctfs. of

indebtedness...

Special deposits...

Cash for coupons..

Cash............

Total current

assets.........

Total assets.... $\overline{\$ 381,541,940} \overline{\$ 220,737,257} \overline{\$ 145,779,850} \overline{\$ 106,377,767} \overline{\$ 95,599,300} \overline{\$ 84,418,952} \overline{\$ 75,077,255}$

\section{Liabilities-}

$7 \%$ pfd. stock. . . \& $\$ 14,908,000 \$ 14,908,000 \$ 14,908,000 \$ 14,908,000 \$ 14,908,000 \$ 14,908,000 \$ 14,908,000$

$8 \%$ pfd. stock.... $14,908,000$

Com. stock... 29,724,000

Common stock....

Com. "stock, class

Funded debt........

Reserves...........

Appropriated surp.

Profit \& loss surp..

1916

1915

1914

1913

1912

1911

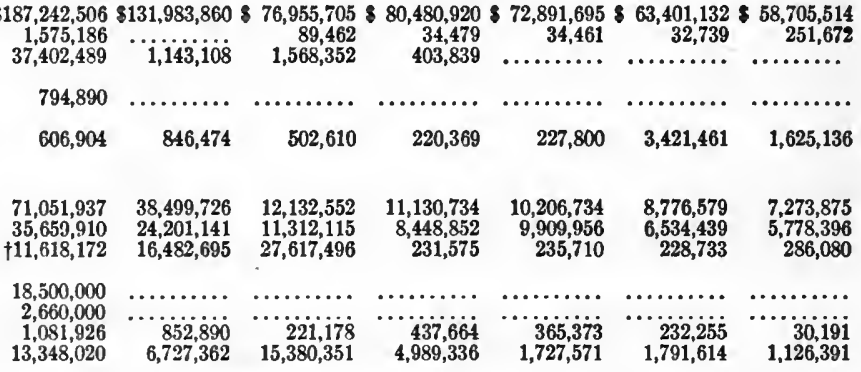

$\$ 153,919,965 \& 86,763,814 \& 66,663,721 \& 25,238,160 \& 22,445,344 \& 17,563,620 \& 14,494,933$

$14,862,000$

$44,586,000$ $132,938,000$ $4,985,863$

$47,500,000$

$11,013,615$ $\because 14 \% 200$

$14,862,000$

$68,590,000$

$2.586,590$

$60,000,000$

$9,370,198$

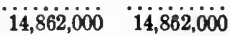

$\ddot{3} 1,099,000$

$1,303,146$

$25,000,000$

$6,278,390$
$36,207,700$

$12,688,496$

$12,500,000$

$2,059,137$ $\because 4, \ddot{862,0000} \quad \because \ddot{14}, 862,0000 \quad \because 4 \ddot{8}, \ddot{862,000}$

$33,599,033$

$12,389,129$

$7,500,000$

$2,214,517$ $1,017,954$

\section{$32,441,533 \quad 26,291,533$

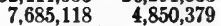


Current Liabilities- 1917

Notes payable.... $5,051,638$

Acets. payable, etc. $73,376,273$

Interest accrued.. $\quad 1,514,625$

Coupons paysble.. $\quad 1,081,920$

Total current

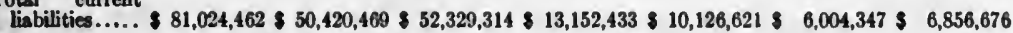

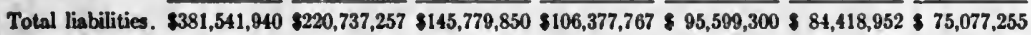

-Net work. capital $\overline{\$ 72,895,503} \overline{\$ 36,343,345} \overline{\$ 14,334,407} \overline{12,085,727} \overline{\$ 12,318,723} \overline{11,559,273} \overline{7,638,257}$

-Based upon statement of current assets and current liabilities as above.

tInchuding Liberty bands subecribed for employes.

\section{CAPITAL STOCK.}

Preferred, 8\% cum. conv. (par $\$ 100$ )

Authorized Outstanding $\$ 30,000,000 \quad \$ 29,724,000$

$15,000000 \quad 14,908,000$

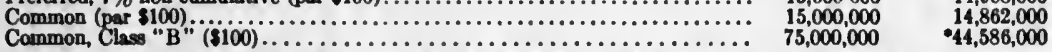

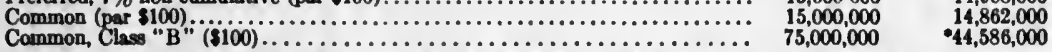
-\$30,000,000 unissued Class " $\mathrm{B}$ " common stock is reserved for the conversion of the $8 \%$ cumulative convertible preferred stock.

NOTE.-All stock is fully paid and non-asessable and nompersonal liability attacbes to shareholders.

Trenser Office.-Equitable Trust Co., New York.

\section{STOCK PROVISIONS.}

8\% Cumulative Convertible Preferred.-The $8 \%$ cumulative convertible preferred stock is preferred as to dividends over the $7 \%$ preferred and common stocks snd shares pari-passu with the $7 \%$ preferred in a distribution of assets. It is convertible at any time at the option of the holder into class "B" common at 115 and redeemable on 90 dass' notice any time after three years from date of issue at 115 and accrued dividends in its entirety or in amounts of not less than $\$ 10,000$ each. No voting power attaches to the $8 \%$ preferred.

$7 \%$ Non-Cumulative Preferred.-The 7\% non-cumulative preferred stock shares pari-passu with the $8 \%$ preferred in a distribution of assete. Disbursements are limited to $7 \%$ per annum. Has equal voting power with the class "A" common.

Class "A" Common.-Class "A" common stock has equal voting power with the $7 \%$ preferred and shares equally with the class " $\mathrm{B}$ " common in a distribution of assets.

Class " $B$ " Common.-Class " $B$ " common stock ranks equally with the class " $A$ " common except in that it posecsses no roting power.

\section{HIGH AND LOW PRICES OF STOCKS.}

(New York Slock Exchange.)

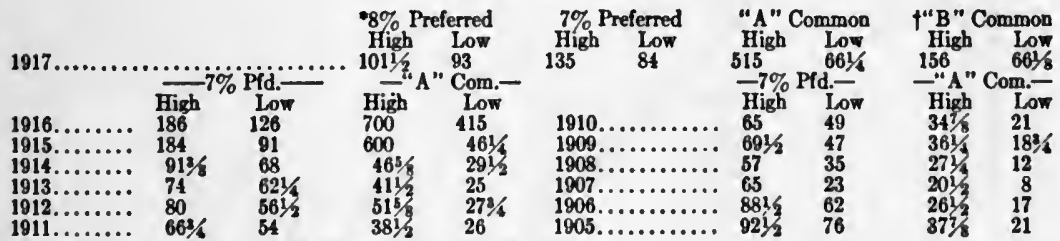

Listed on the New York Stock Exchange Dec. 12, 1917.

tListed on the New York Stock Exchange Oct. 4, 1917. 

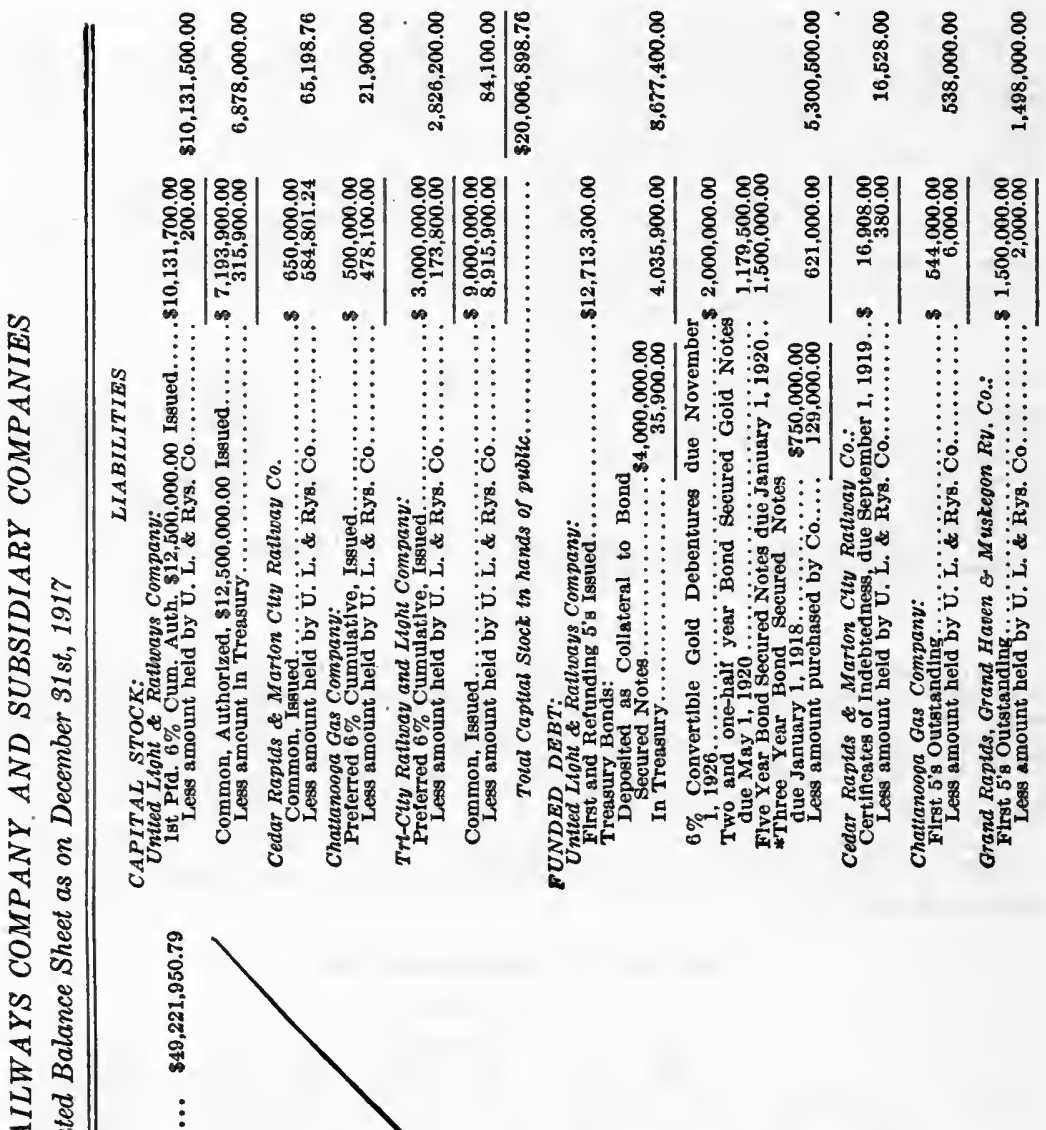

志

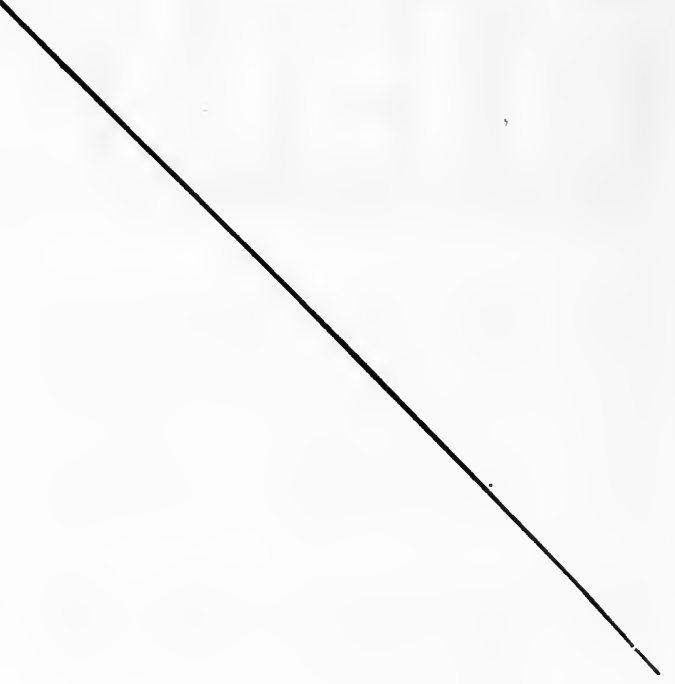




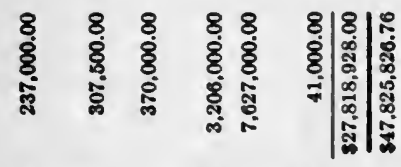

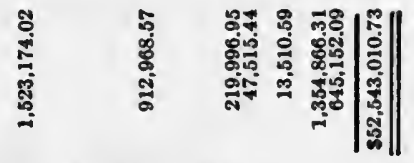

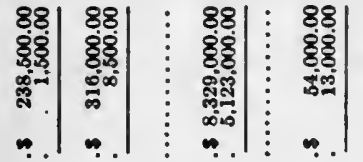

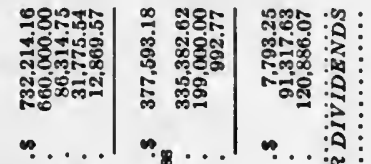

:

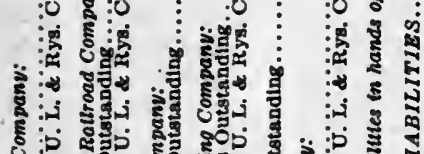

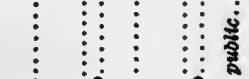

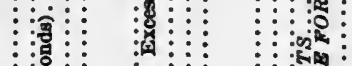

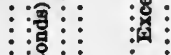

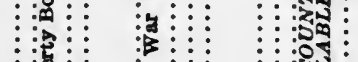

$\vdots:$ :

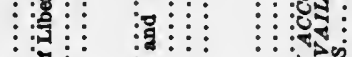

: :

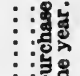

淃

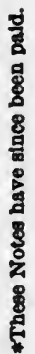

d

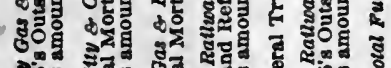

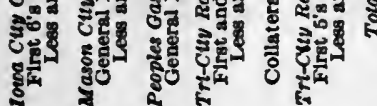

इ

7 No

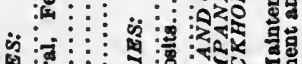

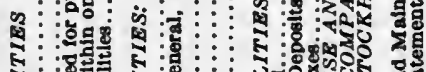

$\checkmark$ 넌

ตี่

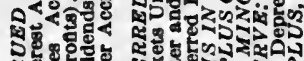

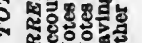

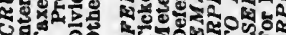

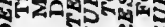
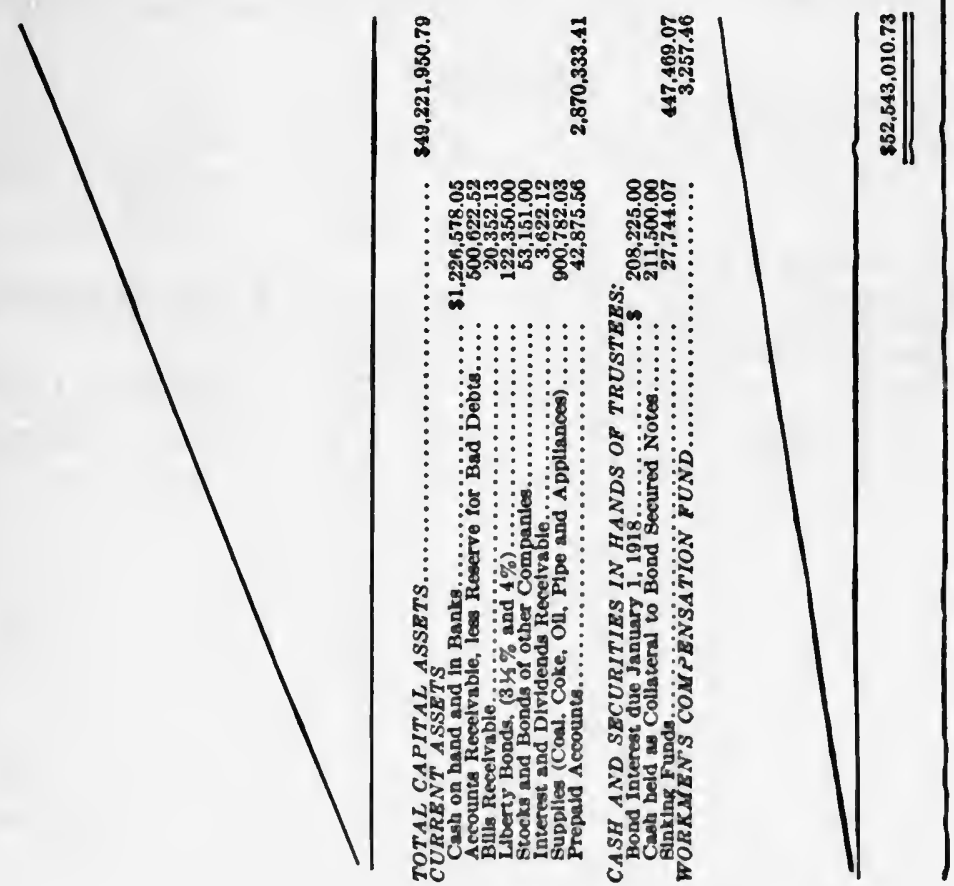


\section{MIDWEST REFINING COMPANY}

Financial Statement as of December 31, 1917, 1916, 1915

ב-

ANSETS

Current Assets:

\begin{tabular}{cr}
1917 & 1916 \\
$\$ 3,862,203$ & $\$ 879,033$ \\
$1,514,655$ & 13,978 \\
$1,767,859$ & $1,020,642$ \\
$1,613,360$ & 669,874 \\
387,509 & 55,936 \\
$2,233,933$ & 241,045 \\
\cline { 1 - 1 } & $\$ 2,880,508$ \\
45,158 & 19,344
\end{tabular}

1915

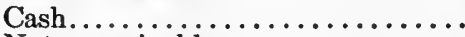

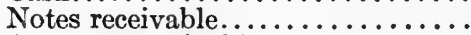

Accounts receivable.................

Refined products..............

Crude oil on hand..............

Supplies (inventory)

Total current assets............

Deferred charges.

45,158

Fixed Assets:

Property, leases and contracts......

Field and refinery construction.....

Investments....................

Treasury stock................

Total fixed assets.............

Total Assets

$\$ 27,626,141$

$6,489,640$

$6,911,395$

$\$ 17,163,621$

$1,555,421$

$9,927,596$

…… $\quad 664,000$

$\$ 41,027,176$

$\$ 29,310,638$

$\$ 52,451,854$

$\$ 32,210,490$

$\$ 1,139,781$

37,697

580,952

566,691

$\ddot{138} 3 \dot{388}$

$\$ 2,463,509$

31,620

$\$ 17,321,186$

317,079

933,356

$2,000,000$

$\$ 20,571,621$

$\$ 23,066,751$

\section{LIABILITIES}

Current Liabilities

Accounts payable..............

Other liabilities.

\begin{tabular}{|c|c|}
\hline $\begin{array}{r}\$ 615,644 \\
75,274\end{array}$ & $\begin{array}{r}\$ 544,750 \\
300,000\end{array}$ \\
\hline$\$ 690,918$ & $\$ 844,750$ \\
\hline
\end{tabular}

$\$ 725,758$ 560,000

Capital and Surplus:

Capital stock...............

Reserve for depreciation...........

Reserve for taxes..............

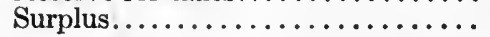

$\$ 25,558,350$

$5,417,589$

$2,762,144$

$18,022,852$

$\$ 20,000,000$

$3,007,554$

$\dot{8} \ddot{3} \ddot{3} \ddot{8}, \ddot{1} \dot{8} \dot{6}$

$\$ 20,000,000$

$\$ 1,285,758$

Total liabilities.

$\$ 52,451,854$

$\$ 32,210,490$

i,780,993

$\$ 23,066,751$ 


\section{MAY DEPARTMENT STORES CO. ${ }^{2}$}

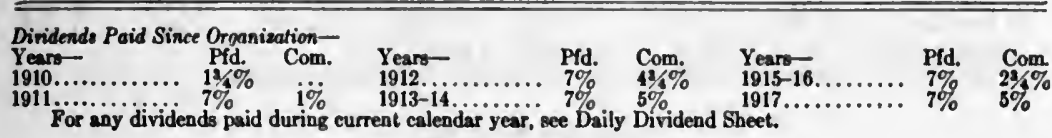

EIGHT-YEAR ANALYSIS OF INCOME ACCOUNT

Years Ended Janwary $s 1$.

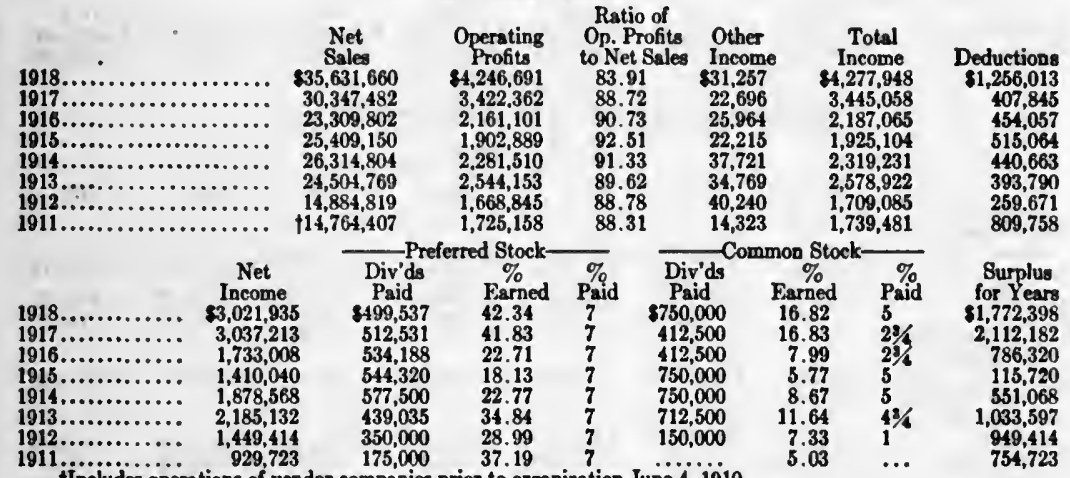

fincludes operations of vendor companies prior to organization June $i_{i}, i 910$.

COMPARATIVE INCOME ACCOUNT, YEARS ENDED JANUARY 31.

\begin{tabular}{|c|c|c|c|c|c|c|c|}
\hline \multirow{2}{*}{$\begin{array}{l}\text { Net sales.......... } \\
\text { Operating expenses } \\
\text { Operating profits } \\
\text { Other income..... }\end{array}$} & $\begin{array}{c}1918 \\
\$ 35,631,660 \\
31,384,969\end{array}$ & $\begin{array}{c}1917 \\
\$ 30,347,482 \\
26,925,120\end{array}$ & $\begin{array}{c}1916 \\
823,309,802 \\
21,148,701\end{array}$ & $\begin{array}{c}1915 \\
\mathbf{8 2 5 , 4 0 9 , 1 5 0} \\
23,506,261\end{array}$ & $\begin{array}{c}1914 \\
\$ 26,314,804 \\
24,033,294\end{array}$ & $\begin{array}{c}19 \text { io } \\
224,504,769 \\
21,960,616\end{array}$ & $\begin{array}{c}1912 \\
\mathbf{8 1 4 , 8 4 8 , 8 1 9} \\
13,215,974\end{array}$ \\
\hline & & $\begin{array}{r}3,422,362 \\
22,696\end{array}$ & $\begin{array}{r}2,161,101 \\
25,964\end{array}$ & $\begin{array}{r}1,902,889 \\
22,215\end{array}$ & $\begin{array}{r}2,28 \\
3\end{array}$ & $\begin{array}{r}2,544,153 \\
34,769\end{array}$ & 81,6 \\
\hline \multirow{4}{*}{$\begin{array}{l}\text { Total income... } \\
\text { Deductions- } \\
\text { Gen. exp. and taxes } \\
\text { Bad debts......... } \\
\text { Depreciation..... } \\
\text { Interest.......... } \\
\text { Prov. for inc. and } \\
\text { excess profits taxe }\end{array}$} & S $4,277,948$ & $3,445,058$ & \& $2,187,065$ & s $1,925,104$ & \& $2,319,231$ & \& $2,578,922$ & \& $1,709,085$ \\
\hline & & & 99.055 & & & 139,817 & 95,143 \\
\hline & $\begin{array}{r}195,857 \\
22,829\end{array}$ & $\begin{array}{r}190,506 \\
12,988\end{array}$ & $\begin{array}{l}176,342 \\
126,362\end{array}$ & & $\begin{array}{r}212,030 \\
46,395\end{array}$ & $\begin{array}{r}218,227 \\
36,046\end{array}$ & 164,528 \\
\hline & 850,000 & & ........ & & $\ldots$ & & \\
\hline Total deductions & \& $1,256,013$ & 407,843 & 454,057 & 515,064 & 440,663 & 393,790 & 259,671 \\
\hline $\begin{array}{l}\text { Net } \\
\text { Prefer } \\
\text { Comn }\end{array}$ & $\begin{array}{r}3,021,935 \\
\quad 499,537 \\
\quad 750,000\end{array}$ & $\begin{array}{r}3,037,213 \\
512,531 \\
412,500\end{array}$ & $\begin{array}{r}1,733,008 \\
534,188 \\
412,500\end{array}$ & $\begin{array}{r}1,41 \\
54 \\
75\end{array}$ & $\begin{array}{r}1,8 \\
5 \\
7\end{array}$ & $\begin{array}{r}2,18 \\
4 \\
7\end{array}$ & $\begin{array}{r}1,4 \\
3 \\
15\end{array}$ \\
\hline urplus.... & $\begin{array}{l}1,7 \\
3,7\end{array}$ & $\begin{array}{l}2,11 \\
1,88\end{array}$ & $\begin{array}{r}786,320 \\
2,365,355\end{array}$ & $\begin{array}{r}115,720 \\
2,288,802\end{array}$ & 1,55 & 1, & \\
\hline Total sumplus & $5,492,105$ & $3,993,340$ & $3,151,675$ & I $2,404,522$ & ₹ 2,2 & 2,4 & 81,7 \\
\hline & 247,500 & 247,500 & 192,500 & & & 700,000 & 300,0 \\
\hline $\begin{array}{l}\text { of investments. } \\
\text { Adjustm't acct. of } \\
\text { sale of business of } \\
\text { Boggs \& Buhl } \\
\text { Pitteburgh, as of }\end{array}$ & 13,625 & 4,861 & 2,467 & 4.701 & & & \\
\hline $\begin{array}{l}\text { Diec. on acquisition } \\
\text { of pfd. stock for }\end{array}$ & & & & & & & \\
\hline $\begin{array}{l}\text { retirement..... prem. paid on pid. } \\
\text { Prem }\end{array}$ & & & 7,497 & ..... & $\cdots \cdots \cdots$ & ........ & \\
\hline & 15,841 & 21,274 & & 34,463 & & & \\
\hline & & & 1,158 & $2,365,355$ & $2,288,802$ & $1,737,734$ & 80 \\
\hline
\end{tabular}

1 From Standand Corporation Records. Copyright 1918 by Standard Statistics Co., Inc., 47-49 Weat St.,

N. Y. This information, while rot guaranteed is believed to be correct. 


\begin{tabular}{|c|c|c|c|c|c|c|c|}
\hline & 1918 & 1917 & 1916 & 1915 & 1914 & 1913 & 1912 \\
\hline $\begin{array}{l}\$ 0 \mathrm{n} \text { pfd. stock.. } \\
\text { On com. stock. }\end{array}$ & $\begin{array}{l}42.34 \% \\
16.82 \%\end{array}$ & $\begin{array}{l}41.83 \% \\
16.83 \%\end{array}$ & $\begin{array}{r}22.71 \% \\
7.99 \%\end{array}$ & $\begin{array}{r}18.13 \% \\
5.77 \%\end{array}$ & $\begin{array}{r}22.77 \% \\
8.67 \%\end{array}$ & $\begin{array}{l}34.84 \% \\
11.64 \%\end{array}$ & $\begin{array}{l}28.99 \% \\
7.33 \%\end{array}$ \\
\hline
\end{tabular}

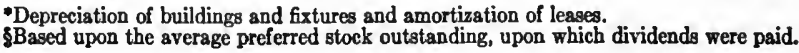

Capital Stock Outstanding.

(Upon Which Diridends Were Paid.)

$\begin{array}{lccccccc} & 1918 & 1917 & 1916 & 1915 & 1914 & 1913 & 1912 \\ \text { Preferred stock.... } \$ 7,136,250 & \$ 7,260,000 & \$ 7,631,257 & \$ 7,776,000 & \$ 8,250,000 & \$ 6,271,900 & \$ 5,000,000 \\ \text { Common stock.... } & 15,000,000 & 15,000,000 & 15,000,000 & 15,000,000 & 15,000,000 & 15,000,000 & 15,000,000\end{array}$

GENERAL BALANCE SHEET-WORKING CAPITAL.

(As of January s1.)

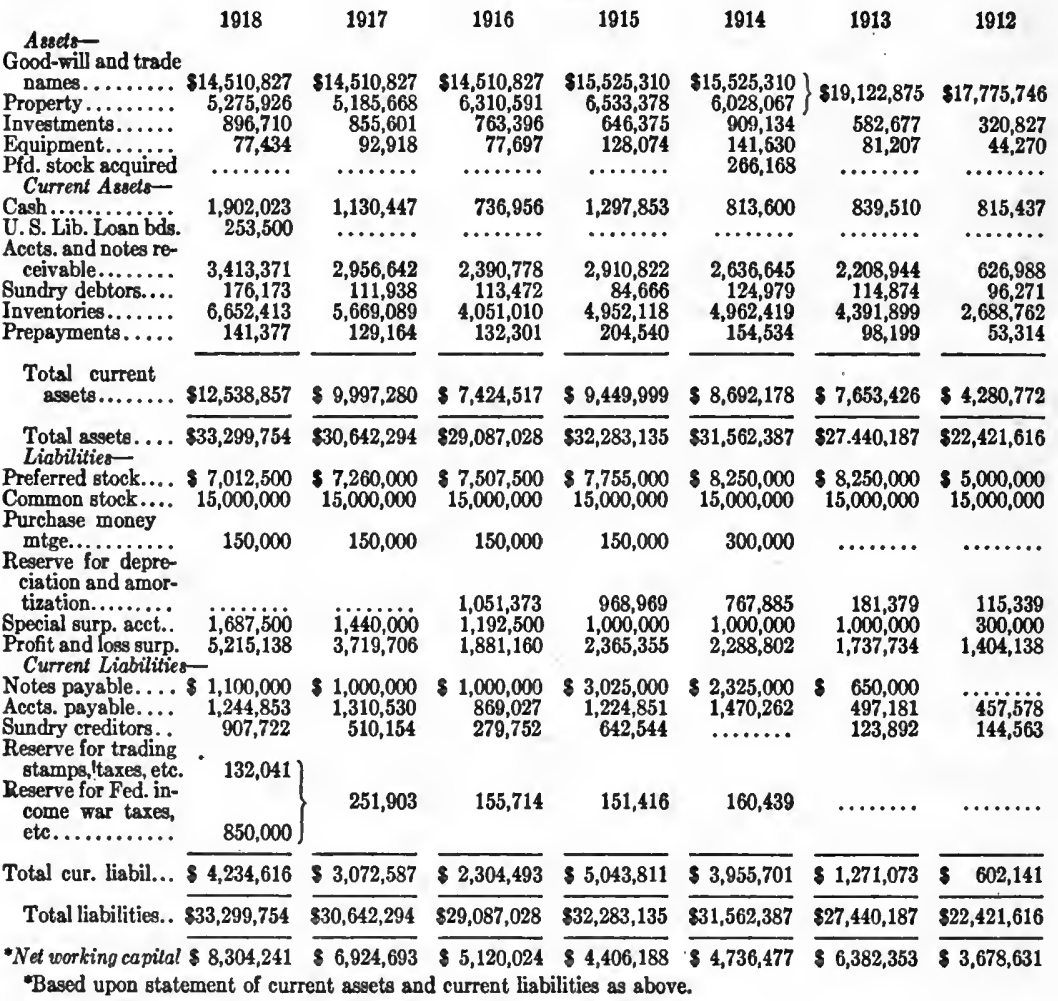

Earning Power.

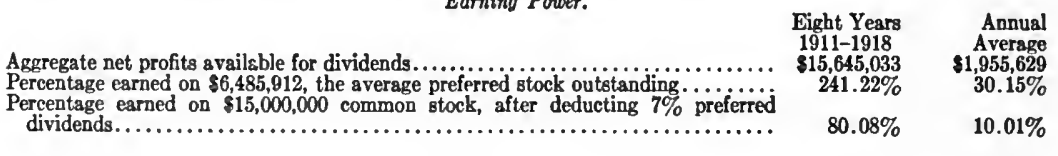




\section{JOINT ACCOUNT LETTERS AND FORMS 1}

LETTERS STATING A JOINT ACCOUNT AGREEMENT UNDIVIDED AS TO LIABILITY, DIVIDED AS TO CARRYING

Messrs. Brown \& Co.,

$$
\text { July 8th, } 1915 .
$$

Dear Sirs:-We are writing to confirm our telephone conversation of this morning to the effect that you would join Smith \& Co. and ourselves in a joint account for the purchasc and sale of $\$ 1,500,000$ City of Springdale, Iowa, 5\% 20 year bonds due August 1st, 1935, for which bids will be received by the city treasurer on the 17 th inst.

You are taking a participation of $\$ 300,000$ in the account.

We are to be Manager of the Account and submit a bid of @100.55, payment and delivery in Springdale, Ia., in the name of Jones \& Co., Brown \& Co. and Smith \& Co. in the order stated.

The account will be Divided Carrying, Unlimited Liability. The rules for the conduct of the Account will be agreed on in event that we are the successful bidders, and in general the terms used and the account agreement will be understood as stated in the Joint Account forms published by the Investment Bankers Association of America.

Will you please let us know if your understanding of our agreement is in accord with this letter?

Very truly yours,

JONES \& CO.

Messrs. Jones \& Co.

July 12th, 1915.

Dear Sirs:--Your letter of the 8th inst, referring to the Joint Account for the purchase of City of Springdale, Ia. bonds correctly states our understanding.

Very truly yours,

BROWN \& CO.

Messrs. Brown \& Co.,

July 20th, 1915.

Dear Sirs:-We are writing to confirm the understanding for rules of the account reached at a meeting held at our office this morning of the members of our joint account in City of Springdale, Ia. bonds.

\footnotetext{
1 From a booklet of this name by Hastings Lyon, published by the Investment Bankers Association of America.
} 
We determined that the selling price should be $\$ 102.75$, and interest. A member shall have a selling commission of a half and may allow a broker's commission of a quarter. Expenses of a member for purposes of the account shall be deducted from the amount allowed him as commissions. Delivery shall be only on the manager's order, and on receipt by him of the selling price and interest without allowance for commissions. Members may offer and sell the bonds without restriction as to territory. All advertising shall be done and circulars prepared and printed by the Manager at the expense of the Account in the name of Jones \& Co., Brown \& Co., and Smith \& Co. in the order stated. Unless earlier terminated by agreement the Account shall continue until all the bonds are sold. In general the terms used and the rules of the account will be understood as stated in the joint account forms published by the Investment Bankers Association of America.

Will you please confirm this understanding of the rules of the account?

Very truly yours,

JONES \& CO.

Messrs. Jones \& Co.

Dear Sirs:-Your letter of the 20th inst, referring to the ules of the Joint Account for the purchase of City of Springdale, Ia. bonds, correctly states our understanding.

Very truly yours,

BROWN \& CO.

\section{AGREEMENT FORMING THE ACCOUNT}

Four matters must be decided in making this agreement. They are :-

1:-Name-

The name or names in which the bid is to be submitted (or the purchase made) and the order in which they are to appear.

2:--Purchase Price-

$3:-$ Carrying-

Divided, Undivided or Special. 


\section{4:-Liability-}

Unlimited, Limited, or Limited but Unlimited as to Selling; and Option to Limit and Proportional Lessening.

All other matters of the Account are to be provided for in Rules of the Account expressed in a Supplementary Agreement.

\section{AGREEMENT FORMING THE ACCOUNT}

An agreement for a joint account hereinafter called the Account,

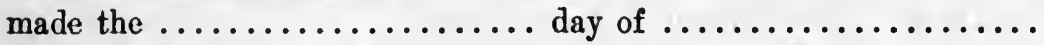
$19 . .$. by and between

Party of the first part, as Account Manager, hereinafter called the Manager, and

Party of the second part, hereinafter, with the Manager, called the Members, and each of whom is hereinafter termed the Member. The Manager or any Member, whether partnership, corporation or individual, is referred to herein as "he" or "him."

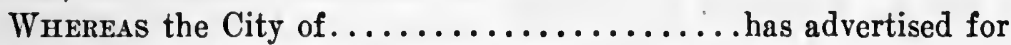

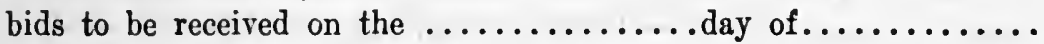
$19 . .$. for an issue of bonds, as follows:-

or (Alternative clause for a corporation issue).

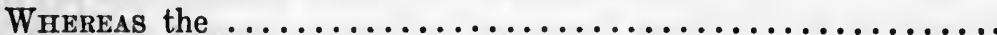
a corporation of the State of $\ldots \ldots \ldots \ldots \ldots \ldots$, having its head

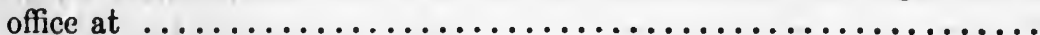
desires to sell bonds as follows:-

Whereas the Members desire to form with the Manager an Account for the purchase and sale of the said bonds.

Now, Thenefore, This Agreemext Witnesseth, That in consideration of the premises, and of their mutual promises the parties hereto agree with each other as follows:-

Section 1. The parties hereto, not as partners, though acting jointly for the special purposes hereof, form an Account to purchase the said bonds, and, if and when the Account has purchased the said bonds, for the purpose of selling or disposing of them, all on the terms and conditions hereinafter set forth.

Sec. 2. Each Member shall set opposite his name subscribed hereto the amount of his participation in the Account in terms of the par 
value of the bonds, expressing his proportionate interest in the Account undertaking; and each Member shall be liable for and called upon to pay only such a proportion of the total obligation of the Account as his participation shall bear to the total amount of the said bonds, unless otherwise hereinafter set out.

Sec. 3. The Manager shall submit the bid of the Account for the said bonds (or shall negotiate for the purchase of the said bonds), and shall carry out all matters connected therewith. If the bonds shall be sold to the Account, the Manager shall, on payment by the Members as hereinafter provided in Section 5, make payment therefor and take, or give directions for delivery thereof.

Sec. 4. The Manager is authorized, on behalf of the said Account, to submit for the said bonds a bid (or, to purchase the said bonds) in the names of and in the order stated $. . . \ldots \ldots \ldots \ldots \ldots . . .$. of...$\ldots \ldots \ldots \ldots \ldots$ which is called herein the Purchase Price, and accrued interest $\ldots \ldots \ldots \ldots \ldots \ldots \ldots \ldots$ payment at

delivery at

Sec. 5. Carrying the Bonds.

\section{A.-Divided Carrying.}

At a day fixed in the reasonable discretion of the Manager to enable him to make payment for the bonds, and on notice given in his reasonable discretion before the day so fixed, each Member shall pay the Manager at the Purchase Price and interest an amount sufficient to pay for and shall take delivery of his proportion of the bonds. The Member shall thereafter carry for the Account his proportion of the Account bonds in the manner provided herein and in an agreement to be made supplementary thereto. The Member carrying the bonds shall bear any loss, and benefit by any gain, in respect to the bonds he is carrying, which may arise through any difference between the interest accruing on the bonds and the interest charge or other expense incurred in carrying them.

\section{B.-Joint Carrying. \\ (Alternative Clause)}

The Manager shall arrange a loan or loans upon the said bonds as collateral therefor, and at a day fixed in his reasonable discretion to enable him to make payment for the bonds, and on notice given at a day in the Manager's reasonable discretion before the day so fixed, each Member shall pay the Manager that Member's proportion of the margin or amount beyond the amount of the loan necessary 
to pay for the bonds. Any profit or loss made in the carrying shall be borne by or accrue to the benefit of the Account.

If the Manager is unable to arrange for a loan to carry the bonds as herein provided, the Manager shall notify the Members and each Member shall, on or before the day fixed for delivery, as requested by the Manager, pay the Manager for, at the Purchase Price and accrued interest, and take delivery of his proportion of the bonds, and any profit or loss made in the carrying shall accrue to the benefit of or be borne by the Member carrying the bonds.

C.-One Mramber Carrying All Bonds, Eto.

(Alternative Clause)

(If it is desired that one Member of the Account carry all or any special proportion of the bonds in lieu of selling or for any other reason, and enjoy the profits of the Account, or be liable for the losses, in any special proportion, the stipulation must be expressly drawn. It does not seem possible to draw a clause of sufficiently general applicability to fit this case.)

\section{Sec. 6. Liability.}

\section{A.-Unlimited Liability.}

Each member, irrespective of the amount of bonds he may sell, shall share any profits of the account in the proportion of his participation. He shall remain until the close of the account fully liable to other members of tho Account for, and shall assume, and pay through the Manager on an accounting by him, any losses as a result of the Account transaction, and at the close of the Account shall take for his own account and ribk any bonds remaining unsold, all in such proportion as his participation shall bear to the total bouds of the Account.

\section{B.-Limited Liability. \\ Limited Selling \\ (Alternative Clause)}

Each Member shall sell, and may not be compelled to part with the right to sell, the amount of bonds comprising his own participation in the Account, and at the termination of the Account shall take for his own account and risk any part of that amount then remaining unsold; and, except that he shall be liable for his proportion of the joint expenses, he shall assume no other liability hereunder, anything else herein to the contrary notwithstanding. He shall be entitled to the profit or shall bear the loss on his sale of the bonds of his participation at whatever price he may actually sell them, which, however, shall always be the Selling Price of the Account at the time the Member makes the sale. 


\section{C.-Limited Liability. \\ Unlimited Selling. \\ (Alternative Clause)}

Each Member may be required to sell the amount of bonds comprising his own participation in the account, or at the termination of the Account may be required to take for his own account and risk any part of that amount then remaining unsold; and except that he shall be liable for his proportion of the joint expenses, he shall assume no other liability hereunder, anything else herein to the contrary notwithstanding. He shall be entitled to the profit or shall bear the loss on his sale of the bonds of his participation at whatever price he may actually sell them which, however, shall always be the Selling Price of the Account at the time the Member makes the sale.

So long as the Account continues, however, any Member who has sold an amount of bonds equal to his participation may continue to sell bonds of the Account, and, as hereinafter provided, call upon the Manager to deliver, or order delivered, to him unsold bonds of the Account. If he sells bonds of the Account in excess of his participation he shall be entitled to the profit on the sale of bonds so sold. In that event he shall share the expense of the Account in proportion to the bonds he actually sells, and other Members shall bear the expenses in proportion to the bonds they sell, and shall be entitled to the profits only on the sale of the bonds they actually sell.

\section{Sec. 7. Price Agreement.}

During the existence of the Account no Member shall sell any of the bonds at a price less than the Account price, to be determined by the Supplementary Agreement provided for herein.

Sec. 8-Agreement for Supplementary Agreement.

As soon as practicable after the purchase of the bonds, the Members, at the request of the Manager, or, if he fails to request, then at the request of any of the Members, shall enter into a supplementary agreement stipulating the selling price and all other matters necessary or deemed desirable for the conduct of the Account. The vote of a majority in interest of the Members shall be sufficient to determine the stipulations of the supplementary agreement and this vote and any other vote provided for therein or herein may be given orally in person at a meeting of the Members called by the Manager for this. purpose, and entered by him on the records, or may be given by letter or telegram. But if the place of business of any member is not in the same city or town as the place where the meeting is called, 
then that member may vote by letter or telegram, or in the discretion of the Manager, unless a majority in interest request by letter or telegram to the contrary, any vote may be taken wholly by letter or telegram. Notice, which shall state the purpose of the rote, sufficient in the reasonable discretion of the Manager to enable every member to vote, shall be given by letter or telegram of every vote to be taken. The terms of the supplementary agreement need not all be stipulated at one time but each term of the agreement shall become binding on the account as agreed upon by the majority in interest.

In Witness Whereof, the Manager, party of the first part, has subscribed the original hereof, and the Members, parties of the second part, have subscribed the original or counterparts thereof as of the day and year of the date hereof, and have added to their subscription the address to which all communications hereunder are to be directed.

Name

Address

Amount

In response to some demand for a modification of the unlimited liability principle the following suggestions have been made, which if not acceptable exactly as they stand, may serve as the basis of discussion of the matter. They have been inserted out of order because of their special nature.

\section{D.-Option to Limit Liability. \\ (Alternative Clause)}

When any member shall have sold, or taken up at the Take Down Price to be agreed on in an agreement supplementary hereto, as hereinafter provided, or, in event of divided carrying, declared that he holds for his own account and risk the bonds he is carrying, up to a total amount of bonds equal to the amount of his participation, he may notify the Manager of his withdrawal from the Account. Thereupon he shall be free from further liability to other members of the Account for losses incurred thereafter or bonds unsold as a result of the Account transaction, except for the expenses of the Account theretofore incurred. He shall not, however, be entitled to any profits until all the bonds are sold or the Account closed and unsold bonds distributed, whereupon he shall be entitled to share, in proportion to his participation, any profits that then appear in the account.

\section{Proportional Lessening of Liability.}

\section{(Alternative Clause)}

Each member, irrespective of the size of his participation, may and shall continue to sell bonds so long as the account shall continue, and 
shall share any profits in proportion to the size of his participation. The selling price shall never be less than the purchase price, but in the event that it is not found possible to dispose of the bonds at the purchase price or better, the account shall be closed, and the unsold bonds shall be distributed as follows:

Each member who has sold bonds in excess of the amount of his participation shall have his proportional amount of the unsold bonds reduced by an amount which shall be the same per cent of the unsold bonds as he has. sold of the account in excess of his participation. The total of these reductions shall be added to the amounts of those members who have sold less than their participations in proportion to that percentage of the account by which their sales have fallen short of their participations.

RULES OF THE ACCOUNT (SUPPLEMENTARY AGREEMENT).

MUST PROVIDE FOR

\section{Seliting Price.}

2. BRoKeR's CoMmission.

3. Mearber's Seliting Commission.

Shall there be any at all?

If a commission, shall it begin at once?

Or only after the member has sold his proportion?

4. Duration of Accodnt.

To continue until securities disposed of unless earlier terminated by agreement of Members.

To continue for a definite period and to be terminated at the end of that period unless members then agreed to extend.

5. Take Down Price.

Selling Price.

Or Selling Price less Member's Commission.

Purchase Price less any pro rata already paid by Members. Selling Price less any pro rata already paid by Members.

Selling Price less Commission and any pro rata already paid by Members. 


\section{Delivery.}

Only on Manager's order.

Without Manager's order.

\section{\%. Territory.}

Unrestricted.

Restricted.

\section{Advertising.}

By Manager in name of all at expense of account. Or by each in the name of all and at his individual expense. Or by each in his own name and at his own expense.

\section{RULES OF THE ACCOUNT (SUPPLEMENTARY AGREEMENT).}

An agreement made the ...... day of ...... 19..., in accordance with an agreement, herein called the First Agreement, entered into the.$\ldots \ldots \ldots$ day of $\ldots \ldots \ldots 19 \ldots$. creating a joint account, therein and hereinafter called the "Account," for the purchase and sale of $\$ \ldots \ldots \ldots$ of the bonds of $\ldots \ldots \ldots \ldots \ldots$ by and between the parties thereto, who are also the parties thereto,

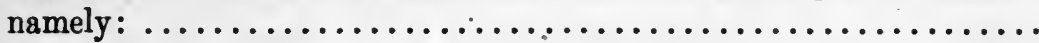

Joint Account Manager herein called the "Manager," party of the first part, and.

party of the second part, herein with the Manager called the Members, and each of whom is herein termed the Member, hereby enter into this Supplementary Agreement, which becomes a part of the said First Agreement and together with it forms one agreement, the terms whereof are agreed upon by the vote of a majority in interest in the Account created by the said First Agreement, and as therein stipulated.

\section{Section 1.-SELLING PRICE.}

No Member shall offer or sell any of the said bonds at a price less

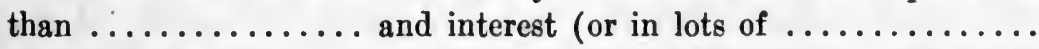
at a price less than .............. and interest.) This shall be, and is called herein, the Selling Price. If voted by a majority in interest of the Members the Manager shall change the Selling Price to the price so voted. The Manager shall notify all the Members of the Selling Price and any change thereof. 


\section{Sec. 2-BROKER'S COMMISSION.}

A Member may allow a commission of ........... per cent of the par value of ten bonds to brokers, and to them only, under an agreement with the broker, which may be oral, that the broker will not split the commission or sell the bonds at a price less than the Selling Price hereinabove set forth. In the settlement of the Account this commission shall be deducted from the Member's selling commission, if any is stipulated for herein. If roted by a majority in interest of the Members the Manager shall change the Broker's Commission to the commission so voted and shall notify all the Members of the change.

\section{Sec. 3-SELLER'S COMMISSION.}

On all sales made by a Member (or-alternative-beyond the amount of his participation) the Member shall be allowed a seller's commission of ......... per cent, of the par value of the bonds, which in the settlement of the Account shall be added to his share in the profits, or allowed him in deduction from his proportion of the losses. Expenses of a member for purposes of the account shall be deducted from the amount allowed him as commissions. Or (alternative) Expenses of a member for purposes of the account shall not be deducted from the amount allowed him as commissions.

\section{Sec. 4-DELIVERY.}

\section{A.-(Delivery Only on the Manager's Order.)}

A Member shall deliver bonds he is carrying for the Account only on the order of the Manager, and a Member shall at any time deliver such bonds to the Manager's order on receiving the purchase price therefor. When a Member reports a sale to the Manager, if the Manager instructs the Member to make the delivery from bonds of the Account the Member is carrying, the Member shall so make the delivery; otherwise the Member shall remit to the Manager for the bonds the Take. Down Price agreed on herein, and on receiving it the Manager shall deliver or cause to be delivered to the Member the bonds required.

B.-Delivery Withodt the Manager's Order-Divided Carrying. (Alternative Clause)

A Member shall at any time deliver bonds he is carrying of the Account to the Manager's order on receiving the purchase price therefor. But so long as a Member is carrying bonds which the Manager has not instructed him to deliver otherwise, a Member shall make deliveries on his own sales from bonds of the Account he is carrying. If a Member has no bonds of the Account to deliver on his own 
sale, he shall remit to the Manager for the bonds the Take Down Price agreed on herein, and on receiving it the Manager shall deliver or cause to be delivered to the Member the bonds required.

Sec. 5. -TAKE DOWN PRICE.

When and as a Member shall wish to procure bonds through the Manager, as herein provided, he shall pay the Manager an amount equal to

(a) The Selling Price agreed upon hereunder and accrued interest without allowance for any commissions;

or (b) (alternative) the Selling Price agreed upon hereunder and accrued interest less the selling Member's commission.

or (c) (alternative) an amount sufficient to pay off enough of the said loan to procure the release of the bonds as collaterali. e., the Purchase Price and accrued interest less any pro rata for each bond paid by the Member when the joint loan was arranged;

or (d) The Selling Price less any pro rata paid by each Member when the loan was arranged;

or (e) The Selling Price less the Seller's commission and less any pro rata paid by each Member when the loan was arranged.

Note.-Obviously (a) and (d) leave all profits including commissions in the hands of the Manager, and (b) and (e) all profits except commissions in his hands; (c) would leave all profits in the hands of the Members to be accounted for to the Manager. Obviously, too, (c), (d) and (e) are provisions in the event of carrying by a joint loan.

Whereupon the Manager shall procure, in the manner herein stipulated, the bonds called for and deliver them to the Member. The price here provided for shall be known herein as 'The Take Down Price.

Sec. 6-NOTIFICATION.

On making a sale a Member shall immediately notify the Manager 
by telephone or telegraph and shall confirm this notification by let. ler.

Sec. 7.-TERRITORY.

\section{A.-UNRESTRICTED.}

Members may offer and sell the bonds without restriction as to territory.

It is agreed that

$$
\text { B.-Restricted. }
$$

(Alternative Clause)

shall offer or advertise the bonds only in, or sell them only to purchasers residing in

(Repeat until all the Members are provided with territory.)

\section{Sec. 8.-DURATION OF ACCOUNT.}

\section{A.-Time Limited.}

Unless all the bonds are earlier sold, whereupon the Account shall be closed, selling under this Account shall come to an end at the close of the ......... day of .........., 19..., and Members shall then take for their own account in proportion to their participation herein, unless otherwise herein expressly provided, any bonds then remaining undisposed of, and the Manager shall proceed to a settlement of the Account. If, however, a majority in interest in the Account before the said day shall so vote, the Manager shall forthwith give notice to all the Members that the Account will continue in accordance with the vote of the majority in interest.

\section{B.-Time Indeterminate. \\ (Alternative Clause)}

Unless earlier terminated as herein provided this agreement shall continue until all the bonds are sold or disposed of. Whereupon the Manager shall notify the Members that the Account is closed and proceed to a settlement of the Account. If, however, a majority in interest herein of the Members shall so vote, the Manager shall forthwith give notice to all the Members that the Account will be closed on a day named in the notice and the Members shall take up in proportion to their participation herein any bonds then remaining undisposed of, unless otherwise herein expressly provided. 
Sec. 9.-ADVERTISING.

All adrertising in newspapers or periodicals shall be done, and all circulars prepared and printed by the Manager at the expense of the Account in the names of .................. The terms of this provision may be changed by the note of a majority in interest.

\section{B.- (Alternative Clause.)}

Each Member may advertise the bonds in newspapers and printed circulars thereon at his own expense in the names of ............. But all such advertising and circulars shall be approved by the Manager. The terms of this provision may be changed by vote of a majority in interest.

\section{C.-(Alternative Clause.)}

Each Member may advertise the bonds in newspapers and periodicals, and may issue circulars thereon at his own expense and in his own name. But all such advertising shall be approved by the Manager. The terms of this provision may be changed by vote of a majority in interest.

Sec. 10.-POWER OF ATTORNEY TO MANAGER.

The Members nominate and appoint the Manager their agent and attorney, with full power and authority to do any and all acts and to enter into and execute any and all agreements or other instruments necessary or proper, or by the Manager deemed expedient in the premises, to carry out the purposes of this agreement. The Manager shall have the sole direction, management and the entire conduct of the Account, and the enumeration of particular or specific powers in this agreement shall not be considered as in any way limiting or abridging the general power or discretion intended to be conferred upon and reserved to the Manager in order to authorize him to do any and all things proper, necessary or expedient in his discretion to carry out the purposes of this agreement.

\section{Sec. 11.-EXPENSES AND PROFITS AND LOSSES.}

The Manager shall keep the books of the Account, and apportion the expenses and the profits or losses in accordance with the provisions of this agreement. All expenses incurred by the Manager on account of the Account, including counsel fees, the expense of receiving and delivering bonds, and all other disbursements and expenses made by him in connection with the carrying out of the purpose of this 
agreement shall be a charge to the Account. Also expenses of members for telegrams, telephone calls, postage, printing and other purposes incurred by them in carrying out the purposes of this agreement shall be allowed by the Manager in his reasonable discretion as expenses of the account and charged to it.

Sec. 12.-Each Member hereby ratifies, assents to and agrees to be bound by any action of the Manager taken under this agreement, and agrees to perform all of his undertakings hercunder from time to time on the call of the Manager to the full extent of his liability hereunder.

Sec. 13.-Each and erery Member, will, upon reasonable request, execute and deliver any further writing or writings which may be necessary or proper to carry this agreement into effect.

Sec. 14.-The failure of any Member to perform any of his undertakings hereunder shall not release any other Member, but if any Member fails to perform any undertaking hereunder his liability shall be borne by the other Members in proportion to their participation in the Account.

Sec. 15.-All notices issued by the Manager hereunder shall be telegraphed or mailed to or delivered at the addresses of the Members as given below, opposite their respective names. Requests of Members to the Manager shall be in writing mailed or delivered or shall be transmitted by telegraph to the address of the Manager given below.

Sec. 16. - In event of the resignation of the Manager a majority in interest herein of the Members shall choose a successor and the successor shall hare all the duties and powers of the Manager as herein set forth.

In Witness Whereof, the Manager, party of the first part, has subscribed the original hereof, and the Members, parties of the second part, have subscribed the original or counterparts thereof as of the day and year of the date hereof.

Name.

Address. 


\section{VALUATION OF PUBLIC UTILITY PROPERTY ${ }^{1}$} TABLE OF CONTENTS PAGE

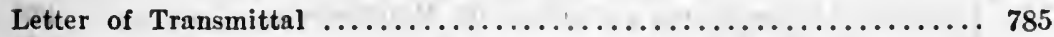

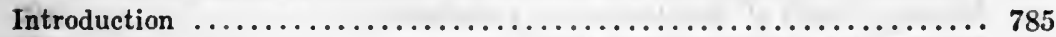

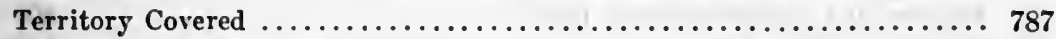

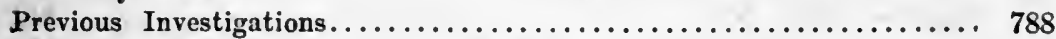

Some Contrasts with Other Companies................... 790

The Problem Before Us.............................. 791

Gross Earuings, Expenses and Profits.................... 793

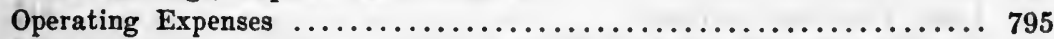

Payment to the American Telephone and Telegraph Company......... 796

Maintenance and Depreciation Reserve....................... 799

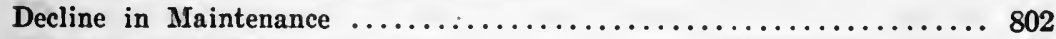

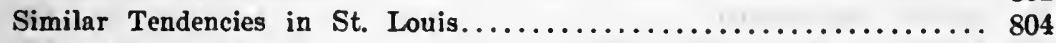

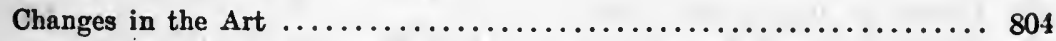

Long Life Property, Proportion of. . ................... 808

Depreciation Reserve of the Company..................... 809

The Appraisal $\ldots \ldots \ldots \ldots \ldots \ldots \ldots \ldots \ldots \ldots \ldots \ldots \ldots \ldots \ldots \ldots \ldots \ldots \ldots \ldots$

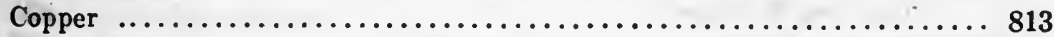

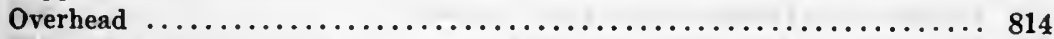

Land, Base and Overhead $\ldots \ldots \ldots \ldots \ldots \ldots \ldots \ldots \ldots \ldots \ldots \ldots \ldots \ldots$

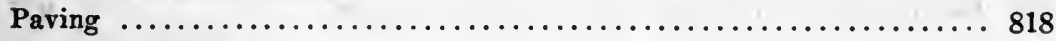

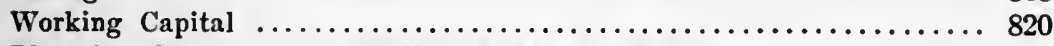

Plant Development, Cost of ......................... 821

Development of Business, Cost of ..................... 822

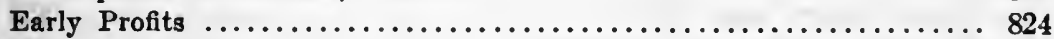

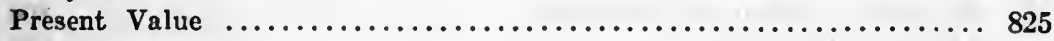

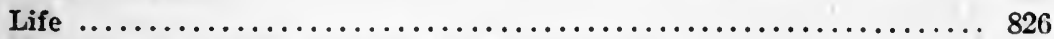

Depreciated or Present Value.......................... 828

Method of Building Up a Depreciation Reserve.................. 830

Maintenance and Depreciation in Other Bell Companies............ 832

Rate of Return ............................ 837

Possibilities of Reduction $\ldots \ldots \ldots \ldots \ldots \ldots \ldots \ldots \ldots \ldots \ldots \ldots \ldots \ldots . \ldots . \ldots$

Toll Earnings and Expenses......................... 843

Municipal Requirements-The Subway .................. 843

Depreciation, Extraordinary .......................... 844

Office Buildings and Equipments, Displacement of ............ 847

Semi-Mechanical Switchboards ........................ 850

Extraordinary Depreciation, Conclusions on ............... 850

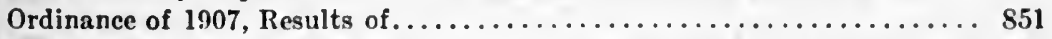

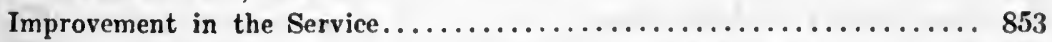

City Telephone Burea $\ldots \ldots \ldots \ldots \ldots \ldots \ldots \ldots \ldots \ldots \ldots \ldots \ldots \ldots . \ldots \ldots . \ldots \ldots$

Measured Service for Resilences ...................... 854

Meters ................................... 854

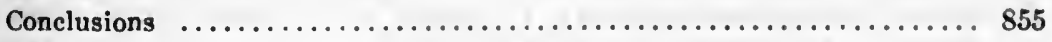

Table. LIST OF TABLES

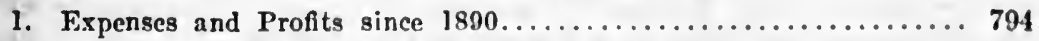

2. Percentage of Expenses and Profits to Investment............ 794

1 From Report on the Investigation of the Chicago Telephone Company submitted to the Committee on Gas, Oil nnd Electric Light (Hon. Anton J. Cermak, Chairman) by Prof. Edward W. Benis. 
3. Rentals to American Telephone and Telegraph Company......... 799

4. Depreciable Property and Percentage for Maintenance.......... 801

5. Declining Ratio of Maintenance to Investment.............. 802

6. Repairs and Reconstruction, $1903 \ldots \ldots \ldots \ldots \ldots \ldots \ldots \ldots \ldots \ldots . \ldots . \ldots . \ldots$

7. Appraised Value New ......................... 812

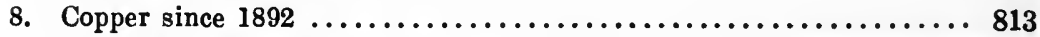

9. Overhead, Summary of $\ldots \ldots \ldots \ldots \ldots \ldots \ldots \ldots \ldots \ldots \ldots \ldots \ldots \ldots$

10. Land Appraisal and Cost........................ 816

11. Land, Base and Overhead...................... 817

12. Rejected Items and Conceded Value $\ldots \ldots \ldots \ldots \ldots \ldots \ldots \ldots \ldots . . .625$

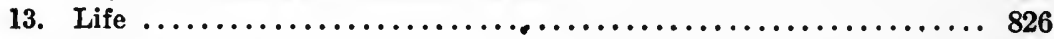

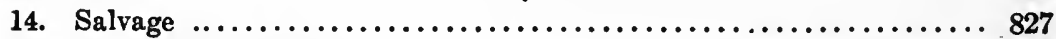

15. Annual Depreciation . . . . . . . . . . . . . . . . . . . 827

16. Present or Depreciated Value......................... 828

17. Maintenance and Depreciation of Bell Companies, including Long

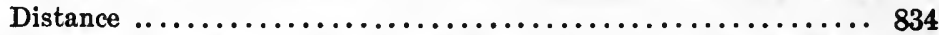

18. Maintenance, Depreciation and Investment of Bell Companies, aside from Long Distance ........................ 835

19. Expenses and Profits Within City, Revised.............. 842

20. Earnıngs and Telephones since $1904 \ldots \ldots \ldots \ldots \ldots \ldots \ldots \ldots \ldots \ldots . \ldots \ldots 2$

21. Declining Rate of Return, with Additional Bonds............ 857

\section{LIST OF APPENDICES}

Appendix.

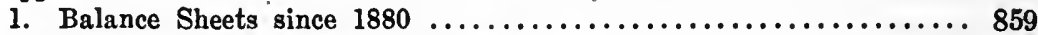

2. Appraisal, Chicago and Suburban .................. 866

3. Appraisal, City ............................ 867

4. Cost of Property New, City and Suburban............... 868

5. Growth of Plant ............................. 869

6. Plant and Cost Statistics:

A. Underground Conduit $\ldots \ldots \ldots \ldots \ldots \ldots \ldots \ldots \ldots \ldots \ldots . \ldots 70$

B. Underground Cable and Wire $\ldots \ldots \ldots \ldots \ldots \ldots \ldots \ldots \ldots . \ldots 1$

C. Underground Conduit and Cable................ 871

D. Central Office and Subscribers' Station Equipment...... 872

E. Total Equipment and Stations................. 872

F. Maintenance since $1890 \ldots \ldots \ldots \ldots \ldots \ldots \ldots \ldots \ldots \ldots \ldots$

G. Oonduit and Wire since $1883 \ldots \ldots \ldots \ldots \ldots \ldots \ldots \ldots . \ldots . \ldots$

H. Wire and Stations since $1883 \ldots \ldots \ldots \ldots \ldots \ldots \ldots \ldots . \ldots \ldots 74$

7. Base Figures vs. Book Value........................ 874

8. Base, Overhead and Total Appraisal................. 877

9. Buildings, Appraisal vs. Book Value.................. 880

10. Defense of Building Appraisal, by J. G. Wray............. 880

11. Subway Construction of, Effect of (According to J. G. Wray) ....... 885

12. Growth of Investment and How Paid For................ 889

13. Depreciation, How Treated by Company................ 890

14. Maintenance and Addition to Reserve, in City, 1908-12......... 892

15. Composite Life, Salvage and Annual Depreciation............. 893

16. Quantities According to Inventory, City and Suburbs.......... 894

17. City Purchase, Provisions of Ordinance................ 895 
City Hall, Chicago, Oct. 25, 1912.

Alderman Anton J. Cermak, Chairman Committee on Gas, Oil and Electric Light of the City Council, Chicago, Ill.

\section{Dear Sir:}

I herewith transmit the results of my studies of the Chicago Telephone Company, so far as they related to the ability of the Company to reduce rates or improve the service.

Until the Committee shall decide upon the wisdom of my recommendations upon these matters, an apportionment of the total amount of reduction in rates to the various classes of service need not be made.

Invaluable assistance has been rendered from the beginning to the present time by the accounting firm of Marwick, Mitchell, Peat \& Co., and particularly by the head of the Chicago branch, Mr. James Hall, and his assistant, Mr. Andrew Sangster. Their work not only appears in the special report which they submitted to me some time ago, and which is herewith transmitted to the Committee, but in the constant assistance they have rendered in following out, at my suggestion, special lines of inquiry into the accounts of the Company.

In the large amount of investigation which has been necessary in the preparation of this report, the Chicago Telephone Company has fully co-operated. The ordinance of November 6, 1907, gives the City access to the plants and accounts of the Company. But the officials have gone further than this, and have assisted in working out data and in making investigations requested by the City's representatives.

Very respectfully submitted,

Edward W. Bemis.

\section{INTRODUCTION}

The regulation of telephone rates in large cities by any public body is practically a virgin field. Aside from the action of the Chicago City Council, November 6, 1907, fixing the rates now clarged in Chicago, there have been only two notable studies of the subject in this country. One in 1909-10 by the Massachusetts Highway Commission for Boston and its suburbs, and one in 1911 by the Maryland Public Service Commission, for the City of Baltimore.

There have been, to be sure, several investigations of the telephone rates in smaller places, by the Wisconsin Railroad Commission and 
the New Jersey Public Utilities Commission, but they have little direct bearing upon Chicago conditions. The same lack of application to conditions here applies to an investigation in Los Angeles and one in Seattle, in each of which cities there are two competing companies of substantially equal size.

No court or commission has thus far brought together such tabulated comparisons of operating expenses, construction costs, etc., per unit of telephone plant or of service rendered, as is the case with gas, electric light and street railways.

This has been partly due to the rapid growth of the telephone business and partly to the reliance hitherto upon competition in most sections outside of New England, rather than upon public regulation. With the tendency of late to division of territory between the Bell Company and the independent companies, the need of information to serve as a basis for public regulation is now seriously felt.

Furthermore, the relations of local Bell companies to the American Telephone and Telegraph Company, hereafter to be referred to by its usual abbreviation, the A. T. \& T., are so close that it is difficult to study local conditions without the help of the National Government as to the facts with regard to the parent company, whose business is nation wide. Fortunately, the power to secure this information has just been granted to the Interstate Commerce Commission, but it will take time to secure results from this source.

In Europe and Australia the telephones are so largely owned by the national governments, and conditions are so different from here, that little help can be secured in that direction.

All this, together with the magnitude of the interests at stake, make the Chicago investigation difficult. We have here to deal with the second largest telephone company in the world. Only New York has more telephones than Chicago. Contrast the 251,614 'phones in Chicago, January 1, 1912, with the 220,781 in London, 85,961 in Paris and 133,860 in Berlin, at the same time, and with the 453,000 in Greater New York, of which number 326,122 were in the Borough of Manhattan. According to the United States Consular Reports for 1912 (page 357), the entire number of telephones taken over by the British Government on January 1 from the National Telephone Company was only 560,000 for all of Great Britain and Ireland, or only $72 \%$ more than were operated by the Chicago Telephone Company in the city and suburban district, and only $2 \frac{1}{4}$ times the number within the city limits. The number of telephones throughout Canada in 1911, according to the United States Consular Report from March 28, 1912, was only 302,759 , or less than in Chicago and its suburbs. The American Telephone and Telegraph Company gives the following 
as the number of telephones (partly estimated) in various countries, January 1, 1912. The number in use by the Chicago Telephone Company in the city and suburbs are given for comparison:

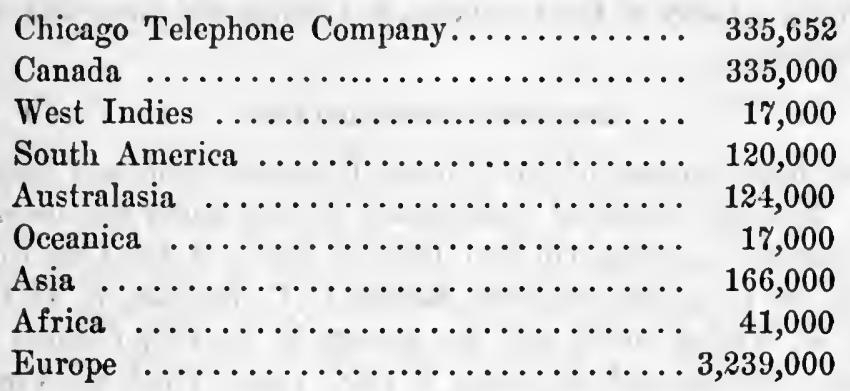

All the world outside the United States, Europe and Canada is reported as having only 517,000 'phones, or less than twice the number in the Chicago district.

\section{TERRITORY COVERED}

The Chicago Telephone Company embraces two divisions, the city and the suburban. The city division, with a population of $2,185,283$ in 1910 , covers the area of the eity, which since July 17, 1911, has been 194.4 square miles. The suburban division, with a population of 656,655 in 1910 , embraces 5,194 square miles, extending fully 100 miles along the lake and from 30 to 60 miles back from the lake. Thus the Company, covering 388 square miles, embraces Lake, Cook, McHenry, Kane, DuPage, Kendall, Grundy and Will Counties in Illinois, and Lake and Porter Counties in Indiana. It includes, Elgin, Aurora and Joliet, Ill., Gary and Valparaiso, Ind., and toll lines to Kenosha and Lake Genera, Wis.

There are 33 exchanges in the city and 95 in the suburban division; 25 of those in the city are of the central battery type, with a capacity of 4,900 to 10,500 subscribers. Of the exchanges in the suburbs, 23 are of the same type, averaging a eapacity of about 4,900 subscribers. There are in the eity eight local battery type offices, often called magneto offices, and 72 in suburban districts; they average only 200 subscribers. Conditions in every way are quite different in the city and suburban district; in the former the wires are mostly in underground conduits, while in the latter they are in overhead cables or are bare wire on poles. In the city a large part of the service is on a measured basis; in the suburbs it is on a flat rate basis, such as is common in small cities and rural communities. The revenues and expenses, naturally, differ in these two sections. The city only has jurisdiction of the rates and services within the city, and special attention, there- 
fore, must be given to that part of the business of the Company. Since, however, it is one company in both city and suburbs, and since it is impossible to separate entirely the two branches, it is well to begin with a study of the Company as a whole and then take up the city division.

\section{PREVIOUS INVESTIGATION}

Three investigations of the Chicago Telephone Company have been made. The first, covering substantially a year, under the auspices of the Committee on Gas, Oil and Electric Light of the City Council, aided by the telephone engineers, Messrs. D. C. Jackson, W. H. Crumb and G. W. Wilder, ended with the passage by the City Council of the telephone ordinance of November 6,1907, under which the Company is now operating. The second investigation concluded May 9, 1910, was by Messrs. D. C. and W. B. Jackson, engineers, and Messrs. Young \& Company, accountants, for the year ending March 31, 1910. This was made to the City Comptroller, Mr. W. H. Wilson, and was a supplement to a report they had already made, December 30,1908 , outlining a plan of accounting for the Telephone Company. The report of May 9, 1910, was considered by the Committee on Gas, Oil and Electric Light, in various sessions, from May 19 to June 2, 1910. The fact that the accountants employed were also accountants for the Telephone Company led the Committee to vote on June $2 \mathrm{~d}$ that other experts should be employed to go over the report.

On June 16, 1910, the Committee on Gas, Oil and Electric Light were informed by its sub-committee that Mr. W. J. Hagenah, of Madison, Wis., had been engaged to do this work. From January 5 to January 23, 1911, the Committee considered Mr. Hagenah's report covering the calendar year 1909. To enable Mr. Hagenah to report on the changes in each of the several classes of rates that could be wisely made in connection with a total reduction of about $\$ 200,000$, the Committee, on January 23, took a recess.

The consideration of the final report of Mr. Hagenah, dated May 2, 1911, was postponed until after the consideration of the gas ordinance. Immediately thereafter, on July 17 th, the undersigned was asked to take up the investigation. A prior engagement caused more or less delay, until it finally seemed wise to include not only the prosperous experience of the Company in 1910, under the reduced rates of the 1907 ordinance, but also to include the rapid growth of the Company and its continued prosperity in 1911. It also developed, near the close of 1911, that the Company, in the summer of 1911, had undertaken an expensive and exhaustive inventory and appraisal of all its property. It was so evidently unwise to ignore such an ap- 
praisal that no apology nced be made for delaying the report until the Company was able, August 17, 1912, to place the entire results of this valuation at the disposal of the City, and until those results could be given the consideration which their importance and bulk, in nine large volumes, demanded.

According to the Jackson-Young report, the existing rates yielded only $3.83 \%$ on the investment. After paying $5 \%$ interest on the bonds and $8 \%$ dividends on the stock, properly applicable to the inrestment within the city limits, there was, if the report be accepted, a deficit for March 31, 1909-10, on business within the city limits, of $\$ 908,533.52$. These figures were based upon the theory of the investigators that the Company was not allowing a sufficient amount for depreciation. The Company had spent $\$ 622,296$ that year on reconstruction and replacements. The investigators considered that the depreciation for the year was in excess of this amount by $\$ 956,626.20$.

In his final report, for May 2, 1911, page 64, Mr. Hagenah estimated that the Company, after paying interest on its bonds and $8 \%$ on the balance of what he considered its depreciated investment within the city limits, would have had a surplus in 1909 of $\$ 309,488.36$.

When the Committee on Gas, Oil and Electric Light were considering substantially these figures, on January 23, 1911, and were about to make a motion to reduce the rates charged by about $\$ 216,000$, or about $2 \%$ of the gross receipts, the other $\$ 100,000$ of surplus being considered as needed by the Company for emergencies, Mr. B. E. Sunny, President of the Chicago Telephone Company said:

"An attempt to distribute that amount, $\$ 216,000$, would be futile, first, because the amount is wholly erroneous; second, that it would give the Telephone Company rates which would be unreasonable and which it could not accept. - There is no chance in the world of the Telephone Company being able to accept rates on the basis suggested."

The Committce voted, however, as follows:

"That Mr. Hagenah be instructed to proceed with the preparation of the schedule of telephone rates on the analysis contained in the report made to the Committee, and that he reduce the rates to the extent of the surplus, of approximately $\$ 216,000$, where his cost analysis shows the present schedule to be excessive or inequitable, and that the said schedule of telephone rates be reported back to this Committee for its future action."

Mr. Hagenah held that the plant had depreciated $22.5 \%$ and must set aside yearly $\$ 2,717,890$ within the city for maintenance and to meet depreciation, or $13.65 \%$ of the then value and $11.61 \%$ of the book cost of the property, including land and working capital.

In this situation, with Mr. Hagenah basing the possibility of a reduction of $\$ 216,000$ upon the assertion of an amount of depreciation 
which President Sunny denied, it became exceedingly important to have the fullest access to the books of the Company throughout its history, and to study the appraisal just completed for the Company by Messrs. Byllesby and Arnold.

\section{SOME CONTRASTS WITH OTHER COMPANIES}

The Chicago Telephone Company differs from many other public utilities in several very important respects:

1. The Company has not only thrown open all of its books and other accounts and plants to the inspection of the City's representatives, as contemplated in the ordinance of $190 \%$, but it has freely given much other valuable material and assistance which it was under less obligation to furnish. Inquiries which called for considerable investigation were much more promptly and fully answered than is customary, or than could have been legally demanded. There has been no evidence of an attempt to keep back anything that was asked for relative to the Company.

2. There have been no fires, suspicious or otherwise, to destroy the early records of the Company.

3. There has been no change of ownership to complicate the situation. One company, and that one always controlled by the A. T. \& T. Co., has been in charge since the first consolidation in 1881, two years after the beginning of the telephone business in Chicago.

4. There has been no telephone competition in the city since 1880, with the exception of the thus far negligible competition of the Chicago Tunnel Company.

5. There were no early losses or failure to pay both development costs and good dividends out of the revenues of the Company from the very start.

6. While there have been increases of plant out of earnings and increases of stock to represent this new plant, without direct payment at the time by the stockholders, the par value of the outstanding stocks, bonds and notes has rarely exceeded, and on January 1, 1912, did not exceed, the present value of the physical assets of the Company. In other words, water, in the sense of the excess of outstanding securities above tangible assets, does not appear in the stock of the Company.

\%. A depreciation reserve of about $\$ 5,000,000$, or over $15 \%$ of the outstanding stocks and bonds, has been accumulated out of earnings to meet depreciation, and has been invested in extensions.

Some of these points will be enlarged upon elsewhere. It is sufficient now to congratulate the Chicago Telephone Company upon its unique position in combining so many good features. 
The investigation of the profits and the regulation of rates are made far less difficult by the above situation.

On the other hand, because of the great size of the Company, with over $\$ 35,000,000$ of assets, and with a service touching most closely the homes and comfort and business of the entire city, and because of the novelty and complexity of the problems to be handled, there is call for the most thorough investigation and the most judicial thought that can be brought to the task.

The revenues of all the gas, water and telephone properties controlled by the Wisconsin Railroad Commission are no greater than those of the Chicago Telephone Company.

\section{THE PROBLEM BEFORE US}

The problem before us arises from the ordinance of November 6; 1907, giving a franchise to the Chicago Telephone Company until January 8, 1929.

It provided, with reference to that portion of the Company's business within the city limits, a complete control by the City Council of rates for periods of five years each, after the expiration of the first thirty months. The rates for the first two and one-half years were prescribed in the ordinance of $190 \%$. Since the City Council has not prescribed new rates since $190 \%$, those ordered for the first thirty months, ending in April, 1910, have continued.

The full provisions of the city ordinance of November 6, 1907, on this point are here quoted:

“7. Future Rate Regulation-Special Ordinance-Right Reserved-Consent of Company.

"The City Council, as one of the conditions of the grant of the privileges herein confered upon the Chieago Telephone Company, hereby reserves to itself the right from time to time during the period of this grant, by speeial ordinance amendatory hereof, to hereafter establish, fix, preseribe and regulate the rates, charges, prices and tolls, or other compensation or any limitations thereupon, for each and every kind of service, facilities and equipment which the Chicago Telephone Company furnishes or supplies, or may furnish or supply, in the City of Chicago, under this ordinanee, and also the basis, method, manner and means of computing, exaeting, imposing, paying and collecting such rates, charges, prices and tolls, or other compensation of said Chicago Telephone Company.

"Included in the right or rights above reserved to the City Couneil is the right to hercafter alter, change or reduce the maximum rates for any service, facilities or equipment hereinbefore deseribed, and any other rates, eharges, prices, tolls or compensation for any service, facilities or equipment which may now or hereafter under this ordinanee be established, fixed, prescribed, imposed or collected by said grantee, as the City Council may deem er- 
pedient and reasonable, and to pass, by a special amendatory ordinance, from time to time, all reasonable rules and regulations relative to the rates, charges, prices, tolls or other compensation of said grantee, for any service, facilities or equipment. The Chicago Telephone Company, by the filing of the acceptance of the terms and conditions of this ordinance hereinafter provided for, shall be understood as expressly consenting and agreeing to promptly accept, adopt, put into effect and operate its system of wires, cables, electrical conductors, poles and conduits, in the City of Chicago, under any reasonable schedule or schedules of rates, charges, prices, tolls or compensation for telephone service, instruments, facilities or equipment, or for all or any of them, or any reasonable schedule or schedules of limitations upon such rates, charges, prices, tolls or compensation, or any reasonable rules and regulations relating thereto, and also the basis, method, manner and means of computing, exacting, imposing, paying and collecting such rates, charges, prices and tolls, or other compensation of said Chicago Telephone Company. which the City of Chicago may, by special amendatory ordinances, establish, fix or prescribe from time to time, after the expiration of thirty months from the time this ordinance goes into force and effect, and any reasonable schedule or schedules of rates, charges, prices, tolls, or other compensation for any other service, instruments, facilities or equipment, other than those herein mentioned, or for all or any of them, or any reasonable schedule or schedulcs of limitations upon such other rates, charges, prices, tolls or compensation, or all or any of them, or any reasonable rules and regulations relative thereto, which the City of Chicago may, by special ordinance, establish, fix or prescribe from time to time after this ordinance goes into force and effect. Provided, that any schedule or schedules of rates, charges, prices, tolls or compensation or of limitations thereupon, which are established, fixed or prescribed as aforesaid shall not be fixed by the City of Chicago to continue for a period of more than, or of less than, five years, unless at the time of the passage of any such special amendatory ordinance the unexpired term of this grant is less than five years.

"Whenever the City desires to take up the regulation of rates as hereinbefore provided for, the Comptroller shall give to the Chicago Telephone Company at least thirty days' notice, and shall require the Company to produce, and the Company shall produce, all the facts, data and information in its possession which the City may require to assist the City to make a proper and reasonable regulation of rates.

"If at any time said Chicago Telephone Company shall in any way contest or deny the reasonableness of any rates, charges, prices, tolls or other compensation, or any limitation or limitations thereupon, for any kind of service, facilities or equipment prescribed by a special amendatory ordinance, as hereinbefore provided, or by a general ordinance as hereinafter provided, and pending the detemination of any proceeding, litigation or contest whatever, shall collect or receive rates, charges, prices, tolls or other compensation in excess of the rates, charges, prices, tolls or other compensation, or any limitation or limitations thereupon fixed by ordinance, said Chicago Telephone Company shall upon the final determination of any such proceeding, litigation or contest repay to each and all of its lessees, subscribers and patrons the excessive amount which it has collected or received therefrom, together with interest thereon at the rate of five per cent. $(5 \%)$ per annum from the date of said collection or receipt unless the unreasonableness of the rates, charges. 
prices, tolls or other compensation, or any limitation or limitations thereupon, which have been attacked, shall have been established.

"Right of Regulation by General Ordinance Reserved.

"Nothing in this ordinance contained shall be construed or taken as preventing the City of Chicago whenever it shall be empowered by the General Assembly so to do from passing from time to time any general ordinance or ordinances establishing, fixing, prescribing or regulating the rates, rentals or charges of telephone companies for any service, instruments, facilities, equipment or licensing, regulating or taxing telephone companies, it being the intention of this ordinance that the City of Chicago shall in no way surrender any right it may now have or may hereafter acquire to tax, license or regulate telephone companies or to establish, fix, prescribe or regulate the price, rates, rentals, charges or compensation to be charged for telephones, or any service, facilities or equipment, provided, also, that nothing in this ordinance contained shall be construed as preventing the City of Chicago from granting an ordinance to any other telephone company. The Chicago Telephone Company by the acceptance of this ordinance shall be understood as agreeing to comply with the terms and conditions of any reasonable, general ordinance or ordinances passed as aforesaid."

Evidently the first question to be determined is the amount of profit that the Company has made during the four years of operation of the existing ordinance, and the ratio of that profit to the actual investment in the property.

Other questions will follow, such as the relation of investment to present value, the amount needed for depreciation, the reasonable rate of return, prospects of future profits and costs as affected by possible competition, the building of subways, etc.

\section{GROSS EARNINGS, EXPENSES AND PROFITS}

In the following tables are presented the actual receipts and the actual expenditures as shown by the books of the Company since 1890. Allowances for depreciation and other reserves not actually expended are omitted. The accountants have made a few minor adjustments of the books in the table below, but only one is of sufficient importance to deserve mention, and that is of not any large importance.

Unusual expenditures of 1911 of $\$ 144,583.92$ on account of the appraisal and $\$ 44,453.40$ in connection with a strike, or a total of $\$ 189$,037.32, were in large part thrown back and apportioned over the last seven years, thus making the burden less severe in 1911 .

The investment in Table 2 is based on the cost reported by the Company on its books without any deductions for depreciation. 
TABLE 1

EXPENSES AND PROFITS, CITY AND SUBURBAN

Before Making Additions to the Depreciation Reserves

\begin{tabular}{|c|c|c|c|c|c|}
\hline $\begin{array}{c}\text { Year } \\
\text { Ended } \\
\text { Dec. } 31\end{array}$ & & & & $\begin{array}{l}\text { Miscellaneous } \\
\text { Revenue }\end{array}$ & Net Profit \\
\hline 1891 & 0 & & & & $\$$ \\
\hline & & & 1.28 & & \\
\hline 1893 & $7,829.73$ & 51.53 & $536,378.20$ & & \\
\hline 1894 & 1,4 & 7.02 & 1.83 & & \\
\hline & & 1,036 , & 579 & & 4.02 \\
\hline & & & 3.17 & & 40.68 \\
\hline 1897 & & & & & \\
\hline 98 & 2,1 & 1,2 & & & 5.01 \\
\hline 189 & & & 1,00 & & 7.66 \\
\hline 1900 & & .19 & & & 3.09 \\
\hline 1901 & & .28 & .67 & & 7.56 \\
\hline & & & & & \\
\hline & & & & & 10 \\
\hline 904 & & & & & \\
\hline & & & & & \\
\hline & .54 & 4,9 & & & 2.59 \\
\hline & & & & & \\
\hline & & & & & \\
\hline & 4.46 & 8.52 & $2,507,265.94$ & & $2,561,855.01$ \\
\hline & & & & & \\
\hline & & 40 & $3,637,194.66$ & $43,540.78$ & $3,680,735.44$ \\
\hline
\end{tabular}

TABLE 2

PER CENT. EARNINGS, EXPENSES AND NET RETTIRN TO AVERAGE INVESTMENT, ELIMINATING ALLOWANCE FOR DEPRECIATION

City and Suburban

\begin{tabular}{cllllc}
\hline $\begin{array}{c}\text { Calendar } \\
\text { Year }\end{array}$ & $\begin{array}{c}\text { Total } \\
\text { Eelephone }\end{array}$ & $\begin{array}{c}\text { Expenses } \\
\text { of } \\
\text { Operation }\end{array}$ & $\begin{array}{c}\text { Net } \\
\text { Telephone } \\
\text { Earnings }\end{array}$ & $\begin{array}{c}\text { Miscel- } \\
\text { laneous } \\
\text { Revenue }\end{array}$ & $\begin{array}{c}\text { Net Return } \\
\text { to Average } \\
\text { Investment }\end{array}$ \\
\hline 1891 & $51.01 \%$ & $29.40 \%$ & $21.61 \%$ & $.18 \%$ & $21.79 \%$ \\
1892 & 42.11 & 26.02 & 16.09 & .14 & 16.23 \\
1893 & 38.23 & 23.77 & 14.46 &.$\% 7$ & 14.46 \\
1894 & 35.83 & 21.84 & 13.99 & .07 & 14.06 \\
1895 & 36.52 & 23.42 & 13.10 & .43 & 13.53 \\
1896 & 37.42 & 22.05 & 15.37 & .46 & 15.83 \\
1897 & 36.92 & 20.10 & 16.82 & .37 & 17.19 \\
1898 & 37.61 & 21.29 & 16.32 & .28 & 16.60 \\
1899 & 36.68 & 21.85 & 14.83 & .27 & 15.10 \\
1900 & 34.39 & 24.74 & 9.65 & .25 & $\mathbf{9} .90$ \\
1901 & 33.59 & 21.19 & 12.40 & .27 & 12.67 \\
1902 & 33.17 & 21.50 & 11.67 & .22 & 11.89 \\
1903 & 34.54 & 22.74 & 11.80 & .29 & 12.09 \\
1904 & 36.77 & 21.14 & 15.63 & .35 & 15.98 \\
1905 & 37.77 & 23.40 & 14.37 & .23 & 14.60 \\
1906 & 36.67 & 23.10 & 13.57 & .25 & 13.82 \\
1907 & 33.90 & 26.00 & 7.90 & .22 & 3.12 \\
1908 & 29.77 & 22.95 & 6.82 & .28 & 7.10 \\
1909 & 31.40 & 23.32 & 8.08 & .17 & 8.25 \\
1910 & 33.13 & 23.37 & 9.76 & .13 & 9.89 \\
1911 & 33.53 & 23.76 & 9.77 & .12 & 9.89 \\
\hline
\end{tabular}




\section{OPERATING EXPENSES}

No conclusions can be drawn from the tables just given until a study is made of the operating expenses, investment and reasonable allowance for depreciation. Operating expenses will be first considered.

Of the total average expenditures for operation and new construction in 1911 of about $\$ 13,183,339.79$, of which $\$ 8,836,827.49$ was for operation, the payroll amounted to $\$ 6,332,485$ and taxes to $\$ 720,000$. There is no evidence that these expenses can te materially reduced. Expenditures this year in the department of station removals and changes are falling, but on the whole the upward trend of wages found in other industries has affected and will still continue to affect the telephone business.

In a report of the United States Department of Commerce and Labor to the Senate, February 23, 1910, upon telephone companies (61st Congress, 2d Session, Document No. 380), it is shown (page 94) that outside of Colorado and farther west, Chicago was paying higher monthly wages to its operators than in most other cities.

The total number of employees in $190 \%-6,843$ - had an average monthly payroll of $\$ 43.97$. The 8,475 employees in 1911 had an average payroll of $\$ 51.31$. While the number of employees had increased $23.8 \%$, the monthly payroll was increased $44.5 \%$.

Of more interest, perhaps, are the figures for the traffic department, containing the operators who handle all the messages. These increased from 4,090 in 1907 , with an average monthly wage of $\$ 31.1 \%$, to 5,116 in 1911 , with an average monthly wage of $\$ 35.23$. The arerage pay per employe increased $13 \%$.

The pay for an eight-hour day for an ordinary operator doing no Sunday or holiday work rises from $\$ 23.84$ a month during the first six months of employment to $\$ 39$ the last half of the third year, and by successive steps to $\$ 49.86$ the tenth year. Higher wages are given to supervisors, whose pay gradually increases to $\$ 56.36$ a month in the seventh year.

Plans are now being considered for a pension scheme in all the Bell companies, which will add somewhat to the expenses of the Company. Further increase of wages, with increased cost of living and the increase of wages elsewhere, are also likely during the next five years.

Since the Company, however, has successfully met previous increases and seems to be doing quite as well by its employces as do other telephone companies, there does not appear to be any reason for giving further consideration to the subject at the present time.

The Chicago Telephone Company spends more moncy per telephone than do other large Bell companies in operators' wages, schooling, rest and lunch room expenses. In this respect the eost per telephone in 
Chicago last year was $\$ 1.87$ greater than the average of all the Bell companies, and $\$ 1.40$ greater than in the seaboard states from Maine to Virginia.

To what extent this excess of expenses in the traffic department is due to the large number of nickel 'phones and the extent of the flat rate service, and to what extent it is due to better wages and greater interest in the welfare of the employees, it has been found impossible to determine. Certain it is that the welfare work, such as rest and lunch rooms, schooling, etc., among the employees is carried much farther in Chicago than in most, and probably than in any other places.

The yearly expense here is 73 cents a telephone for these purposes, as compared with 31 cents on the average, for the country as a whole, and 41 cents on the average for New England and the other seaboard states north of the Potomac.

Practically all supplies and materials for construction, outside of buildings, are obtained from the Western Electric Company. Since the majority of its stock is owned by the A. T. \& T., which also owns over $95 \%$ of the stock of the Chicago Telephone Company, there is naturally some suspicion of the prices paid by the local company. Investigation elsewhere, as well as studies that it has been possible to make in preparation of this report, have not confirmed these suspicions. At least, so far as the present report is concerned, this particular matter may be omitted from further consideration.

Two other expenses, aside from those of the traffic department, are materially greater in Chicago than elsewhere. One of these is the expense for station removals and changes, and the other is the expense for repairs.

The considerable percentage of the population of Chicago which moves every year, and the extent to which the cheaper type of telephone, the nickel 'phone, has been extended, are supposed to account for the difference in expenses with regarc. to station removals, which average over \$2 per telephone. The larger cost of repairs in Chicago than elsewhere probably has a tendency to keep down the need for renewals and will be considered further in connection with the subject of depreciation.

\section{PAYMENT TO THE A. T. \& T.}

The operating expenses thus far considered were higher, in some respects, than in other companies, but have a sufficient justification to warrant our acceptance of the same in this report.

Very different in character is the yearly payment by the local company, in common with every other Bell Company, of $4 \frac{1}{2} \%$ of its gross 
receipts from telephones to the A. T. \& T. Co.-a company, it must be remembered, which, by its ownership of the majority of the stock of these various companies, stands at both ends of the bargain. The more, however, that the right hand-the A. T. \& T. Co.-decides that its left hand-the Chicago Telephone Company-shall pay, in the form of a percentage of the gross receipts, the higher must be the charges against the subscriber, to pay this disguised dividend. The payment made by the Chicago Telephone Company in 1911, of $\$ 537$,585.12 , amounted to $\$ 1.69$ for each of the 318,135 telephones, often called stations, in use on the arerage, during the year. It was equivalent to $1.45 \%$ of the average investment of $\$ 37,194,587.95$. (Hall's Report, pages 4, 36-9.) The payment for the City portion of the business was $\$ 445,550.42$ and will doubtless be about $\$ 500,000$ in 1912 .

In return for this payment, the Chicago company receives three advantages: First, the rental, with all repairs and renewals, of the electrical portion of the subscribers' equipment-the transmitter, receiver and induction coil ; second, certain patents; and third, legal, accounting and engineering assistance from time to time. These points will be considered in the above order:

\section{Transmitter, Receiver and Induction Coit:}

The Western Electric Company, which makes these instruments, has refused the writer's request for information on their cost, or the cost of maintenance and renewals. The Kellogg Switchboard Company, of Chicago, claims to sell an equally good sct for $\$ 2.80$, with a reduction of $15 \%$ if bought even in small lots, in connection with the Bell cord, stand and other small parts that go with a desk or wall outfit. If the price, under these circumstances, and with the discount, is only $\$ 2.38$, it may fairly be presumed that the cost, with a fair profit to the Western Electric, which supplies all these parts for over $4,000,000$ telephones, must be below this figure.

For our present purposes, one needs to know not only the cost new, and the fact that about one-fourth of the number are yearly returned by the Chicago Telephone Company for some repairs, but also the cost of these repairs, and the life of the instrument as a whole. In the refusal of the Western Electric to give this information, we may fall back upon the fact that on September 6, 1907, the Chicago Telephone Company met the bids of independent companies for the sale of transmitters, receivers and induction coils, by agrceing to rent the same to the City of Chicago and repair and renew them, for 50 cents apiece per year. The city accepted the offer, and took 1,557 such sets for the Police, Fire and Street departments, at this rate, and would have probably continued to act on this contract had not the ordinance of 
November 6, 190\%, given the City, in return for the franchise, the right to use the transmitter and receiver free of charge. In the absence of any access to the books of the Western Electric Company, it must be assumed that the contract with the City by the Chicago Telephone Company was not a losing one. It would indeed be fair to assume that if the company could afford to make a 50 cent price in competition with other companies for the small number needed by the City departments, it could afford to make a still lower price to the Chicago Telephone Company for the vastly larger number needed by the latter.

\section{Patents:}

The Chicago Telephone Company does not appear to buy patents as such, but to buy from the Western Electric Company goods many of which are patented. Since most of the goods, however, have been sold of late on substantially the same terms to independent telephone companies, the question at issue relates only to the few patented articles which the Western Electric Company refuses to sell to other than the Bell companies. The only one of these patented articles upon which the Chicago Telephone Company lays any stress, is the so-called Pupin coil, invented by Prof. Pupin of Columbia University, New York City, about twelre years ago. Its purpose is to reinforce the electric current at various points along the telephone line so that a small wire will carry the sound as distinctly as a larger and therefore more expensive wire would otherwise do. Its chief use is on long distance lines. In Chicago it is only used on some of the connecting trunk lines from one central office to another when the latter is over nine miles distant. Figures have been presented by the Chicago Telephone Company to prove that even on these lines the Pupin coils have saver an investment of $\$ 2,000,000$ worth of copper wire, whose yearly value, on a $7 \%$ basis, with an allowance of $1 \frac{1}{2} \%$ depreciation, is $\$ 170,000$ a year.

There is, however, another side to this question. It is not only what these patents may be worth to the local company, but their cost to the parent company. Especially is this important when the parent company absolutely owns and controls the policies of the local company, and all bargains which it may make. Now, the A. T. \& T., in its Annual Reports up to and including those for 1907, gave a yearly statement of the value of all its patents. It is to be regretted that this policy of publicity was not continued. However, since the Pupin coil was patented about 1900, and since no important patents since 1907 have been emphasized as defenses for the payments by the local companies, the Balance Sheet of the A. T. \& T. for January 1, 1908, may be quoted as very significant. According to that report the entire 
value of all the patents owned by the A. T. \& T. at the close of 1907 , was giren to the stockholders as only $\$ 277,937.35$. Since the total number of telephones belonging to the Bell companies in the United States at that time was $3,035,533$, the value of these patents per telephone was only 9 cents, and the entire capital value to be apportioned to Chicago, on the basis of the 202,600 stations then in service by the local company, was less than $\$ 20,000$. To be sure, the smaller companies have less use for the Pupin coil than has Chicago, but by far the greatest use is on the long distance lines.

\section{Engineering, Accounting and Legal Services:}

The company undoubtedly receives some benefit from the parent company in these ways. Whether the latter does not receive a sufficient reward in the dividends on the majority of the stock owned by it, in every local company, is another question.

As regards all three of the abore lines of service from the national company, it may be said that the reports of this company to the Massachusetts Highway Commission, indicate a rery large profit from the aid giren in the above ways to the local companies.

The $4 \frac{1}{2} \%$ payment to the A. T. \& T. yielded in 1911 for business within the city $\$ 445,550$. This was $\$ 1.76$ for each of the 253,753 phones in use on the average last year. Of this $\$ 1.76$ per phone, the amount justly earned by the A. T. \& T. does not appear to be over $\$ 1$ made up as follows:

\section{TABLE 3}

\section{RENTALS TO AMERICAN TELEPHONE AND TELEGRAPH COMPANY}

Rental of transmitter, receiver and induction coil............\$0.50

Interest, depreciation, taxes, royalties, etc., on patents, estimated at $22 \%$

of the cost-0 cents per phone-of said patents, as above....... 02

Services and unknown or undervalued items, not over...............

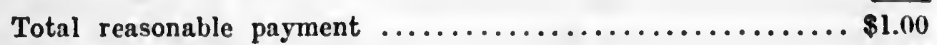

Amount of excess payment per phone......................... 76

Amount of excess payment, total. . . . . . . . . . . .

Per cent. of said excess payment to the present conecded value of all the

telephone property in the city, of $\$ 25,495,036 \ldots \ldots \ldots \ldots \ldots \ldots \%$

There may be a legal question as to the power of the city to reduce this payment direetly, but that these considerations should have some bearing on the fixing of rates, which in the end inure to the benefit of the A. T. \& T. now owner of over $95 \%$ of the stock, is clear.

\section{MAINTENANCE AND DEPRECIATION RESERVE}

The final element in operating expenses centers around the effort to keep the original value of the property intact. 
Before we can consider a fair return on the cash put into a property by the stockholders and bondholders, we must assume that the principal of the investment has not depreciated in value. Otherwise the investor will have the right to demand in his turn not only a fair profit, but insurance against loss of the original investment.

Now a telephone company, like other municipal utilities, has to face a tendency to the decline in value of its property from four causes, viz., physical decay, inadequacy, obsolescence, and municipal requirements. A word may be said with regard to each.

1. Physical decay or wear and tear: All material things wear out in time, or are liable to destruction by accident. Repairs must be constantly made, and in time the plant must be renewed or replaced.

2. Inadequacy: The development of the business of a telephone plant often requires the substitution of larger switchboards, underground cables with more wires, etc.

3. Obsolescence: Invention frequently leads to the substitution of new plant for old. For example, we no longer are content with the ringing of a bell in order to secure the attention of "C'entral," but seek immediate attention by the mere removal of the receiver from the hook. New types of cable and duct are introduced from time to time.

4. Municipal requirements: Cities more and more require the burial of wires in expensive conduits, and sometimes require the relocation of the conduits themselves to make room for subways, etc.

All four forms of decline in value have been encountered here. Three lines of expense have been incurred to meet them,-repairs, reconstruction and depreciation reserves. The first two, repairs and reconstruction, or renewals, are often classed together under the name of maintenance. They alone represent actual expenditures, directly designed to keep the plant intact. The Chicago Telephone Company, however, has accumulated a reserve to meet extraordinary requirements and such depreciation from inadequacy and obsolescence as in a rapidly growing plant might not be fully met from the maintenance account.

Postponing for the moment any other method of meeting depreciation, attention should be called first to the amount the company has actually expended for repairs and reconstruction, during the last 20 years.

Until 1904 the company carried all its expenditures to meet these various forms of depreciation in one account, known as the maintenance account. In 1904 two divisions were made,-that of "repairs," and that of "rconstruction and renewal." In January, 1910, a third division was created, known as "station removals and changes." This account had previously been carried in the maintenance account. The 
present system of accounts is much better. A large part of the expense of change and removal of the telephone transmitter, receiver and house wiring is not an expense of repair or renewal, but a mere removal, or change of location. The estimate of the accountants (Hall's Report, pages 23-24) relative to the amount of repairs and reconstruction follows in the table below:

It gives the average investment, except land, working capital, furniture, fixtures, tools, vehicles and construction in process, as found by Hall, and the actual expenditures for repairs and renewals since 1890. The average investment is found by adding to the investment of January 1st of each year, half of the additions of the year.

\section{TABLE 4}

AVERAGE INVESTMENT IN DEPRECIABLE PROPERTY AND ACTUAI. EXPENDITURES FOR THE MAINTENANCE AND RENEIVAL OF THE SAME, 1891-1911

\begin{tabular}{|c|c|c|c|}
\hline Year & $\begin{array}{c}\text { Average } \\
\text { Depreciable } \\
\text { Investment. }\end{array}$ & $\begin{array}{l}\text { Maintenance and } \\
\text { Reconstruction. }\end{array}$ & $\begin{array}{c}\text { Percentage of } \\
\text { Maintenance and } \\
\text { Reconstruction to } \\
\text { average investment. }\end{array}$ \\
\hline 1891 & $\ldots \ldots \ldots \ldots \ldots \ldots \$ 1,901,859.40$ & $\$ 200,304.50$ & $10.53 \%$ \\
\hline 1892 & $\ldots \ldots \ldots \ldots \ldots \quad 2,580,278.78$ & $255,014.45$ & 9.88 \\
\hline 1893 & $\ldots \ldots \ldots \ldots$ & $276,627.40$ & 8.33 \\
\hline 1894 & $\ldots \ldots \ldots \ldots$ & $352,082.68$ & 9.44 \\
\hline 1895 . & $\ldots \ldots \ldots \ldots$ & $435,669.12$ & 10.86 \\
\hline 1896 & $\ldots \ldots \ldots \ldots$ & $413,886.99$ & 9.49 \\
\hline 1897 & $\ldots \ldots \ldots \ldots$ & $355,453.96$ & 7.55 \\
\hline 1898 & $\ldots \ldots \ldots \ldots$ & $452,645.93$ & 8.74 \\
\hline 1899 & ........... & $515,218.40$ & 8.35 \\
\hline 1000 . & $\ldots \ldots \ldots \ldots$ & $883,761.27$ & 11.55 \\
\hline 1901 & $\ldots \ldots \ldots \ldots \ldots \quad 0,560,846.96$ & $816,851.97$ & 8.54 \\
\hline 1902. & $\ldots \ldots \ldots \ldots \ldots 11,981,429.11$ & $1,025,846.49$ & 8.56 \\
\hline 1903 . & $\ldots \ldots \ldots \ldots \ldots 14,312,487.60$ & $1,272,578.20$ & 8.89 \\
\hline 1904 & $\ldots \ldots \ldots \ldots \ldots 15,909,051.27$ & $1,102,970.74$ & 6.93 \\
\hline 1905 & $\ldots \ldots \ldots \ldots \ldots 17,304,637.09$ & $1,560,822.09$ & 9.01 \\
\hline 1906 & $\ldots \ldots \ldots \ldots \ldots 19,785,525.00$ & $1,435,440.69$ & 7.26 \\
\hline 1907 . & $\ldots \ldots \ldots \ldots \ldots 23,549,541.08$ & $2,311,304.05$ & 0.81 \\
\hline 1908 & $\ldots \ldots \ldots \ldots \ldots 26,293,430.46$ & $2,271,707.11$ & 8.64 \\
\hline 1909 & $\ldots \ldots \ldots \ldots \ldots 27,754,261.76$ & $2,336,507.47$ & 8.42 \\
\hline 1910 & $\ldots \ldots \ldots \ldots \ldots 29,854,483.44$ & $2,323,353.78$ & 7.78 \\
\hline 1911 & $\ldots \ldots \ldots \ldots \ldots 33,277,902.01$ & $2,313,597.12$ & 6.95 \\
\hline 1912* & $\ldots \ldots \ldots \ldots 37,350,508.47$ & $2,759,830.68$ & 7.39 \\
\hline
\end{tabular}

- Based on the first six months-January 1-June 30, which showed a net increase of construction of $\$ 1,952,052.31$, which should be added to the depreciable property December 3,1911 , of $\$ 35,425,456.16$. The current repairs of $\$ 1,401,933.94$ less $\$ 365,053.60$ station removals, leaves $\$ 1,030,880.34$. To this should be added replacements of $\$ 343,035$, or a total for the half year of $\$ 1,379,915$. This is at the rate of $\$ 2,759,830.68$ for the year. 


\section{DECLINE IN MAINTENANCE}

While there have been frequent fluctuations from year to year in the percentage of actual expenditures for repairs and renewals to the investment for the year, there has been, on the whole, a steady decline in this percentage. It is best shown in the following way:

During the first three years of 1891-1893, inclusive, the total expenditures for maintenance and reconstruction were $\$ 731,949.35$, and the sum of the average investments of the three years was $\$ 7,804$,971.31. The percentage was 9.38. Then in the same way the percentage can be found for 1892-1894, inclusive, 1893-1895, inclusive, etc., down to and including 1910-1912, inclusive. In the same way a five year period may be taken, beginning with 1891-1895, inclusive, following with 1892-1896, inclusive, etc. Finally, a seven year period may be taken, beginning with $1891-189 \%$, inclusive, etc. The results are here tabulated:

TABLE 5.

DECLINING RATIO OF MAINTENANCE AND RENEWALS TO AVER. AGE INVESTMENT BY GROUPS OF YEARS.

\begin{tabular}{|c|c|c|c|c|}
\hline $\begin{array}{l}\text { Last Year } \\
\text { of Period. }\end{array}$ & $\begin{array}{c}\text { One-Year } \\
\text { Period. }\end{array}$ & $\begin{array}{c}\text { Three-Year } \\
\text { Period. }\end{array}$ & $\begin{array}{l}\text { Five-Year } \\
\text { Period. }\end{array}$ & $\begin{array}{l}\text { Seven-Year } \\
\text { Period. }\end{array}$ \\
\hline 1891 & $\ldots \ldots \ldots \ldots \ldots \ldots 10.53$ & & & \\
\hline 1892 & $\ldots \ldots \ldots \ldots \ldots \ldots 989$ & & & \\
\hline 1893 & $\ldots \ldots \ldots \ldots \ldots \ldots$ & $9.38 \%$ & & \\
\hline 1894 & $\ldots \ldots \ldots \ldots \ldots \ldots \quad 9.44$ & 9.17 & & \\
\hline 1895 & $\ldots \ldots \ldots \ldots \ldots \ldots 10.86$ & 9.62 & 9.78 & \\
\hline 1896 & $\ldots \ldots \ldots \ldots \ldots \ldots \quad 9.49$ & 9.93 & 9.63 & \\
\hline 1897 & $\ldots \ldots \ldots \ldots \ldots$ & 9.21 & 9.11 & 9.30 \\
\hline 1898 & $\ldots \ldots \ldots \ldots \ldots$ & 8.58 & 9.14 & 9.11 \\
\hline 1899 & $\ldots \ldots \ldots \ldots \ldots \ldots \quad 3.35$ & 8.24 & 8.90 & 9.00 \\
\hline 1900 & $\ldots \ldots \ldots \ldots \ldots \ldots 11.55$ & 9.74 & 9.34 & 9.52 \\
\hline 1901 & $\ldots \ldots \ldots \ldots \ldots \ldots 8.54$ & 9.48 & 9.09 & 9.30 \\
\hline 1902 & $\ldots \ldots \ldots \ldots \ldots$ & 9.34 & 9.11 & 9.00 \\
\hline 1903 & $\ldots \ldots \ldots \ldots \ldots \ldots$ & 8.69 & 9.09 & 8.94 \\
\hline 1904 & $\ldots \ldots \ldots \ldots \ldots$ & 8.06 & 8.59 & 8.58 \\
\hline 1905 & $\ldots \ldots \ldots \ldots \ldots$ & 8.28 & 8.37 & 8.66 \\
\hline 1906 & $\ldots \ldots \ldots \ldots \ldots \ldots$ & 7.73 & 8.07 & 8.39 \\
\hline 1907 & $\ldots \ldots \ldots \ldots \ldots \ldots$ & 8.75 & 8.46 & 8.47 \\
\hline 1908 & $\ldots \ldots \ldots \ldots \ldots \ldots$ & 8.64 & 8.44 & 8.50 \\
\hline 1909 & $\ldots \ldots \ldots \ldots \ldots \ldots$ & 8.92 & 8.65 & 8.48 \\
\hline 1910 & $\ldots \ldots \ldots \ldots \ldots \ldots$ & 8.26 & 8.39 & 8.32 \\
\hline 1911 & $\ldots \ldots \ldots \ldots \ldots$ & 7.67 & 8.21 & 8.18 \\
\hline 1912 & $\ldots \ldots \ldots \ldots \ldots$ & 7.39 & 7.77 & 7.96 \\
\hline
\end{tabular}

The large jump upward in 1900 was due to the almost revolutionary changes incident to the rapid introduction of ten-party lines and many changes in switchboards. 
A smaller impulse appeared in 1907-8, with the discontinuance of ten-party lines and with the many other changes that attended the passage of the present ordinance in $190 \%$.

A trend line has been drawn, showing the general tendency. Its prolongation to 1917 reveals $7.5 \%$ in 1912 and $7.2 \%$ in $191 \%$, or an arerage of $7.35 \%$ as the probable expenditure, yearly during the coming fire years, - that is, the average percentage of expenditures for maintenance to the average depreciable investment. This closely approaches the average of $7.39 \%$ for 1912 and for the three years 1910-12, inclusive, and $7.59 \%$ for the four years $1909-12$, inclusive. ${ }^{1}$ It therefore seems fair to assume $7.5 \%$ as a conservative percentage for maintenance for the next five years, unless the causes of the present conditions cease to operate, or are counter-balanced by other influences.

In his annual report, January 18, 1899, Mr. John M. Clark, the then president of the telephone company, anticipated the decline in maintenance, when he wrote: "The business is still to some extent in the experimental stage, but it is confidently believed that that stage will soon be passed, and that when the various kinds of apparatus which are required shall become standard, when new and expensive switchboards will not become obsolete within two or three years from the date of their completion, that a better service will become possible, and that lower rates may prevail in the interest of the subscribers and in fairness to the company."

The following table gives the separation that has been made on the books of the company between repairs and reconstruction since the attempt was made to keep them separately in 1904.

TABLE 6

REPAIRS AND RECONSTRUCTION SINCE 1903

\begin{tabular}{rrcrc}
\hline Years & Repairs & $\begin{array}{c}\text { Percentagc of } \\
\text { Repairs to } \\
\text { Averagc } \\
\text { Investment }\end{array}$ & $\begin{array}{c}\text { Reconstruc- } \\
\text { tion }\end{array}$ & $\begin{array}{c}\text { Percentage of } \\
\text { Reconstruc- } \\
\text { tion to Aver. } \\
\text { Investment }\end{array}$ \\
\hline 1904 & $\$ 1,008,730.56$ & 6.34 & $\$ 94,240.18$ & 0.59 \\
1905 & $1,144,847.97$ & 6.61 & $415,947.12$ & 2.40 \\
1906 & $1,274,071.10$ & 6.44 & $161,369.59$ & .82 \\
1907 & $6,796,855.29$ & 7.63 & $514,448.76$ & 2.18 \\
1908 & $1,306,415.07$ & 4.97 & $965,292.04$ & 3.67 \\
1909 & $1,421,313.66$ & 5.12 & $915,193.81$ & 3.30 \\
1910 & $1,769,706.64$ & 5.93 & $553,647.14$ & 1.85 \\
1911 & $1,815,292.40$ & 5.45 & $498,304.72$ & 1.50 \\
$1912 *$ & $\$ 11,537,259.69$ & $\overline{5.96}$ & $\$ 4,118,443.36$ & 2.12 \\
\hline
\end{tabular}

*Based on the first six months.

1 Detailed computations for four-year period are omitted. 
This matter of increase of life and reduction of repair and renewal charges is so important that further discussion of the subject is desirable.

This is especially true in consequence of the elaborate studies that have been recently made by the company to show the probable upward trend of maintenance in case of a great reduction in the rate of growth and no increase in the length of life of the telephone plant.

It should be noted, however, that a reduction in the rate of growth will check that large source of present maintenance charges, viz., the necessity of tearing out good cables and switchboards to make room for larger ones.

Inadequacy in the telephone business is an important cause of expenditure for maintenance. The slower the growth, the fewer would be the 100-pair and 300-pair cables pulled out to make room for 600-pair cables, and the less would central stations have to be enlarged and built to make room for more switchboards.

\section{SIMILAR TENDENCIES IN ST. LOOIS}

The Bell Telephone Co. of Missouri has a property whose present physical value in St. Louis and other parts of Missouri, has recently been reported by the well known engineering firm of Westinghouse, Church, Kerr \& Co., as about $\$ 7,000,000$. An appraisal by these engineers and a report by the accountants, Haskins \& Sells, was made in March, 1911, to a committee of the Board of Directors of the Missouri company. It is shown that the total expenditures for maintenance and renewals, 1901-10, inclusive, fell from an average of $7.71 \%$ of the value of the depreciable property, during the first six years, to $5.65 \%$ during the last four years of the ten year period. Haskins \& Sells thus discussed the matter.

"Throughout the ten-year period the annual average has amounted to 6.46 per cent. of the value of the depreciable property and 24.61 per cent. of the gross earnings. The decrease during recent years in the relative amount of these expenditures is the natural consequence of the improvement in the character of construction which has taken place within the last ten years, such as the use of conduits, installation of cables-underground and aerial-and the increased stability of the art of telephony."

\section{CHANGES IN THE ART}

A review of the development of the company indicates that far greater and more revolutionary changes have taken place in the past than are likely to occur in the future. Switchboards and subscribers' stations may change, but conduits and cables have come to stay. The repair of all classes of telephone property is admittedly less expensive than formerly. Some illustrations will make this clear: 


\section{Aerial Construction:}

All telephone transmission prior to 1884 , was upon poles, in the outlying districts of the city, and on the housetops in the business districts. Later all the wiring was placed underground.

These changes were brought about not only by the requirements of the city ordinances, but also by the discovery by the company that with improved methods of burying the wires, and the ability to place several hundred pairs of wires in a single duct and with the avoidance of injury from sleet storms, mischief-makers and other troubles, conduits were cheaper in the city than pole lines. Even the wires that do remain upon poles within the city, are mostly not part of the original pole lines, but are short stretches in alleys.

The change has been less rapid in the suburbs, yet in the territory as a whole the percentage of open wire on poles declined from $84 \%$ of the total wire in use in 1885 to $8 \%$ in 1911 . Within the city less than one per cent. of the milage is open wire.

\section{Conduits:}

The original conduit installation, of any magnitude, was in 1884 . The history since then may be divided into seven chapters:

1. The original installation of the so-called Dorsett conduit, a 6" compound duct. It was in 3-foot lengths, and made of a composition of tar, sand and cement. It was divided into two halves by a horizontal shelf partition or covering. Manholes, consisting of a cylinder four feet in diameter, with a bell-shaped top, were built of the same material, and located along the line of the conduit, 300 or 400 feet apart.

2. The Brooks conduit, in 1886 , of steel pipe from $2^{\prime \prime}$ to $4^{\prime \prime}$ in diameter, with splicing boxes at various intervals, in the form of a ball.

3. A square trough, about one foot on each side and about half filled with sand and cement.

4. A vitrified tile duct, in 1889 and 1890,3 feet long and 10" square, with a horizontal dividing shelf, known ordinarily as $10^{\prime \prime} \times 10^{\prime \prime}$. This conduit was laid in a rough support at the joints upon bricks, the joints being covered by a cemented burlap bandage. Brick manholes, generally square, were constructed; some small concrete vaults were also built. These are the first conduits of which any sections remain. At the close of $1888,3,127$ miles of wire had been laid underground.

5. Cement lined iron pipes, consisting of a $3^{\prime \prime}$ tube of stovepipe sheet iron, lined with cement, was the next improvement after 1892. At the same time creosoted wooden pump log, resembling but in- 
ferior in various points to a somewhat similar construction to-day, was also introduced at this time.

6. In 1896 the $10 \times 10$ single duct vitrified tile, known as camp tile, came into use. The duct was surrounded by a concrete envelope.

7 . In 1900, the McRoy or Multiple duct, likewise a vitrified clay product, was introduced, and later it came into general use. For several years it has been the standard duct, and little improvement is considered likely.

\section{Methods of Installation of Wires and Conduits:}

1. The Dorsett conduit above described contained one, two and sometimes three small cables. For an outside protection the whole was wound with hemp, which was impregnated with an asphaltum mixture.

After the cables were pulled into both the Dorsett and the Brooks conduits, from 1884 to 1888 , the entire conduit was filled with oil. The cable itself was boiled in kettles of hot oil. These kettles, with the necessary fuel for heating, were carried from place to place.

After the cable was installed, in this expensive and difficult manner, no access could be had without excavation. There was a great objection among the people and the city authorities to the smoke and stench coming from the oil. It was with great difficulty that the men were permitted to do the work except on Sundays or at night.

2. About 1888, a lead pipe armor, or protection of the hemp and tar compound, both for aerial and underground cables, was introduced. The cables, with their wires insulated with cotton were drawn by hand through 50 to 100 feet sections of these lead pipes. The sections were then soldered together by a plumber, and the entire cable subjected to heat, filled with hot paraffin, sealed, wound on a reel, and made ready for shipment.

\section{Cables:}

While revolutionary changes were taking place in the poles, conduits and wires, an equally important change was taking place in the grouping of wires into cables for installation upon pole lines, or to a vastly larger extent, for insertion in conduits.

1. Cables of twenty No. 18 gauge rubber-covered, untwisted wires, introduced in 1884, in the Dorsett circuit already described.

2. Cotton insulated, straight wires, pulled into the Brooks circuit of wire pipe, 1886, filled with hot oil, as already described.

3. The introduction of a lead pipe covering, in 1888, to protect the wires against moisture and other damage, in both aerial and underground cables. Untwisted cotton insulated wires were wound with string into a tight cable, and then pulled into the lead pipe, 
which was then filled with hot paraffin. The cable was exceedingly noisy, and not at all practicable. The pulling of these cotton insulated wires by hand, sometimes 90 pairs at a time, into 50 or 100 feet sections of lead pipe at the factory, before insertion of the hot paraffin, was a tedious job.

4. Twisted pair cables appeared in 1892 , and were the next improvement. But the cables were solid and inaccessible, the location and remoral of trouble was unsatisfactory and expensive.

5. The present day type of paper insulated, twisted pair cables was developed between 1892 and 1895 .

6. Increase in the number of pairs possible in a cable and therefore in the duct of a conduit. The increase was from 90 pairs in the 80 's to 120 pairs of No. 19 cable in 1892,400 pairs of No. 22 gauge cable in 1900 and 600 pairs of the same cable in 1904.

7. Loading coils, in 1906 and 190\%, and the installation of special toll cables of large gauge conductors, were some of the most recent steps in the evolution to the present type of cable, which, like the type of wire and of conduit, appears to have reached a point of slow advance instead of the progress by leaps and bounds that had been going on up to about five years ago.

Central Office Switchboards:

1. The telegraphic switchboard, adapted for telephone use. In this board, in 1880, the telephone operator at Central received the call for a subscriber on a tape register. He would then connect his telephone with the subscriber's line and ask what was wanted. The whole process was tedious.

2. The subscriber was given a means of signalling the operator direct on the same wires that he talked over.

3. The multiple switchboard was invented in the later 80 's, and one of the largest of its kind, at the time, was installed in Chicago.

4. The so-called "Express" board, invented about 1894, partly displaced the magneto board. Lamp signals took the place of drops, and the so-called Fuller battery, at the subscribers' instrument, was replaced by a storage battery. The subseriber could now signal the operator by merely removing the telephone transmitter from the hook, instead of turning the crank, as in the magneto system.

5. The present type of relay common battery switchboard was invented about 1898, but so many improvements were subsequently made, up to about five years ago, that it has been necessary to reconstruct most of the earlier switchboards of this type.

These various improvements reduced the average time necessary for making connection for calls, according to President Sunny, from 90 seconds in 1886 to 18 seconds in 1908 . 'This has, of course, been 
accompanied with a large reduction of expense of the operator's time in handling messages.

If the semi-mechanical system now in operation in the big laboratory building of the A. T. \& T. and of the Western Electric in New York shall prove the success it promises, it will be used for new central stations and will justify its introduction by the large decline it will effect in the number of operators and in other costs.

Wire:

1. Iron Wire. Prior to 1890 practically all the wire used in the outside plant was No. 12 iron.

2. Copper Wire. About 1890 , when 15,000 miles of wire were in use, copper wire began to supercede iron wire, although there was a short interval in which trial was made of some phosphor bronze wire.

3. About 1892, owing to the interference of the high voltage of electric railways and lighting plants, the telephone company began to change its single wire copper lines to 2-wire metallic circuits. Each of the above transformations, from iron to a single copper wire, and then to a 2-wire circuit involved a complete transformation of the wire system.

The telephone ordinance compels the Company to place and keep in underground conduits all its wires from the Chicago River on the North to Twelfth street on the South, and from Lake Michigan on the East to the South branch of the Chicago River on the West, while in nearly all the rest of the city it must place all its wires underground, with the exception of wires not to exceed two blocks in length from underground connections to subscribers stations. Even these wires cannot be placed on poles on streets if there are alleys.

In a general way it may be said that the Chicago Telephone Company can only use pole lines North of Howard avenue, West of Western avenue and Fortieth avenue, and South of Serenty-ninth street. The exact boundaries are to be found in paragraph 10 of the Ordinance of $190 \%$.

PROPORTION OF PROPERTY OF LONG LIVED CONSTRUCTION

At the close of 1895 only $50 \%$ of the wires in the Chicago telephone territory, city and suburban, were underground. At the close of $1905,64 \%$ were under ground, and at the close of $1911,81 \%$ were under ground.

So great, however, has been the reduction in the cost of construction per foot of conduits and cables that the proportion of the entire investment in land, buildings, right of way, and under ground construction, exclusive of toll properties whose data is not fully avail- 
able, has only increased throughout the Chicago telephone territory from $37.6 \%$ of the total, in 1891 , to $40.1 \%$ in 1911 , and in the city the increase has been from $39 \%$ to $43.9 \%$. These figures are readily computed from the data given in Mr. Hall's Exhibits B, C and D.

The life, however, of both conduits and cables has itself so much increased that the real average life has undoubtedly increased much more than is indicated by the above figures. The cost of repairs, as already remarked, has undoubtedly declined with the growth in the art. This view is confirmed by President Vail, of the A. T. \& T. in his report for 1910. (Page 7.) :

"The present policy of the Bell System is to provide against every probable contingency and to base the amount and extent of such provision on past experience-not on future expectations. It is conjectured that the future will show a decrease in the depreciation or reconstruction due to decay, wear and tear, and obsolescence. Changes-improvements-are going on as rapidly as in the past, but the general character of plant and methods is assuming more permanency. The improvements are being evolved from and are being grafted on to the old system and methods. The disturbing and sometimes seemingly destructive conditions following the rapid development of high pressure power and transmission have been to a great measure overcome.

"All this has been made possible through the unremitting study and research of the staff of the Engineering and Experimental Departments of the Company, who, by close attention, observation and study, anticipate and provide for all such contingencies and conditions as can possibly be anticipated or provided for in advance.

"Under these conditions there is small probability that any such causes as those which forced the wholesale reconstruction or rearrangement of plant in the past will again oscur; it is, however, for the benefit of the public and of the corporation to have an ample rescrve for any contingency which may happen."

\section{THE COMPANY'S DEPRECIATION RESERVE}

The Chicago Telephone Company has collected from the subscriber and set aside as a depreciation reserve, a further sum of $\$ 5,091,823.19$ to meet depreciation that may be revealed at some time in the future. Of this fund about $\$ 2,241,141$ was set aside in 1910 and 1911 . This depreciation, assumed to exist after all current expenditures for repairs and renewals may be called residual depreciation. The property of the company on January 1, 1912, had been built up from the following sources:

First mortgage $5 \%$ bonds... . . . . . . . . . . \$5,000,000.00

Loans by banks. . . . . . . . . . . . . . . . . $1,000,000.00$

Capital Stock. . . . . . . . . . . . . . . . . . .

Depreciation reserve.................... \$5,091,823.19

$\$ 33,000,000.00$

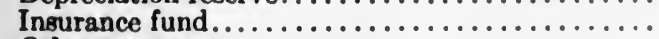

Other reserves.................................

$307,548.21$

244,735.49 
In addition to the above, current assets of cash, bills, accounts receivable and prepaid expenses amounted to $\$ 1,690,06 \% .42$, but these were balanced by current liabilities of accounts payable and accrued liabilities not due, amounting to $\$ 1,886,285.34$. Leaving out of account these latter items of current assets and current liabilities, which virtually offset each other, there remains as just stated two chief sources of the property of the Telephone Company, to wit: $\$ 33$,000,000 furnished by the stock and bond holders and banks, and about $\$ 5,650,000$ supplied by the telephone users, in order to keep the investment of the stock and bondholders intact.

The question will later arise whether the $\$ 2 \%, 000,000$ supplied by the stockholders came in part from earnings in addition to large dividends, but that problem does not arise at this point.

The depreciation reserve above referred to is not the only amount that the company set up in the past as representing depreciation. From 1894 until $190 \%$ the company, after distributing dividends of $10 \%$, had charged to operations $\$ 3,767,233.55$, which was written off the plant account. Early in 1908 the company appears to have concluded that the property had not depreciated to any. such extent. The whole of this $\$ 3, \% 67,233.55$ was transferred to surplus, leaving the plant account as it would have been without any such deduction. This credit to surplus formed the basis of the stock dividend of $\$ 4,500,000$ in that year. Not only was the above amount of $\$ 3,767$,233.55 charged to operations and maintenance, but it has been shown that an additional amount of $\$ 1,575,000$ was charged during the above period as maintenance, which likewise erentually found its way into the surplus. (Hall, page 20.) The total amount thus included in operations, purporting to represent a provision for depreciation, or for deferred maintenance, but which was diverted to the benefit of the stockholders, was therefore $\$ 5,342,233.55$. The dividends were indeed reduced in 1908 from $10 \%$ to $8 \%$, so that the total dividends were not materially changed. But in so far as an $8 \%$ dividend is less subject to public criticism and less liable to reduction in a change of rates than is a $10 \%$ dividend, the stockholders gained.

In another way, they also gained. By writing up the plant investment several million dollars, the justification for the increase of stock and for a profitable return thereon, was given to the public.

The important feature of the transaction was the revelation that the company considered that there had been less depreciation by $\$ 4,845,000$, than the books had hitherto shown. Consequently the telephone users, in paying such cliarges as to permit the accumulation of that fund, in reality had not been accumulating a fund with which to meet depreciation, but had been increasing the profits of the com- 
pany, which the latter had invested as surplus in extension and then capitalized.

Naturally, such a transaction makes one a little critical with regard to the new accumulation of $\$ 1,971,823.19$ in one depreciation account and of $\$ 120,000$ in another.

\section{THE APPRAISAL}

At this point the appraisal made for the Company by Byllesby \& Arnold becomes of vital importance. Does this appraisal, made with great care and regardless of expense, show that enough has been collected from the subscriber to keep intact the investment by the stock and bondholders, of approximately $\$ 33,000,000$ ? If not, then the investor is justified in calling on the telephone user for a larger yearly addition to the depreciation reserve. On the other hand, if the payments by the subseriber to this fund have more than kept the property intact, a smaller contribution may henceforth be reasonably made by the public.

In approaching this appraisal, however, hasty conclusions must not be drawn. An attempt must be made to correct the appraisal where it is found to be in error, even if in so doing, the value of the property may be reduced and the need for a depreciation reserve be thereby increased. In the long run the public will gain by a complete knowledge of the situation, and will not desire to take any unfair advantage of the appraisal.

On its face the appraisal would indicate that not only had the actual expenditures for maintenance kept the value of the property up to the above $\$ 33,000,000$, but the appraisal would also indicate that in the opinion of Byllesby \& Arnold, the property was worth much more to-day than even the sum of this $\$ 33,000,000$ of investment and of the depreciation reserve. The following table will make this clear. 
TABLE 7

APPRAISED VALUE NEW AUGUST 1, 1911 PHYSICAL PROPERTY

\begin{tabular}{|c|c|c|c|}
\hline Subject & $\begin{array}{l}\text { Chicago } \\
\text { Reproduction } \\
\text { Value }\end{array}$ & $\begin{array}{c}\text { Suburban } \\
\text { Reproduction } \\
\text { Value }\end{array}$ & $\begin{array}{c}\text { Total } \\
\text { Reproduction } \\
\text { Value }\end{array}$ \\
\hline 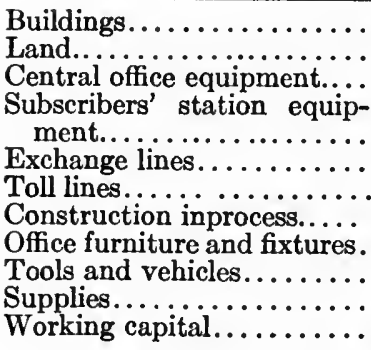 & $\begin{array}{r}6,409,151.00 \\
14,746,383.00 \\
934,369.00 \\
1,392,861.00 \\
245,151.00 \\
275,426.00 \\
660,288.00 \\
887,250.00\end{array}$ & $\begin{array}{r}1,281,074.00 \\
5,388,296.00 \\
1,936,761.00 \\
196,340.00 \\
20,957.00 \\
99,222.00 \\
261,308.00 \\
162,750.00\end{array}$ & $\begin{array}{r}7,690,225.00 \\
20,134,679.00 \\
2,871,130.00 \\
1,589,201.00 \\
266,108.00 \\
372,648.00 \\
921,596.00 \\
1,050,000.00\end{array}$ \\
\hline Total.... & $\$ 34,325,894.00$ & $\$ 10,572,210.00$ & $\$ 44,898,104.00$ \\
\hline $\begin{array}{l}\text { Plant development expense. } \\
\text { Total physical property ..... } \\
\text { Cost of deveolping the busi- } \\
\text { ness .................. }\end{array}$ & $\begin{array}{r}\$ 564,636.00 \\
34,890,530.00 \\
4,753,993.00\end{array}$ & $\begin{array}{r}\$ 183,352.00 \\
10,755,562.00 \\
2,340,253.00\end{array}$ & $\begin{array}{r}\$ 747,988.00 \\
45,646,092.00 \\
7,094,246.00\end{array}$ \\
\hline Total property and business. & $39,644,523.00$ & $\$ 13,095,815.00$ & $\$ 52,740,338.00$ \\
\hline
\end{tabular}

Referring to the totals in the last line, before deducting the depreciation, Byllesby and Arnold write (Appraisal Vol. 1, Page 24-25):

"These totals represent the investment of the Chicago Telephone Company in its property and its attached business on the basis outlined, and include in addition to the appraised value of the physical property and the development cost of such property, no element of what is commonly designated as "going concern" value other than that represented by the cost of establishing the business, which cost has been worked out on the definite, conservative premises hereinabove described."

It would be fortunate indeed for the city, if the Chicago Telephone Company were really entitled, in this rate investigation, to this value new of $\$ 52,740,338$ or even to the present value of $\$ 42,-$ 915,926 based on the largest amount of observed and estimated depreciation which the appraisers were able to compute. The less the depreciation the lower need be the rate of return to secure a fair profit on the investment. If there were no net depreciation whatever, not only would depreciation charges be eliminated, but the property would appear so much safer to the average investor that he would furnish money for needed extensions, at a lower rate of return, than if the physical property every year bore a lower and lower proportion to the outstanding securities. The larger the physical value back of stocks and bonds, the lower the rate of return, other things being equal, that will be demanded by the in- 
vestor. A continual rise, for example, in the price of labor and material, would increase the cost of construction and the appraised value of the property, but would lessen the percentage of the present investment that would be borne by the old investment that is scrapped from time to time.

It seems necessary, however, to dissent from some of the positions taken by Byllesby and Arnold, and consequently to differ from some of the conclusions reached by them. In this no reflection is intended upon their well known ability and integrity of purpose.

\section{COPPER}

Among the doubtful points in the appraisal may be mentioned the price of copper and the assumed life and net salvage employed by the appraisers. Copper was taken at 16 cents a pound, as of August 1, 1911. The following table gives the average yearly price for each of the 19 years, 1893-1911, inclusive, as taken from the Iron Age by the Chicago Telephone Company. These prices are a little lower than those given in the Telephony Directory of the telephone industry, 1912 edition (page 333):

\section{Table 8}

AVERAGE PRICE OF COPPER

\begin{tabular}{|c|c|c|}
\hline \multicolumn{2}{|c|}{ 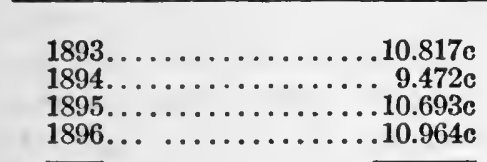 } & 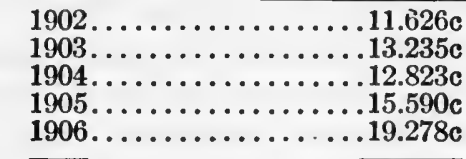 \\
\hline \multicolumn{2}{|c|}{$1893-6 \ldots \ldots \ldots \ldots \ldots .10 .487 c$} & $1902-6 \ldots \ldots \ldots$ \\
\hline \multicolumn{2}{|c|}{ 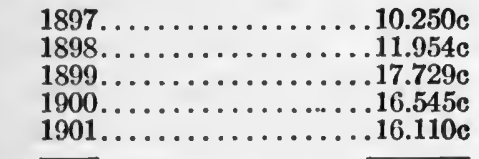 } & 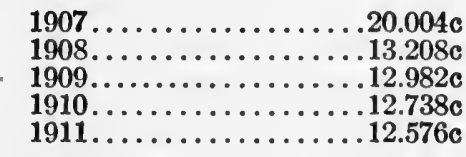 \\
\hline \multicolumn{2}{|c|}{$1897-1901 \ldots \ldots \ldots \ldots \ldots . .518 c$} & $1907-11 \ldots \ldots \ldots \ldots \ldots . \ldots \ldots .302 c$ \\
\hline \multicolumn{3}{|c|}{$\begin{array}{l}\text { Average for } 1893-1901 \ldots \ldots \ldots \ldots \ldots \ldots \ldots \ldots \ldots \ldots \ldots \ldots \ldots \ldots \ldots \ldots \ldots \ldots \ldots \ldots \ldots \ldots \\
\text { Average for } 1902-1911 \ldots \ldots \ldots \ldots \ldots \\
\end{array}$} \\
\hline \multicolumn{3}{|c|}{ Average for $1891-1911 \ldots \ldots \ldots \ldots \ldots \ldots \ldots \ldots \ldots \ldots \ldots \ldots . \ldots \ldots$} \\
\hline \multicolumn{3}{|c|}{ 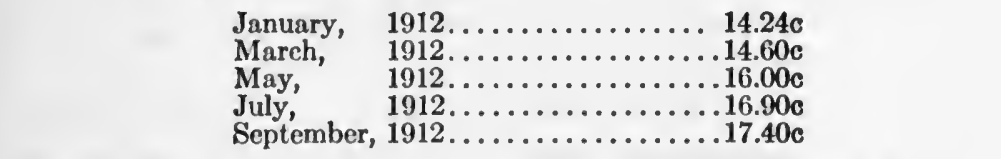 } \\
\hline \multicolumn{3}{|c|}{ Average, January to September..............15.82c } \\
\hline
\end{tabular}

The above table would indicate that 16 cents was high. The company, however, has established an elaborate trend curve of prices of 
copper to show that 16 cents a pound is in line with the trend or tendency of prices, at the time of the appraisal. Since the earliest quotations at hand beginning in 1883 , copper has averaged less than 16 cents every year save in 1888, 1899-1901, inclusive, and 1905-190\%, inclusive. During those years only 309,433 miles of wire out of 807,571 in use at the close of 1911 , or $38 \%$ were laid. It wculd be easy to show that copper had not from the beginning averaged over 15 cents and had not even averaged that during any period of five or more years preceding the appraisal. At the same time if the test of value is not to be the actual cost or recent costs, but probable costs of material and labor during the next five years, then 16 cents may be accepted as a probable price.

\section{OVERHEAD}

We will first take up the appraisal of the property new and later consider the depreciation.

The appraisers, Byllesby \& Arnold, have assumed that the Telephone Company's property and business are not in existence, but are to be constructed new. After an exhaustive inventory of the principal items of the property, they have estimated the cost of materials, tools and labor required to reproduce new each item in place as of date of August 1, 1911. In this base figure were included all contractors' charges, which would embrace his costs, his profits and his allowance for contingencies. No general contractor was assumed, but a contractor was allowed only for such portions of the work, as have usually been put in by contract, such as buildings and central office switchboards. To the base cost obtained as above, a percentage, varying with the different classes of work, was added for reorganization, engineering and incidentals. In these items were included general office expenses in securing bids, awarding contracts. making out bills of material, purchasing materials, legal expenses and salaries of the officials, whose work is chargeable to construction. Engineering includes preparation of plans, drawings and specifications, and the expense of general supervision and inspection in the carrying out of the plans and specifications. Incidentals include insurance against fire and accident, and all general expenses lying outside of the estimated contract cost; such as small changes in design. They might be included as extras on the contract price.

These expenses vary from 5 to $15 \%$ in the various schedules, aggregating $12.19 \%$. In case of land only $5 \%$ was added, which was intended to cover selection of site, search of title, purchase fees and such of the reorganization and incidental expenses mentioned above as were applicable. 
After adding to the base figures the above allowance of 11 to $12 \%$ for reorganization, engineering, etc., a further percentage of about $7 \%$ was added to cover interest and taxes during construction, and other so-called carrying charges and cost of obtaining money. They have all been termed brokerage. This was small in the case of substation equipment, tools, rehicles and supplies, which, it is assumed, are put in service immediately upon purchase. The following table summarizes the matter of overhead.

TABLE 9

SUMMARY OF OVERHEAD

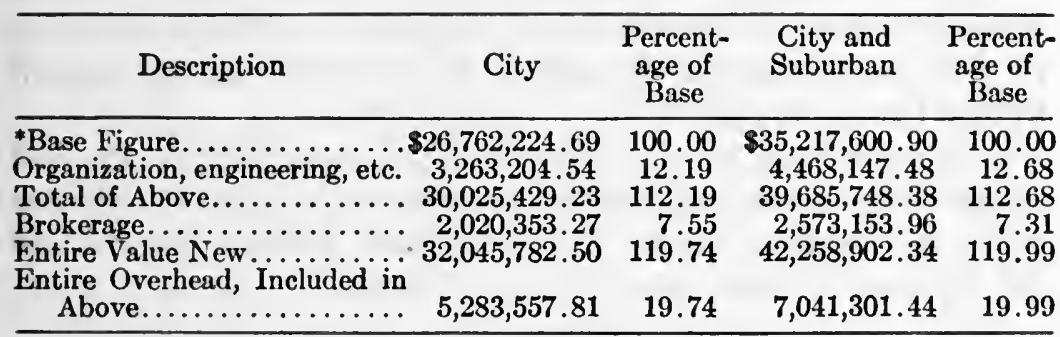

* Aside from construction in process and working capital.

If the value of this plant is to be determined by what it would cost to duplicate it,-if all knowledge of the present location of the conduits and central stations, etc., were suddenly obliterated from the mind of man,-then this allowance of $19.99 \%$ for overhead on top of contractors' profits on each portion of the work is no higher than engineers often claim in such appraisals.

The writer, however, has always contended that one could not assume such a fanciful theory as the above, but must assume that the knowledge now possessed, and indeed, in large part reduced to writing in the inventory, cannot be blotted out of men's minds even for the purpose of an appraisal.

The Wisconsin Railroad Commission only allows $12 \%$ above base figures and in its base does not include so much contract work. The Massachusetts Gas and Electric Light Commission will have nothing of this theory of reproduction, but sticks to the historical costs.

All of the installation of cables and much of the subscribers' substation and some of the central office equipment were done direct by the Chicago Telephone Company, without any contractor and probably with less than $15 \%$ for overhead instead of $19.99 \%$.

As for brokerage, of which the chief item is interest during construction, this Chicago company has always earned enough to pay all such charges and large dividends besides. If brokerage had been 
charged to construction in the past, operating expenses would have appeared less and profits greater. A greater reduction of the rates in 1907 might then have been secured. The company having secured the benefits of charging brokerage to operating expenses can hardly put the charge now into construction.

If the overhead allowed by the appraisers had been only $15 \%$, instead of $19.74 \%$ in the city, and $19.99 \%$ in the entire territory, the appraisal new would have been reduced $\$ 1,268,696$ in the city, and $\$ 1,757,684$ in the entire territory.

LAND

The land owned by the company in the city and suburbs, cost the company, according to their books, $\$ 601,801.14$. Its present value is given by Byllesby \& Arnold at $\$ 1,331,642.60$, an increase of $\$ 729,841.46$ or $121 \%$.

In the following table is given the book value; that is, the cost as appearing on the books, and the appraised value, after the addition of all the overhead charges and the relation between the cost and the appraisal for each piece of land in the city.

TABLE 10

LAND APPRAISAL AND COST

\begin{tabular}{|c|c|c|c|c|}
\hline & Appraisal & Book Value & $\begin{array}{c}\text { Increase } \\
\text { over } \\
\text { Book Value }\end{array}$ & $\begin{array}{c}\text { Per } \\
\text { cent. } \\
\text { Increase }\end{array}$ \\
\hline Austin Office.. & $\$ 16,124.06$ & $\$ 9,200.00^{*}$ & $\$ 6,924.06$ & 75.3 \\
\hline Calumet Office & $61,425.00$ & $33,513.08$ & $27,911.92$ & 83.3 \\
\hline Canal Office..... & $7,371.00$ & $6,000.00$ & $1,371.00$ & 22.8 \\
\hline Central Division Headquarters & $21,498.75$ & $17,539.75$ & $3,959.00$ & 22.6 \\
\hline Cortland Street Lots......... & $2,457.00$ & $1,652.49$ & 804.51 & 48.7 \\
\hline Douglas Office............. & $19,751.99$ & $18,084.00$ & $1,667.99$ & 9.2 \\
\hline Edgewater..... & $3,071.25$ & $2,000.00$ & $1,071.25$ & 53.6 \\
\hline rison Street Lot... & $257,985.00$ & $176,972.77$ & $81,012.23$ & 45.8 \\
\hline Humboldt Office............ & $5,769.34$ & $4,200.00$ & $1,569.34$ & 37.4 \\
\hline Hyde Park Office.. & $6,142.50$ & $5,687.50$ & 455.00 & 8.0 \\
\hline g Park Office.. & $6,081.08$ & $3,530.00$ & $2,551.08$ & 72.3 \\
\hline $\mathrm{Ke}$ & $4,422.60$ & $3,120.00$ & $1,302.60$ & 41.8 \\
\hline W Office & $4,422.60$ & $3,360.00$ & $1,062.60$ & 31.6 \\
\hline dale Office. . & $7,033.16$ & $4,000.00$ & $3,033.16$ & 75.8 \\
\hline ln Office. & $5,307.12$ & $5,500.00$ & $192.88 \dagger$ & 3.5 \\
\hline Main Office...... & $462,723.58$ & $40,420.00$ & $422,303.58$ & $1,044.8$ \\
\hline Office.... & $24,692.85$ & $14,362.50$ & $10,330.35$ & 71.9 \\
\hline No & $22,113.00$ & $21,525.00$ & 588.00 & 2.7 \\
\hline Div. Headquarters. . & $25,798.50$ & $14,488.35$ & $11,310.15$ & 78.1 \\
\hline Offi & $10,411.54$ & $10,500.00$ & $88.46 \dagger$ & \\
\hline o Headquarters. & $7,383.29$ & $7,175.00$ & 208.29 & 2.9 \\
\hline hern Div. Headquarters. . & $12,511.04$ & $7,000.00$ & $5,511.04$ & 78.8 \\
\hline ash Office............ & $144,840.15$ & $96,026.17$ & $48,813.98$ & 50.8 \\
\hline Wentworth Office........... & $7,371.00$ & $5,610.00$ & $1,761.00$ & 31.4 \\
\hline & $2,616.71$ & $4,090.00$ & $1,473.29 \dagger$ & 36.0 \\
\hline & $1,228.50$ & $1,000.00$ & 228.50 & 22.8 \\
\hline Western Div. Headquarters... & $17,291.01$ & $10,550.00$ & $6,741.01$ & 63.9 \\
\hline Yard Office............ & $6,093.36$ & $4,550.00$ & $1,543.36$ & 33.9 \\
\hline Total.. & $73,936.98$ & $531,656.61^{*}$ & $642,280.37$ & $\overline{119.4}$ \\
\hline
\end{tabular}

* Given in the appraisal by mistake $\$ 4,700$ less.

$\dagger$ Decreases. 
TABLE 11

LAND BASE AND OVERHEAD

\begin{tabular}{|c|c|c|c|c|}
\hline Description & City & $\begin{array}{c}\text { Percentage } \\
\text { Overhead } \\
\text { to Base }\end{array}$ & $\begin{array}{l}\text { City and } \\
\text { Suburban }\end{array}$ & $\begin{array}{c}\text { Percentage } \\
\text { Overhead } \\
\text { to Base }\end{array}$ \\
\hline Base Figure .................. & $\$ 955,585.65$ & & $\$ 1,083,958.15$ & \\
\hline 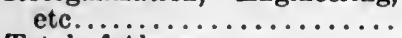 & $47,779.28$ & 5.00 & $54,197,091.00$ & 5.00 \\
\hline Total of Above... & $1,003,364.93$ & 105.00 & $1,138,156.06$ & 105.00 \\
\hline Brokerage . . . . . . . . . . . . & $170,572.05$ & 17.85 & $193,486.54$ & 17.85 \\
\hline Total Value $\ldots \ldots \ldots \ldots \ldots \ldots$ & $1,173,936.98$ & 122.85 & $1,331,642.60$ & 122.85 \\
\hline Overhead Included in Above.. & $218,351.33$ & 22.85 & $247,684.45$ & 22.85 \\
\hline
\end{tabular}

How to treat the increase in land values, in a rate case like this, has been and still is a much disputed and unsettled question. The tendency of the courts has been toward the recognition of this increased value. Such has also been the practice of the Wisconsin Railroad Commission. On the other hand, the Massachusetts Gas and Electric Light Commission, which has, by far, the greatest age and prestige of any of our commissions, has always refused to recognize increase in the regulation of rates. It is held that only on the sale of such land can the company divide as a surplus the unearned increment, and it is not certain that even then the Massachusetts Commission would not compel the use of the proceeds of the sale in mecting needed extensions. The only other commission of any age which has considered this question very fully is the Public Service Commission of the First District of New York, covering the City of New York.

In the cases of the Queens Borough Gas and Electric Company, decided June 23, 1911; the Brooklyn Borough Gas Company, decided August 18, 1911, and the Kings County Lighting Company, decided October 20 and November 17, 1911, this Commission held that if the company were entitled to capitalize the increased value of its land, then the annual increase of such value should form part of the reasonable rate of return to which it was entitled and the returns from the consumer in charges should be proportionately reduced.

Commissioner Lane of the Interstate Commerce Commission, in rendering the report of the Commission, relative to the proposed advances in the Western Trunk Line Trans-Missouri and Illinois Freight Committee territories, held (20 I. C. C. Rep. page 344):

"Whatever the true economic or legal view may be as to the right of a carrier to consider the inerease in value of its land as a part of the value upon which it is entitled to a reasonable return, such inerease in value does not of itself establish the right of a carrier to inerease rates upon a given serviee. Certainly if the Supreme Court may deeline to lay down the absolute rule that 'in every case failure to produce some profit to those who have invested their 
money in the building of a road conclusive that the tariff is unjust and unreasonable.' (Reagan v. Farmers' Loan \& Trust Co., 154 U. S. 412.)

"It is a conservative statement of the law to hold that a railroad may not increase the rates upon a number of commodities solely because its real estate has risen in value."

If the appraisal be correct, the value of the land has increased from $\$ 601,801.14$ to $\$ 1,331,642.60$. This is a yearly arithmetical increase of $10.5 \%$ on its original cost. The method by which this result is reached is as follows: The cost of the land on December 31, 1887 , was $\$ 40,420$. Now, $\$ 40,420$ used for 24 years to the close of 1911 is equivalent to $\$ 1,018,080$ used for one year. By December 31,1892 , an additional amount of land had been acquired costing $\$ 182,634$. This for 19 years is equivalent to $\$ 3,470,046$ for one year. Reckoned in this way the land is equivalent to $\$ 6,995,621$ for one year. The total increase of value of $\$ 729,841.46$ is $10.43 \%$ of this. An increase of $10.43 \%$ of the original cost $(\$ 601,801.14)$ owned on August 1, 1911, the date of the appraisal, is $\$ 62,768$ a year. This is the annual amount of increase of land values which on the basis of its past history the Company may reasonably expect to receive during the next few years. It represents an addition to its income of about one-quarter of $1 \%$ on its stock, and is taken into consideration by the New York Public Service Commission, First District, in fixing rates.

\section{PAVING}

The appraisal value of the paving over the conduits in the city is $\$ 2,198,916$. Of all the conduits, $84 \%$ are under the paving, but $2 / 7$ of this paving was put down after the laying of the conduits, and represents no investment by the Telephone Company. The appraisal of this portion of the paving, $\$ 628,262$, should be deducted. This is in accordance with the ruling of the Wisconsin Railroad Commission, the New, York Public Service Commission of the First District, the Massachusetts Gas and Electric Light Commission, the Iowa State Supreme Court, recently confirmed by the United States Court in the Cedar Rapids gas case, and by Judge McPherson of the United States District Court in the Des Moines gas case.

Commenting on the matter of paving, and on the general theory of considering only the cost of reproduction, which is the method used by Byllesby and Arnold, Judge McPherson in his opinion, August 21, 1912, says :

"But the question is as to its value to-day with reference to income. What it may have cost is pertinent. What it will sell for is to be considered. And if destroyed by any agency, such as rust, crystalization, or other forces, what must be paid to reproduce it is a subject of inquiry. All of these may be con- 
sidered. In my opinion those who maintain that what it will cost to reproduce the plant, less depreciation, is the true value, in many instances, confound the real question with one of many evidences of the real value. Reproducing cost is an evidence of what the real value is after substracting the depreciation. But what is to be done with the value of stocks and bonds on the reproductive theory? And what becomes of the original cost on the reproduction theory? And what becomes of the question of the increase or falling off in numbers of consumers? And the same as to increased or diminished expenses?

"The theory at first thought in all cases is plausible and attractive, but in the end is oftentimes utterly illogical and unreliable, originally adopted as a mere time-saver by mere theorists, and sought to be enforced as against substantial unbending facts. If the plant is to be reproduced, when is it to be done? If reproduced, will the streets then be paved, and, if paved, paved with what? Must it ull be reproduced at once, or the same covered by a number of years? If but gradually reproduced, why should not such cost go into either operating or maintenance accounts? No one can state when it must be reproduced, and a material question arises: What, then, as compared with the present, will be the price of labor, material and freight? But finally and to my mind the conclusive reason against the soundness of the reproduction under paved streets theory is, that to allow that theory to prevail, and to increase the capitalization now to the extent of $\$ 140,000$, is to allow such gas rates as will pay a dividend on such sum from and after this date. But the sum of $\$ 140,000$ is not put in the capital or value account until the plant is reproduced.

"As, of course, streets paved or unpaved make no difference in the earning power of the gas plant, and but little, if anything, goes more directly and accurately to the question of value of any structure or plant than its rental, earnings, or as a dividend producer.

"There are many instances in which the reproduction theory is the best of all methods for getting at the present value, and in other instances the most misleading. And it is deceptive, in my opinion, to now add the cost of taking up and replacing pipe under paved streets at an estimated cost of $\$ 140,000$ extra, and does not warrant an increased dividend of $\$ 8,400$ or some greater sum. Such a dividend is a mere paper dividend, and is arrived at, not because of increased earnings, not because of increased capital or investments, not because of increased operating or maintenance expenses, but solely by reason of a supposed necessity of at some time replacing the same, in some manner, under a then some kind of street, on a mere guess of what labor and material would then cost. Many of the principles with relation to railway rates are applicable to gas rates. And perhaps the latest analysis of the reproduction theory is found in the recent case of Louisville R. R. v. Railway Commission, 196 Fed. Rep. 800 , in an opinion of Judge Jones of the Alabama District. He shows the value of this theory, but likewise shows that it is not a hard and fast rule covering all phases. Finally, pipes under a paved street are of very long life; many times longer than if the street were not paved.

"The theory applied to paved streets is but a theory, is illogical and.against facts, and was properly denied by the Master."

An added reason of great importance in this case for excluding paving since the laying of the conduit is in the ordinance of November $6,190 \%$. This provided that if the city should purchase the 
property on January 1,1919 , or 1924 , or after the expiration of the franchise January 8, 1929, should transfer to any other company such right, the rules governing the valuation to appraisers should be as follows:

"The appraisers shall determine what tangible property, real and personal, owned by the said Company, and used for the purposes of this grant, is reasonably required for its continued operation, taking into consideration the then condition of the art, and in determining the fair cash value of said property they shall not take into consideration its earning power, or the value of the rights or privileges hereby granted, or the value of any license or franchise, but shall allow for the property the then cost of duplication, taking into consideration the then condition of the art, less depreciation. In considering the cost of duplication of underground conduits, wires, cables, electrical conductors and any other underground construction located in any street, alley or other public way which was or were placed therein at a time when such street, alley or other public way was unpaved, the said appraisers shall not take into consideration the cost and expense of removing or replacing any paving, or part thereof, in such street, alley or other public way. An award in writing, signed by a majority of the appraisers, shall be valid and binding upon the parties."

\section{WORKING CAPITAL}

The appraisers not only appraised working assets, such as supplies, at $\$ 921,596$, but they assume that the Company needs, in cash or its equivalent, $\$ 1,050,000$. This form of working capital they divided between the city, $\$ 887,250$, and the suburban division, $\$ 162,750$. The total when added to the supplies makes a total working capital of $\$ 1,971,596$. Even the estimate made by Mr. Hall, of $\$ 1,750,000$. seems large.

Expenses for one and one-half months would be one-eighth of the $\$ 8,836,827.49$ of total expenses in 1911. In other words, it would amount to $\$ 1,104,603.44$. In a company which collects its revenue monthly and receives some of it in advance, a working capital equal to the expenditures for one and one-half months. would appear to be ample, especially in view of the fact that it can obtain at least 30 days' credit on most of its purchase of supplies. Now, one-eighth of the entire payroll for the year 1911 , of $\$ 6,332,485$, is only $\$ 791,561$. The current assets of cash and dividends, bills and accounts receivable, and prepaid expenses at the close of 1911, exceeded the accounts payable by only $\$ 475,212.1 \%$. Such a sum added to the entire appraised value of the supplies, of $\$ 921,596$, would be only $\$ 1,396$,808.1\%.

In view of all this, $\$ 1,500,000$ would appear to be a maximum amount necessary to allow for all forms of working capital. This is $\$ 578,404$ in excess of supplies on hand. However, as the matter 
relatively is not of large importance, $\$ 1,750,000$ may be used for the entire working capital, or $\$ 828,404$ for that portion of the same, viz., cash or its equivalent, for which the appraisers allow $\$ 1,050,000$. A reduction from the appraisal may thus be made of $\$ 221,596$.

If this be apportioned between the city and suburban territory, in the ratio of the reproduction value, then $76.26 \%$, or $\$ 168,989$, would be taken from the working eapital allowed by the appraisers for the City.

\section{COST OF PLANT DEVELOPMENT}

After reaching a reproduction value new for the physical property of $\$ 44,898,104$, or one-third more than the $\$ 33,000,000$ of stock, bonds and loans from the banks, the appraisers add $\$ 747,988$ for changes that may be made in the plans as the work of construction during the assumed five-year period proceeds. In the words of the appraisers:

"The expenditures cover a variety of items, such as the alteration or reconstruction of buildings to provide for the enlargement of the plant, and reconstruction or enlargement of equipment incident to the growth of the business. For example, certain exchange offices when built were of ample capacity to handle the needs of the company at the time they were constructed. They, however, were built with provision for extension at a future time, and at a later date they were reconstructed and enlarged as necessary to handle the needs of the company. As a result the total expense of buildings to the telephone company, including this reconstruction, is greater than the value of the property as determined by inventory of the building as it now stands.

"In a similar way, many changes in telephore equipment have been made due to the development of the business, which have entailed expenditure that would not be included in any value arrived at by the inventory. It is the in. tention to include in the plant development expense such an amount as would represent the normal expenditure that would be made in case the property is reproduced within the assumed construction period of from five to eight years."

The allowance for this purpose is $2 \%$ on the cost of buildings, central office equipment, subscribers' station equipment and exchange and toll lines.

It may be a logical consequence of the theory of reproduction to allow this plant development cost, but to one who holds that a voucher is better than an estimate, and that the cost of recent construction furnishes better unit figures for reconstruetion than does the judgment of even the best engineers, it does not appear to be a correet view. Since the entire construction cost that has gone on the books of the Company is only five-sixths of the estimated reproduction cost as estimated by Byllesby and Arnold, a further addition of nearly $\$ 750$ 000 for estimated changes of plant during construction seems hardly warranted. The cost of such changes must have been put upon the books and must have appeared in the book value of the property, or 
must have been charged to operating expenses and thus have been paid for by the telephone subscriber. In the former case, the Company secures the equivalent of the above cost. 'In the latter case, it does not appear entitled to this value, if secured from the consumers under the guise of operating expenses. If the latter, as put upon the books, had been less, the profits would have appeared to the community greater, and there might have been an even larger reduction of rates in the November, 190\%, ordinance than was made.

\section{COST OF DEVELOPING THE BUSINESS}

For the cost of developing the business in the city, the appraisers have added $\$ 4,753,993$, and in the entire territory $\$ 7,094,246$. The estimate is so large and the matter so important that the argument of the appraisers may be quoted:

"It is needless to say that the physical plant of the company has no value other than second-hand or scrap value, unless the plant is utilized for the purpose for which it is constructed, and the plant cannot be utilized for this purpose unless the business has been secured.

"In estimating this element of value, the following method has been pursued. It has been assumed, as stated before, that the property could be reproduced within a period of five years. A construction schedule has been prepared, in which dates are assigned for the construction of various portions of the property now existing. In making up this schedule the plant has been reproduced somewhat as follows:

"It has been assumed that, first, certain pieces of real estate for downtown offices will be purchased, and, next, that the exchange buildings will be constructed, building space to be of the present capacity, and that central office equipment or a fraction of the present capacity will be installed as the first installation; also that the conduit lines in the given section will be built complete, and that sufficient cables will be installed with the first installation to serve the partial equipment installed in the offices. Furthermore, it is assumed that a certain number of subscribers will be obtained as soon as this equipment is ready for service, and at that time the substation equipment will be provided. During a later year additional offices will be constructed and additional units will be installed in the offices already partially equipped.

"An additional item of expense, which is part of the cost of securing business, is included in this schedule at this point, representing the cost of securing subscribers and printing the first issue of the directory, which amounts, as shown by study of the present operating statistics, to slightly over $\$ 4.00$ per subscriber, and the total obtained by multiplying the total number of subscribers by this amount is included in the proper column in the table.

"The schedule thus arranged provides for the completion of the entire property within five sears. The amount expended during this time is the amount shown in the appraisal exclusire of carrying charge. It has further been assumed that that company has a right to earn a fair return on the amount of money invested, and during any given period in the schedule after the first period a return has been figured on the investment at the end of the preceding period." 
The appraisers give further explanation and elaborate computations to show how, if a company started a new plant in Chicago today, with a field clear from competition, it would cost $\$ 7,000,000$ to develop the business of the present company. In other words, the appraisers are seeking to estimate what is usually considered a form of "going value" based on a $10 \%$ return on the investment in the developing plant. Byllesby and Arnold prefer to eall this by another name. It is the idea rather than the name that is important.

The theory assumes, although it does not directly state, that the people of Chicago are to forget their knowledge of telephones and must be solicited, at much expense, in order to become acquainted with them. To imagine such a condition of sudden collapse of memory in this or any other city might be natural to builders of air castles or to the well-nigh extinct type of pure theorists among college professors who have been so much of a butt of ridicule among "practical men," but it seems curious when coming from prominent engineers. If Chicago were suddenly bereft of all telephone service by a San Francisco earthquake or some other catastrophe the present subscribers would need no soliciting to resume the service at the very earliest possible moment. Indeed, one of the notable features of Chicago telephone history has been the almost entire absence of expense for soliciting of new business. In this respect it more closely resembles the street railway than the lighting utilities.

It is indeed true that without business the physical plant would only have a scrap value. The cost of construction of the plant, even if it be $\$ 40,000,000$, would not give value without a demand for the service. In assuming a demand sufficient to give a value equivalent to the cost of the physical property a certain type of going value is thereby generally conceded.

If the courts shall insist upon allowing public utilities a further value beyond the investment, our public service commissions are likely to reduce the rate of return correspondingly, leaving to the companies but little more than just enough to escape the charge of ordering a confiscatory rate.

The United States Supreme Court, after listening to able arguments on behalf not only of good will but of going value in the Consolidated Gas case of New York in 1898-9, and in the Cedar Rapids gas case in 1912, entirely ignored the claim, while in the Knoxville water case, decided January, 1909, the court allowed it, but distinctly stated that it was not to be considered a precedent.

None of the six prominent public utility commissions of Massachusetts, New York, Wisconsin, New Jersey and Maryland have so far allowed any going value, except in Wisconsin, and there only 
where, in the long run, the dividends in the past have not appeared to the commission to be fair and reasonable. No such claim of lack of good dividends in the past can be made here.

\section{EARLY PROFITS}

In 1881, the first year of the Company's history, no dividends were paid. From that time until 1908 the dividends were never less than $10 \%$. They were reduced to $8 \%$ in 1908 and have been of that amount since then; but the reduction from $10 \%$ to $8 \%$ was accompanied by an increase of stock out of earnings from $\$ 22,500,000$ to $\$ 2 \%, 000,000$. The actual dividend, thus, on the stock representing any cash contribution from the stockholders, scarcely declined at all.

In other words, the dividends now paid of $\$ 2,160,000$ on $\$ 27,000$,000 of stock represent $9.6 \%$ on the $\$ 22,500,000$ worth of stock outstanding at the close of $190 \%$, before the capitalization of surplus earnings.

It is interesting to observe that had the stockholders been content with $10 \%$ on their actual contributions from the start, and had they been further content to pay off the stock out of earnings in excess of $10 \%$ on their outstanding stock when there were such earnings, the stock would have all been redeemed and all the extensions would have been paid for out of earnings on January 1, 1912, with the exception of $\$ 5,000,000$ of bonded debt.

The method of computing this may be illustrated by the first three years of the Company. In 1881, when no dividends were paid on the $\$ 5,000,000$ of stock, $10 \%$ allowance, or $\$ 50,000$, would on this theory be added, making the claim of the stockholders $\$ 550,000$ on January 1, 1882. Ten per cent. on this, or $\$ 55,000$, that year would raise the claim to $\$ 605,000$, less the dividends actually paid of $\$ 148$,000 . This leaves the net claim against the public on this theory of $\$ 45 \%, 000$.

In 1883 an allowance of $10 \%$ on this, together with $\$ 100,000$ of new stock for money put into the plant, makes the total claim $\$ 602,700$ less $\$ 220,000$ actually paid in dividends, or a net claim December 31, 1911 , of $\$ 382,700$. In this way the property would have all been paid for by $188 \%$ and no stock would have been needed again until 1901, and that stock would have finally been canceled with $10 \%$ thereon before January 1, 1912.

These computations are not given here for anything more than an illustration of the profitableness of the business. It is only under municipal ownership, when well managed, that profits above $4 \%$ to $5 \%$ interest on the bonded debt are devoted to retiring the debt and thus decapitalizing the business. 
The total dividends paid by the Chicago Telephone Company, from 1881 to the close of 1907 , when the present ordinance went into effect, were $\$ 16,951,765$. This was an average of $12.66 \%$ of the sum of the average outstanding stock of the several years. Had the addition of $\$ 1,000,000$ to the stock in 1900 , without any direct payment therefor by the stockholders, been omitted from the calculation of average stock outstanding, the dividends would have averaged over $13 \%$.

TABLE 12

APPRAISAL OF PHYSICAL PROPERTY AND REJECTED ITEMS

\begin{tabular}{|c|c|c|}
\hline Description & City & $\begin{array}{l}\text { City and } \\
\text { Suburban }\end{array}$ \\
\hline 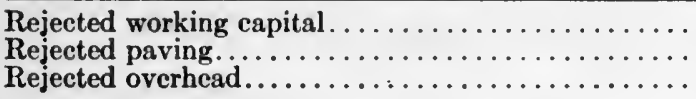 & $\begin{array}{r}\$ 168,989 \\
628,262 \\
1,268,696\end{array}$ & $\begin{array}{r}\$ 221,596 \\
628,262 \\
1,757,684\end{array}$ \\
\hline 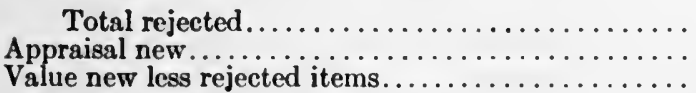 & $\begin{array}{l}\$ 2,065,947 \\
34,325,894 \\
32,259,947\end{array}$ & $\begin{array}{l}\$ 2,607,542 \\
44,898,103 \\
42,290,561\end{array}$ \\
\hline
\end{tabular}

The rejection of the items of plant development and the cost of developing the business reduces the appraisal of the physical property new to:

City and suburban property, City property only,

$\$ 42,290,562$

$32,259,947$

The rejected paving item of $\$ 628,216$, laid since the conduits were put in, belongs entirely to the city portion of the plant. The rejected part of the working capital has been apportioned to the city in the same percentage of the whole $(76.26 \%)$ as is the proportion of the entire city property, aside from cash and its equivalent, to the total.

PRESENT VALUE

The last two of the nine large volumes of the appraisal are devoted to the determination of the present or depreciated value of the physical property. No depreciation is recognized in the items of "plant development" and "cost of developing the business."

Following a common practice, no depreciation is found in land or construction in process, or such part of the working capital as is represented by cash or fluid assets readily convertible into cash. The other $90 \%$ of the physical property is depreciated by the appraisers $77.28 \%$ in the city and $76 \%$ in the atire system. The method taken may be briefly examined. 


\section{LIFE}

The appraisal gives two columns of estimated life. In one column, known as $b$, the appraisers take an estimated life for each portion of the property based on.its probable duration, if affected only by wear and not at all by obsolescence or inadequacy, or other causes. In the second column, known as $a$, they take a shorter estimated life, based on conditions of obsolescence, inadequacy, etc., which have been observed in Chicago and similar large cities. Column $b$ is called a life "due to age and wear only," and column a is called a life "due to service." In the table following three columns are added to include the estimates of the Chicago Telephone Commission, of D. C. Jackson, Wm. H. Crumb and Geo. W. Wilder, in April, 1907; the estimates of Westinghouse, Church, Kerr \& Co., in their report in March, 1911, and the estimates of E. L. Cline, in Telephony, July 2, 1910.

TABLE 13

LIFE

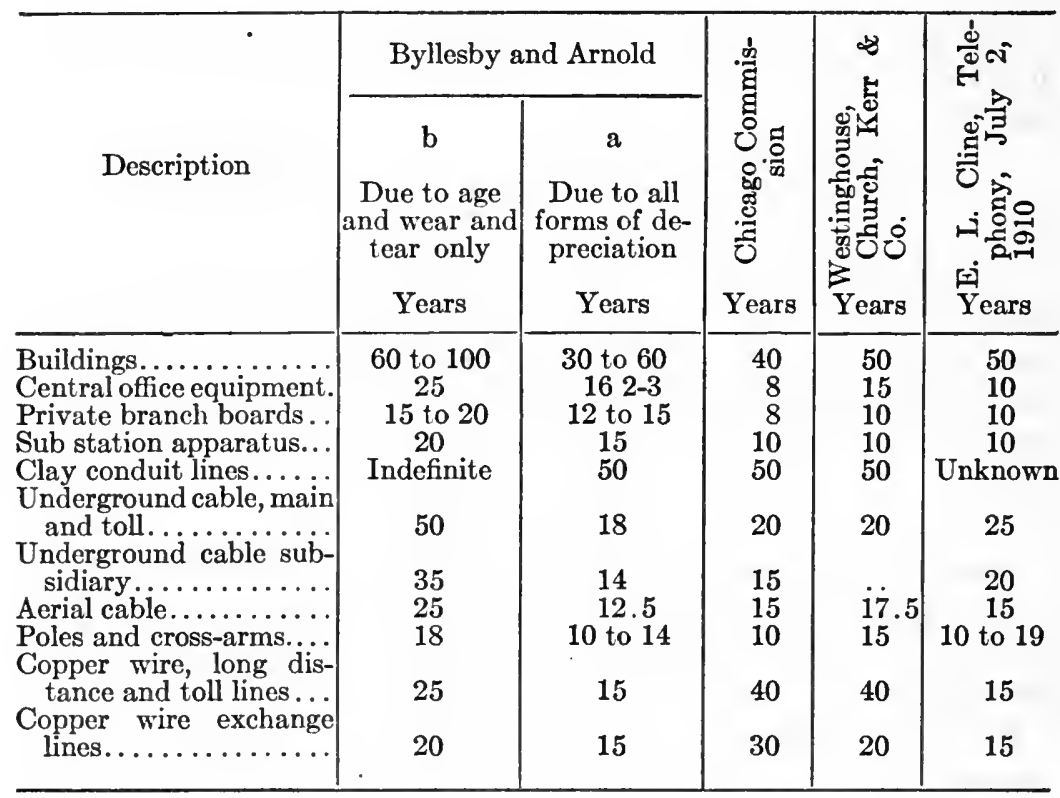

It will be observed that Byllesby and Arnold in Column a assumed a longer life for central office and sub-station equipment and a shorter life for conduits and cable than do the others. 
Table 14

SALVAGE

\begin{tabular}{|c|c|c|c|c|c|}
\hline \multirow[b]{2}{*}{ Description } & \multicolumn{2}{|c|}{ Byllesby and Arnold } & \multirow{2}{*}{ 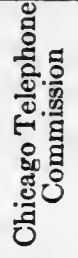 } & \multirow{2}{*}{ 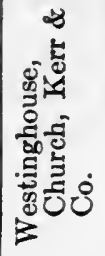 } & \multirow[b]{2}{*}{$\begin{array}{l}\stackrel{\Xi}{0} \\
\dot{0} \\
\dot{\theta}\end{array}$} \\
\hline & $\begin{array}{l}\text { b } \\
\text { Age and } \\
\text { wear only }\end{array}$ & $\begin{array}{c}\text { a } \\
\text { All forms of } \\
\text { depreciation }\end{array}$ & & & \\
\hline 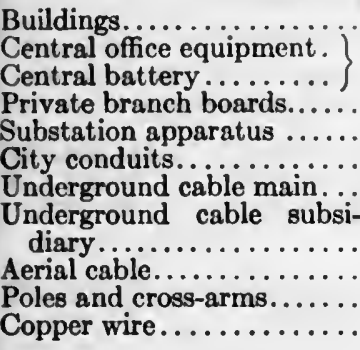 & 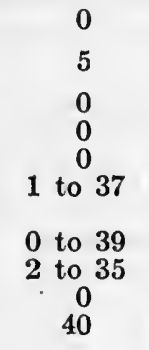 & $\begin{array}{c}0 \\
12 \\
10.5 \\
10.5 \\
0 \\
35.2\end{array}$ & $\begin{array}{r}20 \\
20 \\
10 \\
0 \\
40\end{array}$ & $\begin{array}{r}40 \\
30 \\
0 \\
50\end{array}$ & $\begin{array}{c}40 \\
40 \\
0 \text { to } 20 \\
70\end{array}$ \\
\hline
\end{tabular}

Byllesby and Arnold estimated less net salvage (column a) than do others. The net salvage allowed on some parts of the property are here given :

Sub-station equipment

Underground cables, mains,

Underground cable, subsidiary,

$10.46 \%$

$35.67 \%$

House cable,

$9.5 \% \%$

Aerial cable,

$4.55 \%$

Aerial wire,

$19.54 \%$

$29.32 \%$

Table 15

\section{ANNUAL DEPRECIATION}

Percentage of Cost

\begin{tabular}{|c|c|c|c|c|c|}
\hline \multirow[b]{2}{*}{ Description } & \multicolumn{2}{|c|}{ Byllesby and Arnold } & \multirow{2}{*}{$\begin{array}{l}\text { Chicago } \\
\text {-Telephone } \\
\text { Company } \\
\text { Sinking } \\
\text { Fund }\end{array}$} & \multirow{2}{*}{$\begin{array}{c}\text { Westing- } \\
\text { youse } \\
\text { Church } \\
\text { Kerr \& Co. }\end{array}$} & \multirow[b]{2}{*}{$\begin{array}{l}\text { E. L. } \\
\text { Cline }\end{array}$} \\
\hline & $\begin{array}{c}\text { b } \\
\text { Age and Al } \\
\text { wear only dep }\end{array}$ & $\begin{array}{l}\text { a } \\
\text { All forms of } \\
\text { epreciation }\end{array}$ & & & \\
\hline Buildings. & 1 to 2 & 1.5 to 2 & 1.33 & 2.0 & 2 \\
\hline ice equipment & 3.8 & & 11.25 & 5.3 & 8 \\
\hline Private branch boards. . & 5.0 & 6.67 & 11.25 & & \\
\hline Substation apparatus .. & 5.0 & 6.67 & 8.73 & 8.5 & \\
\hline Clay conduit lines. . & 0.0 & 2.00 & .89 & & 1 \\
\hline Underground cable...... & .1 .26 to 1.98 & 5.50 & 3.72 & 3.0 & 2.4 \\
\hline $\begin{array}{l}\text { Underground cable sub } \\
\text { sidiary } \ldots \ldots \ldots\end{array}$ & & 7.00 & & & \\
\hline Aerial cable............ & .2 .60 to 3.92 & 8.00 & 5.38 & 4.0 & 4 \\
\hline Poles and eross arms. & .4 .16 to 5.55 & 6.66 & 8.73 & 6.6 & to 11.25 \\
\hline Copper wire........... & 2.4 & & 5.38 & 2.5 & \\
\hline
\end{tabular}


Byllesby and Arnold estimate (column a) less depreciation yearly on central and sub-station equipment and more depreciation on underground and aerial construction than do the others.

Applying the above percentages of depreciation, based on the age, salvage and assumed life of the several parts of the telephone property, the appraisers reached the following results :

TABLE 16

DEPRECIATED OR PRESENT VALUE

\begin{tabular}{|c|c|c|}
\hline Description & City & $\begin{array}{l}\text { City and } \\
\text { Suburbs }\end{array}$ \\
\hline 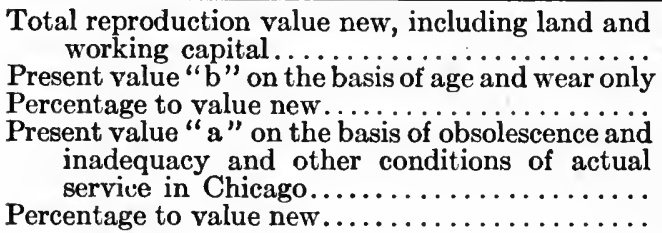 & $\begin{array}{l}\$ 34,325,894 \\
29,838,803 \\
86.58 \% \\
\\
27,312,425 \\
79.03 \%\end{array}$ & $\begin{array}{c}\$ 44,898,103 \\
38,201,873 \\
84.73 \% \\
\\
35,073,692 \\
77.59 \%\end{array}$ \\
\hline
\end{tabular}

According to the books of the Company, the total cost of the property in the city and suburbs on August 1, 1911, amounted to $\$ 36,852$,122.15 , or, with a proper allowance for cash and its equivalent, about $\$ 37,700,000$. From this, however, $\$ 417,871.38$ should be deducted for property that was scrapped before December 31, 1911, or more properly the $\$ 364,778.41$ scrapped before August 1, 1911, which, by an oversight, was not noted in the books (Hall's report, page 14). This would leave the cost, according to the books, about $\$ 3 \%, 300,000$. The present value of this property would be determined by deducting the amount of the credit of the depreciation reserve August 1, 1911. The addition to the reserve for the year 1911 was slightly over $\$ 1$,200,000 , or approximately $\$ 700,000$ for the seven months. This added to the $\$ 3,700,000$, December 31,1910 , gives $\$ 4,400,000$ contributed by the telephone users up to August 1, 1911. The present value, according to the books, is therefore $\$ 32,900,000$, which confirms the value found below from the appraisal, viz., $\$ 32,813,246$.

If we apply to the appraisal new less the items rejected in the present report, the same percentages of depreciation as were used by Byllesby and Arnold for all items, namely $20.97 \%$ for the city and $22.41 \%$ for city and suburbs, the present value of the conceded items of the appraisal new of $\$ 32,259,947$ within the city and $\$ 42$,290,561 in the city and suburbs will be:

Conceded present value in city,

Conceded present value in city and suburbs, 
It thus appears that the corrected present value for the entire property to August 1st, of $\$ 32,813,246$, is nearly equal to the $\$ 33$,000,000 of stocks, bonds and loans from the banks on December 31, 1911. By that date, however, the addition of $\$ 2,095,270$ to the physical property during the last five months of 1911, brought the value of the physical property on the above basis to $\$ 34,908,516$, or in round figures, $\$ 35,000,000$. This is $\$ 2,000,000$ more than the investment by the stock and bondholders and the banks on the date in question, December 31,1911 , and is substantially equivalent to the non-interest bearing liabilities.

Possibly a more exhaustive examination of the appraisal might make such further reductions as to bring the value on December 31 st down to $\$ 33,000,000$. On the other hand, the Company might succeed in showing that too much has been rejected in the above computations.

The important point in this particular matter is that through the rise of land values, the inerease in the cost of labor and materials and the investment of reserves of $\$ 5,091,000$ collected from the telephone users, the plant on December 31, 1911, was worth about $\$ 2,000,000$ more than the outstanding stocks, bonds and obligations to the banks. These three items, aggregating $\$ 33,000,000$, represent the investment of capital in the Company.

Prior to 1891 the dividend rate was always $30 \%$ to $51 \%$. During that time $\$ 494,352$ of new stock was subscribed for from the dividend, or was allotted to the stockholder simultaneously with the payment of the dividends. Stock dividends of $\$ 1,000,000$ in 1900 , and of $\$ 4,500,000$ in 1908 , were issued to represent surplus earnings that have gone into the plant, in addition to the regular dividends which, prior to 1908 , had never been under $10 \%$. Since these stock dividends of about $\$ 6,000,000$ out of the existing $\$ 27,000,000$ of stock represented actual investment in the property, even though paid for by the telephone user, the present stock, as well as the bonds, represents actual capital rather than what is usually meant by "water."

The question of how the capital was secured has more importance when the present $8 \%$ dividend rate is considered.

In addition to expenditures for maintenance that have gradually declined from $10 \%$ to $7.4 \%$ of the average depreciable investment, $\$ 5,000,000$ appears to have been necessary to keep the investmnt intact through the past 20 and more years. This, however, is far from establishing the propriety of collecting over $40 \%$ of this, or $\$ 2,241,141$, during 1910 and 1911 . The fact appears to have been that substantially all the surplus earnings above $8 \%$ on the stock 
during the past two years were added to the surplus. It was legal, and it may have been a wise and proper atonement for the neglect to do this in the past, or for transferring from reserve to surplus and distributing, as a stock dividend in $1908, \$ 4,500,000$ previously accumulated to meet depreciation.

The actual treatment of the subject on the books of the Company was not sufficiently scientific to be a guide in adjusting rates for the next five years.

\section{DEPRECIATION IN NEW AND OLD PLANTS}

In a new plant which has not yet reached its "gait" of renewals, a depreciation reserve appears desirable. In the case of a company as old as the Chicago Telephone Company, the time may soon arrive when renewals will take sufficient care of depreciation, as in the case of our older gas companies and railroads.

A depreciation reserve has thus far been needed by the Chicago Telephone Company.

\section{METHODS OF BUILDING UP A DEPRECIATION RESERVE}

Where, as is usual in telephone companies, a depreciation reserve is invested in the plant itself, there are two methods of determining the amount needed from year to year to reach the fixed amount at the end of a definite period. Both methods start with an assumption of the probable life and of the value new of each class of property that is subject to depreciation. The sinking fund method shows what percentage new must be put into a fund at an agreed rate of interest, usually $4 \%$, in order, when compounded, to reach the full value at the end of the estimated life of the property.

Of course, the only loss to be made up by the sinking fund is the difference between the cost new and the net salvage. By net salvage is meant the value of the property when scrapped, less the cost of its removal and sale.

Having thus determined the percentage of depreciation to be applied in any given year to each class of property, the amount of depreciation in dollars is computed. Then the addition of these various sums required for the sinking fund gives the total amount to be apportioned that year to the depreciation reserve. This amount will vary from year to year and is a complicated method to apply to. the bookkeeping of the past. It is of easier application when applied to the property today as an estimate for the future. In the case of the Chicago Telephone Company, the appraisal just made shows that the actual excess of depreciation over appreciation in the past thirty 
years has been about $\$ 5,000,000$. One can determine what uniform per cent. of the average investment of all the depreciable property would have been necessary within the last 21 years, in order to reach at $4 \%$ compound interest this $\$ 5,000,000$.

One per cent. yearly on the arerage depreciable investment since 1890 at $4 \%$ would have yielded $\$ 3,465,860.91$ in 1911 . To have secured $\$ 4,000,000$ by this method would have required $1.151 \%$; to hare secured the actual amount accumulated, of $\$ 5,091,000$, would have required $1.469 \%$. The other method of reckoning the depreciation, one apparently in universal use among telephone engineers, is the so-called straight line method, where interest and the compounding of the same is disregarded. The difference between the cost of the property and the net salvage-in other words, the true depreciation, is equally divided by years over the assumed life of the class of property in question. The amount yielded in this way by $1 \%$ yearly of the average depreciable property of the Chicago Telephone Company since 1890 is $\$ 2,731,97 \%$. To accumulate $\$ 4,000,000$ in 1911 by this method would, therefore, require $1.464 \%$ a year. To accumulate $\$ 5,091,000$ would require $1.8635 \%$. A yearly addition to the reserve of $1.5 \%$ would yield $\$ 4,097,966$. A yearly addition of $1.86 \%$ would yield $\$ 5,081,47 \%$. If the first method, or sinking fund, is applied to the past history of the plant, the rate of return must be reckoned upon the first cost new of the property in use.

If, however, the second or straight line method be used, the rate of return but not the depreciation should be reckoned from year to year on the depreciated value of the property. An illustration will make this latter point clear. Suppose the property cost new $\$ 100,000$, and that $7 \%$ be assumed as a fair return on the investment, but let it be further assumed that the property will last only $33 \frac{1}{3}$ years, and therefore will require $3 \%$, or $\$ 3,000$ a year, without interest, to make good the depreciation. Besides enough for operating expenses, the users pay $\$ 10,000$ to the company the first year. Of this amount, $\$ 7,000$ is profit and $\$ 3,000$ makes good the depreciation. If the company is a growing one, it will need even more than $\$ 3,000$ for extensions, which it will pay for, in part, with the above $\$ 3,000$ furnished by its customers, and in part through further stock and bond issues. If $\$ 4,000$ were needed for extensions during the first year and $\$ 3,000$ were paid in by the customer, the real capital at the beginning of the second year would be $\$ 101,000$. If no addition to the investment were required, the capital would ho $\$ 97,000$, and the company would have $\$ 3,000$ to put into similar investments elsewhere. If the company could not get $7 \%$ elsewhere, that would indicate that the 
rate of return to the company in question had been put too high, since the rate of return should represent, as nearly as possible, what investors demand and get in similar investments under similar conditions. The objection may be raised that if the property were a stagnant one the rate of return each year, say $7 \%$, would be on a reduced capital and therefore the rates would fall as compared with a new investment of similar character elsewhere. This is of slight importance, because the problem is the determining of what is just in each community.

Under this theory, of course, if a stagnant plant begins to grow rapidly, and a large amount of new capital were called in, or if the plan were entirely rebuilt, there might have to be a temporary increase of rates, but that, under a system of public regulations and publicity of accounts, could be allowed. Such suppositions, however, of stagnant plants, have little application to most municipal utilities and no application to the Chicago Telephone Company.

In the case of the latter company, another argument is raised. This plant for the present may be assumed to have cost the security holders-that is the stock, bond and note holders- $\$ 33,000,000$, and to have cost the telephone subscriber $\$ 5,000,000$ for a depreciation reserve.

The Company claims that it has had the burden of investing and saring for this $\$ 5,000,000$ of depreciation reserve, which has been put into extensions, and should have a reward for the same. To this it should be replied, first, the salaries of all the officials and managers :hat supervised these extensions have been paid out of operating :xpenses and will be so paid in the future. Second, the security to the stockholders has been increased by this depreciation reserve collected from the subscriber and put into extensions. Third, if the depreciation reserve had been placed in an outside sinking fund, the owners of the property would have had to put their hands into their pockets for the extensions which have been paid for by the subscribers, while the total value of the telephone property would not have been changed thereby, and the investment in the sinking fund would have been scarcely more secure than the investment actuall;; made in extensions. The straight line method will be followed in this report, and the yearly depreciation will be taken from the cost new of the depreciable investment.

MAINTENANCE AND DEPRECIATION IN OTHER BELL COMPANIES

The experience of the entire group of Bell companies with their $4,474,171$ stations in use at the close of 1911 , should be observed. The percentage of station removals, maintenance and depreciation to 
PHYSICAL VALUATION OF CHICAGO TEL. COS. 833

the entire investment in telephone property was given in the last report of the A. T. \& T.:

$\begin{array}{ll}1895, & 9.1 \% \\ 1900, & 8.4 \% \\ 1905, & 8.9 \% \\ 1910, & 9.5 \% \\ 1911, & 9.2 \%\end{array}$

In Chicago and suburbs in 1911, when the average depreciable property of $\$ 33,27 \%, 902$ was $89.47 \%$ of the total property of $\$ 3 \%$,$194,588,9.2 \%$ of the entire property would be $10.28 \%$ of the depreciable property. But this included station removals. This item in Chicago in 1911 was $\$ 730,10 \% .20$, or $2.194 \%$ of the average depreciable property, but was only $1.85 \%$ in 1910 , and apparently will be about that figure in 1912 . A reduction of $1.85 \%$ from $10.28 \%$ would leave $8.43 \%$ of the depreciable investment as applicable to maintenance and a depreciation reserve in Chicago, outside of station removals, if the average of all the Bell companies, save the long distance lines, were to prevail here. If the long distance lines be included, there is data from the last three reports of the A. T. \& T. for a more detailed comparison, as follows:

The last report of the American Telephone and Telegraph Company gives not only the telephone plant in use on December 31, 1911. of $\$ 666,660,702$ ( $p .13$ ) for the entire Bell system in the United States, but it gives the plant additions for each of the previous 12 years. (Report, p. 5.) The working capital is omitted, but land is included in addition to the depreciable property. The report also states (p. 6) :

"During the year $\$ 58,840,000$ was applied out of revenue to maintenance and reconstruction purposes; of this, over $\$ 12,000,000$ was unexpended for those purposes.

"The total provisions for maintenance and reconstruction charged against revenue for the last nine years was over $\$ 342,300,000 . "$ 
From this data the following computation is easily made:

TABLE 17

MAINTENANCE AND DEPRECIATION EXPENSES AND RESERVES OF ALL BELL COMPANIES, INCLUDING LONG DISTANCE LINES

Average plant investment, including land, but not working capital, of all Bell companies. $\$ 584,208,500.00$

Ditto, for Chicago Telephone Company..... 30,451,278.00

Other Bell companies. .............553,757,222.00

Total maintenance, station removals and depreciation reserve..................

Percentage of maintenance, station removals, $52,028,009.00$

$\$ 638,830,314.00$ $33,883,648.00$ $604,946,666.00$ and depreciation reserve to average plant investment, including land but not working capital in all Bell companies........

Maintenance, station removals and depreciation of Chicago Telephone Company....

Percentage of maintenance, station removals and depreciation reserve in the Chicago Company to its average plant investment,

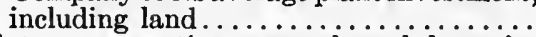

Maintenance, station removals and depreciation in other Bell companies after deduct-

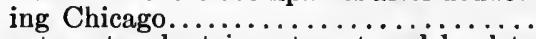

Percentage to plant investment and land to these other companies..............

$\begin{array}{cc}8.91 \% & 9.21 \% \\ 3,888,533.00 & 4,228,221.00 \\ & \\ 12.76 \% & 12.48 \% \\ 48,139,476.00 & 54,622,129.00 \\ 8.69 \% & 9.03 \%\end{array}$

In the above computation, the investment of the Chicago Company, as it appears on the books of the company, is used. If the property ( $\$ 417,871.38$, Hall, page 14) that was scrapped before the close of 1911, had been deducted from the Chicago investment, the contrast would have been slightly increased. As it is, however, the other Bell companies are spending only about $9 \%$ of their entire investment outside of their working capital for both maintenance, station removals and yearly additions to their depreciation reserves. The Chicago company, on the other hand, is spending or setting aside about $12 \frac{1}{2} \%$ for the same purpose. Some allowance may be made for the increased cost of station removals here, but a difference of even $3 \%$ when applied to the investment of the Chicago company for both city and suburbs in 1911, would amount to about $\$ 1,000,000$ and to the city alone of about $\$ 750,000$. 
TABLE 18

MAINTENANCE, RECONSTRUCTION AND PLANT INVESTMENT OF ALL THE BELL COMPANIES, 1903-11, INCLUSIVE

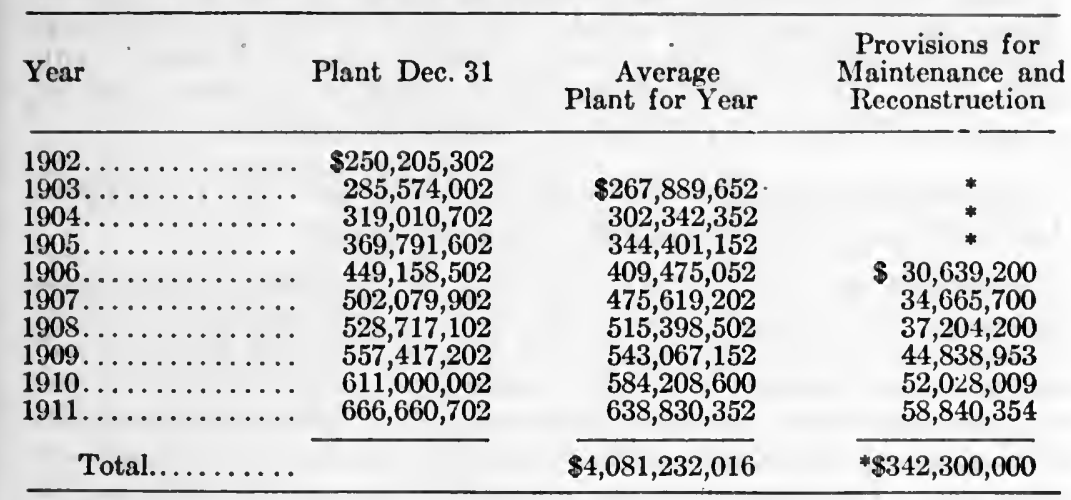

* The total for the nine years is given in the recent reports of the A. T. \& T., but the separation between the first three of the years is not shown.

The report for 1911 gives the provision for maintenance and reconstruction, and the total for the nine years, 1903-11, but reliance is had upon the previous reports for the amount for some of the years covered by the total. The entire provision for maintenance and station removals and to meet depreciation during the last nine years for all the associated Bell companies of the United States, has been only $\$ 342,300,000$ or $8.387 \%$ of the aggregate of the average investments during those nine years of $\$ 4,081,232,600$.

An appraisal of all these Bell plants in 1907 gave a value to these properties of $\$ 35,000,000$ in excess of the obligations outstanding against them. If a maintenance, station removal and depreciation reserve expense of $8.39 \%$ can do this elsewhere, it might seem sufficient in Chicago with its large proportion of long lived investment. At least $8.5 \%$ would appear sufficient for maintenance and depreciation reserve, if station removals be separately allowed in Chicago.

Commenting on this situation, President Vail, in his report for 1908, wrote:

"The result of the appraisement and studies on depreciation, given below, establislies the fact that our charges against revenue for maintenance and reconstruction are conservative and on the right side.

"There exists much misunderstanding as to the permanent value of a modern telephone plant. Originally, exchange plants were open wire construction, largely on house-top fixtures and to n certain extent, on poles. The central offices were in leased buildings, seldom fireproof, the equipment was of various types and standards, due to the rapid improvement or development then tak. ing place. 
"Now the central offices in all the principal centers and in many of the less important are in fireproof buildings built for the purpose and owned by the companies.

"From these offices radiate the underground conduits connecting the central offices with each other and the various districts of the exchange territory. Through the subways the wires are run in cables of copper wire, sheathed with lead covering. The extensions of these lines are open wire, generally copper, or aerial cables strung on pole lines of substantial construction."

Commenting upon this matter again in his report for 1910, President Vail made the following significant statement:

"The present policy of the Bell system is to provide against every probable contingency and to base the amount and extent of such provision on past experience-not on future expectations. It is conjectured that the future will show a decrease in the depreciation or reconstruction due to decay, wear and tear, and obsolescence. Changes-improvements-are going on as rapidly as in the past, but the general character of plant and methods is assuming more permanency. The improvements are being evolved from, and are being grafted on to, the old system and methods. The disturbing and sometimes seemingly destructive conditions following the rapid development of high pressure power and transmission have been to a great measure overcome.

"All this has been made possible through the unremitting study and research of the staff of the engineering and experimental departments of the company, who by close attention, observation and study, anticipate and provide for all such contingencies and conditions as can possibly be anticipated or provided for in advance.

"Under these conditions there is a small probability that any such causes as those which forced the wholesale reconstruction or rearrangement of plant in the past will again occur; it is, however, for the benefit of the public and of the corporation to have an ample reserve for any contingency which may happen."

That the Chicago Telephone Company has pursued the same conservative policy as the other Bell companies is indicated in the report of the then president of the company, John M. Clark, in his annual report for 1900 . He then said:

"This company has aimed to keep fully up with the improvements that are continually being made in apparatus and in methods of handling the business. In fact, some of the most important of these have been made by electricians and experts in the employ of this company.

"The expenditures have been largely increased not only by the growing cost of opcration, but also through the necessity of replacing old switchboards and apparatus with new and improved equipment, in order to maintain the quality of the service at the highest modern standard. New switchboards and apparatus were installed during the year, costing $\$ 282,160.38$."

It is, moreover, interesting to note that such well established independent telephone companies as the Tri-State of Minneapolis, Keystone of Philadelphia, Kinloch of St. Louis, Federal of Buffalo, and the Kansas City Home Telephone Company, are devoting less than 
8.5\% yearly of their plant investment to maintenance and depreciation.

That the entire Bell system has so completely taken care of depreciation with a total expenditure of $9 \%$ of the plant investment for maintenance, including renewals, and for station removals and for additions to the depreciation reserve investment as compared with over $12 \%$ here during the last two years, is significant.

The fairness of the above comparison is strengthened by the fact that all the Bell companies, including the long distance lines had in permanent underground conduit only $53 \%$ of their entire mileage of wire in December, 1911, and outside of Chicago only $51 \%$, while the Chicago Telephone Company had $81 \%$ in underground conduits. This would naturally mean that the maintenance expenses would be somewhat larger in the average Bell telephone company than in Chicago.

Real estate and underground conduits and cables, which constitute the most permanent portion of the telephone plant, were given in the 1908 annual report of the A. T. \& T. Co., as amounting to only $29 \%$ of the total value of the telephone plants owned by that company; that is, the entire Bell system.

According to the appraisal of Byllesby and Arnold, this portion of the plant of the Chicago company constitutes $39.5 \%$ of its entire investment.

\section{RATE OF RETURN}

Any one familiar with the numerous decisions of rate commissions is aware of how uncertain and vague are most of their expressions upon the proper rate of return. The courts have been inclined to uphold any rate which yielded from $4 \%$ to $6 \%$ return. Their theory has appeared to be that if the rate was as high as bonds were netting the investor in the locality, which was usually from $4 \%$ to $5 \frac{1}{2} \%$, the rate was not confiscatory. State commissions have held to a higher rate.

New securities in the lighting business in Massachusetts, however, have been ordered by the State Gas and Electric Light Commission to be sold at such premiums as to net the investor only $5 \%$ to $6 \%$.

In the case of a large, old and well established enterprise, like the Chicago Telephone Company, the proper test would appear to be such rate of return as would render possible the sale of additional stock and bonds when needed from time to time for extensions. In other words, the rate should be such as to keep the securities at par, or slightly above. The market for the securities of a well-known 
company is highly competitive. If investors are willing to buy stock on a $6 \%$ basis, and the company insists upon paying $8 \%$ dividends, the investors will quickly run up the price to such an amount, say $133 \frac{1}{3}$, as will net the investor only $6 \%$ on what he pays for the stock. We may argue that the business is such that the investor ought to have $8 \%$; but the investor, having his own opinion on the subject, insists upon buying on a $6 \%$ basis, or whatever may be the actual market quotation.

Applying these observations to the local telephone situation, we find that during 1911 the Company had outstanding $\$ 5,000,000$ of $5 \%$ bonds, which have been constantly sold above par since their issue in 1908. Furthermore, the Company during the present year has made another issue of $\$ 14,000,000$ of such bonds, which are alsa selling above par. Its $\$ 1,000,000$ of loans from the banks were obtained at $4 \%$ to $4 \frac{1}{2} \%$ interest. The $\$ 27,000,000$ of $8 \%$ stock sold at 120 to 130 during most of the three years prior to the exchange of nearly all of that which was owned by the minority stockholders in 1911 , for the $8 \%$ stock of the A. T. \& T. The $8 \%$ stock of the latter company has been selling for some time at 140 to 144 ; yet this is in the face of the announcement in the last report of the A. T. \& T. that on its capital and that of the associated Bell companies it will not hereafter expect or encourage more than $8 \%$.

Now an investor in an $8 \%$ stock at 140 nets on the investment only $5.71 \%$. Even at 130 he only nets $6.15 \%$, and at 125 he nets $6.4 \%$. An investor content with $6.5 \%$ return would only pay 123 for the stock. Since the stock has been above that price most of the time during the last three years, it may be inferred that the investor in Chicago Telephone Company stock not only does not ask a return of $6.5 \%$ on his actual investment in order to buy it, but that in the bidding of the competitive market he forces up the price so that he cannot make $6.5 \%$; in fact, by forcing the price above 133 , as has been the case recently, the investing market makes it impossible to realize even $6 \%$.

To all this it is urged that the stock, at least of the local company, is more precarious than the stocks of the local gas or electric light companies, because of the existence of competition from the Illinois Tunnel Company. That competition has not been serious thus far, and the investor, judging from the above named market quotations, evidently does not expect it to be; neither do the officers of the Chicago Telephone Company express any fear from that source.

Of more force is the claim that stockholders may pay more for stock in expectation of occasionally having a chance to buy new stock issues at par. 
In view of all these facts, it would seem as if $6 \frac{1}{2} \%$ to $7 \%$ were as reasonable a rate of return for Chicago telephone stock as for the Consolidated Gas Company stock of New York, with reference to which a $6 \%$ return was considered reasonable by the United Statc. Supreme Court in January, 1909.

Again it is urged that the City has the right of purchase at the appraised value at the end of the grant, or at $5 \%$ in excess of the appraised value on January 1, 1919, and 1924, and the City may transfer its right on the latter date. As long, however, as the Company gives good service and is not overcapitalized, it seems to have little to fear in this direction. Certainly an appraisal on the basis of that of Byllesby and Arnold would involve a payment to the stockholders of a large premium in case of city purchase.

The stock outstanding was increased in 1908 from $\$ 22,500,000$ to $\$ 27,000,000$, without any contribution from the stockholders. To be sure, the dividends were reduced at the same time from $10 \%$ to $8 \%$, the total annual dividends remaining about the same. The increase of stock has been defended by the Company on the ground that the accumulations from the subscribers to meet depreciation were not found to be needed for that purpose, but represent surplus earnings, which could be capitalized. Whatever be said of that procedure, the fact stands out that a stockholder possessed of $22 \frac{1}{2}$ shares early in 1908 , became a possessor a little later of 27 shares.

Now a dividend of $6 \%$ on 27 shares is equivalent to $7.2 \%$ on $22 \frac{1}{2}$ shares. Similarly, a dividend of $6.5 \%$ on 27 shares is equal to $7.8 \%$ on $22 \frac{1}{2}$ shares, and $7 \%$ on 27 shares is equal to $8.4 \%$ on $22 \frac{1}{2}$ shares.

Since, however, with the addition of the $\$ 4,500,000$ the outstanding securities of the Company appear to be no greater than the value of the physical property, a return on the stock of $6.5 \%$ to $7 \%$ may be reasonable.

In all this it must be emphatically asserted that a return of $6.5 \%$ to $7 \%$ is not here considered. as a fair return in the carly days of the Telephone Company, when the risks of developing a new art were great. As is elsewhere shown, the returns in these early days were fully commensurate with the risks assumed.

The problem before us now is not so much an ethical problem of what a company ought to receive as it is what return, as a matter of fact, will tempt the investor to furnish the moncy needed for the growth of the business. If the lessons of the stock market point to $5 \%$ on bonds, and to $6.5 \%$ to $7 \%$ on stock, as sufficient for this purpose, in the case of the Chicago Telephone Company, then such a rate of return is reasonable.

On December 31, 1911, there were 4,474,171 telephones in use 
among the Bell companies in the United States. Of this number, only $38 \%$ were managed by companies paying $8 \%$ dividends. Outside of the New York and Chicago companies only $11 \%$ of all the telephones were in the hands of the companies paying $8 \%$. No companies paid over $8 \%$, or, so far as can be learned, any amount between $7 \%$ and $8 \%$. Three companies in New England and the Rockies paid $7 \%$. About half of all the telephones in the country were owned by companies paying over $6 \%$, but only $23 \%$ were owned outside of the New York and Chicago companies.

The companies controlling the other half of the Bell system and located largely, like the Central Union, in districts especially subject to competition from the independent companies, have paid no dividends, or not to exceed $6 \%$.

These and the other facts at hand lead to the conclusion that the $8 \%$ dividends from a few of the Bell companies, notably New York and Chicago, together with the $4 \frac{1}{2} \%$ payment on gross receipts from all the companies, and the profits of the iong distance business, help the A. T. \& T. to carry some of the companies that are competing with the independent companies, or are having other difficulties. Whether the Chicago company should thus collect from the subscribers here to support the parent company, which has always owned over half of its stock and which receives all of the $4 \frac{1}{2} \%$ payment on gross receipts for the benefit of the stockholders of the National Company, or for the benefit of the telephone system elsewhere, need not here be argued.

\section{POSSIBILITIES OF REDUCTION}

It has appeared that operating expenses should not include more than $\$ 1$ per telephone for payments to the National Company. It has also been shown that the station removals are very high, but that in 1912 they were beginning to fall. The repairs, which averaged about $6.5 \%, 1904-7$, fell to about $5.5 \%$ during the next four years; 1908-11. The average, however, of all the Bell companies last year, was under $4 \%$ of the investment. It was under $4 \%$ also in the largest cities outside of Chicago. Local conditions may prevent for awhile a further reduction here, but it is reasonable to suppose that the present $5.5 \%$ will approach $4.5 \%$ and the station removals, which are now about $2 \%$ in the city, will decline to $1.5 \%$.

The entire expenditure for repairs, renewals, station removals and additions to the depreciation reserve is over $13 \%$ of the average investment in the city, as compared with $8.5 \%$ to $9.5 \%$ on the average elsewhere.

Repairs and renewals have been steadily falling from about $9.5 \%$ twenty years ago to $7.39 \%$ the last three years, ending with the close 
of 1912. The appraisal has shown that a further expenditure of $1.86 \%$ annually of the property subject to depreciation would result in the accumulation of the $\$ 5,091,000$ actually collected.

Furthermore, this amount still leaves the investment intact, although about $\$ 10,000,000$ of the appraised values of Byllesby and Arnold were rejected. If this $\$ 5,091,000$ of depreciation in the property had been accumulated by setting aside yearly a percentage that should decline with the decline in maintenance, then the percentage would have started during the seven years, 1891-7, with $2.77 \%$, would have fallen during the next seven years, 1898-1904, to $2.06 \%$, and during the last seren years, $1905-11$, would have fallen to $1.66 \%$, with every prospect of a further decline below $1.5 \%$.

From this point of view, one could estimate the repairs and renewals, known as maintenance, at about $7.4 \%$, or at the most $\% .5 \%$, during the next two years, with a further addition to the reserve fund of $1.5 \%$, making a total of $9 \%$ for maintenance and depreciation. This is aside from the expense for station removals and changes, which keep the installation of wires and fixtures inside the subscriber's premises intact, and practically free from depreciation.

The matter may be approached from another point of view. We may assume that the average repairs for the next five years will be $5 \%$ and the amount necessary for the depreciation reserve $1.5 \%$, making a total for these two items of $6.5 \%$, with a possibility of $7 \%$. There remains the problem of renewals. From figures prepared by the Company it appears that with an average life gradually increasing from twelve years in the 90 s to nineteen years now, and with a very moderate rate of growth, giving an investment of $\$ 103,000,000$ in 1930, the renewals for the next five years, 1913-17, would average $1.78 \%$ of the depreciable property, and during the following thirteen years, $2.88 \%$. The addition of $1.78 \%$ for renewals to the $6.5 \%$ to $7 \%$ already mentioned for repairs and depreciation reserve would give $8.28 \%$ to $8.78 \%$ for repairs and renewals and for an addition of $1.5 \%$ yearly to the depreciation reserve. During the remaining thirteen years the repair item might be estimated at $4.5 \%$, which is still much higher than in other companies. This, with $1.5 \%$ for the reserve, and $2.88 \%$ for renewals, would be $8.88 \%$.

The Telephone Company does not accept as long a life today as nineteen years. The appraisal, however, used estimates of life which amount to a composite life on all the property of almost exactly nineteen years, viz., 18.961 years. It seems certain that the whole tendency in the Chicago plant is toward reaching in a comparatively short time the age adopted by Byllesby and Arnold, if that time has not yet been reached. 
Byllesby and Arnold find that the average depreciation allowance on a straight line basis is $4.068 \%$. If, however, they had taken the allowances for salvage which have been found by the Chicago company to be applicable to its condition here, the salvage would have been raised from $22.862 \%$ to $29.234 \%$, and the annual depreciation and renewal allowance on a straight line basis on all the plant in service, including land, but not including working capital, construction in process, tools, teams, furniture and fixtures, would have been reduced to $3.732 \%$. With the almost certain continuance of the increase in cost of labor and materials and of other increments of value that are often allowed in appraisals, the rate of depreciation and renewals may be kept down to between $3.5 \%$ and $4 \%$, as we have seen has been the experience of the last twenty years. Everything points to an allowance for maintenance and depreciation of $8.5 \%$ to $9.5 \%$. At $9 \%$ the Company could continue to pay $5.5 \%$ for repairs during the next five years, meet all renewals that would come on the assumption of a nineteen-year life, such as was used by Byllesby and Arnold, and would have $1.72 \%$ for a depreciation reserve or other extraordinary expenditures, or almost as large an amount as the $1.86 \%$ of the last twenty years. As already observed, this percentage might well decline with the decline of the maintenance account and be taken at $1.66 \%$ during the past seren years.

With the data at hand and the conclusions already reached above, the operating expenses in the city for 1911 might be thus treated:

TABLE 19

REVISED EXPENSES AND PROFITS WITHIN THE CITY IN 1911

\begin{tabular}{|c|c|c|}
\hline Description & $\begin{array}{c}\text { With Maximum } \\
\text { Expenses }\end{array}$ & $\begin{array}{l}\text { With Minimum } \\
\text { Expenses }\end{array}$ \\
\hline Operating expenses......... & $\$ 7,584,289.80$ & $\$ 7,584,289.80$ \\
\hline Excess payments to A. T. \& T. Co. & & 18.00 \\
\hline $\begin{array}{l}\text { Expenses less excessive rentals............ } \\
\text { Expenditures for repairs and renewals... }\end{array}$ & $\begin{array}{l}7,584,28 \\
1,836,50\end{array}$ & $\begin{array}{l}7,39 \\
1,8\end{array}$ \\
\hline Expenditures less repairs and renewals....... & $5,747,783.20$ & $5,555,965.20$ \\
\hline $\begin{array}{l}\text { Add for corrected repairs, renewals and depre } \\
\text { ciation } \ldots \ldots \ldots \\
\end{array}$ & $* 2,395$ & $\uparrow 2,26$ \\
\hline 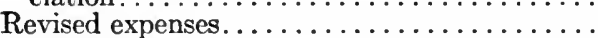 & $\therefore 8,143$ & $7,822,429.32$ \\
\hline & $10,410,770$ & $10,410,770.59$ \\
\hline Profit: & $2,266,011.04$ & 2,58 \\
\hline $\mathrm{Co}$ & $\ddagger 1,765,995$. & $-1,513,710.00$ \\
\hline g profits.......... & 501,016 & $1,074,631.27$ \\
\hline Contingencies and surplus $\ldots \ldots \ldots \ldots \ldots \ldots$ & $150,000.00$ & $100,000.0$ \\
\hline $\begin{array}{l}\text { Possible reduction in rates aside from conside } \\
\text { ation of claims for extraordinary depreciatior }\end{array}$ & $351,016.04$ & $974,631.27$ \\
\hline
\end{tabular}

*At 9.25 per cent. of average depreciable property new of $\$ 25,902,447$.

†At 8.75 per cent. of average depreciable property new of $\$ 25,902,447$.

$\ddagger$ Taken at 7 per cent. of $\$ 25,228,500$, the latter being equivalent to such a per cent. of the $\$ 6,000,000$ of bonds and notes and $\$ 27,000,000$ of stock as the total of appraised property in the city, new, was to that in the city and suburbs.

TEstimated at 6 per cent. on $\$ 25,228,500$, the city portion of the property. 
The above figures do not take into account the claims for extraordinary depreciation bronght to the writer's attention during October, in which month the report was being put into final shape. Attention, will be given to it in the pages immediately following. Aside from that item the conclusions from the above table would be that a reduction in the telephone rates of about $\$ 700,000$ could be fairly made.

\section{TOLL EARNINGS AND EXPENSES}

All the expenses of the toll business in the city are included in the operating expenses of the city exchange. The toll revenues include all the money apportioned to the city by the Company. A careful investigation of the subject by Mr. Hall confirms this apportionment, which is like that made by Arthur Young \& Co., accountants, to the Comptroller of the City of Chicago, Walter H. Wilson, February 9, 1911 (Hall, pages 50-1).

The general principle guiding the apportionment of earnings is the assignment to the city of the usual commission to the office originating the call, together with the apportionment of the balance of the receipts on a mileage basis.

\section{MUNICIPAL REQUIREMENTS}

An important source of extraordinary expense to the Telephone Company in the past has been municipal requirements. First came the elevation of the steam railroads, with large expenses required of the Telephone Company in the relocation of its wires. 'Then came various city ordinances, requiring the removal of poles from the streets in all but the outskirts of the city. The expenses for these purposes have been included in the maintenance account, which has shown such a downward trend in the last 20 years. The relocation and burial of the wires have diminished the expenses for maintenance.

Now the Company claims that it may be called on during the next five years to change all of its conduits in the streets where subways have been recommended. These streets are given in the joint report of the Harbor and Subway Commission, and the sub-committee of the City Council Committee on Local Transportation, September 10, 1912. Along the 56 miles of subway recommended to be built during the next five years the Company claims it will lose, in the value of abandoned conduits and cables, $\$ 1,840,000$, and another $\$ 250,000$ in temporary work during subway construction.

After explaining the necessity for abandoning not only conduit lines in the streets to be occupied by the subways, but also "certain subsidiary intersecting underground conduit and cable leads that now eross the proposed subway, the Company estimates that the loss on the underground conduit upon which there will be no salvage will be 
$\$ 1,165,000$, and the loss upon the cable after deducting its salvage value will be $\$ 675,000$. Since the proposed subways will practically cut many of the exchange districts in halves, the maintenance of sufficient crossings to give service to all subscribers is estimated to cost $\$ 250,000$. These estimates are based on the present telephone plant."

The Company asserts that on account of the installation of several large sized telephone cables each year, the cost above mentioned on account of subways will be increased $\$ 100,000$ a year for every year of postponement of subway construction.

While personally a believer in subways for. Chicago, it does not appear to the writer likely that the subway program will be sufficiently advanced to require, within five years, an expenditure by the Telephone Company of more than one-fourth of this $\$ 2,090,000$, or say $\$ 500,000$. Surely no more than this will be required during the first three of the coming five years. Any excess above this, if there be such, during the last year or two of the period, might be considered so extraordinary as to justify its temporary capitalization.

In this connection it may be noted that when the subway plans had not been developed on so large a scale as shown by their latest report, the chief engineer of the Chicago Telephone Company wrote, on March 27, 1912, that a comprehensive system of subways would involve a loss of $\$ 2,300,000$ to the Telephone Company. He wrote:

"We find, however, that the plans for immediate subway construction now being considered by the Subway Commission will involve on!y our plant on Harrison street between Fifth avenue and State street, on State street, from Harrison street to Randolph street, and on Randolph street from State street to Fifth avenue, and a few crossings at other locations. The value of telephone plant which will be destroyed by the subway work involved in these plans is at least $\$ 200,000$.

"That you may get some quantitative idea of the problem, I would advise that we will abandon on Harrison street thirty-two manholes and two conduit runs, which now consist of from twelve to twenty ducts each. Also we will abandon about 22,000 feet of cable.

"In State street we will abandon fifteen manholes and a run of conduit between Madison and Van Buren, with a cross-section of six ducts. We will abandon also in this street about 2,400 feet of cable.

"We will also have fifteen crossings to reroute on Harrison, State and Randolph streets. It is planned that we will require probably seven new crossings."

\section{EXTRAORDINARY DEPRECIATION}

Aside from the startling claim of the Company that its subscribers should pay to it, during the next five years, $\$ 2,090,000$ for expenses on account of the proposed subways and $\$ 100,000$ a year for every year's postponement of such construction, another $\$ 4,216,000$ is claimed on account of extraordinary depreciation. The magnitude of these 
claims was first brought to the writer's attention in letters from the Company October 1st and 5th. Previous letters and conversations had referred only to an expense of about $\$ 200,000$ on account of subways and to the substitution of some new switchboards and the abandonment of two or three central exchanges. The present claim of the tompany, as put in final shape in the enclosed letter of October 10th, has necessitated a few days' further examination. The letter from the Company's chief engineer is given in full:

Oct $10,1912$.

Prof. E. W. Bemis,

City Hall, Chicago.

Dear Sir:

\section{EXTRAORDINARY DEPRECIATION}

We have reviewed carefully our figures submitted in letters to you of October 1st and 5th on extraordinary depreciation and would like to make some modifications which I believe will more clearly represent the true costs involved. The losses involved in the abandonment of buildings and switchboards because of inadequacy or improper location are as follows:

TABLE A

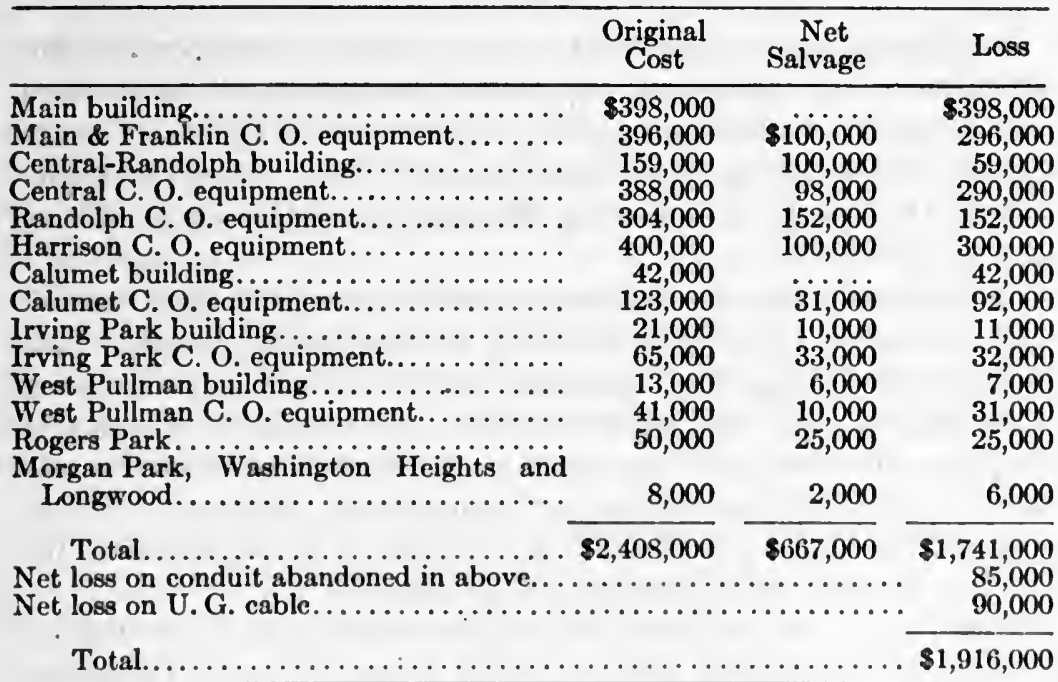

The introduction of the semi-automatic switchboard which you and $I$ saw in New York last spring will also result in the abandonment of the " $B$ " boards and the reconstruction of the " $A$ " boards in all other offices as estimated in the following statement: 
TABLE B

Original cost of Chicago central office switchboards not included in above statement................................. \$3,000,000

Salvage............................... 700,000

Loss on account of semi-automatic switchboard.

$\$ 2,300,000$

The following table will show in detail how we estimated the salvage of $\$ 700,000$ in Table B:

\section{TABLE C}

Total answering jacks, all Chicago exchanges.............. 140,000

Total answering jacks in offices of Table A.................... 40,000

Total answering jacks in offices of Table B................. 100,000

Total "A" sections, all Chicago offices....................... ${ }_{407}$

Total " $\mathrm{A}$ " sections in Table A............................... 154

Total "A" sections in offices of Table B....................

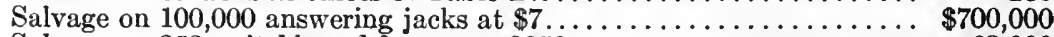

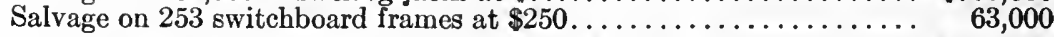

Gross Salvage..................................... $\$ 763,000$

Coat of remodeling 253 " $\mathrm{A}$ " sections at $\$ 200 \ldots \ldots \ldots \ldots \ldots \ldots \ldots \ldots \ldots \ldots, \quad 50,000$

Net salvage.............................. \$713,000 (Say $\$ 700,000$.)

In addition to the above noted losses on buildings and central office equipment which the Company must face, large sums will be involved in the loss of conduit and underground cables should the City go ahead with the subway system now planned. These losses will aggregate $\$ 1,165,000$ for conduit and $\$ 675,000$ for underground cable, a total of $\$ 1,840,000$.

In addition to the above amount, which covers the direct loss of plant destroyed, it would be necessary to do a large amount of temporary work during the construction of the subways in maintaining crossings, etc., over the obstructed streets. In a number of instances the proposed subways will practically cut our exchange districts into halves, and it will be necessary of course at all times to maintain sufficient crossings to enable us to give service to all subscribers. We estimate that this item will amount to $\$ 250,000$.

These two items, or direct loss on plant destroyed and the expense incident to maintaining service during actual subway construction work, together amount to $\$ 2,090,000$, and this figure would represent the estimated total loss to the Telephone Company on account of the construction of passenger subways in these streets.

I have summarized the extraordinary reconstruction in the above tables in the following table: 


\title{
Table D
}

Buildings and switchboards abandoned on account of inadequacy of being not well located ..................................... $\$ 1,916,000$

Additional central office switchboards to be abandoned on account of semi-automatic........................... $2,300,000$

Underground conduit to be abandoned on account of subway con-

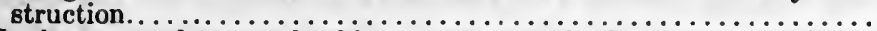

Net loss on underground cables on account of subway construction..

Cost of maintaining service in cables during construction..........

$1,165,000$

675,000

250,000

Total

$\$ 6,306,000$

All of the above estimates have been made on the basis of the present telephone plant. As this plant is growing rapidly, delays in the subway work or in the adoption of the semi-mechanical switchboard or for any other reason, will result in substantial increases in investment for switchboards in the offices involved, and for cables in the streets involved in subway construction, and corresponding increases in the losses which must be met. I would expect these to increase at not less than $\$ 150,000$ per year. Yours truly,

\author{
J. G. WraY, \\ Chief Engineer."
}

It will be observed that this estimates an extraordinary expense during the next five years of $\$ 6,306,000$. Deducting the $\$ 2,090,000$ on account of subways, there remains $\$ 4,216,000$ because of the proposed abandonment of certain buildings and central office equipment.

This matter appeared so serious that the writer felt justified in delaying the report until he could visit all the properties which it was proposed to scrap. We will here consider them in the order in which the chief engineer of the Company believes they should be changed or scrapped.

The scrapping of certain buildings with their equipment, in order to put up better buildings or change the location of the exchanges, will be first considered. We will then take up the displacement of other central office equipment to make room for the semi-mechanical or semi-automatic switchboards.

\section{A. DISPLACEMENT OF OFFICE BUILDINGS AND EQUIPMENTS}

The proposed improvements and changes will be considered below in the order which the chief engineer holds will be followed in actual reconstruction:

1. Harrison Central Office Equipment. This equipment of about 17,389 'phones will soon be transferred to the new Wabash Exchange on Federal street. The Harrison Exchange is in a rented building and some of the switchboards are fourteen years old and somewhat worn. After allowing $\$ 100,000$ for salvage, the net cost of the prop- 
erty discarded plus the cost of moving, are estimated by the Company to involve a net loss of $\$ 300,000$.

2. The Central Exchange. This is a rented building with about 14,000 'phones and is to be transferred within two or three years to the adjoining building known as the Randolph Exchange, on the south side of Washington between Clark and Dearborn. Some of these switchboards were installed as early as 1898 , but some are only six or seven years old, with the latest equipment. The net cost of this re. moval, from Central to Randolph, is given as another $\$ 300,000$.

3. The Morgan Park, Washington Heights and Longwood Exchanges. These exchanges, with only 1,152 'phones in the aggregate, occupy the second floor of rented buildings in the southwestern part of the city. They are to be concentrated in a single exchange at a net cost of $\$ 6,000$.

4. The Irving Park Exchange. This is located on Irving Park boulevard, near $42 \mathrm{~d}$ avenue, and has 5,138 'phones. It is said to be located too far west for the district, whose growth is eastward. The loss in removal from this well-equipped station and good building owned by the Company is given as $\$ 31,000$.

The cost of the four changes above described is estimated by the Company at a total of $\$ 629,953$, but they also claim a further expense during the next five years of $\$ 1,011,047$, as follows:

5. The Rogers Park Exchange. This supplies 2,846 telephone stations and is located near Clark street and Lunt avenue, on the north side. The Company claims that it is too far north and that it should be abandoned, at an expense of $\$ 30,000$.

6. The Calumet Exchange. This is near $22 \mathrm{~d}$ street and Michigan boulevard and supplies about 8,048 stations. It is well equipped, but is in a rear brick building which may be too small if, as is expected, business develops more rapidly in this section than has hitherto been the case. Instead of the rear building, the Company desires to tear down the row of residences which they own in front of the building now occupied by the exchange and put up a large new building. The prospect of doing this within the next five years does not appeal to the writer as very certain.

\%. The Central-Randolph and Randolph Exchanges. Still less likely of immediate accomplishment appears the proposition of scrapping the entire Randolph Exchange, and the Central Exchange, which is to be transferred soon to the Randolph, the idea being to put everything downtown into the Wabash and Main Exchanges, at a cost for scrapping and removal of $\$ 263,000$. The building is comparatively new and is owned by the Company, and serves about 13,000 stations.

8. Main Office Building. Next in point of time is the proposed 
replacement of the main office building on Washington street, with its 16,653 telephones, by a much higher building that will provide room for growth, and be in other ways better fitted for the needs of the Company. The net depreciation on the present building and its equipment is estimated by the Company at $\$ 694,000$. The decision to make this change within the next five years has not been reached and does not appear sufficiently probable to justify its inclusion in the present estimates.

9. The West Pullman Exchange. This exchange, with about 3,092 'phones, is well housed in a building owned by the Company, but a new location a mile farther northwest is thought desirable. The loss in the transfer is computed at $\$ 3,300$, but the Company considers that this can come later than the changes in the main building. It may be omitted from any consideration at present.

If all the nine exchanges were to be removed or scrapped, the Com. pany estimates a net loss in abaidoned conduit and cable of $\$ 175,000$. This added to the $\$ 1,741,000$ loss on buildings and equipments means a total loss, according to the Company, of $\$ 1,916,000$ from the proposed changes in the above central stations. The Company, however, has made a mistake of much importance in its computations. The Company has reached its estimate of losses by a deduction of the estimated salvage from what it calls the original cost in each case. The figures given, however, are not the original cost, but are the higher appraised value new of Byllesby and Arnold.

But a larger mistake than that was made. Byllesby and Arnold depreciate by $\$ 901,964$ the buildings and office equipments which it is proposed to scrap. Since this depreciation was made up by the depreciation reserve already discussed, only the depreciated value less the salvage can nuw be considered. Making this correction on buildings and equipments and in the same manner about $20 \%$ on the conduits and cables, there is left only about $\$ 800,000$ of net loss instead of $\$ 1,916,000$ in case all these exchanges are abandoned within the next five years, as suggested. If only the first six of the exchanges named are thus abandoned, which appear to be the only ones definitely determined upon, the loss after deducting the accumulated depreciation reserve on the particular property in question will not exceed $\$ 350,000$, while if Rogers Park and Calumet are undisturbed the loss will not excecd $\$ 250,000$.

The Company does not claim that in most cases they are under the necessity of removing these exchanges except to secure greater economies in future construction and operation. It may safely be assumed that any expense incurred beyond the $\$ 350,000$ will come back to the Company and the subscriber in economies of one kind or another. 
In taking this position, no reflection is intended upon the sincerity or wisdom of the Company in looking forward to all these changes as desirable. Probably most of them will come in time. The only question is as to how soon.

\section{B. SEMI-MECHANICAL SWITCHBOARDS}

The A. T. \& T. has been making successful use in its laboratory building in New York of a new switchboard sometimes called the semimechanical, sometimes the semi-automatic, which will render possible, it is claimed, not only cheaper operation, but better service. A central station is soon to be equipped in the East with a new board. If it continues to work successfully the chief engineer of the Chicago Telephone Company expects that some boards can be secured in a year and a half or two years for Chicago.

This is the basis for the estimate of the Company that they will displace $\$ 3,000,000$ worth of central office switchboards, at a net loss of $\$ 2,300,000$, during the next five years, or practically in the last three years of the five-year period, and thus make room for the new board. The writer does not see his way to adding anything to the operating expenses of the Company on this account. The practicability of the new switchboard is as yet to be determined. So far as the new board may be introduced it is likely to reduce the operating expenses enough to cover, in a reasonable time, the depreciation charged.

About $25 \%$ of the operators are at the so-called. B boards, which would be no longer needed with the new switchboards. Operators' wages average $\$ 6.76$ per year per station. One-fourth of this, or $\$ 1.69$ would be saved, if the Company's claims for the new switchboard prove true. The saving on the 400,000 telephones which will be in use in the city by the Company by 1915 would be $\$ 676,000$ a year. It would, therefore, seem proper for the savings from the new board to pay for its introduction, which at this rate, it would speedily accomplish, rather than to treat the possibility of introducing this board as a factor in the fixing of rates to-day. The new switchboard may cost more than the old, but any increased interest thereon would leave intact much of the above saving of over $\$ 600,000$ a year.

Furthermore, the appraisers have written off from the present switchboards under discussion over $\$ 800,000$ which is already provided for in the depreciation reserve. This will reduce the amount that would have to be raised from other funds to about $\$ 790,000$.

\section{CONCLUSIONS ON EXTRAORDINARY DEPRECIATION}

If subways should entail a $\$ 500,000$ cost upon the Company, and if a further loss of $\$ 250,000$ in comparison with the present appraised value is incurred in the abandonment or removal of many of its cen- 
tral exchanges, or a total of perhaps $\$ 750,000$, this might mean a further burden upon the subscriber of $\$ 150,000$ a year for the next five years. It is quite possible, however, that the subway cost, when it comes, could be wisely capitalized. With the growth, moreover, in revenues and the larger growth that might come from a reduction in charges, the above mentioned burden would not necessarily be followed by such a reduction in the earnings of the Company as might at first thought be expected. It is, indeed, possible that these anticipated burdens will not materialize to any more serious degree than those which the Company has met in the past without any considerable increase in expenses or reduction in its depreciation reserve.

\section{RESULTS OF THE ORDINANCE OF 1907}

In 1906 and 1907 large reductions were made in telephone rates. No attempt has been made to go back of 1900 , but since January 1 of that year the chief changes have been as follows:

Flat rate business phones were charged $\$ 175$ a year in parts of the city outside of the business center, until 1906, when a court decision led to the reduction of this rate to $\$ 125$. At the same time, in 1906, the charge of $\$ 175$ for a copper metallic circuit, or two-wire system, was reduced to $\$ 125$, and the grounded one-wire circuit disappeared.

The above changes meant a reduction of $\$ 50$ to all flat rate users having return metallic circuit and a reduction of $\$ 50$ to every flat rate business user outside of the center of the city.

On December 1, 1907, the flat rate single line residence 'phones were reduced from $\$ 100$ to $\$ 72$, while the two-party line was reduced from $\$ 75$ to $\$ 56$ and the four-party line at $\$ 60$ was abolished. The fourparty line users could secure a two-party line at $\$ 4$ less than the fourparty line had cost.

Message rate were reduced from 1,000 messages for $\$ 95$ in 1906 to $\$ 80$ in $190 \%$ for the same number of messages, and $\$ 60$ thereafter. The charge for 3,000 messages similarly fell from $\$ 162$ in 1906 to $\$ 150$ in 1907 , and $\$ 114$ in 1908 , while for 5,000 messages it fell from $\$ 222$ in 1906 to $\$ 210$ in 1907 , and $\$ 160$ in 1908.

Extension phones which had been $\$ 12$ to $\$ 30$ in 1905 , were reduced to $\$ 6$ in December, $190 \%$.

On nickel 'phones great reductions were made in 190\%. Instead of guarantecing 10 cents a day and securing two messages on a ten-party line, a business man now, for $12 \mathrm{r} / 2$ cents, can have two messages a day on a two-party line and extra messages at 5 cents each. On a twoparty nickel line a business man formerly must guarantee 20 cents securing thus four messages. He is now charged the same amount on a single party nickel line. 
In case of residences, a person now guaranteeing a nickel a day has the use of a four-party line, while before December, 1907, he had only the use of a ten-party line for the same charge.

A subscriber to a neighborhood exchange formerly paid 10 cents toll for telephoning to anybody outside of his exchange, while a person outside telephoning him must also pay 10 cents; but since December 1 , $190 \%$, the charge to the neighborhood exchange subscriber was reduced to 5 cents and no charge was made to any other subscriber within the city limits for telephoning messages to the neighborhood exchange subscriber.

The total reduction in earnings per telephone was from $\$ 49.74$ in 1906 to $\$ 39.72$ in 1908 . This total fall of $\$ 10.02$, if multiplied into the number of telephones in use at the close of 1908 of 231,180 , would mean a reduction of over $\$ 2,300,000$ that took place in the city and suburbs-mostly in the city-during those two years. This decline in revenue per telephone, together with the cost of transforming the 10-party to 4-party lines, made a considerable reduction in the ratio of net earnings to investment.

The net return, before making any allowance for additions to the depreciation reserve, fell from $13.82 \%$ in 1906 to $7.10 \%$ in 1908 . The dividends, however, were not affected, but during 1908 and 1909 nothing was added to the depreciation reserve. The growth of business and earnings was so great in 1910 and 1911 that over $\$ 1,000,000$ a year in the city and suburbs was put into the depreciation reserve in addition to the regular $8 \%$ dividend.

The earnings before deductions for depreciation reserve bore the following relation to the average investment as shown by the books during the year in question. The number of telephones at the end of each year is also given for city and suburbs:

Table 20

EARNINGS AND TELEPHONES SINCE 1904

\begin{tabular}{|c|c|c|}
\hline Year & $\begin{array}{l}\text { Ratio of } \\
\text { Earnings to } \\
\text { Investment } \\
\text { (Per Cent.) }\end{array}$ & $\begin{array}{l}\text { Number of } \\
\text { Telephones }\end{array}$ \\
\hline 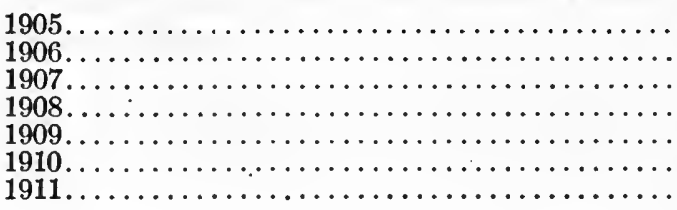 & $\begin{array}{r}14.60 \\
13.82 \\
8.12 \\
7.10 \\
8.25 \\
9.89 \\
9.89\end{array}$ & $\begin{array}{l}143,223 \\
170,834 \\
202,681 \\
231,180 \\
262,359 \\
300,618 \\
335,652\end{array}$ \\
\hline
\end{tabular}




\section{IMPROVEMENT IN THE SERVICE}

The public have a right to be, and are, as much interested in good service as in low rates. Poor service, with resulting dissatisfaction, even though accompanied with a saving in operating expenses, is no benefit in the long run to a company.

Widely diverse opinions prevail in the city as to the success of the Company in trying to give good service. No system of regulation, however, which stops short-as all regulation everywhere has doneof allowing the public regulating body to appoint both the manager and a majority of the board of directors, would promise any complete solution. Such a solution might easily involve other difficulties as great as those removed by it, and anyway need not be considered as needed or practicable in Chicago.

Something, however, could and should be done. Some means should be deyised for better protection to the public against possible carelessness and give it greater confidence that its just complaints are being properly met.

\section{CITY TELEPHONE BUREAU}

It would be to the advantage alike of the Company and of the public if the city maintained a properly equipped bureau for receiving and investigating all complaints of service. Telephone users often believe that they cannot secure proper consideration of their grievances, and so do not attempt to present them, but disseminate somewhat widely among their friends their opinion of the company.

If such a bureau were open for all complaints and took them up promptly with the Company, the latter would soon be spurred on by public opinion to approve any conditions that could easily be improved If this could be done, the bureau's reports to the Council would doubtless be followed by efficient action. Provided, as the evidence seems to show, that the Company really desires to give good service, such a bureau would be a great help also to the Telephone Company. The latter would, in some cases, learn, and thus more speedily improve, the weak points in the system, and in other cases it would doubtless convince the bureau, and through the latter the public, that some of the complaints were not well founded.

There is ample precedent for such a course by the city in the offices which are now being maintained for the inspection of gas and electricity and traction service. If desired, the scope of the bureau could include the systematic gathering of information so that councilmanic action may be easier when it next becomes necessary, five years hence, to fix the rates. Such investigations are constantly being made for the Massachusetts Highway Commission, which controls the New England Telephone and Telegraph Company. 
The present telephone ordinance (Sec. 2) lodges some of the work here proposed with the City Comptroller, but it does not go far enough. It gives him the right to examine the accounts and records of the Company, but does not appear to create any complaint department or intermediary between the public and Company, such as is now proposed. Whether the power of the Comptroller should be increased to cover the whole subject, or whether the work should be given to the City Electrician, to the Secretary of the Gas, Oil and Electric Light Committee, or some one else, is a question both of law and policy upon which no opinion is now expressed.

\section{MEASURED SERVICE FOR RESIDENCES}

While the present report does not take up specified changes in rates, but only the question of whether the rates as a whole can be changed and how much, it is nevertheless important, and in accordance with the desire of the Committee, that a reference be made to three other subjects, nickel 'phones, subscribers' meters and the character of the service.

The nickel coin box is popular and needed in drug stores and many other public places. In many residences it is also desired. This is especially true where there is danger of abuse by neighbors imposing on the good nature of the telephone subscriber, or where it is desired to pay 5 cents per call rather than to pay a month's use at one time.

On the other hand, some are much opposed to the nickel 'phones, and a considerable portion of the subscribers to the 2-party and 4-party nickel 'phones in residences apparently would be better pleased to pay for their calls by the month without any use of nickels or slugs. Such a service is offered in some other large cities in the form of a measured residence service for either 1-party, 2-party or 4-party lines. It is believed that a rate can be adopted sufficiently attractive to enable those who are dissatisfied with the nickel 'phones to take the new service. A certain payment per month would be guaranteed, and all calls in excess of what that amount calls for at, say, 5 cents, would be paid for at the end of the month as in the case of the nickel 'phones; or, a readiness to serve charge per month could be made, and a lower calling rate than 5 cents could be adopted.

\section{METERS}

The Company has already equipped a large portion of its present measured service lines, which are chiefly on business places, with meters at the central offices, known as Central Office Message Registers, and 
expects to finish the entire installation within four months. A meter for the use of subscribers, whether business or residence, who have a single-party measured line, has been developed by the A. T. \& T. and sufficiently tested on about 200 business premises in Chicago to show that it is practicable.

When the Maryland Public Service Commission issued on order, some months ago, for abolishing all flat rate business lines-an order whose execution has been postponed pending further investigation-it was provided that any parties who desired one of these meters could have it on payment of 25 cents a month, or $\$ 3$ a year. The Commission inrestigated the meters on the market and considered the one offered by the A. T. \& T. to be the best and most reliable. The cost of $\$ 3$ a year was considered by the Commission to be only a fair payment for the investment and for the care and depreciation of the same. Not one per cent. of those who were expecting to come immediately under the metered service erer applied for a meter.

Very few using the meters in this city think there is sufficient evidence of mistakes in the bills of the Company to warrant their bothering to have the device, even if free. Very few, indeed, express any belief that it is useful enough to warrant their paying even the small rental for it.

Under these circumstances it would seem a mistake to burden the rates of all the subscribers with a device which few appear to want, yet it would be well to provide that any one might have this meter if he desires to pay $\$ 3$ per year for it.

There appears to be no meter on the market to-day for 2-party and 4-party measured lines. Where such service is given, as in Boston and Baltimore, a record is kept on paper slips by the operators, as has been the case until recently, and still is to some extent with measured business lines here.

A recording device that will show to the subscriber the number of coins or slugs that have gone into the coin box would be popular with the subscriber and would also be a check for the telephone company upon its collectors. But there seems to be no such device at present in use by any telephone company, whether Bell or independent. If the suggestion for measured service is adopted for residences there would be less need for such registers, since many of those who are dissatisfied with this and other features of the coin box would doubtless change to measured service.

\section{CONCLUSIONS}

In the light of all the above, a reduction of $\$ 700,000$ in the charges of the Chicago Telephone Company within the city limits appears reasonable. Such a reduction can be met by the Company in several ways. 
1. Instead of putting about $\$ 975,000$ into the depreciable reserve, as in the city exchange in $1911, \$ 500,000$ may be set aside for that purpose until repairs and the cost of station removals, now amounting to about $7.5 \%$ of the plant investment, shall decline further, as they are likely to do. Even the $\$ 500,000$ left in the reserve on this supposition, together with the actual repairs and removals of 1911, would bring the total maintenance and depreciation expense only to $9 \%$. This item, like the Chicago expense for station removals, is higher than the average for the Bell companies, either as a whole or in the larger cities.

If $\$ 475,000$ of the proposed reduction of $\$ 700,000$ be taken from the depreciation reserve, the remaining $\$ 225,000$ may be secured by a reduction of the dividend on the company as a whole from $8 \%$ to $7.1 \%$, or on the city portion thereof to $63 / 4 \%$. Since the American Telephone and Telegraph Company, which owns nearly all of the stock, collects in rentals within the city about $\$ 200,000$ more than the service appears to cost, or about $1 \%$ on the stock, a reduction in the dividend rate to $6 \frac{1}{2} \%$ or $7 \%$ seems not unreasonable.

2. For maintenance and depreciation $91 / 2 \%$ might be allowed. On this basis the reduction in last year's additions to the reserve would be about $\$ 350,000$. The remaining reduction of $\$ 350,000$ could be secured by a reduction of the dividend on the city part of the stock to $61 / 4 \%$. Since the A. T. \& T. would, on this hypothesis, continue to receive the excess rental, that would virtually mean a three-fourths per cent. further dividend.

3. Another solution, in lieu of part of the reduction of dividends, suggested above, would be the reduction of the rental. This is about $13 / 4 \%$ on all the property and about $21 / 4 \%$ on the stock, or about $\$ 1.75$ per 'phone. Of the $\$ 445,550.72$ paid in 1911 and of the $\$ 175,000$ or more that will be paid in 1912, $\$ 200,000$ could apparently be deducted by the local company, and still leave the A. T. \& T. a reasonable return.

4. Still another treatment of the matter would be a smaller reduction in the dividend and the utilization of the $1 \%$ profit obtaining by loaning to the Central Union at $6 \%$ the proceeds of over $\$ 10,000,000$ of the $\$ 14,000,000$, of $5 \%$ bonds lately sold by the Chicago Telephone Company. As this money is gradually withdrawn from the Central Union to meet the construction needs of the Chicago Company, the maintenance of a $7 \%$ or $8 \%$ dividend rate will represent a smaller percentage of the total investment than now. Taking the city and suburban divisions together, the case stands thus: 
PHYSICAL VALUATION OF CHICAGO TEL. COS.

TABle No. 21

DECLINING RATE OF RETURN

\begin{tabular}{|c|c|c|c|c|c|c|}
\hline & \multicolumn{2}{|c|}{ Amount } & \multicolumn{2}{|c|}{ Return } & \multicolumn{2}{|c|}{$\begin{array}{c}\text { Per Cent. of } \\
\text { Return on } \\
\text { Total } \\
\text { Securities }\end{array}$} \\
\hline & 1911 & 1916 & 1911 & 1916 & 1911 & 1916 \\
\hline & & & \multicolumn{2}{|c|}{ Dividends at $8 \%$} & & \\
\hline \multirow[t]{2}{*}{ Stock. . } & \multirow[t]{2}{*}{$\$ 27,000,000$} & \multirow[t]{2}{*}{$\$ 27,000,000$} & $\$ 2,160,000$ & $\$ 2,160,000$ & & \\
\hline & & & \multicolumn{2}{|c|}{ Interest at $5 \%$} & - & \\
\hline Bonds and notes & $6,000,000$ & $20,000,000$ & 300,000 & $1,000,000$ & & \\
\hline Total..... & $\$ 33,000,000$ & $\$ 47,000,000$ & $\$ 2,460,000$ & $\$ 3,160,000$ & 7.45 & 6.72 \\
\hline
\end{tabular}

Without any reduction in the rate of return on the stock and bonds the larger proportion of bonds now assured will reduce the average rate of return on all these securities from $7.45 \%$ to $6.72 \%$. It may be remarked that all of the new $5 \%$ bond issue of $\$ 14,000,000$ has netted the Company about par or a trifle above.

5. Outside of the expense that may be entailed by subway construction in 1915-17, or the last three years of the coming five-year period, there seems little in the claim for a special allowance for extraordinary depreciation.

It is assumed that little if any expense will be incurred on account of subway construction in 1913 , and that the expense to the Chicago Telephone Company will not exceed $\$ 125,000$ a year thereafter, or that the excess should be capitalized. When the rates are again adjusted, five years hence, this matter can be more intelligently treated.

It is believed that a reduction of $\$ 700,000$ in telephone rates will stimulate the growth of the company, and leave enough in the maintenance and in the depreciation reserve to meet the needs of the next five years, and with such extraordinary needs as are likely to develop from the change of central stations, displacement of switchboards or subway construction. It will also leave a fair return to the owners of the property. If, however, the new ordinance should provide, as it well may, for a measured service to take the place of the nickel service for those who desire to make the change, the cost to the company of this change, divided over the five-year period, should be deducted from the above $\$ 700,000$ a year.

Moreover, the ability of the company to stand this reduction in revenue will be affected by how it is done. The importance of a wise readjustment of the rates among over twenty classes of service can hardly be exaggerated. 
If the Company were not confronted with the expenses and loss of business that to some extent may attend the competition of the rival company-the Illinois Tunnel Company-with its automatic telephones, a lower rate of return on capital might be demanded. If this competition, however, should become at all serious, the Chicago Telephone Company might be expected to reduce rates voluntarily as much as is here advised.

While operating expenses per telephone are increasing, the investment per telephone is decreasing and the business is rapidly growing. The number of telephones in the city, aside from the 25,000 or more of the rival company, grew from 268,383 on December 31,1911 , to 298,380 on Octiber 28, 1912, an increase in the ten months of about 30,000 , as compared with an increase of only 29,300 in the previous twelve months.

This situation, joined to the ability of the Company to finance its extensions for three or four years out of the $\$ 14,000,000$ of $5 \%$ bonds just floated, may permit the Company to make the suggested reduction in rates without any cut whatever in its $8 \%$ dividend or in its rental to the A. T. \& T.

In no inrestigation hitherto conducted by the writer has a company pursued as open a policy with respect to its books and methods as has the Chicago Telephone Company, and in turn the writer has endeavored to give due weight to all considerations affecting both the welfare of the Company and the just demands of the public.

EDWARD W. BEMIS. 
Appendix 1

CONDENSED BALANCE SHEETS, 1881 TO 1911, INCLUSIVE*

Assets

Invested in plant.

Invested in real estate.

Other investments.

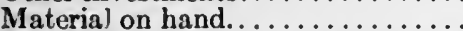

Furniture, fixtures, tools and teams.

Bonds (sundry)................

Bills and accounts receivable......

Balanee of bills and accounts.......

Payable and receivable..........

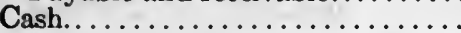

Total assets.

Liabilities

Capital stock.

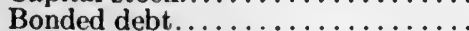

Reserve for deferred maintenance..

Reserve for taxes..............

Reserve for insurance fund.........

Reserve for depreeiation on buildings

Bills and accounts payable.........

Balance of bills and accounts payable and receivable............

Miscellaneous reserves............

Surplus...................

Total liabilities.

1881

$\$ 490,928.99$

$2,537.00$

8,65738

$99,432.13$

$50,089.92$

$\$ 651,645.42$

1881

$\$ 500,000.00$

$46,284.32$

$25,883.71$

$21,931.05$

$34,000.00$

$71,361.10$

$\$ 651,645.42$

1882

$\$ 561,038.19$

$2,537.00$

$5,068.42$

$30,000.00$

$21,614.52$

39,006. 16

1882

$\$ 500,000.00$

$\$ 600,000.00$

$\$ 621,606.72$

$2,000.00$

$6,309.60$

$50,000.00$

$37,224.16$

$34,332.09$

$\$ 751,472.57$
$\$ 659,264.29$

1883

$50,000.00$

$83,380.58$

$\$ 659,264.29$
$58,500.00$

$71,041.52$

$\$ 751,472.57$

*Mr. Hagenah's Report, pages 7-10, for 1881-1900, and Hall's Report, Exhibit M., for 1901-11.

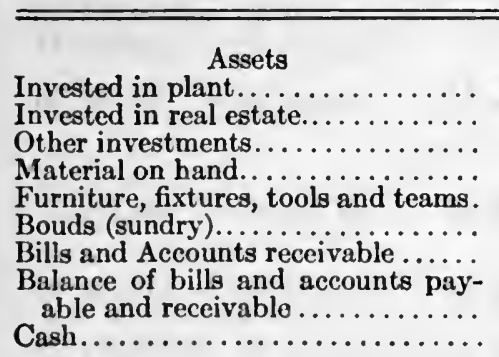

Total assets.

Liabilities

Capital stock.

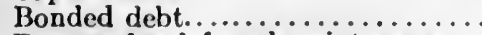

Reserve for deferred maintenance..

Reserve for taxes.............

Reserve for insurance fund.........

Reserve for depreciation on buildings

Bills and aceounts payable.........

Balance of bills and accounts payable and receivable..............

Miscellaneous reserves............

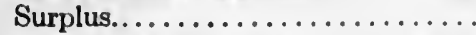

Total liabilitics.............
1884

$\$ 653,743.16$

$1,000.00$

$7,773.25$

$50,000.00$

$34,050.18$

1885

$\$ 732,388.05$

500.00

$11,470.71$

$10,770.33$

$50,000.00$

$115,022.74$

$50,000.00$

$117,445.54$

$45,236.55$

$\$ 791,803.14$

1884

$\$ 693,000.00$

$54,899.32$

$62,903.30$

$\$ 964,280.82$

$\$ 1,046,437.89$

1885

$\$ 762,300.00$

1886

$\$ 838,600.00$
$27,131.53$

$127,440.71$

$118,656.15$

$65,500.00$

$6,171.61$

$\$ 791,803.14$
$74,500.00$

40.11

$82,500.00$

$6,681.74$
$\$ 964,280.82 \quad \$ 1,046,437.89$ 
Appendix 1-Continued

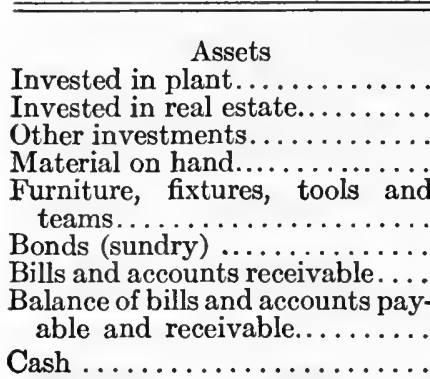

Total assets.............

\section{Liabilities}

Capital stock

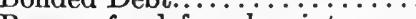

Reserve for deferred maintenance

Reserve for taxes............

Reserve for insurance fund......

Reserve for depreciation on buildings

Bills and accounts payable.......

Balance of bills and accounts pay-

able and receivable..........

Miscellaneous reseves............

Surplus.................

Total liabilities...........
1887
$\$ 884,313.15$

$92,722.32$

$8,970.38$

$25,000.00$

$175,998.12$

$49,064.31$

$\$ 1,236,068.28$

1887

$\$ 964,400.00$

$175,908.01$

$144,339.29$

$145,091.04$

$92,500.00$

$3,260.27$

$\$ 1,236,068.28$

1890

1891

$94,000.00$

$8,046.13$

$\$ 1,336,185.42$

$\$ 1,574,720.41$
Assets

Invested in plant............

Invested in real estate.........

Other investments ..........

Material on hand.............

Furniture, fixtures, tools and

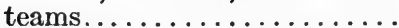

Bonds (sundry).............

Bills and accounts receivable...

Balance of bills and accounts payable and receivable..........

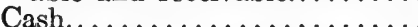

Total assets............

\section{Liabilities}

Capital stock

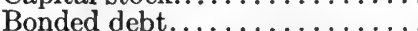

Reserve for deferred maintenance

Reserve for taxes............

Reserve for insurance fund......

Reserve for depreciation on buildings..................

Bills and accounts payable......

Balance of bills and accounts payable and receivable.........

Miscellaneous reserves...........

Surplus....................

Total liabilities............
$\$ 1,734,212.73$

$34,098.51$

$\$ 2,160,392.41$

$150,127.25$

$52,606.81$

$596,698.49$

$99,784.02$

$30,159.66$

$\$ 2,395,169.39$

1890

$\$ 1,754,700.00$

$58,473.54$

$\$ 2,521,384.03$

1891

$\$ 2,000,000.00$

$35,308.02$

$397,056.85$

$242,493.13$

$125,700.00$

$117,712.54$

$\$ 2,395,169.39$
$133,462.97$

$110,119.91$

$158,306.07$

$110,094.33$

$\$ 2,521,384.03 \$ 3,825,457.73$
$16,628.67$

$260,228.66$

$\$ 3,082,262.20$

$332,761.17$

$74,760.30$

$142,191.17$

$193,482.89$

$\overline{\$ 3,825,457.73}$

1892

$\$ 3,280,200.00$ 
Appendix 1-Continued

\begin{abstract}
Assets
Invested in plant..............

Invested in real estate...........

Material on hand.............

Bills and accounts receivable....

Cash....................
\end{abstract}

Total assets.

\section{Liabilities}

Capital stock............... Reserve for deferred maintenance Reserve for taxes............. Bills and accounts payable...... Miscellaneous reserves.......... Surplus.

Total liabilities

$$
\text { Assets }
$$

Invested in plant............

Invested in real estate..........

Material on hand................

Bills and accounts receivable....

Cash.

Total assets.

Liabilities

Capital stock.

Reserve for deferred maintenance Reserve for taxes.

Bills and accounts payable......

Miscellaneous reserves.........

Surplus.

Total liabilities.
1893

$\$ 3,668,190.38$

$332,849.17$

$118,078.67$

$156,772.67$

$90,806.38$

$\$ 4,366,697.27$

\section{3}

$\$ 3,796,200.00$

..........

$57,358.06$

$197,122.39$

$187,092.77$

$128,924.05$

$\$ 4,366,697.27$

1896

$\$ 4,255,047.92$

$352,861.42$

$73,199.00$

$93,223.87$

$315,647.18$

$\$ 5,094,979.39$

1896

$\$ 4,336,500.00$

$200,889.40$

$81,428.31$

$143,311.56$

$17,643.47$

$315,206.65$

$\$ 5,094,979.39$
1894

$\$ 3,821,356.76$

$338,632.62$

$59,800.00$

$151,399.39$

$139,906.08$

$\$ 4,511,094.85$

1894

$\$ 3,796,200.00$

$120,000.00$

43,702.36

$220,375.64$

$189,960.81$

$140,856.04$

$\$ 4,511,094.85$

1897

$\$ 4,192,868.40$

$352,861.42$

$70,407.99$

$87,882.07$

$453,454.69$

$\$ 5,157,474.57$

1897

$\$ 4,336,500.00$

$100,000.00$

$90,747.85$

$188,165.58$

$22,541.02$

$419,520.12$

$\$ 5,157,474.57$
1895

$\$ 4,169,686.09$

$351,753.20$

$54,234.84$

$165,309.74$

$83,417.31$

$\$ 4,824,401.18$

1895

$\$ 3,796,200.00$

$200,889.40$

$77,065.26$

$329,656.24$

$156,364.61$

$264,225.67$

$\$ 4,824,401.18$

1898

$\$ 4,814,774.55$

$359,973.92$

$102,726.45$

$229,566.53$

$181,902.02$

$\$ 5,688,943.47$

1898

$\$ 4,336,500.00$

$474,782.22$

$60,536.97$

$257,549.72$

$26,482.16$

$533,092.40$

$\$ 5,688,943.47$

APPENDix 1-Continued

Assets

Invested in plant.

Invested in real estate.

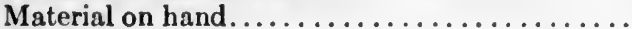

Bonds (sundry).....................

Bills and accounts receivable..............

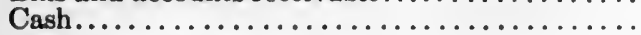

Total assets.

\section{Liabilities}

Capital stock. . . . . . . . . . . . . . . . . .

Reserve for deferred maintenance............

Reserve for taxes.....................

Bills and accounts payable................

Balance of bills and accounts payable and receiv-

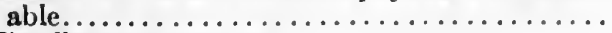

Miscellancous reserves...................

Surplus.........................

Total liabilities.
1900

$\$ 7,190,012.19$

$932,040.42$

$221,338.67$

$15,000.00$

$202,762.11$

$73,597.13$

$\$ 7,070,683.82$

1899

$\$ 5,000,000.00$

903.934 .14

$99,569.71$

$387,686.24$

$2039 \ddot{3} \ddot{3}$

$650,102.38$

$10,03 \dot{0} 3 \dot{3}$

$\$ 8,368,430.63$

1900

$\$ 7,000,000.00$

$463,578.49$

$73,222.74$

..........

$637,500.62$

$17,897.14$

$176,231.64$

$\$ 8,368,430.63$ 
Appendix 1-Continued

$==1$ Assets $1901-1902-1903$

Investment in real estate, plant, etc..................... Real estate..................... Plant, equipment, etc....... Construction in process........

Total investment in real estate, plant, etc................

Current and working assets-

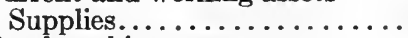

Total working assets.......... Cash and deposits........... Bills receivable................ Accounts receivable.......... Prepaid expenses............

Total current assets...........

Total current and working assets.

Stocks and bonds..........

Total.................

.

$\begin{array}{r}\$ 1,045,658.77 \\ 8,882,483.67 \\ 5,338.03 \\ \hline\end{array}$

$\$ 1,111,644.96$ $10,543,174.81$ $679,034.43$

$\$ 1,273,735.59$ $12,635,532.79$

$\$ 9,933,480.47 \$ 12,333,854.20$

$\$ 13,909,268.38$

\section{}

$\$ 355,215.77$

$355,215.77$

$353,703.80$

$3,410.06$

$329,141.12$

$11,893.29$

$698,148.27$

$\frac{\$ 1,053,364.04}{15,000.00}$

$\$ 312,242.90$

$312,242.90$

$434,541.52$

$3,396.93$

$549,431.16$

$15,006.62$

$1,002,376.23$

$\$ 11,001,844.51$

$\$ 1,314,619.13$

$14,500.00$

$\$ 366,103.78$

$366,103.78$

$547,640.00$

$1,569.31$

$719,758.30$

$26,223.40$

$1,295,191.01$

$\$ 1,661,294.79$

$125,036.75$

$\$ 15,695,599.92$

Liabilities

1901

1902

1903

Capital liabilities-

Capital stock...

$\$ 9,315,900.00 \$ 11,993,400.00 \$ 14,000,000.00$ $100,000.00$

Total capital liabilities.

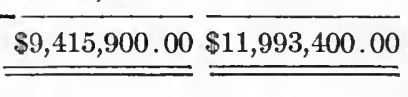
$\overline{\$ 14,000,000.00}$

Current liabilities-

Accounts payable........... Accrued liabilities not due.... Unearned revenue. .........

Total current liabilities.........

Depreciation and other reservesDepreciation of plant......... Other reserves................

Total depreciation and other reserves...................

Surplus.

\begin{tabular}{|c|c|c|}
\hline $\begin{array}{r}\$ 837,436.01 \\
140,611.28 \\
5,484.71\end{array}$ & $\begin{array}{r}\$ 371,381.91 \\
183,419.61 \\
36,591.38\end{array}$ & $\begin{array}{r}\$ 277,497.06 \\
238,972.29 \\
46,336.56\end{array}$ \\
\hline$\$ 983,532.00$ & $\$ 591,392.90$ & $\$ 562,805.91$ \\
\hline
\end{tabular}

\begin{tabular}{rrr}
$\$ 296,432.87$ & $\$ 346,551.32$ & $\$ 646,551.32$ \\
$5,875.74$ & $304,246.44$ \\
\hline
\end{tabular}

$\frac{\frac{\$ 302,308.61}{\$ 300,103.90}}{=\frac{\$ 650,797.76}{\$ 427,382.67}}=\frac{\$ 668,026.81}{\$ 464,767.20}$

Total................ $\$ 11,001,844.51 \$ 13,662,973.33 \$ 15,695,599.92$ 
PHYSICAL VALUATION OF CHICAGO TEL. COS. 863

Appendix 1 - Continued

$\begin{array}{llll}\text { Assets } & 1904 & 1905 & 1906\end{array}$

Investment in real estate, plant, etc. -

Real estate...............

Plant, equipment, etc..........

Construction in proeess.......

Total investment in real estate, plant, etc................

Current and working assets:

Office furniture and fixtures...

Tools and vehicles...........

Supplies..................

Total working assets...........

Cash and deposits..........

Bills receivable..............

Aceounts receivable.........

Prepaid expenses.........

Total current assets

$\$ 1,346,560.20$

$13,208,689.17$

$\$ 1,509,895.25$

$14,317,138.17$

$\ldots \ldots \ldots \ldots . \quad 88.87$

$\$ 1,764,281.40$

$16,706,425.90$

\$36.28

$\$ 14,555,249.37 \$ 15,827,122.29 \$ 18,470,371.02$

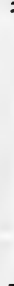

Total current and working assets.

.Stocks and bonds...........

Total.

$\$ 10,137.29$
$27,799.50$
$173,156.42$
$211,093.21$
$511,312.69$
$501,709.09$
$762,384.17$
$13,124.91$

$\$ 1,788,530.86$

$\$ 1,999,624.07$

$\$ 114,650.07$

$\overline{\$ 16,669,523.51}$



1904

1905

$\$ 19,745.56$

$83,885.85$

$125,424.67$

$229,056.08$

$251,321.36$

$852,581.59$

$489,946.91$

$3,667.33$

$\$ 1,597,517.19$

$\$ 1,826,573.27$

$\$ 104,263.39$

$\overline{\$ 17,757,958.95}$

$17,757,958.95$

$\$ 44,958.70$

$169,056.85$

$411,445.63$

$625,461.18$

$19,084.94$

$12,547.21$

$674,646.28$

$1,833.33$

$\$ 708,111.76$

$\$ 1,333,572.94$

$\$ 93,876.74$

$\overline{\$ 19,897,820.70}$

Liabilities

1906

Capital liabilities-

Capital stock....

Loans by banks. ...............

$\$ 14,000,000.00 \$ 14,000,000.00$

$\ldots \ldots \ldots \ldots \ldots \ldots$

$\$ 14,000,000.00 \$ 14,000,000.00$

Total capital liabilities.

Current liabilities-
Bills payable (Western Elec-

tric Company) ...........

Accounts payable...........

Accrued liabilities not duc....

Unearned revenue. .........

Total current liabilities.........

Depreciation and other reservesDepreciation of plant.........

Insurance fund.............

Other reserves.............

Total depreciation and other reserves...................

Surplus..................

Total...............

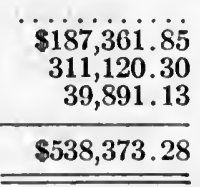

$\$ 913,825.83$

$\ldots \ldots \ldots \ldots$

$588,941.12$

$\$ 1,502,766.95$

$\$ 628,383.28$

$\$ 16,699,523.51$

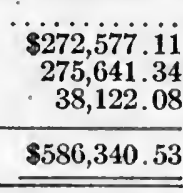
$\$ 1,295,155.61$
$150,000.00$
$871,268.52$

$\$ 500,000.00$

$1,188,901.94$

$370,708.04$

$34,242.31$

$\$ 2,093,852.29$

$\$ 1,692,066.24$

$175,000.00$

$613,563.50$

\footnotetext{
* Decrease.
} 
Appendix 1-Continued Assets
$\begin{gathered}\text { Investment in real estate, plant, } \\ \text { etc. - }\end{gathered}$

Real estate................ Plant, equipment, etc.......... Construction in process........

Total investment in real estate, plant, etc.................

Current and working assets-

Office furniture and fixtures...

Tools and vehicles...........

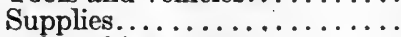

Total working assets..........

Cash and deposits............

Bills receivable...............

Accounts receivable..........

Prepaid expenses...........

Total current assets.............

Total current and working assets.

Stocks and bonds..........

Total.

$\$ 2,320,934.53$

$24,151,045.70$

$173,066.33$

$\$ 26,644,146.56$

$=$

$\$ 104,776.34$

$263,296.53$

$399,997.23$

$768,070.10$

$157,837.03$

$12,356.20$

$864,668.69$

$30,745.79$

$1,065,607.71$

$\$ 1,833,677.81$

$\$ 92,819.93$

$\$ 28,570,644.30$

$\$ 2,551,487.92$
$25,206,641.39$
$909,225.82$

$\$ 2,749,985.66$

$26,787,282.71$

$1,053,058.65$

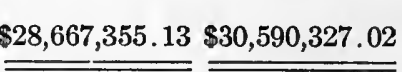

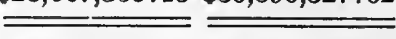

$\$ 145,692.99$

$288,570.48$

$458,221.16$

$892,484.63$

$455,364.17$

$12,429.61$

$771,079.24$

$5,951.23$

$1,244,824.25$

$\$ 2,137,308.88$

$\$ 82,933.27$

$\overline{\overline{\$ 30,887,597.28}}$

$\$ 36,157,170.80$

$\$ 167,158.95$

$261,530.67$

$521,111.25$

$949,800.87$

$3,758,692.10$

828.79

$727,823.80$

$57,110.22$

$4,544,454.91$

$\$ 5,494,255.78$

$\$ 72,588.00$

Liabilities

1907

1908

1909

Capital liabilities:

Capital stock

First mortgage $5 \%$ bonds.....

Loans by banks.

Total capital liabilities. ........

Current liabilities-

Bills payable (Western Electric Company) .............

Accounts payable............

Accrued liabilities not due....

Total current liabilities........

Depreciation and other reservesDepreciation of plant......... Insurance fund..............

Other reserves.................

Total depreciation and other reserves....................

Surplus.

$\$ 17,564,811.78 \$ 27,000,000.00 \$ 27,000,000.00$

$\because \ldots \ldots \ldots \ldots \ldots \ldots$

$5,000,000.00$

$1,385,000.00$

$\$ 18,949,811.78 \$ 27,000,000.00 \$ 32,000,000.00$

$=$

$=$

$\$ 300,000.00$

$1,371,687.26$

$290,093.33$

$\$ 397,580.48$ $295,679.92$

$\$ 430,066.31$

$618,226.99$

$\$ 1,961,780.59$

$\$ 1,899,613.46$

$200,000.00$

$\$ 693,260.40 \$ 1,048,293.30$

$449,495.78$

$\$ 1,901,739.25$

$211,809.10$

$396,110.50$

$\$ 1,901,739.25$

$278,298.22$

$183,454.44$

$\$ 2,549,109.24 \quad \$ 2,509,658.85 \quad \$ 2,363,491.91$

$\$ 5,109,942.69$

$\$ 684,678.03$

$\$ 745,385.59$

Total

$\$ 8,570,644.320$ 


\section{APpENDIx $1-$ Continued}

\section{Assets}

Investment in real estate, plant, etc.-

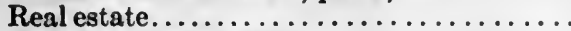

Plant, equipment, etc...............

Construction in process.

Total investment in real estate, plant, ctc....

Current and working assets-

Office furniture and fixtures.............

Tools and vehicles................

Supplies.

Total working assets. . . . . . . . . . . . . . .

Cash and deposits. ...............

Bills receivable......................

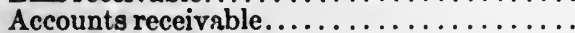

Prepaid expenses. . . . . . . . . . . . . . . .

Total current assets..................

Total current and working assets.........

Stocks and bonds

Total.

\section{Liabilities}

Capital liabilities-

Capital stock.

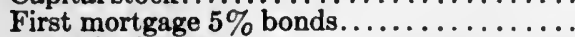

Loans by banks. ....................

Total capital liabilities

\section{Current liabilities-}

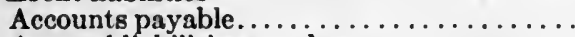
Accrued liabilities not due............

Unearned revenue.

Total current liabilities.

Depreciation and other reserves-

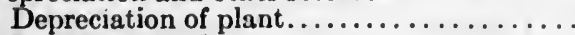

Insurance fund $\ldots \ldots \ldots \ldots \ldots \ldots \ldots \ldots$

Other reserves.

Total depreciation and other reserves

Surplus.

Total.

1910

1911

$\$ 2,868,606.51$ $29,229,242.13$

$1,261,689.21$

$\$ 33,359,537.85$

$\$ 126,869.53$

$284,467.69$

$703,414.63$

$1,114,751.85$

$1,820,503.51$

$289,757.84$

$592,857.04$

$68,379.31$

$2,771,497.70$

$\$ 3,886,249.55$

$\$ 642,966.24$

$\$ 37,888,753.64$

1910

$\$ 27,000,000.00$ $5,000,000.00$

.............

$\$ 32,000,000.00$

ב.-.

$\$ 950,872.61$

$585,795.18$ $1,950.91$

$\$ 1,538,618.70$

$\$ 3,695,160.95$

$291,400.65$

$268,500.41$

$\$ 4,255,062.01$

$\$ 95,072.93$

$\$ 37,888,753.64$
$\$ 3,204,445.31$

$33,250,656.82$

$1,258,076.27$

$\$ 37,713,178.40$

$\$ 178,635.70$

$304,100.40$

$831,629.65$

$1,314,365.75$

$874,947.62$

636.14

$686,973.76$

$127,509.90$

$1,690,067.42$

$\$ 3,004,433.17$

$\$ 10,393.90$

$\overline{\$ \$ 40,728,005.47}$

1911

$\$ 27,000,000.00$ $5,000,000.00$

$1,000,000.00$

$\$ 33,000,000.00$

$\$ 1,214,855.25$

$671,430.09$

............

$\$ 1,8 \$ 6,285.34$

$\$ 4,971,823.19$

$307,548.21$

$364,735.49$

$\$ 5,644,106.89$

$\$ 197,613.24$

$\$ 40,729,005.47$ 
APPENDIX 2

CHICAGO \& SUBURBAN APPRAISAL

VALUES AS OF AUGUST 1, 1911

APPRAISAL BY THE BYLLESBY AND ARNOLD COMPANIES

August 28, 1912.

\begin{tabular}{|c|c|c|c|c|c|c|}
\hline \multicolumn{3}{|c|}{ Account } & $\begin{array}{l}\text { Book } \\
\text { Galue }\end{array}$ & $\begin{array}{l}\text { Reproduc- } \\
\text { tion Value }\end{array}$ & $\begin{array}{c}\text { Present } \\
\text { Value }\end{array}$ & $\begin{array}{c}\text { Present } \\
\text { Value }\end{array}$ \\
\hline 103 & $\left\{\begin{array}{l}10 \\
20\end{array}\right.$ & 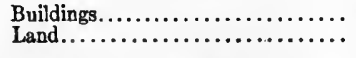 & $\begin{array}{r}\$ 2,570,280.15 \\
601,801.14\end{array}$ & $\begin{array}{r}\$ 2,962,903.27 \\
1,331,642.60\end{array}$ & $\begin{array}{r}\$ 2,526,717.00 \\
1,331,642.60\end{array}$ & $\begin{array}{r}\$ 2,714,719.91 \\
1,331,642.60\end{array}$ \\
\hline \multirow[t]{2}{*}{$105-07$} & $\left\{\begin{array}{l}17 \\
27 \\
37\end{array}\right.$ & $\begin{array}{l}\text { Central Offce Operating Equipment. } \\
\text { Exchange Furniture and Fixtures... } \\
\text { School Equipment................ }\end{array}$ & $\begin{array}{r}5,192,417.01 \\
87,897.14 \\
13,203.18\end{array}$ & $\begin{array}{r}5,588,700.62 \\
97,963.47 \\
21,306.93 \\
\end{array}$ & $\begin{array}{r}3,853,700.50 \\
78,062.90 \\
13,238.56 \\
\end{array}$ & $\begin{array}{r}4,318,912.77 \\
72,062.90 \\
13,238.56\end{array}$ \\
\hline & & Total $105-07 \ldots \ldots \ldots \ldots \ldots$ & $\$ 5,293,517.33$ & $\$ 5,707,971.02$ & $\$ 3,945,001.96$ & $\$ 4,410,214.23$ \\
\hline \multirow[t]{2}{*}{$105-08$} & \multirow[t]{2}{*}{$\begin{array}{l}18 \\
28 \\
38 \\
48 \\
58 \\
68\end{array}$} & \multirow{2}{*}{ 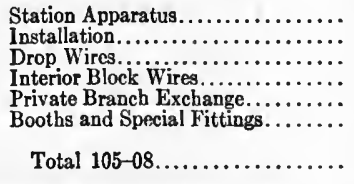 } & & $\begin{array}{r}2,644,586.81 \\
2,784,445.03 \\
927.433 .64 \\
19,388.51 \\
1,240,991.34 \\
73,378.76 \\
\end{array}$ & $\begin{array}{r}1,890,208.52 \\
2,640,594.82 \\
683,605.23 \\
14,139.52 \\
970.689 .48 \\
48,819.18 \\
\end{array}$ & $\begin{array}{r}1,959,554.62 \\
2,371,106.82 \\
727,518.33 \\
15,212.50 \\
1,040,037.55 \\
55,034.06\end{array}$ \\
\hline & & & $\$ 7,252,801.53$ & $\$ 7,690,224.09$ & $\$ 6,248,056.75$ & $\$ 6,168,463.88$ \\
\hline \multirow{5}{*}{107} & $\left(\begin{array}{l}01 \\
02 \\
03 \\
04\end{array}\right)$ & \multirow{2}{*}{ 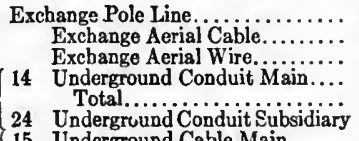 } & $\begin{array}{r}\$ 2,988,561.50 \\
1,571,150.43 \\
2,280,366.76\end{array}$ & $\begin{array}{r}\$ 3,963,423.00 \\
1,840,029.00 \\
1,186,770.00\end{array}$ & $\begin{array}{r}\$ 2,270,076.00 \\
1,325,487.00 \\
948,861.00\end{array}$ & $\begin{array}{r}\$ 2,541,981.00 \\
1,587,544.00 \\
980,181.00\end{array}$ \\
\hline & 04 & & $3,984,762.14$ & $5,866,070.00$ & $4,516,703.00$ & $5,406,696.00$ \\
\hline & \multirow{4}{*}{06} & \multirow{4}{*}{ 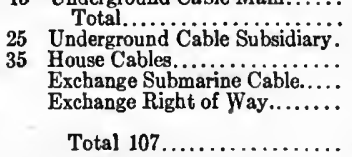 } & $5,554,569.62$ & $6,944,364.00$ & $5,565,063.00$ & $6,406,707.00$ \\
\hline & & & $\begin{array}{r}53,874.99 \\
993.43\end{array}$ & $215,036.00$ & $157,726.00$ & $185,738.00$ \\
\hline & & & $30,329.50$ & $118,987.00$ & $106,084.00$ & $118,327.00$ \\
\hline • & & & $, 464,608.37$ & $\$ 20,134,679.00$ & $\$ 14,890,000.00$ & $\$ 17,227,174.00$ \\
\hline
\end{tabular}

APPENDIX 2-Continued

CHICAGO \& SUBURBAN-Continued

\begin{tabular}{|c|c|c|c|c|c|c|}
\hline & \multicolumn{2}{|r|}{ 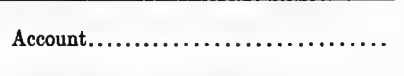 } & $\begin{array}{l}\text { Book } \\
\text { V lue }\end{array}$ & $\begin{array}{l}\text { Reproduc- } \\
\text { tion Value }\end{array}$ & $\begin{array}{l}\text { Present } \\
\text { Vahue } \\
\text { (a) }\end{array}$ & $\begin{array}{l}\text { Present } \\
\text { Value } \\
\text { (b) }\end{array}$ \\
\hline \multirow[t]{2}{*}{109} & \multirow[t]{2}{*}{$\begin{array}{l}01 \\
02 \\
03 \\
04 \\
05 \\
06 \\
09\end{array}$} & \multirow[t]{2}{*}{ 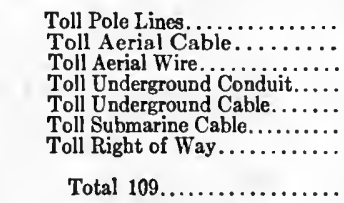 } & $\begin{array}{r}\$ 548,701.70 \\
34,504.44 \\
578,798.33 \\
393,748.16 \\
410,221.46 \\
27.44\end{array}$ & $\begin{array}{r}\$ 787,369.00 \\
57,371.00 \\
1,041,391.00 \\
399,486.00 \\
585,513.00\end{array}$ & $\begin{array}{r}1 \$ 465,939.00 \\
44.088 .00 \\
828,677.00 \\
321,210.00 \\
480,443.00\end{array}$ & $\begin{array}{r}1 \$ 509,186.00 \\
50.528 .00 \\
884,602.00 \\
371,110.00 \\
542,316.00\end{array}$ \\
\hline & & & $\$ 1,966,001.53$ & $\$ 2,871,130.00$ & $\$ 2,140,357.00$ & $\$ 2,357,742.00$ \\
\hline 110 & \multirow{4}{*}{$\begin{array}{l}01 \\
02 \\
03\end{array}$} & Construction in Process........ & $\$ 1,513,525.00$ & $\$ 1,589,201.00$ & $\$ 1,589,201.00$ & $\$ 1,589,201.00$ \\
\hline 111 & & Office Furniture and Fixtures... & $157,600.76$ & 266107.79 & $214,027.06$ & $214,027.06$ \\
\hline 112 & & 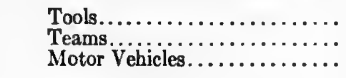 & $\begin{array}{r}105,814.82 \\
132,142.63 \\
42,551.47\end{array}$ & $\begin{array}{r}154,660.14 \\
159,349.45 \\
58,638.82\end{array}$ & $\begin{array}{r}92,796.15 \\
118,943.50 \\
44,077.05\end{array}$ & $\begin{array}{r}92,796.15 \\
118,943.50 \\
44,077.05\end{array}$ \\
\hline 113 & & 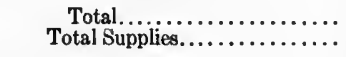 & $\begin{array}{r}\$ 280,508.92 \\
751,477.42\end{array}$ & $\begin{array}{r}\$ 372,648.41 \\
921,596.00\end{array}$ & $\begin{array}{r}\$ 255,816.70 \\
882,871.15\end{array}$ & $\begin{array}{r}\$ 255,816.70 \\
882,871.15\end{array}$ \\
\hline 120 & & $\begin{array}{r}\text { TotaL } \ldots \ldots \ldots \ldots \ldots \ldots \ldots \\
\text { Working Capital..................... }\end{array}$ & $\$ 36,852,122.15$ & $\begin{array}{r}\$ 43,848,103.18 \\
1,500,000.00\end{array}$ & $\begin{array}{r}\$ 34,023,691.22 \\
1,050,000.00\end{array}$ & $\begin{array}{r}\$ 37,151,872.53 \\
1,050,000.00\end{array}$ \\
\hline & & Grand Total......... & & $\$ 44,898,103.18$ & $\$ 35,073,692.00$ & $\$ 38,201,873.00$ \\
\hline
\end{tabular}

Note-1 Present value sub-divisions of the 107 and 109 accounts are based on appraisal figures but we have pro-rated the overhead costs against the various classes of plant. 
ApprNdIX 3

CHICAGO EXCHANGE APPRAISAL

VALUES AS OF AUGUST 1, 1911

APPRAISAL BY THE BYLLESBY AND ARNOLD COMPANY

August 28, 1912.

\begin{tabular}{|c|c|c|c|c|c|c|c|}
\hline & \multicolumn{3}{|c|}{ Account } & $\begin{array}{l}\text { Book } \\
\text { Value }\end{array}$ & $\begin{array}{l}\text { Reproduc- } \\
\text { tion Value }\end{array}$ & $\begin{array}{l}\text { Present } \\
\text { Value } \\
\text { (a) }\end{array}$ & $\begin{array}{l}\text { Present } \\
\text { Value } \\
\text { (b) }\end{array}$ \\
\hline 103 & $\left\{\begin{array}{l}10 \\
20\end{array}\right.$ & \multicolumn{2}{|c|}{ 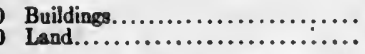 } & $\begin{array}{r}\$ 2,328,433.31 \\
526,956.61\end{array}$ & $\begin{array}{r}\$ 2,642,405.59 \\
1,173,936.98\end{array}$ & $\begin{array}{r}\$ 2,253.975 .80 \\
1,173,936.98\end{array}$ & $\begin{array}{r}\$ 2,418,266.91 \\
1,173,936.98\end{array}$ \\
\hline $105-07$ & $\left\{\begin{array}{l}17 \\
27 \\
37\end{array}\right.$ & \multirow{2}{*}{\multicolumn{2}{|c|}{$\begin{array}{l}\text { Central Office Operating Equipment. } \\
\text { Exchange Furniture and Fixtures.... } \\
\text { School Equipment................ } \\
\text { Total } 105-07 . \ldots \ldots \ldots \ldots \ldots \ldots\end{array}$}} & $\begin{array}{r}4,564,693.90 \\
73,997.58 \\
13,203.18\end{array}$ & $\begin{array}{r}4,857,496.48 \\
81,869.41 \\
21,306.93\end{array}$ & $\begin{array}{r}3,357,489.16 \\
64,769.68 \\
13,238.56\end{array}$ & $\begin{array}{r}3,758,548.30 \\
64,769.68 \\
13,238.56\end{array}$ \\
\hline & & & & $\$ 4,651,894.66$ & $\$ 4,960,672.82$ & $\$ 3,435,497.40$ & $83,836,556.54$ \\
\hline $105-08$ & $\left\{\begin{array}{l}18 \\
28 \\
38 \\
48 \\
58 \\
68\end{array}\right.$ & \multicolumn{2}{|c|}{ 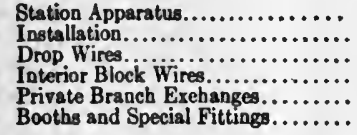 } & & $\begin{array}{r}2,180,563.31 \\
2,296,822.34 \\
673,885 \cdot 74 \\
17,385.95 \\
1,180,171 \cdot 05 \\
60,322.27\end{array}$ & $\begin{array}{r}1,593,092.64 \\
2,178,225.90 \\
495,203.94 \\
12,756.98 \\
923,423.28 \\
40,214.85\end{array}$ & $\begin{array}{r}1,647,973.41 \\
1,962,953.13 \\
527,704.48 \\
13,602.43 \\
988,258.92 \\
45,241.70\end{array}$ \\
\hline 1 & \multicolumn{3}{|r|}{ Total 105-08.. } & $\$ 6,115,389.57$ & $\$ 6,409,150.66$ & $\$ 5,242,817.59$ & $\$ 5,185,734.07$ \\
\hline & {$\left[\begin{array}{l}01 \\
02 \\
03 \\
04\end{array}\right.$} & \multirow{5}{*}{\multicolumn{2}{|c|}{ 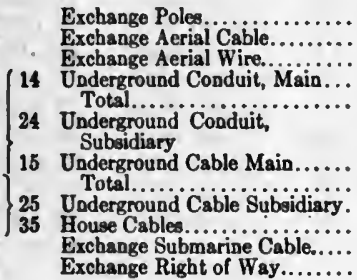 }} & $\begin{array}{r}\$ 1,146,320.74 \\
1,116,775.78 \\
1,673,757.58\end{array}$ & $\begin{array}{r}\$ 1,600,289.00 \\
1,263,470.00 \\
374,359.00\end{array}$ & $\begin{array}{r}19833,638.00 \\
889,936.00 \\
303,544.00\end{array}$ & $\begin{array}{r}1,108,722.00 \\
1,081,989.00 \\
316,239.00\end{array}$ \\
\hline 107 & 04 & & & $3,532,836.35$ & $5,062,428.00$ & $3,875,283.00$ & $4,672,668.00$ \\
\hline & & & & $4,848,264.39$ & $6,168,669.00$ & $4,927,359.00$ & $5,687,207.00$ \\
\hline & 06 & & & $\begin{array}{r}52,685.31 \\
993.43\end{array}$ & $211,744.00$ & $155,018.00$ & $182,799.00$ \\
\hline & & & & $17,626.77$ & $65,424.00$ & $58,219.00$ & $65,099.00$ \\
\hline
\end{tabular}

APPENDIX 3-Continued

CHICAGO EXCHANGE-Continued

\begin{tabular}{|c|c|c|c|c|c|c|}
\hline & \multicolumn{2}{|c|}{ Account } & \multirow{2}{*}{$\begin{array}{r}\begin{array}{l}\text { Book } \\
\text { Value }\end{array} \\
\\
\\
1,603.07 \\
22,651.28 \\
32,122.84 \\
321,124.44 \\
383,989.60\end{array}$} & \multirow{2}{*}{$\begin{array}{r}\begin{array}{r}\text { Reproduc- } \\
\text { tion Value }\end{array} \\
\\
97,381.00 \\
17,254.00 \\
159,409.00 \\
253,503.00 \\
406,822.00\end{array}$} & \multirow{2}{*}{ 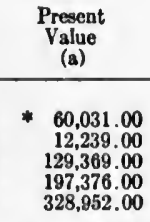 } & \multirow{2}{*}{$\begin{array}{c}\begin{array}{c}\text { Present } \\
\text { Value } \\
\text { (b) }\end{array} \\
\quad 67,564.00 \\
14,727.00 \\
132,987.00 \\
233,973.00 \\
375,202.00\end{array}$} \\
\hline 109 & $\left\{\begin{array}{l}01 \\
02 \\
03 \\
04 \\
05\end{array}\right.$ & 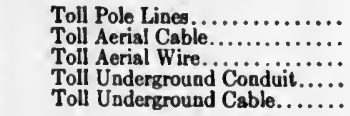 & & & & \\
\hline & & Total $109 . . . \ldots \ldots \ldots \ldots . . . .$. & $\$ 761,551.23$ & $\$ 934,369.00$ & $\$ 727,967.00$ & $\$ 824,453.00$ \\
\hline 110 & & Construction Process............. & $\$ 1,326,534.32$ & $\$ 1,392,861.00$ & $\$ 1,392,861.00$ & $\$ 1,392,861.00$ \\
\hline 111 & & Office Furniture and Fixtures....... & $126,479.17$ & $245,150,59$ & $196,983.03$ & $196,983.03$ \\
\hline 112 & $\left\{\begin{array}{l}01 \\
02 \\
03\end{array}\right.$ & 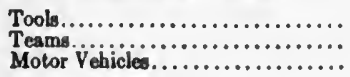 & $\begin{array}{r}72,492.69 \\
105,066.16 \\
28,896.35\end{array}$ & $\begin{array}{r}104,810.18 \\
125.773 .61 \\
42,842.41\end{array}$ & $\begin{array}{l}62,886 \cdot 12 \\
92,957 \cdot 87 \\
30,631.79\end{array}$ & $\begin{array}{l}62,856.12 \\
92,957.87 \\
30,631.79\end{array}$ \\
\hline & & Total $112 \ldots . .$. & $\$ 206,435.20$ & $\$ 273,426.21$ & $\$ 186,475.78$ & $\$ 186, \mathbf{4 7 5 . 7 8}$ \\
\hline 113 & & Total Supplies.................. & $\$ 513,721.00$ & $\$ 660,287.65$ & $\$ 621,562.80$ & $\$ 621,562.80$ \\
\hline 120 & & 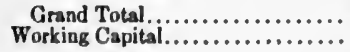 & $\$ 28,946,775.42$ & $\begin{array}{r}\$ 33,438,643.50 \\
887,250.00\end{array}$ & $\begin{array}{r}\$ 26,425,174.38 \\
887,250.00\end{array}$ & $\begin{array}{r}828,951,553.21 \\
887,250.00\end{array}$ \\
\hline
\end{tabular}

Notz $\rightarrow$ Present value sub-divisions of the 107 and 109 accounts are based on appraisal figures but we have prorated the overhead costs againat the various classes of plant. 


\section{APPENDIX 4}

\section{COST OF THE PROPERTY NEW}

\section{Chicago and Suburban}

The following table is the cost as of December 31st, as shown by the books, or each year since 1890:

\begin{tabular}{|c|c|c|c|c|}
\hline Year & $\begin{array}{c}\text { Depreciable } \\
\text { Property* }\end{array}$ & $\begin{array}{l}\text { All Physical } \\
\text { Property }\end{array}$ & $\begin{array}{l}\text { Working } \\
\text { Capitalf }\end{array}$ & Total \\
\hline 1891. & $\$ 2,144,570.28$ & $\$ 2,184,990.28^{\circ}$ & $\$ 100,000$ & $\$ 2,284,920.28$ \\
\hline 1892. & $3,015,987.28$ & $3,239,041.20$ & 150,000 & $3,389,041.20$ \\
\hline 1893. & $3,629,678.99$ & $3,852,820.91$ & 175,000 & $4,027,820.91$ \\
\hline 1894. & $3,830,964.42$ & $4,058,606.34$ & 175,000 & $4,233,606.34$ \\
\hline 1895. & $4,189,900.08$ & $4,417,542.00$ & 200,000 & $4,617,542.00$ \\
\hline 1896 . & $4,537,146.16$ & $4,764,788.08$ & 225,000 & $4,989,788.08$ \\
\hline 1897. & $4,870,554.46$ & $5,098,196.38$ & 250,000 & $5,348,196.38$ \\
\hline 1898. & $5,484,892.92$ & $5,719,647.34$ & 300,000 & $6,019,647.34$ \\
\hline 1899. & $6,857,940.65$ & $7,153,580.07$ & 350,000 & $7,503,580.07$ \\
\hline 1900. & $8,446,058.27$ & $8,790,688.27$ & 400,000 & $9,190,688.27$ \\
\hline 1901. & $10,675,635.65$ & $11,051,328.15$ & 500,000 & $11,551,328.15$ \\
\hline 1902. & $13,287,222.57$ & $13,667,353.42$ & 650,000 & $14,317,353.42$ \\
\hline 1903. & $15,337,752,64$ & $15,723,177.09$ & 700,000 & $16,423,177.09$ \\
\hline 1904. & $16,480,349.91$ & $16,907,094.87$ & 750,000 & $17,657,094.87$ \\
\hline 1905. & $18,128,924.28$ & $18,644,573.54$ & 850,000 & $19,494,573.54$ \\
\hline 1906. & $21,442,125.73$ & $22,097,577.82$ & $1,000,000$ & $23,097,577.82$ \\
\hline 1907 & $25,656,956.43$ & $26,654,433.57$ & $1,200,000$ & $27,854,433.57$ \\
\hline 1908. & $26,929,904.49$ & $28,737,322.99$ & $1,300,000$ & $30,037,322.99$ \\
\hline 1909 & $28,578,619.03$ & $30,634,737.09$ & $1,400,000$ & $32,034,737.09$ \\
\hline 1910 & $31,130,347.86$ & $33,371,331.79$ & $1,550,000$ & $34,921,331.79$ \\
\hline 1911. & $35,425,456.16$ & $37,717,844.09$ & $1,750,000$ & $39,467,844.09$ \\
\hline
\end{tabular}

*Hall, Schedule 2.

tHall, Schedule 3 .

†Here it is not actual cost as shown by the books, but what Mr. Hall considers reasonable as per Schedule 3. 
PHYSICAL VALUATION OF CHICAgO TEL. COS. 869

APPENDIX 5

GROWTH OF CHICAGO TELEPHONE COMPANY'S PLANT*

\begin{tabular}{|c|c|c|c|c|c|c|c|c|}
\hline 总 & 总 & 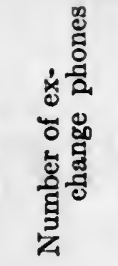 & 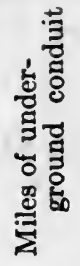 & 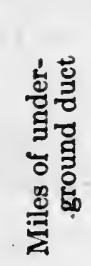 & 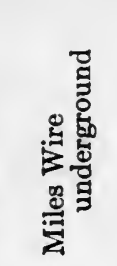 & 总 & 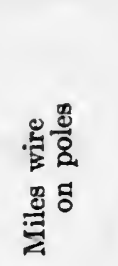 & 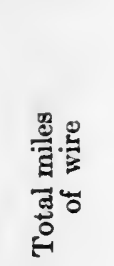 \\
\hline 1881. & 4 & & $\cdots$ & & & & I & I \\
\hline $1882 .$. & $\begin{array}{r}8 \\
10\end{array}$ & 3,479 & & & & $\cdots$ & I & \\
\hline $1883 \ldots$ & $\begin{array}{l}10 \\
10\end{array}$ & $\begin{array}{l}3,479 \\
3,927\end{array}$ & & & . & & $T_{4250}$ & $\begin{array}{l}3,517 \\
4,250\end{array}$ \\
\hline $1885 . \ldots \ldots$ & 10 & 4,455 & & & 760 & & 4,000 & $.4,760$ \\
\hline $1886 .$. & 10 & 4,867 & . & $\ldots$ & 2,000 & & 4,300 & 5,762 \\
\hline $1887 .$. & 10 & 5,382 & $\cdots$ & $\ldots$ & 3,127 & & 4,392 & 6,392 \\
\hline $1888 \ldots \ldots \ldots$ & 10 & 5,427 & & & 1,462 & & 5,932 & 9,073 \\
\hline $1889 \ldots \ldots \ldots$ & 10 & 6,394 & • & $\ldots$ & 3,272 & $\ldots$ & 6,691 & 9,963 \\
\hline $1890 \ldots \ldots \ldots$ & 10 & 7,456 & $\ldots$ & $\ldots$ & 6,456 & $\ldots$ & 8,199 & 15,593 \\
\hline 1891.. & 13 & 9,024 & & & 7,319 & & 10,191 & 17,505 \\
\hline 1892. & 12 & 10,431 & $\cdots$ & .. & 14,093 & & 15 , & 29,281 \\
\hline $1893 \ldots \ldots$. & 12 & 10,376 & & & 18,654 & & 15,6 & 34,268 \\
\hline $1894 \ldots \ldots$. & 15 & 12,049 & 49 & 160 & 18,820 & 5,802 & & 36,522 \\
\hline $1895 \ldots$ & 22 & 13,869 & 52 & 171 & 19,050 & 6,991 & 12,127 & 38,168 \\
\hline 1896. & 31 & 15,384 & 54 & 185 & 20,548 & 7,189 & 12,713 & 40,450 \\
\hline 1897. & 42 & 16,909 & 58 & 234 & 24,324 & 7,864 & 13,932 & 46,120 \\
\hline $1898 \ldots \ldots$ & 58 & 21,188 & 61 & 267 & 30,259 & 11,225 & 15,629 & 57,113 \\
\hline 1899. & 70 & 27,663 & 104 & 527 & 41,757 & 14,445 & $18,692^{\circ}$ & 74,894 \\
\hline 1900. & 84 & 36,414 & 121 & 874 & 68,593 & 19,194 & 22,818 & 110,605 \\
\hline 1901. & 95 & 53,511 & 156 & 1,019 & 87,685 & 25,976 & 32,124 & 145,785 \\
\hline 1902. & 112 & 79,043 & 197 & 1,192 & 123,708 & 32,570 & 38,742 & 195,020 \\
\hline 1903. & 114 & 101,187 & 235 & 1,372 & 149,234 & 40,480 & 41,484 & 231,198 \\
\hline 1904. & $\$ 111$ & 117,893 & 254 & 1,468 & 161,202 & 46,697 & & 253,088 \\
\hline & 156 & 143,223 & 335 & 1,755 & 187,231 & 51,711 & 52,213 & 291,155 \\
\hline 1906 . & 162 & 170,834 & 389 & 1,964 & 248,939 & 53,031 & 57,016 & 358,986 \\
\hline 1907. & 163 & 202,681 & 431 & 2,309 & 352,098 & 56,492 & 62,578 & \\
\hline 1908 . & 163 & 231,180 & 598 & 2,579 & $.423,082$ & 64,013 & 63,350 & 550,445 \\
\hline 1909. & & 262,359 & 614 & 2,685 & 493,787 & 69,666 & 62,985 & 626,438 \\
\hline & 138 & 300,618 & 647 & 2,775 & & 71,984 & 60,612 & 668,733 \\
\hline & 140 & 325,652 & 703 & 3,110 & 653,989 & 90,575 & 63,006 & 807,571 \\
\hline
\end{tabular}

*From Mr. Hagenah's report, save for 1910-11.

tThe exchanges in Chicago exchange system are eounted as one.

\pm Decrease from combination.

No record. 
Appendix 6

PLANT AND COST STATISTICS 1

City and Suburban

As per Hall

Table No. A

INVESTMENT IN UNDERGROUND CONDUIT AND TOTAL DUCT MILES OF CONDUIT

\begin{tabular}{|c|c|c|c|}
\hline Years & $\begin{array}{l}\text { Investment in } \\
\text { Underground } \\
\text { Conduit }\end{array}$ & $\begin{array}{c}\text { Duct Miles } \\
\text { of } \\
\text { Conduit }\end{array}$ & $\begin{array}{l}\text { Investment } \\
\text { per } \\
\text { Duct Foot }\end{array}$ \\
\hline $\begin{array}{l}1891 . \\
1892 . \\
1893 . \\
1894 . \\
1895 . \\
1896 . \\
1897 . \\
1898 . \\
1899 . \\
1900 . \\
1901 . \\
1902 . \\
1903 . \\
1904 . \\
1905 . \\
1906 . \\
1907 . \\
1908 . \\
1909 . \\
1910 . \\
1911 .\end{array}$ & 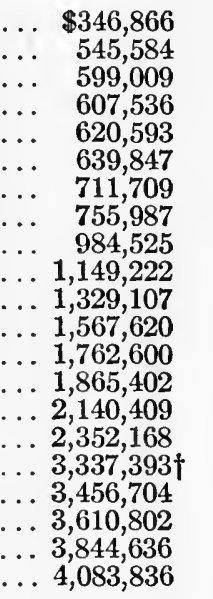 & $\begin{array}{l}109 \\
154 \\
160 \\
160 \\
171 \\
185 \\
234 \\
267 \\
527 \\
874 \\
1,019 \\
1,192 \\
1,372 \\
1,468 \\
1,755 \\
1,964 \\
2,100 \text { estimate } \\
2,252 \text { estimate } \\
2,403 \\
2,493 \\
2,794\end{array}$ & $\begin{array}{l}60 \mathrm{c} \\
67 \mathrm{c} \\
71 \mathrm{c} \\
72 \mathrm{c} \\
69 \mathrm{c} \\
65 \mathrm{c} \\
58 \mathrm{c} \\
54 \mathrm{c} \\
35 \mathrm{c} \\
25 \mathrm{c} \\
25 \mathrm{c} \\
25 \mathrm{c} \\
24 \mathrm{c} \\
24 \mathrm{c} \\
23 \mathrm{c} \\
23 \mathrm{c} \\
30 \mathrm{c} \\
29 \mathrm{c} \\
28 \mathrm{c} \\
29 \mathrm{c} \\
28 \mathrm{c}\end{array}$ \\
\hline
\end{tabular}

${ }^{1}$ These figures are illustrated by charts in Hall's Report and are taken from the records of the company. Aerial wire and poles are omitted because the appraisal showed the books on these matters were incorrect.

†In 1907 ducts above ground connecting cable with tunnel were charged to underground construction. 
TABle No. D

INVESTMEN'T IN CENTRAL OFFICE AND SUBSCRIBERS' STATION EQUIPMENT

\begin{tabular}{|c|c|c|c|}
\hline Years & $\begin{array}{c}\text { Investment in } \\
\text { Equipment }\end{array}$ & $\begin{array}{l}\text { Number of } \\
\text { Stations }\end{array}$ & $\begin{array}{l}\text { Investment } \\
\text { per Station }\end{array}$ \\
\hline 1891 & $\$ 418,762$ & 9,043 & $\$ 46.31$ \\
\hline 1892 & 579,657 & 10,431 & 55.57 \\
\hline 1893 & 720,431 & 11,408 & 63.15 \\
\hline 1894 & 796,107 & 12,222 & 65.14 \\
\hline 1895 & 905,497 & 13,542 & 66.87 \\
\hline 1896 & $1,020,870$ & 15,024 & 67.95 \\
\hline 1897 & $1,086,093$ & 16,462 & 65.98 \\
\hline 1898 & $1,257,165$ & 20,512 & $61: 29$ \\
\hline 1899 & $1,627,179$ & 26,825 & 60.66 \\
\hline 1900 & $1,952,983$ & 35,347 & 55.25 \\
\hline 1901 & $2,757,502$ & 53,511 & 51.53 \\
\hline 1902 & $3,744,330$ & 79,043 & 47.37 \\
\hline 1903 & $4,674,471$ & 101,187 & 46.20 \\
\hline 1904 & $5,066,024$ & 117,893 & 42.97 \\
\hline 1905 & $5,626,443$ & 143,223 & 39.28 \\
\hline 1906 & $6,614,655$ & 170,834 & 38.72 \\
\hline 1907 & $8,226,293$ & 202,681 & 40.59 \\
\hline 1908 & $8,848,913$ & 231,180 & 38.28 \\
\hline 1909 & $9,621,100$ & 262,359 & 36.67 \\
\hline 1910 & $11,151,334$ & 300,618 & 37.09 \\
\hline 1911 & $13,193,538$ & 335,652 & 39.31 \\
\hline
\end{tabular}

Table No. E

TOTAL INVESTMENT IN EQUIPMENT AND CONSTRUCTION AND TOTAL NUMBER OF STATIONS

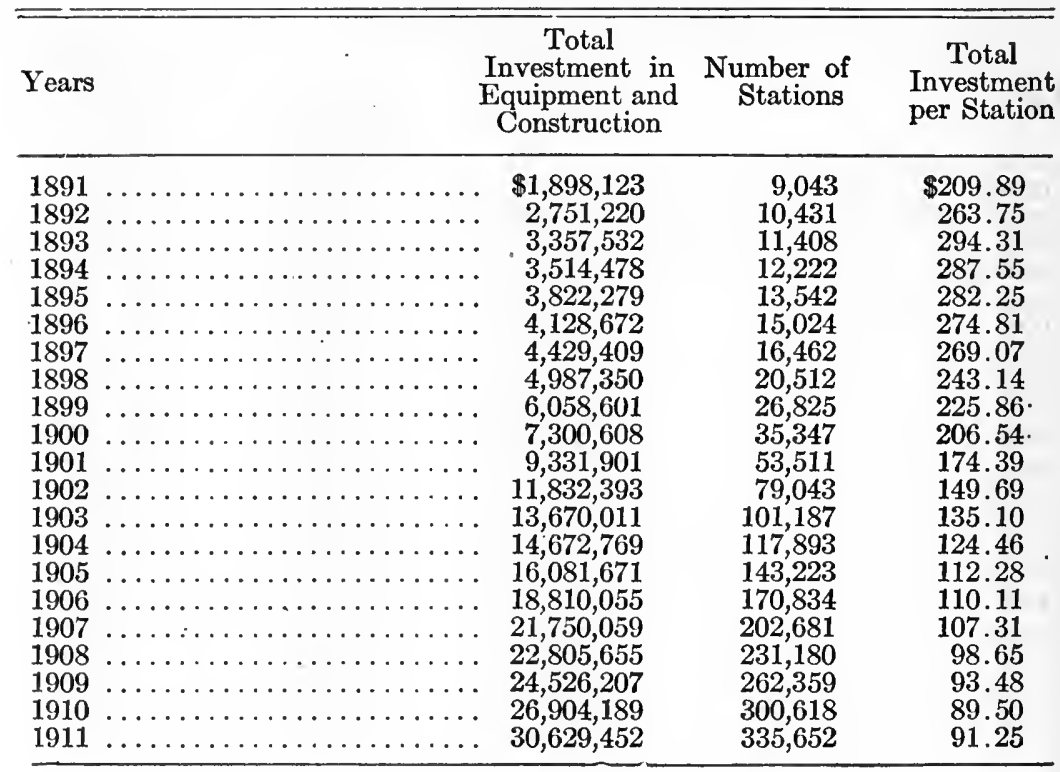


PHYSICAL VALUATION OF CHICAGO TEL. COS. 873

TABLE No. F

MAINTENA NCE AS A PERCENTAGE OF AVERAGE INVESTMENT

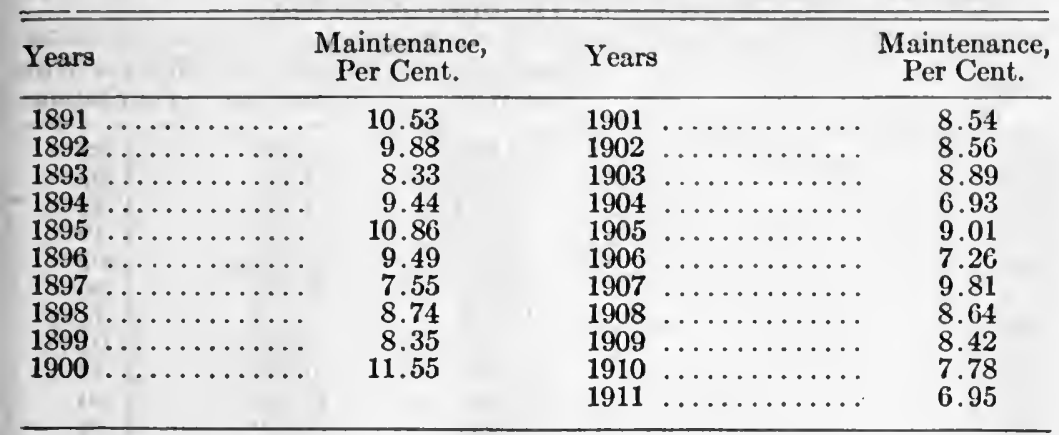

TABLe No. G

EXTENSION OF CONDUIT AND U NDERGROUND WIRE

\begin{tabular}{|c|c|c|c|}
\hline Years & $\begin{array}{c}\text { Miles of } \\
\text { Underground } \\
\text { Wire }\end{array}$ & $\begin{array}{l}\text { Duct Miles } \\
\text { of Conduit }\end{array}$ & $\begin{array}{c}\text { Miles of } \\
\text { Underground } \\
\text { Wire per } \\
\text { Miles of } \\
\text { Conduit }\end{array}$ \\
\hline 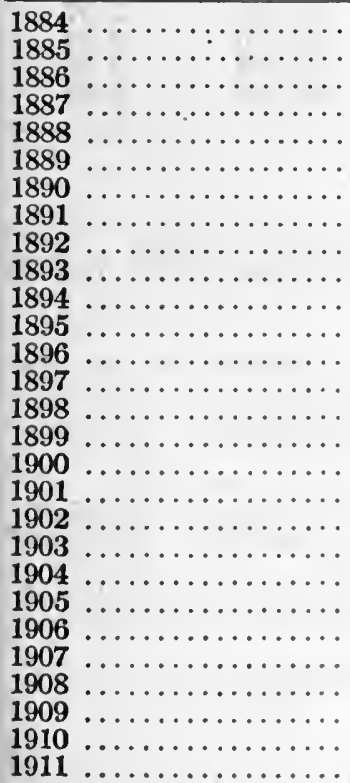 & $\begin{array}{r}760 \\
1,462 \\
2,000 \\
3,141 \\
3,272 \\
6,456 \\
8,291 \\
14,183 \\
17,143 \\
18,820 \\
19,050 \\
20,548 \\
24,324 \\
30,259 \\
41,757 \\
68,593 \\
87,685 \\
123,708 \\
149,234 \\
161,202 \\
187,231 \\
248,939 \\
343,069 \\
398,177 \\
466,796 \\
509,143 \\
626,935\end{array}$ & $\begin{array}{l}\cdots \cdots \\
\cdots \cdots \\
\cdots \cdots \\
\cdots \cdots \\
\cdots \cdots \\
109 \\
154 \\
160 \\
160 \\
171 \\
185 \\
234 \\
267 \\
527 \\
874 \\
1,019 \\
1,192 \\
1,372 \\
1,468 \\
1,755 \\
1,964 \\
2,100 \\
2,252 \\
2,403 \\
2,493 \\
2,794\end{array}$ & $\begin{array}{r}\cdots \cdots \\
\cdots \cdots \\
\cdots \cdots \\
\cdots \cdots \\
\cdots \cdots \\
76.06 \\
92.09 \\
107.14 \\
117.62 \\
111.40 \\
111.07 \\
103.95 \\
113.33 \\
79.23 \\
78.48 \\
86.05 \\
103.78 \\
108.77 \\
109.81 \\
106.68 \\
126.76 \\
163.32 \\
176.81 \\
194.25 \\
204.22 \\
224.39\end{array}$ \\
\hline
\end{tabular}


TABLE No. H

MILES OF EXCHANGE WIRE AND NUMBER OF STATIONS EXCLUDING EXTENSION STATIONS

\begin{tabular}{|c|c|c|c|}
\hline Years & $\begin{array}{l}\text { Total Miles } \\
\text { of Wire }\end{array}$ & $\begin{array}{l}\text { Total No. } \\
\text { of Stations }\end{array}$ & $\begin{array}{l}\text { Miles of Wire } \\
\text { Per Station }\end{array}$ \\
\hline 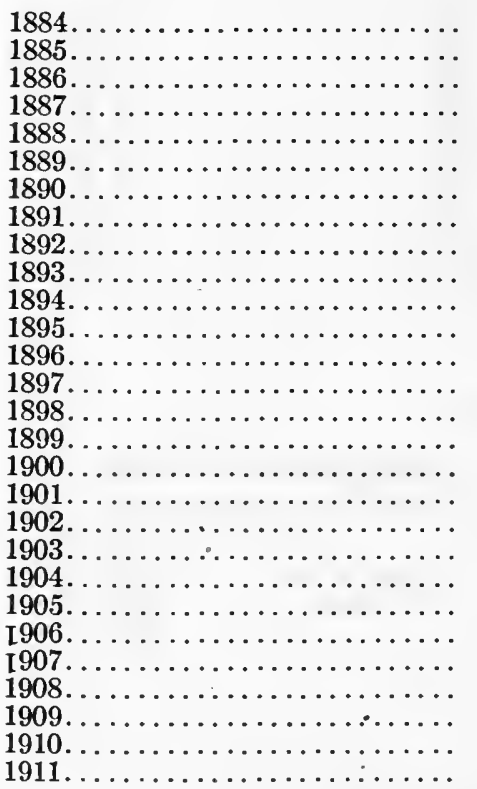 & $\begin{array}{r}4,250 \\
4,760 \\
5,762 \\
6,392 \\
9,073 \\
9,963 \\
13,426 \\
18,206 \\
25,883 \\
31,920 \\
33,934 \\
35,148 \\
36,731 \\
41,760 \\
51,566 \\
67,607 \\
101,430 \\
135,234 \\
183,270 \\
218,101 \\
238,277 \\
274,944 \\
341,108 \\
444,010 \\
508,329 \\
582,818 \\
625,237 \\
763,390\end{array}$ & $\begin{array}{r}3,927 \\
4,455 \\
4,867 \\
5,382 \\
5,427 \\
6,394 \\
7,772 \\
9,043 \\
10,431 \\
11,408 \\
12,222 \\
13,542 \\
15,024 \\
16,462 \\
20,274 \\
26,075 \\
34,351 \\
50,984 \\
75,755 \\
96,823 \\
112,560 \\
136,500 \\
162,795 \\
190,061 \\
213,964 \\
241,570 \\
276,908 \\
309,349\end{array}$ & $\begin{array}{l}1.08 \\
1.07 \\
1.18 \\
1.19 \\
1.67 \\
1.56 \\
1.73 \\
2.01 \\
2.48 \\
2.80 \\
2.78 \\
2.59 \\
2.44 \\
2.54 \\
2.54 \\
2.55 \\
2.95 \\
2.65 \\
2.42 \\
2.25 \\
2.12 \\
2.01 \\
2.10 \\
2.34 \\
2.37 \\
2.41 \\
2.26 \\
2.47\end{array}$ \\
\hline
\end{tabular}

\section{APPENDIX 7}

BASE FIGURES OF APPRAISAL VS. BOOK VALUE

COMPARISON OF APPRAISAL BASE FIGURES AND BOOK VALUE (Chicago and Suburban)

As at August 1, 1911

\begin{tabular}{|c|c|c|c|}
\hline & Book Value & $\begin{array}{c}\text { Appraisal } \\
\text { Base Figures }\end{array}$ & $\begin{array}{l}\text { Increase } \\
\text { Decrease }\end{array}$ \\
\hline 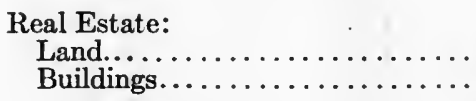 & $\begin{array}{l}\$ 601,801.14 \\
2,568,777.87\end{array}$ & $\begin{array}{r}\$ 1,083,958.15 \\
2,260,033.01\end{array}$ & $\begin{array}{l}482,157.01 \\
308,744.86^{*}\end{array}$ \\
\hline Total Real Estate... & $\$ 3,170,579.01$ & $3,343,991.16$ & $173,412.15$ \\
\hline $\begin{array}{l}\text { Central Office Equipment: } \\
\text { Operating Equipment........... } \\
\text { Furniture and Fixtures......... } \\
\text { School Equipment........ }\end{array}$ & & $\begin{array}{r}4,386,011.81 \\
84,816.87 \\
16,837.07\end{array}$ & \\
\hline Total Central Office Equipm't. & $4,986,077.83$ & $4,487,665.75$ & $498,412.08^{*}$ \\
\hline Subscribers Station Equipment. & $\$ 6,985,798.56$ & $\$ 6,906,778.32$ & $79,020.24^{*}$ \\
\hline
\end{tabular}

NotE-Figures in italic with asterisk denote decrease. 
PHYSICAL VALUATION OF CHICAGO TEL. COS. 875

Aerial Construction:

Pole lines.............. \$3,525,809.63

Cable.................. 1,605,654.87

Wire............... 3,065,865.09

Total Aerial Construction.... \$8,197,329.59

Underground, etc.:

Conduit..............\$4,371,715.30

Cable............... 5,932,910.74

Submarine Cable................

993.43

House Cable............ $\quad 53,874.99$

Total Underground, etc. . . \$10,359,494.46 \$11,786,304.00 \$1,426,809.54

Right of Way ............ $30,356.94$

Toll Line Adjustment...........

Total Plant in Operation. . . \$33,729,636.39 $\$ 33,863,099.23$

$\$ 3,873,436.00 \quad \$ 347,626.37$

$1,546,937.00 \quad 58,717.87 *$

$1,816,676.00 \quad 1,249,189.09^{*}$

$\$ 7,237,049.00 \$ 960,280.59^{*}$

$\$ 5,475,288.00 \$ 1,103,572.70$

$6,135,690.00 \quad 202,779.26$

$993.43^{*}$

$175,326.00 \quad 121,451.01$

$97,905.00 \quad 67,548.06$ $3,406.00 \quad 3,406.00$

$\$ 133,462.84$

Construction in Process....... 1,513,525.13

Office Furniture and Fixtures.... $\quad$ 133,092.79

Tools and Tcams........... 246,320.14

Working Capital (Estimated).... 1,750,000.00

$1,589,201.39$

$230,396.41$

$322,639.75$

$1,851,465.51$

$75,670^{\circ} .26$

$97,303.62$

$76,319.61$

$101,465.51$

$\$ 484,227.84$

Total

$\$ 37,372,574.45 \$ 37,856,802.29$

$\$ 484,227.8$

COMPARISON OF APPRAISAL BASE FIGURES AND BOOK VALUE (Chicago only)

As at August 1, 1911

\begin{tabular}{|c|c|c|c|}
\hline & $\begin{array}{l}\text { Book Value } \\
\text { Adjusted }\end{array}$ & Appraisal & $\begin{array}{l}\text { Increasc } \\
\text { Decrease }\end{array}$ \\
\hline 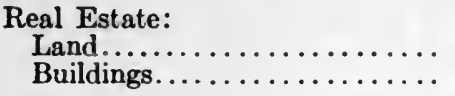 & $\begin{array}{r}\$ 526,956.61 \\
2,326,931.03\end{array}$ & $\begin{array}{r}\$ 955,585.65 \\
2,015,564.87\end{array}$ & $\begin{array}{c}\$ 428,629.04 \\
\$ 11,366.16^{*}\end{array}$ \\
\hline Total Real Estate......... & $\$ 2.853,887.64$ & $\$ 2,971,150.52$ & $\$ 117,262.88$ \\
\hline $\begin{array}{l}\text { Central Office Equipment: } \\
\text { Operating Equipment......... } \\
\text { Furniture and Fixtures....... } \\
\text { School Equipment.......... }\end{array}$ & $\begin{array}{r}4,257,254.40 \\
73,997.58 \\
13,203.18\end{array}$ & $\begin{array}{r}3,806,604.21 \\
70,882.61 \\
16,837.07\end{array}$ & $\begin{array}{c}\$ 450,650.19^{*} \\
3,114.97^{*} \\
3,633.89\end{array}$ \\
\hline Total Central Office Equipm't & $\$ 4,344,455.16$ & $\$ 3,894,323.89$ & $\$ 450,131.27^{*}$ \\
\hline Subscribers Station Equipment.. . & $\$ 5,848,386.60$ & $\$ 5,756,119.87$ & $\$ 92,266.73^{*}$ \\
\hline 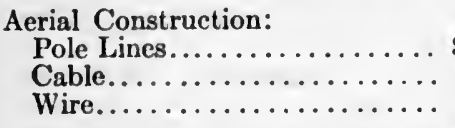 & $\begin{array}{r}\$ 1,136,530.24 \\
1,139,427.06 \\
1,912,580.42\end{array}$ & $\begin{array}{r}\$ 1,384,151.00 \\
1,044,205.00 \\
435,194.00\end{array}$ & $\begin{array}{r}\$ 247,620.76 \\
95,222.06^{*} \\
1,477,386.42^{*}\end{array}$ \\
\hline Total Aerial Construction... & $\$ 4,188,537.72$ & $\$ 2,863,550.00 \$$ & $\$ 1,324,487.72^{*}$ \\
\hline 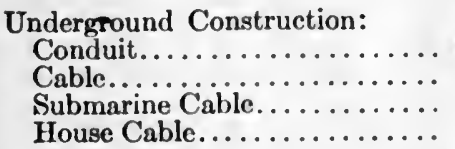 & $\begin{array}{r}\$ 3,847,265.79 \\
5,200,373.65 \\
993.43 \\
\mathbf{5 2 , 6 8 5 . 3 1}\end{array}$ & $\begin{array}{r}\$ 4,665,298.00 \\
5,357,491.00 \\
172,640.00\end{array}$ & $\begin{array}{r}\$ \$ 18,032.21 \\
157,117.35 \\
993.43^{*} \\
119,954.69\end{array}$ \\
\hline
\end{tabular}

Total Underground Construc-

tion................ \$9,101,318.18 \$10,195,429.00\$1,094,110.82

NotE-Figures in italic with asterisk denote decrease. 


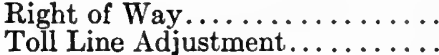

Book Value
Adjusted

Total Plant in Operation

$\overline{26,354,212.07}$

$17,626.77$

\begin{tabular}{r} 
Appraisal \\
\hline $54,229.00$ \\
$3,406.00$
\end{tabular}

$\$ 25,738,208.28$

Construction in Process....... 1,326,534.32

Office Furniture and Fixtures....

Tools and Teams.............

Working Capital (Estimated)....

$106,281.34$

$181,056.75$

$1,500,000.00$
$\$ 1,392,861.04$

$212,251.59$

$236,732.65$

$1,462,282.17$

\section{Increase \\ Decrease* \\ $36,602.23$ \\ $3,406.00$}

$\$ 616,003.79^{*}$

$66,326.72$

$105,97.25$

$55,675.90$

$87,717.83^{*}$

Total

$\$ 29,468,084.48$

$\$ 29,042,335.73$

$\$ 425,748.75^{*}$

COMPARISON OF APPRAISAL BASE FIGURES AND BOOK VALUE (Suburban Only)

As at July 31,1911

\begin{tabular}{|c|c|c|c|}
\hline & Book Value & Appraisal & $\begin{array}{l}\text { Increase } \\
\text { Decrease* }\end{array}$ \\
\hline 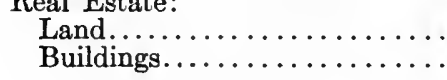 & $\begin{array}{r}74,844.53 \\
241,846.84\end{array}$ & $\begin{array}{l}128,372.50 \\
244,468.14\end{array}$ & $\begin{array}{r}\$ 53,527.97 \\
2,621.30\end{array}$ \\
\hline Total Real Estate...... & $316,691.37$ & $372,840.64$ & $56,149.27$ \\
\hline $\begin{array}{l}\text { Central Office Equipment: } \\
\text { Operating Equipment.......... } \\
\text { Furniture and Fixtures } \ldots \ldots \ldots \\
\text { School Equipment............ }\end{array}$ & & $\begin{array}{r}579,407.60 \\
13,934.26\end{array}$ & \\
\hline Total Central Office Equipm't & $\$ 641,622.67$ & $\$ 593,341.86$ & $\$ 48,280.81$ \\
\hline Subscribers Station Equipment. & $\$ 1,137,411.96$ & $\$ 1,150,658.45$ & $\$ 13,246.49$ \\
\hline 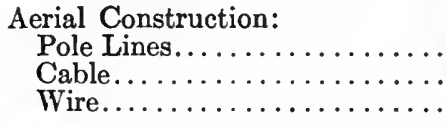 & $\begin{array}{r}\$ 2,389,279.39 \\
466,227.81 \\
1,153,284.67\end{array}$ & $\begin{array}{r}\$ 2,489,285.00 \\
502,732.00 \\
1,381,482.00\end{array}$ & $\begin{array}{r}\$ 100,005.61 \\
36,504.19 \\
228,197.33\end{array}$ \\
\hline Total Aerial Construction.. & $4,008,791.87$ & $\$ 4,373,499.00$ & $\$ 364,707.13$ \\
\hline 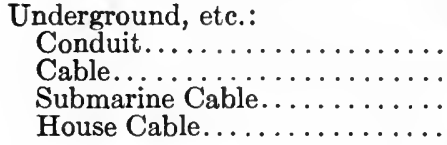 & $\begin{array}{r}\$ 524,449.51 \\
732,537.09\end{array}$ & $\begin{array}{r}\$ 809,990.00 \\
778,199.00\end{array}$ & $\begin{array}{r}\$ 285,540.49 \\
45,661.91\end{array}$ \\
\hline Total Underground, etc.. & $\$ 1,258,176.28$ & $\$ 1,590,875.00$ & $\$ 332,698.72$ \\
\hline Right of Way............. & $12,730.17$ & $43,676.00$ & $30,945.83$ \\
\hline Total Plant in Operation. . & $\$ 7,375,424.32$ & $\$ 8,124,890.95$ & $\$ 749,466.63$ \\
\hline $\begin{array}{l}\text { Construction in Process........... } \\
\text { office Furniture and Fixtures.... } \\
\text { Tools and Teams. } \\
\text { Working Capital (Estimated)..... }\end{array}$ & $\begin{array}{r}186,990.81 \\
26,811.45 \\
65,263.39 \\
250,000.00\end{array}$ & $\begin{array}{r}196,340.35 \\
18,144.82 \\
85,907.10 \\
389,183.34\end{array}$ & $\begin{aligned} 9,349.54 \\
8,666.69^{*} \\
20,643.71 \\
139,183.34\end{aligned}$ \\
\hline Total. & $\$ 7,904,489.97$ & $\$ 8,814,466.56$ & $\$ 909,976.59$ \\
\hline
\end{tabular}

Note-Figures in italic with asterisk denote decrease. 


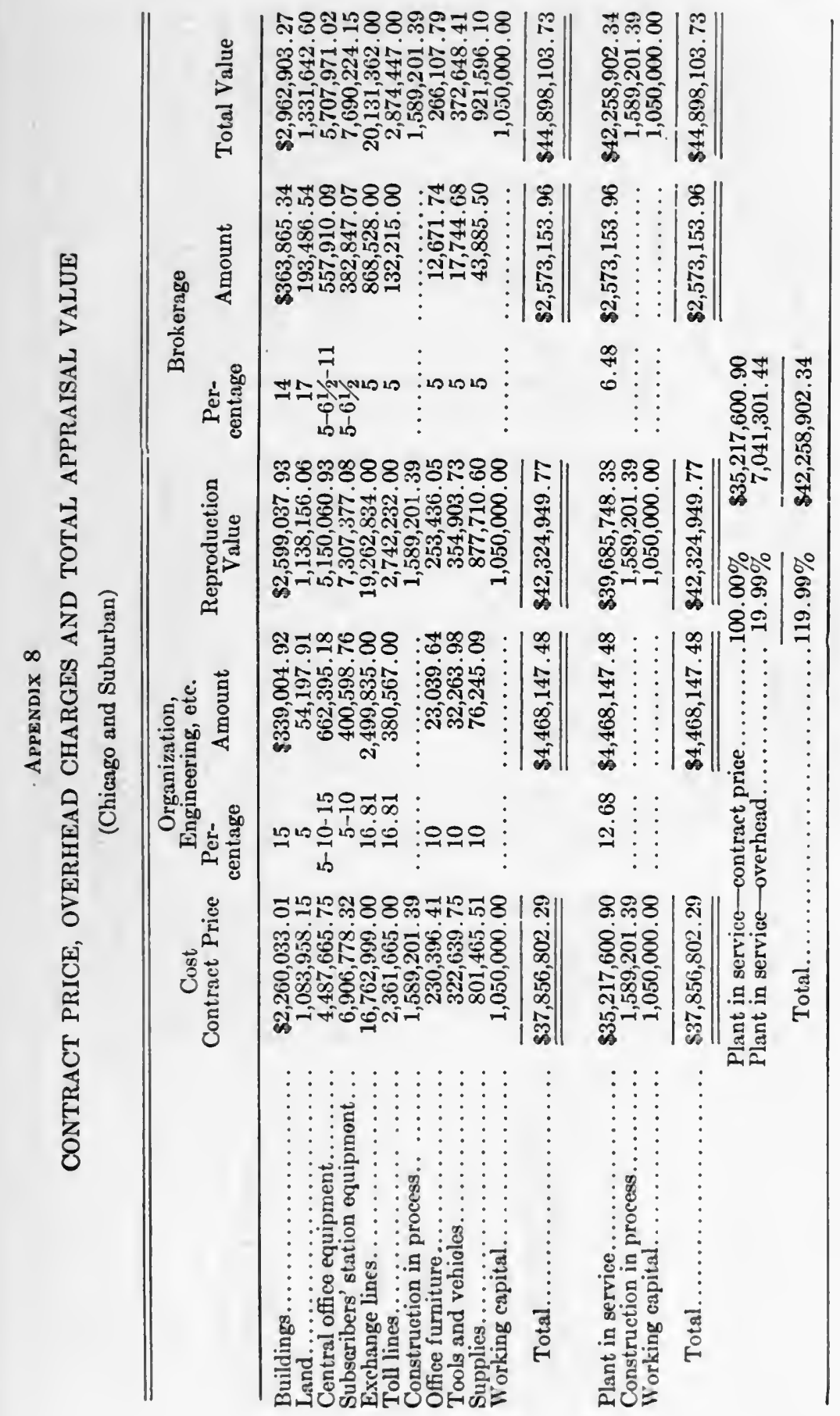




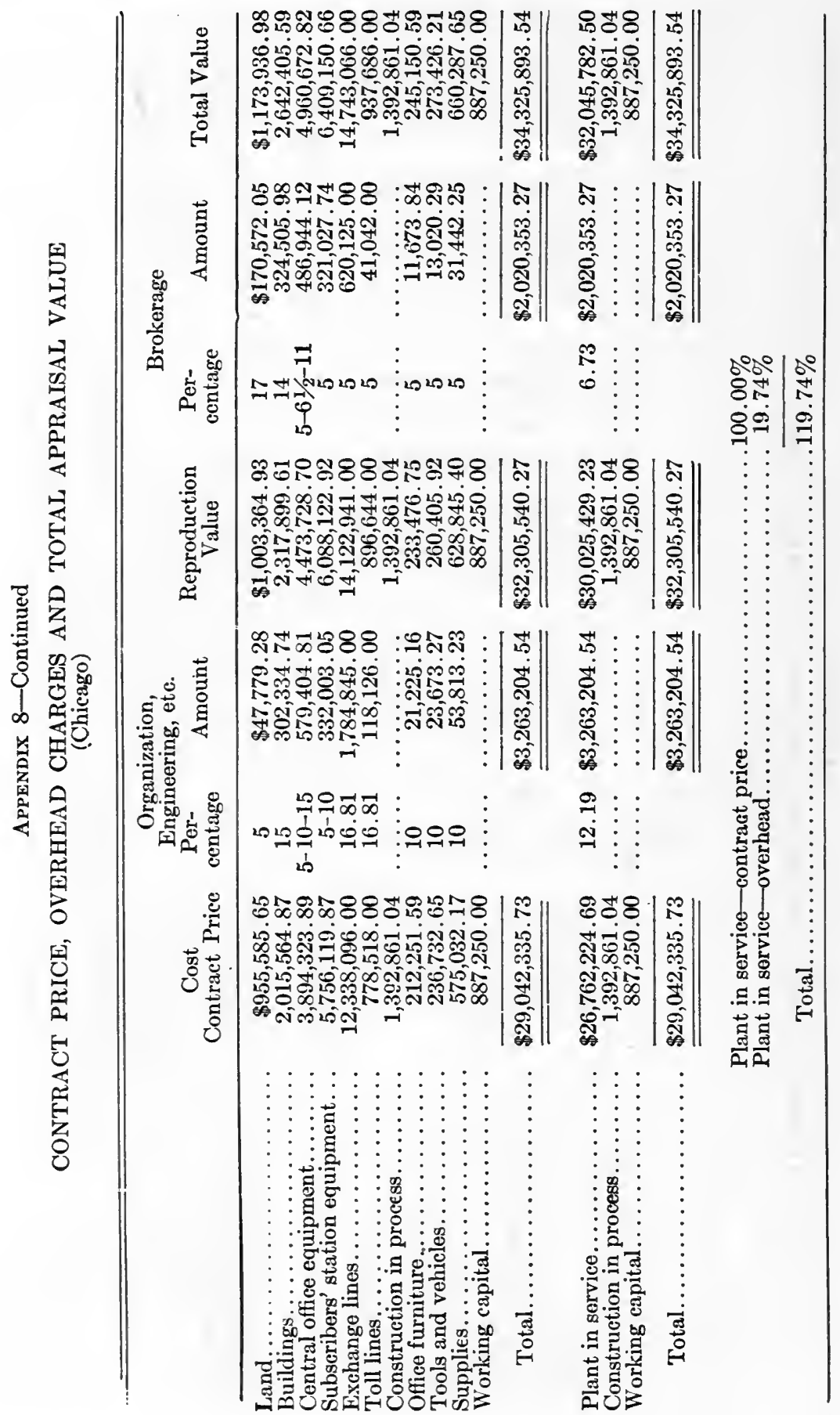


PHYSICAL VALUATION OF CHICAGO TEL. COS, 879

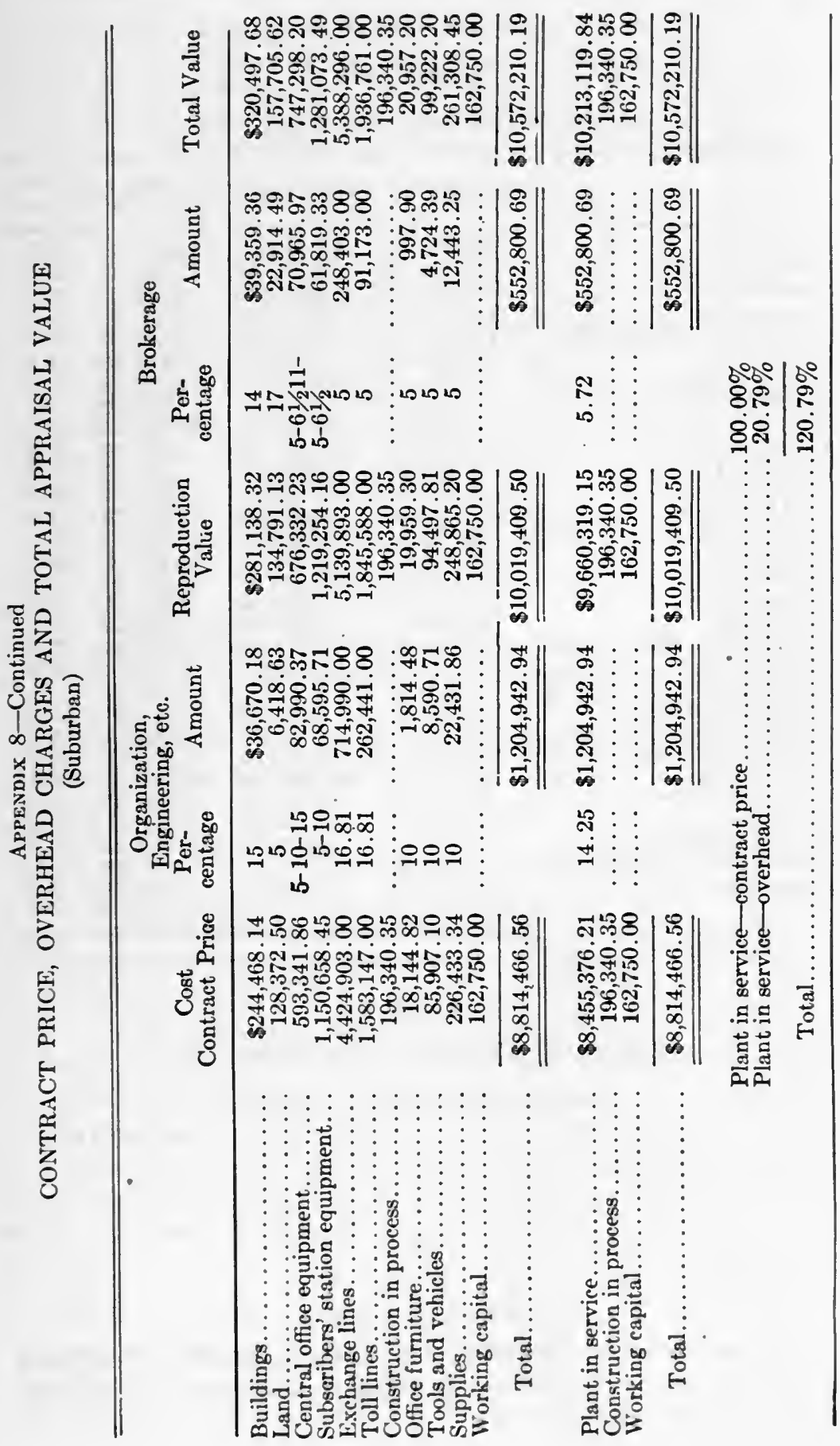




\section{APPENDIX 9}

BUILDINGS

Appraisal Compared with Book Value

\begin{tabular}{|c|c|c|c|c|}
\hline & Appraisal & Book Value & $\begin{array}{l}\text { Increase on } \\
\text { Book Value }\end{array}$ & $\begin{array}{l}\text { Per cent } \\
\text { Increase }\end{array}$ \\
\hline 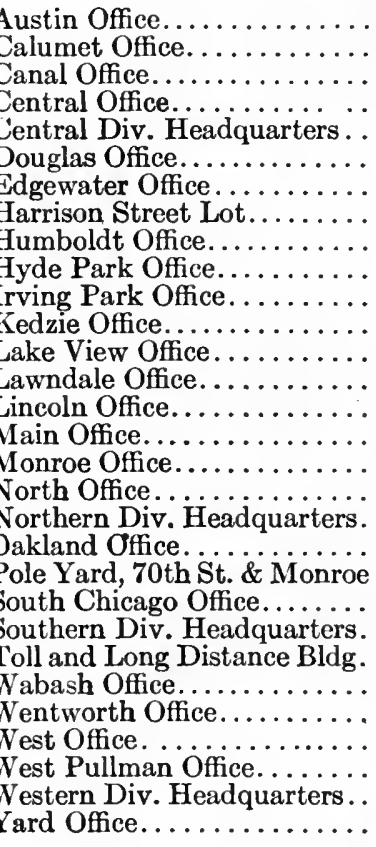 & $\begin{array}{r}\$ 32,962.92 \\
49,247.56 \\
27,313.29 \\
159,214.01 \\
119,685.19 \\
45,796.14 \\
62,660.56 \\
325.89 \\
42,230.51 \\
30,354.29 \\
15,298.80 \\
57,814.62 \\
54,060.15 \\
59,102.70 \\
93,885.52 \\
398,704.76 \\
78,871.34 \\
65,405.01 \\
36,061.56 \\
71,843.79 \\
211.24 \\
13,586.23 \\
45,082.41 \\
523,623.16 \\
345,443.69 \\
91,010.01 \\
52,108.08 \\
11,492.30 \\
131.16 \\
58,878.70\end{array}$ & $\begin{array}{r}\$ 26,004.71 \\
24,412.15 \\
19,884.71 \\
136,136.78 \\
104,635.37 \\
31,385.34 \\
52,884.21 \\
\ldots \ldots \ldots \ldots . .2 \\
30,136.26 \\
25,927.09 \\
14,031.51 \\
49,822.51 \\
44,638.42 \\
46,176.36 \\
74,686.47 \\
385,895.12 \\
75,953.19 \\
53,653.52 \\
33,544.00 \\
66,958.61 \\
\ldots .391 .37 \\
8,331.37 \\
39,781.77 \\
490,615.84 \\
299,056.17 \\
97,480.08 \\
47,610.77 \\
10,505.36 \\
\ldots \ldots 930.42\end{array}$ & $\begin{array}{r}\$ 6,958.21 \\
23,835.41 \\
7,428.58 \\
23,077.23 \\
15,049.82 \\
14,410.80 \\
9,776.35 \\
325.89 \\
12,094.25 \\
4,427.20 \\
1,267.29 \\
7,992.11 \\
9,421.73 \\
12,926.34 \\
19,199.05 \\
12,809.64 \\
2,918.15 \\
11,751.49 \\
2,517.56 \\
4,885.18 \\
211.24 \\
5,254.86 \\
5,300.64 \\
33,007.32 \\
46,387.52 \\
6,470.07 \\
4,497.31 \\
986.94 \\
131.16 \\
1,701.72\end{array}$ & 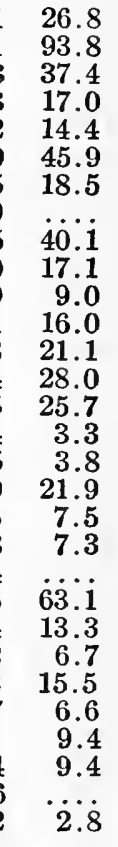 \\
\hline Total................ & $, 642,405.59$ & $\$ 2,351,728.11$ & $\$ 290,677.48$ & 12.4 \\
\hline
\end{tabular}

APPENDIX 10

CHICAGO TELEPHONE COMPANY

Defense of Building Appraisal

Oct. 8, 1912.

Prof. E. W. Bemis,

City Hall,

$$
\text { Chicago, Ill. }
$$

Dear Prof. Bemis:

\section{BUILDING COSTS}

I return herewith typewritten table showing analysis of building costs, as shown by the Chicago Appraisal and also the Chicago Telephone Company's books. 
As you know, the costs of material and labor entering into the construction of buildings are considerably higher now than in former years. The low building costs of the earlier years of this Company's history are reflected in the higher reproduction new figures shown in the appraisal, except in those instances where one or more additions have been made to the building, involving construction costs that the appraisers did not make allowance for in estimating the reproduction new cost of the property.

Land values in Chicago also have, in general, increased, and such an increase is reflected in the higher present values shown in the appraisal in practically all cases, except where the price paid for the land included building since destroyed, and, of course, not appearing in the appraisal. In such eases the appraisal of the land shows little or no increase, or even a decrease, although land values in the vicinity have gone up since the purchase of our property.

I will point out some specific instances illustrating the above statements :

\section{Austin:}

The appraisal shows an increase of $27 \%$ in land value, consistent with the increase in land values in this vicinity. This lot was purchased about ten years ago. The building shows an increase of $26.8 \%$, which I think fairly represents the added cost of buildings to-day over the cost of 1904 , when this building was erected.

\section{Calumet:}

The land for Calumet was purchased, part about 1891, and part in 1901 , and has appreciated very much, principally in recent years since the automobile industry has brought business down into the district. The appreciation shown by the appraisal is $83.3 \%$, and I believe it is very fair.

The appraisal shows an appreciation in the reproduction new cost of buildings of $93.8 \%$. This is brought about by the fact that five old houses and a barn were bought with the land, and were entered in our books at the estimated then value. Naturally, the appraisal and value of reproduction new would be materially higher, and I think that this, with the higher present cost of construction readily accounts for the appreciation.

\section{Canal:}

The $22.8 \%$ inerease in land value is readily accounted for by the increase in values in the district. The $37.4 \%$ increase in building value can be accounted for by the increase in building costs. This building was erected in 1903 , when building costs were low. 


\section{Central:}

The Central Building was erected in 1905, when buildiug costs were lower than now, and under a favorable contract. The appreciation of $17.4 \% \mathrm{I}$ believe to be reasonable.

\section{Central Division Headquarters:}

The Central Division Headquarters and Cortlandt St. lots were both purchased on very favorable terms, and land has since increased rapidly in value.

\section{Douglas:}

This building was erected in 1903, when building costs were much lower than at present, and the appreciation of $45.9 \% \mathrm{I}$ believe is reasonable. Land values in this district are practically at a standstill.

\section{Edgewater:}

The $53.6 \%$ increase in land reflects the rise in land values in this district. Our lot was bought at a favorable price.

\section{Harrison Street Lot:}

This lot, located at Harrison Street and Pacific Ave., just at the edge of the business district, has increased very much in value due to the expansion of the business district.

\section{Humboldt:}

This building was erected in 1905 , when building costs were low. It was constructed under a very favorable contract. Land prices have also increased.

\section{Lincoln:}

I am advised that the original price of the land included an old building that was afterwards destroyed. This explains the apparent decrease in land value. Other land in the vicinity shows some increase.

\section{Main:}

The land purchased for the original Main also included an old building, which was torn down. The land value in this instance would have shown a slightly greater appreciation, were it not for this fact. The main building shows only a small increase in reproduction cost because of the fact that additions have been made, and the extra cost of such additions is not included in the appraisal. The original building was erected in $188 \%$, when building costs were low.

\section{Monroe:}

The Monroe land shows a substantial increase in value, consistent with the other land values in the vicinity. The Monroe building shows a very small increase in value. Here again, several additions 
have been made since the erection of the original building in $\mathbf{1 8 9 9}$. The appraisal figure does not take into account the extra costs involred; hence, little appreciation is shown, notwithstanding the fact that the original building and soine of the additions were made when building costs were much lower than at present.

\section{North:}

This building was erected in 1900 , when building costs were low. There have been no additions. The land shows a small increase in value, and I learn that land values in this district have been nearly stationary. It is possible that an old building may have been included in the original price paid for the land.

\section{Oakland:}

The appraisal figure for Oakland Building is but little orer the book value. Several additions were made to the Oakland Building, and the extra cost of these, of course, was not taken into account in the appraisal. The estimated cost to reproduce new, the old fiat buildings purchased, fails to much more than make up for this deficiency. Land values in this territory have been practically stationary.

\section{South Chicago:}

The appraisal shows a rery small increase, only $2.9 \%$, for South Chicago land, notwithstanding the general increase of values in the district. This is accounted for in the fact that the book figures for land include also the cost of two houses and a barn. One of the houses was destroyed before the present Central office building was erected. The substantial increase in building values of $63.1 \%$ is accounted for in the fact that the original South Chicago Building was erected in 1902, when the construction costs were low, and further in the fact that the reproduction new estimate includes the cost of reproducing a house and barn now on the property, the original cost of which is included in the land value.

\section{South Division Headquarters:}

The land values in this district have increased very much. The property is on the 55th Strect Boulevard.

\section{Toll and Long Distance Building:}

Although this building was erected in 1908, when building prices were somewhat lower than now, the contract was not a favorable one; it was cost plus $10 \%$. As a result, the appraisal figure is but $6.7 \%$ in excess of the books. 


\section{Wabash:}

The land values in this district have greatly increased in the last three or four years due to the expansion in the business district. This accounts for the increase in value of $50.8 \%$.

\section{Wentworth:}

The original Wentworth Building was erected in 1900, when building costs were low. Several additions have since been made, however, and the appraisal fails to take into account the extra costs involved. Because of this, it shows a decrease of $6.6 \%$.

The land value increase of $31.4 \%$ is consistent with similar values in the vicinity.

\section{West:}

This building was erected in 1900 , when construction costs were low. The small increase of $9.4 \%$ is because the appraisal figures fail to take into account the extra cost of two building additions made since then. The land shows a decrease of $36 \%$. While values in this district seem to have remained about stationary, or may have decreased a little, the large decrease in value can probably be accounted for in the fact that an old building was purchased with the lot, and since destroyed, and is included in the book value of the land. I am unable, however, to verify this.

\section{West Pullman:}

This building was erected in 1901, when construction costs were low. The small increase of $9.4 \%$ as shown by the appraisal is accounted for in the fact that the figures do not take into account the extra cost of an addition to the building.

\section{Western Division Headquarters:}

The land for these headquarters was bought on very favorable terms, and land values in the vicinity have gone up to a marked extent.

\section{Yards:}

The Yards Building was erected in 1900, when building costs were low. The decrease of $2.8 \%$ shown in the appraisal is due to the fact that the appraisal figures fail to take into accounts the extra costs of making additions since the erection of the original building. Land values in this vicinity have gone up consistent with the appraisal figures, showing increase of $33.9 \%$. Yours truly, 
APPENDIX 11

EFFECT OF SUBWAY CONSTRUCTION

Oct. 9, 1912.

Professor E. W. Bemis,

City Hall,

Chicago, Illinois.

\section{DeAr Sir:}

TELEPHONE PLANT DISTURBED BY PROPOSED PASSENGER SUBWAY

Referring to the system of passenger subways, construction of which is proposed by the Chicago Harbor and Subway Commission in their report of September 10th, 1912, I wish to discuss the plant of the Chicago Telephone Company, which will be destroyed or will have to be abandoned on account of the construction of this subway system.

The Harbor and Subway Commission proposes to construct passecger subways in the following streets-

In Evanston Arenue from Lawrence Avenue to Halsted Street.

In Lincoln Avenue from Lawrence Avenue to Clark Street.

In Elston Avenue from Kedzie Avenue to California Arenue.

In California Avenue from Elston Arenue to Milwaukee Avenue.

In Armitage Arenue from 40th Arenue to Milwaukee Avenue.

In Milwaukee Avenue from California Arenue to Canal Street.

In Halsted Street from Evanston Arenue to 79th Street.

In Clark Street from Lincoln Arenue to Polk Street.

In Washington Street from Canal Street to State Street.

In Madison Street from 40th Avenue to Clark Strect.

In Harrison Street from Halsted Street to State Street.

In State Street from the Chicago River to 55 th Street.

In Blue Island Avenue from Ashland Avenue to Halsted Street.

In 22nd Street from Marshall Boulevard to Ashland Avenue.

In 26th Street from 40th Arenue to Marshall Boulevard.

In 55th Street from Western A venue to Cottage Grove A venue.

In Cottage Grove Arenue from 55th Street to 79th Street.

There will also be several short connecting lines which I have not enumerated.

The construction of these passenger subways will necessitate the abandonment and removal of a rather large amount of telephone underground conduit and underground cable, and I will enumerate below the general locations and amounts of underground plant which will be involved. 
In Evanston Avenue:

From Berteau Avenue to Halsted Street 2 ducts of conduit and 1 cable.

In Lincoln Avenue:

From Cullom Avenue to Belle Plaine Avenue 4 ducts of conduit and 1 cable.

In Elston Avenue:

From Kedzie Avenue to California Avenue 6 ducts of conduit and 2 cables.

In Milwaukee Avenue:

From California Avenue to Western Avenue an average of 9 ducts of conduit and 5 cables.

From Western Avenue to Robey Street an average of 6 ducts of conduit and 1 cable.

From Noble Street to Chicago Avenue 16 ducts of conduit and 4 cables.

From Chicago Avenue to Halsted Street 28 ducts of conduit and 3 cables.

From Halsted Street to Canal Street an average of 10 ducts of conduit and 2 cables.

In Halsted Street:

From Grace Street to Addison Street 2 ducts of conduit and 1 cable.

From Wrightwood Avenue to Belden Avenue an average of 6 ducts of conduit and 2 cables.

From Shades Place to Blackhawk Street 4 ducts of conduit and 1 cable.

From Rees Court to Division Street 1 duct of conduit and 1 cable.

From Chicago Avenue to Madison Street an average of 5 ducts of conduit and 3 cables.

From Madison Street to Harrison Street 18 ducts of conduits and 5 cables.

From Harrison Street to 12th Street 18 ducts of conduit and 2 cables.

From 12th Street to the south branch of the Chicago River an average of 16 ducts of conduit and 2 cables.

From the south branch of the Chicago River to 26 th Street 12 ducts of conduit and 2 cables.

In California Avenue:

From Wrightwood Avenue to Milwaukee Avenue 3 ducts of conduit and 1 cable. 
In Clark Street:

From Lincoln Arenue to Division Street an average of 17 ducts of conduit and 11 cables.

From Division Street to Chicago Avenue an arerage of 27 ducts of conduit and 11 cables.

From Chicago Avenue to Illinois Street an average of 24 ducts of conduit and 12 cables.

From Illinois Street to Kinzie Street 18 ducts of conduit and 15 cables.

From South Water Street to Washington Street an average of 10 ducts of conduit and 1 cable.

From Washington Street to Van Buren Street an average of 15 ducts of conduit and 4 cables.

In Madison Street:

From 40th Arenue to Central Park Arenue an average of 7 ducts of conduit and 6 cables.

From Central Park Avenue to Sacramento Arenue an average of 10 ducts of conduit and 6 cables.

From Ashland Avenue to Canal Street an average of 30 ducts of conduit and 17 cables.

In Harrison Street:

From Halsted Street to Clinton Street 12 ducts of conduit and 3 cables.

From Clinton Street to 5th Avenue an average of 14 ducts of conduit and 7 cables.

From 5th Avenue to Sherman Strect 18 ducts of conduit and 12 cables.

From Sherman Street to Clark Street 48 ducts of conduit and 12 cables.

From Clark Street to State Street an average of 25 ducts of conduit and 16 cables.

In Blue Island Avenue:

From Harrison Strect to 12 th Strect 8 ducts of conduit and 2 cables.

From 12th Street to 14th Street 8 ducts of conduit and 3 cables.

From 14 th to 19 th Street 10 ducts of conduit and 4 cables.

From 19th to 22nd Street 6 ducts of conduit.

In 26th Street:

From Whipple Street to Springficld Arenue an arerage of 3 ducts of conduit and 1 cable.

\section{In State Street:}

From Madison Street to Van Buren Street 6 ducts of conduit and 2 cables.

From 26th Strect to 27th Street 4 ducts of conduit and 1 cable.

From Root Street to 43d Strect 7 ducts of conduit and 1 cable. 


\section{In Cottage Grove Avenue:}

From 55th Street to $63 \mathrm{~d}$ Street an average of 8 ducts of conduit and 1 cable.

From 63 d Street to 69 th Street 8 ducts of conduit and 2 cables.

From 69 th Street to 71 st Street 8 ducts of conduit and 3 cables.

From 71st Street to 75th Street 3 ducts of conduit and 2 cables.

From 75th Street to 79th Street 7 ducts of conduit and 1 cable.

The passenger subway as proposed at numerous locations will occupy the same streets occupied now by the Telephone Company with its main conduit and underground cable leads; and incident to the destruction of these main telephone underground leads, it will be necessary to abandon certain subsidiary intersecting underground conduit and cable leads that now cross the proposed subway.

We estimate that the loss to the Telephone Company due to the destruction of its underground plant in those streets which the proposed passenger subway will occupy, and the necessary abandonment of subsidiary underground conduits and cables, will amount to approximately $\$ 1,840,000.00$. This amount is made up of two items; namely,

Underground Conduit......... $\$ 1,165,000.00$

Underground Cable.......... 675,000.00

In considering the estimate for the loss of underground cable, account has been taken of the net salvage return, that is, gross salvage value less the cost of removing the cables, which could be obtained upon the cables involved.

With underground conduit there would not be any salvage value and it is further assumed that it would be unnecessary for the Telephone Company to remove it from the streets.

In addition to the above amount, which covers the direct loss of plant destroyed, it would be necessary to do a large amount of temporary work during the construction of the subways in maintaining our service in various crossings over the obstructed streets. In a number of instances the proposed subways will practically cut our exchange districts in halves and it will be necessary of course at all times to maintain sufficient crossings to enable us to give service to all subscribers. We estimate that this item will amount to $\$ 250,000.00$

These two items, of direct loss on plant destroyed, and the expense incident to maintaining service during actual subway construction work, together amount to $\$ 2,090,000.00$ and this figure would represent the estimated total loss to the Telephone Company on account of the construction of passenger subways in these streets.

All the above estimates have been made on the basis of present telephone plant. In a great many instances, especially where main telephone routes are involved, the provision of required telephone facilities 
will necessitate the installation of several large sized telephone cables in each year and any delay in the construction of the subways will result in substantial increases in the losses incident to the abandonment and destruction of the telephone plant involved.

I would estimate that the loses which will be involved in subway construction as above outlined, will increase at the rate of at least $\$ 100,000.00$ per year. Yours truly,

$\mathrm{CB}: \mathrm{RT}$

(Signed) J. G. WRAY,

Chief Engineer.

APPENDJX 12

THE PLANT AND HOW PAID FOR*

\begin{tabular}{|c|c|c|c|c|c|}
\hline Year & $\begin{array}{c}\text { Investment } \\
\text { Dec. 31st }\end{array}$ & $\begin{array}{c}\text { Capital } \\
\text { Stock }\end{array}$ & Bonds & $\begin{array}{l}\text { Reserve for } \\
\text { Depreciation }\end{array}$ & $\begin{array}{c}\text { Total } \\
\text { Liabilities }\end{array}$ \\
\hline 1881 & $\$ 493,465.99$ & $\$ 500,000$ & & & $\$ 500,000.00$ \\
\hline 1882 & $563,575.19$ & 500,000 & & & $500,000,00$ \\
\hline 1883 & $623,606.72$ & 600,000 & & & $600,000.00$ \\
\hline 1884 & $654,743.16$ & 693,000 & & $\ldots \ldots \ldots$ & $693,000.00$ \\
\hline 1885 & $732,888.05$ & 762,300 & & & $762,300.00$ \\
\hline 1886 & $805,318.72$ & 838,600 & & $\ldots \ldots \ldots$ & $838,600.00$ \\
\hline 1887 & $977,035.47$ & 964,400 & & & $964,400.00$ \\
\hline 1888 & $1,131,342.03$ & $1,089,800$ & $\ldots$ & & $1,089,800.00$ \\
\hline 1889 & $1,302,625.49$ & $1,253,300$ & : & $\cdots \ldots \ldots$ & $1,253,300.00$ \\
\hline 1890 & $1,734,212.73$ & $1,754,700$ & & & $1,754,700.00$ \\
\hline 1891 & $2,310,519.66$ & $2,000,000$ & & $\ldots$ & $2,000,000.00$ \\
\hline 1892 & $3,415,023.37$ & $3,280,200$ & $\ldots \ldots$ & & $3,280,200.00$ \\
\hline 1893 & $4,001,039.55$ & $3,796,200$ & & & $3,796,200.00$ \\
\hline 1894 & $4,159,989.38$ & $3,796,200$ & : & $\$ 120,000.00$ & $3,916,200.00$ \\
\hline 1895 & $4,521,439.29$ & $3,796,200$ & & $200,889.40$ & $3,997,089.40$ \\
\hline 1896 & $4,607,909.34$ & $4,336,500$ & . & $200,889.40$ & $4,537,389.40$ \\
\hline 1897 & $4,545,729.82$ & $4,336,500$ & $\ldots \ldots \ldots$ & $100,000.00$ & $4,436,500.00$ \\
\hline 1898 & $5,174,748.47$ & $4,336,500$ & & $474,782.22$ & $4,811,282.22$ \\
\hline 1899 & $6,615,922.64$ & $5,000,000$ & $\ldots \ldots$ & $903,934.14$ & $5,903,934.14$ \\
\hline 1900 & $8,122,052.61$ & $7,000,000 \dagger$ & & $421,172.53$ & $7,421,172.53$ \\
\hline 1901 & $9,933,480.47$ & $9,000,000$ & & $296,432.87$ & $9,296,432.87$ \\
\hline 1902 & $12,333,854.20$ & $11,993,400$ & & $346,551.32$ & $12,339,951.32$ \\
\hline 1903 & $13,909,268.38$ & $14,000,000$ & & $646,551.32$ & $14,646,551.32$ \\
\hline 1904 & $14,593,186.16$ & $14,000,000$ & & $913,825.83$ & $14,913,825.83$ \\
\hline 1905 & $15,930,664.83$ & $14,000,000$ & & $1,295,155.61$ & $15,295,155.61$ \\
\hline 1906 & $18,683,669.11$ & $14,000,000$ & & $1,692,066.24$ & $15,692,066.24$ \\
\hline 1907 & $27,007,758.41$ & $16,908,500$ & $\cdots \ldots$ & $1,899,613.46$ & $18,808,113.46$ \\
\hline 1908 & $29,090,647.83$ & $27,000,0009$ & & $1,901,739.25$ & $28,901,739.25$ \\
\hline 1909 & $31,001,017.78$ & $27,000,000$ & $\$ 5,000,000$ & $1,901,739.25$ & $33,901,739.25$ \\
\hline 1910 & $33,737,612.48$ & $27,000,000$ & $5,000,000$ & $3,695,160.95$ & $35,695,160.95$ \\
\hline 1911 & $37,137,217.75$ & $27,000,000$ & $5,000,000$ & $4,971,823.19$ & $\mathbf{3 6}, 971,823.19$ \\
\hline
\end{tabular}

*Working capital for which the Company claims about $\$ 1,900,000$ is here omitted because the exant increase from year to year cannot be definitely ascertained. All of the existing capital, however, must have been accumulated out of earnings. The figures are taken from Hagenah's balance sheets down to 1900 and thereafter.

$+\$ 1,000,000$ was a stock dividend.

$\$$ The following balance inust be taken into account for the years 1906 and 1907:

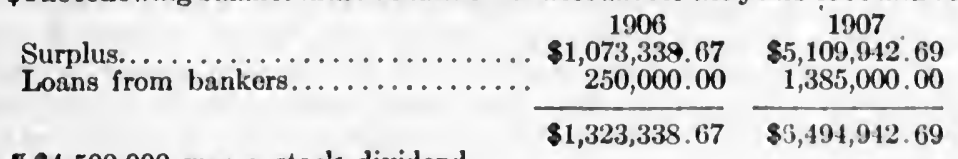

II \$4,500,000 was a stock dividend. 


\section{Appendix No. 13 \\ THE COMPANY'S TREATMENT OF DEPRECIATION}

(From Hall's Report, pp. 20-23.)

Whatever may have been the ruling policy as regards the anticipation of the future, the records show that a reserve for deferred maintenance was inaugurated in 1894 to which certain annual credits were made, emanating from the maintenance accounts. These credits continued until 1907 and amounted to $\$ 6,765,595.05$, made up as follows:

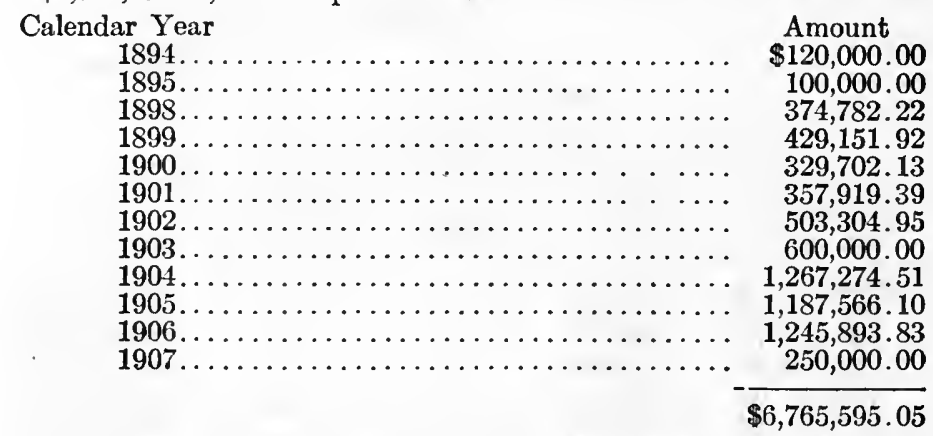

Of this amount, however, $\$ 1,575,000.00$ was transferred to surplus, leaving a net credit of $\$ 5,190,595.05$ as a fund ostensibly for the dual purpose of providing for deferred maintenance and for contingencies. Doubtless, owing to this twofold character, certain sums were charged each year to the fund and deducted from the investment account, representing estimated depreciation which bas taken place, while a steadily increasing balance was allowed to remain in the fund, accumulating to $\$ 1,836,714.26$ at the close of 1907 . The following summary shows the position with regard to the fund, December 31, 1907:

Net amount credited to fund................\$\$, 190,595.05

Less: Estimated depreciation written off investment as follows:

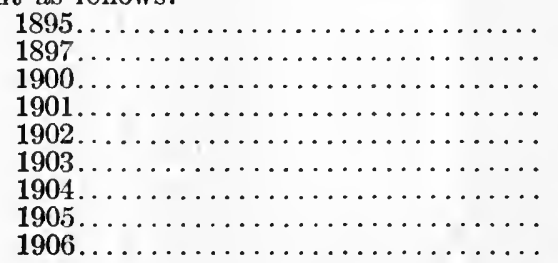

$\$ 19,110.60$

$100,889.40$

$412,463.74$

$469,612.35$

$300,000.00$

$300,000.00$

$500,000.00$

$400,000.00$

$700,000.00$

Adjustment of maintenance accounts, supplies, etc. $\begin{array}{r}\$ 3,202,076.09 \\ 151,804.70\end{array}$

Balance at credit of fund December 31,1907 .

$3,353,880.79$

$\$ 1,836,714.26$

It might be inferred from the above that, inasmuch as the investment was being written down to the extent of the above charges, the actual depreciation of the plant, over and above replacements each year, was, in the opinion of the management, developing with considerable momentum. That this view was not altogether steadfast is apparent from the fact that at December 1, 1907, the whole of these deductions, together with certain other credits to investment account which were charged direct to maintenance and to surplus, were reversed, leaving the investment at its original book cost. As a result of this transaction the plant account was increased by the sum of $\$ 3,767,233.55$, this 
amount being credited to the surplus account in place of the above reserve, which had contributed practically the whole of the amount. Looking to the fact that this credit to surplus account was diverted from its primary purpose to serve as a means to an end diametrically opposite, namely, the distribution of a stock dividend of $\$ 4,500,000.00$ in the following year, little, if any, importance can be attached to its treatment in the accounts of the company as having any bearing on the question of depreciation. Neither can any significance be attached to the balance of $\$ 1,836,714.26$ remaining in the reserve fund, as indicative of the physical condition of the plant at that time. It may have been, and doubtless was, regarded as the nucleus of the fund now standing in the books.

The history of the fund from January 1, 1908, to the present time may best be seen from the following synopsis showing how the fund at December 31, 1911 , namely, $\$ 4,971,823.19$, was accumulated:

Balance at credit January $1,1908 \ldots \ldots \ldots \ldots \ldots$

From reserve for depreciation of buildings - balance

at December $31,1908 \ldots \ldots \ldots \ldots \ldots \ldots$. . . . .

Sundry credits added in $1908 \ldots \ldots \ldots \ldots \ldots \ldots \ldots$

From surplus - balance as at December 31,1909 .

From maintenance-1910..............\$1,500,000.00

Less: Reconstruction and replacements....... $553,647.14$

$\$ 1,836,714.26$

From maintenance-1911 .............. $\frac{\overline{1,620,000.00}}{\overline{1,0}}$

Less: Reconstruction and replacements........ $\quad 445,211.75$

$847,068.84$

$946,352.86$

Sundry credits added in $1911 \ldots \ldots \ldots \ldots \ldots \ldots$

$1,174,788.25$

$101,873.99$

Balance at credit, December $31,1911 \ldots \ldots$.

$\$ 4,971,823.19$

It will be observed that the credit of 1909 consisted of a transfer of the balance in surplus account at the close of that year. The credits for 1910 and 1911 appear to have been regulated substantially by the balance of profit remaining after meeting all expenses and the eight per cent. dividend, the undivided profit added to surplus for each of these years amounting to $\$ 95$,072.93 and $\$ 102,540.31$, respectively. In view of all the facts concerning this fund, it is perhaps not irrational to regard it as a general reserve for the purpose of providing for contingeneies and for automatically regulating the dividend. Whether or not this fund is adequate for the present purpose may perhaps be best judged from the experience of the company in the past in regard to actual exp,enditures for maintenance and renewals. This consideration may be regarded as the element affecting the present value of the plant, the other two elements having also to be taken into aceount in determining the sufficiency of the fund in its complete aspeet.

This more direet view of the question may be obtrined in a study of the actual expenditures in the past in respect of repairs and renewals. The percentage of the average annual expenditure thus ascertained, to the investments which do depreciate may be regarded as the basis for the nnnual allow. ance to be set aside for the purpose in view. It should be observed that it is not possible to differentiate between current repairs and reconstruction outlay until within the last seven or eight years. It is reasonable, however, to assume that although this period may not be suffieiently full to determine an average for reconstruction, it may be regarded as of sufficient duration to give the average for current annual repairs. The average for the total expenditure being determinable, it is thus possible to deduce the average for reconstruetion outlay indirectly. 


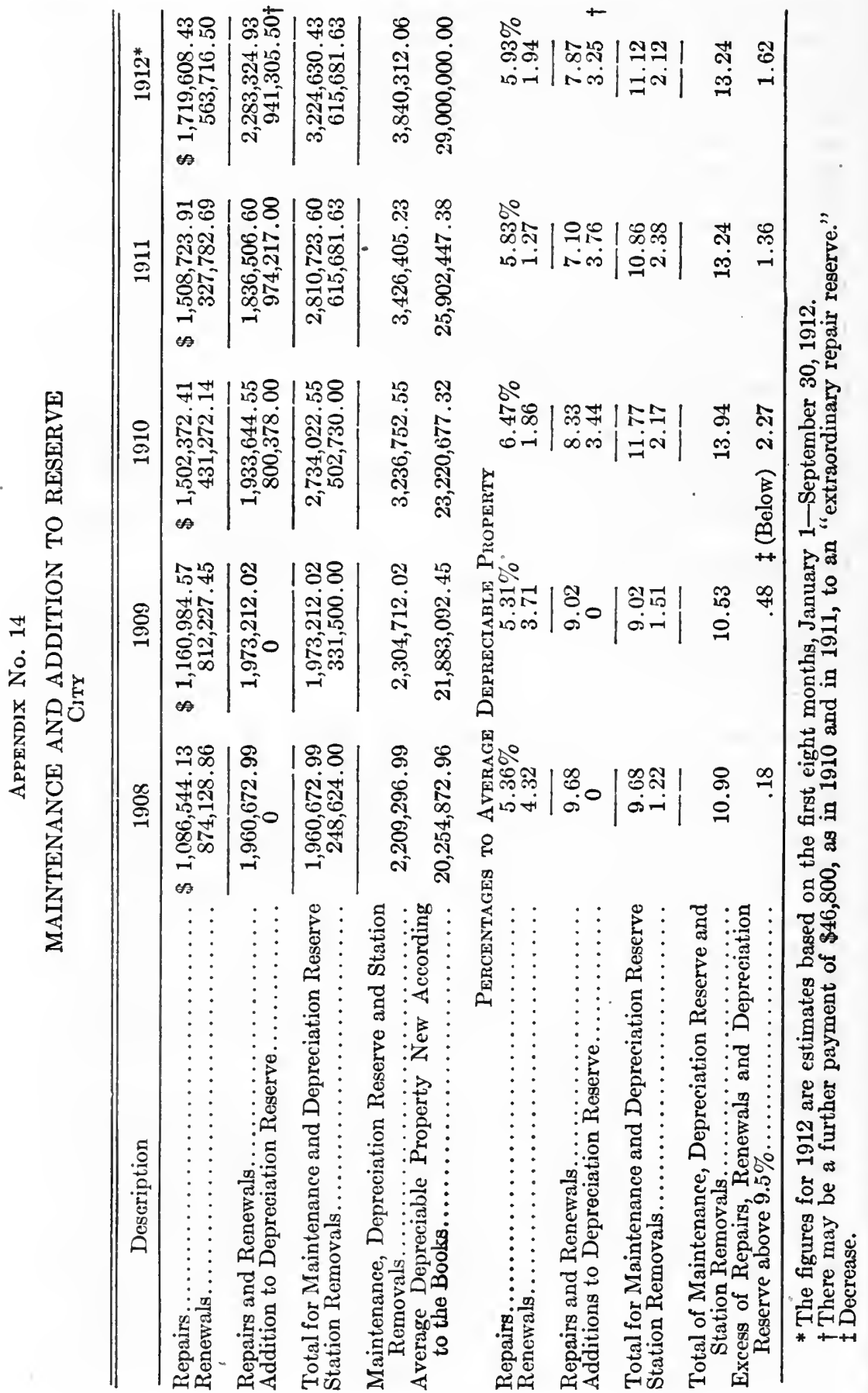


PHYSICAL VALUATION OF CHICAGO TEL. COS. 893

APpendix No. 15

\section{COMPOSITE LIFE, SALVAGE AND ANNUAL DEPRECIATION}

230 West Washington Strect, Chicago, October 24, 1912.

Prof E. W. Bemis, City Hall, Chicago.

Dear Sir:

DEPRECIATION

Since talking to you this noon we have checked over our depreciation figures very carefully and find the following:

CHICAGO TELEPHONE COMPANY

APPRAISAL VALUES OF PLANT AS OF AUGUST 1, 1911 CHICAGO EXCHANGE

Chicago Telephone

Byllesby \& Arnold Life and Salvage Life and Salvage

Composite Life.

13.455 years

Salvage................... $29.234 \%$

Annual Depreciation Allowance......

$5.260 \%$

18.961 years

$22.862 \%$
$4.068 \%$

BOOK VALUES OF PLANT AS OF AUGUST 1, 1911

CHICAGO EXCHANGE

Chicago Telephone

Life and Salvage

Byllesby \& Arnold

Life and Salvage

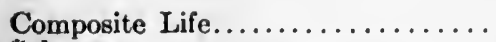

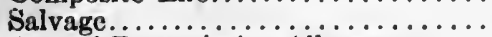

Annual Depreciation Allowance.....

12.802 years

$29.196 \%$

$5.531 \%$

18.318 years

$22.542 \%$

$4.228 \%$

Nore-The percentages in the above tables are based on total plant in service, including land, but not including working capital, construction in process, tools, teams, and supplies, and furniture and fixtures. The depreciation allowance is figured on straight line basis. Salvage is made to includo land and installation of subscribers' instruments.

Yours truly,

JGW-FF

(Signed) J. G. WRAY, Chief Engineer 
APpendix No. 16

QUANTITIES OF PHYSICAL PLANT IN CHICAGO AND SUBURBAN TERRITORY, CHICAGO TELEPHONE COMPANY AS OF AUGUST 1, 1911, ACCORDING TO APPRAISAL ACCOUNT 103-REAL ESTATE

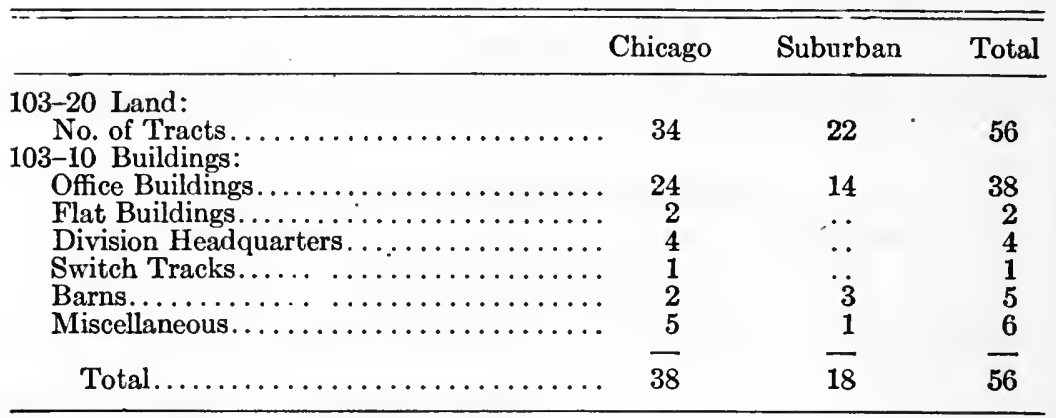

105-EQUIPMENT

17-CENTRAL OFFICE OPERATING EQUIPMENT

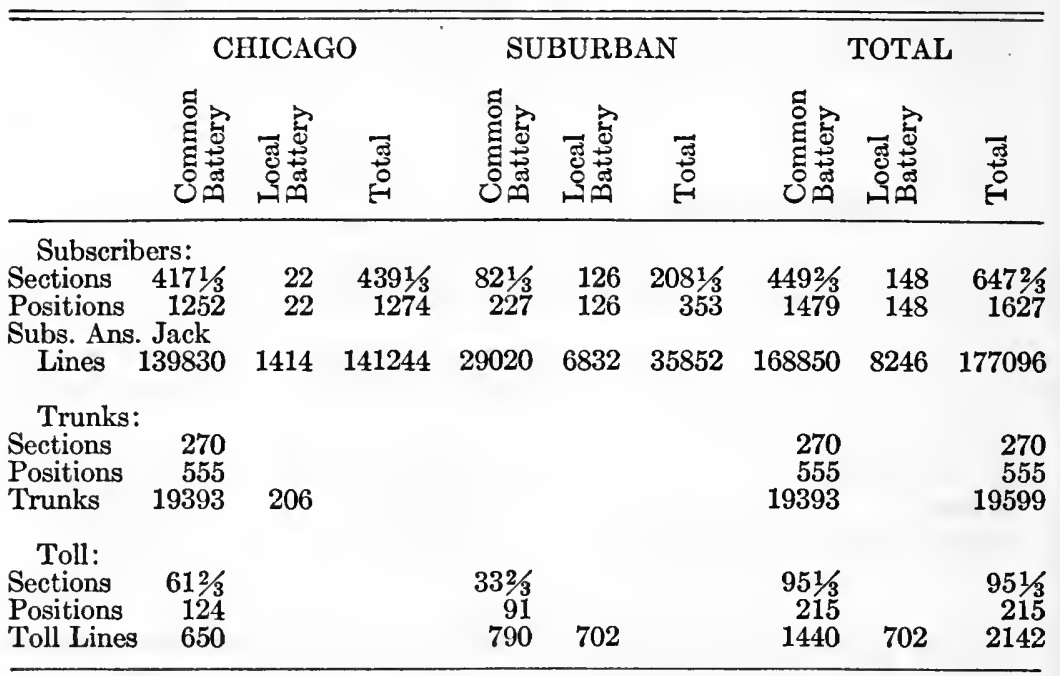

105-EQUIPMENT

18-STATION APPARATUS

\begin{tabular}{|c|c|c|c|}
\hline & Chicago & Suburban & Total \\
\hline Stations. & 254742 & 64118 & 318860 \\
\hline
\end{tabular}

105-08-SUBS. STATION EQUIPMENT 38-DROP WIRES

Drops............................. 161825 
105-EQUIPMENT

48-INTERIOR BLOCIK IVIRES

\begin{tabular}{llllr}
\hline & Chicago & Suburban & Total \\
\hline No. 18 Twist. Pair............... & $305897 \mathrm{ft.}$ & $51994 \mathrm{ft}$. & $357891 \mathrm{ft}$.
\end{tabular}

105-EQUIPMENT

58-PRIVATE BRANCH EXCHANGES

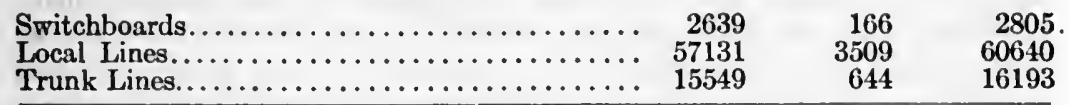

\section{SUMMARY OF 107-109 ACCOUNTS EXCHANGE AND TOLL LINES}

\begin{tabular}{|c|c|c|c|c|}
\hline $\begin{array}{l}\text { Sub. } \\
\text { Acct. }\end{array}$ & Item & $\underset{\text { Quantity }}{\text { CHICAGO }}$ & $\begin{array}{c}\text { SUBURBAN } \\
\text { Quantity Unit }\end{array}$ & ${ }_{\text {Quantity }}^{\text {TOTAL }}$ Unit \\
\hline $\begin{array}{l}01 \\
02 \\
03 \\
14\end{array}$ & $\begin{array}{l}\text { Pole I.ines } \\
\text { Aerial Cable } \\
\text { Aerial Wire } \\
\text { U. G. Conduit }\end{array}$ & $\begin{array}{l}81822 \text { Poles } \\
\text { 56324.29 Cond. Mi. } \\
7920.86 \text { Cond. Mi. } \\
12069228 \text { Duct. Ft. }\end{array}$ & $\begin{array}{l}229195 \text { Poles } \\
29767.60 \text { Cond. Mi. } \\
37247.51 \text { Cond. Mi. } \\
2218889 \text { Duct. Ft. }\end{array}$ & $\begin{array}{l}311017 \text { Poles } \\
86091.89 \text { Cond. Mi. } \\
45168.37 \text { Cond. Mi. } \\
14288117 \text { Duct Ft. }\end{array}$ \\
\hline 24 & $\begin{array}{l}\text { Main } \\
\text { U. Gonduit } \\
\text { Subsidiary }\end{array}$ & 913399 Duct. Ft. & 271999 Duct. Ft. & 1185398 Duct $\mathrm{Ft}$. \\
\hline 15 & $\begin{array}{l}\text { U. G. Cable } \\
\text { Main }\end{array}$ & 518299.13 Cond. Mi. & 52665.17 Cond. Mi. & 570964.30 Cond. Mi. \\
\hline 25 & $\begin{array}{l}\text { U. G. Cable } \\
\text { Subsidiary }\end{array}$ & 21562.58 Cond. Mi. & 4526.02 Cond. Mi. & 26088.60 Cond. Mi. \\
\hline 53 & House Cables & 43885 Pairs & 1000 Pairs & 44885 Pairs \\
\hline
\end{tabular}

112-TOOLS AND VEHICLES

Chicago Suburban Total

02 Teams and Vehicles:

Outfits............................

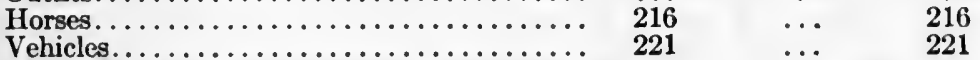
$\begin{array}{lll}\cdots & 71 & 71\end{array}$

03 Motor Vehicles:

Auto. and Motorcycles................ $45 \quad 40 \quad 85$

APpendix No. 17.

CITY PURCHASE.

Being Section 16 of Ordinance Regulating Telephone Charges in the City of Chicago, November 6, 1907.

16. Right to Purchase Plant Reserved by City-Price Fixed by Appraisers.

The City of Chieago shall have the right on the first day of January, 1919, or on the first lay of January, 1924, or within thirty (30) days after either of said dates, if it shall so elect, to terminate the grant of privileges of said Chieago Telephone Company conferred hereby, and on either of the said dates, or at the expiration of the term hereof, or within thirty (30) days after wither of the times mentioned, to take over for munieipal, state or federal uperation the plant and system of the grantee, or its sucecssor or successors, including the property hereinafter mentioned; provided that twelve (12) 
months' previous notice in writing shall have been given of the intention of the City to take over the telephone plant system of the grantee, or its successor or successors, within the City of Chicago, including all appurtenances, appliances, equipment, lines, leaseholds, buildings, stores, furniture and fixtures, suitable to and used by it for the purposes of this grant, taking into consideration the then condition of the art, and in the event that the City Council shall so terminate this grant, or that said grant shall have expired, and the City Council shall take over the property of said Company above mentioned, then the City shall pay therefor in cash the then cost of the duplication, taking into consideration the then condition of the art, less depreciation, of said telephone plant and system and other property aforesaid, together with, if the said grant shall not then have expired, five per cent. (5\%) thereon in addition as compensation for the compulsory sale, but there shall be no allowance for earning power, or for the value of the rights and privileges hereby granted, or for any franchise or license value.

In the event that the City shall desire to purchase the property of the company within the City of Chicago, as aforesaid, the purchase price of said property shall be determined by appraisement as follows:

One appraiser shall be appointed by the City in such manner as the City Council shall direct; one shall be appointed by the company and a third shall be appointed by the two so selected. Either party may appoint its appraiser at any time after the giving of the notice of intention to take over the telephone plant and system of the grantee, and serve written notice of such appointment upon the other party, and said other party within thirty (30) days after service of notice of such appointment shall appoint its appraiser and serve written notice of such appointment upon the other party; whereupon the two appraisers so appointed shall appoint a third appraiser.

In the event that the party first receiving the notice of the selection of an appraiser by the other party, shall refuse or fail to appoint an appraiser and give notice thereof as above provided, or in the event that the two appraisers first appointed shall fail to agree upon a third appraiser within thirty (30) days after the giving of notice of the appointment of the second appraiser, either party, upon giving a written notice of ten (10) days to the other party, may apply to the then judges of the Appellate Court for the First District of Illinois, or a majority of the judges of the said Appellate Court, for the appointment of an appraiser, and if the appraiser appointed by the judges of the said court, or by a majority of them, shall be the second appraiser, then the third appraiser shall be selected by the two appraisers, or if they fail to agree, by the said judges of the said court, or a majority of them, in the manner hereinbefore provided, and any appraiser or appraisers appointed by said judges, or a majority of them, shall have the same powers and duties as if regularly appointed in the manner as first hereinabove provided.

The appraisers shall determine what tangible property, real and personal, owned by the said company and used for the purposes of this grant is reasonably required for its continued operation, taking into consideration the then condition of the art, and in determining the fair cash value of said property they shall not take into consideration its earning power, or the value of the rights or privileges hereby granted, or the value of any license or franchise, but shall allow for the property the then cost of duplication, taking into consideration the then condition of the art, less depreciation. In considering the cost of duplication of underground conduits, wires, cables, electrical conduc- 
tors and any other underground construction located in any street, alley or other public way which was or were placed therein at a time when such street, alley or other public way was unpaved, the said appraisers shall not take into consideration the cost and expense of removing or replacing any paving, or part therenf, in such street, alley or other public way. An award in writing, signed by a majority of the appraisers, shall be valid and binding upon the parties.

Within ninety (90) days after the making of said written award by the said appraisers, or a majority of them, the Chicago Telephone Company shall cause to be duly made, executed and delivered proper bills of sale and deeds of the said telephone plant and system and tangible property covered by said award, and the City of Chicago, upon the delivery of said bills of sale and deeds, and the delivery of, or the transfer of control over, said telephone plant and system and tangible property, shall make payment in cash therefor, as hereinbefore provided.

If said award shall not have been made until after the date named in the written notice given by the City of its intention to take over the telephone plant and system of the grantee, or its successor or successors, as hereinbefore provided, such delay on the part of the said appraisers, or a majority of them, in making their award, shall not affect the right of the City of Chicago to take over the said telephone plant and system and tangible property of the Chicago Telephone Company.

Said City of Chicago shall pay the expenses and charges of the said ap. praisers for their services under a contract which shall be authorized by the City Council and entered into by each of said appraisers at the time of his appointment. Such contract shall not allow to each of said appraisers more than one hundred dollars per day as compensation and shall bind them to complete their award within a stipulated time, or be subject to a specified reduction per day in compensation. Such contract shall also forbid any of the said appraisers from contracting for or aceepting any otler or additional compensation for his or their services (from any person, firm or corporation) except that provided in said contract. The other terms of said contract shall be such as may meet the approval of the City Council. Provided, that the City of Chicago may deduct from the purchase price fixed by said award onehalf of the total amount paid as the total expenses and charges of said appraisal.

The appraisers selected in the manner aforesaid, or a majority of them, shall have and may exercise at all times the right to make a complete examination of the records, books of account, vouchers, bills, contracts and documents of said company, for the purpose of fully informing themselves as to the actual cost, value and depreciation of the plant and system of said company, includ. ing all appurtenances, appliances, equipment, lands, leaseholds, buildings, stores, furniture and fixtures and other property.

Any vacancy or vacancies occurring at any time in said Board of Appraisere by death, resignation, disqualification or inability to act, may be filled within fifteen days, by the party or body making the original appointment, and if not so filled, by the judges of said court, or a majority of them, upon the application of either party thereto, provided five days' previous notice in writing of such application shall have been given to the other party.

The Chicago Telephone Company by the filing of the acceptance hereinbefore provided for shall be understood as granting and does hereby grant to the City of Chicago, and the said City of Chicago hereby reserves to itself the 
right to designate any person, firm or corporation having lawful authority to acquire, own and operate a telephone line or lines or a system in said City of Chicago (hereinafter called the "licensee") who or which shall have the right to purchase the plant, system, rights and property of said Chicago Telephone Company at the expiration of the term of this grant, or within thirty (30) days thereafter, in the same manner which the City hercunder has the right to purchase the same within such time, and any person, firm or corporation so designated by said City of Chicago as licensee twelve or more months prior to the expiration of this grant shall for all the purposes of this section stand in the position of said City of Chicago. The right of the licensee of said City of Chicago to acquire said telephone plant, system, rights and property by purchase under the provisions of this ordinance shall in no way be impaired or diminished by any lack of authority or power on the part of the City of Chicago itself to acquire the said telephone plant, system, rights and property for municipal or other use and operation.

Nothing in this section, however, shall have the effect or be construed to have the effect of lessening or limiting the right of the City of Chicago to alter, change or reduce the charges, rates, tolls or other compensation to be charged by said licensee in the operation of said plant and system, or of lessening or limiting any of the authority, power or rights reserved by said City of Chicago to itself by this ordinance, or of changing, lessening or limiting any of the duties, obligations or restrictions imposed by this ordinance upon the grantee.

Nothing in this ordinance shall have the effect or be construed to have the effect of extending, so far as the licensee is concerned, the term of this grant beyond January 7, 1929. Upon the purchase of said plant, system, rights and property under the provisions of this section either by the City of Chicago, or by any licensee of said City, all the rights of said Chicago Telephone Company, its licensee or assigns, in or to said plant, system, rights and property, or any part or parts thereof, or the operation thereof, or receipts therefrom, shall wholly cease and determine. If at the expiration of this grant the City shall not have elected to purchase the plant, system and other property. of said company hereinbefore mentioned, and shall not have designated any licensee, the failure on the part of the City to purchase, or elect to purchase, or elect to designate a licensee, shall not be construed as an extension of this grant, or any of the rights and privileges hereby granted.

The authority, powers, privileges and rights by this section reserved by and granted to the City of Chicago to itself purchase the plant, system and property of said Chicago Telephone Company are so reserved and granted upon the understanding that they and each of them may be exercised only if at the time said City of Chicago seeks to exercise the same, or any of them, it shall possess the charter power so to do. But said Chicago Telephone Company by the acceptance of this ordinance shall be understood as precluded from in any manner attacking or questioning the power of the City of Chicago to exercise the authority, powers, privileges and rights hereby reserved or granted, or any of them. 


\section{DIVERGENT VIEWS ON DEPRECIATION ${ }^{2}$}

\section{James Campbell on Depreciation}

Under the heading of "General" in the annual report of the North American Company for the fiscal year ended Dec. 31, 1913, James Campbell, formerly president of the Company and now chairman of the Board, says in discussing the question of depreciation:

"The fact that the subsidiary companies in which your company is interested appropriate large reserves each year for the present maintenance and future preservation of their physical properties should not be without its influence on the value of your equities. Many other public utilities are at present operated under the assumption that a provision for ordinary maintenance is sufficient to arrest depreciation. Examination, however, of the causes leading to the abandonment of various items of physical property shows that in the majority of instances the replacement becomes necessary before the item has been worn out. Maintenance will do little other than permit the realization of the expected life, whercas depreciation is designed to insure the replacement which will increase the useful life of the property.

"The determination of the proper allowances for maintenance and depreciation of properties is not without its difficulties. In fact, it calls for the exercise of conservative judgment and possibly modification from time to time as the necessity therefor develops. The estimates made by regulating commissions in cases involving the regulation of rates are at best crude guesses, and are rarely substantiated by accurate statistical information. That the principle of providing for depreciation is sound appears evident when it is recognized that it is necessary to provide to-day replacements to be made in later years in order that to-day's users of service may bear the cost thereof."

During the year the companies controlled by the North American Company expended $\$ 10,528,891$, which was charged to capital account, and provided out of earnings reserves for depreciation aggregating $\$ 3,401,029$, and in addition thereto expended $\$ 3,116,082$ on maintenance. The proportion of gross revenues expended on maintenance and appropriated for depreciation during the year 1913 by the rail-

1 Reprinted from the Electric Railway Journal. 
ways controlled by the company are shown by the following tabulation:

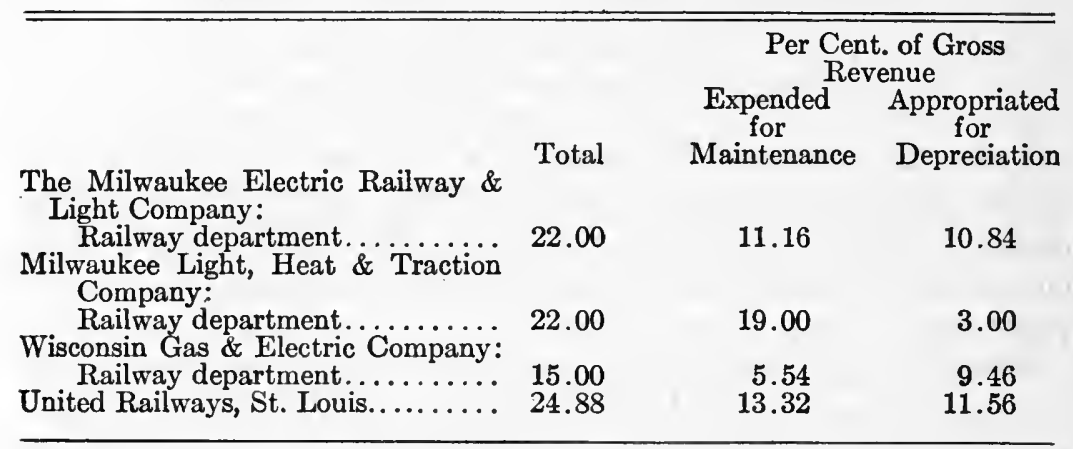

\section{H. M. Byllesbi on Depreciation}

In the recent annual report of the Northern States Power Company, H. M. Byllesby, president of the Company, gives the following interesting discussion concerning the manner of appropriating amount out of the earnings of public utilities for depreciation:

"All of the properties of the Company have been fully maintained to 100 per cent efficiency. The cost of this maintenance has been charged to operation. Beyond this no arbitrary charge has been made out of current earnings to represent any accruing depreciation which has not become evident, except in certain particular instances amounting to the sum of $\$ 67,861$. The question of an allowance for accruing depreciation beyond the full maintenance of the property is one which is under discussion at the present time and upon which the most divergent views are expressed by operating officials. On the one hand, it is contended that beyond maintenance to 100 per cent efficiency no further arbitrary depreciation should be charged. On the other hand, it is contended that in addition to the full maintenance a certain definite allowance for accruing depreciation should be made. The amounts so to be allowed, whether based on percentages of gross income or percentages of depreciable value of the property, vary from the smallest amounts to amounts which are far beyond the possibilities of any property to sustain with present rates.

"In the meantime, no distribution has been made on the common stock of the Northern States Power Company since its formation. The earnings which have accrued on the operating statements as applicable to that purpose have been reinvested in the plant and extensions to the service. 'This policy will be continued until such time as a more definite program as to depreciation has been generally 
adopted by public service companies similarly situated or until, by the establishment of public utility commissions in the states wherein the company operates, more definite rules on this subject are laid down for the guidance of the officers. Then the officers will put into effect in this property a working plan for the definite providing of accrued depreciation beyond the full maintenance which the properties always have.

"Certain of the real estate holdings of the company have increased pronouncedly from the general appreciation in values in their vicinity. These appreciations in value should be taken into account in any consideration of the more or less academic question of accruing depreciation where properties have been fully maintained." 


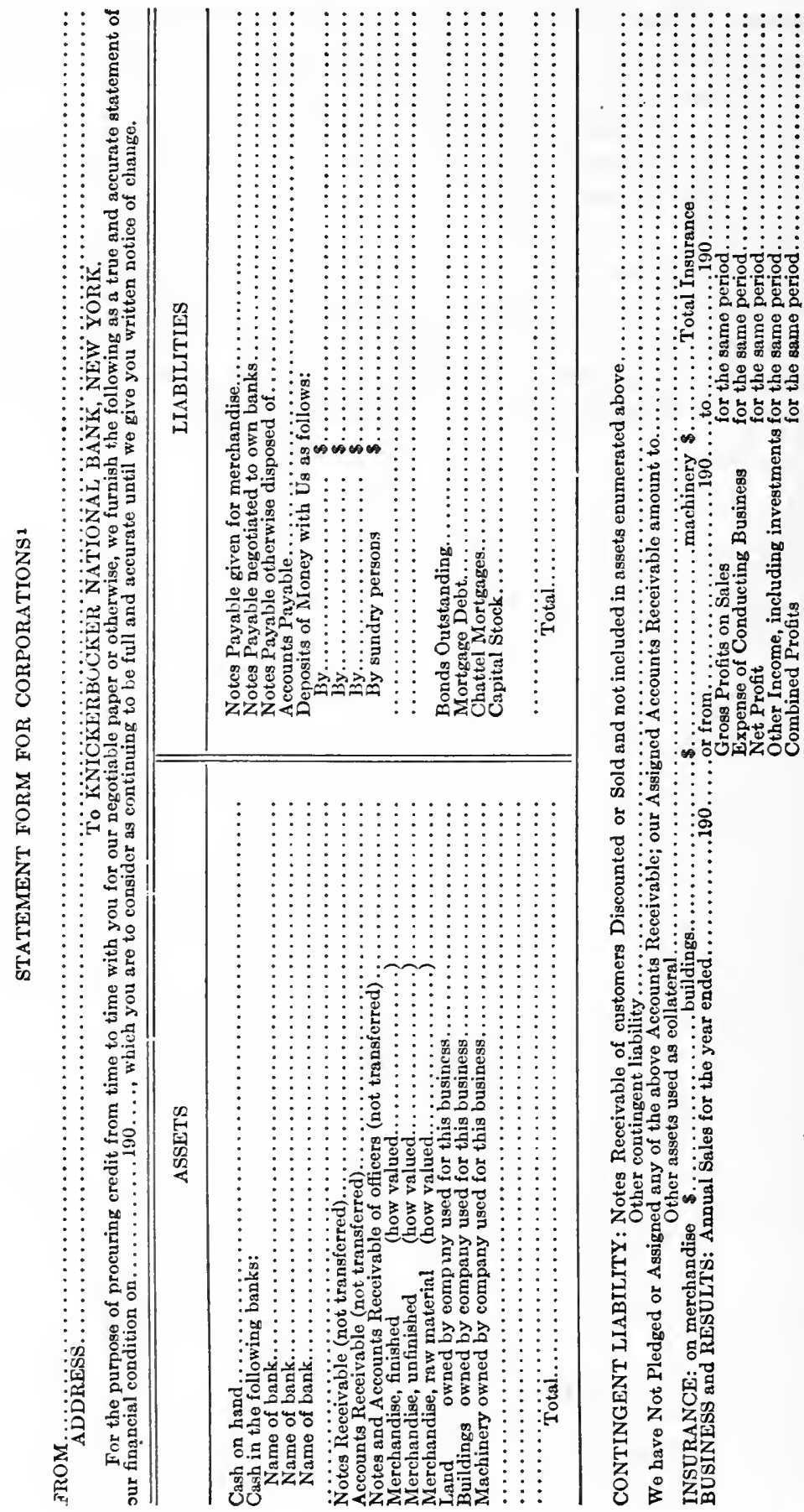


APPLICATION FOR BANK LOAN 903

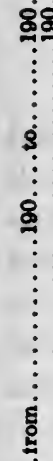

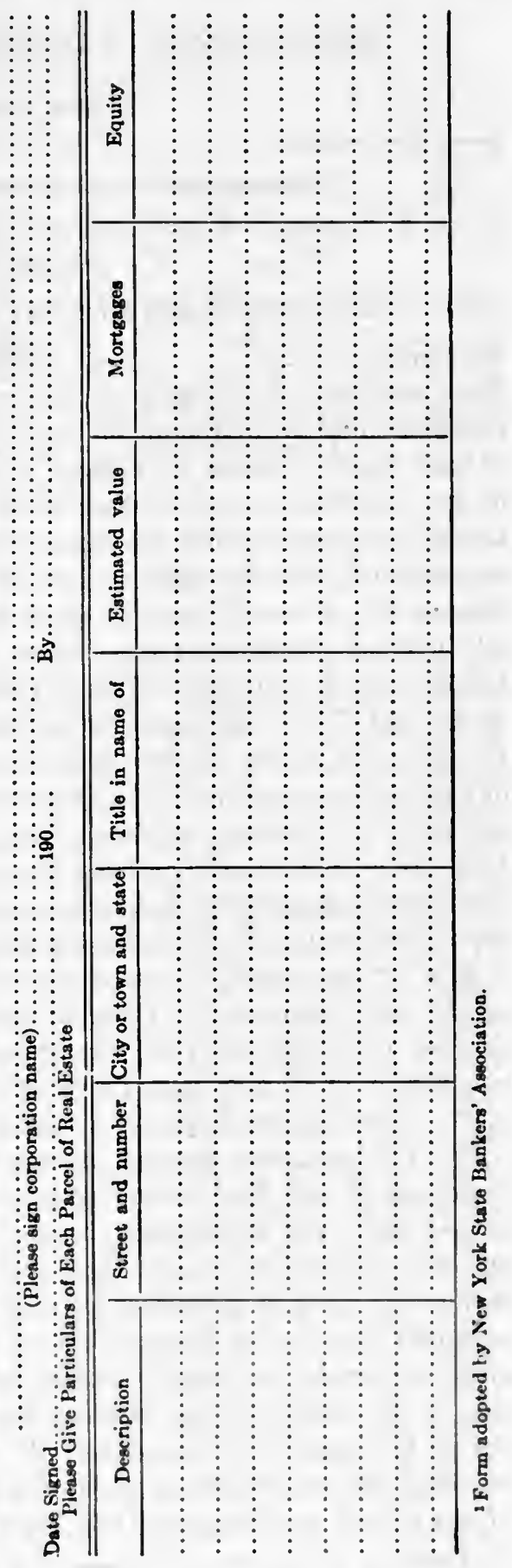




\section{NOTE USED TO PROTECT OVERDRAFTS}

New York, ..............

$\$$

On demand for value received,...... promise to pay to National Bank of Finance ${ }^{1}$ in New York,

or order,

at the office of said Bank in the City of New York,

the sum of $\ldots \ldots \ldots \ldots \ldots \ldots$ Dollars, hereby agreeing that said Bank shall have a lien upon all property of the undersigned and all collaterals pledged by the undersigned, now or hereafter in possession of said Bank, or under its control, as security for any indebtedness of the undersigned now existing or to become due or that may be hereafter contracted, with the right at any time to demand additional security and with the right, in case of failure to comply with such demand for additional security or in case of default in payment, to. sell witbout advertisement or notice to the undersigned, at any broker's board in the City of New York, or at public or private sale in the said City or elsewhere, or to otherwise dispose of the same in the discretion of any of the officers of the said Bank, without notice of amount due or claimed to be due, without advertisement, and without notice of the time or place of sale, each and every of which is hereby expressly waived, applying the proceeds thereof upon the said indebtedness, together with interest and expenses, legal or otherwise, the undersigned to be liable for any deficiency.

It is iurther agreed, that upon any sale by virtue hereof, the holder hereof may purchase the whole or any part of such property discharged from any right of redemption, which is hereby expressly released to the holder hereof, who shall have a claim against the maker hereof for any deficiency arising upon such sale.

It is further agreed that any moneys or property at any time in the possession of said Bank belonging to any of the parties liable hereon to said Bank, and any deposits, balance of deposits, or other sums at any time credited by or due from said Bank to any of said parties may at all times at the option of said Bank be held and treated as collateral security for the payment of this note or the indebtedness evidenced hereby whether due or not due, and said Bank may at any time at its option without demand for payment and without notice charge this note to the account of the undersigned with said Bank, or set off the amount due or to become due hereon against any claim. of any of said parties against said Bank.

1 Fictitious name. This note, however, is in actual use. 


\section{COLLATERAL NOTE}

$\$ \ldots \ldots \ldots$

New York,...............19

................ after date, for value received the undersigned promises to pay to The National Park Bank of New York, or order, at its banking house in the City of New York,........... .Dollars,.........., having deposited with said Bank, as collateral security for the payment of this note and of any other liability or liabilities, direct or contingent, due or not due, of the undersigned to the said Bank, or claims of said Bank against the undersigned, whether now existing or hereafter incurred, or acquired by said Bank, the following property, viz.:

the undersigned also hereby giving to the said Bank a lien, for the amount of all the aforesaid liabilities and claims upon the title or interest of the undersigned in any other property or securities left with the said Bank for safekeeping or otherwise, or coming to the possession of said Bank in any way, and also upon the balance of any deposit account of the undersigned with the said Bank at any time existing, such deposit balance and other property to be regarded as additional collateral security for such liabilities and claims, with the right to the said Bank in its discretion to resort first to any part of the collateral. In case any of the securities above pledged should decline in market value, the undersigned hereby agrees to deposit with the said Bank, without notice or demand, additional collateral security satisfactory to it; and further agrees that in case of failure to deposit such additional collateral, or in case of the failure of the undersigned to meet at maturity any liability of the undersigned, either to said Bank or to any other party, or upon the declared insolvency or failure in husiness of, or appointment of a receiver for, or commencement of bankruptcy proceedings by or against the undersigned, or the entry of any judgment against the undersigned, or in case of any such default, insolvency, appointment of receiver, bankruptcy proceedings or judgment by or against any endorser or guarantor of this note, all liabilities of the undersigned to said Bank including this note, shall, at the option of said Bank, without demand of payment thereof, immediately mature and become forthwith due and payable. The undersigned further agrees that upon failure to pay this note at maturity or upon its becoming due in accordance 
with any of its provisions, said Bank may forthwith proceed to collect and receive and realize upon any deposit balance or any accounts, bills, notes or claims held by it as collateral, and also, without demand, advertisement, notice to redeem or other notice to the undersigned, to sell at public or private sale or at the New York Stock Exchange, or at any other exchange or brokers' board, at such prices as it may deem best, and either for cash or on credit or for future delivery, any or all securities or property of any kind held by it as collateral security for the indebtedness of the undersigned as hereinbefore provided, with the right to said Bank at any such sale, public or private, to purchase the whole or any part of any securities or property so sold, free from any right or equity of redemption in the undersigned, which is hereby expressly waived, applying the net proceeds to the payment of this note and of any other liabilities of the undersigned to said Bank, and accounting for the surplus, if any, to the undersigned, who hereby expressly agrees to remain bound for the payment of any deficiency, with legal interest. The above described property may from time to time, by mutual consent, be exchanged for other property, which shall be held by said Bank subject to all the terms of this note. Upon any transfer of this note the collateral held therefor at the time of transfer or any part thereof may be delivered to the transferee, who shall thereupon become vested with all the rights and powers above given to said Bank in respect thereto.

Due....................

${ }^{1}$ In consideration of the making, at the request of the undersigned, of the loan evidenced by the within note, upon the terms thereof, which are hereby agreed to by the undersigned, and of the sum of one dollar, the receipt of which is acknowledged, the undersigned (who, if two or more in number, shall be jointly and severally bound) hereby guarantee to the National Park Bank of New York, its successors, endorsees and assigns, the punctual payment of the within note at maturity or whenever it becomes due in accordance with any of the terms thereof, and hereby consent that the securities for said loan may be exchanged or surrendered, from time to time, or the payment of the within note or of any of the liabilities of the maker thereof may be extended or any of the provisions of said note may be modified, without notice to or further assent by the undersigned, who will remain bound hereon, notwithstanding such exchange, surrender or modification. The undersigned hereby waive demand of payment from the maker of said note, and also waive notice of nonpayment thereof, notice of sale of any of the collateral therefor and all other notices in connection therewith.

${ }^{1}$ Indorsed on back of above note. 
signatures of its officers authorized to sign in its behalf as registrar. The International Paper Company will be pleased to furnish upon request, any further information regarding the above plan of registration. DISCOUNT

FOR VALUE RECEIVED, we, the undersigned, have bargained, sold, assigned, transferred and set over and by these presents do sell, assign, transfer and set over unto L. SPIEgELBERG \& Sons, their successors and assigns, the claims and accounts more specifically set forth in the statement annexed hereto and made part hereof, which is a copy of the original claims and accounts, assigning, transferring and conveying to the said L. SpIEgelberg \& Sons all our right, title and interest in and to the same and in and to the merchandise, the sale of which created said accounts with full power to reclaim said merchandise as heretofore stated.

To HaVE AND TO Hold the same unto L. SPIEgelberg \& Sons, their successors and assigns and we hereby constitute and appoint said L. SPIEgelberg \& Sons our true and lawful attorneys irrevocably in our name or otherwise but to their own use and benefit to collect and receive all moneys due or to grow due upon said accounts and to collect, sell, assign, transfer, set over, compromise or discharge the whole or any part of said accounts and to receive, reclaim and without notice to us, dispose of the merchandise, the sale of which created said accounts (in the event that for any reason said merchandise in whole or in part shall come back upon said accounts) and for those purposes do all acts and things necessary or proper in the premises. This assignment is made for due and valuable considerations, having been paid to the undersigned by L. Spiegelberg \& Sons and also is 
made in furtherance of an agreement about to be made between the undersigned and L. SpIeaklbero \& Sons and as further collateral security for the payment of any indebtedness arising as a result of said agreement and otherwise.

We hereby guarantee payment of said accounts at maturity and hereby represent that the accounts so assigned are just and true and are the result of bona fide sales and that the merchandise, the sale of which created the accounts hereby assigned, belonged to us solely and absolutely and was not in whole or in part consigned to us and that the debtors therein named have agreed to accept the same; that no payment has been made on said accounts; that there are no setoffs or counterclaims thereto and that the terms of credit are as specified and that any and all remittances on said accounts coming direct to us shall be received by us in trust for L. SpIEgELbera \& Sons only and that the identical remittance in whatever form it may be received by us shall be immediately handed over to L. SpIEaklbera \& SoNs and that all deductions on said accounts will be made good by us to L. Spiegelbera \& Sons by payment of the same in cash or by payment of the same out of any balance to our credit in the hands of L. Spiegelderg \& Sons, if any, and should the purchasers reject, return or refuse to accept any or all of the merchandise mentioned in said accounts that we will immediately give notice thereof to L. SPIEGEI BERg \& Sons and it shall then be optional with L. SPIEgelberg \& Sons to surrender to us the said merchandise refused, rejected or returned upon receiving payment thereof in cash or if they so elect, to deduct from any balance which they may have on hand or out of any sum which they may thereafter have on hand to credit the amount of said merchandise.

The said representations are made to induce Messrs. L. SpIEaELBERG \& SoNs to make advances to us on the faith of the said accounts herein assigned by us.

The said account so assigned by us shall in the event of the under. signed making an agreement with Messrs. L. Spiegelbera \& Sons for further advances on other merchandise become part of the accounts under said contract and shall be treated in the same manner as provided for in said contract.

IN WITNESS WhEREOF

its hand and seal this
Company has hereunto set day of December, 1910.

L. S. 


\section{THE FACTS CONCERNING THE RECAPITALIZATION OF THE CHICAGO \& ALTON RAILROAD CO. ${ }^{1}$}

In view of the evident misunderstanding of the facts respecting the recapitalization of the Chicago \& Alton Railroad Co. resulting from the recent inquiry by the Interstate Commerce Commission, the following statement of facts, which has been prepared primarily for the information of the holders of Chicago \& Alton securities, is authorized on behalf of the syndicate which acquired control of the property in 1899 :

Early in the year 1899 over 97 per cent. of the capital stock of the Chicago \& Alton Railroad Co. was acquired by the purchasing syndicate at an aggregate cost of over $\$ 39,000,000$ at the rate of $\$ 175$ a share for the common and $\$ 200$ a share for the preferred stock, in response to an offer to.all stockholders contained in a widely published circular. That the stockholders at that time were fully apprised of the future course of the company with respect to the capitalization of previous expenditures of income for permanent improvements and the declaration of a substantial dividend therefrom, is shown by the following public circular which, in February, 1899, was addressed to the stockholders by Mr. T. B. Blackstone, who for upward of 20 years had been the president and moving spirit of the Chicago \& Alton Co.:

\section{To Chicago \& Alton Stockholders:}

February, 1899

In my communication addressed to you under date of 31st of January [1899], I made certain statements with reference to an offer made by Mr. J. J. Mitchell to purchase your shares. I now wish to supplement that statement by advising you that in case a majority of the shares of the company are not sold to the syndicate represented by Mr. Mitchell, I shall advise that you authorize the refunding of the outstanding bonds of the company and the issue of a stock dividend to represent earnings heretofore invested in permanent improvements.

T. B. Blackstone.

The syndicate comprised upward of 100 individuals, firms, and corporations, and for over a year certificates representing participations in this syndicate were dealt in upon the open market. The plan of recapitalization was intended to create low interest bearing preferred securities (bonds and preferred stock) based upon the past earnings of the property, which preferred securities were to repre-

\footnotetext{
${ }^{2}$ Circular reprinted as an exhibit in the so-called Congressional Money Trust Investigation of the Pujo Committee.
} 
sent the greater part of the syndicate's investment; and also common stock which would represent the future of the property and the additional earning capacity which was expected to result from the application of progressive methods of management and a liberal expenditure of new capital for the improvement of the property and the expansion of traffic and of the service to the public. Every step in the recapitalization was taken publicly, under the advice of eminent counsel, and all the facts stated below and all the facts brought out in the recent investigation have been publicly stated in applications for listing the securities upon the New York Stock Exchange, in annual reports of the company and in other public documents which have been accessible to everybody.

The complicated legal and bookkeeping technicalities incident to the scheme of readjustment have been misunderstood, with the result that the increase in capitalization and the profits of the syndicate have been absurdly overestimated.

On December 31, 1898, immediately prior to the acquisition of control by the syndicate, the market value of the securities representing the capitalization of the Chicago \& Alton Railroad Co. was substantially as follows:

Par value:

Market value.

$\$ 8,650,850$ high interest bearing bonds (market value, say, at 105 per cent.)............\$9,083,392.50 $\$ 3,693,200$ guaranteed stocks (including $\$ 1,750$,0006 per cent. preferred stock and $\$ 114,200$ common stock of Kansas City, St. Iouis \& Chicago R. R. Co., outstanding in the hands of the public, but not taken up in the report of $1898)$ at 150 per cent................. $5,539,800.00$ $\$ 3,479,5007$ per cent. preferred stock (at 200 per cent.) ; $\$ 18,751,100 \%$ per cent. common stock (at 175 per cent.) $39,773,425.00$

Total value as of Dec. $31,1898 \ldots \ldots \ldots \ldots \ldots \$ 54,396,617.50$

To this amount should be added the subsequent expenditures for improvements and additions as follows:

Actual cost of Springfield \& Peoria line, about... Cash spent subsequent to Dec. 31, 1898, for im$3,000,000.00$ provements, new equipment, reconstruction, etc., up to June 30,1906 , about. ............ 19,500,000.00

Total investment on cash basis, about....... $\$ r 6,896,617.50$ 
As the result of the recapitalization and capital expenditures the amounts of securities outstanding on June 30, 1906, were as follows: $\$ 37,350,000$, par value, 3 per cent. bonds representing

a value at the average price realized, say 90 per cent.

(the remaining $\$ 8,000,000$ bonds of this issue being pledged to secure notes mentioned below or being held in the treasury), about.............\$33,615,000.00 $\$ 22,000,000$, par value, $3 \frac{1}{2}$ per cent. bonds actual value

at average price, say $82 \frac{1}{2}$ per cent., about....... 18,150,000.00 $\$ 8,016,918$, par value, notes and car trusts, value say.. $\quad 7,800,000.00$ $\$ 3,693,200$, par value, guaranteed stock, cash value say

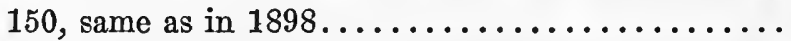
$\$ 899,300$, par value, 4 per cent. prior lien stock, at par. $\$ 19,544,000$, par value, 4 per cent. preferred stock, at $899,300.00$

par .......................... 19,544,000.00 $\$ 19,542,800$, par value, common stock, at par..... 19,542,800.00

Total capitalization $\$ 105,090,900.00$

This shows an increase, as compared to December 31, 1898, of about $\$ 28,000,000$, taking the new common and preferred stock at par. As a matter of fact, these stocks have always sold considerably below par. At its issue the common stock sold at about 33 and the preferred stock at about 70 .

The fixed charges on the outstanding securities under the recapitalization, including full dividends upon the preferred stock, are less than the aggregate amount which, under the former management, the company had been paying out annually by way of interest and dividends, plus interest upon the new capital expended for improvements and additions. This appears from the following comparison:

For the year ending Dec. 31, 1898, the amount paid out

by the company by way of interest upon its funded debt, rentals, and dividends (7 per cent.) upon its capital stock (after crediting $\$ 231,232$ interest and dividends collected on bonds and stocks owned by the company) $\$ 2,339,448.05$

The annual fixed charges as of June 30,1906 , including interest upon all obligations, rentals, and 4 per cent. dividends upon the preferred stock (after crediting $\$ 240,000$ interest on bonds owned by the company) were

An increase of......................... 
This increase is considerably less than interest at $4 \frac{1}{2}$ per cent. per annum upon $\$ 19,500,000$ of the new capital which the present management has expended upon the property and $\$ 3,000,000$ paid for the Springfield and Peoria line, which interest aggregates....\$1,012,500.00

It will thus be seen that the net result of the recapitalization was the creation of preferred securities consisting of bonds and preferred stock, the interest and dividends upon which absorb only such earnings as the company had already been paying out for many years under unprogressive management and unfavorable conditions. The common stock was created to represent the future of the property and the increased earning capacity which was expected to result from progressive management and a radical increase in the company's facilities. This was precisely the basis of capitalization which at that period was being applied in the readjustment and reorganization of many railroad enterprises in the United States. That the Chicago \& Alton was in need of readjustment is apparent from the fact that for years it had been steadily deteriorating in physical condition, in the quality of its service to the communities along its lines, and in earning power.

The fact that the property has not made as large earnings upon the new common stock as was expected is due to the fact that the capital expenditures required to modernize the property proved to be much greater than was anticipated and also to the very great decline in freight rates in the company's territory which has taken place in the last few years. The official statements show an aggregate decline in the freight rates of the Chicago \& Alton since 1898 of approximately 30 per cent. as compared to present rates. Even with this decline it is estimated that in the current fiscal year the Chicago \& Alton will make substantial earnings on its common stock.

With respect to the sale of 3 per cent. bonds in 1899 at 65 , it is pointed out that the bonds were sold, not to favored individuals, but without discrimination to all stockholders, including the large number of holders of syndicate participations, and that the sale of both bonds and stock to stockholders at less than market value has been a common and generally approved expedient. While the low interest rates which prevailed in 1899 , and the fact that the bonds became savings bank investments, made it possible to market them at a substantial profit, the stockholders, in taking them at 65 , took them upon an interest basis of about $4 \frac{7}{8}$ per cent. per annum. In other words, the effect of the transaction, so far as the company was concerned, was precisely the same as if 5 per cent. bonds had been sold to the stockholders at a price slightly above par. 
That the public has enormously benefited from the improvement of the property, and the application of progressive methods to its management is shown by the fact that since 1898 the volume of freight traffic upon the Chicago \& Alton has more than doubled, while the amount of freight carried for every dollar paid out in interest and dividends has increased more than 80 per cent. The capacity of the freight equipment has been increased over 200 per cent., that of the passenger equipment nearly 100 per cent., and the traction capacity of locomotives over 130 per cent.

In capitalizing part of the company's expenditures for improvements and distributing $\$ 6,669,180$ of this addition to surplus by way of an extra dividend of 30 per cent. upon the old stock, the directors were simply carrying out the purpose of the former management of the company, as contemplated in the public circular of Mr. Blackstone, quoted above.

An apparent misapprehension has resulted from the testimony of a witness that the mortgage securing the $3 \frac{1}{2}$ per cent. bonds covered, as an unimportant part of the security a short piece of road which the company was authorized to build, but which had not been actually constructed. This provision is in accord with the common practice with respect to general mortgages of railroad companies and it conferred no pecuniary adavantage whatsoever on any one.

For the information of bondholders it is stated that eminent counsel have advised that there is not the slightest doubt as to the validity of both issues of bonds. Copies of counsel's opinion will be furnished to bondholders upon application to the president of the company.

Chicago, January 31, 1899.

To the stockholders of the Chicago \& Alton Railroad Co.:

John J. Mitchell, of Chicago (the undersigned), has entered into a certain agreement, dated January 28, 1899, and lodged with the United States Trust Co. of New York, providing for the purchase, upon the terms and conditions thereof, by certain parties therein named, of any or all of the outstanding capital stock of the Chicago \& Alton Railroad Co. Said agreement is conditioned, among other things, upon the acceptance of the offer of the said parties to so purchase, by the holders of a majority of the outstanding capital stock, irrespective of classification, on or before March 1, 1899. The terms of purchase are at the rate of $\$ 200$ per share for each share of preferred stock and $\$ 175$ per share for each share of common stock. The agreement provides also that without the mutual consent of the 
parties thereto there shall be no sale unless a majority accept the offer as stated in the agreement. Stockholders may inspect the original agreement so lodged with the United States Trust Co.

The agreement also provides:

1. That the acceptance of shareholders shall be evidenced by the deposit of share certificates duly indorsed in blank with said United States Trust Co., for which said trust company shall issue negotiable receipts to depositors, subject to the terms and conditions of the said agreement.

2. That if said majority aforesaid shall have been deposited with said trust company on March 1, 1899, then, and in that event, the time for remaining holders of common or preferred stock to accept said offer and deposit their certificates with said trust company shall be extended to and including Aprii 1, 1899.

3. That persons away from home or outside of the United States shall have until and including June 1; 1899, to deposit their stock, provided notification is given to the United States Trust Company, by or for them, on or before April 1, 1899, that they accept the offer to purchase and that they will deposit their stock indorsed in blank with said United States Trust Company on or before June 1, 1899; also that guardians, trustees, executors or administrators who are without power to accept said offer and deposit their stock without an order of court shall likewise have until June 1, 1899, to accept the same and to deposit their certificates indorsed in blank with said United States Trust Company, provided notification is given said trust company, by or for them, on or before April 1, 1899, of their intention, if authorized by order of court, to accept the said offer and to deposit their stock indorsed in blank as aforesaid on or before June 1,1899 , and of their purpose to present to the proper court a petition asking for authority to accept said offer and to deposit their stock subject to the terms of said agreement.

4. That if such purchase be consummated payment for all stock sold shall be made at the office of said United States Trust Company on or before March 15, 1899, but that from the purchase price shall be deducted any and all dividends declared and paid subsequent to the date of the said agreement, and also the necessary internal revenus taxes. Thereafter payments for additional stock, deposited within the limitation of time provided in the agreement shall be made within three days of deposit.

The undersigned, in view of the said offer, herewith submits the same to the stockholders of the Chicago \& Alton Railroad Company, with the suggestion that stockholders promptly consider the same, 
and in the event of acceptance, forward their certificates indorsed in blank to the said United States Trust Company.

I inclose herewith blank form of letter for use by those desiring to deposit their stock.

I also inclose blank form of letter addressed to the secretary of the company so that the undersigned may be advised of the receipt by you of this communication.

Respectfully,

JoHN T. MitcheLL.

The foregoing is upon the request of the parties to said agreement, submitted to the stockholders by the unanimous order of the Board of Directors.

Respectfully,

H. E. R. Wood, Secretary.

\section{CHICAGO \& ALTON SYNDICATE}

[Syndicate agreement of March 2, 1899.]

The United States Trust Company of New York is prepared to deliver on or after October 25, 1900, in settlement of Chicago \& Alton purchase money certificates, for each $\$ 1,000$ face value of such certificates, $\$ 375$ face value of temporary certificates of interest for Chicago \& Alton Railroad Company, 3 per cent. refunding 50-year gold bonds; $\$ 500$ face value of Chicago \& Alton Railway Company first lien $3 \frac{1}{2}$ per cent. gold bonds; $\$ 100$ face value of Chicago \& Alton Railway Company 4 per cent. noncumulative preferred stock; $\$ 250$ face value of Chicago \& Alton Railway Company common stock; $\$ 10$ cash (including adjustment of interest to July 1, 1900).

The certificates of interest for Chicago \& Alton Railroad Company 3 per cent. refunding 50-year gold bonds provide for the right of sale until July 1, 1901, of all or any part of the bonds which have been deposited with the United States Trust Company of New York, at the price of 95 per cent. and accrued interest. If the bonds remain unsold, the certificates of interest are to be exchanged for the actual bonds on and after July 1, 1901. If sold, the certificates will be redeemed in cash on or before the above date, at 95 per cent. and the accrued interest from April 1, 1900; if only part are sold, redemption will be made proportionately in cash and bonds. These 3 per cent. refunding bonds certificates of interest, as well as the Chicago \& Alton Railway Company $3 \frac{1}{2}$ per cent. coupon bonds are of the denomination of $\$ 1,000$ each, and the shares are of the par value of $\$ 100$ each. 
Holders entitled to fractional amounts of certificates, bonds or shares, can either sell the fractions or can purchase sufficient to entitle them to an entire certificate, bond, or share. Holders transmitting Chicago \& Alton purchase money certificates by mail or express should indicate whether they wish to sell or purchase fractional amounts, and whether they wish the securities sent by registered mail or express at their expense and risk.

New York, October 22, 1900.

\section{OHIOAGO \& ALTON SYNDICATE-NEW SECURITIES}

Chicago \& Alton Railroad Company 3 per cent, refunding 50-year gold bonds, due 1949.-CTotal authorized amount $\$ 40,000,000$, of which $\$ 31,988,000$ par value have been issued. These bonds are secured by mortgage dated October 1,1899 , to the Illinois Trust and Savings Bank as trustee. Out of the proceeds of the bonds already issued, the prior bonds which matured during this year have been paid off, and funds have also been deposited with the United States Trust Company of New York to redeem the principal, and to pay the interest thereon until maturity of all outstanding prior bonds amounting to $\$ 6,789,850$ face value.

The privilege of subscription was exercised for the syndicate in respect of its holdings at the time the refunding bonds were offered to the railroad company's shareholders. Of the bonds received for syndicate account, a sufficient amount has been sold to provide, together with dividends received, the funds for the cash requirements of the syndicate. The bonds now distributable among certificate holders represent the balance of the bonds subscribed for syndicate account.

The further issue of 3 per cent. refunding mortgage bonds beyond the first $\$ 40,000,000$ is restricted to funding the existing leasehold obligations of the railroad company, now amounting to about $\$ 233,000$ net per annum, and to providing funds for building, completing, or acquiring additional railroad in extension of the present property, for which latter purpose an amount not exceeding $\$ 10,000,000$ may be issued, and to providing funds for future requirements and betterments undertaken or contracted for after January 1, 1900, for which purpose an additional $\$ 5,000,000$ may be issued. These additional bonds, over the $\$ 40,000,000$ now authorized, can only be issued when authorized by the holders of two-thirds of the outstanding preferred and common stock of the railroad company.

Of the 3 per cent. refunding mortgage bonds subscribed for syndicate account a portion has been sold, and the remaining bonds have 
been deposited with the United States Trust Company of New York against which negotiable receipts in the denomination of $\$ 1,000$ will be issued to the holders of Chicago \& Alton purchase money certificates. The receipts provide for the right of sale until July 1, 1901, of all or any part of the deposited bonds at the price of 95 per cent. and accrued interest. If the bonds remain unsold, the receipts are exchangeable for the deposited bonds on and after July 1, 1901. If the bonds are sold, the receipts will be redeemed in cash on or before the above date at 95 per cent. and the accrued interest from April 1, 1900 ; and if only part of the bonds are sold redemption will be made proportionally in cash and bonds.

Chicago \& Alton Railway Company securities.-The Chicago \& Alton Railway Company was incorporated in April, 1900, under the laws of the State of Illinois, with a capital of $\$ 20,000,000$ noncumulative 4 per cent. preferred stock and $\$ 20,000,000$ common stock. The preferred stock is entitled to noncumulative preferential dividends not exceeding 4 per cent. annually, and the balance appropriated in any year to dividends goes to the common stock. The Chicago \& Alton Railway Company has acquired the railroad from Springfield to Peoria, formerly owned by the St. Louis, Peoria \& Northern Railway Company, and it has leased the lines of the Chicago \& Alton Railroad Company for the term of 99 years from April 3, 1900, at a rental equal to the net earnings of the lines of the railroad company after payment of all fixed charges, taxes, etc. The new company has also purchased 183,224 shares of the common stock and 34,722 shares of the preferred stock of the Chicago \& Alton Railroad Company (out of a total of 187,511 shares of common and 34,795 shares of preferred stock outstanding).

The Chicago \& Alton Railway Company has also created an issue of $\$ 22,000,000$ first lien $3 \frac{1}{2}$ per cent. gold bonds maturing July 1 , 1950 , but redeemable at par at any time on six months' notice. These bonds are secured by a mortgage to the Farmers' Loan \& Trust Company of New York, as trustee, mortgaging the railway line and the entire corporate property of the railway company, including leaseholds and pledging 34,722 shares of preferred stock and 183,224 shares of common stock of the Chicago \& Alton Railroad Company, certificates for which have been deposited with said trustee. This mortgage provides that the railway company as owner of stock of the railroad company will not give its consent to the issue of any of the refunding 3 per cent. bonds of the Chicago \& Alton Railroad Company in excess of the $\$ 40,000,000$ now authorized, except when such additional issue is expressly authorized by a three-fourths vote of the entire Board of Directors of the railroad company and approved by a 
three-fourths vote of the entire Board of Directors of the railway company. All the bonds and the entire capital stock of the railway company have been issued with the exception of 4,572 shares of common and 4,560 shares of preferred stock, which have been reserved to acquire, if practicable, the 4,287 shares of common stock of the Chicago \& Alton Railroad Company outstanding in the hands of others than the railway company.

The position of the Chicago \& Alton Railway Company at this time is as follows:

Interest on $\$ 31,988,000$ Chicago \& Alton R. R. Co. 3 per cent. refunding mortgage bonds (assumed under

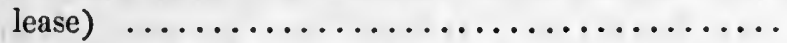

Annual net rentals of the Chicago \& Alton R. R. Co. . 233,030.00 Interest on $\$ 22,000,000$ Chicago \& Alton Ry. Co. first lien $3 \frac{1}{2}$ per cent. bonds............... $770,000.00$

Total requirements for fixed charges, including rentals ${ }^{1} \$ 1,962,670.00$

The gross earnings of the Chicago \& Alton Railroad Company for the year ending June 30, 1900, during which year the road lacked much needed improvements and betterments which are now progressing, and suffered from want of equipment now acquired and in course of delivery were $\$ 7,796,450$; net earnings, $\$ 2,964,628$.

In the two months of the current year ending August 31, the gross earnings increased over $1899, \$ 432,551$; and the net earnings increased over $1899, \$ 151,783$.

In the above figures the earnings of the line from Springfield to Peoria are not included.

New York, October 25, 1900.

1 The railroad and railway companies have agreed to take over on or before January 1, 1904, if previously not otherwise disposed of, the terminals in the city of Chicago, Ill., leased on October 1, 1898, to the St. Louis, Peoria \& Northern Railway Co. by the Chicago Terminal Transfer Co., upon the terms and conditions of the agreement of lease between the two companies as modified by the supplemental agreement of May 25, 1899. 


\section{CONDEMNATION OF CHICAGO-ALTON RECAPITALIZATION ${ }^{1}$}

Now it appears that for many years before the road was acquired by this syindicate in $1899, \mathrm{Mr}$. Blackstone had managed the Chicago \& Alton Railroad; that it had been exceedingly prosperous; that it had paid exceeding 8 per cent. dividends to its stockholders; that it had a low capitalization; that it was a model railroad, as we all understood it in the West, in capitalization and in management. To be accurate, the book cost of the road, as it appeared by the books of the Alton Company, was $\$ 34,153,92 \%$. It had other assets of a little over $\$ 5,000,000$. Its total capitalization, including stock, funded debt, and other liabilities, was $\$ 33,951,40 \%$. It owned over 843 miles of railroad, 6,377 cars, 232 locomotives, and 148 passenger cars. In less than seven years these gentlemen had expanded that indebtedness, according to the last report of the Alton, to about $\$ 122,000,000$; but as it is claimed there are some duplications, I will take the lowest figures shown by these reports. They had expended it to $\$ 113,894,356$, an increase of about $\$ 80,000,000$. And out of this increase they had spent upon the property but $\$ 18,000,000$, of which $\$ 3,000,000$ was for a railroad that the men who reorganized it sold to the Alton Company. In other words, they increased its liabilities about $\$ 62,000,000$ or $\$ 65$,433 a mile on 946.66 miles of road owned by the company, for which they did not give the company one dollar-not one dollar-of property or money expended.

Now, in all this time it had only increased its mileage 103 miles, and 58 of that was the $\$ 3,000,000$ road bought of Harriman and his associates; only increased its locomotives 18, its passenger cars 69 ; and its freight cars 3,730 . I have no doubt it improved the quality of this equipment; but to say that it was necessary to expand the liabilities of this company any such sum as that for the purpose of adding $\$ 18,000,000$ to a road which had a credit so good that its bonds then were selling on a basis of a little over $3 \frac{1}{2}$ per cent., is to my mind incredible. I do not believe it. Why, the amount of money that these gentlemen added to this capitalization without giving it a dollar of assets is more than the capitalization per mile of the majority of the great western lines of road-the Milwaukee, with $\$ 32,000$ and a little over per mile; the Northwestern, with $\$ 32,000$ per mile; the Burlington, about the same or a little more; the Rock Island, $\$ 45,000$; the Great Northern, $\$ 38,000$. Of course there are other roads in the United States that far exceeded that.

1 From the report of the oral argument of Frank B. Kellogg, attorney for the Interstate Commerce Commission, before that Commission, April 5, 1907. 
It is said they spent $\$ 22,000,000$. They did not spend $\$ 22,000,000$ out of this expanded capitalization. Mr. Harriman said they had spent $\$ 22,000,000$. On cross-examination he admitted his figures were given him by Mr. Felton and that he did not personally know anything about it, except in a general way. When Mr. Felton went on the stand he said that from the day these gentlemen took hold of the road down to the present time this winter, the company had (including the 58 miles of road they bought) expended $\$ 22,327,219.04$, but that $\$ 2,708,000$ was equipment trust notes not included in this capitalization made since July 1st last, and $\$ 1,000,000$ was taken out of earnings and not included in this capitalization. So that, according to his figures, it would be $\$ 18,547,219$. I said about $\$ 18,000,000$, for the reason that Mr. Mahl, the comptroller of the Union Pacific road, added this clause to Mr. Hillard's statement, Mr. Hillard now being the coniptroller of the Alton road, and that statement was that they added but about $\$ 18,000,000$, and he was about right.

What is this capitalization and for what was it spent? It is admitted that at the time this road was recapitalized or reorganized it had a bonded indebtedness of about eight and a half million dollars. The report of the Alton-the last one made by Mr. Blackstone, I believe in 1898-showed that these bonds were short-time, high interestbearing bonds. They were bonds which matured a few months less than three years thereafter, some of which were selling in the market at a rate to yield $3 \frac{1}{2}$ per cent., substantially all of which might have been retired within the next three years, and a number of them within a few months. With the credit of that line of railroad it stands undisputed that it might have sold its 4 per cent. bonds at par, and instead of increasing its fixed charges from $\$ 1,000,000$ to over $\$ 2,600$,000 per annum, could have made all of these improvements by increasing its interest account $\$ 720,000$ or $\$ 750,000$.

From this report for 1898 it will be seen that $\$ 1,785,000$ of the Louisiana \& Missouri River Railroad first-mortgage sevens matured August 1, 1900, within a year after they sold these $\$ 40,000,000$ or $\$ 32,000,000$ of bonds they put upon the road; of Louisiana \& Missouri River Railroad second sevens, $\$ 300,000$ on November 1, 1900; $\$ 1,695,000$ of the Chicago \& Alton sinking fund sixes, May 1, 1903, and $\$ 4,379,850$ of Chicago \& Alton sixes, July 1, 1903.

These included all of the bonds except $\$ 191,000$, making a total of $\$ 8,159,850$ in bonds.

Now, what did they do? Mr. Harriman, Mr. Schiff, Mr. Gould, and Mr. Stillman bought the control of this stock.

What became of this $\$ 40,000,000$ of bonds? Immediately after they acquired this stock they placed a $\$ 40,000,0003$ per cent. fifty-year 
mortgage upon the property. It does appear, and could not appear in any other way, that if the Chicago \& Alton Railroad stock was worth $\$ 39,000,000$, its 3 per cent. bonds were worth more than 65 . They certainly sold for about two years at 90 or above, or substantially that and they certainly could have borrowed all the money the Chicago \& Alton wanted at 4 per cent. To take up the eight million six hundred and some thousand dollars of prior mortgage bonds and the interest and for other corporate purposes, this mortgage was placed upon the property. They sold through Kuhn, Loeb \& Co. to Goldman, Sachs $\&$ Co., who sold then to the New York Life $\$ 10,000,000$ of these bonds at 96 cents on the dollar.

What was the average price of these bonds? It does appear that the $\$ 10,000,000$ not only sold for 96 but that Kuhn, Loeb \& Co. sold $\$ 1,000,000$ to the Equitable Life Insurance Company in 1901 at 92 and $\$ 550,000$ in 1902 at 88 so that for nearly three years-over two yearsthese bonds sold between 88 and 96 . As a matter of fact, during the months of October, November and December of 1899, all of 1900, and January, February and March of 1901, these bonds never went below $92 \frac{1}{2}$.

Now, those men, according to these market prices, could have sold those bonds at 90 . Why, the Alton bonds were then selling in the market on a $3 \frac{1}{2}$ per cent. basis, according to the Financial Chronicle, which is in evidence; and Union Pacific fours, the Northern Pacific fours, and other high-class railroad first mortgage 4 per cent. bonds, with no better credit than the Chicago \& Alton were selling in this country above par. We do not deny that at times railroads cannot do that, and they cannot do. it now; but they could have done it then, and the Alton had exceptionally fine credit. It was, in fact, a shining mark.

Even had these 3 per cent. bonds been placed on a 4 per cent. basis they would have sold at 78.45-that is, placed on a basis that they would produce during the fifty years 4 per cent. But they were sold to these gentlemen at 65 . No amount of explanation will show that to be good conservative railroad financing, and it is no answer to say that it was done in other railroads. It was certainly done in this.

Shortly after the purchase of this stock these gentlemen paid to themselves a dividend of 30 per cent. out of the proceeds of this mortgage. They owned all the stock except 73 shares of preferred and 4,287 shares of common. They controlled the company. If you deduct this dividend which they took out of the mortgage, they really paid about 48 or 49 cents on the dollar for the bonds.

The fallacy, it seems to me, of Judge Lovett's argument that a road should be judged by what it has paid out in dividends and interest 
is this : He said, "We haven't paid out in dividends and interest much more since the reorganization than was paid out before." But remember that Mr. Blackstone was paying his stockholders 8 per cent. dividends, while the reorganized Alton was only paying 4 per cent. on its preferred stock and nothing on its common.

Furthermore, the time may come when the Commission would say that 8 per cent. dividends was rather large, if dividends are to be taken as the basis for rate making. I do not say whether it is or not. A railroad should have good earnings. Dividends should not be small. It is not in the interest of the country to make rates so low that railroad securities, which form a large part of the wealth of the people, should not receire a reasonable income, and should be depressed.

If the Commission and the country have no interest at all in investigating the question of overcapitalization, if they have no interest in the stability of securities placed on the market in which people invest their savings and which they buy on the faith of the security, then perhaps Judge Lovett's theory is correct, that the amount of the securities issued is entirely immaterial. I prefer to adopt Mr. Cravath's suggestion that the people have an interest in this, and that there should at this day be reasonable regulations which will insure the stability and the safety of railroad securities and make them a desirable investment.

I do not deny that in the construction of new lines of railroad, especially into new country, it has been necessary to issue bonus stock and sell railroad securities much below par. I do not deny that this has tended to develop the great western country, to furnish it lines of transportation, and to add millions to the wealth of the nation. But I belicre the time is coming when Congress should reasonably limit the inflation and manipulation of railroad securities, in order that their stability may be insured and their value maintained. 'Investors cannot inquire into the history and value of the property and the basis of credit of all railway securities; they must accept them on the faith of their earning capacity and the integrity of the management. This regulation should not be unreasonable. It should not hamper the capitalization or the increase of capitalization of railways; it should not retard the construction of new lines, and the development of the country; but it should prevent great railway systems, which are today reasonably capitalized and have high credit, from being shining marks of manipulation in Wall Street or any other financial market. That is what I say.

There is another thing the Commission should consider, and that is the system of bookkeeping by railroads. What becomes of these dividends? Why, the counsel says they were openly, notoriously paid. 
Nobody denied it. But I think the law requires that dividends should be reported to this Commission in the annual reports; and that 30 per cent. dividend, I am informed, was never reported to the Commission. It is not in the annual reports to the Commission at all, and not shown. The $\$ 8,150,000$ of discount on bonds is not shown in the reports to the Commission or in the annual reports of the company; and Mr. Hillard says they were charged against this $\$ 12,444,176.66$, which was expenditures uncapitalized, in order to cover it up.

What is this $\$ 12,000,000$ that so much has been said about? In the report of 1899 to the Interstate Commerce Commission there appears an item credited "Construction expenditures uncapitalized, $\$ 12$,444,176.66." What was that? These gentlemen went back into the history of the Alton road; they took the report made ten years before by Mr. Blackstone to his stockholders, in which, with commendable pride, he pointed out to them that the Alton road was worth at least $\$ 11,000,000$ more than it was capitalized for, owing, partly at least, to the losses of the original stockholders of the old Joliet and Chicago road, which had been foreclosed way back in war times before 1863 . And I believe that this is the first time I have ever heard of waiting thirty years and recapitalizing losses of stockholders of another road made in foreclosure proceedings years before. That looks to me somewhat like robbing the graveyard.

Let us see whether I am correct in that. I would like to call your attention for a moment to Mr. Blackstone's report of 1898. Well, I will find it.in Mr. Harriman's testimony, page 66. Here is what Mr. Blackstone says:

"Taking into account the loss sustained by the original corporations which constructed that part of your lines between Joliet and Alton and operated it until it passed from their hands to yours by foreclosure and sale under the original mortgages, and the amount which your company has expended for additional property not represented by stocks or bonds, we find not only that your company has never issued a share of stock or an obligation of any kind that did not represent at its par value an equal amount of cash or its full equivalent of property at the time actually received, but also that the original cash cost of your property, as nearly as it can be ascertained, was $\$ 10,989$,878.15 , or, in round numbers, $\$ 11,000,000$, more than the par value of the total amount of stocks and bonds which your company has issued or assumed.

"To ascertain the difference between the original cost of your property and the amount of stocks and bonds for which your company is responsible now outstanding, $\$ 725,000$ should be added to the amount above stated, being the amount of bridge and sinking-fund bonds 
since paid and canceled, in place of which no stock or bonds have been issued."

In other words, they paid their debts and canceled the bonds; and these gentlemen took the losses of the original stockholders, money expended twenty or thirty years ago and charged off, and bonds paid and canceled, as the starting point of their recapitalization of the Chicago \& Alton Railway.

I will go further than that. I say that they not only did that, but they took from that time on the annual appropriations made by the board of directors-who had it in control, and who were entitled to speak and had the authority to charge it off-they took the annual sum for ten years which had been spent in betterments and improvement of that property to keep it up to the standard to which Mr. Blackstone thought it should be kept up, and they took that and added it to the $\$ 11,000,000$ and made $\$ 12,444,176.66$.

I would like to refer to the details of that, because I believe that that sort of bookkeeping is not lawful. I do not mean that it is criminal; I mean that it is not lawful, in that the board of directors had disposed of it and no subsequent board of directors had a right, in my opinion, to repeal those resolutions, to dig up those amounts, add them to capitalization, and pay it out in dividends, or charge it to discount on bonds.

On pages 204 and 205 of the exhibits of Mr. Hillard, who is now the comptroller of the Alton, will be found the items of those sums, and from 1889 down to 1898 the annual sums appropriated were charged off. I have all the reports here. I will not stop to read them, but I will give the Commission an illustration. For instance, in the income account, after the payment of the interest on the funded debt and the dividends and the rentals each year, the company made this charge: "Appropriated from this account for additional property, real estate, and new tracks, $\$ 18,764.71$." Some years it was more; one year it was $\$ 238,000$; one year it was $\$ 32,000$; another year, $\$ 26,000$. I am giving round numbers. Those sums had been annually appropriated.

Now, I deny the right of any subsequent board of directors ten years later, or any time later, after the board of directors has passed on that question, to take all those sums and capitalize them and pay them out in dividends. We all know that every railroad which is kept up to the standard it ought to be, must -spend a large sum of money in betterments which are not strictly new construction and should not be charged to capital account. Railroads must be maintained, and there is not a well-managed railroad in the United States that undertakes to capitalize every dollar spent for betterments. Every well- 
managed railroad capitalizes certain amounts-new construction, usually double tracking, sometimes additional weight of rails-but I think the conservative men will admit that it is necessary every year to spend a large sum of money which is in the nature of betterment of property, in order to keep it up to the standard; because otherwise, if you capitalize every dollar, the time will come when your indebtedness will break any road in the United States.

At least I deny that it is conservative railroad management to go back thirty years, take the losses of the original stockholders, take all the money used during those years for the improvement and betterment of the railway, and charge them up as a part of the capital account, borrow money on a mortgage to pay it back to the railway company, and then turn around and pay it out to themselves in dividends and in profits on bonds sold to themselves at unreasonable and absurdly low prices.

Against that $\$ 12,444,177$ they charged this dividend of $\$ 6,669,180$, and $\$ 8,155,751$ of discount on bonds. Now, what was that? It was not the discount on the $\$ 32,000,000$ of bonds at 35 , which would be the ordinary way. I have never known-I am not an expert in railroad accounting, but $I$ have never before known discount on bonds to be charged in that way. But $\$ 8,155,000$ for some reason seems to have been charged as discount on bonds, as against $\$ 12,444,000-\mathrm{I}$ cannot for the moment think for any other reason than to cover it up. That probably, I suggest, may have been profits to these gentlemen on those bonds. Whether it was or not, it is certainly a discount on bonds charged against a raked-up old account of the Chicago \& Alton for construction expenditures uncapitalized and losses of prior stockholders.

A few words more on that point. These gentlemen, having bought the Chicago \& Alton Railroad stock, organized the Chicago \& Alton Railway Company. They placed their stock in the treasury and they mortgaged it for $\$ 22,000,000$. That transaction took this form-and I do not deny that it is a form which is sometimes used in transferring property into a railroad in order to get out the securities-but it did take this form. These gentlemen transferred their stock to Mr. Louis Stanton and transferred, or at least nominally transferred, this 58 miles of road to Mr. Stanton. Mr. Stanton made a proposition to the new Chicago \& Alton Railway Company to sell it 34,722 shares of preferred stock, which had cost them $\$ 6,944,400$, and on which they had received a dividend of $\$ 1,041,660$, leaving a net cost of $\$ 5,902,-$ 740 - they proposed to sell that to the new company for $\$ 10,000,000$ in cash. The 183,224 shares of common stock which they had bought, which had cost them $\$ 32,064,200$, on which they had received a divi- 
dend of $\$ 5,496,720$, they proposed to sell to the new company for 390,318 shares of its stock, one-half of which was preferred and onehalf common. It does not appear what these gentlemen got for their common stock or their preferred stock, but if they sold it for anywhere near the market price, as shown by the table which Mr. Lovett put in evidence, they must have made a very large profit on this transaction.

Now, they were to get $\$ 10,000,000$ for this stock and they were to get $\$ 3,000,000$ for the railroad, making $\$ 13,000,000$; and the records show they sold the $\$ 22,000,000$ of bonds for $\$ 13,000,000$. But, as a matter of fact, they transferred all the stock and all the bonds for the securities.

That is the practical effect. But the bonds, if sold for $\$ 13,000,000$, would be a little less than 60 cents on the dollar, and they never sold thereafter at anywhere near that low price; in fact, they averaged from 1900 down to the present time from $76 \frac{1}{2}$ to $86 \frac{1}{2}$, and during the two or three years after their issue they sold for $82 \frac{1}{2}$ to 86 .

There was the issuance of $\$ 40,000,000$ of common stock and $\$ 22$,000,000 of bonds which have been put on the market in addition to the $\$ 40,000,000$ of bonds, much of which was an increase of the capitalization of this company.

There is another item that I wish very briefly to call to the Commission's attention, and that is the item of $\$ 973,477$ of funded interest account which was added to the capital of this road. That mortgage was made to take up the prior bonds and coupons. From June, 1901, down to 1906, there was carried in the treasury of the Chicago \& Alton Company $\$ 973,477$ worth of the coupons of its prior mortgage bonds which had been paid. It was carried as an asset in the treasury of the Chicago \& Alton Company. I take it that coupons from the bonds paid with that mortgage should have been canceled, and were not legitimate assets in the treasury. As a matter of fact, in 1905, after having carried them for four years as an asset, they were charged to capital account.

Again, it may not have been illegal, but it was bad business to mortgage that 34 miles of road in process of construction, sell all the bonds, and leave no way of raising funds to complete it.

Mr. Cravath. To build that road?

Mr. Kellogg. To build that road; yes. As a matter of fact, when the new management took hold of the Chicago \& Alton Company what was its condition? After having expanded its securities from $\$ 33,000$,000 to $\$ 114,000,000$, and only having spent $\$ 18,000,000$ on the property, it found itself confronted with the necessity of buying additional equipment, and was compelled to issue $\$ 2,780,000$ of trust certificates to do so. It was reduced to the necessity of giving its equipment notes 
in order to obtain the facilities with which to serve the public. Not only that, but it had no money in the treasury, and no way of raising money, to complete the 34 miles of road in process of construction. Here was the Alton company, with all its splendid credit, in six years of prosperous times, unable to meet its demands, after this enormous recapitalization, made (as $\mathrm{Mr}$. Harriman said) to meet modern conditions.

Now, I deny the necessity, I deny the morality, and I deny that it is good financiering, whether it was within the law or whether it was not. I believe that is a most conspicuous instance of taking a railroad with a splendid credit, with low capitalization, making it the object of speculation, for the purpose of increasing its securities and unloading them on the public for the purpose of enriching the managers, when the earnings of the road do not and cannot justify the increased capitalization. I deny that it is necessary, and I believe the law should not permit such transaction; that the law should require that money borrowed be used for corporate purposes of construction and acquisition of the property, improvement of the railway, or the funding of prior indebtedness, and that reasonable restrictions should at this date be placed upon the unlimited issue of securities of railroads.

One other suggestion. I do not believe that it is wise, as I said before, that unreasonable restrictions should be placed upon the acquisition of stocks and securities of connecting railways; but I do not believe it is in the interest of the railways themselves, or of the public, that they should be allowed to become great financial investment institutions, dealing in the stocks and securities of other railways. Their credit should be used in the expansion and development of their lines in the transportation business of the country. Their securities should return reasonable and generous dividends. Their credit should be of the highest. I should deplore action or legislation which would hamper them or show an unreasonable spirit toward their expansion, for the expansion of the railway systems of the country must go hand in hand with its prosperity and its development. But I do not believe that the enormous credit of railway companies should be used for the purpose of purchase and sale of securities of other lines or used for other than transportation business, and that their solvency should not be imperiled by the rise and fall in the prices of stocks. 


\section{READJUSTMENT OF PUBLIC UTILITY ${ }^{1}$}

President F. G. Drum, of the Pacific Gas \& Electric Co., San Francisco, in a circular of June 3 , says in part (compare ann. report in V. 98, p.1773):

This plan is submitted after many months of deliberation, pursuant to an order of the California Railroad Commission requiring us to provide for existing short-term obligations and for future capital needs. The effect of its adoption will be as follows:

Reclassification (Without Increase) of Present Maximum Auth. Stock, Common Stock, no change, except the decrease of authorized maximum by $\$ 50,000,000$ to ...... $\$ 100,000,000$

First Pref. (p. \& d.) Stock-6\% cumulative, dividends quarterly, a new class of stock authorized in place of a like amount of unissued common stock. It is to be issued as fully paid with the express covenant that it shall not be subject to assessment for any purpose. Present issue $(\$ 12,500,000)$, and all future issues to be made only with authority of California Railroad Commission for extensions, additions, betterments and for refunding as provided in the P. U. Act of California. Tax-

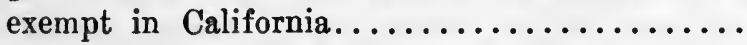

Preferred Stock-(Present issue 6\% cum.) now to $50,000,000$ be made 2 nd pref, with the right of exchange after July 1, 1916, for the new first pref. at the rate of 1.025 shares of the new stock for each share of the old $\ldots \ldots \ldots \ldots \ldots \ldots \ldots \ldots \ldots \ldots \ldots \ldots \ldots \ldots \ldots, 10,000,000$

Necessity of Plan.-The recent annual report (V. 98, p. 1773) clearly shows the extraordinary growth of our business, the gross revenue having increased from $\$ 8,947,162$ in 1906 to $\$ 16,202,337$ in 1913 , being an average annual increase for the seven years of $\$ 1,036,453$, and for 1913 an increase of $\$ 1,457,686$. The future promises a stil] more rapid growth, for which additional capital must necessarily be obtained.

The present eapitalization limits the practicable means of raising new capital to the General and Refunding M. $5 \%$ bonds, and the major portion of new capital.required within recent years has been obtained in this way. This policy has made it necessary to reinvest in the property an undue proportion of the earnings, thereby divert-

'From The Commercial \& Financial Chronicle. June 13, 1914. 
ing from the holders of the common stock a substantial portion of the profits of the business to which they were legitimately entitled, and which, under the present plan, will for the future be available for distribution. The Railroad Commission has also indicated quite clearly that it views with disfavor the practice of raising new capital entirely from the sale of bonds.

Our stockholders are familiar with recent conditions which have rendered it difficult for even the most prosperous enterprises to secure new capital in large amounts at reasonable rates through the sale of bonds. Your company's experience in this respect, notwithstanding its constantly growing profits, has been no different from that of other corporations, and since March, 1913, it has been compelled to carry on the largest construction program in its history entirely from earnings and from the proceeds of money secured on short-term notes.

This condition is reflected in our balance sheet (V. 98, p. 1778) in the item of "uncapitalized advances to Construction Account," amounting to $\$ 11,586,662$ at April 30,1914 . Short-term notes are an admittedly costly form of financing and the diversion of earnings for plant additions affords little satisfaction to the stockholders, who are thereby deprived of dividends, but the unquestioned necessity of completing the new hydro-electric plants on the South Yuba and Bear Rivers, and of making other extensions and additions to meet the growing demand for the company's products, left no desirable alternative. Current returns indicate a saving in operating expenses of at least $\$ 400,000$ from the operation of the new Drum power house during 1914.

Object of Present Issue.-While the results amply justify the course pursued, the provision must now be made for the payment of $\$ 7,000,000$ one-year notes maturing March 25, 1915, and of certain other obligations aggregating about $\$ 1,000,000$. It is proposed to accomplish this by the sale to the stockholders of $\$ 12,500,000$ of the new first preferred $6 \%$ stock at $821 / 2$, a price which will yield approximately $\$ 10$,300,000 in cash. This amount will be sufficient to pay the entire floating debt, and with other assets accruing on account of past construction will give the company a net working capital in excess of $\$ 3,000,000$, and place its treasury in the strongest position it has occupied since organization.

Outlook as to Dividends.-Annual dividends on the new issue of $\$ 12,500,000$ preferred stock will amount to $\$ 750,000$. As the payment of the floating debt will, however, reduce annual interest charges by about $\$ 400,000$, and as the money remaining from the proceeds 
of the stock sale, after the payment of this debt, will be profitably employed, the additional dividend charges ahead of the present preferred and common stocks will be negligible. During the year 1913-14 net earnings after bond interest and discount were $4 \frac{1}{2}$ times the amount necessary to pay the annual dividends on the new preferred issue and during the fiscal year 1915 such earnings will undoubtedly exceed five times the dividends on the new stock.

Contingent upon the new stock being subscribed for, your board, in view of the present earnings, will feel warranted in resuming dividends on the common stock on a permanent basis at the beginning of the year 1915 at the minimum rate of $1 \%$ quarterly. While our estimates for the year 1915 indicate that a higher rate might be paid, it is our desire to be as conservative as possible in naming this as the minimum disbursement.

Advantages of Plan to Preferred Stockholders-Right of Exchange for First Preferred after Two Years.-The existing floating debt precedes the equity of the present preferred shareholders and lays these open to the application of statutory remedies against stockholders; if funded by a junior bond issue it would place ahead of the present preferred stock a forecloseable interest-bearing obligation. The plan herein proposed aroids this and extends to the holders of the present preferred stock the right, after two years, of exchanging their present stock for the new stock at the rate of ten shares of the old stock for $10 \mathrm{r} / 4$ shares of the new. This additional exchange value, at the present offering price of the new stock, is equivalent to $\$ 20.60$ on each ten shares. This amount, added to the regular dividends, is equivalent to $7 \%$ return per annum on the par value of the old stock during the interim, pending exchange. [Under the plan the present common and preferred will retain their assessable feature.-Ev.]

Subscriptions.- Subject to the adoption of the plan and to the approval of the Railroad Commission, your board has authorized the tender to the stockholders of the right to subscribe at $\$ 82.50$ per share, for 125,000 shares of the new first preferred stock in the proportion of approximately $30 \%$ of their holdings of all existing stock, both common and preferred. Subseriptions must be received on or before July 15,1914 , and may be paid as follows : $\$ 5$ per share July 15, 1914; $\$ 15$ August 15,$1914 ; \$ 12.50$ October 1,$1914 ; \$ 12.50$ January 1,1915 ; $\$ 12.50$ April 1, 1915; $\$ 12.50$ July 1,$1915 ; \$ 12.50$ October $1,1915$. Interest at $6 \%$ per annum will be paid by the company on all installments. Subscribers may pay any unmatured installments at any time. Upon the payment of all installments a full-paid certificate of stock 
will be issued on the first day of the next succeeding dividend period and will bear dividends at $6 \%$ per annum from date of issuance.

Stockholders may increase their subscriptions beyond the amount allotted subject to allotment of any part of the $\$ 12,500,000$ not taken as above.

If by August 15, 1914 the company shall not have received subscriptions for, or otherwise disposed of, at least $70 \%$ of the stock herein offered, the amounts paid on all subscriptions will be returned not later than September 1, 1914, with interest at $6 \%$ per annum.

At $\$ 82.50$ per share this stock yields $7.27 \%$ per annum on the investment.-V. 98, pp. 1760, 1778. 


\section{READJUSTMENT OF DEBT OF HUDSON \& MANHATTAN RAILROAD COMPANY}

To the Holders of the First Mortgage Four and One-half Per Cent. Bonds and of Preferred and Common Shares (and Voting Trust Certificates) of the Hudson \& Manhattan Railroad Company.

At the request of holders and representatives of a large majority of the above bonds and shares, the undersigned have caused to be made, by independent competent experts, an examination of the properties, earnings and financial condition of the Hudson \& Manhattan Railroad Company. Summaries of the reports of this investigation are appended hereto. These reports show that the Hudson \& Manhattan Railroad Company has not earned, and is not now earning, the full interest upon its outstanding First Mortgage Four and OneHalf Per Cent. Bonds. It, therefore, cannot market securities to provide funds to pay the cost of improvements and betterments, nor has it the funds to pay such of its car trust obligations as are approaching maturity, and, unless its fixed charges are reduced through the action of the bondholders and the needed funds are furnished by the stockbolders, it will be impossible to avoid the foreclosure of the mortgage securing the First Mortgage Four and One-Half Per Cent. Bonds.

The undersigned have accordingly formulated the within plan for the readjustment of the debt of the Company, which has been approved by the holders and representatives of a majority of the First Mortgage Four and One-Half Per Cent. Bonds and of the Preferred and Common Shares of the Company. The undersigned have also agreed to form a Syndicate to purchase from the Hudson Companies the New First Mortgage Bonds and Adjustment Income Bonds which it will receive upon the consummation of the Readjustment, in order that it may be in a position to take up its outstanding collateral trust notes and participate in the Plan of Readjustment.

The undersigned believe that the within plan is fair to all interests. It should be promptly accepted with substantial unanimity by the holders of the First Mortgage Four and One-Half Per Cent. Bonds and of the Preferred and Common Shares of the Company in order to avoid a forced reorganization based upon the foreclosure of the First Mortgage.

Bondholders and stockholders, to assent to the plan and become parties to the Readjustment Agreement, must deposit their bonds or stock certificates or voting trust certificates, with Guaranty T'rust Company of New York on or before February 14, 1913, after which 
date no deposits will be received except with the consent of, and upon such terms as may be imposed by, the Readjustment Managers. All bonds deposited should be in bearer form, with February 1, 1913, and all subsequent coupons attached, and all stock certificates or voting trust certificates should be endorsed in blank or be accompanied by proper instruments of transfer in blank.

The undersigned will, if desired by depositing bondholders, advance to them upon their bonḍs, at the time of deposit of the same, the amount of the coupon due February 1, 1913.

In case the within Plan of Readjustment should be abandoned and a modified or substitute plan adopted by the Readjustment Managers, at least thirty days' notice of the terms thereof will be given in the manner provided in the Readjustment Agreement, and depositors of bonds and shares will be given an opportunity of withdrawing without any payment for expenses.

New York, January 14, 1913.

$\left.\begin{array}{r}\text { KUHN, LOEB \& CO., } \\ \text { New York. } \\ \text { ROBERT FLEMING \& CO., } \\ \text { London. } \\ \text { HARVEY FISK \& SONS, } \\ \text { New York. }\end{array}\right\} \begin{gathered}\text { Managers. } \\ \text { Readjustment }\end{gathered}$




\title{
HUDSON \& MANIIATTAN RAILROAD COMPANY
}

\author{
Plan for Readjustment of Debt

\section{PRESENT SECURITIES OUTSTANDING}

Debt to be comprised in readjustment:

First Mortgage Four and One-Half Per Cent. Gold Bonds, due

February 1, 1957 (hereinafter called the "Present First-

Mortgage Bonds") ........................ \$67,148,000.00

Equipment obligations maturing prior to September 1, 1913... $113,000.00$

Debt not to be disturbed by readjustment:

New York and Jersey Railroad First Mortgage Five Per Cent.

Thirty-Year Gold Bonds, due February 1, 1932.........

Equipment obligations maturing from September 1, 1913, to

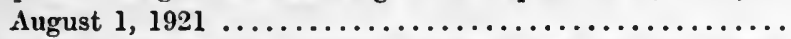

Real Estate Mortgages (including mortgages upon real estate

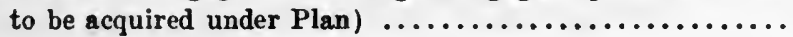

Total debt $\ldots \ldots \ldots \ldots \ldots \ldots \ldots \ldots \ldots \ldots \ldots \ldots \ldots \ldots \ldots+\$ 74,731,500.00$

Capital Stock:

Five Per Cent. Non-Cumulative Preferred Stock...........

Common Stock

$\$ 5,242,151.25$

$39,994,890.00$

$\$ 45,237,041.25$

\section{II}

\section{CASII REQUIREMENTS (ESTIMATED)}

To acquire from the Hudson Companies, at cost, real estate on the blocks occupied by the Terminal Buildings (subject to

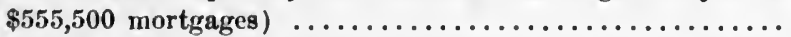

Payment in lieu of interest due February 1, 1913, on Present First Mortgage Bonds (excluding $\$ 7,148,000$ of the bonds held by IIudson Companies) $\ldots . \ldots \ldots \ldots \ldots \ldots \ldots . . . . . .$.

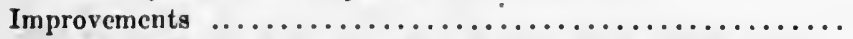

Car trust obligations maturing prior to September 1, 1913....

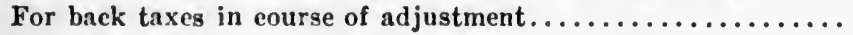

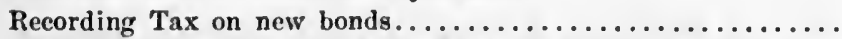

For working capital, expenses of readjustment including compensation of Readjustment Managers and other corporate purposes

$\$ 435,000.00$

$1,350,000.00$

$150,000.00$

$113,000.00$

$325,000.00$

$353,045.00$

$1,119,103.50$

Total (equal to cash to be provided by payment of $\$ 8.50$ per share by stockholders) 


\section{PROPOSED ISSUE OF NEW BONDS}

Five Per Cent. First Mortgage Bonds, bearing interest from February 1, 1913,1 and secured (subject only to existing liens) by a mortgage upon the property covered by the Present First Mortgage and upon the Equity in the additional real estate to be acquired or by such mortgage and by the pledge of the bonds secured by the Present First Mortgage which become subject to the Plan; present issue. $\$ 37,035,000.00$

Five Per Cent. Adjustment Income Bonds bearing interest (if earned) from February 1, 1913,1 secured by a mortgage upon all the property which is to be subject to the new First Mortgage subject to the prior lien of that mortgage, the interest charge against income to be non-cumulative until January 1, 1920, and cumulative thereafter; total

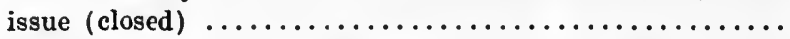

$33,574,000.00$

\section{IV}

\section{DISPOSITION OF NEW BONDS}

New Five Per Cent. First Mortgage Bonds.

To be issued to holders of existing First Mortgage Bonds at the rate of $\$ 500$ of new bonds for $\$ 1,000$ of old bonds..... $\$ 33,574,000.00$

To be issued to preferred and common stockholders for cash payment of $\$ 8.50$ per share at the rate of $\$ 900$ face value of bonds for $\$ 1,000$ of cash paid $2 \ldots \ldots \ldots \ldots \ldots \ldots \ldots$

Total to be presently issued $\$ 37,035,000.00$

Five Per Cent. Adjustment Income Bonds.

To be issued to holders of existing First Mortgage Bonds at the rate of $\$ 500$ of Adjustment Income Bonds for $\$ 1,000$ of

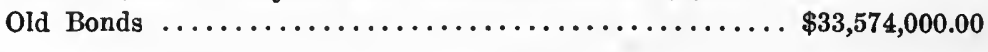

BASIS OF PARTICIPATION IN PLAN BY EXISTING BONDHOLDERS AND STOCKHOLDERS

Holders of Present First Mortgage Bonds to receive for each $\$ 1,000$ thereof:

${ }^{2}$ In case the Hudson \& Manhattan Railroad Co. should make any payment on account of interest accruing from February 1, 1913, on its Present 41/2\% First Mortgage Bonds, any amount so paid for any half yearly period, shall, to the extent of $\$ 12.50$ per Bond, be considered as payment on account of the corresponding interest on the New First Mortgage 5\% Bonds, and any amount over $\$ 12.50$ per Bond, as interest on the New 5\% Adjustment Income Bonds.

2 See footnote, p. 937. 
New First Mortgage Five Per Cent. Bonds..............\$500.00

New Adjustment Income Bonds.................... 500.00

Cash in lieu of interest due February 1, 1913 (excepting interest upon

$\$ 7,148,000$ of bonds owned by Hudson Companies, which interest

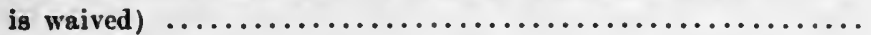

22.503

Preferred and common stockholders to retain their present shares and, on the payment of $\$ 8.50$ per share, to receive (subject to an adjustment of accrued interest as of the date of payment) :

New First Mortgage Five Per Cent. Bonds (face amount) $2 \ldots . . .$. .

No payment need be made by stockholders at the time of the deposit of their stock, but said payment at the rate of $\$ 8.50$ per share shall be made to the Depositary in respect of all deposited stock within such period (not less than ten days) after notice from the Readjustment Managers, given as provided in the Agreement, as may be specified in such notice. In case any Depositor shall fail to make such payment, the stock deposited by him shall be forfeited to the Readjustment Managers, who may acquire such stock for themselves or transfer it to others, upon payment to the Depositary of said amount of $\$ 8.50$ for each share of such stock; and for such payment New First Mortgage Bonds shall be issued as in the case of other payments by stockholders.

\section{VI}

\section{SECURITIES OUTSTANDING UPON CONSUMMATION OF PLAN}

New York and Jersey Railroad First Mortgage Five Per Cent.

Thirty-Year Gold Bonds ..................... \$5,000,000.00

Five Per Cent. Equipment obligations maturing from Septem-

ber 1,1913 , to August $1,1921 \ldots \ldots \ldots \ldots \ldots \ldots \ldots \ldots .1,263,000.00$

Real Estate mortgages $\ldots \ldots \ldots \ldots \ldots \ldots \ldots \ldots \ldots \ldots \ldots \ldots, 1,207,500.00$

Five Per Cent. First Mortgage Bonds.............. 37,035,000.00

Five Per Cent. Adjustment Income Bonds........... $\mathbf{3 3 , 5 7 4 , 0 0 0 . 0 0}$

Total obligations $\ldots \ldots \ldots \ldots \ldots \ldots \ldots \ldots \ldots \ldots \ldots \ldots \$ 78,079,500.00$

Five Per Cent. Non-Cumulative Preferred Stock.........\$\$,242,151.25

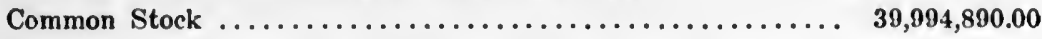

Total Capital Stock ................... \$45,237,041.25

- 2 For fractional amounts of bonds there will be non-interest bearing scrip exehangeable in amounts of $\$ 500$ or $\$ 1,000$ for bonds carrying the interest not paid on the scrip.

- In case the Hudson \& Manhattan Railroad Company should make any payment on account of the interest due February 1, 1913, on its present $4 \frac{1}{2} \%$ First Mortgage Bonds, any amount so paid is to be deducted from said amount of $\$ 22.50$. 


\section{VII}

\section{POSITION OF NEW BONDS IN RESPECT OF INCOME}

The position of the new bonds in respect of income is estimated by Messrs. Barrow, Wade, Guthrie \& Co., Chartered Accountants in a letter dated January 13, 1913, addressed to the Readjustment Managers, as follows:

\section{Dear Sirs :}

At your request, we have made an examination of the books and accounts of the Hudson and Manhattan Railroad Company, and beg to state that for the year ended December 31, 1912, we find the earnings applicable to the payment of interest on new bonds to be issued in lieu of the First Mortgage $41 / 2 \%$ Bonds, after charging taxes and all other prior sums, and writing off adequate depreciation on both the Railroad properties and the Terminal Buildings, are as stated below:

The result here shown is after taking into account the saving of interest in respect of debts and obligations paid or to be paid in accordance with the readjustment plan, credits for net rentals of properties to be acquired, and the expected savings in the Special Franchise Tax for the year:

Total Net Earnings $\ldots \ldots \ldots \ldots \ldots \ldots \ldots \ldots \ldots \ldots \ldots \$ 2,567,781.85$

Interest on $\$ 37,035,0005 \%$ First Mortgage Bonds . . . 1,851,750.00

$\$ 716,031.85$

Less: Amortization of Debt Discount annual charge... $\quad 47,493.33$

Leaving applicable to interest on the $\$ 33,574,000$ new $5 \%$ Adjustment Income Bonds equal to about $2 \%$ per

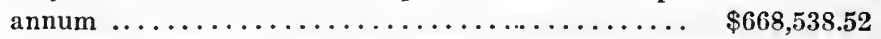

Yours very truly,

Barrow, Wade, Guthrie \& Co.,

Chartered Accountants.

\section{VIII}

TERMS OF NEW MORTGAGES

The New First Mortgage.

The mortgage securing the new First Mortgage Bonds shall contain the following provisions:

(a) The aggregate principal amount of bonds to be secured thereby shall be limited to $\$ 65,000,000$. The bonds shall mature February $1,195 \%$.

(b) Such an ainount of bonds as the Readjustment Managers deem proper shall be reserved to proride for the purchase, redemption, retirement or payment of the underlying First Mortgage Five Per Cent. Thirty Year Gold Bonds of the New York and Jersey Rail- 
road Company $(\$ 5,000,000)$, the equipment obligations maturing from September 1, 1913, to August 1, $1921(\$ 1,263,000)$ and the underlying real estate mortgages $(\$ 1,207,500)$.

(c) Bonds other than those issued under the Plan and reserved to retire underlying liens as above provided, shall be used only (1) for additions, betterments, equipment and extensions (which extensions must be free from prior encumbrance), provided that no bonds shall be issued for such extensions of the Company's lines of railroad unless the net income of the Company for the last preceding calendar year available for interest upon the New First Mortgage Bonds shall be one and a half times the annual interest upon the New First Mortgage Bonds at the time outstanding and those then about to be issued; or (2) to an amount not to exceed $\$ 6,000,000$ for an extension of the Company's line to the Grand Central Railroad Station (which extension must be free from prior encumbrances), provided that no bonds shall be issued for such extension unless the net income of the Company for the last preceding calendar year available for interest upon the New First Mortgage Bonds shall be one and a half times the annual interest upon the New First Mortgage Bonds at the time outstanding.

(d) The bonds secured by the mortgage shall be in denominations of $\$ 1,000$ and $\$ 500$, and the principal and interest thereof, besides being payable in New York, shall also be payable in London in Pounds Sterling at the fixed rate of exchange of $\$ 4.86 \frac{1}{2}$ per Pound Sterling.

(e) The bonds issued under the Plan shall be redeemable in whole or in part at $105 \%$ and interest upon any semi-annual interest date. Bonds subsequently issued shall not bear interest at a rate higher than $5 \%$ per annum and may be redeemable at any price that may be specified in the bonds.

\section{The Adjustment Income Mortgage.}

The Mortgage securing the Adjustment Income Bonds shall be limited to said amount of $\$ 33,574,000$ and shall contain the following provisions:

(a) The interest upon the income bonds shali be payable on the first days of April and October of each year. The first interest shall be payable on October 1, 1913, and shall be payable out of the surplus ineome for the five months ending June 30 of that year. For every subsequent year the interest payment due on the first day of October shall be payable out of the surplus income for the half year ending on the last preceding 30 th day of June, and the interest payment due on the first day of April shall be payable out of the remaining surplus 
income of the Company for the year ending on the last preceding thirty-first day of December.

The entire net income of the Company for each year (and of said period of five months ending June 30,1913) over the interest upon the First Mortgage Bonds at the time outstanding, as such net income is ascertained by the Company's Board of Directors in accordance with the provisions of the Mortgage, shall be payable by way of interest upon the Adjustment Income Bonds up to the full amount of such interest for such period (including accumulations of arrears of interest accruing from earnings from January 1, 1920), except that the semi-annual interest payments need not be in fractions other than one-quarter of one per cent. upon the Adjustment Income Bonds outstanding or multiples thereof; but any smaller fractional amount of earnings remaining after an interest payment shall, for the purpose of determining the income payable by way of interest upon said Adjustment Income Bonds, be carried into the next succeeding half-yearly period.

(b) The Adjustment Income Bonds shall be denominations of $\$ 1,000$ and $\$ 500$, and the principal and interest thereof besides being payable in New York, shall also be payable in London in Pounds Sterling at the fixed rate of exchange of $\$ 4.86 \frac{1}{2}$ per Pound Sterling.

(c) The Adjustment Income Bonds shall mature February 1, $195 \%$, but shall be redeemable in whole or part on any semi-annual interest day at par and accrued interest.

\section{IX}

\section{VOTING TRUSTEES}

The deposited capital stock of the Company is to be deposited with a Bank or Trust Company under an agreement which will vest the voting power in respect of such stock for a period of five years from the date of the agreement in voting trustees to be named by the Readjustment Managers. Said Voting Trust Agreement shall provide that whenever and so long as five per cent. interest has not been paid on all the Adjustment Income Bonds outstanding during the last preceding fiscal year, the persons elected to the Board of Directors of the Company shall be persons approved or nominated at a meeting of the holders of the Adjustment Income Bonds, until one less than a majority of the Board of Directors shall be persons so approved or nominated, provided that the action of the meeting of the holders of the Adjustment Income Bonds, approving or nominating the necessary candidates for election shall be taken within a reasonable time after the opportunity to do so is given. 


\section{$\mathrm{X}$}

\section{READJUSTMENT MANAGERS}

Said Plan is to be carried out by Messrs. Kuhn, Loeb \& Co., Robert Fleming \& Co. and Harrey Fisk \& Sons, as Readjustment Managers, acting under an agreement of even date herewith, an original of which is lodged with the Depositary liereinafter named, where it is subject to the inspection of bondholders and stockholders. Reference is hereby made to said agreement for a statement of the powers of the Readjustment Managers and for further details of the Plan. In case of conflict between the Plan and the terms of said agreement, the latter shall govern. The action of Kuhn, Loeb \& Co. and one other of said firms (as now or hereafter constituted) acting as Readjustment Managers, shall have the same effect as if concurred in by all of them. Either on their own account or as managers of, or participants in, any present or future syndicate, any or all of the Readjustment Managers may purchase, or be interested in the purchase of, securities from the Company or from the Hudson Companies, or may furnish said Companies, or either of them, with moneys to enable them, or either of them, to carry out, or participate in, said Plan or readjustment, or any other plan, or may make, or be interested in, any other purchases of securities or advances of moneys in connection with said readjustment, or any modified or substituted plan of readjustment or reorganization. The Readjustment Managers shall not be responsible for the accuracy of any of the statements or figures contained in this Plan.

\section{$\mathrm{XI}$}

\section{MEANS BY WHich THE READJUSTMENT MAY BE ACCOMPLISHED}

Said readjustment of the debt of the Company may be accomplished in such manner and by such means as to the Readjustment Managers may seem wise or proper in their discretion. "The New First Mortgage Bonds may be issued either under a new mortgage or under the existing mortgage modified in such manner as the Readjustment Managers may determine. The Readjustment Managers shall have power to determine when a sufficient number of the existing First Mortgage Bonds and shares of stock have been deposited with the Depositary to make it advisable to declare the Plan operative.

Exeept as herein otherwise specifically provided, the terms of the new First Mortgage Bonds and Adjustment Income Bonds and of the mortgages by which the same are secured and of any instruments modifying the Existing First Mortgage and of the voting trust agreement, and of any other instruments deemed by the Readjustment 
Managers to be necessary or proper in connection with the consummation of the Plan, shall be such as the Readjustment Managers shall, in their discretion, deem wise and proper. Any of said mortgages, bonds and other instruments may vary from the requirements of this Plan and of the Readjustment Agreement, provided that, in the opinion of the Readjustment Managers, the variations are not substantial or are not of material disadvantage to any class of Depositors.

\section{XII}

PROVISION FOR A MODIFIED OR SUBSTITUTE PLAN

In case the Readjustment Managers shall, for any reason, deter-. mine that it is impracticable or inadvisable to carry out said Plan of Readjustment, they shall have the power to modify the same or to substitute a new plan and to carry the modified or substitute plan into effect, but in case of the adoption of any such modified or substitute plan, at least thirty days' notice of the terms thereof and an opportunity of withdrawing deposited securities and cash (without interest) shall be given to depositors hereunder in the manner provided in said agreement; no payment being required from depositors withdrawing except reimbursement witl interest to the managers for any advances that may have been made in lieu of interest upon the securities to be withdrawn.

\section{XIII}

\section{METHOD OF DEPOSIT UNDER THF PLAN}

The holders of the Present First Mortgage Bonds and shares of stock (and voting trust certificates) of the Company desiring to participate in the Plan may assent thereto and become parties to said agreement in the manner following:

(1) Holders of First Mortgage Bonds must deposit their bonds, together with the February 1, 1913, and all subsequent coupons, with Guaranty Trust Company of New York (herein called the "Depositary") at its office in the City of New York or at the London office of its agents in London, Messrs. Robert Fleming \& Co. Bonds registered as to principal must be restored to bearer form before deposit, and registered bonds must be exchanged for coupon bonds or registered in the name of the Depositary.

(2) Holders of the Common and Preferred Stock or voting trust certificates therefor must deposit with the Depositary the certificates representing their shares of stock duly endorsed for transfer in blank, or accompanied by proper instruments of transfer in blank.

(3) The Depositary shall issue transferable certificates of deposit for all bonds, stock certificates or voting trust certificates deposited 
hereunder and every holder of such certificates of deposit shall be bound by the provisions of this Plan and of the Readjustment Agreement.

The Readjustment Managers may limit or extend the time for the deposit of any bonds and stock hereunder and impose conditions in respect of any such deposits, as provided in the Agreement.

Dated January. 14, 1913.

The Hudson \& Manhattan Railroad Company hereby approves the foregoing plan for the readjustment of its debt and hereby requests the Readjustment Managers to endeavor to carry the same into effect; and in consideration of the premises, agrees with them as follows:

(a) To take all lawful action on its part required to carry said plan into effect;

(b) To compensate the Managers for their services in connection with said plan and the consummation thereof; and

(c) To take such action, as may be requested by the Readjustment Managers, to cause the New First Mortgage Bonds and the New Adjustment Income Bonds issued under said plan to be tax exempt in the State of New York, provided no payment in excess of one-half of one per cent. of the principal amount of said bonds shall be required for that purpose.

\section{Hudson \& Manhattan Railroad Company,}

$\mathrm{By}$

(Corporate Seal.)

W. G. McAdoo,

President.

\section{Attest:}

L. R. ThurLow,

Secretary.

ADDITIONAL REPORTS ON HUDSON \& MANHATTAN RAILROAD COMPANY

Messrs. J. F. Calderwood, Vice-President and General Manager of the Brooklyn Rapid Transit System, and W. S. Menden, Engineer of Rapid Transit Development of Brooklyn Rapid Transit System, report as follows in a letter dated November 27, 1912, addressed to the Readjustment Managers, concerning the railroad property of the Hudson \& Manhattan Railroad Company:

\section{Gentlemen :}

In compliance with your request, we have examined the properties of the Hudson \& Manhattan Railroad Company; analyzed the various reports of earn. ings and expenses, also the reports prepared by Barrow, Wade, Guthrie \& Co., Accountants; examined the contraets and franchises under which the proper- 
ties were constructed and are now operated, and beg to report as follows concerning the railroad property, exclusive of the Hudson Terminal Buildings.

The property is of first-class construction, fully equipped and in good physical condition. The car and power equipment will care for a traffic $20 \%$ greater than the present, which present traffic is only about $40 \%$ of the total capacity of the existing lines. All equipment, other than car and power, is sufticient for the operation of existing lines to their full capacity.

The report of the accountants covers the first full year's operation of the complete system. We are of the opinion that gross earnings will show a gradual increase and that the present unit cost of operation should not ma* terially increase. While the operating expenses are Iow in percentage of gross, on account of the short haul, they are reasonably high when expressed in unit cost of operation.

We have conferred with Barrow, Wade, Guthrie \& Co. regarding the amount to be included in the deductions for depreciation and believe that the amount charged in their report fully covers the depreciation chargeable against the operation for the year 1912.

We believe that gross earnings will show a gradual increase for the following reasons:

(1) Increase in the population now served by all lines crossing the Hudson River.

(2) Improved facilities on the lines now delivering traffic to the Hudson \& Manhattan Railroad Co. in New Jersey.

(3) Additional connections provided by the enlarged transit plans of Manhattan, Brooklyn and Queens.

(4) Increased passenger traffic to New York on the steam railroads terminating in New Jersey delivering their passengers to the Hudson \& Manhattan Railroad Co.

(5) The diversion of a portion of the traffic now using the ferries to the Hudson \& Manhattan tunnel lines by reason of the improved conveniences and accessibility. (The present traffic erossing the Hudson River is $160,000,000$ per annum, of which the Hudson \& Manhattan Railroad Co. now carries less than $40 \%$.)

The above should result in an increase in the gross earnings in addition to the normal rate of increase per annum (which in Greater New York is about $6 \%$ ). This future increase in traffic on the Hudson \& Manhattan Railroad should be carried at a less cost per passenger than the traffic in 1912, and the net earnings should therefore inerease at a correspondingly higher rate.

Yours very truly,

J. F. Calderwood, W. S. Menden.

Messrs. Geo. R. Read \& Co. and Mr. J. H. Ward, appraiser for the Title Guarantee \& Trust Company report as follows in a letter dated November 26, 1912, addressed to the Readjustment Managers, concerning the Hudson Terminal Buildings.

\section{Dear Sirs :}

At jour request we have made an examination of the Hudson Terminal Buildings and beg to report as follows:

This property consists of two 21-story modern fireproof office buildings, with extensions; one bounded by Church, Cortlandt and Dey Streets, and the othet 
by Church, Dey and Fulton Streets, and are maintained and operated in connection with the Hudson \& Manhattan Company's tube system, and being the New York Terminal for same.

The location of these properties is a strong one and one that we believe will retain its strength. The buildings covering these plots are substantial and are entirely adequate for the purpose for which they were planned and neet well the demands of tenants. The tenant occupation is a very desirable one, comprising many large and prominent corporations who would find it difieult to obtain like facilities elsewhere. The care, maintenance and upkeep of the buildings have been and are well looked after, reducing the loss from depreciation thereby to a minimum. We believe the system of operation to be well organized and efficiently performed at a moderate and reasonable cost. The buildings are well rented at conservative rates, which, in our opinion, can be maintained.

\section{Yours very truly,}

Geo. R. Read \& Co.,

J. H. WARD,

Appraiser for Title Guarantee \& Trust Co. 


\section{HUDSON \& MANHATTAN RAILROAD COMPANY READJUSTMENT OF DEBT}

\section{AGREEMENT}

AGREEMENT made this fourteenth day of January, one thousand nine hundred and thirteen, between Kuns, Loeb \& Co., RoberT Fleming \& Co., and Harvey Fisk \& Sons (hereinafter called the "Managers"), parties of the first part; GUarantr Trust CoMpanY of NEw YorK (hereinafter called the "Depositary"), party of the second part; and Holders of the First Mortgage Four and OneHalf Per Cent. Gold Bonds, of the Preferred Capital Stock and of the Common Capital Stock of Hudson \& Manhattan RaILroad Company (or voting trust certificates representing such stock), who SHaLl BECOME PARTIES to this AgREEMENT (hereinafter called "Depositors"), parties of the third part,

Witnesseth that the parties hereto, for and in consideration of the covenants and promises hereinafter recited, and for the purpose of consummating the foregoing plan for the readjustment of the debt of Hudson and Manhattan Railroad Company (hereinafter called "the Company") of even date herewith, or some modified or substitute plan for such readjustment, have mutually agreed and hereby do severally agree, and each Depositor has agreed and hereby does agree, with the other Depositors and with the Managers as follows:

First.-The said plan for the readjustment of the debt of the Company is hereby adopted and approved, and shall be taken to be a part of this agreement with the same effect as though each and every statement and provision thereof had been embodied herein, and said plan and this agreement shall be read as one and the same instrument; but no estimate, statement, explanation or suggestion nor anything else contained in the said plan or in this agreement, or in any circular issued or which may hereafter be issued by the Managers, is intended or is to be taken as a representation or warranty, or as a condition of or inducement for deposit or assent, under the plan and this agreement or any modification thereof or amendment thereto, and no defect or error herein shall release any deposit thereunder, or affect or release any assent thereto, except by written consent of the Managers.

Counterpart originals of this agreement, signed by the Managers, or by a majority thereof, and by the Depositary shall be lodged with the Depositary, and with Messrs. Robert Fleming \& Co., the agents of the Depositary in London, England, and with any other Depositary 
or Depositaries appointed as hereinafter provided; and each of said originals shall be taken as a complete and original instrument, but all together shall constitute one agreement. This agreement shall be deemed to be, and sliall be construed as, a New York contract.

Second.-Holders of the First Mortgage Four and One-half Per Cent. Gold Bonds and of the Preferred Capital Stock and of the Common Capital Stock of the Company and of voting trust certificates for such stock may become parties to this agreement in the manner provided in Artiele XIII. of the foregoing plan and upon compliance with such further requirements and regulations as the Managers shall from time to time establish by written notice to the Depositary, and the Depositors agree respectively at any time on demand of the Managers to execute any and all other transfers, assignments or other writings required for vesting in the Managers or their nominees ownership of and all powers of ownership in respect of the bonds and stock deposited hereunder or assigned to the Managers. The Managers, in their discretion and upon such terms and conditions as they shall prescribe, may permit the Hudson Companies or other holders of bonds or stock of the Company to become parties to the plan and this agreement, or to a modified or substituted plan and agreement, without the actual deposit of securities and all security holders so becoming parties are intended to be embraced within the term "Depositor" whenever used in this agreement. Voting Trust Certificates issued under the Voting Trust Agreement dated June 15, 1908, made between holders of stock in the Company and Dumont Clarke, Pliny Fisk and William M. Barnum, may be accepted by the Managers in lieu of the stock certificates against which . such voting trust certificates shall have been issued; and the provisions of this agreement with respeet to the stock of the Company deposited hereunder shall apply to said voting trust certificates deposited hereunder. The Managers are hereby authorized, if they deem advisable, to take all action necessary to secure the termination of said voting trust in adrance of the date specified for termination by the provisions thereof and to secure the return of the stock certificates deposited thereunder; which stock certificates so returned shall be deemed to be deposited hereunder.

Depositors of certificates of preferred and common stock of the Company hereunder severally and respectively agree, immediatcly upon the deposit hereunder of their respective certificates of stock, to deliver to the Depositary proxies or powers of attorney in respect thereof authorizing the Managers, or such person or persons as shall be designated by them and their substitute or substitutes to represent 
and vote the deposited shares of preferred and common stock at any regular or special meeting of the stockholders of the Company upon any question that may come before the said meeting. Every such power of attorney, proxy and every assignment of a deposited security provided for in this agreement shall be in the respective forms approved by the Managers, and such powers of attorney shall give to the Managers, their nominee or nominees and their substitute or substitutes, full right and power to vote on behalf of the stock therein referred to at all meetings of stockholders of the Company. All powers of attorney and proxies delivered to the Depositary shall be irrevocable and shall at all times be subject to the order of the Managers. The Syndicate Managers are hereby given full power and authority to vote and act for all the shares of stock in the Company represented by the deposited certificates at any meeting of stockholders or for any purpose with the same force and effect as if the separate proxies herein provided for had been given.

All Depositors shall receive Certificates of Deposit, in a form to be prescribed by the Managers and approved by the Depositary, specifying the bonds or stock deposited, and the holders of such Certificates of Deposit issued hereunder shall be entitled only to the rights and benefits specified in the plan and this agreement as accruing to the holders of the bonds and stock represented by such certificates respectively, or granted by the Managers pursuant to the powers conferred upon them hereunder; and thereafter the holder of any such certificate or of any certificate issued in lieu thereof or in exchange therefor shall be subject to the plan and this agreement and entitled to have and exercise only the rights of the original Depositor under the certificate issued to him in respect of the bonds or stock therein mentioned. Guaranty Trust Company of New York shall act as Depositary under the plan and this agreement, and Messrs. Robert Fleming \& Co. may act as the agents of the Depositary in London, England. The Managers may appoint additional trust companies or incorporated banks in other cities to act as additional Depositaries under the plan and agreement or, with the approval of the Depositary, as agents for said Depositary.

All bonds and stock deposited hereunder shall be held in escrow by the Depositary, and shall not be delivered to the Managers except such delivery as may be necessary, appropriate or incidental to the presentation thereof for allowance in any receivership, foreclosure, insolvency or bankruptcy proceedings which may be instituted against the Company, and the assignments and transfers of any of the deposited bonds and stock to the Managers shall not become effective unless and until the acceptance thereof shall be signified by the 
Managers by filing with the Depositary a certified copy of a resolution adopted by the Managers stating that it has determined to accept the transfer to them of the deposited bonds or stock, or both, described or referred to in such resolution. Immediately upon the filing with the Depositary of a certified copy of such resolution, the title of the deposited bonds or stock described or referred to in said resolution and all transfers and assignments thereof and security therefor shall forthwith immediately pass from the respective Depositors to, and vest in, the Managers, who shall thereupon be and become the owners and holders thereof, and which shall thereafter be held by the Depositary subject to the order of the Managers. Meanwhile, and until the filing of such certified resolution, the Depositors shall, subject as aforesaid, be deemed to retain, and shall have, the ownership of, and title to, their respective bonds and stock. At all times the Depositary shall deliver in accordance with the request of the Managers all or any of the deposited bonds and stock, provided such request shall state that such deposited securities are to be used for the purpose of presentation thereof for allowance in any receivership, foreclosure, insolvency, bankruptcy or other proceedings which may be instituted or for use in connection with such purpose. All deposited securities so delivered to or upon the order of the Managers in pursuance of any such request shall, unless meanwhile the title thereto shall have become rested in the Managers, as herein provided, be redelivered to the Depositary as soon as such purpose shall have been accomplished. After title thereto shall have become vested in the Managers, as herein provided, the Depositary shall dispose of the deposited bonds and stock of the Company in such manner as the Managers or a majority thereof may from time to time direct, and any direction given by the Managers or by a majority thereof as to any matter whatsoever shall be full and sufficient authority for any action of the Depositary.

Third.-Certificates of Deposit issued hereunder and the interests represented thereby shall be transferable only subject to the terms and conditions of the plan and this agreement and in such manner as the Managers may approve; and upon such transfer, all rights of the Depositors in respect to the deposited bonds and stock represented by such Certificates of Deposit, and all rights under the Certificates of Deposit transferred, shall pass to the transferee, and the transferees and holders of such Certificates of Deposit shall for all purposes be substituted in place of the prior holders, subject to the plan and this agreement. All such transferees, as well as the original holders of Certificates of Deposit issued hereunder, shall be embraced under the terms "Depositors," whenever used herein. Each Certifiente 
of Deposit may be treated by the Managers and by the Depositary as a negotiable instrument, and the holder for the time being may be deemed to be and be treated as the absolute owner thereof, and of all rights of the original Depositor of the bonds or stock in respect of which the same was issued, and neither the Depositary nor the Managers shall be affected by any notice to the contrary. By accepting any such Certificate of Deposit, every recipient or holder thereof shall thereby become a party to the plan and this agreement with the same force and effect as though an actual subscriber hereto. The term "Depositor," whenever used herein, is intended, and shall be construed, to include, not only persons acting in their own right, but also trustees, guardians, committees, agents and all persons acting in a representative or fiduciary capacity, and those represented by or claiming under them, and partnerships, associations, joint-stock companies and corporations. No rights hereunder shall accrue to any Depositor in respect of any bonds and stock mentioned in the plan and in this agreement unless and until the same shall have been fully subjected to the control of the Managers and the operation of the plan and this agreement as herein provided. The Managers may, in their discretion, fix or limit the period or periods within which holders of any bonds and stock may deposit their bonds and stock, and within which they may become parties to the plan and this agreement, and the Managers in their discretion, either generally or in special instances, may extend or renew the period or periods so fixed or limited for such further periods and upon such terms and conditions as they may see fit. Holders of bonds and preferred and common stock not deposited within the periods respectively fixed or limited therefor will not be entitled to deposit the same or to become parties to this agreement or to share in the benefits hereof, and shall acquire no rights hereunder, except upon obtaining the express consent of the Managers, who may withhold or give such consent in their absolute discretion and upon such terms and conditions as they may see fit. The Managers shall have power to make equitable provision for any lost or destroyed bonds, certificates of stock, voting trust certificates or certificates of deposit.

As provided in the plan, depositors of certificates of preferred and common stock of the Company must pay to the Managers at the office of the Depositary, in the City of New York, in New York funds, or, at the office of Messrs. Robert Fleming \& Co., in the City of London, England, in sterling, at the value of exchange to be fixed by the Managers, or, to the extent that the Managers may permit, to such other agents and at such other places as the Managers shall designate for such purpose, $\$ 8.50$ in respect of each share of stock of the par 
value of $\$ 100$ deposited. Such payment need not be made at the time of deposit of the certificates representing said shares of stock, but must be made on such date or dates as shall be fixed by the Managers by advertisement as provided in Article Twelfth hereof, of a notice calling for such payment, the first advertisement of the notice of such call to be at least ten days prior to the date when the cash therein called for shall be payable. Such payments shall be receipted for by the Depositary, or by its agent in London above named, or by some one of such other agents as the Managers may designate, by stamping or otherwise, on the respective Certificates of Deposit issued for deposited stock, upon presentation at the Depositary or such other agent for that purpose of the said certificates of Deposit. Any or all of the moneys paid or accruing under the plan or this agreement may be used at any time by the Managers or with their approval for any of the purposes of the plan and of this agreement.

The Depositors of preferred and common stock of the Company severally and respectively agree, on behalf of themselves and of their respective transferees and assigns, that prompt payment of the cash, which under the terms of the plan and of this agreement they are required to pay in order to entitle them to the new First Mortgage Five Per Cent. Bonds mentioned in said plan, is an essential condition to the acquisition by them respectively of such bonds, and that any Depositor who shall fail to make prompt payment of said cash payable as provided in the plan or in this agreement on or before such date as shall be fixed or limited for such payment by the Managers shall forthwith and without further or other notice or action cease to have any right to acquire the new First Morgage Five Per Cent. Bonds mentioned in said plan, which pursuant to the provisions of the plan or of this agreement they are permitted to acquire, and shall cease to have any rights in the shares of stock deposited by them or their proceeds, or under the Certificates of Deposit issued to them, and shall cease to be entitled to any rights or benefits under the plan or under this agreement, and no such Depositor or his successor in interest shall be entitled to the return of the shares of stock deposited as represented by his Certificate of Deposit, or to have any further interest or right in or in respect thereof, and such shares of stock shall be forfeited to the Managers, their successors or assigns, who may use the said shares of stock, for any purpose deemed by the Managers appropriate for carrying out the plan and this agreement, and who may acquire the same for themselves or transfer them to such person or corporation as the Managers in their discretion shall determine, upon payment to the Depositary of the amount of $\$ 8.50$ frr each such 
share of stock; and in case of any such failure or default, the Depositary is hereby authorized and directed, upon payment of such amount, to deliver such stock to the party paying the same. For payments made upon such shares of stock by the Managers or such other person or corporation, New First Mortgage Five Per Cent. Bonds shall be issued as in the case of other payments by depositing stockholders. The Managers, however, in their absolute and uncontrolled discretion, may waive any such default, may accept payment of the cash from any Depositor at any time overdue and with or without the imposition of such terms and conditions as they may prescribe; they may also waive and remit any penalty prescribed either in the plan or in this agreement or in pursuance thereof.

Fourth.-The Managers shall have, and are hereby granted, the power and authority to carry out and effectuate this agreement and said plan for the readjustment of the debt of the Company, not only in the manner specified in said annexed plan, but in whatever lawful manner may seem to them expedient and for the best interests of the Depositors or likely to accomplish in substance the results contemplated by the plan.

Fifth.-The Depositors hereby request the Managers to carry out the plan and this agreement, in its entirety or in part, to such extent and in such manner and with such additions, exceptions and modifications as the Managers shall deem to be for the best interests of the Depositors. It is hereby declared that the Managers shall forthwith upon the deposit of the bonds and stock hereunder be fully authorized to vote and consent as holders of said bonds and stock to any corporate action, and to sign any written consent required or permitted by law to be signed, and file the same; and each and every Depositor, for himself and not for any other, does, subject to the provisions of Article Second hereof, hereby sell, assign, transfer and set over to the Managers, and to their successors, assigns and nominees, each and every bond and share of stock deposited hereunder or assigned to the Managers, and every Depositor hereby agrees that the Managers shall be, and they are hereby, vested with all the rights and powers of owners of the bonds and stock deposited hereunder, including the right to transfer the same into their own names, or into the name of any other person or persons, party or parties, whom they may select or to deposit the same under a voting trust, and (without limiting the foregoing provision) to use every such bond or share of stock as fully and to the same extent as the owner or holder thereof; to declare due the principal of the bonds deposited hereunder, and to revoke any such declaration whenever made; to give all bonds of indemnity or other bonds, and to charge therewith the bonds and 
stock deposited hereunder or the new securities to be issued hereunder or any part thereof; to institute or to become parties to any legal proceeding; to compromise any litigation now or at any time existing or threatened, in whole or in part, with plenary power to enter into any arrangement tending towards, or deemed by them, in their discretion, likely to promote, the consummation of the plan and of this agreement; $t$ ) do. whatever, in the judgment of the Managers, may be necessary to promote or to procure the sale as an entircty, or the separate sales, or any lands or other property of the Company, wherever situated; to adjourn any sale at their discretion; to bid, or to refrain from bidding, at any sale, either public or private, either in separate lots or as a whole, for any property, or any part thereof, including or excluding any particular property, real or personal; to hold any property purchased by them either in their name or in the name of persons or corporations by them chosen for the purposes of this agreement and to resell the same. The amount to be bid or paid by the Managers for any property shall be absolutely discretionary with them; and, in case of the sale to others of any property, the Managers may receive, out of the proceeds of such sale, or otherwise, any dividend or payment in any form accruing on any bonds and stock held by them. The Managers may apply any bonds, stocks or other property held by them hereunder in satisfaction or partial satis: faction of any bid. In case at any time the Managers shall have determined to use or apply any of the deposited securities for any of the purposes herein set forth and the title to the securities shall not have vested in the Managers, then the Depositary, upon the delivery to it of a cerified copy of a resolution of the Managers, shall permit the Managers to apply the securities, or any of them, for the purposes stated in such resolution, and such resolution shall be full and sufficient authority for any action by the Depositary. The Managers shall further be authorized to receive and dispose of, in accordance with any of the provisions of the plan and this agreement, any new securities to be created, and the Managers may vote upon the bonds and stock of the Company or obligations or stock of any new company for all purposes in their judgment necessary or advisable until the said obligations or stock shall be delivered to the Depositors or whoever shall be entitled to receive the same.

Sixth.-The Managers may construe the plan and this agreement, and their construction thereof or action thereunder, in good faith shall be final and conclusive. They may supply any defect or omission, or reconcile any inconsistencies, in such manner and to such extent as shall be deemed by them necessary to carry out the plan properly and effectively, and they shall be the sole judges of sucb 
necessity. They shall be the sole and final judges as to when and whether the assent of a sufficient number of the holders of the First Mortgage Four and One-Half Per Cent. Gold Bonds and of the Preferred Capital Stock and of the Common Capital Stock of the Company shall have been obtained to warrant them in declaring the plan operative, or attempting to carry the same or any part thereof into effect; and they shall have power whenever they shall deem proper to alter, modify, depart from or abandon the plan of readjustment, or any part thereof except as in said plan provided. They may at any time or times, after any such partial abandonment, restore to the plan any abandoned part or parts thereof, and may seek to carry the same into effect as fully as if such part or parts had not been abandoned. They may also attempt to carry the plan into effect rather than to abandon the same, or adopt a modified or substitute plan as hereinafter provided, even though it be manifest that, as carried out, the plan must depart from the original plan or from some part thereof The Managers may adopt a plan of reorganization based upon the foreclosure of one or more of the mortgages which are now a lien upon the property of the Company and the organization of a new company. The Managers shall be free to give such title to the new bonds or other securities proposed to be issued under the foregoing plan or which may be issued under any modified or substituted plan, and to the mortgage or other instrument securing the same, as to them shall appear desirable. Any change or modification made by the Managers shall become and be part of the plan and this agreement; and all provisions concerning the present plan shall apply to the plan so changed or modified. In case any modified or substitute plan shall, in the opinion of the Managers, substantially meet the requirements stated in the annexed plan, or shall so nearly meet such requirements that in the opinion of the Managers the submission of the substitute or modified plan to the Depositors is unnecessary, the Managers may proceed with the execution of such modified or substitute plan as though the same had been herein set forth in full and expressly assented to by each Depositor. If, however, any modified or substitute plan shall so far depart from said requirements that in the opininn of the Managers it is advisable that the same should be submitted to Depositors, the Managers shall file a statement of such proposed. change or modification with the Depositary and give notice of the fact of such filing as hereinafter provided in Article Twelfth; and within thirty days after first publication of such notice all holders of the outstanding Certificates of Deposit for bonds or the class of stock so affected by any such change or modification may surrender their respective certificates, properly endorsed, and withdraw their 
bonds or stock of such particular class, or the proceeds thereof or substitutes therefor, then under the control of the Managers, to the extent applicable in respect of such Certificates of Deposit; every holder of a Certificate of Deposit so withdrawing shall thereupon, without any further act, be released from the plan and this agreement and shall cease to have any rights thereunder. No payment shall be required of any Depositor withdrawing his securities except to the extent of any sums that may have been advanced by way of interest upon deposited bonds, or in lieu of such interest, and interest thereon. Every Depositor not so surrendering and withdrawing within such thirty days after first publication of said notice shall be deemed to have assented to the proposed change or modification, and, whether or not otherwise objecting, shall be bound thereby as fully and effectively as if he had actually assented thereto. In every case of withdrawal, any amounts actually collected by the Managers on the deposited securities will, in case of such withdrawal, be accounted for by the Managers to the Depositors for such securities. The Managers may, in their discretion, decline to further represent any class of securities deposited hereunder, while continuing to represent the remaining securities, in which event they shall publish, in the manner prescribed in Article Twelfth hereof, a notice specifying the securities which they decline further to represent and giving the holders thereof an opportunity of withdrawing them without any payment upon the surrender of their respective Certificates of Deposit. At the expiration of ten days from the first publication of such notice, the Managers will cease to be under any responsibility to represent the securities of the class mentioned in such notice. In case the Managers shall finally abandon the entire plan, the bonds and stocks and cash deposited hereunder shall be delivered to the several Depositors in amounts representing their respective interests upon surrender of their respective certificates, properly endorsed, and payment of such expenses as shall have been incurred by the Managers and not reimbursed from other sourees and, in the case of deposited bonds, of any advances by way of, or in lieu of interest, and interest thereon, and the Managers shall have power, in their discretion, to determine and to apportion among the bonds and the two classes of stock deposited hereunder the share of expense to be borne by each. The Managers may also, in their discretion, upon the request of the holder of a Certificate of Deposit and surrender thereof, whenever and upon such terms as they shall deem proper, from time to time release and discharge from participation in the plan and from the operation of this agreement the securities represented by any such Certificate of Deposit. The Managers shall not be liable for loss of any money collected, disbursed 
or expended by them for the purposes of the plan or of this agreement, nor for any interest on any money collected hereunder, nor for any depreciation in value of any property purchased by them, and the Depositors shall have no claim for the repayment of any such moneys except to the extent of their ratable shares (as apportioned by the Managers) of such moneys or their proceeds at the time remaining in the hands of or subsequently collected by the Managers after payment of all such expenses. If the Managers shall at any time advance interest on any bonds deposited hereunder, such advance shall bear interest at the rate of six per cent. per annum, and shall be secured by the bonds in respect of which the advance is made. In case of the withdrawal of bonds under the provisions hereof any advance in respect of such bonds shall be repaid with interest as a condition of such withdrawal and in case of the consummation of said plan such advances shall be repaid from the cash paid by depositing stockholders as provided for in the plan and the interest on such advances shall be treated as part of the expenses of the readjustment.

Seventh.-The Managers may proceed under the plan and this agreement or any part thereof in such manner as to them shall seem advisable. The Managers may, in their discretion, purchase obligations of or claims against the Company and deposit the same subject to said plan and agreement, and may provide for the purchase price thereof by the sale of obligations and claims of the Company, or of any new company which may be organized for the purpose of carrying out said plan. Any action contemplated in the plan and this agreement to be performed on or after completion of the plan of readjustment may be taken by the Managers at any time when they shall deem the plan advanced sufficiently to justify such course, and the Managers, as they may deem necessary, may defer the performance of any provision of the plan and this agreement, or may commit such performance to the Company or any successor company. They may also in their discretion set apart and hold in trust, or place in trust, any part of the new securities to be issued, as they may deem judicious for the purpose of securing the application thereof for any of the purposes of the plan and this agreement or for the uses of the Company or of a new company. The Managers may cause to be formed the voting trust contemplated by the plan, or a different voting trust, under a voting trust agreement containing such terms and provisions as the Managers shall prescribe, and may cause the deposited stock of the Company to be transferred to such trustees, to be held upon the terms of such roting trust agreement, and may cause voting trust certificates of such form and tenor as the Managers may prescribe to be issued in exchange for such stock. For all purposes of the plan and of this 
agreement, the issue, transfer and delivery of voting trust certificates to the Depositors hereunder shall be deemed to be a delivery of stock certificates for the return of the stock of the Company.

Eighth.-From time to time, for the purpose of carrying said plan and this agreement into effect, or of obtaining assents thereto, the Managers, either generally or in specific instances, may make contracts with any person, syndicate or corporation in respect of any matter connected with said readjustment, including an agrcement to submit to any person, firm or committee any modification of the plan before adopting the same; and in their discretion, either generally or in specific instances, and upon such general or special terms and conditions as they may deem proper, may arrange to procure the deposit of bonds or stock hereunder or to purchase and deposit the same; they may also, from time to time, by loan, pledge, guaranty, or sale of the deposited bonds and stocks or of the new securities to be created or property purchased, or otherwise, upon such terms, conditions and rates as said Managers shall deem proper, obtain any moneys required to carry out the plan and this agreement; and for the performance of any contract made by them said Managers may charge the deposited bonds and stocks, or the new securities to be created, and may pledge the same for the payment of any moneys borrowed and interest thereon, and the performance of any other obligations incurred under the powers herein conferred. As provided in said plan, any or all of the Managers, either on their own account or as Managers of, or participants in, any present or future syndicate, may purchase, or be interested in the purchase of, securities from the Company or from the Hudson Companies, or may furnish said companies, or either of them, or any other company formed to carry out the purposes of this agreement, with moneys to enable them, or either of them, to carry out or participate in, said plan or any other plan, or may make or be interested in, any other purchases of securities or advances of moneys in connection with the readjustment contemplated by said plan or any modified or substitute plan of readjustment or reorganization. The Managers may employ counsel, agents and all necessary assistance; may take any action, which they are authorized hereunder to take, by means of agents; and may incur and discharge or assume the payment of any and all expenses by them deemed reasonable for the purpose of this agreement. The compensation and expenses of the Managers shall be paid as part of the readjustment by the Company or by any new company to be formed, and, to secure the payment of such expenses, the Managers shall have, if all ${ }^{2}$ plan of readjustment or

1 So in original. 
reorganization hereunder is abandoned, a first lien upon the bonds and stock deposited and cash paid hereunder. The Managers may prescribe or approve the form of all instruments at any time to be issued or entered into. The Managers may, at public or private sale, or otherwise, dispose of, or purchase for their own account, any securities left in their hands because of any failure or default on the part of the depositor to make deposits or payments hereunder. In so disposing of any such securities or claims thus left in their hands, they may use the same or the proceeds thereof for the purpose of carrying out the readjustment or defraying any expense thereof in such man$\mathrm{nr}$ as they may deem expedient and advisable. At the time of the creation of the new securities, or as soon thereafter as may be, the Managers may take such action as they may deem necessary to guard against the issue of particular securities in any manner or to any extent inconsistent with the purposes of the plan.

Ninth.-The Managers, under this agreement, shall have the sole control, direction and management of the said plan. The action of Kuhn, Loeb \& Co., and one other of the firms constituting the Managers shall have the same force and effect as if concurred in by all the Managers, and no action shall be taken except with the assent of at least such majority of the Managers. Any one of the firms constituting the Managers may act by proxy given to any other of said firms. The Managers may act either at a meeting or without a meeting. In case of the resignation or retirement of Kuhn, Loeb \& Co., said firm may appoint its own successor as one of the Managers, and in case the resignation or retirement of any other of the firms constituting said Managers, a successor to said firm may be appointed by the other firms which constitute the Managers; and the successor in any case so appointed shall have all the powers conferred hereby upon the firms now constituting the Managers. The Managers may at any time in their discretion appoint two or more persons who, upon executing a counterpart of this agreement and delivering it to the Depositary shall take the place of the Managers and thereafter have and exercise all the powers hereby conferred upon the Managers who shall thereupon be relieved from all further responsibility hereunder. All the powers conferred by this agreement upon the Managers shall be exercised by the persons or firms who for the time being constitute such Managers. The Managers undertake to endeavor to execute the plan and this agreement, but neither the Managers nor the Depositary assume any individual responsibility for the execution of the plan or of this agreement, or any part of either, nor for the result of any steps taken or acts done for the purposes thereof. The Readjustment Managers shall not be responsible for the accuracy of any of the state- 
ments or figures contained in the Plan. Nor shall the Managers or the Depositary be individually liable for any act or omission of any agent or employee selected by them, nor for any error of judgment or mistake of fact or law, nor in any case except for his, its or their own individual willful malfeasance or neglect; nor shall any of the Managers be liable for the acts or defaults of any other thereof or of the Depositary; nor shall the Depositary be liable for any act or default of the Managers or otherwise than for its own willful malfeasance or neglect. The Managers shall have the right to sell, or cause to be sold, or to buy for their own account, any securities of any new Company not required for exehange under said plan, for the purpose of procuring cash to purchase any obligations or claims that in the opinion of the Managers should be purchased for deposit under the plan. The Managers shall have the right to form, or procure the formation of, any syndicate or syndicates which they may deem necessary or advantageous for the purpose of providing funds needed for any of the purposes of this agreement, and any of them may act as members or managers of any such syndicate or syndicates without being accountable to the Depositors, or any of them, and the terms of any such syndicate shall be fixed by the Managers, even though the firms constituting the Managers hereunder are also managers of or interested in the Syndicate, and the terms as so fixed shall be binding and conclusive upon all parties. The accounts of the Managers shall be filed with the Board of Directors of the Company, or any successor company, within one year after the readjustment shall have been completed, unless a longer time be granted by said board with which they are to be filed. The accounts, unless disapproved by such Board of Directors within thirty days after such filing, shall be final, binding and conclusive upon all parties having any interest therein, and thereupon the Managers shall be discharged. The acceptance of new securities by any Depositor shall prevent such acceptor from questioning the conformity of such securities in any particular to any provisions of the plan.

Tenth.-The enumeration of specific powers hereby conferred shall not be construted to limit or to restrict general powers herein eonferred or intended so to be; and it is hereby distinctly declared that it is intended to confer on the Managers, in respect of all bonds and stock and cash deposited or to be deposited, and in all other respects, any and all powers which the Managers may deem necessary or expedient in or towards carrying out or promoting the purposes of the plan and this agreement in any respect as now existing, or as the same may be modified or amended, even though any such power be apparently of a character not now contemplated; and the Managers 
may exercise any and every such power as fully and effectively as if the same were herein distinctly specified, and as often as, for any cause or reason, they may deem expedient. The methods and means to be adopted for or towards carrying out said plan of readjustment and this agreement shall be entirely discretionary with the Managers.

Eleventh.-The bonds and stock deposited under the plan and this agreement, and all obligations and securities purchased or otherwise acquired under this agreement, shall remain in full force and effect for all purposes, and shall not, unless the Managers shall otherwise direct, be deemed merged, satisfied, released or discharged by any delivery of new securities; and no legal right or lien shall be deemed released or waived. Any purchase or purchases by or on behalf of the Managers shall vest the property purchased in the Managers free from all interest or claim on the part of any stockholders, creditors or other parties. No right is conferred or created hereby, nor is any liability or obligation incurred, by the plan and this agreement, or assumed hereunder, in favor of any creditor, stockholder or other person or of any holder of any claim whatsoever against the Company, nor in favor of any company now existing or to be formed hereafter, with respect to any bonds or stock deposited under this agreement or any moneys paid to, or received by, the Managers or by the Depositary hereunder, or with respect to any property acquired by purchase, or with respect to any new securities to be issued hereunder, or with respect to any other matter or thing. This agreement shall be construed strictly between, and as solely affecting and relating to, the parties hereto.

Twelfth.-All calls for the presentation or surrender of Certificates of Deposit issued hereunder, all calls for the payment of any amount payable in respect of deposited certificates of preferred or common stock, all notices fixing or limiting any period for the deposit or withdrawal of bonds and stock, and all other calls or notices hereunder, shall be inserted in two daily papers of general circulation published in the City of New York, and, if deemed necessary by the Managers, in two daily papers of general circulation published in the City of London, England, at least twice in ten successive days, beginning on any day of the week. Any call or notice whatsover, when so published by the Managers, shall be taken and considered as though personally served on all Depositors and certificate holders and on all parties hereto and upon all parties bound hereby, as of the day of the final insertion thereof, and such publication shall be the only notice required to be given under any provision of the plan and this agreement. When a call or notice shall have been advertised as above specified, publication shall be complete as regards all holders of Certificates of Deposit, and no further publication or notice shall be required so far as the 
holders of such Certificates of Deposit are concerned. Depositors may, however, furnish an address to the Depositary, where such notices may be mailed, and the mailing of a copy of such notice to said address shall be sufficient, whether or not received by the addressee, and whether or not such notice shall have been published as above provided.

Thirteenth.-The plan and this agreement shall bind and benefit the several parties, including the Depositors hereunder and holders for the time being of Certificates of Deposit, their and each of their survivors, heirs, executors, administrators, successors and assigns. Each of the firms constituting the Readjustment Managers act as a copartnership and this agreement shall extend to said firms as from time to time constituted.

Is witness whereof, the Managers, or a majority of them, and the Depositary have executed these presents in three counterparts the day and year first above written, and an original has been lodged with the Depositary, and the Depositors have become parties hereto by depositing their bonds or stock or assignments thereof, or accepting Certificates of Deposit hereunder.

$\left.\begin{array}{l}\text { KuHN, Loeb \& Co., } \\ \text { Robert Fleming \& Co., } \\ \text { Harvey Fisk \& Sons, }\end{array}\right\} \begin{gathered}\text { Readjustment } \\ \text { Managers. }\end{gathered}$

Guaranty Trust Company of New York,

(Corporate Seal.)

\section{Attest:}

A. J. HeMphiLL,

President.

E. C. HebBard,

Secretary. 
Income Accodnt for Year Ended December 31st, $1912^{1}$

Gross revenue, passenger fares.

$\$ 3,404,519.67$

Miscellaneous revenue for railroad operations:

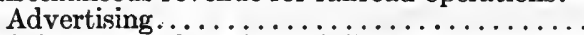

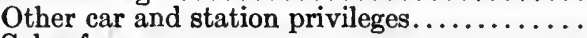

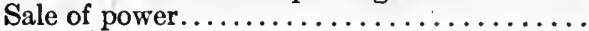

Miscellaneous transportation revenue........

Other miscellaneous revenue.

. . . . . . . . .

Total miscellaneous railroad revenue......

Total railroad revenue................

Operating expenses of railroad:

Maintenance of way and structures $\left\{\begin{array}{l}\text { Actual. . } \\ \text { Reserve. }\end{array}\right.$

Maintenance of equipment $\left\{\begin{array}{l}\text { Actual........... } \\ \text { Reserve....... }\end{array}\right.$

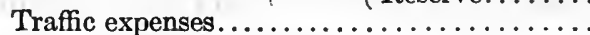

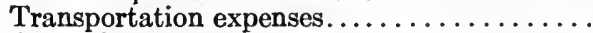

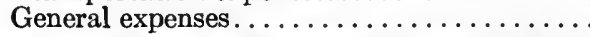

Total operating expenses of railroad......

$\$ 151,381.89$

$59,620.96$

$9,061.95$

13.06

$5,463.57$

$\$ 225,541.43$

$\$ 3,630,061.10$

$\$ 190,859.58$

$14,527.50$

$91,213.07$

$7,400.25$

$11,471.20$

$844,453.14$

$148,180.02$

Net operating revenue from railroad $\ldots \ldots \ldots \ldots \ldots \ldots \ldots \ldots$

Taxes on railroad operating properties.

$\$ 2,321,956.34$

$209,473.66$

Net income from railroad operation

Net income from Hudson Terminal Buildings.

Net income from Greenwich and Tenth Street

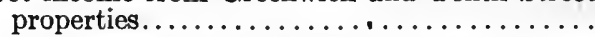

Total net income from outside operations. .

$\$ 946,369.64$

$\$ 2,112,482.68$

Total net income from all operating sources............

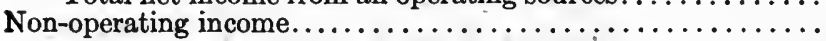

$3,369.12$

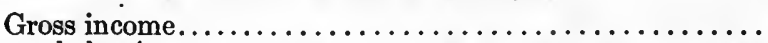

Income deductions:

Interest on total interest-bearing bonds......

Less interest chargeable to construction.....

Balance being interest on capital employed in operation and chargeable against income. .

Interest on car purchase agreements........

Interest on real estate mortgages. . . . . . . . . .

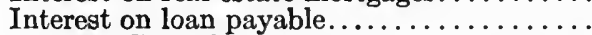

Rentals, City of New York.............

Rental tracks, yards and terminals.........

Amortization of debt discount...............

Total income deductions................

$\$ 2,943,196.06$

$64,114.77$

$\$ 2,879,081.29$

$72,666.66$

$20,433.34$

$23,692.43$

$61,953.66$

$62,459.81$

$48,649.59$

Net loss carried to corporate deficit account................

$\$ 949,738.76$

$\$ 3,062,221.44$

$32,183.13$

$\$ 3,094,404.57$

Note-As additional property has been put into operation, bond interest has been applied against income, as follows:

April 1st, 1909 to July 19th, 1909, on $\$ 13,512,000$ Bonds

July 19th, 1909 to Aug. 2nd, 1909, on $\$ 18,691,000$ Bonds

Aug. 2nd, 1909 to Sept. 20th, 1909, on $\$ 33,991,000$ Bonds

Sept. 20th, 1909 to Jan. 1st, 1910 , on $\$ 35,028,000$ Bonds

Jan. 1st, 1910 to Jan. 1st, 1911, on $\$ 45,028,000$ Bonds

Jan. 1st, 1911 to Dec. 1st, 1911, on $\$ 50,000,000$ Bonds

Dec. 1st, 1911 to April 14th, 1912, on $\$ 60,000,000$ Bonds

April 14th, 1912 to Jan. 1st, 1913, on \$65,000,000 Bonds

1 The following income statements and balance sheets for the year previous to and the first ten months subsequent to the readjustment were copied from the application for listing on the New York Stock Exchange the new securities referred to in the Readjustment Agreement above. 


\author{
Balance Sheet as of December 31st, 1912
}

\title{
Assets
}

Property accounts.......................\$119,013,500.22

Materials and supplies and disused construction

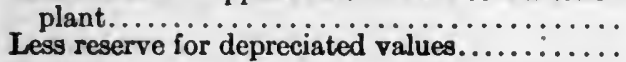

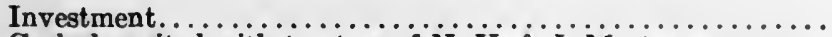

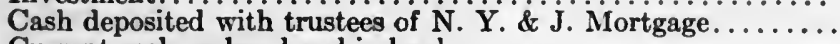

Current cash on hand and in bank..................

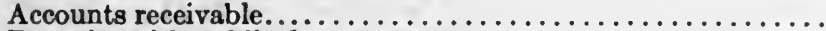

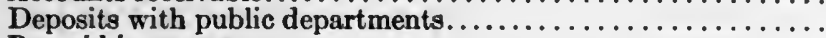

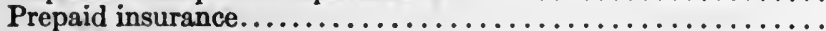

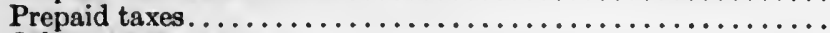

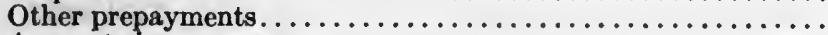

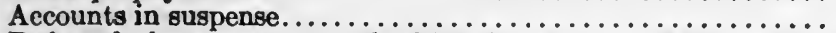

Deferred charges-unamortized bond discount and expense...

Profit and loss, deficit.

Total assets.

$\$ 239,083.51$

$1,000.00$

$114,099.14$

$334,058.23$

$178,492.75$

$12,932.66$

$17,863.63$

$5,097.65$

$2,784.18$

$12,616.06$

$2,137,199.86$

$96,041.32$

$\$ 122,164,769.21$

\section{Liabilities}

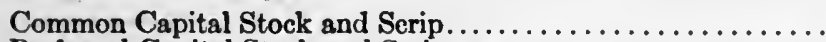

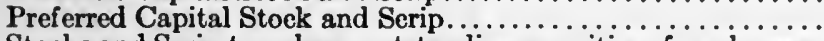

Stocks and Scrin to redeem outstanding securities of predecessor

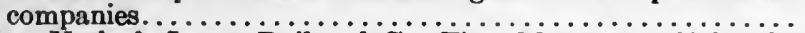

New York \& Jersey Railroad Co. First Mortgage $5 \%$ bonds, due 1932

Hudson \& Manhattan Railroad Co. First Mortgage $41 / 2 \%$ bonds, due $1957 \ldots \ldots \ldots \ldots \ldots \$ 60,000,000.00$

H. \& M. R. R. Co. First Mortgage bonds bearing no interest until Feb. 1, 1914, and thereaiter at $41 / 2 \%$ per annum until maturity, with an additional $2 \%$ per annum until Feb. 1 , 1920 , if and to the extent earned........ 7,500,000.00

Less Treasury bonds deposited as collateral. . . $\begin{array}{r}\$ 67,500,000.00 \\ 352,000.00\end{array}$

Real estate mortgages payable...................

Deferred installments on car purchase agreements............

Loan payable (collateral, 352 bonds as above) . ...............

Current aecounts payable.

Accrued bond interest payable February ist.................

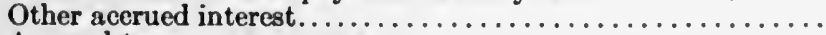

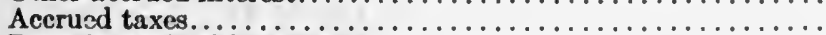

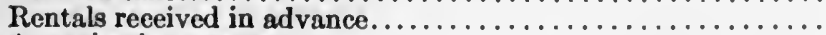

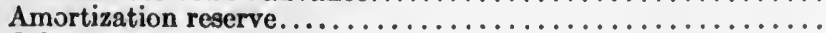

Other reserves.

$\$ 39,994,890.00$

$5,242,151.25$

$12,908.75$

$5,000,000.00$

$\$ 67,148,000.00$

$652,000.00$

$1,376,000.00$

$250,000.00$

$151,068.94$

$1,226,492.37$

$30,025.00$

$517,170.22$

$17,513.66$

$512,794.14$

$33,754.88$

Total Liabilities. 
Condensed Statement of Income, Ten Months Ended November 30, 1913

Gross revenue from all souroes.....................

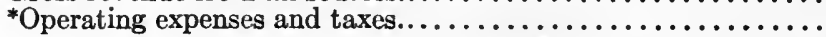

Gross income applicable to fixed charges...............

Income deductions other than bond interest.

Net income applicable to bond interest...............

Deduct interest on bonds prior to adjustment income bonds....

Balance of net income for the period, available for interest on

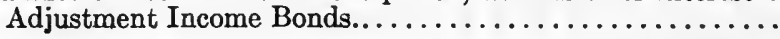

$\$ 4,535,389.38$ $2,091,930.93$

$\$ 2,443,458.45$ $221,110.07$

$\$ 2,222,348.38$ $1,680,960.56$

$\ddagger \$ 541,387.82$

$\ddagger$ Includes $\$ 276,070.68$, the first installment of interest, at $\$ 8.34$ per $\$ 1,000$, earned during five months prior to July 1, 1913, declared August 21, 1913, paid September 30,1913 , leaving $\$ 265,317.14$ available for distribution.

${ }^{*}$ Depreciation included in operating expenses..............

Percentage of railroad operating expenses vs. railroad revenue. .

Number of revenue car miles operated. . . . . . . . . . . . . .

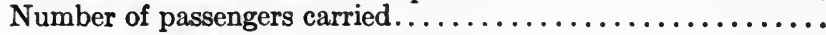

Total railroad revenue per car mile.................

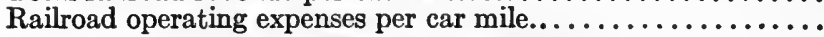

Net railroad revenue per car mile..................

$\$ 134,900.80$

$39.24 \%$

$6,564,143$

$48,628,676$

46.65

18.31

28.34

Condensed Balance Sheet as of November 30, 1913.

Assets

Property accounts.

Less reserve for amortization. $\$ 120,216,679.99$ $637,082.20$

Investment (Tunnel Advertising Co. stock)

$\$ 119,579,597.79$ $1,000.00$

Proceeds of sales of property released from the lien of New York \& Jersey Railroad Company mortgage deposited with trustee

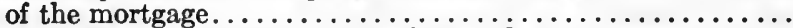

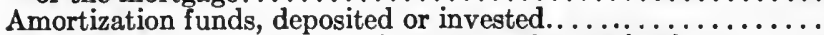

*Bond discount and expense in process of amortization.......

\section{Working Assets:}

Current cash account..................

Current accounts receivable..............

Deposits with public departments..........

Prepaid insurance, taxes, etc............

Materials and supplies-less reserves.......

Accounts in suspense................

Total working assets...............
$\$ 1,158,882.43$

$214,366.90$

$9,060.66$

$69,176.39$

$1,471.73$
206,721.97
$114,099.14$

$169,108.33$

$3,659,711.09$ 
Liabilities and Capital

Common capital stock and scrip.

Preferred capital stock and scrip....

Stocks held in reserve to redeem outstanding securities of predecessor companies.

New York \& Jersey Railioad Company $5 \%$ Mortgage Bonds...

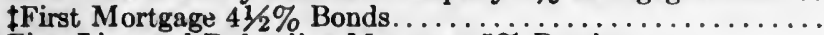
First Lien and Refunding Mortgage $5 \%$ Bonds............

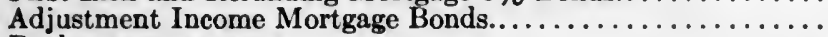

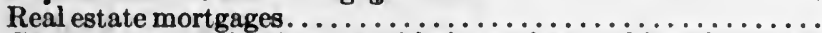
Car purchase obligations payable in semi-annual instalments to

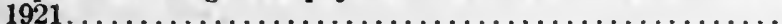

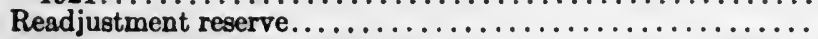

$\$ 39,994,890.00$

$5,242,151.25$

$12,908.75$

$5,000,000.00$

$944,000.00$

$36,562,633.66$

$33,102,000.00$

$1,207,500.00$

$1,192,000.00$

$613,422.52$

\section{WORKING LIABILITIES:}

Current accounts payable...............

Accrued interest.....................

Accrued taxes..........................

Rentals received in advance...

$\$ 249,176.56$

$731,245.76$

Temporary operating reserves

$14,419.33$

$3,291.27$

$48,240.19$

Surplus income for distribution as interest on adjustment Income

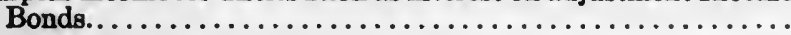

$1,046,373.11$

$265,317.14$

$\$ 125,183,196.43$

*Charged off monthly to eliminate debt during the life of bond.

The balance of the issue of old $41 / 2 \%$ bonds $(\$ 66,204,000)$ has been deposited with the trustees of the new first lien and refunding mortgage and the adjustment income mortgage in accordance with the terms thereof. 


\title{
REORGANIZATION OF THE BALTIMORE AND OHIO RAILROAD COMPANY ${ }^{1}$
}

\author{
PLAN AND AGREEMENT
}

[Dated June 22, 1908.]

Reorganization Committee-Louis Fitzgerald, chairman, August Belmont, Edward R. Bacon, Henry Budge, Eugene Delano, William A. Read, Howland Davis. H. C. Deming, secretary. William C. Gulliver, counsel to Reorganization Committee.

Reorganization Managers-Speyer Bros., 7 Lothbury, London. Speyer \& Co., 30 Broad Street, New York. Kuhn, Loeb \& Co., 27 Pine Street, New York.

Counsel to Reorganization Managers-Seward, Guthrie \& Steele, 40 Wall Street, New York. Evarts, Choate \& Beaman, 52 Wall Street, New York. Freshfields \& Williams, London.

Advisory Committee-Louis Fitzgerald, Edward R. Bacon, Henry Budge, William A Read. Alvin W. Krech, secretary, 120 Broadway, New York. William C. Gulliver, counsel to Advisory Committee.

Depositary-The Mercantile Trust Co., of New York. London and Westminster Bank, Limited, London agent.

The undersigned committee, at the request of holders of a large amount of the securities, has been for a long time past engaged in an examination of the affairs of the Baltimore \& Ohio system and the relative value and earning capacity of the various lines comprised therein, with a view to formulating a plan of reorganization therefor which should fairly recognize the rights of all security holders, and at the same time bring the fixed charges of the reorganized company safely within the net earning capacity of the system. Much time and attention have been deroted to acquiring full and accurate information as to all details, including a careful examination of the company's accounts for the period of nine years and six months, made by $\mathrm{Mr}$. Stephen Little on behalf of the committee. The aim of the committee has been to formulate a plan for the reorganization of the system which should accomplish the following results:

(a) The reduction of the fixed charges to a limit safely within the net earning capacity of the reorganized properties; (b) adequate capital for present and future requirements; (c) the payment of floating debt and provision for existing car-trust obligations; (d) the preservation of the integrity of the system as far as the same can be econ-

${ }^{1}$ Reprinted in the so-called Congressional Money Trust Investigation Report of the Pujo Committee. 
omically and advantageously accomplished and such control of the reorganized company as shall secure a satisfactory management of the property for a period of years.

Having these objects in view, the annexed plan has been prepared, and Messrs Speyer \& Co. and Messrs Kuhn, Loeb \& Co., of New York, and Messrs. Speyer Bros., of London, have been selected by the committee to act as reorganization managers to carry out the plan.

Messrs. Louis Fitzgerald, Henry Budge, Edward R. Bacon, and William A Read have been appointed an advisory committee to continue and complete the work of the Reorganization Committee and to consult and cooperate with the reorganization managers. Any vacancy in the Advisory Committee occasioned by death, resignation, or otherwise may be filled by the joint action of the reorganization managers and of the remaining members of the Advisory Committee.

Louis Fitzarerald, August BeLMONT, EdWARD R. Bacon, Henry BuDge, Eugene Delano, William A. READ, Howland Davis,

New York, June 22, 1898.

Reorganization Comittee.

PLAN FOR THE REORGANIZATION OF THE BALTIMORE \& OHIO RAILROAD CO.-CONDITIONS OF PARTICIPATION

Participation under this plan of reorganization in any respect whatsoever is dependent upon the deposit of securities with the Mercantile Trust Co., of New York, the depositary named in the reorganization agreement, either at its. office, No. 120 Broadway, in the city of New York, or at the London \& Westminster Bank (Ltd.), its agency in the city of London, England, within such timc as may be fixed by notice, and the plan will embrace only securities so deposited. No securities will be reccived on deposit unless in negotiable form, and bonds must carry all coupons (or claims for interest on registered bonds) maturing on or after July 1, 1898. The first-mortgage 6 per cent. bonds of the Washington City \& Point Lookout Railroad Co. must also carry all matured and unpaid coupons.

Pursuant to the offer of the syndicate hereinafter stated, holders of the first and sccond preferred and common stock of the Baltimore \& Ohio Railroad Co. may purchase from the syndicate the new preferred and common stock by depositing their old stock with the Mer- 
cantile Trust Co. or its agency in London as abore stated, on the following terms: As consideration for shares of the new company, depositors of first preferred stock must pay \$2 per share deposited for new preferred and common stock; depositors of second preferred stock must pay \$20 per share deposited for new preferred and common stock; and depositors of common stock must pay $\$ 20$ per share deposited for new preferred and common stock, all as hereinafter indicated on page 978 .

The payments by depositors of such preferred and common stocks must be made for account of the syndicate at the office of the Mercantile Trust Co., in New York, or at its agency in London abore named, in not less than three installments at least thirty (30) days apart, when and as called for by adrertisement published in each instance at least twice a week for two weeks in at least two of the daily newspapers of general circulation published in the cities of New York, Baltimore and London, respectively.

All payments must be receipted for by the depositary or its London agent on the certificates of deposit.

Failure to pay any installment when and as payable will subject the deposited stock and all rights on account of any prior payments to forfeiture to the syndicate as provided in the reorganization agreement.

The depositary will issue proper receipts or certificates of deposit for all securities deposited.

The following bonds, coupons, and stocks may be deposited on the terms hereinafter provided:

Baltimore \& Ohio Railroad Co. bonds, loan of 1853 , extended to 1935 at 4 per cent.

Baltimore \& Ohio Railroad Co. 100-year 5 per cent. consolidated mortgage bonds of 1888 .

Baltimore \& Ohio Pailroad Co. sterling 6 per cent. loan of 1872, due March 1, 1902.

Baltimore \& Ohio Railroad Co. sterling 6 per cent. loan of 1874 , due May 1, 1910.

Baltimore \& Ohio Railroad Co. 6 per cent. loan of 18\%9, due April 1, 1919 (account Parkersburg Branch Pailroad Co.).

Baltimore \& Ohio Railroad Co. 5 per cent. bonds, loan of 1885 (account Pittsburgh \& Connellsville Railroad Co.).

Baltimore \& Ohio Railroad Co. $\frac{11}{2}$ per cent. terminal mortgage bonds of 1894 .

Baltimore \& Ohio Railroad Co. sterling $4 \frac{1}{2}$ per cent. loan of 1883 , Philadelphia Branch. 
Baltimore \& Ohio Railroad Co. sterling 5 per cent. loan of $18 \%$, due June 1, 1927 (account Baltimore \& Ohio \& Chicago Rsilrosd Co.).

Baltimore \& Ohio Railroad Co. first preferred stock.

Baltimore \& Ohio Railroad Co. second preferred stock.

Baltimore \& Ohio Railroad Co. common stock.

Pittsburgh \& Connellsrille Railroad Co. first-mortgage bonds, extended to 1946 at 4 per cent.

Pittsburgh \& Connellsville Railroad Co. first-mortgage 7 per cent. bonds, due July 1, 1898.

Pittsburgh \& Connellsville Railroad Co. 6 per cent. consolidated mortgage bonds.

Akron \& Chicago Junction Railroad Co. first-mortgage 5 per cent bonds.

Akron \& Chicago Junction Railroad Co. preferred stock.

Washington City \& Point Lookont Railroad Co. 6 per cent. bonds.

Matured and unpaid conpons (and claims for interest on registered bonds), appertaining to any of the abore-named bonds except those of the Washington City \& Point Iookout Railroad Co. may be deposited separate from the bonds as hereinafter stated.

\section{NEW RAILEOAD COMPANT}

Unless the reorganization managers shall decide to proceed without foreclosure or sale, the rarious properties will be sold under foreclosure of one or more of the existing mortgages, or otherwise dealt with, and a successor company or companies will be organized. The term "new company," as hereinafter nsed, is intended to mean either the existing company or the new proprietary company or companies which may be organized.

\section{DEPOSITED SECURITIES}

The securities deposited hereunder will be held by the depositary subject to the order and control of the reorganization managers as provided in the reorganization agreement.

All securities deposited under the plan are to be kept alive so long as deemed necessary by the managers for the purposes of reorganization or the protection of the new company or its security holders.

All matured and unpaid coupons and claims for interest on registered bonds (excepting the unpaid coupons on the first-mortgage 6 per cent bonds of the Washington City \& Point Lookout Railrasd Co., which matured and unpaid coupons, howerer, must be deposited with the bonds as above stated), may be deposited separate from the bonds, and the same will be paid in cash as soon as practicable after the plan 
is declared operative, with interest on such coupons (and claims for interest on registered bonds) at the rate of 5 per cent. per annum from the date of maturity up to the date when the same are finally paid. Interest will also be paid in cash upon the completion of the reorganization on all deposited bonds (excepting the first-mortgage 6 per cent. bonds of the Washington City \& Point Lookout Railroad Co. above mentioned), at the rate provided in the old bonds, up to July 1,1898 , from the coupon date last preceding.

The syndicate will purchase such coupons (and claims for interest on registered bonds) matured prior to July 1, 1898, from holders who do not desire to deposit the same under the plan (provided, and so soon as, the bonds to which such coupons, and claims for interest on registered bonds, appertain, have been deposited), at their face value with interest at the rate of 5 per cent. per annum from the respective dates of maturity of such coupons or claims for interest, to date of purchase, provided such coupons and claims for interest on registered bonds shall be presented for sale to the syndicate, at the office of the Mercantile Trust Co., in New York, or at its London agency above mentioned, on or before July 22, 1898.

The syndicate has agreed to purchase for cash, upon the plan being declared operative, all Baltimore \& Ohio Railroad Co. 100-year 5 per cent. consolidated mortgage bonds, deposited under the plan, whose holders prefer to accept cash rather than to take the new securities, at the price (in New York) of 110 and interest accrued and unpaid since the maturity of the last paid coupon, provided such holders shall signify their election to take cash in the manner and within the time hereinafter limited: Depositors electing to receive cash for their bonds must signify their election by presenting their Mercantile Trust Co. certificates of deposit at the office of that company in New York or at its London agency above specified, within 60 days from the time the plan shall be actually issued, to be stamped as electing to accept such cash payment, and will thereupon be entitled to receive such cash payment so soon as the plan is declared operative by the reorganization managers, upon surrender of their certificates of deposit so stamped.

\section{NEW STOCKS AND BONDS}

The new company is to authorize the following securities:

First. $\$ 70,000,000$ prior lien $3 \frac{1}{2}$ per cent. gold bonds, due 1925 .

These bonds will bear interest from July 1, 1898, and are to be secured by a mortgage upon the main line and branches, Parkersburg Branch and Pittsburg Division (see appendix, Table C) when acquired by the new company, covering about 1,017 miles of first track, 
and about 964 miles of second, third and fourth tracks and sidings and also all the equipment now owned by the company of the value of upward of $\$ 20,000,000$ (sce appendix, Table E) or hereafter acquired in any manner except by the use of the $\$ 34,000,000$ reserved first mortgage bonds, as hereinafter stated.

The right will be reserved to issue, after January 1, 1902, not to exceed $\$ 5,000,000$ additional of these bonds, at the rate of not exceeding $\$ 1,000,000$ a year, for the enlargement, betterment or extension of the properties covered by the prior lien mortgage, or for the acquisition of additions thereto.

In case delay should occur in acquiring any of the said lines of railway, the execution of the plan will not for that reason necessarily be postponed, but the existing bonds upon such line deposited under the plan may be pledged under the prior lien mortgage, as security for the bonds issued thereunder, until such line of railway shall be acquired by the new company and subjected to the lien of said mortgage.

The prior lien bonds are to be applied as follows:

In partial exchange for existing bonds (see page 975 ) .......\$60,073,090 Purchased by syndicate to provide cash requirements of plan (see page 975$)$. . . . . . . . . . . . . . . . . . . . . . . .

$9,000,000$

$\$ 69,073,090$

For contingencies (any surplus to new company)...........

926,910

$\$ 70,000,000$

Second.- $\$ 63,000,000$ first mortgage 50-year 4 per cent. gold bonds.

These bonds will bear interest from July 1, 1898, and are to be secured by a mortgage which will be a first lien on the Philadelphia, Chicago and Akron divisions and branches, and the Fairmont, Morgantown and Pittsburg Railroad, covering about 570 miles of first track, and about 332 miles of second, third and fourth tracks and sidings (see appendix, Table D), and also on the properties now included in the present Baltimore \& Ohio terminal mortgage of 1894, when said lines and properties are acquired by the new company; also on the Baltimore Belt Railroad, if and when the same shall be acquired by the new company; and a lien subject to the prior lien mortgage upon the lines, property and equipment covered by the latter.

The right will be reserved to increase the amount of these bonds to $\$ 90,000,000$ for the enlargement, betterment or extension of the railroads and properties covered by the prior lien mortgage and also those covered by the first mortgage, or for the acquisition of exten- 
sions or additions thereto or equipment for use thereon, at the rate of not exceeding $\$ 1,500,000$ a year for the first four years after the organization of the new company and at the rate of not exceeding $\$ 1,000,000$ a year thereafter. The right will also be reserved to call in and redeem all or any part of the first mortgage bonds after 25 years, at 105 , and also to issue not to exceed $\$ 75,000,000$ additional of said bonds or such lesser amount as may be required to retire the prior lien bonds when due.

In case delay should occur in acquiring any of the said lines of railway or properties to be included under the first mortgage as above stated, the execution of the plan will not for that reason necessarily be postponed, but the existing bonds upon such line or property deposited under the plan may be pledged under the first mortgage, as security for the bonds issued thereunder, until such line or property shall be acquired by the new company, and subjected to the lien of first mortgage.

The first mortgage bonds are to be applied as follows:

In partial exchange for existing bonds (see page 975 ) .......\$36,384,535 Purchased by syndicate to provide cash requirements of plan (see

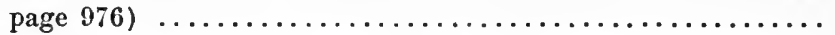

For contingencies (any surplus to new company) ............ 1,165,465 $1,165,465$

$\$ 50,000,000$

Reserve for new company $\ldots \ldots \ldots \ldots \ldots \ldots \ldots \ldots \ldots \ldots \ldots \ldots, 7,000,000$

$\$ 57,000,000$

Reserve to be issued only to retire Baltimore Belt Line 5s (see

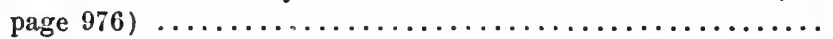

$6,000,000$

$\$ 63,000,000$

Third. $\$ 40,000,0004$ per cent. non-cumulative preferred stock.

This stock will be entitled to receive non-cumulative dividends at the rate of 4 per cent. per annum before the payment of any dividend on the common stock. This stock will be applied as follows:

For reorganization purposes (see page 977 ) ............\$17,218,700

Purchased by syndicate to provide cash requirements of plan (see

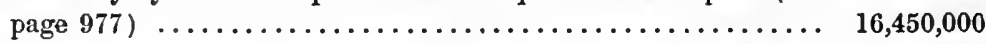

For adjustment with various outstanding bondholders' and stockholding interest, contingencies, etc. (any surplus to new com-

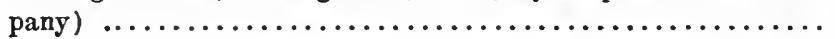

Reserve for new company....................... $5,000,000$ 
Fourth. $\$ 35,000,000$ common stock.

This stock will be applied as follows:

For reorganization purposes (see page 977 ) . . . . . . . . . $\$ 31,178,000$

For adjustment outstanding securities, contingencies, etc. (any

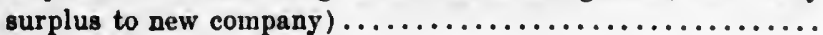

$3,822,000$

$\$ 35,000,000$

\section{BESTRICTIONS AS TO ADDITIONAL MORTGAGE DEBT AND PREFERRED} STOCK

Provision is to be made that no additional mortgage shall be put upon the property to be acquired by the new company hereunder, and that no increase in the amount of the preferred stock authorized under this plan shall be made, except in each instance after obtaining the consent of the holders of a majority of the whole amount of preferred stock outstanding given at a meeting of the stockholders called for that purpose, and the consent of the holders of a majority of such part of the common stock as shall be represented at such meeting, the holders of each class of stock voting separately. During the existence of the roting trust similar consent of holders of like amounts of the respective classes of certificates of beneficial interest shall also be necessary for the purposes indicated.

\section{VOTING TRUST}

The preferred and common stock of the new company (except such number of shares as may be disposed of to qualify directors) shall be vested in the following five voting trustees: William Salomon, Abraham Wolff, J. Kennedy Tod, Louis Fitzgerald, and Charles H. Coster.

In the event of the death or failure or refusal to serve of any person designated as a voting trustee prior to the creation of the roting trust, the vacancy shall be filled by the reorganization managers. The stock shall be held by the voting trustecs, and their successors, jointly (under a trust agreement prescribing their powers and duties and the method of filling vacancies) for five years, although the roting trustees may, in their discretion, as provided in the trust agreement, deliver the stock at an earlier date. Until delivery of stock is made by the voting trustees they shall issue certificates of beneficial interest entitling the registered holders to receive, at the time therein provided, stock certificates for the number of shares therein stated, and in the meanwhile to receive payments equal to the dividends collected by the voting trustees upon the number of shares therein stated, which shares, however, with the roting power thereon, shall be vested in the voting trustees until the stock shall become deliverable, as pro- 
vided in the trust agreement and in the certificates of the voting trus. tees issued thereunder.

\section{SYNDICATE}

A syndicate has been formed by Messrs. Speyer Bros., of London, and Messrs. Speyer \& Co., Kuhn, Loeb \& Co., August Belmont \& Co., Hallgarten \& Co., and Vermilye \& Co., of New York, which will be conducted by the first-named three firms as syndicate managers, and which agrees-

(1) To purchase $\$ 6,975,000$ of the new preferred stock and $\$ 30$,250,000 of the new common stock and to offer the same for sale to depositing holders of old first and second preferred and common stock of the Baltimore \& Ohio Railroad Co., as stated on page 968 of this plan.

(2)' ' To purchase $\$ 9,000,0003 \frac{1}{2}$ per cent. prior lien bonds, $\$ 12,-$ 450,000 first mortgage 4 per cent. bonds, $\$ 16,450,000$ preferred stock.

(3) To protect the new company in the ownership and possession of the properties covered by $\$ 49,974,098$ (sterling issues being figured at $\$ 4.8666$ ) of the existing mortgage bonds of the old company of different issues, by agreeing to purchase from the new company the new securities not taken, but to which the holders of such bonds would have been entitled if deposited under the plan, at a price equal to the prinicpal of the respective old securities, and also to make advances and perform other obligations essential for the purposes of the plan.

\section{APPLICATION OF SECURITIES}

It is contemplated that as a consideration for the property and se-. curities to be conveyed and delivered to the new company, or which it shall acquire pursuant to the plan, it shall deliver the new bonds and stock, excepting such final amounts of the new bonds as shall be reserved for the future use of the new company. The requisite deliveries of the new securities to depositors and subscribers under the plan will thus be provided for.

The following details show the disposition to be made under the plan of the securities of the new company:

\section{DISPOSITION OF NEW SECURITIES IN DETAIL}

The new prior-lien $3 \frac{1}{2}$ per cent. gold bonds will be disposed of as follows :

Present authorized issue $\ldots \ldots \ldots \ldots \ldots \ldots \$ \$ 70,000,000$ 
To be used in partial exchange for existing bonds, as follows:

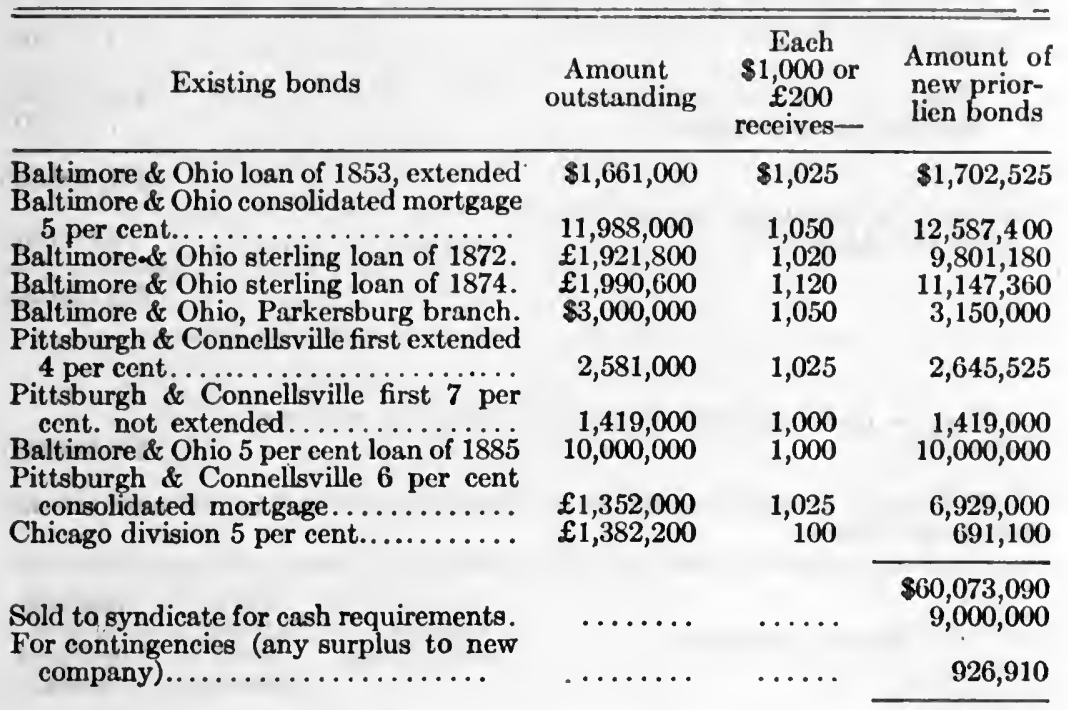

$\$ 70,000,000$

The new first mortgage 4 per cent. bonds will be disposed of as follows:

Present authorized issue $\ldots \ldots \ldots \ldots \ldots \ldots \$ 63,000,000$

To be used in partial exchange for existing bonds, as follows:

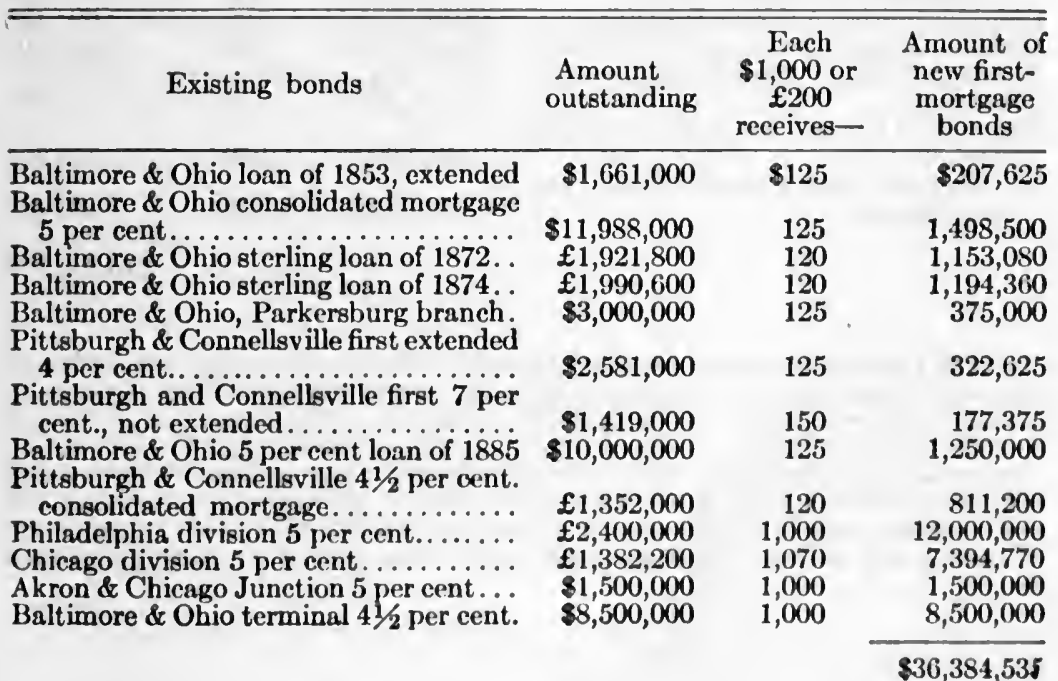


Sold to syndicate for cash requirements.

For contingencies (any surplus to new company)

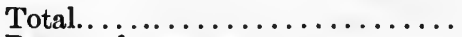

Reserve for new company.........

Reserve to be issued only to retire Baltimore Belt Line fives ${ }^{1} . . . \ldots \ldots \ldots . .$.

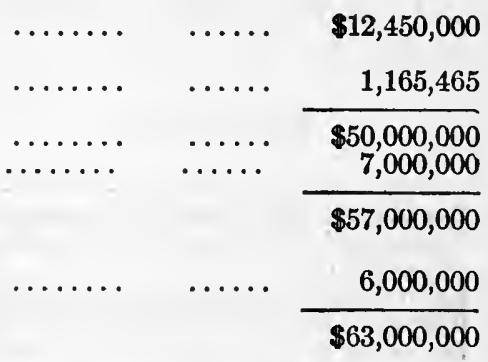

The new preferred stock is to be disposed of as follows:

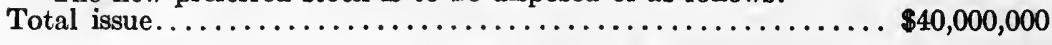

To be used in partial exchange for existing bonds and to purchase existing stocks, as follows:

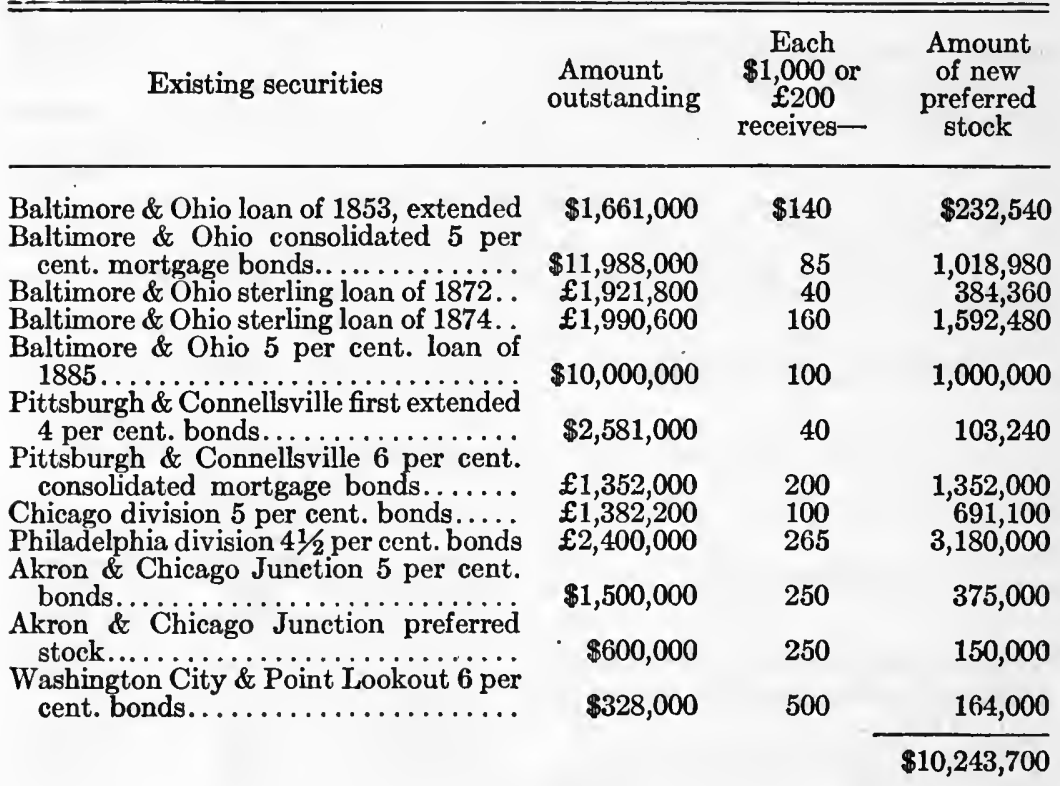

${ }^{1}$ The properties covered by the Baltimore Belt Line mortgage will be leased at a rental equivalent to interest at 4 per cent. on the existing belt line 5 per cent. bonds, which is to be in full payment of said interest. The rental agreement will provide that in consideration of the rental the new company shall have an option to purchase all the said belt line 5 per cent. bonds at par and accrued interest at any time within 5 years on 60 days' notice, and that in case the company shall not purchase such bonds within the 5 years specified it will, at the termination of that period, assume the ultimate payment, when due, of the principal of such bonds. 
Purchased by syndicate and offered for sale to depositing holders of $\$ 25,000,000$ of old common stock, being 20 per cent. of the par value thereof ............

Purchased by syndicate and offered for sale to depositing holders of $\$ 3,000,000$ of old first preferred stock, being $521 / 2$ per cent. of the par value thereof........

Purchased by syndicate and offered for sale to depositing holders of $\$ 2,000,000$ of old second preferred stock, being 20 per cent. of the par value thereof...

\author{
$1,575,000$
}

400,000

$6,975,000$

$\$ 17,218,700$

$16,450,000$

Sold to syndicate for cash requirements.

$\$ 33,668,700$

For adjusting existing securities, contingencies, etc. (any surplus to new

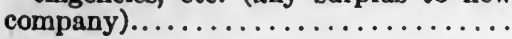

Reserve for new company

$\ldots \ldots \ldots$

.........
$35,000,000$ $5,000,000$

$\$ 40,000,000$

The new common stock is to be disposed of as follows:

Total issue .................. \$35,000,000

To be used in exchange for existing bonds and to purchase existing stocks, as follows:

\begin{tabular}{|c|c|c|c|}
\hline Existing securities & $\begin{array}{l}\text { Amount } \\
\text { outstanding }\end{array}$ & $\begin{array}{c}\text { Each } \\
\$ 1,000 \\
\text { receives- }\end{array}$ & $\begin{array}{c}\text { Amount } \\
\text { of new } \\
\text { common } \\
\text { stock }\end{array}$ \\
\hline $\begin{array}{l}\text { Akron \& Chicago Junction preferred } \\
\text { stock.......... }\end{array}$ & $\$ 600,000$ & $\$ 1,000$ & $\$ 600,000$ \\
\hline $\begin{array}{l}\text { Washington City \& Point Lookout } 6 \text { per } \\
\text { cent. bonds......................... }\end{array}$ & 328,000 & 1,000 & $\frac{328,000}{\$ 928,000}$ \\
\hline $\begin{array}{l}\text { Purchased by syndicate and } \\
\text { offered for sale to deposit- } \\
\text { ing holders of } \$ 25,000,000 \\
\text { of old common stock, be- } \\
\text { ing } 100 \text { per cent. of the par } \\
\text { value thereof... }\end{array}$ & & & \\
\hline $\begin{array}{l}\text { Purchased by syndicate and } \\
\text { offered for sale to deposit- } \\
\text { ing holders of } \$ 3,000,000 \\
\text { of old first preferred stock, } \\
\text { being } 75 \text { per cent. of the } \\
\text { par value thereof....... } 2,250,000\end{array}$ & & & \\
\hline
\end{tabular}

Purchased by syndicate and offered for sale to depositing holders of $\$ 2,000,000$ of old second preferred stock, being 150 per cent of the par value thereof. . 
For adjustment outstanding securities, contingencies, etc. (any surplus to new

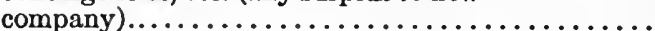

Non-interest-bearing scrip, exchangeable in round amounts for the new securties, will be issued for fractional amounts of new bonds and stocks.

\section{LEASED ROADS}

Holders of bonds or stocks of the following companies are requested to communicate with the advisory committee, giving the amount of their noldings and stating how the same are held: Columbus \& Cincinnati Midland Railroad, Cëntral Ohio Railroad, Newark, Somerset \& Straitsville Railroad, Sandusky, Mansfield \& Newark Railroad, Schuylkill River, East Side Railroad, Winchester \& Potomac Railroad, Winchester \& Strasburg Railroad.

In order to deal with the holders of these leased-line securities, it is deemed necessary to consider each case separ?tely and upon its merits. After hearing from the holders of a large proportion of each class of securities of said leased lines the matter of adjustment will be considered.

\section{EXISTING GUARANTIES.}

If the managers shall deem it advisable to proceed without foreclosure and sale, they will endeavor to secure snme satisfactory arrangement in connection with the existing guaranties of the company.

\section{PRESENT FIRST PREFERRED STOCK.}

Upon completion of the reorganization the managers, on behalf of the syndicate, will deliver to each depositor of first preferred stock who shall have paid, for account of the syndicate, $\$ 2$ per share deposited, as provided on page 968 of this plan, the following new securities: For each share of first preferred stock deposited $\$ 52.50$ in new preferred stock trust certificates, $\$ 75$ in new common stock trust certificates.

\section{PRESENT SECOND PREFERRED STOCK.}

Upon completion of the reorganization the managers, on behalf of the syndicate, will deliver to each depositor of second preferred stock who shall have paid, for account of the syndicate, \$20 per share deposited, as provided on page 968 of this plan, the following new securities: For each share of second preferred stock deposited $\$ 20$ in new preferred stock trust certificates, $\$ 150$ in new common stock trust certificates.

\section{PRESENT COMMON STOCK.}

Upon completion of the reorganization the managers, on behalf of the syndicate, will deliver to each depositor of common stock who shall 
have paid, for account of the syndicate, $\$ 20$ per share deposited, as provided on page 968 of this plan, the following new securities: For each share of common stock deposited $\$ 20$ in new preferred stock trust certificates, $\$ 100$ in new common stock trust certificates.

Estimated cash requirements as of July 1, 1898, and provision therefor.

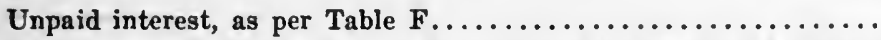

To provide for existing car trusts, receivers' certificates, and other

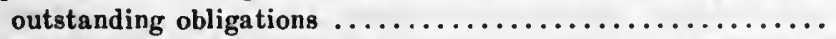

For floating debt, improvements, equipment, working capital, and other purposes of the new eompany, including also expenses of the reorganization, commission to syndicate, and compensation of the reorganization managers and their assoeiates in the formation of the syndicate....................

$\$ 4,565,375$

$19,192,225$

$12,334,900$

$\$ 36,092,500$

To meet these requirements the syndicate will contribute $\ldots \ldots \ldots \ldots \ldots \ldots \ldots \ldots \ldots \ldots \ldots \ldots \ldots \ldots \ldots \ldots \ldots \ldots \ldots \ldots$

The sale of certain securities in treasury is estimated to yield $\ldots \ldots \ldots \ldots \ldots \ldots \ldots \ldots \ldots \ldots \ldots \ldots, \quad 3,500,000$

Making a total of $\ldots \ldots \ldots \ldots \ldots \ldots \ldots \ldots \ldots \ldots \ldots \ldots \ldots \ldots \ldots \ldots, 0 \ldots 2,500$

POSITION OF THE NEW COMPANY.

The fixed charges for year ending June 30,1897 , as reported by the

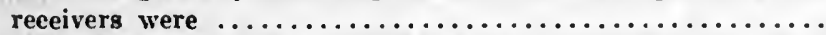

The annual fixed charges after reorganization and retirement of existing bonds as proposed, it is estimated, will be stated in

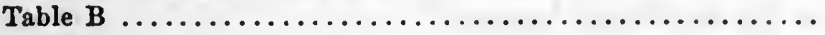

Decrease of annual fixed eharges...

$\$ 7,771,111$

$6,252,351$

$1,518,760$

The net earnings for year ending June 30, 1896, were, including

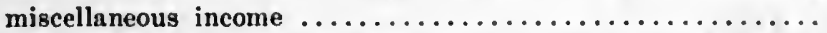

The net earnings for year ending June 30,1897 , were, including

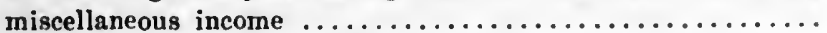

(For the fiscal year ending June 30, 1897, equipment of the company valued on its books at $\$ 1,155,829.95$ was put out of service and charged not to operating expenses but to "Profit and loss," because it represented the depreciation of a number of years. As against this, however, extraordinary expensesestimated at not less than $\$ 750,000$-for the maintenance of the property generally were incurred during the year and charged to operation. For the year 1898, as stated in the annual report of last year, all equipment when put out of service is replaced with equipment of equal value, as shown on the books of the company, and the cost thereof charged to "Mainlenance of equipment.") 
The net earnings from the operations of the property for the present fiscal year (April, May and June approximated) have (notwithstanding liberal charges for maintenance) as compared with the same period of the preceding fiscal year increased.

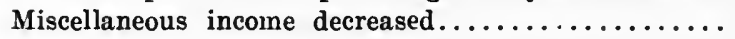

$\$ 1,443,909$

62,114

Net increase $\ldots \ldots \ldots \ldots \ldots \ldots \ldots \ldots \ldots \ldots \ldots \ldots \ldots \ldots \ldots \ldots \ldots \ldots \ldots \ldots \ldots$

Estimated net earnings for the fiscal year ending June 30, 1898 , including miscellaneous income.......... \$7,975,785 (Taxes not deducted, they being included in fixed charges. See Table B.)

From which, however, will have to be deducted the sum of about $\$ 251,000$, representing the decrease in the amount of miscellaneous income which will be occasioned by the proposed sale of securities and the cancellation of sinking-fund investments under the reorganization.

The company, as shown by Mr. Stephen Little's expert examination and report, dated July 11, 1896, from September 30, 1888, to November 30,1895 , a period of seven years and two months, earned net, including miscellaneous income, a yearly average of $\$ 7,234,000$, without deduction, however, of average taxes amounting to $\$ 437,000$.

The fixed charges of the new company, on completion of the reorganization, will be well within the past net income of the property, even that of the last fiscal year of extreme depression.

The new company will be relieved from floating debt and the embarrassment of car and wheelage trust payments, and will start not only with a substantial working cash capital, but also with power to provide facilities for the increase of business.

The by-laws of the new company will provide that its accounts shall be audited annually by accountants of established reputation.

JUNE, 22, 1898. 


\section{APPENDIX}

TABLE A-Showing the Amount of Cash and New Securities Which Depositcd Securities Will be Entitled to Receive on Completion of Rcorganization

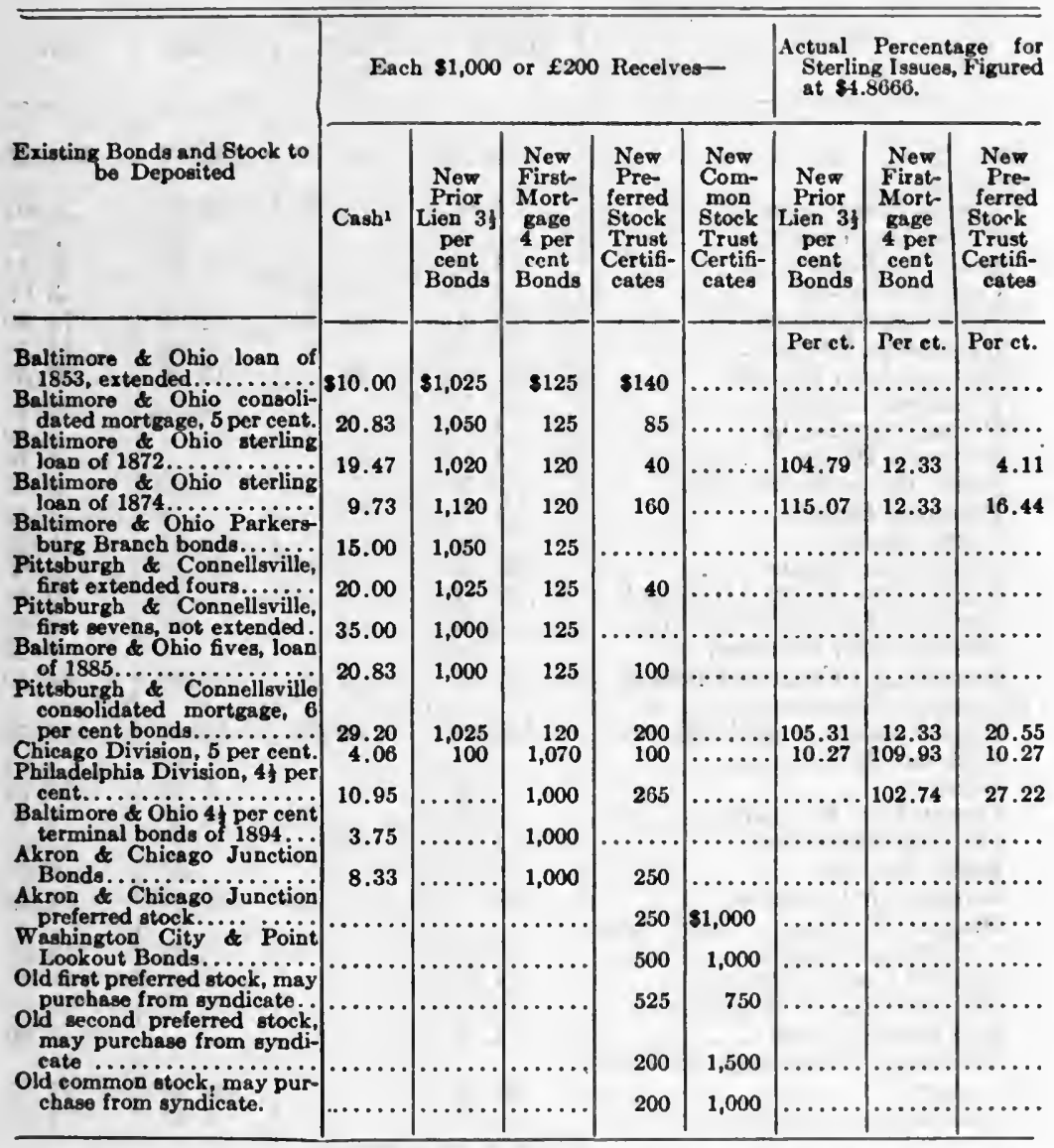

1 Interest at the rate provlded in the old bonds, from the date of the last matured coupon next preceding July 1, 1898, up to the date when the n 3 w bonds begin to bear interest, namely. July 1 , 1898 (excluaive of previously matured coupons otherwise provided for, see p. 968).

\section{TABLE B-Fixed Charges on Completion of Reorganization and Retirement of Existing Bonds}

$\$ 70,000,000$ prior lien $31 / 2$ per cents .................... \$2,450,000

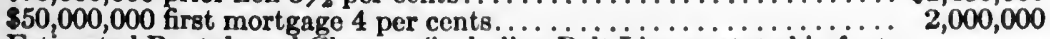

Estimated Rentals and Charges (including Belt Line as stated in foot-

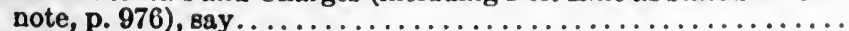

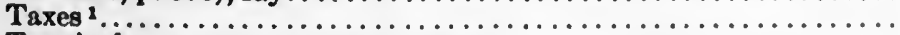

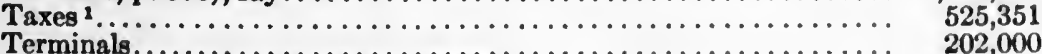

Terminals. . . . .

Total............................. $\$ 6,252,351$

I In case foreclosure shall be found necessary, the exemption from taxation under the charter of the old company may be lost and the amount of annual taxes be increased. 
TABLE C-Mileage of Roads to be Included in the Prior-Lien Mortgage

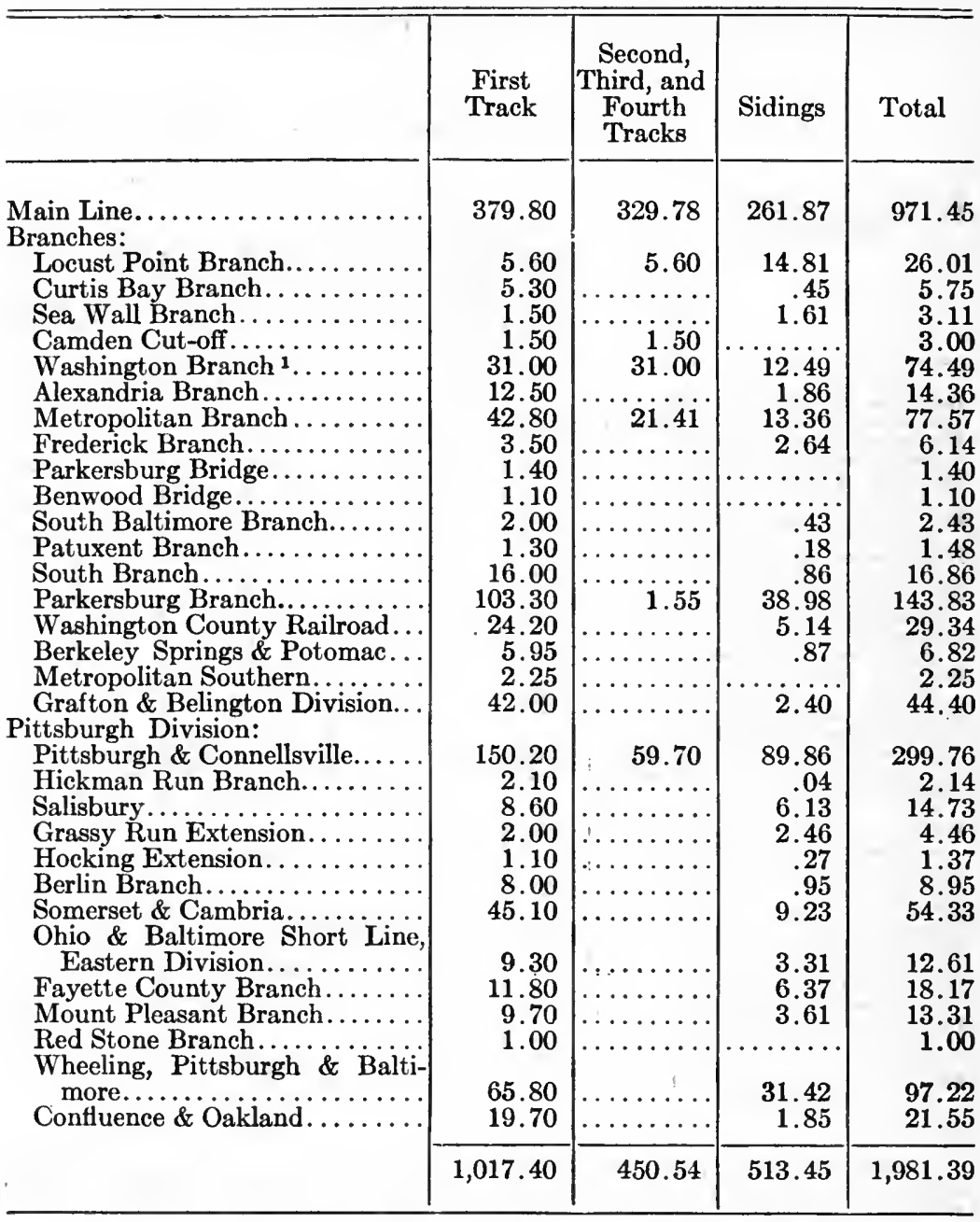

1 This line cannot be directly mortgaged, but will be controlled by deposit with the trustee under the new prior-lien mortgage of two-thirds of its capital stock. The line is not subject to any existing mortgage. 
TABLE D-Mileage of Roads to be Included in the First Mortgage and Other Properties Covered Thereby

\begin{tabular}{|c|c|c|c|c|}
\hline f & $\begin{array}{l}\text { First } \\
\text { Track }\end{array}$ & $\begin{array}{c}\text { Second, } \\
\text { Third, and } \\
\text { Fourth } \\
\text { Tracks }\end{array}$ & Sidings & Total \\
\hline 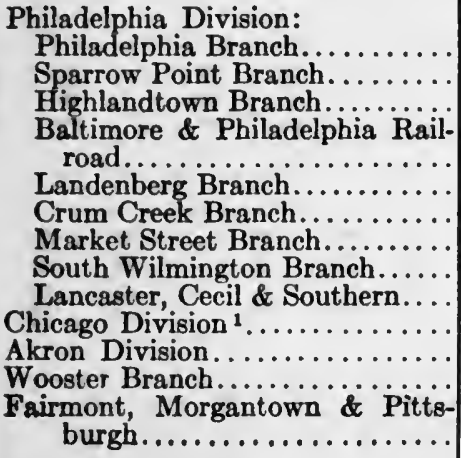 & $\begin{array}{r}52.60 \\
1.60 \\
.90 \\
36.80 \\
14.30 \\
2.40 \\
3.02 \\
2.80 \\
4.00 \\
282.37 \\
76.66 \\
36.26 \\
\\
56.60\end{array}$ & 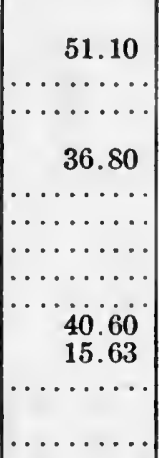 & $\begin{array}{r}23.98 \\
2.97 \\
\ldots \ldots \ldots \\
\ldots \ldots \ldots . \\
\ldots \ldots .20 \\
113.47 \\
12.37 \\
3.24 \\
15.08\end{array}$ & $\begin{array}{r}120.48 \\
1.60 \\
.90 \\
97.58 \\
17.27 \\
2.40 \\
3.02 \\
2.80 \\
4.20 \\
436.44 \\
104.66 \\
39.50 \\
71.68\end{array}$ \\
\hline & 570.31 & 144.13 & 188.09 & 902.53 \\
\hline
\end{tabular}

The first mortgage will also be a first lien on the properties now covered by the Baltimore \& Ohio terminal mortgage of 1894 when acquired.

Table E-Equipment to be Included in Prior-Lien Mortgage

Rolling equipment:

Electric motors............................. 4

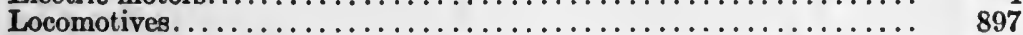

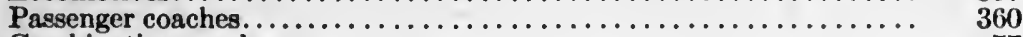

Combination coaches..................................... 77

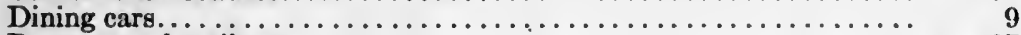

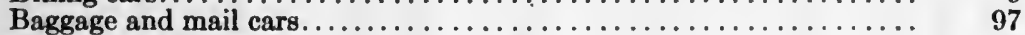

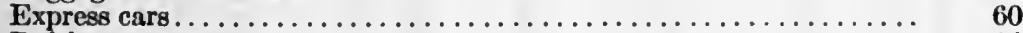

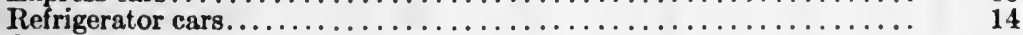

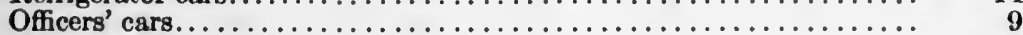

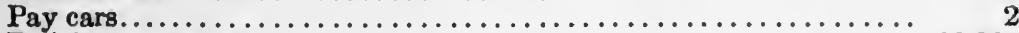

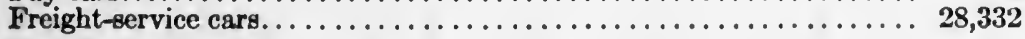

Floating equipment:

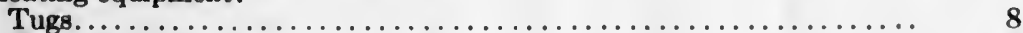

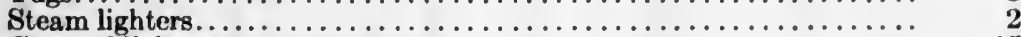

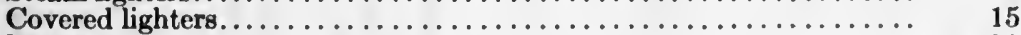

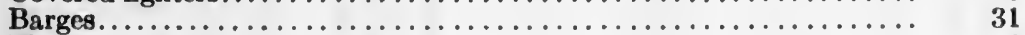

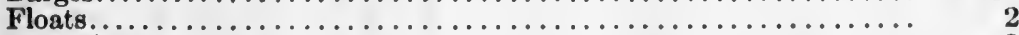

Pile drivers. . . . . . . . . . . . . . .

Open lighters...................................... 4

I Of the mileage given for the Chicago Division 34.94 miles are not owned, but are beld under trackage rights. 
984 MATERIALS OF CORPORATION FINANCE

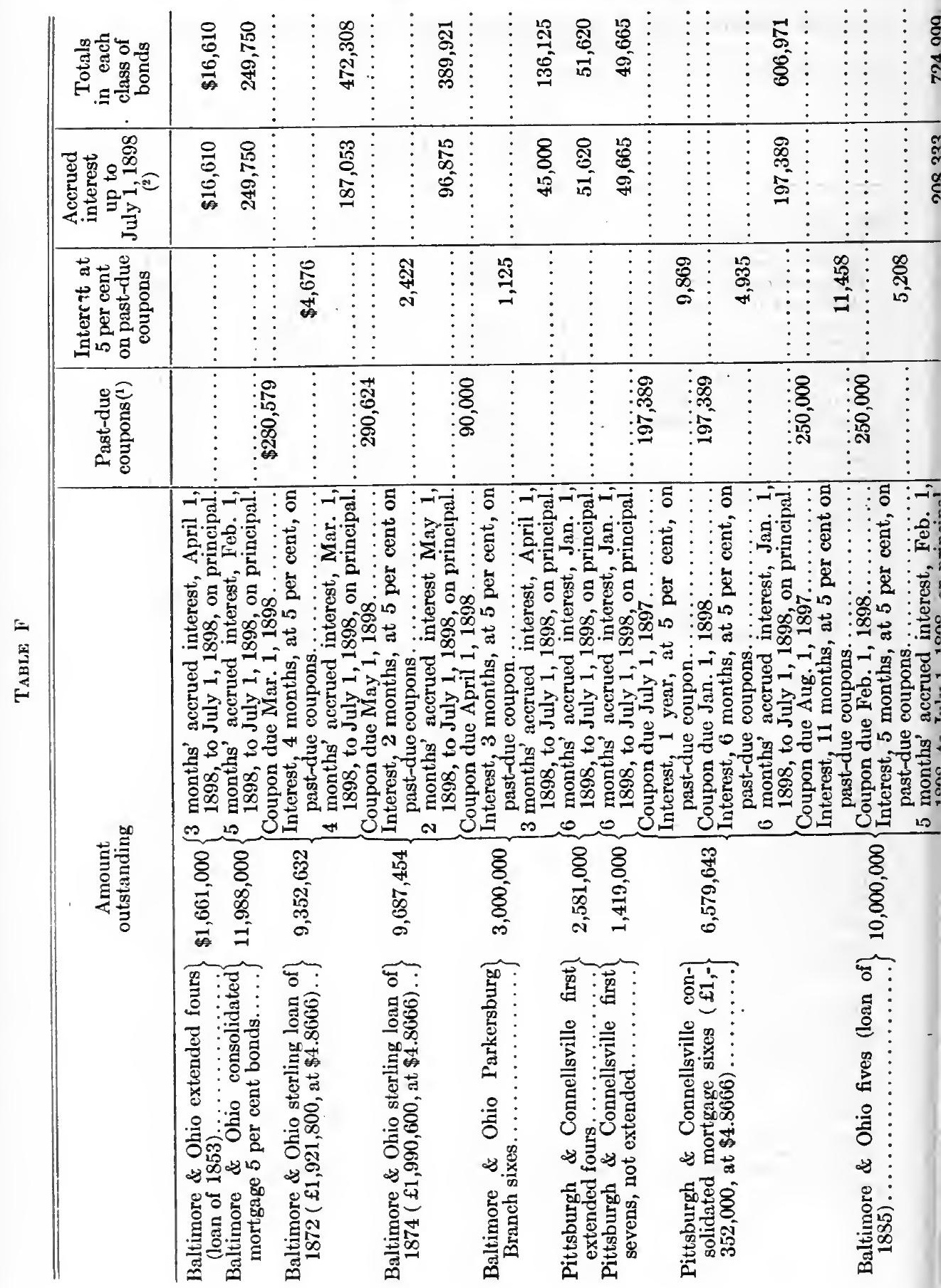




\section{REORGANIZATION AGREEMENT.}

An agreement made this 22d day of June, 1898, between Louis Fitzgerald, August Belmont, Edward R. Bacon, Henry Budge, Eugene Delano, William A. Read and Howland Davis (hereinfater called the "Reorganization Committee"), parties of the first part; Speyer \& Co. and Kuhn, Loeb \& Co., of New York, and Speyer Bros., of London (hereinafter called the "Managers"), parties of the second part; holders of the mortgage bonds, stocks, and evidences of indebtedness hereinafter mentioned, who shall become parties to this agreement (hereinafter called "Depositors"), parties of the third part and the Mercantile Trust Co., of the city of New York (hereinafter called the "Depositary"), party of the fourth part.

Whereas, the Baltimore \& Ohio Railroad Co. has made default in the payment of its obligations, and receivers of its railroads and property have been appointed:

And whereas, the plan referred to in this agreement has been proposed by the Reorganization Committee for the reorganization of the railroad company: Now, therefore, it is mutually agreed by and between the respective parties hereto as follows:

First. A printed copy of this agreement, signed by the parties hereto of the first; second, and fourth parts, shall be lodged with the Mercantile Trust Co., in the city of New York, and a duplicate, signed in like manner, shall be lodged with the London and Westminster Bank (Ltd.), in the city of London. Each of said copies shall be taken as a complete and original instrument, but both shall constitute but one agreement. The foregoing plan is and shall be taken to be a part of this agreement, with the same effect as though each and every provision thereof had been embodied herein, and said plan and this agreement shall be read as parts of one and the same paper; but no estimate, statement, explanation, or suggestion contained in the said plan or this agreement, or in any circular issued, or which may hereafter be issued, by the Depositary or by the Reorganization Committee, or by the Managers, is intended, or is to be accepted as a representation or warranty, or as a condition of deposit or assent under the plan and this agreement, and no defect or error shall release any deposit under this plan and agreement, or affect or release any assent thereto, except by written consent of the Managers.

Holders of the following-named bonds and coupons (or claims for interest on registered bonds) and stocks, or any of them, may become parties to this plan and agreement by depositing their securities with the Depositary upon the terms and conditions specified in the plan and this agreement, or hereafter defined, and within the periods which shall be fixed or limited by the Managers: 
Baltimore \& Ohio Railroad Co. bonds, loan of 1853 , extended to 1935, at 4 per cent.

Baltimore \& Ohio Railroad Co. 100-year 5 per cent. consolidated mortgage bonds of 1888 .

Baltimore \& Ohio Railroad Co. sterling 6 per cent. loan of 1872, due March 1, 1902.

Baltimore \& Ohio Railroad Co. 6 per cent. sterling loan of 1874, due May 1, 1910.

Baltimore \& Ohio Railroad Co. 6 per cent. loan of 1879, due April 1,1919 (account Parkersburg Branch Railroad Co.).

Baltimore \& Ohio Railroad Co. 5 per cent. bonds, loan of 1885 (account Pittsburgh \& Connellsville Railroad Co.).

Baltimore \& Ohio Railroad Co. $4 \mathrm{~L} / 2$ per cent. terminal mortgage bonds of 1894.

Baltimore \& Ohio Railroad Co. sterling $41 / 2$ per cent. loan of 1883 , Philadelphia Branch.

Baltimore \& Ohio Railroad Co. sterling 5 per cent. loan of $187 \%$, due June 1, 1927 (account Baltimore \& Ohio and Chicago Railroad Co.).

Baltimore \& Ohio Railroad Co. first preferred stock.

Baltimore \& Ohio Railroad Co. second preferred stock.

Baltimore \& Ohio Railroad Co. common stock.

Pittsburgh \& Connellsville Railroad Co. first mortgage bonds, extended to 1946 at 4 per cent.

Pittsburgh \& Connellsville Railroad Co. first mortgage 7 per cent. bonds, due July 1, 1898.

Pittsburgh \& Connellsville Railroad Co. 6 per cent. consolidated mortgage bonds.

Akron \& Chicago Junction Railroad Co. first mortgage 5 per cent. bonds.

Akron \& Chicago Junction Railroad Co. preferred stock.

Washington City \& Point Lookout Railroad Co. 6 per cent. bonds.

Matured and unpaid coupons (and claims for interest on registered bonds) appertaining to any of the above roads, except those of the Washington City \& Point Iookont Railroad Co.

Also such other mortgage bonds or stocks, if any, of any other railroad company or companies heretofore known as parts of the Baltimore \& Ohio Railroad system as the Manngers may hereafter decide to admit to participation in the plan upon terms to be fixed by the Managers.

Such holders must in all cases deposit the certificates for their stock, or their bonds or coupons, or claims for interest on registered bonds or other securities, with such transfers, assignments, and powers of attor- 
ney, as may be required by the Managers in order to vest in them, and to enable them to transfer the complete and absolute title to such stocks, bonds, coupons, claims for interest, or other securities, and the Depositors agree, respectively, at any time on demand of the Mana. gers to execute any and all other transfers, assignments, or writings required for vesting the complete ownership of the bonds, coupons, claims for interest, and stocks deposited hereunder in the Managers or their nominees. All.Depositors shall receive certificates of deposit in form to be prescribed by the Managers specifying the respective bonds, coupons, claims for interest, or stock deposited, and the holders of such certificates of deposit issued hereunder shall be entitled, subject to any provisions contained in such certificates, only to the rights and benefits specified in the plan and this agreement as accruing to the holders of the bonds, coupons, claims for interest, or stocks of the class represented by such certificates, respectively, or granted by the Managers pursuant to the powers conferred upon them, and thereafter the holder of any such certificate or any certificate issued in lieu thereof or in exchange therefor shall be subject to the plan and this agreement and entitled to have and exercise only the rights of the original depositor under the certificate issued to him in respect of the securities therein mentioned.

Such certificates of deposit issued hereunder and the interests represented thereby shall be transferable only subject to the terms and conditions of the plan and this agreement, and in such manner as the Managers shall approve; and upon such transfer all rights of the Depositors or in respect of the deposited bonds, coupons, claims for interest, or stock represented by such certificates, together with all installments paid by the Depositors of such stock, or their transferees, and all rights under the certificates of deposit transferred, shall pass to the transferees, and the transferees and holders of such certificates or deposit shall for all purposes be substituted in place of the prior holders, subject to this agreement. All such transferees, as well as the original holders of certificates of deposit issued hereunder, shall be embraced under the term "Depositors" whenever used herein. Each certificate of deposit may be treated by the Managers and by the Depositary as a negotiable instrument, and the holder for the time being may be deemed to be the absolute owner thereof, and of all rights of the original Depositor of the bond, coupon, claim for interest, stock, or other security in respect of which the same was issued, and neither the Depositary nor the Managers shall be affected by any notice to the contrary. By accepting any such certificate, every recipient or holder thereof shall thereby become party to the plan and this agreement with the same force and effect as though an actual subscriber hereto. The 
term Depositor, whenever used herein, is intended, and shall be construed, to include not only persons acting in their own right, but also trustees, guardians, committees, agents, and all persons acting in a representative or fiduciary capacity, and those represented by or claiming under them, and partnerships, associations, joint-stock companies, and corporations. No rights hereunder shall accrue in respect of any securities hereinbefore mentioned unless, or until, the same shall have been subjected to the control of the Managers and to the operation of the plan and this agreement as herein provided.

The Depositary shall receive the deposited stocks, bonds and coupons, claims for interest, or other securities, and shall hold the same respectively subject to the order and control of the Managers.

The Managers may in their discretion fix or limit the period or periods within which holders of bonds, coupons, claims for interest, or stock or other securities, or any class thereof, may deposit their securities, and within which they may become parties to the plan and this agreement, and the periods within which must be paid the installments of cash payable by depositing holders of first and second preferred and common stock as consideration for new preferred and common stock, and in their discretion, either generally or in special instances, may extend or renew the period or periods so fixed or limited, on such terms and conditions as they may see fit.

Holders of securities, not deposited within the periods respectively fixed or limited therefor, will not be entitled to deposit the same or to become parties to this agreement or to share in the benefits thereof, and shall acquire no rights thereunder, except upon obtaining the express consent of the Managers, who may withhold or give such consent in their absolute discretion and upon such terms and conditions as they may see fit.

The several installments of cash, payable by depositing stockholders as provided in the plan and this agreement, must be paid to the Managers for account of the syndicate, and must be receipted for by the Depositary on the respective certificates of deposit issued for such stock. The depositing stockholders agree that all such installments of cash may be used at any time by the Managers, for any of the purposes of the plan and this agreement. Depositors of stock and holders of certificates of deposit for deposited stock respectively agree that prompt payment of the several installments of cash payable by them respectively on the terms of the plan and this ngreement is an essential condition to their acquisition of new stock by purchase from the syndicate under the plan and this agreement, and that any depositor, or any holder of a certificate of deposit for stock who shall fail to make prompt payment of any installment of cash payable as provided in the plan 
within the periods fixed or limited by the Managers for such payment shall forthwith, and without further or other notice or action, cease to have any rights, or to be entitled to any benefits hereunder, and in every such case the deposited stock and any cash paid as provided prior to the date of such default shall vest in and belong to the syndicate, and that no such defaulting depositor or certificate-holder shall be entitled to the return or repayment thereof, or to have any further interest or rights in respect thereof. The Managers, however, in their discretion, may on behalf of the syndicate waive any such default and accept payment of overdue installments due from any depositor at any time before final settlement of accounts with the syndicate.

Second. The depositors hereby irrevocably request the Managers to endeavor to carry into practical operation the plan and this agreement in its entirety or in part, to such extent and in such manner and with such additions, exceptions, and modifications as the Managers shall deem to be for the best interests of the depositors or of the properties finally embraced in the reorganization. Each and every depositor, for himself and not for any other, does hereby sell, assign, transfer, and set over to the Managers as co-partners, and to the survivor and survivors of them, and to their successors, each and every bond, coupon, claim for interest on registered bonds, share of stock, security, or obligation or evidence thereof deposited hereunder, and every depositor hereby agrees that the Managers shall be and they are hereby vested with all the rights and powers of owners of the stocks, bonds, coupons, claims for interest, securities and obligations deposited hereunder, including the right to transfer the same into their own names, as copartnerships and as Managers, or into the names of any other person or persons whom they may select; and (without limiting the foregoing provision) it is hereby declared that the Managers shall be fully authorized to vote thereon at any meeting of stockholders or bond or certificate holders or creditors to use every such stock, bond, coupon, claim for interest, receipt, security, or obligation as fully and to the same extent as the owner or holder thereof; to declare due the principal of any bond or other obligation deposited hereunder, and to revoke any such declaration whenever made; to call or attend, and, either in person or by proxy, to vote at any and all meetings of stockholders, bondholders, or creditors of any corporation however convened; to terminate or to seek to dissolve or modify any trust, contract, or lease, in whole or in part; to apply for the determination of the validity thereof, or for the removal of any trustees or the substitution of other trustees, or to take any other steps in respect of any trust, contract, or lease, or under any provision thereof; to purchase at any time or times, at such prices as they shall deem proper, or to pay, compromise, 
or settle with the holders of any coupons, notes, or other indebtedness or car trust or other obligations of any of the railroad companies, or any receiver's certificates or obligations issued or which may be issued or incurred by the receivers thereof, and to apply for that purpose any moneys received from the sale of trust certificates for stock in the new company, or which may otherwise be received or raised by them; to borrow money for any of the purposes of this agreement, and to charge or pledge any deposited securities, property purchased, or new securities to be issued, for the payment of any moneys borrowed; to give all bonds of indemnity or other bonds, and to charge therewith the securities deposited hereunder, or any part thereof; to institute or to become parties to any legal proceeding; to apply for receivers, or for the removal of receivers and the substitution of other receivers, or for the termination of any receivership and the delivery of any property to its owners; to settle any litigation now or at any time existing or threatened in whole or in part, with plenary power to enter into arrangements for decrease, or for facilitating or hastening the course of litigation, or in any way to promote the consummation of the plan; to do whatever, in the judgment of the Managers, may be necessary to promote or to procure the sale as an entirety or the joint or separate sales of any lands, property, or franchises herein contained, wherever situated; to adjourn any sale or any property or franchises, or any portion or lot thereof, at discretion; to bid, or to refrain from bidding, at any sale, either public or private, either in separate lots or as a whole, for any property or franchises, or any part thereof, whether or not owned, controlled, or covered by any deposited security, including or excluding any particular rolling stock or other property, real or personal ; and at, before, or after any sale to arrange and agree for the resale of any portion of the property which they may decide to sell rather than to retain; to hold any property or franchises purchased by them either in their name or in the name of persons or corporations by them chosen for the purposes of this agreement, and to apply any security embraced hereunder in satisfaction of any bid or toward obtaining funds for the satisfaction thereof; and the term property and franchise shall include any and all railroads, railroad or other transportation lines, branches, leaseholds, lands, rights in lands, mining rights, stocks, or other interests in corporations in which the railroad company has any interest of any kind whatever, direct or indirect. The amount to be bid or paid by the Managers for any property or franchises shall be absolutely discretionary with them; and, in case of the sale to others of any property or franchises, the Managers may receive, out of the proceeds of such sale, or otherwise, any dividend in any form accruing on any securities held by them. 
Third. The Managers may procure the organization of one or more new companies, or they may adopt or use any existing or future companies, and they may cause to be made such consolidations, leases, sales, or other arrangements and may make or cause to be made such conveyances or transfers of any properties or securities acquired by them, and may take such other proceedings as they may deem proper for the purpose of creating the new securities provided for in this plan and agreement and for carrying out all or any of the provisions thereof. The Managers shall further be authorized to receive and dispose of, in accordance with any of the provisions of this plan and agreement, the new securities to be created, and the Managers may vote upon all the stock of such new corporation for all purposes in their judgment necessary to carry out the plan until the same shall be delivered to the voting trustees or to the depositors who shall be entitled to receive the same.

Fourth. The Managers may construe the plan and this agreement; and their construction thereof, or action thereunder, in good faith, shall be final and conclusive. They may supply any defect or omission, or reconcile any inconsistency in such manner and to such an extent as shall be necessary to carry out the same properly and effectively, and they shall be the sole judges of such necessity. They shall be the sole and final judges as to when and whether the assent of enough parties interested in the railroad company shall have been obtained to warrant them in declaring the same or any part thereof operative, or in carrying the same or any part thereof into effect, and as to when and whether a sufficient number of the existing bonds upon the lines of railway to be included in the prior lien or first mortgages, respectively, have been deposited, to warrant the execution by the new company or such prior lien or first mortgage, respectively, and the issue of bonds thereunder, pending the acquisition of such lines of railway by the new company, and they shall have power whenever they shall deem proper, at any time before the new securities shall have been issued and delivered to the Depositors, to abandon or to alter, modify or depart from, the plan of reorganization, or any part thereof, except the provisions for the voting trust. They may at any time or times after any such partial abandonment, restore to the plan any abandoned part or parts thereof, and may seek to carry the same into effect, as fully as if such part or parts had not been abandoned. They may also attempt to carry the plan into effect rather than abandon or modify the same, even though it be manifest that, as carried out, the plan must depart from the original plan or from some part thereof. But in case of any intentional change or modification, or departure from the plan, which in their judgment shall materially affect any of the several classes of 
Depositors, or their mutual relations, a statement of such proposed change, modification, or departure shall be filed with the Depositary in New York, and also with its agent, the London \& Westminster Bank (Lta.), in London, and notice of the fact of such filing shall be given as hereafter provided in article twelfth; and within two week after final publication all holders of the outstanding certificates for such particular class or classes of securities affected thereby may surrender their respective certificates therefor and withdraw securities of such particular class or classes, or the proceeds thereof, or substitutes therefor then under the control of the Managers, to the amount indicated in such certificates, provided, however, that in every case of withdrawal and cancellation the certificate holders shall, respectively, make payment of their shares of the expenses of the Managers, as apportioned by the Managers. Every depositor of securities not so surrendering and withdrawing within such two weeks after final publication shall be deemed to have assented to the proposed changes or modifications, and whether or not otherwise objecting, shall be bound thereby as fully and effectively as if he had actually assented thereto. Any changes or modifications finally made by the Managers shall be part of the plan and this agreement; and all provisions and references concerning the plan shall apply to the plan so changed or modified. In every such case of withdrawal any cash advanced to depositors and any interest paid or advanced to holders of certificates of deposit in respect of deposited bonds, represented by such certificates of deposit, or in respect of the new bonds to be issued in exchange therefor under the plan must he repaid, if the Managers so require, by the holders of such certificates before the deposited bonds, represented by such certificates of deposit shall be surrendered in exchange therefor; but any interest collected by the Managers on deposited securities will, in ease of such withdrawal, be accounted for by the Managers to the holders of the certificates of deposit for such securities. In ease the Managers shall finally abandon the entire plan, the stocks and bonds and coupons deposited hereunder or their proceeds, or any stocks, bonds, coupons, securities, or elaims or representatives thereof, then under the control of the Managers, shall be delivered to the several Depositors in amounts representing their respective interests upon surrender of their respeetive certificates and payment of such actual expenses as shall have been incurred by the Managers, and the Managers shall have power to determine and to apportion upon the several elasses of securities deposited hereunder the share of expense to be borne by each security. In any such case any moneys paid by the depositing stockholders, or any coupons, receiver's certificates, or other obligations, claims, or property acquired therewith, or the proceeds thereof when received, remaining 
after deducting therefrom the share of the expenses incurred by the Managers under this agreement apportioned upon such depositing stockholders shall be equitably distributed or adjusted among the respective holders of certificates of deposit therefor. But the Managers shall not be held liable for loss of any such money disbursed by them for the purposes of this agreement nor for the depreciation in value of any property or securities purchased by them, and the depositing stockholders or holders of such certificates of deposit shall have no claim for the repayment of any such moneys except to the extent of their ratable shares of such moneys or their proceeds at the time remaining in the hands of or subsequently collected by the Managers after payment of such expenses.

Fifth. The Managers may proceed under the plan and this agreement or any part thereof with or without foreclosure, and in case of foreclosure may exercise any power either before or after foreclosure sale; and in every case all the provisions of the plan and this agreement shall equally apply to and in respect of any physical properties embraced under the reorganization and to and in respect of any securities representing any such property, it being intended that for all purposes thereunder any such property and any security representing such property may be treated by the Managers as substantially identical. In case any separate plan shall in the opinion of the Managers become necessary or expedient to effect the reorganization of any subordinate or other company, the Managers may promote and participate in any such reorganization and may deposit thereunder any securities thereby affected.

In case of any claim, lien, or obligation not herein fully provided for and affecting the railroad company, or any property or franchises thereof, the Managers may from time to time( subject, however, to article sixth hereof) make such compromise in respect thereto or such provision therefor as they may deem suitable, using therefor any securities not expressly required for settlement with Depositors or not expressly reserved for liens or obligations specified in the plan, but the total amount of new securities to be created as set forth in the plan shall not thereby be increased.

Any action contemplated in the plan and this agreement to be performed on or after completion and reorganization may be taken by the Managers at any timewhen they shall deem the reorganization advanced sufficiently to justify such course, and the Managers as they may deem necessary may defer the performance of any provision of the plan and this agreement, or may commit such performance to the new company.

They may also in their discretion set apart and hold in trust or place in trust with any trust company any part of the new securities to be 
issued and cash which may be received from sales of new securities or otherwise as they may deem judicious for the purpose of securing the application thereof for any of the purposes of the plan and this agreement.

Sixth. From time to time, for the purpose of carrying this agreement into effect, or of obtaining assents thereto, the Managers, either generally or in specific instances, may make contracts with any person, syndicate, or corporation; and, in their discretion, either generally or in specific instances and upon such general or special terms and conditions as they may deem proper, may arrange to procure the deposit of securities hereunder; they may also, from time to time, by loan, guaranty, or by sale of the new securities to be created or otherwise upon such terms, conditions, and rates as said Managers may deem proper, may obtain any moneys required to carry out the plan and this agreement, including such sums as the Managers may deem expedient to provide for the uses of the new company; and for the performance of any contract said Managers may charge the deposited securities and the new securities to be issued any may pledge the same for the payment of any moneys borrowed and interest thereon, and other performance of any other obligations incurred under the powers herein conferred. The Managers may employ counsel, agents, and all necessary assistance, and may incur and discharge any and all expenses by them deemed reasonable for the purpose of this agreement. They may preseribe the form of all securities, mortgages, and all instruments at any time to be issued or entered into. They may create and provide all necessary trusts, and may nominate and appoint trustees thereunder, excepting that the voting trustees shall be appointed as stated in the plan. The Managers may, at public or private sale, or otherwise, dispose of any bonds and trust certificates for stock of the new company left in their hands because of any failure to make deposits hereunder. In so disposing of any such new securities thus left in their hands they may use the same or the proceeds thereof for the purpose of earrying out the reorganization in such manner as they may deem expedient and advisable. At the time of the creation of the new securities or as soon thereafter as may be the Managers may take such action (either by creating lesser amounts of securities or otherwise) as they may deem necessary to guard against the issue of such particular securities in any manner or to any extent inconsistent with the purposes of the plan.

Seventh. The said firms of Speyer \& Co. and Kuhn, Loeb \& Co., of New York, and Speyer Bros., of London, shall be the Managers under this agreement. So far as practicable the three firms as such Managers shall act and concur in all steps and proceedings hereunder, but 
in the event of the three firms not concurring, the concurrent action of any two of said firms shall be the action of the Managers, and no action shall be taken except with the assent of at least two of said three firms. The said firms as managers shall each act as a copartnership, and in case of any change in either of said firms, the respective firms of Speyer \& Co., Kuhn, Loeb \& Co., and Speyer Bros., or their respective successor firms, as from time to time constituted, shall continue as Managers, with all the powers, rights and title vested in the Managers hereunder. Neither the Reorganization Committee nor the Managers nor the Depositary assume any personal responsibility for the execution of the plan, or of this agreement, or any part of either, nor for the result of any steps taken or acts done for the purposes thereof; the Managers, however, undertaking in good faith to endeavor to execute the same. No member of the Reorganization Committee, nor any Depositary nor any of the Managers shall be personally liable for any act or omission of any agent or employee selected in good faith, nor for any error of judgment or mistake of law, nor in any case except for his, its, or their own individual wilful malfeasance or neglect, and no member of the Reorganization Committee shall in any case be personally liable for the act or omission of any other member, nor for the acts of any Depositary or of the Managers; nor shall any Depositary or any of the Managers be personally liable for the acts or defaults of the Reorganization Committee or any member thereof, or of any other Depositary, or Manager, or of any trust company. The Managers may act through any committee or agents, and may delegate any authority, as well as discretion, to any such committee or agent, and the members of such committee or such agents may be allowed a reasonable compensation for their services hereunder. The Managers shall be entitled for a compensation for their services, which shall be fixed by agreement between the Managers and the Reorganization Committee, and as so fixed, shall be finally binding and conclusive upon all parties. The Managers shall have the right to form or procure the formation of any syndicate or syndicates which they may deem necessary or advantageous for carrying out the purposes of the plan, and may act as Managers of such syndicate or syndicates. Any member of either firm of the Managers or Depositaries, or any member of the Reorganization Committee, at any time, may be a voting trustee, and any of said firms or any member thereof or any Depositary or any member of the Reorganization Committee may be or become pecuniarily interested in any contracts, property, or matters which this agreement concerns, including participation in or under any syndicate agreement, as Syndicate Managers, or otherwise, whether or not mentioned in the plan. Any direction given 
by the Managers shall be full and sufficient authority for any action of the Depositary or of any trust compuny or of any other custodian or of any committee or agent.

The Reorganization Committee sliall be entitled to compensation for their services, which shall be fixed by agreement between the Managers and the Reorganization Committee, and as so fixed, shall be finally binding and conclusive upon all parties. It may discharge any and all reasonable expenses, including counsel fees, by it incurred for any of the purposes of this agreement. Its accounts shall be filed with the Managers, and when approved by the Managers, shall be finally binding and conclusive upon all parties having any interest therein. The compensation of the said Reorganization Committee shall be paid as part of the expenses of the reorganization.

Eighth. The Managers may negotiate and contract with any and all companies or persons for obtaining or granting running powers, terminal facilities, exchanges of property, or any other convenience which they may deem necessary or desirable to obtain or to grant, and may make contracts therefor binding upon such new company, and generally may ratify and make such purchases, contracts, stipulations, or arrangements as will in their opinion operate directly or indirectly to aid in the preservation, improvement, development, or protection of any property now constituting the Baltimore \& Ohio Railroad system, or which the railroad company or any subordinate company has contracted to acquire, or to prevent or avoid opposition to or interference with the successful execution hereof.

Ninth. The accounts of the Managers shall be filed with the board of directors of the new company within one year after its organization shall have been completed, unless a longer time be granted by the said board. The accounts, when approved by such board of directors, shall be final, binding, and conclusive upon all parties having any interest therein, and thereupon the Managers shall be discharged. The acceptance of new securities by any depositor shall estop such acceptor from questioning the conformity of such securities in any particular to any provisions of the plan; and the acceptance of new securities by the holders of a majority in amount of the certificates or deposit for any class of securities shall in each case respectively estop all holders of certificates of deposit for securities of that class.

Tenth. The enumeration of specific powers hereby conferred shall not be construed to limit or to restrict general powers herein conferred or intended so to be; and it is hereby distinctly declared that it is intended to confer on the Managers, in respect of all securities deposited, or to be deposited, and in all other respects, any and all powers which the Managers may deem necessary or expedient in or toward 
carrying out or promoting the purposes of the plan and this agreement in any respect, even though any such power be apparently of a character not now contemplated; and the Managers may exercise any and every such power as fully and effectively as if the same were herein distinctly specified, and as often as, for any cause or reason, they may deem expedient. The methods to be adopted for or toward carrying out this agreement shall be entirely discretionary with the Managers.

The bonds, coupons, claims for interest on registered bonds, and other obligations deposited under the plan and this agreement, and all receivers' certificates, coupons, and claims purchased or otherwise acquired under this agreement, shall remain in full force and effect for all purposes, and shall not be deemed satisfied, released, or discharged by any delivery of new securities; and no legal right or lien shall be deemed released or waired, but said bonds and other claims, and any judgment upon any of such claims, including claims and judgments for deficiencies, and all liens and equities, shall remain unimpaired, and may be enforced by the Managers or by the new company or by any other assign of the Managers until paid or satisfied in full or expressly released. Neither the Managers nor any bondholders or creditors of the railroad company, by executing this agreement, or by becoming parties thereto, release, surrender, or waive any lien, right, or claim in favor of any stockholders of other creditors of such company, and all such liens, rights, or claims shall rest unimpaired in the Managers and in the new company, or its assigns, severally and respectively; and any purchase or purchases by or on behalf of the Managers, or the new company, under any decree for the enforcement of any such lien, right, or claim, shall vest the property purchased in the Managers or the new company free from all interest or claim on the part of any such stockholders, creditors, or other parties. No right is conferred, nor any trust, liability, or obligation (except the agreements herein contained in favor of the holders of certificates of deposit hereunder) is created by the plan and this agreement, or is assumed hereunder, or by or for any new company in favor of any bondholder, or any other creditor, or of any holder of any claim whatsoever against the railroad company, nor in favor of any company now existing or to be formed hereafter (whether such claim be based on any bonds, coupons, stocks, securities, lease, guaranty or otherwise), with respect to any securities deposited under this agreement or any moneys paid to or received by the Managers or by the Depositary hereunder or with respect to any property acquired by purchase at any foreclosure sale, or with respect to any new certificates to be issued hereunder, or with respect to any other matter or thing. 
Eleventh. All moneys paid under or with reference to the plan and this agreement shall be paid over to the Managers, who shall, as bankers, hold the same subject to application for any of the purposes of the plan and this agreement as may be most convenient, and as from time to time may be determined by the Managers, whose determination as to the propriety and purpose of any such application shall be final and nothing in the plan shall be understood as limiting or requiring the application of specific moneys to specific purposes. Any obligation in the nature of floating debt or otherwise against any company or property embraced in the plan either as proposed or carried out, or any securities held as collateral for any such obligation, may be acquired or extinguished or held by the Managers at such time, in such manner and upon such terms as they may deem proper for the purposes of reorganization, but nothing in the plan and this agreement contained is intended to constitute, nor shall it constitute, any liability or trust in favor or in respect of any such obligation.

Twelfth. All calls for the payments to be made by depositing stockholders or for the surrender of certificates of deposit issued hereunder, all notices fixing or limiting any period for the deposit of securities or for such payments, and all other calls or notices hereunder, except when herein otherwise expressly provided, shall be inserted in the New York Times and the New York Tribune, or in two other daily papers of general circulation published in the City of New York; the Baltimore Sun and the Baltimore American, or in two other daily papers of general circulation published in the city of Baltimore, Md., and in two daily papers of general circulation published in the city of London, twice in each week for two successive weeks, beginning on any day of the week. Any call or notice whatsoever when so published by the Managers shall be taken and considered as though personally served on all parties hereto and upon all parties bound hereby, as of the respective dates of insertion thereof, and such publication shall be the only notice required to be given under any provision of this plan and agreement. When a call or notice shall have been advertised as above specified in New York or in London, publication shall be complete as regards all holders of certificates of deposit, issued by the depositary in the city in which such publication shall have been made, and no further publication shall be required in such city.

Thirteenth. The plan and this agreement shall bind and benefit the several parties, including the depositors hereunder, their and each of their survivors, heirs, executors, administrators, successors and assigns.

In witness whereof, a majority of the Reorganization Committee, the Managers, and the Mercantile Trust Co. of New York have caused 
these presents to be duly executed, the day and year first above written, and the parties of the third part have become parties hereto by depositing their securities and accepting certificates of deposit therefor hereunder. 


\section{THE DISSOLUTION OF TIIE POWDER TRUST 1}

It is thereupon, on this 13th day of June, A. D. 1912, ordered, adjudged and decreed as follows, to wit:

2. That the remuining twenty-seven defendants, namely: Hazard Powder Company, Laflin \& Rand Powder Company, Eastern Dynamite Company, Fairmont Powder Company, Judson Dynamite \& Powder Company, Delaware Securities Company, Delaware Investment Company, California Investment Company, E. I. duPont de Nemours \& Company of Pennsylvania, duPont International Powder Company, E. I. duPont de Nemours Powder Company, E. I. duPont de Nemours \& Company, Thomas Coleman duPont, Pierre S. duPont, Alexis I. duPont, Alfred I. duPont, Eugene duPont, Eugene E. duPont, Henry F. duPont, Irenee duPont, Francis I. duPont, Victor duPont, Jr., Jonathan A: Haskell, Arthur J. Moxham, Hamilton M. Barksdale, Edmund G. Buckner and Frank L. Connable, are maintaining a combination in restraint of interstate commerce in powder and other explosives in violation of section I, of an Act entitled "An Act to Protect Trade and Commerce against Unlawful Restraints and Monopolies," approved July 2, 1890, and have attempted to monopolize and have monopolized a part of such commerce in violation of section 2 of said Act.

Wherefore, It is further ordered, adjudged and decreed that the twenty-seven (27) defendants above mentioned, and each of them be enjoined from continuing said combination and monopoly, and that said combination and monopoly be dissolved.

3. That the petitioner having availed itself of the permission granted in said interlocutory decree and having presented a certain plan for the dissolution of said combination and the dissolution of said monopoly, so far us the present situation of the parties and the properties involved will permit, to which plan the said twentyseven (27) defendants do not object, which said plan is as follows:

First: Dissolve the defendant corporation E. I. duPont de $\mathrm{Ne}$ mours \& Company (1902, Delaware corporation) and distribute its property among its stockholders.

Second: Dissolve the defendant corporation Hazard Powder Company and distribute its property among its stockholders.

1 Quoted by W. S. Stevens in his Industrial Combinations and Trusts from the opinion of Court and Final Decree in the case of The United States of America v. E. I. duPont de Nemonrs \& Company and Others, in the District Court of the United States, for the Distriet of Delaware in Equity No. 280. 
Third: Dissolve the defendant corporation Delaware Securities Company and distribute its property among its stockholders.

Fourth: Dissolve the defendant corporation Delaware Investment Company and distribute its property among its stockholders.

Fifth: Dissolve the defendant corporation Eastern Dynamite Com. pany and distribute its property among its stockholders.

Sixth: Dissolve the defendant corporations California Investment Company and Judson Dynamite and Powder Company and distribute their property among their stockholders.

Seventh: Organize two corporations in addition to E. I. duPont de Nemours Powder Company (1903, New Jersey Corporation) which slall be capitalized as hereinafter provided, or reorganize the Laflin and Rand Powder Company and the Eastern Dynamite Company, or either of them, to be used instead of one or both of said two corporations, and in case the said Eastern Dynamite Company is so selected, then it need not be dissolved as hereinbefore provided. In case the Laflin and Rand Powder Company is not used under this paragraph dissolve said company and distribute its property among its stockholders.

To the first of said corporations transfer the following plants:

For the Manufacture of Dynamite:

Plant at Kenville, New Jersey,

Plant at Marquette, Michigan.

Plant at Pinole, California.

For the Manufacture of Black Blasting Powder:

Plant at Rosendale, New York,

Two (2) plants at Ringtown, Pennsylvania,

Plant at Youngstown, Ohio,

Plant at Pleasant Prairie, Wisconsin,

Plant at Turck, Kansas,

Plant at Santa Cruz, California.

For the Manufacture of Black Sporting Powder:

Plant at Hazardville, Connecticut.

Plant at Schaghticoke, New York.

To the second of said corporations transfer the following plants:

For the Manufacture of Dynamite:

Plant at Hopatcong, New Jersey,

Plant at Senter, Michigan,

Plant at Atlas, Missouri,

Plant at Vigorit, California. 
REORGANIZATION OF DUPONT POWDER CO. 1003

For the Manufacture of Black Blasting Powder:

Plant at Riker, Pennsylvania,

Plant at Shenandoah, Pennsylvania,

Plant at Ooltewah, Tennessee,

Plant at Belleville, Illinois,

Plant at Pittsburg, Kansas.

And permit the said defendant E. I. duPont de Nemours Powder Company to retain the following plants:

For the Manufacture of Dynamite:

Plant at Ashburn, Missouri,

Plant at Barksdale, Wisconsin,

Plant at duPont, Washington,

Plant at Emporium, Pennsylvania,

Plant at Hartford City, Indiana,

Plant at Louviers, Colorado,

Plant at Gibbstown, New Jersey,

Plant at Lewisburg, Alabama.

For the Manufacture of Black Blasting Powder:

Plant at Augusta, Colorado,

Plant at Connable, Alabama,

Plant at Oliphant Furnace, Pennsylvania,

Plant at Mooar, Iowa,

Plant at Nemours, West Virginia,

Plant at Patterson, Oklahoma,

Plant at Wilpen, Minnesota.

For the Manufacture of Black Sporting Powder:

Plant at Brandywine Delaware

Plant at. Wayne New Jersey.

For the Manufacture of Smokeless Sporting Powder:

Plant at Carney's Point, New Jersey,

Plant at Haskell, New Jersey.

For the Manufacture of Government Smokeless Powder:

Plant at Carney's Point, New Jersey,

Plant at Haskell, New Jersey.

Eighth: Transfer to or furnish the first of said two corporations with a plant for. the manufacture of smokeless sporting powder and the brands now or heretofore owned by the Laflin and Rand Powder Company. Such plant to be located at Kenville, New Jersey, or some other suitable Eastern point, and to be of a capacity sufficient to manufacture 950,000 pounds per annum of smokeless sporting powder of the brands to be assigned to the first of said corporations. 
Ninth: Furnish said two corporations respectively with sufficient working capital and the necessary cash and facilities to enable them to efficiently carry on the business which will attend the properties so to be transferred to them.

Tenth: Transfer said properties to said two corporations respectively upon a valuation thereof based on the last inventory of said properties, to include a fair valuation for brands and good will, and issue to said E. I. duPont de Nemours Powder Company in payment therefore ${ }^{1}$ securities of said two corporations respectively at par value as follows: Fifty per cent. $(50 \%)$ of said purchase price in bonds not secured by mortgage which shall bear interest at the rate of six per cent. (6\%) per annum, payable if earned by the company during said year, or to the extent thereof earned but not otherwise; nor cumulative; payable not less than ten years from date; the form of said bonds to be approved by the Attorney-General or the Court, which bonds shall be subject to call at one hundred and two (102) ; and the other fifty per cent. (50\%) of said purchase price in the stock of said two corporations respectively, which for the time being shall be their entire stock issues. Upon the receipt of said stock and bonds by E. I. duPont de Nemours Powder Company, distribute the said stock and one-half of said bonds or the proceeds of the sale of said bonds among the stockholders of E. I. duPont de Nemours Powder Company. In the organization or reorganization of said two corporations to which said properties are to be transferred, provide two issues of stock in said two corporations respectively, one of which shall have voting power and the other of which shall have no voting power. So distribute said stocks among the stockholders of E. I. duPont de Nemours Powder Company that any amounts thereof which upon said distribution shall go to any one of the twenty-seven defendants hereinbefore mentioned shall consist of one-half of said stock with voting power and one-half of said stock without voting power, and provide that upon the transfer through death or by will from any one of said twenty-seven defendants of any stock which has no voting power, to some person or persons other than one of said twenty-seven defendants herein, or upon the sale by any one of said twenty-seven defendants of any stock which has no voting power, to some person or persons other than one of said twenty-seven defendants herein, or their respective wives or children, said stock so sold or transferred may be exchanged for stock with voting power.

Eleventh: Transfer to said two corporations, respectively, so far as practicable, a fair proportion of the business in explosives now con-

${ }^{2}$ Thus in original.-Ed. 
trolled by E. I. duPont de Nemours Powder Company under time contract.

Twelfth: During a period of at least five years furnish each of said two corporations respectively, under such arrangements as may be reasonable, such information from the records of the Trade Bureau maintained by E. I. duPont de Nemours Powder Company as may be desired.

Thirteenth: During a period of at least five years furnish to each of said two corporations such facilities, information and use of organization, as E. I. duPont de Nemours Powder Company may operate or possess in reference to purchase of materials, experimentation, development of the art and scientific research, as said two corporations may desire from time to time, in the interests of their business, and upon some reasonable terms as to the cost thereof to said two corporations.

And said plan having been duly considered by the Court, it is ordered, adjudged and decreed that the said defenants are respectively directed to proceed forthwith to carry said plan into effect, and it is further

Ordered, adjudged and decreed, that if said defendants shall not have carried said plan into operation and effected the same on or before the fifteenth day of December, 1912, then and in that event an injunction shall issue out of this Court restraining the said defendants in paragraph two of this decree mentioned and each of them, and their agents and servants from thereafter in any manner whatsoever placing the products of any of the factories owned by said defendants or said combination into the channels of interstate commerce, or such other relief shall be granted by the appointment of a receiver or otherwise as this Court may determine.

4. That should the defendants find it impossible to perfect the details of said plan on or before the said fifteenth day of December, 1912 , they may have leave to apply to the Court for further time to carry out said plan.

5. That until said plan is 'carried into operation and effect, the said twenty-seven defendants hereinbefore named in paragraph two of this decree, are, and each of them is, and the agents and servants of them are jointly and severally hereby enjoined from doing any acts or act which shall in any wise further extend or enlarge the field of operations, or the power of the aforesaid combination.

It is further ordered, adjudged and decreed that the said twentyseven (27) defendants, their stockholders, officers, directors, servants, agents and employees be and they are hereby severally enjoined and restrained as follows: 
From continuing or carrying into further effect after said fifteenth day of December, 1912, the combination adjudged illegal in this suit, and from entering into or forming among themselves or with others any like combination or conspiracy, by any method or device whatsoever, the effect of which is or will be to restrain interstate commerce in explosives or to renew the unlawful monopoly of such commerce obtained and possessed by the defendants as adjudged herein, in violation of "Act to Protect Trade and Commerce Against Unlawful Restraints and Monopolies," approved July 2, 1890, and especially :

1. By causing the conveyance of the factories, plants, brands of business of either of said two new corporations to the other corporation to E. I. duPont de Nemours Powder Company or vice versa after the segregation of the properties among said corporations shall have taken place as herein provided; by placing the stocks of either of said corporations in the hands of voting trustees or controlling the roting power of such stocks by any device:

2. By making any express or implied agreement or arrangement with one another or with others relative to the control or management of either of said corporations, or the price or terms of purchase, or of sale of explosives or relative to the purchase, sale, manufacture, or transportation of explosives which will have the effect of restraining interstate commerce; or by making any agreement or arrangement of any kind between said corporations under which trade or business is apportioned between said corporations in respect either to customers or localities.

3. By offering or causing to be offered or making or causing to be made more favorable prices or terms of sale for the products manufactured by them or either of them to the customers of any rival manufacturer or manufacturers than they at the same time offer to make their established trade, where the purpose is to unfairly cripple or drive out of business such rival manufacturer or manufacturers or otherwise unlawfully to restrain the trade and commerce of the United States in any of said products; provided that no defendant is enjoined or restrained from making any price or prices in the sale of said products, or any thereof, to meet or to compete with prices made by any other defendant, or by any rival manufacturer; and provided, further, that nothing in this decree shall be taken in any respect to enjoin or restrain fair, free and open competition.

4. By either of said corporations retaining or employing the same clerical force or organization, or keeping the same office or offices as any other of said corporations. 
5. By either of said corporations doing business directly or indirectly under any other than its own corporate name or the name of a subsidiary corporation controlled by it; provided, however, that, in case of a subsidiary corporation, the controlling corporation shall cause the products of such subsidiary corporation which are sold in the United States and bear the name of the manufacturer to bear also a statement indicating the fact of such control.

It is further ordered, adjudged and decreed that said defendants cancel and annul:

a. Agreement of October 2, 1902, between William Barclay Parsons, of the City of New York, and the Delaware Securities Company. Petitioner's Record, Exhibits, Volume 4, page 1984.

b. Agreement of October 6, 1902, between H. deB. Parsons of the City of New York, and the Delaware Securities Company. Petitioner's Record, Exhibits, Volume 4, page 1986.

c. Agreement of the second day of October, 1902, between Schuyler L. Parsons, of the City of New York, and the Delaware Securities Company. Petitioner's Record, Exhibits, Volume 4, page 1988.

$d$. A like and identical agreement made about the same date between J. A. Haskell and the Delaware Securities Company, described in Petitioner's Testimony, Volume 2, page 1012.

It is further ordered, adjudged and decreed that during a period of five years from the date hereof each of said corporations, the E. I. duPont de Nemours Powder Company and said other two corporations, their stockholders, officers, directors, agents, servants and employees, be hereby enjoined and restrained as follows:

1. None of said corporations shall have any officer or director who is also an officer or director in any other of said corporations.

2. None of said corporations shall employ the same agent or agents for the sale in interstate commerce of explosives which might be sold in competition with each other; provided that any one of said corporations may sell its products on commission through a merchant or dealer who is similarly employed by either or both of said corporations.

3. None of said corporations shall directly or indirectly acquire any stock in another of said corporations or purchase or acquire any of the factories, plants, brands or business of such other corporation.

It is further ordered, adjudged and decreed that each and all of the individual defendants by this decree adjudged to be engaged in said combination, while holding stock in said two corporations and I. I. duPont de Nemours Powder Company or any two thereof be enjoined and restrained from at any time within three years from the date hercof acquiring, owning or holding, directly or indirectly, 
any stock or a legal or equitable interest in any stock in either of said two corporations to which said properties shall be transferred, in excess of the amount to which he may be entitled under the provisions of the plan herein mentioned when the same shall have been carried out as proposed; provided, however, that any of said individual defendants may notwithstanding this prohibition acquire from any other or others of said defendants, or in case of death, from their estates, any of the stock held by such other defendant or defendants in said corporations and may acquire their proportions of any increase of stock.

It is furthed ordered, adjudged and decreed that any new company or companies organized for the purpose of taking property under the provisions of this decree or otherwise, necessary to the carrying out of this plan, shall, after their formation and by appropriate proceedings, be made parties to this cause, and subject to the provisions of this decree and bound by the injunctions herein granted.

It is further ordered, adjudged and decreed that any party hereto may make application to this Court for such orders and directions as may be necessary or proper in relation to the carrying out of such plan and the provisions of this decree.

It is further ordered, adjudged and decreed that the twenty-seven (27) defendants hereinabove mentioned, do pay to the United States Government its cost in this cause.

It is further ordered, adjudged and decreed that jurisdiction of this cause is retained by this Court, for the purpose of making such other and further orders and decrees as may become necessary for carrying out the plan herein set forth.

It is further ordered, adjudged and decreed that after the plan hereinabove mentioned shall have been carried into effect a report shall be made to this Court for its approval, setting out the manner in which said plan shall have been carried out. 


\title{
REFUNDING WITHOUT THE AID OF A BANKER
}

\section{Chicago Elevated Railways}

\author{
TWO-YEAR FIVE PER CENT. SECURED GOLD NOTES
}

\section{To the Holders of Said Notes:}

The above obligations were issued July 1, 1914, as part of a plan of temporary financing. Since that date, the City of Chicago has appointed a Commission of eminent engineers to study transportation conditions and to formulate a concrete plan for the unification of all the elevated and surface lines in the city. This Commission is now actively engaged in its labors. Pending the promulgation of such plan and of appropriate municipal action in the matter, it is neither practicable nor desirable to undertake permanent financing; and an extension of the maturity of said notes to July 1, 1919, is advisable and necessary.

The Chicago Elevated Railways has arranged to materially increase the value of the security for all extended notes, and proposes such extension thereof under the provisions of an Extension Agreement upon the following terms:

1. The interest on the extended notes will be increased from the present rate $(5 \%)$ to six per cent. $(6 \%)$ per annum, payable semiannually. New coupon sheets to evidence such future interest will be attached to each extended note.

2. The sum of $\$ 15$ in cash will be paid in respect of each $\$ 1,000$ face amount of extended notes.

3. In addition to and by way of material increase of the value of the security for said extended notes:

(a) Chicago Elevated Railways will acquire and pledge as security under the Extension Agreement promissory notes of the Railroad Companies, shares of whose capital stock now constitute the sole collateral securities pledged under the Trust Indenture of July 1, 1914, under which the Gold Notes were issued. These promissory notes will aggregate, approximately, $\$ 1,070,000$; and, until so acquired and pledged, they rank in priority to the collateral securities under the Trust Indenture of July 1, 1914;

(b) Chicago Elevated Railways will cause to be similarly pledged under the Extension Agreement as security for the payment of the extended notes, claims or notes representing alditional floating indebtedness of the Railroad Companies amounting approximately to

Advertisement in New York Times, June 21, 1916. 
$\$ 1,000,000$, incurred principally as a result of betterments made to the railroad properties, and now likewise ranking in priority to the collateral securities pledged under the Trust Indenture of July 1, 1914 ; and

(c) Chicago Elevated Railways will procure an agreement with Commonwealth Edison Company whereby all claims for power supplied to the Railroad Companies after June 30, 1916, and until the Extended Notes shall have become due, will be assigned to a trustee and will be paid only if and as other floating debt of subsidiary companies (except capital debt), is not increased. In case other collateral securities pledged for the Extended Notes shall upon sale prove insufficient to pay such Extended Notes in full, the said power claims then unpaid will be placed on a parity with the Extended Notes.

Except only as the same may be modified and supplemented by the Extension Agreement in respect of Noteholders assenting thereto, the provisions of the Trust Indenture of July 1, 1914, will remain in full force and effect.

The extension of the notes has not been underwritten. The success of the proposed extension depends therefore solely upon the cooperation of the noteholders in availing themselves of the substantial benefits above outlined. The extension does not involve the payment of commissions, and all incidental expenses will be borne by the Chicago Elevated Railways.

Holders of Gold Notes may become parties to said Extension Agreement by depositing of said notes, having first detached therefrom the July 1, 1916, coupon, with the Depositary: The National City Bank of New York, New York; or with either of the following sub-depositaries: Illinois Trust and Savings Bank, Chicago; International Banking Corporation, London.

All deposits must be made on or before July 15, 1916, or such later date, if any, as may be prescribed therefor in the exercise of the discretion and in the manner in the Extension Agreement provided. Should the Extension Agreement not become definitive and effective as therein provided, the deposited notes (or an equal face amount of the same issue), in either event in unextended form, will be returned, without charge, to the holders of certificates of deposit, on surrender of such certificates to the Depositary which issued the same.

The July 1, 1916, coupons will be paid at maturity.

CHICAGO ELEVATED RAILWAYS.

New York, June 19, 1916. 


\section{FROM THE CERTIFICATE OF INCORPORATION OF WEST- ERN MARYLAND RAILWAY COMPANY}

The capital stock of Western Maryland Railway Company, the consolidated corporation hereby created, shall be Seventy-eight Million Dollars $(\$ 78,000,000)$, which shall be divided into and represented by Seven hundred and eighty thousand $(780,000)$ shares of the par value of $\$ 100$ each, and each of which shares shall be entitled to one vote at any meeting of the stockholders of the consolidated corporation. Of such capital stock One hundred and eighty thousand $(180,000)$ shares, of $\$ 100$ each, may be issued as first preferred stock, One hundred thousand $(100,000)$ shares, of $\$ 100$ each, may be issued as second preferred stock, and Five hundred thousand $(500,000)$ shares, of $\$ 100$ each, may be issued as common stock.

The first preferred stock shall be entitled to receive, in preference and priority over the second preferred stock and the common stock of said consolidated corporation, out of the surplus or net profits of said corporation, quarterly dividends in each and every fiscal year at such rate, not exceeding seven per cent. per annum, as shall be declared by the board of directors, but shall have no further interest or rights in said surplus or net profits.

Annual dividends upon the first preferred stock shall be cumulative from July 1, 1918.

In the event of any liquidation, dissolution or winding up, whether voluntary or involuntary, of said consolidated corporation, the holders of the first preferred stock shall be entitled to be paid in full out of the assets of said consolidated corporation the par amount of their shares, together with any dividends accrued or cumulated thereon, before any amount shall be paid out of said assets to the holders of the second preferred stock or of the common stock.

Said first preferred stock shall have no further preference or priority over the second preferred stock and the common stock except as in this article provided.

The second preferred stoek shall be entitled to receive, in preference and priority over the common stock of said consolidated corporation, out of the surplus or net profits of said corporation, dividends in each and every fiscal year at such rate, not exceeding four per cent. per annum, as shall be declared by the board of directors; but shall have no further interest or rights in said surplus or net profits.

Annual dividends upon the second preferred stock shall be noncumulative; and if in any one year dividends amounting to four per 
cent. shall not be paid on the second preferred stock, the deficiency shall not be paid upon such second preferred stock out of the surplus or net profits for any subsequent or preceding year. In the event of any liquidation, dissolution or winding up, whether voluntary or involuntary, of said consolidated corporation, the holders of the second preferred stock shall be entitled to be paid in full out of the assets of said consolidated corporation the par amount of their shares and all dividends thereon declared and unpaid before any amount shall be paid out of said assets to the holders of the common stock.

The second preferred stock shall be redeemable as an entirety at any time at the option of said consolidated corporation at the price of One Hundred Dollars $(\$ 100)$ per share, provided that published notice be given in a manner to be determined by the board of directors of said consolidated corporation, at least once a week for four successive weeks prior to the date of said redemption.

The holders of the second preferred stock may at any time prior to the call of the same for redemption, exchange the same for common stock of said consolidated corporation at par-that is to say, for each share of second preferred stock so exchanged one share of common stock.

Said second preferred stock shall have no further preference or priority over the common stock except as in this article provided.

Any second preferred stock which may be surrendered for exchange into common stock may be reissued as common stock, and the amount of authorized second preferred stock shall thereby be correspondingly reduced and the amount of authorized common stock correspondingly increased, but without reduction or increase of the total authorized capital stock of the consolidated corporation. 
FROM THE CERTIFICATE OF INCORPORATION OF AMERICAN INTERNATIONAL CORPORATION

\section{ILLUSTratiNg MANAGER' SHAREg}

ThIrd. The amount of capital stock of the corporation is Fifty million Dollars $(\$ 50,000,000)$, of which One million Dollars $(\$ 1,000,000)$ is preferred stoek (to be known as "Managers' Shares"), and Forty-nine million Dollars $(\$ 49,000,000)$ is common stock.

The preferred stock shall be entitled to receive, out of surplus profits, dividends at the same rate as that paid on the common stock, until dividends aggregating seven per cent. (7\%) shall have been paid or declared on both elasses of stock during any one year. Thereafter, the preferred stock shall be entitled to reeeive one-fifth $(1 / 5$ th $)$ of any further distribution of surplus during that year, and the common stock shall be entitled to receive fourfifths (4/5ths) thereof.

Upon the liquidation of the corporation and the distribution of its assets, the preferred stock shall be entitled to receive an amount equal to the amount paid thereon, before any distribution shall be made to the common stock, which shall be entitled to receive out of the assets then remaining an amount equal to the amount paid on such common stock; after which, the preferred stock shall be entitled to receive one-fifth $(1 / 5$ th) of the assets, if any, then remaining undistributed, and the common stock shall be entitled to receive four-fifth $(4 / 5$ ths $)$ thereof.

Fourtr. The number of shares of which the capital stock shall consist is Five hundred thousand $(500,000)$, of the par value of One hundred Dollars $(\$ 100)$ each. The corporation may issue the whole or any part of its capital stock as partly paid stock, subject to calls thereon until the whole thereof shall have been paid in.

The amount of capital with which the corporation will begin busi. ness is Three thousand Dollars $(\$ 3,000)$. 


\section{STOCKHOLDERS' RIGHTS 1}

Boston, Mass., June 20, 1911.

\section{To the Stockholders:}

This Company hereby offers to its Stockholders shares of new stock for cash at par, one hundred dollars $(\$ 100)$ per share, as follows:-

Each Stockholder of record at the close of business on Friday, June 30,1911 , will be entitled to subscribe for such new stock in the proportion of one share for every five shares that he then holds; that is, a right will attach to each share of the then outstanding stock to subscribe for one-fifth of a share of new stock, but subscriptions ${ }^{3}$ must be for full shares.

This right to subscribe will expire at the close of business on Thursday, August 31, 1911.

Subscriptions under holdings that are not multiples of five shares may be adjusted by the purchase or sale of rights. Sellers of rights should not subscribe thereunder. The Company can neither buy nor sell rights.

Subscriptions and assignments will be received either at the office of the Treasurer in Boston, No. 125 Milk Street, or at his office in New York, No. 15 Dey Street.

Payment for shares subscribed for must be made to the Treasurer, as follows:-

Twenty-five dollars per share on or before Wednesday, November 1, 1911.

Twenty-five dollars per share on or before Thursday, February 1, 1912.

Twenty-five dollars per share on or before Wednesday, May 1, 1912.

Twenty-five dollars per share on or before Thursday, August 1, 1912.

For the convenience of subscribers these payments may be made, either at the Treasurer's office in Boston, No. 125 Milk Street, or at his office in New York, No. 15 Dey Street.

Payments of the first three instalments will bear interest from the due dates thereof until July 1, 1912, at the rate of dividend paid on the stock of this Company for the same period, and the interest accrued in any dividend period will be paid on the same date the dividend is payable provided no default has been made in the payment of any instalment of the subscription. Checks for this interest will

Circular sent to stockholders of the American Telephene and Telegraph Company, offering them new stock at par at a time when the old stock was selling at a premium. 
be mailed to the subscribers of record except those to whom negotiable receipts have been issued. Such negotiable receipts will be issued when requested and will entitle the person named or his assigns of record in the office of the Treasurer to the interest herein specified and to the shares of new stock named therein. The new stock will participate in any dividend payable after August 1, 1912.

Subscribers wishing to prepay may pay in full on any one of the respective due dates for the payment of instalments, and will be paid interest on such prepayment at the rate of four per cent. per annum from such due date of payment to the date when each instalment so prepaid becomes payable.

Certificates of stock will be dated August 1, 1912, and will be delivered as soon thereafter as they can be prepared.

Warrants speeifying the amount of stock for which stockholders are entitled to subscribe under this circular will be issued to each stockholder by the Treasurer as soon after June 30,1911 , as practicable, and must be returned to the Treasurer with the subscription endorsed thereon duly signed on or before August 31, 1911, otherwise the right to subscribe will be void and the warrants of no value.

Receipt of such warrants and subscriptions will be acknowledged by the Treasurer.

The rights specified in such warrants may be sold and transferred by assignment executed in the form prescribed and printed thereon.

Stockholders who may wish to subseribe for a portion of the stock covered by a warrant and dispose of the balance or who may wish to dispose of a portion to one person and the balance to another should return their warrants to the Treasurer at either of the above-named offices, to be exchanged for other warrants, specifying the number of warrants desired in exchange and the number of shares to be covered by each.

All correspondence relating to the foregoing should be addressed to the Treasurer, William R. Driver, 125 Milk Street, Boston, Mass.

By order of the Directors,

THEODORE N. VAIL, President.

\section{MEMORANDUM}

The proceeds of this issue of capital stock will he mainly used to provide the associated companies of the Bell System outside of the State of New York with funds for current and ordinary construction and extension of plant, and will be represented in the trensury of the 
American Telephone and Telegraph Company by the share capital or the capital advance notes of such companies.

A part will be used for extensions to plant (Long Distance service) of the American Telephone and Telegraph Company outside of the State of New York, and a part to maintain the cash balances now being drawn upon for all the above purposes.

Reference to the Annual Report for 1910, end of page 7 and page 8, under head of "Depreciation," sets forth the great advantage and economy of advance construction. Advance construction must be planned and cared for, and the cash provided in advance, if it is to be done in the best and most economical way.

The charges of this proposed issue on this year's revenue will be hardly appreciable. As a matter of fact, the usual yearly dividend on the whole amount could be met out of this year's revenue and still leave a surplus.

The business of the current six months of this year will show a continuation of increases in gross and net, although the toll and longdistance business as usual shows the effect of business depression.

The increase of subscribers' stations directly connected with the systems of the associated companies shows an increase over any previous year. The year will probably show a greater increase of stations, including those of connected or sub-licensed independent companies, thar any previous year.

In any comparisons with the figures so far of the present year, consideration should be given to the fact that the year's surplus earnings will be reduced at least $\$ 150,000$ by increased charges against it, due to conversion of bonds into stock, and also about $\$ 315,000$ by the decrease of interest income, due to the exchange of capital advance notes of the associated companies held by the American Telephone and Telegraph Company into capital stock of such companies, upon which no dividends as yet have been credited.

All the above facts taken in connection with the growing and more favorable sentiment of the community, which is evidenced by the passage in some states, and general advocacy and favorable consideration in others, of bills allowing opposition telephone companies to merge, together with the very broad and exhaustive decisions in supporting our contentions in the very few cases where we have had to go to the courts for protection against adverse legislation, presage for the next and future years a continuation of our past prosperity.

THEODORE N. VAIL, President. 


\section{STOCKHOLDERS' RIGHTS}

Form of Assignable Warrant Evidencing Right of Stockholder to Subscribe to New Stock.

Face of Warrant

Void and of no Value After Close of Business November 15, 1915

$$
\text { ASSIGNABLE WARRANT }
$$

No. $\$ \ldots \ldots \ldots$

FOR SUBSCRIPTION RIGHT IN RESPECT OF

Seven Per Cent. Cumulative Preferred Capital Stock of the

\section{AMERICAN COAL PRODUCTS COMPANY}

This is To Certify that on the terms and conditions of the Resolutions of the Board of Directors, adopted October 5, 1915,

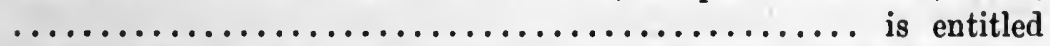
to the rights hereinafter stated in respect of a subscription privilege for .............. Dollars of the Seven Per Cent. Cumulative Preferred Capital Stock of the American Coal Products Company. This warrant, and all rights represented hereby, are transferable by assignments, whereupon the holder thereof will be entitled, on surrender hereof, to all rights of the original holder. In cases where warrants are part "subscribed" and balance "assigned" same must be presented at the Registrar and Transfer Company, 32 Nassau St., New York City, to be re-issued in separate warrants.

This warrant, and other warrants for amounts aggregating full shares and multiples thereof, shall be presented and surrendered at the office of the Company, 17 Battery Place, New York City, N. Y., on or before the close of business November 15th, 1915, together with payment of twenty-five dollars $(\$ 25.00)$ per share of stock subscribed for (same being twenty-five per cent. of the total amount to be paid) in order to participate in the issue. Warrants not 80 presented are void and of no value. The balance of seventy-five dollars (\$r5.00) per share subscribed for is due and payable December 20, 1915. Pay- 
ments on these warrants not subject to interest or participation in dividends. No subscriptions for a fraction of a share will be accepted.

Engraved Certificates of Stock will be issued on and after January 17, 1916, in exchange for all full paid subscription receipts.

By order of the Board of Directors

american Coal Products Company

Treasurer

Registrar \& Transfer Company

Secretary

Dated 1915

Reverse Side of Warrant

\section{SUBSCRIP'TION}

To the AMERICAN COAL PRODUCTS COMPANY

The undersigned hereby subscribes for the stock mentioned in this warrant under conditions therein stated and agrees to make paymente as therein provided.

Dated

Residence.

Post Office Address.

\section{ASSIGNMENT}

FOR VALUE RECEIVED the within warrant and all rights evidenced thereby are hereby transferred to

\section{WITNESS :}

NOTICE: The signature to this assignment must correspond with the name as written upon the face of the warrant in every particular. without alteration, enlargement or any change whatever. When, assignments are executed by administrators, executors, trustees, guardians, attorneys, etc., proper evidence of their authority so to act must be on file with the Company. 


\section{CONSOLIDATION}

\section{Valuation of Dissenting Stockholder's Stock}

Proceedings were instituted under section 7 of the Business Corporations Law (Consol. Laws, c. 4) for the consolidation of two domestic corporations, the Yellow Taxicab Company and the MasonSeaman Transportation Company, under the latter name.

The respondent, who is the owner of 173 shares of the preferred and 640 shares of the common stock of the Yellow Taxicab Company, objected to the consolidation. Three appraisers were thereupon appointed, as provided in section 8 , for the purpose of determining the value of his stock. After numerous hearings, they filed a report in which they determined the value of the preferred to be $\$ 88.43$ per share, or $\$ 15,298.39$, and the common stock of no value. The report, upon motion of the respondent, was confirmed, and the Transportation Company directed to pay to him, upon the surrender of his common and preferred stock, the sum of $\$ 15,298.39$. From this order the Transportation Company appeals.

1. The appraisers determined the assets of the Yellow Taxicab Company, as of March 9, 1914, the date when the respondent objected to the consolidation, to be $\$ 1,201,728.14$, which included the valuation of the good will at $\$ 366,707.52$. The appellant urges that the appraisers erred in fixing the value of the good will. The Yellow Taxicab Company commenced business on May 21, 1912, and the appraisers found that the net earnings of the company, for the year ending May 21, 1913, were $\$ 203,766.43$, and for the subsequent period ending March 9, 1914, $\$ 15,239.48$, making the total net earnings during the period mentioned $\$ 219,005.91$. They divided the total net earnings by $211 / 2$, approximately the number of months during which the corporation had been in business, and found the average monthly profit to be $\$ 10,186.32$, and the average yearly profit $\$ 122,235.84$. They then multiplied the yearly profit by 3 , and took the result, $\$ 366,707.52$, as the value of the good will.

The general method adopted in determining the value of good will is that suggested in Von $A u v$. Magenheimer, i15 App. Div. 84, 100 N. Y. Supp. 659, where it is stated that:

"The value of good will may be fairly arrived at by multiplying the average net profits by a number of years, such number being

1 Opinion in case of Seaich v. Mason-Seaman Transp. Co., 156 N. Y. S. 579. December, 1915. 
suitable and proper, having reference to the nature and character of the particular business."

The appraisers, however, did not, as suggested on the second trial of the Magenheimer Case, 126 App. Div. 257, 110 N. Y. Supp. 629, affirmed $196 \mathrm{~N}$. Y. $510,89 \mathrm{~N}$. E. 1114 , deduct from the average net profits interest on the capital invested in the business, and of this the appellant complains. I am of the opinion that interest should have been deducted. There are several authorities which indicate that interest on capital invested ought to be deducted from the average profits of a business before using such profits as a basis for determining good will. Von Au v. Magenheimer, supra; Matter of Ball, 161 App. Div. 79, 146 N. Y. Supp. 499; Matter of Board of Water. Supply, 81 Misc. Rep. 19, 142 N. Y. Supp. 83; Matter of Keahon, 60 Misc. Rep. 508, 113 N. Y. Supp. 926.

It is impossible to accurately determine from the record before us the capital upon which interest should have been allowed; but I think substantial justice will be done to both parties if interest be allowed on the value of the assets as determined by the appraisers on March 9, 1914, excluding the value of the good will. If this be done, then the value of the assets on the day named was $\$ 835,020.62$. Six per cent. interest on that sum for one year is $\$ 50,101.24$. If this amount be deducted from the average yearly profit, then that amount would be $\$ 72,134.60$, instead of $\$ 122,235.84$, as found by the appraisers; and multiplying this profit by 3 , the method adopted by the appraisers, the value of the good will was $\$ 216,403.80$, instead of $\$ 366,70 \% .52$, and the assets of the corporation were $\$ 1,051,424.42$, instead of $\$ 1,201,728.14$.

2. The appellant also urges that other reductions should have been made; but only one of them, I think, requires serious consideration, viz., the one relating to the value of the taxicabs. In ascertaining that value, the appraisers first determined their value on May 21, 1912, the time when the corporation commenced business, to be $\$ 539,100$. From this amount they deducted for depreciation and obsolescence at the rate of 10 per cent. per annum. The finding of the appraisers that the value of the taxicabs was $\$ 539,100$ on May 21 , 1912 , is sustained by the evidence; but, when all of it is considered, I am of the opinion that 20 per cent. per annum, instead of 10 , should have been allowed for depreciation and obsolescence. If this be done, then the value of the taxicabs on March 9, 1914, was $\$ 362,275.20$, instead of $\$ 446,374.80$. The assets of the corporation on March 9, 1914, as determined by the appraisers, as already indicated, were $\$ 1,201,728.14$. From this amount they deducted the con- 
ceded liabilities, $\$ 457,809.89$, which left a surplus of $\$ 743,918.25$, and it was upon this amount that they determined the value of the petitioner's preferred stock to be $\$ 88.43$ per share. But, as has been pointed out, I think the appraisers overvalued the corporate good will to the extent of $\$ 150,303.72$, and the value of the taxicabs $\$ 84,099.60$, making in all an overvaluation of $\$ 234,403.32$, which amount should be deducted from $\$ 743,918.25$, the surplus of assets over liabilities as found by the appraisers. After making this deduction then the surplus of assets over liabilities on March 9, 1914, was $\$ 509,514.93$, and the value of petitioner's preferred stock, based on these assets, is $\$ 60.57$ per share, or $\$ 10,478.61$.

In reaching this conclusion I recognize the impossibility of fixing, with a desired degree of accuracy, the value of the petitioner's stock, but I think that the result reached approximates as near as can be the true value of the stock and accomplishes substantial justice between both parties.

The order appealed from, therefore: is modified as indicated in the opinion, without costs. All concur. 


\title{
SHORT T'ERM NOTES
}

\author{
Redemption and Sales Prices ${ }^{1}$
}

$\$ 50,000,000$

\section{Bethlehem Steel Corporation}

\section{Secured Serial $7 \%$ Gold Notes}

Dated July 15, 1918. Due Series A, B, C and D, $\$ 7,500,000$ each July 15, 1919-1922, inclusive, Series E, \$20,000,000, July 15, 1923.

TO BE AUTHORIZED AND ISSUED $\$ 50,000,000$

Coupon notes in denomination of $\$ 1,000$; registrable as to principal only. Interest payable January 15 and July 15, without deduction for any tax or Governmental charge except any Federal Income Tax in excess of 2 per cent. per annum.

Redeemable at the option of the Corporation at any time upon 30 days' notice, as a whole or in series, (in which event all the notes of one or more of the series first maturing must be called for redemption) at

102 for Notes with 4 years or more to run.

$1011 / 2$ for Notes with 3 years or more but less than 4 years to run. 101 for Notes with 2 years or more but less than 3 years to run. $1001 / 2$ for Notes with 1 year or more but less than 2 years to run. 100 for Notes with less than 1 year to run.

Notes to be convertible at the option of the holder at par into new Bethlehem Steel Corporation Consolidated Mortgage 30-Year Sinking Fund 6\% Gold Bonds, Series A, due August 1, 1948, when pledged under the indenture, at a price for said bonds equivalent to a $61 / 2 \%$ income basis at the time of such conversion.

We offer these Notes, when, as and if issued and received by us, and subject to approval of counsel.

1-Year Notes due July 15, 1919, Price 991/2 and interest to yield about $71 / 2 \%$

2 -Year " "July 15, 1920

3 -Year " " July 15,1921

4 -Year " " July 15, 1922,

5-Year

“ July 15, 1923,

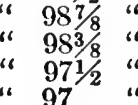

${ }^{1}$ From advertisement in New York Times, July 16, 1918. 


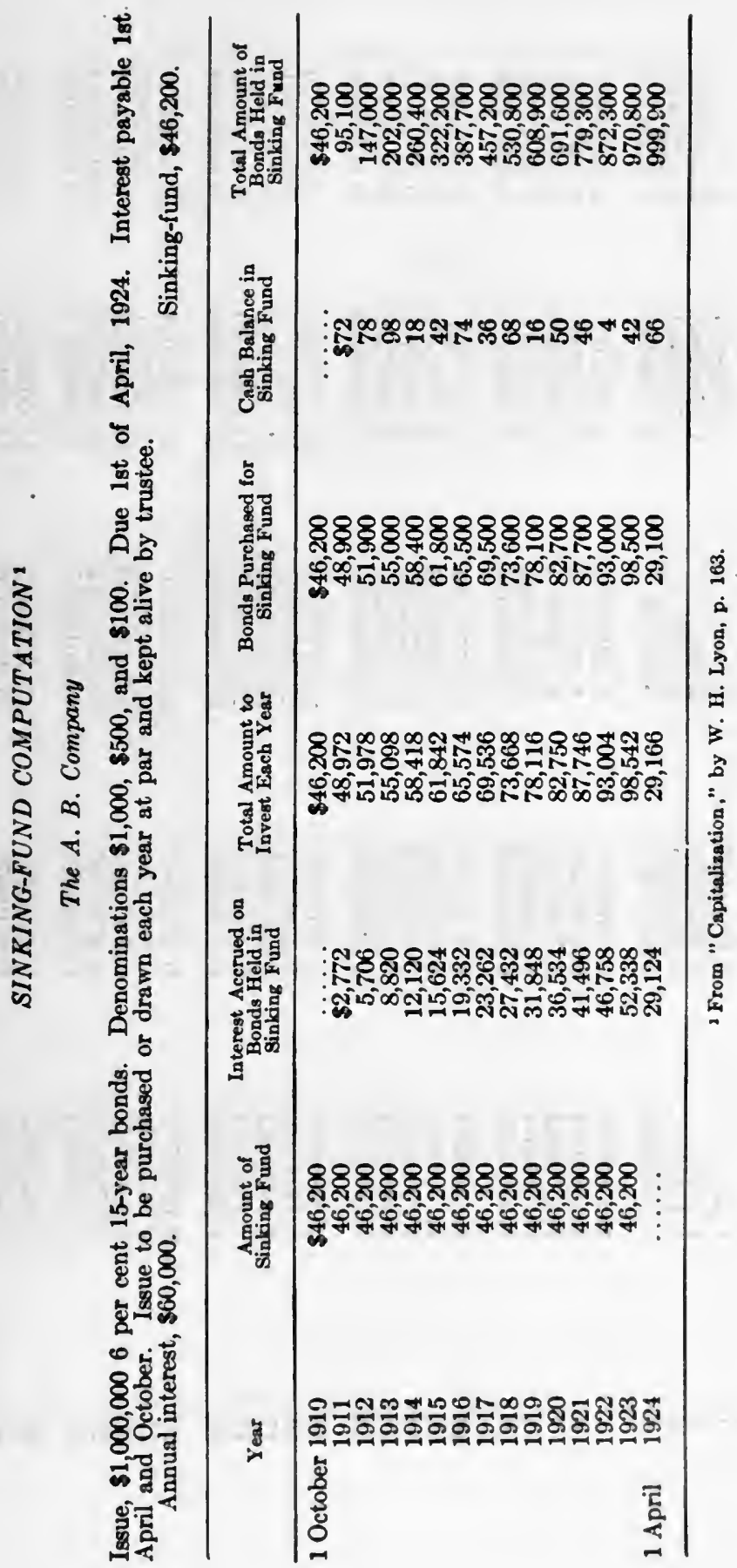


1024 MATERIALS OF CORPORATION FINANCE

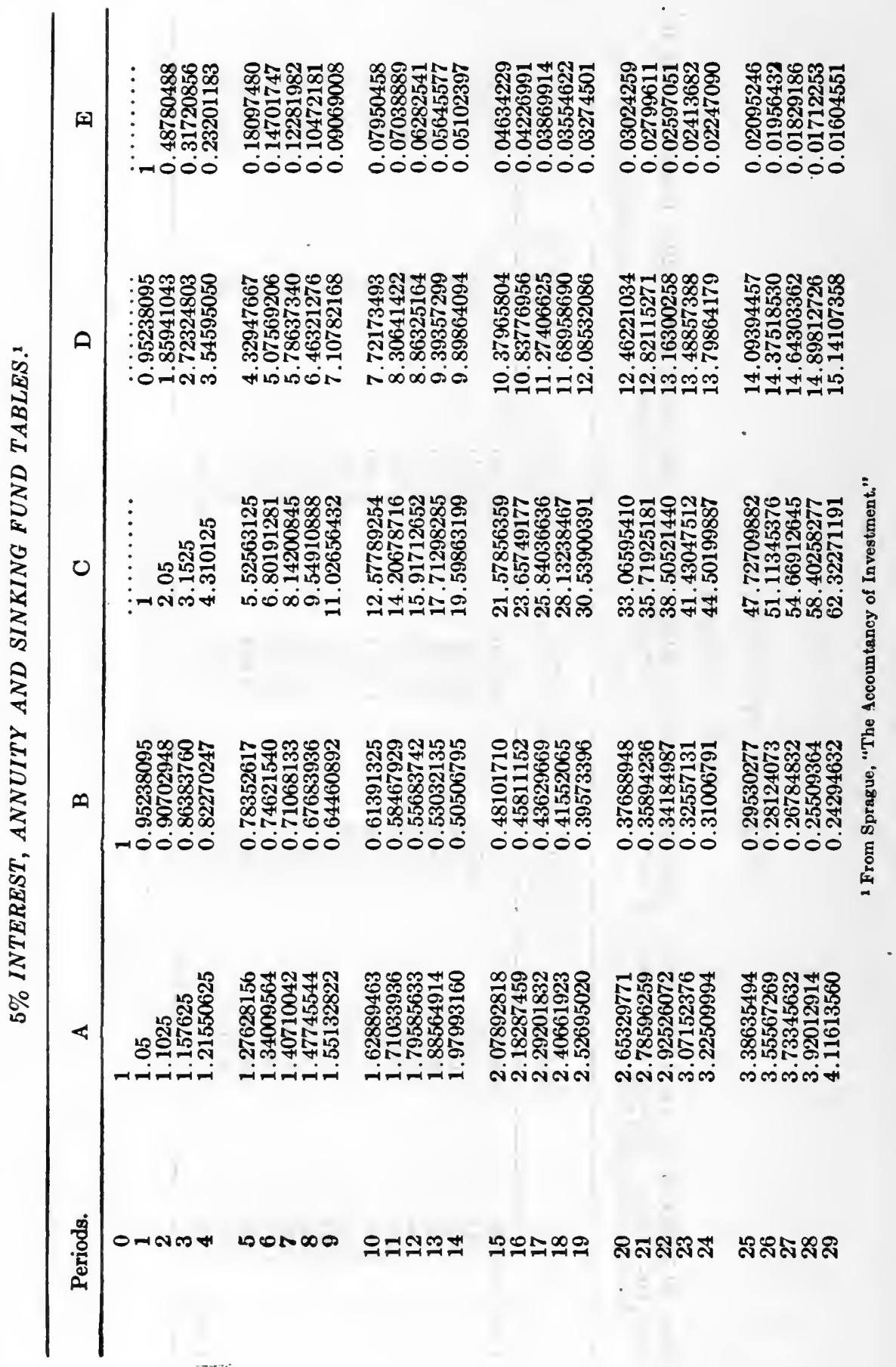




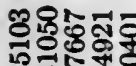

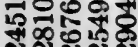
సิำ

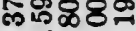
pisinge

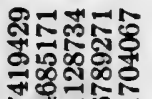
슘츄응 0000
"ृ:

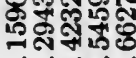
츠든
뚜유도ำ \&ํํㅇำ 가읒ㅇ 당ㅇㅇㅇ $\sim N \infty \infty$

우눙쥼ำ

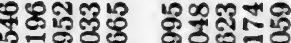
ส다누 मे

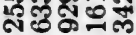
$\infty \infty \infty \sigma^{\circ}$ -1.

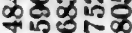
-0000 용ㅇㅇ \%

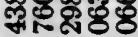

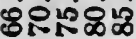

요유. 品

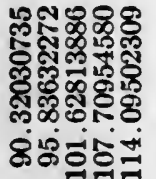

포능요요 भิष 동드잉

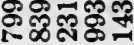

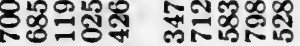

is

నo:

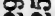
แ चี

พ⿻ 乃ํ.

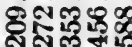

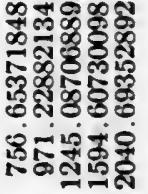

芯

ํㅜㄴ대요 윰ํํㅇ m. ఇ. 0000

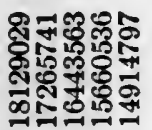

오웅요

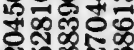
숭: สำ 00000

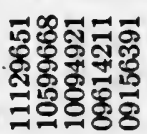

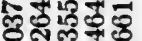
고ำ

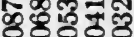
00000
๓온

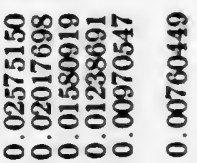

ชं

这崖

당

है

要

롤.

उ.

的

응

है a

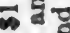
$\div 53$ 继 药. है. है. 这紫 .2 .2 .9 <U: 도의 ⿷

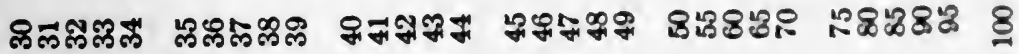




\section{SERIAL BONDS.}

Table showing maturities of a $\$ 1,682,500$ bond issue dated February 4,1918 , arranged so that payment of interest and repayment of principal will aggregate approximately the same amount each year after the fifth year. Denominations are $\$ 1000$ and $\$ 500 .^{1}$

\section{Maturities.}

$\begin{array}{rcc}\text { Amount } & \text { Maturity } & \text { *Price } \\ \$ 51,000 & \text { August 1, 1923 } & 95.55 \\ 54,000 & \text { August 1, 1924 } & 94.85 \\ 56,000 & \text { August 1, 1925 } & 94.19 \\ 59,000 & \text { August 1, 1926 } & 93.57 \\ 62,000 & \text { August 1, 1927 } & 93.08 \\ 65,000 & \text { August 1, 1928 } & 92.43 \\ 68,000 & \text { August 1, 1929 } & 91.90 \\ 71,000 & \text { August 1, 1930 } & 91.41 \\ 75,000 & \text { August 1, 1931 } & 90.95 \\ 79,000 & \text { August 1, 1932 } & 90.51 \\ 83,000 & \text { August 1, 1933 } & 90.10 \\ 87,000 & \text { August 1, 1934 } & 89.71 \\ 91,000 & \text { August 1, 1935 } & 89.35 \\ 96,000 & \text { August 1, 1936 } & 89.00 \\ 101,000 & \text { August 1, 1937 } & 88.67 \\ 106,000 & \text { August 1, 1938 } & 88.37 \\ 111,000 & \text { August 1, 1939 } & 88.07 \\ 116,000 & \text { August 1, 1940 } & 87.81 \\ 122,000 & \text { August 1, 1941 } & 87.55 \\ 129,500 & \text { August 1, 1942 } & 87.31\end{array}$

* Plus accrued interest yielding about $6 \%$.

1 From advertisement of Mississippi County, Arkansas Drainage District No. 17 5\% Bonds in New York Times, May 21, 1918. 


\section{INDEX}





\section{INDEX}

\section{A}

Accounts receivable, Assignment of, 908

Advertising securities, Bond circular, 374, 404; Preferred stock circular, 367 ; Stock promotion prospectus, $377,387,398,399$

Agreement, Syndicate underwriting, $405,530,769$

Albany \& Susquehanna Rd. Co., Convertible bonds, 326

American Car \& Foundry Co.. Conditional sale agreement, 299

American Cigar Co., 516

American Coal Products Co., Stockholders' rights, 1017

American International Corp., Managers' stock, 1013

American Power and Light Co., Short term notes, 291

American Smelting \& Refining Co., Financial statements, 759

A merican Snuff Co., Formation of, 511

American Telephone \& Telegraph Co., Convertible bonds, 329 ; Valuation of Chicago Co., 783; Stockholders' rights, 1014

Amortization table, 1023

Analysis, of a Public Utility, 620; Of Chicago, Milwaukee \& St. Paul Ry., 753; Of Bethlehem Steel, 761; Of May Department Stores, 767

Annual report, See Report

Annuity table, 1024

Application, For bank loan, 202; For listing on New York Stock Exchange, 162

Appraisal of Chicago Telephone Co., 783

Approval of public utility issues, 350 , 351

A rbitrage dealings, N. Y. Stock Ex. change, 139

Articles, of co-partnership, 1 ; Of association, 105; Of incorporation, 101 ; Of joint-stock company, 6

Assets, Stock preferred as to, 44, 58, $61,103,110$; Stock not proferred as to, 28, 105

Assignment of accounts receivable. 908
Assignment of stock, See Transfer of certificates

Atchison, Topeka \& Santa Fe Ry. Co., Convertible bonds, 325

Atlantic Fruit \& Steamship Co., Con . vertible bonds, 322

Authentication of trustee, 264, 304, 293,316

\section{B}

Balance sheet, See Reports

Ballot for voting for directors of cor poration, 90

Baltimore \& Ohio Rd. Co., Income statement, 625 ; Reorganization, 960

Bank loan, Application for, 902

Banker, Refunding with aid of, 320 ; Refunding without aid of, 1009

Bankers Trust Company, 313

Bartica Company, Circulars and reports, 383, 384, 387

Beemis, Prof. E. W., 783

Bethlehem Steel Corp., Analysis of a. nancial statements of, 761 ; Redemption and sales prices of notes, 1022

Bids and offers, New York Stock Ex. change, 127

Black Wonder Mill \& Mines, Advertisement of stock, 398

Blair \& Co., 321, 374

Board of Directors, Sce Directors

Bond, Form of, 190, 255; Authentication by trustee, 264, 293; Baltimore \& Ohio Ri., 975, 984; Circular, 324, 374, 404; Classification of, XIII; Collateral trust, 255; Conversion into stock, 322, 324, 353; Equip. ment trust, 301, 315; Iegal invest. ments, 447: Redemption of, 219 , $325,336,1022,1023$; Refunding of, 320; Regulations concerning trans. fer of, 171: Serial, 1026: Serial ma. turities, 20] ; Sinking fund, 1023

Bond house letter, 404

Boston Flevated Ry. Co. lease, 555

Brooklyn Rapiul Transit System, Convertible Innile, 325

Brooklyn Union Gaa Co., Convertihlo bonils, 330

Bucket-shops, New York Stock Ex. edange, Rules regarding, 142 
By-Laws of United States Steel Corporation, 66

Buying and seling stock, 421, 435

\section{C}

California Petroleum Corporation, Charter of, 101; Buying its stock to support market, 435

Calls and puts, 438, 444

Car Trust notes, 299, 315

Certificate of beneficial interest in voting trust, 91,98

Certificate of incorporation, Company having stock without par value, 43 ; American International Corporation, 1013; Atchison, Topeka and Santa Fe Ry. Co., 54; California Petroleum Co., 101; Chicago, Milwaukee \& St. Paul, 105; May Department Stores, 107; United States Steel Corporation, 59; Western Maryland Ry. Co., 1011; Wisconsin Edison Co., 43

Certificate of limited partnership, 4

Certificate of stock, 150

Charter, Of General Electric Company, 26 ; See also Certificate of incorporation

Chicago \& Alton Rd. Co., Recapitalization of, 910

Chicago Elevated Railways, Refunding notes without aid of banker, 1009

Chicago, Milwaukee \& St. Paul Ry. Co., Articles of association, 105; Analysis of financial statements, 753

Chicago Telephone Cos., Valuation of, 783

Clayton Law, 595

Clearing House, New York Stock Exchange, 130

Closing contracts, In New York Stock Exchange, 131

Collateral note, 905

Collateral trust mortgage and bonds, 255

Commissions. New York Stock Excliange, 135

Common stock, See Stock

Comparison of incorporation taxes and requirements in different states, 51

Comparisons, Rules on New York Stock Exchange, 128

Compound interest table, 1024

Conditional sale agreement, 299

Consolidated British American Mines, Certificate of stock, 150

Consolidated Gas Co., Convertible bonds, 330

Consolidation, Advantages of, 570; Agreement, 538; Basis of, 536; Form of consent, 545 ; Holding com- panies, 570; Lease of assets, 555; New York Central, 542; Notice to bondholders, 542, 544; Plan of, New Orleans utilities, 526; Promotion of, 489 ; Purpose and method of, 548; Sale of assets, 522; Typ1cal agreement, 538; Valuation of dissenting stock, 1019

Construction of interurban railway, 458

Conversion of bonds into stock, 322 , 324

Convertible bonds, 324

Convertible notes, 1022

Convertible stock, 105, 398, 1011

Co-partnership, Articles of, 1

Corporation, Acts requiring consent or vote of stockholders, 99, 182; Advantages and disadvantages of, 22 ; Ballot for voting for directors, 90 ; By-laws, 66 ; Classification and definitions of, 24; How created, 22, 26, 43, 54, 59, 80, 101, 105; How ended, 22 ; Law, first general, . 31; Law, general, 34; Lease of assets, 555; Liability of members to ereditors, 23 ; Notice of annual meeting, 88; Notice of special meeting, 89; Proxy for annual meeting, 88; Relation of members to the whole, 23 ; Taxes and requirements, 51, 52, 53; Transfer of certificates, 111, 117, 122, 171; Voting trust, 91

Coupon bond, 260, 293, 303

Cuba, Republic of, $5 \%$ bond underwriting agreement, 405

Cumulative income bonds, 940

Cumulative preferred stock, 28, 44, $61,101,107$

Cumulative voting, 35

\section{D}

Deering Harvester Co., 499

Delaware \& Hudson Co., 326

Delivery, New York Stock Exchange rules, 129,424

Department Stores, See May Department Stores

Depreciation, Divergent views on, 899

Depreciation and maintenance, Chieago Tel. Cos., 799

Detrnit Edison Company, Convertible bonds. 330

Directors. Ninutes of first meeting, 83

Discounting of accounts receivable, 908

"Discovery" of consolidation, 489

Dissenting stock in consolidation, Valuation of, 1019

Dissolution of the Powder Trust, 1001

Distillers' Securities Corporation, 331 
Dividends, New York Stock Exchango rules, 134; Cumulative, 28, 44, 61, 101,107

Domestic corporation, 24

Dupont' Powder Co., Reorganization of, 1001

\section{E}

Earning power in consolidations, 536

Engineer's preliminary report, Character and importance of trade, 470 ; Cost of construction, 464; Description of route, 459; General proposition, 457; Passenger income, 483; Plan of construction, 462; Population tributary, 484; Principle features, 458; Revenues expected, 486 ; Rights of way and franchises, 459 ; Statement of revenue and operating expense, 489

Equipment note, form of, 301, 313

Equipment trust agreement, 299, 315

Erie Railroad Co., Ccnditional sale agreement, 299, 313; Convertible bonds, 327

\section{F}

Failure, Causes of, 418

Federal Trade Commission Law, 610

Financial statements, See Reports

First Trust \& Savings Bank, Chicago, 183

Foreign corporation defined, 24

Forms of business associations, 22

Forms used in Joint Account, 769

Fractional lot trading, 429

Franchise of public utility corporations, 583

\section{G}

Gas plant, Elements of cost and value of, 455

General Corporation Law of Illinois, 34

General Flectric Company, Charter, 26

Going concern value, 823

Great Northern Iron Ore Properties, Certificate of beneficial interest. 98 Guaranty Trust Co., New York, 291

\section{H}

Halsey \& Co., N. W., 404

Ilamilton Automohile Co., 80

Haskins ve. Rynn, 489

Hocking Valley pool, 436

Holding companies, In public utility field, 570; Financial statement of, 764 ; Formation of, 526
Hudson \& Manhattan Rd. Co., Read. justment of, 933

Hull and Moran, 1

\section{I}

Improvement fund for bondholders' protection, 163

Income Account, See Report

Incomo bonds of Hulson \& Manhat$\tan$ Rd. Co., 939

Incorporation, Sce Certificate of Incorporation; General incorporation law, 31,34

Intercorporate relations, See Consolidntion, Lease, Holding companies, Pooling agreement, Salo of nssets

Interest, New York Stock Exchange rules, 134,426

Interest table, 1024

International Harvester Co., 91

International Paper Co., 332, 907

International Steam Pump Co., 332

Investments, legal. Sce Legal investments

Iowa Central Ry. Co., 522

\section{J}

Japan Mail Steamship Co., 622

Joint account letters and forms, 769

Joint adventure, How created, 22; How ended, 22; Illustration of, 769 ; Liability of members to creditors, 23; Relation of members to the whole, 23

Joint stock company, Articles of, 6; How created, 22; How ended, 22; Liability of members to creditors, 23; Relation of members to the whole, 23

Jones \& Laughlin Steel Co., Mortgnge, 183 ; Bond circular, 374

\section{$\mathbf{K}$}

Kansas City, Mexico \& Orient Ry. Co., 412,418

Kansas City, Southern Ry. Co., Rules governing transfer of securities, 171

Knickerbocker Trust Co., 322

$\mathbf{L}$

Iackawanna Steel Company, Convertible bonds, 333

I,ease of assets, 55\%

Isnse of equipment, 209, 313

Legal investments, 447 
Letters of a Joint Account, 769

Lima Eastern Railway Company, 457

Limited partnership, Certificate of, 4 ; How created, 22; How ended, 22; Liability of members to creditors, 23; Relation of members to the whole, 23

Listing of stock on exchange, 151, 162

Loans, Assignment of accounts receivable, 908; Collateral note, 905; Form of application for, 902; Note to protect overdrafts, 904 ; See Notes

Louisville \& Nashville Rd. Co., 336

\section{$\mathbf{M}$}

Maintenance and depreciation, Chicago Tel. Cos., 799

Managers' shares, 1011

Manipulation of listed stock, 435

Margin trading, 421

Mason Seaman Transportation Co., Seaich vs., 1019

Massachusetts Electric Companies, 11

Massachusetts Trust, 11; Certificates of interest, 98

May Department Stores Company, Charter of, 107 ; Financial statements of, 767

Meetings, notices of, 88,89

Midwest Refining Co., Financial statements, 766

Minneapolis \& St. Louis Rd. Co., 522

Minutes, of first meeting of directors, 83 ; Of organization meeting, 80

Moneyed corporation, defined, 24

Monopoly, Clayton law, 575; Dissolution of Powder Trust, 1001; Federal Trade Commission law, 610; Sherman Anti-trust law, 590

Morgan, J. P. \& Co., 499

Mortgage Bond Company, Mortgage, 255

Mortgage, Corporate, 183, 255; Affecting after acquired property, 194, 203; Authentication of bonds, 200; Execution of bonds, 196; Improvement fund, 163; Pledged stocks, 195, 207; Redemption of bonds, 219, 336 ; Registration of bonds, 200;

Release of mortgaged property, 236 ; Replacement of bonds, 201; Requiring net assets to exceed stock, 210 ; Requiring quick assets to exceed lia: bilities, 210; Sale or lease by subsidiary, 208; Sinking fund, 219; Tax on bonds, 202; Temporary bonds, 202; Trustees, Duties of, 240. Mortgage, Real estate, 176

Municipal corporation, Defined, 24

\section{$\mathbf{N}$}

National Lead Company, 489

New Jersey Public Utilities Act, 337

New York Central lines, Consolidation of, $542,544,548$

New York, New Haven \& Hartford Rd. Co., Annual report, 663; Convertible bonds, 327; Stockholders' rights, 358

New York Stock Exchange, By-laws and rules, 126; Application for listing on, 162; Method of trading, 421 ; Rules of committee on stock list, 151

New York, Westchester and Boston Ry. Co., Statement, 751

Nippon Yusen Kaisha, 622

Non-eumulative preferred stock, 57, 106

Non-participating preferred stock, 28, $45,57,61,107,1011$

Non-stock corporation, defined, 24

Non-voting stock, 104

Northwestern Elevated Rd. Co., 327

Notes, Collateral, 905; Equipment trust, 301, 313; Overdraft, 904; Redemption price of, 1022; Refunding of, 320, 1009 ; Registration of, 907; Short term, 291

Notice, Of annual meeting, 88; of special meeting, 88

Odd lot trading, 429

Offer to purchase bonds from sinking funds, 336

Offers and bids on New York Stock Exchange, 127

Oil company, Midwest Refining Co., 766

Opening a brokerage account, 433

Option warrant, 293

Options, Puts and calls, 441, 444

Orders, For purchase of securities, 433

Overdraft, Note to protect against, 904

\section{$\mathbf{P}$}

Pacific Gas \& Electric Co., Bond circular, 404 ; Readjustment of, 929

Pacific Light \& Power Co., Application for listing stock, 162

Participating preferred stock, 102, 106, 1013

Partnership, Agreement, 1; How created, 22 ; How ended, 22 ; Liability of members to creditors, 23 ; Limited certificate of, 4 ; Of munieipality with public utility, 583; Relation of members to the whole, 23 
Par value, Stock without, 43, 47

Payment and delivery, New York Stock Exchange, 129

Pennsylvania Coal \& Coke Co., 336

Pennsylvania Rd. Co., 328

Physical valuation of Chicago Telephone Cos., Appraisal, 812; “Going. value," 823; Maintenance and de. preciation, 799, 830 ; Rate of return, 837; Reproduction v8. actual cost, 819 ; Table of contents, 783

Pieree Fordyce Oil Association, 6

Pooling agreement, Hocking Valley, 496; Steel rail, 436

Powder trust, Dissolution of, 1001

Preferred stock. See Stock

Premium, N. Y. Stock Exchange, 134

Price, Of short term notes, 1022; Of serial bonds, 1026

Profit and Loss Statement, See Reports

Promoter's letters, 383, 412, 415

Promotion, American Cigar Co., 516; American Snuff Co., 511; Bartica Co., 387 ; Black Wonder Mines, 398; Deering Harvester Co., 499, 508; Discovery of new consolidation, 489 ; Elementa of cost of new gas plant, 453; Engineer's preliminary report, 457; Sterling Debenture Corp., 383; Supporting the market, 435 ; Syndicate agreement, 405, 410; United Dry Goods Co., 367; United Lead Company, 489.

Prospectus of mining company, 377, 398

Protected preferred stock, 107

Proxy, Form of, 88

Public Utilities Commission, Act of New Jersey, 338; Approval of security issues, 350,351

Public utility, Holding companies, 570; Analysis of, as investment, 620 ;. Lease of assets, 555 ; Partnership with municipality, 583; Readjustment of, 929, 933; Restriction on issue of securities, 351 ; Valuation of, 453, 783

Purchase of assets, 501

Puts and calls, 438, 441, 444

\section{$\mathbf{R}$}

Readjustment, Hudson \& Manhattan Rd. Co., 933; Pacific Gas \& Electric Co., 929; See also Reorganization, Recapitalization and Receivership

Real Estate mortgage and hond, 176, 180

Recapitalization of Chicago \& Alton Rd. Co., 910; See also Receivership, Readjustment and Reorganization
Receivership, Kansas City, Mexico \& Orient Ry. Co., 418; See also Reor. ganization, Readjustment and Rocapitalization

Redeemable preferred stock, 45, 103, 107

Redemption of bonds, $219,336,1023$, 1026

Redemption price of short term notes, 1022

Refunding, With aid of banker, 320 ; Without aid of banker, 1009

Registration of commercial paper, 907

Registry, New York Stock Exchange, 135

Reorganization, Baltimore \& Ohio Rd. Co., 966 ; Dupont Powder Co., 1001; see also Readjustment, Recapitaliza. tion and Receivership.

Reports, annual, American Smelting \& Refining Co., 759 ; Baltimore \& Ohio Rd. Co., 625; Bethlehem Steel Corp., 761; Chicago, Milwaukee and St. Paul Ry. Co., 753; Hartford and New York Transp. Co., 749; May Department Stores.Co., 767; Midwest Refining Co., 766; New York, New Haven \& Hartford R. R. Co., 663; New York, Westchester \& Boston Ry. Co., 751 ; Nippon Yusen Kaisha, 622; United Light \& Ry. Co. and Subsidiaries, 764; Westinghouse Electric and Mfg. Co., 627

Reproduction v8. Actual cost, Chicago Telephone Cos., 819

Restrictions, On security issues of pub. lie utilities, 351 ; On issue of bonds in open end mortgage, 197

Rights, Stockholders', 358, 363, 773, 1014, 1017; Formula for valuing, XV

\section{$\mathbf{S}$}

St. Prul Ry., See Chicago, Nilwaukee \& St. Pnul Ry. Co.

Sale of assets, 499,522

Berip, Convertihle. 105

Seaich vs. Mason Beaman Transp. Co., 1019

Selling of securitins, 367-404; 1014 $1018 ; 1022$

Berial bonis, Maturities of, 201, 1026; Prices of, 1026

Settlement of contracts, New York Stock Exchnnge, 130

Shnres of stock. Without par value, 43, 47; See nlso Stock and Transfer of certifieates

Sherman anti-trust $\ln w, 590$

Short term notex. 291; See aluo Noten

Short relling, 423 
Sinking fund, Amortization table, 1023; Bonds, 219, 336; Improvement fund, 163; Tables, 1024

Smelting and refining, See American Smelting \& Refining Co., 759

Southern Pacific Company, 363

Special act to incorporate General Electric Co., 26

Spencer Trask \& Co., 324

Standard Steel Car Company, 313

Statements, Customers', 426; see also Reports

Steel rail pool, 496

Sterling Debenture Corporation, 383, 384

Stillwell, A. E., 412, 415, 418

Stock, Approval of issue, 350; Buying and selling, 421, 435; Certificate of, 150 ; Common, 15, 87, 150; Convertible, 105, 1011; Convertible into funeral, 399; Cumulative, 28, 44, 61, 101, 107; Managers', 1013; Noncumulative, 57, 106; Non-participating, 28, 45, 57, 61, 107, 1011; Nonvoting, 104; Pooling agreement, 436; Preferred, 16, 28, 44, 58, 61, $101,105,107,367,1011$; Redeemable, 45, 103, 107, 1011; Transfer law of New York, 117, 111; Vetoing, 58, 103; Valuation of, 1019; Without par value, 43,47

Stock corporation, Defined, 24

Stock Exchange, New York, See New York Stock Exchange

Stockholders, Corporate acts requiring consent or vote of, 99,182 ; In voting trust, 91 ; Liability to creditors, 23 ; Relation to corporation, 23; Rights, XV, 358, 363, 1014, 1017

Stop loss orders, 424

Subscription to stock, 1014, 1017

Supporting the market, 435

Syndicate underwriting agreement, $405,430,769$

\section{$\mathbf{T}$}

Tangible and intangible property, Valuation of, 536, 538, 1019

Taxes, Incorporation, 51; Transfer of stock, 117,122

Toledo Traction Company, 320

Transfer of stock, In Wall Street, 421; Certificates, 111, 117, 120, 135, 424; Form of assignment, 160 ; Options, 441; Puts and calls, 438; Regulations, 171; Stock Exchange rules, 126; Tax law regarding, 117; To support the market, 435
Transfer tax law of New York, 117, 122

Trust agreement, Mortgage Bond Co., 255

Trust, Collateral mortgage, 255; Equipment, 299, 315; Massachusetts, 11; Voting, 91, 940, 973; See also Monopoly

Trustee, Authentication of, 264, 293, 304,316 ; Certificate of beneficial interest, 98; Legal investments for, 447 ; R. R. equipment notes, 299

\section{U}

Underwriting, Agreement, 405, 530, 769 ; Selling stock without, 412, 1009 ; Supporting the market, 435; Statement of Joint Account, 769

Union Pacific Rd. Co., 329, 363

United Dry Goods Companies, 367

United Fruit Co., 333

United Light \& Railways Co., and subsidiaries, Financial statement of, 764

United States Realty \& Improvement Co., 334

United States Steel Corporation, Certificate of incorporation, 59 ; $\mathrm{By}$. laws of, 66 ; Notice of annual meet. ing, 88; Notice of special meeting, 89; Proxy for annual meeting, 88

\section{V}

Valuation, Of gas plant, 455; Of Chicago Tel. Cos., 783 ; Of property of consolidated companies, 501, 536, 538 ; Of stock of dissenting owner, 1019

Voting trust agreement, 91, 940, 973

Voting, Form of proxy, 88, 89 ; Form of ballot, 90 ; Cumulative, 35

\section{W}

Wall Street ways, 421

Warrant, Option, 293; Stockholders' rights, 1017

West End St. Ry. Co., 555

Western Maryland Rd. Co., Convertible bonds, 329 ; Extract from charter, 1011

Western Union Telegraph Co., 334

Westinghouse Elec. \& Mfg. Co., Convertible bonds, 335 ; Report, 627

Wisconsin Edison Company, 43 


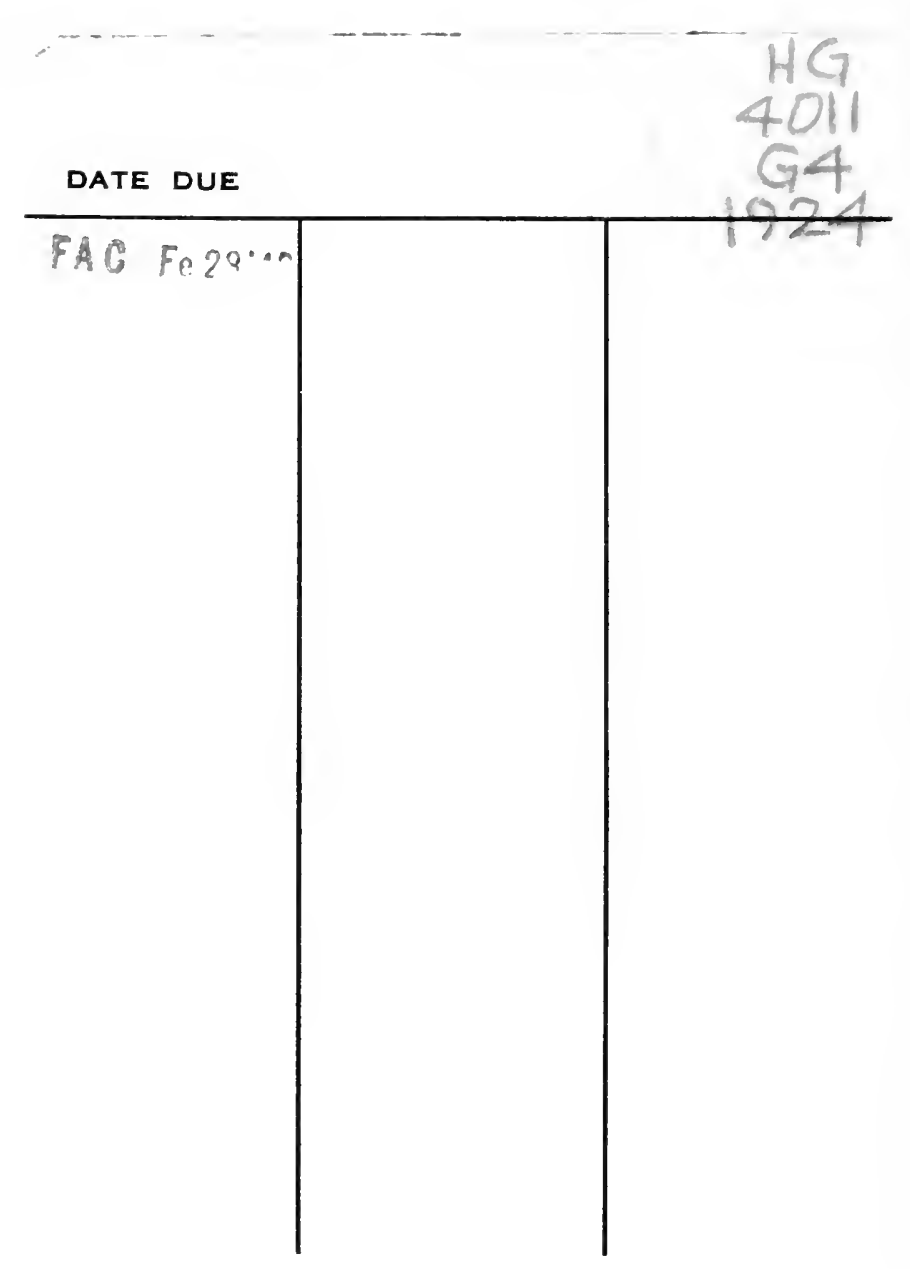




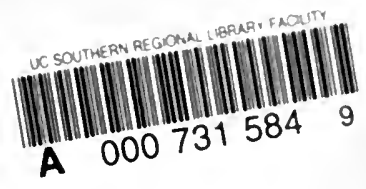


